\title{
Antoon Coolen, 1897-1961 : biografie van een schrijver
}

Citation for published version (APA):

Slegers, C. (2001). Antoon Coolen, 1897-1961 : biografie van een schrijver. [Doctoral Thesis, Maastricht University]. Universiteit Maastricht. https://doi.org/10.26481/dis.20011114cs

Document status and date:

Published: 01/01/2001

DOI:

$10.26481 /$ dis.20011114cs

Document Version:

Publisher's PDF, also known as Version of record

\section{Please check the document version of this publication:}

- A submitted manuscript is the version of the article upon submission and before peer-review. There can be important differences between the submitted version and the official published version of record.

People interested in the research are advised to contact the author for the final version of the publication, or visit the DOI to the publisher's website.

- The final author version and the galley proof are versions of the publication after peer review.

- The final published version features the final layout of the paper including the volume, issue and page numbers.

Link to publication

\footnotetext{
General rights rights.

- You may freely distribute the URL identifying the publication in the public portal. please follow below link for the End User Agreement:

www.umlib.nl/taverne-license

Take down policy

If you believe that this document breaches copyright please contact us at:

repository@maastrichtuniversity.nl

providing details and we will investigate your claim.
}

Copyright and moral rights for the publications made accessible in the public portal are retained by the authors and/or other copyright owners and it is a condition of accessing publications that users recognise and abide by the legal requirements associated with these

- Users may download and print one copy of any publication from the public portal for the purpose of private study or research.

- You may not further distribute the material or use it for any profit-making activity or commercial gain

If the publication is distributed under the terms of Article $25 \mathrm{fa}$ of the Dutch Copyright Act, indicated by the "Taverne" license above, 
Antoon Coolen 1897-1961 
ISBN $90-70641-63-1$

Vormgeving: Grafisch Ontwerpbureau Kees Kanters, Breda

Druk: $\quad$ Drukkerij Leonard bv, Oosterhout

Afwerking: Binderij Hexspoor, Boxtel

Niets uit deze uitgave mag worden verveelvoudigd en/of openbaar gemaakt door middel van druk. fotocopie, microfilm of op welke andere wijze ook zonder voorafgaande schriftelijke toestemming van de uitgever. 


\section{Antoon Coolen 1897-1961}

\section{Biografie van een schrijver}

\section{PROEFSCHRIFT}

ter verkrijging van de graad van doctor aan de Universiteit Maastricht, op gezag van de Rector Magnificus,

Prof. dr. A.C. Nieuwenhuijzen Kruseman, volgens het besluit van het College van Decanen, in het openbaar te verdedigen op woensdag I 4 november 2001 om 16.00 uur door

\section{Cees Slegers}


Promotor:

Prof. dr. W. Kusters

Co-promotor:

Dr. J. Perry

Beoordelingscommissie:

Prof. dr. M. Meijer (voorzitter)

Prof. dr. D. De Geest (Katholieke Universiteit Leuven)

Dr. A. van Iterson

Prof. dr. A. Knotter

Prof. dr. P.J.A. Nissen (Katholieke Universiteit Nijmegen) 


\section{Inhoudsopgave}

Inleiding

1 Jeugd (1897-1914)

"Ik ben maar van eenvoudigen kom-af."

Afkomst 18; Het gezin 18; Vestiging in Deurne 20; Het lezen 24; Deurne begin deze eeuw 25; Gevoel voor tijd en ruimte 28; Ouwerling, een dwarsligger 30; Gymnasium 32; De schoolverlater en zijn begeleiders 36; Opinies 38; Literaire invloeden 40; Kiemen voor het latere werk $4 \mathrm{I}$

2 Aankomend journalist (1914-1919)

"Ik vind zoo weinig sympathieks en zoo weinig om innig lief te hebben in onzen Katholieke Godsdienst."

Een kleinerende kritiek 45; Een raadsman biedt zich aan: Wouter Lutkie 46; Integralisme en modernisme 47; Ernest Hello: richtlijnen voor een journalist $5 \mathrm{I}$; De kennismaking 53; De eerste krantenartikelen 55; Geloofstwijfels 58; Beīnvloeding 6r; Andrejew en Querido 65; Goed en kwaad 67; Bij het Eindhovensch Dag. blad 68: Van Eindhoven naar Maastricht en weer terug 69; Liefde en literatuur 72; De Rozenberg: Van Eeden of Andrejew? 73; De Sterke! 75; Ruzie met de krant 76; Een nieuwe liefde 79; Ontslag en vertrek uit Brabant 80

3 Van Brabant naar het Gooi (1919-1922) 85

"Dien avond heb ik er van gedroomd, met dat geboeide hunkeren, dat ik schrijver worden zou"

Utrecht 85 ; Dreiging van ontslag 86; Voorzichtige opstandigheid 88; De verkering 90; Een nieuwe bundel, een nieuwe roman en een nieuwe woonplaats 91; Vreugde 93; Lentebloesem 96; Weer een vernietigende kritiek 99; Exodus 102; Exit Liesje 104; Exit Lutkie 105; Banden met Brabant verbroken 107

4 Een nieuwe vriendschap (1923-1925) "Brabant!"

Journalist bij De Gooische Post IIr; De literaire sfeer aan het begin van de jaren twintig 11 2; Jantje den schoenlapper en zijn Weensch kiendje I14; De kennismaking met Van Duinkerken II 5; Van Duinkerken als bewonderaar én criticus I 1 8; Coolen verdedigt zich I1 19: Schrijfverbod voor de seminarist Asselbergs I21; De barensweeën voor het nieuwe werk I23; Een nieuwe liefde 127; Op de bres voor Brabant 130

5 De aanloop tot succes (1926-1928)

"Ik kén de peelstrekenbewoners dóór en dóór"

De eerste roman: De rauwe grond 133; Katholieke pers en uitgevers 136; Scheiding der geesten 136; Peerke, dat manneke 140; Peerke: "geen 'echte' Brabander" I41; Coolen als 
vrijdenker 144; Van Duinkerken ook journalist 149; Hun grond verwaait I50; Coolenland en zelfportret 152; De kritiek 154; De dubbelster Coolen-Van Duinkerken 154

6 Succes en bekroning (1929-1930)

161

"In de Peel ben ik thuis."

Kinderen van ons volk 16r; Achtergronden en intenties 163; De ontvangst 166; Huwelijk met Gerda de Jong 168; Het donkere licht 174; Een sociale roman 177; Geen moraal maar mededogen 178 ; Eerste reacties van vrienden 179 ; Plagiaat 180 ; Coolens idioom I8I; Eerste kennismaking met Streuvels I83; Kunst en politiek 184; De C.W. van der Hoogt prijs 187; Extra aandacht voor Coolen en Het donkere licht 188; Geboorteplaats verdoezeld 190

7 Bekroond en aangevallen (zomer 1930 - zomer 1932) 193 "Van dezen tijd wordt bar veel kwaads gezegd."

Serenitas 194; Peelwerkers 195; Gunstige kritieken 200; Vader 202; Streuvels op bezoek 205; De goede moordenaar 206; Echt gebeurd 208; De kritiek 210; Bestempeld tot katholiek romancier 211; Geestelijk klimaat in Hilversum 214; Boekenweek 215; Het regionalismedebat 217 ; Imago 220

8 De Schoone Voleinding (1932-1933) 223

"De eindelooze schoonheid en beminnenswaardigheid van het leven."

Coolen en zijn uitgevers 223; De schoone voleinding 224; Compositie 226; Waarneming en herinnering 227; Het 'Roomsche leven' en het beeld van de clerus 229; Exegese en kritiek 231; Nieuwe perspectieven: Duitse vertalingen 233; Redactielid van De Gemeenschap 234; Ontslag bij De Gooische Post 235; Naar het land der vaderen 237; Columnist bij de Bossche krant 238; Aarden in Deurne 238; Literair credo 239; Bejubeling van het zuiden 240; Politiek en volkskracht 24I; Vlaams avontuur 242; Het nationale en het regionale 243

9 Terug in de Peel (1933-1934)

"De reinigende kracht van het natuurgebonden leven."

De man met het Jan Klaassenspel 247; Fermate en rondo 249; De kritiek 250; Conflict bij De Gemeenschap 254; Een nieuw jaar: grote productiviteit 256; Verhouding tot Duitsland 257: De monarchie, de natie en het boerengezin 259: Overlijden vader Coolen 261; Zegen der goedheid 26r; Ontvangst 262; De vier jaargetijden 264; Slotakkoord 267

10 Maas en Jordaan (1935-1936) 269

"... die beginnen iets van de geheimen te zien."

Een nieuwe roman 269; Hendrik Wiegersma 270; Deurne, een trefpunt van kunstenaars 272; Dorp aan de rivier 273; Een echte 'Coolen' 276; Stijl en idioom 278; De ontvangst 279; Hagelbuitjes: een andere Coolen 282; Reis naar Palestina 283; De vreemdeling 286; Kritiek van twee kanten 287 
"We zijn nog net zo ver als in de barbaarse tijd; men neemt het begeerde met knuppel en knots."

Coolens pacifisme 29I; Vakantie 296; De drie gebroeders 297; Coolen over zijn boek 299; Een goede ontvangst 301; Rancune van een oude vriend 303; De Peel en de zee 304; Reden voor de verhuizing: weg van Wiegersma? 305; Louis de Bourbon 306; Reizen naar Duitsland 307; Speldenprikjes in de Roomsche familie 3ro; Twijfel als redacteur van De Gemeenschap 311 ; Vertalen en vertaald worden 312; Kerstmis in de Kempen 314

12 Van de Peel naar de Kempen (1938-1939)

"Niet altijd weten wij wat we doen."

Waalre 317; De klokkengieter, een 'mannelijk' stuk 318; Opnieuw twijfels over De Gemeenschap 320; Vlaanderen en verzuiling 322; 'De Oost-Brabanters' 323; Brabantia Nostra 326; Coolen en Brabantia Nostra 328; Herberg In 't Misverstand 331; Een staalkaart van Coolens talent 333; Kritiek 336; Boekenweekgeschenk 338; Uit het kleine rijk 338; Dickens en Streuvels 34I; Vrede op aarde 342

13 De Duitse inval (1939-1940)

"Niemand wil oorlog en toch komt hij."

Diksmuide 345; Nederland neutraal 346; Franz Herwig en Groot-Duitsland 348; De laatste winter voor de bezetting 350; Neutraliteitspolitiek 351; De winter van 1939I 940 352; Vriendschappen 354; De meidagen 356; Bezoek Töpfer 357; Materiële zorgen snel opgelost 358; Positie bepalen 359; De Nederlandse Unie 363; Hulde van het Provinciaal Genootschap 365; Een vaderlandslievend verhaal en een literair experiment 367

14 De Kultuurkamer (1940-1942) 369

"Mijn standpunt is: principieel en volstrekt weigeren."

Partij kiezen 369; Louis de Bourbon burgemeester van Oss 371; Schrijven, vertalen, redigeren 374; Duitse toenaderingen 376; Wiegersma, volkskunst en sprookjes 379; Van Kultuurraad naar Kultuurkamer 383; Meedoen of weigeren? 384; Een andere 'baan' 386; De druk neemt toe 388; Van Duinkerken gegijzeld 390; Een dreigende aanmaning 39r; Wel melding, geen aanmelding als lid 392; Kopfschüttelend Abschied nehmen 394; Nasleep na de oorlog 395

\section{Burgemeester van Waalre? (eind 1942-1944)}

"Het benoemingsbesluit moet nu nog door de spitsroeden van de bezettende macht."

Problemen van collega-schrijvers 399; Hoop en angst 40I; Ambitie voor burgemeesterschap 403; Aanleiding tot de sollicitatie 405; Een waarschuwende toespraak 406; De sollicitatie springt af 408; Coolens versie 4I2; Burgemeester: goed of fout? 412 ; Hoop op bevrijding 414; Zonder vaste woonplaats 415; Dolle dinsdag, 5 september 1944 4I 9; Bevrijding in Deurne 420; Thuis in Waalre: anticlimax en verbittering $42 \mathrm{I}$ 
"De principiële man wilde geen lid zijn van een door de vijand verplicht gestelde instelling. Hij zei dan ook néé."

Van Doorne 425; Het begin van de persstrijd 426; Het Licht en De Deumesche Courant 427; Persoonlijke vete 429; Lid van het Tribunaal voor bijzondere rechtspleging 430; De persstrijd in een stroomversnelling 43r; Rechtszaak 435; Coolen wekt wrevel 439; Bemiddelingspogingen $44 \mathrm{I}$; Einde van de persstrijd en Coolen weg bij het Tribunaal 442; Een literaire verwerking van het conflict 445 ; De nasleep 448

17 Bevrijd Europa (1945-1947) 453

"Ik spreek slechts aarzelend over het onderwerp zo gauw het politiek raakt waarvan ik weinig weet."

Vrij Volk 453; Coolen en Streuvels 456; Bevrijd Vaderland 460; Dagboek of positionering 463; Kritiek en lof 464; Vriend en biograaf 465; Overlijden van Herman de Man en Felix Timmermans 466; r947: jaar van uitersten 467; De dood van Peter 468; Boekenweek - De Ontmoeting 469; Vijftigste verjaardag en Tsjecho-Slowakije 472; Tsjechische Suite 476; Veelzijdig boek 478

18 Katholiek schrijver na de oorlog (1948-1949) $48 \mathrm{I}$

"Er is eigenlijk geen verboden terrein voor de katholieke romancier."

Coolen en het katholicisme 482; De Linie 483: 'Splendid isolation' 484; De romancier en het leven 489; Bekende Brabander 492; Liefde, dood en minne 493; Met de heiligen het jaar rond 495; Onder de Canadassen 495; Problemen met Stijn 499; Canonisatie: een voorlopige balans 500

19 Op het Brabantse podium (1950-1951)

"Wat mijn werk betreft blijft het moeilijk de draad te hervinden met een verleden, waarvan zulk een caesuur scheidt."

Dat kan ik beter 503; Huispoëet van De Kersouwe 504; Legenden in toneelvorm 505; De ontvangst 506; Het toneel in Coolens werk 507; Culturele en economische opleving van Brabant 508; Land en volk van Brabant 509; De Bourbon 512; Het prijzencircus 513; Gouden legenden 514; Geschiedenis en fictie van oorlog en verzet 516; GrootKempische Cultuurdagen 517; Geschiedenis van Eindhoven 519; Redactielid Brabantia 520; Ook redactie van Roeping vernieuwd 522

20 De muziek van de verloren tijd (1952-1953) 525

"De verknoeide bladzijden van de eerste eeuwhelft doorvlekken die van de tweede en doordrenken ze met hun angsten."

De nieuwe en oude generatie 525; Het nieuwe Brabant 528; Van Duinkerken naar Nijmegen 532; Verhuizing 532; Even terug naar het Gooi 534; De vrouw met de zes slapers 534; De muziek van de verloren tijd 537; De kritiek 541; Terug naar de oase 543; De schandalen en De vrouw met de zes slapers 545 
"Het feodalistische gevoel is het plattelandsvolk hier in de ziel blijven zitten."

Buitenlandse contacten 549; Ships that pass in the night 550; Brabantse activiteiten 551; Nobelprijs? 555; Zestig jaar 556; Werken in De Pauwhof 560; De grote voltige 560; Tijdsbeeld en sleutelroman 563; Het circus 565; Emigratie 566; Coolenland 567; De kritiek 568; Het motief 570

22 De praalwagen van de dood (1958-1961)

"Goededag, nuttige leden van de maatschappij."

De grote afwezige 573; Een literaire bekentenis 574; 'Het onbekende meisje' 577; Herinnering aan eigen onderduik 578; Verfilming van Dorp aan de rivier 579; Research aan de Maas 581; Stad aan de Maas 582; Coolenstad 584; Praalwagen van de dood 586; De kritieken 587; Somberte 588; De Vondelprijs 590; Het laatste jaar 59r; Ongeluk op de spoorbaan en overlijden 593; Begrafenis 595; In Memoriam 597

\section{Summary}

601

Archivalia en niet-gedrukte bronnen 607

Gedrukte bronnen en literatuur 6II

Bibliografie Antoon Coolen 625

Brieven van De Romeijn en van De Kempen 635

Index van geografische namen

Index van persoonsnamen 



\section{Inleiding}

Dit is het levensverhaal van de schrijver Antoon Coolen, zoals ik het nu denk te kunnen vertellen. In zijn vroege verhalen en romans gebruikt Coolen een stijlfiguur die kenmerkend is voor de wijze waarop hij tegenover zijn personages staat: "Da menschke is blij! Dat zegt Bart, dieje mensch" of "Pastoor Vogels, dieje man, hij zit ineens verstomd en gebroken." Coolen kijkt met mededogen naar zijn personage en zegt tegen de lezer: kijk nou toch eens naar deze mens, hoe blij hij is of hoe verdrietig. De verteller doet, als een schilder, een stap terug en overziet met mededogen de toestand waarin de door hem geschapen figuur verkeert. In enkele regels schetst Coolen een beeld en zegt: Ecce homo. Coolen is niet een afstandelijke beschrijver van zijn personages, maar leeft met ze mee. In de roman Herberg In't Misverstand schrijft hij: "Niet omdat de mensen zo goed of zo mooi zouden zijn, moet ge van hen houden, maar omdat ge hun getuige zijt en hun deelgenoot."

Met deze zelfde instelling heb ik het leven en werk van Antoon Coolen bestudeerd. Door het lezen van zijn verhalen en de vele egodocumenten ben ik zijn 'getuige en deelgenoot' geworden. Ik ben ten opzichte van Coolen in dezelfde positie gekomen als waarin Coolen tegenover zijn romanpersonages stond. Ik ben getuige geweest van de vreugde over zijn eerste successen, van verschillende grote conflicten in zijn leven, van zijn afkeer om in het openbaar de strijd aan te gaan, zijn zelfbeschadiging als hij dat een keer wel doet en de somberte die hem, vooral na de oorlog, vaak overvalt. Ik heb zijn zelfvertrouwen zien groeien in de 'gouden decade' van zijn romanproductie: de tijd van 1928 tot en met 1938 , toen er bijna elk jaar een succesvolle roman van zijn hand verscheen. En ik voel mét hem de enorme teleurstelling als niet lang na zijn veertigste levensjaar, wanneer zijn literaire ster in heel Europa begint te rijzen, er voor de tweede keer een wereldoorlog uitbreekt. Als pas in 1953 zijn eerste grote roman van na de oorlog verschijnt, maakt de dan zes en vijftigjarige Coolen zijn lezers deelgenoot en getuige van zijn teleurstelling over het verloop van de eeuw die bijna gelijk loopt met zijn leven.

"Wij geborenen van de vorige eeuw," zo noemt hij zijn generatie, "Wij jonge mensen waren nog vol hoop en verwachting. Het was zeker de beloftenvolle schemering geweest aan de avond van de voorbije eeuw vóór de morgen van de nieuwe, zoals een klare lenteavond die dralende en bedwelmende schemering kan hebben vol beloften voor de zomer, die komt." Als Coolen deze regels schrijft lopen de spanningen in de Koude Oorlog al weer zo hoog op dat het gevaar voor een derde wereldoorlog heel reëel is. De vooruitgang van techniek en wetenschap heeft niet datgene gebracht waar zijn generatie op hoopte.

Het leven van Coolen speelt zich grotendeels af in de turbulente tijd van de eerste helft van de twintigste eeuw. Tijdens de Eerste Wereldoorlog schrijft hij voor kranten in Helmond, Eindhoven en Maastricht. Van jongs af aan is Coolen van één ding bezeten: hij zal en moet schrijver worden. Het werk als journalist ziet hij vanaf zijn zeventiende als een tijdelijke, verwante bezigheid om dit doel te bereiken. Door een zeer uitgebreide briefwisseling uit die levensfase zijn we in staat om deze strijd en dit wordingsproces te volgen. De drang tot schrijven komt niet voort uit de behoefte om een boodschap uit te dragen. Coolen wil in de eerste plaats ontroeren. "Trèft 't?, dat wil ik weten," schrijft hij ongeduldig 
als iemand weer eens alleen maar ingaat op het katholieke gehalte van zijn werk.

In het interbellum moet hij als journalist en schrijver van katholieke huize zijn koers bepalen tussen de verschillende stromingen op politiek en literair gebied. Er wordt zware druk uitgeoefend om te kiezen tussen Mussert of Moskou, tussen katholiek of anti-rooms, tussen 'vorm of vent' en tussen regionalisme of kosmopolitisme. Maar Coolen is geen polemist; hij schuwt de openbare woordenstrijd. Slechts eenmaal, kort na de oorlog, laat hij zich daartoe overhalen, maar dat is hem achteraf toch niet goed bevallen. Coolen maakt zijn eigen typische keuzes.

In zijn werk kiest hij voor de oprecht levende mensen en niet voor de moraalridders. Hij trekt dit onderscheid dwars door beroepen en stromingen heen; beide typen mensen komen immers in alle systemen, stromingen en religies voor. Coolen kiest in zijn romans voor de simpele ziel die een wijze van nature kan zijn, voor de moordenaar die niet weet waar die verschrikkelijke drang tot moorden vandaan komt, voor de zwerver, de stroper en de randfiguur van de samenleving. Hij verafschuwt de betweter, de arrogante, de hooghartige en de gierige. Coolen voert, als verteller, de lezer mee in het door hem geschapen 'Coolen-land'. Door zijn speciale stijl, waarin de nieuwsgierige dorpelingen gissen en roddelen over de gebeurtenissen, waant de lezer zich al gauw tussen de personages. Hij wordt 'getuige en deelgenoot' van zowel het menselijk tekort als de grootse dingen waar mensen toe in staat zijn. De verbondenheid met de natuur en de wisseling van de seizoenen geven nog een extra accent aan zijn werk. Het werk van Coolen vertoont veel kenmerken van het naturalisme: zijn personages zijn gedetermineerd door afkomst, omgeving en het lot. Zijn katholieke omgeving heeft hier grote moeite mee. Regelmatig spoort men hem aan om zijn protagonisten tot echte katholieke helden te maken. Hij geeft hier geen gehoor aan en weigert zich zelf een katholiek romancier te noemen. Hij schrijft niet met een vooropgezet plan of bedoeling, zegt hij in het begin van de jaren dertig in een interview. Hij is katholiek en schrijft romans die bovendien ook nog in een streek spelen waar het katholicisme iets vanzelfsprekends is. "Dat vanzelfsprekende heb ik gemeen met alle menschen hier, ik kan het leven niet van uit een andere gezichtshoek zien en het verklaarbare ervan uit niets anders verklaren."

De emancipatie van de katholieke zuil en van Brabant als voormalig 'wingewest' vallen samen met het leven van Coolen. De 'ontluiking' en de bloei van 'het rijke roomsche leven' in de jaren twintig en dertig gaan gelijk op met Coolens roem als schrijver. De zelfbewustheid en de 'voltige', de omwenteling van Brabant in de jaren vijftig, vallen in dezelfde tijd dat Coolen een bekende Brabander is en dat ook hij een grote ommekeer in zijn leven doormaakt. Al die aspecten zijn terug te vinden in het literaire en journalistieke werk van Coolen. We zullen zien hoe hij ook hierin zijn weg kiest en er mede vorm aan geeft. Tijdens de bezetting wordt het maken van keuzes onvermijdelijk voor elke kunstenaar. Deze episode is zeer boeiend, omdat we door zijn brieven en andere egodocumenten zien hoe Coolen zijn beslissingen neemt.

Hij hoopt met vele kunstenaars en politici dat het einde van de oorlog een nieuwe maatschappij zal opleveren zonder de zuilen van vroeger. De verwachte doorbraak blijft echter uit; de oude hokjesgeest keert weer terug. Vanuit de reactionaire katholieke hoek wordt Coolen verweten dat hij niet katholiek genoeg is. Pas halverwege de jaren zestig gaan de ramen echt open, maar dan is Coolen al enkele jaren overleden. 
In de jaren vijftig behoort het werk van Coolen nog steeds tot de meest gelezen romans. Er is dan een nieuwe generatie schrijvers in opkomst die meer expliciete aandacht voor de psychologie van hun personages hebben. Coolens werk wordt steeds vaker ingedeeld bij de streekroman, de rurale versie van de dokters-, ziekenhuis- of kasteelroman. Men is vergeten of wil niet zien dat 'Coolenland' niet zo arcadisch en ongecompliceerd is. Coolen geeft op een andere manier een invulling aan het innerlijk van zijn personages. Hij beschrijft hun bewogenheid en aandriften als de invoelende verteller. De lezer voelt de radeloosheid van Peerke dat manneke, die vernederd en bespot zijn huis moet verlaten, de eenzaamheid van een kind met voortdurend ruziënde ouders en de wroeging en het verdriet van de moordenaar die later zelf een kind verliest.

Daar komt nog bij dat de officiële literaire kritiek lange tijd minder bewondering voor de 'vertellers' in de literatuur heeft gehad. Dit alles verklaart de positie die het werk van Coolen na zijn dood in de literaire canon heeft gekregen: nauwelijks zichtbaar en onder een verkeerd etiket.

Coolen moest niet veel hebben van het spitten in zijn levensgeschiedenis. In een gesprek dat een maand voor zijn dood plaatsvond, zei hij dat hij er van huivert om té veel te weten over een mens:

"dan ril je al bij de gedachte dat je iemand tot op de bodem leert kennen uit wat hij aan notities, brieven en dagboeken nalaat. Ik heb zelf wel enkele niet gesorteerde kisten en klappers met persoonlijke papieren, zoals iedereen die publiceert zulks wel in 30 a 40 jaren kan vergaren, maar soms denk ik: zou je alles niet in je tuin verbranden voordat een of andere doctorandus er in gaat sorteren en registreren voor de biografie van een tijdperk en een schrijver."

Toch ben ik vrij onbevangen aan dit werk begonnen. De directe aanleiding was een artikel in het blad Brabantia in 1992, waarin een Coolen-verzamelaar zich er over verbaasde dat er nog steeds geen biografie voorhanden was van een van Brabants grootste schrijvers. Een inventarisatie leverde op dat er al wel enorm veel over Coolen is geschreven, maar dat alles ver ligt verspreid. Nog tijdens zijn leven zijn twee biografische schetsen over Antoon Coolen verschenen. De eerste werd geschreven ter gelegenheid van zijn vijftigste verjaardag in 1947 door zijn vriend Anton van Duinkerken. De tweede was van zijn Hilversumse vriend Piet Oomes uit Hilversum; deze schreef in 1959 een beknopte levensschets met een overzicht van het werk in de serie Ontmoetingen. Ter gelegenheid van Coolens zestigste verjaardag verschenen er, naast tal van krantenartikelen, twee themanummers van culturele tijdschriften, Roeping en Brabantia, die volledig aan Coolen waren gewijd. $\mathrm{Al}$ in de jaren dertig en veertig stond zijn werk centraal in enkele dissertaties bij universiteiten in Brussel, Luik en Leuven. In 1992 schreef Ronald Groeneweg een doctoraalscriptie over Coolen.

Ik ben begonnen de romans en de novellen van Coolen te lezen en te herlezen en werd getroffen door het feit dat de meeste verhalen ook nu nog ontroeren. Bij de bestudering van het leven van een schrijver komt zijn literaire werk natuurlijk op de eerste plaats. Om een schrijver te leren kennen, moet men zijn oeuvre kennen. Ik zal om die reden ook uitgebreid citeren uit zijn romans, novellen en verhalen. Hoewel daarmee altijd voorzichtig dient te worden omgesprongen, worden soms ook lijnen getrokken tussen de fictie van 
zijn werk en de realiteit van zijn leven. In een enkel geval fiatteert Coolen dit zelf door in zijn correspondentie op een relatie tussen werk en leven te wijzen. Echter meer nog dan door feiten uit het eigen leven wordt door zijn literaire werk duidelijk hoe Coolen naar zijn omgeving en de medemens kijkt. Zijn boeken geven aan hoe nauwgezet, invoelend en met gevoel voor detail hij het menselijk bedrijf gadesloeg en wat voor invloed de natuur op hem had.

Toen ik hierna in 1994 de uitgebreide briefwisseling die van 1914 tot 1922 tussen de jonge Coolen en Wouter Lutkie werd gevoerd, had gelezen, was ik voorgoed verkocht. De gedrevenheid van de aankomend journalist die koste wat het kost schrijver wilde worden, zijn twijfels aan alles wat de gevestigde autoriteiten verkondigden en zijn interesse voor onorthodoxe, niet katholieke auteurs wierpen een heel nieuw licht op zijn persoonlijkheid en maakten mij benieuwd hoe zijn verdere leven zou verlopen. Een geluk bij deze zoektocht was dat Coolen veel langlopende correspondenties heeft onderhouden. Kort nadat de briefwisseling met Lutkie was geëindigd, ontmoette hij Anton van Duinkerken met wie hij vanaf 1925 levenslang bleef corresponderen. Na zijn vertrek uit Hilversum in I933 schreef hij tot zijn dood met grote regelmaat openhartige brieven aan zijn vriend Piet Oomes. Eveneens vanaf het begin van de jaren dertig onderhield Coolen een continue briefwisseling met Stijn Streuvels en Louis de Bourbon. Deze vijf grote verzamelingen verschaften me een betrouwbare hoofdlijn voor het denken en handelen van Coolen. Zijn motieven, twijfels en keuzen zijn hier goed te traceren.

Naast zijn literaire werk en zijn brieven is er nog een derde stroom documenten: zijn journalistieke werk. Al op jeugdige leeftijd schreef hij onder eigen naam op de voorpagina van De Zuidwillemsvaart artikelen over de mobilisatie en de dreiging van de wereldoorlog, die op slechts enkele tientallen kilometers afstand in België woedde. Ook toen hij full-time schrijver was, bleef hij artikelen schrijven voor kranten en tijdschriften. Ik zal veel gebruik maken van zijn wekelijkse 'Brieven van De Romeijn' (en later van De Kempen) die hij van 1933 tot mei 1940 in de Provinciale Noordbrabantsche en 's-Hertogenbossche Courant schreef. Deze krantenartikelen vormen een aanvulling op zijn mensbeeld zoals dat uit het literaire werk sprak en op zijn privé-opvattingen zoals die uit zijn brieven naar voren kwamen. Hieruit leren we hoe Coolen aankeek tegen de dreigende ontwikkelingen die er toen in Europa plaatsvonden.

Uit dit driestromenland heb ik getracht aan te geven hoe Coolen getuige en deelgenoot was van zowel de personages die hij zelf schiep als van zijn tijd en zijn tijdgenoten. Om het beeld van Coolen te complementeren heb ik daarnaast uitgebreid aandacht geschonken aan de manier waarop anderen tegen hem en zijn werk aankeken. Door reacties van tijdgenoten op zijn werk te gebruiken en door recensies en secundaire literatuur te verwerken wordt zijn levensverhaal genuanceerd.

Velen hebben me met raad en daad terzijde gestaan. Ronald Groeneweg, die in 1992 een doctoraalscriptie over Coolen had geschreven, hielp me op weg met een groot aantal knipsels, aantekeningen en een eerste overzicht van de voornaamste vindplaatsen van bronnen. Coolen-kenner en Streuvels-verzamelaar Bertus van den Belt was zo vriendelijk om mij de briefwisseling van Coolen met zijn Tsjechische contactpersoon te laten bestuderen. Theo Hoogbergen stimuleerde me in 1996 door zijn aanbod de biografie te zijner tijd in de reeks 
van het Zuidelijk Historisch Contact uit te geven. Marcel van der Heijden las als kenner van de Brabantse letterkunde de oerversie van het manuscript. Met veel tact liet hij me weten dat het een zeer interessante biografie zou worden, maar dat er natuurlijk nog veel moest gebeuren. In r 997 constateerde Wiel Kusters dat er een mogelijkheid was om de biografie de vorm van een proefschrift te geven en verklaarde zich bereid de herschrijving als promotor te begeleiden. Eind I 999 stelde hij voor dat de historicus Jos Perry als copromotor zou optreden. Ik dank hen beiden voor de enthousiasmerende en nauwgezette manier waarop zij zich als kritische lezers en adviseurs van hun taak hebben gekweten. Ik heb de besprekingen van de 'groeiversies' van het manuscript als uiterst vruchtbaar ervaren.

De redactieleden van de reeks Zuidelijk Historisch Contact dank ik voor het enthousiasme waarmee ze de komst van het boek hebben verwelkomd en werk hebben gemaakt van de uitgave en de vormgeving.

Helma van Heel van het bureau van de Raad voor WOC heeft me vanaf het prille begin zeer geholpen met typewerk en de nauwgezette en correcte verwerking van de talloze wijzigingen en aanvullingen in kladversies.

Felix Coolen en zijn vrouw Koosje verleenden mij vele dagen gastvrijheid om stukken uit het archief van vader Coolen te bestuderen. Ik kreeg inzage in vele ordners - die dus niet in de tuin verbrand zijn-om hiaten in briefwisselingen op te sporen of andere kennis te vergaren.

Mijn vrouw Rit dank ik als zorgvuldige lezer, strenge criticus en onmisbare hulp bij tegenslagen en problemen, maar toch vooral als meest nabije en enthousiaste supporter.

Cees Slegers,

Augustus 2001 



\section{Jeugd}

\section{"Ik ben maar van eenvoudigen kom-af."}

$1897-1914$

Er is trubbel tussen de families als Jan Coolen en Maria Swinkels eind $189 \mathrm{r}$ in ondertrouw zijn. De bruiloft die was vastgesteld op Nieuwjaarsdag, is verschoven naar Vastenavond 22 februari 1892 en er is verdriet bij beide moeders. Waarom is niet duidelijk. Vanuit haar klooster in Leiden schrijft Cato Coolen in mooi nonnenhandschrift een lange brief aan haar toekomstige schoonzuster.' Zij is teleurgesteld over het uitstel, want ze ziet er erg naar uit de familie weer eens te zien.

"Dat Ge tegen 't trouwen op gaat zien kan ik mij best voorstellen, bij al den trubbel, die Gij er meê gehad hebt. En daarbij komt dan nog dat onuitstaanbare gepraat en geklets van andere menschen. Geloof mij, dat het verkeerde heen en weer vertellen van een en ander voor een groot gedeelte de oorzaak is van twist en ongenoegen."

Ze heeft van haar broer Jan gehoord dat moeder Swinkels voortdurend weent, maar ze hoopt dat op de bruiloft het verdriet aan de kant wordt gezet en er feest kan worden gevierd. "Als alles zoo effen en stil afloopt en de gezichten staan zoo strak, dan zou de vroolijkste mensch er bij aan 't kniezen raken. Kom, dat moet Ge niet doen. Ge hoeft daarom nog geen groote bruiloft te houden, wel neen, want dat zou zonde zijn van de kosten, maar verzoek natuurlijk uwe eigen broeders en zusters en ons Cor en mij; dan is 't allemaal eigen volk. Wij brengen dan in gezelligheid samen den dag door, en zullen wel zorgen dat uwe Moeder lacht in plaats van weent."

Zuster Cato denkt dat het voor beide moeders goed zal zijn "dat er op uw trouwdag een beetje leven gemaakt wordt; dan vergeten zij beiden hun verdriet; zij praten genoegelijk te samen, als ook uwe broers en zusters, en zoodoende heerscht er 's avonds liefde, tevredenheid en vroolijkheid, in plaats van droefheid en ongenoegen."

De kloosterzuster zou het niet kunnen verdragen "dat wij allen, uwe Moeder, uwe broers en zusters en ons Moeder geene goede vrienden waren, en zou alles doen, wat ik kon, om de warmste genegenheid tusschen de beide familiën tot stand te brengen." Het is immers van het grootste belang dat het jonggetrouwde paar de zegen van de ouders van beide kanten meedraagt. Ze schrijft ook over het voorgenomen vertrek naar Wijlre in het uiterste zuiden van Limburg.

"En dat Ge naar Wijlre moet is toch zoo erg niet; ik zit ook wel vèr van huis en nog treur ik er niet om. ' $t$ Is wel onplezierig, dat Ge de menschen er niet verstaat, maar Ge zult eens zien hoe gauw dat aanleert, en Ge hebt dan Jan ook, om U te helpen. Jan zal wel zóó wit zijn met zijn vrouwtje, dat je aan Deurne niet veel meer denkt."

Tenslotte vraagt ze wat de bruid graag als geschenkje wil. Van anderen zal ze wel iets "voor de pronk" krijgen, daarom geeft Cato liever iets nuttigs, voor de linnenkast of de keuken.

Of de brief van de kloosterzuster de sfeer verbeterd heeft, is niet bekend. Wel staat vast dat de 34 -jarige bruidegom en zijn 26-jarige bruid op Vastenavond zijn getrouwd en daarna 
inderdaad zijn vertrokken naar Wijlre, waar Jan Coolen gaat werken als brouwersknecht bij Brand's bierbrouwerij De Kroon. Hier wordt op 17 april 1897 Antoon Coolen geboren. Zijn geboortehuis - dat inmiddels is verdwenen - stond op de hoek van de Dorpsstraat en de Brouwerijstraat. $^{2}$

Als hem later, als hij al een bekend schrijver is, in De Maasbode wordt verweten, dat hij zich ten onrechte Brabander noemt, verweert hij zich in een ingezonden brief hevig en stelt dat hij zich wel degelijk een Brabander mag noemen, omdat zijn beide ouders uit oude Brabantse geslachten stammen en in de Peelstreek zijn geboren. "Hun tijdelijk verblijf elders brengt mijn onvermengde en zuiver Brabantse afkomst, naar ik meen, allerminst in twijfel." $^{\text {s }}$

\section{Afkomst}

Antoon Coolen heeft gelijk: zijn voorouders zijn diep geworteld in de westelijke rand van de Peel. Een van hen, Michiel Coolen, was in het begin van de zeventiende eeuw 'borgemeester' van Asten. Johannes Coolen leefde van 1744 tot 1823 in Asten als een welvarend schoenmaker en schepen. Hij leende regelmatig geld aan dorpsgenoten en kocht huizen en stukken grond. Uit zijn huwelijk met Johanna de Laat werd Leonardus Coolen geboren ( 1780 - 1846). Ook hij werd schoenmaker en trouwde met Wilhelmina IJsbouts uit Someren. Hun zoon Wilhelmus Coolen (de grootvader van Antoon) werd geboren op 20 juli 1824 en stierf in 1889 . Deze winkelier en bierbrouwer was getrouwd met Maria Gordina van den Braken. Hij woonde in Mierlo. Uit hun huwelijk wordt in Mierlo op 29 april I 858 Johannes Henricus Antonius geboren, de vader van Antoon Coolen. Als deze trouwt met Maria Goordina Swinkels is zijn moeder al drie jaar weduwe.

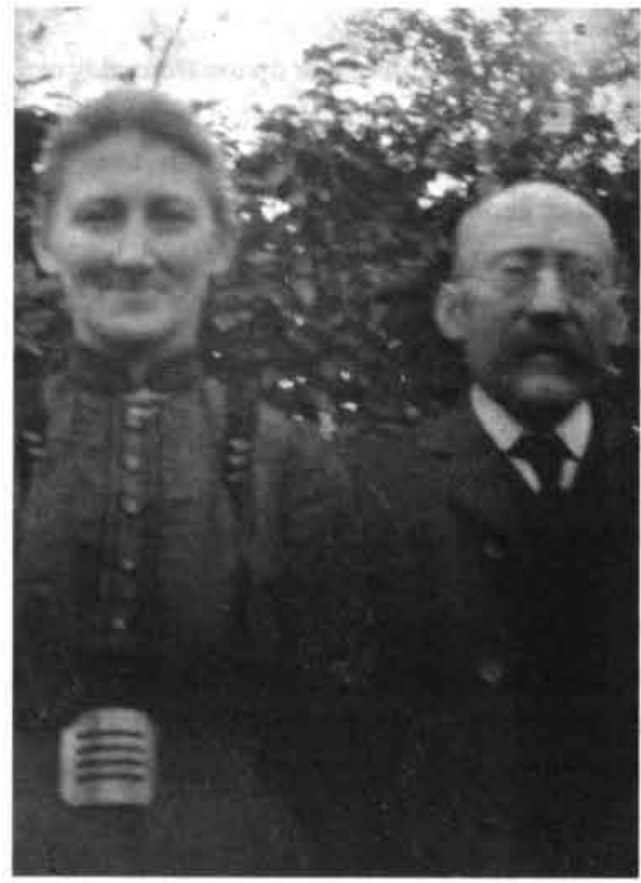

De ouders van Antoon Coolen op oudere leeftijd.
Maria Swinkels, de moeder van Antoon Coolen, is op 31 maart 1866 geboren als dochter van Godefridus Swinkels en Johanna Wilhelmina van Zurk. Godefridus was winkelier, bij de geboorte van zijn dochter luidt zijn beroep koopman. In het jaar van Maria's geboorte werd het iets noordelijker gelegen Deurne ontsloten door de aanleg van de spoorweg van Eindhoven naar Helmond, Deurne en Venlo.

\section{Het gezin}

Het plan van het jonge echtpaar Coolen-Swinkels om zo ver weg hun geluk te gaan beproeven is in die tijd geen gewone zaak. Het is een teken van durf en ondernemingslust van de 34 jarige bruidegom. Zuid-Limburg wordt in die tijd nog ervaren als een ver bui- 


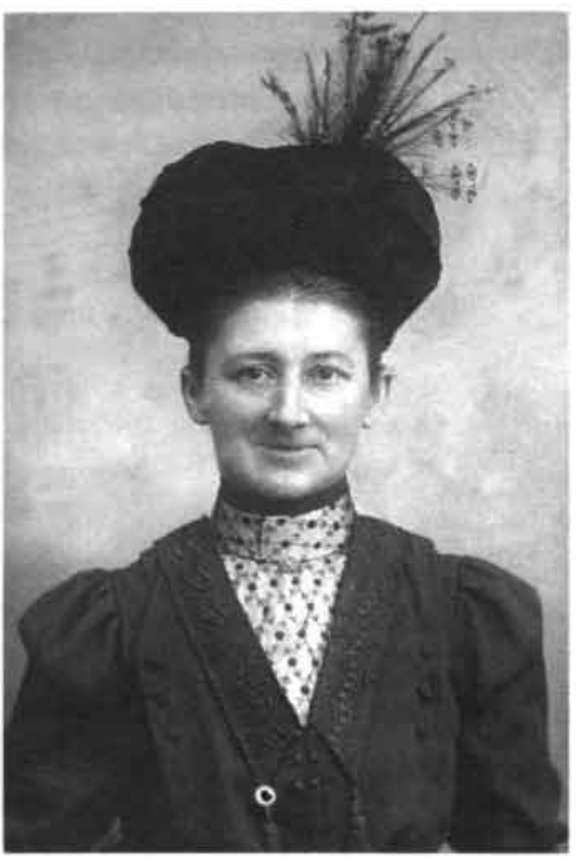

Moeder Maria Coolen-Swinkels.

tenland. Het kan zijn dat het verdriet van de moeder van de bruid vooral hierdoor is veroorzaakt. Maar ook moeder Coolen zal het er moeilijk mee hebben dat ze, slechts enkele jaren na de dood van haar man, nu ook haar zoon verliest.

Het lijkt een merkwaardige beslissing om zo ver weg als brouwersknecht te gaan werken, juist in een tijd dat de eigen streek, kort daarvoor ontsloten door spoor en kanaal, meer mogelijkheden begint te bieden en Deurne hard op weg is uit te groeien tot het 'Millioenenparadijs', zoals het later genoemd wordt. Jan Coolen is even bierbrouwer geweest in Hilvarenbeek. Bij de dood van zijn vader in 1889 heeft hij diens brouwerij in Mierlo niet erg succesvol voortgezet. In 1892 is er een opleving van brouwerij Brand in Wijlre. Deze wordt op dat moment geleid door de weduwe Brand. Haar zonen doen in die tijd ervaringen op bij buitenlandse brouwerijen. Zij zelf voert met behulp van een Duitse brouwmeester plannen uit om het oude bedrijf technisch te vernieuwen en aan te passen aan de moderne brouwtechniek. ${ }^{4}$ Dit zal de reden geweest zijn dat Jan Coolen naar deze grotere brouwerij trekt. Hij wil leren van de technische vernieuwingen die daar worden toegepast.

Het jonge paar vertrekt meteen na het huwelijk naar Wijlre en al op 24 oktober 1892 wordt daar hun eerste kind Wilhelmus Johannes (Willem) geboren. Het kan natuurlijk een acht-maandskindje zijn geweest, maar het is ook mogelijk dat het paar in de tijd tussen de geplande bruiloft van Nieuwjaar en de feitelijke op Vastenavond al een voorschot op het huwelijk heeft genomen. Dit laatste zou wel volledig tegen de normen van die tijd indruisen.

Op 6 januari 1894 wordt Wilhelmina Godefrida geboren. Op 30 augustus 1895 volgt dochter Catharina Adesta (Cato), die haar hele leven op officiële stukken blijft volhouden dat ze op de 3rste augustus is geboren, om zodoende op Koninginnedag tegelijk met Wilhelmina jarig te zijn. ${ }^{5}$

1 Collectie Jef Coolen, Brief van Cato Coolen aan Maria Swinkels, november 1891.

2 Kusters, 'Limburg', 592.

3 Coolen, [Ingezonden brief], in: De Maasbode, 27 juni 1930.

4 Brand's Bierbrouwerij. Honderd joar Brand, 75-79.

5 In de collectie Jef Coolen zijn notariële aktes, met door haarzelf foutief opgegeven data. 


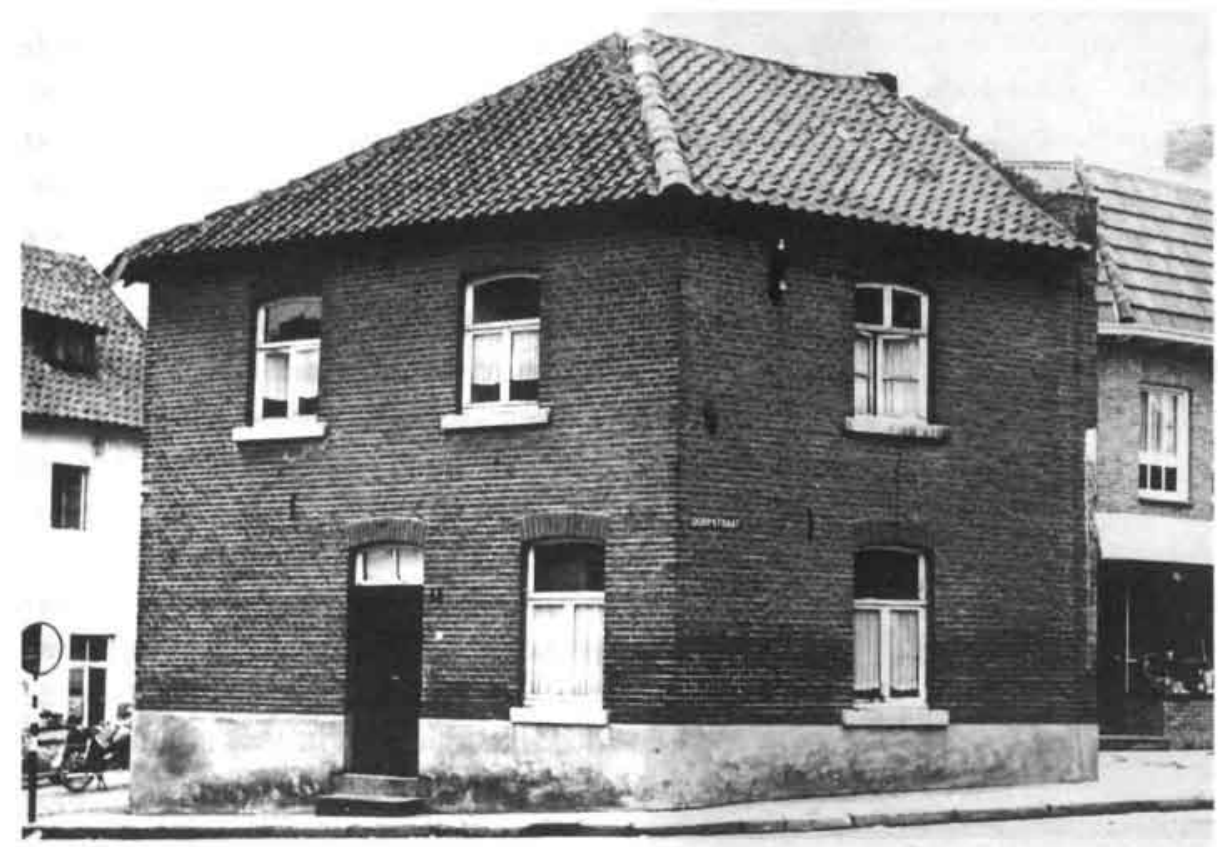

Geboortehuis (bestaat niet meer) van Antoon Coolen in Wijlre.

Op I maart 1897 overlijdt Wilhelmina Godefrida op drie-jarige leeftijd. Zeven weken later, op 17 april I897, wordt Antoon Franciscus geboren. Hij zal zich van het huis in Wijlre niets meer herinneren want kort na zijn tweede verjaardag, op 24 april r899, verhuist het gezin naar Zevenbergen in West-Brabant en gaat daar wonen aan de Molenstraat A 201.

De reden voor deze verhuizing is waarschijnlijk dat de zonen Henri en Mathieu Brand vanaf 1897 de leiding van het bedrijf op zich hebben genomen. Jan Coolen heeft als ervaren brouwer de weduwe bijgestaan in een overgangsperiode. Coolen verandert niet van beroep: ook in Zevenbergen wordt hij ingeschreven als brouwersknecht. In Zevenbergen worden nog twee kinderen geboren: Maria Francisca (Miet) op 3 september 1899 en Leonardus Adrianus (Nard) op 2 I februari 1902.

$\mathrm{Na}$ vier jaar in Zevenbergen trekt het echtpaar met hun kinderen terug naar de streek die het elf jaar daarvoor verlaten heeft. Enkele weken na de zesde verjaardag van Antoon Coolen, op I4 mei I903, wordt het gezin Coolen ingeschreven in de gemeente Deurne. Hier zullen nog twee kinderen worden geboren: Josephus Petrus Gerardus (Sjef) op 9 januari r 904 en Johannes op 4 april 1909 . Johannes zal net als Antoon over artistiek talent beschikken. Hij wordt later documentair-en reclamefilmer en maakt onder andere The story of time voor de firma Rolex en The story of light voor Philips. Vóór deze Johannes is nog een Jantje geboren, dat maar enkele dagen geleefd heeft; het sterven van dit kindje maakt grote indruk op Antoon.

Antoon Coolen groeide dus op met vier broers en twee zussen. Van de zeven in leven gebleven kinderen was hij de derde in de rij.

\section{Vestiging in Deurne}

De familie Coolen gaat in Deurne wonen aan Lage Kerk A 45I, later de Liesselseweg gehe- 
ten. ${ }^{6}$ Als beroep van de vader wordt nog steeds opgegeven 'brouwersknecht'. Hij werkte vermoedelijk bij brouwerij De Pelikaan.

Vader Coolen wordt later een kleine zelfstandige. Na eerst bij een brouwer in HeldenPanningen te hebben gewerkt en vervolgens bij een Deurnese brouwerij begint hij voor zichzelf. Hij verhuist naar het Vloeieind B 386 , later Vlierdenseweg genoemd, en gaat wonen in het eerste huisje achter de spoorwegovergang op de weg van Deurne naar Vlierden. Dan luidt zijn beroep bij de burgerlijke stand 'bierbrouwer', Dit stelt in die tijd niet zo veel voor; in elk dorp is wel een aantal kleine brouwerijtjes. De bedrijvigheid vindt achter het huis plaats; in het voorhuis beginnen Jan Coolen en zijn vrouw een winkel. Al gauw wordt er weer verhuisd, nu naar de Molenstraat A 264, maar hier staat de eigenaar niet toe dat er winkelnering plaatsvindt. Zo belandt het gezin in 1906 op zijn vierde adres in Deurne: de Wiemel, later de Wever geheten.

Na nóg een verhuizing komt er wat rust. De familie Coolen woont dan enige tijd op het Haageind A 248. Aan de schoolfoto's die in I 906 worden gemaakt, waarbij de leerlingen naar straat zijn gegroepeerd, is de snelheid van de verhuizingen nog af te lezen. Oudste broer Willem Coolen poseert op 25 september r 906 zowel bij de groep jongens uit de Wiemel als bij die van de Spoorstraat en het Station.?

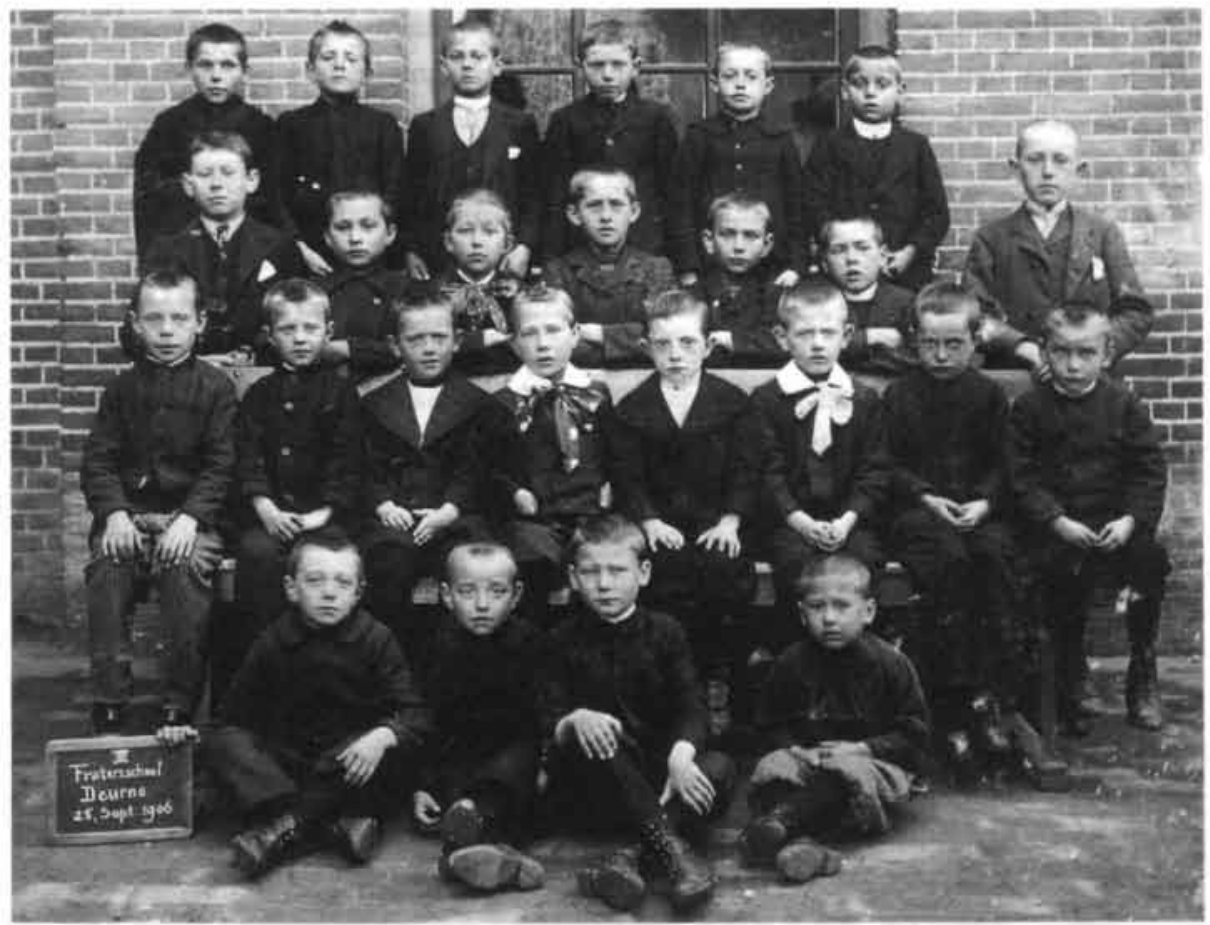

Antoon Coolen zit op de eerste rij, derde van links. Naast hem zijn broer Jan, vierde van links. Op de op een na achterste rij staat helemaal links zijn broer Willem.

6 Deze en volgende gegevens komen uit een brief van het streekarchivariaat Peelland van 16 september 1977. De vergelijkingen met de oude adressen zijn dus naar de toestand van de jaren zeventig.

7 Martens, Kent u ze nog ... De Deurenaren?, 8. 
Het Haageind bestaat nog, maar het gedeelte waar de familie Coolen de winkel had, heet nu Kerkstraat. Het huis is afgebroken; later werd op die plaats een filiaal van de Edah gevestigd. In 1916 , als Antoon Coolen al niet meer zo veel thuis is, verhuist de familie naar de Zeilberg. Dit gehucht heeft het jaar daarvoor, na een lange strijd met de kerkelijke autoriteiten, van het bisdom uiteindelijk het recht gekregen om een eigen parochie te vormen. Er worden een kerk, klooster en een jongens- en meisjesschool gebouwd. ${ }^{8}$ Vader Jan Coolen ziet hier goede toekomstmogelijkheden, verlaat de 'toplocatie' aan het Haageind en vestigt een zaak tegenover de nieuwe kerk. De monopoliepositie die hij daar op de Zeilberg aanvankelijk heeft, blijkt al uit de naam: De Winkel van de Zeilberg.

Bij een van die vele verhuizingen, waarschijnlijk bij die naar het Haageind, heeft zich het drama voltrokken dat een levenslange indruk op Antoon Coolen heeft gemaakt: het sterven van een pasgeboren kind, zijn broertje Jan. Veelvuldig komt het sterven van een kind in zijn romans voor, maar één keer heeft hij hierover zuiver autobiografisch geschreven in een verhaal dat is opgedragen aan zijn moeder: Ons Jantje stierf. ${ }^{9}$ Het verhaal speelt zich af als Antoon tien jaar is tijdens de drukte van een verhuizing, in april. Het kindje wordt ziek, dokter Crobach ${ }^{10}$ komt op bezoek, maar het is niet meer te redden. Antoon mag nog even de handjes, "die dingen van niks," in zijn handen nemen. Jantje overlijdt en zijn moeder wil het kistje niet laten wegnemen.

"De menschen uit de buurt kwamen om [haar] te bedaren. Vader zelf heeft het kistje gedragen onder zijnen arm. Er lag een witten doek over het kistje, mee een blauw kruis erop. Wij keinder zijn mee geweest en hebben het gezien, hoe de doodgraver voor goed het kistje neerlei in den grafkuil, voor eeuwig en altijd in den donkeren grond weggestopt."11

Zijn vader werkt hard aan een bestaan als zelfstandige. De omschrijving van zijn beroep, bij de verschillende geboorteaangiftes, wisselt nog al eens. Achter de winkel heeft hij een magazijn; hij noemt zich niet alleen brouwer, maar ook wel eens fabrikant. Hij geeft onder meer opdrachten aan thuiswevers.

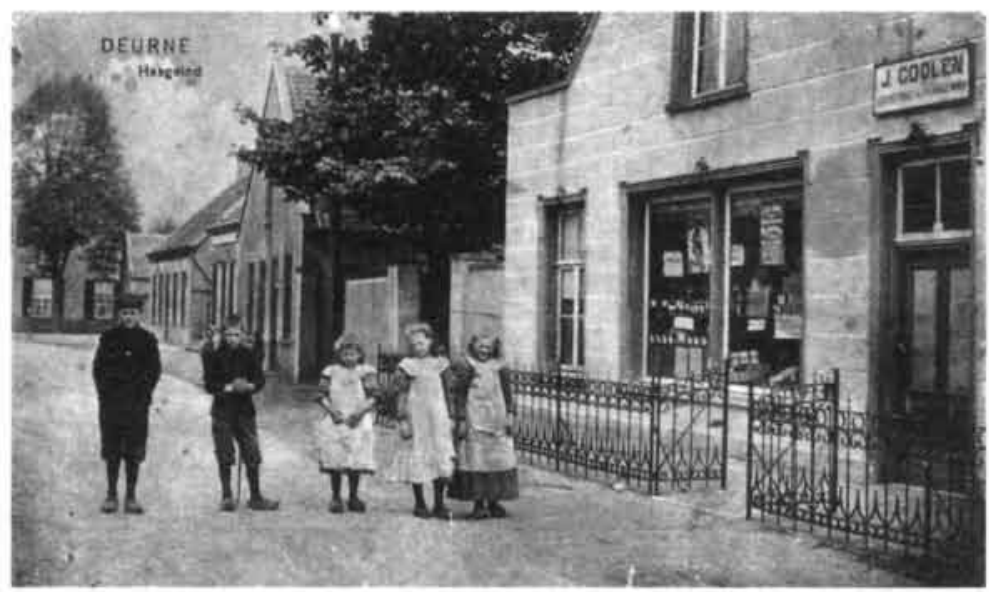

Rond 1908. Van links naar rechts: Janus Köhnen, Antoon Coolen, Maria Coolen,

Dina Dijsselbloem en Nel Beekers 
Op een foto van zijn winkel aan het Haageind is op de ramen te lezen: J. Coolen. Koloniale Waren, Gedestilleerd en Tabakswaren. Op die foto staat een groepje kinderen op klompen. Drie meisjes met schorten, de kopjes scheef en de ogen dichtgeknepen tegen de zon. Helemaal links een kaarsrecht poserende jongen met pet en daartussen in, blootshoofds, ietsjes losser met twee handen op een stok, de jonge Antoon Coolen, een jaar of tien oud. Enkele jaren later schrijft hij in de inleiding van Opinies. "M'n vader [..] winkelt zoowat en moeder heeft d'r handen vol aan 't huishouden. $1 \mathrm{k}$ ben dus maar van eenvoudigen komaf." 12

Dat eenvoudige sluit aandacht voor niet-materiële zaken niet uit. De moeder vindt naast het huishouden kennelijk toch de tijd en de energie om verhalen te vertellen:

"De eerste vertellingen heb ik, dat staat vast, in de winteravondschemering onzer brabantsche keuken van mijn moeder gehoord. Ze waren boeiend, fantastisch en vol spanning. Reed er een ridder op een klepper door den hollen nacht, dan werkten de regen, de huilende storm en de krassende weerhaan op het eenzame kasteel mee aan het huiveringwekkende der inleiding. Mijn moeder hield van nauwgezette en uitvoerige plastische schilderingen in haar verhaal. Die waren voor mijn kinderverbeelding zó suggestief, dat ik geloofde dat moeder de gebeurtenissen, die ze vertelde, zelf had gezien. In haar herinnering zag ik ze met haar mee en onbewust begon ik eerbied te krijgen voor dat geheimzinnige en verre rijk der verhalen. Dit waren de eerste vage hunkeringen der verbeelding. ${ }^{13}$

Het kan zijn dat de 35 -jarige Coolen deze jeugdherinnering wat heeft geromantiseerd, maar de ervaring lijkt authentiek. Over zijn vader heeft hij zich minder uitgelaten. Toch zijn er aanwijzingen dat Coolen naast het vertellertalent van zijn moeder de liefde voor muziek van zijn vader heeft. ${ }^{14}$ Vader Jan Coolen speelt zelf viool. Aan het begin van de nieuwe eeuw ligt het voor een middenstander in een dorp eigenlijk meer voor de hand om een blaasinstrument in de plaatselijke fanfare of harmonie te spelen. Zijn muzikale belangstelling is groot: "In de dagen van mijn kleinste jeugd heb ik al voor die winkelruiten /van boekhandel Van Piere in Eindhoven, C.S.] gestaan in de Rechtestraat en de Kerkstraat, naast mijn vader, die er lang naar de muziekuitgaven keek." ${ }^{15}$

Antoon Coolen zal zelf ook een goede muzikale smaak ontwikkelen. In zijn journalistentijd recenseert hij vaak concerten en recitals. In zijn latere romans - vooral De vrouw met de zes slapers - wemelt het van verwijzingen naar muziek. In een terugblik op zijn gymnasiumtijd haalt hij ook het vioolspel van zijn vader aan: "Jantje van Meerwijk, die viool

8 Van den Mortel en Bouwmans, Zeilberg. Van Gehucht tot parochie.

9 Coolen, 'Ons Jantje stierf', 1929.

10 De naam is authentiek; hij was de gemeentearts van Deurne en grootvader van Jan Hanlo.

11 Coolen, 'Ons Jantije stierf', 235.

12 Coolen, Opinies, 8.

13 Coolen, 'Hoe ik er toe kwam', 34-35.

$14 \mathrm{Er}$ is ook wel eens sprake van een jonggestorven broer van zijn vader, die literair actief zou zijn geweest. Ritter maakt hier gewag van in zijn Nederlandse Bibliografie, 1936. Het betreft hier echter Antoon Coolen de Oudere uit Helvoirt, een schrijver die in het begin van de eeuw schetsen voor De Telegraaf schreef, die later gebundeld zijn in Helvoirt aan de Lei.

15 Coolen, Van en over een honderdjarige, 9. 
speelde en van wien ik menig muziekblad copiëerde, alleen om mijn vader thuis, die ook viool speelde, te laten zien welke moeilijke stukken een jongen van een onzer klassen op zijn repertoire had. ${ }^{16}$ Veel later zal collega-journalist Bernard Bekman de vioolspelende vader beschrijven. Nadat hij ter gelegenheid van de zestigste verjaardag van Coolen heeft geschreven dat diens werk met al zijn vezelen verbonden was met zijn geboorteland, volgt: "Ik heb dat nooit beter beseft dan toen ik hem eens naast zijn vioolspelende vader zag staan op een zondagmiddag in het Deurnese ouderlijk huis. Twee artisten, door het leven op verscheiden wegen gevoerd, maar die op hun voordeligst uitkwamen voor de achtergrond van dat ruige zandland aan de Peelgrens. ${ }^{17}$

De ouders van Coolen zijn in ieder geval meer dan gemiddeld ontvankelijk voor literatuur, verhalen en muziek. In het gezin heerst een sfeer waarin vertellen, lezen en muziek maken niet alleen mogelijk zijn, maar ook gewaardeerd en gestimuleerd worden. Zijn vader leest veel, onder andere Chesterton en vertaalt later ook brieven voor de pleegouders van de Oostenrijkse oorlogskinderen. Hij is ook enige tijd 'hulponderwijzer' geweest bij ene Borsten. ${ }^{18}$ De moeder blijkt later verstand te hebben van de boeken die Coolen als adolescent leest en ze weet dat sommige daarvan kritisch zijn ten opzichte van het geloof of zelfs ronduit antikatholiek. Dit blijkt uit bezorgde brieven aan geestelijken. De meeste moeders in het Deurne van die tijd zullen de meer algemene bezwaren tegen boeken en geleerdheid hebben gehad: Ge verleest oew verstand nog!

\section{Het lezen}

$\mathrm{Er}$ is in het gezin Coolen in ieder geval de mogelijkheid om te lezen. "Als kinderen in ons ouderlijk huis spraken wij van leesboeken, het woord roman kenden wij niet. [...] Hoe herinner ik mij uit die kindertijd de winteravonden met het boek. De ellebogen op tafel in de lichtkring van de lamp, de handen tegen de oren geklemd om me van de woonwereld af te scheiden, zat ik verdiept, nee verzónken in die wijdere wereld van het boek." ${ }^{19}$ In het begin leest hij van alles: spannende boeken als Onder politietoezicht, Onder de Worgers, maar ook Jules Verne en De negerhut van oom Tom. "Sensatie, emotie, ontroering, een letterlijk weggesleept worden: het waren de primitieve reacties op het boek en de volle overgave eraan. Maar wat een leesplezier, een leesgeluk! En wat een wereld ging er open voor de verbeelding."

Toch zijn boeken schaars in het gezin Coolen, maar juist daarom wordt een boek met onderscheiding behandeld. "Een premieboek van een krant werd ingepakt, opgeborgen en we mochten het slechts lezen aan een geschuierde tafel met alle aanzeggingen, er netjes en voorzichtig mee te zijn," schrijft hij en hij noemt nog enkele titels van wat zij als kinderen lazen: Genoveva van Brabant, Rosa van Tannenberg, Kapitein Hatteras, patersalmanakken, ingebonden jaargangen van de Katholieke Illustratie. Uit dit laatste blad herinnert hij zich verhalen als De kraaien zullen het uitbrengen van de Brabantse schrijver August Snieders en De erfgename van Duivenvoorde van J.A. Vesters. In weer een ander weekblad leest hij Onder Politietoezicht dat gaat over "een tobbende, brave moeder met kapotte handen aan de waskuip. en van een helemaal niet braven zoon, met wien het slecht afliep. Bij ons, kinderen, bereikte de schrijver zijn doel: wij besloten braaf te blijven, zóals we met die tobbende moeder hadden te doen." Coolen zal het thema zelf gebruiken in een van de verhalen van zijn bundel Lentebloesem: 'Opgebracht'. De herinnering aan de 'werkelijke literatuur' is echter anders dan 
die aan de 'leesboeken'. Hij ontdekt nieuwe namen, echte literaire schrijvers, waaronder degene die hij zijn hele leven zijn grote voorbeeld zal blijven noemen: Stijn Streuvels.

"De eerste auteur, waar ik kennis mee maakte is Stijn Streuvels. Dat was in r9r1. Voor dien tijd, las ik graag Buffalo Bill- en Lord Lister-romans, die ik verslond. Toen op een dag kreeg ik van 'n vriend De Oogst van Streuvels. Dat vond ik geweldig mooi. Waaróm kan 'k niet goed zeggen, maar dat was zoo geheel iets anders [...] vanuit die bladzijden kwam een gloed van 'n tot dan niet gekend schoon, dat sleepte me mee. In veertien dagen las ik zes of zevenmaal De Oogst. 's Nachts droomde ik van dien Rik. Toen ben 'k meer van Streuvels gaan lezen en ook van andere schrijvers. Van lieverlede is literatuur me een noodzakelijk ding geworden. En nu vind ik niets mooier dan dàt." ${ }^{20}$

De vriend die hem De Oogst heeft gegeven is H.N. Ouwerling, onderwijzer, amateurhistoricus en hoofdredacteur van De Zuidwillemsvaart; de man die veel invloed op Coolen zal hebben en hem uiteindelijk in de journalistiek brengt.

\section{Deurne begin deze eeuw}

Als men het Peelgebied op oude kaarten als moeras ingetekend ziet, lijkt het op een halve maan, met de bolle zijde naar Limburg gericht. Deurne ligt dan in de holte aan de westkant, en is aan drie kanten omgeven door de Peel.

Tot het midden van de negentiende eeuw worden de gronden als gemeenschappelijk bezit, de gemeynt, beschouwd. De boeren halen er voor zichzelf turf uit voor brandstof en plaggen om in de potstal onder de koeien en schapen te gooien. Later worden ze dan vermengd met de mest op de schrale zandgrond gebracht. In 1853 beginnen de gebroeders Van de Griendt op grote schaal met de productie van turfstrooisel. Er ontstaan nieuwe dorpen: Helenaveen en Griendsveen. De gebroeders graven zelfs een eigen kanaal, de Helenavaart, om hun product af te voeren naar de Zuid-Willemsvaart. Enkele jaren later begint ook de gemeente Deurne met een eigen verveningsbedrijf. Als Deurne ook de Helenavaart wil gebruiken voor de afvoer wordt dat door de Gebroeders van de Griendt geweigerd. Zo wordt Deurne gedwongen een eigen Deurnes kanaal te graven in 1876 , dat over een lengte van vier en een halve kilometer parallel loopt aan de Helenavaart. ${ }^{21}$ Wellicht is het daaraan te danken dat het gebied tot op de dag van vandaag behouden is als natuurgebied; het ligt als een eiland omsloten door kanalen.

Turfstrooisel wordt gemaakt van de bovenste laag turf, de bonksellaag, die niet geschikt is om te stoken. Het strooisel kan meer absorberen dan stro en is daarom zeer geschikt voor de paardenstallen. Niet alleen het leger is een grote afnemer, maar ook grote steden als Londen en Parijs gebruiken het graag voor hun openbaar vervoer. In Parijs staan 's nachts 50.000 paarden in de stallen bij de tramremises op turfstrooisel uit de Peel. Deurne wordt er een welvarend dorp door en krijgt rond de eeuwwisseling de bijnaam 'Het

Coolen, Het Gouden Gymnasium, 12.

Bekman, 'De journalist Coolen', 636.

AMVC, inv. nr. C 3475, brief Coolen aan Streuvels, 19 september 1934.

Coolen, 'Over de vreugde van het lezen'.

KDC, inv. nr. 101, brief Coolen aan Lutkie, 8 december 1914.

Gegevens ontleend aan: Iven, Mensen in de Peel, 47. 
Millioenenparadijs'. Het dorp met slechts 6000 inwoners bouwt een enorm raadhuis in classicistische stijl ( 1896 ) en een even pompeus postkantoor er pal naast. Deze gebouwen zijn dus nog gloednieuw als Antoon Coolen er als kind komt wonen. "Een jonge man ben ik, middelmatig van gestalte en 'k woon in 't Millioenen-paradijs Deurne," zo zal hij enkele jaren later zijn eerste publicatie beginnen. ${ }^{22}$ Als hij later op zestigjarige leeftijd op het dorp van zijn jeugd terugblikt, schetst hij het beeld wat armoediger.

"Toen wij, de ouderen van nu, kinderen waren, was ons dorp nog een afgelegen oord. Het lag weliswaar aan een spoorweg, en er stopten een paar treinen daags. Er was ook wat goederenvervoer, hooi en stro van de boerenbond, die in die dagen begon, en haksel en hulzen, want er was ook een strohulzenfabriekje in ons dorp, we hadden ook een steenfabriek, maar veel had dat allemaal niet te betekenen. [...] het was in het begin van deze eeuw, misschien brak de dageraad van de nieuwe tijd al door, maar als we eraan terugdenken, dan moeten we maar niet al te zeer dat weemoedig gevoel onderzoeken, dat ons doet spreken van de goede oude tijd."2s

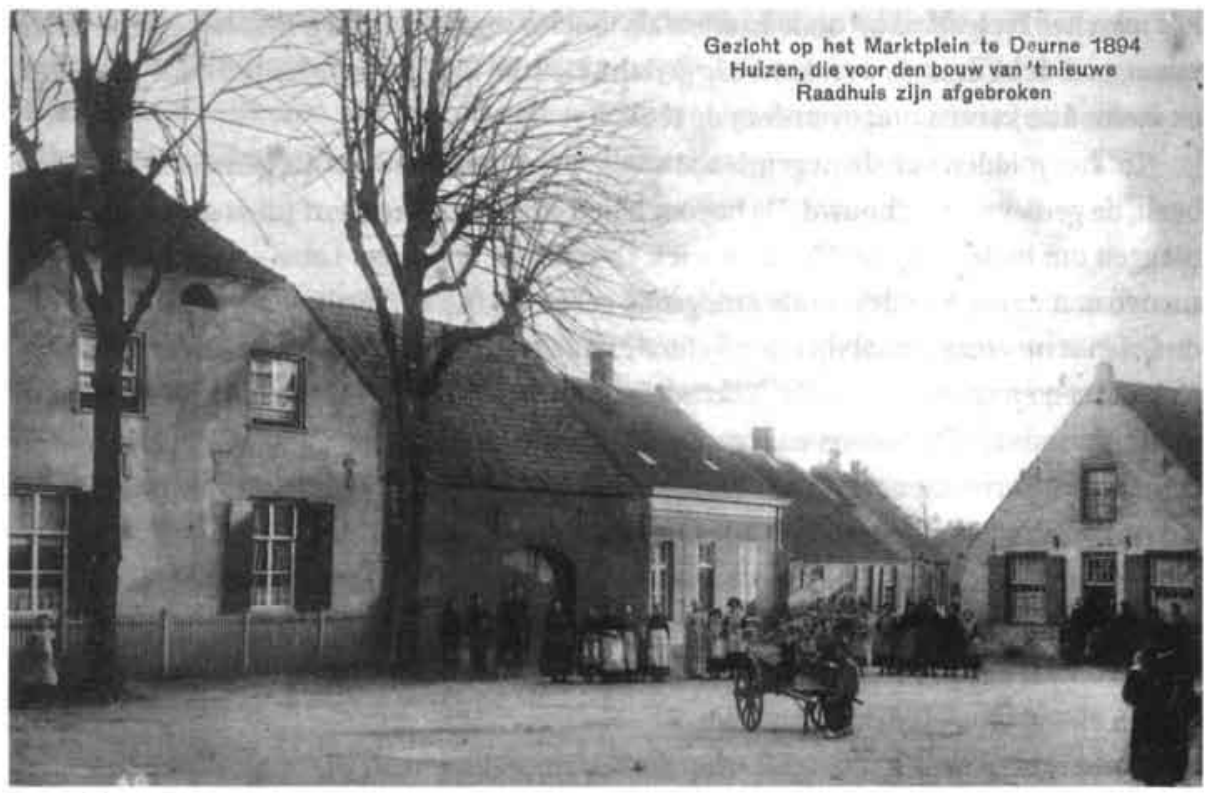

De markt van Deurne.

Coolen heeft als jongen het langst gewoond in de winkel aan het Haageind tegenover de oude Willibrorduskerk, het gedeelte dat nu Kerkstraat heet. Het Haageind is van oudsher al een van de beste wijken van Deurne; het strekt zich helemaal uit van de dorpskern tot het kasteel. Aanvankelijk is het een boerenstraat, maar er vestigen zich al gauw ook burgerfamilies. ${ }^{24}$ Het contrast tussen deze families in Deurne en de dagloners, wevers en peelwerkers in het buitengebied is enorm. Vooral in de winter wordt er in de Peel bittere armoede geleden; de kindersterfte is er zeer hoog.

Coolen heeft de eenzaamheid en de troosteloosheid van de Peel gezien, maar tegelijkertijd bewondert hij de woeste schoonheid van dit landschap in de verschillende seizoenen. Hij doet echter niet alleen indrukken op van de Peel. Een zoon van een winkelier in het 
Millioenenparadijs ziet meer en maakt meer mee van de 'wereld' dan een kind dat achteraf opgroeit in een peelwerkershutje. Af en toe komt er een circus in het dorp, dat aangekondigd wordt op bonte aanplakbiljetten - "die fel gekleurde bladzij uit het jeugdalbum"25 - of een man in een groen narrenpak met belletjes, die komt bedelen. Aanvankelijk zijn er nog 'gastarbeiders' die ervaring hebben met het ontginnen van veengronden zoals Friezen en Drenthen, maar ook 'Poepen' uit Westfalen. De mensen uit Deurne gaan zelf soms ook elders werken. Deze wegtrekkende en weer terugkerende arbeiders komen vaak voor in de latere romans van Coolen. "Daar woonde Willem Versteynen, een seizoenarbeider in de venen of op de steenfabriek, hij ging ook met de hannekemaaiers naar Pruisen en je kon hem hier in de oogsttijd bij het maaien van rog en haver aan het werk zien." ${ }^{26}$

De winkel van de familie Coolen is centraal gelegen, vlakbij de kerk, het gemeentehuis, het postkantoor en de herberg De Gouden Leeuw, die rond rgro wordt afgebroken en waar op dezelfde plaats op $\mathrm{I}$ augustus I9I4, op de dag dat de Eerste Wereldoorlog uitbreekt, de eerste steen wordt gelegd voor de herberg De Swaen. ${ }^{27}$ Het komen en gaan van vreemdelingen en het dagelijkse bezoek van allerlei dorpstypen maken een grote indruk op een ontvankelijke jongen als Antoon Coolen.

Als misdienaar heeft hij de preken van de redemptoristen meegemaakt. Deze paters komen periodiek langs alle parochies om een zogenoemde volksmissie te houden. De gelovigen moeten dagen achter elkaar naar de kerk, waar de paters in boetepreken de geloofsleer, de katholieke moraal en de consequenties daarvan voor het dagelijkse leven van een katholiek er nog eens inhameren. De redemptoristen hebben vanaf het midden van de negentiende eeuw een enorme reputatie opgebouwd. Hun kanselwelsprekendheid "was in hoge mate suggestief en naderde soms de demagogie," schrijft Rogier ${ }^{28} \mathrm{Zij}$ schilderden drastisch de verschrikkingen van de hel, maar ook de heerlijkheid van de hemel. "Het was een prediking, die verschrikte en vertederde, die een primitief gemoed heftig beroerde met donkere dreigementen [...] Hel en duivel en vooral de zonde der onkuisheid schilderden zij in alle monsterlijkheid." Het gevolg was meestal een stormloop op de biechtstoelen; de mensen wilden hun ziel reinigen zodat zij, bij een ontijdige dood, niet voor eeuwig in de hel zouden branden. Coolen beschrijft veel later de sfeer van een volksmissie in zijn roman De vrouw met de zes slapers:

"In die vakantiedagen hadden wij in ons dorp een volksmissie. Dan luidt als een noodklok voor de ziel elke avond de zondaarsklok, en de ramen in de kerk zijn op een onge-

22 Coolen, Opinies, 7. Ook Ouwerling noemt Deurne het Miljoenenparadijs, als hij schrijft over de vondst van de Romeinse helm in de Peel.

23 Coolen, De grote voltige, eerste regels van het hoofdstuk 'De Hardloper'.

24 Ouwerling, Geschiedenis der dorpen, 46.

25 Coolen, De grote voltige, 41.

26 Coolen, De grote voltige, 35.

27 De gevelsteen en een zwaan in het bovenlicht zijn nog te zien, de herberg is nu een Chinees-Indisch restaurant. Er was nog een andere herberg, Het vergulde zwijnshooft. Ook deze werd afgebroken; hiervoor kwam in de plaats een modemagazijn "in stadsarchitectuur met grote etalages." In Het nieuwe Brabant (1952) merkt Coolen wel op dat niet alles wat afgebroken is zonde is, er verdween ook veel lelijks: "een onooglijke verzameling van verzakte bouwvallige huisjes en scheve schopjes en schuurtjes." 
woon avonduur verlicht, schaars maar, want er is geen eigenlijke dienst, alleen maar een preek met een korte sluiting, en de redemptoristen houden van een vaag door-

schemerd donker, dan hebben ze des te meer vat op de mensen." 29

Antoon Coolen weet meer over de paters dan een doorsnee schooljongen. Als zij preken over matigheid, ziet hij wat de knecht van het liefdesgesticht en de pastoorsmeid zoal voor de bij hen logerende paters komen kopen: "macaroni, parelrijst, kerrie, champignonnetjes, vanielje, puddingpakjes, gedroogde pruimen en abrikozen om te stoven bij het gevogelte. ${ }^{n 0}$ Misschien kunnen de paters er niets aan doen, want nonnen en pastoorsmeiden hebben nu eenmaal de gewoonte om de geestelijkheid te vertroetelen. In de ogen van de jonge Coolen komt dit echter over als schijnheilig gedrag en een dubbele moraal. In bijna al zijn romans en verhalen komen personages voor die deze karaktertrekken vertonen.

\section{Gevoel voor tijd en ruimte}

De bedelaars, circusmensen, gastarbeiders, teuten ${ }^{31}$ en redemptoristen zijn personen die een vleugje van het vreemde, het exotische met zich meebrengen in het afgelegen dorp. Hét symbool van het onbekende dat in de verte verborgen ligt, is de spoorlijn die in een kaarsrechte lijn van Helmond naar Venlo vlak langs het dorp loopt. De rails die aan de horizon elkaar raken, de telegraafpalen met de zoemende draden die er langs staan en de treinen die daaroverheen razen, moeten de verbeelding van de jonge Coolen hebben geprikkeld. Na de verhuizing van het gezin naar de Zeilberg wordt het contact met de spoorlijn nog intensiever. Vanaf dan zal hij altijd het pad langs de spoorlijn moeten aflopen; de Zeilberg ligt ruim een kilometer oostelijk van het station.

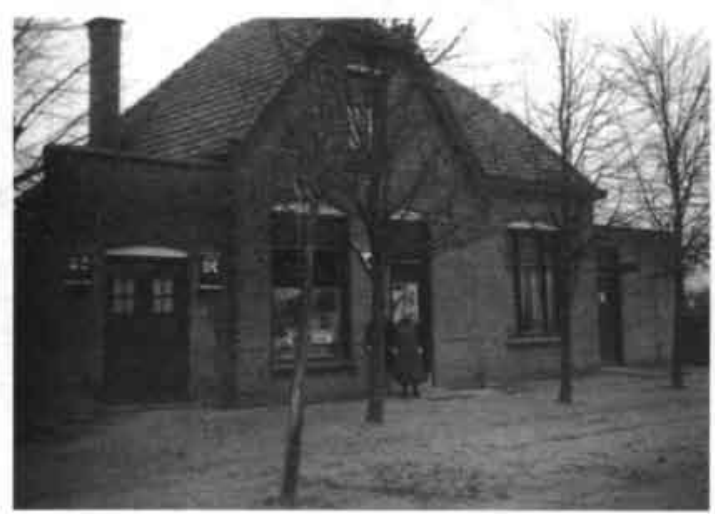

De winkel van de Zeilberg. Rechts moeder Maria CoolenSwinkels; half achter de boom vermoedelijk haar dochter Miet.
De spoorlijn komt in bijna alle Peelromans voor, maar ook in zijn latere werk speelt het spoor een haast symbolische rol. Altijd koppelt hij de convergerende rails, de voorbij zoevende trein, de telefoondraden die een vaag gezoem in de palen teweegbrengen en het getingtang van de seinklok aan een vage weemoed naar onbekende verten, waarbij het geluid van de draden "een donker lied" is, "dat komt van beide zijden der aarde, van verre vlakten en van

bosschen en van verre steden." ${ }^{32}$ Bovendien zal Coolen, als bewonderaar van Zola, ook diens roman over het spoor, La bête humaine, hebben gelezen. Hierin wordt de eenzaamheid van de vrouw van een overwegwachter nog benadrukt door de voorbijkomende mensen in de treinen van en naar Parijs. "Het leek haar grappig dat zij eenzaam, diep in deze verlatenheid leefde zonder iemand die zij in vertrouwen kon nemen, terwijl dag en nacht, onophoudelijk, zoveel mannen en vrouwen voorbijkwamen, als in een stormvlaag, in treinen die het huis deden schudden en die in volle vaart wegvluchtten." ${ }^{33}$ Steeds zien de roman- 
personages een glimp van de reizigers achter de verlichte coupévensters.

Coolen is zijn hele leven een beschouwer en een buitenstaander geweest. Het is aannemelijk dat de verhuizingen, toen hij drie was naar Zevenbergen en vooral die op zesjarige leeftijd naar Deurne, daarbij een rol hebben gespeeld. Je bent dan voor de dorpsjeugd een vreemd jongetje, dat van ver komt. Ook zijn latere vriend en eerste biograaf Van Duinkerken is ervan overtuigd dat aan het beeld van de spoorweg een jeugdherinnering ten grondslag ligt. De melancholie van dat herinneringsbeeld komt steeds terug in zijn werk, vooral als een eenzaam personage een onbekende toekomst tegemoet gaat. Volgens Van Duinkerken moet dat te maken hebben met "een reeds jeugdig waargenomen drang naar verten. ${ }^{34}$

Een andere verklaring, die de vorige overigens niet uitsluit, is dat het geluid van de spoorlijn (de draden, de trein, de klok) voor Coolen is wat de Madeleine was voor Marcel Proust: het brengt zijn verbeelding op gang en plaatst hem terug in de tijd. In zijn meest autobiografische roman, De Vrouw met de zes slapers, reikt hij de lezer een sleutel aan voor deze gedachte. In de roman onderneemt hij op zijn manier ook een zoektocht naar de verloren tijd. ${ }^{35}$ De hoofdpersoon Cordewever verzint plezierige dingen

"die er niet waren, maar die later zouden komen. [...] Want een heden is er eigenlijk niet. Het wezen zelf van de tijd is dat hij beweegt en voorbijgaat, heeft een wijsgeer gezegd, en dat van de duur, dat hij niet duurt. Er is niets, dat tot een stilstand en een blijven wordt bereikt, er zijn alleen maar verwachtingen en herinneringen. [...] Wij beleven de dingen niet op het ogenblik, de verwachting wordt pas in de herinnering vervuld." ${ }^{36}$ Het lijkt er veel op dat Coolen deze stelregel, al dan niet bewust, voor zijn schrijven heeft gehanteerd. Hij neemt steeds afstand: zowel in tijd als in ruimte. De meeste Peelromans spelen enkele decennia eerder dan de tijd waarin hij ze schrijft: soms in de tijd van zijn eigen jeugd, maar vaak ook in die van de jeugd van zijn ouders. In die zin zijn het spoor en de trein ook symbolen van de nieuwe tijd in het oude land. Er is ook vaak afstand in de ruimte. De Peelromans worden bijna allemaal in Hilversum geschreven, terug in Deurne schrijft hij over de Maaskant en Friesland en vanuit Waalre worden Deurne en Grave weer het decor voor zijn laatste drie romans. Tijdens de oorlog trekt hij zich terug in een 'innere Emigration' en kiest voor het schrijven van sprookjes, dus voor de grootst mogelijke afstand in tijd en ruimte: Er was eens ... in een ver, exotisch land.

29 Coolen, De vrouw met de zes slapers, 27-28.

30 Coolen, De vrouw met de zes slapers, 39.

31 Teuten waren rondtrekkende kooplieden uit Belgisch Noord-Limburg. Het woord heeft niets met Duits of Teutoons te maken. De etymologie is onzeker, het kan zijn dat de naam ontstaan is door het geluid van het fluitje waarmee ze hun komst aankondigden. Bron: Etymologisch woordenboek, Van Dale, Utrecht/Antwerpen, 1991, 746.

32 Coolen, Het Donkere Licht, 131.

33 Zola, Het beest in de mens, 40.

34 Van Duinkerken, Antoon Coolen, 11.

35 J, van de Sande wees daar al op in zijn bijdrage aan het symposium in Deurne ter gelegenheid van de I00ste geboortedag van Coolen op 19 april 1997.

Coolen, De Vrouw met de zes slapers, 14-15. 


\section{Ouwerling, een dwarsligger}

Een ontvankelijk en gevoelig kind, dat op het juiste tijdstip in aanraking wordt gebracht met een nieuwe wereld van cultuur en boeken, kan voorgoed in de ban raken van het lezen en het schrijven. Het feit dat Coolen op het Haageind de buurjongen is van de onderwijzer, schrijver en journalist Ouwerling heeft onmiskenbaar een grote invloed op hem gehad. Zo kijkt hij er ook zelf later op terug:

"Naast ons woonde een gewichtig en geleerd man, die later mijn vriend werd, de publicist en historicus H.N. Ouwerling. Die had waarlijk de muren in zijn huis vól boeken, van onder tot boven. Voor die boeken, onverschillig hoe hun inhoud was, heb ik bevend van eerbied gestaan. Toen gebeurde er iets aangrijpends en ontroerends: ik kreeg van die boeken er enige te leen, om te lezen. Lézen! Ik las. Boeken van Conscience, van Reinier en August Snieders en later van Stijn Streuvels. Dat is een tijd geweest! Het huis van Ouwerling werd later een tweede tehuis, het róók er naar Conscience, Snieders en Streuvels, een lucht die ik gretig inademde. In een der kamers vormde een groot crayonportret van Conscience het schoorsteenstuk. - Die man heeft zijn volk lezen geleerd, zei de heer Ouwerling, wijzend op die beeltenis, en vol bewondering keek ik naar dien heroieken kop." ${ }^{37}$

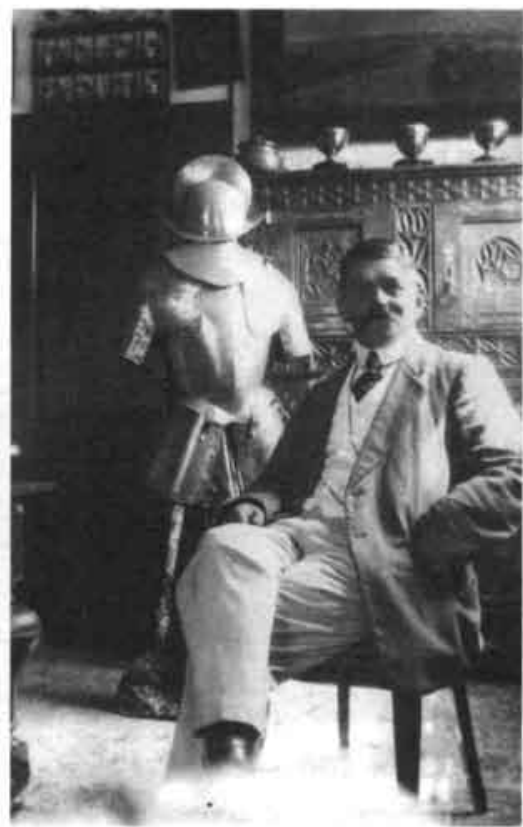

Hendrik Ouwerling, onderwijzer, journalist en heemkundige.

Coolen hoort bij deze buurman heel andere dingen dan op de fratersschool. Ouwerling, ongeveer even oud als de ouders van Antoon Coolen, ${ }^{38}$ was aanvankelijk onderwijzer in Liessel en Deurne. Hij had de naam een vrijdenker te zijn, maar bleef toch zijn hele leven katholiek. In het begin van zijn loopbaan was hij voortdurend in conflict met de besturen van katholieke scholen, die volledig afhankelijk van de geestelijkheid waren. In Deurne werd hij in de jaren negentig plaatsvervangend hoofd van de openbare lagere school. Zijn vriend en leerling H.J.J. Maas (ook onderwijzer en schrijver van Peelromans) herinnert zich nog goed hoe kwaad Ouwerling was tijdens de schoolstrijd en dat hij "met gebalde vuist voor de Deurnese pastorie stond en gesmoord uitstootte: 'Die kerels zijn de schuld van driekwart van het leed op de wereld!" ${ }^{39} \mathrm{Er}$ was toen een campagne om openbare scholen te vervangen door katholieke scholen. Toen de fraters in 1896 een katholieke school oprichtten, liep het leerlingenaantal op zijn openbare school snel terug. Na enige tijd op wachtgeld te hebben gestaan kreeg hij in november 1900 eervol ontslag. ${ }^{40}$

$\mathrm{Al}$ in $\mathrm{r} 896$ was Ouwerling de journalistiek in gegaan als redacteur (later hoofdredacteur) van de krant De Zuidwillemsvaart in Helmond. Hij had een haat-liefdeverhouding tot de streek waar hij leefde. Hij schreef scherpe commentaren in zijn krant over onderwijs, 
opvoeding, kunstmest, de boerenbond en pater Van den Elsen, maar spaarde ook de peelbewoners zelf niet door hen achterlijkheid en domheid te verwijten.

In 1904 woedde een felle polemiek tussen Ouwerling in De Zuidwillemsvaarten de boerenapostel Van den Elsen; deze twist werd al gauw 'de boteroorlog' genoemd. Het ging hierbij om de voor- en nadelen van de particuliere tegenover de coöperatieve boterhandel. Ouwerling was voor de particuliere handel omdat deze zich naar zijn mening uit eigenbelang deskundiger en efficiënter ontwikkeIde. ${ }^{41}$ Het meningsverschil zat echter dieper: het was een verschil in visie op de boerenstand en op de emancipatie van de Noordbrabantse plattelandsbevolking en de dorpssamenleving. Van den Elsen zag hierin nog de organische samenleving van de Middeleeuwen, waarin waardevolle elementen "als godsdienstzin, reinheid van zeden, gehechtheid aan traditie, saamhorigheidsgevoel, landelijke eenvoud en goede trouw ${ }^{\prime 42}$ een belangrijke rol speelden. Het is niet toevallig dat de schrijver over de Peel, Maas, het begrip 'landelijke eenvoud' in ironische zin gebruikte als titel van een roman en dat even later de jonge journalist Coolen het boven een krantenstukje zette. Hieruit blijkt dat ook toen lang niet iedereen het idyllische beeld van het platteland accepteerde.

De verheerlijking van de Middeleeuwen, de gilden en de gemeenschapsbeleving die men daarmee associeerde, zullen de hele eerste helft van de twintigste eeuw een rol blijven spelen. We zien ze sterk terugkomen bij katholieke intellectuelen rond de Tilburgse Hogeschool, Brabantia Nostra en in de Nederlandse Unie in de eerste jaren van de Tweede Wereldoorlog. Uit deze denkwereld komen ook de corporatieve ideeën voort volgens welke de werkgever en zijn werknemers hetzelfde belang hebben en klassenstrijd dus overbodig wordt.

Ouwerling stond zeer sceptisch tegenover deze verheerlijking. In zijn boek Uit donkere gewesten prikt hij in het hoofdstuk 'Geleuter over den goeden ouden tijd' het paradijselijke beeld van de Middeleeuwen door en noemt de gilden machtige syndicaten, die al gauw een aristocratisch karakter kregen, waardoor de werklui door de kooplieden werden uitgebuit. ${ }^{43}$ Antoon Coolen wordt door de ideeën van Ouwerling beïnvloed en deze zullen hem blijvend wantrouwig maken jegens stromingen binnen de politiek en de kerk die deze middeleeuwse 'orde' op een of andere manier willen invoeren, zoals het integralisme en het fascisme.

Ouwerling had oog voor het machtsmisbruik door wereldlijke en geestelijke autoriteiten en het drankmisbruik en de criminaliteit waarmee het volk zichzelf te gronde richtte. Hij legde in plaats van de materiële voordelen die de Boerenbond bood zwaar de nadruk op de verbetering van het onderwijs en de infrastructuur. "Goede scholen, goede

37 Coolen, 'Hoe ik er toe kwam', 36.

38 Hij werd geboren op 24 december 1862 te 's-Hertogenbosch; een dag eerder dan Onze Lieven Heer zoals hii zelf zei.

39 Stadsarchief Helmond, inv. nr.I, brief van H. Maas aan J. Heeren, 23 januari 1948.

40 Huiskamp, 'Hendrik Nicolaas Ouwerling'.

41 Hollenberg, Van den Elsen, 162.

42 Hollenberg, Van den Elsen, 163.

43 Ouwerling, Uit donkere gewesten, 120. 
wegen, brengen aan den lande zegen," schreef hij boven zijn eerste artikel in De Zuidwillemsvaart. ${ }^{44}$ Daarnaast interesseerde hij zich voor de technische verbeteringen binnen de landbouw (machines, kunstmest, bodemverbetering, ontwatering) en was daardoor een medestander van kapelaan Roes, die later pastoor van Deurne zou worden. Ouwerling komt de eer toe dat hij een van de eersten was die de bewoners van de Peel heb. ben wakker geschud en gewezen hebben op de mogelijkheden die de moderne landbouw bood. Roes heeft daar op voortgebouwd in zijn geschriften en door op vergaderingen en in voordrachten er voortdurend op te hameren dat alleen kennis, "gepaard met toegewijden arbeid en eendrachtige samenwerken in vereenigingen vermag, den bodem de grootst mogelijke oogsten te doen voortbrengen. De bevolking heeft geluisterd en gehandeld. Dit alles legde den grondslag voor een nieuwe Peel en opende de deur voor vooruitgang en welvaart. $^{m 5}$

Ouwerling schreef Uit donkere gewesten in december 1907. De aanleiding hiervoor was een negatieve kritiek op het boek Verstooteling van H.H.J. Maas. Er was in het zuiden inderdaad veel mis, maar dat lag ook aan de mensen zelf. Hij hekelde de toestanden bij kermis. sen, begrafenissen en lijkmalen. Als je de kermissen bezag, was je volgens hem eerder geneigd de oorsprong daarvan in de hel te zoeken dan in de kerk; het drankmisbruik leid. de tot zoveel steek- en kerfpartijen dat de provincie wel eens spottend 'Moordbrabant' werd genoemd. Er kan nooit ontwikkeling komen als kinderen meteen na hun Eerste $\mathrm{H}$. Communie, op II-jarige leeftijd, moeten gaan werken, schreef hij. Hij prees Maas voor zijn eerlijk boek: "Uw boek heeft een rilling doen gaan door 't Zuiden. De bevolking die gewoon was te zingen: 'Mijn landeke, wat zijt ge schoon!' hebt ge toegeroepen met machtige stem: Tk zal je wat anders laten zien; met je geleuter over landelijke cenvoud, en geluk en tevre. denheid zal 't voortaan uitwezen." 46

\section{Gymnasium}

Het contact van de leergierige Antoon Coolen met deze vrijdenkende en geleerde buuman zal een extra stimulans zijn geweest om verder te leren na de lagere school. De enige manier voor een jongen van gewone komaf in een Brabants dorp van die tijd om 'door te leren' aan een gymnasium is het klein seminarie. Hiervoor zijn speciale fondsen opgericht. Antoons studie wordt betaald uit het Fonds van de St. Charles Stichting van de Witte Paters uit Boxtel. ${ }^{47}$ Al op de lagere school worden de goede leerlingen door de fraters aangespoord om na te gaan of ze geen 'roeping' hebben, dat wil zeggen een innerlijke drang, een diep gevoeld verlangen om priester te worden. In Brabant zijn er, naast de twee groot seminaria in Haaren en Hoeven en de klein seminaria Beekvliet en Ypelaar van de bisdommen Den Bosch en Breda nog vele groot en klein seminaria die verbonden zijn aan kloosterorden en congregaties. De jongens op een klein seminarie worden hier al vroeg op hun geestelijke status voorbereid. De klassen dragen klassieke namen als Kleine Figuur, Grote Figuur, Poésis en Retorica. Sigaren roken wordt niet alleen toegestaan, maar zelfs gestimuleerd; sigaretten daarentegen zijn streng verboden. Tijdens verlofdagen en vakanties worden de leerlingen thuis bijna als hogere wezens behandeld.

In 5909 gaat Antoon Coolen als interne leerling naar het gymnasium van de Norbetimen in Heeswijk. Over het verblijf van Coolen op dit seminarte is uit rechtstreekse bromen niet veel bekend. ${ }^{\text {* }}$ Het is een geordend leven met in de vrije tijd lange wande- 
lingen. Zo lopen de leerlingen in juni $191 \mathrm{r}$ langs de Zuid-Willemsvaart naar Den Bosch om de demonstraties van de Bossche luchtvaartpionier Henri Bakker boven De Pettelaarschans te zien. ${ }^{49}$ Deze vliegshows zijn in die tijd populair. Enkele weken later ziet Felix Timmermans er een boven Lier. Hij geeft de 'vliegmachine' prompt een plaats in zijn Pallieter, een boek waar verder geen modern vervoermiddel in voor komt. ${ }^{50}$

Later heeft Coolen enkele malen teruggeblikt op deze tijd, de eerste keer ter gelegenheid van het achtste eeuwfeest van de abdij in 1934 en twee jaar later bij het vijftigjarig bestaan van het gymnasium. Nog twee jaar later in 1938 , bij de opening van de nieuwbouw, is hij zelfs ghost-writer voor de toespraak van de burgemeester van Heeswijk, die aanvangt met "Hoogwaardig Heer." (Hier is geen e vergeten; de officiële titel van de abt van Berne is Het Hoogwaardig Heer)

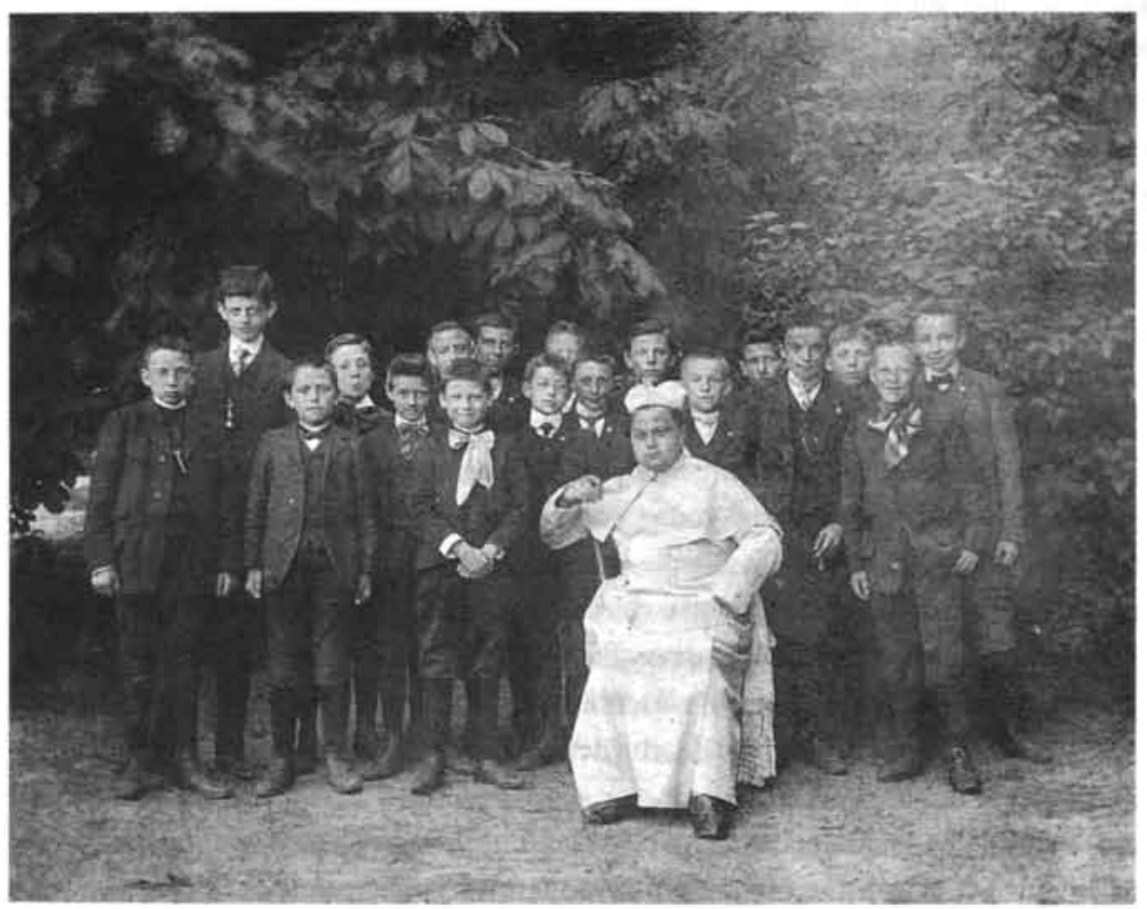

Klas in Heeswijk in 1911 of 1912 . Coolen, vierde van links, draagt reeds een stippeltjesdas.

44 Hollenberg, Van den Elsen, 163.

45 Dilling, De Peelstreek, 7.

46 Ouwerling, Uit donkere gewesten, 161.

47 Van den Hurk, 'Antoon Coolen als Heeswijkse gymnasiast', 58.

48 In het archief van de Abdij van Berne, waar de gegevens van het gymnasium St. Norbertus bewaard worden ontbreekt de leerlingenkaart van Antoon Coolen. Er is een overzicht van de prijsuitreikingen tussen 1904 en 1916, doos 23, boekje 54.

49 Coolen, 'Brieven van de Romeijn', 18 april 1935. In deze column betreurt Coolen het dat de uitvinding op dat moment zo wordt misbruikt in de oorlog in Abessinie.

50 Durnez, Felix Timmermans, 191. 
Natuurlijk speelt de nostalgie van de 37 -jarige een rol bij de terugblik van 1934 . Hij benadrukt dat de indrukken die men in zijn kindertijd opdoet lang in de ziel blijven voorleven en daar zelfs nooit helemaal uit verdwijnen. Hij herinnert zich de grote kastanjeboom - die later gerooid werd - vóór de kapel, zijn geliefde Canadassen, de smalle gracht om de abdij en de sfeer in de tuin tussen de hoge Amerikaanse eiken. In het dorp de "ancestrale hoefsmid," de twee molens en de stoffige zomerwegen waarover de tram van Helmond naar 'sHertogenbosch door het dorpje heen "huppelde en belde en smookte." De studenten maken er veel wandelingen naar het kasteel of over de grindweg richting Schijndel tot aan het kanaal De Zuid-Willemsvaart en weer terug. Over de school zelf en het onderwijs rept hij met geen woord in dit artikel. Hij besluit aldus: "Ook om dit alles heb ik aan de abdij, die nu haar achtste eeuwfeest viert, herinneringen, die tot de innigste en gelukkigste behooren van mijn jongenstijd." ${ }^{51}$

Bij het gouden jubileum van het gymnasium in 1936 benadrukt hij opnieuw het belang van jeugdherinneringen: "van geen leeftijd worden de indrukken krachtiger en blijvender vast gehouden. ${ }^{52} \mathrm{Hij}$ kijkt dan al graag naar de vallende sneeuw tijdens de lessen in de winter. Hoewel in de recreatiezaal kan worden gebiljart, geschaakt, gedamd en postzegels geruild of geplakt, voelt Coolen zich toch het meest aangetrokken tot het schooltoneel. Ook nu weer beschrijft hij uitgebreid de omliggende natuur. Echter, de meeste indruk heeft professor [zo werden de leraren aan een klein seminarie genoemd, C.S.] J.M.J. Knaapen op hem gemaakt. "Hier stond een man voor ons, die had stijl, die had charme en hart, die had surplus, wat den docent zijn vermogen tot begeesteren geeft." Knaapen leidt het toneel en doorbreekt de gewoonte van de "gekostumeerde patronaatsstukken." Hij leest hen de Gijsbrecht van Aemstel voor. Coolen bekent dat hij, steeds als hij dit stuk ziet in Amsterdam, terug moet denken aan die Heeswijkse pianokamer, eigenlijk heeft hij het nooit mooier gehoord dan daar. Knaapen vertaalt ook de zogenaamde Sacramentsstukken als Gastmaal der Armen en Het Schouwtoneel der Wereld van Calderón, de Spaanse toneelschrijver uit de zeventiende eeuw. Hij vertelt hele stukken na als de Graalsage uit Parcival of de Ring des Nibelungen. Hij verstaat daarbij de kunst de tekst voor de ogen van de leerlingen tot een echt drama te maken.

$\mathrm{Na}$ Ouwerling heeft de leraar Knaapen de jonge Còolen weer een stap verder in geestelijk contact met de buitenwereld gebracht. Knaapen staat ook open voor 'moderne' literatuur en is lid van de Katholieke Kunstkring De Violier in Amsterdam. Het officiële orgaan van deze kunstkring was het blad Van Onzen Tijd. "Er is geen beter middel om een diepe indruk te bekomen van wat in weinige jaren tijds verrassend was opgebloeid op een zo lang dor gelijkende akker dan het nauwgezet bestuderen van het tweede vijftal jaargangen van Van Onzen Tijd, ${ }^{53}$ schrijft Rogier. Hij bedoelt in dit citaat de periode I905 tot 1910; het is dus heel goed te begrijpen dat Knaapen zijn enthousiasme over deze geestelijke herleving op zijn leerlingen heeft overgebracht.

Coolen werkt ook aan zijn muzikale vorming. Hij zingt mee in het koortje van de heer Dobbelsteen en leert daar de schoonheid van de motetten van Palestrina kennen, die zij ten gehore brengen in het avondlof van de Meimaand. Zo'n lof wordt vaak besloten door de heer Van Veghel met een eigen Marialied: "Hoe luisterden wij dan bewonderend naar die gelijktijdig zoo volle en vloeiende stem van deze bescheiden, prachtigen zanger. ${ }^{" 54} \mathrm{Op}$ Cuneradag als alle "brave boersche Meieryers naar de abdij kwamen," geeft de harmonie 
van de studenten een openluchtconcert. Coolen is hiervan geen lid geweest.

Kort na het verlaten van het gymnasium meldt hij zich aan als aspirant-lid van de Harmonie Deurne en hoopt na "voldoende geschiktheid" ingeschreven te kunnen worden als werkend lid. Men heeft hem afgeraden om een koperinstrument te blazen. Hij denkt zelf dat de klarinet iets voor hem is. ${ }^{55}$ Echter, het lidmaatschap gaat niet door en hij heeft ook later geen instrument leren bespelen. Wel houdt hij zijn hele leven een grote belang. stelling voor muziek.

Het is natuurlijk interessant om te weten of Coolen in Heeswijk ook al op literair gebied actief is. Zijn opstellen worden door de leraren zeer gewaardeerd. Antoon Coolen stuurt onder de naam van zijn zus Cato een verhaal naar het katholieke jeugdblad De Engelbewaarder. Het wordt geplaatst met de vermelding "één van de 49 I puikbeste opstel. len." Het gaat over een broertje en zusje die soldaatje spelen: "dan ben jij Frankrijk en ik Duitschland." Het echte geweer gaat per ongeluk af. Het meisje is gewond, de jongen ligt te huilen in bed.

"Wij hadden er een kleine letterlievende kring met een vervoerend enthousiasme voor Streuvels, Gezelle en Jacobus van Looy, die wij, onbewust van jongeren-bewegingen welke zich beter wanen dan de oudere, nadichtten en naschreven in ons album, dat wij, zelf in het prille morgenrood van ons leven, den gecalligrapheerden titel 'Aurora' meegaven op het eerste blad, en dat overigens, meen ik, als contrabande, eens in beslag is genomen." 56

Later wordt dit inderdaad bevestigd door de heer Heijman, de archivaris van Berne; alleen gaat het hier niet om dat album maar om een te gewaagd boek. Hij herinnert zich dat Coolen met de 'schoolrecherche' in aanraking is gekomen, "toen hij Een Paladijn van Simons-Mees onvindbaar dacht te hebben weggeborgen tussen het ondergoed in zijn slaapcel." ${ }^{57}$ Dit boek is een toneelstuk uit 1908 - een "fantastische comedie in vier bedrij$v^{n}{ }^{n 58}$ - en gaat over een ijdele koopman, die tevens redacteur van een tijdschrift voor Kunst en Wetenschappen is. Tijdens een verblijf in Cannes laat hij zich, vanwege zijn gelijkenis, door een hotelier overhalen om zich uit te geven voor een Russische grootvorst die zijn verblijf heeft afgezegd. Al gauw hangt er een Amerikaanse miljonairsweduwe om zijn hals en even later zitten er twee demi-mondaines, Mimi en Loulou, op zijn knie. Bij thuiskomst vindt zijn vrouw zijden onderbroeken in zijn koffer, maar zelfs dan heeft zij niets in de gaten. De koopman-redacteur wordt door zijn uitgever als paladijn van eer en deugd geëerd. Alleen het publiek weet hoe huichelachtig de man is.

Zo'n boek gaat natuurlijk te ver voor de paters van Berne. Vooral het feit dat de hoofdfiguur aan het eind niet gestraft wordt voor zijn daad, dat zijn vrouw hem nog steeds nobel

51 Coolen, 'Heeswijk Lustwarande in het Hart van Brabant', 231.

52 Coolen, 'Het Gouden Gymnasium', 5.

53 Rogier, Katholieke Herleving, 412-413.

54 Coolen, 'Het Gouden Gymnasium', 13.

55 Streekarchief Peelland, Deurne, inv, nr. 7, brief van Coolen aan de Koninklijke Harmonie van Deurne van 13 juli 1913.

56 Coolen, 'Het Gouden gymnasium', 12.

57 Heijman, 'Antoon Coolen en Heeswijk', 632.

58 Simons-Mees, Een Paladijn. Eerste opvoering op zaterdag 20 december 1908. 
vindt en dat hij zelfs een artikel over huwelijkstrouw schrijft in zijn eigen tijdschrift, zal de doorslag hebben gegeven om hèt boek te verbieden. Coolen zal niet alleen genoten hebben van de opgeblazenheid van de hoofdfiguur, maar vooral ook van de scène waarin een jonge schrijver hem verwijt dat deze hoofdredacteur een artikel van hem onder zijn eigen naam heeft gepubliceerd. Het feit dat Antoon Coolen het boek in zijn bezit heeft, betekent dat hij gespitst is op nieuw verschenen literatuur. Dit zal voortdurend blijken.

Waarom breekt hij al na vier jaar zijn opleiding af? Niet vanwege de studieresultaten, die zijn goed. Uit alles blijkt dat hij met een behoorlijke algemene ontwikkeling en talenkennis de journalistiek en de schrijverij in zal stappen. Van Duinkerken is van oordeel dat hij aan het eind van zijn gymnasiumjaren "behoorlijk Latijn, goed Fransch en zeer goed muziekgeschiedenis" kent. ${ }^{59}$ Uit de brieven die hij kort na zijn schoolverlaten schrijft kunnen we afleiden dat dit klopt. De liefde voor de (vooral ook Franse) literatuur, de muziek en het toneel zal zijn hele leven merkbaar zijn.

Gebrek aan 'roeping' voor het priesterschap is de officiële reden voor het voortijdig verlaten van de school. Een klein seminarie was erop gericht om eventuele kiemen van roeping bij jongens tot wasdom te brengen. In de vijfde of zesde klas moest dan de beslissing genomen worden of men wilde doorgaan met de priesteropleiding op het groot seminarie. Coolen heeft zich er niet meer op zijn plaats gevoeld. Coolen studeert immers op kosten van een missiefonds en dat schept toch verplichtingen.

Ook lijkt het erop dat hij niet meer wachten kan om echt te gaan schrijven en daarom het gevoel heeft dat hij in Heeswijk zijn tijd verdoet. De hunkering om uiting te geven aan zijn verbeelding, om schrijver te worden en zelfs een groot schrijver, is sterker dan de vrees voor de maatschappelijke schande die het afbreken van een priesterstudie toen nog betekende. Zo lovend als hij in zijn jubileumtoespraak in de jaren dertig is, zo negatief beschrijft hij zijn Heeswijkse tijd vlak na zijn vertrek. Hij heeft zijn tijd meer met niets doen doorgebracht dan met studeren, schrijft hij even later aan zijn nieuwe vriend, de priesterstudent Lutkie: "Wat Latijn-kennis heb 'k van die school mee naar huis gebracht, meer niet." ${ }^{n 0} \mathrm{Er}$ zit misschien wat quasi-onverschilligheid in de toon, maar toch is het duidelijk dat Antoon Coolen het klein seminarie op dat moment niet de juiste plek voor zichzelf vindt.

\section{De schoolverlater en zijn begeleiders}

Antoon Coolen verlaat het gymnasium in Heeswijk op 23 mei $1913 .{ }^{61}$ In die tijd nadert het nieuwe huis van Ouwerling aan de Stationsstraat ${ }^{62}$ zijn voltooiing. Het is een grote vrijstaande villa in de archaïsche bouwstijl van architect Roffelsen uit Helmond. ${ }^{65}$ De naam wordt De Romeijn, vanwege de Romeinse helm die in de negentiende eeuw in de Peel is gevonden. Uit alles blijkt dat Coolen daar vaak geweest is. Het huis van de vrijgezel is een trefpunt van de intellectuelen uit de streek, meestal onderwijzers met literaire, politieke en sociale interesses. Er komen onder andere J.J.M. Heeren (1888-1967), onderwijzer in Beek en Donk en later stadsarchivaris van Helmond, en ook de al eerder genoemde onderwijzer, schrijver en onderwijsvakbondsman H.H.J. Maas (1877-1958). Deze laatste volgde een cursus voor de hoofdakte bij Ouwerling. Al in 1896 loopt hij hiervoor iedere zaterdag de ruim twintig kilometer van Venray door de Peel naar Deurne. Maas heeft in het jaar dat 
Coolen Heeswijk verlaat ( $\mathrm{r}_{9} \mathrm{r}_{3}$ ) net een boek over de schoolstrijd geschreven: Om de school, een roman uit de schoolstrijd. In het eerste decennium van de eeuw heeft hij Verstooteling (I907), Het goud van de Peel (r909) en Landelijk Eenvoud (r910) gepubliceerd. In al die boeken delft de kleine mens, de keuterboer, de veenarbeider het onderspit tegenover walgelijke pastoors en rijke machthebbers en magistraten. In Het goud van de Peel worden in de personages van een idealistische dorpsonderwijzer en een machtsbeluste pater portretten geschilderd van Ouwerling en Van den Elsen.

Heeren herinnert zich Coolen als jongen bij Ouwerling ontmoet te hebben.

"In De Romeyn heb ik Coolen voor het eerst ontmoet, kort nadat hij in de zomervakantie r9r4 [dit moet zijn mei r913, C. S.] het Heeswijkse gymnasium verlaten had. In die eerste tijd kwam de jonge Coolen heel veel bij Ouwerling en deze zag direct dat er iets bijzonders stak in de 17 -jarige jongeman. [...] In mijn herinnering leeft nog die avond waarop Ouwerling, Coolen en ik samen waren, toen ik, aan beiden het hypertrofische stukje 'Waar dacht je aan, mijn Lief' uit de roman Een Liefde van Jeanne Reyneke van Stuwe voorlas, wat Ouwerling mooi vond en Coolen, toen, óók. Vaak las Ouwerling aan Coolen voor, bijvoorbeeld uit Historische Landschappen van Hofdijk, of Conscience's Loteling of Een Speeldag van Streuvels (..) En ik weet dat, in de tijd dat Coolen ging schrijven, Ouwerling altijd tegen hem zei: 'Jongen, ge hebt 'es een goej stukske ${ }^{64}$ over'ne boer in de kermisbioscoop geschreven, schrijft toch over deze streek, over de boeren en peelwerkers en over onze mensen."m65

Coolen zal deze raad, zoals later blijkt, opvolgen. Hij zal ook steeds Ouwerling als zijn mentor opvoeren, een van de strenge soort: "Hij was geen zachtzinnig leermeester en volstrekt niet barmhartig in zijn critiek. ${ }^{n 66}$ De door Ouwerling geroemde Maas heeft veel minder, of nauwelijks invloed op Coolen. Zij hebben elkaar een keer ontmoet in De Romeijn, maar de sfeer waarin dat gebeurt is niet zo hartelijk. Vlak na de dood van Ouwerling in 1932 schrijft Maas op verzoek van Heeren hoe dat contact was.

"Het was in die dagen van Coolens [eerste boekpublicatie, C.S.] Opinies. Ik wist van zijn bestaan niets. Ouwerling had mij te logeren gevraagd. Na het eerste gesprek van de begroeting zei hij: 'Nu moet ik je vóór alles iets vertellen over vandaag; zo dadelijk krijgen we bezoek van een jongmensch, die jou wil zien ... Hij heeft jouw boeken gelezen en wil ook schrijver worden. Hij heet Coolen.' En al gauw was Coolen gearriveerd. Hij praatte nogal dweperig over Verstooteling, Landelijke Eenvoud, Het Goud van de Peel en Om de School. Vooral Het Goud van de Peel had hem - zoals hij herhaaldelijk verzekerde - de drang ingestort om ook letterkundig schrijver te gaan worden. Ik weet niet anders, of

59 Van Duinkerken, Antoon Coolen, 13.

60 KDC, inv. nr.101, brief Coolen aan Lutkie, 13 december 1914.

61 Van den Hurk, 'Antoon Coolen als Heeswijkse gymnasiast', 59.

62 Dit stuk van de Stationstraat is later herdoopt in de Romeijnstraat. Het huis staat er nog. Op 9 november 1997, de sterfdag van Coolen in het herdenkingsjaar van zijn 100ste geboortedag, is hier een borstbeeld van hem geplaatst.

Dezelfde architect die in 1922 het huis 'de Wieger' voor Wiegersma zal bouwen.

Coolen, 'Hoe ik er toe kwam', 37. 
de dag is toen heel goed verlopen. Maar nadien heb ik hem nooit meer ontmoet en correspondentie is er tusschen ons niet gevoerd. ${ }^{n 6 /}$

Coolen herinnert zich deze ontmoeting ook.

"Toen Maas daarna, ik meen met de trein uit Venlo, kwam, ontmoette ik in hem een welgekleed man met hoge boord, erg zwijgzaam en stil en van mij nam hij vanzelfsprekend weinig notitie. Maar ik zag erg tegen hem op, omdat hij boeken, moderne romans, had geschreven en uitgegeven, in die naturalistische stijl van toen. [...] Al hadden Maas en ik ten naaste bij dezelfde streek voor onze belangstelling, ik geloof niet, dat Maas van invloed op mijn visie is geweest, tenzij wat de armelijkheid en de achterlijkheid betreft. Maar ik zag toch een gemoedsleven en achtergronden, die Maas niet onderkende; bij Maas zit om zo te zeggen een ressentiment tegen zijn streek zelf." ${ }^{68}$ Hier kan wel sprake zijn van aanpassing van de eigen autobiografie. Coolen heeft er geen enkel belang bij om zich schatplichtig te maken aan Maas, gezien de lage status die deze schrijver heeft in de jaren vijftig als deze herinneringen worden genoteerd. Coolen beschouwt zich als een leerling van Streuvels. Maas was geen literator maar eerder een kroniekschrijver. Hij vond dat in een roman nauwkeurig de waarheid moest worden weergegeven. "Een boek, roman of novelle, moet werkelijke personen en werkelijke feiten weergeven: de schrijver moet van elke persoon (onder gefingeerde naam) de werkelijke naam en adres kunnen opgeven. Anders is het hele geschrift holle fantasterij, jammer van het verknoeide papier."69 Dit schreef hij in dezelfde tijd dat hij een boze brief schreef aan L.J. Rogier die zich in een rede positief over Coolen had uitgelaten:

"Ik vond het best, opperbest dat men de beschrijvingen van Coolen mooi, meesterlijk enz. vindt. Maar absoluut niet best, dat men ze beschouwt als een afspiegeling van de werkelijkheid betreffende het volk, de massa, de toestanden. Ze zijn onwaar. Voor de rest mogen ze mijnentwege mooi geheten worden .. Coolen heeft zelf ook, naar aanleiding van kritieken (niet van mij!) bekend, dat hij niet de werkelijkheid heeft beschreven. ${ }^{70}$

\section{Opinies}

Een eerste proeve van Coolens literaire kunnen laat niet lang op zich wachten. Ouwerling bemiddelt voor Coolen, zodat hij geplaatst kan worden als volontair bij drukkerij August Pellemans te Helmond, het bedrijf dat de krant van Ouwerling, De Zuidwillemsvaart, drukt. Al meteen mag hij af en toe ook een stukje voor de krant schrijven. Aanvankelijk schrijft hij onder het pseudoniem Willer ${ }^{n}$, maar al gauw onder zijn eigen naam, wat tamelijk ongewoon is voor krantenartikelen in die tijd. Wellicht herinnert Coolen zich nog de literaire diefstal in het toneelstuk De Paladijn dat hij het jaar daarvoor op het gymnasium las. Hij produceert opstellen en schetsen, nog niet helemaal vrij van de bravoure en de gekunsteldheid van de middelbare scholier. Hij leert hier echter toch al aardig het journalistieke vak en het werken met een deadline. Een keer als op Paaszaterdag blijkt dat er nog geen Paasartikel gereed is, zegt Ouwerling, die al met zijn hoed op gereed staat om te vertrekken, tegen Coolen: "Je hebt nog een half uur [...] Pak je potlood en schrijf maar zoiets van: Alleluia, blijde feesten! ... Bonjour!"'72

Het is een goede leerschool. Later, als Coolen zijn brieven uit De Romeijn en De Kempen als column in de zaterdagse Provinciale Noord-Brabantse en 's-Hertogenbossche 
Courant schrijft, is precies te zien wanneer hij gemotiveerd is of niet. Interessante beschouwingen worden gevolgd door stukjes over de lente, de regen of het paasfeest, die duidelijk op de 'automatische piloot' zijn geschreven.

Door het uitbreken van de Eerste Wereldoorlog in augustus 1914 ontstaat papierschaarste en is er op de drukkerij weinig te doen. Toen "heb ik voor eigen plezier en eerzucht eens een bundeltje pennevruchten gezet, die ook gedrukt zijn op een grote pers. ${ }^{.73}$ Het staat er wat terloops, maar het zetten van zo'n boekje is toch een hele klus voor een amateur. Het verklaart wel waarom Coolen zijn hele leven veel aandacht voor de vormgeving en typografie van zijn boeken heeft gehad. Het boekje heet Opinies en verschijnt in november 1914 bij de N.V. Aug. Pellemans te Helmond. Coolen heeft het nooit op een officiële lijst van zijn werken laten zetten en beschouwt het duidelijk als een jeugdwerk. ${ }^{74} \mathrm{De}$ bundel wordt ingeleid met een portret van de jeugdige schrijver en een zelfverzekerde inleiding die klinkt als een klok.

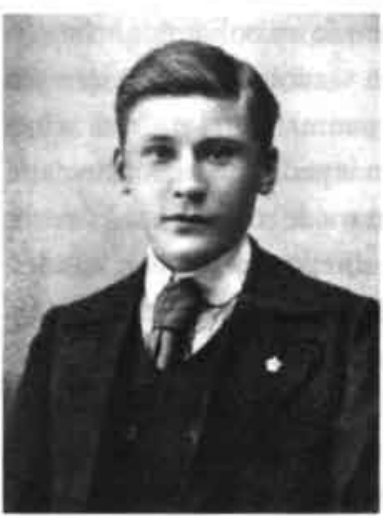

Antoon Coolen, 17 jaar, 1914.

"Een jonge man ben $i k$, middelmatig van gestalte en ' $k$ woon in 't Millioenen-paradijs Deurne. Onder de vele gebreken, waarmee ' $k$ behept ben, munten vooral uit: m'n brutaliteit, m'n gewoonte van nooit te liegen en, 't voornaamste van al, m'n trotschheid." Hij vindt een kolensjouwer die goed zijn werk doet belangrijker dan een rijke 'niksnutter', maar hij is geen socialist. Zijn stijl is af en toe rechtstreeks ontleend aan Multatuli, vooral in zijn herhalingen: "maar van eenvoudigen kom-af was ik", "maar trotsch was ik." Die trots is tot het hoogtepunt gestegen nu de artikeltjes die hij onder het pseudoniem Willer in De Zuid-Willemsvaart heeft geschreven, zijn gebundeld.

67 Brief van Maas aan Heeren zonder datum waarschijnlijk 1932 of 1933, geciteerd door de laatste in 'Ouwerling en Coolen', april 1957. Toen dit artikel gepubliceerd werd reageerde de inmiddels tachtigjarige Maas negatief. Hij vond het hele Brabantia-nummer vieierij. Hij constateerde dat de besturen van het Provinciaal Genootschap en Brabantia Nostra, waar Coolen zelf in zat, dit eerbetoon aan Coolen op touw hebben gezet. ledereen voelde zich verplicht om iets bij te dragen aan de huldiging': "een gedicht uit plicht gelukt niet licht." Hij gaf ook een nog negatievere schets van zijn ontmoeting uit 1914: "Ik herinner mij nog levendig, dat Ouwerling tegen mij zei: 'Dadelijk komt een jonge kaerel, een verwaande schreeuwer,'enz. En dat bleek ook. Hij deed net, alsof hij me om den hals wou gaan hangen. Van die kunsten was ik niet gediend." Stadsarchief Helmond, inv. nr. I, brief van Maas aan Heeren d.d. 25 april 1957.

Brief van Coolen aan Heeren, geciteerd door de laatste in 'Ouwerling en Coolen'.

69 Stadsarchief Helmond, inv, nr.1, brief van Maas aan Heeren, 11 juni 1953.

70 Van den Dam en Lucassen, H.J.J. Maos, 47.

7 Voor de keuze van het pseudoniem Willer zijn verschillende verklaringen mogelijk. Het kan een toespeling zijn op het begrip 'volontair' in samenhang met zijn wil om te schrijven. Het zou echter ook een hommage aan Ouwerling kunnen zijn voor wie de wil een noodzakelijke voorwaarde voor de vooruitgang is.

72 Bekman, 'Antoon Coolen als journalist', 635.

73 Coolen, 'Hoe ik er toe kwam', 1932.

74 In de bibliografie van Coolen door T. Renes, die is bijgewerkt tot 17 april 1957 en die in overleg met Coolen tot stand is gekomen, is Opinies niet opgenomen. 
wijd-spannend zich welfde over de vlakke landschappen heen." ${ }^{\text {BO }}$

Ook de manier waarop hij het 'buurten' van de mensen weergeeft getuigt van zijn scherpe waarneming. In zo'n gesprek komt van alles aan de orde, men springt van de hak op de tak en blijft sommige zinnen als maar herhalen. Bijvoorbeeld als een boer het heeft over de varkens die gestorven zijn aan de vlekziekte: "En 't waore schôn denger..., mardiesche schôn denger, dè zè' $k$ oe, dè 't schôn denger warre."Bt

In het slotwoord van zijn bundel steekt de jonge schrijver een sigaar op (de seminarieachtergrond verloochent zich niet), luistert op zijn kamertje naar de huilende storm en mijmert over zijn toekomstige lezers. Sommigen zullen de schouders ophalen, anderen zullen denken: "Dat wordt iets." Hij wil nu weer alleen gelaten worden.

"Want een geestesstorm van grootsche gedachten woedt in m'n hoofd en m'n hart is vol van hooge passies en ik voel, hoe er mijn heele lijf door iets opkropt omhoog, wát dat is, dat weet ik niet, maar 't is iets heel heerlijks en 't moet er noodzakelijk uit ... en na geregeld denken geleidelijk aan worden neergeschreven op groote vellen papier ... en van die vellen papier zal ik boeken maken ... vele en mooie ... later ... [...] En hiermee, critiek, m'n eerste boek!" ${ }^{\text {"82 }}$ 
80 Coolen, Opinies, 57.

BI Een van de eerste kritieken van Van Duinkerken op Coolen betrof deze stijlfiguur. Hij noemde deze een repeterende breuk. Coolen verdedigt zich dan door te stellen dat de mensen in Oostbrabant anders praten dan rond Bergen op Zoom waar Van Duinkerken vandaan kwam.

82 Coolen, Opinies, 88. Hieruit blijkt wel hoe goed hij Nieuw Holland van Van Deyssel heeft gelezen: "Wij zijn menschen, begrijpt gij dat, suffe broekjes van de vorige generatie, wij zijn menschen met groote, diepe heftige aandoeningen; wij schrijven onze zielen op vellen papier, ze worden gedrukt, ze komen uit, - en op allerlei stille kamers in nauwe straten, die gij niet weet, worden wij gelezen, en overal in de stad en het land ontstaan bewonderingen, en leven menschen, die aandachtig beginnen te lezen aan hun tafels, met een emstig gezicht." 



\section{Aankomend journalist}

"Ik vind zoo weinig sympathieks en zoo weinig om innig lief te hebben in onzen Katholieke Godsdienst."

1914 - 1919

\section{Een kleinerende kritiek}

Op I december I9I4 verschijnt een kritiek op Opinies in de landelijke katholieke krant $D e$ Maasbode, 'de conservatieve Rotterdamse tegenhanger van De Tijd. Het is ongelofelijk zoals de anonieme criticus tekeer gaat tegen een jonge debutant. Wanneer hij "het 17-jarig jongmensch Antoon F. Coolen, formeerder en schrijver van Opinies eens bij zich op het bureau kon krijgen, zou hij hem ongeveer aldus toespreken: 'Antoon, Toontje, kom eens hier, doe je handen eens uit je broekzakken, zet je petje eens af, jongen, ga dan eens op dat lage stoeltje zitten en luister eens aandachtig."'

In die stijl gaat het een hele kolom van de krant, van boven tot beneden, door: hij mag geen brutaal gezicht trekken, wat is Toontje toch een onbesuisd jochie; hij heet nu eens een haantje, dan weer een pauw zonder veren. De verhalen zijn, volgens de criticus, als flessen met misleidende opschriften: Cicero, Handelsbrieven, Etiquette, Buffalo Bill. Men zou de meest kittelende Amerikaanse mixtures verwachten, maar er komt niets anders uit dan verdunde karnemelk. Coolens kritiek op de critici heeft de recensent kennelijk het meest geërgerd: "Zeg Antoon, waarom heb je dat nu gedaan vent, - zoo'n critiek op critici te schrijven?" Coolen mag nog blij zijn dat niet een andere criticus, die niet zo meelijdend is, eens flink zou rondtrappen in Opinies, want dan zouden de letters terugspringen naar hun oorsprong: "de O naar de Onnoozelheid, de P naar de Pedanterie, de I naar de Impotentie, de N naar de Nonsens, nog eens I naar de Ikkigheid, de E naar den eigenwaan en de S naar de Stijlloosheid." De recensent zegt dat hij niet boos is op de jonge schrijver; hij wil hem alleen maar waarschuwen voor de gevaren van hoogmoed en zelfoverschatting. Coolen moet trouwens niet denken dat hij het boek helemaal gelezen heeft; hij laat zich niet volstoppen met banaliteiten en heeft er trouwens niet het geduld en het digestievermogen voor. Hij eindigt aldus:

"nu, verdwijn en schrijf niet meer!

Heusch, Antoon, schrijf niet meer!

Exeunt comediae personae!"

Zo'n kritiek verraadt natuurlijk ook veel over de recensent. Hij hoort zichzelf erg graag en hanteert een literatuurderige stijl, parodistisch en vol bombastische vergelijkingen. Hij heeft zich kennelijk geërgerd aan de combinatie van de aanmatigende toon én de vele ver- 
wijzingen naar niet-katholieke schrijvers en denkers. Dan nog blijft het opvallend dat er zoveel woorden aan het debuut van een zeventienjarige worden besteed. Trouwens, hoe weet hij dat de auteur zeventien jaar is? De recensent is kennelijk door iemand die Coolen kent ingelicht, met het doel hem een toontje lager te laten zingen. De kritiek past binnen het beleid van de krant; De Maasbode strijdt tegen alles wat naar modernisme binnen het katholicisme riekt. Jong talent dat zich hier niet naar voegt, wordt op deze botte manier de grond in geboord en bang gemaakt. Een van de meest vernederende zinnetjes uit het stuk is daarop gericht: "Ik ben heus niet boos op je, ik wil je alleen maar wijzen op de gevaren, waaraan je jezelf blootstelt. Want je schijnt bevangen door den waan, dat je in de zoetste veiligheid verkeert."

\section{Een raadsman biedt zich aan: Wouter Lutkie}

De recensie wordt opgemerkt door de 27-jarige priesterstudent te Haaren, Wouter Lutkie. Deze schrijft op Sinterklaasavond, 5 december 1914, een enthousiaste brief aan de jonge debutant. Hij vindt het stuk in de Maasbode een quasi-kritiek, die laag en dom is. Hij raadt Coolen aan om Léon Bloy en Ernest Hello te lezen en biedt zich tevens aan als begeleider. Echter, ook hij ziet de gevaren, waar de criticus van De Maasbode over schreef. "Zou ik U mogen helpen bij de verdere ontwikkeling van Uw talent en in het vermijden van mogelijke fouten en verdolingen in de toekomst? ${ }^{\text {22 }}$ Antoon Coolen is blij met de belangstelling van de priesterstudent en antwoordt niet zonder fierheid: "Ik ken U niet, maar uit Uw schrijven is $\mathrm{U}$ mij gebleken een erg sympathiek en tevens een zonder eenige dweperij kalm-verstandig denkend man. ${ }^{35} \mathrm{Hij}$ kent de schrijvers Bloy en Hello niet die Wouter Lutkie noemt, maar schrijft uitgebreid wat hij zo al leest. Als Lutkie het boekje Opinies wil lezen, moet hij ' $t$ zelf maar bij Pellemans in Helmond bestellen. ${ }^{4}$

Coolen is het met Lutkie eens dat het een quasi-kritiek was, want van de honderd en zes regels zijn de meeste besteed aan het belachelijk maken van zijn persoon en met karikaturen geven krijgt men geen gewonnen spel. Een criticus moet aandachtig lezen en de indrukken die hij heeft opgedaan zo goed mogelijk weergeven. Hij stuurt een knipsel uit een plaatselijk blad mee, waarin een zekere Observer een "heel raak stukje" over zijn boek heeft. Dit stukje is niet gevonden, maar het is vrijwel zeker Ouwerling geweest, die reclame gemaakt heeft voor zijn pupil.

\section{PINIES \\ Door}

ANTOON F. COOLEN.
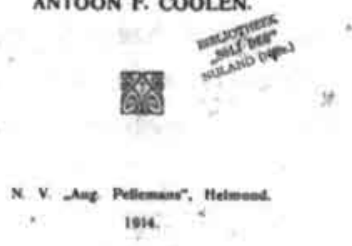

Titelpagina van Opinies met opdracht aan Ouwerling en stempel van Lutkie's huisbibliotheek.

(origineel, Lex van de Haterd, Amersfoort) 
Wouter Lutkie zal acht jaar lang de vertrouwensman van de jonge journalist Coolen zijn. In de ogen van de dogmatische en orthodoxe Lutkie zijn er voor iemand die de pen hanteert inderdaad vele mogelijkheden tot "fouten en verdolingen." De katholieke wereld in Europa is in die tijd tot op het bot verdeeld. Lutkie heeft hierin partij gekozen en zoekt jong talent om mee te strijden aan zijn zijde. Deze Sturm und Drang-periode werpt een bijzonder licht op de ontwikkeling van het schrijverschap, de geloofsbeleving en de levensvisie van Antoon Coolen. Voor een goed begrip volgt hier eerst een schets van de spanningen in het katholicisme en de voornaamste protagonisten.

\section{Integralisme en modernisme}

Het is geen toeval dat juist in De Maasbode die negatieve kritiek verschijnt. Dit conservatieve ochtendblad is een concurrent van De Tijd en beducht voor elke vorm van modernisme. De strijd tussen modernisme en integralisme is ontstaan in het begin van de twintigste eeuw en is in feite een conflict tussen vooruitstrevende en behoudende katholieken. Tussen I9Io en I9I4 escaleert de zaak zo hevig dat de katholieke wereld verscheurd dreigt te raken en bijna in sekten uiteen valt.

De modernisten willen de kerk hervormen en zeker niet afbreken. Bij hun streven worden zij volgens Rogier bezield door een "apostolische deernis met de schare." $\mathrm{Zij}$ willen de kerk verzoenen met de moderne levensstromingen. Binnen de modernisten vindt men katholieken van divers pluimage: sommigen zijn artiesten die ervan houden de burgers te choqueren en die neerkijken op het geloof van de eenvoudige, anderen koesteren een "hooghartig, liefdeloos, soms Nietzsche-achtig nonconformisme" en weer anderen zoeken naar een synthese tussen christendom en socialisme. ${ }^{5}$ In 1907 veroordeelt Paus Pius X het modernisme in de encycliek Pascendi. Hij gebruikt hierin de termen integralisme en integraal katholicisme. De paus creëert hiermee een tovenaarsleerling die nog maar moeilijk in bedwang is te houden. Integralisme wordt de naam voor een grote stroming van "ketterjagers en samenzweerders" die volledig doorslaat naar een inktzwarte reactie. In Nederland hebben de modernisten maar weinig aanhang, maar de integralisten des te meer. Een van de aanvoerders is de hoofdredacteur van De Maasbode, de priester M.A. Thompsom. Deze werpt zich "bij gebrek aan echte boosdoeners [...] op iedereen die in zijn ogen ook maar de geringste afwijking in de rechtzinnigheid vertoonde," waardoor krantenlezend Nederland in twee kampen wordt verdeeld. Men leest De Tijd of men leest De Maasbode. ${ }^{6}$ Ook de geestelijkheid van Nederland is hierdoor verdeeld; de priester-hoofdredacteur van De Tijd, P.J.H. Geurts, heeft er zelfs in I $9 \mathrm{Ir}$ het veld voor moeten ruimen.

In het buitenland zijn de Fransman Léon Bloy en de Oostenrijker Richard Kralik bekende voormannen van het integralisme. $\mathrm{Zij}$ worden weldra warm geprezen "door Nederlandse integralisten, fascisten en andere 'totalitair'-denkenden als Vincent Cleerdin,

2 KDC, inv. nr. 101, brief Lutkie aan Coolen, 5 december 1914.

3 KDC, inv. nr. 101, brief Coolen aan Lutkie, 8 december 1914.

4 Dat blijkt hij gedaan te hebben. Het origineel, met stempel van Soli Deo Nuland, is rijkelijk voorzien van potloodstrepen. Collectie Lex van de Haterd, Amersfoort.

5 Rogier, Katholieke Herleving, 432.

6 Schrama, Dagblad De Tijd, 173. 
Wouter Lutkie, H. van Haastert, Gerard Bruning, Pieter van der Meer de Walcheren en anderen.". De meeste van deze personen zullen een rol spelen in het leven van Antoon Coolen. Vincent Cleerdin (1888-1946) heeft in datzelfde jaar I9I4 juist een aantal artikelen gebundeld, waarin hij zijn afkeer van realisme betuigt. Bij hem is niet Zola het slachtoffer, maar Ibsen met zijn drama Bouwmeester Solness en Hauptmann, de schrijver van het sociaal-realistische toneelstuk De wevers. Cleerdin pleit voor het idealisme. Hij ziet het realisme als een afdaling, als het brengen van de kunst naar het volk. Nee, het volk moet gebracht worden naar de kunst. "Het volk, dat met realisme is gevoed, om het voor idealisme vatbaar te maken, wordt als het kind, dat men in de jeugd zoet wil houden door sterken drank, en dat later altoos meer alcohol verzwelgen zal. ${ }^{8}$ Cleerdin zal samen met Lutkie een boek over Kralik schrijven en wordt in het interbellum bekend als publicist over Brabantse dorpen en sagen. Coolen zal hem later nog tegenkomen als Cleerdin voorzitter is van het Provinciaal Genootschap en ook als griffier van Provinciale Staten van Noord-Brabant.

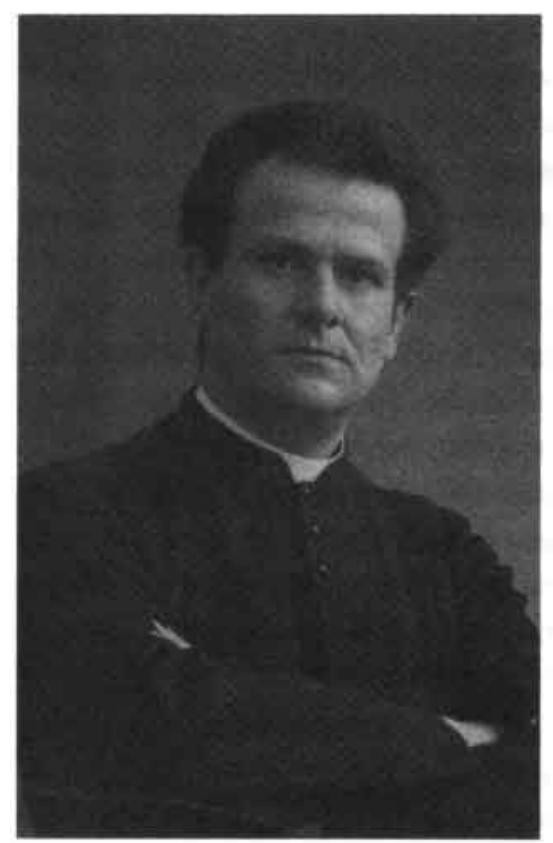

portret van Wouter Lutkie, 1919

Voorlopig echter speelt Lutkie een hoofdrol in Coolens leven. Wouter Lutkie (1887-1968), geboren in 's-Hertogenbosch, heeft niet de normale weg gevolgd naar het groot seminarie. Tot zijn vijfentwintigste jaar was hij op verschillende manieren maatschappelijk actief. Na een aantal jaren aan de middelbare Handelsschool in Nijmegen, werkte hij als verkoper bij een bandenfabriek en later in de traanhandel. In zijn vrije tijd bemoeide hij zich intensief met drankbestrijding, het oprichten van patronaten en het organiseren van sociale cursussen. Hij behaalde het diploma Esperanto, deed aan apologie en was zijdelings betrokken bij de oprichting van de KAB in Den Bosch. ${ }^{9}$ Later zal hij op deze 'linkse' activiteiten met enige gêne terugzien en noemt hij die "zijn democratische periode. ${ }^{10}$ In I 912 gaat hij als late roeping naar het groot seminarie van Haaren. Alles wijst er echter op dat hij zich in zijn studie eerder wil voorbereiden op een meer politiekgetinte toekomst dan op een zuiver kerkelijke functie.

Gemotiveerd door de lectuur van kritische Franse katholieken wil hij op twee fronten strijden. In de lectuur van Bloy vindt hij zijn inspiratie voor de strijd tegen het verderfelijke modernisme en Ernest Hello (1828-1885) geeft hem argumenten voor zijn aanval op de gezapigheid, de burgerlijkheid en de middelmatigheid van de Kerk, de geestelijkheid en de gelovigen. Lutkie zal pleiten voor 'Magnanimiteit', voor zielegrootheid en daarmee tegen 'T'homme médiocre', waarvan Hello zegt dat het de kleinzielige is die meejankt met de wolven in het bos. "Kleinzieligheid draagt vele namen. Schrielheid, benepenheid, berekendheid, philisterij, burgerlijkheid, schoolvorserij." "Volgens Hello is de mens van de grijze 
middelmaat zelfs bang van het katholicisme en zijn heiligen en grote mannen. 'Lhomme médiocre' vindt het katholicisme een overdreven godsdienst en houdt veel meer van het protestantisme dat veel gematigder is. Deze mens is lauw: "il n'admire rien avec chaleur. [...] il aimera mieux ses ennemis s'ils sont froids, que ses amis s'ils sont chauds. Ce qu'il déteste par dessus tout, c'est la chaleur."12 Ook Lutkie voelt veel meer voor 'l'homme supérieur', zoals al gauw zal blijken uit zijn mateloze bewondering voor Mussolini.

Door deze combinatie van denkbeelden is het te begrijpen dat Lutkie nooit in de hiërarchie van de Kerk heeft gepast. Om dezelfde reden zal hij later ook niet toetreden tot de kleinburgerlijke NSB of fascistische organisaties als Zwart Front, ondanks het feit dat hij het gedachtegoed van vooral deze laatste beweging innig heeft omarmd. Dit heeft hem gered van berechting na de Tweede Wereldoorlog, want voor velen was hij, zoals Van Duinkerken hem noemde, "een priester die hartstochtelijk fascist was. ${ }^{13}$

Een van Lutkie's grootste voorbeelden is de Franse schrijver Bloy (1846-19I7), een hartstochtelijk modernistenjager die echter even goed tekeer ging tegen het gezag in de kerk. Zo noemde hij Paus Benedictus XV een aartsketter en Paus Leo XIII een verrader. Hij liet de opvolger van Pius IX [hij noemde de naam Leo XIII niet, C.S.] tegen God zeggen: "Ik heb als herder de schapen verraden om de honden met de wolven te verzoenen; ik heb (met Rerum Novarum) het canaille aangemoedigd; ik heb mij geheel gegeven aan hen, die Christus mishandelen, de slachtoffers, die mij 'vader' noemden, vergeefs laten roepen en gezwegen, als de sterken de zwakken vermoordden; ik heb zoveel als ik kon, het geloof vernietigd." ${ }^{\text {14 }}$ Daarnaast moest Bloy niets hebben van democratie en sociale voorzieningen.

Léon Bloy is tijdens de Eerste Wereldoorlog zeer geliefd bij jonge katholieken die verandering willen in de Kerk. Niet alleen Wouter Lutkie bewondert hem, maar ook de in Parijs wonende journalist Pieter van der Meer de Walcheren (I880-1970) die we nog zullen leren kennen als toekomstig voorman van de jonge katholieke schrijvers in Nederland. In zijn dagboek noteert Van der Meer dat sommige van zijn vrienden niet begrijpen wat hij in Bloy ziet. Zij vinden dat Bloy er ideeën op na houdt van acht eeuwen oud, die in de duisterste en meest achterlijke tijden van de Middeleeuwen thuishoren. Hij schreeuwt en brult tegen iedereen en dan verbaast hij zich nog dat men hem doodzwijgt. "Hetgeen de enige houding is tegenover een wild beest als Bloy. ${ }^{15}$ Toch wordt Van der Meer onweerstaanbaar tot hem aangetrokken. Bloy is een man naar zijn hart.

7 Schrama, Dagblad De Tijd, 440.

8 Cleerdin, Omtrekken en Figuren, 45.

9 Joosten, Katholieken en fascisme, 23.

10 Schaik, Dr. Hendrik Moller, 157.

11 Lutkie, Onze rol spelen, 25.

12 Hello, L'Homme, la vie, la science, lart, 59.

13 Schrama, Dagblod De Tijd, 321.

I4 Bloy, Les dernièrres colonnes de l'Eglise, 56-57. "A I'heure oủ j'écris, le successeur de Pie IX est sur le point de mourir. Peut-être est-il déjà mort et devant Dieu, face à face. Que va-t-il dire au pasteur qui lui redemandera son troupeau?"

De in de tekst geciteerde vertaling is uit: Rogier, Katholieke Herleving, 439.

15 Van der Meer de Walcheren, Mijn Dagboek 1907 - 1911, 51. 
"Hij durft de uitersten in het aangezicht te zien, zijn wezen is liefde, en zijn stem klinkt, klinkt luider en schoner dan al dat weeë gefluister van de algemeen bekende en veel gelezen schrijvers die den smaak van het publiek vleien, wèl soepel en tact-vol zijn en nimmer den last kenden in hun pover brein van een hoge, buitensporige gedachte! ${ }^{16}$ Ook Van der Meer haat de mediocriteit. Al gauw bezoekt hij Bloy op de Butte Montmartre, de bohémienbuurt vlak achter de nieuwe Sacré Coeur, het centrum van schilders, journalisten en dichters. Van der Meer ontmoet daar onder andere Picasso, de Hollandse schilder Kees van Dongen en de anarchist Alexander Cohen. Hij komt via bemiddeling door Bloy in contact met een katholiek priester. Deze bereidt hem voor op zijn doop, die plaatsvindt op 24 februari 1911 . Bloy fungeert als peetvader.

Pieter van der Meer de Walcheren deelt met Bloy de afschuw van de bourgeois in al zijn gedaanten. Van der Meer heeft evenals Bloy een zwak voor de armen; hij kan de tegenstelling met de rijken niet verdragen. Hij is mét de armen tegen de rijken, schrijft hij. Hij is zelfs even anarchist en socialist geweest, maar is daar vlug van genezen. Al gauw, schrijft hij in zijn dagboek, merkt hij dat het socialisme wel de stoffelijke belangen van de misdeelde kan behartigen, maar niet kan voldoen aan de verlangens van de ziel en van de geest. "Bovendien kweekt het socialisme een bizonder onaangenaam soort van halfweters, verwaande warhoofden die over de geschiedenis, over het ontstaan der werelden, over sociologie, over kunst en godsdienst allertreurigste en meest oppervlakkige gemeenplaatsen te berde brengen als waren het eeuwige waarheden." ${ }^{17} \mathrm{Hij}$ bekritiseert verder dat ze populaire wetenschappelijke boekjes verslinden en bluffen met theorieën en hypothesen, waar ze zelf niets van begrijpen.

Bloy is een radicale, absolutistische schrijver. Zijn motto bij zijn dagboeken is: "Le temps est un chien qui ne mord que les pauvres." Zijn liefde voor de armen (een van zijn boeken heet Le Sang du pauvre) gaat zo ver dat hij bij de grote brand bij de Bazar de Charité op 4 mei I897 met nauwelijks onderdrukte vreugde in zijn dagboek schrijft dat een groot aantal mooie dames is verkoold in minder dan een uur tijd. Aan een vriend schrijft hij dat er eindelijk een begin van gerechtigheid is, en dat uitgerekend in een bazar met de naam Charité. Er is slechts een minpunt, het aantal slachtoffers: "Le petit nombre des victimes, il est vrai, limitait ma joie. ${ }^{18}$ In de brief, waarin hij zich verder opzweept, ziet hij de brand als een soort reiniging.

Hij beschouwt Napoleon als een grote held, die ver boven alle pausen was verheven. In zijn boek LAme de Napoléon (I9I2) geeft hij blijk van een fel nationalisme en anti-Engelse gezindheid. Daarvoor, in de jaren negentig van de vorige eeuw, was hij anti Dreyfusard en natuurlijk ook anti Zola. Een collega die hem tot andere gedachten probeert over te halen herinnert hij eraan "que la place d'un artiste n'est pas dans les ordures." ${ }^{19}$ Deze verwijzing naar de vuilnishoop waar de varkens rondwroeten, zal Lutkie ook hanteren als Coolen meldt dat hij graag Zola leest.

Bloy heeft van Hello de eschatologische visie overgenomen. Alles is gericht op het lot van de mens na de dood; het heil is alleen te bereiken door te leven volgens een onverzoenlijk katholicisme.

Bloy is ook gevoelig voor het mythische in de godsdienst. Zo hecht hij grote waarde aan de 'menaces', de bedreigingen, voor de toekomst van het zondige Frankrijk die Maria aan een eenvoudig koeienhoedstertje in La Salette heeft geopenbaard. Hoezeer deze openba- 
ring de katholieken van Coolens generatie bezighoudt blijkt uit het feit dat nog in I94I Van Duinkerken vier afleveringen van zijn literaire rubriek in De Tijd wijdt aan het boek Celle qui pleure dat Bloy over La Salette schreef.

Bloy's radicale oplossingen, gebaseerd op een mythisch vage visie op de maatschappij en de geschiedenis, gepropageerd door personen met een sterk charisma, wijzen als het ware vooruit naar het latere fascisme van Mussolini. Voor jonge katholieken die verandering willen is er veel aantrekkelijks in de publicaties van deze man. Deze felle manier van leven en denken met zijn afschuw van de lauwe en de middelmatige en gekoppeld aan de angst voor het goddeloze bij de 'socialen' en de communisten, zal later bij vele katholieken leiden tot een keuze voor rechts-extreme stromingen. Wouter Lutkie is een van hen. Léon Bloy, die in 1917 overlijdt, is deze keuze bespaard gebleven. Pieter van der Meer de Walcheren schampt langs de rand. Hij blijft in zijn denken tweeslachtig. Zijn vriend Helman heeft opgemerkt dat Van der Meer nog tijdens de Tweede Wereldoorlog onderscheid maakt tussen goed en slecht fascisme, ${ }^{20}$ een bewijs dat hij gelooft in de grondbeginselen van een fascistische maatschappijvorm.

\section{Ernest Hello: richtlijnen voor een journalist}

Het is deze strijd tussen integralisten en modernisten in de kerk die Wouter Lutkie ertoe drijt om zijn begeleiding op te dringen aan een debuterende leerling-journalist en schrijver in de dop. Het is hem natuurlijk niet ontgaan dat er in het bundeltje Opinies gevaarlijke tekenen van modernisme te bespeuren zijn. Coolen schrijft hierin dat hijgeen onderscheid wil maken tussen gefortuneerde en fortuinloze mensen en dat hij een kolensjouwer die zijn werk goed doet hoger acht dan een rijke nietsnut. Hij vindt socialisten dikwijls gekken, maar als de mensen hem zo willen noemen moeten ze dat maar zelf weten. Hij, Coolen, neemt de zaken zoals ze zijn: een fabrikant die zorgt voor de bloei van de nijverheid en de werkgelegenheid vindt hij ook een verdienstelijk persoon, schrijft hij in de inleiding. Kortom, hij is niet voor de klassenstrijd, maar wel voor verbetering van de sociale voorzieningen. In een artikel over schuld maken, waarbij hij bij Multatuli's Vorstenschool aanhaakt, distantieert hij zich nog verder van de socialisten. Deze praten over 'uitzuigen' waar het helemaal niet te pas komt. De winkelierster en huismoeder die niet rond kan komen, terwijl er zoveel schuldmakers in het dorp goede sier maken van het geld dat zij te goed heeft, is slachtoffer van "onmenschelijke afpersing" en "hemeltergende uitzuigerij." Het is duidelijk dat hij zich ergert aan luiheid en profiteurs, maar ook bezorgd is over het lot van de armen. Van een socialistische maatschappijvisie is echter geen sprake. De kritiek van Lutkie richt zich dan ook meer op de toon van de jonge schrijver en het feit dat hij namen noemt van schrijvers en denkers uit het vijandelijke kamp.

16 Van der Meer de Walcheren, Mijn Dagboek 1907 - 1911, 126.

17 Van der Meer de Walcheren, Mijn Dagboek 1907 - 1911, 42.

18 Bloy, Journol 1896 - 1899, aantekening 5 mei 1897 en brief van 9 mei: "A mon ami Andrée R".

19 Bloy, Journal 1896 - 1899, aantekening 24 februari 1898.

20 Helman, Mijn vriend Pieter, 214.

21 Coolen, Opinies, 56. 
Het is zeer waarschijnlijk dat Lutkie het met de inhoud van de kleinerende kritiek in De Maasbode eens is geweest, maar, anders dan de recensent, heeft hij het schrijverstalent wel opgemerkt. Antoon Coolen moet doorgaan met schrijven, maar dan wel over zaken die Lutkie belangrijk vindt. In de stukjes over de rol van de kritiek, ziet hij juist een aanknopingspunt. Zijn grote Franse voorbeelden Hello en Bloy hebben veel geschreven over de rol van journalisten, kunstenaars en de pers. Als de jonge Coolen daar kennis van neemt kan hij beter beslagen ten ijs komen.

Nog in dezelfde maand december 1914, waarin Lutkie voor het eerst aan Coolen schrijft, wordt het contact verstevigd. Lutkie stuurt hem Hello's Le Siècle. Les Hommes et les Idées. Antoon Coolen is meteen enthousiast. Hij denkt er zelfs over om er stukjes uit te vertalen voor de krant. Het illustreert hoe groot de Franse invloed op de katholieken in die tijd is. Het katholieke leven en de katholieke vroomheid dragen, met een korte onderbreking, al eeuwenlang een Frans cachet. "Tal van Nederlandse gebedenboeken uit die tijd zijn vertalingen uit het Frans, tot in het begin van de twintigste eeuw toe de enige moderne taal, die op alle seminaries werd onderwezen," schrijft Rogier. ${ }^{22}$

Ernest Hello was een voorloper van Bloy. Deze zoon van een hoge Franse magistraat leefde op het voorvaderlijk erfgoed in Lorient in Bretagne. Na enkele jaren rechten studeerde hij theologie en filosofie. Hij had een onoverwinnelijke drang naar een allesomvattende katholieke waarheid. Hij wilde het hele leven, de mens, de wetenschap en de kunst in een katholiek kader plaatsen. Hij ergerde zich aan de suikerzoete Kitsch-devotie en de bijbehorende etiquetteboekjes voor religieus-correct gedrag. "Ces affreux petits livres de piété" noemde hij volgens Rogier "deze bundelingen van zoetelijke vroomheid, vervat in de clichés van een valse retoriek." ${ }^{n 3}$ Rogier constateerde deze ontwikkeling ook in Nederland. Hier kwam een grote verbrokkeling in congregaties voor, waarbij de MoederOverste alleen verantwoordelijkheid hoefde af te leggen aan de pastoor. Er ontstond een situatie van geestelijke inteelt waardoor leidinggevende personen zonder theologische kennis of zielkundig inzicht hun gang konden gaan en die "op de wordende congregaties al te vaak voor een lengte van jaren een stempel van starheid en bloedarme vlakke burgerlijkheid zette, de lang als nonnenvroomheid beruchte cultus van de Kitsch in het devote leven." 24

Het ergste vond Hello nog de onwetendheid van de moderne mens in religieus opzicht. Hij constateerde dat ieder ontwikkeld mens zich schaamt als hij moet bekennen bepaalde feiten uit de geschiedenis niet te weten, maar dezelfde persoon kleurt niet als hij betrapt wordt op een onwetendheid over het Christendom. Hij is er eerder trots op om hier niets van te weten. Het gaat er om het nieuws van alle dag bij te houden: "En revanche, il ne tient pas du tout à connaître la Verité, ${ }^{25}$ Hello trok hier de conclusie uit dat er een ontzaglijke plicht, "un immense devoir," op de schouders van journalisten en critici rust. Zij worden het meest gelezen, zij oefenen de grootste invloed uit op het gros van de lezers die immers krantenlezers zijn.

Hello werkt deze gedachten verder uit in een aantal artikelen, die tien jaar na zijn dood gebundeld zijn in het boek Le siècle. Les hommes et les idées. Ze gaan over filosofie, kunst, politiek, literatuur, wetenschap en de menselijke verhoudingen in de nieuwe tijd. Het boek is verschenen in 1895 , toen de Dreyfus-affaire Frankrijk verdeeld hield. De schrijver van het voorwoord, Henri Laserre, verwijst daarnaar als hij zegt dat de mensen honger en dorst 
hebben naar rechtvaardigheid en waarheid, naar liefdadigheid en schittering in die trieste tijd van ongelijkheid, leugen, haat en vulgariteit. Antoon Coolen leent dit boek van Lutkie. In zijn artikelen over de rol van de pers in de Eerste Wereldoorlog die al gauw in De Zuidwillemsvaart zullen verschijnen, zal Coolen laten blijken dat hij de hoofdstukken over de rol van de pers en de journalist goed gelezen heeft.

Hello constateert dat de pers in de negentiende eeuw een enorme invloed heeft gekre. gen. In het hoofdstuk 'Les Journaux' schrijft Hello dat vroeger slechts weinig mensen lazen, maar dat degenen die lazen de teksten echt bestudeerden. In de negentiende eeuw lezen veel mensen, maar zij doen het slechts om feiten op te doen; men wil op de hoogte blijven en weten wat er gebeurt. In die zin heeft de krant het boek verdrongen. De krant is ook niet zo afstandelijk als een boek. De krant is snel, heeft een hoge frequentie, de krant heeft voeten en vleugels en dringt binnen in de huizen, de krant wordt een persoonlijk vriend van elke dag. Omdat ook iedereen er in kan schrijven vervaagt de grens tussen toeschouwer en acteur. Iedereen heeft een actieve rol en moet zich uitspreken. Hello spreekt van een "devoir immense et sacrén ${ }^{26}$ van publiek, journalisten en krant. Iedere intelligente persoon is een soldaat in de grote slag om de moraal op het slagveld van de pers; onverschilligheid is niet toegestaan en ook niet mogelijk. In het hoofdstuk 'La Presse' beschrijft hij hoe het leven en de dood zonder plichtplegingen ons huis zijn binnengekomen via een drukwerk. De pers is ons geestelijk voedsel geworden. Zoals het brood dat is voor ons lichaam, is de pers het voor de geest en de ziel. "La presse nourrit le monde." ${ }^{\text {"27 }}$ Ook hier weer wijst hij op de "immense devoir" die de pers voor alle mensen schept. Deze simpele maar ontzaglijke plicht luidt: het leven doen toekomen aan andere mensen.

Over de schrijver Zola oordeelt Hello negatief in het hoofdstuk 'Le mouvement de l'art'. Zola wordt, in tegenstelling tot de door hem vereerde Victor Hugo, door geen enkele visie gekweld. "Il ne cherche ni l'idéal, ni lui-même. Il ne peint que ce qu'il regarde." ${ }^{28}$ In het naturalisme van Zola wil de natuur het rijk alleen hebben; het is de realiteit en de waarheid. De personen van Zola kom je niet op straat tegen, zoals die van Hugo en Balzac, je moet ze zoeken in hun schuilhoeken. De suggestieve vergelijking met ongedierte en zaken die het daglicht niet kunnen verdragen is gemaakt.

\section{De kennismaking}

Binnen twee weken na de eerste brief, op 17 december I914, bezoekt Coolen Lutkie op het grootseminarie te Haaren. Lutkie maakt een aantekening van dit bezoek: "Gisteren bezoek van Antoon Coolen. Hij praat niet zoo als hij schrijft. Daar zijn nog twee menschen in hem." Lutkie vindt dat hij nog teveel de "lummelachtige modernen" nabootst. 
"Hij schrijft omdat hij moet [...] Ja, als hii zoo praatte - maar hij schrijft toch alleen maar zoo! [...]' $t$ Is een heel naief jongske en bescheiden en stil, in de stilte van een energieke vastberadenheid, [...] Ouwerling is hem alles: zijn meester, opvoeder, leider, beschermer, opwekker en vriend [...] De kapelaan, zijn biechtvader, had met heel goede bedoelingen, langs zijn ouders getracht, hem van het schrijven af te houwen [...] en Ouwerling won het natuurlijk van de kapelaan. ${ }^{29}$

Lutkie ziet meteen het contrast tussen de zachte bescheidenheid van de jongeman en zijn trotse, een tikje arrogante manier van schrijven. Het is niet onwaarschijnlijk dat Antoon Coolen tijdens zijn bezoek aan Haaren met enthousiasme over zijn 'vriend en leider' Ouwerling heeft gesproken. Lutkie kent Ouwerling via zijn publicaties en weet dus ook dat deze zich niet in de eerste plaats om de godsdienstzin van de jonge volontair zal bekommeren. Ouwerling gaat het veel meer om de sociaal-economische en culturele verheffing van de streek. Hij ziet in de artikelen van Antoon Coolen een goede aanvulling op zijn eigen bijdragen over onderwijs, ruilverkaveling, criminaliteit, kunstmest, enzovoort. Zijn pupil zou dan misschien meer als literair schrijver een culturele bijdrage aan de vooruitgang van het Peelgebied kunnen leveren. Wie weet, heeft hij een soort Conscience of Streuvels voor de Peel in gedachte.

Lutkie is in de eerste plaats een moralist. Hij ziet in Antoon Coolen een mogelijke propagandist en uitdrager van ideeèn zoals die van Bloy en Hello. Hij deelt het standpunt van de laatste dat een goed kunstenaar of schrijver in de eerste plaats een goed katholiek moet zijn. Voor Lutkie is de invloed van Multatuli en de Tachtigers op Antoon Coolen, die zo duidelijk uit Opinies blijkt, een gruwel. Hij moet meteen vermoed hebben dat die boeken van Ouwerling afkomstig zijn; in ieder geval zullen ze niet op de lijst van het klein seminarie hebben gestaan. Lutkie schrijft, achter de rug van Antoon Coolen om, een brief aan Ouwerling, waarin hij om inlichtingen vraagt over hun jonge wederzijdse vriend. Kennelijk was zo'n verzoek om inlichtingen in die tijd normaal, zeker als een priester (zij het in opleiding) de vrager is. Maar in het verzoek zitten ook, nauwelijks verstopt, richtlijnen voor Ouwerling: behoed hem voor dit, leer hem dat en verlos hem van de invloed van mensen die hem niet waard zijn, met andere woorden de goddeloze schrijvers. Om een beter beeld te krijgen van de man, die de volgende acht jaar zo'n grote invloed zal hebben op Antoon Coolen, volgt een wat langer citaat uit de brief aan Ouwerling:

"U (zou) mij kunnen van dienst zijn met eenige inlichtingen over hem, die ik hemzelf niet kan vragen.

Welke is Uw verwachting van zijn talent en welk Uw plan voor zijn toekomst? - Want $\mathrm{U}$ zult meer dan zijn 'vriend' zijn, $\mathrm{U}$ moet zijn leider en beschermer zijn - Hij leek me hier al pratend, een naîef, goed manneke; van veel meer bescheidenheid dan zijn opstellen doen vermoeden. En hij scheen ook vol van idealen en illusies. Zóózeer zelfs dat ik bang was hem met ' $n$ woord-te-veel te desillusioneeren. I $k$ was bang dat ik hem ontmoedigen zou als ik dingen zei die niet in overeenstemming waren met wat $\mathrm{U}$ hem hadt te hopen gegeven.

Zoo vertelde hij, U hadt hem gerustgesteld over die Msb. [Maasbode, C.S.] critiek, U zou er wel eens naar de redactie over schrijven, en ze zouen hem zeker als medewerker aannemen, zoo gauw er een plaatsje open was. Hij verwachtte nog recensies van Telegraaf en Boekenschouw - Hij scheen in argelooze naieveteit te meenen dat de menschen heel 
blij met zijn boekske zouden zijn.

Ik deelde niets van zijn optimisme en geen enkele van al zijn verwachtingen. Maar ik dacht dat $\mathrm{U}$ ze hem hadt ingegeven en dat $\mathrm{U}$ er Uw goede reden voor zoudt hebben - $\mathrm{U}$ die toch zelf al zoo lang, tot op cynisme af, omtrent de menschen moet ontnuchterd zijn - en ik wou dus Uw invloed niet tegenwerken.

Maar zeg mij eens wat Uw bedoeling hiermee is, en hoe $\mathrm{U}$ meent hem te zullen sterken tegen heel veel teleurstellingen?

$\mathrm{U}$ zult hem toch behoeden voor een altijd en in alle opzicht noodlottige zelfgenoegzaamheid, nietwaar. Ik hoop, U zult vóór alles een goed mensch en christen van hem maken. Conditio sine qua non om een goed en groot kunstenaar te worden.

En wil hem ook leeren, zijn eigen toon te vinden. Hij heeft al eigen opmerkingen en eigen gedachten. Maar de klank van zijn woorden is nog al te zeer ontleend aan anderen. Hij leeft teveel nog onder suggestie van eenigen die hem niet waard zijn. - Hoed hem voor frazenmakerij. En houd hem nederig, opdat hij macht en recht verkrijge, om anderen te leiden en te wijzen.

Mag ik hierop Uw antwoord verwachten? Het is gezegd in het belang van Uw beschermeling, aan wien ik mij ter beschikking heb gesteld. ${ }^{30}$

Uit dit fragment blijkt meteen al dat Lutkie's bemoeienis niet zonder doel is, zijn reactie op Opinies is onderdeel van een weloverwogen strategie. Hij wil van Antoon Coolen een katholiek kunstenaar en journalist maken in de zin zoals Hello dat bedoelt. En om die 'ontzaglijke plicht' te kunnen vervullen moet hij in de eerste plaats een goed christen zijn. Lutkie wil met dit ongevormde 'materiaal', dit jonge talent, een eigen doel nastreven. Antoon Coolen moet een nieuwe strijder voor het integralisme worden, een strijder die kritisch is ten opzichte van de gevestigde macht in de Kerk, maar loyaal aan de oude katholieke en christelijke waarden.

\section{De eerste krantenartikelen}

Ondertussen publiceert Antoon Coolen met vaste regelmaat in De Zuidwillemsvaart, nu niet langer onder het pseudoniem Willer, zoals in I9I4, maar ondertekend met A.F. Coolen. Zijn stukjes staan meestal op de voorpagina, soms naast de artikelen van Ouwerling. De toon en inhoud zijn soms badinerend, maar de artikelen die over de oorlog gaan zijn altijd ernstig en pacifistisch van aard. Dit is niet zo gewoon als het lijkt, want over het algemeen is de toon over de oorlog in die dagen nogal luchtig. Zo toont de Katholieke Illustratie regelmatig 'kiekjes' van het front in België waar Duitse soldaten de was doen of een pijpje roken.

Die oorlog speelt zich slechts op enkele tientallen kilometers van Deurne af. De neutraliteit van België is geschonden en Brabant zit vol met Belgische vluchtelingen en met gemobiliseerde Nederlandse soldaten. In het grensgebied wordt veel gesmokkeld. Zo laat Coolen het een van zijn romanfiguren zeggen: "We kregen in ons dorp ook soldaten ingekwartierd. Er kwam schaarste aan alles, en voedselnood. [...] Als we op de hei in de richting

$29 \mathrm{KDC}$, inv. nr. 101, aantekening van Lutkie, 18 december 1914.

30 Stadsarchief Helmond, inv. nr. 93, brief Lutkie aan Ouwerling, 14 februari 1915. 
van de zuidergrens met ons oor gedrukt tegen de grond gingen liggen, dan hoorden we in die trillende klankbodem het dreunen van de dikke Berta's in Antwerpen." ${ }^{31}$ Antoon Coolen schetst in zijn stukjes de invloed van de soldaten en de tegenstelling tussen de Hollanders en de boeren van de streek, ${ }^{32}$ een andere keer gaat het over een clandestiene herberg waar de jenever voor de soldaten verdund wordt. ${ }^{35}$

In de zomer van r915 maakt hij voor de krant een reisverslag van een bezoek aan Amsterdam. ${ }^{34}$ Het is interessant om te lezen hoe de achttienjarige jongen uit Deurne, nog niet zo lang van het seminarie, als man van de wereld zijn verslag doet. Hij beschrijft de drukte bij het station van taxi's en huurrijtuigen en daarna een bezoek aan de Flora-revue Loop naar den duivel: een spektakel met "artistiek-lenig zich bewegende danseressen" en met realistisch uitgebeelde bombardementen en zeeslagen. Dit was zeer actueel, want nog geen maand daarvoor, op 7 mei 1915 , torpedeerden de Duitsers zonder waarschuwing het passagiersschip Lusitania bij de lerse kust, waarbij enkele duizenden mensen verdronken. Er spreekt ook een zekere houding van 'épater le bourgois' uit, want toneel is in die dagen in katholieke kring al een verdachte zaak, maar cabaret en music-hall vormen reeds het voorgeborchte van de hel. Het is pas in hetzelfde jaar 1915 dat er voor het eerst besloten toneelvoorstellingen zijn voor de lezers van De Tijd en De Amstelbode. ${ }^{35}$ Daarvoor worden toneelrecensies zelfs nauwelijks gedoogd. De jonge Coolen beperkt zich niet tot toneel, maar zwerft ook door de stad, bezoekt enkele "luxueuze inrichtingen" en mijmert enige tijd aan de Prins Hendrikkade bij het zien van drie schoorsteenpijpen van een oceaanstomer over de geneugten van het reizen.

In de tweede aflevering wordt een boottochtje van Amsterdam naar IJmuiden beschreven. Bij het zien van de vredige natuur denkt hij aan de tegenstelling met de oorlog: "ver weg.. 'n historie van ondenkbaar en godverguizende - alleronmenschelijkst - wrede barbaarsheden, gepleegd in den jongste tijd door menschen."

Hij makt zich werkelijk druk om de oorlog en vooral om de rol die de pers daarbij speelt. De Nederlandse kranten worden door de oorlogvoerende partijen bestookt met berichten, waarin propaganda voor het eigen standpunt wordt gemaakt. Daarbij wordt soms geprobeerd een krant om te kopen. De Engelsen [Nederland was toen nogal Duitsgezind, alleen De Telegraaf was toen anti-Duits, C.S.] bieden De Limburger Koerier een negatief artikel over de Duitsers aan met de belofte de kosten voor het zetten en drukken te betalen. Dezelfde krant krijgt ook van de andere kant een aanbieding: het comité catholique van de Alliance Francaise doet het voorstel om een aantal pro-Franse artikelen op te nemen in ruil voor een lucratief advertentiebestand. ${ }^{36}$

Coolen schrijft een fel stuk waarin hij de Engelsen verwijt dat ze zelf ook geen makke lammeren zijn en verwijst naar hun acties in Transvaal, waar in het begin van de eeuw voor het eerst werd geëxperimenteerd met concentratiekampen. De pot moet de ketel niet verwijten dat hij zwart ziet, schrijft hij. Humaniteit en oorlog zijn strijdige begrippen, oor$\log$ is altijd onmenselijk. "Wat de Duitschers doen is onmenschelijk. Wat de geallieerden doen is onmenschelijk." ${ }^{-37}$

Coolen vindt dat de Nederlandse kranten neutraal moeten blijven en er niet de oorzaak van moeten zijn dat Nederland meegesleurd wordt in de oorlog, zoals vlak daarvoor Italië "met moedwil, met voorbedachte rade en met lage omkooping gesleurd werd in den algemeenen jammer." Hoofdredacteur Ouwerling schrijft nog enkele regels onder "dit sympa- 
thieke stukje van onzen jongen medewerker." Hij hoopt dat, nu de zenuwen van de eerste maanden van de zomer van r $9 \mathrm{r}_{4}$ voorbij zijn, de neutraliteit gehandhaafd zal blijven.

De oorlog blijft de jonge volontair bezighouden: in oktober 1915 verschijnt in twee afleveringen zijn stuk 'Schlachtenbummlerij'. Het Duitse woord 'Schlachtenbummler' is een negatieve benaming voor oorlogscorrespondenten, boemelaars, die in de bars van hotels hun stukjes schrijven over de gebeurtenissen op de slagvelden. Het begrip wordt al gebruikt door Multatuli tijdens de Frans-Duitse oorlog in $1871{ }^{38} \mathrm{Zij}$ zijn leveranciers van oorlogsberichten, de dagelijkse portie nieuws en feiten die de lezers verwachten. In deze stukjes blijkt dat hij zijn huiswerk van Lutkie, het bestuderen van Hello, met vrucht gedaan heeft. Hello maakt een vergelijking: zoals het dagelijks brood nodig is voor ons lichaam, zo is de pers het dagelijks voedsel voor de geest geworden. Daarom heeft een schrijver die in dienst is van de pers of de publiciteit een 'immense devoir'. Coolen geeft vervolgens een letterlijke vertaling van Hello's credo "Faire parvenir la vie aux autres hommes" ${ }^{\text {"59 }}$ in de krant: "Deze ontzaggelijke plicht is het leven doen toekomen aan den medemensch." Coolen gebruikt hier een Frans citaat van Hello, maar hij blijkt ook heel goed in Duizend-en-enige-hoofdstukken van Multatuli gelezen te hebben. Ook Multatuli zag in de 'Schlachtenbummler' een dagelijkse leverancier van oorlogsberichten, die wel eens vooruitliep op oorlogsberichten "om den geeuwhonger naar oorlogsnieuws enigszins te beteugelen" en waarvan sommigen hun stukjes vanachter het bureau schreven. ${ }^{40}$

Coolen bekritiseert de journalisten, die een lui leventje leiden op kosten van de redactie "en dagelijks een stuk of wat berichtjes leveren aan een billijken prijs." En die berichten zijn dan altijd gekleurd, nooit gaan ze over verliezen aan de eigen kant. Caesar hemelde in De Bello Gallico zijn eigen veldtochten al op, schrijft hij en bepleit daarmee in zekere zin een geëngageerde journalistiek avant la lettre. Om de felheid van het stuk te proeven een wat langer citaat:

"De Pers in de oorlogsvoerende landen en onze vaderlandsche Pers gedeeltelijk ook, dat is de leugen, de gróóte leugen, één groote internationale snertzooi van bedrog, ophitsing, bombast en snoeverij!

Wat gaat 't aan, kilometers van grond te winnen, als daarvoor in de plaats moeten gegeven worden, zoovele menschenlevens, als er centimeters bevat zijn in die mijlen! 't Winnen van hoeveel gronds ook, weegt niet op tegen 't leven van ook maar één mensch.

Coolen, De vrouw met de zes slapers, 111.

32 Coolen, 'Militaire opsnijerij en landelijke eenvoud'. Landelijke eenvoud is ook de titel van een roman van H.J.J. Maas.

33 Coolen, 'Bij Nilliske'.

34 Coolen, 'Reisschetsen deel I en deel II.'

35 Schrama, Dagblad De Tijd, 204.

36 Van Iddekinge, 'Spreekbuizen van de hat', 597.

37 Coolen, 'Omkooperij'.

38 "In Uw hoedanigheid van Schlachtenbummler, ware dat beschrijven uw taak." Multatuli, Ideeèn, Idee 77, deel 4, 494. Hello, Le Siecle, 56.

40 Multatuli, notitie in handschrift bij Specialiteiten, WW deel 5, 665. 
Wat gaat 't aan, zoovele duizenden vijanden te dooden, als die vijanden hun leven gegeven hebben niet dan tegen gelijke prijs! En is het niet barbaarsch te zeggen: $\mathrm{O}$, menschen, verheugt $u$, verheugt $u$, er zijn weer zoovele andere menschen van dat gindsche land, waarover wij 't recht om ze te dooden, ons hebben aangematigd, gesneuveld! Wees blij, ómdat die gesneuveld zijn, wees vroolijk, ómdat daarginds weer ontelbare moeders en kinderen, weduwen en weezen zijn geworden.

La presse nourrit le monde. ' $t$ Is zoo bitter waar.,"41

Zo'n tekst is recht uit het hart geschreven. Antoon Coolen stuurt de knipsels naar Lutkie op en meldt tevens wat hij zo al leest. Het knipsel op zich moet bij Lutkie al gemengde gevoelens hebben opgeroepen. Hij merkt dat zijn pupil de passages van Hello over de rol van de pers en de journalist heeft begrepen, maar hij is het zeker oneens met de pacifistische strekking van het stuk. Zijn geloof in 'l'homme supérieur' laat dat niet toe: je hebt een overtuiging en je moet die vervolgens te vuur en te zwaard verdedigen.

Het zal echter vooral de lijst met leeservaringen zijn die Lutkie ongerust maakt, want er staan nog steeds niet-katholieke, atheïstische en socialistische auteurs op. Coolen schrijft dat Multatuli hem blijft interesseren. Hij herleest in deze tijd Vorstenschool, waaruit hij in Opinies al citeerde, en Duizend-en-enige-hoofdstukken-over-Specialiteiten. Daarnaast leest hij van Heijermans Ahasverus en van Ibsen Steumpilaren eener maatschappij, de schetsen van de Brabantse schrijver Hollidee, werk van Potgieter en daar tussendoor Hello. ${ }^{42}$ Coolen is van plan een brief aan Kloos te schrijven, maar dit is er waarschijnlijk niet van gekomen; de brief is niet gevonden. Hij is alweer bezig aan een tweede boek dat zal gaan heten Bij de menschen van 't zuiden. Later dat jaar is de titel veranderd; het wordt nu Inkwartiering.

Zijn schrijfdrift is enorm. In het Kerstnummer van De Zuidwillemsvaart heeft hij 'Kerstvrede' geschreven, een mijmering over dit feest van vrede in volle oorlogstijd. Op Kerstavond schrijft hij een brief aan Lutkie. Hij constateert dat het geloof van de mensheid in zichzelf aan het wankelen slaat "en wij staan met angstigstarende en verwonderd-open oogen bij de puinhoopen van ons eigen vernieling en weten ons schuldig." Aan het slot van zijn brief komt de beschrijving van de kerstnacht, een beschrijving die nog zo vaak in zo vele vormen zal terugkeren in zijn werk.

"Nu ik dit schrijf weet ik niet of in den mysterievollen nacht de sneeuw zal stuiven in rijkvallende vlokken over de velden en over de verre wegen, die zich door de velden slingeren... Met een soort van weemoed heb ik 't bezien, dat oude, oude schilderijtje van den kouden Kerstnacht, als alle huizen en alle stille boomen dikwit zijn en 't vaalblank is langs alle wegen onder den zwartblauwen hemel die wijd over de wereld welft in de stille glorie van lichtend gouden sterrengruis en wijl wat zwartschimmige menschjes gaan over die winterwitheid overal naar de kerk toe, die boven de andere huisjes uitsteekt, stralend de ramen van matgelen schijn en 'et is er héél stil en 'et is er héél vredig. ${ }^{445}$

\section{Geloofstwijfels}

Er heerst echter geen vrede in het gemoed van de jonge Coolen. Hij ziet de praktijk van het geloof van alledag, de hypocrisie van de geestelijkheid en de leegheid en de bombast van hun zondagse preken. Hij zet zich daar tegen af en leest met grote instemming de nietkatholieke schrijvers als Multatuli, Zola en Tolstoj, allemaal schrijvers die door de integra- 
listen worden verketterd. Hij begint zijn katholieke plichten als mishoren en het ter communie gaan te verzaken, zodat zijn moeder ongerust raakt. Bezorgd schrijft zij een brief aan Lutkie, waarin ze de onkerkelijkheid van haar zoon wijt aan de invloed van Ouwerling, die als vrijdenker bekend staat, en zijn vrienden: "die gaan ook niet te communie als eens in 't jaar en 's zondags naar een korte H. Mis." Ze heeft van een vriend van Antoon van het kantoor in Helmond gehoord dat hij "de heele werken van Zola heeft gelezen." Hoe groot haar nood is, blijkt wel uit de verzuchting "indien ik zijn dood moest betreuren door een Godsvruchtig afsterven dan zou er nog een troost te vinden zijn!"44

Deze brief is voor Lutkie het signaal om een waar offensief voor het geloofsbehoud van zijn pupil te beginnen. Temeer daar Coolen hem pas nog over zijn plannen, zijn schrijverschap en leeservaringen heeft geschreven. Hierin staan voor Lutkie alarmerende dingen: "Soms is het me een overtuiging dat ik een groot schrijver worden zal. Ik heb af en toe geweldige ideeēn waarvan ik zelf verbaasd sta, en gedachten die ik niet begrijpen kan dat ze in me opkomen. ${ }^{\text {45 }}$

Als Coolen Multatuli, Zola en Tolstoj leest is het of hij zelf altijd al zo gedacht heeft. Vooral Multatuli vindt hij de grootste Nederlandse schrijver die we ooit gehad hebben. Lutkie heeft al teruggeschreven dat Zola een varken is, "even smerig en even kunstloos" en Multatuli "een verdwaalde, misleide genie. ${ }^{n 46} \mathrm{Hij}$ schrijft aan de kapelaan van Deurne, die bemiddelt: "Zeg aan z'n moeder dat ze hem niet te veel lastig moet vallen, want dat zal eerder een tegenovergestelde uitwerking hebben. ${ }^{47}$ Aan Coolen zelf schrijft hij minder relativerend; in een ernstige brief benadrukt hij dat het nu zaak is om zijn ziel in het reine te brengen. ${ }^{48}$

Per omgaande legt Coolen in een lange brief uit wat hem beweegt. Heel duidelijk schetst hij zijn afkeer van de alledaagse praktijk van het katholieke geloof. Zijn eigen godsgeloof ervaart hij veeleer in en door de natuur; maar bovenal uit hij zijn liefde voor de literatuur. De stijl van de brief is helemaal die van de opstandige jongere, maar tegelijkertijd is er al veel van de rijpere Coolen in te herkennen: “Nu ik Uw schoonen brief van liefde en zóó een heiligen ernst gelezen heb, zou ik best kunnen huilen van zorg om al die beroerdigheden waarin ik zóó verward ben geraakt, dat er geen uitkomen meer aan is." Tijdens het schrijven van deze brief wordt hij van zijn kamer geroepen om het avondgebed mee te doen: "dat is om vijftig maal achtermekaar te komen zeggen 'Wees gegroet Maria' enz." en na een witregel schrijft hij ironisch:

'Ziezoo! Ik heb een stuk of wat halve 'weesgegroeten' met de anderen mee opgezegd en ik weet niet juist hoeveel keeren het 'bid voor ons' afgerammeld. Nu is het goed! Nu zijn mijn beste vader en moeder weer tevreden over hun jongen, omdat hij zoo ijverig heeft

42 KDC, inv, nr. 101, brief Coolen aan Lutkie, 28 maart 1915.

43 KDC, inv. nr. 101, brief Coolen aan Lutkie, 24 december 1915.

44 KDC, inv. nr, 10I, brief van moeder Coolen-Swinkels aan Lutkie, 16 maart 1916.

$45 \mathrm{KDC}$, inv. nr. 10I, brief Coolen aan Lutkie, 5 januari 1916.

$46 \mathrm{KDC}$, inv. nr. 101, brief Lutkie aan Coolen, ongedateerd, ergens in januari 1916.

47 KDC, inv. nr. 101, brief Lutkie aan kapelaan Bartels, 17 maart 1916.

$48 \mathrm{KDC}$, inv. nr. 101, brief Lutkie aan Coolen, 21 maart 1916. 
meegedaan aan 't huishoudelijke en op vasten tijd bepaalde ziel-tot-God-verheffen. Nu is het goed."

Hij krijgt steeds minder vertrouwen in de katholieke leidsmannen en vooral in hun gedrag:

"àl het kleine fanatiek verdacht maken en niet willen erkennen van alles en allen wat valt buiten datgene wat hen tot een dweepzieke categorie vereenigt. Ik vind zoo weinig sympathieks en zoo weinig om innig lief te hebben in onzen Katholieke Godsdienst. [...]

Zondag op Zondag moet ik in de kerk vanaf den preekstoel allerlei gruwelijke met Gods-straf-dreigerijen hooren, die als banvloeken over de gewillige luisterende schaar van te goeder-trouw geloovende worden uitgeslingerd. 't Is altijd: Gij zijt allen zondaars. God zal U straffen! Dat moet ge doen, en dàt moet ge doen, en o wee! o wee! komt er niet aan te kort, want dan gaat ge allemaal naar de hel toe en zijt ge voor eeuwig tot een razendmakend ongeluk gedoemd. Wat denkt ge wel, aardwormen? Vreest God! Gij zijt niet waardig tot hem op te zien. Gedenk den oordeelsdag, den dag waarop God meedogenloos al degene die (of ze er iets aan konden doen of niet) van zijn bevelen afweken in de eeuwige verdoemenis werpen zal enz. enz."

Dit beeld van God is volledig tegengesteld aan zijn eigen opvatting:

"Is dat nu die goede, lieve, heerlijke God, dien ge weenend zoudt kunnen zeggen dat ge Hem liefhadt, als ge in den zonnedag loopt over de stil te zingen liggende wijde hei, purperen rood in Augustusbloei, onder den bevend-teeren blauwen hemel van zonnegoud doorstoven? Of als ge dwaalt door een groot bosch van àlmaar rechte dennen, waarin de wind het liefdelied van Godzelve zingt van zóó een roerenden weemoed, dat ge uw eigen ziel in God's mooiheid van geluk als uitzetten voelt!"

Aan het eind van de brief vertelt hij, niet wetend van de schriftelijke contacten die er tussen Lutkie en kapelaan Bartels geweest zijn, over een bezoek van de plaatselijke geestelijkheid aan zijn 'kamerke':

"En dan, O! ik heb de geestelijke heeren van ons dorp bij me gehad, Ze wouen dien jongen dwaas, die zulke rare artikels schrijft in onze gewestkrant, en zelfs een boekje in 't licht zond, de vermetele, waarvoor notabene de Maasbode, 't onfeilbaar orakelend vat van wijsheid, 'm eens 'danig-lekker' op den kop had gezeten, ze wouen dien z'n eigen ondergang tegemoet loopenden trotschaard wel eens onderhanden nemen! Die boeken, die hij daar had, moesten weg! Wat zijn dat voor manieren, zulke slechte boeken allemaal? En niet denken, vooral niet denken, dat deugt nergens toe. Maar veel bidden, dat is beter. En aan literatuur doen? Neen hoor, dan val je van je geloof af. En schrijven? Geen kwestie van! O! O! dat in géén geval zijn niet alle schrijvers slecht? Kijk eens Zola! En Rousseau en Voltaire en Mirabeau, Ibsen, Tolstoi, Multatuli, Kloos, Couperus, ja waarachtig Streuvels moet 't nog ontgelden Ik kan er niets aan doen, maar ik vind Kloos honderdmaal grooter dan Jonckbloet, Van Deyssel honderd maal grooter dan Linnebank, Couperus en Streuvels beter dan de zich schrijver wanende pater die en die. ${ }^{m 9}$

Het kan niet anders of Lutkie moet door deze oprechte brief danig in tweestrijd zijn gebracht. Antoon Coolen bewijst hierin immers in geen geval een 'homme médiocre' te zijn. Hij is niet lauw, maar zeer fel, en voldoet daarmee aan het karakter dat Hello en Bloy 
van schrijvers en intellectuelen eisen. Van de andere kant beledigt hij de spreekbuis van de integralisten in Nederland: De Maasbode. Maar die belediging wekt ook weer ambigue gevoelens, want Lutkie zou zijn ideeën eigenlijk veel liever in de meer intellectuele kwaliteitskrant De Tijd geventileerd zien. De Maasbode is toch meer de krant van de kleine middenstand en de 'doeners' in Rotterdam. Bovendien staat Lutkie zelf ook kritisch tegenover de gezeten geestelijke macht.

Vanuit dit dubbele gevoel is het te verklaren waarom hij eerder instemmend dan afwijzend op de felle brief reageert. Er klinkt iets samenzweerderigs in door, een woord van verstandhouding van mannen onder elkaar die boven het gekissebis van de gewone geestelijkheid staan, als hij schrijft: "Gij zijt vreemd voor hen. Zij hebben zulk geval niet onder hun oog gehad, in hun handboeken staat daar niets van. ${ }^{\text {.50 }} \mathrm{Hij}$ trekt Coolen naar zijn niveau en zegt in feite: van de problemen waar wij samen het over hebben, begrijpen die dorpsgeestelijken niets.

\section{Beïnvloeding}

De bijna negentienjarige Coolen wordt dus door twee heel verschillende personen gesteund in zijn afkeer van de kleinzieligheid van het dorpse parochieleven. Een wereldse en rationalistische visie wordt hem bijgebracht door Ouwerling. Hierdoor krijgt Coolen zicht op het belang van onderwijs, economie, openbaar vervoer en het welzijn van de mensen in de Peel. Ouwerling vindt dit soort zaken belangrijker dan de stipte naleving van de zondagsplicht en de regelmatige gang naar de biechtstoel. Daarnaast ontwikkelt hij onder invloed van Ouwerling een gevoel voor de schoonheid en het belang van literatuur. Dat wil zeggen literatuur zonder een religieuze boodschap, die ruim voorradig is in de bibliotheek van deze vrijgezel.

De bedoelingen waarmee Lutkie Coolen voorzichtig steunt in zijn afkeer van de dorpse geestelijkheid zijn volstrekt anders dan die van Ouwerling. Hij wil van Coolen een medestrijder maken, een deelnemer aan de herstelbeweging binnen de katholieke kerk. Daarom blijft hij Coolen ook overladen met geschriften van Hello en Bloy. Deze rechtsradicale stroming van katholieke integralisten heeft, zoals Rogier terecht beweert, louter negatieve programmapunten: "tegen alle feminisme, tegen coëducatie, tegen alle sexuele voorlichting aan de jeugd, tegen alles wat zich progressief noemt in de politiek, de kunst of de wetenschap. Dit alles wordt samengevat als 'de verdediging van een integraal katholicisme'. ${ }^{51}$ De aanhangers vechten ook tegen de versufte geestelijkheid die hier niet met elan tegen ten strijde trekt.

Beide partijen, de vooruitstrevende onderwijzer, historicus en hoofdredacteur Ouwerling en de integralist en priesterstudent Lutkie, zien de gevestigde macht van overheid en geestelijkheid, die op het Brabantse platteland van die tijd nauw verweven zijn, als hun vijand. Het grote verschil is dat zij beiden een ander maatschappelijk ideaal voor ogen hebben. Ouwerling heeft een rationalistisch en liberaal getint ideaal voor ogen en streeft naar een samenleving, die door onderwijs, techniek, wegen en verbetering in de landbouw

49 KDC, inv. nr. 101, brief Coolen aan Lutkie, 22 maart 1916.

$50 \mathrm{KDC}$, inv. nr. 101, brief Lutkie aan Coolen, 23 maart 1916.

51 Rogier, Katholieke Herleving, 443. 
zich zelf zal verheffen, waardoor een einde komt aan het drankmisbruik, de achterstand en de domheid van de Peelbevolking. Lutkie wil terug naar een hiërarchische katholieke samenleving, waarin iedereen zijn door God toebedachte rol speelt. Samenleven is samenwerken; deze samenwerking eist harmonie, anders loopt het spaak. Hij is duidelijk voor een corporatistische staat, waarin iedereen een vaste rol heeft en waar dus klassenstrijd niet nodig is. Hij verpakt deze boodschap in zijn geschriften in een onbegrijpelijke brij van korte zinnetjes. Een voorbeeld levert een artikel over magnanimiteit dat hij enkele jaren later, in r920, schrijft: "Geef groot spel in magnanimiteit. Speel hoog spel. Speel bewust het spel van uw rol. Weet achter de rol de werkelijkheid van speler en van spel. Gedenk de werkelijkheid. Voor allen eender. God telt de rol niet. God telt de speler en het spel." Zo gaat het bladzijden achter elkaar door. ${ }^{52}$

Het begrip 'magnanimiteit', zielegrootheid, heeft Lutkie overgenomen van Bloy, waar deze het gebruikt in een kenschets van de door hem verachte schrijver J.K. Huysmans. Het zou hem ontbreken aan "la pensée personelle et la magnanimité."

Eind april besluit Lutkie naar Deurne te reizen om de verschillende partijen te spreken. Het bezoek wordt geen succes. De priesterstudent Lutkie die al een zekere bekendheid geniet, wordt teveel in beslag genomen door Ouwerling, maar ook door de plaatselijke geestelijkheid. Daardoor is er weinig tijd voor Coolen overgeschoten. Lutkie heeft er veel óver Antoon gesproken, maar slechts korte tijd mét hem. Ondertussen heeft Lutkie wel zijn ogen goed de kost gegeven toen hij op de kamer van Coolen was. "Ik heb ook in oe boekenkastje gekeken, Antoon, ge hebt wél boeken gelezen die oe kwaad hebben gedaan en zeker vele die oe geen goed deden. [...] Bloy moogt ge lezen doch ik heb liever dat ge er niet over praat en hem ook niet aan een ander te lezen geeft. ${ }^{.53}$

Deze waarschuwing wijst er op dat de ideeën van 'le pélerin absolu', zoals Bloy genoemd wordt, geen gemeengoed zijn bij de plaatselijke geestelijkheid. Coolen laat zich niet paaien door deze uiting van vertrouwelijkheid. Hij is zeer ontevreden over dit bezoek, blijkens een lange brief, waarin hij zich opvallend genoeg van beide mentoren distantieert:

"Wij hadden 's avonds, nadat U met moeder gesproken zoudt hebben, liever samen moeten zijn, zonder 't bijzijn van derden tot op 't laatste moment toe. 'n Half uurtje bij Mr. Ouwerling was wel voldoende geweest. De wel eenigzins op drogredenen gelijkende uitspraken van Mr. Ouwerling omtrent de mogelijkheid de daden van een wijsgeerig mensch te toetsen aan het leven in de practische samenleving, interesseerden me toen al heel weinig. En dat discuus over't al dan niet authentieke van verschillende Tomas à Kempis overzettingen ging me minder aan. Ik had 't me anders voorgesteld." Al schrijvend wordt de toon van deze (lange) brief heftiger. Hij daagt zijn vertrouwensman steeds meer uit en zegt ronduit dat hij het geloof van Lutkie niet deelt: "Dat ik Uw geloof niet heb, is zeker, maar dat ' $k$ 't gemis daaraan niet voel, is evenzeker." Over zelfmoord schrijft hij in die brief:

" $\mathrm{lk}$ kan me best begrijpen dat er menschen zijn (en deze juist met een meer dan gewoon verstand en gevoel) die 't één na één ontglippen van àl hun idealen besluiten met door eigen hand een einde te maken aan hun bestaan. 't Is niet flink, maar wanneer 't geschiedt gaat de daad nóóit met vrees voor de gevolgen, of twijfel daaraan, gepaard, dàt weet ik wel zeker." 
Ongetwijfeld heeft Antoon Coolen, zoals velen op die leeftijd, wel eens met de gedachte aan zelfmoord gespeeld. Het citaat wijst er ook op dat hij het hoofdstuk 'Les Suicides' uit Hello's boek Le Siècle heeft bestudeerd. De zelfmoord is inderdaad niet flink, schrijft deze. Zelfmoord is omgekeerd heroïsme, een heroïsme tegen zichzelf. De dader denkt inderdaad niet aan het hiernamaals, want "le suicide, c'ést la négation totale réduite en acte." 54 mens heeft volgens Hello twee instincten: het geloof en het zelfbehoud. De zelfmoordenaar vernietigt deze twee instincten en ontkent alles; een angst voor het hiernamaals kan hem dus niet tegenhouden.

In de romans en verhalen van Coolen komen veel zelfmoordenaars voor waar deze redenering voor op gaat. Corneliske Schoonderwiel uit De man met het Jan Klaassenspel heeft al zijn vertrouwen in de toekomst verloren en is zo bang voor de schande die hem te wachten staat dat zijn angst voor het hiernamaals er bij in het niet verdwijnt. Het meest schrijnende voorbeeld staat in Herberg In 't Misverstand. Hierin pleegt een kind zelfmoord omdat het de eeuwigdurende ruzie tussen zijn ouders niet meer kan verdragen. Tot die tijd had het steeds bij de geringste verbetering in de verhouding tussen zijn ouders gejuicht en op zijn oogleden gedrukt om "uit dat vermiljoene licht der doorzinderde, grondeloze diepte de bloemen te zien komen, die naar achteren wegschijverden en daar breder en vlammender werden dan vuren." ${ }^{55} \mathrm{Na}$ de zoveelste ruzie komen die bloemen en vuren van de blijdschap der wereld niet meer uit de afgrond en verdrinkt de jongen zich. Op zijn kamertje vinden de ouders zijn kerkboek waarvan de pagina's voor het gebed voor vader en moeder met het prentje van het heilig huisgezin het meest beduimeld zijn. De jongen heeft inderdaad zijn instinct tot zelfbehoud en geloof vernietigd en kan niet bang zijn geweest voor wat er eventueel daarna zou komen.

Over literatuur schrijft Coolen in dezelfde lange brief aan Lutkie:

"Ik heb m'n literatuur, dat is heerlijk. O, m'n laatste stukken zijn zo mooi! Daar zit zooveel liefs in, zooveel rijks, zooveel van 't innigste van m'n warme voelen, en zoo heelemaal niets, dat zweemt naar inhoud of strekking van Opinies. In den herfst van dit jaar wordt m'n tweede boek, door onze firma uitgegeven. Zie je, dàt is een geluk, voor mij het éénigste."

Gekalmeerd door de gedachte aan zijn literatuur vervolgt hij:

"Kom, ik neem 'n nieuw vel, en misschien aanstonds nog al een, als 'k niet uitgepraat ben, tenminste. 't Lijkt me, of ik nóóit zoo kalm was als thans. In den avond is 't heel stil over de straat en wijd in de lucht. De rust van den voorbijen dag hangt zoo dood-, doodgewoon in de eenvoudige ruimte van m'n kamerke en ' $\mathrm{k}$ schrijf nu aan U, een héél lieven vriend van me, die later met aandachtige oogen regel na regel, die zich uit m'n pen boven mekaar reien, zult overgaan."

De kalmte duurt echter niet lang. De volgende regel al, ingaand op de brief van Lutkie, wordt hij feller: "Wat houd ik U in Godsnaam toch verborgen? En welke boeken deden me 
niet goed en waren van nadeeligen invloed voor me?"

Coolen weet heel goed wat hij verborgen houdt voor Lutkie. Hij heeft een verhouding met een meisje, een nichtje uit Helmond; zijn moeder heeft hierover bezorgd aan Lutkie geschreven. Coolen doet daar heel badinerend over. Het is een gewoon meisje dat hem nauwelijks kent en al helemaal niet weet wat hem bezighoudt. Waarschijnlijk om de aandacht af te leiden schrijft hij uitvoerig over de zusjes van dat meisje. Het zijn "modelkinderen, zoo wat lichaam als wat geest betreft." Er is niets ongeoorloofds in die verhouding en als die verklaring niet voldoende is voor Lutkie, dan kan hij er verder ook niets aan doen. Hij krijgt de neiging om te schreeuwen "dat 't langs de muren van m'n kamerke schalt: 't Kan me niks bommen!" Het is kennelijk niet lang aan geweest, want na deze brief wordt niets meer van het nichtje vernomen. ${ }^{56}$

De schommelingen in de gemoedstoestand van Antoon Coolen, tijdens het schrijven van deze brief op zijn 'kamerke' boven de nieuwe winkel in de Zeilberg, zijn hevig en gevarieerd. Hij voelt zich verraden door de enige vriend die hij volledig dacht te kunnen vertrouwen. Hij heeft het strategische aspect gezien van het gedrag van Lutkie, die Ouwerling noch de plaatselijke geestelijkheid voor het hoofd wil stoten, maar evenmin zijn pupil verliezen. De toon tegen Lutkie is afwisselend aantrekkend en afstotend. Hij voelt dat hij door Lutkie in een richting gedreven wordt die hij niet wil, maar van de andere kant wil hij het contact met hem niet verbreken. Daar zal de charismatische kant van de priesterstudent mede debet aan zijn geweest, maar daarnaast biedt hij Coolen zicht op een heel andere culturele wereld en fungeert hij ook als intellectuele sparringpartner.

In de zomer van r 916 probeert moeder Coolen zoveel mogelijk het contact tussen Antoon en Ouwerling te verhinderen. Zij moet bij het bezoek van Lutkie door hem gesterkt zijn in haar wantrouwen jegens deze vrijdenker. Zij schakelt de heer Hendriks, directeur van De Zuidwillemsvaart, in. Aan Lutkie rapporteert zij dat deze Hendriks Coolen zo veel mogelijk weghoudt van Ouwerling en dat hij de ouders tevens raad geeft. ${ }^{57}$ Ook Antoon zelf zoekt nu liever contact met Lutkie dan met Ouwerling. Hij nodigt hem uit voor een bezoek aan Deurne zonder andere afspraken: "Dan laten we Ouwerling naar de maan lopen, de pastorie desnoods ook en dan zijn we een hélen dag samen, wat bijzonder prettig zal zijn." ${ }^{\text {68 }}$

Het is dus niet alleen door de invloed van zijn moeder en Lutkie dat Coolen langzamerhand afstand neemt van Ouwerling. De verwijdering ontstaat ook door het uiteenlopen van interessen. Coolen krijgt steeds meer aandacht voor literatuur, filosofie en religie. De veel oudere Ouwerling is toch meer op sociaal-economische zaken en onderwijs geconcentreerd. Bovendien kan Coolen bij de priesterstudent Lutkie ook makkelijker terecht met zijn morele problemen over de omgang met de 'andere kunne'.

In de tweede helft van het jaar r9r6 keert de rust voorlopig weer. Naast zijn werk voor de krant en een opdracht voor de Katholieke Illustratie schrijft hij elke nacht. Van de twee titels die hij eerder in gedachten had, De Mensen uit het Zuiden en Inkwartiering wordt niet meer gerept. Het tweede boek dat na Opinies zal verschijnen zal Lentebloesem heten, schrijft hij aan Lutkie, en pater Hendrichs uit Maastricht heeft hem al een schitterende recensie in het blad Het Centrum beloofd. ${ }^{59}$ Het zal overigens nog zes jaar duren eer Lentebloesem er ligt. 
Pater F. Hendrichs S.J. is een van de weinige jezuieten, die tot de integralisten behoorden en is een medestander van hoofdredacteur Thompson van De Maasbode. Volgens Rogier was het een geruchtmakend man, zeer emotioneel en met weinig stabiele opinies. Hij schreef onder pseudoniem detectiveromans en recenseerde die dan positief onder zijn eigen naam in De Tijd. ${ }^{60}$

In het Kerstnummer van De Zuidwillemsvaart schrijft Coolen weer een kerstvertelling: 'Janneke'. Het verhaal gaat over een ziek kind dat in de kerstnacht overlijdt na een lang gesprek met de moeder over de hemel. In de beschrijving van het wilde en ontembare verdriet van de moeder zal de herinnering verwerkt zijn van zijn nachtwake met zijn eigen moeder bij het sterven van zijn broertje Jan, toen hij zelf tien jaar was.

\section{Andrejew en Querido}

De werklust die Coolen in het najaar van 1916 heeft, is in het begin van het nieuwe jaar verdwenen. Hij voelt zich depressief. Zelfs het feit dat hij in februari igi 7 een nieuwe baan krijgt bij het Eindhovens Dagblad beurt hem niet op; hij voelt zich ziek van beroerdigheid en weet niet wat hij aan moet vangen. Hij leest Noodlot van Couperus en heeft daarna lang in zijn bed liggen huilen. Tegelijk is dit lezen toch zijn allerhoogste geluk; de auteur wordt op die manier een geliefde vriend. Dit geldt niet voor de auteurs die Lutkie hem heeft aangeraden. In een lange brief stort hij zijn hart uit:

"Maar Hello is toch mijn speciale vriend niet; ik heb wel 's stukkies van 'm vertaald, en ik lees nog wel eens in hem, maar mijn groote liefde, mijn groote vereering heeft hij toch niet. Hij is een bizonder filosoof, goed. Maar hij is niet een bizonder kunstenaar. Een kunstenaar, dat is een enorm voelend en enorm - door wat of hoe komt er niet op aan - zich uitzeggend mensch, moet uit zich zelf filosoof zijn en gróót filosoof, en omgekeerd geldt dezelfde stelregel. [...] Er zijn in Holland wel vijfentwintig auteurs waar ik meer van hou dan van Hello. [... En Bloy is wel een pootige bliksem, en Bloy is wel van een hevig revolutionair temperament, en hij is wel te eerbiedigen als wezenlijk groot mensch, maar ik ben toch niet verbazend met hem ingenomen, en allebei met mekaar zijn ze nooit in staat geweest mij ook maar het vijfde gedeelte der ontroering te geven, welke ik bijv. in mij voelde schreien toen ik dat allersubliemste schetsje 'Schweigen', uit het bundeltje novellen van Andrejew, dat ik van je kreeg, gelezen had. ${ }^{n 61}$

Coolen doelt hier op Andrejew (ook gespeld als Andrejeff, Andreev of Andrejev) Leonid Nikojajevitsj (1871-19r9). Deze Russische schrijver studeerde rechten, werkte als journalist en publiceerde zijn eerste verhaal in 1898 . Zijn verhalen zijn commentaren op de opstanden en revoluties, op de verstikkende atmosfeer van een kleinburgerlijk milieu, de gruwelen van de Eerste Wereldoorlog en de verschrikking van een terechtstelling. In de

$56 \mathrm{KDC}$, inv. nr. 101, brief Coolen aan Lutkie, 2 mei 1916.

57 KDC, inv. nr. 101, brief moeder Coolen-Swinkels aan Lutkie, 25 juli 1916.

58 KDC, inv. nr. 101, brief Coolen aan Lutkie, 5 augustus 1916.

$59 \mathrm{KDC}$, inv. nr. 101, brief Coolen aan Lutkie, 21 november 1916.

60 Rogier, Katholieke Herleving, 499.

61 KDC, inv. nr. 101, brief Coolen aan Lutkie, I1 februari 1917. 
eerste decennia van de twintigste eeuw was zijn werk ook buiten Rusland zeer populair en viel in de smaak bij zowel linkse als rechtse critici. ${ }^{62}$ Uit stijl en onderwerpkeuze blijkt dat Andrejew het werk van Coolen meer beïnvloed heeft dan Hello en Bloy samen. Het gaat Coolen niet om het propagandistische aspect van kunst, maar om de intrinsieke waarde, de ontroering en het meeslepende. Deze stijl, die hij al eerder ontdekte bij Streuvels, herkent hij ook bij de Russische auteur. Een voorbeeld uit Andrejews novelle De roode lach maakt dit duidelijk. De zon, die zo genadeloos schijnt op de arbeiders in De oogst van Streuvels, is ook onbarmhartig voor de soldaten in De roode lach:

"De gloeiende, heete lucht trilde, de steenen sidderden eveneens, alsof ze zich gereed maakten, geluidloos weg te vlieden. [...] De reusachtige, zoo nabije, ijzingwekkende zon deed op iederen geweerloop, op ieder stukje metaal duizenden kleine, verblindende zonnen ontgloeien en deze schitterden van alle kanten in de oogen, vurig-helle, scherpe, witgloeiende bajonetspitsen gelijk.".63

$\mathrm{Na}$ de beschrijving van een massaslachting zingen de waanzinnig geworden en dronken soldaten. De tekst heeft Coolen voorgoed beïnvloed; door de inhoud krijgt zijn pacifisme gestalte en ook de vorm, met het vele gebruik van kleuren, zal hij overnemen. Een voorbeeld van Andrejew:

"Ja, zij zongen - en alles in den omtrek was rood van het bloed. De hemel zelf vertoonde zich in roode kleuren en men had kunnen denken, dat er zich in het heelal een catastrophe, een vreemde verandering had afgespeeld, die met een vernietiging der kleuren gepaard ging, het blauw, het groen, de andere gewone, rustige tinten waren verdwenen en de zon gloeide als een rood Bengaalsch vuur. 'De roode lach,' sprak ik. Maar hij begreep mij niet." ${ }^{\text {"4 }}$

Ook in Andrejws toneelstuk De smarten van Belgie ${ }^{55}$ zitten beelden die Coolen vaak bij de beschrijving van de oorlog zal gebruiken: het luiden van de klokken, het gedreun van de machines, wapenen en paarden, waardoor men met een seismograaf de troepenbewegingen zou kunnen volgen. Het stuk begint met een dove tuinman, die aanvankelijk niet begrijpt dat de oorlog begonnen is en zich daarna bezorgd maakt om zijn bloemen. Andrejew gebruikt ook graag de tegenstelling tussen enerzijds de oorlog, de dood, het geweld en de angst en anderzijds het leven, het moederschap, de natuur en de vreugde. Ook deze vergelijking zien wij door het hele oeuvre van Coolen terugkeren.

Op deze ontvankelijke leeftijd is Coolen helemaal weg van het werk van Andrejew. Hij raakt niet uitgeschreven over zijn leeservaringen. Een van zijn brieven aan Lutkie besluit hij zo:

"Och, wat heeft me dat schetsje gepakt, och, wat was dat schoon! Kunst is toch alles, kunst is de ziel van het leven zelf, kunst is het eerste hoogere plan, waarop de kunstenaar tijdens dit leven, en de nog geen kunstenaar zijnde eerst nà dit leven zich te stellen hebben om vooruit te komen op den weg die tot God leidt."

Om daarna zonder overgang over te stappen op het werk van Querido (1872-1932):

“Kent ge Querido's werk? Gelooft ge aan de mogelijkheid dat kunst onzedelijk kan zijn? [...] Onzedelijke kunst is tendenz-kunst, en dus geen eerlijke uiting van een eerlijke Godgevallige ziel. [...] Querido is, dunkt mij, zoo enorm - hevig eerlijk. Die heeft met gloeiende blikken, zonder ook maar één oogenblikje om publiek of critiek te den- 
ken, en met opgestroopte mouwen, z'n werken samen zitten hameren. God, wat een menschen, wat een ontzaggelijk-mooi uitgebeelde menschen van vleesch en bloed, wat klopt de slagader van 't grootestadsvolksleven bijv. door iedere pagina van Jordaan. Hoe is het toch mogelijk, dat ze een zoo geweldig kunstenaar als Querido van smerige bijoogmerkjes betichten kunnen! Want als je Jordaan leest, je hùilt ervan, omdat 't leven toch eigenlijk zoo erg droevig is en zoo vreeselijk. Ik heb bij dit boek zachtjes zitten schreien -.. Want, wie zal me zeggen, wat dat toch eigenlijk is; het leven; en wat dàt is: de ziel van een mensch, en wat dàt is: zóó diep indringen in de mysteriën van beide, dat ge er gek van worden zoudt omdat ge er niet aan uit kunt. Wat is nou zonde? ?66 $^{\text {no }}$

De dorpsjongen uit Deurne herkent zich in de Amsterdamse jongen, Manus Peet, uit het Amsterdamsch Epos De Jordaan van Querido. Beiden zijn eenzaam: Coolen past niet in het dorpse katholieke milieu en Manus Peet is ook een buitenbeentje in een socialistische omgeving. Deze Amsterdamse jongen zondert zich, als hij verliefd is, af en gaat De Navolging van Christus van Thomas a Kempis zitten lezen. Peet moet niets hebben van "een behoeftige-huisgezinnen-bezoekend-dogmen-diaakje, van een leuterende armenvertrooster der calvinistische nooddruftigheid of van een zoetfleemigen broeder-in-ChristusDarbist. ${ }^{" 67}$ Hij verafschuwt oppervlakkige godloochenarij, koestert zelf een mystieke ontroering en leest Ruusbroeck en Meester Eckhart. Deze romanfiguur leest echter ook met instemming boeken over de Franse Revolutie en daar heeft Lutkie meer problemen mee.

\section{Goed en kwaad}

Het werk van zowel Andrejew als Querido heeft veel kenmerken van het naturalisme en staat ver af van de idealistische romans, waarin uitgelegd wordt wat goed en kwaad is en waarin de held getuigenis aflegt van de enige goede visie. De personages van de Russische respectievelijk Amsterdamse schrijver hebben twijfels, zij ervaren slechte en goede kanten bij vriend en vijand. In De gouverneur van Andrejew schrijft een arbeider dat hij niet gelooft in de macht van het proletariaat: "Ik voor mij, ben vóór de revolutie, alleen als propaganda-middel, om tot betere toestanden te geraken, in de zin zoals de martelaren dit voor het Christendom waren, want ik ben er van overtuigd, dat de arbeider, zelf overwinnaar, ook een schavuit zou zijn en evengoed door een schelmenstuk de overwonnenen zou vernietigen." ${ }^{-68}$

Manus Peet is aan het eind van het boek ook gedesillusioneerd: bij de socialisten heeft hij "halstarrige betweters en bekvechters" ontmoet, bij de communisten "dogmatische redetwisters en betweters," bij de anarchisten waren er tussen de "kwart-, half-en heel-

62 Karel van het Reve in de Grote Winkler Prins, 1973 deel 2, 84-85.

63 Andrejew, De roode lach, 11. Het exemplaar uit de bibliotheek van de Theologische Faculteit Tilburg draagt het stempel van Bibliotheek 'Soli Deo' Nuland NBr. En daarnaast nog handgeschreven Wouter Lutkie, priester.

64 Andrejew, De roode lach, 33.

65 Andrejew, De smarten van Belgie

66 KDC, inv. nr. 101, brief Coolen aan Lutkie, 17 februari 1917.

67 Querido, Amsterdamsch Epos, 103.

68 Andrejew, De gouverneur, 50. 
individualisten veel koppige schepseltjes en miniatuurgodjes." Bij al deze mensen die over het Wij spreken, ziet hij toch steeds weer dat het om het Ik gaat. ${ }^{69}$

Deze schrijvers bepalen, met Multatuli, Streuvels, Zola en Nietzsche, voorgoed de richting van het denken van Antoon Coolen. Hij weigert zich te laten indelen bij een partij of ideologie; zijn helden dragen geen leer uit. Hij wil boeken schrijven waarin de lezer meeleeft met het vallen en opstaan van de personages en zal zo bijvoorbeeld het goede ontdekken in een moordenaar en het kwade in een pastoor.

Coolen schrijft aan Lutkie dat hij zich niet kan indenken dat de Grote Schepper zich druk maakt of iemand de ene dag een stukje spek eet, ${ }^{70}$ en morgen niet, en overmorgen weer wel; hij vindt dat "zoo miezerig." Hij vindt dat de Katholieke Kerk zo neerkijkt op al het andere en dat dat alleen maar leidt tot een vieze partijstrijd, zoals in het blaadje De Roskam. Dit blad was sinds 1912 een bijvoegsel van de krant van de katholieke arbeidersbeweging, Het katholiek Volk, een voorloper van De Volkskrant. De Roskam wilde een satirisch bijblad zijn met veel spotprenten als tegenhanger van de socialistische Notenkraker met de bekende prenten van Albert Hahn. Het noemde zich "het eerste katholieke spotblad."11

Wouter Lutkie schrikt niet zo van deze kritiek op de kerk; hij maakt zich veel meer bezorgd over de keuze van de literatuur van Coolen. Heel voorzichtig probeert hij bij te sturen, door bijvoorbeeld terloops te vermelden dat hij De Jordaan van Querido enkel van verveling niet uit heeft kunnen lezen: "zulke zielloze platte praat. En daarvoor Hello en Bloy opzijschuiven! Kunt ge hun ernst niet goed verdragen of begrijpt ge ze niet? Een oprecht antwoord graag," ${ }^{n 2}$

Dat antwoord zal lang op zich laten wachten. Tot tweemaal toe schrijft Lutkie een aansporing. Op 20 maart zegt hij ongerust te zijn en dat hij vurig op een antwoord hoopt: "Anders vrees ik dat ge heel ongelukkig zijt wijl ge niet meer geholpen wilt worden uit bangheid voor ernst. Morgen?" Een week later, op 27 maart, schrijft hij nogmaals, nu met een ondertoon van beëindiging van de vriendschap:

"i pl v nog een dag heb ik een week gewacht. Durf niet meer op een antwoord hopen. Voel me niet ontstemd of beledigd, heb alleen medelijden. Als je ooit sterker dan en nederig genoeg bent om een ernstig woord te kunnen verdragen ben ik altijd bereid. Stuur m'n boeken terug, zodat ik er anderen een dienst mee kan doen. Jij hebt er toch niets aan. Het dagboek van P. van der Meer de Walcheren heb ik zelf slechts te leen gekregen om jou te sturen."

\section{Bij het Eindhovensch Dagblad}

Coolen heeft even niet zo'n behoefte meer aan de raad van Lutkie. Hij ontpopt zich bij het Eindhovensch Dagblad, waar hij sinds februari r 917 werkt, al gauw als een kritisch journalist. Hij is het er niet mee eens dat zijn eigen krant vraagtekens zet bij het Vlaams activisme van de dichter René de Clercq. De krant is het niet eens met zijn pleidooi voor een Vrij Vlaanderen, kan zeker niet instemmen met het werk van de Raad van Vlaanderen en besluit aldus: "Laten we bewondering gevoelen voor René de Clercq als dichter, maar onze afkeuring uitspreken over hem in zijn positie van Vlaamsch activist. ${ }^{\text {"7s }}$ Het behoud van de schone Vlaamse taal is in beter handen bij de grote Frans van Cauwelaert, vindt de krant. Als De Clercq in Eindhoven komt spreken is Coolen als journalist onder zijn gehoor. De 
schilder Peter van den Braken is er ook bij. Hij herinnert zich de bijeenkomst aldus:

"Spoedig daarna kwam Toon in Eindhoven, als verslaggevertje bij het E.D. - gewapend met een 'perskaart' nam hij me nogal eens mee naar vergaderingen van de gemeente, maar ook naar andere bijeenkomsten, waarvan ik er één niet zal vergeten. Ze werd gehouden in 'Phoenix' in een klein bovenzaaltje, waar je de rook wel kon snijden. En door wie werden we daar ontvangen? Door niemand minder dan René de Clercq-in die tijd een felle strijder voor Vlaanderen - Hij slingerde het de zaal in: Vlaanderen! 'K sta récht voor $\mathrm{U}$, ' $\mathrm{k}$ Vecht voor $\mathrm{u}$ ! Bij deze gelegenheid maakten we ook kennis met een zekere Heer Merks (of Mertens?). Hij wees de dichter op Antoon Coolen en zei: Ja, mijnheer de Clercq, deze jonge man kán een groot schrijver worden, als hij wil. ${ }^{\text {m/4 }}$

Coolen is kennelijk niet bang om zijn baantje te verliezen, want hij schrijft in De Zuidwillemsvaart een behoorlijk fel stukje tégen het Eindhovensch Dagblad. "De Clercq is geen politicus, De Clercq is een zeer groot en zeer waar dichter [...] die vecht voor zijn geliefde taal [...] en als zoodanig is hij een van de grootste mannen van zijn tijd. ${ }^{775}$

Het hele jaar is er geen schriftelijk contact met Lutkie. Coolen woont dan in de Dommelstraat 20 in Eindhoven. Pas op 19 december 1917 schrijft hij aan zijn vertrouwensman dat hij "wederom surtout et avant tout Roomsch-Katholiek" is geworden en wekelijks ter communie gaat. Per omgaande bestookt Lutkie hem met vragen: "Waarom schrijft ge me niet uitvoeriger? Hoe is de ommekeer gekomen? Hoe is de verhouding met vader en moeder? Werkt ge nog aan het E'h Dagblad? ${ }^{76}$

\section{Van Eindhoven naar Maastricht en weer terug}

Het antwoord op al die vragen komt verpakt in een Nieuwjaarswens. ${ }^{n}$ De euforie blijkt maar van korte duur geweest, want de geloofstwijfels blijven Coolen kwellen. Hij schrijft dat de mens niets kan weten over een buitenwereldlijk leven en dat het ijdelheid is om daarover iets vastgestelds te geloven. Daarom verkneukelt hij zich zo over het vernuftig cynisme van Multatuli, daarom vindt hij Zola zo mooi en geniet hij van Couperus' Noodlot. Dat neemt echter niet weg dat hij toch katholiek wil zijn. Van de andere kant kan hij niet geloven dat sommige mensen - die niet gevraagd hebben om er te zijn - toch in de hel moeten branden. De brief eindigt in opperste vertwijfeling. "En nou kan ik niet verder schrijve [sic], ineens niet meer, het hangt me zoo vreeselijk de keel uit, dat is nou zeker de twintigste keer dat ik mijn brief afbreek, ik kàn niet verder, en nu stuur ik $\mathrm{U}$ dit maar vast, wat moet ik nou doen? AntoonFC."

Het was voor katholieken verboden om op vrijdag en op vastendagen vlees te eten.

71 Perry, Roomsche kinine, 230.

$72 \mathrm{KDC}$, inv, nr. 101, brief Lutkie aan Coolen, 28 februari 1917.

73 Eindhovensch Dagblad, zaterdag 14 april 1917.

74 WE, brief van Peter van den Braken aan Remery, november 1970.

75 De Zuidwillemsvaart, 21 april 1917.

76 KDC, inv. nr. 101, brief Lutkie aan Coolen, 20 december 1917.

$7 \mathrm{KDC}$, inv. nr. 101, brief Coolen aan Lutkie, 1 januari 1918. 


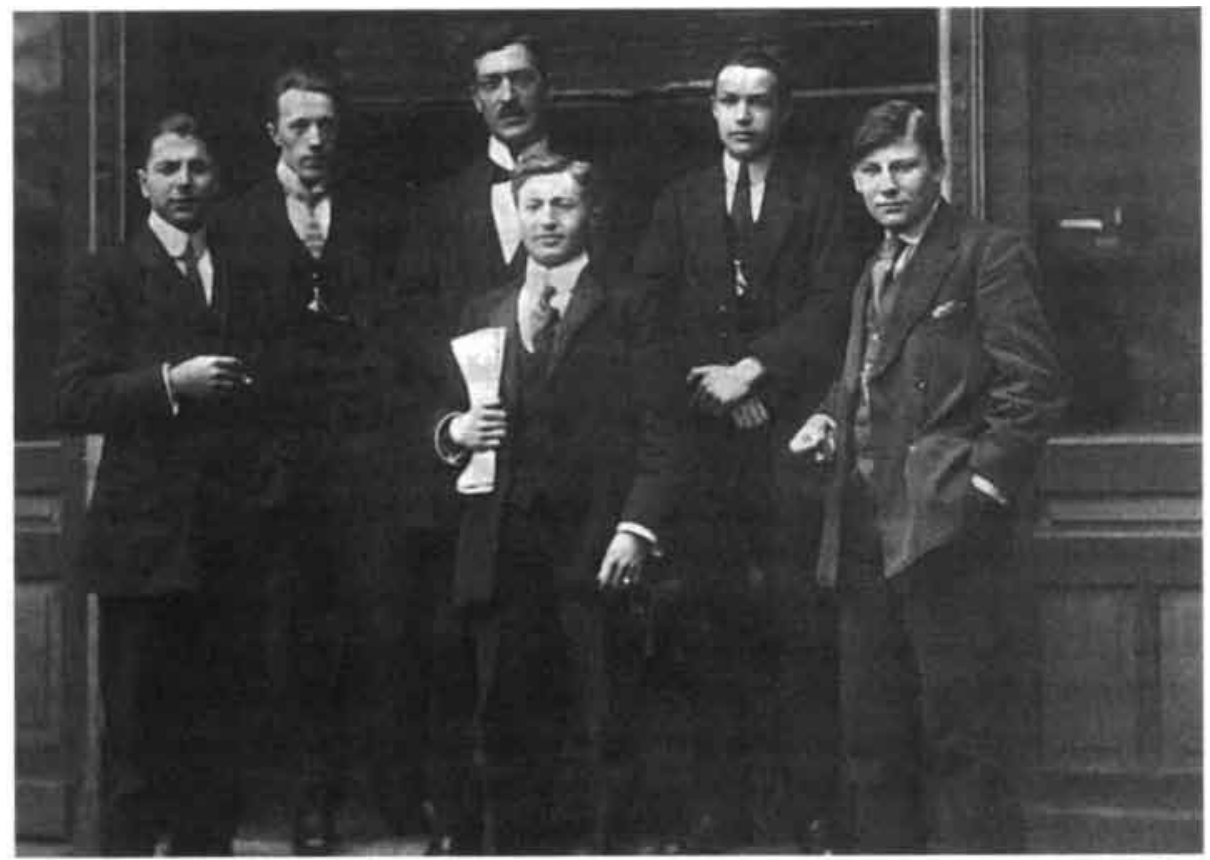

Antoon Coolen (uiterst rechts) en de redactie van het Eindhovensch Dagblad in 1918.

Begin april 1918 verhuist hij naar Maastricht; hij is redacteur van De Limburger Koerier geworden. De reden voor dit kortstondig Maastrichts avontuur [reeds in november zal hij terugkeren naar Eindhoven, C.S.] is niet duidelijk. Het meest voor de hand liggend is dat hij eens in een heel andere sfeer wil werken.

De mooie oude stad maakt grote indruk op hem, maar ook de maatschappelijke ontwikkelingen laten hem niet onberoerd. In de grote steden van Nederland wordt steeds meer honger geleden. Hier en daar leidt dat tot plundering en onlusten. In Maastricht worden hongeroptochten gehouden en vlak na zijn aankomst, op 3 april, is er een massale demonstratie van de opstandige bevolking. ${ }^{78}$ Coolen heeft deze tocht gadegeslagen en hij zal deze ervaring gebruiken in de opzet voor een nieuwe roman De Sterke! ${ }^{79}$

Hij woont in de St. Hubertuslaan 5. Slechts een paar huizen daarvandaan, op nr. 17. woont Marie Koenen. ${ }^{80}$ Deze in 1879 in 's-Hertogenbosch geboren schrijfster heeft het jaar daarvoor De moeder geschreven. Coolen gebruikt een ingezonden verhaaltje voor Jong Leven, waarvan Marie Koenen redactrice is, als voorwendsel om haar te bezoeken, herinnert hij zich later. In de loop van het gesprek zegt zij hem dat ze de toevoeging van de F. achter zijn voornaam geschrapt heeft. "Daarmee voelde ik mij lelijk betrapt op een mannelijke manier van doen - in die initialen! - maar zoals Marie Koenen de ondertekening gemaakt had, zo is 't in de toekomst toen gebleven." ${ }^{\text {"I }}$

Hoewel zijn salaris hoger is geworden - dit bedraagt nu honderd gulden per maand - is zijn financiële positie nog steeds slecht. Hij zit tot over zijn oren in de schuld, "het is net een moeras," schrijft hij aan Lutkie. In zeven kantjes stort hij zijn hart uit en vertelt over zijn wederwaardigheden. Coolen heeft vanaf Nieuwjaar tot Pasen geen kerk van binnen gezien, daarna heeft hij gebiecht en is ter communie gegaan, maar de twijfels zijn er nog altijd. 


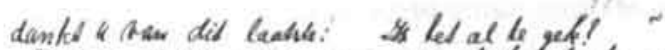

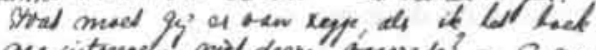

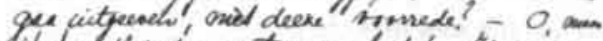

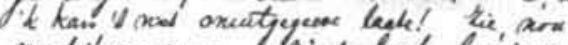

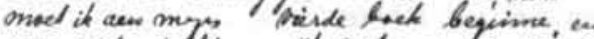

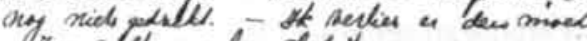
tho obtorme is, det it gees per onese os let pepies ral tigen, eorlary and iels

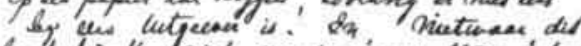

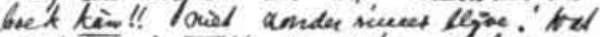

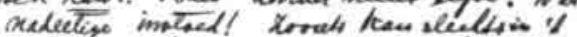

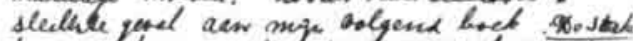

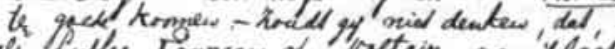

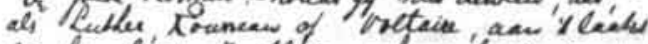

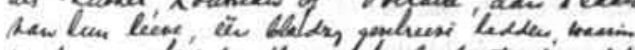

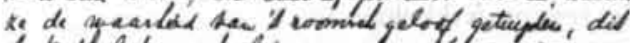

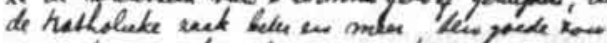

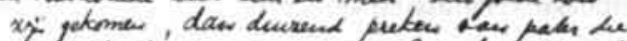

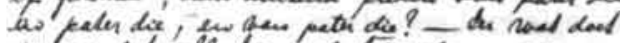

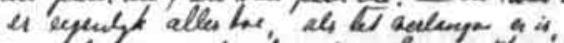

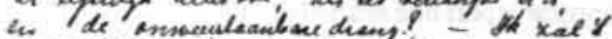
nagi Mealeulof ence of Alancturad en

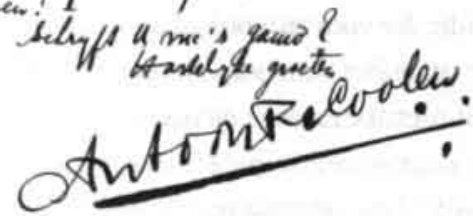

Handschrift en handtekening uit een brief aan Lutkie in september 1918. Later verdwijnen de $F$. en de drie punties.
Soms vindt hij rust in een avond. lof: "Een deemoed met mezelf, om m'n eigen armzaligheid, en een weemoed naar dat oude teedere: een kerk bij avond; en de overtuiging de wondere poësie van de mystiek van het katholieke geloof als een troost te zullen vinden en voelen. ${ }^{\text {"82 }}$

In deze 'onkerkelijke' tijd in de winter van 1917 op I 918 heeft hij het manuscript voltooid van een roman De Rozenberg met als hoofdfiguur een zekere Van Tuyl, "een would-be filosoof." Uit verdere brieven zal blijken dat deze een portret van Coolen zelf is met alle verscheurdheid en twijfel. Nogmaals belijdt hij zijn liefde voor Zola (het sublieme boek Le Rêve), maar prijst ook, waarschijnlijk om Lutkie gunstig te stemmen, de in november 1917

overleden Léon Bloy zonder overigens op de inhoud van zijn boeken in te gaan.

In Maastricht heeft hij verschillende vrienden: "een Bosschenaar, Piet Lautenslager [die woont] op de Markt. Dan nog een schilder, een bohème type. Anders had ik geen vrienden. Hier in Maastricht heb 'k als vriend den jongen dichter Kemp, dien ge ongetwijfeld wel kennen zult uit zijn werk." Pierre Kemp (1886-1967) was toen, na een kort verblijf in Amsterdam, weer terug in Maastricht. Hij was toen nog vastbesloten schilder te worden, maar hij had ook al enkele gedichten gepubliceerd. Uiteindelijk zal de poëzie het winnen van de schilderkunst. Kemp wordt een van de grootste dichters van de twintigste eeuw. Hij zal zijn hele leven in Maastricht blijven wonen. Veel van zijn gedichten zijn ontstaan tijdens zijn dagelijkse treinpendel naar de mijn Laura in Eijgelshoven, waar hij werkt op het loonbureau. ${ }^{83}$ Die schilder is Peter van den Braken, die met hem van Eindhoven naar Maastricht is meeverhuisd. Ze spraken samen veel over hun toekomst, herinnert Van den Braken zich, toen ze in Maastricht aan de Hubertuslaan samen woonden.

Perry, Roomsche kinine, 249.

80 Kusters, 'Limburg', 580.

81 Coolen, 'De Limburgse Sagendichteres', 41- 44.

82 KDC, inv. nr. 101, brief Coolen aan Lutkie, 27 april 1918.

83 Van Leeuwen, Pierre Kemp, 18. 
"Op een avond hadden we Pierre en Mathias Kemp op bezoek. Toen wij hen uitlieten zei Toon: 'Soms ben ik van één angst bevangen n.l. deze: wat moet ik doen als de bron van inspiratie (vanwaar uit ik mijn dorst les) me niet meer te drinken geeft?' Toen niemand van ons antwoordde, schokte hij met zijn schouders en schreeuwde het uit: 'Jullie weten het niet. Ik wél, als het wezenlijk zo ver komt, dan gooi ik me voor de trein."mb4

\section{Liefde en literatuur}

Er zijn echter niet alleen vrienden; er is ook een vriendin. Aan Lutkie schrijft hij:

"Iemand waar ' $k$ dagelijksche omgang mee heb, dat is een pensiongenoote, een protestant meisje, een bizonder meisje dat zeer ontwikkeld is en dat al heel wat meer van de wereld gezien heeft dan ik: zij is een beste vriendin en vraagt me altijd ' $n$ boel dingen over 't Katholicisme [...] ik had in den beginne 'n gevoel van schaamte, dat ' $k$ zoo met leege handen stond en zo poover, en weggeworpen had wat zij juist zo mooi vond, en zij, buiten alle godsdienst (want het protestantisme liet haar zo onbevredigd dat ze ' $t$ vaarwel zei) tóch juist die dingen nastreefde, die voor mij ook al aanleiding waren om m'n geloof te laten varen, en die ik, in mijn ongeloof, dan ook allereerst over boord wierp. ${ }^{\text {"85 }}$ Coolen voelt zich nu gelukkig en dat komt niet alleen door de invloed van dat meisje, maar ook door Lutkie, vervolgt hij, door "mijn voortdurende gedachte aan jou, jouw prachtige overtuiging, die mijn geweten gaande hield." Zijn 'levensangst' is verdwenen; hij heeft die beschreven bij Van Tuyl, de 'would-be-filosoof' uit De Rozenberg. Hij besluit met een antwoord op de vraag over het onderscheid tussen goed en kwaad. Hij is verbaasd in de biechtstoel soms te horen dat iets groot kwaad is, en doet misschien nog wel meer dingen die kwaad zijn:

"Gister had 'k 't er met mijn hoofdredacteur over, of je àlles lezen mocht. Ik zei van wel, hij zei van niet. Bijv. het Darwinisme. Als je daarvan wat weten woudt, dan moest je het een of ander werk van een of ander hoogstaand Katholiek, (liefst een Jezuiet) daarover lezen. Ik vond dat je dan beter deed de boeken van Darwin zelf op te slaan, ik hield voet bij stuk. En toen werd mij gezegd, dat ' $k$ zoo doorgaande in botsing zou komen met de Kath. journalistiek, en dat 'k nog wel 's wijzer zou worden."

Lutkie is het eens met die hoofdredacteur en belooft een kritische studie van een Jezuiet op te sturen: "Jezuieten houden zich meestal met dergelijke vraagstukken bezig. ${ }^{n 6} \mathrm{Hij}$ maakt zich bezorgd over het feit dat Coolen het onderscheid tussen goed en kwaad niet wil of kan zien. Vanuit een orthodox katholiek standpunt gezien is Darwins werk inderdaad gevaarlijk voor een jonge schrijver. The descent of man was voor Nietzsche een belangrijk uitgangspunt. De strekking van zijn werk Menschliches Allzumenschliches is dat de mens niet door morele opvattingen, maar door instinctieve driften tot zijn daden komt. De mens als kuddedier heeft medelijden uit eigenbelang of offert zich op tot behoud van de 'kudde'. De oorzaak ligt in het instinct. Naar aanleiding van zijn eerste novellen zal Van Duinkerken hem verwijten dat Coolens hoofdpersonen teveel vanuit deze instinctcausaliteit handelen. Ondanks die kritiek blijft dit gegeven door het hele werk van Coolen herkenbaar. We komen hier nog uitgebreid op terug. 


\section{De Rozenberg: Van Eeden of Andrejew?}

Het lezen van het manuscript van De Rozenberg stelt Lutkie almaar uit. Pas in juni gaat hij er op in. Hij vindt het wel een bewijs dat Coolen schrijven kan, maar het is nog teveel een imitatie van Van Eeden: een soort tegenhanger van diens Van de koele meren des doods. Artistiek gezien zijn sommige passages béter dan Van Eeden, maar het geheel ontbeert een boodschap. "Het is echter geen katholiek werk, dat voelt ge zelf heel goed en allerminst 'n man als Bloy zou zulk werk getolereerd hebben. Als er nou nog'n persoon in was gebracht, die antwoord gaf op de 'would-be-filosoof' van deze personaadjes. ${ }^{87}{ }^{87} \mathrm{Hij}$ vindt het meer een intiem dagboek van het eigen geestesleven van Coolen en vraagt om het zo ook te behandelen. Wat hem dwars zit komt aan het eind: hoe zit het met dat protestantse vriendinnetje? Het antwoord van Coolen is zeer zelfverzekerd en er klinkt opstandigheid in door:

"Zoo, is Rozenberg geen katholiek werk. Dat het niet staat in het teeken der propaganda voor de katholieke zaak, dat wist ik wel, maar mij dunkt, dat men best katholiek kan zijn in zijn leeve [sic] zonder te schrijven met tendenz in deze richting. Zoo de fatalistische schets Langs de Wegen van den katholieke Streuvels. De vraag is voor mij, kan ik persoonlijk, na de publicatie van Rozenberg - desnoods in gewijzigde vorm - als lid der Roomsch-Katholieke kerk getolereerd blijve [sic]: zie, ik zou voor geen schatten der aarde pervers, pornoografisch of anti-katholiek auteur willen zijn [...] het geldt hier een geval van gecompliceerde psychologie, en de ondergang van dezen rampzaligen woudbe-filosoof (vTuyl) zal toch op zijn minst voor velen een ernstige waarschuwing zijn. In 1914 schreef ' $k$ Opinies en dat werd gedrukt, in 1915 Inkwartiering en dat bleef liggen; in I916 volgde Lentebloesem en dat bleef evenzeer liggen, in 1917 eindelijk Rozenberg, en dat boek dat Gij toch ook knàp werk vindt, moet onuitgegeeve [sic] blijven net als de andere?"

Hij vindt zijn betrekking ondergeschikt aan zijn literaire arbeid. Ze zouden hem kunnen ontslaan, maar hij zou onder pseudoniem kunnen schrijven of anders kan hij terug naar het Eindhovensch Dagblad, waar de directie hem een jaarwedde van 1600 gulden heeft geboden met een jaarlijkse verhoging van roo gulden. Hij vraagt nogmaals of Lutkie voorstellen heeft om het manuscript zo te veranderen dat het wel uitgegeven kan worden. De laatste alinea van zijn brief wijdt hij aan zijn vriendin:

"En met mijn prtsche [protestantsche, C.S.] vriendin gaat 't wel, wij zijn de bèste vrienden. Zij is een meisje ongeveer als Warenka uit Anna Karenina van Tolstoi, waarvan de auteur zegt: 'men kon haar geen bepaalden ouderdom toekennen, zij kon evengoed 19 als zo jaar zijn: zij had een fraai figuur, zij geleek een schoone bloem.' Gij veronderstelt tusschen ons toch geen andere verhouding dan een platonische? $\mathrm{Zij}$ is tien jaar ouder dan ik! $!^{\text {88 }}$

84 WE, brief Peter van den Braken aan Remery, november 1970. Bij deze uitspraak moet wel in aanmerking genomen worden dat Van den Braken die doet na Coolens treinongeluk. Deze gebeurtenis kan zijn geheugen gekleurd hebben.

$88 \mathrm{KDC}$, inv. nr. 101, brief Coolen aan Lutkie, 3 juni 1918. 
In de roman van Tolstoj is dit meisje gezelschapsdame van de zieke Russische mevrouw Stahl; ze is geen familie, maar ook geen betaalde hulp. Coolen laat het dubbele in de beschrijving van Tolstoj weg. Deze schreef immers dat ze een goed figuur zou hebben, als ze niet zo mager was geweest; en dat ze op een mooie bloem lijkt, die al haar blaadjes nog heeft, maar toch al is uitgebloeid en niet meer geurt. Warenka zou voor mannen niet aantrekkelijk zijn omdat ze geen besef heeft van haar eigen bekoorlijkheden en geen levensdrift heeft. In de roman wekt Warenka de nieuwsgierigheid van het personage Kitty. Deze voelt zich tot haar aangetrokken door de grote tegenstelling tot haar eigen leven. "Zij voelde, dat zij in Warenka, in haar manier van leven, een aanwijzing zou kunnen vinden voor wat zijzelf zo wanhopig zocht: een nieuwe belangstelling voor het leven, nieuwe levenswaarden, ${ }^{89}$ Dit is precies wat Coolen zoekt en waarschijnlijk hoopt te vinden bij een tien jaar ouder, protestants 'meisje' in Maastricht.

Lutkie blijft bij zijn kritiek op De Rozenberg, maar formuleert deze zeer positief. Hij vindt het werk een bewijs dat Coolen schrijven kan, maar het is nog slechts een oefening voor het definitieve werk. Hij moet het niet uitgeven, maar ook niet vernietigen. Dan zal hij zien dat hij veel beter kan als hij ongekunsteld schrijft. Zijn brieven zijn veel beter geschreven dan dit manuscript. Lutkie stelt de Franse schrijvers van de Revue des Jeunes ten voorbeeld. "Men wil niet meer bazelen en mooipraten men veracht 't faire de la litérature. Kunst heeft een hoger doel, in Frankrijk begrijpt men dat."

Het gaat in de eerste plaats om de inhoud, en die inhoud van De Rozenberg is niet katholiek; de hoofdpersoon wordt slechts gedreven door het noodlot. De lezers van zo'n roman zouden niet snappen dat de schrijver hem als een 'would-be filosoof' heeft bedoeld. Dat brengt hem weer bij de vraag hoe het nu eigenlijk zit met het onderscheid tussen goed en kwaad bij Coolen en hoe zich dat uit in de praktijk bij lezen, doen of begeren? Hij weigert het manuscript terug te sturen als Antoon hem hier op geen antwoord geeft. Coolen gaat uitgebreid in op de kritiek op De Rozenberg en ontkent de invloed van Van Eeden, waarvan hij alleen de Johannesboeken, wat verzen en de Tagorevertalingen heeft gelezen. Van de koele meren des doods kent hij niet eens en wat hij er van zijn vriendin Tonie van gehoord heeft, loopt het eerder parallel met De Rozenberg dan dat het er een tegenhanger van is, zoals Lutkie op I juni schreef. Hij geeft wel toe dat hij een andere schrijver als voorbeeld heeft: "De invloed van Andrejew valt niet te ontkennen." Daarna gaat hij in op de opmerking dat de lezers niet zien dat het personage Van Tuyl maar als een would-be-filosoof is bedacht.

"Laat ik'et rechtuit zeggen, hij is ook als zoodanig niet bedoeld. Terwijl ik hem schreef zat bij mij geen poozietieve bedoeling voor, ik heb gewoon wille geeve wat er aan gedachten en gevoelen heevig in mij omging, en dat is deze mensch geworre, dat schrijven ging zeer makkelijk, omdat 'et meestentijds was, alsof ik in een spiegel zag en mijn eigen beeld, mijn eigen ziele- en geestesleevenbeeld maar had af te teekenen en ziedaar teevens een vingerwijziging naar de practische consekwensies, die ik aanging uit het successievelijke verlies aan het vermogen om goed en kwaad juist te onderscheiden. Is $\mathrm{U}$ dit voldoende, of verlangt U nog een nadere présiezeering? Rozenberg, daar hebt U gelijk in, is fragmentaaries, een dagboek van mij.,"

$\mathrm{Hij}$ is het eens met Lutkie om het boek niet uit te geven; eerlijk gezegd is hij van Van Tuyl, en dus van zichzelf geschrokken. Hieruit blijkt wel hoezeer Coolen in deze levensfase 
experimenteert met het schrijven. Zowel in zijn brieven als zijn aanzetten tot een roman geeft hij zich behoorlijk bloot. Aan Lutkie schrijft hij dat hij dacht dat het voldoende was om te verklaren dat het personage als een would-be filosoof bedoeld was:

"Toen dacht ik de zaak is klaar, en later dacht ik weer anders, en nou verkies ik het boek ook niet meer uit te geeven.[...] Ol ik zie zoo goed, de ondeugdelijkheid, de ondegelijk. heid, de onbeduidendheid, de kleinmenschelijke en tot een gering kringetje van literaire visie beperktheid van De Rozenberg: de schrijver ervan heeft zich vergaapt aan zijn eigen vermogen van faire de la litératuur! De winter van 1917-1918, de winter van Rozenberg is een droeve winter geweest."

Dan slaat de toon om en schrijft hij over zijn dagelijkse belevenissen in Maastricht met de gebroeders Kemp, de schrijfster Marie Koenen en zijn vriendin Tonie. Zijn positie ziet er niet al te rooskleurig uit. Hij is niet ingegaan op het aanbod van het Eindhovensch Dagblad omdat enkele eisen van zijn kant over individuele vrijheid niet ingewilligd zouden worden. Hij heeft ondertussen wel zijn baan in Maastricht opgezegd, zodat hij na augustus I9r 8 zonder werk zit. Dan is hij nog gebrouilleerd geraakt met een vriend, een schilder, die zijn vriendin Tonie misleidde (stof voor een roman, voegt hij eraan toe). Vervolgens heeft hij ruzie gekregen met de enige verstandige tante van zijn hele familie. Er is nog een tweede Warenka: met enthousiasme beschrijft hij de kennismaking met een West-Indische dame in het pension, "een protestantsch meisje, dat zeer cynisch staat zoowel tegenoover 't protestantisme als het katholicisme, en van wie een aantrekkelijkheid uitgaat om ' $r$ mee te 'boomen', zoals wij dat hier zeggen, zoo is er van alles."

\section{De Sterke!}

Elke dag groeit er echter een plan voor een nieuwe roman, getiteld De Sterke' Hij heeft geen vertrouwde vriend of raadsman, heeft ook geen moeite gedaan zo iemand te vinden; hij praat af en toe met interessante jongeren over kunst en literatuur. Hij heeft geen contact meer met Pater Hendrichs. Deze heeft zijn fiat gegeven aan Lentebloesem, maar daarna heeft Coolen nooit meer iets van hem gehoord. Drukkerij Helmond heeft er, toen het boek inclusief het omslag persklaar was, plotseling de brui aan gegeven: het kon niet, het was te druk. Later heeft drukkerij Van Leeuwen in Leiden nog toegezegd het te drukken zo gauw het papier tot de helft van de kostprijs gedaald zou zijn en nu ligt de kopij in zijn kast. "Nu hebt $\mathrm{U}$ antwoord op al wat $\mathrm{u}$ hebt gevraagd, een andere keer schrijf ik $\mathrm{U}$ iets van mijn nieuwe boek. Zendt U mij Rozenberg?" Hij zal deze vraag de komende maanden nog vaak moeten herhalen. Het lijkt er op dat Lutkie de zaak niet vertrouwt en koste wat kost wil voorkomen dat het boek De Rozenberg toch wordt uitgegeven.

Op 27 augustus 1918 meldt Coolen dat hij toch weer op de redactie van het Eindhovens Dagblad werkt. Hij woont nu in Strijp in een pension aan de Iepenlaan 4 ro en vraagt om het manuscript terug te sturen mèt de aantekeningen. "Ik vier tegenwoordig orgiën van literaire genietingen," schrijft hij aan Lutkie en somt studies op over Schopenhauer, Nietzsche, Goethe, Van Eeden, Multatuli, Stilgebauer over Rousseau, Prentice Mulford, van

89 Tolstoj, Anna Karenina, 251.

$90 \mathrm{KDC}$, inv, nr. 101, brief Lutkie aan Coolen, 26 juni 1918.

$91 \mathrm{KDC}$, inv. nr. 101, brief Coolen aan Lutkie, 21 juli 1918. Onderstreping van Coolen. 
Tolstoi Opstanding, Marcus Aurelius en 'Allan Poo', met deze laatste is waarschijnlijk Edgar Allen Poe bedoeld. Hij zou Lutkie graag weer eens ontmoeten, want hij heeft "een macht te zeggen," ze zouden dan tevens de opzet van zijn nieuwe boek De Sterke! kunnen bespreken.

Nog steeds is De Rozenberg in zijn gedachten. Hij heeft nu een inleiding geschreven, waardoor het boek wèl uitgegeven zou kunnen worden, maar dan moet het manuscript natuurlijk terug in zijn bezit komen. Herhaalde malen verzoekt hij begin september om terugzending; echter zonder resultaat. Hij denkt er over om in de herfst of de winter naar het groot seminarie in Haaren te gaan en Lutkie op te zoeken.

\section{Ruzie met de krant}

Hij houdt van die streek in dat jaargetijde omdat het hem herinnert aan zijn eerste bezoek in de winter van r914 op I915: "Midden in den winter. Dat is de plezierigste tijd. De daage van Opinies. Wat is er sindsdien al 'n inkt uit m'n pen gevloeid! U moest eens zien: 'n kast vol beschreeve velle papier. Ongeteld dan nog 't vuile werk dat ik voor die vuile kranten maak. Ik haat de zjoernalistiek!" Hierop volgt een lange boutade tegen dit vak: er is "geen stommer, geen idioter vak dan het mijne." Weer vraagt hij het manuscript terug: "Wat moet gij er van zegge, als ik het boek gaa uitgeeven, mèt deze voorrede? - $\mathrm{O}$, maar ' $\mathrm{k}$ kan 't niet onuitgegeven laate! Zie, nou moet ik aan mijn vierde boek beginne, en nog niets gedrukt (...) dit boek kàn!! niet zonder succes blijve." ${ }^{n 2}$

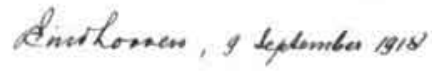

Beste Quiend.

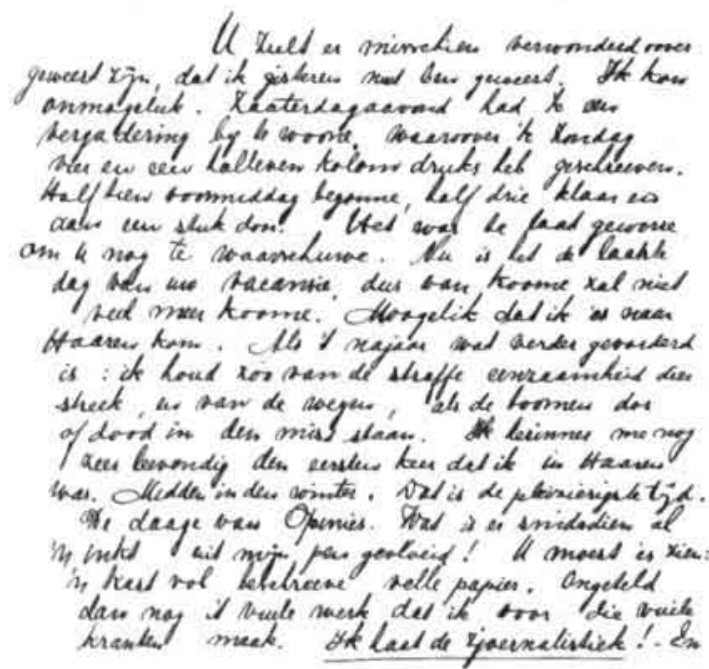

Handschrift van bovenstaande brief van Coolen aan Lutkie,

9 september 1918.
Lutkie vindt het goed dat Coolen bij hem op bezoek komt. Hij heeft het manuscript mee naar Haaren genomen: "dan kunnen we er samen over praten," ${ }^{, 93}$ ook over de inleiding. Hij stuurt het manuscript niet terug. Wel waarschuwt hij ervoor om niet overspannen te raken en geeft de raad om de moderne Fransen te lezen: "Veel vindt ge er van in 't nieuwe boekje van Greshoff Latijnsche Lente." Hij is nieuwsgierig naar de opzet van het nieuwe boek en maakt een opmerking over de drie karakteristieke puntjes in Coolens handtekening. ${ }^{94}$ Lutkie is argwanend. Misschien wel omdat hij weet dat die drie puntjes ook wel gebruikt worden als geheim teken door leden van de

vrijmetselarij, een groepering die traditioneel argwanend wordt bekeken door orthodoxe katholieken.

Twee weken later zit Coolen helemaal in de put. Op 30 september $1918 \mathrm{schrijft} \mathrm{hij} \mathrm{van-}$ 
uit de Dommelstraat 20 in Eindhoven dat hij sinds enkele dagen werkloos is; hij heeft nu geen lust om de hele 'poespas' te vertellen maar het is een ontslag op staande voet geweest.

Kort daarvoor heeft Coolen een nogal kritische recensie in het Eindhovensch Dagblad geschreven over een tentoonstelling van zijn vriend Peter van den Braken in de bioscoop Chicago. Hij verwijt Van den Braken dat hij er kopieën van prentbriefkaarten heeft tussen hangen. De ruzie met deze schilder, waarover Coolen in augustus schreef, zal daar mee te maken hebben. Het Eindhovensch Dagblad plaatst daarop een positieve bespreking, waarna Coolen via een ingezonden stuk in De Meierijsche Courant als volgt reageert:

"Ondergeteekende, tot gister eerste redacteur aan 't Eindhovensch Dagblad, verklaart hierbij nadrukkelijk, dat de in 't nummer van 't Eindhovensch Dagblad van gister voorkomende recensie van de schilderij- en beeldhouwtentoonstelling, in de ChicagoBioscope, geheel buiten zijn weten, en buiten weten ook van de overige redactie, en uitsluitend en alleen door de directie is geplaatst geworden." ${ }^{.95}$

Het zit goed fout tussen Coolen en het Eindhovensch Dagblad. Hij krijgt zelfs niet de kans om in zijn eigen krant te bewijzen dat er sprake is van kopieerwerk en moet dit daarom noodgedwongen doen in de Meierijsche Courant van I oktober 1918.

Coolen zit nu zonder inkomsten en wil daarom niet langer wachten met het sturen van $D e$ Rozenberg naar een uitgever. In de brief van 30 september herhaalt hij tot driemaal toe het verzoek om terugzending. Hij kan het niet komen halen wegens "volslagen geldgebrek." Eindelijk wordt het verzoek ingewilligd. Op I oktober stuurt Lutkie het manuscript met onuitgewerkte aantekeningen terug: "Ik neem op geen enkele manier verantwoordelijkheid voor de eventuele uitgave op mij. [...] Ik weet niet wat ik van de laatste bokkesprongen moet denken: zijt ge niet te overspannen?"

Coolen dankt op 4 oktober voor het spoedige [sic] zenden van het manuscript. Hij heeft het opgestuurd naar uitgeverij Schoonderbeek in Laren. Hij stelt voor de passages die Lutkie aangestreept heeft, weg te laten: "Dat is toch het meest aanstootelijke, zoover daar sprake van kan zijn, nietwaar? Mijn verlangen om dit onernstig werk uittegeeve is niet zoo groot, maar ik zit zonder pooziessie en zonder geld, dus moet er wat gedaan worden." Hij zegt nog eens: "Ik ken uw franschen niet," alleen Clemenceau "en diens zjoernalistieken handlangers." Vervolgens geeft hij de opzet van zijn nieuwe - "veel ernstiger" - boek weer, waar hij veertien dagen geleden aan begonnen is: het al eerder genoemde De Sterke!

"Het is een groote roman, nogal gekompliesseerd van kompooziessie, er komen zeven karakters in, drie mannen en vier vrouwen, en het hedendaagsch maatschappijtje daaromheen, het speelt in dezen oorlog. Gedeeltelijk in Holland, langs de zee, in Bergen of Katwijk gedeeltelijk in Brabant, gedeeltelijk in een oude stad in 't Zuiden (Maastricht). Op het menschelijke type van den verganen tijd, (een van Tuyl-type) maar niet 'gerede-

$92 \mathrm{KDC}$, inv, nr. 101, brief Coolen aan Lutkie, 9 september 1918. Onderstreping en afwijkende spelling van Coolen.

$93 \mathrm{KDC}$, inv. nr. 101, brief Lutkie aan Coolen, 15 september 1918.

94 Dit is de handtekening op de omslag van deze biografie. Later tekende Coolen met zijn voornaam voluit zonder de letter F. van zijn tweede naam.

95 De Meierijsche Courant, zaterdag 21 september 1918. 
neerd' doch (aangeduid) geschreven, zal de sterke mensch van den nieuwen tijd antwoord geven. Deze sterke mensch is een musicus, een temperament van zoo alzijdige heevigheid als er in de Neederlandsche literatuur nog wel niet geschreeve zal zijn. Hij bouwt aan een pooziessie geruggesteund door de bekendste menschelijke deugden, in de praktiik gebracht. Hij heeft zijn naasten lief, hij vecht zich los uit dezen tijd. Hij filozofeert niet, gaat niet teleurgesteld van dominee of pastoor weg, hij verliest ook den kop niet bij Spinoza, Schopenhauer of het uebermensliche beest Nietzsche. Hij wordt gevormd door menschen (gewone, gezond van vleesch en bloed en van geest, en 'n paar spiritueele eksessen), die zich gevormd wanen door hem, en, wil 'k psychologisch juist blijven, dan moet ik 'm menschelijkerwijze gesproken, laten duikelen. Dat doet ie dan ook, om laater de oogen te zien oopengaan voor de waarachtigheid zijner overwinning. Het boek wil tragedisch zijn en van een obzjektiviteit, die bij den objectieven Zola tevergeefs zal zijn te zoeken. Er is ook geen onbeduidend gebeuren in. Het gebeuren van Rozenberg zou in m'n nieuwe boek anderhalve paaginaa van noode hebben. De stijl is sober, en verpuurd, maar niet aanstellerig, doch mooi om zijn eenvoud, geloof ik. Het is eigenlijk een boek van het héévige leeven. Van Ravenstein, de musicus, is onbeperkt in zijn sympathieën en antipathieën, is ook onbeperkt in ' $t$ in de praktijk brengen van wat hij zich tot plicht heeft voorgeschreven omdat 't goed, en noodig was voor de dagelijksche verbeetering van zijn bestaan. Hij zou, geloof ik, kunnen heeten l'homme de l'absolu. Hij is een man niet van de theorie, maar van de praktijk, een onharmonisch brok mensch, dat harmonisch wordt. Hij is geteekend net als Milet zijn boeren teekent, met dikke forsche lijnen, en overdreeven, soms. Vooral als hij den drang niet meer weerstaat om zijn groote physieke kracht eens den vrije teugel te laten. Naast hem staat een schilder, een bohemer, (overeenkomstig $\mathrm{m}$. van Tuyl) en een vrouw (mijn prot. vriendin v. Maastricht). Het boek geeft ook groote flinke kijken op den hedendaagse maatschappij (Sportfeesten, hongeropstooten, zooals ik door de oude straten van Mtrcht [Maastricht] ooit eenige duizenden socialisten morrend zag voortgolven, passage van troepen, schouwburgen en concertzalen vol menschen enzoovoorts."

Door het einde van de Wereldoorlog met de wapenstilstand van in november $1918 \mathrm{komt}$ Coolen weer aan het werk. Hij heeft het hele jaar de rubriek buitenland verzorgd en door te schrijven over het vluchtelingenprobleem na de wapenstilstand "rolde hij er weer in." Zo kan hij op 2 I november melden dat hij weer redacteur is bij het Eindhovensch Dagblad. Hij heeft nu een kamer vlakbij het kantoor: Kleine Berg rgb. Zijn kostjuffrouw is achtentwintig. Zijn moeder is hem daar komen opzoeken: de verhouding met zijn ouders is weer goed. "Ik heb gejuicht in het Eindh Dagblad bij gelegenheid van de heugelijken wapenstilstand. Het ja van de hemel heeft gezegevierd over het neen van de hel."

Hij is hard bezig aan zijn nieuwe boek. Hij spreekt over de hedendaagse ziekte, waarmee de toen heersende Spaanse griep bedoeld wordt en die duizenden doden tot gevolg heeft. In het nieuws is dit feit enigszins verdrongen door de Wapenstilstand. Ook Lutkie is geveld door de griep en schrijft vanaf zijn ziekbed thuis in Den Bosch. Hij vraagt om vast het gedeelte van het manuscript dat af is, op te sturen. "Hoe is ook al weer de titel van dat boek van Maas dat ge zo goed vondt?" En wederom een sturing naar zijn voorkeur: "En hebt ge m'n boek over de jonge franse letterkunde al met aandacht doorgelezen? ${ }^{m 97} \mathrm{Hij}$ doelt op het eerder toegezonden boek van Greshoff, Latijnsche Lente. 


\section{Een nieuwe liefde}

$\mathrm{Na}$ de heftige briefwisseling van het afgelopen jaar heeft Coolen in de eerste helft van I9I9 weinig schriftelijk contact met zijn geestelijk leidsman. Lutkie bereidt zich voor op zijn priesterwijding ${ }^{98}$ en wordt daarna benoemd tot kapelaan in Gemonde, een dorp in de buurt van Boxtel.

Pas eind augustus 1919 geeft Coolen in twee lange brieven aan Lutkie een overzicht van de gebeurtenissen van dit jaar. Coolen is ondertussen verliefd geweest op zijn kostjuffrouw, die hij omschrijft als "een dertigjarig meisje, dat met d'r ouwe vader woonde." ${ }^{n 99}$ Het is niet de eerste en ook niet de laatste keer dat hij verliefd is op een vrouw die veel ouder is dan hij. De verliefdheid is in augustus alweer over, maar veel belangrijker is dat hij zijn baan bij het Eindhovensch Dagblad voorgoed kwijt is. Hij heeft enige tijd "rondgetold in de maalstroom van het leven" ${ }^{\prime 100}$ en woont sinds begin augustus weer bij zijn ouders. Nu het weer goed met hem gaat, kan hij kennelijk weer open schrijven aan Lutkie. In een lange brief van acht kantjes, een soort belijdenis, doet hij relaas van zijn belevenissen in Eindhoven. Hij biecht op dat zijn relatie met het dertig jarige 'meisje' ontaard was in "een oppervlakkigst sensueele passie: de weederzijdsche benaadering van twee godsdienstlooze materialisten, waarvoor 'vrije liefde' nog een te goede benadering is - Toen zag ik in van Tuyl weer mezelf."

Echter, het grootste nieuws is toch zijn verkering met Liesje Staels uit Woensel. Hij heeft haar via haar zusje leren kennen toen hij een "lezinkje" gaf voor de Eindhovense Literaire Vereeniging. Coolen had dit zusje, dat piano speelt, een paar dagen eerder leren kennen en haar een portretje van Grieg gegeven "omdat ze daar zoo mee dweepte." Toen hij ze uitnodigde voor de lezing, bracht ze een ouder zusje mee

"en dat zusje is m'n meisje geworre. - Het is het meest eenvoudige meisje ter wereld [...] zij raakte meenigmaal mijn zieleprobleem aan - om de warmte die er daadelijk in onzen omgang was, om de groote kracht van haar geloof, om - ik weet eenvoudig niet waaróm juist - kreeg ik 'r lief. Ik heb gestreeden voor ik haar vroeg bang voor ikzucht, en bezorgd over ' $r$ verleden, en als er Augustinus niet was geweest, die een enorm kerkleeraar móés worre na zóó groot een vergeeving, als er niet zooveel andere schoone voorbeelden waren van de vergeevende liefde (van God) dan had ik 'er zeker niet gevraagd. Zij stemde niet onmiddellijk toe. Zij schreide zacht, haar lichaam schokte, van de aangedaanheid harer zenuwen, zij bloedde uit den neus (misschien detailleer ik teveel) en zei langen tijd geen woord - Het was een voorzomersche, wondere aavond ik onderga nog zoozeer de bekoring van die zoete leevensdingen." ${ }^{10 t}$ Hij benadrukt haar godsdienstigheid. Zo wilde ze als een soort bezegeling van hun verloving samen met hem ter communie in het kleine bedevaartsplaatsje Meerveldhoven. $\mathrm{Ze}$

$96 \mathrm{KDC}$, inv. nr. 101, brief Coolen aan Lutkie, 4 oktober 1918, onderstrepingen en spelling van Coolen.

$97 \mathrm{KDC}$, inv. nr. 101, brief Lutkie aan Coolen, 28 november 1918.

98 De wijding vindt plaats in juni 1919. Hij draagt zijn eerste $\mathrm{H}$. Mis op in een kazuifel dat door de vrouw van Pieter van der Meer de Walcheren, Christine, is geborduurd. Zaal, De Herstellers, 25.

$99 \mathrm{KDC}$, inv. nr. 10I, brief Coolen aan Lutkie, 28 augustus 1919.

$100 \mathrm{KDC}$, inv. nr. 101, brief Coolen aan Lutkie, 23 augustus 1919.

$101 \mathrm{KDC}$, inv, nr. 101, brief Coolen aan Lutkie, 28 augustus 1919. 
zijn gegaan en "op den terugweg streed ik, net zóó als van Tuyl vóór zijn biecht - Vreemd toch, dat ik dat noodig vind - Nadien heb ik haar bij stukken en brokken m'n verleden aangeduid en zonder positieve feiten te verlangen te kènnen, heeft zij in haar liefde de kracht gevonden tot vergeving."

Lies is niet intellectueel, maar ze heeft vroeger wat Frans geleerd en ze schrijft vlot en aardig brieven en "haar thuis is net zoo eenvoudig als het mijne. Maar zeeker groot is de diepte van haar gemoed en de beschaafdheid ervan." Ze voeden elkaar wederzijds op en voelen beiden de grote rijkdom van het geloof: "Te gelóóven, o, ik begrijp niet hoe er buiten het geloof nog zelfgerustheid zijn kan."

Haar ouders hebben al toestemming gegeven, maar zijn eigen moeder wil er niets van weten, omdat hij vroeger niet deugde en in die tijd zijn moeder miskende.

Deze met vuur geschreven brief vol verliefdheid en zelfbeschuldiging vormt een staalkaart van het gemoed en de ideeën van de jonge Coolen. Er blijkt uit hoezeer hij zichzelf tekent in zijn romanpersonages en hoe groot de worsteling met het geloof is. Maar ook zijn liefde voor de natuur zit er in: zijn liefde voor het jaargetijde van de 'voorzomer', de late lente, zal in heel zijn werk zichtbaar blijven.

\section{Ontslag en vertrek uit Brabant}

Over zijn ontslag bij het Eindhovensch Dagblad brengt hij verslag uit dat bij nader onderzoek vraagtekens oplevert. Aan Lutkie schrijft hij dat hij een gunstige recensie over een lezing van een zekere Van Ginkel over de theosofische oplossing van het levensraadsel - "omdat ik momentelijk zeer verdraagzaam stond tegenover de charmante theosofie" - had geschreven, waarna er een boze brief kwam van een pater Augustijn. De week erna verscheen een artikel van twee colommen in de concurrent De Meijerijsche Courant, dat geschreven was door de hoofdredacteur daarvan, Vervoort. Volgens Coolen was de teneur van het artikel van deze "nijdas" zó negatief dat het hem zijn baantje kostte. Dat was niet nodig geweest, voegt hij eraan toe, want alles zou te rectificeren zijn geweest.

Coolen schrijft dit eind augustus en de zaak speelde al in maart r919. Uit niets blijkt dat de redactie hem heeft gedesavoueerd, integendeel zijn recensie wordt in een openbare reactie zelfs objectief genoemd. Hoe is die zaak in werkelijkheid verlopen? Coolens recensie verschijnt in het Eindhovensch Dagblad van dinsdag 18 maart I919. De verslaggeving verraadt duidelijk sympathie. Coolen meldt dat de spreker de zaaleigenaar bedankt dat de zaal niet op het laatste ogenblik is geweigerd, hetgeen dreigde te gebeuren, en constateert dat ten spijt van deze oppositie de belangstelling boven verwachting groot was. "t Onderwerp was dan ook belangwekkend genoeg en Van Ginkels voordracht van begin tot eind boeiend." De theosofie wijst volgens Van Ginkel de zoekende de weg: "de theosofie, de goddelijke wijsheid die het licht is dat ieder in de wereld komenden mensch verlicht." Het gehoor vond het prachtig: "Zijn moedgevend schoone welsprekende woord werd in ademlooze stilte aangehoord: zijn toehoorders hingen aan zijn lippen. Na afloop der voordracht werd er nog lang van gedachten gewisseld." Bovendien werd aangekondigd dat er bij voldoende belangstelling een theosofische cursus zou worden georganiseerd.

$\mathrm{Al}$ op donderdag 20 maart verschijnt er een ingezonden brief in het Eindhovensch Dagblad ondertekend met: Uw. Dw dr. P.F. Thom v.d. Vloodt OSA, Lect. Philosophiae. Deze Augustijner pater valt er over dat de theosofie een goddelijke wijsheid is genoemd, terwijl 
deze leer mét het socialisme tot de meest gevaarlijke dwalingen gerekend kan worden. De theosofie is pantheistisch, alles is God. Een gedachte die Coolen ook tegen Lutkie heeft geuit: God is de natuur. Bovendien bestaat er volgens de pater in deze leer geen hel; iedereen komt na een aantal louteringsprocessen in de schoot van de Godheid, het Alwezen terecht. "Vooral deze laatste dwaling is oorzaak dat de Theosofen laag op de Katholieke Kerk neerzien, die zij van overdreven strengheid betichten." De redactie van het Eindhovensch Dagblad plaatst onder deze brief een naschrift. Ze plaatst de brief met voldoening, want ze acht het voor de hand liggend dat de krant het niet eens is met de rede van de heer van Ginkel. "Het plaatsen van het zeer objectieve verslagje - de geciteerde omschrijvingen zijn van den heer van Ginkel, niet van ons - geschiedde alleen ter vervollediging van onzen berichtendienst. Wat hierboven door den eerwaarden inzender is gezegd omtrent de dwalingen der theosofie is geheel en al de formuleering van onze meening." Naar buiten toe valt de redactie van het Eindhovensch Dagblad Antoon Coolen dus niet af; men vindt het een 'zeer objectief verslagje'. Ook het verkleinwoord houdt niets negatiefs in, want het was inderdaad een zeer kort verhaal. Het is niet ondenkbaar dat Coolen op verzoek van de redactie dit naschrift zelf heeft geschreven.

De Meierijsche Courant ziet echter een doelwit. De twee kranten die in Eindhoven elkaars concurrent zijn, leveren voortdurend slag met elkaar. Vanuit het Eindhovensch Dagblad wordt de Meierijsche Courant voortdurend domheid, knulligheid en kleinzielig. heid verweten. Vanuit de Meierijsche Courant wordt het Eindhovensch Dagblad steeds aangevallen op al of niet vermeende afwijkingen van de katholieke leer. De Meierijsche Courant verwijt het Eindhovensch Dagblad dat het te liberaalkatholiek is. Reeds op zaterdag 22 maart r919 worden drie kolommen van de voorpagina aan de theosofiekwestie besteed. De Meierijsche Courant had van tevoren geen aandacht aan de lezing van Van Ginkel besteed, omdat men hoopte dat deze wegens zaalweigering niet door zou gaan. De Meierijsche Courant zou de bijeenkomst genegeerd hebben, maar nu blijkt dat de redacteur van het Eindhovensch Dagblad op zijn post was. Het is onvergeeflijk dat er een verslag is gekomen zonder een "behoorlijk afkeurend commentaar. Hier heeft de katholieke pers geen vrijheid van handelen; zij wordt tot zulk een commentaar gedwongen om het beginsel dat zij heeft te dienen." Vervolgens wordt het verslag van Coolen integraal weergegeven. "Zie daar! Wat zegt men daar nou van? Is het niet gewoon schandelijk?.." Ook de ingezonden brief van de Augustijn en het nawoord van de redactie van het Eindhovensch Dagblad worden weergegeven. Dit nawoord is misleidend vindt de Meierijsche Courant, want Van Ginkel kan nooit van zijn eigen toespraak hebben gezegd dat die "moedgevend schoon en welsprekend" en "van begin tot het eind boeiend" was. De Meierijsche Courant kan maar tot één conclusie komen: de redacteur van het Eindhovensch Dagblad is zelf een theosoof De Meierijsche Courant wist het al lang, maar heeft het voor zich gehouden omdat het aan "bedrijfsafgunst" zou zijn toegeschreven. Nu weet het katholieke Meierijsche volk wat ze van het Eindhovensch Dagblad kan verwachten.

De naam Coolen wordt in deze week van de theosofie in Eindhoven niet genoemd, maar kennelijk weet iedereen wie die theosofische redacteur is. Het eigenaardige is dat uit niets blijkt dat de hoofdredactie of directie van het Eindhovensch Dagblad Coolen op het matje heeft geroepen, laat staan ontslagen heeft vanwege deze kwestie. Integendeel, ruim een maand later, op 29 april r9r9, verschijnt in het Eindhovensch Dagblad een zeer positief 
verslag van een lezing van Coolen over Streuvels; het hiervoor genoemde 'lezinkje' waar hij zijn toekomstige verloofde Lies Staels leert kennen. De recensie rept over enthousiasme en literair inzicht van de spreker. Streuvels is volgens Coolen geen fatalist of uitgeleerd filosoof-psycholoog. Hij noemt Streuvels een natuurpsycholoog en toont het verschil aan met Querido, die volgens hem een literatuurpsycholoog is, aan de hand van Mooie Karel uit De Jordaan en Jan uit Langs de Wegen. Volgens het verslag was het een echte literaire gebeurtenis mede "door het enthousiaste woord van den heer Antoon Coolen." Daarnaast staan er in de maanden mei tot en met augustus ook nog verhalen van Coolen in de rubriek 'Mengelwerken'. Het zijn de verhalen van Lentebloesem, de bundel die pas twee jaar later, in I921, zal verschijnen. ${ }^{102}$

Wat de uiteindelijke reden voor het ontslag kan zijn geweest, is niet duidelijk. Kennelijk heeft Coolen er behoefte aan om zich naar buiten toe als een vrijgevochten persoon te presenteren. Uit de jongste brief aan Lutkie weten we echter dat hij ook weer veel steun heeft aan het geloof. Het lijkt er veel op dat hij afstand wil nemen van het milieu en de regio waar hij is opgegroeid om een heel ander, nieuw leven te beginnen.

Het is mogelijk dat het subjectieve stuk in het Eindhovensch Dagblad over stakingen in de Peel de doorslag heeft gegeven. Een niet ondertekend verslag uit die tijd onder de kop 'Staking in de Peel' vertoont Coolens stijl. Stakers in Helenaveen droegen borden met "steunt ons R.K. en Chr. arbeiders in onzen strijd tegen ongerechtigheid, willekeur en slavernij." De staking was tegen de maatschappij Helenaveen gericht. De verslaggever trekt partij: "Het loon is zeer laag. De arbeiders moeten 's morgens voor dag en dauw er op uit naar de verre turfvelden om het goud van de Peel te delven uit poelen en putten in de brandende zon voor een schamel stuk brood." ${ }^{103}$ Het verslag wijst echter op een nog groter onrecht: als de arme afgetobde man thuiskomt kan het zijn dat hij zijn vrouw in tranen aantreft, omdat de directie weer een van de kinderen heeft opgeëist als werkkracht. Als de peelwerker het hier niet mee eens is kan hij vertrekken. De stakingen in augustus I9I9 werden georganiseerd door de Roomsch Katholieke en Christelijke Landarbeidersbond. In de kranten werd ook melding gemaakt van pogingen om bolsjewistische propaganda onder de arbeiders te voeren door een Utrechtse HBS-leraar die tijdelijk in Best woonde. ${ }^{104}$

Na een paar weken werkloos te zijn geweest heeft Coolen even een baantje gehad bij de gemeentebedrijven in Helmond. Wouter Lutkie biedt aan om hem aan te bevelen bij $D e$ Maasbode, de krant waarin Coolen vijf jaar eerder zo denigrerend bekritiseerd werd, maar al eind augustus r919 kan de dan tweeëntwintigjarige melden dat hij een nieuwe baan heeft bij De Stichtse Post in Utrecht. 
102 Voorpublicaties uit Lentebloesem in het Eindhovensch Dagblad:

'Kwezelke', door A.C., zaterdag 24 mei 1919;

'De uiterste Dag', een Brabantsche schets van A.C., zaterdag 31 mei 1919;

'Het menschbloempje van de zandzee', een Brabantsch sprookje door A.C., zaterdag 7 juni 1919;

'De Helm', een historie van de Brabantsche Peelvakte door A.C., zaterdag 14 juni 1919;

't Was in de Lente', Uit de correspondentie van een wildzang aan haar grootvader door A.C, 30 augustus 1919.

103 Artikel 'Staking in de Peel', Eindhovensch Dagblad, maandag II augustus 1919. In een Naschrift bij de derde druk van Het goud van de Peel citeert H.H.J. Maas deze passage, maar noemt als bron De Telegraof van [zondag] 10 augustus 1919.

104 Eindhovensch Dagblad, 9 en 16 augustus 1919. 


\section{Van Brabant naar het Gooi}

"Dien avond heb ik er van gedroomd, met dat geboeide hunkeren, dat ik schrijver worden zou."

$1919-1922$

\section{Utrecht}

Op 12 september I 1919 verhuist Coolen naar Utrecht om te gaan werken bij De Stichtse Post. Voor het eerst in zijn leven woont en werkt hij in een omgeving waar niet iedereen vanzelfsprekend katholiek is. De krant waarvoor hij schrijft is echter door en door katholiek. Deze moet voor de katholieken in de diaspora een baken zijn en streng in de leer, schrijft hij aan Lutkie.' 'Ik zit hier als roomsch zjoernalist in een streek waar het antiklerikalisme veel aanhang heeft en fel naar buiten komt, maar waar anderzijds ook ijverig met [sic] het roomsch beginsel naar buiten gedraage wordt." Voor de rest voelt hij zich goed, zoals uit de wat bohémien-achtig geformuleerde brief blijkt: "Ik heb hier te U eerst wat gezwerrefd, voor ' $k$ 'n pension had: nu eevenwel ben ik goed gesitueerd met 'n tikkie komfor, m'n boeke, m'n plaate, m'n portrette waaronder ' $n$ vijftigtal van binnen en buitenlandsche literatoren, zoo alles ' $n$ beetje artistiek om me heen."

De directie, die wat huiverig voor hem was, is heel streng en heeft gezegd dat kopij die in strijd is met de roomse beginselen te allen tijde tot onmiddellijk ontslag kan leiden. Die regel past wel in die tijd, waarin de eerste tekenen te zien zijn van wat later genoemd is het Rijke Roomsche Leven. De katholieken, vooral die in het Noorden van Nederland, hebben er behoefte aan zich te manifesteren en hun geloof uit te dragen. In diezelfde maand september dat Coolen in Utrecht komt wonen, wordt daar in Tivoli de eerste Katholiekendag gehouden. Binnen enkele jaren groeit die dag uit tot een 'vlootschouw' van katholiek Nederland, zoals het Eucharistisch Congres in 1924 in Amsterdam. In 1919 wordt ook een Comité tot Bekering van Nederland opgericht. Er ontstaan allerlei verenigingen op katholieke grondslag, zoals bijvoorbeeld de R.K. Artsenvereniging in 1919, waarmee Coolen nog te maken zal krijgen, maar ook R.K. Geiten-en Konijnen-fokverenigingen. De schoolstrijd is net ten einde met de pacificatie van 1917 ; de rechten van het bijzonder (en dus ook het katholiek) onderwijs worden in 1920 in een wet vastgelegd. Er wordt hard gewerkt aan de oprichting van een katholieke universiteit, die uiteindelijk na lang touwtrekken met Tilburg en Den Bosch in 1923 in Nijmegen gevestigd zal worden. Jonge katholieke vrouwen organiseren zich in de Graalbeweging en houden weldra grote manifestaties.

Op sociaal-politiek terrein proberen de Nederlandse katholieken een antwoord te vinden op de sociale onrust en het opkomend socialisme. Zoals gemeld is Coolen in april r 918

I KDC, inv, nr. 101, brief Coolen aan Lutkie, 18 september 1919. 
getuige geweest van de grote hongeroptocht in Maastricht. In diezelfde tijd wordt in een Paasmanifest gepleit voor solidariteit tussen de klassen in plaats van klassenstrijd. Dit manifest is opgesteld door de vier katholieke standsorganisaties van werkgevers, arbeiders, boeren en middenstanders. Zij stellen voor om bedrijfsraden op te richten en collectieve arbeidsovereenkomsten te ontwerpen. Het idee wordt sterk bestreden door pater $\mathrm{F}$. Hendrichs s.j., de pater die eerder het manuscript voor Lentebloesem van Coolen heeft beoordeeld. De pater gebruikt als argument "dat Rerum Novarum noch Thomas van Aquino het systeem van bedrijfsraden hadden gekend, zodat de idee er van toch wel nauwelijks orthodox kon zijn en als verdacht moest worden afgewezen."

In die sfeer van zelfbewustwording en demonstratie van het geloof kan een katholieke krant het zich niet veroorloven om relativerend of kritisch over het eigen geloof te schrijven. Coolen heeft in deze tijd echter in de eerste plaats een probleem met de toepassing van de roomse beginselen in zijn privé-leven. In zijn brieven aan Lutkie wordt veel plaats ingeruimd voor zijn liefde voor Liesje. Ze heeft hem een boek gegeven met een paars leeslint er in met daarop in lila letters 'lieveling'; paars en lila zijn zijn lievelingskleuren. Het lint lag bij de spreuk: "De man moet strijden-de vrouw lijden. Elkaar te steunen, is de taak van beiden." Daarnaast besteedt hij veel aandacht aan de houding van de Kerk ten opzichte van de seksualiteit. In een boek van $\mathrm{dr}$. Forel $^{3}$ heeft hij met verbazing gelezen wat voor vragen biechtvaders op seksueel gebied aan hun biechtelingen stellen.

"lk heb verbaasd gestaan oover zoo perverse onbeschroomdheid, en vooral waar het navrage geldt naar vermoedde seksueele eksessen is er zóózeer gedetailleerd, dat het mij voorkomt dat 't hooren van zulke dingen in de biecht ' $n$ eenigszins daarvoor vatbaar meisje (om van mann. biechtel. $n$. te spreeke) honderdmaal meer erooties Igevoelens] zal vermoogen op te wekken als de schunnigste bladzij die Zola ooit schreef: dat dus zoo ietsveel meer kwaad doet dan dàt waarover de Kèrk den banvloek uitsprak." ${ }^{n}$ Lutkie verzoekt hem het boek van Forel op te sturen en de citaten aan te wijzen. Hij gelooft er niets van; aan priesterstudenten wordt geleerd de mensen niet teveel uit te vragen, omdat ze het kwaad daardoor juist zouden leren. Maar yerder is hij tevreden over Antoon: "Je hebt de 'stille lach' in de ziel en dat is te danken aan dat meisje met 'haar mooie zielke."'5

Op 25 oktober meldt Coolen aan Lutkie dat Lieske en hij "offiesjeel" verloofd zijn. Hij roemt de eenvoud van haar wijsheid en haar oprechtheid en naïviteit.

\section{Dreiging van ontslag}

Van de krant heeft hij een motor gekregen voor het verslaggeverwerk, maar hij heeft er nauwelijks op gereden. Coolen blijft zijn hele leven reizen met het openbaar vervoer. Journalisten op de motor zijn in de mode in die tijd; er is een foto van zijn collega Herman de Man in leren jas op een motorfiets. Een motor en motorkleding passen echter niet bij het beeld van Coolen die zich vanaf die tijd met steeds meer zwier gaat kleden. Soepel vallende jasjes, een slappe vilthoed en een artistiek geknoopte vlinderdas met stippels, de zogenaamde lavallière, geven Coolen een dandy-achtige uitstraling. Op foto's uit de Eindhovense tijd valt hij door zijn kleding nog niet op tussen zijn collega's. Pas na zijn verhuizing naar Utrecht heeft hij dit nieuwe imago gecreëerd.

Tegenover Lutkie betreurt hij het dat hij slechts een anonieme redacteur is. 's Nachts schrijft hij onverdroten voort aan zijn literaire werk. Hij kondigt aan dat binnenkort het 
eerste boek van een roman in twee boekdelen uit zal komen.

De rollen tussen Coolen en Lutkie zijn nu enigszins omgedraaid. In de wintēr van $1919 / 1920$ is Lutkie druk bezig met het regelen van transporten van Weense kinderen, die hier na de ontberingen van de Eerste Wereldoorlog komen aansterken. Daar in Wenen heeft hij de integralist Richard Kralik leren kennen, in wie Lutkie na de dood van Léon Bloy een ander lichtend voorbeeld heeft gevonden. Hij gebruikt nu Coolen als contactman om zijn reisbrieven over Wenen en Kralik in De Tijd geplaatst te krijgen. Coolen heeft daar, door de samenwerking van De Stichtse Post met De Tijd, contacten met onder andere hoofdredacteur Alphons Laudy. Lutkie heeft door al deze activiteiten steeds minder oog voor de morele en literaire problemen van zijn pupil.

Hierdoor krijgt hij pas in februari 1920 in de gaten dat er tussen de twee geliefden iets aan de hand is. Hij heeft een brief van Liesje gehad. Als hij om opheldering vraagt, krijgt hij van Coolen een uitgebreid relaas. Antoon voelt "demonische geneigdheden." Hij en Liesje tobben er samen over dat ze veel te hartstochtelijk op elkaar gericht zijn, dat ze fysiek te veel naar elkaar verlangen. Al gauw blijkt dat het vooral Liesje is die daar over tobt. De katholieke moraal staat echter seksuele omgang vóór het huwelijk onder geen enkele omstandigheid toe. De katholieke omgeving verbiedt zelfs dat verloofden 's nachts onder één dak verblijven. Dit verbod is niet zomaar een loze letter: in maart krijgt hij te horen dat hij per I juni ontslagen zal worden bij De Stichtse Post. Er zijn drie redenen: hij had op een vrijdag een boterham met vlees gegeten, met Driekoningen de $\mathrm{H}$. Mis verzuimd en ... "ik heb met mijn meiske vier daagen onder één dak vertoefd, wat mijn directeur allerschandelijkst noemt en in flagranten strijd met het katholiek beginsel. ${ }^{16} \mathrm{Hij}$ acht zich nu verloren als katholieke journalist, omdat dit de tweede keer is dat hij door een geloofskwestie ontslagen wordt. Lutkie, aan wie Coolen de hele zaak genuanceerd heeft uitgelegd, geeft een ééndimensionaal antwoord: die demonische geneigdheden zijn maar flauwe praatjes. Het betekent "hetzelfde als 't betekent in de mond van elke baliekluiver en soldaat en studentboemelaar en kroegslampamper en kermispoen. Nee jongen dat is niet demonies, maar ploertig vlegelachtig is dat en plat-ordinair."7

Wat Coolen niet weet is dat Liesje ook intensief correspondeert met Lutkie. Ze doorspekt haar brieven met aanroepen als Oh Priester, en Kapelaan. Al in oktober r 9 r 9 heeft ze geschreven dat Antoon zijn hartstochten niet kan bedwingen en dat hij niets meer gelooft. Antoon woont in Utrecht bij mensen "die niet meer katholiek zijn en zelfs SDAP zijn geworden. ${ }^{8}$ Ook heeft hij volgens haar een vriend die theosoof en vrijmetselaar is. Ze zet zich helemaal in voor de opvang van de Weense kindertransporten en heeft daardoor ook veel met Lutkie te maken.

3 Dr. Auguste Henri Forel (1848-1931) was in die tijd een gezaghebbend psychiater, die veel publiceerde over de seksuele ethiek en het seksuele vraagstuk. KDC, inv. nr. 101, brief Coolen aan Lutkie, 18 september 1919.

5 KDC, inv, nr. 101, brief Lutkie aan Coolen, 22 september 1919.

6 KDC, inv. nr. 101, brief Coolen aan Lutkie, 3 maart 1920.

$7 \mathrm{KDC}$, inv. nr. 101, brief Lutkie aan Coolen, 6 maart 1920.

8 KDC, inv, nr. 117, brief Lies Staels aan Lutkie, 16 dec 1919. 
Steeds weer blijkt Coolen in deze tijd heen en weer geslingerd te worden tussen felle opstandigheid en gedweeë volgzaamheid. Hij biedt zijn excuses aan Lutkie aan en verhaalt enthousiast over zijn ontmoeting met Alphons Laudy van De Tijd. Nu hem zijn ontslag bij De Stichtse Post is aangezegd heeft hij daar gesolliciteerd, maar dat is niet doorgegaan. Laudy vond Coolens werk geen werk van "sterke hersenen," maar meer van gevoel en over de door Coolen zelf geconstateerde "achterlijkheid in sociologische kennis" had Laudy gezegd dat hij die kennis maar moest verwerven als hij daar last van had. ${ }^{9}$

Enkele weken later gaat hij nog een stap verder in zelfkritiek; hij vindt dat hij aan "karakterzwakte" lijdt en dat het een directeur zijn goed recht is hem daarom te ontslaan. Om zich bij Lutkie te rehabiliteren, schetst hij uitvoerig de positieve personages van zijn nieuwe boek, De Sterke!, en neemt ver afstand van zijn vorige manuscript De Rozenberg.

"Wat mijn boek betreft, ik heb alle redenen mij daaroover te verheugen en er goede verwachtingen van te koestere - de slechte kwaliteiten van Rozenberg zijn er vreemd aan - de goede kwaliteiten die Rozenberg biezonder mist hééft dit boek - Karakterologies bijvoorbeeld was Rozenberg zwak - in dit nieuwe boek heb ik karakters gemaakt, zéér uiteenloopende zelfs - alleen in den dialoog hebben allen op vele plaatsen iets met elkander gemeen - het is heel moeilijk om de gedachten van elk dier breinen en de stemmingen en zoo van elk dier zielen in den juisten - psychologies - juisten verschijningsvorm te brengen, elk naar den typiesen aard. Dat kost langduurigen, nauw gezetten arbeid - en ik zal er nog aan moeten schaaven hier en daar-Dan is ook de stijl veel en veel zuiverder - en het zwaar-op-de-handse retoriese, dat in Rozenberg zoo hindert is hier nergens te zien. Dat wat de literair-artistieke kwaliteiten betreft - ('n paar van die kwaliteiten). Ooverigens reikt het gebeuren in dit boek vijfentwintig maal hooger dan het geval van Rozenberg - ik geloof er een daad mee te doen, ik geloof er werkelijk den mensen die het gaan leezen iets mee te geeven - Ook is er geen sprake van dat ik - zooals bij Rozenberg - omtrent eenige passage in twijfel zou zijn - het is alles rustig en zeker verantwoord. Dit alles geeft mij rede tot vreugde - het is een zuiver genot zoo te kunnen schrijven." 10

Het is opvallend hoe luchtig Coolen schrijft over de afwijzing van Laudy en daarmee de kans om voor een katholieke kwaliteitskrant als De Tijd te mogen werken. Maar Coolens ideaal ligt niet in een carrière als topjournalist of redacteur. Hij wil literatuur schrijven en zolang hij daar niet van kan leven moet het journalistieke werk brood op de plank brengen. $\mathrm{Hij}$ is er echter nu van overtuigd dat hij met zijn nieuwe boek De Sterke! een enorme groei als literator doormaakt. Deze overtuiging geeft hem op dit moment houvast en compenseert daarmee al zijn twijfels met betrekking tot het geloof, de liefde, de seksualiteit, de journalistiek en zijn begeleiders.

\section{Voorzichtige opstandigheid}

Lutkie zelf heeft ondertussen ook een boek geschreven. Hij stuurt aan Coolen zijn opstellen over Bloy en Kralik, het boek Nooddruft en Liefdedrang. Coolen reageert positief en verzekert hem ervan dat zijn eigen werk hier helemaal mee overeenkomt:

"Ik heb inderdaad veel gehad aan deze lektuur [...] èrg treffend op de plaatsen, waar gij uw eigen woord rechtstreeks tot de lezer richt. [...] En er staat zoveel in uw bladzijden wat ik op mezelf toepassen kan - en op bladzij 70 hebt gij zeker in mij-juist om mij- un 
bon entendeur getroffe. En zelfs heb ik hier en daar vergelijkpunten aangetroffen met reegels uit mijn boek, dat ik thans onder handen heb [...] omdat erdoor mijn oovertuiging voedsel krijgt, dat ik in mijn boek wel werkelijk den mensen iets zal geeven dat er sinds Roozeberg verheugende avanse in de ontwikkeling van mijn schrijverschap gekoome is."

Hij vergelijkt een passage uit Lutkies boek met een dialoog uit zijn eigen roman in wording De Sterke!. Omdat alleen dit citaat van de roman bewaard is gebleven volgt hier de volledige passage:

"Een enkel eksempeltje. Zoo schrijft Gij in Uw opstel over Kralik en Bloy (blz.77): 'Bloy oordeelt bitter over de menschen, hard, meedoogenloos. Dus niet goed. Wijl niet in liefde. Maar Jezus oordeelt óók zoo over de Farizeeën! Doch Jezus was God. Die doorvorschte harten en nieren. Die wist, dat hij zich niet vergiste.' Ik sieteer, ter vergelijking het volgende stukje dialoog uit mijn boek [De Sterke!, C.S.]: '... De Pausen, door Satan geplaatst op de tinnen der menschelijke vereering, zeggen niet: 'ga weg satan!'- en 'er staat geschreven'-, maar zij aanvaarden het Vatikaan. Kom daar als visscher eens binnen! Dat is de woonstede, de materieele levensgesitueerdheid van den Plaatsbekleeder van Hèm, die, toen Hij op aarde kwam, zijn voedstervader hielp timmeren en geen steen had om het hoofd op neer te leggen. Fré hoorde Caspar graag zoo bezig, ried hem aan, dat hij den oorlog tegen Rome zou prediken aan de hoeken van straten en pleinen.

- Nee, zei Fré, dat zou juist niet christelijk zijn. Nee, ik mag dat oordeel niet uitspreken ook. Als ik 't, in mijn hart, zoo zie, dan mag ik me er alleen om bedroeven ... en òm dat inzicht wordt mijn plicht om me zelf dag-aan-dag te beteren nog duurder.

- Maar Christus dan - schold die de Farizeeën niet voor huichelaars en slangengebroed? - Ik ben Christus niet, en de vergelijking gaat al niet op hierom, omdat ik maar een mensch ben. Bovendien, den rijke jongeling heeft Christus niet uitgescholden en tegenover den zondigenden Petrus was hij zachtmoedig,"m11

Naarmate deze lange brief vordert komt er meer kritiek door heen schemeren, niet alleen op Bloy en Kralik, maar ook op Lutkie zelf. Hij vindt de felle uitvallen in het opstel van Lutkie als "de lummel Maeterlinck" en "de ploert Léon Taxil" te scherp: "Ik zou niet kunnen, niet durven, zeeker niet het Maeterlinck lummel noemen." Maar hij besluit toch met de opmerking, dat hij nog nooit zo ingenomen is geweest met een "skripta van een Roomsch priester." Lutkie is wel vereerd, maar neemt zijn woorden over Maeterlinck niet terug, integendeel: "Ja Maeterlinck, belachelijk would-be-fielosoof en - mistikus, flirtende en sigarettenrokende kwast, is mij niet meer dan een lummel, 'n vlegel., ${ }^{12}$ Coolen trekt zich er schijnbaar niet veel van aan. Waar hij kán prijst hij Lutkie, maar als hij het echt niet met hem eens is, schrijft hij dat ook uitdrukkelijk. Als hij moet bemiddelen tussen Lutkie en Laudy om het artikel 'Onze Internationale' in De Tijd geplaatst te krijgen, maakt Coolen van de gelegenheid gebruik om de paus tegenover Lutkie te verdedigen. Lutkie had

9 KDC, inv. nr. 101, brief Coolen aan Lutkie, 3 april 1920.

$10 \mathrm{KDC}$, inv. nr. 101, brief Coolen aan Lutkie, 18 april 1920.

11 KDC, inv. nr. 101, brief Coolen aan Lutkie, 1 juni 1920.

12 KDC, inv. nr. 101, brief Lutkie aan Coolen, 6 juni 1920. 
geschreven dat de paus retoriek gebruikt in zijn encyclieken en andere geschriften. Coolen wijt dit aan de wisselwerking met de pers. Door de retorische reacties van kranten en tijdschriften wordt de paus op zijn beurt weer gedwongen op dezelfde toon te reageren, "zoodat hij aan het zoeken en schiften gaat en volzinnen kompliesseert [...] En als de Paus zóó werkzaam is - zoo uitsluitend verstandelijk - dan komt de èchte eenvoudige idealiste-ziel die deze Benedictus tóch schijnt te hebben - zie maar 'es de naïveteit in zijn wereldvredebeschouwingen - die komt dan, jammer genoeg, heel niet aan 't woord." ${ }^{\text {'s }}$

Steeds weer blijkt dat Coolen niet houdt van de polemische toon van Lutkie en diens voorbeeld Bloy. Het is curieus dat de twijfelaar Coolen hier de paus verdedigt tegen Lutkie, die Roomser dan de paus wil zijn. Kralik leest hij daarentegen met plezier: "Het is voor mij moeizaame inspannende lektuur. [...] Wat weet deze mens veel en hoe verbluffend veelzijdig is hij in zijn kennis. Ik weet niet wat hij 't eerst is, 't grootst: historikus, artiest of fielozoof." $^{\text {"14 }}$

Hij bekent dat hij de lectuur ook afwisselt met "lichtzinnige Duitse romannetjes." Uitgebreid corresponderen ze over een kneuterige vertaling van De navolging van Christus. Lutkie vindt dat alle vertalers verraders zijn, tradutore - traditore, en daarom is hij voorstander van het Esperanto. ${ }^{15}$ Als Coolen Lutkies boek Nooddruft en Liefdedrang moet recenseren voor De Gooische Post-zoals De Stichtse Post inmiddels is gaan heten - geeft hij op een slimme manier zijn negatieve oordeel over Bloy, waarbij Lutkie een aai en Pieter van der Meer de Walcheren een trap krijgt: "Dit is een mooi boek, dit is boeiende lektuur." Hij prijst Lutkies oordeel over Bloy "dat, om het bezonkene reeds zoveel sympathieker aandoet dan bijvoorbeeld het fanatieke en eenzijdige dwepen met Bloy van Van der Meer de Walcheren en de zijnen." ${ }^{16}$

\section{De verkering}

Door zijn correspondentie met zowel Liesje Staels als Coolen, wordt Lutkie van twee kanten op de hoogte gehouden van hun verhouding. Deze boekverkoopster spant zich zelfs op de feestavond van de Bond van Handels- Kantoor - en Winkelbedienden in voor de Weense kinderen door voor dit goede doel te collecteren. Voortdurend uit ze haar zorgen over de geloofsbeleving van Antoon. Ze heeft voor hem De navolging van Christus gekocht, in de gewraakte vertaling van pater Hendrichs. $\mathrm{Zij}$ is de eerste geweest die heeft verteld dat ze vijf dagen onder één dak in Utrecht hebben doorgebracht. Uit haar brief blijkt dat ze er veel over gepraat hebben, want ze heeft het over het "demonisch temperament" dat Coolen zegt te bezitten. ${ }^{17} \mathrm{Zij}$ heeft op de terugweg gebiecht bij de paters in Den Bosch, maar Antoon blijft maar zeggen dat liefde nooit iets kwaads kan zijn. Al in maart schrijft ze aan Lutkie dat ze van Antoon af zal gaan als hij zijn kuisheid niet kan volhouden. Ze gaat niet meer naar Utrecht; "die kamer is verdoemd. ${ }^{18}$ In september 1920 is de verkering met Liesje echter nog steeds aan en al een jaar oud. De strijd tussen de katholieke moraal en de dagelijkse praktijk van de liefde wordt heviger voor Coolen, die zich tegelijkertijd bewust wordt van de geestelijke en intellectuele kloof tussen hem en zijn meisje. Ook hij vraagt raad aan Lutkie: "Ik moet U nog wat vertellen - Enkele uit 't Eindhoovense vriendenkringetje hadden - nogal kinderachtig - zich uitgelaate, dat zij 't voor onmoogelijk hielden, dat ik (- een schrijver en zoo -) blijvend een algeheele voldoening zou vinden in Liesje, een eenvoudig brabants kind - en er mee zou gelukkig zijn. ${ }^{19}$ Vervolgens citeert hij uitgebreid een brief 
van Liesje, waarin ze hem verzekert dat die vrienden zelf later wel zullen zien hoe goed zij (Liesje en Antoon) het met elkaar hebben. Hij besluit triomfantelijk: "Ik geloof, dat Lieske hier toch mijn knappe vrienden te knap af is - hè?"

Het doet een beetje denken aan de man die zogenaamd voor een delicaat probleem van zijn vriend de dokter consulteert. Maar Lutkie geeft hem geen kans om ook maar een kiem van waarheid in de opvatting van 'zijn vrienden' te zien: "Ge zult er 't weerzinwekkende niet voldoende van gevoeld hebben. Schrijver-zijn, geleerd-zijn, beroemd-zijn, 't is me allemaal geen knip voor de neus waard, bij een nobel zielke rijk van liefde en van eenvoud [...] Eenvoud is de grootste weelde, kostbaarste schat, onuitsprekelijke rijkdom. ${ }^{20} \mathrm{Coolen}$ mag, kortom, God op zijn blote knieën danken voor een meisje als Liesje. Lutkie, die in contact staat met hen beiden hoopt zo de wankele ziel van Coolen te behoeden voor afdwalingen.

\section{Een nieuwe bundel, een nieuwe roman en een nieuwe woonplaats}

Tussen het schrijven voor de krant en het werk aan zijn romans heeft Coolen ook gewerkt aan schetsen. Hij is van plan de beste te bundelen onder de titel Lentebloesem. Hij benadert hiervoor als uitgever Het Nederlands Boekenhuis te Tilburg. De tijd en zijn omstandigheden zijn zeer onrustig. Hij verhuist enkele keren achter elkaar. Eerst van de J.P. Coenstraat in Utrecht naar een pension elders in de stad, waar hij al dezelfde avond weer vertrekt, omdat zijn medecommensalen 's avonds op zijn kamer moesten eten. Vervolgens woont hij vanaf $\mathrm{I}$ augustus $\mathrm{r} 920$ in de Adriaan van Ostadelaan ros in Utrecht, om tenslotte op ro novenber 1920 naar Hilversum te verhuizen, naar de Koningstraat 37. De reden hiervoor is dat het kantoor van De Gooische Post naar Hilversum is verplaatst. Het is dan één krant met drie kopbladen geworden. Coolen heeft het erg druk en moet alle drie de kopbladen bedienen met "lappen kopij."

Hij is zo druk met de journalistiek, het leren van Esperanto (op instigatie van Lutkie), de eindeloze onderhandelingen over de uitgave van Lentebloesem, het schrijven van wéér een nieuwe opzet voor een roman, Quid Veritas, dat hij Liesje bijna verwaarloost. Zij klaagt bij Lutkie dat Antoon al twee zondagen niet geweest is en dat ze slechts enkele koele woorden door de telefoon heeft ontvangen. Maar Coolen stelt Lutkie gerust; het gaat goed tussen hun beiden en hij heeft haar Zola's De Droom te lezen gegeven. Verdedigend voegt hij eraan toe dat een onderwijzeres en een pater het goed vonden, bovendien staat het boek niet op de index. Hij verwacht dat Lentebloesem in de winter zal uitkomen, maar in de roman Quid

KDC, inv. nr. I0I, brief Coolen aan Lutkie, 9 juni 1920.

KDC, inv. nr. 101, brief Coolen aan Lutkie, 4 juli 1920.

KDC, inv. nr. 101, brief Lutkie aan Coolen, 5 juli 1920.

[Recensie Lutkie's Nooddruft en Liefdedwang], in: De Gooische Post van 28 juli 1920. Hier zou wel eens een van de oorzaken kunnen liggen waarom Van der Meer de Walcheren het jaar daarop Coolens nieuwe boek zal afkraken. De jonge Coolen heeft nu eenmaal een pedante stij; hij schrijt niet zoals hij praat.

KDC, inv. nr. 117, brief Lies Staels aan Lutkie, 27 februari 1920.

KDC, inv. nr. 117, brief Lies Staels aan Lutkie, 10 maart 1920.

KDC, inv. nr. 101, brief Coolen aan Lutkie, 9 augustus 1920.

KDC, inv. nr. 101, brief Lutkie aan Coolen, 10 augustus 1920.

KDC, inv. nr. 101, brief Coolen aan Lutkie, 9 november 1920. 


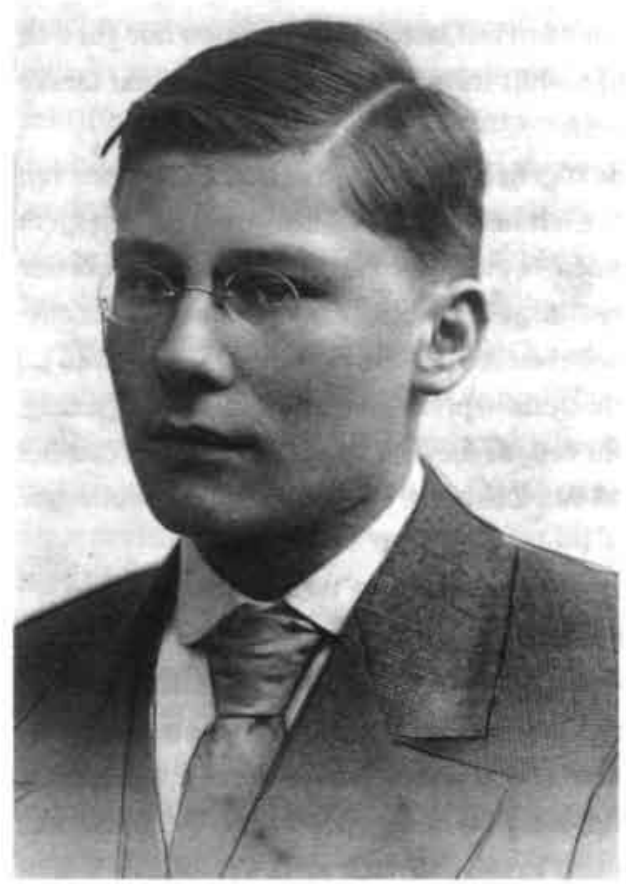

1920, journalist in Hilversum.

Veritas zit weinig vooruitgang door de drukte op de krant. Bovendien twijfelt hij weer over de typering van zijn personages: "Die Max begint me soms leelijk te verveele en die Ellen Gadiot niet minder. Nee, dan zult $\mathrm{u}$ in Lentebloesem andere mensen te zien krijgen. Zoo de vader en de moeder uit de schets 'Het kindje' en Gondeke uit 'Menschbloempje'."22

Er huizen twee zielen in zijn borst. Zo gauw hij schrijft over zijn schetsen en zijn kerstverhalen is zijn toon warmer. In zijn aanzetten voor romans ( $D e$ Rozenberg,

De Sterke!, Quid Veritas) lijkt hij steeds vast te lopen in de gekunsteldheid van zijn hoofdfiguren. Hij heeft er vooral moeite mee, het hardvochtige, het egoistische en onmenselijke personage te schetsen. De portretten van de eenvoudige en de sloebers vloeien hem makkelijker uit de pen; en hij is dan ook trots op het resultaat. Zo heeft hij van het openingsverhaal 'Het Kindje' voor de nog steeds niet verschenen bundel Lentebloesem een apart uitgaafje laten maken, dat hij met Sinterklaas aan Liesje geeft. ${ }^{23}$

"En nog deeze dagen schreef ik een schets 'Als het hart maar rijk is' die in 't Kerstnummer van een brabants blad komt, één en al frisheid en idealisme en eenvoud." ${ }^{24}$ Het is opvallend hoe dicht de hoofdpersonen Wim en Thilde van dit verhaal bij de werkelijkheid van Antoon en Liesje zitten. De jongen Wim is een klerk op een gemeentesecretarie. Hij komt uit een arbeidersgezin en heeft zich opgewerkt, hetgeen wel geleid heeft tot een breuk met de familie. Thilde is wees en naaister. Als hij vlak voor Kerstmis ziek wordt, beseft ze hoe arm hij is. Ze gaan samen naar de nachtmis, waarna zij gaat slapen bij de familie van de gemeentesecretaris. Ze lezen in de bijbel dat Jozef en Maria ook arm waren. Dan beseft Thilde hoe rijk ze is. Het verhaal eindigt aldus: "En dan, opstaande en naar hem toekomende zei ze - en dat was een stil juichen :- Wat ben ik heerlijk rijk, wat zijn we samen héérlijk rijk, hè? Dit is het allermooiste Kerstfeest, het allermooiste, mijn jongen, van mijn hele leven."

Het is verleidelijk om elementen uit dit verhaal en de zorgvuldigheid waarmee beschreven wordt hoe de overnachting van het meisje geregeld wordt, toe te passen op de situatie van Coolen. Men moet altijd oppassen om autobiografische gegevens te zeven uit een literair werk. Helman stelt dat een ervaren schrijver van alles door elkaar mengt. "Soms echter, bij beginnelingen vooral, is de over allerlei romanfiguren verspreidde 'ikkigheid' zo weinig gecamoufleerd en zo precies naar een direct beleefde realiteit beschreven, dat het geheel iets weg heeft van een sleutelroman, een stuk vermomde, scheefgetrokken autobiografie. ${ }^{25}$ In hetzelfde nummer van De Gooische Post verschijnt nog een tweede kerstver- 
haal 'Kinderen van de armen' ondertekend met A.F.C. Hierover schrijft hij later aan Lutkie dat dit toch nog te veel door Streuvels is geïnspireerd "en niet zoo direct uit het gemoed, uit het hart geschreven als die andere." ${ }^{26}$

\section{Vreugde}

Lutkie vindt de verhalen prachtig en vraagt Coolen ze in te zenden voor een nieuw door hem op te richten tijdschrift, waarvan dr. Moller de hoofdredacteur zal zijn. Dr. Moller was tot kort voordien rector van de Katholieke Leergangen in Tilburg. Een controverse met zijn curatorium en vooral met de voorzitter, het Tweede Kamerlid voor de R.K. Staatspartij, mr. dr. A.I.M.J. baron van Wijnbergen, heeft in december r 920 tot zijn ontslag geleid.

Moller (1869-1940) is opgeleid als jezuiet. Nadat hij de lagere wijdingen reeds heeft ontvangen, besluit hij echter geen priester te worden. Hij is gepromoveerd op een Vondelstudie Heerlijkheid der Kerke en wordt de oprichter van de Katholieke Leergangen. Dit is een instelling voor de opleiding van leraren die opgericht is in Amsterdam in I9I2 en daarna enkele jaren in Den Bosch gevestigd is. Het begrip leergangen is volgens Lutkie ontleend aan Les cours catholiques in Lille, omdat in die tijd de naam universiteit aan een katholieke instelling voor hoger onderwijs nog niet werd 'gegund'. ${ }^{27}$ Als de Leergangen in I9I9 van Den Bosch naar Tilburg verhuizen barst een al langer sluimerend conflict los. Katholieke intellectuelen als Gerard Brom en politici als baron van Wijnbergen verwijten Moller dat hij op weg is de leergangen uit te bouwen tot een katholieke universiteit. De katholieken willen wel een universiteit, maar los van de Leergangen en het liefst in Nijmegen.

Mollers ontslag ontketent een hevige opschudding in de katholieke wereld van Nederland, vooral bij de jongeren. Volgens Van Schaik ${ }^{28}$ heeft geen zaak in het interbellum de gemoederen in Brabant zo beziggehouden als deze. Lutkie ziet hier een kans om zich te profileren. Hij dringt zich op aan Moller als zijn verdediger en schrijft begin januari r $92 \mathrm{I}$ een serie artikelen in De Nieuwe Tilburgsche Courant onder het motto 'De levenden eren'. De artikelen vertonen zijn bekende bombastische stijl. Hij refereert aan Ernest Hello en diens opvatting over de eeuwige strijd tussen 'l'homme de génie' (lees: Moller) en 'l'homme médiocre' (lees: Van Wijnbergen). ${ }^{29} \mathrm{Al}$ gauw zal blijken dat deze bundel artikelen Moller meer kwaad dan goed doet; ze hebben ertoe bijgedragen dat de deur voor Moller bij de Leergangen voorgoed dicht valt.

Lutkie heeft echter nieuwe plannen. De oprichting van het nieuwe blad Vreugde is bedoeld als een eerbetoon aan Moller. In januari en februari ig2 I werkt hij hard aan de realisering

22 KDC, inv, nr. 101, brief Coolen aan Lutkie, 18 december 1920.

23 Ibidem.

24 Dit verhaal verscheen ook in het Kerstnummer van De Gooische Post op vrijdag 24 december 1920.

25 Helman, Mijn vriend Pieter, 74.

$26 \mathrm{KDC}$, inv. nr. 101, brief Coolen aan Lutkie, 10 januari 1921.

27 Lutkie, Doctor Moller, 30.

28 Van Schaik, Dr. Hendrik Moller, 144.

29 Lutkie, Doctor Moller, 30-31. 
van het blad dat tegen het verburgerlijkte en ingeslapen katholieke establishment is en voor de vreugde en het idealisme. Een aantal jaren daarvoor heeft Vincent Cleerdin al gepleit voor de koppeling van vreugde en literatuur. Hij ziet de vreugde als een levensbehoefte en een levenskracht, die ver staat boven het lawaai en de herrie van de schijnpret en de pretgelegenheden, waar "mannen en vrouwen met de doffe, dierlijk-glinsterende oogen, met de vaalbleeke of koortsig-gloeiende gezichten" ronddwalen binnen de steden en "vér van de natuur, waar vroegere geslachten hun vreugdefeesten wisten te vieren, in het besef, dat daar wel kracht en sterkte en zuiver genot te vinden is. ${ }^{n 0}$ De literatuur moet weer deze vreugde beschrijven en niet de troosteloze kanten van het leven zoals "de eeuwige klagers en schreiers, de altoos-ontevredenen, de steeds mokkenden en morrenden." Ook de jeugd lijdt gebrek aan vreugde. Zo luidt zijn oproep: "Meer vreugde! Komt, kunstenaars, helpt toch mede, om nieuwe levensstromen door de wereld te stuwen. [...] Gij ook, opvoeders en zielzorgers, brengt de vreugde in de wereld terug." ${ }^{\text {31 }}$

Lutkie ziet hier een podium voor Coolen: "Daar moet gij ook medewerker van worden. Stuur er oe beste stukken naar toe. Ik zal oe wel aanbevelen. Stuur zo gauw mogelijk. We zijn kopie voor vijf afleveringen aan 't verzamelen. Voor we die hebben komt er niets uit. Stuur wat ge hebt naar mij, ik geef 'et dan over aan dr. Moller. Doch alleen wat werkelijk goed is kan worden opgenomen. En 't is ' $n$ uitgesproken katoliek ondernemen. Zulke stukjes als die twee mooie kerstvertellingen van jou, die ik daarjuist gelezen heb, zulke moogde wel inzenden. ${ }^{32}$ Coolen is blij met de kans die hem geboden wordt in een blad dat "louter aan kunst gewijd [is] en onder hoofdredactie van den eminenten dr. Moller, met wiens laatste ervaaringen we hier zoo hebben meegeleefd. ${ }^{33} \mathrm{Er}$ is onlangs ook een nieuw tijdschrift De Kempen opgericht en tot opluchting van Lutkie werkt Coolen daar niet aan mee. ${ }^{34}$ Deze vindt er te weinig de Kempische ziel in, maar aan Vreugde zal hij daarentegen graag kopij inzenden. Hij heeft een groot verhaal onderhanden, waarvan 'Als het hart maar rijk is' een onderdeel is. Dat zal hij graag inzenden voor het nieuwe tijdschrift.

Hij meldt enthousiast dat Lieske in de boekhandel waar ze werkt al heel veel exemplaren van Lutkie's boek heeft verkocht en dat er nu ook gauw zijn eigen boek zal liggen. Hij is bezig met de correctie van de drukproeven van zijn bundel Lentebloesem. Lutkie vraagt, vanwege zijn connecties in Wenen om de drukproeven én zijn nieuwe romanaanzet 'Als het hart maar rijk is' op te sturen voor een eventuele Duitse vertaling. ${ }^{35}$ Coolen is nog steeds met vele zaken tegelijkertijd bezig. Hij stuurt de drukproeven van Lentebloesem en het eerste deel van zijn roman. Die roman zou hij in een ommezien af kunnen hebben, maar "nou ga ik eerst weer een toneelstuk schrijven - voor een wedstrijd is dat, en de manuskripten moeten voor $\mathrm{I}$ maart zijn ingezonden. Ik heb - in een zeldzame materialistiese bui - een begeerig oog laten slaan op den eersten prijs van $\mathrm{f}_{500 .}{ }^{.36}$

Lutkie geeft het blad Vreugde als ondertitel 'weekbrief voor idealisten: ter verrijking van het inwendige leven'. Het is de bedoeling dat Moller het gaat leiden, die naam staat in ieder geval in deze periode voor gratis publiciteit. In februari en maart I92I worden potentiële abonnees en schrijvers via een brochure opgewekt om mee te doen en op 7 maart I92I verschijnt een Uitnoodiging om in te tekenen.

"We gaan een tijdschrift oprichten: Vreugde -'n Tijdschrift voor idealisten. Hij [Moller, C.S.] zal er de leider van zijn. Het moet bestaan zonder fondsen, zonder waarborgen. 
Enkel van onze offers, ons eigen offers. Doet ge daar aan mee? Hebt ge er een offer voor over? Daar zullen we vrij ons kunnen uiten. Al wat we te zeggen hebben. En we vormen, schrijuers en lezers, één grote vriendenkring." ${ }^{\text {"II }}$

Coolen hoort met mensen als Gerard Bruning, Vincent Cleerdin, Gerard Knuvelder, Pieter van der Meer de Walcheren en pater Molenaar tot de zeventig ondertekenaars van de Uitnoodiging. ${ }^{38}$ Het eerste en, zoals zal blijken, enige nummer van Vreugde, van 3 maart I92I, is voor mgr. A.F. Diepen, bisschop van Den Bosch, aanleiding om het blad ten sterkste af te keuren. Hij wil geen twee soorten katholieken. Hij vreest dat er rond het blad een groep 'Ideaal-katholieken' zal ontstaan, op dezelfde manier als vroeger de 'Integraal-katholieken' de eenheid in de Kerk bedreigden. ${ }^{39} \mathrm{Hij}$ verbiedt Lutkie in ieder geval om er aan mee te werken. Moller heeft dan al een plan voor een ander blad: Roeping.

Moller en Lutkie schrijven eind maart een 'Bijvoegsel' bij de eerder verzonden Vitnoodiging, waarin zij aankondigen het blad Vreugde op te heffen. De toon daarvan is er niet een van bij de pakken neerzitten. Coolen reageert er enthousiast op. ${ }^{40} \mathrm{Hij}$ prijst de schrijvers dat de teleurstelling over het stoppen van het tijdschrift geen afbreuk heeft gedaan aan hun idealisme: "De ware idealist vindt 't heerlijk, dat op deze wijze zijn idealisme op de proef gesteld wordt. Terwijl hij God dankt voor de genade dit te kùnnen heerlijk vinden." Coolen vindt dat de poging niet zonder vrucht is gebleven. "Vrucht bracht de uitnoodiging al. Dat was taal, die den ontvankelijke er voor werkelijk goed deed. Vrucht wekt ook dit 'bijvoegsel' door de daad, de wijze van reageeren van U en Moller op het bisschoppelijk verzoek." Coolen is al vanaf februari r 921 op de hoogte van de plannen voor een ander tijdschrift en informeert of het waar is dat ook Roeping gevaar loopt niet uit te komen. Roeping komt inderdaad voorlopig niet uit; het zal nog tot oktober 1922 duren voor het zover is.

Coolen heeft weinig tijd om artikelen te schrijven: hij solliciteert naar een baan bij de Zeeuwsche Courant, maar krijgt bij de sollicitatie al spijt en schroeft zijn financiële eisen zo hoog op, dat het niet doorgaat. Hij heeft zijn toneelstuk Exodus afgeschreven en ingestuurd voor een prijsvraag en hij is in Hilversum verhuisd naar de Asterstraat $65 .{ }^{41}$ Daags voor Coolens vierentwintigste verjaardag schrijft Lutkie aan hem dat hij blij is om zijn reactie op het 'Bijvoegsel': "Meer dan aan al 't andere merk ik aan deze laatste uiting van jou: aan

30 Cleerdin, Omtrekken en figuren, 100.

31 Cleerdin, Omtrekken en figuren, 102.

$32 \mathrm{KDC}$, inv. nr. 101, brief Lutkie aan Coolen, Driekoningen [6 januari 1921].

33 KDC, inv. nr. 101, brief Coolen aan Lutkie, 10 januari 1921.

34 Het tijdschrift De Kempen heeft het slechts tot één nummer gebracht. Er werd onder andere aan meegewerkt door Ernst Michel, die later de fascistische kant zou uitgaan. Van der Heijden, 'Brabant krijgt literair een eigen stem', 403.

$35 \mathrm{KDC}$, inv. nr. 101, brief Lutkie aan Coolen, Maria Lichtmis [2 februari 1921].

$36 \mathrm{KDC}$, inv. nr. 10l, brief Coolen aan Lutkie, 3 februari 1921.

$37 \mathrm{KDC}$, inv. nr. 101, brief Lutkie aan Coolen, 21 februari 1921.

38 Van Schaik, Dr. Hendrik Moller, 163.

39 Van Schaik, Dr. Hendrik Moller, 164.

$40 \mathrm{KDC}$, inv. nr. 101, brief Coolen aan Lutkie, 10 april 1921.

$41 \mathrm{KDC}$, inv. nr. 101, brief Coolen aan Lutkie, 1 maart 1921. 
jouw reaktie èn op de Uitnood. èn op 't Bijvoegsel, hoeveel er in oe veranderd is, hoeveel ge groter en beter zijt geworden. ${ }^{442}$ Lutkie begint te geloven dat hij Coolen eindelijk bewust heeft gemaakt van zijn maatschappelijke rol.

Op ro juni, "la deka de Junio," r921 stuurt Coolen een brief in het Esperanto. Er is uit op te maken dat hij Lutkie vraagt of Moller het verhaal 'Als het hart maar rijk is' wil terug sturen. Dat was dus de reden, schrijft Lutkie op II juni, "dat uw reaktie op mijn verjaardagsbrief zo lang uitbleef: 'ge wilde in het Esperanto schrijven'." Hij zal het opstel terugvragen "want met Roeping wil het nog niet vlotten."

Gedurende de rest van het jaar 1921 hebben ze weinig contact. In september beklaagt Lutkie zich dat hij al lang niets meer van Coolen heeft gehoord. Van Liesje heeft hij echter vernomen dat ze trouwplannen hebben. Het stemt hem ernstig. Hij hoopt dat Coolen gelukkig zal zijn, en sterk genoeg is om Liesje waardig te blijven. ${ }^{43}$ De laatste keer dat ze met drieën bij elkaar waren heeft Lutkie over Mara voorgelezen. Mara is een personage uit het bijbelboek Ruth. Mara is een andere naam voor de schoonmoeder van Ruth, Naömi. Het verhaal van Ruth, die wegtrekt van haar land en familie heeft grote indruk op Coolen gemaakt; het thema zal regelmatig opduiken in zijn werk.

\section{Lentebloesem}

In het najaar van I 92 I verschijnt dan eindelijk de bundel schetsen, Lentebloesem. "De schetsen zijn ontstaan in de lente, 't ontluiken van mijn nieuwe en definitieve geluk. Dat vruchtbaar maakte en bloesem ontbloeien deed. ${ }^{n 4}$ De bundel bestaat uit twaalf korte verhalen die zeer verschillend zijn van sfeer en inhoud. De verhalen spelen bijna allemaal in de lente of de vroege zomer; vooral de seringen (of kruidnagelen) en witte rozen worden vaak genoemd. Twee verhalen gaan over de geboorte van een kind. Het ene komt in een gelukkig gezin ter wereld, het andere wordt geboren in de kerstnacht, waarbij moeder in het kraambed sterft, "Bij de doode bleef de vader, gebroken, ontzet, wanhopig door de groote ramp, wanhopig, o, zoo wanhopig, schreien en weeklagen."

Twee verhalen gaan over de invloed van de fabriek, de industrialisatie. Hierin zijn vroege voorlopers van Het donkere licht te herkennen. In het verhaal 'De Fabriek' raakt het uit tussen een jongen en een meisje, omdat hij er achter komt dat zij vroeger in een fabriek heeft gewerkt. Zij vertelt hem niet dat ze dat slechts drie maanden deed om geld voor haar zieke ouders te verdienen. Het verhaal ademt de sfeer van 'het doel heiligt de middelen,' maar Coolen laat hier toch al zien dat neerkijken op fabrieksmeisjes in het algemeen niet juist is. Kapelaan Frencken uit Breda is in die tijd al bezig om binnen het kader van de Eucharistische Kruistocht het catechisatiewerk onder fabrieksmeisjes te starten.

Ook in het verhaal 'Opgebracht' staat het werken in een fabriek in een somber licht. Een arme weduwe heeft een zoon die niet wil deugen. Hij gaat naar de fabriek "en werd daar een gretig gezocht aas voor het bederf, dat op fabrieken tiert." In de voorzomer koopt ze voor zijn verjaardag een houten pijp. Als ze uit de winkel komt ziet ze dat haar zoon door de politie wordt opgebracht wegens dronkenschap en blijft eenzaam met de pijp in de zomerse straat achter.

Drie verhalen gaan over de liefde op wat gevorderde leeftijd. Het is niet ondenkbaar dat Coolens ervaringen met de wat oudere ongetrouwde vrouwen op zijn vroegere kostadressen hiervoor de inspiratie hebben geboden. In 'Kwezelke' vat de bloemist in de maand mei, 
als de seringen bloeien, liefde op voor het altijd biddende en werkende Leentje van 30 jaar. $\mathrm{Zij}$ wil bij hem witte rozen kopen voor de Lieve Vrouw, maar hij schénkt ze aan haar. Aan het eind van de meimaand krijgt ze van hem rode rozen. Ze trouwen nog vóór Maria Hemelvaart op 15 augustus.

In 'De Bruidsparen' is Peer de Wever, man van in de vijftig, na de dood van zijn moeder ingetrokken bij twee ongetrouwde zusters, Anna en Trui. Als Anna met Wannes de smid trouwplannen heeft, vindt Trui dat zij en Peer niet ongetrouwd onder een dak kunnen blijven wonen vanwege de praat en trouwen zij dus ook maar.

In 'Menschbloempje' (in de tweede druk 'Liefdezuster' getiteld) ontmoet Gondeke die met haar moeder op de hei woont, een reiziger en praat met hem over de stad. Hij schetst de armoede rond de fabrieken en zegt dat ze te benijden is hier op de hei. Zij zegt dat ze nooit weg zou lopen van de arme mensen in de stad, zoals hij doet, maar hen zou helpen. De reiziger verdwijnt. Later als haar moeder dood is, ziet ze in de stad een affiche: de reiziger blijkt een beroemd violist. Ze bezoekt zijn concert en slaapt daarna op de trappen van een kerk. Ze wordt ziekenzuster en helpt de lijdende mensen in de stad.

Heel anders van toon zijn twee echte meisjesverhalen. In 'Meibruidje' lezen we in dagboekvorm hoe een "bakvisch" denkt dat de kennis van haar broer verliefd op haar is. Ze merkt niet wat de lezer al lang ziet: dat hij verliefd is op haar zuster. Het haar dat ze inmiddels al opgestoken had, gaat weer terug in een vlecht. In het verhaal 't Was in de Lente' lezen we een briefwisseling tussen een 'wildzang' en haar opa. Zij schrijft vanuit Maastricht en haar brieven vormen een lofzang op die stad en het uitzicht vanaf de St. Pietersberg. Ze logeert bij een broer en zus, die zij oom en tante noemt. Een huisvriend Max én de zogenaamde oom zijn verliefd op haar. Ze verlooft zich met Max, een ingenieur uit Den Bosch.

Een verhaal, 'De Helm', gaat over de beroemde Romeinse helm, die in het begin van de eeuw in de Peel werd gevonden en nu in het Rijksmuseum voor Oudheden in Leiden wordt bewaard. Coolen beschrijft hoe hier vroeger een paltsgraaf - in de tweede druk van 1929 is de paltsgraaf veranderd in een Romeinse honderdman - een groen licht ziet, ernaar toe loopt en wegzinkt.

Een eigenaardig verhaal is 'De uiterste dag'. De buurt treft voorbereidingen voor een gouden bruiloft. Godefridus Smits die lezen en schrijven kon en verstuikingen, brandwonden en tandpijn kon genezen, leest in de krant dat de wereld zal vergaan. Alle voortekenen wijzen erop. Men is bang dat de bruiloft niet doorgaat, maar dat is wel het geval. In de H. Mis houdt de pastoor een preek vol gezwollen bombast en clichés en denkt bij zichzelf: "Wat had hij 't toch weer schoon en goed gezegd." ledereen zingt aan het eind van het feest: "De Wereld zal nooit vergaan!"

In het verhaal 'Bart Verroke's vreemde dood' komt de verteller in het najaar voor het eerst bij de kluizenaar Bart, wint zijn vertrouwen en praat veel met hem, onder andere over zijn vrouw, die bijna twaalf jaar geleden op de twaalfde slag van twaalf december is overleden. De kluizenaar heeft twee boeken in huis: Het masker van de wereld afgetrokken van 
Adriaen Poirters en De navolging van Christus van Thomas a Kempis. Uit dit laatste leest de verteller hoofdstuk 23 voor dat over de voorbereiding op de dood gaat. Op twaalf december waakt de verteller bij Bart. Hij doezelt in en luistert naar de wind in de schoorsteen, die vertelt over verre landen en rivieren en vervolgt dan met: "Dien avond heb ik er van gedroomd, met dat geboeide hunkeren, dat ik schrijver worden zou. Daar zijn dingen, groote mooie dingen, die ik alleen maar wist, en die ik voor de menschen zou vertellen... Levendig werd het verlangen, om vooral een gróót schrijver te worden." ${ }^{45}$ De verteller schrikt wakker van de twaalf slagen van de klok: Bart Verroke is dood.

In dit laatste verhaal komt al het talent van Coolen naar voren om de invloed van de natuur op het gemoed te schilderen, zoals hier, waar de eerste ontmoeting van de verteller met Verroke wordt beschreven:

"Ik bleef toen wachten onder den boom, ik bleef luisteren naar het waaien van de wind daarboven in de dorrende kruin: dat kan zoo onafgebroken duren, duren, soms éventjes aanzwellen, héél kort maar, om meteen weer af-te-nemen: het is stil over 't land in de avond, ergens ver blaft een hond, ginds, ineens, pinkt een lichtje uit een venster, dan wordt dat lijze waaien van de wind in een eenzame boom een wonderlijk weemoedig geluid, dat heel de avond vult, het maakt de ziel bedroefd en verlangend gelijktijdig naar men weet niet wat, het uitzicht van het land en het aanschijn van het leven worden inniger, zoeter, en den mensch die voorbijgaat groet men met een stil en zacht en vriendelijk gezegden groet: goedenavond. ${ }^{46}$

Later zal Van Duinkerken schrijven dat het idioom van Lentebloesem nog niet de latere taal van Coolen is. "Het is een gevoelerig Nederlands gelijk men dit kent uit de dorpsromantiek." ${ }^{47}$ Dit oordeel mag misschien waar zijn voor de verhalen over de bakvis en het kwezeltje, maar het geldt niet voor de hele bundel. De slotpassage van Bart Verroke beschrijft de hoofdpersoon die, na hulp gehaald te hebben bij een andere boerderij, naar huis loopt:

"Ik hoorde nog eenige tijd over 't wije veld het gaan van enkele menschen in den nacht, - langer hoorde ik 't gedokker van stootende wagen-wielen in de karresporen, ik liep langzaam die geruchten achterna: de hond van het erf blafte nog één keer, kroop weer in zijn kot, twee drie keer schudde hij zijn keten en ging er gerinkel van ijzer tegen hout. $^{.48}$

Lutkie is enthousiast. Hij heeft de schetsen doorgestuurd naar dr. Oberhausen in Wenen om te kijken of ze in het Duits vertaald zouden kunnen worden. Hij vindt vooral het Brabantse aspect in de schetsen belangrijk:

"Want nu heb ik gevonden wààrop gij oe bovenal moet toeleggen: Op het bestuderen, op et uitbeelden van onze mooie, goeie Brabantse ziel. Lees ook Marie Gijssen. Niet om te kopiëren. Doch iets leren kunt ge allicht bij haar. [...] Bart Verroke is 't beste van allemaal. Daar is óók 't meeste van Brabant in. Ik heb er voor Oberhausen 'Brabant' bij gezet, bij drie van de vijf, - omdat hij 't allerliefst iets specifieks Nederlands wilde hebben. En ik heb hem ook al eens over Brabant gespróken. Dat er nog iets anders dan 'Holland' in Nederland is! Dat wij ons geen 'Hollanders' voelen! Goed, dus ge gaat nu vóór alles over Brabant schrijven. Ge hebt nu in de vreemde, met dikwijls een bezoek hierheen, nog beter gelegenheid om 'et te kennen en beminnen. Door de tegenstelling en door wat weemoed om de scheiding." ${ }^{49}$ 
Hier slaat Lutkie de spijker op de kop: de afstand tot de streek van zijn jeugd zal Coolen in staat stellen om er over te schrijven. Later zal Coolen steeds benadrukken dat het Ouwerling was die hem aanspoorde om over Brabanders en de Peel te schrijven. Waarschijnlijk heeft hij Lutkie dan wat weggemoffeld, omdat deze steeds openlijker in het kamp van de Mussolini-vereerders aanwezig is. Het motief van de afstand tot de streek waar hij opgroeide neemt hij van Lutkie over: "Misschien heeft tenslotte het heimwee om het afscheid en om het ver van brabant verwijderd zijn het gedaan."

De aanmoediging treft op dat moment in ieder geval onmiddellijk doel bij de Hilversumse journalist: "Ja, daar geeft ge me een goede raad, om me op het bestudeeren en schrijven van de brabantse ziel toe te leggen. Daar voel ik me het meest thuis en het meest vertrouwd in - en het bekoort mij ook boven alles - en ja, ik heb weezenlijk Brabant lief - Ik zal dan ook die raad goed ter harte nemen. Ge hebt wel gevoeld, dat al die poespas van Rozenberg en Quid Veritas onecht is, en feitelijk niets in vergelijk met zoo'n simpel iets als 'Opgebracht' of zoo."

\section{Weer een vernietigende kritiek}

Echter, niet iedereen denkt daar zo over. Er verschijnen enkele korte, badinerende kritieken in onder andere De Haagsche Post. ${ }^{52}$ Die spreekt van aardige verhaaltjes, lectuur voor het hele gezin. De conclusie is dat Lentebloesem een aardig boekje is "voor bakvisschen, die geen zijden kousen dragen!" Het Algemeen Handelsblad is venijniger. Moet deze bundel een belofte zijn voor de toekomst? vraagt de recensent zich af. De wrakke knopjes en de tere bloempjes van dit talent zouden iets roerends kunnen hebben. "Maar .. het bloesemknopje blaast zich op als was het een heuschelijke vrucht; echte literatuur met expresselijk daartoe vervaardigde zinsconstructies, ja en dan worden we boos, och! Niet kwaad, maar zo'n beetje verstoord om de stoutheid. ${ }^{53}$

Zeven jaar na de kleinerende kritiek in De Maasbode, na zeven jaar van ploeteren en zwoegen aan talloze concepten, krijgt Coolen opnieuw kleinerende en neerbuigende recensies. De felste kritiek komt ook nu weer uit de katholieke hoek; niet van een anonieme schrijver maar van een opinieleider van een toonaangevend weekblad, namelijk Pieter van der Meer de Walcheren in het oktobernummer 1921 van De Nieuwe Eeuw uit Helmond. Deze heeft lang geaarzeld of hij deze prozabundel van Anton [sic] Coolen wel zou bespreken en of het wel de moeite waard was iets over dit "boekske" te beweren. Hij heeft het uiteindelijk toch gedaan omdat het noodzakelijk is dat iemand eens eerlijk zegt dat het niet aangaat om zulk "onrijp werk" uit te geven. Hij heeft niets tegen jong werk, maar dit is vol-

Coolen, Lentebloesem, 162.

Coolen, Lentebloesem, 145-146.

Van Duinkerken, Antoon Coolen, 1949.

48 Coolen, Lentebloesem, 165-166.

49 KDC, inv, nr. 101, brief Lutkie aan Coolen, 5 februari 1921.

50 Coolen, 'Hoe ik er toe kwam', 38.

51 KDC, iñv. nr. 101, brief Coolen aan Lutkie, 8 februari 1921.

52 'Lentebloesem', in: De Haagsche Post.

53 'Lentebloesem', in: Algemeen Handelsblad. 
strekt onbeduidend. Hij is met sympathie en goede wil beginnen te lezen, hopend dat hij iets goeds zou tegen komen.

"Maar als ik vijftig pagina's gelezen heb over Het Kindje, het Meibruidje, Kerstkindje, 't

Was in de Lente, en ik voel mij verzinken in een put van onnoozelheid en sentimentaliteit, dan komt er een eind aan mijn lankmoedigheid en sla ik het boek met geweld dicht op gevaar af van het Kindje, Bruidje, Leentje, Truike, Doortje, Gondeke en den sympathieke jongen schrijver zeer te doen."

$\mathrm{Hij}$ is er van overtuigd dat de schrijver een gevoelige jongeman is, maar hij had dit kinderachtig geschrijf in portefeuille moeten houden. Er steekt volgens Van der Meer wel enig talent in Coolen, maar de weinige passages die dit laten zien liggen begraven onder breedsprakigheid. Het verhaal over Bart Verroke vindt hij het meest geslaagd. Zijn conclusie biedt niet veel perspectief:

"Wanneer Anton Coolen, die gevoel voor de natuur en deernis met de sjofelen en de misdeelden heeft, hard werkt en zich niet meer tevreden stelt met onbeduidendheidjes als de verhaaltjes die hij in dit boekje gebundeld heeft [...] dan is het wel mogelijk, . en ik hoop het van ganser harte, - dat men nog eenmaal iets goeds, - al zal het vermoedelijk niet iets buitengewoons zijn, - van hem verwachten mag. ${ }^{\text {"54 }}$

Deze kritiek heeft Coolen aan het denken gezet; de scherpe woorden van Van der Meer hebben hem doen inzien dat hij in deze bundel niet zichzelf is. Hij merkt dat hij zich teveel laat beïnvloeden door anderen. Hij heeft tot nu toe zelf die schetsjes ook steeds geroemd, maar de meeste zijn al twee en een half jaar daarvoor gepubliceerd in het Eindhovensch Dagblad en ondertussen heeft hij hard gewerkt aan de concepten van wel drie romans. Hij ziet in dat hij zich bij het schrijven van literair werk voor publicatie onbewust laat leiden door de wens om zowel bij Lieske als bij Lutkie in de smaak te vallen; bovendien weet hij dat deze twee steeds vaker met elkaar corresponderen over geloofszaken en de publicaties van Lutkie. Door deze kritieken moet Coolen zich er van bewust geworden zijn dat hij van zijn literaire producten juist de verkeerde publiceert: de onschuldige schetsjes, die bij Lutkie in de smaak vallen. Hij weet dat hij ook iets anders kan maken. Om daarmee voor de dag te kunnen komen moet hij zich eerst losmaken van zijn begeleider, maar ook van zijn meisje. De negatieve ontvangst van Lentebloesem is de directe oorzaak van het uitraken van de verkering, maar leidt indirect ook tot de breuk tussen Coolen en Lutkie, een klein jaar later. De kritiek heeft hem de ogen geopend en doen beseffen dat hij bezig is zich in een keurslijf te persen.

Hóe de recensie in oktober 192 I bij Coolen heeft geleid tot een andere kijk op zijn meisje beschrijft hij enkele maanden later uitgebreid in een Nieuwjaarswens aan Lutkie. ${ }^{55}$ Op de dag, dat de recensie verschenen was, stond hij op het perron in Bussum om haar op te halen en bedacht dat Van der Meer gelijk had en dat zijn Lentebloesem inderdaad sentimenteel en onbeduidend was. Tegelijkertijd dacht hij hoe zijn verloofde zo meteen uit de trein zou stappen "klein tussen de mensen, met haar hoofdje scheef en haar bekende lachje" en bedenkt dat zij sentimenteel, "dikwijls onfrisch sentimenteel" is. Als ze dan inderdaad op de beschreven manier op hem toeloopt, merkt hij dat de liefde over is en in gedachten begaat hij de "wreedheid" om haar de schuld te geven van de negatieve recensie. Door haar sentimentaliteit is het boekje zo geworden als het was. In het exemplaar van Lentebloesem voor Liesje heeft hij een opdracht geschreven: "aan mijn lieveling, uit wier hartje en in wier 
liefde deze bladzijden zijn geschreven." Uit deze liefde heeft hij geput voor zijn verhalen en daardoor is het voor een niet verliefde en nuchtere lezer "onbeduidend van banale oppervlakkige sentimentaliteit," zoals Van de Meers oordeel luidde. Coolen zegt dat Lutkie dat wel antipathiek zal vinden, maar dit is geen reden om het te verzwijgen. Wel zegt hij erbij dat hij er nu niet zo meer over denkt, maar dat neemt niet weg dat hij niet meer van haar houdt. Waarom weet hij niet: "Ik kan geen feit vinden." Ze boeit hem niet meer, erger nog ze verveelt hem, hij ergert zich aan haar brieven, aan de taalfouten die ze maakt. Opvallend zijn de voorbeelden die Coolen geeft van ergernissen uit het dagelijks leven: haar manier van lopen en lachen, maar ook haar geëxalteerde manier van schrijven en de spelfouten erin. In zijn latere beschrijving van ruziënde echtparen wordt er altijd veel nadruk op gelegd hoe de een zich aan alles (eten, slapen, gewoonten) van de andere ergert.

Eigenlijk voelt hij zich opgelucht. Hij werkt hard en schrijft veel en met Kerstmis is hij thuis geweest en heeft hij "een echt gezellig Kerstfeest gehad. Moeder was zoo goed voor me, en ik voor haar." Toch vraagt hij na enkele weken of Lutkie het adres van Lieske weet. Lutkie antwoordt dat hij haar adres ook niet weet. Ze heeft hem een paar weken terug geschreven dat ze een tijdje naar haar zuster zou gaan, maar waar die woont weet hij niet. Het briefje verwondert hem; de liefde was toch dood? "Plaag het kind dan niet meer en laat haar in vrede. En plaag ook oe eigen niet met hersenschimmen na te jagen. Werk maar liever hard en - edelmoedig. Ja, bidden doe ik natuurlik voor jou." 56

Per omgaande antwoordt Coolen dat hij helemaal niet van plan is het kind te plagen. Hij weet nu waar ze is. $\mathrm{Hij}$ is wel eens bij die getrouwde zuster van haar geweest, maar kan zich de naam van die plaats en van die mensen niet meer herinneren. Toen hij een brief van Liesje kreeg had hij "van die momenten van ontzettende Sehnsucht [...] kon de gedachten niet verdragen, dat ik niet wist waar ze was. Ik dramatiseerde dat heengaan wat -voila le [sic] chose." ${ }^{57} \mathrm{Hij}$ is blij met 't laatste zinnetje uit Lutkie's brief en vraagt of hij het eerste bedrijf van zijn toneelstuk Exodus wil doorlezen.

Als er geen antwoord komt, schrijft hij verontwaardigd dat hij er niets van begrijpt. Het is nu maart en Lutkie heeft nog steeds niet geantwoord op zijn lange brief van tien kantjes van 4 januari 1922. Hij heeft alleen een kort antwoord gehad op zijn vraag naar het adres van Liesje, maar nu hij een heel bedrijf van een toneelstuk heeft opgestuurd "moet hij maar vertrouwen op de Nederlandsche Posterijen en gelooven, dat 't goed is overgekomen in Gemonde. ${ }^{.58} \mathrm{Hij}$ vraagt wat de reden van het zwijgen is. Vervolgens meldt hij dat hij aan een nieuwe roman bezig is en dat die bijna af is. Hij is er helemaal vol van en kan er bijna niet over zwijgen. Een paar maanden later meldt hij nog een keer dat hij aan groot werk bezig is. "En aan mijn roman ben ik bezig de laatste hand te leggen. De stoere P vd M d W zal, als dit boek uitkomt (ik stuur 't naar het boekhuis) het wel weer sentiementeel en onbeduidend vinden. Misschien gebruik ik als bijschrift bij de titel: 'een simpel verhaal van eenvoudige mensen' - of zooiets.. ${ }^{59}$ Jammer genoeg wordt over deze zoveelste aanzet

54 Van der Meer de Walcheren, 'Lentebloesem door Anton [sic] Coolen', 19.

$55 \mathrm{KDC}$, inv. nr. 10I, brief Coolen aan Lutkie, 4 januari 1922.

$56 \mathrm{KDC}$, inv, nr. 101, brief Lutkie aan Coolen, 21 februari 1922.

57 KDC, inv. nr. 101, brief Coolen aan Lutkie, 22 februari 1922.

$58 \mathrm{KDC}$, inv. nr. 101, brief Coolen aan Lutkie, II maart 1922. 
tot een roman verder niets meer vernomen, doordat de correspondentie met Lutkie weldra wordt afgebroken. Geen van de manuscripten is bewaard, met uitzondering van het toneelstuk Exodus.

Hij schrijft dat Liesje vandaag jarig is en dat hij haar toch gefeliciteerd heeft. De brief heeft hij naar haar familie in Woensel gestuurd, met het verzoek om deze eventueel door te sturen. Dan volgt een lang citaat uit Strindberg over verwijdering die tussen echtgenoten of verloofden kan ontstaan. Hij onderstreept daarin hoe deze begint - "Alle Verdienste verwandeln sich in Fehler" -, maar ook het gemis na de scheiding: dan "begint das Leiden der Sehnsucht, das grösser ist als die grössten Leiden, die das Leben bieten kann." Dit laatste duurt bij hem nu al weken en weken.

\section{Exodus}

$\mathrm{Nu}$ antwoordt Lutkie wel meteen. Hij gaat eerst in op het toneelstuk Exodus. Hij vindt de geest goed, het bevalt hem beter dan vorig werk. Hij zal kijken of hij er nog opmerkingen bij zal maken. Daarna schrijft hij over de liefdesperikelen:

"Zeg, gooi die malle duitse fielosofie dan óók maar overboord. Dat zou beter in de geest van dit werk zijn. Of die hoge wijsheid waar is of niet waar, daar zullen we maar niet over twisten. En 't heeft geen zin. Maar dit is duidelijk: dat gepieker doet niets goeds. Doet geen goed aan oe energie. Sticht noch sterkt oe wil. En daarom: gooi die ballast overboord. en i.p.v. zo'n wilsbelemmering, neem iets wat bevordert, wat oe vooruit helpt. Is oe roman in dezelfde geest als Exodus?" ${ }^{m 0}$

Coolen is blij dat hij weer over zijn werk kan schrijven. Hij vraagt zich af of Lutkie al enig idee heeft over hoe Exodus zal aflopen, hij heeft immers alleen nog maar het eerste bedrijf kunnen lezen. Zijn roman is weer iets heel anders. Deze is

"als een mooie lieve droom, waaraan ik het vruchtbaarst schrijf in zeer milde stemmingen en sentimenteel buien. [...] Ik kan zeker niet uitdrukken in wat voor stemmingen ik soms ben, als ik daaraan schrijf, maar, kijk, je zou de halve wereld willen omhelzen, voor een ieder mild-goed willen zijn, een ieder voor een goed mensch willen aanzien en ieder van menselijke goedheid willen spreken."

Hij heeft opgekeken tegen die filosofie van Strindberg en, hoewel hij blij was weer het geluid van Lutkie te horen, vindt hij die filosofie toch niet zo gek. Hij herkent waarover Strindberg schrijft en daarom heeft het waarde voor hem. Als hij Entzweit und Einsam, de autobiografie van Strindberg, een half jaar eerder gelezen zou hebben, zou zijn verloving misschien niet uit geraakt zijn. Hij gaat alinea's lang in tégen de opvatting van Lutkie. Dat is nieuw in zijn brieven. Hij zegt dat zijn lijden door het gescheiden zijn van Liesje ontstellend reëel is. Hij heeft zoveel positieve herinneringen aan haar: "Die groote, geweldige zoomer, de dagen, dat Liesje en ik, in deze vakantie, daar in 't zuiden van Limburg waren." Dan volgt een lange loftuiting op zijn voormalige verloofde en - misschien ter verdediging van de 'demonen' in hem zelf - haar hartstocht:

"Liesje was hartstochtelijk, dat weet gij misschien niet zoo niet, maar zij was het erg. $\mathrm{Zij}$ kon me klemmen in haar kleine armen als om bezit van me te nemen voor heel het leven, en in zulk een omhelzing dan trilde door heel haar lijfje en sprak uit het glanzen van dien wonderlijk gelijktijdig droef en blije blik van haar oogen de liefde die naar buiten wou, als een hévige schreeuw, een màcht, die zij voelde, overstelpend, en waar- 
in zij sprakeloos was, omdat zij 't niet zeggen kon." ${ }^{\text {"61 }}$

$\mathrm{Na}$ enkele bladzijden waarin hij betreurt dat hij gespot heeft met haar sentimentaliteit en haar fijngevoeligheid bewondert, besluit hij met de verzuchting: "Lieve deugd, wat een sentimentaliteit! Waar moet ik het vinden, dàt, dat mij vooruit helpen zal. Ik zit volkomen vast in de weemoedige herinneringen."

Hij praat er af en toe over met een oudere dame in de buurt, die naar hem wil luisteren en Lutkie moet deze twaalf (!) vellen maar beschouwen als een fragment van een dagboek. Pas op 22 mei vraagt Coolen of Lutkie het derde bedrijf van Exodus heeft ontvangen. Voorzichtig vraagt hij hem of hij het vlug wil doorlezen en daarna het hele stuk wil terugsturen. Hij is zeer benieuwd naar het oordeel van Lutkie en vreest dat het stuk bij hem anders over is gekomen dan bedoeld, omdat hij het met lange 'entre-actes' in brokstukken heeft moeten lezen.

Het toneelstuk Exodus dat nooit is uitgegeven of gespeeld, is symbolisch voor de situatie waarin Coolen op dat moment verkeert. Een jongeman, Fré de Raadt, die slechts vier jaar van de HBS heeft afgemaakt, vertrekt naar Indië om daar tot zichzelf te komen en zich voor te bereiden op een goed huwelijk. In lange gesprekken met zijn vriend Fernand Wilke die in de eerste concepten van het stuk een personage was dat geen boeken las, komt hij tot de conclusie dat hij van zijn leven tot nu toe niet veel gemaakt heeft en niet geschikt is voor het huwelijk. De zaak wordt vanuit het vrouwelijk aspect bekeken in een lang gesprek tussen Lans, zusje van Fré, en Tilly, het zusje van Fernand. Lans vindt dat een man zijn zaken vóór het huwelijk op orde moet hebben, maar Tilly denkt dat een vrouw een man binnen het huwelijk op de rechte weg kan brengen door haar liefde. Niet voor niets noemt Coolen Tilly de hoofdfiguur van het stuk "een meisje waar je god op je blote knieën voor zou danken." Opvallend is dat er in het hele stuk geen enkele verwijzing naar godsdienstige of religieuze moraal te vinden is.

Coolen geeft de volgende toelichting aan Lutkie:

"De tietel behoeft natuurlijk geen eksplikaassie. Die wordt symbolies verstaan, en is, in dezen symboliessen zin ontleend aan den naam van het bijbelboek. Gij houdt niet van realistische komedie, onze eigen wereld, die wij zelf beleven, vertoonend in een spel. Dit neemt niet weg, dat gij toch objectief in uw beoordeling zijn zult en afgaat, natuurlijk op den indruk, die de lektuur van dit stuk maakt, als lektuur dus. In Nooddruft en Liefdedrang, laat ge, in deze meening, voorbehoud vermoeden ten aanzien van het zoogenaamde vergeestelijkte toneel. Nu, daar houd ik helemaal niet van. ${ }^{62}$

Hij gelooft nog in de realistische komedie over "het leven dat we zelf hebben" en houdt ook niet van de mysteriespelen en de bijbehorende uitdossing van de spelers, de verheven taal en de fraaie verzen. Hij vindt dat net zo mal als de een of andere held die zijn ogen laat rollen "om te doen zien, hoe ie van binnen gefolterd wordt." De inhoud van dit stuk zal Lutkie hier en daar herinneren aan Rozenberg en Fré heeft veel vergelijkpunten met die mijnheer uit Rozenberg die Lutkie "een luuksen lanterfanter" noemde. Echter daar staat in het eerste

$59 \mathrm{KDC}$, inv, nr. 101, brief Coolen aan Lutkie, 22 mei 1922

$60 \mathrm{KDC}$, inv, nr. 101, brief Lutkie aan Coolen, 13 maart 1922.

$61 \mathrm{KDC}$, inv, nr. 101, brief Coolen aan Lutkie, 14-18 maart 1922

$62 \mathrm{KDC}$, inv, nr. 101, brief Coolen aan Lutkie, 22 mei 1922. 
bedrijf al onmiddellijk Fernand tegenover en in het tweede en derde bedrijf dat geïdealiseerde meisje, waarin volgens de schrijver trekken van Liesje te herkennen zijn.

Hij weet nog niet wat hij met het stuk gaat doen: naar een uitgever of naar een gezelschap gaan, waarschijnlijk eerst maar eens een drukker. Hij vraagt of het klopt dat Roeping binnenkort uit zal komen: hij heeft nog een paar mooie schetsen liggen. Hij is ondertussen verhuisd naar de Taludweg 69 in Hilversum.

Van het drukken van het toneelstuk komt niets terecht; hij komt in een vicieuze cirkel. Het Nederlands Boekhuis in Tilburg wil alleen een uitgave overwegen als het stuk gespeeld is. ${ }^{65}$ Het Schouwtoneel, waarmee Coolen contact heeft gelegd, wil er echter niet aan beginnen: men heeft bezwaren tegen de dialoog die te boekerig is en tegen de lengte van het stuk. ${ }^{64}$

\section{Exit Liesje}

De communicatie tussen Lutkie en Coolen wordt steeds eenzijdiger en alleen op het doen en laten van de laatste gericht. Als Coolen in de zomer van 1922 vraagt waar zijn manuscript blijft, komt er een adreswijziging. Lutkie is verhuisd naar Nuland. "Ik lees anders nog al vaak de kerkberichten, maar deze benoeming is mij toch ontgaan." ${ }^{65}$

Het is ook geen benoeming als parochiegeestelijke. Lutkie is overspannen en woont nu in een buitenhuisje van de familie Ras-van den Eerenbeemt. Lutkie is eind 1921 enige tijd in Poznan geweest. De metropoliet van de Oekraiense katholieken in Polen had hem gevraagd om zijn apostolaat te ondersteunen. ${ }^{66}$ Dit is de reden dat er het laatste kwartaal van 1921 zo weinig correspondentie tussen Coolen en Lutkie is geweest. Bij terugkomst verbood mgr. Diepen Lutkie om zijn standplaats te verlaten. Toen hij om een rectoraat verzocht werd hem dit onthouden. Lutkie zal vanaf nu niet meer in een parochie werkzaam zijn. Hij zal zijn hele leven lang een ongebonden priester blijven en in het huisje in Nuland, dat hij 'Soli Deo' zal noemen, blijven wonen.

Hij heeft dus andere dingen aan zijn hoofd dan het manuscript van Coolen. Deze herinnert hem op 18 juni nogmaals aan zijn verzoek om het terug te sturen, omdat in Bussum een groep "toneelisten" die het jaar daarvoor met veel succes een éénakter van hem gespeeld heeft nu ook Exodus wil opvoeren. Hij wil het aan hen voorlezen, dan weten ze meteen hoe hij 't gespeeld wil hebben: "naar binnen toe." Het moet een innigheid hebben die het hart van de toeschouwer dadelijk treft en steeds boeit.

Zonder overgang vervolgt Coolen:

"Heeft Liesje U op de hoogte gehouden van haar omgang met m'n broer? Dat is heel eigenaardig. Met Paschen heb ik haar ontmoet, en, kijk een uur na de ontmoeting was alles bij 't oude. We hebben erregends in een dennebosch op een stil plekske zoo innig gelukkig weer gezeten. En tweede Paasdag - Liesje had me verteld, dat mijn broer van 'r was gaan houden, en dat ze zoozeer medelijden met hem had, dat hij nu zoo teleurgesteld moest worre, maar kijk, tweede Paaschdag, liet ze me een brief aan mijn broer lezen en daaruit las ik, nu - ik las eenvoudig, dat al eenige tijd m'n broer en Liesje zich in stilte hadden verloofd!"

Het wordt nog erger als zijn broer hem met Pinksteren vertelt, dat Liesje over die Paasdag gezegd had dat deze de finale ontmoeting met Antoon was. Verbitterd schrijft hij dat Liesje is als de meeste andere meisjes en te licht was vergeleken bij het ideaal dat hij van haar had. 
Hij is zeer ontgoocheld; hij vindt zichzelf te "boekerig" en te romantisch. Hij beseft nu dat liefde ook een doodgewone, praktische kant heeft en dat hij in Thilde uit Exodus Liesje wel héel erg geïdealiseerd heeft. Een broer als mededinger: vijf jaar later zal hij het gegeven gebruiken in zijn roman Hun grond verwaait.

Pas eind juni komt er een kattebelletje van Lutkie dat hij het stuk in Den Bosch zal posten. "De geest van het stuk is goed en ge weet dat et mij bevalt. Behalve dat ge deze mensen geen bron van levenskracht hebt gegeven. Geen God, geen godsdienst - waarom niet? ?"68 $^{20}$

Dit berichtje wordt gevolgd door een langere brief waarin hij vertelt dat hij niet verplaatst is, maar nog steeds kapelaan in Gemonde is. Hij is op voorschrift van de dokter en met verlof van de bisschop in Nuland in het huisje Soli Deo gaan wonen. "Zenuwstoornissen en reumatische aandoeningen zijn de oorzaak." Verandering van omgeving was noodzaak en daarom woont hij sinds 6 juni daar. Over zijn moeilijkheden met de bisschop rept hij niet. "Genoeg hierover dat komt wel terecht."

Het toneelstuk Exodus is bij hem in goede aarde gevallen. Hij prijst Coolen dat hij er iets mee te zeggen heeft, maar "ge hebt liever dat ik op fouten wijs."

"De hoofdfout: dat ge de sterkte van oe held niet verklaard hebt. Hoe komt hij er aan?

Niemand ziet 't! [...] Ik bedoel: zulk karakter steunt voortdurend, zichtbaar, merkbaar, op de oorzaak van zijn sterkte. 't Kan niet anders dan dezen oorzaak verraden. Verraden? Prediken! Maar opzettelijk prediken. - Niet alleen doet ge hem niet in vertrouwelijkheid met God leven, doch zelfs laat ge hem zeggen, dat hij niet aan lezen doet, dus in 't geheel geen omgang heeft met grote geesten. Ge voelt toch wel, dat dit geheel en al onmogelijk is!"70

Helemaal aan het eind volgen een paar woorden over Liesje. Lutkie heeft haar geschreven. $\mathrm{Zij}$ ontkent echter met Antoons broer verloofd te zijn geweest en geeft een andere voorstelling van zaken. Hij eindigt - zonder in te gaan op de twee lange smartelijke brieven van Coolen - zeer laconiek: "Och, daar kan ik zo moeilijk inkomen. Laat dat maar op zijn beloop. Werkt ge veel? Beste groeten."

\section{Exit Lutkie}

Aan niets is te merken dat Coolens brief van 2 I juli 1922 zijn laatste zal zijn aan Lutkie. Hij dankt voor de aandacht waarmee het manuscript gelezen is en is blij dat Lutkie aan de beterende hand is. Het lijkt wel of hij niet helemaal gelooft dat Lutkie reuma en zenuwstoringen heeft; hij dacht altijd dat Lutkie over een ijzeren constitutie en sterke zenuwen beschikte. Hij vindt Soli Deo een mooie naam voor een huisje. "Hier heten de huisjes Kitty Lane en Lily Cottage en dan veel indiese namen -tot Saidjah en Adinda toe." Hij neemt de

63 FPC, brief van Het Nederlands Boekhuis aan Coolen, 20 september 1923.

64 FPC, brief van Het Schouwtoneel aan Coolen, 10 juli 1923.

65 KDC, inv. nr. 101, brief Coolen aan Lutkie, 8 juni 1922

66 Van Schaik, Dr. Hendrik Moller, 173.

$67 \mathrm{KDC}$, inv. nr. 101, brief Coolen aan Lutkie, 18 juni 1922.

68 KDC, inv. nr. 101, brief Lutkie aan Coolen, 29 juni 1922.

69 KDC, inv. nr. 101, brief Lutkie aan Coolen,13 juli 1922. 
kritiek van Lutkie serieus: "Wat een nonsjalanse van me omdat zoo te schrijve, dat die Fernand in Exodus niet las. Ik heb 't gauw veranderd. [...] Fernand is trouwens niet de held van het stuk: dat is Tilly. Dat is nou mijn keuze, zo'n meisje daar zou ik god op mijn blote knieën voor danken."

Daar slaat hij de spijker op de kop en wijst het verschil tussen hem en Lutkie aan: "Uw hoofdaanmerking, dat 't stuk niet predikt: de oorzaken der sterkte dier mensen zal echter blijven bestaan - het komt mij voor, dat ik dat in dit stuk niet nóódig heb uitdrukkelijk en predikend aan te duiden. Maar ontroert het, grijpt het aan, doet het innig aan, trèft het - dat wilde ik ook weten." Veertien dagen geleden heeft hij het stuk voorgelezen in kleine kring en daar was een mevrouw bij die aan 't eind zat te huilen, schrijft hij.

Symbolischer kan deze passage in de laatste brief niet zijn: de onoverbrugbare kloof tussen Lutkie die wil preken, bekeren en een beweging losmaken en Coolen die wil ontroeren en deernis met ongelukkigen opwekken.

Hij meldt nog dat hij een "roman of groote novelle" naar Het Boekhuis heeft gestuurd, maar die ligt al weer terug op zijn tafel met een briefje "dat ze al te veel uitgaven op hun program hebben." Hij vindt dat vervelend en trekt er allerlei "naargeestige conclusies" uit. "Me dunkt, as die mensen toevallig De Nieuwe Eeuw over Lentebloesem geleezen hebben, dan durven ze eenvoudig geen nieuwe uitgave van mij meer aan. Dat is moorddadig schrijven, zooals P vd M d W't deed. En 'n uitgever moet uit zulk een beoordeeling wel lezen, dat hij zich eenvoudig kompromitteert as-ie zich nog verder met zoo'n schrijvertje inlaat. Van dat woord: 'hij zal misschien nog wel eens iets goeds schrijven, al zal 't niet veel buitengewoons zijn' - zooals P vd M d W schreef - dat is om ziek van te worre -Wat zal ik nou doen met dat voltooide boek? [...] Als ik het eens naar De Beiaard zond? Maar dan beeld ik me in, dat de autoriteit van $\mathrm{P}$ vd $\mathrm{M} \mathrm{d} \mathrm{W}$ me ook daar een slechte reputatie zal hebben bezorgd.. Ik weet beslist zeker dat mijn voltooide boek op z'n minst heel wat beter is dan de laatste verhaaltjes van tante Melati van Java ${ }^{n}$. Maar die krijgt in De Nieuwe Eeuw gùnstige recensiën! O, die kritiek! Ik denk dikwijls aan dat geval van Heijermans, die, toen ie met Dora Kremer debuteerde, unaniem voor een 'peuterend auteurtje' werd uitgemaakt, en eenige goede weken later toen ie met Ahasverus kwam onder den naam Jelakowits tot een genie werd geproclameerd-Misschien had ik beter gedaan Lentebloesem onder een Chineese naam uit te geven."

De brief eindigt met een alinea over de affaire Liesje. Hij gelooft niet dat ze niet met zijn broer verloofd is geweest, want hij heeft haar onstuimige brieven aan zijn broer "net precies zoo als ze ze vroeger aan mij schreef met dezelfde karakteristieke uitdrukkingen en benamingen" gelezen. "Maar zeker, ik laat 't op zijn beloop - het is het beste." Hij denkt op het laatst van augustus nog eens langs te komen. ${ }^{70}$

Op 17 september r 922 schrijft Lutkie zijn laatste brief aan Coolen. Hij memoreert dat hij daags tevoren de schilder en illustrator Collette heeft gesproken bij de opening van een tentoonstelling van zijn werk in Nijmegen. Deze heeft aan Coolen te danken dat hij ‘Gooische prentjes' voor zijn krant mocht tekenen. Dit doet Lutkie goed: “Ge handelt hiermee helemaal in de geest van het 'Vreugde'-plan: een vriendenkring van idealisten die elkander, stoffelijk, geestelijk in alles zouden helpen." Hij informeert naar Exodus en de roman die Het Boekhuis niet wou hebben. Roeping zal binnenkort verschijnen en "als het 
goed werk is (maar 't moet héél goed zijn) dan kan er misschien wel 'n fragment van in Roeping komen."

$\mathrm{Na}$ deze vage toezegging eindigt de brief, en daarmee de hele briefwisseling die bijna acht jaar geduurd heeft, met een zakelijke oproep:

'Ge moet veel intekenaren voor 'Roeping' werven, dan reken ik wel op de eerste aflevering in Okt. Formaat kwarto, kunstdrukpap. +80 blz. telkens, ook platen - louter kunst, àlle kunst - prijs $\mathrm{f}$ r6,- per jaar. Ik denk dat ik vooreerst nog wel hier zal blijven. Komt ge niet eens kijken? Ge gaat nog wel 'ns naar huis en dan hier langs?

in Christus

Wouter Lutkie pr."n

Lutkie kiest vanaf die tijd een andere koers. Hij neemt niet deel aan de redactie van Roeping. maandschrift voor schoonheid van Moller, maar "occupeerde zich intussen met een ander orgaan, dat in hetzelfde jaar 1922 het licht zag, dat in plaats van exclusief esthetisch, in de aanvang exclusief staatkundig georienteerd was. ${ }^{73}$ Het gaat om het tweewekelijks blad Katholieke Staatkunde van dr. Verviers uit Leiden, die wel de eerste fascistisch denkende politicus onder de Nederlandse katholieken is genoemd. Volgens Joosten wees Verviers in zijn eigen politieke tijdschrift de weg die Mussolini enkele maanden later metterdaad zou bewandelen. Het lijkt erop dat Lutkie op dat moment inziet dat hij Coolen niet als medestrijder voor deze zaak zal kunnen winnen.

\section{Banden met Brabant verbroken}

Na de verbreking van de verkering met Liesje en de contacten met Lutkie is Coolen nog meer los komen te staan van Brabant, al blijven de banden met zijn familie, vooral zijn ouders, bestaan. Hij is nu vijfentwintig jaar oud en wijdt al zijn tijd aan schrijven. Naast zijn journalistieke werk heeft hij tientallen verhalen, (aanzetten tot) romans en toneelstukken geschreven, waarvan er slechts twee in druk verschenen zijn. Beide werden publiekelijk afgekraakt: Opinies in 1914 in De Maasbode en Lentebloesem in $192 \mathrm{I}$ in De Nieuwe Eeuw door Pieter van der Meer de Walcheren.

Het lukt Coolen niet meteen aansluiting te vinden bij de groep jonge katholieke schrijvers rond Roeping. Hij stuurt wel regelmatig kopij in, maar eerst komt er van publicatie niets terecht omdat de start van het maandschrift steeds wordt uitgesteld. Ook na de start in oktober 1922 wordt er voorlopig niets van hem geplaatst.

Waarom Coolen niet meteen aansluiting heeft met de groep rond Roeping is verklaarbaar. Ook hier is hij een buitenbeentje. Hij is afkomstig uit een puur katholieke omgeving, waarvan hij de goede maar ook de bekrompen en verwerpelijke kanten heeft gezien. Vooral het prekerige en het betweterige stoten hem af; hij wil boeken en verhalen schrijven die de mensen ontroeren. De godsdienst en de religie kunnen daarin een rol spelen,

$70 \mathrm{KDC}$, inv, nr. 101, brief Lutkie aan Coolen, 21 juli 1922.

71 Melati van Java was een pseudoniem voor Nicoline Maria Christina Sloot (Java 1853 - Noordwijk aan Zee 1927). Zij was schrijfster van romantische boeken. Zij schreef ook nog onder het pseudoniem Max van Ravestein. Zie Van Duinkerken, Verzamelde Geschriften, III, 882.

$72 \mathrm{KDC}$, inv. nr. 101, brief Lutkie aan Coolen, 17 september 1922.

73 Joosten, Katholieken en fascisme, 26. 
maar dan meer als een natuurlijk gegeven, als het klimaat van een dorp in Oost-Brabant in die tijd.

De verklaringen voor het menselijk gedrag zoekt hij liever bij filosofen en schrijvers als Nietzsche, Ibsen en Multatuli. Van Duinkerken ziet hierin later een reden waarom Coolen zich pas in 1924 bij de groep van Roeping aansluit. Als Coolen uit die groep zou zijn voortgekomen, stelt Van Duinkerken, zou "zijn eerste drama [...] vermoedelijk absolutistisch godsdienstig geweest zijn. ${ }^{774}$ Het is zeer de vraag of die redenering klopt. Coolen kwam niet uit de groep voort, maar hij heeft zich er ook niet bij aangesloten. Het lijkt veel waarschijnlijker dat de groep, de redactie, pas in 1924 een eerste product van Coolen heeft goedgekeurd en dat eerdere inzendingen niet voldoende gedrenkt waren in "godsdienstige motiveeringen." Coolens eerste bijdrage verschijnt pas in oktober r 924 en is een kunstkritiek over kerkramen. Daarna, in december 1924 , zal zijn eerste novelle gepubliceerd worden.

Deze novelle wordt opgemerkt door de priesterstudent Anton van Duinkerken. Deze seminarist die al gauw een journalistieke en letterkundige loopbaan gaat volgen, is zes jaar jonger dan Coolen en zal diens derde 'begeleider' en vertrouwensman worden. De vijfendertig jaar oudere onderwijzer Ouwerling was de eerste. Hij heeft Coolens belangstelling voor cultuur en literatuur gewekt. De tien jaar oudere Lutkie heeft Coolen begeleid als jong journalist en beginnend schrijver.

Coolen heeft in deze fase van zijn leven een enorme drang gehad om zichzelf binnenste buiten te keren en de waarheid over zijn persoon ergens neer te leggen, hoe onaangenaam die waarheid af en toe ook was. Tussen r 914 en 1922 heeft Lutkie de functie van repoussoir vervuld. Coolen kon zich tegen hem afzetten om zijn eigen positie te kiezen. 
74 Van Duinkerken, Antoon Coolen, 26. 
IIO 


\section{Een nieuwe vriendschap}

\section{"Brabant!"}

$1923-1925$

\section{Journalist bij De Gooische Post}

De klap van de kritiek van Pieter van der Meer de Walcheren op Lentebloesem is hard aangekomen. Niet alleen is deze aanleiding tot de breuk in zijn relatie met Liesje, maar Coolen zal een paar jaar naast zijn journalistieke werk niets publiceren. "Na een mislukten novellenbundel, naar hier meegenomen jeugdwerk, en die mij in aanraking bracht met de hardheid van de letterkundige critiek, durfde ik niet goed meer. Ik bepaalde mij tot het werk aan de krant en nam litterair toen vijf jaar het diepste stilzwijgen in acht," schrijft hij later.' Deze vijf jaar zijn enigszins overdreven, want eind 1924, drie jaar na Lentebloesem, verschijnt zijn eerste novelle in Roeping.

Dertien jaar heeft Coolen in Hilversum gewoond, maar in zijn literaire werk zijn er nauwelijks sporen van achtergebleven. Hoewel hij er zich later, in een rede in 1953 waaruit het bovenstaande citaat komt, vriendelijk over uitlaat, hebben het dorp en het land. schap hem niet echt geboeid. Hilversum was oorspronkelijk een weversdorp, waar rond de eeuwwisseling een ring van villawijken omheen was gebouwd. Aan Lutkie schreef hij al over de nette burgerhuisjes met de tuttige Engelse namen. Ook aan de getrimde natuur in gazons en bloemperken heeft hij nooit echt zijn hart verloren. Dan verkiest hij toch "mijn Brabants dorp met de linden op het oude plein, die bloeien als de hooggeladen boerenhooiwagens er onder door rijden en als voor mijn venster het koren stuift, dat ik kort daarna de boeren zie maaien." ${ }^{2}$ Niet alleen het dorpsgezicht en de natuur verschillen veel van Deurne en de Peel, ook het sociale en geestelijk leven is heel anders. Hilversum kent een grote katholieke enclave, ook wel 'Klein Rome' genoemd, met de St. Vituskerk als dominant middelpunt. Hier werd De Gooische Post "huis-aan-huis in de brievenbus gefrommeld." De beleving van dat katholicisme is er anders dan in Brabant: minder losjes, veel strenger en volgens de letter van de wetten en voorschriften van de R.K. Kerk. Een krant als De Gooische Post is daar niet zomaar een krant, maar tevens een baken van 'roomsche' strijd. vaardigheid en getuigenis.

Een regionale katholieke krant moet echter ook aandacht besteden aan andere zaken. De journalist Coolen is voortdurend op pad om gemeenteraadsvergaderingen in de omlig. gende dorpen te verslaan en muziek-en toneelvoorstellingen bij te wonen en te recenseren. Een collega herinnert zich dat hij als jongste broekie in die tijd met Coolen, die "ietwat 
ANTOON COOLEN

unovernus be snamadie rost

artistiek gekleed en gekapt" ging, per fiets mee naar een raadsvergadering in Bussum reed en dan vanuit de raadszaal een pendeldienst onderhield naar de drukkerij met steeds een paar velletjes kopij. ${ }^{4}$ Coolen had bovendien zijn eigen cursiefjes 'Podium' en 'Kalenderblaadjes' en schreef elk jaar een of meer kerstverhalen. Samen met zijn col-

lega's Bernard Bekman en Ben Hulsman vormt hij onder leiding van de hoofdredacteur/directeur Clemens Aleven de redactie van de krant. Bekman schrijft later dat Coolen zijn werk zeer nauwgezet deed, niet enkel om den brode of om een financiële basis te hebben voor zijn literaire werk: "Hij deed dit alles met een angstvallige zorg en een verantwoordelijkheidsgevoel, die op mij-de zoveel jongere - een diepe indruk maakten en die voor mij een voortreffelijke leerschool bevatte." Hij meldt ook dat Coolen de moderne muziek bijhield en grammofoonplaten kocht, zeer geinteresseerd was in de nieuwe bouwstijl van Dudok en op de hoogte was van de allernieuwste Franse letterkunde. Bekman beschrijft hoe Coolen over de kleine plaatselijke krant dacht en legt daarmee een relatie met zijn latere literaire werk: "En dat gevoel voor die kleine krant is niet verrassend in de man, die ook over kleine mensen zulke grote romans schreef." 5

Hoofdredacteur Clemens Aleven was een onaangenaam mens. De onderwijzer aan de St. Josephschool, Fennis, die bevriend was met Coolen, heeft Aleven in een aantal anekdoten scherp gekarakteriseerd. Aleven woont in een villaatje aan de Koninginneweg en is parochiaan van de O.L.Vrouwekerk, waar hij dagelijks de mis bezoekt. Als zijn zoontje een keer zijn petje afneemt voor de koster van die kerk krijgt hij een draai om zijn oren, om zijn standsbewustzijn aan te scherpen. Aleven heeft nauwe contacten met de geestelijkheid, die hij te pas en te onpas gebruikt om zijn macht te handhaven. Zijn gedrag op de redactie gaat gepaard met "een ontaard getier en gebulder." Coolen kan daar volstrekt niet tegen en wordt daar zeer door gedeprimeerd. Hij is veel te gevoelig en zacht om daar weerwerk aan te bieden, al bezit hij wel weer de humor om deze aanvallen te betitelen als 'delirium clemens',

Ook Alevens bemoeienis met Coolens privé-leven gaat vrij ver. Coolen woont sinds januari r 923 op de Vaartweg 68a bij juffrouw Fuchs, volgens Fennis een corpulente Duitse dame over wie Coolen hem verteld heeft dat ze verloofd is met een Duitse officier. ${ }^{6}$ Het blijkt dat Coolen een eigenaardige verhouding met zijn oudere hospita heeft. Hijgeeft haar zijn hele salaris in beheer en noemt haar 'moedertje'. Fennis denkt dat er meer is dan een soort sentimentele moederbinding. Volgens hem was Coolen "verstrikt in de amoureuze netten van de hospita." Ze ging voortaan altijd mee als hij een recensie van een toneel of muziekuitvoering moest maken. "Niet hij chaperonneerde haar, maar zij hem," aldus Fennis. Volgens hem sprak heel Hilversum over deze affaire. Aleven dreigt Coolen met ontslag als hij de verhouding niet verbreekt of ordentelijk met haar trouwt. Coolen doet geen van beide. Toch blijft hij tot januari 1926 bij haar in pension.

\section{De literaire sfeer aan het begin van de jaren twintig}

Het feit dat Coolen de eerste jaren niet publiceert wil niet zeggen dat de drang tot het schrij- 
ven van literatuur verdwenen is. Hij leest het blad Roeping dat vanaf 13 oktober 1922 begint te verschijnen. De eerste jaargangen van dit 'maandschrift voor schoonheid' bevatten werk van zowel zijn vroegere vertrouwensman, Lutkie, als van de toekomstige, Van Duinkerken. Vanaf eind 1923 beginnen de bijdragen van de op dat moment twintigjarige Anton van Duinkerken te verschijnen. In een feuilleton over 'de Ravenzwarte', dat in 1928 in boekvorm wordt uitgegeven, wil hij via een kinderlijk simpele hoofdpersoon zijn levensfilosofie uitleggen. In het hoofdstuk 'Op wandel met de Ravenzwarte' schrijft hij: "Een wijsgeer is de Ravenzwarte niet. Voor hem is denken identiek met dood zijn."7 Het heeft iets gekunstelds als de intellectuele gesprekspartner (Toon) aan de Ravenzwarte voorleest uit Emst Hello's Philosophie en Archeisme, waarna een theologisch debat ontstaat. Het boek heeft ook veel overeenkomsten met Manus Peet van Querido; ook deze hoofdpersoon filosofeert heel wat af. Veel critici zien positieve waarden in het boek, vooral waar het gaat over de verhouding tussen God, de mens en de natuur. Henk Kuitenbrouwer zal later schrijven dat het boek minder geslaagd is, maar dat vooral het hoofdstuk 'De visvangst van de Ravenzwarte' iets "jongs en bloeiends, 'n sfeer van zuivere vreugde en verrukte verwondering" heeft. ${ }^{8}$

Het zijn juist deze elementen die de journalist Coolen in Hilversum enthousiast hebben gemaakt en waarschijnlijk ook nieuwsgierig naar deze jonge schrijver. Ook Coolen heeft in de aanzetten van zijn romans zijn personages verwoed laten debatteren, zoals Fré en Caspar in De Sterke! Als Van Duinkerken in november 1923 in een artikel over 'Joseph de Maistre en onze tijd' refereert aan Franse schrijvers als Hello, Bloy, Barbey d'Aurevilly en Villiers de l'Isle-Adam neemt de interesse van Coolen toe. Deze interesse slaat om in bewondering door het gedicht Het lied van Brabant, dat in maart 1924 in Roeping verschijnt. Later zal Coolen schrijven dat hij dat gedicht wel twintig keer voorgelezen heeft "voor wie maar luisteren wilde." ${ }^{* 9}$ Aan dit gedicht zal nog vaak gerefereerd worden. Coolen zal er de titels voor zijn eerste drie peelromans aan ontlenen.

Deze eerste jaargangen van Roeping, en vooral de bijdragen van Van Duinkerken, hebben Coolen weer tot schrijven gebracht. Terugkijkend zegt hij: "In de lentelijke atmospheer echter van het uit Brabant stammende tijdschrift Roeping begon ik in Hilversum weer te schrijven, in herinnering aan wat ik in mijn jeugd in de Brabantse Peelstreek zo krachtig geabsorbeerd had, en door de herinnering zelf en op den afstand min of meer vermooid en verdichtelijkt gezien. ${ }^{10} \mathrm{Zo}$ ontstond een kleine novelle:

"In den zomer van r 923 dwong een ongesteldheid mij tot een rustperiode. In een Gooische tuin onder de boomen, in een naar hier 'verdwaalde' dekstoel van een Indiëvaarder, ging ik op een inval schrijven over een schoenmakertie, dat in Deurne dicht bij ons huis woonde, en over een Weensch kindje, dat bij mijn ouders thuis was en dat ik daar in haar spel met zonnebloemen had bezig gezien. In twee dagen was

5 Bekman, 'De journalist Coolen', 636.

6 CS, [typoscript] Fennis, Herinneringen, 1.

7 Van Duinkerken, 'Op wandel met de Ravenzwarte', 138.

8 Roes, Een schaduw die verschuift, 69-70.

9 BA, brief Coolen aan Van Duinkerken, 16 februari 1925.

10 Coolen, 'De Glimlach van het Gooi', 10. 
Jantje den Schoenlapper en zijn Weensch kiendjegeschreven. Een goed jaar nadien heeft dat in Roeping gestaan. En in 1927 is het als afzonderlijk boekje bij de Waelburgh (Nijgh \& van Ditmar) verschenen. Dit is, ernstig gesproken, mijn eigenlijke eerste boekje." Opvallend is dat hij "ernstig gesproken" Lentebloesem en Opinies dus niet meetelt en er zelfs met geen woord over rept. Deze bundels ontbreken ook in het bibliografisch overzicht dat hij met bovenstaande tekst voor het Boekenweekgeschenk 1932 inzendt.

\section{Jantje den schoenlapper en zijn Weensch kiendje}

In oktober 1924 verschijnen in Roeping twee bijdragen van Coolen tegelijkertijd: een kunstkritiek getiteld 'Kerkramen en paneelen van Lodewijk Schelfhout' en een vertelling 'Van het zegenend geluk'. In dit laatste verhaal vertelt hij over Bart en Leen die in een huisje wonen waar de lemen vloer is vervangen door rode en blauwe plavuizen. Bart komt thuis met een wieg, gevlochten door blinde Cis. Driemaal geuren de seringen als Leen tegen Bart zegt dat ze een 'kịendje' krijgen en daarna nog een vierde keer. Leen geeft de kleertjes die ze al gemaakt heeft aan Nelleke Pot, de vrouw van de geitenvilder en toddenman. Zo delen ze hun geluk. Het eindigt als volgt: “- Da menschke is blij! Dat zegt Bart, dieje mensch. - Ze kan niet zoo blij zijn as ik. Dat zegt Leen de vrouw, die moeder worrende."

Het thema van het weggeven van kinderkleertjes gebruikt hij enkele jaren later nog eens in een triest kerstverhaal, 'Uw wil geschiede'. Hier geeft een moeder die bijna gek is van verdriet door het verlies van haar eigen kind, ook een steeds terugkerend onderwerp, op aandringen van haar man de kleertjes weg aan een arm gezin.

In het november-en decembernummer van r 924 verschijnt dan in twee afleveringen de novelle Jantje den Schoenlapper en zijn Weensch kiendje. Deze novelle gaat over de gebochelde schoenmaker Jantje die samenwoont met zijn zuster Regien. Zoals na de Eerste Wereldoorlog veelvuldig voorkwam, hebben ze een Weens kindje, Alexandrine of Xandrieneke, in huis genomen. ${ }^{12}$ "Alexandrine, dat Wenerke ligt op de brabantse dries van Jantje de Schoenlapper. Het is in de tijd dat de kersen rijpen." Hij roept haar binnen: "Wier moeten essen. ${ }^{13}$ Het meisje voelt zich tevreden: "Dat komt van de zomer en de zoete avond. Dat komt van de rust. Dat komt van Brabant." ${ }^{n 4}$ Op humoristische wijze worden de klanten van de schoenlapper beschreven en de manier waarop hij rekeningen schrijft: "Voor geleverde ripperazien, kortju, wat een woord. En Jan zet het regel na regel: zoolle en haken. Waarom zet hij na de eerste regel niet: idem, idem? Zeker omdat hij geen Latijns kent. Als Jan zes keer zoolle en haken gezet heeft, dan is het genoeg. ${ }^{n 15}$ Alexandrine speelt met de zonnebloemen en voert er hele gesprekken mee: "ze doen voor Jantje de meesterschoenmaker niet onder en praten het weens met het Wenerke mee." ${ }^{16}$ Via een koffievisite bij Regien horen we de dorpsroddels. De vrouwen - in de eerste druk nog 'wijfkes'- moeten er zelf van huilen, met uitzondering van Regien. "Ze kijkt naar buiten, waar brabant blond en zomerend ligt onder de gouddoorstoven zinderende blauwe hemel, het land, het koren, de zandwegen en daar, aan de rand van de dries, Xandrieneke, het Wenerke." Coolen de aandacht op Brabant, bijvoorbeeld als Jantje een brief uit Wenen krijgt: "Holland, stond erboven, mee grote letters en onderaan 't adres: brabant. Ja, asteblief, brabant! Hoe wisten ze 't in Wenen, dat er ginds bij de zee, even zuidelijk van Scandinavië nog wat anders is dan dat kleine land: Holland, water en daarlangs kleine stroken land, dat er in dat Holland een Brabant is. ${ }^{18}$ Jantje maakt schoentjes voor Xandrienekes verjaardag. Als 
zij hem dankbaar kust - "de handen boven het bultje, en bij zijn weten voor het eerst van zijn leven wordt Jan gekust" ${ }^{\prime 19}$ - wordt dat gezien door de lange Mie Grijzel, de pastoorsmeid. Zij meldt het aan de pastoor en de volgende dag wordt Xandrieneke door Gondeke Timmermans van het huisvestingscomité - "een jongerse dochter van die geheimzinnige leeftijd van vrouwen die niet ouwer worre als ze de dertig zijn gepasseerd ${ }^{\mathrm{n} 20}$ - weggehaald en naar een nonnenklooster gebracht. 's Avonds staan de nieuwe schoenen bij de stoel met haar kleertjes, "maar de zolen en hakken zijn vuil van de beslijkte, beregende weg die het kind straks ging."

In deze kleine novelle toont Coolen al het volledige palet van zijn latere werk: de liefde voor de natuur, het mededogen met de eenvoudige, de aandacht voor het speelse van een kind, maar ook de dorpsroddel, een thema dat in de eerste drie novellen telkens een rol zal spelen. Als het verhaal enkele jaren later in boekvorm is verschenen, schrijft een recensent in De Groene Amsterdammer dat het een simpele geschiedenis is. "Maar het is zoo aandoenlijk, zoo fijn, zoo vlekkeloos-goed tot in de kleinste onderdeelen, het staat daar zoo puur en rank en edel tusschen de gewichtige romans en de geciseleerde verzen van het litteraire jaar, dat er over gesproken moet worden met eerbied en woorden van diepe innigheid." ${ }^{22}$

Coolen heeft het midden gevonden tussen de twee uitersten die de schetsen van Opinies en Lentebloesem nog kenmerken: sentimentaliteit en een luchtige man-van-dewereld toon. De geestelijke worstelingen die zijn concepten voor romans als De Sterke!, Quid Veritas en De mensen in 't Zuiden kenmerkten, zijn verdwenen. In deze novelle staat geen stoere would-be-filosoof centraal, maar een eenvoudig, gebocheld schoenlappertje.

\section{De kennismaking met Van Duinkerken}

De jonge seminarist Willem Asselbergs (pseudoniem: Anton van Duinkerken, 1903-1968), publiceert al vanaf de tweede jaargang in Roeping. Hij wordt door dr. Moller meteen gezien als een representant van de katholieke jongeren én van het katholieke Brabant. Het eerste literaire werk is gefixeerd op Brabant. Van de katholieke jongeren uit het zuiden wordt het heil verwacht, tot verdriet van noordelijke, Utrechtse katholieken als Jan Engelman. Niet lang daarna, in 1925, zal door de laatste het tijdschrift De Gemeenschap worden opgericht, waarvan Van Duinkerken later redacteur wordt.

11 Coolen, 'Hoe ik er toe kwam', 37.

12 Coolen heeft iets met die naam: als zijn tweede kind een meisje was geweest had het Alexandrine Paula geheten. AMVC, inv. nr. C 3475, brief van Coolen aan Streuvels, 8 december 1931.

13 Coolen, Jantje den Schoenlapper, 11.

14 Ibidem.

15 Coolen, Jantje den Schoenlapper, 19.

16 Coolen, Jantje den Schoenlapper, 25.

17 Coolen, Jantje den Schoenlapper, 30.

18 Coolen, Jantie den Schoenlapper, 34

19 Coolen, Jantie den Schoenlapper, 38.

20 Coolen, Jantje den Schoenlapper, 42.

21 Coolen, Jantje den Schoenlapper, 50.

22 [Recencie Jantije den Schoenlapper]. 
In 1924 vinden verschillende bijeenkomsten plaats van jonge en oudere katholieke schrijvers. Op een van die bijeenkomsten hebben Coolen en Van Duinkerken elkaar voor het eerst ontmoet. Volgens Van Duinkerken was dat op dinsdag na Pasen in april 1924 in Tilburg; volgens Coolen was het in december 1924 in het Parkhotel in Amsterdam. Van Duinkerken herinnert het zich later als volgt: "Ik had Coolen voor het eerst ontmoet op Dinsdag na Paschen 1924 tijdens een bijeenkomst van jonge katholieke letterkundigen in het hotel Marinus te Tilburg. Wij kenden elkaars luttele publicaties reeds en hadden eenige brieven gewisseld. Sedert die eerste ontmoeting werden wij vrienden. ${ }^{n 23}$ Coolen geeft een andere lezing:

"Kort na dien tweeden Roepingjaargang en nadat ik in het tijdschrift zelf de novelle Jantie de Schoenlapper en zijn Weensch kiendje had gepubliceerd [in het november-en december nummer van 1924, C.S.J, heb ik van Duinkerken persoonlijk leeren kennen. In het Parkhotel te Amsterdam was een ontmoetingsbijeenkomst belegd tusschen de jongeren en de oude katholieke letterkundigen uit de Van onze Tijd- en De Beiaardverbanden [...] waar ik meest tusschen vreemden zat en me door dr. Moller Van Duinkerken liet aanwijzen. [...] Het eerste woord dat Van Duinkerken en ik bij die Amsterdamsche ontmoeting tegen elkaar zeiden was het woord 'Brabant'. Wij spraken het, in plaats van onze namen te noemen, vragend aan elkaar uit. De handdruk, die er ons beider antwoord op gaf, was de aanvang van een vriendschap, die heel gauw voor het eerste enthousiasme uitweg zocht in een veelvuldige uitwisseling van lange brieven." ${ }^{24}$

Toch herhaalt Van Duinkerken in 1957 bij de zestigste verjaardag van Coolen als plaatsnaam Tilburg en als datum dinsdag na Pasen r 924 ; alleen is hotel Marinus nu een café geworden. "Het is op die ontmoetingsdag geweest (en niet anderhalf jaar later op de kerstvergadering van 1925 in hotel Parkzicht te Amsterdam) dat ik met Antoon Coolen kennis maakte." Nu echter voegt hij er de wijze waarop aan toe, zoals Coolen die in 1953 beschreef: "Hij maakte zich bekend, maar dit ging eigenlijk zo, dat wij als korte onderbreking in Engelmans toespraak elkaar de hand gaven en enkel 'Brabant' zeiden." In 1962, in zijn boek Brabantse Herinneringen, gaat Van Duinkerken er nog uitgebreider op in. Van Duinkerken zou in café Marinus spreken, maar door een misverstand dacht men dat hij geen verlof had van de seminariepresident. In zijn plaats sprak Jan Engelman die zijn leedwezen uitsprak over de afwezigheid van Van Duinkerken, terwijl die vlak voor zijn neus zat. Van Duinkerken was daar uiteraard verbaasd over.

"Zo trok mijn verbazing de aandacht van een man met een liggende boord en vlinderende das, die bij het binnenkomen mijn nieuwsgierigheid had opgewekt. Hij hield zich van het gezelschap opvallend afzijdig, gelijk een journalist zou doen, maar zodra hij begreep wie ik was, schoof hij zijn stoel iets dichter naar mij toe. Hij maakte zich bekend als Antoon Coolen. Dit deed hij niet met name. Hij stak zijn hand naar mij uit en zei enkel 'Brabant'. Ik antwoordde met dezelfde groet. Wij hadden tot dan toe elkaar nooit gezien en ook geen kans gekregen om elkaar te leren kennen uit portretten. Van zijn gestalte had ik mij een heel andere voorstelling gevormd, hij waarschijnlijk ook van de mijne. Onze begroeting benam ons iedere twijfel. Wij waren allebei het meest naar deze bijeenkomst getrokken door de mogelijkheid, elkaar te zullen zien. In een seconde werden we vrienden voor heel het verdere leven. ${ }^{.25}$ 
Het is opvallend dat het woord 'Brabant' in Coolens versie vragend wordt uitgesproken (komt gij ook uit Brabant?) en bij Van Duinkerken als een groet. De laatste versie heeft toch wel trekken van mythologisering. Wat het tijdstip betreft heeft Coolen in ieder geval gelijk. De bijeenkomsten in april in Tilburg en in december in Amsterdam hebben overeenkomsten. Bij beide gelegenheden gaat het om een discussie tussen de oudere en de jongere katholieke schrijvers en intellectuelen; beide keren was dr. Moller aanwezig. Daar komt bij dat Van Duinkerken een zekere naam heeft in slordig citeren: zo maakt hij de gang van zaken in een van de bovenstaande citaten nog onduidelijker door de bijeenkomst in het Parkhotel in december 1925 te plaatsen, in plaats van in december 1924 . Van Coolen is het bekend dat hij zeer precies en zorgvuldig is. Het uiteindelijke bewijs komt uit de briefwisseling van de twee schrijvers zelf. In zijn eerste brief aan Van Duinkerken van 16 februari 1925 schrijft Coolen in antwoord op de eerste brief van Van Duinkerken: "Ik was echt blij met je brief, opnieuw blij, want ik was ook al lang blij kennis met jou gemaakt te hebben in Amsterdam."

We gaan hier uitgebreid in op deze kennismaking, omdat het half jaar verschil een ander licht werpt op de eerste bijdragen van Coolen aan Roeping. Tussen Pasen en Kerstmis van 1924 opereren zij nog los van elkaar. De Jaargangen van Roeping lopen van oktober tot oktober. De eerste bijdragen van Coolen verschijnen in de eerste nummers van de derde jaargang eind 1924. Dit betekent dat deze bijdragen opgenomen worden vóórdat Van Duinkerken en Coolen elkaar ontmoeten. Op het moment van de kerstvergadering in het Parkhotel op december 1924 heeft dus niet alleen Coolen werk van Van Duinkerken gelezen (zoals diens gedicht Het lied van Brabant, zijn proza De Ravenzwarte en een essay als 'Joseph de Maistre en onze tijd', bijdragen die allemaal in de tweede jaargang van Roeping verschenen), maar heeft Van Duinkerken ook bijdragen van Coolen gelezen; dit zou met Pasen 1924 nog niet mogelijk zijn geweest. $^{26}$

Van Duinkerken correspondeert na Pasen I924 al intensief met de 'Utrechters' Jan Engelman en de gebroeders Kuitenbrouwer. Coolen kan dan nog niet door zijn publicaties bekend zijn, tenzij men zich zijn Lentebloesem van twee jaar daarvoor nog herinnert. Deze Utrechters willen Van Duinkerken bij hun plannen voor de oprichting van het blad De Gemeenschap winnen en hem losweken van Moller en Roeping. Van Duinkerken voelt zich wel enigszins aangetrokken tot dit milieu, maar blijft toch solidair met Brabant. De toon van die brieven uit Utrecht is wat jennend en denigrerend naar het boerse Brabant, dat verstoken is van allerlei stedelijke uitingen van cultuur. Volgens Jan Engelman zou Van Duinkerken eens een Dada-avond moeten bijwonen of de wandluizen uit een volkslogement van een grote stad over zijn huid moeten voelen kruipen. Tegelijkertijd complimen-

Van Duinkerken, Antoon Coolen, 32-33.

Coolen, 'Anton van Duinkerken als vriend', 24.

Van Duinkerken, Brabantse Herinneringen, 229.

Ook Michel van der Plas neemt in zijn biografie over Van Duinkerken aan dat de ontmoeting derde Paasdag 1924 in Tilburg plaats heeft gevonden. Hij zegt dat Coolen zich vergist. Als hij schrijft dat daarna Van Duinkerken een intensieve briefwisseling met de jonge katholieke schrijvers is begonnen vermeldt hij in een hele rij namen (Engelman, de beide Kuitenbrouwers en Bernard Verhoeven) ook Coolen, maar de eerste brieven tussen Coolen en Van Duinkerken zijn pas in januari en februari 1925 gewisseld. 
teert hij hem halfhartig door te stellen dat als hij boven de rivieren was geboren hij "een der onzen door dikst en dunst" zou zijn geweest. ${ }^{27}$

Van Duinkerken moet dan ook blij zijn geweest toen hij daarna, in het najaar van 1924 een duidelijk Brabants 'schoenlapperke' en daarmee een streekgenoot in Roeping ontdekte. Het woord 'Brabant' moet daar in Amsterdam temidden van de diaspora-katholieken eenzelfde klank en lading hebben gehad als het 'Mr. Livingstone, I presume' in het donker Afrika van de vorige eeuw.

Kort na de kennismaking in het Parkhotel met Kerstmis 1924 begint een briefwisseling waarin de dominante, extraverte Van Duinkerken de stillere Coolen zal stimuleren. Coolen heeft weer een vertrouwensman gevonden bij wie hij zijn ideeën en twijfels kwijt kan, maar tegen wie hij ook een beetje op kan zien. Later zegt hij er zelf over:

"Als ik zeg, dat Brabant een binding is geweest tusschen van Duinkerken en mij, dan bedoel ik inderdaad met dat Brabant een zekere karakteristiek van een persoonlijkheidssfeer, die Van Duinkerken sterk heeft, adaequaat aan verschijnselen die mij in den Brabantschen eigenaard zoozeer aantrekken: gulheid van gemoed, hartelijkheid, trouw in gehechtheden, zin voor traditie, neiging tot gezelschapsverkeer, blijmoedigheid, hartelijkheidsgehalte in het gedeelde genieten van de goede geneugten van aarde en leven." ${ }^{28}$

\section{Van Duinkerken als bewonderaar én criticus}

Voor de hervatting van het schrijverschap van Coolen zijn de eerste jaren van de vriendschap met Van Duinkerken van het grootste belang. Coolen maakt dankbaar gebruik van de mogelijkheid hem als een soort klankbord te gebruiken. De briefwisseling in 1925 geeft een goed inzicht in het ontstaan van de eerste peelromans. In januari 1925, gedateerd op het feest van St. Pieter van Nola, schrijft Van Duinkerken een hartelijke brief van vier kantjes. Van Duinkerken heeft de vooral bij priesters in zwang zijnde gewoonte aangenomen om de datering aan te geven met katholieke feestdagen. Maar ook hier is zijn slordigheid lastig. Er bestaat wel een St. Felix van Nola, maar geen Pieter. Hij bedoelt St. Pieter Nolasco, wiens feestdag op $3 \mathrm{r}$ januari valt. De brief bevat een letterkundige bemoediging én kritiek. Het is het begin van een briefwisseling die tot het overlijden van Coolen onderhouden zal worden.

Van Duinkerken valt meteen met de deur in huis: "Goeie kerel, dat was goed zeg, die schoenlapper van jou! Je bent de bovenste beste Brabander en ik zou wel tranen 'mee teuten' kunnen 'schruwwen' van purelijke blijheid, dat zo'n vent als jij tot de schepping behoort. ${ }^{n 29}$ Hij schrijft dat hij van plan is over Marie Gijsen en Coolen te publiceren in een artikel 'Brabant en de letterkunde'. Marie Gijsen dient dan om Coolen reliëf te geven. Hij geeft echter ook kritiek: door de herhalingen als stijl te gebruiken krijgt de tekst teveel het karakter van "een repeterende breuk." Daarnaast moet Coolen het woordje 'Brabants' niet te hooi en te gras gebruiken, maar hij moet nog wel "veel moois over ons volk zeggen en hoe langer hoe dieper er op ingaan, zodat enige gevoelige dingetjes, die nu 'wel aardig' zijn, worden getransponeerd naar 'n rake objectiviteit, waar ze mooi zijn en 'schoon' (zo is bijv. dat rekening schrijven van Jantje schoon)." Hij vindt dat Coolen dezelfde fout maakt als hij zelf in zijn Ravenzwarte. er zit te weinig vooruitgang in feiten. "Telkens ver-nauwkeurigt de volgende zin de vorige, maar het verhaal schiet niet op." Voor het vorige vertelsel, Van het 
zegenend geluk, geldt deze opmerking nog meer.

"Het objectief gegeven was wel-gewogen een almanak-vertelseltje. 'n Stichtelijkheidje, niet waar? Maar jouw originele geschrijf 'Cis, dieje timmerman' (3x) maakte het tot wat het was. Dit is goed in een enkele schets, maar in een bundel verveelt het. De lezer krijgt het gevoel van voor-den-aap-te worden gehouden. Telkens denkt ie: nou komt het, met die tafel, met die plavuizen gebeurt iets, doch pas in de 6e regel van onder begint iets te gebeuren, dat in generlei verband staat met de plavuizen-leggerij van Cis, diejen metselaar, dieje mens."

Bovendien vindt hij het fout dat Cis de meest belichte figuur van het verhaal is, terwijl zijn vrouw de hoofdpersoon is, die de feitelijke handeling stelt. Hij raadt Coolen aan om La guérison des maladies van de Zwitser C.F. Ramuz te lezen: "een katholieke dorpsgeschiedenis, in jouw stijl, (wanneer jouw stijl tenminste nog meer volmaakt kompakt is geworden)." Ook Timmermans lijkt hem stilistisch wel iets voor Coolen, en als contrast zijn Marie Gijsen en Streuvels goed. Hij voegt eraan toe dat de geest van het werk van Coolen dieper is dan die van hen: "Hun pessimistiese zienswijze geeft hen de schijn dieper te kijken." Hij vindt dat de Brabander en vooral de West-Brabander een diep-pessimistische trek heeft. "Die trek is dominant, maar niet z'n diepste zieletrek. Die is zuiver behouden voor ' $t$ geloof en is naief gebleven doordat geen renaissantiese kultuur over ons heen gegaan is. Bemerk dat geloof, en je krijgt Breughel, laat het weg: je hebt van Goch." Van Duinkerken mist deze twee polen nog in de Brabantse letterkunde; hij ziet zich samen met Coolen als de wegbereiders:

"En noch ik, noch jij zullen die hoogte bereiken. Maar ik geloof, Toon, dat wij de Spieghel en de Coornhert zijn voor dien eventuele Vondel. Waarlik: er wordt een nieuwe Sint Jan gebouwd in onze dagen. En met een karieljon, waarvan de klanken over moeten waaien naar 't bovenmoerdijkse. Brabant te heiligen om Holland te kerstenen. Kerel, dat is onze kultuurtaak. [...] Wil het serebraal-vermoeide, dood-óppe Holland niet ondergaan in overbeschaafdheid, dan zal het de zegen hebben te wachten van ons, onderdrukte, maar nimmer getemde barbaren."

Van Duinkerken ziet zich met Coolen al een duo vormen, waarbij hij voor Coolen vooral de taak ziet om via zijn literaire werk het Brabantse volk te kenschetsen:

"Dat is het dood-ongelukkige in Brabant: Het spreekt hier allemaal vanzelf. Als je dat in 'n novelle kon laten voelen, die diep-ongemerkte tragiek van ons volk, kon laten voelen zonder pessimisme, Toon, als je dát kon, zou ik zo veel van jou houden dat ik je altijd bij me hebben wou. Kerel, jij kúnt, jii bent kunstenaar. Help ons volk. Je hoeft niet populair te zijn, niet eens te trachten. Geen Brabantse Legendená la Cleerdin. ${ }^{30}$ Werk aan de kernen. Help ons."

\section{Coolen verdedigt zich}

Op 16 februari 1925 antwoordt Coolen met een lange brief. Opvallend is dat Coolen, ondanks zijn grote bewondering voor Van Duinkerken - een bewondering die hij in zijn

Brief Engeiman aan Van Duinkerken, 13 november 1924, Van der Plas, Daarom mijnheer, 73.

Later verschijnt nog een bundel legenden van Vincent Cleerdin: Sagen van Brabant, Rotterdam 1929. 
brief overigens niet onder stoelen of banken steekt - toch vrij zelfverzekerd de meeste punten van kritiek weerlegt. Hij verontschuldigt zich voor de late reactie, maar de krant heeft hem geheel en al in beslag genomen. Hij schrijft al lang te genieten van Van Duinkerkens verzen in Roeping:

“Jouw 'Kinderen van een sterk volk zijn brabants menschen' heb ik wel twintig keeren voorgelezen voor wie maar luisteren wilde, en de litanie der zonderlinge zielen en den lof der zeevaarders ken ik van buiten. In dat laatste zit een stem, een geluid sterk als een gong, als een Sint Jansklok, het zet de menschen in geestdrift as ze 't hooren - het heeft zeker zijn nut van orientatie voor oe, dat ge dat weet, en ik ben er maar weer blij om en vertel iedere keer erbij: da komt uit brabant! - Ja, beste kerel, da is wat anders dan de mijn-ziel-is-als-een-glazen-glas-poezie!"31

Hij verdedigt de "repeteerende breuk": "zoo is onze taal, de taal van den oost-brabanter die verzekert " $t$ is goei weer, ja, ja, da zeg ik, dat 't goei weer is.' Mee die herhaling wil 'k soms teekenen, en ik heb er plezier in die herhalingen te schrijven, maar ik zal er toch mee oppassen en het dan maar heel schaars doen." Hij weet dat de herhaling van het woordje 'brabants' een zwak van hem is, "maar daar is ook bijna geen woord wat ik zoo graag schrijf as dit." Daarna ontzenuwt hij het derde kritische punt van Van Duinkerken. Typisch voor Coolen is dat hij bijna ongemerkt laat weten dat de naam van de echtgenoot uit het verhaal niet $\mathrm{Cis}$ is maar Bart:

"In Het zegenend geluk ben ik zeker niet duidelijk genoeg, niet suggestief genoeg geweest. Mee die plavuizenleggerij en het timmeren van die tafel heb ik niet de verwachting willen wekken, dat met die dingen iets gebeuren zou. Ik heb er Bart's liefde voor zijn vrouw mee willen teekenen. Hij staart niet in haar oogen en aanbidt de blonde pracht van d'r haren niet, maar hij legt plavuizen voor haar en timmert een tafel voor haar en uit zijn goedheid is de hare te verklaren die haar plotseling dringt tot de sublimiteit van dat kleine offer, de kleertjes, die ze zelf maakte voor haar eigen kind en die ze weggeeft. En dan nog: Bart, dieje timmerman, dieje vloerlegger. Dat is-ie ommers niet, een timmerman of een vloerlegger, maar voor háár is ie alles tegelijk."

Hij maakt een groot verschil tussen Timmermans en Streuvels:

'Ik kan bezwaarlijk gelooven, dat Timmermans' naiveteit écht en niet pose is en dat hij in 't behoud van het katholiscisme en zijn tradities het behoud van zijn volk ziet. Het is bij hem sfeer, decor met soms als zoodaanig zelfs nog twijfelachtige waarden, want zóó gegeven, dat de noorderling, de niet-katholiek van bóven-af met een glimlach er op néér zie. Men vindt het 'charmant' bij hem, en dat is eigenlijk al iets bedenkelijks, het is een attribuut, bedoel ik vooral, van zijn kunst en het is er niet substantie, diep wezen, in. Van Streuvels hou ik veel meer, ofschoon ik dien weer zijn fatalisme niet vergeven kan. Streuvels is veel grooter dan Timmermans, - terwijl het jammer is dat Pallieter de Streuvels-reputatie in 't Noorden kan verdringen is het een bewijskrachtig teeken dat ie gróóter, dieper is, Streuvels!"

Met Marie Gijsen heeft hij minder op: "Misschien heb ik niet genoeg van haar gelezen om een goed oordeel over haar te geven. Als ik haar lees ontkom ik niet aan een agressief gevoel: nee, dat is toch ons volk niet. Zij ziet het niet tot op den kern van zijn wezen en niet tot op zijn schoone ziel, zij ziet verschillende kwaliteiten en geeft die zoo dat men ze als karakteristiek van den brabanter herkent." 
Over het pessimisme van de Brabander heeft Coolen ook zo zijn bedenkingen. Hij vindt dat meer attribuut dan substantie. "Vergeef me deze repeterende breuk," schrijft hij erbij. Hij geeft een voorbeeld uit zijn eigen boek: "Ge weet, die moeders bij Regien uit Jantje, ze zitten allemaal maar te klagen over haar moederverdriet, maar ik heb het maar niet zoo ernstig genomen, ze drinken er een gezellig bakske koffie bij en eten een sneeke koek en Jeroen den bakker jaagt zijn vrouw met al haar moederverdriet door de gaten in zijn watermikken!" Coolen speelt hier met het algemene gezegde over een slechte bakker die broden verkoopt die wel groot zijn, maar niet aan het gewicht omdat er zulke grote gaten in zitten. Hij is blij dat Van Duinkerken hem oproept tot 'het apostolaat van het hart' en wijst op de grote invloed van boeken van Bloy (Le sang du pauvre) en van Hello (Le Siècle), waarbij de laatste steeds heeft gewezen op 'l'immense devoir' van de schrijver om te schrijven. Wat Coolen er niet bij vermeldt, is dat hij die immense plicht van de schrijver op een heel eigen manier invult. Coolen voelt zich niet geroepen om een boodschap uit te dragen of zijn lezers voor een idee te winnen. Hij wil ontroering teweeg brengen door de mensen met al hun tekortkomingen te schetsen.

\section{Schrijfverbod voor de seminarist Asselbergs}

Van Duinkerken antwoordt met een ongedateerde kaart met als opdruk: "Voor eigen land. Aan allen die Brabant liefhebben. Brabant let op uw zaak." Hij bedankt voor Xandrieke, "al is 't slot (de onopgeloste verhouding Jantje - pastoor) juist 'n bevestiging, me dunkt, van het 'pessimisme' of minstens 'malisme' om nu een superlatief te vermijden. Maar je eigen uitleg, die weliswaar de zaak verduidelijkt, moest totaal overbodig zijn, nietwaar? Wil je dat we lezen wat er niet staat, dwing er ons dan toe." Dit doet hem denken aan een citaat van Poe: "It is not excellence if it is not demonstrated as such." ${ }^{32}$ Hij belooft in een brief uitgebreid op Coolens reactie terug te komen.

Dit komt er echter niet van omdat de priesterstudent Van Duinkerken een schrijfverbod krijgt opgelegd. In een ongedateerde brief schrijft hij dat dit voor Coolen een soort doodsbericht is:

"Ik zal n.l. niets meer publiceren, zelfs niet meer schrijven, geen jongeren tijdschriften meer lezen, geen relaties meer aanhouden met jonge artiesten, enfin alle literaire gedachten bannen uit mijn brein.[...] De bisschop heeft in de jonge kunstbeweging gevaar gezien voor de katolisiteit en wil niet dat ik op enigerlei wijze daaraan meewerk of daardoor beinvloed word in mijn gedachtenleven. Zelfs Roeping staat voor mij op den index. Het laatste nummer heb ik niet eens gelezen. Ja man, nu zul jij ook mijn Brabantse schrijverstaak op je moeten nemen en ik zal dat niet lezen, tenzij wanneer je soms een boek uitgeven zou." ${ }^{33}$

Op pathetische toon, toch al eigen aan Van Duinkerken, maar nu heel begrijpelijk vanwege het enorme keerpunt dat zich in zijn leven gaat voordoen, zegt hij dat de relatie verbro-

31 BA, brief Coolen aan Van Duinkerken, 16 februari 1925.

32 "Edgar Poe is de enige letterkundige, die ik sinds Nieuwjaar met smaak heb gelezen," schrijt Van Duinkerken in die tijd aan Piet Kerstens. Van der Plas, Daarom mijnheer, 78.

33 BA, brief Van Duinkerken aan Coolen, ongedateerd, waarschijnlijk maart 1925, met vignet van de heilige Theresia en opdruk 'Pax Christi'. 
ken zal worden en herhaalt nog eens dat dit voor hem zijn doodsbericht is. Hij geeft nog richtlijnen mee: "Daarom wens ik, dat je tot helderheid komt in die pessimisme-kwestie, die ik expres scherp opzette tegen je, om je, door de weerlegging, die je zelf moest geven, te dwingen in te zien hoeveel valsheid er zit in het werk van Marie Gijsen, waarvan jij de bestrijder moet zijn. Jouw oeuvre moet duidelijk maken, dat de oer-sterke Brabander de macht bezit, zelf zijn levensgeluk af te dwingen van zijn hard leven." Hij voegt eraan toe dat hij zelf nu zijn leven moet ombuigen: "Wacht echter niet op mij, poeta nascitur - poeta moritur." Hij ondertekent niet met zijn schrijversnaam maar met Willem Asselbergs.

Coolen heeft het op dat moment heel druk door ziektegevallen op het "redaktie-buroo" en is bovendien ook zelf ziek geweest. Hij zal de publicaties missen, maar hoopt dat Van Duinkerken, als hij eenmaal priester is, weer gaat schrijven. Opvallend is dat hij geen woord van opstand of verontwaardiging tegen de kerk of de bisschop uit, hetgeen wellicht verband houdt met enige vorm van briefcensuur, die in die tijd op seminaries niet ongebruikelijk is. Hij prijst Van Duinkerken zelfs om zijn reactie: "Maar dat je op de bisschoppelijke wens zoo reageert, dat is subliem, dat is een sterk en schoon offer, jij, kerel die ombuigt in andere lijn en niet breekt." ${ }^{34}$

Van Duinkerken heeft aan veel vrienden een 'doodsbericht' gestuurd. De meeste reageren evenals Coolen met respect voor de beslissing. Zo zegt Jan Engelman dat hij vol moet houden om zo "onze beste priester" te worden. Alleen Bernard Verhoeven reageert geschokt en roept hem op om zijn kunstenaarschap niet op te offeren. ${ }^{35}$

$\mathrm{Al}$ is de relatie verbroken, Coolen heeft toch nog zijn verzen en de herinnering aan "de ontmoeting in Amsterdam." Hij werkt op dit moment aan een roman: "As mijn boek uitkomt, krijgde gij het eerste exemplaar. De titel heb ik ontleend aan de regel uit jouw vers: Kinders van een sterk volk zijn brabantse mensen - de titel zal toch zijn Kinderen van ons volk - Jouw versregel gaf me die zoo in. ${ }^{36} \mathrm{Hij}$ heeft zojuist een grote novelle naar Roeping gezonden: Dat sprookje het feodale kasteel. Deze zal in de zomer in twee afleveringen gepubliceerd worden. Al op Witte Donderdag 1925 schrijft Van Duinkerken dat hij de relatie met Coolen aanhoudt, als ze het maar niet over literatuur hebben. Zo heeft hij ook B. Verhoeven en J. Engelman 'aangehouden'. Hij heeft een verzoek over de titel van de komende roman: "Zou het teveel gevraagd zijn als je de hele versregel "Kinders van sterk volk zijn Brabantse mensen" als motto plaatste met aanduiding van herkomst? Dat zou ik op prijs stellen, zo'n lijkkrans!" Hij stelt ook voor om een opdracht aan Moller op te nemen ("Aan de grote strijder voor Brabants heilige zaak"), maar voegt er meteen aan toe dat Coolen misschien niet zo voor opdrachten is of dat het mogelijk is dat hij helemaal niet zo met Moller dweept.

Coolen heeft het kennelijk nog steeds druk, want op de 'voordag' van Pinksteren klaagt Van Duinkerken dat hij niets van hem hoort. "Ik wijt dat maar aan scheppings-drukte! Alle literair nieuws blijft me vreemd, behalve de kroniek der N. E. [De Nieuwe Eeuw, C.S.] waar gisteravond nog Jozef van Aalst jou m'n opvolger noemt. Is het ijdelheid van me, dat ik je als zodanig zeer lief heb en veel van je verwacht?" Hij zal op zaterdag 6 juni r 925 de tonsuur (kruinschering) ontvangen. Coolen is daarbij aanwezig geweest, want reeds de volgende dag schrijft Van Duinkerken een dankbrief: "Goeie kerel, nee, op zoveel had ik niet gerekend!" Aan het eind van de brief blijkt dat hij een boek van Augustinus heeft gekregen. $\mathrm{Hij}$ is zich bewust dat hij zijn literaire roem opoffert. Hij vergelijkt zich met de romanfi- 
guur van Querido, Manus Peet, waarmee Coolen zich een aantal jaren daarvoor ook al identificeerde. Daarna houdt hij een lange uitweiding over zijn toekomstig priesterschap. Aan het eind blijkt hoezeer hij met zichzelf bezig is geweest. Hij dicht Coolen ineens een vrouw toe: "Voor jou, voor je vrouw heb ik gebid. Je zei me toch, dat je getrouwd was [...] Was ik maar bij je. Misschien in augustus kom ik praten, alleen maar gelukkig met je zijn, zo samen of met je vrouw, in 'n kamer, bij avond, als 't warm is geweest overdag! [...] Dat je je boek aan me opdraagt is heerlik. Ik had echter gevraagd het aan Moller te doen, de grote Brabander! Onze martelaar! Doch dit hoog geschenk wil ik nu niet afwijzen, tenzij je liever anders doet." ${ }^{37}$

Coolen heeft dit kennelijk beloofd. Het wordt geen opdracht, maar wel ontleent Coolen een motto aan Van Duinkerken: "De rauwe grond die de aarde hun gaf, dat ze vechten zouden." Hier blijkt voor het eerst iets van het wederzijds dienstbetoon dat de twee schrijvers hun verdere leven elkaar zullen bieden. Het is eigenaardig dat Van Duinkerken niet weet dat er geen mevrouw Coolen is. Waarschijnlijk laat de beginnende mannenvriendschap met de literatuur en Brabant als gedeelde interesse weinig ruimte over voor andere zaken. Ze hebben beiden ook nog een ander belang bij hun vriendschap. Ze hebben elkaar nodig in de volgende cruciale fase van hun leven. Van Duinkerken gaat een gigantisch netwerk weven van contacten om zijn ambities als essayist, journalist en pleiter voor de katholieke en Brabantse zaak waar te maken. Coolen gaat op zoek naar contacten en podia om zijn nieuwe literaire producten aan de man te brengen.

\section{De barensweeën voor het nieuwe werk}

Coolen heeft bijna geen tijd om te antwoorden: niet alleen zijn de collega's op vakantie, "maar ik heb bijna een heelen roman geschreven!" Het werk aan De rauwe grond schiet goed op. Hij is blij dat het feit dat Van Duinkerken geen literair werk meer schrijft, geen aanleiding is geworden voor een verwijdering tussen hun beiden. Coolen vindt het fijn dat Van Duinkerken hem zal opzoeken maar hij moet hem op een punt teleurstellen:

"Ik ben niet getrouwd. Dus de goede zorgen die ge as gast in een huis waarvan ik kon zeggen 'ons' huis zeker zoudt krijgen, die zal ik oe niet in die mate kunnen geven. Maar ge zijt er even zoo welkom om. [...] Ge weet niet half hoe blij ik ben dat ge komme zult! Nee, niet getrouwd. Zelfs niet verloofd. Maar nou heb ik juist een paar maal een lief meisje ontmoet en die zal ik over veertien dagen weer ontmoeten. [...] I k heb tijden achter de rug van de scherpste twijfels, dat is al lang geleden, en dat is ook niet zoo erg, maar wat erger is, ook tijden van de grootste onverschilligheid. En nu ken ik geen ander verlangen dan me toch maar klein, klein te maken, zooals gij zegt, tot een vod, een dienende hond voor onze lieve heer - onze lieve Heer - Daar hedde gij toe meegewerkt en anderen. Hello voor 't weinige wat ik van hem gelezen heb. Thomas van Aquino, maar gij ook vooral [...] en laatst toen ik met de St. Jansprocessie in Laren was

BA, brief Coolen aan Van Duinkerken, 7 april 1925. 
toen trof de priester die voor't altaar dat midden in Gods natuur was opgesteld preekte mij op dit eene punt, waar hij zei dat er ook zondaren zijn die in hun kwaad uitroepen: ik doe dit kwaad, maar in de zwakte waarin ik het kwaad bedrijf, hou ik tóch zooveel van $U$ lieve Heer, en het leed om mijn zwakte is er te grooter om! Och beste kerel, zeker gij, ik bewonder je orm al je sterke kracht, en gij die dan nog zegt 'n kolossale tobber te zijn, ge vindt in mij broedertobber, broeder-grôôte-tobber. Je kent Bruning uit zijn werk. Nou ook weer in zijn romanfragmenten kwélt me deze getoermenteerdheid. Ik ben er bijna zeker van dat Bruning, de leedgeslagene en zieldoorkorvene, niet die practische aanleidingen tot zulken staat heeft, die ik zou hebben, ik bedoel: die ik heb, zonder die terugslag in leven en werk. Ik schaam me er bijna om. Ik wil er om nog maar kleiner, kleiner zijn. Als je eens wist, hoe weinig ik maar nodig heb om door alles heen te juichen van geluk, dat geluk, dat abondéérende, dat in je keel gaat zitten!"

Aan het slot kondigt hij zijn eerste roman aan: “Dit nog, mijn roman heet: De rauwe grond die de aarde hen gaf. Pieter van der Meer de Walcheren heeft hem ter inzage gevraagd voor Opgang en daarop volgende boekuitgave bij van Munster! ${ }^{n 38}$

Diezelfde dag schrijft Coolen nóg een brief aan Van Duinkerken, die hieronder integraal wordt weergegeven.

"Beste Kerel,

Ik heb nog wat vergeten. Ik wou nog 'n advies vragen - Indertijd zond ik mịn novelle naar P.v.d.M de W met de vraag wat hij dacht van uitgave bij van Munster. Pvdmde W schreef terug dat ze novellen liever niet uitgaven maar as ik eventueel eens een roman schreef, of ik die dan ter inzage wilde zenden. Dezer dagen schreef ik toen dat ik 'n roman had en of 't ' $n$ bezwaar was voor eventueele uitgave dat-ie eerst in Roeping verscheen. Daarop schreef P vd M de W Stuur me 't handschrift eerst toe om te zien of het geschikt is voor Opgang, dan verschijnt het daarna vanzelf as boek bij van Munster. Als ik dat nu doe onttrek ik de roman aan Roeping, en dat doe ik niet graag. Dat is geen pretentie, dat begrijpt ge wel, maar liefde, liefde voor Roeping. - Ge hebt zeker Bernard Verhoeven wel gelezen in de Nieuwe Eeuw over de op en neergangen die Roeping heeft meegemaakt - Roeping is achter elkaar kwijtgeraakt Rob de Wilt, en jou en Jan Engelman en Kuyle e.a. Als Moller nu deze brabantse roman eventueel in Opgang ziet verschijnen, zou hij juist prijs blijken te hebben kunnen stellen op publicatie ervan in Roeping. Wat dunkt jou? Aan de andere kant verzekert een eventueele publicatie in Opgang - want P vd M de W moet hem geschikt vinden - de uitgave as boek. Schrijf me hierover jouw meening eens, ja?

'n Ferme hand van Toon." ${ }^{39}$

Duidelijk blijkt hoe zwaar het oordeel van Van der Meer de Walcheren nog weegt voor Coolen. Uiteindelijk zal De rauwe grond niet in afleveringen in een tijdschrift verschijnen. De roman komt meteen in boekvorm uit. Coolen nodigt Van Duinkerken uit om eind augustus 1925 te komen logeren. Coolen is nu "op reis in Brabant, tuis [sic] en van daaruit hier en daar naar toe," maar hij komt voor de logé terug naar Hilversum. "Mijn kostjuffrouw heeft een brabantse gulhartigheid." Hij heeft de pasgetrouwde Gerard Knuvelder en diens vrouw van de trein gehaald en naar hun hotel in Laren gebracht en later nog met hen gewandeld. Ze vertelden hem van een gelukstelegram, dat niet ondertekend was met Asselbergs, maar met zijn schrijverspseudoniem, Anton van Duinkerken. "Jij, grimmi- 
gaard, van Duinkerken is niet dood!" Hij heeft het meisje waar hij eerder over schreef weer ontmoet:

"Met haar en ' $r$ broer heb ik in het zomerzondagavonduur op het balcon voor mijn kamer gezeten. In de loop van het gesprek kwam ook de jonge dichtkunst ter sprakeToen heb ik ook jouw lied van brabant opgezegd en er misschien wel schandelijk misbruik van gemaakt. Daar komt immers in .. 'kolenhanden die vriendschap kunnen drukken als geen andere'- Toen heeft een 'Coolen'-hand vriendschap gedrukt en een vriendschapdruk teruggekregen." ${ }^{40}$

Van Duinkerken, die nog steeds seminarist is en gebukt gaat onder het schrijfverbod, ziet erg uit naar de logeerpartij. Hij zal zaterdagavond 22 augustus arriveren, niet te laat zodat ze nog kunnen praten; 's zondags doen ze wat Coolen wil. Daarna zal hij nog een paar dagen blijven. Hij wil maandag, als Coolen naar zijn werk is, Jan Engelman bezoeken. Deze blijft pogen om hem bij De Gemeenschap te betrekken. Officieel mag Van Duinkerken zich van de leiding van het seminarie helemaal niet met literatuur bezighouden. Hij heeft zijn zus op Roeping moeten abonneren, om het werk van Coolen te kunnen volgen. Hij heeft daarin nu 'Dat sprookje het feodaal kasteel' van Coolen gelezen en wil daar graag over praten, want hij heeft kritiek: "wordt geen slachtoffer van je goeie manier. Je begint den indruk te maken van het reeds gehoorde, het gehoorde bij jezelf, enfin van een repeterende ... tja 'breuk' lag op m'n pen, maar dat is erg onjuist!!"' Hij wil ook praten over de katholiekendag die hij heeft meegemaakt en over het Vlaams-Hollands congres. "Die verhouden zich rechtstreeks evenredig tegenover elkaar. Die Vlaamsche vitaliteit en die bovenmoerdijkse verduftheid! Praten daar lang over en lollig bij ' $n$ biertje als dat ergens te krijgen is in de buurt."

Coolen belooft voor een biertje te zorgen en de logeerpartij verloopt goed. Nog jaren later kijkt Van Duinkerken er met plezier op terug en vergist zich weer flink in tijd en plaats als hij schrijft over "ons eerste meer vertrouwelijk gesprek in de zomer van 1926 . Ik logeerde toen enkele dagen bij hem in de Gijsbrecht van Aemstelstraat te Hilversum. Hij had het kladhandschrift van De rauwe grond voltooid en was bezig, het werk gereed te maken voor de drukker. ${ }^{\text {"42 }}$ Dit boek verscheen echter begin 1926. Coolen was er in augustus 1925 aan bezig en niet op de Gijsbrecht van Aemstelstraat maar op de Vaartweg. ${ }^{43}$

De priesterstudent neemt het ervan, terwijl Coolen hard aan het werk is. Zo doet Van Duinkerken later verslag van zijn logeerpartij:

"Overdag deed hij zijn werk als journalist. Hij zat op het bureau van De Gooise Post zijn kopij te schrijven met een sierlijk-regelmatige verdeling van de schuinoplopende letters over de bladzijden, wel snel, maar altijd zorgvuldig en met weinig doorhalingen en

BA, brief Coolen aan Van Duinkerken, 15 juli 1925.

42 Van Duinkerken, 'Omgang met Antoon Coolen', 623-625. Coolen leest tijdens deze ontmoeting The importance of being Earnest voor.

43 Later zal Van Duinkerken nog een keer bij Coolen logeren, maar dan woont deze al op de Boschdrift (zie BA, brief 23 augustus 1927). 
tussenvoegsels. Of hij fietste met zijn collega van De Gooi en Eemlander naar een der naburige plaatsen, waar hij de zitting van de gemeenteraad opnam. Hij maakte verslag van provinciale toneelvoorstellingen en van concerten. Hij gold voor de beste muziekreferent uit de omtrek. Ik ging niet met hem mee op deze tochten naar zijn dagwerk, maar haalde hem na een mooie wandeling af op zijn krantenbureau of ontmoette hem in een buitencafé. Hij was nog ongetrouwd. Wij dineerden samen op zijn kamer of in een restaurant en bleven hierna urenlang met elkaar in gesprek." ${ }^{.44}$

Van Duinkerken is er echter niet altijd met zijn gedachten bij; hij staat voor grote keuzes in zijn leven. Als hij enige tijd later bedankt voor de gastvrijheid, blijkt dat hij ook met de Utrechtenaren veel contact heeft gehad: "Pronkjuweel van Brabant, het moet een affreuse indruk op je gastvrij hart hebben gemaakt, dat ik maar zweeg als een salamander in ijswater [...]. Ik ging naar huis met het stellige plan dadelijk Exodus te lezen om dan tegelijk daarna 'n dankbrief aan je te zenden." ${ }^{45}$ Op de terugweg kreeg hij in Utrecht echter Kuyles Zeiltocht mee en de belofte dat Kuyle en Lou Lichtveld naar Bergen op Zoom zouden komen; dus moest hij eerst Zeiltocht lezen. Na een opsomming van zijn beslommeringen en wat hij allemaal leest: "Wat jou aangaat, je portret staat hier te pronk, doch Exodusstaat in de afdeling dikke kwarto-boeken: Académie-dictionnaire, Klassiker der Kunst, Vondels komplete werken in 2 delen, La peinture à Bruges en andere dergelijke afmetingen. Het is er sinds niet uitgeweest. [...] Sukses met de rauwe grond, kerel. Ik verwacht dat dit goed zal doen. jij bent de

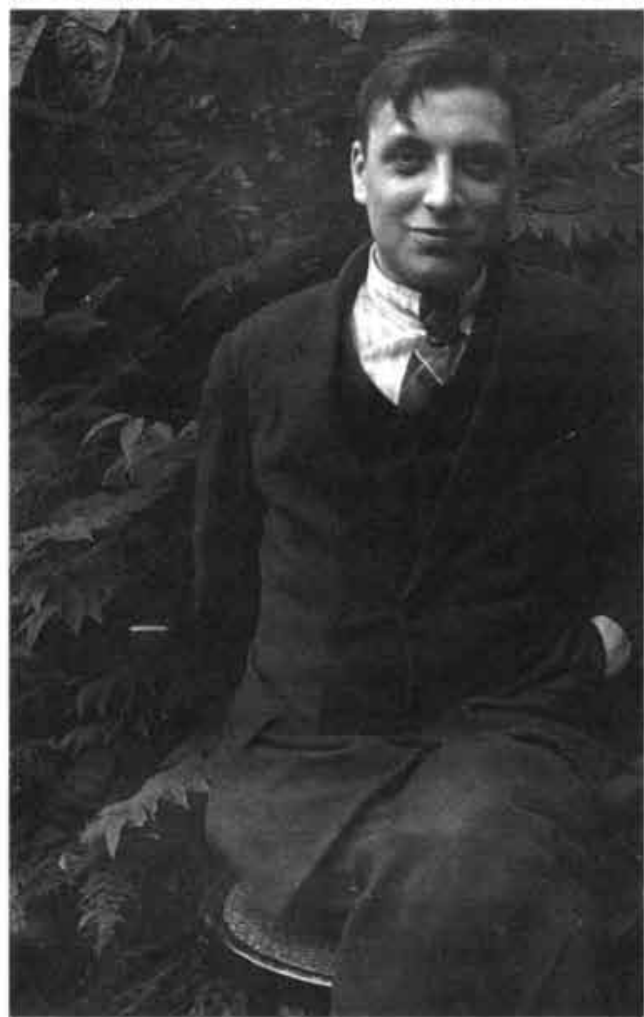

Van Duinkerken schreef achter op deze foto van hemzelf:

"Bij gebrek aan beter dit in ieder opzicht bespottelik portret ter herinnering aan de avonden van ... emst." enige jongere, die objectieve personen weet te maken. De rest is te liries daarvoor."

Het verhaal waar Van Duinkerken kritiek op heeft, 'Dat sprookje het feodale kasteel', gaat over een tegenstelling die Coolen zelf in zijn jeugd ervaren heeft: de twee verschillende werelden van het dorp en het kasteel. Een dorpsjongen, Peer, droomt ervan om de kloof te overbruggen. Hij leest Conscience en is verliefd op de freule. De wereld van het kasteel wordt getekend aan de hand van de bedienden: de huisknecht Franswa en de chauffeur die afwisselend Willem, William of Guillaume heet en met de baron pakken in Engeland gaat kopen. De wereld van het dorp komt tot leven in de beschrijving van de serenade van het Zat Hermenieke en van Frieduske, de koetsier die tijdens het wachten bij het station te veel borrels drinkt. Als Franswa ontslagen wordt wil Peer solliciteren, 
maar durft uiteindelijk niet. 's Avonds moet hij huilen en als zijn moeder vraagt wat er is zegt hij; niks. "In dat niks ligt alles, in dat niks ligt een verdriet grooter dan het heelal. Maar zijn moeder wordt er niet wijzer door. Die freule ook. Die Conscience ook." ${ }^{46}$

Het is verleidelijk om hier de jonge Coolen in Deurne in de plaats van Peer neer te zetten. Ook hij las Conscience en droomde van andere werelden aan het eind van de spoorbaan en achter de muren van kastelen en notarishuizen. Het thema zal hij veel later en uitgebreider gebruiken in zijn roman De urouw met de zes slapers(1953).

\section{Een nieuwe liefde}

In december kan Coolen zijn vriend melden dat zijn boek De rauwe grond ter perse is bij de Waelburgh, maar er is ook ander nieuws dat hem hoog zit:

“En nu het meisje, nu over mijn Gerda -, die intusschen niet mijn meisje, niet mijn Gerda is, nog niet en die het misschien wel nooit zal worre.-Als ik nou maar es een eenigzins chronologische relaas kon geven, dan kreeg je misschien eenigzins kijk op het tragische geval van deze verhouding. [...] Nadat je hier was heb ik haar herhaaldelijk ontmoet en hebben we samen tal van concerten bezocht. [...] Toen bij een concert van het utrechts stedelijk orkest heb ik het haar gezegd, onder de uitvoering van het vioolconcert van Max Bruch, waarvan ik niet weet of je het kent - Zoo iets héél aparts is deze muziek niet [...] er komt een heel mooi adagio in voor, waarvan ik veel houd, en toen heb ik haar gevraagd, of ik aan dit adagio voor haar een herinnering verbinden zou. $\mathrm{Ze}$ knikte ja en nee tegelijkertijd en het volgende oogenblik waren de vier woorden simpel gezegd en luisterden we beiden verder naar de muziek en de inwendige ontroeringen. [...] Toen we naar huis gingen zei ze dat 't niet kon, dat ze wel van me hield, maar niet voldoende, niet zóó, je begrijpt, vriendschap, sympathie, genegenheid, maar niet het heilige, niet de liefde. Toch hebben we de volgende dagen elkaar geregeld en langdurig ontmoet, we zijn door de herfststormen, door regen en stormvlagen de bosschen ingetrokken en menige keer heeft ze met de armen om me heen en d'r hoofd op m'n schouders staan schreien en klagen, een tragisch raadsel, een schreien dat noodzakelijk uit iets anders voortkomen moest dan enkel uit medelijden omdat ik verdriet zou hebben als ze mijn meisje niet werd. [...] Later is haar groot verdriet me éénigzins duidelijk geworre. Ze had in haar leven, dat droevig was, gehunkerd en gebeden om de groote liefde en kon toen deze zoo tot haar kwam er geen afstand van doen, wat ze aan de andere kant na mijn bekentenis moest doen, omdat ze niet wederkeerig mij met dezelfde liefde liefhad. Kun je dat begrijpen? In begin November zijn er van die rustige avonden geweest, wit van maneschijn. Toen zijn we naar de plek gegaan, waar we 't ergst geleden hebben en daar heeft ze een paar avonden achtereen, terwijl ik tegen een boom zat met d'r hoofd in mijn schoot gelegen, zoodat ik neerzag op haar lief, lief gezicht, wit in 't maanlicht met gesloten oogen. [...] Kerel, je weet niet wat je ervaart en ziet uit het beminde gezicht van een meisje, zoo'n rein gesloten gezicht dat zoo rustig neerligt onder je oogen. ${ }^{\text {n47 }}$ 
Hij stuurt haar portret mee maar wil het wel gauw weer terug. Fennis schrijft over deze periode de volgende passage:

"In I926 of daaromtrent kwam er een vrouwelijke collega aan mijn school, [de St Joseph-school, C.S.J, een vlotte hupse type. $\mathrm{Zij}$ heette Gerda de Jong en woonde op de Gijsbrecht van Aemstelstraat. [...] haar vader was een boekhouder, die werkte in Amsterdam. [...] Gerda had een broer, Hans geheten, later bekend als letterkundig recensent onder het pseudoniem Hans van Haren en medewerker o.a. aan De Gooi en Eemlander. Ger vertelde me, dat haar moeder wel genegen was een commensaal te houden. Ik gaf dit door aan Toon Coolen en deze verhuisde van de Boschdrift [Vaartweg, C.S.] naar huize de Jong, waar hij al spoedig bezweek voor de bekoorlijkheden van Ger en tot over zijn oren verliefd op haar werd. Dit laatste was evenwel geen bijzondere prestatie van Toon. Ger had intussen gesolliciteerd naar een betrekking in Rotterdam. $\mathrm{Zij}$ werd benoemd aan een school in de parochie van de $\mathrm{H}$. Familie. Tijdens weekends kwam zij thuis. Dat de verhouding tussen beiden innig was kon ik constateren op een verjaardag van Toon. Vóór schooltijd 's morgens ging ik hem feliciteren. Toon zat beneden op de divan, een broer van hem [van haar, C.S.] speelde fluit in een hoek van de kamer. Ger kwam van boven. De gelukwensende omhelzingen en kussen, waaronder Toon bedolven werd logen er niet om." ${ }^{48}$

Coolen woont tot 9 januari 1926 op de Vaartweg en vanaf die tijd op de Gijsbrecht van Aemstelstraat 23. Nu woont hij dus in het ouderlijk huis van zijn meisje, maar in geen van zijn brieven maakt hij daar melding van. Eigenlijk kan zoiets in die tijd niet en dit zal dan ook de reden zijn, dat, als de relatie serieuzer wordt, hij op I september 1927 weer naar een nieuw adres verhuist. Voorlopig is de relatie nog pril en ook nu weer schrijft Coolen er openhartig over, wat getuigt van vertrouwen van de 28 -jarige journalist in de 22 -jarige priesterstudent:

"Het is merkwaardig zoo as ge ten deele juiste kijk op mijn prachtkind Gerda hebt en ook je vergissing is merkwaardig. Juist, die woorden die gij gebruikt: behoefte aan geruststellende liefde, een liefde waarin zij zich veilig voelt, dat zijn alleen Gerda d'r eigen woorden. Maar juist omdat ze die dingen bij mij vindt en ervaart, daarom wil ze geen afstand doen en zou ze, als ze afstand deed, naar d'r eigen woorden weer trug komme, weer even hard trug komme. We hebben heel ernstig de vraag onder oogen gezien of we niet zouden moeten scheiden en mekaar niet ontzien of gespaard-Ik voelde heel goed, dat Gerda niet gelukkig, niet blij bij mij was. In onze beste oogenblikken, juist in onze beste oogenblikken haperde er iets en als dat bemerkt werd had ze het bitterste verdriet. ${ }^{n+9}$

Coolen dacht eerst dat ze medelijden met hem had en het niet durfde uitmaken, maar dat is niet zo:

"Toen heeft ze eens gezegd dat ze trachten zou me duidelijk te maken wat de hapering was, wat er schortte - En dat heeft ze gedaan - Ze is eerder, eenige jaren geleden, verloofd geweest, met 'n man van het wereldse type dat je wel kent, ruig, sportief, met een imponeerend fiesiek, die haar echter teleurstelde omdat hij geestelijken inhoud miste en beschaving van gemoed en hart - ontwikkeling, enfin, je begrijpt. Welnu, bij mij vond ze alles wat zij in den ander miste, maar miste ... wat ze bij den ander vond en wat haar imponeerde en boeide. [...] Toen zijn we, na 't ergste geleden te hebben, tot de conclusie 


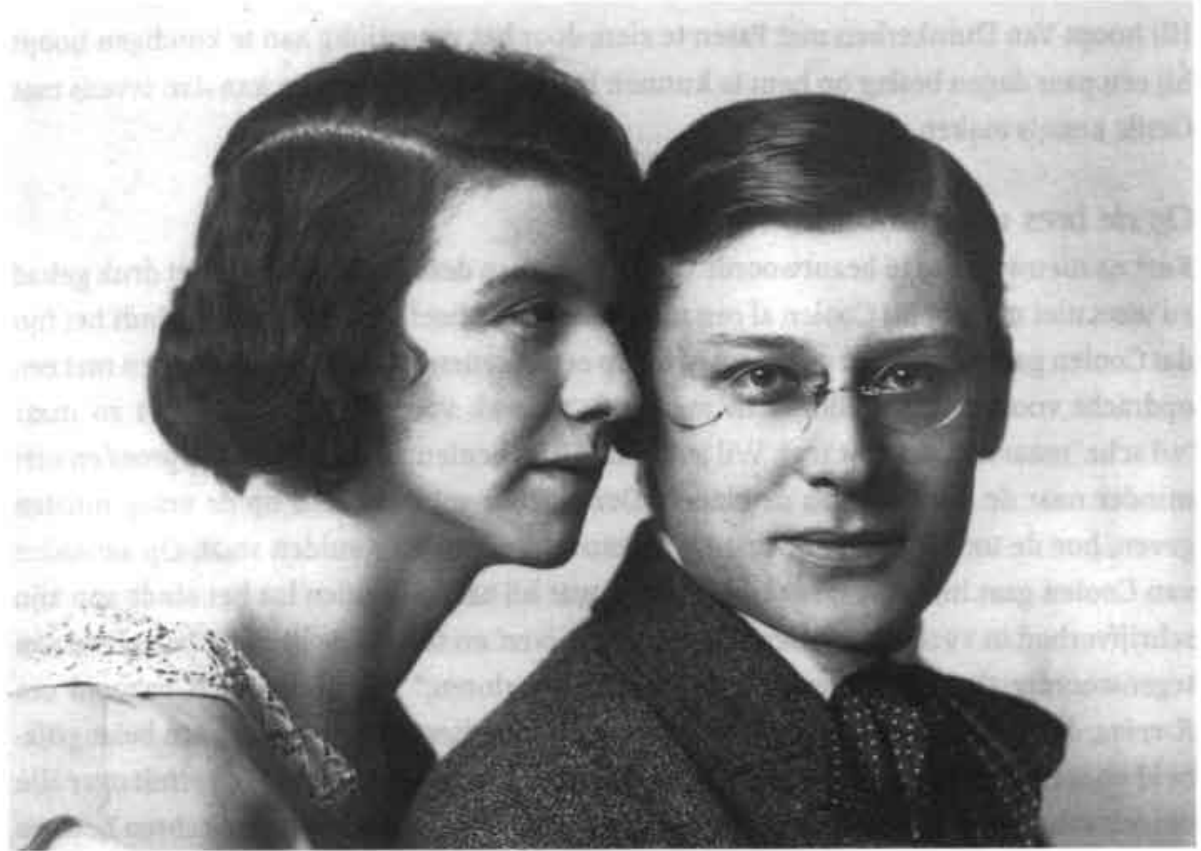

Gerda de Jong en Antoon Coolen.

gekomen dat we moesten scheiden. Totdat enkele dagen nadien zij eigener beweging zei dat het niet meer noodig was, dat we niet meer behoefden te scheiden. [...] Zoo leven we thans in een sterke vriendschap, nee, meer dan dat en 't moge vreemd schijnen, gerust blij, [...] en missen er ook niets aan dat we niet over verloven en trouwen praten. [...] Ik laat haar volstrekt vrij - als er iemand komt in haar leven die haar volstrekter, grooter sterker geluk biedt dan ik, haar krachtiger aangrijpt en ontroert, dan, heb ik haar gezegd, treed ik terug zonder kreten en tranen, zonder vermageringen en zelfmoord-aankondigingen."

Hij schrijft dit allemaal omdat hij Van Duinkerken vertrouwt en vraagt hem veel voor hem te bidden. Hij dankt voor het toegestuurde vers en kondigt nieuw werk aan:

"Ik vind het mooi. Maar je hebt er betere, sterkere, jij dichter van het Lied van brabant en The Gospel of Beauty! Heb je Gijzens [sic] bundel al? ${ }^{50}$ Prachtig is ie. Ik vind de waardering van Panhuysen in De Nieuwe Eeuw nog te matig - Ik vind het verreweg het grootste wat de nieuwere dichtkunst heeft voortgebracht. Tenslotte nog een nieuwtje. Behalve De rauwe grond zal van mij in 't voorjaar verschijnen Peerke dat manneke een novelle. Het verschijnt in de Kleine Librije te Edam. 'k Weet niet of je die boekjes kent. Ernst Claes heeft er ook een paar novellen in gepubliceerd. Ook hier kwam, als bij De rauwe grond, 't verzoek van de uitgever."

49 BA, brief Coolen aan Van Duinkerken, 30 december 1925.

50 Bedoeld wordt de verzenbundel van Marnix Gijsen Het Huis; deze bundel was in die tijd een belangrijke letterkundige gebeurtenis. 
Hij hoopt Van Duinkerken met Pasen te zien; door het vroegtijdig aan te kondigen hoopt hij een paar dagen beslag op hem te kunnen leggen. Van Duinkerken kan dan tevens met Gerda kennis maken.

\section{Op de bres voor Brabant}

Kort na nieuwjaar I 926 beantwoordt Van Duinkerken deze brief. Hij heeft het druk gehad en weet niet meer of hij Coolen al een nieuwjaarswens heeft geschreven. Hij vindt het fijn dat Coolen gaat publiceren en vraagt of hij op een auteursexemplaar mag rekenen met een opdracht voorin: "De bibliofiel in me heeft 'n zwak voor die attenties. Niet zo maar 'v.d.schr.' maar iets, dat wat zegt. Wil je, Toon." Hij is benieuwd naar De rauwe grond en niet minder naar de ontvangst in de bladen. Deze laatste zal antwoord op de vraag moeten geven, hoe de toonaangevende kritiek tegenover het donkere zuiden staat. Op aanraden van Coolen gaat hij een dagboek bijhouden, wat hij zal volhouden tot het einde van zijn schrijfverbod in I928: "' $t$ Is helemaal geen 'schrijven' en toch is de literaire bezigheid van tegenwoordig (lezen, denken) niet voor altijd verloren." Hij maakt zich bezorgd om Roeping, dat hij thuis leest tijdens de vakantie: "Het verliest met de maand aan belangrijkheid en schoonheid. [...] Help jij Moller, als je kunt, ik ben helaas lam." Hij vertelt over zijn bezoek aan Vlaanderen en betreurt het dat Brabant niet als Vlaanderen te vechten heeft en dat Brabant zo slap en tevreden geworden is: "Wij zullen die slapende ziel van Brabant wekken, al moet het met mokerslagen gebeuren. Toon, wij zullen Brabant tot een heerlik land maken en ons volk aan geesteswaarden rijk. Wij zullen het geloof zijn oude vuur hergeven en het aanschijn van die rauwe grond zal veranderd worden." Hij vervolgt met een verwijzing naar het apostolaatwerk van kapelaan Frencken in Breda onder fabrieksmeisjes: "Reeds werkt Christus Eucharisticus wonderen hier onder de meisjes uit fabrieken, onder de sletten uit de goorste wijkjes [...]. Toon, kerel, wij willen ons volk vernieuwen voor den heilige Geest. Werk als een muilezel. Ik zit in mijn stilte niet stil. Hier groeit de vlam. ${ }^{.51}$ 
51 BA, brief Van Duinkerken aan Coolen, ongedateerd [kort na Nieuwjaar 1926]. 


\section{De aanloop \\ tot succes}

\section{"lk kén de peelstrekenbewoners dóór en dóor."}

$1926-1928$

Coolen werkt inderdaad als een muilezel. In de eerste helft van 1926 verschijnen De rauwe grond en Peerke dat manneke. Beide werken voldoen echter niet helemaal aan de verwachtingen die Van Duinkerken ervan had. De situatie doet denken aan de manier waarop Lutkie enkele jaren daarvoor kritiek had op Coolens werk. Wéér heeft Coolen een begeleider die meer van hem verwacht dan een goed doortimmerde roman. Van Duinkerken wil dat Coolen getuigt, het volk verheft en Brabant sterk maakt. Misschien is hij in zijn oordeel beïnloed door vader Asselbergs. Deze is niet erg te spreken over De rauwe grond en vindt dat zijn zoon "ons goed Noord-Brabantsch volk veel schooner, veel edeler, veel pakkender voorstelt."1

Van Duinkerken wil van Coolen romans waar hij mee voor den dag kan komen als strijder voor de Brabantse zaak. Hij wil bovendien het katholiek geloof zijn oude vuur hergeven. Coolen wil met zijn literaire werk geen propaganda maken. Hij wil gevoelens wekken, deernis voor de hoofdfiguren, en ergernis over de achterbaksen, de onechte betweters en de roddelaars. Al die soorten mensen komen voor in het Brabantse volk; en in welk volk trouwens niet. Hij heeft er echter wel belang bij dat zijn boeken gepropageerd worden door Van Duinkerken, die snel bezig is een van de sleutelfiguren van de katholieke jongeren te worden.

\section{De eerste roman: De rauwe grond}

De roman De rauwe grond zou aanvankelijk in afleveringen in Roeping verschijnen, maar is door hoofdredacteur Moller geweigerd. Waarschijnlijk vindt hij evenals vader Asselbergs dat de schoonheid van het Brabantse volk geweld wordt aangedaan.

Hoewel de titel de indruk wekt dat het om een roman over het boerenleven gaat, is het boek veel meer een dorpskroniek. Het heeft als motto een fragment uit Van Duinkerkens gedicht: "De rauwe grond die de aarde hun gaf, dat ze vechten zouden." Slechts zijdelings wordt de lezer een blik op het gebied buiten de dorpskom gegund. De verteller zegt ironisch dat alle beschaving in de kom van het dorp huist.

"Hoe wijdter ge buitenaf komt, hoe minder cultuur. [...] daar komde ge dan al gauw in de velden en de akkers, de ontzeggelijke uitgestrektheden van het land, [...] ja, en hedde ge daar den ouwen peel en den voorpeel, de peel, uitgestrektheden peelgrond, ontstaan

1 Brief vader A.JJ.A. Asselbergs (1877-1940) aan zijn zoon Van Duinkerken, 15 juli 1926, geciteerd in: Van der Plas, Daarom mijnheer, 86. 
in den loop der eeuwen, uit onafzienbare moerassen, uren en uren gaans, de peel, onze peel in Brabant, de rauwe harde grond, daar wonen in hun lage hutten, de schamelen, de sjofelen, de peelwerkers, die taaje kerels van vel en spieren en ergens daar middenin da vel en die spieren hun goed somber hart." ${ }^{2}$

Verder richt de aandacht zich op de 'beschaving' en de mensen in het dorp: de directeur van het postkantoor die met een rijke vrouw getrouwd is, de notaris wiens ongetrouwde dochter op zomeravonden in de geopende serre piano speelt, de dokter en een quasi-intellectuele dorpsonderwijzer. Een nieuwe klerk op het postkantoor brengt onrust in dit peeldorp met kleinsteedse trekjes. Deze meneer Ewich praat "gruts" en legt het aan met Tine, de dochter van de bakker. Haar moeder is tegen zo eentje van boven de Moerdijk en noemt hem "diejen pennelekker" en "diejen grutschen stinker" of "kaaljakker". Meneer Ewich houdt met Tine ernstige gesprekken over de schepping en het godsbeeld. Het heelal en de natuurwetten ontlenen hun orde en bestaan aan een oerkracht. "Dat centrum van oerkracht met zijn attributen, dat noem ik God. Dat alles is zoo ontzaggelijk, dat het gewinkel met medailletjes en scapuliers daarbij wel wat belachelijk wordt."

De klerk hoort in het dorp nergens bij: met de directeur, de dokter en de notaris kan hij 'natuurlijk' niet omgaan. "Maar daar is nog meester Theunissen, een intellectueel!" Ook deze komt van boven de Moerdijk "en in al zijn beminnelijkheid vindt hij de brabanters typisch en kijkt een beetje neer op hun domheid en goedhartigheid." Hij schrijft rekesten aan de minister over militieaangelegenheden. Hij ontvangt de dorpelingen in zijn studeervertrekje met een boekenrekje en hij lacht om hun opmerkingen. "Zóóveel boeken? Dan zullen het wel kwaje zijn, want zooveel goeje zijn er niet. Hoe landelijk! Hoe typisch!"5

In de lente houdt mijnheer Ewich zware gesprekken met Tine "over de natuurwet van de liefde, waarop het maakwerk van de burgerlijke moraal kantelt en omvalt." Deze vormen de eerste stappen in zijn verleidingstactiek. Als ze samen in een greppeltie zitten, zegt hij: "Straks, [...] straks lig ik te woelen op mijn bed. Ik kan niet slapen. Heel mijn lichaam richt zich op naar de verschijning van het jouwe. Nooit bevrediging, nooit de vervoerende kalmte der overgave. Altijd vechten. Altijd lijden, altijd een gewapende houding tegenover mezelf om jou niet te zeer aan te vallen." ${ }^{\text {" }}$ Als Tine op het punt staat toe te geven - "Zij zal zich laten nemen, schreiend, klagend bij het verlies harer krachten om zich te verzetten, mijn God, een offer" - moet mijnheer Ewich niezen, is de betovering verbroken en gaan ze naar huis.

Op een volgende wandeling praat hij weer heftig op haar in en dan geeft zij toe en verliest haar maagdelijkheid. Na afloop huilt zij en geeft hem geen kus bij het afscheid: "Hij heeft haar verloren op het oogenblik waarin hij haar won."

Thuis gaat ze slapen naast haar kleine zus Nelleke die de volgende dag haar communie zal doen, waarvoor de witte kleertjes en schoentjes klaar liggen. Als in het dorp bekend wordt dat Tine een 'kiendje' moet krijgen, gaat mijnheer Ewich bij haar vader, bakker oome Peterus, zeggen dat hij medeschuldig is en dat hij de financiële consequenties wil aanvaarden. Hij spreekt van ridderplicht. De bakker denkt bij dit woord aan zijn optreden bij het amateurtoneel, waarbij hij een edelman moest doorsteken, maar zijn degen achter het scherm had laten liggen. Zijn zoon Jan gooit Ewich naar buiten "alsof hij 'nen roggemik den oven inschiet" en zijn hoed vliegt hem achterna als een vergeten kadetje.

Tijdens de doop van Tines kind overlijdt haar vader, de bakker, bij het werken in zijn 
hof. Kort daarna komt de dopeling thuis: "Dan komt Arnoldus thuis, de kleinzoon van den

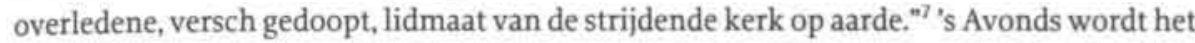
huis van oome Peterus "volgebromd" met gebeden, waar af en toe de "schreikreetjes" van de pasgeborene doorheen klinken. Na de begrafenis wordt er stevig geschranst en gedronken en om de angst te bezweren wordt er ook gespot met de dood.

Tine is gelukkig, maar het dorp roddelt. De pastoor komt aandringen dat het kind een vader moet hebben. Hij heeft hiervoor Willem Crooy op het oog. Het dorp verwacht er niet veel van. "Daar hoefde ge nou heelemaal geen grooten menschenkenner voor te zijn, om te begrijpen, da da niks kan worre mee die twee:" een sjofele peelwerker, "slaaf als hij was van den rauwen grond in ons brabantsch peelland" en een "burgerdurske". Het wordt echter toch iets en ze gaan trouwen. Willem werkt in de Peel in de rauwe grond. De slotzinnen:

"Hij geeft weinig terug, onzen grond, veel onkruid, spieren, kattestaarten en weinig vrucht. We bedauwen hem met ons zweet. De aarde heeft ons dezen grond gegeven die een sterk volk van onze kinderen heeft gemaakt. Omdat wij barbaren zijn is ons lied een schreeuw. Broeders, wij hebben ons brabant lief, wij knielen aan ons land, dat den hemel kan bevatten, en kussen het."

Met dit boek schetst Coolen voor de eerste keer de contouren en personages van zijn eigen Coolen-land. De scherpe waarnemer die hij is, heeft de indrukken van zijn jeugd, het dorp en de omgeving gebruikt om een heel eigen wereld te creëren. Hij schept zelfs een eigen idioom, waarbij niet geprobeerd wordt om het Oost-Brabantse dialect fonetisch weer te geven, maar waarin de toon en cadans van de taal van deze streek worden weergegeven. Door de wijvorm van de verteller wordt voor de lezer het idee nog versterkt dat hij in vertrouwen wordt genomen door een ingewijde. Als Ewich zijn 'ridderlijke' verhaal tegen de bakker afsteekt is het of de verteller samen met de dorpsbewoners mompelt: "Zoo'ne mondfiat!"

In het boek is veel te herkennen uit het persoonlijke leven van Coolen. Hoe onsympathiek het personage Ewich ook is, het vertoont veel trekken van Coolen, die voor Deurne een stadse meneer is geworden. Het kan best zijn dat Coolen zelf, als zwierig geklede journalist uit Hilversum, in Deurne uitgescholden is voor kaaljakker. De gesprekken met Tine over religie, schoonheid en liefde zijn een echo van die met Liesje. De schampere opmerkingen over de onderwijzer met zijn vele boeken, waaronder wel 'kwaaie' moeten zitten, zijn bekend uit de brieven aan Lutkie. De ideeën van meneer Ewich over de oerkrachten van het heelal en god lijken een echo van Coolens sympathie voor theosofie en pantheisme, die hem een paar jaar eerder zijn baan bij het Eindhovensch Dagblad kostte.

3 Denigrerend woord van dorpelingen voor stadse mensen met een versleten jas, een kaal jak. Mensen die zich beter voordoen dan ze zijn. Verhoeven, Herinneringen, 107.

4 Coolen, De rauwe grond, 28.

5 Coolen, De rauwe grond, 31.

6 Coolen, De rauwe grond, 49.

7 Coolen, De rauwe grond, 118.

8 Coolen, De rauwe grond, 176. 


\section{Katholieke pers en uitgevers}

In een recensie in De Maasbode wordt gesteld dat de titel en het motto iets heel anders hadden doen verwachten: een boerenepos over de taaie strijd tegen de grond voor een schamel gewin. In plaats daarvan komt er een idyllische dorpsgeschiedenis, waarvoor De Zonde in het gezapige Dorp een betere titel was geweest. De criticus zet vraagtekens bij het gebruik van halfdialect, waardoor het boek iets tweeslachtigs krijgt. Het werkt wel als Coolen vanuit zijn personages schrijft, maar wanneer hij als schrijver aan het woord is en als kritische buitenstaander doen die dialectische woordjes gezocht en vals aan. De sfeer van de personages en die van de schrijver lopen op die manier in het hele boek achteloos door elkaar. De criticus vindt het echter een goed verteld verhaal uit het Brabantse dorpsleven en al staat er geen nieuws in, "het bevestigt toch den goeden indruk van dit bescheiden, maar groeiend talent." Het is nog wat zoet, maar sinds zijn debuut "met over het algemeen zwakke en sentimenteele schetsen, heeft hij een kostbaar vermogen bij gewonnen: dat der ironie." Waarschijnlijk wordt hier Lentebloesem uit 1922 bedoeld, omdat het niet aannemelijk is dat iemand bij De Maasbode zich nog de vernietigende kritiek in deze krant op Opinies herinnert van twaalf jaar daarvoor. De criticus hoopt dat Coolen nog eens tot meer belang. rijke stof komt, want in zijn werk zitten mogelijkheden die nog niet genoeg tot hun recht kwamen. Hij kan vertellen en figuren scheppen, dus is er "alle reden om te vertrouwen, dat Antoon Coolen in zijn verderen groei en rijping, nog tot grooter werk zal komen. Misschien eens iets over den 'rauwen grond'..?"?

Er zijn echter ook negatieve reacties uit de katholieke pers. Het lijkt wel of juist deze het niet op zijn werk heeft begrepen. Coolen beklaagt zich hierover bij Van Duinkerken, nadat Moller wéér een schets van hem heeft afgekeurd voor Roeping, omdat deze te zinnelijk en te romantisch is. Het gaat om Peerke dat manneke. Hij laat zich er niet door ontmoedigen, want ondertussen werkt hij al weer hard aan zijn volgende roman: Hun grond verwaait. ${ }^{10}$

Coolen heeft zich van begin af aan vrij gevoeld om zijn werk uit te geven bij niet-katholieke uitgevers. Zijn eerste boek, Lentebloesem, komt uit bij het katholieke Nederlands Boekhuis in Tilburg. Daarna verschijnt zijn werk bij Laurens van der Waals. Deze beheert uitgeverijen onder verschillende naam: De kleine Librije in Edam, De Walburgpers en De Waelburgh in Blaricum. De zetterij en drukkerij van uitgever Nijgh \& Van Ditmar drukt voor Van der Waals de boeken. Later gaat Van der Waals op in Nijgh \& Van Ditmar. Coolen zal, met uitzondering van een korte escapade naar de katholieke uitgever Paul Brand in Hilversum, zijn leven lang bij Nijgh \& Van Ditmar blijven. Dit is in die tijd opvallend voor een katholiek auteur.

\section{Scheiding der geesten}

Van Duinkerkens oordeel over Coolens eerste roman is niet onverdeeld gunstig. Uit de reacties van Coolen is op te maken dat Van Duinkerken in de eerste helft van 1926 in een lange brief kritiek heeft gegeven, maar deze is verloren gegaan. Veel later, in het boek ter gelegenheid van Coolens vijftigste verjaardag, maskeert Van Duinkerken dit negatieve oordeel. Hij schrijft dan dat De rauwe grond de confrontatie van de stadscultuur met het verarmde peelvolk "in weezen het vraagstuk van den parochieele zielszorg" aan de orde stelt. Nu de industrialisatie en het snelverkeer invloeden van buiten in de dorpen brengen, kan de geestelijkheid de traditionele moraal niet meer behoeden. Volgens Van Duinkerken 
ziet Coolen als enige oplossing het behoud van de ongereptheid van de dorpsgewoonten en dat dit behoud wordt toevertrouwd

"aan de goedheid des harten, in het bijzonder vertegenwoordigd door den dorpspastoor. De mogelijkheid eener meer individueele godsdienstpaedagogiek bij intensiever cultiveering des geestes, blijft in dit boek, als in het volgende buiten zijn gezichtskring. Hij [Coolen, C.S.] veracht het moderne, stadsche leven namens de eeuwenoude, dorpsche traditie, doch schijnt te voelen, hoe weinig deze traditie bestand is tegen de kennismaking met een rijker genuanceerde beschaving."

Coolen is natuurlijk niet blij met Van Duinkerkens lauwe reactie, maar in de eerder genoemde brief toont hij zich toch vooral gepikeerd ten opzichte van andere katholieke opinieleiders:

"Moller heeft me daar veel leed mee gedaan. Roeping is toch indertijd meer speciaal voor de zuidelijk streken opgericht, bizonder voor de brabanters en terwijl Roeping nu wel een geëxalteerde romanpoging als Brunings Kringloop publiceert moet ik met mijn brabantsche schets naar elders - Ik heb de voldoening dat ik een verzorgde uitgaaf krijg en een honorarium grooter dan de Katholieke uitgevers in 't algemeen voor een heele roman betalen, maar dat helpt me niet over den grief heen door Roeping geweigerd te zijn. Want ook fragmenten uit De rauwe grond heeft Moller niet willen plaatsen. En nog over iets heb ik me te beklagen. Herluf van Merlet ${ }^{12}$ schrijft in De Tijd een benepen en stomme critiek op De rauwe grond, waarin hij in zijn poging om 'n karakteristiek van het boek te geven er absoluut náást is, terwijl de niet-katholieke Telegraafhet boek zonder reserve schoon noemt [...] Pieter van der Meer, die in zijn waardeering van Brunings Kringloop geen termen te krachtig vond, schrijft over De rauwe grond een paar afbrekende oppervlakkigheden, terwijl het sarcastische Het Volk getuigen moet dat op één bladzijde van mij meer brabantsche echtheid staat dan in een heel boek van Marie Gijsen-Het een sluit het ander niet uit, dat is zoo, maar voorzoover de critieken in Tijd en Opgang me op H.v M. en PvdM orienteeren doet het me leed. Willem Nieuwenhuis heeft eens bitter gezegd, dat, als hij een boekje uitgaf, hij meer waardeering en belang. stelling vond bij de niet-katholieke pers dan bij de katholieke - ik geloof dat ik hetzelfde in nog ongunstiger mate ondervind - Daar moet ge me eens op antwoorden en ook over de schets die ik oe nou stuur moet ge me eens schrijven. Ze komt in een speciaal uitgave van Nijgh \& Ditmar, die ook De rauwe grond drukte." ${ }^{13}$

Van Duinkerken reageert nauwelijks op de brief. Hij heeft andere dingen aan zijn hoofd. Hij bedankt per ongedateerde briefkaart vanuit het St. Laurensgesticht in Ginneken waar hij herstellende is van een "zenuwoverspanning". Nadat hij in mei de lagere wijdingen voor het priesterschap heeft ontvangen, is hij in juli ingestort; de spanning die het nog altijd geldende schrijfverbod oplevert is te groot geworden. Hij weet zelf heel goed welke

9 N[ieuwenhuizen], 'Een roman van Antoon Coolen'.

10 BA, brief Coolen aan Van Duinkerken, 13 juli 1926.

11 Van Duinkerken, Antoon Coolen, 37.

12 Herluf van Merlet is het pseudoniem voor $\mathrm{H}$. Baron van Lamsweerde, redacteur van De Tijd en later hoofdredacteur. Van Duinkerken noemt hem later in de Katholieke Encyclopedie een knappe essayist en criticus.

13. BA, brief Coolen aan Van Duinkerken 13 juli 1926 (afgemaakt op 26 juli 1926). 
remedie voor hem geschikt is: "Het enige geneesmiddel is schrijven, begrepen? Schrijven! Anders niet. Schrijven, zegt de dokter. Schrijven, zegt heeroom. Schrijven, zegt het gezond verstand." ${ }^{14}$ In november 1926 wordt op voorspraak van zijn behandelend geneesheer het schrijfverbod opgeheven, maar hij mag dan alleen publiceren in tijdschriften die op het seminarie zijn toegelaten. Daartoe behoren niet de periodieken van de katholieke jongeren, Roeping en De Gemeenschap.

Het is eigenaardig dat er in deze moeilijke tijd nauwelijks contact is tussen de twee vrienden. Dat Van Duinkerken niet reageert op de toegezonden novelle Peerke kan aan zijn geestelijke toestand liggen, maar dat Coolen van zijn kant geen belangstelling toont voor Van Duinkerken moet andere oorzaken hebben. Het enige teken van leven is een prentbriefkaart uit Versailles ${ }^{15}$ in de zomer van 1926 geweest. Coolen is daar met Gerda, hoewel het in die tijd zeker niet gewoon is met je meisje een buitenlandse reis te maken.

Pas in december neemt Coolen weer contact op, als hij tot zijn verbazing merkt dat Van Duinkerken weer publiceert. Hij weet dus niets van de opheffing van het schrijfverbod. In de aanhef noemt hij zijn vriend nog Willem en niet Anton of -voor intimi- Toon, zijn schrijversvoornaam. "Het laatste wat ik van je hoorde was je bericht uit het ziekenhuis, dat je van een lange ziekte herstellende was. Nu lees ik je prachtige stukken in De Nieuwe Eeuw over Martien [Beversluis, C.S.] Ik leid er uit af, dat je God zij dank dus weer gelukkig hersteld bent." Hij heeft ondertussen iets meegemaakt met Gerda "wat relatief tot gelukkige oplossing is gekomen," maar hij word er totaal door in beslag genomen. Hij verzucht: "Nou zou ik zo graag de zoo lang onderbroken correspondentie met jou weer opnemen, goeje kerel." $^{16}$

Het antwoord van Van Duinkerken is niet zo enthousiast, eerder knorrig. Hier botst de apologeet van de katholieke leer en aanhanger van het idealisme in de literatuur met 'de katholieke vrijdenker' Coolen, die veel meer zijn voorbeelden zoekt in het naturalisme en de ideeën van Nietzsche, Darwin en Multatuli. Coolen schetst geen helden, maar mensen die met al hun gebreken en aandriften door het leven gaan; hun afkomst en omstandigheden bepalen hoe ze zich gedragen. Het is deze 'wetmatigheid' in het leven, die de naturalisten vergelijken met een fysiologisch proces, die Van Duinkerken verafschuwt. Hij spreekt van "instinkt-kausaliteit" die de mens verlaagt tot een dier en de werking van een goddelijke genade ontkent:

"Over jou schrijf ik voorlopig niet. Er zijn te veel dingen waarmee ik het niet eens ben (in beginsel verfoei ik je instinkt-kausaliteit) om niet eerst een hogere stijging van je geest te verwachten. Schrijf ik, dan zal de inhoud van het artikel weinig verschillen van de brief, die ik je stuurde na lezing van De Rauwe Grond [de brief die verloren gegaan is, C.S.] Ik geef toe dat de lopende kritiek je talent heeft miskend, tenminste de principiële kritiek. Maar we wachten af."

De rest van de brief is onpersoonlijk en behandelt alleen de ontwikkelingen in de literaire wereld. Hijzelf is bezig aan een program-artikel 'Naar een Brabantse Beweging' en hij signaleert een nieuw populair tijdschrift, Brabant geheten. De manier waarop het geredigeerd is wekt weinig artistiek vertrouwen, maar hij heeft er toch een kort gedichtje aan afgestaan. Hij roemt de pas overleden dichter Gerard Bruning, vermeldt dat hij werkt aan een studie over Jan Hendrik Leopold en schrijft er terloops snerend bij: “Jij leest natuurlijk te weinig gedichten om die kerels te kennen. Toch moet je mijn kritiek eens lezen [...] Gaat 
met Gerda alles goed? Schrijf gauw uitvoeriger: op je korte episteltje heb ik te weinig vat voor een fatsoenlijk antwoord."17

De vriendschap staat op een heel laag pitje. Van Duinkerken heeft in het afgelopen half jaar, dat hij overspannen is, veel steun gehad van en veel gecorrespondeerd met zijn studiegenoten Lambert Bijnen en Jan de Lepper. Coolen heeft, afgezien van die ene ansichtkaart, sinds juli niets meer van zich laten horen. Daar komt bij dat Van Duinkerken het eens is met het negatieve oordeel in een deel van de katholieke pers over het nieuwe werk van Coolen. Na zijn kritiek op De rauwe grond heeft hij het niet nodig gevonden eerder te reageren op Peerke, dat hem in juli toegestuurd was. Hij vindt Coolens romanpersonages niet geschikt als helden van het nieuwe Brabant dat hem voor ogen staat. Ze lijken weer te zeer op de aan het noodlot onderworpenen waar Ouwerling al zo'n kritiek op had. Het lijkt erop alsof Coolen zich eerst maar eens moet rehabiliteren, voor hij weer serieus met hem wil corresponderen.

Van Duinkerken wordt op zijn wenken bediend. Per omgaande schrijft Coolen een uitvoerige brief, waarin hij zijn credo verwoordt. Na enige inleidende positieve opmerkingen over de kwaliteiten van Martien [Beversluis, C.S.] en wat negatiefs over Roeping dat nu de 'goedkope' stukken van Henri Bruning publiceert, brengt hij zijn eigen werk en de kritiek daarop ter sprake:

"Te schreef me indertijd dat je benieuwd was, hoe bizonder in 't Noorden de critiek op De Rauwe Grond zou reageeren. Je hebt zeker wel een en ander gelezen? Las je De Nieuwe Gids?: 'Een boek, dat onmiddellijk zijn plaats inneemt in de litteratuur en den schrijver recht geeft op een allerhartelijkste ontvangst' enz. nog een aantal regels in denzelfden toon plus een citaat. Een ernstiger bespreking bracht Stemmen des Tijds waarin o.a. onderscheid werd gemaakt tusschen de humor zonder scherpte en spot in de beschrijving der 'humorischen effecten van de volkspsyche' en 'de scherpheid en spot, die zich, met al de vlijming waarover deze auteur beschikt, richten tegen menschen, die den eenvoud van de eerlijke brabanter belagen en een schijn voeren van boven dezen eenvoud door hun beschaving en ontwikkeling verheven te zijn, terwijl hun realiteit daar ver beneden blijft.' - Dit is de eenige critiek, die blijk gaf deze intentie te hebben verstaan. Ze was van een dr. Tazelaar. Ken je dien?

- Zeg, las je ook dit Voorbijgaan ${ }^{18}$ Ik geloof van wel, nu je een vroeger bezwaar herhaalt en spreekt van 'instinkt-causaliteit' - Ik stel natuurlijk absoluut niet het Nietzschiaansche theologische probleem van gelooven (instinct) en weten (verstand, doelbewustheid), maar men zal geen trouw beeld van den landschen oostbrabanter kunnen geven indien men de resultante van goed en schoon in zijn daden niet voor 't grootste gedeelte toeschrijft aan den drang van instinctieve gevoelens, die hij volgt en die bij

14 Brief Van Duinkerken aan Jan de Lepper, 12 september 1926, geciteerd in: Van der Plas,

Doarom, mijnheer, 87.

BA, briefkaart Coolen aan Van Duinkerken, 10 augustus 1926.

BA, brief Coolen aan Van Duinkerken, 7 december 1926.

BA, brief Van Duinkerken aan Coolen, ongedateerd, tussen 8 en 10 december 1926.

Een schets van Coolen die hij tegelijk met Peerke aan Moller aanbood. De schets werd door Moller geweigerd, maar wel gepubliceerd in: Wereldkroniek Kerstboek, 1926-1927. 
hem geleid worden door een van zelf goeden wil, dien hij als natuurlijken aanleg bezit. Het 'klare inzicht' en 'doelbewuste wilskracht' zijn naar mijn meening groote woorden indien ze zouden moeten dienen om de drijfkracht te bepalen die Tine tot haar offer en het ondergaan harer vernedering brengt. De krachten en zelfs intelligenties van het instinct zijn naar mijn gevoelen en middelijke ervaring in het algemeen bij de 'redelijke' mensch zeer groot (het instinct van bezit en van bloed bij het moederschap) en zeker als elementen in de volkspsyche van den landelijken oostbrabanter niet uit te sluiten en te ontkennen. - Heusch, ik kén de peelstrekenbewoners dóór en dóór - In dat opzicht - het door jou gelaakte punt - zal mijn nieuwe roman Hun grond verwaait - die in den zomer bij de Waelburgh verschijnt - dan ook niet sterk van mijn vorig werk afwijken." ${ }^{\text {19 }}$ Met trots voegt hij eraan toe dat er van De rauwe grond al 700 exemplaren verkocht zijn. Tot slot nodigt hij Van Duinkerken uit om nog eens te komen logeren en om in Hilversum Martien Beversluis te ontmoeten. Hij stuurt een kiekje van hem en Gerda op, die nu onderwijzeres in Rotterdam is geworden. Ze schrijven elkaar dagelijks en hij hoopt dat ze zijn vrouw zal worden, maar hij heeft ook redenen om daaraan te twijfelen. Wat er precies aan de hand is tussen de twee is niet duidelijk. De relatie verloopt in ieder geval niet rimpelloos, want in de hiervoor genoemde brief van een week eerder wordt ook al over strubbelingen geschreven.

Coolen houdt dus vol dat ook een redelijk mens, en zeker de Oost-Brabander, door zijn instincten wordt geleid. Tine uit De rauwe grond laat zich niet verleiden door de klerk Ewich op grond van een helder inzicht of omdat ze graag wil vrijen, maar door het verlangen naar een kind. Door dit soort krachten worden ook de personages in Peerke en zijn volgende boeken gedreven.

Zeer belangrijk is dat Coolen de bespreking in Stemmen des Tijds beschouwt als de enige kritiek die er blijk van geeft de intentie van zijn werk te hebben begrepen. Hij wil niet in de eerste plaats grappige volksfiguren schetsen. Hij doet dit óók, en wel met veel liefde en humor, maar het lancet van zijn spot bewaart hij voor de onechte, de verwaande, de gierige en de hooghartige. Het zal hem nog vaak storen dat vooral mensen die in deze laatste categorie vallen, hem regelmatig op de schouder kloppen en hem complimenteren met zijn perfecte schildering van de simpele Brabantse volksziel, terwijl ze niet in de gaten hebben dat ze zelf in het boek het mikpunt van spot zijn.

\section{Peerke dat manneke}

De novelle Peerke dat manneke belicht een ander aspect van het dorpsleven: de agressie die de gemeenschap door de roddel kan ontwikkelen tegen een uitgestotene. Het is de donkere kant van de folklore, die in Oost-Brabant 'tafelen' of 'toffelen' genoemd wordt. Het gaat om een vorm van volksgericht die onder andere plaatsvindt bij afwijking van de codes op het gebied van seksualiteit, huwelijk, verkering en zwangerschap. ${ }^{20}$

Peerke woont achteraf, buiten het dorp. Hij krijgt bij de barbier te horen dat hij goed op zijn vrouw moet letten, omdat hij haar niet alleen heeft. Dat praatje doet allang de ronde en het blijft door zijn hoofd zeuren als hij in zijn schamel bed in zijn huis ligt, waar de wind door de schoorsteen roept en fluit. Hij is niet de enige bedrogen echtgenoot; ook bij het 'wijfke' van 


\section{PEERKE, DAT MANNEKE book: ANTOON COOLEN}

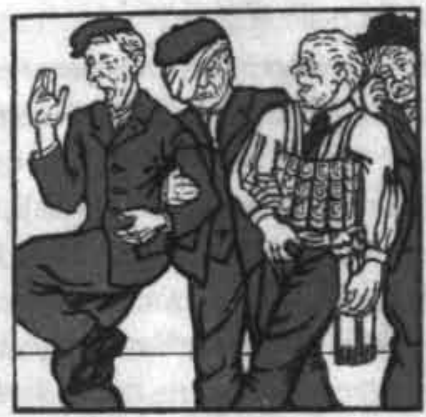

DE KLYNE LIBRYE TE EDAM

de moordenaar die in de gevangenis zit komen voerlui. De lente gaat voorbij, de "groote, groote" zomer komt en het gerucht wordt steeds sterker. Op de kermis wordt in het café een spotlied op hem en zijn vrouw gezongen: "Da Peerke is 'ne flinke vent, Zijn vrouw is mee ééne nie content." Als een dronken gezelschap later in de nacht zijn huis belaagt, steekt hij er een met de riek een oog uit. Peerke krijgt twee maanden gevangenisstraf. Wanneer hij uit de gevangenis komt, zijn de roddels gewoon doorgegaan. Weer fungeert de wind daarvoor als sym. bool: "De wind babbelt in de maisblaren en in de blaren van de schuine populieren die al af beginnen te vallen." Peerke denkt aan zelfmoord, maar besluit uiteindelijk om te verhuizen naar de andere kant van de Peel.

Het verhaal eindigt volslagen uitzichtloos. Hij huurt een handwagen waar alles wordt opgeladen, ook "de schilderij van den heilige Aloysius en de schilderij van den heilige Donatus en den kruislievenheer." Vier keer gaan Peerke en zijn vrouw op en neer door de Peel. Als het echtpaar de laatste keer in het lege huisje rondkijkt, knapt het lampenglas. Samen duwen ze de kar over de spoorovergang. "Er brandt licht in 't wachthuiske en heel in de verte hooren ze 'n signaalklok, ting-tang, langs de lijn." Zijn vrouw Ciska blijft even achter. "Ja, dat manneke in 't wachthuisje! Daar zeejen ze ook van, dat die bij Ciska kwam." Het gaat langzaam. Achter zich horen ze de trein voorbij rijden. "Ciska is een beetje achtergebleven en kijkt naar den trein. Ze ziet in de verte de lichtjes ervan voortkruipen." Dan breekt een wiel van de stootkar. De laatste regels luiden: "Maar neergehurkt bij het kapotte wiel schruwt-ie ineens, ja, hij kan zijn eigen niet meer inhouden, zoo'n tegenslag, zoo'n bezuuking! Hij schruwt bij zijn kapotte wiel en op zijn gezicht vermengen zich de sneeuw en de regen met de tranen van zijn verdriet."

\section{Peerke: "geen 'echte' Brabander"}

Begin januari 1927 krijgt Coolen een koel briefje van Van Duinkerken. Deze heeft de knoop doorgehakt en besloten dat hij geen priester zal worden. Hij gaat weer publiceren in Roeping en zal daar deze keer Peerke en een volgende maal De rauwe grond uitvoerig bespreken. "Mijn oordeel ken je reeds, voor jou zeg ik niets nieuws. Alleen is 't jammer dat ik niet beide tegelijk kan bespreken, dan hief het oordeel over de R.G. dat over Peerke (dat niet zo heel gunstig is) op. Doch dat ging niet. In alle geval wordt nu voldoende aandacht aan je gewijd. Door ziekte kon ik je laatste brief niet beantwoorden. Nog mijn dank." ${ }^{21}$ 
De toon van dit korte briefje voorspelt niet veel goeds en inderdaad is de kritiek vernietigend. Van Duinkerken vindt het verhaal mislukt en bovendien liefdeloos geschreven. "Het wordt in eigen dialekt niet onverdienstelik verteld door Antoon Coolen, die geboortig is uit Deurne. Maar het is niet geworden tot een werk, dat hoge ontroering geeft. Het doet wat onbelangrijk aan: de lezer vindt het misschien wel aardig, legt het weg en richt voorgoed zijn aandacht af van Peerke naar iets anders."

Van Duinkerken geeft als voorbeeld de rechtszitting die volgens hem niet genoeg meegevoel voor Peerke teweegbrengt. Hij vindt enkele humoristische schetsen, bijvoorbeeld het (potver)teren van het schuttersgilde, wel aardig,

"zoals wel schilders van de twede [sic] rang in goede ogenblikken konden maken. [...] Maar de voornaamste reden waarom Antoon Coolens boekje onbelangrijk bleef, is dat hij het bedoelde als een zede-schets van Brabants volk en dat het als zodanig is mislukt. [...] Want om iets uit te beelden in een werk van kunst, moet men er voor een grote liefde of een grote haat er tegen hebben. Hoezeer gevoelerig geschreven, Coolens werk is liefdeloos. Dat Peerke en die Ciska heeft de schrijver niet als mensen van zijn eigen stam bemind, doch slechts geobserveerd als kuriositeiten op een lager plan van de maatschappelijke orde. [...] Peerke is de machteloze bij instinkt."

Dit belet hem zijn vrouw vrij te pleiten van de praatjes over haar en als aan het eind zijn wagenwiel breekt ondergaat hij dat gelaten: "Dat 'manneke' heeft niet de wil tot mannelik verzet, het is de 'homunculus', waarvan de mensen walgen." Vervolgens brandt Van Duinkerken los:

"Geen volk dat door blinde drift wordt gedreven, maar een, dat wils-bewust zijn dageliksen arbeid doet, en zij die ook gering; een, waarin wel de stemmen der natuur een rauwe klank gekregen hebben, maar dat de kracht mist dezen het zwijgen op te leggen, waar een hoger wet gebiedt, een, dat kan vallen en zich diep vergooien, maar een dat heeft gevochten tegen de grond en water en om zijn brood, tegen zijn heersers om zijn God, gevóchten, niet uit vechtlust of verhit van dronkenschap, maar wijl het taai en sterk van willen is, dát is het volk van Brabant."

Hij besluit aldus: "Maar, vraagt ge mij, zo ge dat boekje niet belangrijk acht, wat spilt gij overbodig woorden? De schrijver van dit boekje kan belangrijk zijn, en dient bijtijds gewaarschuwd, en ook gewaarschuwd dient de mens, die heel een ras normeren zou naar deze 'mannekens' en 'wijfkens'."22

Bijna tien jaar later zal Coolen het boek herschrijven in Peerke den Haas dat verschijnt in 1935. Niet alleen in de titel maar ook in het boek zelf zijn dan de verkleinwoorden als manneke en wijfke verdwenen. Het grootste verschil is echter dat in de eerste versie de verteller het vermoeden van overspel wekt door de dorpsgeruchten te herhalen. In de tweede uitgave laat Coolen dit vermoeden via de gedachten van Peerke bij de lezer ontstaan. Al meteen als hij na het bezoek aan de barbier in het begin van de novelle naar huis loopt, schrijft de verteller: "Bij zijn vrouw is het niet goed en bij de menschen is het triestig, de weg er tusschen in geeft hem de troost alleen te zijn. ${ }^{.23}$ In de eerste uitgave loopt hij almaar in zichzelf te zeggen dat hij het niet kan geloven en dat ie toch een goed wijf heeft. In het eerste boek zoekt Peer de warmte van zijn vrouw als hij in bed kruipt, in het tweede keert hij haar zijn gat toe. 
Bij de thuiskomst van Peerke uit de gevangenis heeft hij in deze herschreven versie het probleem, dat men hem in de gevangenis verteld heeft dat Frans den Heete zijn vrouw verleid heeft tijdens zijn afwezigheid. Hij denkt weer aan zelfmoord, maar niet door zich op te hangen zoals in de eerste versie. Dit keer staat hij op de spoorlijn, wil zijn kop op de rails leggen en krijgt de wrange gedachte "hoe Ciska zou staan kijken, als ze hem zóó dood thuis kreeg en haar wroeging hebben zou. ${ }^{24}$

Het grootste verschil tussen beide versies blijkt echter aan het eind van het verhaal. In de eerste versie is het de verteller die het vermoeden van overspel met de seinwachter suggereert als Ciska wat achterblijft bij het spoorhuisje. Even daarvoor heeft hij zijn twijfel geuit door haar lichaam in al zijn armoedige schamelheid te beschrijven:

"Houdt ze 't met anderen? Och d'r lijf, vuil en zwart en zakkerig als'n zak mee zemelen, d'r lijf geel en goor, waar 't trage bloed door-kruipt en de huid niet meer kleurt, dat lijf als'n pergament, kent het de begeerte naar het lijf van het mannetje? Peerke slaapt achter d'r gat en als-t-ie d'r been maar evekes aanraakt, dan stampt ze hem achteruit." 75 In Peerke den Haas volgt de lezer de gedachten in Peerke's hoofd. Hier wordt geen gewag gemaakt van de man in het spoorwachterhuisje. Als Ciska wat achterblijft, heeft Peerke "die belachelijke gedachte, als Ciska nu eens achterbleef en verloren liep over de vlakte, om nooit meer terug te keeren. ${ }^{\text {"26 }}$ Als het wiel breekt lijkt het of Peerke minder berustend is. Hij geeft zijn vrouw de schuld en heeft zelfs plezier in zijn onredelijkheid. "Hij zal het haar niet uitleggen, daar is ze te stom voor. Ja, zij heeft de schuld, zij alleen, van al de armoej en ellende waarin zij zijn geraakt." Hij staat op het punt om van zijn vrouw en de kar weg te lopen. De laatste regels luiden:

"De wagen, zijn boeltje, zijn vrouw, wat is het hem alles waard. Als hij een eindje den weg op gegaan is draait hij om. Wat is het hem waard. Het is voortgejaagd, vervolgd, alles, het is blijven steken, hij is er knecht van, hij is er in de armoejigheid aan geketend. Hij keert er willoos naar terug, den wind, de sneeuw en de duisternis in het gezicht." ${ }^{27}$ Peerke blijft dus een willoze, door de armoede aan zijn lot geketend. In de eerste versie van het verhaal staat Peerke machteloos tegen het overspel en de gevolgen ervan. In de tweede versie ervaart de lezer meer de uitzichtloze situatie van een vastgelopen huwelijk.

Van Duinkerken rept met geen woord over deze veranderingen, als hij later in zijn monografie ter gelegenheid van Coolens vijftigste verjaardag op zijn kritiek terugblikt. Duidelijk blijkt dat hij nog steeds achter zijn negatieve oordeel staat:

"Ik beschuldigde den auteur toen van liefdeloosheid ten opzichte van de figuren, die hij schetste, en ik verweet hem dat hij alle handelingen zijner hoofdpersonen liet ingeven door hun louter instinctieve reacties. Het was mijn vaste overtuiging, dat Coolen

21 BA, brief Van Duinkerken aan Coolen, ongedateerd, begin januari 1927.

22 Van Duinkerken, 'Peerke dat manneke', 284-288.

23 Coolen, Peerke den Haas, 11.

24 Coolen, Peerke den Haas, 63.

25 Coolen, Peerke dat manneke, 72.

26 Coolen, Peerke den Haas, 69.

27 Coolen, Peerke den Haas, 70. 


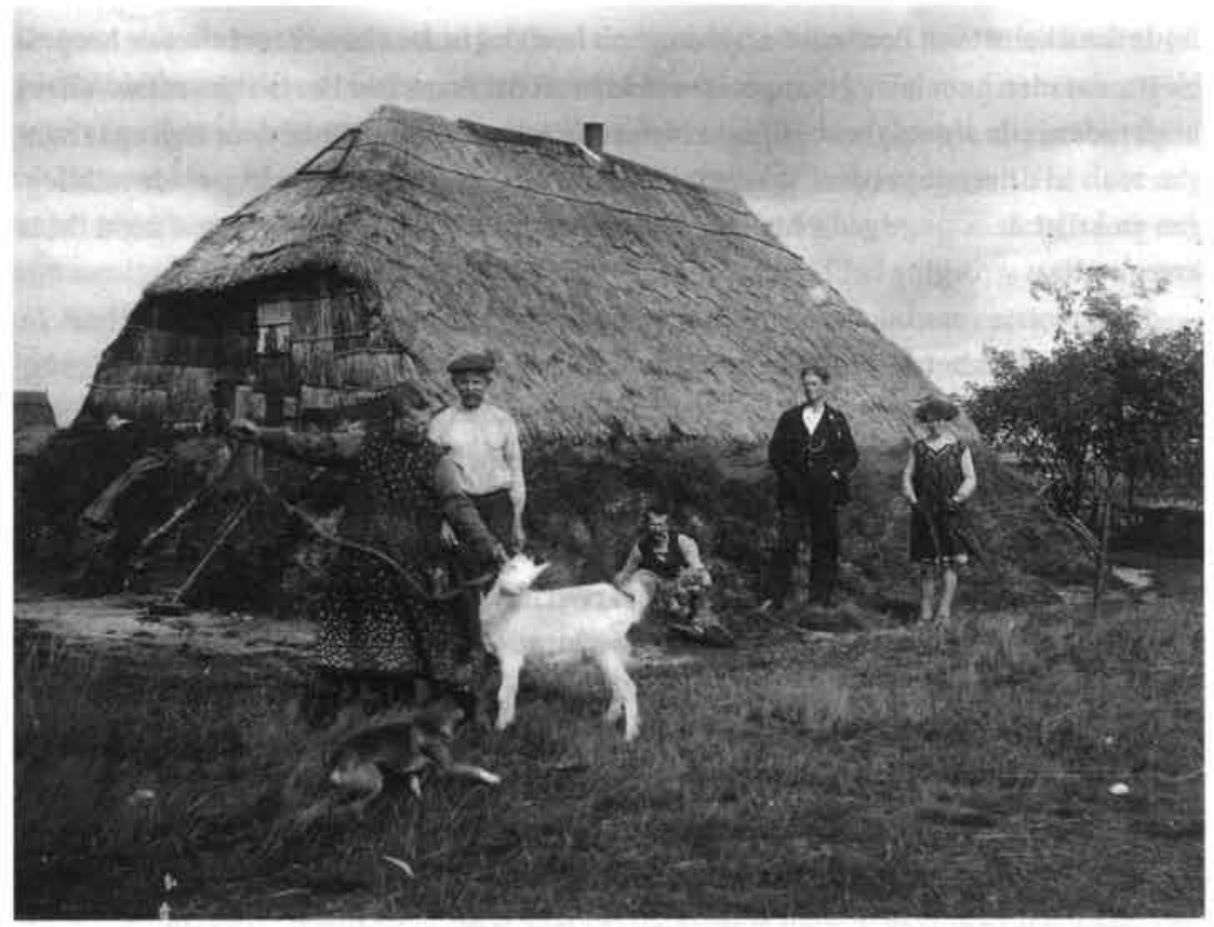

het landvolk van Noord-Brabant niet overeenkomstig de werkelijkheid weergaf en dat hij met name tekort deed aan de strevingen der jonge Brabantsche beweging, die toendertijd in Roeping, later meer nadrukkelijk in Brabantia Nostra haar orgaan had." Hij haalt het slot van zijn kritiek uit 1927 nog eens aan, waarin hij na een ronkende beschrijving van het Brabantse volk schrijft: "Zulk een volk had Antoon Coolen moeten uitbeelden, wilde hij optreden als getuige. ${ }^{n 23}$ Kortom, hij is nog steeds van mening dat Coolen Peerke in deze novelle niet als een 'echte' Brabander heeft neergezet.

Vijf jaar nadat Lutkie, de tien jaar oudere priester, Coolen opriep om zijn boeken en protagonisten in dienst te stellen van een nieuwe vorm van geloof, zoals de integralist Bloy en Hello voorstonden, wordt hij nu door een zes jaar jongere ex-priesterstudent aangespoord om met zijn werk een positieve visie uit te dragen en te getuigen. Deze kritiek van zijn vriend moet voor Coolen - we weten hoe gevoelig hij voor negatieve kritieken is - hard zijn aangekomen. Toch is daar in zijn brieven niets van te merken. Al gauw zal blijken dat hij zich ook in zijn literaire werk niets van Van Duinkerkens kritiek zal aantrekken.

\section{Coolen als vrijdenker}

De kritiek van Van Duinkerken op Peerke snijdt een thema aan dat van belang is in het hele werk van Coolen: de relatie tussen geloof, noodlot, instinct en natuur.

Veel critici hebben over Coolen gezegd dat hij niet diep gaat in het tekenen van de psychologie van zijn personages en dat ook het katholiek geloof niet als gids gebruikt wordt, maar slechts dient als een natuurlijke omgeving van kerk, pastoor en rituelen. De mensen komen en gaan en spelen hun rol in de vertellingen; de lezer is getuige van hun lotgevallen tegen een decor van de seizoenen en het landschap. Uit persoonlijke brieven 
blijkt dat 'begeleiders' als Wouter Lutkie en Anton van Duinkerken liever romanfiguren zouden zien die daadkrachtig hun katholicisme of hun Brabanderschap zouden uitdragen. Zij vinden de personages vaak te weinig principieel, te willoos voortgedreven door hun aandriften en het noodlot.

Van Duinkerken heeft over het werk van Coolen bij diens vijftigste verjaardag geschreven dat het doortrokken is van meegevoel en deernis, waaraan Bernardus de klassieke naam van misericordia heeft gegeven: men heeft hart voor de miserie van de medemens ('miseri cor'). Door niet meer over het ontbreken van 'liefde' voor zijn personages te spreken, maar over Coolens 'misericordia', suggereert Van Duinkerken dat Coolen katholiek geinspireerd is in zijn meegevoel.

Misericordia typeert inderdaad het werk van Coolen. Coolen is echter wars van medelijden en daarin wellicht een volgeling van Nietzsche. Medelijden is volgens Nietzsche een negatieve factor voor het levensgevoel: het werkt deprimerend. Nietzsche refereert aan Aristoteles die het medelijden als een ziekelijke en gevaarlijke toestand zag, "waarvan men zich het beste af en toe door een purgeermiddel kon herstellen: als zo'n purgeermiddel zag hij de tragedie." ${ }^{29}$ In zijn Umwertung aller Werte is medelijden een subtiele vorm van wreedheid en misprijzen. 'Misericordia' zoals ze bij Coolen gestalte krijgt, is niet meewarig het hoofd schudden bij zoveel miserie en ongeluk en de ongelukkige helpen met een schouderklopje, wat brood of geld, zoals zoveel personages in Coolens romans doen. Coolen spot zelfs met deze snelle hulp, die voortkomt uit een medelijden dat zich niet bekommert om datgene wat er achter het 'ongeluk' van de ander zit. Coolen wil dit juist openleggen en laat de lezer het lot van de ander 'invoelen', zoals hij meesterlijk zal doen in de tekening van de stamgasten van Herberg In 't Misverstand. Hij heeft aandacht voor wat er achter het ongeluk zit en trapt hiermee niet in de val die Nietzsche signaleert bij weldoeners, die willen helpen zonder iets te weten van de innerlijke opeenvolging en vervlechting van het ongeluk van een ander. Achter ieders ongeluk schuilt een heel verleden, een hele economie. "De gehele economie van mijn ziel en de vereffening daarvan door het 'ongeluk', het openbreken van nieuwe bronnen en behoeften, het dichtgroeien van oude wonden, het afstoten van een heel verleden," zoals Nietzsche schrijft. ${ }^{30}$ Hier put Coolen inspiratie uit voor zijn verhalen. Wij als lezers zijn getuigen geweest van 'de economie' van een aantal zielen. Wij begrijpen ze nu beter, maar beseffen ook dat er in veel gevallen niet veel met medelijden te helpen valt.

Het werk van Coolen komt in een ander licht te staan, als we hem niet in de eerste plaats beschouwen als een katholiek schrijver, maar eerder als een 'vrijdenker in gebondenheid' die voor de buitenkant leeft als een praktiserend katholiek, maar innerlijk toch wel andere wegen gaat. De kiem hiervoor is gelegd in de bibliotheek van Ouwerling. Hier heeft hij, op de ontvankelijke leeftijd, auteurs leren kennen die in geen enkele parochie- of katholieke schoolbibliotheek te vinden waren. Hij maakte hier niet alleen kennis met het werk van Nietzsche, maar ook met dat van Multatuli, Zola, Tolstoj, Querido en Voltaire. Steeds

30 Nietzsche, De vrolijke wetenschap, 197-198. 
verdedigde hij deze schrijvers tegen de aanvallen en de beschimpingen van Lutkie. De 'geestelijke heren' van het dorp controleerden zijn boekenbezit en ontdekten naast de bovengenoemde ook nog Couperus' Nóodlot, Ibsen, Rousseau en Kloos. ${ }^{31}$

In I 918 las hij ook Darwins The descent of man, ondanks de aanbeveling van Lutkie dat hij beter een boek van een Jezuïet óver Darwin kon lezen. Juist in deze tijd werkte hij aan De Rozenberg, waarin de hoofdpersoon duidelijk zijn zelfportret is. Later in datzelfde jaar heeft hij het boek De Sterke! op stapel staan en las hij, naast Nietzsche, ook Schopenhauer en Goethe. De hoofdfiguur in De Sterke! maakte hij, om Lutkie gunstig te stemmen, meer aanvaardbaar. Deze filosofeert niet en verliest niet zijn kop bij Spinoza, Schopenhauer of het "übermenschliche beest Nietzsche." ${ }^{32}$ Even later bleek echter toch weer dat hij de oplossing voor zijn eigen problemen, nu rond zijn verkering, niet in de katholieke leer of moraal zocht, maar bij Strindberg of de filosofen. Lutkie gebood hem om "die malle duitse filozofen" overboord te gooien als ballast, maar ook dit had geen effect. In het toneelstuk Exodus kwam geen enkele verwijzing naar godsdienst of religieuze moraal voor. Kort hierna kwam het tot een breuk met Lutkie.

Bij de kennismaking met Van Duinkerken, enkele jaren later, speelde hun gezamenlijke afkomst uit Brabant een grotere rol dan het katholieke geloof. Coolen bewonderde Van Duinkerkens gedichten over Brabant en was blij met de lof die Van Duinkerken hem toezwaaide. Hij accepteerde diens stilistische kritiek, maar trok zich minder aan van de kritiek op de morele en levensbeschouwelijke kanten van zijn werk. De eerste, minder bekende romans van Coolen zijn echt niet als katholieke literatuur te beschouwen. In De rauwe grond laat Coolen een klerk-een 'kaaljakker' - zeggen, dat er in het heelal een centrale oerkracht is die hij God noemt en die zo ontzaglijk is dat het hele gedoe met medailletjes en scapulieren belachelijk wordt. Bij de doop van een pasgeborene wordt ironisch vermeld dat er weer een lidmaat van de strijdende kerk op aarde bij is. In Peerke, dat manneke is de hoofdfiguur onderworpen aan een noodlot waar hij niets aan kan veranderen. Van Duinkerken noemde Peerke de machteloze uit instinct, een 'homunculus' die niet de wil heeft tot mannelijk verzet en betreurde het dat aldus de Brabantse bevolking wordt getypeerd. Aan Coolen zelf schreef hij dat hij diens 'instinct-causaliteit' verfoeide.

Van Duinkerken koppelt hier ten onrechte twee grote kritiekpunten op het Christendom uit het werk van Nietzsche aan elkaar. Nietzsche vindt op de eerste plaats dat het Christendom de ontkenning van de overlevingsinstincten tot een ideaal verheven heeft. Terwijl de instincten juist door het streven naar macht leiden tot groei en bestendigheid van een sterk leven, worden zij door het Christendom beschouwd als bronnen van bekoring, zonde en misleiding. ${ }^{33}$ Op de tweede plaats ontkent het Christendom volgens Nietzsche de causaliteit: het gezonde begrip van oorzaak en gevolg. Volgens hem verstoren de priesters dit begrip door in plaats van met de natuurlijke gevolgen van een daad aan te komen met morele consequenties, zoals loon, straf, genade, verlossing en vergeving. Christenen hebben daarom een verkeerd causaliteitsbesef. ${ }^{34}$

Van Duinkerken interpreteert deze standpunten negatief. Het volgen van je instinct leidt volgens hem tot machteloosheid en het gevolg daarvan is dat de mens dan lichamelijk en geestelijk ten gronde gaat. Maar het belangrijkste kritiekpunt zal voor hem toch geweest zijn dat het beginsel van de 'instinct-causaliteit' strijdig is met het zo belangrijke 
katholieke leerstuk van 'de vrije wil'. Volgens de katholieke kerk kent de mens het onderscheid tussen goed en kwaad en heeft dus ook de vrijheid en de mogelijkheid om te kiezen tussen goed en kwaad. De opvatting van Darwin, ook herkenbaar in de naturalistische romans van Zola, dat het menselijk gedrag voortkomt uit het onbegrepen instinct en daardoor gedetermineerd is, wordt dan ook ten zeerste verworpen.

Coolen heeft naar aanleiding van de kritiek over die 'instinct-causaliteit' geantwoord dat hij in Peerke niet het Nietzschiaanse probleem van geloven en gevoel (instinct) tegenover weten (verstand, doelbewustheid) heeft willen stellen. In de uitleg die daarop volgt, schrijft hij echter dat men de Oostbrabander niet kan begrijpen als men de resultante van goed en kwaad in zijn daden "niet voor het grootste gedeelte toeschrijft aan den drang van instinctieve gevoelens." Daarmee verraadt hij dat hij wel degelijk naar Nietzsche heeft gekeken. Wel voegt hij eraan toe - en dat is de inbreng van Coolen zelf of, zo men wil, een 'katholiek' element - dat die gevoelens geleid worden door een goede wil die iedere Brabander in natuurlijke aanleg bezit. "De krachten en zelfs intelligenties van het instinct zijn naar mijn gevoelen en middellijke ervaring in het algemeen bij de 'redelijke' mensch zeer groot [...] en zeker als elementen in de volkspsyche van den landelijke oostbrabanter niet uit te sluiten en te ontkennen. ${ }^{35}$ Het denken in termen van volkspsyche en volkskarakter heeft in die tijd niet de zeer negatieve connotatie die de naoorlogse lezer erbij heeft.

Tussen het schrijven van De rauwe grond en Hun grond verwaait leest Coolen naast veel Franse schrijvers ook Nietzsche's Götzendämmerungen Zarathustra. Het boek Hun grond verwaait staat vol termen als bloed, geslacht, grond en volk. Evenals bij Nietzsche hebben deze termen niets van doen met het latere misbruik ervan door het nationaal-socialisme. Ze zijn bij Coolen vooral bedoeld om de verscheurdheid van de hoofdfiguur tussen zijn achtergrond in een dorpse rituele, bijna heidense cultuur en de 'aanwaaisels' van een nieuwe cultuur te schetsen.

Pas bij het verschijnen van Kinderen van ons volk (1928), dat hierna uitvoerig aan de orde zal komen, zal Van Duinkerken schrijven dat dit een echte katholieke roman is. Toch is bij nauwkeurige lezing te merken dat enerzijds de sympathie van Coolen bij de goede mens pastoor Vogels ligt, maar dat hij van de andere kant het niet-katholieke gedachtegoed van de notaris, met wie de pastoor zo graag schaakt, heel positief beschrijft. De notaris is niet bang voor de dood en zal als een man de sprong in het duister wagen. Het licht van het verstand zal daar niet veel bij helpen; de voorstelling van het hiernamaals komt ondermeer voort uit de vrees van het instinct, denkt de notaris. ${ }^{36} \mathrm{Hij}$ heeft alle boeken van het katholieke geloof gelezen, maar om bijvoorbeeld in de aanwezigheid van God in brood te kunnen geloven zouden er nieuwe hersens in zijn schedel geplaatst moeten worden. Hij erkent dat zijn verstand niet opgewassen is tegen zijn instinct, dat hem toch van het leven doet

31 KDC, inv, nr. 10I, brief Coolen aan Lutkie, 22 maart 1916.

32 KDC, inv. nr. 101, brief Coolen aan Lutkie 4 oktober 1918.

33 Nietzsche, De Antichrist, 10.

34 Nietzsche, De Antichrist, 82.

35 BA, brief Coolen aan Van Duinkerken, 11 december 1926

36 Coolen, Kinderen van ons volk, 155. 
houden en de dood doet vrezen, maar uiteindelijk berust hij toch in een dood zonder hiernamaals. Het ongelovige sterven van de notaris die zelf zijn doodskist bestelt bij de timmerman, staat tegenover het ritueel rond het overlijden van Mieke Vuil met alle wijwater, zalvingen en Latijnse gebeden. De sympathie van de schrijver staat duidelijk aan de kant van de notaris, zonder dat hij daarmee zijn eerbied voor de rituelen verloochent.

In Dorp aan de rivier (1934) zal Coolen nog verder gaan en een echte Übermensch (in de juiste Nietzscheaanse betekenis) schetsen. Dokter Van Taeke staat "jenseits von Gut und Böse," zoals Ter Braak opmerkt. Hij is heidens en staat boven de slavenmoraal van de gelovigen en de priesters zelf. Hij heeft zowel de muze, de schilderkunst als de medische wetenschap tot zijn beschikking en, voegt Ter Braak eraan toe, de geneeskundige praktijk is voor de dorpelingen altijd verbonden met het geheimzinnige. ${ }^{37}$

De positieve bespreking van Ter Braak van Dorp aan de rivierstaat in schril contrast met zijn aanvallen op Van Duinkerken en De Gemeenschap in 1930. Hij verwijt hen dan dat de katholieke jongeren af en toe wel fulmineren tegen de kerkelijke autoriteiten, maar dat ze, zo gauw de censor even dreigt, alles weer inslikken. Hij vindt dat katholieken niet weten wat geloven is; voor hen is het een zaak van redding, van zelfbehoud. "Zoals de Duitsers uit Nietzsche's Übermensch een platvloers wezen hebben geconstrueerd [...] zo heeft het katholicisme zich uit de esoterische waarheden van het Nieuwe Testament een potpourri van oneetbare, kinderachtige feiten gebrouwen. ${ }^{38}{ }^{38}$ De tijd is al lang voorbij dat er gevochten moet worden tegen katholieke geloofswaarheden, zegt Ter Braak, het gaat nu alleen nog om de onwaarheid dat het katholieke geloof een kracht is die anderen met pedagogische arrogantie ketters mag noemen. Van Duinkerken is volgens hem de ware apologeet, de geloofsverdediger. De moderne katholiek neemt een vragende houding aan als het over zijn geloofswaarheden gaat, want hij voelt de verlegenheid en de geheime schande, dat zijn filosofie geen fundering heeft dan slechts dogma's. Van Duinkerken heeft daar geen last van, want zijn demonische kracht "is zijn listige subtiliteit, zijn handig intrigeren, zijn schitterend taalmisbruik. ${ }^{39}$

Het is begrijpelijk dat wanneer Coolens hoofdfiguur door Ter Braak prijzend wordt beschreven als een "ongelovig katholiek, lezer van Voltaire en Erasmus, en tóch vriend van de nonnetjes," dit als negatief wordt beschouwd door sommige van zijn katholieke vrienden. Van Duinkerken is dan wel weer tolerant genoeg om niet over het heidense van de hoofdfiguur te vallen. Af en toe lijkt het wel of Coolen fijnzinnig spot met de apologeet Van Duinkerken en een ironisch commentaar op het katholieke leven en de moraal geeft. Ter Braak noemt Van Duinkerken soms een "getrouw lidmaat der strijdende kerk." We hebben al gezien dat Coolen deze term een paar maal letterlijk hanteert bij de beschrijving van een doop: "Dan komt Arnoldus thuis, de kleinzoon van den overledene, versch gedoopt, lidmaat van de strijdende kerk op aarde."40

Wanneer men op dit soort passages let, ziet Coolens werk er heel anders uit. De Übermensch-gedachte zit niet alleen in Van Taeke, maar zelfs in het hedonistische Vuil Leenke uit Peelwerkers (1930) en zeker in de toneelstukken De ureemdeling en De klokkengieter, ook weer stukken die vanuit de katholieke hoek zullen worden aangevallen. Vooral de hoofdfiguren in deze toneelstukken en ook de zieners en koningen die in de openluchtspelen van de jaren vijftig voorkomen, zijn mensen die door loutering tot inzicht komen en daardoor 'jenseits von Gut und Böse' komen te staan. 
Van Duinkerken zal pas later, na de dood van Coolen, in een In Memoriam schrijven dat Coolen zeer belezen was in Nietzsche. ${ }^{41}$

\section{Van Duinkerken ook journalist}

Coolen heeft in de winter r926-1927 hard gewerkt aan zijn tweede roman, die eigenlijk al in het voorjaar, rond zijn dertigste verjaardag, zou moeten verschijnen; door vertraging wordt het najaar 1927. Op het toch schokkende bericht dat zijn vriend Van Duinkerken besloten heeft geen priester te worden, reageert hij tamelijk laconiek. Coolen beschouwt het als een mededeling en wil er als Van Duinkerken dat wenst, best eens over praten.

Weer blijkt dat het nuttigheidsaspect van de relatie voorop staat en dat ze beiden geen echte belangstelling hebben voor het persoonlijk leven van de ander. Het interesseert Coolen veel meer dat zijn vriend weer actief is in de literatuur, redacteur van Roeping is geworden en aangeboden heeft het nieuwe werk van Coolen te bespreken. Coolen wil alleen een fragment van zijn nieuwe roman Hun grond verwaait afstaan als hij zeker is van plaatsing, want het zit hem nog steeds dwars dat de schets Dit voorbijgaan en Peerke geweigerd werden door Moller met de opmerking dat ze "te romanties en te zinnelijk" zouden zijn. Maar zijn resolute opstelling zegt natuurlijk ook iets over zijn gestegen gevoel van eigenwaarde als literator.

Hij is blij met het aanbod van Van Duinkerken om zijn werk te bespreken en somt nogmaals de recensies over De rauwe grond op: "Las je misschien al De Nieuwe Gids, Gulden Winkel, Stemmen des Tijds - Nederland? In Stemmen des Tijds gaf dr. Tazelaar er een merkwaardig artikel over met tamelijk veel citaten. Verder hadden nog Boekenschouw, Handelsblad, Haagsche Courant, Rotterdammer en De Groene tamelijk uitvoerige recensies." ${ }^{\text {42 }}$ De negatieve kritieken noemt hij niet, zoals de recensie in Groot Nederland die geen raad weet met de positie van de verteller. "Op welk plan bevindt hij zich eigenlijk? In de nuchtere en kale sfeer van boerenverstand en boerenvisie of met den schrijver daar ver boven, waar zooiets als een niet geheel volwassen, een embryonale hartstochtelijk-rauw-grondmystiek schijnt te zweven? ?43 $^{\text {43 }}$

Ook nu, bij De rauwe grond, blijft een recensie van Van Duinkerken in Roeping of in een ander periodiek uit. Van Duinkerken komt terug op zijn aanvankelijk enthousiasme, maar wil zijn vriend in het openbaar niet te hard aanvallen, omdat hij nog steeds gelooft dat hij uiteindelijk met zijn vertelkunst die grote Brabantse en katholieke roman zal schrijven waar hij op wacht.

De vrienden hebben niet veel schriftelijk contact. In de zomer van 1927 komt Van Duinkerken op bezoek in Hilversum en als hij doorreist naar Amsterdam ontmoet hij, bij een bezoek aan het Kasteel van Aemstel, vrij toevallig hoofdredacteur Laudy. Na een

37 Ter Braak, 'Veelschrijvers', 448.

38 Ter Braak, Waarom Ketters?', 357-358.

39 Ter Braak, 'De moderne ketterjager', 389.

40 Coolen, De rauwe grond, 118.

41 Van Duinkerken, 'In memoriam Antoon Coolen'.

42 BA, brief Coolen aan Van Duinkerken, 8 april 1927.

43 [Recensie De rauwe grond] in: Groot Nederland, 447. 
gesprek van een half uur wordt hij redacteur van De Tijd, een functie waarnaar Coolen een paar jaar geleden vergeefs een gooi had gedaan.

Per I september 1927 zegt Coolen zijn kamer in het huis van de ouders van zijn meisje (dat al enige tijd in Rotterdam werkt) aan de Gijsbreght van Amstelstraat 23 op en huurt een kamer aan de Boschdrift 76 . Hij logeert in het najaar enkele dagen bij de ouders van Van Duinkerken in Bergen op Zoom. Zijn vriend is nu op slag een beroemdheid geworden, met een wekelijkse literaire rubriek in De Tijd, de krant die door alle katholieke intellectuelen gelezen wordt en op geen pastorie ontbreekt. In september is ook nog een gedichtenbundel Onder Gods Ogen verschenen bij Stols. In De Maasbode schrijft L.J.M. Feber, de voorzitter van de bijeenkomst van katholieke jongeren in Parkzicht waar Coolen en Van Duinkerken elkaar leerden kennen, een tweedelige bespreking van de bundel. Coolen reageert enthousiast: "Op kantoor van de krant heb ik het feuilleton dat Feber over je schreef in De Maasbode voorgelezen. De fascineerende klaroenstooten hadden succes. Er werden onmiddellijk drie exemplaren van besteld [...]. Als jij bij wijze van contraprestatie vier verwaaiende gronden pousseert, dan ben je een prachtkerel. ${ }^{44}$

Bij het bezoek aan Van Duinkerken heeft hij boeken van hem geleend. Hierbij is Tribulat Bonhomet van de negentiende eeuwse Franse schrijver Villiers de l'Isle-Adam, waarover Van Duinkerken in oktober in zijn rubriek De Tijd op Zondag heeft geschreven. Coolen vindt het "bijtend-mooi, hard en wrang mooi bitter en wreed mooi." Hij vergelijkt de hoofdfiguur met Droogstoppel uit de Max Havelaar. Ook Coolen is verslingerd aan de Franse literatuur. Hij leest, naast Villiers l'Isle-Adam, ook Barbey d'Aurevilly, Huysmans, Daudet, Verlaine, een biografie van Baudelaire, vier of vijf romans van Mauriac, maar toch ook nog altijd Nietzsche: Götzendammerung en Zarathustra.

Coolen wil duidelijk de banden met zijn vriend weer aanhalen en nodigt hem uit om met Kerstmis te komen logeren; hij heeft lekkere chianti in huis. De verhouding tussen de twee is echter wat eenzijdig geworden. Het is nog voornamelijk Coolen die lange brieven schrijft waarop af en toe korte antwoorden van Van Duinkerken komen. Aan het eind van I927 bedankt de laatste hartelijk voor de boeken die Coolen hem heeft toegestuurd: de nieuwe roman Hun grond verwaait en Jantje den schoenlapper, de novelle die eerder in Roeping verschenen is. Hij heeft het echter te druk om ze te lezen, want naast het schrijven moet hij nu, als bekende dichter en journalist ook regelmatig lezingen houden. ${ }^{45} \mathrm{Er}$ valt, in ieder geval op papier, geen woord over de vernietigende kritiek van Van Duinkerken op Peerke. Coolen verwacht geen kritiek meer over De rauwe grond. Hij vraagt de kritische brief terug die Van Duinkerken anderhalf jaar eerder over deze roman schreef. Van Duinkerken had zijn eigen brief weer terug gevraagd om te dienen als materiaal voor zijn (nooit geschreven) recensie. ${ }^{46}$

\section{Hun grond verwaait}

Het boek Hun grond verwaait ligt sinds november 1927 in de boekwinkels. Hiermee wordt een traditie gevestigd: steeds ligt vóór Sinterklaas een nieuwe ‘Coolen' klaar. Later schrijft hij zelf over dit boek: "De roman behandelt de verwording van het oude inheemsche boerenleven in Noordbrabant en de opleving van het moderne economische leven, dat daarvoor geleidelijk in de plaats komt." ${ }^{47}$ Toch gaat ook deze roman maar heel zijdelings over 
het boerenleven; het is veel eerder een verhaal over kinderen die zich ontworstelen aan hun dorpse milieu en daarmee een verhaal over de jonge Coolen zelf.

Het paar Johannes van Gogh en Leen Baerschot krijgt drie zonen, Lodewijk, Bertus en Friedus. De nieuwe tijd wordt in het leven van deze jongens weerspiegeld. Lodewijk heeft na zijn communie besloten om pastoor te worden en wil daarom naar het seminarie. Bovenmeester W.F. Frunt adviseert de moeder hem zijn zin te geven.

"'Hij heeft een heldere kop, een studeerkop, zee meester Frunt, hij is mijn vlugste leerling. [...] en houdt hij het niet vol, dan is de studie nog niet verloren. Ontwikkeling vrouw Van Goch,' zee meester Frunt en viet zijnen bril af, 'ontwikkeling, dat is de kostbaarste gave, die ge uw kind mee kunt geven."'

Lodewijk verlaat voortijdig het seminarie, gaat in de stad werken en voelt de afstand tussen zichzelf en zijn familie groter worden. Hij drinkt water bij zijn eten, eet met mes en vork, en is, veel meer dan zijn broers, ontvankelijk voor de schoonheid van het land en de natuur.

"Och, hij had het bloed van zijn voorvaders, kind als hij was uit een oud Brabants geslacht, en wellicht ontkiemde in hem het conflict tussen geslachten van een natuurvolk aan den enen kant, en aan den anderen kant, wat aanwaaisels ener cultuur van anderen bodem en anderen stam, cultuur, die hier kan gedijen. Hij wilde het land vluchten, maar in zijn vlucht trok hij zeker de banden te strak, die hem bonden aan 't land aan den grond waaraan en waaruit hij was gegroeid. ${ }^{48}$

Lodewijk krijgt verkering met Lammeke en gaat ook ergens anders wonen, "ergens in een stad in 't noorden van 't land, wijd weg." Later betrapt hij zijn broer Bertus - die door een ongeluk kreupel is - en Lammeke in een vrijpartij. Hij denkt: "Hebben de tederheden van zijn fijn gevoel zo weinig tot dit meisje gezegd, dat de kus van iemand als zijn broer haar't zelfde is? ' $t$ Zit hem in Bertus zijn mank been. Bertus mee zijn ruige lichamelijke kracht en dan 'n mank been, da werkt op het instinct van de vrouw. ${ }^{\text {m99 }}$

De twee broers staan model voor twee typen: de werkman en de intellectueel. De manke Bertus is de man die zich schikt. Eerst is hij boerenknecht. Als hij aan het ploegen is denkt hij: "Het is zijn paard niet, dat hij beveelt. Het is zijnen grond niet, dien de ploeg openscheurt. Niets is van hem dan zijn arbeid, waarin hij loopt met zijnen manke poot." ${ }^{50}$ Bertus is de werkman en Lodewijk de intellectueel. Daardoor is ook hun verhouding met de vrouw anders. De verteller maakt dit in een alinea met afwijkende lay-out duidelijk:

"Stemmen.

De vrouw zegt tot Lodewijk: Zie mij aan. Mijn gezicht is vriendelijk en stil.[...] Mijn haren zijn blond als het licht en hebt ge er wel op gelet, dat mijn jonge borsten zwellen en dat mijn armen koel zijn en geschapen om te omhelzen? [...] Misschien krijgen wij samen een kind. Misschien. Ik zal het je zeggen in de tijd dat de meidoorn zwaar is van

BA, brief Coolen aan Van Duinkerken, 21 november 1927.

Van der Plas, Daarom, mijnheer, 105.

Deze brief is verloren gegaan.

Coolen, 'Hoe ik er toe kwam', 38.

Coolen, Hun grond verwaait, 75.

Coolen, Hun grond verwaait, 145.

Coolen, Hun grond verwaait, 190-191. 
geur, dan zul je knielen en je armen om mijn heupen slaan en mijn sidderende schoot kussen, waar ons vernieuwde leven groeit verbonden aan den slag van mijn bloed.

De vrouw zegt tot Bertus: Ik heb een rond en blozend gezicht. Ik heb armen om te werken en om oe te omknellen [...] We zullen kinderen krijgen [...] Bij ieder kind, dat we krijgen, zal ik eerst moeten weten of allebei zijn beentjes recht zijn." ${ }^{\text {sI }}$

Lodewijk wordt op een gegeven moment ontslagen als klerk op het fabriekskantoor wegens bezuinigingen. Op een dag zwerft hij "de hunkering van zijn herinnering" achterna en keert terug naar zijn geboortestreek. Hij ziet er huizen van nieuwe steen en een autobus met boerenvrouwen. Dan denkt hij aan zijn jeugd en de tijd dat hij daar ravotte.

"Dit is Brabant, dit alles, deze wereld van peelgronden, van korenlanden, van boerenhoeven, van uitgestrekte hei, van bossen. Dit is Brabant, deze grond, deze rauwe stugge grond waarmee ons vlees en ons hart zijn verbonden. Dit is Brabant, dit alles, deze grond en deze mensen, deze allen onze broeders, dit is Brabant, dat we liefhebben mee een liefde geworteld en taai als de dennen. We zijn schamel en nederig, we hebben manke benen en deuken in ons wezen, onze grond verwaait en we schreien bij dit verwaaien. ${ }^{552}$ De tweede broer, Friedus, is de nietsnut met artistieke inslag; hij speelt harmonika. Hij droeg vroeger al confectiepakjes; hij was "ene grutse stinker" met bruine schoenen op zondag. Hij wordt humorist - 'kemiek' - en gaat in Antwerpen wonen als "koopman in manufacturen en salonhumorist." Hij trouwt daar, maar niemand gaat naar de bruiloft. Als zijn vrouw hem in de steek gelaten heeft, komt hij evenals Lodewijk weer naar huis.

Uiteindelijk heeft de manke Bertus, die altijd dicht bij huis en de grond gebleven is, nog de beste vooruitzichten.

\section{Coolen-land en zelfportret}

Hun grond verwaait bezit een ironische ondertoon, waar het gaat om de volksopvoedende activiteiten van schoolmeester W.F. Frunt. Coolen uit hier zijn afkeer van schoolmeesterswijsheid en pedanterie. "Hij leerde het geslacht van straks de sommen en de spelling en de namen van steden en van rivieren mee hun zijrivieren en de jaartallen. Zo bouwt hij uit aan de ontwikkeling, zo ijvert en werkt hij voor de ontwikkeling. Als ge nog iets hogers en voornamers weet voor de opvoering tot hoger van ons volk, dan wor je beleefd verzocht dat eens te vertellen, aan den heer W.F. Frunt, onderwijzer, H.d.S. alhier. ${ }^{n 3}$ Zijn manier van neussnuiten wordt hyperbolisch beschreven. Hij "snuit mee een krachtig geluid, een geluid dat zijn moment heeft in de eeuwigheid, zoals meester Frunt zijn plaats heeft in het heelal." Als oprichter van de Stichting De Goede Woning moet hij constateren dat de bewoners soms hun geiten in de voorkamer laten en zelf in 't achterkamertje huizen. Hij heeft plannen voor een conservenfabriek, maar die komen niet tot uitvoering.

Frunt is na meester Theunissen in De rauwe grond de tweede karikaturale onderwijzer. In domme grootheidswaan en pedanterie doen ze geen van beiden onder voor Meester Pennewip uit Multatuli's Woutertje Pieterse. Er zullen er in de volgende romans nog vele volgen. Van Duinkerken schrijft later dat Coolen onbarmhartig is "jegens alle schoolmeesterswijsheid en boekjesgeleerdheid, omdat zij de ontvankelijkheid voor de lessen des levens verminderen." Volgens hem gelooft Coolen niet in de ontwikkelingsavonden en vakopleiding, maar eerder in "een activeering der aanwezige goedheid van gemoed." ${ }^{54}$

Het boek is zwaar van de begrippen grond, bloed, aarde en volk. De rol van de vrouw is 
daar aan gekoppeld. "Zij is een vrouw, zij is een schakel in 't eeuwige leven, ook zij. [...] De zon ging onder en kleurde den hemel mee een klaren brand, die brandde rood door de ruit van de opkamer, waar Leen haar offer leed, het bloedig sacrificie van de vrouw, die in smarten het kind baart en den kreet verbeidt, die haar doet lachen." 55

In de opening klinkt de inhoud van Ouwerlings Uit donkere gewesten door, maar nu via de pen van Coolen:

"Dat we een volk van woestelingen en barbaren waren, da's lang gelejen. [...] de tijden, dat we beesten waren hier in 't donkere zuiden, die tijden schijnen voorbij. [... De criminaliteit, daar zijn statistieken van, en van 't zuipen onzer onmiddellijke voorvaders. Wat zeggen die dorre statistieken? Zóveel gevallen van dronkenschap, zóveel gevallen van messetrekkerij. [...] en als ze feest vierden staken ze de messen in elkanders buik, en trokken ze er dampend van bloed weer uit en veegden ze af aan de bokspijpen." ${ }^{.56}$

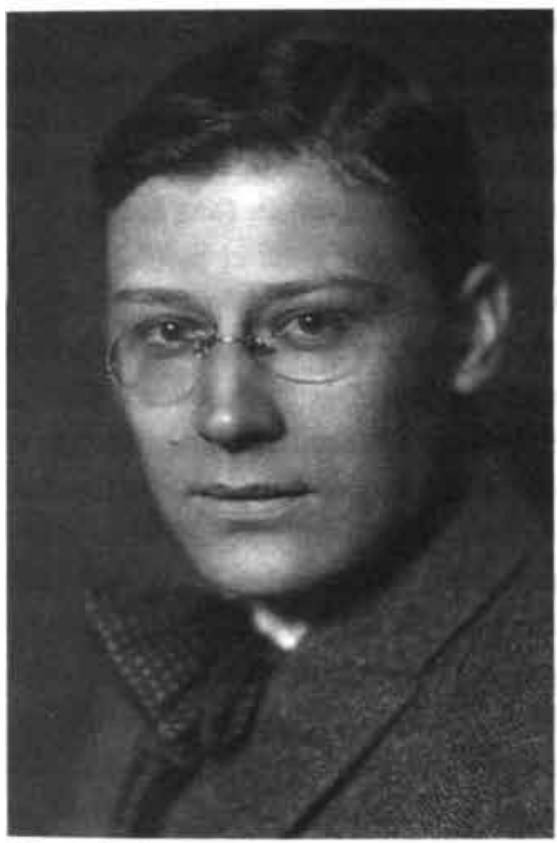

Antoon Coolen in 1926.

$\mathrm{Er}$ zitten veel autobiografische trekken in deze roman. In de persoon Lodewijk herkennen we veel van de jonge Coolen. Ook Lodewijk verlaat voortijdig het seminarie, krijgt verkering en gaat ver van huis wonen. Evenals bij Coolen in Hilversum blijft zijn land van herkomst trekken. In een passage over het personage Lodewijk en zijn meisje Lammeke worden bijna dezelfde woorden gebruikt als in zijn brief aan Van Duinkerken van 2I december 1925 over een avond met Gerda. In de brief schrijft hij: "terwijl ik tegen een boom zat met d'r hoofd in mijn schoot gelegen, zoodat ik neerzag op haar lief, lief gezicht, wit in 't maanlicht met geslooten oogen." In het boek staat: "Onder een berk gaan zij zitten en Lammeke laat zich languit op den grond glijden en ligt achterover mee haar hoofd op zijn benen. Hij neemt d'r hoofd dicht bij zich en ziet neer op de rust van haar gesloten gezicht, wit van het maanlicht. ${ }^{\text {"5/ }}$ Ook de affaire die Liesje vroeger gehad zou hebben met een broer van Antoon Coolen krijgt hier een literaire tegenhanger.

51 Coolen, Hun grond verwoait, 192-194.

52 Coolen, Hun grond verwaait, 196.

53 Coolen, Hun grond verwaait, 107.

54 Van Duinkerken, Antoon Coolen, 39.

55 Coolen, Hun grond verwaait, 20 en 40.

56 Coolen, Hun grond verwaait, 7-8.

57 Coolen, Hun grond verwaait, 91. 


\section{De kritiek}

De Maasbode schrijft enthousiast dat er veel diepte in Hun grond verwaait is. Het geeft een levensperspectief, "al zien wij het beeld Gods slechts nu en dan in de verte in zijn volle licht stralen." De krant valt wel over het ordinaire taalgebruik van de personages en omdat de beschrijving "van zekere betrekkingen" erg vrij is, moet het boek streng voorbehouden worden aan rijpere lezers. ${ }^{58} \mathrm{De}$ Groene Amsterdammer vindt Coolens manier van schrijven eigenaardig en vaak gekunsteld, vooral door de stijlversieringen, de vreemde aanhef van alinea's, de tussenwerpsels en het plots opkomend gebruik van dialect. ${ }^{59}$

Een uitgebreide en heel opvallende kritiek schrijft A.M. de Jong (1888-1943) in de socialistische krant Het Volk. Zijn mening over het boek is positief. Hij ziet het als Coolens eerste proeve van bredere epiek en hij verwacht veel goeds en moois en misschien nog wel iets groots van hem. Hij heeft echter ook kritiek en die kan niet los gezien worden van de hetze die in die tijd, februari 1928, tegen hem en Isr. Querido en hun blad NUwordt gevoerd. Een groot aantal schrijvers heeft meegewerkt aan een ANti-SchUnd vlugschrift, waarvan de $\mathrm{N}$ en de U groot zijn gedrukt. De Gemeenschap brengt het om verschillende redenen onder de aandacht. Een daarvan luidt: "Omdat wij het socialistische en semitische schrikbewind met gepaste minachting willen behandelen, maar hetzelve inmiddels niet uit het oog verliezen." ${ }^{\prime 60}$ In hetzelfde nummer wordt de Merijntje Gijzen cyclus van De Jong de grond in geboord, omdat er geen religieuze waarden in te ontdekken zijn.

De Jong heeft enkele kritische punten in zijn, zoals gezegd, positieve kritiek. Hij vindt dat Coolen blijft steken in een dualiteit, zowel in zijn gebruik van het dialect als in zijn verheerlijking van Brabant. Hij vindt dat hele "moeder Brabant" gedoe nagepraat van de Vlamingen en ziet er een neiging tot een star en bedenkelijk chauvinisme in. De jonge katholieken wordt die hele geschiedenis van de Generaliteitslanden weer aangepraat, waarin ze als wingewesten zouden zijn behandeld. En nu gaat deze jonge, zéér talentvolle Brabantse schrijver Coolen deze "machteloze puur (en klein)-politieke beweging" in de literatuur brengen. De Jong heeft niets tegen liefde voor de geboortestreek, maar het voorstellen of de Brabanders dag in dag uit door de bovenmoerdijkers worden gehoond en vertrapt, dat is onwaar en "zelfs belachelik van valse voorstelling." Hij heeft een persoonlijke reden waarom hij uitvoeriger dan in een normale letterkundige kroniek op dit boek ingaat. Hij merkt namelijk dat sommigen de neiging hebben om hem bij de Brabantse schrijvers in te delen. Dat wil hij niet, niet omdat hij Coolen compromitterend gezelschap vindt, "maar omdat ik me niet wil laten inlijven bij iets anders dan de Nederlandse schrijvers en elk provincialisme ver van mij wijs. ${ }^{n 1}$ De Jong is geboren in Brabant, hij woont er op dat ogenblik weer en hij heeft een serie boeken geschreven die er spelen, maar als hij morgen een boek over Parijs schrijft, is hij nog geen Fransman. Hij hoopt dat "de buitengewoon begaafd schrijver" Antoon Coolen zich niet vastbijt in dat schrale stukje grond, "want het kan zijn eerzucht niet zijn een ietwat schreeuwerige Brabantse, agressieve Cremer $^{62}$ te worden."

Later worden beide schrijvers in een badinerende recensie nog samen genoemd. "Jaja diejen Coolen. Hij kan het, en beter dan zijn Westelijke makker A.M. de Jong, die uit het Westen nichts Neues vertelt." ${ }^{n 3}$

\section{De dubbelster Coolen - Van Duinkerken}

Door de goede ontvangst van Hun grond verwaait stijgt Coolens gevoel van eigenwaarde. 
Het steekt hem echter dat zijn vriend Van Duinkerken nauwelijks aandacht aan dit werk besteedt. $\mathrm{Al}$ in november 1927 heeft Coolen het aan Van Duinkerken toegestuurd. Deze heeft echter behalve de zeer negatieve kritiek op Peerke nog niet verder over Coolens werk gepubliceerd. Er liggen nu al een novelle en twee romans van Coolen, die allemaal door de kritiek zijn gesignaleerd, behalve door Van Duinkerken.

Dat is een gevoelig gemis, want de ster van Van Duinkerken stijgt snel. Hij schrijft nu niet alleen voor Roeping, maar ook voor De Gemeenschap. Zijn voorkeur zal steeds meer naar het laatste blad uitgaan, waarvan hij in januari 1929 redactielid zal worden. In januari 1928 logeert Van Duinkerken een paar dagen bij Coolen. Nadat Van Duinkerken in februari even tussendoor zijn beroemde brochure Verdediging van Carmaval heeft geschreven, nodigt hij Coolen zelfs uit om in mei voor een dag of acht, samen met Bernard Verhoeven, naar Parijs te gaan. Men verwacht een "affirmatief" antwoord. ${ }^{64}$ Coolen heeft echter niet de losheid van zijn vriend. Hij zou graag meegaan als hij "vrij man" was, maar als hij in mei 8 dagen vakantie neemt, gaan die af van de 13 die hij er in totaal heeft. Hij heeft dan slechts vijf dagen over als Gerda in augustus haar schoolvakantie heeft. Hij benijdt hen wel om die reis. Hij vraagt om aan hun gezondheid te denken als ze zich aan absinth te buiten gaan, om een kaart "met de curiositeit van jullie beider vereenigde handteekeningen" en een boek van 7 of ro francs, bijvoorbeeld een niet al te onbetrouwbare biografie van Rimbaud. ${ }^{65}$ In deze lange brief schrijft Coolen de bijdragen van Van Duinkerken in De Tijd steeds te volgen. Hij maakt gewag van een verslag van een voordrachtsavond in Culemborg, waar voor de pauze ernstige gedichten werden voorgelezen en na de pauze enige humoristische verzen, zoals Lof der zeevaarders, Litanie der zonderlinge zielen en Volk in de processie van Anton van Duinkerken. "Zoo reageeren de eenvoudigen van geest op je, onbetaalbare humorist!"

Terwijl Coolen hard werkt aan de voltooiing van Kinderen van ons volk dat vóór Sinterklaas 1928 in de winkel moet liggen, krijgt hij een ansichtkaart van de Notre Dame met de handtekeningen van Verhoeven en Van Duinkerken. De kaart is uit de serie Paris.. En flânant. Het tekent het verschil tussen de twee schrijvers. Bij Van Duinkerken gaat alles min of meer vanzelf; hij is in tegenstelling tot Coolen een man die makkelijk contacten legt en snel de informele leider van een groep wordt. Even gemakkelijk als hij redacteur van De Tijd is geworden, vindt hij aansluiting bij de redactie van De Gemeenschap na een logeerpartij bij Jan Engelman in het najaar van 1928. Op zondag na de hoogmis in het café van de Utrechtse jongeren wordt beklonken dat hij met ingang van januari 1929 redacteur zal worden. ${ }^{66}$

58 [Recensie Hun grond verwaait] in: De Maasbode.

59 Middendorp, [Recensie Hun grond verwaait].

60 [Redactie van De Gemeenschap], Waarom wij "Anti-Schund" hebben gevent'.

61 De Jong. [Recensie Hun grond verwaait].

62 1.1. Cremer (1827-1880), schrijver van o.a. Betumsche novellen (1852-1855), Overbetuwsche novellen (18561877 ) en Fabriekskinderen (1863).

63 'Uit Brabant'. Hier wordt verwezen naar het beroemde boek over de Eerste Wereldooriog van Remarque Im Westen nichts Neues.

64 BA, briefkaart Van Duinkerken aan Coolen, 12 maart 1928.

65 BA, brief Coolen aan Van Duinkerken, 20 maart 1928.

66 Van Duinkerken, Brabantse Herinneringen, 296. 
In november 1928 verschijnt Coolens roman Kinderen van ons volk. Deze vormt het voorlopige hoogtepunt van zijn werk en zal hem tot een bekend Nederlands schrijver maken. Eind november bedankt Van Duinkerken wat plichtmatig voor de toezending van deze roman: "Ik vind het erg prettig dat je die motto's aan mijn gedichten ontleend hebt en zo ons brabants contact handhaaft. ${ }^{{ }^{67}}$ Het is duidelijk dat hij er geen al te hoge verwachtingen van heeft, gezien zijn teleurstelling over de twee voorgaande. Het is de derde roman met zo'n motto of titel, maar Van Duinkerken heeft over de eerste twee nog geen woord in het openbaar geschreven.

"Deze keer zal ik je niet teleurstellen, maar zo gauw mogelijk over je schrijven; ik denk in De Tijdeen flink artikel, want ik ried Knuvelder aan het te doen in Roeping omdat hij dan tevens jouw werk kan vermelden en bespreken in Bezuiden de Moerdijk, zijn boek over Brabant en Limburg. Het is echter niet helemaal uitgesloten dat ik over je schrijf in De Gemeenschap, doch misschien is De Tijd wel zo gewenst."

Daarna gaat hij al gauw over op dingen die hem op dat moment zeer bezig houden. Hij kondigt aan dat hij in januari 1929 in Hilversum komt lezen over Tolstoj en vraagt om gastvrijheid. Hij vraagt of Coolen begin januari vóór die lezingen een stuk over hem wil schrijven in zijn krant. Hij overstelpt Coolen ook met producten van eigen hand. Hij vraagt of hij zijn Ravenzwarte gestuurd heeft, anders stuurt hij die gelijk met Vertelsels in de hut. Hij wijst erop dat men bij het decembernummer van Roeping een brochure cadeau krijgt over Het letterkundig onderwijs "waarin van mijn hand een essay staat, dat misschien beter is dan het miskende carnavalsboekje." Hij meldt nog een gedicht, 'Het wereldorgel', te hebben opgestuurd om mee te dingen naar de Dom-prijs. Dan, eindelijk, alsof hij tijdens het schrijven heeft gevoeld dat zo'n opsomming niet zo aardig is tegen Coolen die juist een roman heeft voltooid, schrijft hij: “Jij bent trouwens ook niet zonder ijver. Op den duur is de victorie aan de vitaliteit en ik geloof dat reeds nu de totale zwijgzaamheid der jongeren over jouw werk zich gauw zal wreken. Want als je werkt leer je het vak." ${ }^{\text {"68 }}$

Dit is toch wel een gotspe aan het adres van Coolen, die al veertien jaar zwoegt om die roman te schrijven die hij in zijn hoofd heeft. In de hele brief staat geen woord van waardering van Van Duinkerken zelf. Aan het slot van de brief informeert hij nogmaals of Coolen hem herbergen kan, want bij het bedingen van een honorarium heeft hij eerlijk gezegd op gratis logies gerekend.

Coolen reageert typisch op zijn manier door te melden dat hij zich bezwaard voelt niet gereageerd te hebben op De Verdediging van Carnaval en de vertaling van een bloemlezing uit het werk van Hello, terwijl Van Duinkerken wel meteen schrijft als hij Kinderen van ons volk krijgt toegezonden. Hij ziet dat Van Duinkerken het druk heeft, maar voegt eraan toe dat het werk bij een dagelijkse krant als De Gooische Post misschien nog iets drukker is. Dit kan misschien als excuus gelden voor het feit dat hij zo weinig schrijft, maar hij houdt wel alles bij wat Van Duinkerken publiceert. Hij is verbluft over zijn productie: "je hebt minstens drie uitgevers nodig om dat bij te houden."

Uitgebreid gaat hij in op het boekje De Verdediging van Carnaval, een geschrift dat Van Duinkerken in één ruk tijdens het carnaval van r 928 had geschreven. Deze publicatie ontketende een rel in de katholieke wereld, die nog versterkt werd doordat er tijdens datzelfde carnaval een moord in Den Bosch was gepleegd. Hoe kon je zo'n feest nu verdedigen, 
was de teneur van de persreacties. Coolen is zelf geen uitbundig feestvierder: hij voelt zich eerder aangetrokken tot de iets meer ingetogen rituele feesten van de Brabantse gilden. Toch kiest hij partij voor zijn vriend, al was het maar vanuit zijn afkeer van de regelaars en wereldverbeteraars. Hij vindt niet dat De Verdediging van Camaval miskend is:

"Aan de felle polemiek, die het ontketende, was de ongezochte actualiteit schuld, doordat het verscheen toen de politiek van het Bossche Carnaval een vraagstuk maakte. Ik heb zelfs bemerkt, dat men dacht, dat de Bossche geschiedenis de aanleiding tot je boekje was geweest en dat het in dát debat een stem was, die de Bossche 'uitspatting' verdedigde. In het debat over het Bossche Carnaval-vraagstuk nam intusschen je meesterlijke en meesleepend geschreven boekje de hoogste plaats in en wat tegen Carnaval is gezegd bleef essentieel vrijwel machteloos tegenover de kracht van 't woord van jouw voortreffelijk en begeesterd stuk, het eenige in het heele geding, wat gezag had. De Bossche Carnavalsbestrijders - bestrijders overigens van bijkomstigheden, die ook bij elke bovenmoerdijkse feestviering optreden - waren niet beter dan het toenemend gezelschap der verbodsmaniakken, die de wereld zullen saneren door de menschheid alle gelegenheden, die iets meer dan normaal aanleiding tot kwaad kunnen inhouden, te verbieden en die menen dat het morele peil van het volk stijgen zal naarmate de politieverordening, - dit evangelie in hun handen dat alle tekenen vertoont de inspiratie van den Heiligen Geest te ontberen - wordt uitgebreid. Ik heb ze hier gehad en ze uit je Carnaval voorgelezen en gezegd: Als ge 't brabantsche carnaval wilt weg hebben: Zeg het dan zóó, en als ge meent dat het op den vorm niet aankomt, vergeet dan niet, dat de vorm van je tegenstander zijn kracht ontleent aan de evenredig groote en diepe gedachte waarvan hij de manifestatie is. Je kent de repliek: Met 'literatuur' praat je geen moord-vecht- en drankpartijen goed! En 't is tegenover de nimmer uitspattende weldenkenden in 't voordeel van de heeren dat ze, zoals Bruysten in De Residentiebode, een beetje smalend kunnen zeggen, dat de dichterlijke taal van een jeugdig literator de realiteit voorbijgaat."

Na nog over de vertaling van Hello en Vertelsels uit de hut uitgeweid te hebben, volgt dan eindelijk een voorzichtig kritisch geluid en komt Coolen voor zichzelf op:

"Met voldoening las ik uit je brief, dat je over me schrijven zult. Het eenige woord dat je tot heden aan mij wijdde was naar aanleiding van Peerke-Een andere waardering van jouw kant voor mijn werk heeft men niet - Na wat je me in een brief over De rauwe grond schreef ben ik nu blij, dat je binnenkort over wat na Peerke verscheen schrijven zult. Vanzelf zie ik dat het liefste in De Gemeenschap gebeuren. Maar ook, als ge ' $t$ in De Tijd zult doen is al een heele eerzucht bevredigd. ".69

Van Duinkerken mag natuurlijk komen logeren en Coolen schrijft plichtsgetrouw in zijn krant een mooie aankondiging voor de lezingen over Tolstoj. Hij roemt de jonge letterkundige Anton van Duinkerken met "zijn begaafdheden als diep indringend critisch ontleder, die zijn essayistisch proza onder dat van de katholieke jongeren zoo merkwaardig

67 Niet alleen de titel is uit een gedicht van Van Duinkerken; tweemaal wordt een gedichtfragment van Van Duinkerken als overgang gebruikt (op pagina 79 en 160).

68 BA, brief Van Duinkerken aan Coolen, ongedateerd [eind november 1928].

BA, Brief Coolen aan Van Duinkerken, 2 december 1928. 
maken. ${ }^{70}$ Ondertussen is Coolen al weer aan een nieuw boek bezig over de invloed van de industrialisatie op het platteland. Hij vraagt of Van Duinkerken edelmoedig genoeg zal zijn om er tijdens de logeerpartij een paar kwartiertjes naar te luisteren, want hij is zeer nieuwsgierig naar zijn oordeel.

Op dit moment staat de ster Van Duinkerken als invloedrijk katholieke jongere al hoog aan de hemel, maar die van Coolen is op weg naar hetzelfde punt. Weldra zullen ze als een dubbelster te pronken staan. Ze zijn twee totaal verschillende typen, maar daardoor hebben ze elkaar juist nodig. Coolen wil graag gezien worden als een van de gewone mensen uit de Peel, die hij door zijn scherp waarnemingsvermogen door en door kent. Tegelijkertijd verlangt hij dat de elite hem serieus neemt; hij wil erbij horen. Hij wil dat de opinion leader van het moment hem kent en erkent. Voortdurend rekent Coolen af met het elitaire en betweterige deel dat óók in hem schuilt door er in sommige personages in zijn romans mee te spotten.Van Duinkerken is iemand die juist graag gezien wil worden als de onovertroffen meester, moraalridder en verdediger van het geloof. Hij wordt 'verliefd' op de ander die hem als leider ziet. Het is deze wederzijdse aantrekkingskracht die in hun eerste brieven zo duidelijk naar voren kwam. Ze hebben elkaar nodig: de leider Van Duinkerken wil bewondering en aanhang, de kunstenaar Coolen wil waardering en goedkeuring. 
70 [Coolen, niet ondertekend krantenbericht], in: De Gooische Post, 5 januari 1929. 


\section{Succes en bekroning 6}

"In de Peel ben ik thuis."

$1929-1930$

\section{Kinderen van ons volk}

Antoon Coolen heeft voor zijn doen lang gewerkt aan de roman Kinderen van ons volk. "Ik schreef het boek in het Gooi in de stemming van afstand van tijd en plaats, en heb er ongeveer een jaar aan gewerkt." Terwijl de katholieke jongeren zich roeren in de verschillende tijdschriften en zijn vriend Van Duinkerken zowel in Roeping en De Gemeenschap als in De Tijd publiceert, werkt Coolen aan zijn "roman van het brabantsche platteland van vóór den oorlog. ${ }^{n 2}$ Daarmee zal hij definitief zijn naam vestigen en als schrijver bekend worden bij een groot publiek.

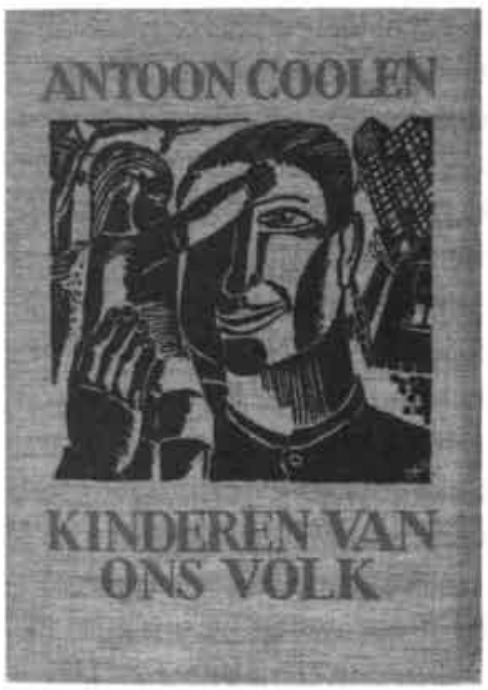

In de roman beschrijft Coolen een dorp in de Peel met een vrome en goede pastoor Vogels, een atheistische notaris, een gewiekste timmerman met een groot gezin en een boerenmeisje met twee minnaars die elkaars rivalen zijn. Het boek opent met een les van pastoor Vogels aan "de jongskens van de catechismus," waarbij hij de jongens aan de hand van de misgewaden spelenderwijs vertelt over het lijden van Christus en de betekenis van de liturgie. Diezelfde avond schaakt de pastoor met zijn vriend, de ongelovige notaris, met een goed glas wijn erbij. De mensen in het dorp vinden dat maar raar, maar men vindt de notaris toch "geenen kwaajen mensch," want als de pastoor geld nodig heeft voor een arm gezin trekt hij zijn "portefullie".

De pastoor staat ook open voor de veranderingen die er voor het boerenbedrijf op komst zijn. Hij roept de boeren na de hoogmis bijeen om over de moderne groepsstal ${ }^{3}$ te praten en hij voorspelt de komst van tractoren en betere wegen.

De timmerman, Doruske Timmer, heeft elf kinderen en hij gebruikt een foto van zijn grote gezin om karweitjes te verwerven bij potentiële opdrachtgevers. Hij is van plan een bok aan te schaffen, "zijnde het mannetje van de geit, de koe der armen. Zoo noemen ze de geit in 't geitenblaaike." ${ }^{n 4}$ Ook dit grote gezin krijgt te maken met de veranderingen in de

1 LMDC, inv. nr. C 3485, brief Coolen aan De Bourbon, 3 mei 1957.

2 Coolen, 'Hoe ik er toe kwam'. Coolen bedoelt hier de Eerste Wereldoorlog.

3 Een stal waar de koeien naast elkaar in een rij staan en waar de mest achter de beesten in een grup of 'groep', een goot, valt.

4 Coolen, Kinderen van ons Volk, 26. 
Peel en als de kinderen groter worden, komt het vraagstuk van hun toekomst aan de orde. De ouders sturen ze liever niet naar de fabriek, maar als het moet dan moet het, zegt de moeder. Later gaat een van de jongens van Doruske naar de stad, naar de strohulzenfabriek.

Als een dramatisch contrapunt fungeert de affaire van het boerenmeisje, Marie Verberne, dat niet kan kiezen tussen de boerenzonen Giel Sleegers en Godefridus van den Breemortel. Ze houdt ze allebei aan het lijntje; de jongens worden rivalen. De zondagse beugel-partijen, een soort kegelen met zware houten bollen, worden venijnig. Giel moet al een keer een bol ontwijken die Godefridus wel erg dicht langs zijn hoofd gooit.

De dreiging wordt onderbroken door een prachtig intermezzo over de aankomst van de bok bij de familie Timmer. Sprookjesachtig is de beschrijving van hoe de kinderen naar hem uitkijken in de vier windstreken. De komst van de bok krijgt iets mythisch; lang voordat hij arriveert is hij door de kinderen al overal 'gezien'.

Als Marie het eerst gebakken brood van de nieuwe oogst naar de pastoor brengt, onderhoudt hij haar over haar keuzeprobleem. Ze moet geen 'streken' hebben: "Laat da aan die stadsche dingen over." Marie trouwt na Pasen, "in mei als de kaarsjes op de kastanjes staan," met Godefridus. Ze gaat in een bonte stoet van huifkarren, een 'boerenovertrek', compleet met varkens met een papieren roos in de "krulstert" en knecht Klauske met de harmonika, naar de boerderij, waar ze door de rivaal en buurman Giel Sleegers verwelkomd worden.

Ook in dit boek treedt weer een pedante onderwijzer op. "Daar hadde ge den bovenmeester, da was toentertijd meester F van Veldhuizen, en die vond het in den grond verkeerd, wa de pastoor deed, dat spelen met de kerkelijke gewaden en het kerkelijke heilige vaatwerk. ' $t$ Is onpaedagogisch, zee meester F. van Veldhuizen en da zal zeker wel het geval geweest zijn, want de pastoor had nooit het driedeelig boek over paedagogie van J.L.C.C. de Koning, hoofd eener school gelezen, laat staan bestudeerd, en dat had meester F. van Veldhuizen wel gedaan, en grondig, hij had zelfs noten op den voet der pagina's er bij geschreven en potloodstrepen gezet bij de passages, die hem troffen." ${ }^{5}$

De notaris wordt ziek en spreekt met de pastoor over de scheiding van zijn vrouw lang geleden en over het geloof. De pastoor ziet het portret van zijn ex-vrouw hangen en vindt dat ze nooit hadden moeten scheiden. Jullie soort mensen praat te veel mooie woorden over de liefde, "maar in de praktijk verstade gellie niet de eenvoudige kunst simpel van elkaar te houden in een wederkeerig offer." ${ }^{\prime 6}$ Daarna spreken ze over het geloof. De notaris vindt pastoor Vogels een goed mens en hij weet dat deze graag zou willen dat hij gelovig zou sterven. Hij zou om zijnentwil kunnen veinzen, kunnen doen alsof hij ook geloofde. Dat heeft echter geen zin. De notaris heeft in zijn boekenkast De navolging van Christus, de Belijdenissen van Augustinus, het leven van de heilige Franciscus van Sales, En route van Huysmans en allerlei geschriften van bekeerlingen. Hij weet dat hij dood gaat. Hij is niet hoogmoedig, maar hij kan niet geloven:

"Het is geen kwestie van twijfel die op te lossen is. ' $t$ Is de overtuiging die mee 't wezen van mijn geest is vergroeid, de keiharde en volstrekte overtuiging, dat oe heele vernuftige, diepe en wijze metaphysiek en godgeleerdheid, logisch op hun veronderstellingen opgetrokken, van onbewezen stellingen uitgaan en speculatie zijn en geen enkel concreet positief houvast bieden." ${ }^{7}$

De notaris kan zich nog wel overgeven aan het woord van de pastoor, wanneer deze zegt dat er een barmhartigheid is die de eeuwigheid vervult. Als een priester echter zegt: "Ik ont- 
bind uw zonden," dan staat hij versteld van het aplomb waarmee dat door een mens gezegd wordt, om vervolgens te lachen om de naiveteit van dat geloof. Hetzelfde geldt voor de Eucharistie; hij vindt het begrip aandoenlijk maar moet daarbij toch alleen maar denken aan de schoonheid van het schilderij van Leonardo da Vinci. Nogmaals zegt hij dat het geen kwestie is van twijfelen of overtuigen: "Gij zoudt de hersens uit mijnen kop moeten nemen en in den leegen schedel er andere, die er wèl toegankelijk voor zijn, moeten inplaatsen, éér gij zoudt kunnen bereiken, dat ik zou kùnnen gelooven. ${ }^{\text {"8 }}$

Vóór het sterven van de notaris wordt nog de dood van Mieke Vuil beschreven. Groot is de tegenstelling tussen het bedieningsritueel van Mieke en de manier waarop de intellectuele ongelovige notaris de dood tegemoet gaat. Bij Mieke ligt de volle nadruk op de mystiek, het ritueel (het heidense, zal dokter Van Taeke later zeggen): de kaarsen, het wijwater, de palmtak, de communie en de latijnse gebeden. "Ook Mieke Vuil behoorde toe de strijdende kerk op aarde en nou behoorde ze toe de zegepralende kerk in den hemel. Waarom die zonderling simpelheid van een op ' $r$ vuil vegeteerend wijfke wel en waarom de weledelgestrenge heer notaris Rosier van Heijste niet?"' vraagt de verteller zich af.

De notaris bestelt zelf zijn kist bij Doruske Timmer en wordt bij zijn dood in ongewijde aarde begraven. De pastoor stuurt een brief van hem naar zijn ex-vrouw, die later kruidnagelen ${ }^{10}$ op zijn graf komt leggen.

In de zomer voltrekt zich het onontkoombare: Godefridus, de man van Marie gooit Giel, die toch nog steeds zijn rivaal is, dood met een beugelbal. Het lijkt op een ongeluk, maar aan de officier van justitie bekent hij dat het met opzet gebeurde. Hij gaat voor lang naar de gevangenis. Het leven in het dorp gaat door. De kinderen Timmer hebben een nieuwe bok en een nieuwe wagen.

De pastoor bezoekt Marie en zij vertelt hem dat ze zwanger is. "Het is met die dingen zoo wonderlijk. Er is eenen mensch gedood en de zijnen zitten in hun smartelijken rouw. Er is een ander, die in 't gevang zit wegens manslag. Hier is een vrouw, die in haar ellende dieper schruwen moet over de vrucht van haar lichaam." Zij zal echter aan haar moederschap een vreugde beleven, die haar ongeluk zal verlichten: "Want wij hebben wonderlijke bewegingen in ons. Wij wandelen schreiend en lachend naar den dood door den nood en de vreugd der dagen. Aan elke hemelkim, aan de grenzen van de tijd wenkt en komt de dood en vervult ons leven."

\section{Achtergronden en intenties}

Later vertelt Coolen in een interview over de aanleiding tot het schrijven van Kinderen van ons volk. Toen hij in Hilversum was had hij heimwee naar het land van zijn kindertijd. Weer een keer thuis zag hij een boerenovertrek, een verhuizing, zoals hij er in zijn jeugd zo vaak

Coolen, Kinderen van ons Volk, 115.

Coolen, Kinderen van ons Volk, 153.

Coolen, Kinderen van ons Volk, 156.

8 Coolen, Kinderen van ons Volk, 157.

9 Coolen, Kinderen van ons Volk, 165.

10 Seringen.

11 Coolen, Kinderen van ons Volk, 208, laatste zin van de roman. 
heeft gezien. Als gevolg daarvan begon hij aan een verhaal met de titel 'De karavaan trekt'. "Bij dat boek kwam nog van alles, allerlei verdriet en geluk van menschen, en het verlangen om over een goeien pastoor te vertellen en die te plaatsen in een sfeer, die mij als kind zo lief was geweest. Zoo is Kinderen van ons volk misschien wel heelemaal achterstevoren geschreven."12

De scene van de boerenovertrek is uiteindelijk midden in de roman terechtgekomen: "Dit is een schoone avond, waarin de karavaan trekt. In de nieuwe lente ligt brabant mild herboren. De aarde wordt niet ouder, ons hart keert open naar de lente, naar avondzon en avondwind en 't is er het lof der sterke verwachtingen. De karavaan trekt, de karavaan van karren, menschen en dieren trekt van uit het oosten naar het westen. ${ }^{n 13}$ Zes pagina's lang dokkeren de karren voort en steeds worden de woorden "de karavaan trekt" herhaald totdat ze op het erf van de nieuwe boerderij zijn aangekomen. Het is Marie die de slinger van de klok aan gang zet en het licht in "den herd" aansteekt en Godefridus die de vensters en de deur sluit nadat Giel Sleegers, de rivaal die nu hun buurman is, als laatste is vertrokken. "Zij hoort het draaien van de vensters op hun hengsels, een geluid, dat evekes jankt als het wielen van een kruiwagenrad." De komst van Giel heeft de sfeer plotseling gespannen gemaakt. Het gesprek is stroef verlopen. Het afsluiten krijgt iets symbolisch: "De hemel en de maan zijn weggesloten. Achterna komt Godefridus binnen. Hij doet de deur dicht. Hij zoekt naar de grendels en schuift ze dicht." Coolen laat na de uitgelaten verhuizing de sombere toon van het noodlot klinken. De lezer voelt het naderend onheil; de scene geeft hiermee een sterke eenheid aan het boek.

Ook van deze roman is de titel ontleend aan het gedicht van Van Duinkerken, waaruit de titels De rauwe grond en Hun grond verwaait zijn voortgekomen:

"De aanhef zelf van het gedicht 'Kinders van sterk volk zijn Brabant's menschen' is de aanleiding geweest tot den boektitel Kinderen van ons volk. Het meervoud kinders paste naar mijn gevoel niet in het Oost-Brabants idioom en in den titel te spreken van 'sterk' volk leek mij te tendenzieus voor de onopzettelijkheid in dit opzicht van het boek. Van Duinkerkens dichtregel en mijn eigen overwegingen over de integriteit ervan samenvoegend vroeg ik mij af: maar wat maak ik dan wèl van die kinderen van ons volk? Daarmee was de titel er en het 'ons' sloeg hierbij op het aanrakingspunt tusschen Van Duinkerken en mij." ${ }^{14}$

Met Van Duinkerken heeft Coolen een jaar eerder de moeilijkheden besproken van de opbouw van een roman met veel personen en nevenintriges. Hij wilde geen raamvertelling maken met een hoofdgebeurtenis die centraal staat, maar eerder het omgekeerde. Van Duinkerken schrijft later dat die vorm eigenlijk een 'straalvertelling' zou moeten heten:

"De hoofdgebeurtenis is niet het kader voor een reeks van verscheiden kortere gebeurtenissen, maar zij is, ook territoriaal, het hart van een aantal gelijktijdigheden. Deze verlopen niet binnen de duur van het bindende hoofdstuk: de reis van een groep pelgrims naar Canterbury of het vastgelopen zijn van een stoomboot op een zandbank in de mist. Ze gaan parallel met de ontwikkeling van het hoofdfeit, dat zij omsluiten in hun gezamenlijke atmosfeer, doch waarvan zij op enigerlei manier de uitstralende drijfkracht opvangen, die hen in voortbeweging brengt." ${ }^{15}$ 
Hoewel Kinderen van ons volk zich afspeelt in de Peel zijn er ook Gooise aspecten in verwerkt. Zo zouden voor het personage van pastoor Vogels zowel kapelaan De Wit van de Hilversumse St. Vitusparochie als pastoor Roes uit Deurne model gestaan kunnen hebben. Van de eerste is zijn onorthodoxe en spontane pedagogie bij de catechismusles overgenomen en de tweede is te herkennen in de moderne ideeën die pastoor Vogels over de landbouw koestert. Ook de kinderrijke timmerman met zijn bokkenwagen was geschetst naar een reëel bestaand persoon in het Gooi.

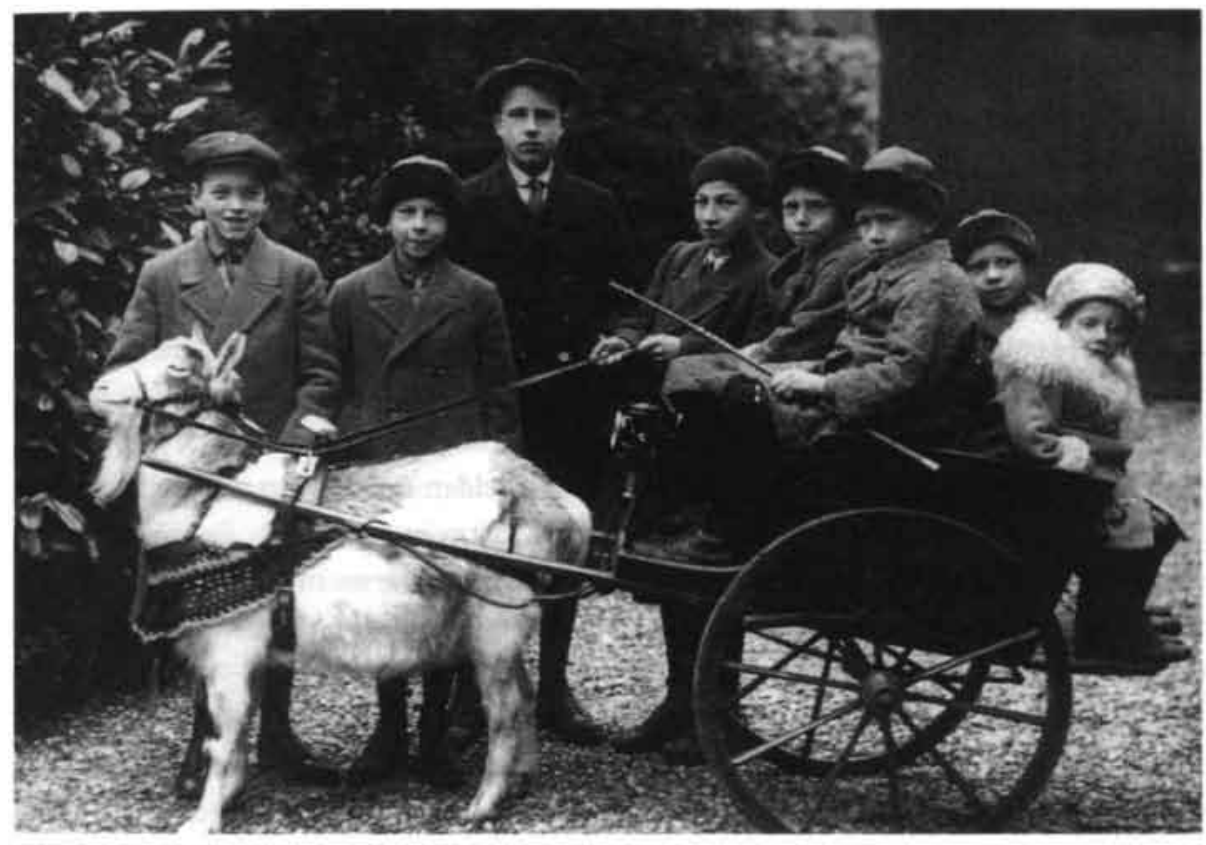

Kinderen van Dorus Fennis uit Hilversum met de bokkenwagen.

De twijfel van Marie over haar keuze tussen Godefridus en Giel herinnert aan de verwarring die Gerda de Jong tijdens de verkering had. Coolen schreef hier openhartig over aan Van Duinkerken, toen Gerda moest kiezen tussen een werelds type "ruig, sportief, met een imponeerend fysiek" en de intellectuele Coolen.

De inhoud van de discussie tussen de notaris en pastoor Vogels, waaruit hiervoor al kort geciteerd is, lijkt op het eerste oog op de meningsverschillen van de jonge Coolen met de integralist Lutkie en ook op de twist van enkele jaren terug met de apologeet Van Duinkerken over het instinct, het verstand en het geloof. De toon is echter anders; de pastoor en de notaris hebben respect voor het standpunt van de ander.

Nadat de notaris gezegd heeft dat er andere hersenen in zijn schedel geplaatst zouden moeten worden om te kunnen geloven, zegt de pastoor dat hij dat droevig vindt. De ster-

12 Sassen, 'Onder 4 oogen met Antoon Coolen', 311.

13 Coolen, Kinderen van ons volk, 103.

14 Coolen, 'Anton van Duinkerken als vriend', 23-25.

15 Van Duinkerken, 'Omgang met Antoon Coolen', 626. 
vende notaris vindt het helemaal niet droevig voor zichzelf; het spijt hem alleen voor de pastoor dat hij het droevig vindt. De notaris zegt:

"Ik beklaag me niet. Ik bewonder het leven niet. Ik glimlach, maar erken dat mijn verstand niet opgewassen is tegen mijn instinct, dat me tòch van het leven doet houden. En de dood? Wéér: ik beklaag me niet. Mijn instinctieve vrees is niet opgewassen tegen mijn verstand dat zich berustend onderwerpt. De dood martelt me niet. Wat zou de opstand van de rede beteekenen tegen heel 's werelds beloop, de rede die er ondergeschikt aan is." 16

De pastoor zegt dat de wereld niet anders te verklaren is dan in de belijdenis van het geloof en zijn dogma's. De notaris zegt dat we de wereld niet kunnen verklaren en dat we "al heel ver in de wijsheid [zijn] als we daar met een glimlach in berusten." De twee geven elkaar geen duimbreed toe. Op het moment van sterven probeert de pastoor het nog eenmaal. De notaris schudt zijn hoofd en tast naar de hand van de pastoor: "- Goede vriend, zegt de notaris heel zachtjes, mee een stem, die van de dood beslagen is. Pastoor Vogels, diejen man, hij zit ineens verstomd en gebroken."17

In deze episode is Coolen helemaal zichzelf. Hij schetst beide personages met veel sympathie zonder voor een van beiden partij te trekken. Hij heeft in de notaris en de pastoor twee kanten van zichzelf getekend: de verstandelijke vrijdenker tegenover de gelovige die zijn hartstocht richt op iets hogers en iets eeuwigs. Beiden zijn vrij van betweterigheid en arrogantie, karaktereigenschappen die Coolen bewaart voor personages als de vrijdenkende onderwijzers, arrogante doktoren en verwaten pastoors die we in Coolenland nog vaak zullen tegenkomen.

\section{De ontvangst}

Kinderen van ons volk wordt een groot succes. De combinatie van humoristische en vertederende alledaagse voorvallen, geloofstwijfel, liefde en moord is door de zeer persoonlijke aanpak van Coolen geloofwaardig. Het is echter vooral zijn invoelende, hartelijke beschrijving van een aantal van zijn personages die indruk maakt. Of het nu het simpele Doruske, de intellectuele notaris, de goede pastoor of de weifelende Marie is, allen worden ze met begrip, hartelijkheid, deernis of respect beschreven.

Begin januari 1929 heeft Van Duinkerken een paar dagen bij Coolen gelogeerd. Kort daarna vraagt Coolen per brief aan hem om nu eindelijk eens een tegenprestatie te leveren in de vorm van een mooie kritiek. Na drie romans waarvan de titels en de motto's zijn ontleend aan dichtregels uit zijn werk mag Van Duinkerken wel eens iets terugdoen. Coolen heeft bovendien nog bij Paul Brand bemiddeld over een mogelijke uitgave van Van Duinkerkens boek over Tolstoj:

"Ik herinner je intusschen aan je belofte om het boek aan mij op te dragen, een belofte die bindend is en te klemmender wordt, omdat ik die opdracht als vriendschapsbewijs buitengewoon en zoo hartelijk als ik maar kan waardeer en op prijs stel! Ik heb heerlijke herinneringen aan de dagen die ge hier hebt doorgebracht en die veel te gauw om waren en ik hoop van heeler harte, dat ge zulke bezoeken zult blijven herhalen en ge moet ervan verzekerd zijn, Toon, dat, als ik straks getrouwd ben, ge bij mijn vrouw niet minder welkom zijn zult dan bij mij." ${ }^{18}$ 
Ook nu weer zit Coolens vraag verstopt tussen loftuitingen en uitingen van genegenheid. Het Tolstoj-boek van Van Duinkerken zal er niet komen. ${ }^{19}$

Van Duinkerken maakt deze keer haast met de recensie van Kinderen van ons volk. Deze verschijnt in het maartnummer van De Gemeenschap. De beginzin is een verklaring waarom hij tot nu toe zo weinig aandacht aan het werk van Coolen heeft besteed; het is lof en kritiek in een adem:

"Nu Antoon Coolen de roman Kinderen van ons volk geschreven heeft, kan men zijn vorige boeken beschouwen, en waar nodig verontschuldigen, als pogingen om tot dit prachtig resultaat te komen. Hij heeft vele en geheel eigenaardige moeilikheden moeten overwinnen, voordat hij een boek als dit kon schrijven en het was door de merkbare strijd met deze moeilikheden, dat De rauwe grond en Hun grond verwaait niet bij machte waren, den indruk te verwekken, die hun schrijver geven wilde. [...] Het bizonder bekoorlike van dit werk ligt in de omstandigheid, dat de atmosfeer, waarin het speelt, geheel vereenzelvigd is met de levenshouding van de schrijver, zodat een bepaalde vizie op de werkelikheden van het alledaagse leven tegelijkertijd het geheel der hier vertelde dorpsgebeurtenissen aaneenbindt en ieder kleinigheid der weergave op èèn zelfde wijze belicht. Zo kon een eenheid-van-gevoel geboren worden, die het ganse boek, regel na regel en bladzij na bladzij beheerst."

Hij roemt de vaardigheid van Coolen om hoofdgebeurtenis en bijgebeurtenissen te combineren, het bijzondere compositievermogen en "bovendien een zeer groot talent om alle dingen te omvatten in één zelfde toon, die de hoofd-toon of de atmosfeer van het boek moet zijn." Coolen doet dit op een aparte manier: niet door aan het persoonlijk conflict van zijn helden een achtergrond van algemene gebeurtenissen te geven, zoals Boudier-Bakker dat doet in De straat of Mathias Kemp in De bonte storm, maar door het algemene leven te verbeelden door tegenovergestelde uitzonderingsbeelden, zoals Stijn Streuvels, Coolens grote voorbeeld, dat heeft gedaan in Minnehandel. Coolen geeft behalve bij Peerke altijd de voorkeur aan deze laatste manier. De moeilijkheid daarbij is dat de eenheid van het boek steeds gevaar loopt. Die eenheid bewaart Coolen door

"de hartelike en onbevangen openheid van de schrijver voor het gehele bewegende leven. [...] Het wisselen van uren en seizoenen; de goede dingen van het leven: de wijn, het brood, het wildbraad; de zachtheden onzer wederzijdse verhoudingen: het handenbewegen, het wijs en mild uitzeggen van een groet in den avond, het naderen van man en vrouw; al deze dingen heeft Antoon Coolen met de groten aandacht der hartelikheid bespied en gebeeld. Deze hartelikheid is zijn kenmerk geworden, zoodat wij hem gerust de meest cordiale prozaschrijver van het jonge Holland mogen noemen." Van Duinkerken vindt het boek méér dan een dorpsgeschiedenis, maar "minder dan de uit-

18 BA, brief Coolen aan Van Duinkerken, 31 januari 1929.

19 Van Duinkerken stapt wel over van zijn Tilburgse uitgever Gianotten naar Paul Brand in Hilversum, wie hij medio 1929 vanuit Noorwegen schrijtt "dat hij voorlopig maar niet moet rekenen op het beloofde boek over Tolstoj." Van der Plas, Daarom, mijnheer, 129. 
spraak van een generatie." Hij vindt dat het boek tussen Herman de Man en Albert Kuyle in staat, maar wel dichter bij De Man. Het belangrijkste is dat "het een zeer goede, inderdaad voor een brede lezerskring vatbare, katholieke roman [is] geworden, waarin de jongere strevingen van 1922 als spontaan en moeiteloos-van-zelf-sprekend zijn bereikt."

In zijn slotzin vermeldt Van Duinkerken voor de derde maal dat er aan dit boek vijf belofterijke pogingen vooraf zijn gegaan: "De stille scheppende arbeidzaamheid van Antoon Coolen, [is] na vijf belofterijke pogingen, er in geslaagd [...] haar uiteindelijke doel te halen. Dit loon is die pogingen waard."20

Hiermee is, gelet op het aanzien dat Van Duinkerken op dat moment al bezit, Coolen officieel ingelijfd bij de jonge katholieke schrijvers.

Herman de Man, die in zijn recensie ironisch beweert dat Kinderen van ons volk vanuit het gezichtspunt van de "tendenzrechercheurs" een doelloos boek is, waarin geen moraal-theologie en geen sociale misstanden worden behandeld, komt tot de conclusie dat Coolen het realisme kerstent, waardoor mededogen ontstaat voor de medemens, ook voor de moordenaar. "En daarom ook is dit Roomsch boek van Antoon Coolen, ondanks zichzelve, een stukje apologie der Eeuwige Waarheid."21

Zelfs Albert Kuyle, die Coolen tot nu toe niet erg goed gezind is, schrijft positief over deze roman in de kritische rubriek 'Hagel' in De Gemeenschap. "En die arme Antoon Coolen. Die heeft na een paar maal misgesprongen te zijn eindelijk de hindernis genomen, en goed. Kinderen van ons volk is een bijzonder boeiend en sterk boek." Hij vervolgt in een reactie op een artikel van pater Van Heugten in Boekenschouw: "Maar waarom draagt dat nu weer kiemen bij zich? Van 'De nieuwe Geboort'22 nog wel. En waarom rekenen we nu weer op die arme kerel? Voor de toekomst ... veel. Er wordt al te veel gerekend. Rammel toch niet altijd met het tuig als het paard uit eigen beweging trekken wil. Dan wordt het schuw." ${ }^{23}$

Kuyle voelt aan wat Coolen ook moet merken: de inlijving door toonaangevende critici van een jonge romanschrijver bij de katholieke canon. Coolen laat zich dat met genoegen aanleunen, zolang hij maar kan schrijven wat hij wil:

Ook Gerard Knuvelder doet mee aan die inlijving. Hij noemt Kinderen van ons volk "het enige creatieve werk der jongeren dat binnen een jaar in ons weinig goed lezend Nederland een herdruk beleefde." Volgens hem heeft Coolen de onnodige platheid van Peerke en de sentimentaliteit van Jantje de schoenlapper achter zich gelaten en spreekt hij nu een visie op het Brabantse volk uit: onder de gemoedelijkheid leven energieën in dit volk "die zich op zekere momenten verdiepen en verhevigen tot levenskrachtige of doodsgerichte momenten van uitbarsting."24

\section{Huwelijk met Gerda de Jong}

Nog voor deze kritieken verschijnen is Coolen al weer bezig met een nieuwe roman die als werktitel De lamp heeft gekregen. Deze zal aan het eind van het jaar als Het donkere licht verschijnen. Hij vraagt aan Van Duinkerken om "gegevens over de zorg voor de brabantsche fabrieksmeisjes, waarover wij spraken toen Kuyle hier met ons at." Hij schrijft er ook over in zijn krant en waarschuwt dat "de eentonige en afmattende arbeid in de fabrieken met zich mede [brengt] dat de meisjes zich in haar vrijen tijd minder aangetrokken voelen tot het zich bekwamen voor haar toekomstige taak als huisvrouw en moeder." ${ }^{25}$ Van 
Duinkerken herinnert zich later niet meer dat hij gegevens beloofd heeft over het meisjeswerk. Hij heeft alleen verwezen naar de 'Eucharistische Kruistocht' en zal daarvan brochures opsturen.

Hoe hecht de band tussen de katholieke schrijvers is, blijkt bij het afscheid van Pieter van der Meer de Walcheren, die weer naar Parijs terugkeert. Eind maart 1929 is er een afscheidsdiner in Amsterdam, waar leden van de redacties van Roeping, De Gemeenschapen De Nieuwe Eeuw en 'losse' schrijvers aanwezig zijn. Willem Nieuwenhuis is tafelpresident en Herman de Man ceremoniemeester, die in die hoedanigheid enige apocriefe telegrammen voorleest. ${ }^{26}$ Verder horen tot de feestcommissie Gerard Knuvelder (penningmeester) en Albert Kuyle. Nog op de middag voor het diner vinden besprekingen plaats over een fusieplan tussen Roeping en De Gemeenschap. 27

Op de foto die ter gelegenheid van het diner wordt gemaakt, staat Coolen - als een van de weinige met partner, zijn verloofde Gerda de Jong - vlak bij Anton van Duinkerken, die -

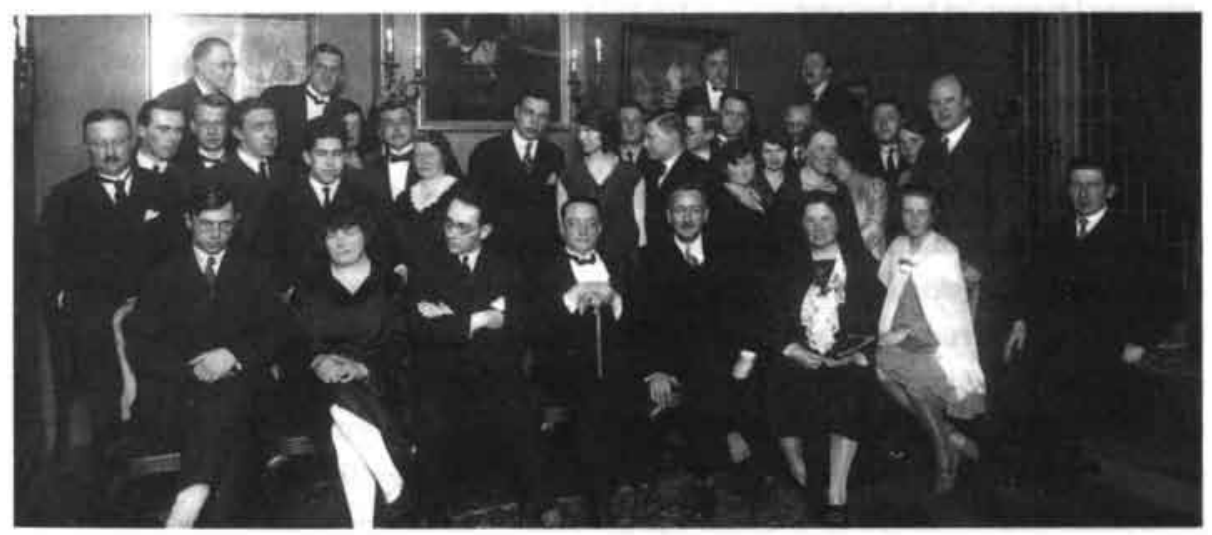

Katholieke schrijvers op het afscheidsdiner van Pieter van der Meer de Walcheren. Eerste rij v.l.n.r.: Willem Maas, onbekend, Jan Engelman, Willem Nieuwenhuis met stok, Pieter van der Meer de Walcheren, zijn vrouw Christine, zijn dochter Anne-Marie, Herman de Man. Iweede rij v.l.n.r.: H. van Haastert, Gerard Wijdeveld, Bernard Verhoeven, C. Vos, Albert Helman, Toni Maas-Bonebakker, G. Kropman, onbekend, Anton van Duinkerken, Gerda de Jong, Henk Kuitenbrouwer, Antoon Coolen, Albert Kuyle, Gerard Knuvelder, twee onbekende dames, Max van Poll, weer twee onbekende dames, Otto van Rees, onbekend, T. Trip. Van de achterste vier heren zijn alleen bekend: Wim van Rossum (uiterst links voor het schilderij) en Kees Meekel (helemaal rechts).

20 Van Duinkerken, 'Een katholieke roman', 102-105.

21 De Man, 'Uit de school van meester Streuvels'.

22 Titel van een gedichtenbundel van de (socialistische) dichteres Henriëtte Roland Holst-van der Schaik.

23 Kuyle, 'De achterban', 314.

24 Knuvelder, Vanuit Wingewesten, 496.

25 Coolen, 'Een ernstig woord'.

26 Van der Meer de Walcheren, Mensen en God, 340.

$27 \mathrm{KDC}$, inv, nr. 117, brief Knuvelder aan een dochter van dr. Moller. Afspraak met Engelman en Helman, 22 maart 1929. 
hoe kan het anders - het compositorisch middelpunt van het groepsportret vormt. Deze foto is later hét groepsportret geworden van de jonge katholieke schrijvers. Niet lang daarna zou zo'n foto niet meer mogelijk zijn vanwege de vele splitsingen. Wouter Lutkie was ook voor de bijeenkomst uitgenodigd, maar is niet aanwezig. ${ }^{28}$

Coolen kent Gerda de Jong nu vier jaar. Hij heeft bijna twee jaar, van januari 1926 tot september 1927, in haar ouderlijk huis in de Gijsbrecht van Amstelstraat op kamers gewoond. Gerda woont al enkele jaren in Rotterdam en werkt daar als onderwijzeres. Het besluit om te trouwen is kennelijk niet lang voor de feitelijke huwelijksdatum genomen. Bij het diner ter gelegenheid van het afscheid van Van der Meer de Walcheren heeft hij er althans niet over gesproken met zijn vriend Van Duinkerken. Coolen wil hem als getuige vragen, maar heeft daar wel lang mee gewacht. In april 1929 is Van Duinkerken onverwacht vertrokken naar Hammerfest in Noorwegen, waar Sjef Theeuwes, die zich voor literatuur interesseert en nog op hetzelfde seminarie heeft gezeten als Van Duinkerken, pastoor is. Daar in Hammerfest zal hij afstand nemen van de atmosfeer van katholieke en literaire kringen in Nederland.

Van Duinkerken is zó plotseling vertrokken, dat Coolen er niets van begrijpt als hij ineens een kaart van hem uit Hammerfest krijgt. Hij bedankt "Mijn allerbeste noordpoolvaarder" voor de kaart, "maar je plaatst me te midden van duizend en een raadsels, waarvan 't meest intrigeerende dit is, wat je in hemelsnaam daar in Hammerfest gaat uitvoeren. Je kaart in zijn simpelheid heeft iets van een telegram-achtig afscheidsgroet, vóór een vlucht wegens bankroof, doodslag of een ander maatschappelijk niet te tolereeren activiteit." ${ }^{29}$

Hij memoreert dat ze elkaar voor het laatst gezien hebben op de "zwelgpartij" ter ere van "den scheideling" Pieter van der Meer de Walcheren. Na vermeld te hebben dat hij pas daarna "het prachtig geschreven en uitstekende stuk" van Van Duinkerken in De Gemeenschap over Kinderen van ons volk heeft gelezen - wat eigenlijk heel eigenaardig is: hij moet daar toch zeer nieuwsgierig naar zijn geweest - volgt op een badinerende toon de aankondiging van zijn huwelijk: "En nu een zaak van minder belang: ik ga 6 juni trouwen." Hij en Gerda waren behoorlijk geschrokken van het kaartje uit Noorwegen, want ze hadden hem en Herman de Man uitgezocht als getuigen. De Man heeft al geaccepteerd. Coolen verkeert nog in de veronderstelling dat het om een kort reisje gaat en verzoekt een spoedig antwoord "want op de ondertrouwbrief [...] worden met den naam van den pastoor die het huwelijk inzegenen zal de namen van de twee getuigen vermeld, althans, indien jij kunt en de beide getuigen dus een paar beroemdheden uit het jonge litteraire Holland zijn zullen."

Van Duinkerken kan echter niet op tijd terug zijn. Hij was er graag bij geweest, maar hij wil in Hammerfest eerst iets nieuws zien en iets leren. "Groet Gerda van mij zo hartelik als jij het alleen doen kunt. Je mag zelfs verder gaan dan de Coolen-handen uit het versje! [...] Voorlopig is het een bruiloft met vreugde, een sacrament met vrucht en een nacht met alles, wat aarde en hemel den mensch vergunnen," schrijft de jeugdige ex-seminarist, die het verder kort maakt want hij moet nog aan zijn eigen meisje schrijven. ${ }^{30}$ Als vervanger voor Van Duinkerken wordt een collega van De Gooische Post, Bernard Hulsman, gevraagd.

Er blijven rond de voorbereiding van dit huwelijk vragen open. Waarom heeft Coolen er niet eerder met Van Duinkerken over gepraat en waarom heeft Coolen Herman de Man gevraagd? Misschien heeft diens optreden als ceremoniemeester bij het diner van Van der Meer de Walcheren de doorslag gegeven. Herman de Man is geboren in een joods gezin als 
Salomon Hamburger. Hij liet zich begin r 925 dopen, iets wat overigens in intellectuele kringen in die tijd meer voorkwam. Ook Frederik van Eeden was enkele jaren eerder katholiek geworden evenals Pieter van der Meer de Walcheren. De romans van De Man spelen voornamelijk in het calvinistische milieu van de waarden in Zuid-Holland en Utrecht, waardoor ervaring met drie godsdiensten in een persoon samenvallen. Ongetwijfeld heeft er bij Coolen een ijdele kant aan de zaak gezeten: het huwelijk van de succesvolle jonge schrijver met twee paranimfen die al iets langer roem genieten. Herman de Man heeft dan al Rijshout en rozen (1924) en Het wassende water (1925) geschreven. Pikant is het feit dat De Man in datzelfde voorjaar van 1929 intensief contact heeft met Wouter Lutkie in verband met een discussieprogramma voor de KRO, 'Krakeel'. De uitzending van zondag 24 maart, enkele dagen voor het afscheidsdiner van Pieter van der Meer de Walcheren, ging over fascisme en democratie. Toen Lutkie riep "weg met de vrijheid, weg met gelijkheid, weg met broederschap" zette Herman de Man als gespreksleider het 'vrijheidslied' in. ${ }^{31}$ De Man blijft zijn hele leven bevriend met Lutkie en publiceerde zelfs nog in 1940 een voorpublicatie van zijn werk in Lutkie's blad Aristo. ${ }^{32}$, een blad dat weliswaar niet antisemitisch maar wel op de leest van het Italiaanse fascisme geschoeid was.

Tot dan toe heeft Coolen nog in de schaduw van anderen gestaan. Vooral door zijn laatste boek treedt hij daaruit te voorschijn. Zeker door de katholieke 'Utrechters' Engelman en de gebroeders Kuitenbrouwer wordt hij echter nog niet helemaal voor vol aangezien. In de woorden van Fennis: "Vanzelfsprekend sprak ik bij de Utrechtenaren veel over Toon en omgekeerd met Toon over de Utrechtenaren. Toon had veel bewondering voor hen. Hij was zeer gevoelig en hunkerde naar waardering. Zijn ster als Brabants novellist begon langzaam te rijzen." Toch keek men van Utrechtse zijde in het begin wat laatdunkend op hem neer. Louis Kuitenbrouwer (Albert Kuyle) gelooft niet zo in de propagandisten van Brabant: "Wat Brabant betreft? Ze menen het vast wel goed! Maar ik geloof dat die 'Brabantsche cultuur' een fictie is. Met 'kunst' hef je geen volk op. Eerst de sociale onderbouw. En of in Brabant de boeren dieptreurig zijn, zou dat Van Duinkerken en Coolen zelf raken? ${ }^{\text {"13 }}$ Als Coolen blijkbaar geen abonnement op De Gemeenschap wil nemen noemt Kuyle hem "da menneke" en vraagt aan Fennis: "Trek jij hem eens aan de slippen van zijn nooit genoeg gehoonde Hamdorff-das, en vraag hem wèl zijn abonnement te nemen en te betalen ook. Hij zal toch zeker alleen aan schoenmakerke [Jantje de schoenlapper, C.S.] wel een tientje hebben overgehouden." ${ }^{34}$

Coolens onbekendheid is voor een deel te wijten aan het feit dat een groot gedeelte van zijn schrijfarbeid voor de krant anoniem is. In het voorjaar van 1929 schrijft Coolen veel over de verzuiling en de verhouding Noord-Zuid in verband met de feesten ter gelegenheid van de voltooiing van de restauratie van de Utrechtse Dom en de herdenking van de Unie

28 Vaarties, Herman de Man, 214.

29 BA, brief Coolen aan Van Duinkerken, 10 mei 1929.

30 BA, brief Van Duinkerken aan Coolen, 20 mei 1929.

31 Vaartjes, Herman de Man, 213.

32 Vaarties, Herman de Man, 367.

33 WE, brief [kopie] Louis Kuitenbrouwer (Albert Kuyle) aan Frans [Fennis], 12 februari 1925.

34 WE, brief [kopie] Louis Kuitenbrouwer (Albert Kuyle) aan Frans [Fennis], 1 april 1925. 
van Utrecht. Naar aanleiding van de weigering van het College van Gedeputeerde Staten van Noord-Brabant om bij de herdenking aanwezig te zijn, herinnert Coolen er fijntjes aan dat de Domtoren van origine een Rooms gebouw is. ${ }^{35}$ Bij het verslag van de viering schrijft hij, die zo op correcte kleding gesteld is, schimpend over het feit dat een socialistisch raadslid geen jacquet wilde aantrekken. ${ }^{36}$

Volgens de kaart van de Burgerlijke Stand zijn Antoon Coolen en Gerda de Jong op 5 juni I929 te Rotterdam voor de wet getrouwd. De volgende dag vond het kerkelijk huwelijk plaats. Fennis heeft daar uitgebreid verslag van gedaan:

"In r 929 was het zover. Drie weken voor het huwelijk kwam Toon vragen of hij zo lang 's nachts bij ons kon slapen. Hij wilde niet trouwen vanuit het huis van zijn bruid. [Hier vergist Fennis zich: Coolen woont al vanaf I september I 927 niet meer op het adres van de familie De Jong, Gijsbrecht van Amstelstraat, maar op de Boschdrift 76. C.S.] Aldus geschiedde. De huwelijksdatum werd vastgesteld op 6 juni. Het jonge paar zou zich vestigen in een pas gebouwd huis aan de Oude Amersfoortseweg no. 102 in Hilversum. We kregen de uitnodiging de huwelijkssluiting in Rotterdam bij te wonen. Op de morgen van donderdag 6 juni begaf Toon zich naar het huis van zijn bruid. Mijn vrouw en ik gingen naar het station. Op het perron troffen we het bruidspaar, de wederzijdse ouders en de heer Bernard Hulsman, die als getuige zou fungeren. Eén genodigde verscheen niet: de heer Aleven. Toen de trein voorreed stapten we in. Toon had voor ons allen een gezelschapsbiljet gekocht. Wie stond ons op het perron van het Centraal Station in Utrecht op te wachten? ... Zijne Hoogheid de heer Clemens Aleven! Hij was in een eerste klas-coupé een trein eerder gegaan. De begroeting verliep stroef. Uitgestoken handen negeerde hij. Op het perron troffen we ook de tweede huwelijksgetuige aan: Herman de Man. Gezamenlijk treinden we naar Rotterdam en begaven ons per taxi naar de kerk van de H. Familie aan de Veurstraat. De huwelijksmis werd gecelebreerd door de Z.E. Heer J.J.M. van Vastenhoven. De plechtigheid in de kerk mocht ik afronden door het zingen van het Panis Angelicus van César Franck. Na afloop begaf de bruiloftsstoet zich naar de pastorie voor het nuttigen van het ontbijt. Tot de gasten behoorde ook het hoofd van de school, waaraan de bruid werkzaam was geweest. Ik herinner me scherp het onsympathieke optreden van de heer Aleven. Hij zat in het midden van de tafel met zijn achterwerk naar een deel der gasten. Hij verzuimde de ingrediënten van het ontbijt door te geven totdat mijn vrouw er ijzig beleefd om vroeg. Enkele gasten waren er al toe overgegaan de broodjes zonder boter en beleg naar binnen te werken. Onderhand sprak Aleven alleen met de pastoor en met Herman de Man, aan wie hij, onbeschoft, in geinig ersatz-Joods grapjes trachtte te slijten. Typerend voor Herman de Man was zijn uitnodiging aan het bruidspaar om na afloop van het ontbijt met hem mee naar de stad te gaan voor het kopen van een huwelijkscadeautje. $\mathrm{Na}$ beëindiging van de plechtigheid keerden de gasten weer huiswaarts. Het bruidspaar vertrok naar Utrecht, waar het de eerste huwelijksnacht doorbracht in een hotel tegenover het Centraal Station. De volgende dag ging het op huwelijksreis naar Parijs. Wat ons altijd heeft bevreemd is het feit, dat op het huwelijksfeest geen enkele broer of zuster van Toon aanwezig was, Ook Hans, de broer van Ger, waar zij toen zo goed mee op kon schieten, bleek niet uitgenodigd. ${ }^{\text {37 }}$ 
Dat betekent niet dat er ruzie met de familie is, maar is eerder een gevolg van de afstandelijke en gereserveerde houding van Coolen en zijn vrouw Gerda. Coolen blijft contact onderhouden met zijn ouders en broers en zussen en stuurt later zelfs Sinterklaaspakketten voor zijn neefjes en nichtjes. ${ }^{38}$

Het jonge paar ontvangt in augustus een jolige brief van Van Duinkerken, die duidelijk opgelucht is dat zijn boek af is: "Hier heb ik Hedendaagse Ketterijen geschreven, het moet wel m'n beste werk zijn." Hij is benieuwd naar de nieuwe roman van Coolen

“die nog zoveel beter zal zijn dan de geschrevene, en jullie weet, hoe gunstig ik daarover te spreken ben. Schrijf je weer wat, Toon of gaat dat nog niet? Het graan des levens is vaak te verkiezen boven de jenever der poësie en ik vermoed een beetje, dat je dat wel doet, zeker nu het graan zich laat genieten in de heerlike gestalte van wittebrood, iets, waar je meer van weet, schavuit, blijkens dat prachtige gouden brood in K.v.o.V. [Kinderen van ons volk, C.S.], dat 'voor de pastoor' is. Het wittebrood, waar de pastoor afblijft is beter, hè? Het zal er bij jullie wel niet te gauw verteerd zijn! De erotische qualiteiten van superieure romanschrijvers zijn onbegrensde heerlijkheden! Of werkt het geluk mee tot de schepping? Dan krijgen we wellicht van de winter De lamp waar je zo vol van was?" 39

Hij verzucht dat iedereen getrouwd is, alleen hij en Nini nog niet. Zij zullen een jaar later trouwen op 9 september 1930 .

Het geluk schijnt inderdaad mee te werken aan de schepping van de nieuwe roman. Na de huwelijksreis gaat Coolen naar de Peel om daar in de zomer "in veertien dagen en later nog vijf dagen" zijn nieuwe roman, die niet De lamp maar Het donkere licht zal heten, te schrijven. In september zendt hij een fragment aan Van Duinkerken ter publicatie in De Gemeenschap "over welk fragment ik met jou en Kuyle sprak [...] Leest ge 't met aandacht en schrijft ge, hoe ge 't vindt? ${ }^{m 40}$ Weer is Van Duinkerken niet tevreden. Hij uit dat door er in eerste instantie niet op te reageren. Op 8 oktober maant Coolen hem tot spoed: "Zoude ge me 't gróóte plezier willen doen om even omgaand te laten weten, of het gezonden fragment van Het donkere licht in De Gemeenschap komt? Ik moet er dan rekening mee houden bij het samenstellen van een tweede fragment voor Dirk Coster. Zouen jullie n.l. dit stuk niet plaatsen dan kon ik een bepaald fragment voor De Stem er mee afzenden." Hij hoopt echter dat het bij de hele redactie van De Gemeenschap genade gevonden heeft. Terwijl Coolen reden genoeg heeft om boos te zijn op Van Duinkerken eindigt hij toch weer met een compliment. "En stuur me de Ravenzwarte want een auteur van jouw kaliber moet met de volledige werken - opera omnia! - in mijn boekenkast staan. Als ge in November komt zal Het donkere licht zijn verschenen, ge krijgt dan oe exemplaar. ${ }^{n+1}$

35 Coolen, [rubriek] 'Kalenderblaadje', in: De Gooische Post, 23 januari 1929.

36 Coolen, [rubriek] "t Podium', in: De Gooische Post, 28 januari 1929.

37 CS, [typoscript] Fennis, Herinneringen, 12.

38 Gesprek Jef Coolen met Cees Slegers, Deurne, 11 januari 2000.

39 BA, brief Van Duinkerken aan Coolen, 10 augustus 1929.

40 BA, brief Coolen aan Van Duinkerken, 21 september 1929.

41 BA, brief Coolen aan Van Duinkerken, 8 oktober 1929. 
Van Duinkerken reageert vervolgens per omgaande met een kaartje, dat hij de kopij na lezing onmiddellijk had doorgezonden maar nog geen beslissend antwoord heeft. "Maar Engelman deelde mijn mening, dat het stuk minder goed is dan de gemiddelde hoogte van K.v.o.V." Toch hoopt hij dat ze het opnemen: "Mij lijkt het geschikt ofschoon minder geslaagd dan K.v.o.V.. Proficiat met de ze prijs uit de wedstrijd v.d. boekhandel. Je verdiende m.i. de re." ${ }^{42}$

Het fragment wordt uiteindelijk niet geplaatst in De Gemeenschap, wel verschijnen er fragmenten in Dietsche Warande en Belfort, twee in De Stem en in Roeping. Het schaadt de verhouding kennelijk niet, want op I november stuurt Gerda Coolen een briefje waarin ze ter gelegenheid van het bezoek van aanstaande maandag Van Duinkerken dringend verzoekt om te blijven eten. "Dr. Ben Boerebach, die zijn proefschrift schreef over Alfred de Vigny, Toon beweert, dat jij 't ter recensie hebt gekregen, komt ook eten en gaat mee naar je lezing. We vinden het prettig dat je weer eens komt. Misschien is Het donkere licht dan ook wel uit." ${ }^{43}$ Boerebach is medewerker voor de Franse literatuur bij de Boekenschouw, het literaire netwerk wordt goed onderhouden.

\section{Het donkere licht}

Over de aanleiding tot het schrijven van Het donkere licht schreef Coolen later: "Ik herinner mij, dat ik in de courant het bericht las over den man, die in Den Bosch voor de rechtbank kwam wegens het delict, dat in Het donkere licht beschreven wordt." ${ }^{44}$ Dit delict is bemiddeling bij of aanzetten tot abortus provocatus. De roman behandelt echter een veel breder onderwerp. Coolen omschrijft het zelf als "de roman van een peelwerkersgezin; het leed der verwording en de ondergang der oudste dochter, die als fabrieksmeisje in de naburige stad te werk komt en haar verderf inloopt." ${ }^{\text {45 }}$

De sfeervolle openingszin luidt: "Toen Simon Wijnands zag, dat het donkeravond begost te worre over de peel, toen lee hij zijn tuig aan den kant." ${ }^{46} \mathrm{Zijn}$ dochter Marieke, de latere hoofdpersoon, wordt geboren en Jan Olie, een filosofisch aangelegde zonderling, wordt peter. Deze is gebiologeerd door het feit dat de wereld rond is. "Simon Wijnands, zeet-ie, de aarde is zoo rond as te mieter. [...] Zoo rond als een bolleke, zegt Jan Olie. Ik heb het wel eens verkleind gezien, zegt hij. Zoo'nen bol op een stang. Ge kant hem mee oe hand ronddraaien." Er treedt weer een karikaturale schoolmeester op, W.J. Bladder. Hij heeft vlak voor de doop van Marie geadviseerd om haar als tweede naam Magdalena te geven. Het meisje wordt gedoopt door pastoor Bartels die voortdurend niest en alleen maar binnensmonds mompelt en snauwt. Deze pastoor kan de dingen moeilijk duidelijk zeggen, "maar waar hij nood en leed zag, daar was hij toch bewogen, midden in de hardheid." De kleine Maria Magdalena ondergaat het doopritueel van het zout op de tong, het wegblazen van de boze en onreine geesten en het 'openen' en reinigen van alle zintuigen en het stromen van het water. Plechtstatig staat er dan: "En den doopeling verzaakt den duivel en al zijn werken en al zijn ijdelheden." ${ }^{n 7}$

In het café, na de doopplechtigheid, onderwijst Jan Olie, dat als je almaar rechtdoor blijft lopen, je weer vanzelf in de Peel uitkomt. Pas als Simon dronken thuis komt, kan hij iets gevoeligs tegen zijn vrouw zeggen over het pasgeboren dochtertje: "Het lijkt op oe." Even worden de zuigelingensterfte en de hygiëne in De Peel aangestipt. Moeder Door wast haar kind op advies van een jonge baker uit de Halt, "die gonk te keer, dat de klein van vui- 
ligheid stierven." Vader Simon houdt filosofische gesprekken met Jan Olie, die twijfelt of God wel bestaat. Olie heeft eigenaardige dromen over iemand die hem de keel wil afsnijden maar er niet bij kan vanwege zijn halve benen. Hij heeft een houten kegelbal op een handvegerhandvat als wereldbol gemonteerd. Voor Sinterklaas leent Simon geld van Jan Olie om een pop, een stukje "sjokla", een gouden griffel en een blikken trompetje voor zijn kinderen te kopen.

"Dan kwam dit vreemde in de stilte van 'nen heeten zomer." Het is de zomer van 1914 waarin op I augustus de oorlog uitbreekt en Nederland mobiliseert om zijn neutraliteit te waarborgen. De klokken luiden en de mensen komen bijeen, er komen stampvolle soldatentreinen voorbij. De verteller voorziet wat er gaat gebeuren. "De angst draaft door de dagen van den grooten tijd en iedere morgen heeft zijn wreeder nieuws van grooter en verschrikkelijker ramp en van legers uit alle landen die gaan vechten met elkaar. ${ }^{43}$

Vader Simon moet opkomen als landweerman. Hij schrijft stijve briefjes naar huis: "En vele groeten van Uwen dierbaren Simon Wijnands, milicien." Jan Olie verdient aan de smokkel. Hij heeft veel geld in huis en krijgt weer angstige dromen. Simon komt met Kerstmis thuis en heeft opstandige, socialistische ideeën in zijn hoofd: "Eenen peelwerker verrekt van de ermoej, zee Simon. Den werkman wordt onderdrukt, zee-t-ie. En hij vloekte. Houdt ze stom en arm, zee-t-ie, dan hedde ge 'nen hendigen aan eenen peelwerker. ${ }^{\text {"99 }}$

Hij gaat weer terug naar de grenstroepen. Jan Olie zou willen, ondanks dat ie aan de oorlog verdient, dat die "hoog mieters" ermee ophouden. In maart trilt de aarde echter nog steeds van de kanonnen: "Als ge mee oe oor gingt liggen op den vochtigen grond, dan hoorde ge den doffen slag en voelde ge de echo van de krachten, die den hemel schokten. ${ }^{.50} \mathrm{Jan}$ Olie leest de kranten van meester Bladder. Waarschijnlijk zit Jan Olie er achter dat er een demonstratie van peelwerkers komt. De demonstratie verloopt zeer amateuristisch. De peelwerkers laten zich gewoon wegsturen en worden dan ook nog belachelijk gemaakt door de wethouder. Deze is tevens bakker en zegt voortaan het brood wat harder te bakken zodat de peelwerkers er langer op kunnen bijten.

Jan Olie voelt door het zien van het opgroeiend Marieke zijn lusten opleven, maar hij zet het slichtmes op z'n pols en zweert dat hij z'n hand zal afkappen als hij de beest wil uithangen. "En de afgekapte hand zou hij in de kachel gooien."

Er zijn ook mensen die niets te lijden hebben van de verandering in de Peel en de oorlog: "Zomer en leven zallen er niet anders om zijn en voor den directeur van de turfstrooiselfabriek zal wel worden gezorgd. ${ }^{\text {"51 }}$ Ook meester Bladder gaat gewoon door. "Een oorlog

BA, brief Van Duinkerken aan Coolen, 10 oktober 1929.

BA, brief Gerda Coolen-de Jong aan Van Duinkerken, I november 1929.

Interview met Coolen in het weekblad Nieuw Vaanderen van 30 mei 1936, geciteerd in: Van Duinkerken, Antoon Coolen, 45.

Coolen, 'Hoe ik er toe kwam', 38.

Coolen, Het donkere licht, 5.

Coolen, Het donkere licht, 19.

Coolen, Het donkere licht, 63.

Coolen, Het donkere licht, 78.

Coolen, Het donkere licht, 85.

Coolen, Het donkere licht, 93. 
is een schokje in de eeuwigheid en in het systeem van het heelal," zegt hij en begint zijn les met de zin dat de Batavieren in honderd voor Christus op holle boomstammen bij Lobith ons land binnen komen. ${ }^{52}$

Pas na de eerste drie delen, al over de helft van het boek, wordt Marie de hoofdfiguur. De oorlog is afgelopen, maar er dreigt revolutie in eigen land: "de jongens uit de peel en uit Limburg, ze moesten naar de groote steden en stonden daar mee de geweren en de bajonetten in de straten. ${ }^{.53}$ Marie gaat naar de fabriek. Het contrast met het dorp en de Peel is groot als zij over het fabrieksterrein loopt in de richting van de "gebouwen die groot en wit geweldig overeind rezen toe aan de zon." lemand met een witte jas wijst haar een plek in "een witte zaal mee heldere ruiten [...] rontelom de lichte helderheid." Als ze 's avonds naar huis gaat gloeien de vlamletters boven op de gebouwen. Ze geniet van de sfeer op het station en in de trein. "Dan, als ze, na de reis, uit den trein gestapt was, ging ze met een groepje durskes [meisjes], dat met haar de peel introk, den weg langs de spoorlijn, den weg door het gehucht, langs de kerk en verder den zandweg de peel in." ${ }^{54}$ Het werk is gemakkelijk; ze moet draadjes inhaken aan glazen staafjes, maar ze geniet ook van het warm en krachtig licht en de witte helderheid in de fabriek.

Er is ook nog een ander, een 'donker' licht, dat een heel andere functie heeft: het lokkende en het verleidelijke van de avondlijke stad. "De lichten verduisteren den hemel en schijnen op de straatsteenen, in de glimming van een vlugge automobiel, waarvan de lichtstralen spuiten en opspeieren langs de wielen en ruggen van fietsers, langs blikkerende ruiten en verhelderde gevels mee plotselingen overvloed van zonhelderte, klaarder dan op den dag." Marie blijft 's avonds in de stad hangen. Na de arbeid zoekt zij "het licht en het klein avontuur van de avondstraat." Het baltsgedrag op straat tussen modieuze jongens met gele schoenen, lichte hoeden, gele en lila petten en meisjes is iets nieuws voor Marie.

In het slotdeel ziet Jan Olie als eerste dat er iets met Marie aan de hand is. Ze is zwanger. De vrienden van haar vriend weten via een drogist adressen in de grote steden. Zonder dat het woord abortus valt, wordt gezegd dat het een kwestie is van een dag en dat ze de vol. gende dag gewoon weer aan het werk kan. "'t Was in minder dan geenen tijd gebeurd en 't had nog minder te beteekenen dan het uittrekken van eenen tand. De dokters deejen het ook en mee alle gerustheid. Honderden en honderden vrouwen, getrouwde en ongetrouwde, lieten zijn eigen helpen en voelden er niks af." ${ }^{55}$ Versuft en wezenloos reist ze voor het eerst van haar leven over de grote rivieren naar het noorden en laat ze zich door de avondstraten van de grote stad meevoeren in een auto. In een donker straatje gaat ze ergens binnen en belandt in een kaal kamertje met een gammel bed tegen een vuilwitte muur.

"Ze was gegrepen door woorden en handen als stormwinden. Zij had toegestemd, zeker. Men pleegde geen aanslag op haar. Men hielp haar. Zeker. Rond haar vermengden zich gedempte stemmen. Zij lag neer en luisterde ernaar. Er was plotseling de stem van een vrouw tusschen. Een vrouw. [...] De vrouw is over haar gebogen mee een val van kantelende schaduwen. [...] Vuisten als steenen slaan het mysterie van haar vrouwenlichaam, een geheim dat zij niet kent. Een vuur dat klauwen heeft, wondt haar tot op de diepste nerven van haar schaamte die tot de dood bezweken ligt achter haar bleeke oogen." 56

Nadat ze 'geholpen' is, denkt ze aan haar vader en moeder. 'Zij weet niet wat zij denkt. Zij is een vrouw. Het leven gaf haar ervaring. Zij schruwt. Misschien denkt zij, hoe haar vader zich over haar moeder gebogen moet hebben, toen zij samen hun eerste kindje gekregen hadden." 
Als ze 's avonds niet thuiskomt, is Jan Olie nog ongeruster dan de ouders. Hij splijt de nieuwe wereldbol die hij van meester Bladder heeft gehad; de staatsgrenzen waren nu toch verouderd, vermeldt de verteller er ironisch bij. Hij hoort 'schruwen'. Het is Marie die ingestort door bloedverlies voor zijn deur ligt. Als ze later in het ziekenhuis ligt, gaat haar vader Simon haar opzoeken. "Ge ligt hier schoon!" Hij geeft haar twee appelsienen

"en ge moet de groeten hebben van moeders. [...] De stilte doordringt de witte muren. Marie heeft vele zusters. Ze heeft het verzamelde leed van veler diepen nood gedragen. Boven haar hangt den kruislievenheer, de voeten naar de aarde, het hoofd naar den hemel. Twee armen gestrekt naar de uiteinden van de wereld, gestrekt toe [tot] wegen naar het midden van de barmhartigheid."

Met deze zinnen eindigt het boek.

\section{Een sociale roman}

Meer dan in Coolens vorige romans het geval was, speelt in Het donkere licht de wereld buiten het dorp een rol. De wereldoorlog en de stakingen in de Peel, maar vooral de enorme verandering die de massa-industrie op het Brabantse platteland teweeg brengt, beïnvloeden het dagelijkse leven van de personages. Jongens en meisjes die eerst geen andere ervaringen hadden dan het gezin, de zondagse kerkgang en af en toe de kermis, komen nu dagelijks met elkaar in contact in de stad. De boeren houden hun dochters nog thuis, maar de peelwerkers kunnen het extra geld goed gebruiken. Coolen laat iets voelen van de bevrijding die de plattelandsjeugd moet hebben gevoeld in de fabriek in de stad. "Ze gongen de deuren in en stoeiden de trappen op, de jongens en de durskes ieder langs hunnen afgeschoten trapkant en dan uit het geduw en de drukte, boven in de witte zalen, daar gongen ze snel aan het wachtende werk." ${ }^{57}$ Binnen de fabriek werden de geslachten dus gescheiden. De aparte trappen zijn nog te zien in de Philipsfabriek aan de Emmastraat in Eindhoven, nu bekend als 'De Witte Dame'.

Coolen heeft zich goed voorbereid, zoals onder meer blijkt uit zijn vragen om informatie over de zorg voor Brabantse fabrieksmeisjes aan Van Duinkerken begin dat jaar. De laatste zond hem toen enkele folders van het werk van de Eucharistische Kruistochtbeweging. Deze beweging was al in I9I 4 gestart in Lourdes en had veel succes in Frankrijk en België. In Brabant richt deze zich vooral op de meisjeszorg die door kapelaan F.B.J. Frencken uit Breda wordt opgezet.

Coolen zit met het onderwerp van zijn roman midden in de actualiteit. Zo vindt bijvoorbeeld bij het verschijnen van het boek een grote enquête plaats over de toestanden van meisjes die werken in fabrieken en ateliers. De resultaten worden in het voorjaar van 1930 gepubliceerd onder de titel $\mathrm{Om}$ de ziel van het arbeidende meisje. ${ }^{56}$

Coolen, Het donkere licht, 107.

53 Coolen, Het donkere licht, 115.

54 Coolen, Het donkere licht, 120-121.

55 Coolen, Het donkere licht, 157-158.

56 Coolen, Het donkere licht, 167-168.

57 Coolen, Het donkere licht, 138.

58 Hiervan wordt melding gemaakt in: Dux, maart 1930. Zie ook: Knuvelder, Vanuit Wingewesten, 167-178. 


\section{Geen moraal maar mededogen}

Het is opmerkelijk dat Coolen in Het donkere licht op geen enkele manier zinspeelt op deze zielzorg. Hij had een kapelaan kunnen opvoeren die het meisje uiteindelijk de goede kant opleidt. Coolen kiest er echter voor om Marie na haar abortus te laten opvangen door de schijnbaar onnozele Jan Olie:

"Jan Olie heeft geen grote woorden, geen gedachten heeft hij voor zijn ontsteltenis. Misschien is het mee [met, C.S.] verbazing, dat Jan Olie in de instincten van zijn wezen de eenzaamheid voelt, binnen de onmetelijke grenzen waarvan dit kind heeft geleden en dat zal het zijn, wat hem mee dit wicht in haren nood vertrouwder maakt en vol van een sombere goedheid en een arm medelijden. ${ }^{59}$

Behalve de niezende en snauwende pastoor Bartels komt in het boek geen geestelijke voor. Coolen is er niet op uit de redding van Marie te schetsen, maar wil vanuit een diep mededogen verklaren hoe ze tot haar misstap is gekomen. Uit de in totaal vier pagina's toevoegingen die hij aanbrengt in de tweede druk, blijkt dit overduidelijk. Als Marie voor de eerste keer met kousen "van de kleur als bloote beenen" thuiskomt, voegt Coolen er in de tweede druk aan toe dat ze daarbij hulp heeft gehad van de meisjes die al langer in de stad werken. De beschrijving van de sfeer op de stations, in de trein en overdag in de fabriek is uitgebreider en wordt min of meer geërotiseerd. Dat geldt voor het gestoei en geravot in de trein, maar vooral voor de sfeer op het werk. De hele dag zijn er werkbazen, opzichters en meisjes die allemaal hun gedachten hebben:

"die zeien ze in een lach tot elkaar, een gedachte, waaraan haar verbeelding haar duistere pleizier had, de groote en donkere gedachte, die mee de verzamelde geur van al 't jong vrouwvolk in de warmte gedurig aanwezig was en in den duur van den dag een beklemmende en gespannen wezen kreeg, waarvan hun samenzijn was doortrokken. Het lichtte in d'oogen. Het zat in haar wezen zelf daar ze zaten, op haar stoelen in haar korte kleer. Het sprak zijn taal als ze liepen van d'een plaats naar d'ander en haastig wat fluisterden in een voorbijgaan, en langs de mannen liepen, die letten op haar gang en daden en hun bevelen en opmerkingen zeejen. ${ }^{260}$

Door een toevoeging aan de caféscène waarin Marie door haar vrienden wordt overgehaald om zich te laten 'helpen', wordt helemaal duidelijk dat het Coolen niet te doen is om te veroordelen, maar om deernis met Marie op te wekken. In de eerste druk laat hij haar na alle verzekeringen dat het allemaal mee zal vallen meteen naar de trein brengen. In de tweede druk beschrijft hij hoe ze daar in het café zit tussen de jongens die alvast maar zijn begonnen om op de goede afloop te drinken:

"Ze zat daar in haar grauwe manteltje, mee d'r gevlochten boterammentasch op haren slip, die tasch hield ze mee een rooj hand vast. Haar slappe zwart klein hoedje stond in haar oogen, haar donkere haren lagen er onderuit tegen het voorhoofd geplakt boven het wit gezicht. Zij had het grove gezicht van haar vader. $\mathrm{Zij}$ had er meer regelmaat in. Haar neus stond breed, haar bleeken mond hield ze gesloten, er was een teerheid in de ronding van haar kin. [...] Voor de jongens er erg in hadden, ineens, zat ze te schruwen, mee heete moeilijke snikken en mee hoesten onderbroken. ${ }^{\text {"61 }}$

Coolen schildert Marie hier in de stijl van een 'Ecce Homo': de vernederde en gehavende Christus. Met haar naamgeving Maria Magdalena aan het begin van het verhaal refereert hij aan de gevallen vrouw die door Jezus verdedigd wordt tegen kwaadsprekerij. In de 
'kruislievenheer' die aan het slot van de roman boven Marie's ziekenhuisbed hangt, voltooit Coolen de parallel met het lijdensverhaal en geeft hij hoop door te wijzen op de barm. hartigheid. Hij legt liever de nadruk op deze algemeen christelijke waarden dan op de katholieke leer van schuld, biecht, boete en vergelding.

Coolen geeft in deze roman duidelijk blijk van zijn pacifistische opvattingen en zijn afkeer van oorlog. Ook hierbij speelt de katholieke leer geen rol. Bij het zien van de treinen vol gemobiliseerde soldaten denkt de verteller aan de verschrikkingen en rampen die de vechtende legers te wachten staan. In de stijl waarin hij dat doet herkennen we die van de stukjes die hij tijdens de Eerste Wereldoorlog schreef in De Zuidwilemsvaart. Ook hier blijkt weer de invloed die Zola op hem heeft gehad. Al eerder is opgemerkt dat Coolen inspiratie geput heeft uit Zola's La bête humaine. Daarin beschrijft Zola hoe in de Frans-Duitse oorlog van 1870 een volle soldatentrein, waar de machinist en de stoker al vechtend vanaf zijn gevallen, op hol is geslagen. Magistraal is de vergelijking die Zola trekt tussen deze trein en de niet te stuiten oorlog:

"Wat deden de slachtoffers er toe die de locomotief onderweg vermorzelde! Ging zij desondanks niet de toekomst tegemoet, zonder zich iets aan te trekken van het vergoten bloed? Zonder bestuurder, midden in de duisternis, als een blind en doof beest dat overgeleverd is aan de dood, reed en reed zij door, beladen met dat kanonnenvlees, met die soldaten die, al afgestompt van vermoeidheid en dronken, zongen." ${ }^{-62}$

\section{Eerste reacties van vrienden}

Van Duinkerken laat Coolen aanvankelijk per briefkaart ${ }^{65}$ weten dat hij Het donkere licht niet zo goed vindt als Kinderen van ons volk. Echter, naar buiten toe, in De Tijd, ${ }^{64}$ schrijft hij dat het boek ondanks veel bezwaren toch een van de beste volksromans is van de laatste jaren. Naar zijn mening is het wel te lang en te wijdlopig en staan er teveel platte uitdrukkingen in. Hij vindt de bijfiguren niet harmonisch: $z o$ is de verleider van Marie slechts vaag getekend, Jan Olie krijgt een hoofdrol die hem niet toekomt en Bladder, als dwaas karikatuur van de schoolmeester, had kunnen wegblijven, evenals de alleen maar "awoe" roepende pastoor.

Deze kritiek van Van Duinkerken op de compositie van het boek en de onevenwichtigheid van de bijrollen is niet terecht. Hij heeft de roman te eng beoordeeld op het verhaal van het fabrieksmeisje Marie. Als het boek in zijn totaliteit wordt gezien, valt op dat het verhaal over Marie en haar ondergang pas op de helft van het boek begint. Vooral in zijn opvatting over het personage Jan Olie laat Van Duinkerken blijken dat hij de subtiele ironie van Coolen niet aanvoelt. In een simpele mens als Jan Olie, die heel goed nadenkt en net zo'n grote kop heeft als meester Bladder en daarom zijn oude hoeden afdraagt, legt Coolen zijn commentaar op en gedachten over de veranderingen in de Peel. Jan Olie beseft

59 Coolen, Het donkere licht, 178-179.

60 Coolen, Het donkere licht, 138-139.

61 Coolen, Het donkere licht, 158-159.

62 Zola, Het beest in de mens, 338.

63 BA, brief Van Duinkerken aan Coolen, 10 oktober 1929.

64 Van Duinkerken, 'Het epos van de gloeilamp'. 
dat de Peel maar een "speldeprikske" is op zijn houten wereldbol. Hij zorgt goed voor zichzelf en doet allerlei dingen die niet deugen, maar als het erop aan komt is hij een goed mens. Hij is het volmaakte tegenbeeld van een betweter als meester Bladder. Van Duinkerken is te zeer gefixeerd op het verhaal van Marie en ziet daardoor onvoldoende het thema dat Coolen in de eerste plaats wil behandelen: "het doorvreten van de industrie naar het platteland, het loswoelen der wortelen van de levensgeest daar, een doorbraak van de industrie, die niet dan met schade en ongelukken voor het platteland geschiedt." ${ }^{\mathrm{s}}$ Veel later, bij Coolens vijftigste verjaardag, herziet Van Duinkerken zijn kritiek en klinkt hij wat milder: "Nooit was Coolen er zoo volledig in geslaagd, het lijden van het volk te doen doorvoelen tot het bitterste uiterste van smart, dat iemand nog verdragen kan. Zijn gegeven is misschien wat simpel voor een roman, doch om te zeggen, dat het onvoldoende 'plan' heeft, moet men toch verstoken zijn van alle werkelijke levenskennis." ${ }^{\text {"66 }}$

Coolen zal zich getroost hebben met de aanbeveling van Dirk Coster, die heel enthousiast is over het boek en er voorpublicaties van plaatst in De Stem. Het hoofdstuk waarin Simon Wijnands met geleend geld van Jan Olie op Sinterklaasavond door de Peel gaat om een pop voor zijn dochtertje te kopen, heeft hem zeer gegrepen. Hij raadt Coolen aan zich niet te veel aan te trekken van kritieken: "U moet enkel luisteren naar Uw kunstenaarsinstinct, kritieken werden niet voor U geschreven, ook de mijne niet. Die heeft geen kunstenaar nodig! ${ }^{\text {n67 }}$ Voor Coster had Coolen de operatie van Marie niet zo vaag hoeven houden, waardoor hij de prachtige climax wat te kort doet. Iedere medicus kan toch vertellen hoe dat in zijn werk gaat, schrijft hij, en hij geeft Coolen in overweging om dit in de tweede druk nog aan te vullen.

Coolen is niet op deze suggestie ingegaan. De wijzigingen die hij in de tweede druk heeft aangebracht, zijn erop gericht om de val van Marie te verklaren en aannemelijk te maken. In de abortusscène handhaaft hij zijn beeldspraak "vuisten als steenen" en het "vuur dat klauwen heeft."

\section{Plagiaat}

Het doet Coolens naamsbekendheid geen kwaad als zich begin december r 929 een geval van 'literaire diefstal' voordoet. Het gaat om een "oorspronkelijke vrouwen-roman" van Annie Hulsman, die op dat moment in afleveringen in De Nieuwe Eeuw verschijnt onder de titel Toen haar tijd gekomen was. Mevrouw Hulsman is een onderwijzeres die ook pedagogische artikelen schrijft in het R.K. Opvoedkundig tijdschrift.

Coolen plaatst een ingezonden brief in De Maasbode, waarin hij haar werk aanmerkt als na-aperij. De geest van het boek, de psychologie, de methode, de zinsbouw, het op het OostBrabants taaleigen ingestelde auteursidioom zijn allemaal nagedaan uit Kinderen van ons volk. Het is geen kwestie van beinvloeding, maar de hele roman is een transcriptie, zegt Coolen. Vervolgens geeft hij een aantal voorbeelden van geplagieerde fragmenten en letterlijk overgeschreven teksten. "Ik waarschuw haar, dat zij met dezen dommen en ergerlijken diefstal niet verder gaat, omdat ik er anders de bescherming der wet tegen zal inroepen." ${ }^{m 8}$

Enkele dagen later verklaart Annie Hulsman in De Morgen dat zij Kinderen van ons volk bewonderde en waarschijnlijk door reminiscenties was beïnvloed. Ze beroept zich erop dat de intrige anders is. De redactie van De Nieuwe Eeuw houdt haar de hand boven het hoofd 
en stelt dat men het haar toch niet kwalijk kan nemen dat het verhaal in een Brabants dorp speelt, want dan zouden Marie Gijsen en A.M. de Jong ook plagiators zijn.

Albert Kuyle grijpt in de rubriek 'Hagel' van De Gemeenschap ${ }^{69}$ de affaire aan om eens lekker uit te halen naar De Nieuwe Eeuw, de vrouwenroman en de moderne opvoedkunde. Hij moet om bij te blijven al het pedagogisch werk van Hulsman lezen, klaagt hij. De lezer hoeft dat niet: "U heeft kinderen en slaat er op, of U heeft geen kinderen." Hij vindt het een vervloekt schandaal dat de redactie van De Nieuwe Eeuw nog probeert de reputatie van Hulsman te sauveren, terwijl Coolen overtuigend heeft aangetoond dat zijn roman Kinderen van ons volk is "leeggeplunderd, leeggestolen."

De Maasbode besteedt veel aandacht aan deze zaak en komt tot de merkwaardige conclusie dat Coolen zich nu ook weer niet zo druk moet maken en zijn eigen verontwaardiging eens goed moet controleren. "Hij kan toch immers niet bedoelen door het schrijven van zijn boeken een alleenrecht te hebben verworven op een bepaald milieu en een bepaald idioom. Men moet trouwens als Christen-menschen niet dadelijk het ergste van zijn evennaaste denken, maar goede trouw blijven veronderstellen zoolang dat maar eenigszins mogelijk is." ${ }^{70}$ De krant geeft wel toe dat hij spreekt van een auteursidioom en dat dat inderdaad eigendom van de schrijver is.

Enkele dagen later krijgt Coolen twee kolommen om zijn beschuldiging toe te lichten. Hij dankt De Maasbode voor de verdediging door het verschil tussen het auteursidioom en het volksidioom aan te geven. Coolen heeft via een door hem "geinaugureerde schrijfwijze" een eigen stem gekregen en de redactie van De Nieuwe Eeuw hoeft niet bang te zijn, dat "Marie Gijzen en andere Brabantsche schrijvers" plagiators zullen worden: “Auteurs van de zuiver eigen stem van Marie Gijzen zullen dat nooit worden, ook al schrijven ze bij tienen bij elkaar over één dorp. ${ }^{\text {"n }}$ Coolen kan de naam A.M. de Jong die hem al eerder juist om zijn auteursidioom had bekritiseerd, niet goed uit zijn pen krijgen en frommelt die weg tussen de "andere Brabantse schrijvers."

\section{Coolens idioom}

Het is niet onwaarschijnlijk dat A.M. de Jong die over het werk van Coolen in het algemeen positief schrijft, er door dit relletje toe komt zijn hekel aan Coolens dialectgebruik nog eens te etaleren in zijn bespreking van Het donkere licht in Het Volk. ${ }^{72}$ Hij vindt het niet logisch dat Coolen zijn personages dialect laat spreken en vervolgens de verteller die geen peelwerker of boer is, maar allerlei beschouwingen houdt en reflecteert, óók dat dialect laat hanteren. Dat klopt volgens hem niet en hij vindt dat Coolens mooie boeken door deze dwaze 'dualiteit' bedorven worden. Op Nieuwjaarsdag r 930 reageert Coolen hierop. In een

LMDC, inv. nr. C 3485, brief Coolen aan Oomes, 16 oktober 1934.

Van Duinkerken, Antoon Coolen, 47.

Brief Coster aan Coolen, augustus 1929. Coster, Brieven 1905 - 1930, 309.

Coolen, 'Ergerlijke literaire diefstal'.

Kuyle, 'Les Femmes savantes', 495-496.

'Nieuw materiaal', in: De Maasbode, 8 december 1929.

Coolen, 'Literaire diefstal'.

De Jong. [Recensie Het donkere licht]. 
brief doet hij het ironisch aanbod om Kinderen van ons volk alsnog op te sturen, omdat hij uit de recensie meent op te maken dat De Jong dat boek nog niet gelezen heeft. Coolen houdt vol dat zijn manier van schrijven beter is dan die van De long:

"Ik voor mij geloof juist dat de toepassing van het idioom in een schrijfvorm als de mijne grooter éénheid brengt, omdat de gesprekken daardoor tusschen de beschrijvingen geplaatst worden, zonder dat die eigenaardige breuk ontstaat [...] wanneer ik dialogen in dialect geplaatst zie tusschen Nederlandsch. Juist bij Uw Merijntje en bij boeken als Querido's Jordaancyclus voel ik telkens dat dualisme, dat overspringen [...] Ik meen dat dát dualisme juist hinderlijk is en dat mijn schrijfvorm, door U dualistisch genoemd, juist veel minder dualistisch is!" ${ }^{\text {73 }}$

Later legt hij het in een interview iets anders uit: hij drukt zich als verteller in het idioom van het volk uit, maar tracht dat idioom om te vormen tot algemeen verstaanbaar Nederlands. Alleen wanneer de personages spreken, gebruikt hij dialect. ${ }^{74}$

Coolen heeft dit eigen idioom langzaam ontwikkeld. In Lentebloesem uit 1921 is er nog niet veel van te merken. Hier is de taal van de verteller algemeen Nederlands en zelfs in de dialogen is het dialect maar summier aanwezig in de gij-vorm, zoals in "geloofde gij het?" Echter, al in zijn eerste bijdrage aan Roeping in 1924, Dat sprookje het feodale kasteel, gebruikt hij niet alleen dialect in de dialogen. Soms laat ook de verteller horen dat hij een ingewijde is, een van ons uit het dorp. Dan lezen we bijvoorbeeld over de Franse bediende: "dat is nou bekant nie 'ne mensch. Hij is Franswa en daarmee uit." De rauwe grond uit 1926 begint met de zin: "Ge kunt zeggen wa ge wilt, maar den directeur van het postkantoor da is 'ne goeje mensch." Dit soort zinnen komt ook voor in Kinderen van ons volken Het donkere licht: "Zoo wier het herfst, dien schoonen tijd."

Het idioom wijkt niet zo erg ver af van algemeen Nederlands, maar heeft wel een Brabants tintje. De Jong heeft geen gelijk als hij zegt dat een verteller die geen peelwerker of boer is, zo niet praat. Onder Brabantse bestuurders, onderwijzers en geestelijken bestond toen - en ook nu nog wel - de gewoonte een lichte vorm van dialect te hanteren. Ongeveer zo schrijft Coolen zijn boeken in een soort algemeen Oostbrabants. Hij doet dat echter op zijn eigen wijze en creëert een taal van Coolense makelij.

Van die taal van de verteller, met de Brabantse klankkleur en woordkeus, wijkt het dialect van de sprekende personages dan weer af. Als de verteller in Kinderen van ons volkeen onweer dichterlijk heeft beschreven, komt het commentaar van Marie daarop in haar eigen taal niet gekunsteld over. Als Marie uit de keuken komt slaat ze "een vinnig kruis, want ze zag door het raam 'nen vierdobbelen bliksem als 'nen bussel van geslingerde striepen door elkaar gehaakt van bovene toe ondere één vuur in de donkere lucht, en meteen daarop splijt en klieft een galmende donderslag op het huis en kraakt en verratelt razend naar de boorden van den hemel." Wanneer haar man veilig thuis is gekomen, antwoordt ze op zijn opmerking dat ze niet bang moet zijn voor onweer: "Ik heb er geenen schrik af [...] Ik was ongerust over où, da ge in d'akker zoudt zijn. Ge hoort dik zat dat er iemes dooddondert in d'akker." 75

Coolen is niet de enige auteur die dit procédé hanteert. Ook Hugo Claus zal later een heel eigen soort Vlaams voor vertellers en personages van zijn verhalen creëren. 


\section{Eerste kennismaking met Streuvels}

Eind 1928 heeft Coolen contact gelegd met Felix Timmermans. Hij zond hem toen Kinderen van ons volk, waarop Timmermans reageerde met: "De schoonste Nieuwjaar die ik thans gekregen heb waren uw Kinderen!" ${ }^{76}$ Tussen beide auteurs ontstaat een vriendelijke briefwisseling en een goede verstandhouding. Timmermans zal Coolen later introduceren bij zijn Duitse uitgever en wordt peter bij de doop van Coolens derde zoon.

Coolen ziet Stijn Streuvels echter als zijn grote voorbeeld. Bij het overdenken van zijn antwoord op de kritiek van De Jong, moet Coolen aan Streuvels gedacht hebben. Het lijkt wel alsof het lezen van deze kritiek aanleiding is geweest om eens contact te leggen met zijn grote voorbeeld uit West-Vlaanderen. Ook Streuvels bracht geen groot verschil aan tussen het idioom van de verteller en dat van zijn personages. Coolen besluit hem te schrijven. Hij schrijft zo'n eerste brief met schroom, omdat hij bang is dat de meester zijn brief en lof voor vleierij zal aanzien.

Van die bescheidenheid heeft collega Herman de Man geen last, want deze correspondeert al sinds 1922 regelmatig met zijn idool Streuvels en in 1927 is Streuvels op een reis door Nederland al bij hem op bezoek geweest." Het zegt iets over de oppervlakkigheid van het contact tussen Coolen en De Man dat de laatste Coolen nooit bij Streuvels heeft geintroduceerd. Het is echter zeer waarschijnlijk dat Coolen daar ook niet om gevraagd heeft.

Coolen stuurt Streuvels samen met zijn eerste brief Kinderen van ons volk en de eerste druk van Het donkere licht. Hij stelt zich voor als bewonderaar van jongs af aan. Al op 13-jarige leeftijd las hij de bloemlezing van dr. Nijland: "de gedeelten uit Oogst, uit Kinderzieltje en Doodendans gaven mij een geestdrift die me nàchten wakker hield." Het laatste dat hij van hem gelezen heeft is Kerstwake. Hij schrijft dat de karakterologie van het Vlaamse Volk "merkwaardige en treffende vergelijkpunten met die van het volk onzer brabantsche Kempen" heeft en groet hem als de grootste en zuiverste schrijver van Vlaanderen en Groot-Nederland. ${ }^{78}$ Streuvels reageert meteen en stuurt een kerstvertelling met opdracht. Kinderen van ons volk is voor hem een "openbaring." Hij vindt het een perfect boek, "in eene gezonde, frissche taal geschreven. Daarenboven is het ethisch hoogstaande kunst, verheffend en zedelijk, zonder tendenz - wat was ik bang dat de notaris zich zou bekeerd hebben!! Gelukkig is hij konsekwent gebleven. ${ }^{79}$

Streuvels begroet in Coolen een schrijver naar zijn hart en zegt dat hij nu met nieuwsgierigheid Het donkere licht gaat lezen. Coolen belooft binnenkort de tweede druk van Het donkere licht op te sturen, die hij inhoudelijk veranderd heeft en waaraan hij nu de voorkeur geeft.

LMDC, inv, nr. C 3485, brief Coolen aan A.M. de Jong, 1 januari 1930.

'Bij Antoon Coolen. Van Nick Carter-verslinder tot romanschrijver.

Coolen, Kinderen van ons volk, 121 en 122.

Brief van 6 januari 1929, geciteerd in: Durnez, Felix Timmermans, 492.

Vaartjes, $U$ hebt mij den weg gewezen, 30.

AMVC, inv. nr. C 3475, brief Coolen aan Streuvels, 30 december 1929.

FPC, brief Streuvels aan Coolen, 8 januari 1930. 

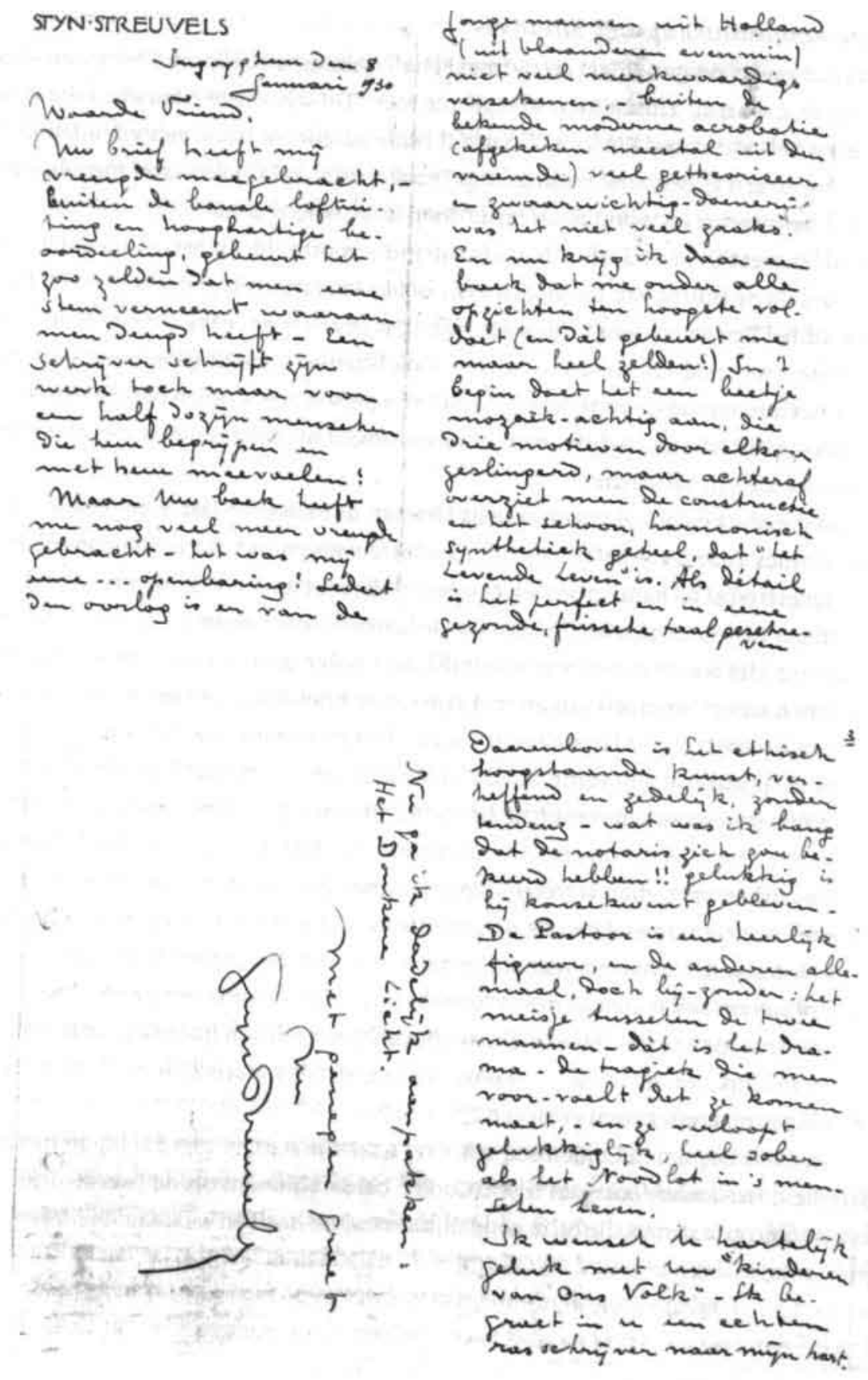

Opnieuw blijkt dat Coolen graag terug wil naar Brabant: "Een betrekking, noodzakelijk voor het bestaan, houdt mij in Hilversum. Ik zou zoo graag gauw naar brabant terug willen." 80

\section{Kunst en politiek}

Terwijl Antoon Coolen door de goede verkoop van zijn laatste boeken er over begint na te denken of zijn 'betrekking' bij de krant nog wel langer nodig is en of hij straks misschien 
niet helemaal van zijn literaire werk in Brabant zou kunnen gaan leven, raken de katholieke jongeren steeds meer betrokken bij sociale, economische en politieke vraagstukken.

Gerard Knuvelder heeft Bezuiden de Moerdijk (1929) geschreven en is bezig aan een volgende publicatie, Vanuit Wingewesten (1930). Deze boeken beperken zich niet tot de culturele achterstand van Brabant, maar bestrijken alle aspecten van het leven. Knuvelder is enthousiast over het laatste boek van Coolen. Hij schrijft in een brief aan Coolen, dat deze in zijn volgende boek, Vanuit Wingewesten, de centrale plaats zal innemen als Brabantse schrijver en niet Van Duinkerken, want "in jouw werk klinkt de stem van het bloed onmetelijk veel sterker." Hij vindt wel dat Coolen wat negatiever over de toestand op de fabrieken had mogen schrijven. ${ }^{81}$ Dit past natuurlijk beter in Knuvelders opzet om Brabant als een uitgezogen en misdeeld gewest af te schilderen.

Van Duinkerken wordt in die tijd zowel van links als van rechts aangevallen. Het nieuwe tijdschrift De Paal noemt hem een dorpskoster, een proleet, een oplichter en "het prototype van hen die in de drabbige moderniteit zitten vast geklonterd." ${ }^{82}$ Tegelijkertijd krijgt hij een meer intelligente kritiek van Menno ter Braak die het boek Hedendaagse Ketterijen weliswaar roemt, maar Van Duinkerken een geniale apologeet noemt en een orthodoxe katholiek die nooit te vertrouwen is. Van Duinkerken reageert niet op De Paal, maar wel op Ter Braak die hij meer van zijn eigen kaliber vindt. Het is de eerste keer dat de twee de degens kruisen in een polemiek die de hele jaren dertig zal duren en waarbij ook het werk van Coolen een rol zal spelen.

Coolen laat zich in deze tijd maar één keer verleiden om een uitspraak te doen over de politiek. Hij stelt dat politiek en kunst niets met elkaar te maken hebben. Dat doet hij in februari en maart 1930, in antwoord op een enquête van De Tijd, "waarbij aan 'mannen van rijpe ervaring op het gebied der praktische staatkunde en van het katholiek openbaar leven, zoowel als aan penvoerders der jongeren' een drietal vragen werd voorgelegd. ${ }^{.83} \mathrm{Aan}$ de jongeren wordt vooral gevraagd naar hun belangstelling voor het politieke leven. Coolen levert zijn bijdrage onder de titel 'Waarom toenadering zoeken?' Hij schrijft dat jongeren niet alleen afzijdig zijn, maar dat er ook "een sterke tegenzin, een afkeer en afschuw" van de politiek valt waar te nemen. Coolen vindt toenadering overbodig en ongewenst, omdat de katholieke emancipatie toch al topzwaar is. De politiek brengt de literaire en artistieke jongeren maar van hun ware roeping af. De jongeren vertegenwoordigen volgens Coolen "voor het eerst in de geschiedenis van de emancipatie een fel-critische, stimulerende, gezónde reactie," waarvan het historische gemis reden was, waarom thans de politiek door "gansch een avantgarde, die het 'nieuwe leven groet' wordt verafschuwd." ${ }^{\text {B4 }}$

Het is Coolen ten voeten uit. Hij wil schrijven zoals hij wil. Hij zegt eigenlijk: laat mij gehoor geven aan mijn literaire roeping en vraag me niet daarbij een of andere boodschap uit te dragen. De formulering doet sterk denken aan zijn hartenkreet in een brief aan Wouter Lutkie van acht jaar daarvoor, waarin hij zegt het verkondigen en preken niet

80 AMVC, inv. nr. C 3475, brief Coolen aan Streuvels, I1 februari 1930.

81 FPC, brief Knuvelder aan Coolen, 9 oktober 1929.

82 Van der Plas, Daarom, mijnheer, 146.

83 Joosten, Katholieken en fascisme, 159.

84 Coolen, Waarom zelf toenadering zoeken?'. Zie ook: Joosten, Katholieken en foscisme, 163. 
nodig te hebben: "Maar ontroert het, grijpt het aan, doet het innig aan, trèft het - dat wilde ik weten." ${ }^{85}$

Het is dan ook niet te verwonderen dat hij zich afzijdig houdt van de woelingen die er onder katholieke jongeren ontstaan naar aanleiding van deze enquête. De redactie van $D e$ Gemeenschap brengt een pamflet uit, getiteld Hagel en Vuur. Veel artikelen hebben een antiparlementaire strekking. Vooral de R.K. Staatspartij en zijn leider, de priester Nolens, zijn mikpunt van spot. De dichter Gerard Wijdeveld verwijt de laatste in zijn gedicht 'De droom van Nolens' opportunisme en verzaking van zijn priesterschap. Gerard Knuvelder van Roeping schrijft gematigd kritisch over de R.K. Staatspartij, maar twijfelt ook aan het nut van de democratie. ${ }^{86}$

Jan Engelman en Albert Kuyle spreken op 18 maart 1930 in Amhem over jongeren en politiek. Engelman wil veel meer inbreng van de jongeren in de politiek. Albert Kuyle wijst op de gevaren van het grootbedrijf, waarbij met name de Eindhovense Philipsfabrieken het moeten ontgelden. Later, in de bundel Alarm (r933), bekritiseert hij fel het opdrijfsysteem en het binnendringen van het alom aanwezige bedrijf in de privé-sfeer van gezin en opvoeding: "Het bedrijf van enormen omvang is gelegen in een katholieke streek, die langzaam maar zeker ontkerstend wordt; het vernietigt en vernielt de resten van een vroegere Brabantsche cultuur; het licht het leven uit zijn verband en mechaniseert de eerlijke functie van ziel, hoofd en hart. ${ }^{n 87}$ Nog later zal hij, op verzoek van Coolen, aan een scenario werken voor een film gebaseerd op Het donkere licht. Het zal niemand verbazen dat de Philips Filmafdeling niet stond te trappelen om mee te werken.

In deze en de komende jaren beginnen zich houdingen en opvattingen af te tekenen, die uiteindelijk zullen leiden tot fascistisch georiënteerde organisaties als Zwart Front en bladen als Aristo-van Lutkie. De romans van Coolen, waarin veelvuldig sprake is van 'grond, bloed, aarde, boerenras' passen goed in de programma's van deze clubs. Coolen heeft zich echter nooit bij hen aangesloten en ook niet in hun bladen gepubliceerd, enerzijds omdat hij zich liever afzijdig houdt van politieke activiteiten en polemieken, anderzijds vanwege zijn afkeer van de personen die er achter zitten. Hij spreekt zich hierover niet openlijk uit. Die taak wordt vervuld door zijn vriend Van Duinkerken. Daarom komt de felste kritiek uit het rechtse kamp neer op dit boegbeeld van de niet met Mussolini dwepende, katholieke jongeren. Zaal noteert over het tijdschrift De Bundel dat enkele jaren later (in 1937) verschijnt:

"De traditie van schimpen op Van Duinkerken bleef in volle glans bewaard, vooral door Paul Vlemminx: 'Ik moet mijn verachting uitspreken over degene, die de grondslagen der natuurlike beschaving (volk, stam, ras, bodem, mythen, recht) verloochent, namelik over Anton van Duinkerken. Wie het natuurlike historiese volksgoed verloochent, wie het volks- en stambewustzijn ondermijnt, noem ik een kultuurnihilist en volksverrader.' Dat was weer eens goed gezegd en voor herhaling vatbaar, waarbij dan ook Van Duinkerkens vriend de onverbeterlijke democraat Coolen klop kreeg. ${ }^{88}$

Het paradoxale ligt in het feit dat noch Van Duinkerken, noch Coolen die "grondslagen der natuurlike beschaving" verloochent. Coolen laat in zijn romans zien dat deze zaken een rol spelen in het leven van de mensen, soms als inspiratie, soms als benauwend kader. Steeds zal het individu hierbinnen moeten kiezen en dan komen andere grondslagen aan de orde zoals barmhartigheid, liefde, deernis en vreugde. De onderwijzers, pastoors, gemeentesecretarissen en invloedrijke boeren kunnen veel bedisselen en uitleggen over de wereld en 
de maatschappij, maar uiteindelijk is de keuze van het individu beslissend. In zijn romans en krantenstukken van de jaren dertig zal Coolen zijn taalgebruik en onderwerpen niet aanpassen. Integendeel, de woorden volkskracht, volksziel, volkseigen en de liefde voor de grond komen veelvuldig voor.

Coolen zal politiek afzijdig blijven. Vooral door zijn geloof in de integriteit en onaantastbaarheid van het individu is hij niet vatbaar voor welke dictatoriale stroming dan ook. Integendeel, hij beschrijft de 'gevallen' Marie, Mieke Vuil, de ongelovige notaris en pastoor Vogels als unieke, waardevolle mensen en valt niet voor een leer waarin het individu ondergeschikt aan de collectiviteit wordt gemaakt.

\section{De C.W. van der Hoogt prijs}

Coolen heeft waarschijnlijk met enige voldoening met Pasen 1930 het leggen van een gedenksteen in het dorp van zijn jeugd, Deurne, bijgewoond. De steen is gelegd ter nagedachtenis aan Aaltje Noorderwier-Reddingius, een zangeres die afkomstig is uit Deurne en ook wel 'de nachtegaal van de Peel' wordt genoemd. Zij is een zus van de dichter Joannes Reddingius die in Hilversum woont. Coolen komt bij hem over de vloer en zal na zijn verhuizing naar Deurne met hem blijven corresponderen. Bij de plechtigheid zijn ook zijn oude vriend Ouwerling en zijn toekomstige vriend Wiegersma aanwezig. Met de eerste heeft hij niet veel contact meer, maar met de tweede nemen de contacten toe. Bij dit soort officiële gelegenheden laat Coolen zich steeds vaker zien. Hij wil beschouwd worden als een Brabants schrijver.

In zijn hoofd is hij al bezig met de opzet van weer een nieuwe roman, waarin ditmaal de peelwerkers centraal komen te staan. Begin mei neemt hij een paar weken vakantie en schrijft in één ruk de roman Peelwerkers. De inlevering van het manuscript - op zich toch al een bevredigend moment - krijgt een extra feestelijke accent, als kort daarna bekend wordt dat hij voor de roman Het donkere licht bekroond zal worden met de C.W. van der Hoogt prijs. Deze is een aanmoedigingsprijs van de Maatschappij der Nederlandsche Letterkunde, die, verwijzend naar het bedrag, ook wel de Duizend-gulden-prijs genoemd wordt. Herman de Man kreeg deze prijs eerder voor zijn roman Het wassende water. Het toeval wil dat het nieuws over de prijs bekend wordt als Coolen in Berlicum, niet ver van Den Bosch, bij Herman de Man op bezoek is. Deze actieve regelaar en ceremoniemeester organiseert meteen iets. In de woorden van Coolen: "En jawel, des avonds kwam de harmonie voor de deur om een daverende serenade te brengen. Die huldiging had ik al vroeg te pakken." ${ }^{* 9}$

Met deze prijs krijgt Coolen ook officieel de status van beroemd en veelbelovend jong schrijver. Hij is dan weliswaar al drieëndertig, maar voor die tijd van gerontocratie, waarin ministers, kamerleden en gevestigde schrijvers voor het grootste deel vijftigers en zestigers zijn, is dat tamelijk jong.

$85 \mathrm{KDC}$, inv. nr. 101, brief van Coolen aan Lutkie, 21 juli 1922.

86 Joosten, Katholieken en fascisme, 158.

87 Kuyle, Alarm, 80.

88 Zaal, De herstellers, 172.

89 'Bij Antoon Coolen. Van Nick Carter-verslinder tot romanschrijver'. 


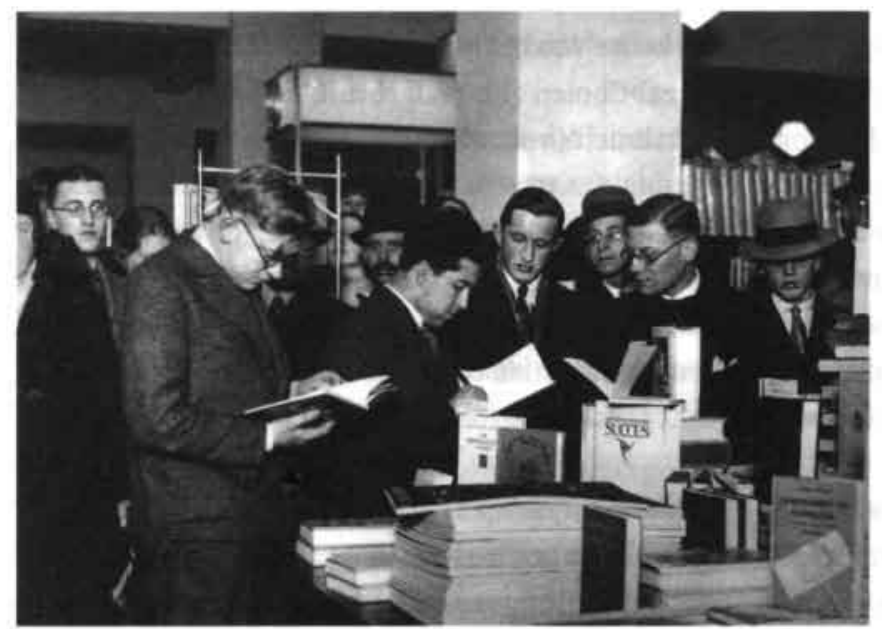

Coolen en Albert Helman signeren.

De Commissie voor Schoone Letteren, waarin onder andere K.J.L. Alberdingk Thijm (Lodewijk van Deyssel) zitting heeft, draagt uit een drietal genomineerden de roman van Coolen voor. De twee andere kandidaten zijn Albert Helman met Hart zonder land en Johan Fabricius met Maria Ferraro's ijdele liefde. In haar motivering zegt de commissie dat het boek van Coolen is opgevallen door zijn ongekunstelde en warme toon en de grote liefde voor het land waarover hij schrijft. De roman is in de eerste plaats een bewogen weergave geworden door de seizoenen heen van de Brabantse Peel en het binnenhuis van de mensen, die erbij behoren. De mensen zelf zijn in dat landschap en het binnenhuis goed gezien, maar als karakters missen zij eenheid en zijn daardoor niet overtuigend; het blijven typen. De roman wordt toch voorgedragen vanwege de niet geringe verdiensten. De Commissie spreekt de hoop uit dat de schrijver door de prijs zal worden aangemoedigd en "geen van zijn goede eigenschappen verliezende zijn liefdevolle aandacht meer en meer zal gaan wijden aan de personen, die zijn boeken de noodige stuwkracht geven. ${ }^{90}$

De Maasbode pakt flink uit. Coolen is drie dagen prominent aanwezig in de kolommen. Eerst plaatst het blad het verslag van de vergadering van de commissie van de Maatschappij der Nederlandsche Letteren, daarna een lang artikel over Het Donkere Licht" en op de derde dag een interview met Coolen. ${ }^{92}$

\section{Extra aandacht voor Coolen en Het donkere licht}

De aanmoedigingsprijs krijgt veel aandacht in de pers. De NRC is het eens met de keuze en prijst in het werk de "forsche, norsche kracht, getemperd en doorgloeid door een zacht menselijke warmte." Naast dat donkere "grondsche" is er hier en daar een "vonkeling van Bruegheliaanschen humor." Het boek wekt de verwachting dat de schrijver nog eens met een schepping zal komen "die het Brabantsche volk en landschap in zijn diepste wezen zal onthullen." ${ }^{.93}$

Anton van Duinkerken schrijft in zijn vaste rubriek in De Tijd dat hij de wordingsprocessen van Coolens romans heeft meegemaakt. Hij heeft ze door Coolen horen vertellen, voordat ze geschreven waren. Zolang Coolen werkt aan een roman lijkt het wel of zijn personages voor hem werkelijk bestaan, zó geestdriftig en levensecht vertelt hij erover. Hij ver- 
gelijkt hem met Dickens die ook van zijn personages houdt; daarom zit er bij beide schrijvers zoveel warmte en sympathie in het werk. Aan het Brabants landschap besteedt Coolen een bijzondere zorg. Het is volgens Van Duinkerken nooit clichématig en zonder "denderende niets-zeggendheden, zoo talrijk aanwezig in een gewrocht als b.v. Merijntje Gijsens jeugd door A.M. de Jong." Van Duinkerken is blij dat, na Herman de Man, nu weer een katholiek auteur is bekroond. "Het beduidt, dat het werk van Katholieke schrijvers niet langer kan worden beschouwd als een aanhangseltje bij de groote Nederlandsche letterkunde." Dat een Brabander wordt bekroond, kan hij alleen maar zien als de culturele herrijzenis van een provincie waar eens het zwaartepunt van de Nederlandse beschaving rustte.

Over de inhoud van het bekroonde boek schrijft Van Duinkerken nauwelijks. We weten echter uit de brieven dat hij er niet zo enthousiast over is. Het lijkt wel of hij wat schuld wil belijden over zijn eigen negatieve kritieken op de vroege romans, als hij vermeldt hoe hij op Coolens kamer in Hilversum inzage kreeg in de kast met oude brieven en jeugd-souvenirs, "het heiligdom van coelibatairs, dat thans onder de bewaking van liefdevolle handen, ' $n$ ordelijk aanzien verwierf en later dienst kan doen als informatie-bureau voor degenen, die Coolen's merkwaardige talent willen bestudeeren." Bij het zien van die kritieken denkt hij aan de zorg die een auteur aan zijn werk heeft besteed, "dat maanden en maanden lang moet groeien en rijpen en dan in een paar uur tijds door een vlot criticus wordt uitgelezen en gevonnist. ${ }^{\text {"94 }}$

In De Telegraaf schrijft J.W.F. Werumeus Buning dat het boek geen zeer bijzondere verschijning is. Coolens grote verdienste is dat hij het thema van stad en platteland niet wijdlopig behandelt, maar sober, krachtig en voor alles zeer simpel en menselijk. Zijn beschrijvingen van vertrek en thuiskomst van de landweerman Simon of het kopen van een Sinterklaasgeschenkje tellen maar een halve bladzijde, maar eenmaal gelezen vergeet je ze nooit meer. Coolen kent de mensen waar hij over schrijft en daardoor leeft Brabant in het boek. Om dezelfde reden mislukt zijn poging om stedelijke literatuur te maken. Werumeus Buning bedoelt hier een gekunstelde, expressionistische vorm en geeft er een voorbeeld van:

"In aanduisterenden schemer van de hooge daken van den hemel, boven een open plein naar verre vlakten van den nacht, staat een licht hoog geheven, breed, groen en rood in starre gestreepte gloeiing, als in vuur uit het zachtblauw gesneden, een leuze, een naam, een bewering, een lied. Groene en roode letters in mat vuur ver getild op een val van hoogten en een statischen storm van cubussen."

Weremeus Buning geeft "dien modieuzen statischen storm van cubussen" graag cadeau voor een paar regels over Brabant. De toekomst moet volgens hem uitmaken of Coolens volgend boek een literaire mislukking wordt of een sober, sterk verhaal van eenvoudig leven..$^{95}$

90 [Verslag vergadering commissie van de Maatschappij der Nederlandsche Letteren] in: De Maasbode, 11 juni 1930.

91 'Coolen bekroond. Het donkere licht'.

92 'Bij Antoon Coolen. Van Nick Carter-verslinder tot romanschrijver'.

93 [Recensie Het donkere licht], in: NRC, 11 juni 1930.

94 Van Duinkerken, 'Antoon Coolen. Winnaar van den Duizend-gulden-prijs'.

95 Werumeus Buning. 'Het Donkere Licht'. 
Volgens Maurits Uyldert van het Handelsblad heeft Coolen sinds hij drie jaar geleden debuteerde [sic] met zijn Brabantse vertellingen niet teleurgesteld. Soms raken de verhalen dicht bij de sensatieroman en eindigen ze met bloed en tranen in de sfeer van de 'gemengde berichten' uit de krant. Toch zit daar niet Coolens kracht; ook zonder deze sensationele zaken kan de lezer genieten. Juist het universele en elementaire in de verhalen hebben een sterke bekoring. Als voorbeeld geeft hij de manier waarop Coolen beschrijft hoe een eenzame hoeve zich voorbereidt op een lange stille groeizame zomernacht. Het is de beschrijving van een eenvoudige werkelijkheid, maar door de toon en het accent roept hij voortdurend het grote levensgeheim op dat zich achter de waarneembare verschijnselen bevindt. De recensent in deze liberale krant voelt dus het algemeen religieuze aspect in de boeken van Coolen goed aan. Hij vraagt zich wél af of deze richting voldoende ontwikkelingsmogelijkheden heeft, want de ene roman zal een herhaling van de andere worden. Coolen zal, als jong kunstenaar, tijdig de bakens moeten verzetten, want volgens Uyldert heeft de naturalistische romankunst die het gewestelijke tot onderwerp heeft, tenauwernood perspectief. ${ }^{96}$

\section{Geboorteplaats verdoezeld}

Verschillende kranten sturen interviewers op de laureaat af. Die van De Maasbode ${ }^{97}$ komt aan terwijl het hele huis in Hilversum vol vrienden zit. Coolen heeft toch tijd voor een gesprek. Vanuit Den Bosch krijgt hij bezoek van Kees Spierings. ${ }^{98}$ Zijn interview wordt geplaatst in De Telegraaf ${ }^{9}$ en daags daarna met enkele aanvullingen overgenomen door de Bossche krant. Coolen smokkelt in dit gesprek een beetje met zijn biografische gegevens. Op de vraag van Spierings of hij geboren is in de Peel, antwoordt Coolen: "Ik ben zelf in de Peel geboren en getogen en ken de menschen, hun taal, hun mentaliteit. Dat is noodzakelijk, want het is heel moeilijk om daar door te dringen in die armoede, die hardheid, die ten hemel schreiende toestanden." Hij verzwijgt zijn eerste bundeltje Opinies en zegt dat Lentebloesem zijn eersteling was. Coolen vertelt dat hij zich vanwege de concentratie liever terzijde houdt van de grote en kleine literaire milieus; hij heeft niets te maken met clubs of 'bents' en kent alleen de praktijk. Hij schrijft geheel naar de werkelijkheid. In de eerste versie van een boek schrijft hij zelfs de werkelijke namen van de personages op en ziet ze dan voor zich. Volgens Coolen praten peelwerkers normaal niet tegen een stadse meneer, maar dat doen ze wel tegen hem, omdat hij hun taal spreekt, hun levensomstandigheden kent en precies weet hoe het turfsteken in zijn werk gaat. ${ }^{100}$

De onderwijzer en latere stadsarchivaris Jac Heeren uit Helmond, die Coolen vroeger bij Ouwerling heeft ontmoet, merkt de onjuistheden over geboorteplaats en eerste boek op. Hij schrijft een kaartje aan Ouwerling en vraagt om biografische gegevens. Het resultaat is een uitgebreid ingezonden artikel in de Bossche krant, getiteld 'Legendevorming rond Antoon Coolen. Geboren Zuidlimburger'. ${ }^{101}$ Hij pakt het breed aan en begint met de zeven steden in Griekenland die beweren dat ze de geboorteplaats van Homeros zijn en de dorpen die Brueghel en Adriaen Poirters betwisten. Daarna geeft hij een complete biografische schets met verhuizingen, kostschool en al. Hij geeft als reden van het afbreken van de studie het uitbreken van "den grooten oorlog" op. Hij constateert dat de bundel Opinies blijkbaar niet meer als eersteling wordt erkend. Hij citeert uitvoerig uit de inleiding en noemt 


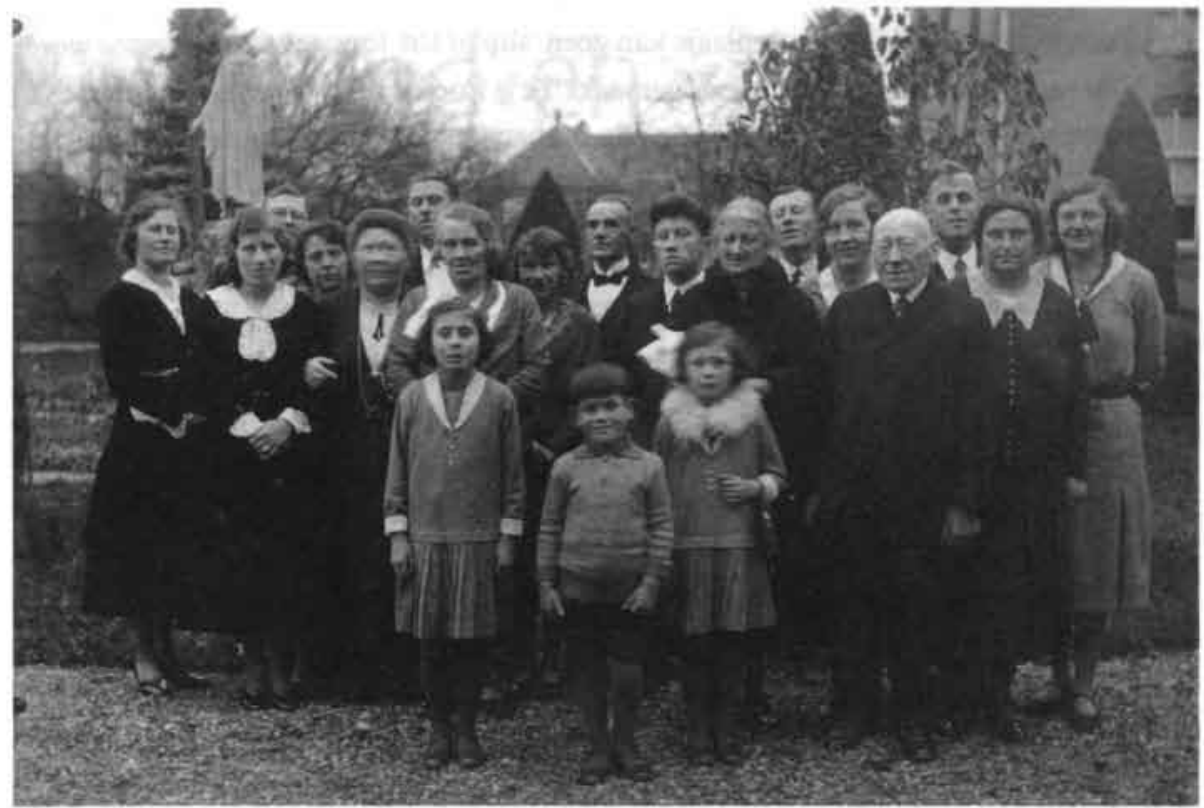

Coolen met zijn familie ter gelegenheid van een bedevaart omstreeks 1930. Van links naar rechts: in zwarte jurken met witte kragen de zussen Cato en Miet; achter Miet half zichtbaar Antoon; op de zesde plaats van links is het hoofd van broer Nard zichtbaar; links van een niet geïdentificeerde man met zwarte strik staat broer Sjef; rechts van hem staat moeder Maria Coolen-Swinkels; achter haar rechts de oudste zoon van het gezin Willem; in donker pak op de voorgrond vader Jan Coolen. Op de foto ontbreekt de jongste zoon Jan jir. (foto: collectie Hans Coolen, Son)

'La Paysanne' het aardigste stukje. Dat heeft Ouwerling hem zeer waarschijnlijk gezegd, want die was vroeger ook al enthousiast over deze schets. Heeren herinnert zich nog goed de recensie uit De Maasbode van die tijd, die "zóó sarcastisch, zóó striemend" was, dat het van moed en taaie wil van Coolen getuigde om toch door te gaan. Dit is nu bekroond met de lauwerkrans van de prijs.

Coolen kan er nu niet onderuit te reageren en legt uit dat hij inderdaad niet in Deurne of de Peel geboren is, maar dat hij wel degelijk een Brabander is omdat zijn beide ouders uit "oude Brabantsche geslachten zijn en uit de Peelstreek geboortig. Hun tijdelijk verblijf [elders] brengt mijn onvermengde en zuiver Brabantse afkomst naar ik meen allerminst in twijfel." $^{\text {102 }}$

96 Uyldert, [Ter gelegenheid van de C.W. van der Hoogt prijs].

97 'Bij Antoon Coolen, Van Nick Carter-verslinder tot romanschrijver'.

98 Kees Spierings (1898-1972) is schrijver van jeugdboeken en vertaler van toneelstukken van Henri Ghéon. $\mathrm{Hij} z \mathrm{al}$ in 1933 samen met Cor Hermus een toneelbewerking maken van Kinderen van ons volk en De schoone voleinding tot één stuk.

99 Spierings, 'Een intervieuw [sic] met Antoon Coolen'.

100 Spierings, 'Een Brabantsche Romancier'.

101 Heeren, 'Legendevorming rond Antoon Coolen'.

102 Coolen, [ingezonden brief], in: De Maasbode, 27 juni 1930 en in: PNHC, 29 juni 1930. 
De opmerking over zijn geboorteplaats kan geen 'slip of the tongue' zijn; daarvoor wordt die in te veel verschillende interviews gemaakt. Er is Coolen alles aan gelegen om zich te afficheren als een rasechte Brabander nu zijn Brabantse romans zo'n succes hebben en de volgende alweer ter perse is. Het moet een soort handelsmerk worden: Coolen staat voor Brabant en de Peel. 


\section{Bekroond en aangevallen}

\section{"Van dezen tijd wordt bar veel kwaads gezegd."}

Zomer 1930 - zomer 1932

In de zomer van 1930 kan Coolen tevreden zijn. De bekroning van zijn laatste boek, de aandacht in de pers en de vele felicitaties - waaronder een van zijn grote voorbeeld Streuvels moeten hem het gevoel geven dat hij op de goede weg is, de weg naar een zelfstandig bestaan als schrijver. Bovendien heeft hij door de publiciteit rond de C.W. van der Hoogt prijs uitgebreid de mogelijkheid gehad om zijn nieuwe boek Peelwerkers aan te kondigen, dat in het najaar zal uitkomen.

Coolen kan er echter niet goed aan wennen dat, nu hij een beroemdheid is, anderen zich met zijn verleden bezig houden. Op een klein incident rond een jeugdfoto reageert hij heel geprikkeld. De recensent van De Maasbode, Jan Nieuwenhuis, heeft Coolen geïnterviewd, waarbij ze samen een foto uit Coolens jeugd hebben bekeken. Nieuwenhuis schrijft hierover de volgende passage:

"De schrijver toonde ons een goedkope prentbriefkaart van Deurne [ ..] Op straat had zich een rijtje kinderen geposteerd, jongens en meisjes uit de buurt, zoo als zij komen toe loopen, wanneer ergens een fotograaf een opname maakt en dan liefst recht voor de lens gaan staan. 'Dat is mijn ouderlijk huis,' zegt Antoon Coolen, 'en dat ben ik.' En hij wijst een van de jongens aan. [...] Hij was toen een doodgewone jongen uit de Peel met een grappig petje op."

De onderwijzer Heeren uit Helmond, die eerder dat jaar al de geboorteplaats van Coolen gecorrigeerd had, heeft nu weer kritiek. Hij noemt de beschrijving van Nieuwenhuis "geheel onjuist en bezijden de waarheid." Hij weet dat De Tijd van plan is om in een artikel aandacht besteden aan beroemde schrijvers en hoe zij dat geworden zijn. ${ }^{2}$ Hij stuurt daarom een brief met de bewuste ansichtkaart van het Haageind aan Van Duinkerken om te laten zien dat Coolen de jongen zónder petje is. (zie afbeelding pagina 22)

Van Duinkerken heeft Coolen de brief van Heeren laten zien. Coolen wordt heel boos en ergert zich aan de 'schoolmeestersmentaliteit' van Heeren. Redacteur Van Duinkerken retourneert op verzoek van Coolen de ansichtkaart aan Heeren met de opmerking: "Wij respecteren het verlangen van de auteur, dat over zijn jeugdjaren geen ontijdige publicaties geschieden [...] met levende mensen solt men niet. ${ }^{33}$ Coolen is blij met de bondigheid van de boodschap aan die 'schoolmeester': "Ik heb de nauwkeurigheid van zijn [Nieuwenhuis, C.S.] beschrijving bewonderd en kan me de doortraptheid van een school-

I Nieuwenhuis, 'Uit 't land van de klot'.

2 [Willem Asselbergs alias Van Duinkerken], 'Het boek als geschenk'.

3 WE, kopie brief (op papier van De Tijd) Van Duinkerken aan Jac. Heeren, 25 november 1930. 
meestersmentaliteit, die zoo'n beschrijving op grond van een petje, dat ik me gráág opgezet zie, 'geheel onjuist en bezijden de waarheid' noemt, waarachtig niet meer verklaren, ondanks alles wat we van schoolmeesters gewend zijn. ${ }^{n 4} \mathrm{Hij}$ heeft geen principieel bezwaar tegen het afdrukken van de foto, maar het zou geen zin hebben omdat het "in de krant toch maar een slechte reproductie geven zou." Steeds als iemand zich voor zijn achtergrond interesseert reageert Coolen gespannen, maar deze keer zit er ook de boosheid op Heeren achter, degene die in juni de legendevorming over Coolens afkomst bekritiseerde in de krant. Hij houdt er niet van dat mensen in zijn leven neuzen.

Het najaar van r930 verloopt rustig. In september is Van Duinkerken getrouwd. Van nu af aan hebben de beide echtparen regelmatig contact. Zo logeert het jonge paar, dat in Amsterdam woont, eind oktober bij de familie Coolen in Hilversum. Coolen en zijn vrouw zijn ook regelmatig in Amsterdam. Samen bezoeken ze de grote Vincent van Gogh tentoonstelling.

\section{Serenitas}

Als de eerste recensies op Peelwerkers al zijn verschenen, maar nog voordat Van Duinkerken er in De Tijd over schrijft, uit Coolen per brief stevige kritiek op Van Duinkerken. Aanleiding is diens recensie van het boek Serenitas van Albert Helman, redacteur van De Maasbode én collega-redacteur van Van Duinkerken bij De Gemeenschap.

Om Coolens reactie te kunnen plaatsen, moeten we eerst het boek en de recensie nader beschouwen. De novelle Serenitas is een eigenaardig verhaal dat gaat over een eenzame dromer, Dorus, met een onvolgroeid geslachtsdeel. Hij wil uit medelijden trouwen met een nicht die een misstap heeft begaan en daardoor volgens haar moeder 'een afgelikte boterham' is. De nicht kiest toch voor haar vroegere verleider, na Dorus verweten te hebben dat hij soms net als een worm is die over de aarde kruipt en de andere keer zo verwaand is als God zelf. Een keer heeft Dorus zeer wellustige gedachten, die Helman in voor die tijd zeer realistische termen weergeeft: "Nu zou ik haar alle kleeren van het lijf willen rukken, en haar jagen in de sneeuw, met al haar witte vleesch en haar rose borsten bloot. Ik zou haar willen openrukken, en mijzelve in haar wroeten, tot het donker om mijn kop was en heel warm en heel bloederig." Dorus vindt toch een levensvervulling. Hij wordt een soort moeder, een voedstervader voor de kinderen van zijn vriend de schilder, die door zijn vrouw verlaten is. Omdat zijn beroep ook nog meubelmaker is, dringt een associatie met Sint Jozef zich op.

Het boek wordt in Helman's eigen krant De Maasbode, geleid door de priester Witlox, zeer negatief besproken door Jan Nieuwenhuis. Het leidde tegen Kerstmis r 930 tot ontslagname van Helman als muziekredacteur met het artikel 'Dag Maasbode, dag R.K. Kerk'. Nieuwenhuis had geschreven dat Helman mee doet aan de tendens om lichamelijke of geestelijke ziekten tot motief voor een roman te maken. ${ }^{5}$ Van Duinkerken schrijft in De Tijdeen genuanceerd artikel en verdedigt Helman tegen de beschuldiging van pornografie. Het boek is "de geschiedenis van een verminkten man, wiens kuisheid louter lichamelijke oorzaken heeft, maar hem niettemin opvoert tot een levensheiliging. ${ }^{n 6} \mathrm{Hij}$ vindt dat ook een katholiek auteur de hele werkelijkheid mag weergeven, maar zegt er wel bij dat het zijn plicht is om die werkelijkheid te bezien in het licht van de waarheid. Een katholiek 
schrijver moet ook over dingen kunnen schrijven die kinderen nog niet mogen lezen. De werkelijkheid levert de grondstof voor de literatuur, zegt Van Duinkerken.

Coolen reageert fris van de lever meteen na lezing van de kritiek in het avondblad en schrijft dat hij Van Duinkerkens gereserveerde waardering niet kan delen: "Deze Serenitas is even verschrompeld en verminkt als de mannelijkheid zelf van dezen held." Het blijft voor hem de geschiedenis van een natuurgril en hij ziet daar geen grond in voor de zelfheiliging van de hoofdpersoon en zijn offer aan de medemensen. Hij ziet geen verband tussen de stijging van de held en het fatum van zijn verminking. "Het genadeleven heeft een uitzonderingsgeval als dat eener verminkte mannelijkheid niet alleen niet noodig maar moet voor ons duizendmaal eerder geschilderd worden met als uitgangspunt het 'natuurlijke' - Helman, wiens talent 'oblige', zal dat zeker in gaan zien en dan tot ander en grootser resultaat komen."7

Het is alsof de zo vaak terecht gewezen auteur hoe dan ook een keer wil terugslaan naar zijn criticus. Want in feite gebruikt Coolen zelf ook de hele werkelijkheid als grondstof in zijn boeken en komen in zijn romans veel lichamelijk en geestelijk verminkten tot een soort van 'levensheiliging'. Het lijkt of hij Van Duinkerken met zijn eigen wapens wil aanvallen; de term 'genadeleven' klinkt in ieder geval katholieker dan we van Coolen gewend zijn. De kritiek blijft echter binnenskamers en belet Van Duinkerken niet om een week later een positieve kritiek te schrijven op Peelwerkers.

\section{Peelwerkers}

$\mathrm{Na}$ enkele voorpublicaties in onder meer De Stem verschijnt Peelwerkers eind oktober 1930. Deze roman is geen roman in de klassieke betekenis. Het boek bevat namelijk geen hoofdintrige, maar geeft een caleidoscopisch beeld van mensen in een Peeldorp. Een van de hoofdrollen is voor Vuil Leenke. Het boek opent op het moment dat ze net uit haar huis is gezet: "Het Vuil Leenke zit met de heel keet in de spoorgraaf, de kanten van de Halt uit, in de peel." Het is een venijnig 'vrouwke' met acht kinderen. "Sakkerdomme, zee Leenke, jong opfokken da kan ik!" ${ }^{8} \mathrm{Ze}$ is altijd vol levenslust en ziet steeds een aanleiding voor een feest. Haar man is een beetje een sul, die ze verwijt dat hij geld achterhoudt. Haar lievelingszoon is Frans die op de harmonika speelt; al pijp rokend zingt ze mee. Ze is het toonbeeld van het matriarchaat dat op het Brabantse platteland heerst: thuis is moeder de baas. Vuil Leenke heeft ook letterlijk "de boks" [de broek, C.S.] aan en nog wel een turkslederen.

Een andere vrouw die buiten de gemeenschap staat is Sandere Mie, de geitenvilster. In de beschrijving heeft zij iets van een heks: lang, mager, zwarte japon, pekzwart haar en holle ogen in donker gezicht. Ze draagt grote gele schoenen. Haar man is er vandoor en de dorpsroddel gist waarheen: "Niemand wist waar Sander was, misschien was hij wel in Pruisen, in den Bels of in Italië, dat wist niemand." ${ }^{\text {"9 }}$ Sandere Mie heeft ook iets van een

BA, brief Coolen aan Van Duinkerken, 26 november 1930.

Vermeulen, De Maasbode, 196-197; Schrama, Dagblad De Tijd, 302-304.

6 Van Duinkerken, 'Het boek van de week: Serenitas'.

7 BA, brief Coolen aan Van Duinkerken, 26 november 1930.

8 Coolen, Peelwerkers, 7-8.

9 Coolen, Peelwerkers, 14. 
schikgodin als ze een inhalig kasteleinsechtpaar hun gedrag verwijt: "Een tanig gele arm, bloot vanaf den elleboog, houdt ze uitgestrekt en ze wijst mee scherpen vinger, en kijkt, haar neus als een klauw over haar rond-open mond getrokken." ${ }^{\text {"10 }}$

In het kasteleinsechtpaar Nelemans is de hebzucht vertegenwoordigd. Nelemans en zijn vrouw kopen van de notoire dronkaard Piet Klep voor honderd gulden het huisje van zijn oude moeder als tegoed voor komende verteringen. Als het geld op is, pleegt Piet zelfmoord. Na de begrafenis loopt Nelemans als eigenaar inspecterend door het huisje van de oude moeder. Ze mag er voor 15 stuiver per week blijven wonen. Sandere Mie heeft meer op met 'den Akkeduut', de harmonikaspeler: "Hier, zegt ze, hier, hier! Er zijn menschen als de Nelemansen, er zijn er als gellie, en er zijn er als ik, hier hedde ge vleesch en ge betaalt me geenen cent, geenen cent."

De tweeling de Ceelemannekes, altijd twistend wie de oudste is, zorgt voor de komische noot. De Ceelemannekes wonen bij elkaar, maar ze betalen allebei hun eigen brood, hun eigen tabak en eigen bronolie [petroleum, C.S.]. Ze stoken ieder om de beurt een week de lamp en "dan mag den eene in den ander zijn licht kijken." Als ze zat zijn in het café geven ze echter alles aan elkaar weg, tot hun zakdoek toe.

De vrouw van Jan Klot krijgt elk jaar een kindje. Zij zit altijd binnen met alle ramen dicht, ook in de zomer, en dan nog ziet ze ogen door alle kieren en spleten. Haar kinderen sterven steeds in hun eerste jaar. Als een somber refrein klinkt elke winter de boodschap van de schoolkinderen: "Wij kommen alsteblief strooisel ophalen voor het kiendje van Jan Klot." Dit strooisel dient om het kinderlijkje te versieren, een mooi en zinnig ritueel, dat in de eerste helft van de twintigste eeuw in Oost-Brabant nog bestond en ongetwijfeld belangrijk was voor het rouwproces.

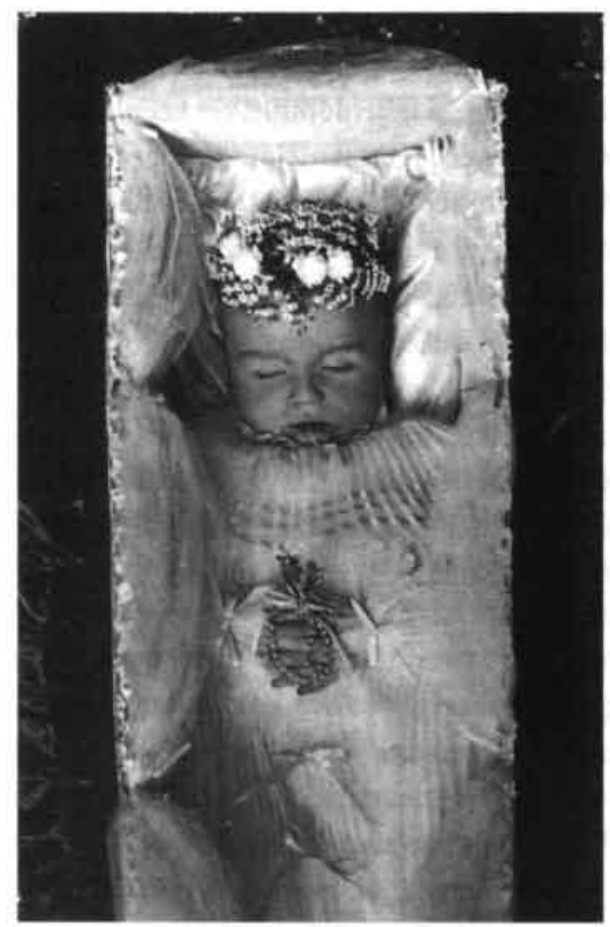

Gekroond kinderlijkje in 1897. Bron: Het licht van de negentiende eeuw, Stichting Brabants fotoarchief Eindhoven 1997, 70. 
De manier waarop Coolen de avond beschrijft dat de kinderen het dode kindje komen 'kronen' is een prachtig voorbeeld van zijn invoelingsvermogen. Om zijn indringende beschrijvingskunst te tonen, waarmee hij de ijver van de kinderen en het verdriet van de ouders schetst, wordt dit fragment hier in zijn geheel weergegeven:

"'s Avonds zitten zij bij Jan Klot in den herd, bij de goede kachel. Zij zitten bij mekaar gehurkt op den grond, op een stoof, op een bankske, en mee hun scharen knippen zij vlijtig het kleurpapier toe strooisel. De grooter durskes zitten aan de tafel, en mee schaar en breinaald en ijzeren draad maken zij fijn witte en roode rozen, en den ijzeren draad, die de steel is, wordt omwikkeld mee groen papier. Ze zitten daar druk bezig, de wimpers over de rooj wangen, de tong uit den mond onder de natte neus. Ge hoort hun gedempte praten. Ge hoort het ritselen van het papier, het vallen van de scharen op tafel, den val van een klomp, die van den voet glijdt, en het getater van de kleinsten, die bij de manden het strooisel zitten te maken. Jan Klot is er bij. Jan Klot heeft het kruis van latten gemaakt. Dat wordt omwikkeld mee palmtakken, dat wordt een breed kruis van palm, en de witte en roode rozen worden er mee den steel in vastgehecht. In den hoek neven de schouw zit moeder, neven haar op eenen stoel staat het dood kiendje voor het lage muurkastje, waarop, weerszijden van een staand kruisbeeld, de waskaarsen branden. Dat kistje, dat klein withouten kistje, dat heeft Jan Klot zelf gemaakt. O, zijn handen, die hebben dat gevormd, die hebben dat geklopt. Die hebben dat gehouden, toen ze van hun werk stil er rontelom lagen.

Als het zilverpapier is geknipt en het kroontje van blauw bloempkes is verrig, dan kommen de keinder, voor de kaarsen, voor het kruisbeeld, bij het kistje staan samengedrongen. Daar ligt het dood kiendje, het dood bloeike. Zijn blauwe oogleden liggen naar het doorzichtig wit van de wangen gesloten. En zijn handjes, de vingers mee de nagelkes liggen gevouwen, gestrengeld van porcelein onder zijn kinneke. Lientje en Netje van Joopke den Haas leggen de witte watten op het dood lijfke toe aan de platte handjes toe. Jan Klot geeft ze vervolgens het mandje zilverstrooisel aan. De durskes, mee vol gegrepen handen, kommen boven het kistje, en uit hun bewegende vingers dwarrelt het zilverstrooisel in en op en langs de watten. Het glinstert en het vonkt in den brand der kaarsen en in den schijn van de goede lamp. Dan nemen Netje en Lientje het kroontje van blauwe rozen uit Jan Klot zijn handen en zetten het op het hoofd van het dood kiendje. Mee open mond en de schoone vrees in de zielkes staan de keinder toe te zien. Het is een engelke dat daar ligt. Een neergevlogen engelke van Onze Lieven Heer zelf, tot Wien het in zijn zielke is weergekeerd, hier ligt het, om begraven te worden. Hier ligt het in wit en zilver en mee bloemen gekroond, mee den schoonen vrede van zijn gesloten oogen en gevouwen knuistjes. Hier ligt het onder de starende oogen van vaders en onder de bewondering van de stille keinder, die hun adem inhouden. Moeder, voor de keinder, is van haar stoel overeind gekomen, ze staat daar donker en stil. Zoo schoon heeft ze haar kiendje niet gezien, dat het zoo schoon is dat is haar zwaar verlies, het is zoo schoon om zijnen dood, daar heeft moeder in het gekropte hart en in 
haar dichte keel het zeer en het ongemak af, het ongemak, daar wringt en nijpt de vrouw de handen van voor haren schoot. Zoo ligt het kiendje, het zielke is door het gesloten venster weggevlogen, achter het zilver en de bloemen ligt den kerkhof mee zijn kruisen en graven gespreid. Zoo ligt het lijkje onder moeders genepen donkere oogen."12

De vrouw van Jan Klot is een eigenaardige, een "aorige", maar met de vrouw van Manders is het nog ernstiger gesteld. Zij heeft kuren dat ze de huisraad kapot gooit en haar kinderen bedreigt met een "slichtmes" en een broodmes. Zeer beklemmend is de manier waarop Coolen zo'n aanval van krankzinnige razernij, gezien door de ogen van de kinderen, beschrijft. Later wordt ze opgenomen in "Vucht". ${ }^{13}$ De kinderen houden met vader een bedevaart naar het naburige Ommel bij Vlierden. De beschrijving van dit dagje uit met de mengeling van kermis met kramen tegen de kerkmuren, de knikengel en de lange weg terug met onderweg pootjebaden in de Aa, vormt een contrast met de toestand van moeder.

De gebeurtenissen in Peelwerkers worden tegen de achtergrond van de wisselende seizoenen beschreven en het lijkt of de "eeuwige wederkeer" van de jaargetijden zich ook herhaalt bij de mensen. Een dochtertje van de krankzinnige Dien vertoont ook al vreemd gedrag, het zoveelste kindje van Jan Klot gaat dood, de dochter van Vuil Leenke wordt al net als haar moeder. De man van Sandere Mie komt na twaalf jaar terug en gaat weer in de Peel werken. Hij neemt zijn tuig, "de stikker, de slichter, de bonkschup en den oplegger," loopt langs de spoordijk en de zoemende palen de Peel in en gaat aan het werk.

Uit alles blijkt dat Coolen in zijn interviews van de afgelopen zomer eigenlijk meer over Peelwerkers dan over het bekroonde boek Het donkere licht heeft gesproken. Hij is met zijn gedachten al niet meer bij de stad en de fabrieken, maar bij de mensen in de Peel.

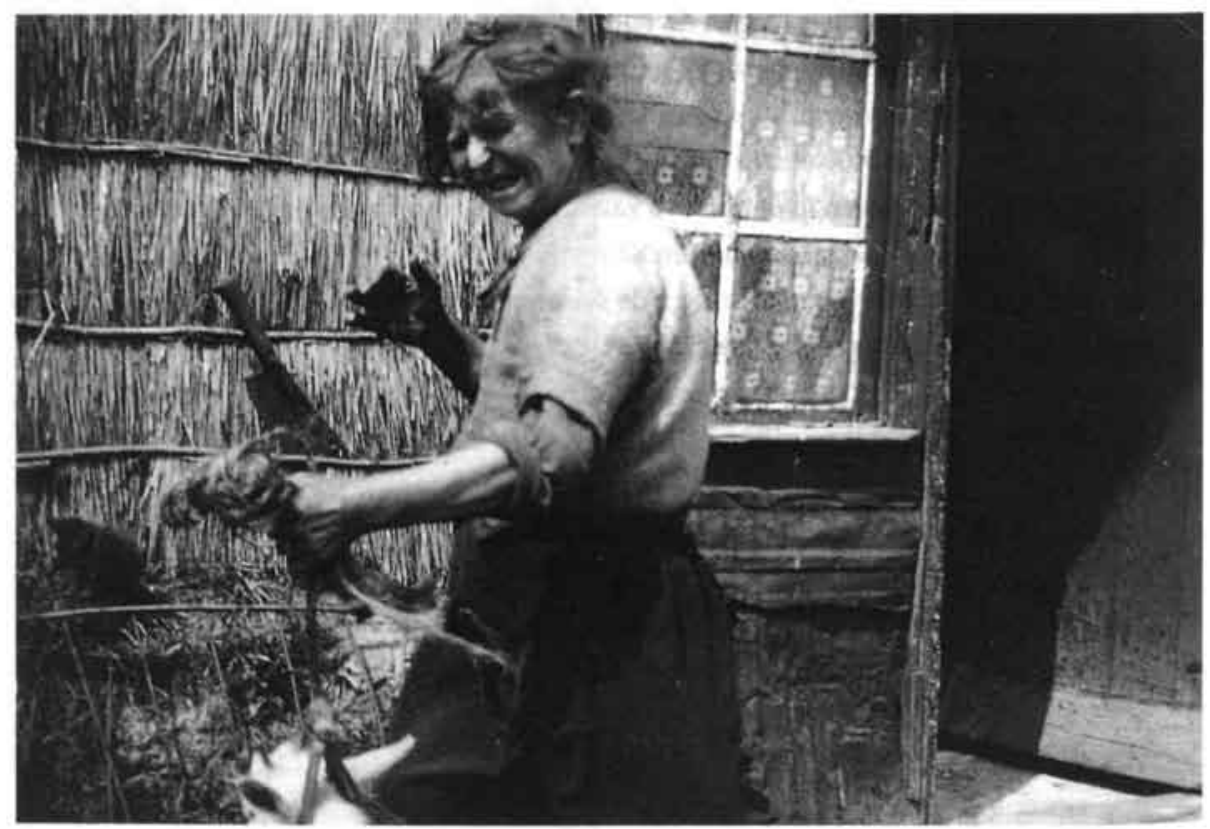

Model voor 'Vuil Leenke' 
De personages uit Peelwerkers zijn op bestaande personen uit Deurne en omgeving gebaseerd. Het verhaal gaat dat Grard Stientje en zijn broers Coolen kort na het verschijnen van het boek met hun biljartkeu hebben opgewacht, omdat hun moeder als Vuil Leenke negatief was geportretteerd. ${ }^{14}$ Een van de interviewers merkte op dat er in de Hilversumse kamer van Coolen een afbeelding van de Lieve Vrouw van Ommel hing. Later schrijft Coolen nog een flaptekst voor een bronnenpublicatie over dit eeuwenoude pelgrimsoord. Hij herinnert zich uit zijn jongenstijd de processies naar Ommel in mei - de "meise voetprocessie" - over de warme stoffige grintweg en de huifkarren "met de biddende boerengezinnen op de biezenstoelen onder het linnen van de spanrepen [...] En in Ommel de breedgedaakte hoeven, de linden met hun honinggeur, de planken op schragen met banken weerszij vóór de herberg, de kramen met het bazaarspeelgoed, snoep, paternosters en de papieren vaantjes van Ommel."15

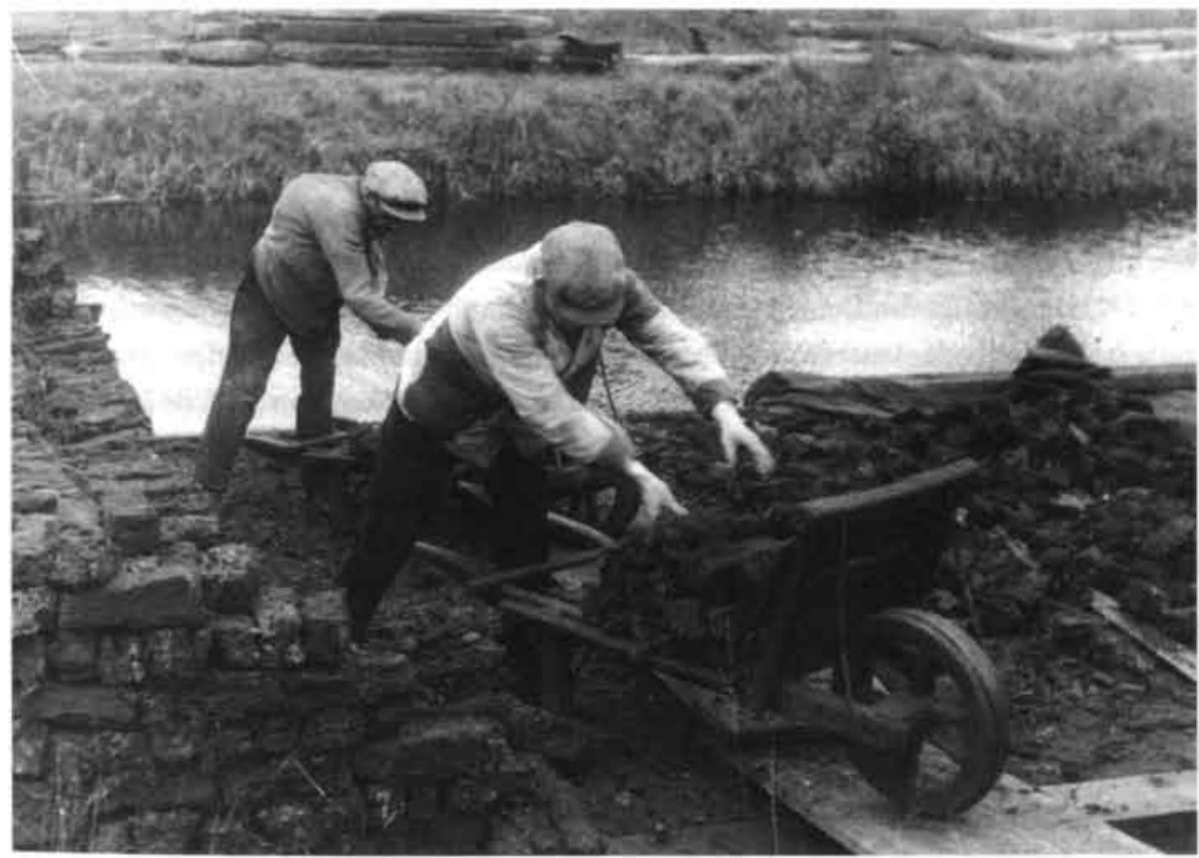

Coolen weet inderdaad precies hoe het turfsteken in zijn werk ging:

"Mee de schup steekt hij eerst de rauwigheid weg, daar komt de klot meteen zwartbruin onder bloot. Toon gooit die plakaten rauwigheid mee de schup achter hem neer in de vochtige diepte. Zoo maakt hij de breedte van zijn veldje over eenen stronk verrig. Dan vat hij zijnen stikker en steekt den klot op maat in de lengte en vervolgens aan

12 Coolen, Peelwerkers, 62-64.

B De psychiatrische inrichting 'Voorburg' in Vught.

14 Monté, 'Antoon Coolen.' 97. Monté vermeldt geen bron bij dit verhaal.

15 De Jong, Onze Lieve Vrouw van Ommel. Op het stofomslag staat aan de binnen-voorkant een artikel van Coolen en aan de binnenkant van de achterzijde een stuk van de pastoor, die J. Vogels (I) heet; dat laatste artikel is gedateerd I juli 1961. 
den achterkant in de breedte, vervolgens licht hij mee den oplegger, klot voor klot eraf en zet elken klot op den smallen kant achter zich neer op de rauwigheid, die hij daar heeft uitgestrooid. Zoo steekt hij. Hij steekt verscheiden klemmen diep. Zoo graaft hij zijn eigen de diepte in. ${ }^{16}$

\section{Gunstige kritieken}

P.H. Ritter jr. noemt het boek groot door zijn eenvoud. Coolens "doordringingsvermogen" leidt tot beschrijvingen die volmaakte kunstwerken zijn. Hij geeft als voorbeeld een lang citaat van de scène van de kinderen die bang zijn voor hun krankzinnige moeder. Ritter vindt het decor van de seizoenen, de natuur, het werk en de feesten volmaakt en acht het bijna ongelooflijk dat zo' $n$ in zijn eenvoud diepzinnig natuurboek werd geschreven "in onzen tijd." Antoon Coolen is volgens hem de literaire evenknie van Vincent van Gogh."

Jan Nieuwenhuis, hiervoor al genoemd in verband met de jeugdfoto in Deurne, constateert in De Maasbode dat Coolen het auteursidioom steeds meer als een volmaakt instrument hanteert. In Het donkere licht waren de overgangen van de gedachten van de schrijver naar die van zijn "sujetten" nog wel eens kunstmatig en onverantwoord, maar nu verlopen ze veel lichter en natuurlijker. "Toch blijft het voor ons gevoelen een riskante onderneming een subtiele schrijversvisie b.v. op de natuur, te verwoorden in een taal en met accenten ontleend aan een dialect van menschen, die aldùs niet zien en niet voelen." [cursivering van [.N.] Het getuigt van Coolens kunstenaarschap dat hij deze gevaren overwint. Coolen onderschat wel de waarde van een goede en weldoordachte intrige. Dat vindt Nieuwenhuis een gemis. Hij denkt dat daarom sommige boeken van A.M. de Jong populairder zijn bij de lezers dan die van Coolen, al is de laatste "verre superieur." De criticus is van mening dat een sterke intrige het werk van Coolen ook literair op een nog hoger plan brengt. Het zou kunnen dat dan de auteur wordt meegesleept en zichzelf in botsing met de karakters brengt, "tot die spanning van de verhoudingen, die diepten van zielsgebeuren, die felheid en bewogenheid van zien, kortom tot die steeds verdere ontwikkeling en ontplooiing van zijn groot talent, waarop we mogen hopen." ${ }^{\text {18 }}$

Ook Van Duinkerken begint zijn kritiek in De Tijd met een opmerking over het gemis van een intrige. Hij vindt dat men om die reden het boek geen roman kan noemen, zelfs niet in de ruime zin waarin dat begrip in die tijd gebruikt wordt. Hij vergelijkt de compositie van het boek met een goede "documentairen" film, waarbij ook het totaalbeeld van het algemene leven ontstaat uit talrijke, sprekende detailbeelden. Hij is het eens met "onze collega van De Maasbode" dat het grote publiek graag een 'verhaaltje' wil, al hebben de taferelen op zich een zuivere sfeer en suggestieve kracht. Hij wijst op een aspect dat andere critici niet hebben opgemerkt: het boek is niet in de eerste plaats een schildering van de Peel, maar van de dood. Coolen heeft op een zeer opmerkelijke manier de atmosfeer van het sterfgeval opgevangen. Hij vertelt niets van het sterven zelf of van de laatste gedachte van de overledenen, maar beschrijft uitgebreid het lijk en de bemoeiingen daar rondom: het kronen van de kinderlijkjes, het waken bij de zelfmoordenaar en het gedoe rond het al of niet begraven in gewijde grond. ${ }^{19}$

Van Duinkerken kan het niet laten even zijn stokpaardje te berijden: de rol van het lot en het fatalisme in Coolens werk. Hij memoreert zijn bespreking van Het donkere licht, waarin de keer van de seizoenen in verband met het menselijk lot "voor het godsdienstig 
katholieke gevoel" een al te fatalistisch verloop aan zijn verhalen geeft. Nu staat daar in Peelwerkers tegenover dat Coolen de kracht van de berusting doet voelen. "Deze berusting verhoogt eenerzijds de tragiek, doch geeft haar ook een hoogere wijding, doordat zij de menschen verheft boven hun eigen machteloosheid naar het gevoelig hart van God. Dit boek is tragisch zonder wanhoop."

$\mathrm{Na}$ het boek aldus ingelijfd te hebben bij de katholieke literatuur moet Van Duinkerken nog afstand nemen van zijn bête noire, de schrijver A.M. de Jong, wiens roman De Martelgang van Kromme Lindert juist verschenen is. Hij noemt zijn naam niet, maar het is heel duidelijk wie er bedoeld wordt als hij schrijft dat Peelwerkers geen "tendenz-roman" is: "Daardoor is zijn [Coolens, C.S.] boek vrij van die tendenzieuze opdringerigheid, welke men soms aantreft in als specifiek-Brabantsch aangediende reportages over het leven van zielige dorps-stumpers, die slachtoffer worden van allerlei aangedikte wantoestanden." 20 Het zal nooit goed komen tussen de twee West-Brabanders. ${ }^{21}$

In zijn biografische schets van Coolen zal Van Duinkerken deze kritiek grotendeels opnemen en eraan toevoegen dat het in dit kader niet interessant is weer te geven hoe het afloopt met de verschillende personages. Uit de veelheid ontstaat "een dwingend totaalbeeld, dat den lezer wellicht levenslang zal bijblijven, ook nog, wanneer hij alle namen, alle feiten uit het boek vergeten zal zijn. Dit fresco-achtige verhaal is onder Coolens geschriften wel bij uitstek het epos van de Peel."22

Coolen is ingenomen met het "prachtig hartelijk stuk" van Van Duinkerken in De Tijd: "ge weet dat ik om die waardering blij ben!" Hij komt ook nog even terug op zijn kritiek op Van Duinkerkens bespreking van Serenitas: "Las je in De Nieuwe Eeuw hoe Marsman mijn oordeel over Serenitas in zijn scherpe critiek feitelijk bevestigde?"23

Naar buiten toe heeft Coolen echter niets dan lof voor Van Duinkerken, zoals hij kort daarvoor heeft verwoord voor de radio. Sinds juni r 930 heeft Van Duinkerken een vaste boekenrubriek voor de KRO-radio. Hij spreekt niet altijd zelf, maar geeft ook veel opdrachten aan bevriende schrijvers, zeker wanneer het om een werk van hemzelf gaat. Coolen heeft de dichtbundel Lyrisch Labyrinth ${ }^{24}$ die nogal negatief door de kritiek ontvangen is, lovend voor de radio besproken. Van Duinkerken heeft dat wegens een ongesteldheid niet kunnen horen, maar Coolen verzekert hem dat hij op zijn tocht door "den lyrischen Doolhof" de loftrompet gestoken heeft. "Ik heb mijn best gedaan om de mooie verzen uit het prachtige labyrinth goed en duidelijk voor te lezen en alles zooveel mogelijk ingesteld

Coolen, Peelwerkers, 26.

17 Ritter, 'Letterkundige Kroniek [Recensie Pee/werkers].

18 Nieuwenhuis, 'Uit ' $t$ land van klot'.

19 Dit laatste heeft te maken met de regel dat iemand die in staat van doodzonde verkeert volgens de R.K. Kerk niet begraven mocht worden in de gewijde grond van het officiele kerkhof. Vaak werd dit toch gedaan omdat men er rekening mee hield dat de zelfmoordenaar tussen zijn daad en het sterven nog berouw kan hebben gehad.

20 Van Duinkerken, 'Peelwerkers'.

21 Polman, De keerzijde van het leven, 95.

22 Van Duinkerken, Antoon Coolen, 49.

23 BA, brief Coolen aan Van Duinkerken, 8 december 1930.

24 Verschenen op Van Duinkerkens trouwdag, 9 september 1930. 
op het zeer gemengde gehoor dat men voor de microfoon voor zich heeft."25

Van Duinkerken geeft wel een heel bijzondere tegenprestatie als hij enkele maanden later in de Haagse Bijenkorf Coolens boek Kinderen van ons volk aanprijst en verkoopt. ${ }^{26}$

\section{Vader}

In januari r931 verwachten Coolen en zijn vrouw hun eerste kind. Van Duinkerken, die geen getuige bij hun huwelijk kon zijn, maakt het nu goed door toe te zeggen samen met zijn vrouw Nini peter en meter te worden. Coolen is er erg blij mee dat zij peetouders willen zijn "van onzen Aurelius Augustinus," schrijft hij al in december. Hij is er kennelijk heel zeker van dat het een jongen wordt. Aan de schilder en dokter Wiegersma uit Deurne, die inmiddels een grote faam geniet, wordt gevraagd het geboorteprentje te tekenen. Eind december schrijft Coolen hem. Na hem geprezen te hebben voor zijn werk en het verzoek om eens in zijn atelier te mogen kijken als hij weer in Deurne is, vervolgt hij: "Nog iets. In Februari komt onze eersteling. Dunkt $\mathrm{Ge}$, dat Ge tijd zoudt kunnen vinden voor een teekeningetje voor het geboortebericht. Daar zoudt Ge mijn vrouw en mij buitengewoon blij mee maken. Als Ge er tijd voor zoudt kunnen vinden, dan stuur ik de tekst ervoor. ${ }^{\text {27 }}$ Het is er niet van gekomen. Wiegersma makt een moeilijk jaar door vanwege een conflict met de Limburgse kunstenaar Joep Nicolas. Zijn hoofd staat er niet naar. "Mijn ziel is zwart," schrijft hij aan Coolen. ${ }^{28}$

Het is de vraag of de naam die Coolens eerste kind ontvangt wel in de eerste plaats naar de kerkvader verwijst. Nog voor de geboorte meldt hij aan zijn geestelijke vader Stijn Streuvels, nu wat voorzichtiger over het geslacht, dat "als het een jongen wordt," deze naar de kerkvader Augustinus wordt vernoemd en dat de roepnaam Stijn zal zijn. ${ }^{29}$ Streuvels stuurt al voor de geboorte een mooie uitgave van Kerstwake - "een vertelsel uit het jaar nul" - als geschenk. Op 15 februari $193 \mathrm{I}$ is het zover:

"Hij werd verwacht in het vijftienhonderdste gedenkjaar van St. Aurelius Augustinus, dit gaf hem zijn plechtigen doopnaam vooruit: Aurelius Augustinus. De groote oom van 't Lijsternest in Ingoyghem [Stijn Streuvels, C.S.], die hem na zijn geboorte reeds de vertelsels van het jaar nul wilde vertellen ${ }^{30}$ gaf hem den vereenvoudigden naam, waarmee wij hem aanspreken: Stijn. Hij werd op den vroolijken vastenavond van 1931 geboren en ' $t$ winterde nog, toen zijn vader de straat op ging, om aan den eerste den beste, die wilde luisteren te vertellen: ik heb een zoon!"31

Coolen is dan al bezig aan zijn volgende roman De goede moordenaar. Het is bepaald geen kinderverhaal, maar toch wordt zijn werk door het hebben van een kind beïnvloed:

"Gij moet het toelaten, dat zij uw pen komen besturen, en voor uw werktafel blinkt het heldere licht van hun oogen. Pietje Pinksteren moest vermoord worden, ik hijgde van angst, omdat ik gedwongen met mijn oogen op het mes van de moordenaar lag. Ik had op mijn manier bij De goede moordenaar het gevoel een gruwelijk boek te schrijven, maar het licht drong er zichzelf doorheen, iets komt de angsten van den moordenaar, de sombere vereenzaming van den kluizenaar en de vertwijfeling van Hanneke den Haan met helderheid doorbreken en het verdriet der aarde verklaren en oplossen in een altijd zuiveren toon: het kind." 32

Ook al vóór zijn vaderschap heeft Coolen er blijk van gegeven zich te kunnen inleven in de 
gevoelens van ouders voor hun kinderen. Een mooi voorbeeld daarvan is al genoemd: de vader van Marieke uit Het donkere licht, die met geleend geld op Sinterklaasavond uren loopt om een pop en een gouden griffel te kopen. Het gaat hem echter ook goed af vanuit het perspectief van het kind te vertellen. Huiveringwekkend is zijn beschrijving van de angst van de kinderen van de psychotische Dien uit Peelwerkers en de argeloosheid van het jongste kind, dat als enige de moeder kan kalmeren als ze weer met een slichtmes staat te zwaaien. Beide boeken zijn vóór de geboorte van Stijn geschreven. Later zal in De schoone voleinding de jongste zoon van Doruske Timmer, Peterke, het apostelke Petrus, de speciale aandacht van zijn vader genieten. Doruske brengt hem op zijn schouders naar de zolder als hij naar bed moet. "In Peterke, den jongste van Doruske Timmer, heb ik Stijntje gegroeid gezien," schrijft Coolen later.

Hoezeer hij gesteld is op zijn kinderen blijkt uit het feit dat hij van nu a an in zijn correspondentie zeer vaak passages over het wel en wee van zijn kinderen opneemt. Zijn zonen herinneren zich later de spannende manier waarop hij verhalen en sprookjes vertelde. Door de drukte rond zoon Stijn is hij voor zijn schrijverswerk het huis uit gevlucht. "We moeten een borrel drinken in de prachtige werkhut, die ik achter in onzen tuin heb laten bouwen," 33 laat hij Van Duinkerken weten. Deze eenvoudige hut met een deur, twee openslaande ramen en een werkblad, zal later steeds mee verhuizen, eerst naar De Romeijn in Deurne en daarna naar De Kempen in Waalre.

De werklust van Coolen in deze jaren is enorm en neemt alleen maar toe. Zijn werk als journalist voor De Gooische Post gaat gewoon door, terwijl hij nu jaarlijks een roman produceert. Hij beweegt zich echter niet of nauwelijks in literaire kringen. Als in januari 1931 de grote polemiek ontbrandt over Prisma, de bloemlezing van Nederlandse poëzie na rgr 8 van Binnendijk, een polemiek die de geschiedenis in zal gaan als de discussie over 'vorm of vent', bemoeit hij zich daar niet openlijk mee. Wanneer echter een bundel van jonge schrijvers uit Noord en Zuid verschijnt, ergert hij zich aan het gecomprimeerde, gespannen, koele proza. "Over al dat kleinwerk wordt drukte gemaakt, tien geslaagde zinnen geven aanleiding tot doorwerkte essays. [...] Gij weet zelf hoe die van een hooghartigheid zijn en van een toegespitste critiek, die het provinciale realisme smaadt!" schrijft hij aan Streuvels. ${ }^{34}$ Stond er maar een verhaal als Kerstwake in, verzucht hij. Hieraan is ten onrechte door de Nederlandse kritiek nauwelijks aandacht besteed. Hij zou de toekomst van de

BA, brief Coolen aan Van Duinkerken, 8 december 1930.

Een experiment van de Bijenkorf in februari 1931 om schrijvers eigen werk te laten verkopen. Eigenlijk moet een dichter zich niet met de materiële kant bemoeien, vond Van Duinkerken, daarom koos hij er voor om het werk van een collega-schrijver aan te prijzen. Van der Plas, Daorom, mijnheer, 160.

27 Archief P. Wiegersma, brief Coolen aan Wiegersma, 30 december 1930.

28 FPC, brief Wiegersma aan Coolen, januari 1930.

Streuvels zal in december 1931 bij de familie Coolen op bezoek komen.

Coolen, Stijntie, 12.

Coolen, Stijntje, 11.

BA, brief Coolen aan van Duinkerken, 8 mei 1931.

AMVC, inv. nr. C 3475, brief Coolen aan Streuvels, 14 januari 1931. 
literatuur somber inzien, als "ik niet het onverwoestbare geloof had dat een volgend geslacht ten onzent de ontzaggelijke vergissingen en ontsporingen van deze jonge schrijversgeneratie zal inzien en herstellen."

De 33-jarige Coolen rekent zich in ieder geval niet tot deze jonge schrijversgeneratie. Hij heeft meer affiniteit met zijn voorbeeld Streuvels, geboren in 1871, maar ook met de tien jaar oudere Dirk Coster. Coolen is bij het tienjarig jubileum van De Stem geweest, het blad waarin hoofdredacteur Coster opgeroepen heeft om in verzet te komen tegen de vergissingen van de avant-garde. Coster zal het mikpunt van spot worden van de groep rond Forum, het nieuwe blad van de 'jonge schrijversgeneratie'. E. du Perron schrijft het sarcastische Uren met Dirk Coster. Ook Coolen zal kritiek uit de kring van Forum krijgen in het zogenoemde regionalismedebat.

Coolen wordt als bekend schrijver steeds meer gevraagd voor spreekbeurten in zalen of voor de radio. Hij spreekt dan over zijn eigen werk en leest er uit voor of bespreekt boeken van anderen. Aan het meer algemene debat over literatuur en de verschillende stromingen doet hij niet mee.

Bij die radiolezingen blijkt hoe miezerig en kleinzielig de verzuilde omroep is. Als hij op verzoek van Van Duinkerken voor de KRO radio een lezing zal houden over het nieuwe boek van Aart van der Leeuw, De Kleine Rudolf, verzoekt de leiding van de omroep hem schriftelijk te bevestigen dat hij zal vermelden dat Van der Leeuw vroeger werken geschreven heeft die niet door de beugel konden. Hij antwoordt daarop dat hij dat zal doen áls hij daar aanleiding voor ziet, maar dat hij vrij wil zijn in zijn formulering van dat eventuele voorbehoud. Hij vraagt aan Van Duinkerken of hij wil informeren of het na dit antwoord nog wel doorgaat. ${ }^{35}$ Coolen voelt verwantschap met Aart van der Leeuw, die ook steeds op zoek is naar de verbinding van het menselijke met het eeuwige. In een interview uit 1925 met 's-Gravesande zegt Van der Leeuw dat zijn uitgangspunt de liefde en de eerbied voor het leven is, maar dat hij zich bewust is van het oneindige. Hij ervaart dat er voor hem steeds een huwelijk van het ding en de onbegrensdheid moet zijn. "Liefde voor het ding alléén zou mij tot naturalisme voeren, en daarheen gaat mijn richting niet; liefde voor de oneindigheid alléén zou mij het aardse doen verzaken, en dat wil ik evenmin." ${ }^{36}$ Dezelfde worsteling is in het werk van Coolen merkbaar.

De hele zomer is Coolen druk met de afwerking van De goede moordenaar, maar daarnaast is er nog tijd voor contact met het echtpaar Van Duinkerken. In augustus wordt ook bij de Van Duinkerkens het eerste kind, Louise, geboren. Bij bezoeken gaat Stijn in de reiswieg mee van Hilversum naar Amsterdam. De technische kant van deze afspraken wordt door de jonge moeders geregeld. Eigenaardig, maar wel typisch voor die tijd, is het briefpapier van Coolens echtgenote Gerda met de opdruk "mevrouw Antoon Coolen-de Jong".

Coolen feliciteert in november Van Duinkerken met diens artikelen in $D e$ Gemeenschap. Van Duinkerken is nu echt het intellectuele geweten van katholiek Nederland geworden. Het artikel dat Coolen bedoelt, is 'De onherkenbare priester' in het septembernummer. Hierin signaleert Van Duinkerken dat de vele priesters die actief zijn in openbare functies, besturen en bij de media, er niet genoeg voor uitkomen dat ze priester zijn. Zo verschijnt pater Hyacinth Hermans van De Maasbode, die in de rubriek 'Hagel' van De Gemeenschap wel wordt aangeduid als de pater met de tulpenbollennaam, 
nooit in zijn Dominicaner habijt op een openbare bijeenkomst en manifesteert de priester Nolens zich voornamelijk als politicus.

Het 'Rijke Roomsche leven' heeft een grote aantrekkingskracht op letterkundigen en journalisten. De dichters A.J.D. van Oosten (1898-1969), Chris de Graaff (1890-1955) en Jan H. Eekhout (r9oo-1978) bekeren zich tot het katholiek geloof. Voor de eerste treedt Van Duinkerken als peter op. De twee laatste zullen zich in de oorlog opnieuw bekeren, maar dan tot de 'nieuwe orde' van de bezetter.

\section{Streuvels op bezoek}

Als in juni I93 I Streuvels' nieuwe boek Alma met de vlassen haren uitkomt, stuurt hij het meteen naar zijn twee Nederlandse 'leerlingen': Herman de Man en Antoon Coolen. Herman de Man leest het in een keer uit en bespreekt het voor de AVRO radio op zondag 6 september. ${ }^{37}$ Coolen vergelijkt het boek met het Genoveva-verhaal, kondigt aan het op 2 augustus te bespreken voor de KRO radio en informeert voorzichtig of er wel een radio op het Lijsternest is. ${ }^{38}$ De uitzending wordt echter steeds uitgesteld en vindt uiteindelijk plaats op zondag 29 november, als Streuvels in Nederland is. In de uitzending zegt Coolen, "dat het beantwoordde aan een langgedragen droom van de schrijver, namelijk het verlangen om het zieleleven uit te beelden van een mens, in wie de kinderlijke ongereptheid bewaard bleef." ${ }^{39}$

Het is vooral Herman de Man die erop aangedrongen heeft dat de beroemde Vlaming eens bij hem in Berlicum op bezoek moet komen. Hij heeft gehoord dat Streuvels in september in Amsterdam is geweest, onder andere om de nog steeds lopende Van Gogh tentoonstelling te bezoeken. De Man voelt zich een beetje gegriefd dat hij niet langs gekomen is, zo blijkt uit een brief: "We wonen vlak bij Den Bosch en 't is, van Amsterdam naar Antwerpen, maar een hortje om. ${ }^{\mathbf{4 0}}$ Het bezoek gaat uiteindelijk door. Streuvels brengt enige dagen door bij De Man in Berlicum, maar gaat eind november 1931, samen met zijn dochter Paula, ook naar de familie Coolen in Hilversum. In zijn bedankbriefje schrijft Coolen dat hij tijdens het bezoek weer de ${ }_{3} 3$-jarige bewonderaar was, die niet kon slapen van de verhalen uit de bloemlezing van Aleida Bijland: "Iets van het kind blijft in ons." Stijntje heeft een mooie geillustreerde uitgave van Prutske gekregen en Streuvels heeft zich bewonderend over de zoon uitgelaten: "Awel, gij zijt een welgezind kind in uwe kevie mijn manneke!" ${ }^{42}$ Dan komt Coolen met een confidentie. Ze durfden het eerst niet te vragen, maar ze zouden graag hebben dat Streuvels en zijn vrouw peter en meter van hun tweede kindje willen zijn. Ze hopen op een meisje dat zal gaan heten Alexandrine Paula [de naam van het Weens kiendje Xandrieneke, C.S.]. Als het een jongen wordt, krijgt hij de

BA, brief Coolen aan van Duinkerken, 8 mei 1931.

36 's-Gravesande, Sprekende schrijvers, 10.

37 Vaarties, $U$ hebt mij de weg gewezen, 37.

38 AMVC, inv. nr. C 3475 brief van Coolen aan Streuvels, 25 juli 1931.

39 Van Duinkerken, Verzamelde Geschriften III, 891.

40 Brief De Man aan Streuvels 7 oktober 1931, geciteerd in: Vaartjes, 4 hebt mij de weg gewezen, 38.

41 AMVC, inv. nr. C 3475, brief Coolen aan Streuvels, 8 december 1931.

42 Coolen, Uit het kleine rijk, 56. Kevie betekent: bed met spijlen, kooi. 
naam Guido. ${ }^{45} \mathrm{Hij}$ krijgt een negatief antwoord op dit verzoek; Streuvels vindt de afstand een bezwaar. Coolen dringt niet meer aan.

In die tijd schrijft Coolen zijn jaarlijkse kerstverhaal, dit keer 'De spreuk het goede paard'. Het verhaal gaat over een echtpaar dat geen kinderen kan krijgen en door ruzies niet meer met elkaar spreekt. Op een gegeven moment laat de boer het paard in de keuken mee-eten. De onmogelijkheid tot communiceren en de wanhoop die daaruit voortkomt, is een geliefd thema van Coolen. Op een gegeven moment laat hij de vrouw uitroepen: "Wat we mekaar aan doen!" Na een bedevaart naar Ommel raakt de vrouw in verwachting. Het kind wordt met Kerstmis geboren.

\section{De goede moordenaar}

Begin november $193 \mathrm{I}^{44}$ verschijnt De goede moordenaar, een roman die is "toegewijd aan de groote en schoone nagedachtenis aan Jeroen Bosch." Deze opdracht is niet zo maar gekozen, want Coolen heeft het plan een biografie over Jeroen Bosch te schrijven: "Ik hoop van ganscher harte nog eens een levensverhaal te schrijven over den vijftiend'eeuwschen schilder Jeroen Bosch," schrijft hij kort daarna in het boekenweekgeschenk. ${ }^{45}$ Ook later, in 1934 . bestaat dat plan nog, "maar de verschijning kan nog wel twee jaar duren."46

De goede moordenaar bevat veel verwijzingen naar de bizarre en gruwelijke taferelen die Jeroen Bosch geschilderd of getekend heeft. Na de idyllische schildering van een Brabants dorp in Kinderen van ons volk, waar - ondanks de moord die erin gepleegd wordt - een zekere gemoedelijkheid heerste en na de invloeden van oorlog, industrialisering en sociale veranderingen in Het donkere licht en in Peelwerkers staat nu de onpeilbare diepte van de menselijke geest, de instinctieve oerdrift centraal. De gruwelijke gebeurtenissen in deze roman worden nauwgezet beschreven, maar altijd op zo'n manier alsof de daders zelf ook toeschouwer zijn. Het overkomt hen. "De menschen doen goed en kwaad, er zijn er die hebben een duistere vreemdigheid alsof ze van den duivel bezeten zijn," ${ }^{4 /}$ luidt de onheilspellende zin op de tweede bladzijde van de roman. Daarvoor introduceert de verteller de hoofdfiguren: Nol Bonk de voerman met zijn simpel vrouwke, Pietje Pinksteren die vermoord zal worden en de drankzuchtige bakker Fons van Willemiene met wie het lelijk af zal lopen. Ook maakt de lezer kennis met een kluizenaar die iets buiten het dorp zijn huis aan het bouwen is.

Nol Bonk wordt bij een diefstal betrapt door Pietje Pinksteren, waarna de laatste door Bonk vermoord wordt. Na de beschrijving van de moord en de arrestatie van Nol Bonk gaat het leven in het dorp door. De vrouw van Nol Bonk, Hanneke, die een beetje simpel is, "ze had een vreemdigheid in den aard," blijft niet alleen als Nol in Leeuwarden gevangen zit. Graart den Beer aast op het paard van den Bonk, maar maakt ook misbruik van Hanneke.

De kluizenaar vervult een heel speciale rol in de roman. Hij vertegenwoordigt het instinctmatig goede en harmonische. De zwangere vrouw van een rondtrekkend zigeunerpaar staat op het punt van bevallen, maar niemand in het dorp wil haar binnenlaten. "Als ge zelf keinder in huis hebt, dan kande ge zoo'n vrouw niet binnen halen en zoo maar ewees een kiendje laten geboren worre in oewen herd. Daarom wieren vrouw en de man afgewezen aan iedere deur." ${ }^{48}$ Dit motief uit het kerstverhaal krijgt een ander einde, want de zigeunervrouw mag bevallen in het huis van de kluizenaar. Als haar man alleen verder 
trekt, komen de vrouwen uit het dorp wel weer kleertjes en dekentjes brengen. Het dorp roddelt over het samenwonen van de kluizenaar met een 'trut'. ${ }^{49} \mathrm{Op}$ een avond is zij ineens verdwenen.

Hanneke die steeds maar zegt dat haar man Nol altijd eene goeie mens is geweest, vandaar de bijnaam de goede moordenaar, krijgt een zoontje dat op Graart den Beer lijkt. Het is geestelijk niet helemaal normaal: "er is iets aan." Als ze uit haar huis gezet dreigt te worden, trekt ze bij de kluizenaar in.

Jaren later komt Nol Bonk uit Leeuwarden terug. Hij geeft zijn vrouw voor het eerst van zijn leven een hand, een omgangsvorm die hij in de gevangenis heeft geleerd. Eerst grijpen ze mis en daarna blijven ze aan het schudden, niet goed wetend hoe je zoiets stopt. Mét de kluizenaar leven ze enige tijd in een mariage à trois. De twee mannen brengen samen klot rond met paard en wagen, klein Nolleke zit op de bok. Op een keer beginnen de mannen plagend te stoeien en plotseling wordt het ernst. Nol Bonk krijgt dezelfde instinctieve vernietigingsdrang als jaren geleden bij de moord op Pietje Pinksteren en bijna wurgt hij de kluizenaar. Nog net op tijd komt hij tot zichzelf. Na de opluchting dat hij niet wéér een moord heeft gepleegd, wordt hij zich bewust van een ander gevaar. Paard en wagen zijn intussen verder gereden. De twee mannen hollen "een nieuwen angst en een nieuw noodlot tegemoet." Even verderop vinden ze het lijkje van Nolleke: "Het ligt dwars over den weg mee zijn kopke in het wagenspoor, de uitgepuilde oogen als van eenen slapenden haas wijd open, de beenkes krom, de armen gestrekt als de armen van een kruis, de vingers gespreid. ${ }^{50}$ Ook nu weer volgt er een uitgebreide beschrijving van het 'kronen' van het dode kindje. Nol maakt laarzen voor de kluizenaar - ook dat heeft hij in Leeuwarden geleerd - en de kluizenaar vertrekt. Hanneke bekent dat het overleden kind niet van Nol was. Nu is ze weer in verwachting, "maar deze keer kande gij er zeker af zijn. ${ }^{.51}$ Van dit kind is Nol de vader.

Als contrapunt voor deze verhaallijn dient het huwelijk van Fons de bakker en zijn "kwaai wijf" Willemien. Fons zuipt en als reactie daarop laat Willemien steeds de varkens los, die Fons dan weer met zijn dronken kop in hun hok moet zien te krijgen. Hij speelt voortdurend met gedachten over de dood van zijn vrouw. "Wie weet of Willemien morgen niet dood naast mij ligt. Zwaar menschen kunnen schielijk sterven. ${ }^{52}$ Ook denkt hij erover haar te vergiftigen. Fons trekt het noodlot aan. Hij wordt bijvoorbeeld in het donker door zijn cafévrienden afgeranseld, omdat ze hem voor iemand anders (de 'kaaljakker' Edmond

43 AMVC, inv, nr. C 3475, brief Coolen aan Streuvels, 6 januari 1932.

44 AMVC, inv. nr. C 3475. Op 17 november 1931 schrijft Coolen aan Streuvels: "Morgen stuur ik U De goede moordenoar."

45 Coolen, 'Hoe ik er toe kwam', 33.

46 LMDC, inv. nr. C 3485, brief Coolen aan Elisabeth Augustin, 11 mei 1934.

47 Coolen, De goede moordenaar, 6.

48 Coolen, De goede moordenaar, 77.

49 Het woord 'trut' wordt steeds voor deze vrouw gebruikt; op de blz. 87, 102 en 104. Het heeft niet de tegenwoordige betekenis, maar staat eerder voor iets als landloopster of slet.

50 Coolen, De goede moordenaar, 208.

51 Coolen, De goede moordenaar, 231.

52 Coolen, De goede moordenaar, 32. 
Havé) houden. Dit leidt tot zoveel complicaties dat zijn been geamputeerd moet worden. "Dat hadden ze in Helmond van hem weggedragen en in den grond gestopt. Onderweg in zijn leven was zijn been alvast in den grond blijven steken." ${ }^{.53}$ Pas als hij gestorven is, voelen z'n cafématen enige schuld: "'t is God geklaagd, da we Fonse zoo kosten vergeten, we hebben hem nooit meer iets in het fleschke gebracht. Wa zal-ie hebben liggen snakken." ${ }^{54}$ Ook nu weer is er aandacht voor huiveringwekkende details rond het lijk. Fons wordt een uur na zijn sterven al zwart en de lucht wordt zo sterk dat zijn vrouw er koppijn van krijgt en de wakers er vandoor gaan. "Het lijk kost [kon, C.S.] niet in de kerk kommen, omdat de kist al dreef, toen hebben ze 's avonds voor dat de lijkmis was, Fons in de schemering maar gauw in de grond gestopt." Tijdens de uitvaartdienst staat een stellage van planken met een zwarte doek erover in de kerk, zodat het uit de verte lijkt alsof er een doodskist staat.

Een bijrol is er voor de leden van de Haagse familie Havé. Zij zijn de bekende 'kaaljakkers' en 'grutsche stinkers'. De dochter brengt de dorpsjeugd het hoofd op hol, terwijl haar oom het aanlegt met het simpele Hanneke. Halverwege het verhaal verlaten ze met schulden het dorp.

\section{Echt gebeurd}

Het gegeven voor het boek is direct gebaseerd op een schokkende gebeurtenis in Deurne op zondag ro april rgro. Coolen zegt in zijn interviews steeds dat hij niets verzint en dat bijvoorbeeld Peelwerkers helemaal op ware feiten berust. Coolen is een goed waarnemer en kan de werkelijkheid haarscherp weergeven, maar door het zo nadrukkelijk te melden wil hij ook zeggen dat al die verschrikkelijke zaken die in zijn romans voorkomen gewoon uit de alledaagse werkelijkheid zijn geplukt en niet uit het brein van een perverse schrijver.

Het verslag van de moord en de beschrijving van de personages in De goede moordenaar lijken zo uit de krant te komen. De moord vond plaats precies een week voor Antoon Coolens dertiende verjaardag. Coolen was die zondag thuis en heeft de consternatie in het dorp gezien. De Zuidwillemsvaart van woensdag 13 april is bijna in zijn geheel aan de zaak gewijd.

De feiten zijn als volgt. Als bij de oude winkelierster in ijzerwaren en huishoudelijke artikelen aan de Wiemel, mej. Marie Berkelmans [in het boek Marjanneke den Schilder], steeds kleine diefstalletjes worden gepleegd, vraagt zij haar zeventigjarige buurman P. Munsters, bijgenaamd Pietje den Bakker [Pietje Pinksteren], op haar huis te passen als zii naar de kerk gaat. Zo gauw zij weg is, komt de voerman Nol van der Zanden [Nol Bonk $]^{55}$ over de zolder in het huisje en treft daar de wakende buurman aan, die hij op gruwelijke wijze vermoordt. Vervolgens doet hij zelf aangifte dat er een moord gepleegd is. Hij gaat nog gewoon naar de Hoogmis. Pas daarna vlucht hij met de bedoeling België te bereiken. De moordenaar is die zondag op verschillende plekken tussen Deurne en Helmond gezien. Niet wetend dat hij al verdacht wordt, komt hij 's avonds terug om afscheid van zijn vrouw te nemen en wordt gearresteerd terwijl hij met zijn klompen in zijn handen aan het raam staat te luisteren.

Ongebruikelijk voor die tijd heeft de krant een grote foto geplaatst van de kamer, waarop de bloedplas voor de tafel en bloedvlekken op de muur duidelijk zichtbaar zijn (zie foto pagina 221). Op de tafel liggen nog de stok en de pijp van de vermoorde. De beschrijving 


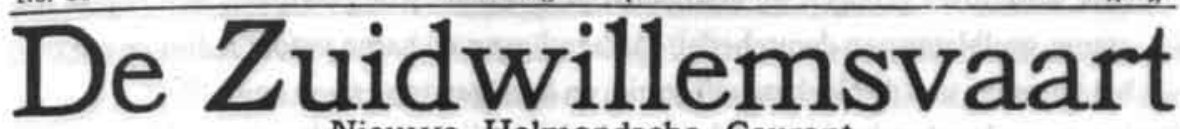

Nieuwe Helmondsche Courant

waarin opgenomen HET NIEUWS VAN DE WEEK, Helmondsche Courant
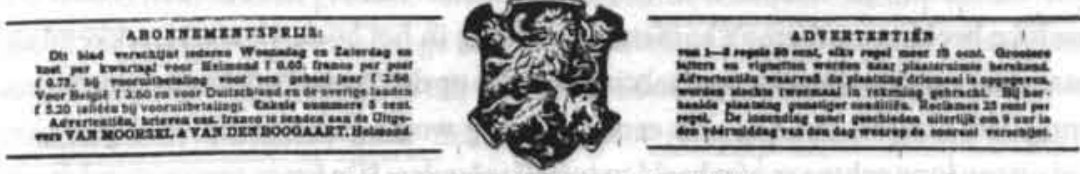

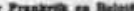

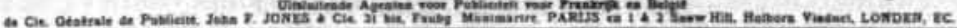

van het lijk laat niets aan de verbeelding over: "de aders en spieren aan den hals, het strottenhoofd, ja zelfs de halswervels en een gedeelte van 't ruggemerg waren doorgesneden en doorkorven evenals een zijner polsen, ook waren hem nog meerdere sneden in aangezicht en hals toegebracht. ${ }^{n 6} \mathrm{Bij}$ de rechtszitting op 31 mei 1910 vertelt de brigadier die het verhoor heeft afgenomen, dat de moordenaar gezegd heeft dat het al lang in zijn bedoeling lag iemand te vermoorden, wie het ook was. Bij de reconstructie van de moord, met brigadier Koolen als slachtoffer [uiteraard zonder mes, staat er bij in de krant, C.S.], blijkt dat de moordenaar zijn linkerknie op de borst en zijn rechter tegen het hoofd van het slachtoffer zette en hem, hoewel hij linkshandig was, met zijn rechterhand vermoordde. Hij krijgt de maximumstraf van twintig jaar."

Deze krantenverslagen werpen een goed licht op de manier waarop verhalen bij Coolen ontstaan. In interviews naar aanleiding van de Van der Hoogt prijs heeft hij het procédé beschreven. Hij kiest reëel bestaande personen en wijzigt zelfs aanvankelijk de naam niet. Ook nu zijn de namen maar weinig veranderd en het ijzerwarenwinkeltje wordt een schilderszaak. De omgeving van de Wiemel en het hele decor van het dorp is op Deurne gebaseerd. ${ }^{58}$ De beschrijving van die zondag tot en met de arrestatie van Nol Bonk's avonds laat beslaat zestig bladzijden van de roman en volgt, wat de feiten betreft, de lijn van het politie-en krantenverslag. Coolen beschrijft de moord als volgt:

"Mee de knieën open over hem heen, te paard, zit den Bonk boven op hem en houdt hem neer. [...] Den Bonk hangt mee open mond erboven, in dat bloed trekt hij het mes dwars over den hals, mee horten en stooten voor den geweldigen tegenstand van felle en taaie spieren. [...] Hij gaat mee alle drift aan het kerven en snijden. Hij hoort duidelijk het schuren van het mes en het natte, smetterend geluid van bloed in de inwendigheid van den wijdgeopenden hals. Daaraan, aan dien gemartelden, verscheurden

53 Coolen, De goede moordenaar, 148.

54 Coolen, De goede moordenaar, 172.

55 Volgens Felix Coolen is Van der Zanden na het verschijnen van het boek in 1931, toen hij al lang weer uit de gevangenis was, er de rest van zijn leven prat op gegaan, dat hij de hoofdfiguur uit De goede moordenoar was.

56 'Het Drama te Deurne'.

57 'De roofmoord te Deurne'.

58 Zoon Felix Coolen wijst er op dat Kinderen van ons volk en De vrouw met de zes slapers vanuit de herinneringen aan het adres Haageind zijn geschreven en dat De goede moordenaar het perspectief van de Molenstraat heeft. 
hals, achterover gebogen, gebroken, hangt den kop op de plavuizen, den kop, blauw grauw, geelblauw aan den schedel, daaraan liggen de haren verdord, dun en nat over het glimmen van de bleekgrauwe kruin, en de oogen rood staan open." ${ }^{59}$

Coolen verandert het krantenverslag in een beschrijving van de gemartelden van het Isenheimer altaar van Colmar of in een scène van het Laatste Oordeel van Jeroen Bosch. Gruwelijke beelden en thema's komen steeds terug in het boek. Het rondtrekkend zigeunerpaar waarvan de vrouw in verwachting is, zingt op de kermis liederen over echt gebeurde misdaden, waarbij aan een stok een afbeelding wordt getoond. Een lied gaat over de moord op een jong echtpaar, afgebeeld in twaalf taferelen: "De jonge vrouw stond er ook op afgebeeld aan eenen boom gebonden, mee de voeten in de ingewanden van het geopende lijk van haren man. Omdat ze nog niet bekennen wou, waar haren geldschat verborgen lag, hadden de moordenaars haar zoo gewurgd. Dat moest ergens in Bels gebeurd zijn." ${ }^{\text {"60 }} \mathrm{Ook}$ de hallucinaties van de alcoholist Fons zouden zó uit een schilderij van Jeroen Bosch kunnen komen:

"Een blauwe stroom, daar dreven de witte geesten en de roode duivels op aan. Er waren daar allerhande vriendelijke dieren tusschen mee de ruggen van oude mannen en achterwaarts gekeerde voeten. Alles glimlachte. Er waren daar zeer groote kevers en sprinkhanen, zij lachten mee hun vleugels. Zij waren misschien heel klein. Dit kwam wellicht omdat zij heel veraf waren. Ja zeker, want als zij op zijn bed waren gekommen, nu zijn ze niet meer zoo klein. Zij drukken mee een zware, brandende last op Fonse zijn lijf. Zij hebben pleizier in zijnen ronden buik. Zij glijden eraf, zij klauteren er weer op. Zij dansen. Zij dwarlen. Zij veeren op! [...] Er komt eenen bruinen kever, maar dat is eenen kleinen grijsaard, die heeft geenen mond, van zijn neus toe zijn kin is het één gesloten vleesch." ${ }^{-61}$

Het is opmerkelijk hoeveel kleuren Coolen in al deze gruwelijke beschrijvingen gebruikt. Zijn studie van het werk van Jeroen Bosch, aan wiens nagedachtenis het boek is opgedragen, is zeer waarschijnlijk van invloed geweest op deze kleurenorgie.

\section{De kritiek}

De kritieken zijn gunstig. In Coolens eigen krant staat een positieve recensie, waarin overigens hoofdzakelijk het verhaal wordt naverteld. ${ }^{62}$ Ook de in het katholieke kamp zo verguisde A.M. de Jong blijft vriendelijk tegenover Coolen. Hij schrijft dat hij een van de gevoeligste en knapste schrijvers van de jonge generatie is, die helemaal apart staat door zijn eigen atmosfeer, stijl en onderwerp. "Onveranderlijk schrijft hij uit het leven van die stille, ruwe peelmenschen, die maar een geringe woordenschat tot hun beschikking hebben, maar in wier harten sterke hartstochten kunnen opstaan tot een noodlottige kracht." Hij herhaalt zijn bezwaar tegen het gebruik van dialect waar de verteller aan het woord is. Hij vindt dat de taal van dit achterlijke volk zich niet leent voor een dichterlijke visie op mensen en dingen, natuur en landschap, gevoelswisselingen en innerlijke beroeringen. Zo'n visie heeft een verfijnde en genuanceerde taal nodig. Echter, hij spreekt zichzelf tegen als hij moet toegeven dat "soms, in de moeizame gepeinzen van de omwolkte geest zijner dubbende figuren deze zelfde taal een aparte kracht is, die sterker de suggesties wekt, door de auteur bedoeld, en de figuren zuiverder aftekent tegen den achtergrond van het wijde peelland, waarbij die taal organies behoort." De Jong vindt dit Coolens sterkste boek; het 
suggestieve taalgebruik verheft het tot de zuiverste kunst. ${ }^{\text {bs }}$

Jan Engelman trekt voor de KRO radio vergelijkingen met schilders: de personages bewegen zich nu eens hard en bitter zoals op de tekeningen van Vincent van Gogh en dan weer dromerig en overhuifd zoals op de schilderijen van Wiegersma. Ook Engelman kan maar niet wennen aan het gebruik van het dialect als de schrijver "hardop denkt." Hij vergelijkt Coolen met Querido die lange stukken jiddisch of bargoens schrijft, maar daar tussendoor steeds ten volle Querido is. Hij vindt de draden van het verhaal te los om een hechte compositie te vertonen, maar denkt dat Coolen bewust een "zekere neuzelende eentonigheid van rythme" heeft betracht om niet zozeer de voortgang van de gebeurtenissen als wel de grote menselijke hartstochten en de natuurkrachten te benadrukken. Dit is gelukt, maar de karakters zijn daardoor niet uitgediept. Dit blijft een moeilijk punt bij Coolen, vindt Engelman. Coolen heeft veel gevoel voor atmosfeer, maar zijn mensenkennis kan aan diepte winnen. Hierdoor is de kluizenaar bijvoorbeeld veel te vaag gebleven. Bij de koortsfantasieën van Fons hebben hem misschien de schilderijen van Jeroen Bosch of Karel van de Woestijne's novelle De boer die sterft voor ogen gestaan, "maar deze twee meesters hadden visies welke zooveel grooter, dieper, schrikkelijker waren." Het werk van Coolen is te arcadisch; hij zou van impressionist eigenlijk expressionist moeten worden. Engelman prijst de humor, maar ook de tederheden in het boek, zoals bij het 'kronen' en begraven van Nolleke. "Dan ziet men dat zachtheid en deernis, een geest van christelijke, menschelijke charitas, de grondtrek is in dezen schrijver." ${ }^{\text {64 }}$

\section{Bestempeld tot katholiek romancier}

Anton van Duinkerken legt in zijn recensie een veel grotere nadruk op het christelijke of beter gezegd op het katholieke aspect van De goede moordenaar. Hij noemt het boek in De Tijd het meesterwerk van deze auteur. Kinderen van ons volk was idyllischer, maar daar schuilde toch het gevaar in dat het bleef steken in de al te gemoedelijke provincieliteratuur. Veel critici hadden daarop gewezen. Volgens hen bezat het boek teveel een sfeer van "bij ons in de Peel" met wat devotie op kerkelijke feestdagen "en een beetje meewarige treurigheid als een van de mannekes of durskes of vroulie doodging." Nu vond Van Duinkerken al dat dit niet opging voor Kinderen van ons volk, omdat dat ver boven de decoratieve landelijkheid uitsteeg. Het gold evenmin voor Het donkere licht, omdat dat de tragiek van het idyllische Brabant liet zien. Peelwerkers oversteeg deze sfeer zelfs door de bijna fatale natuureenheid tussen het landschap onder de wisselende seizoenen en het kleine hart van de zwoegende mens.

In De goede moordenaar komt volgens Van Duinkerken de bekroning, want nu schept Coolen een eenheid. "Het is een epos van natuur en instinct, van buitennatuur en binnennatuur [...] die elkaar verstaan hebben in hun diepste duisterheden van zinneloozen ver-

59 Coolen, De goede moordenaar, 40.

60 Coolen, De goede moordenaar, 93.

61 Coolen, De goede moordenaar, 151-152.

62 [Recensie De goede moordenaar], in: De Gooische Post.

63 De Jong, 'Het nieuwste boek van Antoon Coolen'.

64 FPC, Engelman, [typoscript van] radiorede van den K.R.O, 4 maart 1932. 
nietigingsdrang en roekelooze leefdrift." Alle personages leven hun primitieve bestaan in de natuur, die hoogstens beheerst wordt door de ervaringswijsheid van vorige geslachten en door te weten dat dit "erfelijk bezit der diepste kennis van goed en kwaad iets heel heiligs moet zijn, samengevat in den godsdienst." Hierdoor stijgt het boek uit boven een dorpsnovelle. "Dit boek zou zwart zijn van wurgende noodlotsaanbidding, wanneer het niet zoo door en door Roomsch was." Het boek is geen religieus vertelsel met een godsdienstige strekking. Het gaat over het harde bestaan waarin niets gebeurt zonder gevolg. Nu maakt hij een onderscheid met de vermaledijde 'instinct-causaliteit'. "Zoo primitief is de aangrijpende instincts-tragedie van Den Bonk en Hanneke en Pietje Pinksteren, dat het heele verhaal in den Belgischen Congo gebeurd kon zijn in plaats van in de Peel, waren er niet de eeuwen Christendom, die gingen meeleven als traditie met de natuurbeweging zelf, die het instinctleven richten en het noodlot keeren." Opnieuw benadrukt hij dat Coolen geen tendenz-romancier is, die de lezer godsdienstige of sociale motieven wil opdringen. Coolen is een "Roomsch" auteur "bij wien de traditioneele denkwijs der Moederkerk een milde tweede natuur is geworden en de bestaansoorzaak van een meesleepende hartelijkheid en een bijna moederlijk begrijpen. ${ }^{65}$

Van Duinkerken gebruikt deze kritiek later ook in zijn biografische schets van Coolen. Hij wijst dan op het instinctmatige van de hoofdpersonen.

"Nol Bonk weet niet, welke macht het is, die zijn vingers kromt tot de moordenende wurging, doch het is een overmacht, hem toegestroomd uit de diepe verten eener onpeilbare samenvloeiing van de vlakheid des levens met de oneindigheid der instincten. Hanneke de Haan kent de geheimzinnige bewegingen niet van het nog levend besef in haar duistere brein. Fons en Willemien weten geen verantwoording af te leggen omtrent hun altijddurende, treiterende onderlinge oneenigheid. De kluizenaar vindt nooit de woorden, die zijn goedheid konden verklaren. Al die menschen leven in accoord met het primitieve bestaan van de natuur, onberekenbaar, doch telkens alles aantastend door haar grillige reacties."

Telkens tovert Van Duinkerken een wonderlijke redenering te voorschijn, die moet aangeven waarom dit boek geen vorm van noodlotaanbidding is, maar een innig katholiek werkstuk.

"Eeuwen van Christendom zijn als bevrijdende traditie gaan meeleven met de dreigende natuurbewegingen en zij bezitten door hun overgeleverde wijsheid, evangelische goedheid en erbarmende mildheid het vermogen om de menschelijke instincten ten goede te richten en om aldus het noodlot te keeren. Door dit onophoudelijk in de gedachte te houden, ook waar hij het niet uitspreekt, is Antoon Coolen een onmiskenbaar katholiek romancier." ${ }^{\text {66 }}$

Waardoor nu precies die natuurbeweging en die instincten zijn omgebogen, maakt Van Duinkerken niet duidelijk. Volgens hem zouden vele eeuwen Christendom deel zijn gaan uitmaken van het natuurlijke leven en zouden overgeleverde wijsheid en mildheid deel uitmaken van het bestaan, maar nergens in de roman blijkt daar iets van. Van Duinkerken voegt die katholieke overlevering toe aan Coolens roman om vervolgens te concluderen dat Coolen een katholiek schrijver is. 
Het is deze redeneertrant van Van Duinkerken, waarin woorden als "keistenen" het geloof moeten rechtvaardigen en als "draaitollen" verschillen in betekenis scheppen, waaraan Menno ter Braak zich zo gruwelijk ergert in zijn kort daarvoor verschenen kritiek op Hedendaagse Ketterijen van Van Duinkerken. Hij vindt dat deze apologeet, op overigens magistrale wijze, de taal misbruikt. Van Duinkerken gebruikt woorden als "bedoelingszuiverheid der overgave als wils-act" en "algemeene intentie" en "finaliteit", die volgens ter Braak alleen maar waarde hebben voor hen die in die waarde willen geloven. De zekerheid die Van Duinkerken op die manier schept is "niet eerbiedwekkender [...] dan die van de fetischist uit de afrikaanse binnenlanden. ${ }^{n 67}$ Ter Braak gebruikt hier dezelfde vergelijking als Van Duinkerken op de vorige pagina, waar hij de Congo noemt om het tegendeel te beweren. Van Duinkerken redeneert, volgens Ter Braak, met de "glasheldere termen der scholastiek" die Augustinus geformuleerd heeft en Thomas gebruikte voor de fundering van zijn systeem, waardoor alle dingen op aarde 'goed' zijn als ze ter ere Gods worden genoten en 'slecht' als zij afleiden van God.

Van Duinkerken deelt de romans die hij bespreekt op deze visie in. Zo kan het gebeuren dat hij niet-katholieke auteurs als Querido en Hoornik (de laatste is overigens wel katholiek opgevoed) toch indeelt bij de katholieke, omdat uit hun romans "een katholieke of, in het geval van Hoornik, een christelijk communistische geest spreekt."68

Coolen laat zich de visie van Van Duinkerken aanleunen. Deze komt immers van de toonaangevende criticus in de kwaliteitskrant van katholiek Nederland en dat kan voor zijn imago geen kwaad. Misschien is deze een extra aansporing om een vervolg op zijn meest katholieke roman Kinderen van ons volk met de goede pastoor Vogels te schrijven. Behalve dat vervolg, De schoone voleinding, zullen zijn volgende romans echter niet specifiek katholiek zijn. De protagonist van de twee 'Friese' romans, dokter Van Taeke, vertoont eerder heidense karaktertrekken.

Coolen wordt door Van Duinkerken als dé katholieke romancier van zijn tijd bestempeld. Als na de oorlog aanvallen op de katholiciteit van Coolen worden gedaan, zal Van Duinkerken het voor hem opnemen. ${ }^{69}$ Eerst moet Van Duinkerken hem echter tegen iets anders verdedigen. Coolen en andere schrijvers wier werk sterk aan een regio is gebonden, krijgen het verwijt regionalisme te bedrijven. Het debat gaat over Coolen, maar wordt door Van Duinkerken gevoerd. Coolen heeft er niet zo'n behoefte aan om zich intensief te bemoeien met de manier waarop hij als schrijver ingedeeld wordt. Het laat hem niet koud, weten we uit zijn brieven, maar het voornaamste is toch dat hij door kan gaan met schrijven zoals hij wil en dat hij zoveel lezers krijgt dat hij zijn journalistenbaan kan opzeggen. Anderen moeten maar uitmaken of hij wel of niet een katholiek schrijver is en of zijn romans regionaal of Europees zijn. ${ }^{70}$

\footnotetext{
65 Van Duinkerken, 'De goede moordenaar'.

66 Van Duinkerken, Antoon Coolen, 51-53.

67 Ter Braak, 'De moderne Ketterjager', 392.

68 Polman, De keerzijde van het leven, 185.
}

69 De aanvallen komen vanuit het bisdomblad Omhoog uit Utrecht en De Linie; het kwade genius hierachter is Albert Kuyle. De zaak speelt tussen 1946 en 1949. 


\section{Geestelijk klimaat in Hilversum}

In januari 1932 bereidt Coolen een radiolezing over De stille plantage van Helman voor. De kopij zal hij van tevoren insturen, schrijft hij aan de redacteur van het Boekenhalfuur, Van Duinkerken. Door het controversiële Serenitas is Coolen zich ervan bewust dat Helman als de auteur van dat boek in de KRO kring een "delicaat vraagstuk" is. ${ }^{7}$ De negatieve opvatting van Coolen over het boek Serenitas hebben hem er niet van weerhouden Helman en zijn vrouw, Lou en Leni Lichtveld-Mengelberg, te vragen peter en meter te zijn bij de doop van zijn tweede kind. Zij stemmen toe en zo staat er na de weigering van Streuvels toch weer een schrijver aan de doopvont. Guido Lodewijk wordt op 31 januari 1932 geboren. Het geboortekaartje is verluchtigd met een tekening van Charles Eyck, een medewerker van De Gemeenschap.

Een eervolle uitnodiging om toe te treden tot de redactie van De Gemeenschap wijst Coolen af. Coolen is nog steeds full time journalist bij De Gooische Post en daar zijn de verhoudingen, ondanks de roem van de schrijver/journalist, niet gewijzigd. Zijn directeur/hoofdredacteur Aleven is de baas en laat dat goed merken. Hij heeft Coolen ontraden om toe te treden tot de redactie, bericht hij aan Van Duinkerken. De aanleiding daarvoor is een rede die op 29 december 1931 door de Haarlemse bisschop J.D.J. Aengenent was gehouden in Alkmaar. Deze hield een regelrechte aanval op jonge katholieke schrijvers in. De bisschop riep ouders en schoolhoofden op voorzichtig te zijn in het kiezen van literatuur. Van Duinkerken formuleerde de strekking van de rede als volgt: "Zonder namen te noemen veroordeelde hij vooral Willem Nieuwenhuis om diens politiek, mij om mijn cultuurbeschouwingen, Kuyle om zijn polemiek en Helman om zijn pornografie. ${ }^{n / 2}$ De rede heeft ook gevolgen in het Gooi, schrijft Coolen:

"De befaamde rede van Aengenent heeft bepaalde plaatselijke gevoeligheden reliëf gegeven, en den Heer Aleven vreesde, dat mijn toetreding tot de Gemeenschapsredactie op dit oogenblik daarom tegenover de Hilversumse geestelijkheid weinig tactisch zou zijn. Persoonlijk had ik graag het redacteurschap van De Gemeenschap aanvaard, maar de motiveering van het advies zoowel als de wijze waarop het gegeven werd, een wijze die uiterst welwillend was en waarbij waardeering voor $\mathrm{De}$ Gemeenschap werd voorop gesteld, noodzaakten mij ertoe met dit advies ernstig rekening te houden. ${ }^{73}$

Men zou Coolens reactie kunnen kenmerken als een gebrek aan solidariteit met zijn vrienden Van Duinkerken en Helman, want het is toch niet erg moedig om geen openlijke connecties te willen aangaan met de twee peetvaders van je kinderen, alleen maar om de Hilversumse clerus niet voor het hoofd te stoten. De situatie ligt echter anders: Coolen staat niet echt te dringen om in die redactie te stappen. In zo'n kleine redactie zit hij veel te dicht bij de extraverte, dominante Van Duinkerken. Hij heeft geen zin om door hem geannexeerd te worden. Het komt hem wel goed uit dat hij nu een excuus heeft. Pas een jaar later, als hij als zelfstandig schrijver in Deurne woont, heeft hij voldoende afstand om toe te treden.

De hele affaire is trouwens ook een bewijs hoe nauw kerk, pers en samenleving in een katholieke enclave als Hilversum - maar niet alleen daar - verweven en verknoopt zijn. 


\section{Boekenweek}

Van Duinkerken trekt zich niets van de affaire aan. Na zich in een gesprek met monseigneur Aengenent ervan verzekerd te hebben dat er geen verschijningsverbod dreigt voor $\mathrm{De}$ Gemeenschap, gaat hij in de aanval. ${ }^{74}$ Ter gelegenheid van de eerste Boekenweek in Nederland, van 7 tot en met 14 mei 1932, fulmineert hij in De Tijd tegen de pastoors. Deze blijven maar waarschuwen tegen slechte lectuur en kweken zodoende een volksdeel dat nooit leest en geen boeken koopt, om er toch maar zeker van te zijn nooit een slecht boek in handen te krijgen.

De Vereeniging ter bevordering van de belangen des boekhandels, die Van Duinkerken gevraagd had een feuilleton over de culturele betekenis van het boek te schrijven, heeft nog andere ideeën. De commissie die het eerste Boekenweekgeschenk heeft voorbereid, heeft aan dertig auteurs vijf vragen voorgelegd. De gebundelde antwoorden vormen het geschenk. Dit zijn vragen van een heel andere orde en in ieder geval onschuldiger dan de vragen die aan Van Duinkerken zijn voorgelegd. De commissie wil weten hoe de auteur tot het schrijven van het eerste boek is gekomen, voor welk eigen boek deze een voorkeur heeft, welke liefhebberijen en toekomstplannen deze er op na houdt en welke mening de auteur heeft over de moderne tijd. Het valt Jan Nieuwenhuizen van De Maasbode op dat Coolen "het eenigst kind van de Moederkerk in dit toevallige litteraire oploopje" is, "maar hij is een waardig vertegenwoordiger van zijn geloofsgenoten, want zijn bijdragen zijn niet ijdel, maar hoogst sympathiek en bescheiden. ${ }^{77}$

Coolen schrijft in zijn bijdrage ironisch dat hij, als bij een proefwerk, met de vinger de vragen nagegaan is. Hij heeft kennelijk geen zin zich te branden aan de laatste vraag over de moderne tijd. Hij heeft daarbij het gevoel dat die een 'gericht' provoceert of, met andere woorden, een veroordeling wil uitlokken.

"Van dezen tijd wordt bar veel kwaads gezegd, het behoort tot het fatsoen van een zekeren geestelijke welstand aan de algemeene veroordeeling mee te doen. Ook dit is te ontwijken. Ik bespeur weinig lust, mij voor deze gelegenheid te gaan verdiepen in een onderwerp als dit waaruit zovele vragen rijzen. Het hedendaagsche westersche leven heeft honderdvoudige aspecten en het is geen geringe opgaaf zich deze allen zóó diep

70 In 1936 verschijnt een Franse vertaling door Marcelle Schlomer met een voorwoord van 'de Faulkner van de Midi', Jean Giono. Nog in 1995 verscheen een herdruk van Le Bon Assosin - om niet geheel duidelijke reden onder de nieuwe titel La Faute de Jeanne le Coq, waarmee de nadruk op de misstap van Hanneke den Haan wordt gelegd. Een juichende recensie in Le Monde van 8 september 1995 begeleidde de uitgave onder de kop 'Coolen entre Dieu et diable'. De recensent zegt dat je soms je enthousiasme zonder voorzichtigheid moet kunnen tonen en zeggen: "Le roman d'Antoon Coolen, exhumè par les éditions Autrement, est un chef-d'oeuvre."

71 BA, brief Coolen aan Van Duinkerken, 13 januari 1932.

72 Brief Van Duinkerken aan Martien J.G. de Jong, 30 juni 1962, geciteerd in: Van der Plas, Daarom, mijnheer, 166

73 BA, brief Coolen aan Van Duinkerken, 13 januari 1932.

74 In Frankrijk is niet lang daarvoor het katholieke tijdschrift Le Sillon door de bisschoppen verboden. Aengenent verzekert Van Duinkerken dat zoiets in Nederland niet zal gebeuren. Van der Plas, Daarom, mijnheer, 166.

75 N[ieuwenhuis]. 'De Boekenweek'. 
bewust te maken dat men - het helemaal met zichzelf eens - een behoorlijk verantwoord samenvattend oordeel over dezen tijd kan geven. ${ }^{n 76}$

Coolen weigert dus mee te huilen met de wolven in het bos. Hij gaat buiten de rij staan, conformeert zich niet en houdt vast aan zijn standpunt dat er niet één waarheid is.

Over de toekomst meldt hij dat hij bezig is aan een vervolg op Kinderen van ons volk, zonder de titel De schoone voleinding te noemen. En als een quasi-geheim verklapt hij-"Dit blijft onder ons" - dat hij nog eens het levensverhaal van Jeroen Bosch hoopt te schrijven. De opsomming van zijn liefhebberijen vindt hij overbodig, "omdat ze de liefhebberijen zijn van iedereen. Voor het schrijven als liefhebberij hoef ik geen uitzondering te maken, want deze liefhebberij schijnt tegenwoordig een der meest algemeen beoefende te zijn." ${ }^{n \pi}$ Zijn meest geliefde eigen boek is De goede moordenaar.

"De reden van deze voorkeur is geen erg grondige en standvastige, die reden immers zal het feit zijn, dat ik dit boek het laatst heb geschreven en het pleizier, dat ik aan het schrijven ervan beleefd heb, mij dus nog het meest is bijgebleven. Overigens bespeur ik niet onduidelijk een voorliefde voor het schrijven over primitieve naturen, een voorliefde voor het instinctieve en intuitieve en voor alles wat primair menschelijk is. ${ }^{.78}$ Zo'n opmerking is zeer ongewoon voor een katholiek auteur, want zonder het met zoveel woorden te zeggen geeft hij daarmee blijk van zijn belangstelling voor door de kerk verafschuwde stromingen als het darwinisme en het naturalisme. Vervolgens gaat hij uitgebreid in op hoe hij tot het schrijven is gekomen. Hij noemt de verhalen die zijn moeder vroeger in de keuken voorlas, de boeken van Ouwerling en diens begeleiding. In het hoofdstuk over zijn jeugd is dit al uitgebreid aan de orde geweest.

Uit een briefje dat Coolen op 2 maart aan Van Duinkerken stuurt, blijkt hoe verschillend hun werelden zijn. Uitgebreid vertelt hij over de vragen voor het boekenweekgeschenk. De leden van de commissie zitten echter met een groot probleem: ze vinden maar geen titel voor het boek. Nu heeft hij ze verzekerd dat Anton van Duinkerken "zonder eenige reserve het recht op een kampioenschap in het vinden van geniale, flitsende, synthetische en aforistische titels kan doen gelden en toen is mij verzocht jou te vragen gauw zo'n titel uit te broeden. ${ }^{79} \mathrm{Hij}$ voegt eraan toe dat hij erop vertrouwt dat Van Duinkerken zijn lof over hem niet zal beschamen en wijst er ook nog op dat er spoed bij is. Van Duinkerken heeft het laten liggen, want de titel wordt kortweg Geschenk. Het motto van die eerste Boekenweek is "Wie leest baat zijn geest." Van Duinkerken heeft andere zaken aan zijn hoofd, want hij komt net terug van zijn audiëntie bij monseigneur Aengenent en moet zich voorbereiden op een heel andere bijdrage aan de Boekenweek. Het worden de hiervoor genoemde felle artikelen over de benepenheid en achterdocht van de clerus inzake boeken en de zogenaamde jonge schrijvers die niet echt goed katholiek zouden zijn.

Van Duinkerken vecht tegen vele vijanden. Als apologeet verdedigt hij de katholieke geloofsleer tegen 'ketters' en andersdenkenden. Als literatuurminnaar strijdt hij tegen het conservatieve bolwerk binnen de kerk, dat het liefst bijna alle literatuur zou verbieden. In de kritiek pleit hij voor de vrijheid van de schrijver om over alles wat het leven aan stof biedt te kunnen schrijven. Door deze combinatie van eigenschappen is hij niet vatbaar voor autoritaire politieke of geestelijke stromingen, waarvoor vele katholieke intellectuelen wel zullen vallen. Integendeel, hij zal die veroordelen en bestrijden. Dit heeft ook con- 
sequenties voor Antoon Coolen. Op dezelfde apodictische manier waarop Van Duinkerken vastgesteld heeft dat Coolen een katholiek romancier is, zal hij beslissen dat Coolen geen bloed-en bodemschrijver is, zoals even later Ter Braak ook zal doen.

\section{Het regionalismedebat}

In de zomer van r932 woedt er een korte, maar hevige polemiek over het peil van de Nederlandse letterkunde. Marsman gooit de knuppel in het hoenderhok en beticht de schrijvers van streekromans, zoals Antoon Coolen, Herman de Man en Theun de Vries, van regionalisme en provincialisme en veroordeelt hen tot een lager, niet Europees peil. Van Duinkerken en De Man reageren er fel op, maar Coolen houdt zich stil. De polemiek zal in de jaren die erop volgen voortgezet worden door de Forum-leden Ter Braak en Du Perron en gat de geschiedenis in als het regionalismedebat. Het brengt een blijvende scheiding der geesten teweeg. Coolen zal er zijn hele leven last van hebben. Ondanks de verkoopsuccessen van zijn romans blijft hij een wrok koesteren tegen degenen die hem vernederen, zoals uit zijn correspondentie, maar ook uit satirische romanfragmenten valt op te maken. Op zijn manier van schrijven heeft het overigens geen invloed. Hij blijft zijn eigen weg volgen.

Het is toevallig weer De Nieuwe Eeuw, het blad waarin Pieter van der Meer de Walcheren in I921 Lentebloesem afkraakte, van waaruit de aanval wordt geopend door Marsman met het artikel 'Der Weg zurück: Korte aantekeningen over nieuwe Hollandse romankunst'. Hij schrijft:

"Ik zou tegen Coolen niet scherp zijn, als zijn werk niet verdedigd en bewonderd werd door mensen van inzicht [...] Laat men de waarde van Kinderen van ons Volk liever niet overschatten: het is een leesbaar boek, maar Het donkere licht en De goede moordenaarzijn niet alleen zelf-herhalingen van Coolen, maar ook op zichzelf onleesbaar van armoedigheid, van anecdotische Klein-Malerei, van saai en stuntelig provincialisme. Het is jammer dat iemand van intelligentie en 'zuivere besnaring' als van Engelman enige, en van die van Nijhoff veel waardering had voor zoiets doods en doms. Nijhoff vindt de wijze waarop Coolen een gelagkamer beschrijft niet minder dan 'weergaloos'. Ik [Marsman, C.S.] vind die bewering niet minder dan gek. ${ }^{\text {no }}$

Marsman gebruikt de term provincialisme overdrachtelijk, niet letterlijk. Immers, de meeste provincialen wonen in de steden, en ook een kosmopolitische roman kan door en door provinciaal zijn. Of een boek provinciaal is wordt bepaald door de geest van de schrijver. Een echte schrijver herschept de provincie van zijn gegeven tot de wereld van het zuivere kunstwerk. Hij vindt dat een kunstenaar het anekdotische, het toevallige en het pittoreske moet doen vergeten. De kunstenaar maakt "dat men niet alleen leven kan in het heelal, maar dat men meeleeft in krotten en op bergtoppen waar men anders niet zou wagen te leven. De provincialen echter maken het heelal onbewoonbaar provinciaal, zij verminken de mensen tot tamme en stomme benepenen, zij vernederen het leven en de

77 Coolen, 'Hoe ik er toe kwam', 34.

78 Ibidem.

79 BA, brief Coolen aan Van Duinkerken, 2 maart 1932.

80 Marsman, 'Der Weg zurück'. 
werkelijkheid." Het werk van niet provinciale schrijvers, zoals Helman, Du Perron en Slauerhoff, ligt volgens Marsman op een ander plan, "een plan waarop men kan leven, denken, bewegen en ademen." Hij vindt hun werk on-Hollands in de zin van niet-provinciaal en Hollands in de goede zin van het woord.

Anton van Duinkerken reageert een week later met een artikel in De Tijd. ${ }^{81}$ Hij constateert dat Marsman niet het literaire talent vergelijkt, maar het 'plan' waarop een werk geschreven wordt. Zo bekeken wordt E. du Perron automatisch verheven boven Coolen, alleen maar omdat Du Perron "een andere wereld ordent." Dit waarderingsbeginsel leidt tot absurditeiten, waardoor mislukkingen als Een voorbereiding van Du Perron wegens de goede wil tot Europeanisme verheven wordt boven een roman als De goede moordenaar, omdat die naar de geest 'provinciaal' zou zijn. Van Duinkerken maakt onderscheid tussen enerzijds het vermogen om te vertellen en te beelden en anderzijds de 'hulpvermogens': de intellectuele, psychologische en stilistische vaardigheden van de auteur. Als het eerste niet aanwezig is, hebben de hulpvermogens geen zin. Coolen ontroert de lezer met zijn primaire romanschrijverstalent, al mogen dan zijn hulpvermogens zwakker zijn dan bij Du Perron. "Deze man kan niet boeiend vertellen. Hij kan geen mens 'beelden'." Coolen is misschien minder 'cerebraal-beschaafd', minder 'knap' en minder geneigd tot diepzinnigheid, maar dat is geen reden om zijn werk lager aan te slaan. Van Duinkerken vindt dat de literatuurkritiek in Nederland het secundaire, de hulpvermogens, overschat ten nadele van het primaire kunstenaarschap. Hij vindt dat een typisch decadentieverschijnsel. "Het secundaire 'plan' wordt eerder gezocht en bewonderd dan het primaire 'verhaal van han. delingen'; - de secundaire gevoelstoon wordt verheven boven de primaire ontroeringsmacht; de secundaire ontleding heeft men liever dan de primaire beelding." Het heeft geen zin om provincialisme en Europeanisme als tegenstelling te hanteren. Ze hebben allebei bestaansrecht. Grote schrijvers verenigen deze twee aspecten, het beeldend vertellen en de 'hulpvermogens', in zuivere harmonie. Maar volgens Van Duinkerken ligt Antoon Coolens De goede moordenaar dichter bij dit evenwicht dan de volledige werken van Du Perron, met uitzondering van een enkel gedicht, "waarin de bezieling sterker was dan de hoedanigheden, die in deze auteur bezielingsvatbaar zijn."

In een brief aan Marsman, doorspekt met scheldwoorden, noemt een boze Du Perron Van Duinkerken een "aartsstommeling", die te stom is om te begrijpen "wat hij in zijn katholieke aartsboerelulligheid moest slikken. [...] Als ik jou was, deed ik dezen Van D.ééns de eer aan hem te vertellen hoe dom hij is en hoe hardleersch." $\mathrm{Hij}$ is in ieder geval blij dat zijn hulpvermogens boven die van Coolen gewaardeerd worden. Hij zou Van Duinkerken er bijna sympathiek om vinden "als de kloen minder stom was," ${ }^{82}$

De reactie van Marsman komt nog geen week later in zijn artikel 'Derde dimensie en Europees peil.' Met verwijzing naar Anthonie Donker, die zich in de NRC ook met de zaak bemoeid heeft, stelt hij dat het er niet toe doet dat de personages in het werk van Coolen, De Man, Fabricius en De Vries écht en driedimensionaal zijn, "omdat de hele soort zich beweegt op een te laag plan. Zij komen niet uit boven het gematigde hollandse realisme, zij zijn en blijven - niet slechts van onderwerp, maar ook van geest en structuur - benepen, achterlijk, provinciaal." Hij verwijt ze niet dat ze een provinciaal gegeven tot onderwerp nemen, maar dat ze in geest en hart provincialen zijn en in dit gegeven blijven steken. Hij makt een vergelijking met de schilder Wiegersma, die ook van een gewestelijk gegeven 
uitgaat en boeren schildert. Echter, die "boeren van Wiegersma zijn de boeren van Coolen vóórdat Wiegersma ze verbeeldt en Coolen ze uitbeeldt, maar zij zijn onherkenbaar verschillend na die bewerking. Bij Wiegersma denkt niemand aan provincialisme, bij Coolen doen dat de mensen, die op het plan staan van Wiegersma, tot weewordens toe." Wiegersma staat in de Brabantse grond, "maar zijn blik is tevens de blik van een modern Europeeër."

Marsman herhaalt dat de kunstenaar niet het alledaagse moet uitbeelden, maar dat hij het onalledaagse, het bijzondere, het wezenlijk-levende moet ontdekken. Hij verwerpt de door Van Duinkerken gemaakte interpretatie van de tegenstelling provinciaal - Europees als gelijk aan de tegenstelling primitief - verfijnd. Het gaat om een plan, een Europees peil. Daar gelden juist niet allereerst 'hulpvermogens' als intellect, psychologische en stilistische vaardigheden, "maar kracht van bezieling, ruimte van blik en atmosfeer." Pas vanaf een bepaald niveau kan een boek Marsman interesseren. Die vraag naar rang gaat vooraf en hij begrijpt niet wat Van Duinkerken daar tegen heeft. "Sinds wanneer heeft deze bezwaar tegen hiërarchie," vraagt hij zich retorisch af. Al zijn de personages van Coolen nog zo levensecht, ze interesseren Marsman niet. Hij geeft Van Duinkerken gelijk dat het boek van Du Perron Een voorbereiding mislukt is, maar hij leest het toch wel iets liever dan De goede moordenaar. Bij Coolen verveelt hij zich. Hij interesseert zich niet voor de driedimensionaliteit van de sneeuwpoppen van Antoon Coolen, maar wil wel iedere trilling ervaren van de ziel van Slauerhoffs Larrios, "die in zekere zin een twee-dimensionale schim en dus geen gestalte is." De maatstaf is Europees peil. Volgens Marsman betekent dit dat de schilderijen van Wiegersma, Toorop en Koch in de grote wereldsteden kunnen hangen, dat de verzen van Slauerhoff, Bloem en Nijhoff in een goede vertaling overal gelezen zouden kunnen worden, maar dat de "romans van Herman de Man [...] echter in Purmerend reeds moeilijk te lezen" zijn. ${ }^{83}$

Antoon Coolen hanteert het principe 'wie geschoren wordt moet stil zitten'. Geen reactie komt er uit zijn schrijfhut; niet in het openbaar en ook niet in een brief. Er zijn kennelijk wel mondelinge contacten geweest, want Van Duinkerken stuurt hem een afschrift van een briefje aan Herman de Man, waarin een onenigheid over een recensie in De Tijd afgedaan wordt, met de toevoeging: "We zullen maar zien, wat hij doet. Je hebt n.l. gelijk: bij al zijn hebbelijkheden is hij toch geen kwaaie vent." ${ }^{84}$ Over Marsman en het regionalismedebat geen woord. Toch moet Coolen vergelijkbare gevoelens hebben als zijn huwelijksgetuige, De Man. Coolens werk wordt over het algemeen hoger aangeslagen dan dat van De Man, maar De Man heeft een onweerlegbaar argument in de discussie over regionalisme. Zijn werk wordt veel verder dan Purmerend gelezen; het is al vertaald in het

81 Van Duinkerken, 'Provincie of Europa?'.

82 Brief Du Perron aan Marsman, 21 juni 1932. Perron, Brieven III, 322. Van der Plas wijst er in zijn Van Duinkerken-biografie op dat veel gescholden wordt in de correspondentie van Ter Braak en Du Perron, terwijl bij Van Duinkerken geen onvertogen woord valt.

83 Marsman, 'Derde dimensie'.

84 BA, brief Van Duinkerken aan Coolen, 28 juni 1932. Van Duinkerken besprak in De Tijd op Zondag van 28 mei 1932 De Kleine Wereld van Herman de Man en stelde dat De Man de katholieke geloofsleer fout interpreteert. 
Engels en Duits en een Deense vertaling is onderweg. Van Coolen is op dat moment nog niets vertaald. Het is dan ook een geschenk uit de hemel, dat er juist in die tijd een verzoek uit Duitsland komt voor de vertaalrechten van De goede moordenaar.

Het regionale genre is in de jaren dertig populair. Ook de boeken van Knut Hamsun, Stijn Streuvels, Felix Timmermans en Sigrid Undset worden in heel Europa gelezen. Het zijn juist deze boeken die vertaald worden. Dit is natuurlijk altijd zuur voor de vernieuwers; het publiek maakt zijn eigen keus. Het jaar daarop verwondert Ter Braak zich over de wijze waarop de Nederlandse literatuur in het buitenland vertegenwoordigd wordt met naast vertalingen van Felix Timmermans en Jo van Ammers-Küller "de volstrekt niet bijzonder merkwaardige provinciale beschrijvers van het boerenleven, Herman de Man en Antoon Coolen."

\section{Imago}

In deze polemiek die binnen enkele weken in juni 1932 gevoerd wordt, is in feite het 'definitieve' oordeel over Coolen als romanschrijver geveld. Hij zal altijd gekenschetst worden als schrijver van regionale romans. En een regionale roman schat men in de Nederlandse letteren niet hoog, schrijft Lambert Tegenbosch later ter gelegenheid van Coolens zestigste verjaardag. Met die 'men' bedoelt Tegenbosch de groep rond Forum en de naoorlogse literaire kritiek, want in de jaren dertig is er van enig misprijzen bij andere toonaangevende recensenten nog geen sprake. Tegenbosch vergelijkt Coolen in 1957 met Mauriac, die in zijn 'streekroman' een bezielend engagement legt. Dit engagement ontbreekt niet bij Coolen, "maar het is bij hem een engagement van niet polemische, van mild beamende aard." Coolen heeft niet het engagement van Mauriac maar hij heeft wel, evenals Mauriac, het katholiek-religieuze element teruggebracht in de prozakunst en daarmee de streekroman naar een hoger plan gebracht. Volgens Tegenbosch wilde Coolen éérst de roman en daarna de streek:

"De streek als grond waarop het door lyriek aangedreven wiel vat kon krijgen [...] Antoon Coolen heeft daarvoor in de Nederlandse roman het katholieke sentiment binnengevoerd. Had zijn wiel Chinese grond geraakt in plaats van Brabantse, dan zou dat evengoed hebben kunnen gebeuren, nu dankt hij dat gebeurde niet slechts aan zijn eigen inbreng van katholiek gelovige, maar evenzeer aan het onderwerp dat hij ontdekt had." ${ }^{\text {85 }}$

Kort voor Tegenbosch dit schrijft, houdt Harry Kapteijns een voordracht over de streekroman in Brabant, waarin hij ook terugkijkt op dit regionalismedebat. Hij verdedigt het genre, als het maar goede literatuur is. "Uit de ontmoeting van deze drie elementen: de verbeelding, de streek en zijn bewoners, de hartelijkheid - is in het beste werk van Coolen een vriendschap voor het leven ontstaan, - en verschillende specimina van goede sociografische romans bovendien. ${ }^{m 6}$ Pierre Dubois wijst ter gelegenheid van Coolens zestigste verjaardag op de merkwaardige positie van Coolen. Hij is een van de populairste schrijvers van Nederland en wordt ook in het buitenland veel gelezen. Tegelijkertijd wordt hij door de literaire kritiek in aanzienlijke mate verwaarloosd. Ook hij refereert dan aan deze polemiek over regionalisme en Europees peil. Hij constateert dat het werk van Coolen bewezen heeft dat het universaliteit bezit en daarmee de provinciale sfeer ver overstijgt. Coolens personages zijn simpel, maar daarmee nog niet onecht of onwaar. "Integendeel, zij ver- 
tegenwoordigen een menselijke werkelijkheid die niet minder groot, niet minder belangrijk en zelfs niet minder 'diep' behoeft te zijn." ${ }^{\text {"8 }}$

De zomer van r 932 zal voor Coolen een keerpunt in zijn leven worden. Hij is in die tijd druk bezig met de 'voleinding' van De schoone voleinding, het boek dat hij al eerder aangekondigd heeft als het vervolg op Kinderen van ons volk.

De belangstelling voor zijn werk van Duitse vertalers en uitgevers begint te groeien, waardoor er een perspectief op een enorm afzetgebied ontstaat. Het plan dat hij al langer koestert en al diverse keren in brieven aan vrienden bekend heeft gemaakt, om zijn baan als journalist bij De Gooische Post op te geven, wordt steeds concreter. Nu het hem materieel goed gaat door het succes van zijn boeken, acht hij de tijd rijp om zich helemaal aan zijn literaire werk te gaan wijden en zich weer in Brabant te vestigen.
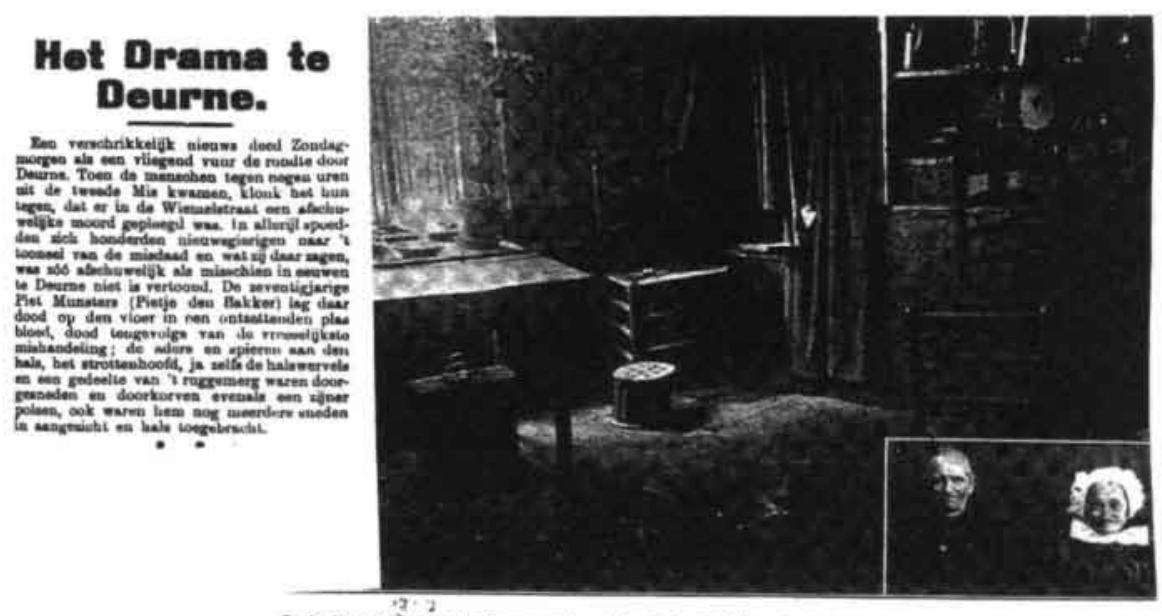

De barbatrache' moord te Denurne gepiesgd, heeft begrilpeli|kerwilxe in de geheele buurt groote verbinering, vervaardiging en veralagenheld gewelat; onderwilt de alleen wonrnde mejultroew $M$, D, ter herke was, hieid de Je P. Munaters de wacht, aabgezien er tifdena hare afwezigheld reeds meermalen kieine diefotallen gepiengd

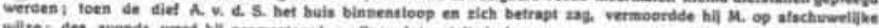

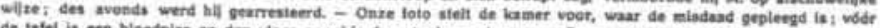

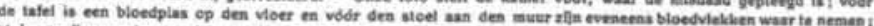
stok en pllp van den weralagene ziet men mede op de foto. - Men had $M$. entreden de wacht te houden: hilf viel

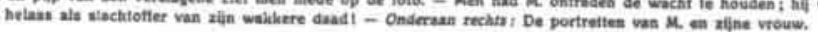

85 Tegenbosch, 'De streekroman', 664.

86 Kapteijns, 'De streekroman', 264.

87 Dubois, 'Antoon Coolen zestig jaar'. 


\section{De Schoone Voleinding}

"De eindelooze schoonheid en beminnenswaardigheid van het leven." $1932-1933$

\section{Coolen en zijn uitgevers}

Met gevoel voor reclame heeft Coolen in zijn bijdrage aan het boekenweekgeschenk van mei 1932 aangekondigd dat er een vervolg op Kinderen van ons volk zal komen. In november verschijnt deze roman, De schoone voleinding, bij de katholieke uitgeverij Paul Brand in Hilversum. Coolen is al in 1929 bij de uitgave van Het donkere licht overgestapt naar de neutrale uitgever Nijgh \& Van Ditmar in Rotterdam, maar hij laat om de eenheid tussen de twee boeken over het dorp van pastoor Vogels te benadrukken dit boek nog bij zijn vroegere Hilversumse uitgever uitkomen.

Het is zeker niet gewoon dat Coolen, die toch algemeen als een katholiek schrijver wordt beschouwd, zijn werk laat verschijnen bij een niet-katholieke uitgever. Het is weer een bewijs dat Coolen niet houdt van een nadrukkelijk katholiek imago. Hij vindt het veel belangrijker dat een uitgever in de eerste plaats hart heeft voor de literatuur.

Nu hij een succesvol schrijver is wil iedereen hem wel uitgeven. Dat geldt ook voor Het Nederlands Boekhuis uit Tilburg, dat in I92 I Lentebloesem uitgaf. Toen werd Coolen behandeld als een bedelaar. Het Boekhuis wil hem slechts 50 gulden geven voor alle rechten, maar zou het tegelijk wel op prijs stellen als hij een abonnement nam op de keurboekerij.' Als een jaar na het verschijnen van Lentebloesem een schetsje uit het boek in De Tilburgse Courant wordt geplaatst, krijgt Coolen een boze brief en wordt hem te verstaan gegeven dat dat niet mag. In dezelfde brief wordt hem ingepeperd dat er nog maar 200 exemplaren zijn verkocht, omdat het publiek nu eenmaal naar de naam en faam van de schrijver kijkt. Vaderlijk besluit de uitgever: "Laat U dit echter, als jong auteur, niet ontmoedigen, doch sta ons toe $\mathrm{U}$ op te merken, dat $\mathrm{U}$ toch ook Uw krachten niet moet overschatten en het o.i. beter is grooter werk, zoals bijv. een roman, voorlopig niet in 't licht te zenden." ${ }^{\text {"I }}$ Als Coolen klaagt dat het boek in Hilversum niet eens in de winkel ligt, antwoordt de uitgever dat er geen belangstelling voor is en dat zeker niet wordt overwogen om een nieuwe uitgave uit te brengen. Acht jaar later echter, bij zijn bekroning met de Van der Hoogt prijs in r 930 , zoekt Het Boekhuis weer contact. Het Boekhuis meent dat Coolen nog steeds geen definitieve uitgever heeft en klopt zichzelf op de borst als "Uw eerste uitgever, als hebbende de hitte van den dag getrotseerd." ${ }^{3}$

Het is wel begrijpelijk dat Het Boekhuis denkt dat Coolen nog geen definitieve uitgever heeft, want hij heeft enkele malen gewisseld. Hij heeft na Lentebloesem zijn boeken uit-

I FPC, brief Het Nederlands Boekhuis aan Coolen, 25 augustus 1920.

2 FPC, brief Het Nederlands Boekhuis aan Coolen, 12 augustus 1922.

3 FPC. brief Het Nederlands Boekhuis aan Coolen, 5 juni 1930. 
gegeven bij Laurens van der Waals. We hebben gezien hoe hij voor de uitgave van Kinderen van ons volknaar de katholieke uitgever Paul Brand in Hilversum overstapte. Het jaar daarop komt hij via Laurens van der Waals, die met zijn uitgeverij onderdeel is geworden van Nijgh \& Van Ditmar, in contact met Doeke Zijlstra. Deze zal vanaf Het donkere licht in 1929 niet alleen Coolens vaste uitgever worden, maar ook een persoonlijke vriend.

Het is voor Paul Brand een bittere pil dat zijn schrijver na het grote succes van Kinderen van ons volk overstapt naar een andere uitgever. Hij reageert bitter als Coolen zijn overstap bekend maakt:

"Uw schrijven is een slag in mijn gezicht, maar hierover verder niets. Erger is, wat U met $U$ eigen hebt uit te maken, 'n woordbreuk in de ergste vorm, misschien om een paar zilverlingen. Foei! Kwaad ben ik niet, maar diep, misschien nog nooit zoo erg in mijn hele leven, ben ik geschokt in mijn vertrouwen jegens mijn geloofsgenoten. Is 't dan toch waar, dat ook bij ons niets dan bedrog en leugen is. Die gedachte is voor mij zwaarder, dan het gemis van Uw uitgave."

Coolen stuurt nog een spijtbetuiging, maar Brand kan die niet aanvaarden. Hij vindt dat elk vertrouwen totaal kapot is nu Coolen zich tot een liberale uitgever heeft 'bekeerd'. Uit de toon en de woorden van die brieven blijkt niet alleen dat Brand een slecht verliezer is, maar ook hoe Coolen wordt aangesproken op zijn positie als katholiek schrijver. Coolen wordt beschouwd als een afvallige die overloopt naar de liberalen en de onderlinge loyaliteit van geloofsgenoten schendt.

Toch verschijnt De schoone voleinding nu dus bij Brand. Ook de volgende drukken van Kinderen van ons volk en De schoone voleinding blijven voorlopig bij Brand verschijnen. Pas vanaf 1939 zullen Kinderen van ons volk (tiende druk) en De schoone voleinding (derde druk) door Nijgh \& Van Ditmar uitgegeven worden. Paul Brand vraagt voor de overname van de rechten van de twee boeken 2500 gulden, Nijgh \& Van Ditmar biedt 300 gulden. Ze worden het eens over rooo gulden. ${ }^{5}$

\section{De schoone voleinding}

De nieuwe roman De schoone voleinding, in linnen band met een houtsnede van Jozef Cantré, is een waardig geschenk voor de decembermaand. Op het schutblad prijkt weer een motto van Van Duinkerken: "'k wil nog een keer met je meegaan, mijn broer, / nu de braambessen blauwen. / Ik zal me zelf wijsmaken: kind te zijn."

In korte paragraafjes wordt het dorp van Kinderen van ons volk en het verglijden van de tijd geschetst. De kinderen van Doruske Timmer zijn groot geworden en er is een twaalfde kind bijgekomen. Hij heeft nu twaalf 'apostelen' en de jongste heet Peterke. Bij pastoor Vogels staat op de schoorsteenmantel een portret van de overleden notaris "die geen geloof had als wij dat hebben." Godefridus van den Breemortel komt thuis uit de gevangenis, waar hij gezeten heeft voor de moord op Giel Sleegers, een rivaal die zijn vrouw Marie niet met rust wilde laten. De ontmoeting met zijn vrouw is heel onwennig en Marie toont hem zijn zoontje dat geboren is toen hij in de gevangenis zat. Als Godefridus pastoor Vogels bezoekt geeft deze hem troost en hoop voor de toekomst. Hij vertelt over de goede moordenaar naast Christus aan het kruis en over een man die biechtte: "Vader, ik heb gemoord." Waarop de priester alleen maar vroeg: "Hoe vaak, mijn zoon?" De onverstoorbare houding van de priester in dit verhaal ontroert Godefridus. Thuis, in bed, valt de schroom tegenover 
zijn vrouw weg en voelt hij "de schoone verteedering, die vooraf gaat aan deze ontbeerde vervulling, waarin een scheiding van jaren wordt overgrepen in de vervloeiende drift eener omhelzing." ${ }^{\text {" }}$

Godefridus zit vaak bij zijn moeder. Zijn vrouw beklaagt zich er bij haar over. Hij wil later, na de dood van zijn moeder, in zijn ouderlijk huis gaan wonen, weg van het huis waar de rivaal heeft rondgehangen. Zijn moeder heeft geprobeerd het goed te maken bij de vader van Giel, maar de oude Sleegers wil haar niet eens binnenlaten. In de lente wordt het tweede kind van Godefridus en Marie geboren, Marieke.

Tegenover de somberte van dit echtpaar staan de drukte en vrolijkheid van het grote gezin Timmers, waar een familiekoor is gevormd. Hierin komt echter later verandering. Nadat een zoon is vrijgeloot voor militaire dienst, treft de tweede zoon Dorus een negatief lot. Tijdens zijn diensttijd verandert hij en wordt "nors en onbesnut" [lomp, onbeschoft, C.S.J. Als hij steeds vaker geld nodig heeft voor de apotheek begrijpt zijn moeder wat er aan de hand is: hij heeft een geslachtsziekte opgelopen. Vader mag er niets van weten. De moeder is ook de spil van het gezin bij de verjaardag van de tweelingzusjes, die in de meimaand steeds hopen dat Maria aan hen zal verschijnen zoals aan Bernadette in Lourdes.

Dorus biecht zijn zonden. Wederom, evenals bij de moordenaar, vindt pastoor Vogels troostende woorden: het lichaam is de tempel van de Heilige Geest en blijft dat ook in geschonden staat. Er is een groot verschil tussen Dorus en zijn onschuldige broertje, het 'apostelke' Petrus. Deze doet zijn communie en op weg naar de kerk plukt hij "eenen kruidnageltak met eenen paarsen tros en de schoon groen blaren, dien houdt hij aan den steel in den mond tusschen de dubbele vlam van zijn rooj wangen."

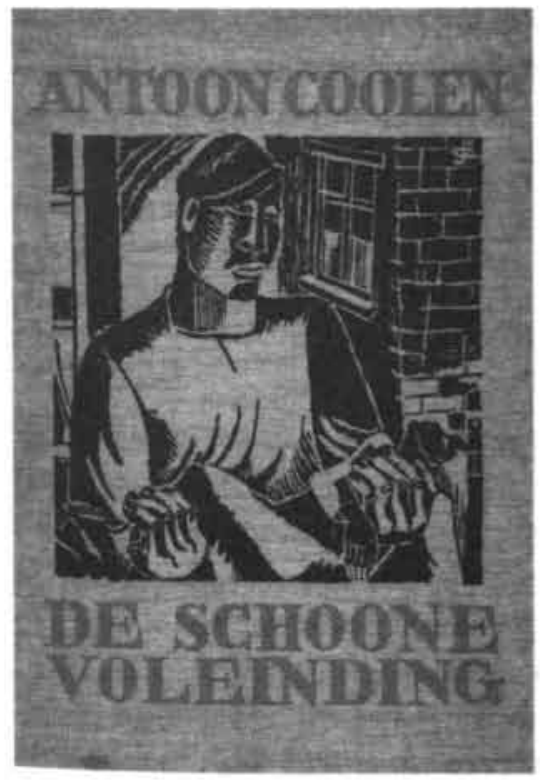

Als de moeder van Godefridus overlijdt, worden de kinderen het niet eens over de vraag wie er in het ouderlijk huis zal gaan wonen. Ze besluiten daarom tot een openbare verkoping. Het huis wordt via een stroman gekocht door de oude Sleegers, die van plan is om het af te breken uit wraak voor zijn vermoorde zoon Giel. Dan gebeurt er een vreselijk ongeluk. Aan het eind van de winter glipt het dochtertje Marieke weg tijdens het voeren van de varkens. Bij het slibberen op een nabijgelegen plas zakt ze door het ijs en verdrinkt. "Dit is nu gebeurd, niets is er anders door. Het had ook evengoed niet gebeurd kunnen zijn: een hand die een schoudertje wendde, voetjes die de richting ingestuurd werden voor een ander spel." Als het ouderpaar bij het dode kind zit,

4 FPC, brief Paul Brand aan Coolen, 31 augustus 1929.

5 FPC, briefwisseling tussen Poul Brand en Nijgh \& Van Ditmar, maart-april 1939.

6 Coolen, De Schoone Voleinding, 22.

7 Coolen, De Schoone Voleinding, 86. 
dat "getooid in zijn kistje in den herd" ligt, denken ze aan hun schuld aan de dood van Giel. Dan zegt Marie: "Wij hebben het af moeten geven, om 't goe te maken voor Giel. [...] Het moest het goe gaan maken bij Giel."

Bij de voorbereiding van het gouden priesterfeest van pastoor Vogels weigert Sleegers in het feestcomité zitting te nemen. Nadat aandrang van het feestcomité niet heeft geholpen, gaat de pastoor zelf naar hem toe. Hij weet dat Sleegers elke dag het Onze Vader bidt en dus ook elke dag vraagt om vergeving van zijn schulden, zoals ook hij aan anderen hun schuld vergeeft. Hij bidt dus elke dag een onwaarheid. De boer zegt eerst niets, maar zijn vrouw spreekt al lopend door het huis haar gedachten uit. Zij voelt als moeder nog steeds het verlies van haar zoon, maar zoals ze bij Van den Breemortel nou "da klein" hebben moeten afgeven, vindt ze ook heel erg. De pastoor gaat met Sleegers in de "goej kamer" zitten en zegt dat er maar één is die Sleegers niet aankan en dat is hij zelf. De boer komt tot zichzelf en ontdooit.

Het feest van de pastoor wordt een groot succes en toont nog eens aan hoe geliefd hij is. Dan komt een daadkrachtige kapelaan met nieuwe ideeën naar het dorp. Hij wil het verenigingsleven en het jeugdwerk nieuw leven inblazen.

Bij Doruske Timmer wordt een kleinkind geboren en de ontspoorde zoon Dorus gaat naar Antwerpen. Pastoor Vogels komt nog een keer bij Marie en Godefridus op bezoek. Godefridus herhaalt dan zelf de opmerking van zijn vrouw als een soort schuldbekentenis: 'Ons Marie zee, da' we het een in den hemel moesten hebben, om het goe te maken mee Giele." De pastoor zegt dat hij in dit huis tranen gehoord heeft, maar dat hij er nu muziek hoort.

Het boek eindigt om in muziektermen te spreken met een 'andante pastorale'. De oude pastoor Vogels groet in de kerk nog een keer alle heiligenbeelden en sterft dan in zijn stoel in de verlaten pastorie bij het open raam met een glimlach op het gezicht. Hij zit daar nog dood als de avond valt en de eerste bromvliegen om hem heen komen zwermen. De verteller richt zich tot de lezer: "Ik weet niet, of Sinte Barbara, uit deze rij getreden, gekomen is, om hem af te halen van deze afgelegde reis. De vliegen rond dit hoofd zijn zichtbaar en hoorbaar. ${ }^{\text {8 }}$

\section{Compositie}

Coolen heeft dit boek op een bijzondere wijze gecomponeerd. De dertien hoofdstukken zijn zó verdeeld over de vier hoofdlijnen dat het verhaal van Godefridus en Marie en het boerenleven centraal staat. De familie van Doruske Timmer vormt een tegenhanger als druk arbeidersgezin. Pastoor Vogels is de verbindende en harmoniërende figuur. Het hoofdstuk waarin de boerderij van de Van den Breemortels verkocht wordt en Marieke verdrinkt is het dramatisch hoogtepunt van het boek en staat precies in het midden.

$\mathrm{Er}$ is nog een dunne vierde lijn. In het huis van de notaris komt zijn vroegere echtgenote wonen. Het dorp weet niet waar zij vandaan komt: ergens "wijd weg." Zij handwerkt wat en speelt af en toe citer, maar zwerft ook vaak rond de Kraayberg, de boerderij van Marie en Godefridus, nieuwsgierig naar de mensen die betrokken waren bij een moord. Zij vraagt om een glas water en zegt tegen Marie, dat een man die dat spontaan voor je doet. een ander doodslaan om je te behouden en te beschermen, je dubbel dierbaar wordt. ondanks het verschrikkelijke. Meteen daarna voelt ze dat ze niet begrepen wordt en arg 


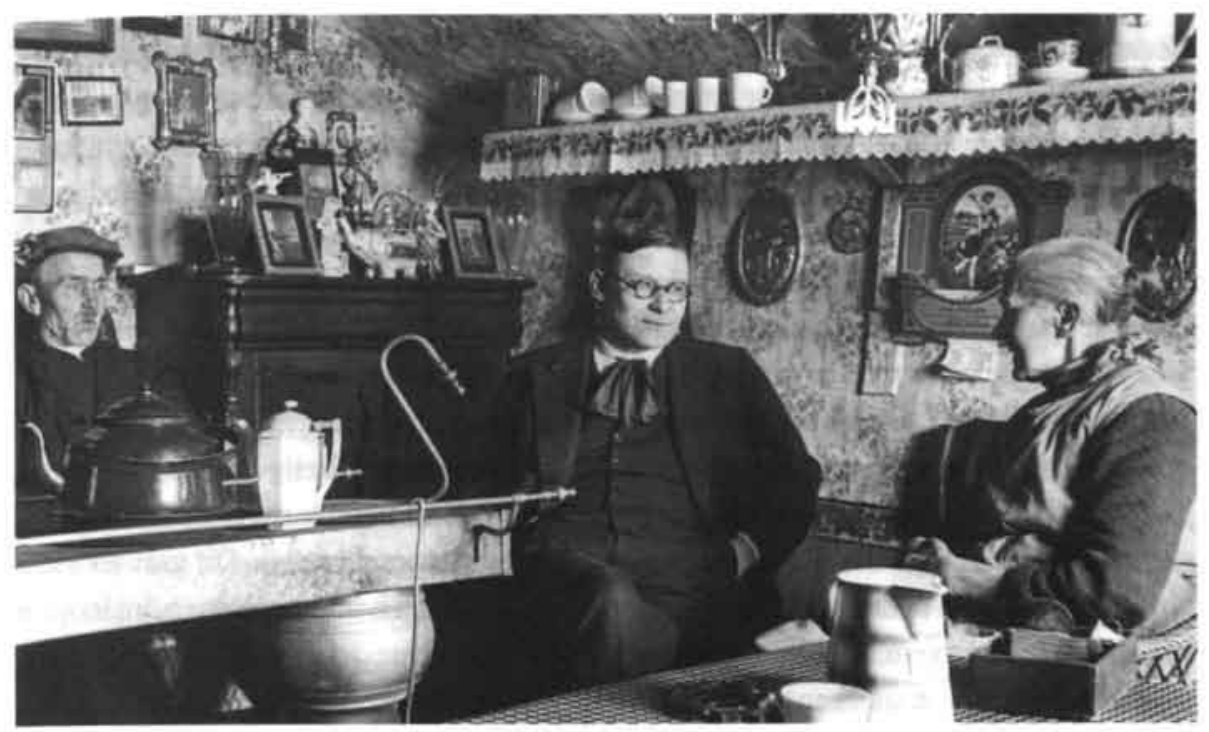

Coolen op bezoek in een Peelwerkers huis.

wanend wordt aangekeken. Ze denkt: "Dat is hier onder dit dak in zoo'n verhouding allemaal ruw en primitief. $O$, wat wil ze toch met die gedachte, dat ze op die wijze verdedigd had willen zijn door een man met de ziel van een boer, die den ander neergeslagen had." ${ }^{\prime \prime}$ Ze beseft dat ze haar gedachten in haar noodlottige eenzaamheid heeft gevormd.

Coolen laat deze gescheiden vrouw - die inmiddels ook al lang weer verlaten is door haar minnaar - een jaloezie voelen naar het weliswaar primitieve, maar toch ook warmere leven van deze boeren. Dit past in een lange traditie in de kunst en de letterkunde, waar de eenvoud van het landvolk dat dichter bij de natuur zou staan, geïdealiseerd werd. In deze verhaallijn zit echter ook veel van Coolen zelf. Het is hetzelfde verlangen dat hij voelt om bij mensen te horen waar hij eigenlijk helemaal niet bij thuishoort. De schrijver die in zijn interviews zegt de peelwerkers zo goed te kennen en hun taal te spreken, staat tegelijkertijd letterlijk en figuurlijk mijlen ver van hen af.

\section{Waarneming en herinnering}

Coolen heeft het vervolg op Kinderen van ons volkniet alleen als een uitwerking van het probleem van schuld en boete geschreven. In het boek schildert hij met de volle rijpheid van zijn talent de seizoenen, de feesten en de gebeurtenissen in een Brabants dorp, maar vooral ook het gedrag van mensen.

Evenals in De goede moordenaar schetst hij heel precies de onwennige manier van het handen geven bij het terugkomen van Godefridus uit de gevangenis en de onmacht van de echtelieden om dan meteen een gesprek te voeren. Het blijft steken in herhalingen van haar vraag of hij blij is dat hij terug is, zijn antwoord dat hij dat zeker is en zijn vraag of zij ook blij is. Na een tijdje volgt dan: "Kijk, daar staat onze rog." Diezelfde onmacht bevangt

9 Coolen, De Schoone Voleinding. 92. 
Godefridus ook als hij aan zijn zoontje wil uitleggen waarom hij in de gevangenis heeft gezeten. Tenslotte weet hij eruit te krijgen, dat hij als hij groot is het zal begrijpen en dat hij dan misschien ook zal geloven dat het een ongeluk is geweest en begrijpen hoe zijn vader en moeder eronder hebben geleden. Het jongetje voelt zich groot en mannelijk, omdat zijn vader daarover met hem heeft gesproken.

Indringend is de beschrijving van de zomer, zoals bij het plotseling opkomen van een onweer: "Daar trekt een schaduw over het schel koren, daarin gaat ook wat wind aan 't waaien en in de verte, vlak boven het wiekenkruis eenen molen, splijt de hemel in de lengte toe een sidderend vuren striep open. ${ }^{10}$ De hitte tijdens het maaien is haast voelbaar:

"Vierhandig naar den grond gebukt, gezwikt en zwaaiend, het gezicht kort en rood onder den grooten stroohoed, slaan de maaiers het heet koren neer in den gloeienden dag, de grond barst van de hitte, de voeten in de klompen branden. Dit gaat voor den hemel hoog gestreden, de schroeiend heete wind stort in het koren samen, hij loopt er zichtbaar overheen, het koren danst en 't valt meteen voor deze onverbiddelijke standvastigheid van maaiers en machien.".

De invloed van Streuvels is onmiskenbaar, zoals uit de volgende passage uit diens roman De oogst blijkt:

"En de zon stak geweldig, maar de pikkers vielen niet slap. [...] ze bogen den kop en de pikke bliksemglimde bij 't op- en neergaan, slag om slinger! Met 't groeien van de hitte stookte er een razernij door hun armen en ze hielden sterk de leden. Nog dieper bogen zij naar de eerde, sloten de tanden en lieten het zweet vrij van zich afleken. [...] Hun pikke sloeg eenbaarlijk, ze zwommen in hun zweet, maar de armen zwaaiden zoveel te vlugger al sloegen de laaivlammen hen om 't lijf--Nu danst de zonne, meende Rik." ${ }^{\text {12 }}$ Coolen heeft Streuvels boek in zijn jeugd ontelbare malen herlezen en zelfs gedroomd dat

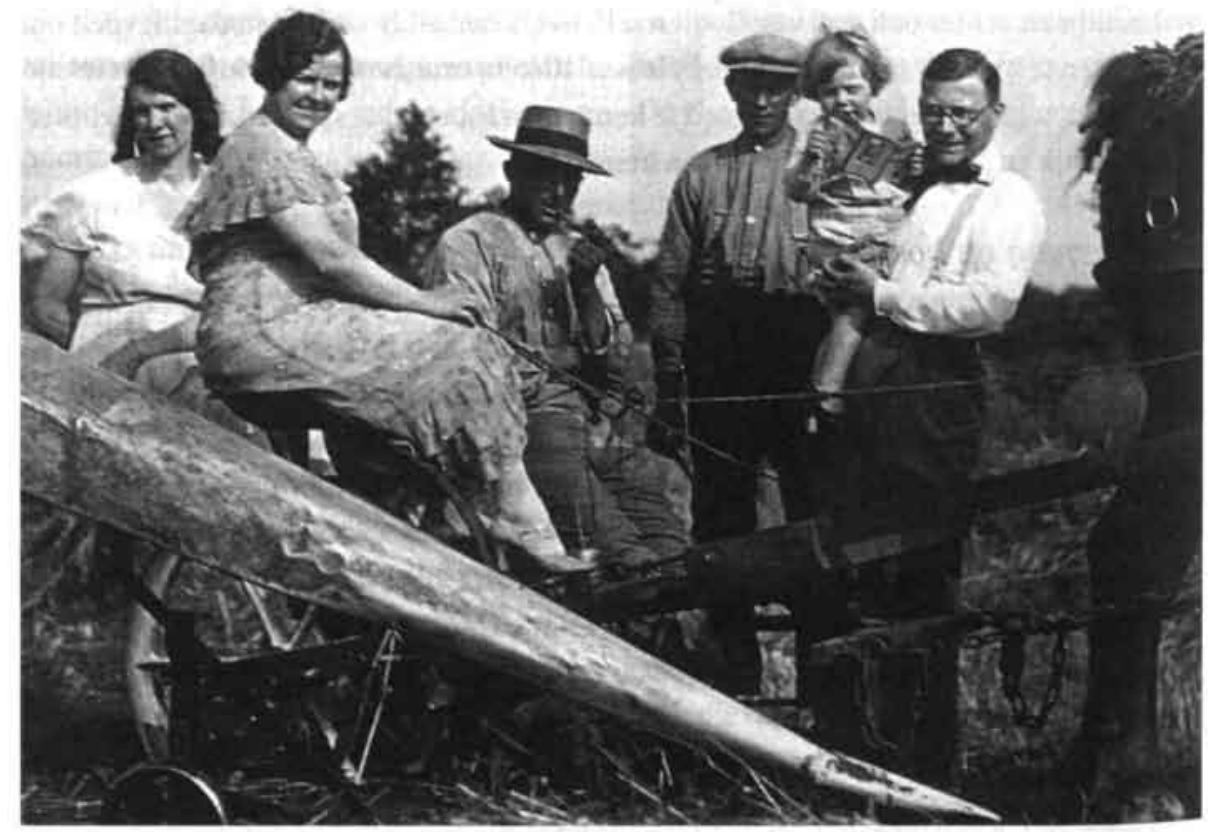

Gerda (links) en Coolen (rechts) met Stijn op de arm. 
hij de hoofdpersoon Rik was. Door een brief van Streuvels ${ }^{13}$ wordt Coolen zich ervan bewust dat hij meestal in de tegenwoordige tijd schrijft. Hij doet dat, "omdat die naar mijn gevoel de toon verlevendigt: men volgt het van vlak bij. elk detail krijgt een natuurlijk leven." Coolen denkt dat, wanneer een schrijver iets gedetailleerds vertelt in de verleden tijd, de lezer zich afvraagt hoe de schrijver dat nog weet. Streuvels is voor een gemengd systeem en Coolen merkt nu pas dat hij dat in De schoone voleinding ook heeft gehanteerd.

\section{Het 'Roomsche leven' en het beeld van de clerus}

In de episode over het gouden priesterfeest van Vogels bewijst Coolen hoe door en door hij het 'rijke Roomsche leven' kent en het gedrag van autoriteiten, geestelijkheid, onderwijzers heeft geobserveerd. De voorbereiding van het feest en de dag zelf vormen de hoofdmoot van het tweede deel van de roman, waarin Coolen zijn satirische en humoristische kant laat zien. Wéér is er een pedante onderwijzer. Deze bereikt niets, maar heeft in het feestcomité het hoogste woord. Hij imponeert de dorpelingen met dure nietszeggende tussenwerpsels. Hij zegt bijvoorbeeld "de houding van den pastoor is in principe er volkomen naast" en "oppervlakkig beschouwd heeft de pastoor gelijk." Hij wil vergaderen "om een houding te bepalen." Achteraf heeft hij alles geweten en als de pastoor de doorbraak bij boer Sleegers heeft volbracht, is hij, E. van Veldhuizen, het geweest die de juiste troef op het juiste ogenblik heeft uitgespeeld. Op het feest besluit hij zijn rede met een citaat van Tollens: "Tel d'uitslag niet, doch zie het doel alleen."

Het feest wordt door Coolen aangegrepen om verschillende geestelijken te portretteren. De pastoor Van de Leemberg die alle menu's bewaart, komt niet, omdat Vogels heeft aangekondigd dat het feest sober zal zijn. Vogels neemt subtiel wraak door hem na afloop een groot pak te sturen, met het volgende briefje:

"Ik maak er een gewetenszaak van. Omdat het zoo sober zou zijn kwaamde ge niet.

Maar mijn parochianen hebben mij een overvloed gegeven, waarop ge gekomen zoudt zijn. [...] Laat deze wijn opnieuw tot rust komen, 't is een teelt van den goeden bodem der oudste dochter van de kerk, het land van Renan en Voltaire, maar [ook $]^{14}$ het land van Jeanne d'Arc, Lodewijk den Heilige en Pasteur, en drink deze wijn, met eerbied voor diens edele hoedanigheid, op de gezondheid van uwen uitgejubileerden dienaar." ${ }^{15}$

De pastoor van Milhoven houdt de feestpredikatie; hij is een beroemde predikant in de streek. Tijdens de receptie glorieert hij nog en voelt zich ver verheven boven de schuchtere burgemeester. "Den pastoor van Milhoven, den feestpredikant, die staat daar ook, den stevigen buik vooruit in den langen toog, een hand in de sjerp voor de borst weggestoken en een sigaar losjes tusschen de lippen. Hij staat daar nog in al de glorie van zijn zeer schitterende feestpredikatie, waar ze hem natuurlijk allemaal nog op aankijken. Hij lacht breed en royaal, terwijl hij naar den burgemeester luistert." ${ }^{16}$

Coolen, De Schoone Voleinding, 98.

Streuvels, De oogst, 55.

AMVC, inv. nr. C 3475, brief Coolen aan Streuvels, 31 januari 1933.

Hier [en in de andere drukken] ontbreekt het woord 'ook'.

Coolen, De Schoone Voleinding. 190.

Coolen, De Schoone Voleinding. 172. 
De preek en het dankwoord van Vogels leveren het contrast, als hij op de nederige rol van de priester wijst: "Het offer van de priester maakt hem tot uw nederigen en armen dienaar. Uw vreugd is de zijne, uw verdriet het zijne, hij moet zichzelf en zijn belangen uitschakelen voor de uwe, hij moet u met heel zijn hart en heel zijn goede wil zijn toegedaan." ${ }^{\text {"17 }} \mathrm{De}$ pastoor Van de Leemberg vindt dat Vogels in deze preek het priesterschap en de priester in de waardering van de parochianen neerhaalt. De volgende dag geeft pastoor Vogels het gekregen geld aan de armen. Hij zegt erbij dat ze het niet tegen de armenmeester en de "Vincentianen" moeten zeggen, anders trekken die het weer af van de bedeling en "dan hedde ge nog niks extra's voor mijn feest."

In dit breed uitgewerkt jubileum kan Coolen zijn visie op de mens kwijt, zoals hij die al in zijn vroege brieven aan Lutkie verwoordde. Coolen heeft een hekel aan verwaten pastoors en onderwijzers, die menen de wijsheid in pacht te hebben, maar ook aan de liefdadige die de baas wil spelen over de behoeftige.

Coolens beschrijving van het feest zal gebaseerd zijn op een mengeling van ervaringen in Deurne en Hilversum en omstreken. Coolen heeft in de afgelopen tien jaar immers hele pagina's van De Gooische Post gevuld met verslagen van zilveren en gouden priester- en kloosterfeesten. Hij heeft de retoriek van burgemeesters, pastoors, onderwijzers en voorzitters van feestcomités moeten aanhoren en de kromme gedichten gelezen op de erebogen. Daarom 'dicht' hij voor pastoor Vogels:

"Heil den Herder uit de Peel

In 't gouden Jubeljaar,

Wij zingen nu bij luit en veêl

Dat God Hem voor ons spaar'.

Hem siere eens in 's Hemels woon

D'onsterfelijke Gloriekroon."

Dit soort pastoorsfeesten begon meestal zondags na de Hoogmis, waarbij het Lof, een korte eredienst in de middag, als een pauze in het diner werd gezien.

In de opvolger van pastoor Vogels, kapelaan Smulders, tekent Coolen een nieuw 'soort' priester. Deze wil het verenigingsleven en de 'standsorganisaties' flink uitbreiden. Vooral het 'jeugdwerk' noemt hij een belangrijke factor. Hij zou heel wat te doen krijgen "om de parochie wat op te halen en een vernieuwd parochieel leven op te bouwen. Opbouwen noemde hij dat." ${ }^{18}$ Dit laatste is heel modern, want in die tijd is er nog maar één opbouworgaan: sinds I 926 in Drenthe. Pas na de Tweede Wereldoorlog zullen in alle provincies opbouworganen . instellingen die zich met de inrichting van het sociale domein bezighouden - verschijnen . Smulders wil de jeugd vormen. Dat doel wordt volgens hem niet bereikt door jongeren in de sacristie rond te laten lopen en een kelk te laten zien of door ze in een mallemolen te laten zitten. De kapelaan preekt over de gevaren van de lichtzinnigheid, de genotzucht en de slechte kleding van de modekoningen uit Frankrijk. Dit is in die tijd trouwens niet specifiek voor het katholieke volksdeel; ook in de socialistische jongerenvereniging AJC worden drank, stad en mode ingeruild voor wandelen en volksdansen in de vrije natuur.

Coolen schetst de houding van pastoor Vogels als sympathieker dan die van zijn kapelaan. Vogels wil preken vanuit het positieve, door de soberheid die er bij de parochianen is aan te moedigen als een volksdeugd. Ook klinkt Coolens liefde voor Frankrijk door. Pastoor 
Vogels heeft een zwak voor deze "oudste dochter van de moederkerk." Er zijn er zoveel die altijd maar zeggen dat Frankrijk slecht is, dat er gerust een paar mogen zijn die het tegendeel beweren, vindt hij.

Coolen staat hier in de traditie van het denkend deel van de katholieken, de lezers van De Tijd, die zeer Frans georiënteerd zijn. Van Duinkerken kreeg bij zijn aanstelling bij De Tijd te horen dat hij vooral over Franse literatuur moest schrijven, omdat die minder discutabel zou liggen bij pastoors en kapelaans. ${ }^{19}$ Coolen ziet echter ook een groep die helemaal niet leest en zeker niets uit Frankrijk, dat al vanaf de tweede helft van de negentiende eeuw, vooral door Parijs, een wufte status heeft gekregen. Hij laat de kapelaan met de moderne ideeën aansluiting zoeken bij de conservatieve smulpaap, de pastoor Van de Leemberg. Beiden spotten met de voorliefde voor Frankrijk van pastoor Vogels en bekritiseren zijn eigengereide vorm van liefdadigheid bedrijven. Een pastoor is volgens hen geen charitatief ambtenaar of filantroop, maar in de eerste plaats zieleherder, gericht op het geestelijk en eeuwig welzijn van zijn kudde. Het dankwoord van Vogels op zijn feest over de nederige priester vinden zij dan ook een aanfluiting voor hun ambt. De moderne kapelaan is even conservatief, verwaand, onbarmhartig en cultuurloos als veel pastoors van de oude garde, is de boodschap van Coolen. De zondigheid verjaag je niet door verboden en straffen, maar alleen door zelf in de praktijk te brengen wat je preekt, zoals Vogels doet.

\section{Exegese en kritiek}

Van Duinkerken verwacht dat De schoone voleinding in pastorieën een prachtige afzet zal vinden, omdat de ideale dorpspastoor erin wordt geschilderd. Hij constateert dat nu, vijf jaar na Coolens eerste grote roman Kinderen van ons volk, zijn talent rijper is geworden. De taal van Coolen, "dat wonderlijk element, waaraan hij geheel eigen vormen gaf, werd gehoorzamer aan zijn drift en aan zijn vaardigheid." Het romanschema is soepeler geworden, waardoor meer afwisseling mogelijk is, terwijl tegelijkertijd de eenheid sterker wordt volgehouden. Coolen is op dit moment de beste beschrijver van het volksleven, vindt hij. Coolen verbindt het geloof in God met zijn geloof in de mensen, vooral in de persoon van pastoor Vogels, "de eenige geslaagde priesterfiguur uit onze moderne letteren." Van Duinkerken roemt Coolens wijsheid:

"Antoon Coolen is geen philosoof en zijn romans zijn nooit geschreven om iets te bewijzen. Maar hij is een kinderlijk-wijze en uit al zijn boeken straalt die wijsheid van zijn goede volk, zooals de zon straalt uit een spiegel, die haar vangt. Meer dan philoso-

phie is deze wijsheid, zooals het leven meer is dan een stelsel. Zij is de persoonlijke stuwkracht van Coolens talent."

In zijn slotopmerking prijst hij De schoone voleinding als het boek van Coolens hart, zoals De goede moordenaar het boek van zijn techniek was. Coolen is volgens hem een spontaan talent, dat op dat moment door niemand wordt overtroffen. Het is mogelijk dat Coolen voor een volgend geslacht niet veel meer zal betekenen dan de "charme der eenvoudigen," 
maar dan is het ook waarschijnlijk dat menig lyrisch talent van dat moment verouderen zal tot de risée der geleerden. Hij wil niet twisten over welk lot het meest begerenswaardig is, maar stelt vast dat Coolen in ieder geval nu bewondering verdient voor de vaardigheden van zijn talent en onze liefde verovert door zijn spontane hartelijkheid. ${ }^{20}$

Het is aardig geformuleerd, maar het lijkt er toch ook een beetje op dat Van Duinkerken zich hier wat indekt tegen mogelijke toekomstige kritiek. In feite zegt hij: het is goed gedaan, maar het is geen literatuur van blijvende waarde.

In een lovende kritiek in de socialistische krant Het Volk koppelt A.M. de Jong zijn bewondering voor Coolen aan kritiek op Van Duinkerken, zonder deze laatste overigens te noemen. Hij vindt ook dat pastoor Vogels iets heeft van een heilige, maar protesteert er tegen dat de goedheid van deze pastoor ingelijfd wordt als Christelijke liefde. Ook Confucius, Boeddha en Mohammed hadden deze goedheid en liefde, "die in zijn diepste wezen de schoonste bloem is van de zuivere, simpele menselijkheid en te vinden overal, in alle kringen, onder alle volken, onder de aanhangers van elk geloof en ... ongeloof." De Jong benadrukt dat Coolen er hetzelfde over denkt. De ongelovige notaris is een goed mens en bij de gelovige pastoors en kapelaans komt veel opgeblazen ijdelheid, genotzucht en kleinzielige eigengereidheid voor. Deze mensen schieten te kort in liefde, ootmoed en eenvoud, die samen het ruggenmerg vormen van het waarachtige christendom. Coolen verdient volgens De Jong lof én eerbied voor de moed waarmee hij deze zaken aan de orde stelt, want het zal hem kwalijk genomen worden.

"Om deze dingen hou ik van Antoon Coolen en zijn vurige geest, katholiek in elke vezel, maar katholiek in zuiver religieuze zin, zonder de in politieke strevingen wortelende geestdrijverij, die het Nederlandsche katholicisme meer en meer een calvinistisch karakter geeft, volgens de onontkoombare wet, die wil, dat concurrenten gedoemd zijn elkaars gehate karaktertrekken over te nemen om de concurrentiestrijd te kunnen volhouden."

Het is opmerkelijk dat de socialist De Jong hier toch dichter bij de bedoelingen van Coolen staat dan de jonge katholiek Van Duinkerken. De recensie van De Jong illustreert hoe literatuurkritiek in die tijd verweven is met levensbeschouwelijke tegenstellingen. Het lijkt wel of Van Duinkerken en De Jong elk aan één arm van Coolen rukken en allebei roepen: "Hij hoort bij óns!"

De Jong ziet wel zwakke plekken in het boek. Hij handhaaft zijn bezwaar tegen het gebruik van het dialect door de verteller. Bovendien valt hem op dat de boeren, de landschappen en de seizoenen steeds meer geïdealiseerd worden, waardoor clichématigheid dreigt. Daar staan echter veel sterke passages tegenover en door heel het boek is er "die zachte, dringende menselijkheid, die maar hoogst zelden naar het sentimentele zweemt." Ondanks diens vijf of zes romans ziet hij in Antoon Coolen nog steeds een jong auteur, "die niet vast mag en naar mijn overtuiging ook niet vast kán lopen in de te beperkte wereld van de Peellanden." 21

Dat is Coolen ook niet van plan. De titel van het boek, De schoone voleinding, zegt het al: het is de laatste van een reeks peelromans en ook de laatste waarin het idioom van de verteller een bijgeschaafd dialect is. Zoals A.M. de Jong opmerkt, komen in deze roman al passages 
voor die in gewoon Nederlands zijn geschreven. Het boek is de weergave van Coolens zonnige kant. Het plezier in het beschrijven van de seizoenen, de mensen bij de openbare verkoop van de boerderij en het priesterfeest spat er op alle bladzijden af. Vooral in de accentuering van de rol van de kinderen en de tekening van het jongste zoontje van het gezin Timmers heeft hij heel zijn ziel van toegewijde en nauwkeurig observerende vader gelegd.

\section{Nieuwe perspectieven: Duitse vertalingen}

De belangstelling voor Coolens werk vanuit het Duitse taalgebied, waar zijn voorbeeld Streuvels al lang heel populair is, neemt toe. Al in I93 1 heeft Coolen veelvuldig schriftelijk contact met Theresia Happak-Metzler uit Wenen. Zij heeft Lentebloesem vertaald en wil nu graag Kinderen van ons volk vertalen. Coolen geeft haar toestemming en mevrouw Happak werkt daar eind I93 I begin I932 aan, zoals blijkt uit correspondentie over vertaalproblemen. ${ }^{2}$ Coolen heeft er echter kennelijk niet zoveel fiducie in en houdt haar aan het lijntje, want in april 1932 klaagt ze dat ze niets meer van hem hoort. In de zomer van 1932 toont Fischer Verlag uit Berlijn interesse in een mogelijke vertaling van De goede moordenaar. Hieruit komt een contact voort met dr. Georg Kurt Schauer, die van plan is deze vertaling op zich te nemen. In november 1932 geeft Coolen ook de vertaalrechten voor Kinderen van ons volken De schoone voleinding aan Fischer. ${ }^{23}$

Kort daarop blijkt dat Coolens uitgeverij Nijgh \& Van Ditmar de rechten liever bij Insel Verlag ziet. Coolen vraagt in november 1932 aan mevrouw Happak om haar vertaling naar de heer Peter Mertens van Insel Verlag te sturen. De heer Mertens is een Vlaming die in België veroordeeld is vanwege zijn Duitsgezindheid in de Eerste Wereldoorlog en is de naaste medewerker van de directeur en stichter van deze uitgeverij, dr. Anton Kippenberg. Deze heeft een grote belangstelling voor Vlaamse en Zuid-Nederlandse literatuur en heeft al vanaf de Eerste Wereldoorlog contact met Stijn Streuvels, wiens werk hij ook uitgeeft, samen met dat van Timmermans en Claes.

Felix Timmermans heeft Coolens werk bij Kippenberg geintroduceerd. Hij schrijft op 8 februari 1933 aan Coolen: "Heb eergisteren met dr. Kippenberg gesproken. Hij vindt uw boek mooil Ik ben blij dat ik U daar heb binnen kunnen brengen. Een schoon Verlag. Over uw boek steek ik voor de Radio een fusee af!"24

Insel Verlag heeft een naam hoog te houden. Al gauw meldt Mertens graag Kinderen van ons volkte willen uitgeven, maar dat de vertaling van mevrouw Happak niet voldoet aan de eisen die de uitgeverij stelt. ${ }^{25}$ Mevrouw Happak eist van Coolen "klare wijn" en stuurt hem een afschrift van een brief van haar aan Insel Verlag, waarin ze stelt dat Coolen "mijn auteur" is. ${ }^{26}$ De brief brengt haar niet het gewenste resultaat. Uiteindelijk wordt, nadat

20 Van Duinkerken, 'De schoone voleinding'.

21 De Jong, 'Boek van schoone menschelijkheid'.

22 FPC, brieven van Theresia Happak-Metzler aan Coolen van 10 mei, 27 juni, 12 november en 21 november 1931 en 9 januari 1932.

23 LMDC, inv. nr. C 34 85, brief Coolen aan G.K. Schauer, 3 november 1932.

24 Durnez, Felix Timmermans, 493.

25 FPC, brief Peter Mertens aan Coolen, 16 januari 1933.

26 FPC, brief Theresia Happak-Metzler aan Coolen, 2 februari 1933 met als bijlage een brief van haar aan Insel Verlag van 27 januari 1933. 
Peter Mertens het een paar maanden zelf heeft geprobeerd, de vertaalopdracht aan het Duits-Nederlandse echtpaar Felix en Elisabeth Augustin gegeven. Deze maken er snel werk van, want de vertaling zal nog voor de zomer van 1933 als Brabanter Volkverschijnen. De kritieken zijn gunstig. Het Berliner Tageblatt schrijft: "Das Dorf wird zur Welt." Het blad Der Kunstwart constateert dat het publiek verzadigd is van de mateloze zucht naar problemen van de geest en stelt dat "diese von Boden, Wind und Heide geformte Sprachgestalt muss uns Deutschen diese Berührung mit einem starken Volkstum, mit einer in der harten Wirklichkeit des Alltages wurzelnden Gesinnungsehrlichkeit wilkommen sein. "27

In februari 1933 is Coolen vrij om ook de rechten voor De goede moordenaar aan Insel Verlag te geven, omdat de onderhandelingen met Hegener, de vertegenwoordiger van Fischer, zijn afgesprongen. ${ }^{28}$ Het eerste contract van Coolen met Insel Verlag wordt getekend op 24 januari r933. Het biedt hem een geweldig perspectief op een grote nieuwe lezersmarkt. Een week later valt er een zwarte schaduw over Duitsland als Hitler op 30 januari met een grote fakkeloptocht door de Wilhelmstrasse in Berlijn gehuldigd wordt als de nieuwe rijkskanselier.

\section{Redactielid van De Gemeenschap}

In eigen land leidt Coolens bekendheid tot nieuwe activiteiten. In het najaar van I932 treedt hij toe tot de katholieke Kunstkring De Violier in Amsterdam. Zijn onzekerheid in dit soort situaties blijkt als hij bij Van Duinkerken informeert of hij bij de installatieplechtigheid een smoking aan moet trekken. ${ }^{29}$

Ineens staat in het januarinummer van 1933 de naam Antoon Coolen bij de redactieleden van De Gemeenschap. Hij blijkt zonder aankondiging of inleiding in de redactie te zijn opgenomen. ${ }^{30}$ Een jaar eerder had hij nog geweigerd, omdat zijn baas Aleven bezwaar had tegen de kritische koers van het blad. Het is niet onwaarschijnlijk dat Coolen, voorzichtig als hij is, nu eerst rugdekking gevraagd heeft aan president-commissaris van De Gooische Post, Wierdels, met wie hij eind december een gesprek heeft gehad. ${ }^{31}$

Het redacteurschap is voor Coolen de eerste officiële bevestiging dat hij ergens bij hoort in het veelkleurige veld van de katholieke jongeren. De reactie op zijn toetreding in het Katholiek Amsterdamsch Studentenblad moet hem in die zin goed gedaan hebben. Het blad schrijft: "In verzet tegen enghartig puritanisme, streven naar een ruimer bewegingsvrijheid van het katholiek gemoed en naar een inniger doorleving van de traditioneelbewaarde levenswaarden, is Coolen bewust een partijganger der Jongerenbeweging en het is den goeden verstaander niet moeilijk, aanknoopingspunten te vinden tusschen zijn werk en het algemeene streven der hedendaagsche jeugd. ${ }^{32}$ Het woord 'partijganger' zal Coolen niet zo goed bevallen zijn; hij wordt niet graag tot een partij gerekend.

De andere redactieleden van De Gemeenschap zijn Henk Kuitenbrouwer, zijn broer Louis [alias Albert Kuyle], de bekeerling A.J.D. van Oosten en Van Duinkerken die als informeel leider optreedt. In de redactievergadering van 2I januari I933 wordt Coolen in een "zeer geanimeerde en prettige vergadering" geinnaugureerd. Enkele dagen later torpedeert Coolen een voorstel van Albert Kuyle om te gaan samenwerken met het extreemrechtse blad De Stormer uit Delft. Hij vindt dat de redactie zich dan te nauw verbindt met een politieke groepering en zich op voorhand vereenzelvigt met een beleid dat men nog niet eens kent. Hij is dus niet bang om al bij een van de eerste gelegenheden zijn nek uit te steken. 
De opstelling van de pas aangetreden redacteur zet kwaad bloed bij Kuyle. Het zal een roerig jaar worden.

Coolen wijdt zich als schrijvend redacteur voorlopig niet aan commentaar en polemiek. Zijn bijdragen van dat eerste jaar bestaan uit legenden en heiligenlevens.

\section{Ontslag bij De Gooische Post}

Vanaf oktober 1932 heeft Coolen zijn gedachten over een mogelijke terugkeer naar Brabant gekoppeld aan een concrete plaats: het dorp Deurne waar hij is opgegroeid. In die maand overlijdt H.N. Ouwerling, de man die Coolen enkele maanden daarvoor in zijn bijdrage aan het Boekenweekgeschenk nog heeft geschetst als de leidsman uit zijn jeugd in Deurne. Bij de begrafenis is Coolen aanwezig. Ouwerling is zijn hele leven vrijgezel geweest en heeft slechts een broer in Tilburg. Vanaf de begrafenis moet Coolen zijn zinnen gezet hebben op het karakteristieke huis De Romeijn in Deurne, het huis dat Ouwerling in 1913 heeft laten bouwen en waar Coolen als aankomend journalist veel over de vloer is geweest.

De beslissing van Coolen om zijn baan op te geven en te verhuizen getuigt van veel zelfvertrouwen. Het is midden in de crisistijd en het derde kind is op komst; het wordt in de eerste maanden van 1933 verwacht. Hij heeft vertrouwen in de toekomst. Zijn boeken lopen goed: van Kinderen van ons volk zijn inmiddels vijf drukken verschenen, Het donkere licht heeft zelfs de achtste druk al gehaald en De goede moordenaar beleeft in het jaar van verschijnen reeds de tweede druk. Zelfs van De schoone voleinding ligt in de laatste maanden van 1932 al een tweede druk in de winkels. Het perspectief van de vertalingen in Duitsland zal waarschijnlijk de doorslag hebben gegeven.

In februari 1933 onderhandelt Coolen met de broer van Ouwerling in Tilburg over het huis De Romeijn. Een week daarna schrijft Coolen aan zijn Duitse vertaler dat hij eind april zal verhuizen "naar de streek waar mijn boeken gesitueerd zijn. Ik ga daar een mooi en groot landhuis bewonen, waar een tuin van $\mathrm{I} / 2$ hectare bij is met een flinken boomgaard." 3

Het werk op de redactie van De Gooische Post, gecombineerd met zijn schrijverschap, heeft hem de laatste jaren bijna dag en nacht in beslag genomen. Sinds er kinderen in het gezin zijn gebeurt het literaire werk aan "een blank-eiken tafel" in een werkkeet achter in zijn tuin. De collegiale contacten met zijn mederedacteuren bij de krant, de senior Ben Hulsman en de jongere Bernard Bekman, zijn steeds goed geweest. De laatste werpt een onverwacht licht op Coolen. Hij herinnert zich diens grote mate van "mallotigheid, van leroen Bosch-achtige clownerie. [...] Wij hebben toen vaak onze onbedaarlijke vreugde

26 FPC, brief Theresia Happak-Metzler aan Coolen, 2 februari 1933 met als bijlage een brief van haar aan Insel Verlag van 27 januari 1933.

27 Citaten zijn overgenomen uit: Sassen, 'Onder vier oogen', 311-315.

28 FPC, brief Coolen aan Insel Verlag, 27 januari 1933.

29 BA, brief Coolen aan Van Duinkerken, 18 october 1932.

30 Scholten, Aspecten van De Gemeenschap, 89.

31 Wierdels was president commissaris van de uitgeverij van de krant. Coolen meldt op 23 december 1932 aan Van Duinkerken dat hij Wierdels spreekt.

32 Geciteerd in: Van Duinkerken, Antoon Coolen, 67.

33 LMDC, inv. nr. C 3485, brief Coolen aan G.K. Schauer, 18 februari 1933. 


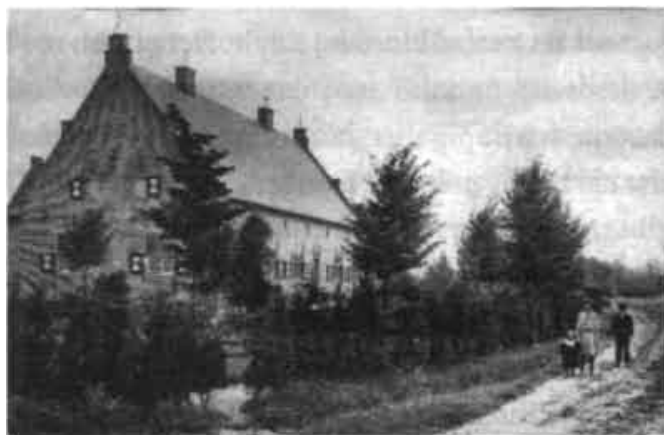

De Romeijn

beleefd aan een bepaalde humoristische karakteristiek in de journalist Coolen, die in brede kring - en laat het zo blijven - geen bekendheid kreeg." ${ }^{34}$

De verhouding met hoofdredacteur Aleven is echter nooit goed geweest. Nu Coolen begin I933 zijn ontslag aanbiedt, gaat Aleven hem dwarszitten en pesten. Het lijkt erop dat jaloezie in het spel is, zoals vaker voorkomt als de ondergeschikte de baas boven het hoofd groeit. Begin april schrijft Coolen aan Van Duinkerken:

“De ontslagtermijn bij De Gooische Post heb ik nog met een maand moeten bekorten, omdat het onder de plagerijen van Aleven niet langer uit te houden was - o.a. heeft hij mijn lezing in Utrecht, voor het Verbond van christelijke letterkundige kringen in Utrecht, op het laatste oogenblik verhinderd, door mij op te dragen een vertooning van de film Koning der Koningen bij te wonen, die ik reeds gezien had en waarover ik al een kolom in de krant had geschreven. Een aanbod van Bekman, die de film overigens ook al gezien had en er ook al in onze krant over had geschreven, om voor mij te gaan werd abrupt afgewezen: ik zou en moest naar de film, het éénige wat er dien avond te doen was, met mijn lezingen zeide Aleven niets te maken te hebben!" 35

Coolen moet om vier uur de lezing afzeggen, die op diezelfde dag om acht uur zou plaatsvinden. De kranten hebben ervoor geadverteerd en er komen 340 mensen voor niets. Op 3 I maart heeft Coolen een onderhoud met Aleven, waarbij deze zich "onhebbelijk gedroeg" en iedere faciliteit voor de voorbereiding van de verhuizing in april weigert. Toen "heb ik er meteen een eind aan gemaakt en heb mijn ontslag op staande voet ingediend,"schrijft hij aan Van Duinkerken. Hij zoekt nog naar een weg om zich voor de president-commissaris van de krant, Wierdels, "voor wien ik een diep respect heb, te rechtvaardigen en bij hem niet een verkeerden indruk van mijn heengaan achter te laten."

Zelfs na zijn verhuizing naar Deurne heeft Coolen nog last van de hoofdredacteur. "Van Aleven ... niets dan kwaads [...] Genoeg van deze vooraanstaande Hilversumse ingezetene met zijn bijzondere verdiensten voor de plaatselijke katholieke pers en voor de bestrijding van de zwembadgruwel, ${ }^{n 6}$ schrijft hij aan zijn vriend Piet Oomes in Hilversum. Een maand later meldt hij: "Van Alevens laatste briefje heb ik nog een restant van onpasselijkheid over, ik ruik en zie liever de Apenkooi in Artis." ${ }^{\text {37 }}$

Coolen heeft nu in De Gemeenschap een podium ter beschikking waar hij zijn boosheid kwijt kan. Het blad heeft een kritische rubriek 'Hagel', waarin op satirische wijze toestanden in de katholieke wereld aan de kaak worden gesteld. Hij schrijft er zelf voorlopig niet in, maar hij is ongetwijfeld de inspirator geweest van twee venijnige 'Hageltjes' in het meien julinummer van 1933. Ze zijn geschreven door H.K. [Henk Kuitenbrouwer, C.S.] en gericht tegen De Gooische Post en vooral de directeur/hoofdredacteur Aleven. De eerste 'Hagel' gaat over de wijze waarop De Gooische Post de driemaal gecoupeerde film Het Teken des Kruises behandelt. Kuitenbrouwer vindt het een draak van een film, maar constateert 
dat De Gooische Post eerst het geld voor de advertentie "dezer poenige film" incasseert en er vervolgens huichelachtig over publiceert.

“Het lijkt onaannemelik dat de opnemer der advertentie, de schrijver der minne beoordeling en de uitgever van De Bron van christelijke Geest ${ }^{38}$ een en dezelfde persoon is. Maar zelfs dat is in de wereld der katholieke pers mogelik. In ieder geval heeft deze directeur-redacteur blijkbaar niet voldoende uit die Bron geput. Is het niet redelik dat de uitgave van dit wekeliks missaaltje in andere handen komt? De poging om twee heren te dienen is in dit geval al te ergerlik." ${ }^{39}$

\section{Naar het land der vaderen}

Slechts enkele maanden voor de verhuizing naar Deurne, op 21 februari 1933, wordt Coolens derde zoon, Felix Paulus, geboren. "Felix Timmermans en Marieke zijn vrouw zijn peter en meter van de knaap, die naar zijn peter Felix en naar den grooten volksapostel Paulus genoemd zal worde," schrijft hij aan Van Duinkerken. ${ }^{40}$ Peter en meter kunnen niet bij de doop zijn. Hun rollen zullen waargenomen worden door Piet en Nettie Oomes uit

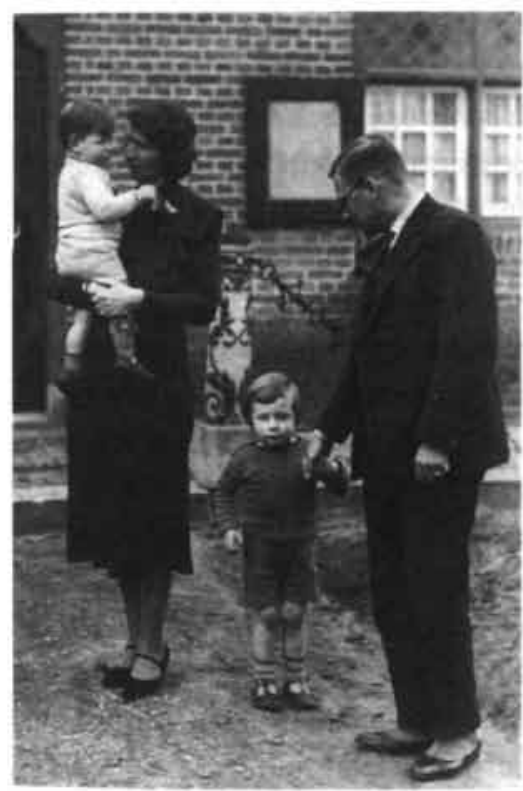

Voor De Romeijn. Hilversum. Coolen is al lang bevriend met de neerlandicus en Vondelkenner Piet Oomes. Door de afstand tussen Deurne en Hilversum zullen zij vanaf de verhuizing een levenslange en frequente briefwisseling onderhouden. Felix Timmermans heeft het geboorteprentje getekend: een sneeuwlandschap waar een kind uit een kool komt voor een huisje met ijspegels. Het huisje draagt het opschrift "Bij Anton [sic] Coolen!"

De familie Coolen wordt op 25 april 1933 uitgeschreven bij het Hilversumse bevolkingsregister en betrekt diezelfde dag huize De Romeijn in Deurne. Het enthousiasme over het huis zal niet blijvend zijn. Het is te vochtig, er is teveel tocht en er zijn ook technische problemen. De watervoorziening is "ondeugdelijk en onvoldoende." $^{n 1}$ De vrijheid en ruimte in de natuur maken echter veel goed. De kinderen

34 Bekman, 'De journalist Coolen', 636.

35 BA, brief Coolen aan Van Duinkerken, 2 april 1933.

36 LMDC, inv. nr. C 3485, brief Coolen aan Oomes, 28 mei 1933.

37 LMDC, inv, nr. C 3485, brief Coolen aan Oomes, 14 juni 1933.

38 Aleven is ook directeur van de uitgeverij Gooi en Sticht. Deze geeft samen met de Nationale Raad voor Liturgie en de Katholieke bijbelstichting het weekblad Bron van christelijken geest uit. Daarnaast is Aleven bestuurslid van de R.K. Vereniging van Nederlandse drukkerspatroons.

39 [Kuitenbrouwer], 'Hagel'.

40 BA, brief Coolen aan Van Duinkerken, 22 februari 1933.

41 LMDC, inv, nr. C 3485, brief Coolen aan Oomes, 28 mei 1933. 
hebben eigen kamers en een ruim grasveld en de werkhut heeft een plaats terzijde van het huis in de boomgaard gekregen. Een nieuwe waterpomp biedt geen oplossing en al in juni heeft "het hele gezin maagaandoeningen en verlies van de gelaatskleur."42 De verhuizing wordt ook nog overschaduwd door "een zware strop." Coolen heeft zijn huurcontract in Hilversum moeten afkopen met $f_{354,-}{ }^{43}$

\section{Columnist bij de Bossche krant}

In de eerste maanden na de verhuizing overheerst echter de euforie. Dat is te merken in zijn nieuwe rubriek in de Provinciale Noordbrabantsche en 's-Hertogenbossche Courant, Het Huisgezin, in de wandeling de Bossche krant genoemd. De column heet 'Brieven van de Romeijn' en staat elke zaterdag op de voorpagina als een forse twee-kolommer. Coolen zal die ruimte, met korte onderbrekingen voor vakanties, nauwgezet vullen tot aan het uitbreken van de Tweede Wereldoorlog. Het motto herinnert aan Alphons Daudets boek Lettres de mon Moulin.

In zijn eerste bijdrage bejubelt hij het zuiden. Onder de kop 'Herkenning in het land der vaderen' stelt Coolen dat zijn verhuizing geen vlucht is geweest, zoals Daudet uit Parijs is gevlucht naar de Provence. "Wij hebben niettemin de landelijke bekoringen van een Zuidelijke ballingschap, waar het goed heen keeren is van een vlucht uit het vermoeiende Noorden." Met trots vertelt hij over zijn tuin van een halve bunder; het is een paradijs en de wilde vegetatie lijkt op de "Dsjoengel". Schamper herinnert hij zich de Hilversumse tuintjes, die bestaan uit grint en een gazonnetje, en die zo klein zijn dat je er niet eens kunt harken of schoffelen vanwege de lengte van de steel. Hij is blij hier weer te wonen, waar de mensen groeten op straat en hij zal de lezers als "gelukkig weergekeerde" niet met sombere stukken lastig vallen. Hij prijst de lezers gelukkig als inwoners van een stad, die de Zuidelijke glorie is der Nederlanden of van de ingetogen dorpen in de Meierij. ${ }^{44}$

Ook zijn tweede bijdrage 'Boven en beneden de grote rivieren' is één grote lofzang op het zuiden. Hij wijst erop dat bijna alle inwoners van provincies die elders gaan wonen daar eigen clubs stichten, alleen de Hollanders die naar het zuiden komen doen dat niet. Dat komt omdat zij niets missen; integendeel, zij vinden hier wat ze altijd gemist hebben. Het noorden is koud en koel, met in de kerken kleurloos glas en een wit interieur. Tegenover de strenge Bach in Naarden staat Palestrina, "de liefelijkste stem van de katholieke kerk." In de zondagse straatjes van Holland hoor je alleen een huisorgel, in het zuiden de feestelijke, schetterende koperklanken van de harmonie na de hoogmis. Het zuiden wint het van het noorden zoals de warmte het, voor het gedijen van het leven, wint van de koude. Zoals de levensvreugd het wint van de levensmoraal. Zoals de kleur het wint van het kleurloze. Zoals het hart het wint van het verstand. ${ }^{45}$

Uit elk woord zingt de blijdschap om zijn terugkeer. Als enkele weken later het gilde van Sint Antonis Abt voor De Romeijn vendelt ter nagedachtenis van Ouwerling, schrijft hij een lovend stuk - 'De Gilde viert! ${ }^{146}$ - over de uitdossing van het Deurnese gilde dat et weer uitziet als in de oude archiefstukken uit de vijftiende eeuw.

\section{Aarden in Deurne}

$\mathrm{Na}$ dertien jaar Hilversum moet Coolen toch ook wel weer even wennen aan "dit stille dorp" Deurne. Hij is er door de familiebanden en regelmatige bezoeken echter geen vreem- 
de. Al gauw verrast de medicus en schilder Wiegersma hem met een schilderij. Deze komt op een middag onder het eten plotseling met zijn auto aanstormen en doet de familie Coolen een groot schilderij cadeau, een uit r93 I daterend zelfportret dat in Den Haag en Utrecht al eens geëxposeerd is, met persoonlijke opdracht bij de signatuur. "Ge begrijpt hoezeer we daarmee verrast en ingenomen waren en dat het ergens in ons huis een pièce de milieu vormt," schrijft hij enthousiast aan Oomes. ${ }^{47}$

Weldra komen er ook mensen logeren. In juni r 933 komt Ad. Sassen, redacteur van De Gemeenschap, die hem een marathoninterview afneemt voor De Boekenschouw. ${ }^{46} \mathrm{Hij}$ wandelt met Coolen in de omgeving en als ze samen in de zwaar gelambriseerde woonkamer zitten, voelt Sassen de sfeer en de plechtstatigheid van de schaakpartijen van pastoor Vogels en notaris Rosier van Heyste uit de roman Kinderen van ons volk. Coolen vertelt hem dat hij steeds gedacht heeft: als ik me nog eens vrij kan maken, kom ik hier weer wonen. Toen dat moment daar was, kwam toevallig dit huis van Ouwerling vrij, het huis waar hij voor het eerst in aanraking kwam met de letterkunde.

\section{Literair credo}

Het interview in De Boekenschouw geeft een goed inzicht in het leven en denken van Coolen op dat moment. Als Sassen het regionalismedebat en de opmerking van Marsman over het Europese niveau aansnijdt, veert Coolen op en laat lovende knipsels uit Duitse kranten zien over het pas vertaalde Kinderen van ons volk.

Op de vraag van Sassen naar de roeping en de taak van de katholieke romancier, antwoordt Coolen dat hij niet met een vooropgezet plan of bedoeling schrijft. Hij is katholiek en schrijft romans die bovendien ook nog in een streek spelen waar het katholicisme iets vanzelfsprekends is. "Dat vanzelfsprekende heb ik gemeen met alle menschen hier, ik kan het leven niet van uit een andere gezichtshoek zien en het verklaarbare ervan uit niets anders verklaren." Coolen voelt er kennelijk niet voor zich een katholiek romancier te noemen.

Coolens literaire voorkeur gaat naast Streuvels vooral uit naar Gorki, Dostojewski en de Skandinavische auteurs. Hij voelt zich een beetje verwant met de Fransen Louis Hémon en Marie le Franc ${ }^{49}$ en voor Mauriac heeft hij een grote bewondering. Van de Nederlandse schrijvers houdt hij het meest van Aart van der Leeuw en Arthur van Schendel, van de vertelkunst van Fabricius en van De stille plantage van Helman. Hij heeft zeer veel bewondering voor de schrijfkunst van Albert Kuyle. Niemand in Nederland weet zo gevoelig de taal te hanteren, oordeelt hij over zijn politieke opponent binnen de redactie van De Gemeenschap.

42 LMDC, inv. nr. C 3485, brief Coolen aan Oomes, 14 juni 1933.

43 LMDC, inv. nr. 3485, brief Coolen aan J. Reddingius, 7 juni 1933.

44 Coolen, 'Brieven van De Romeijn', 3 juni 1933.

45 Coolen, 'Brieven van De Romeijn', 10 juni 1933.

46 Coolen, 'Brieven van De Romeijn', 24 juni 1933.

47 LMDC, inv. nr. C 3485, brief Coolen aan Oomes, 28 mei 1933.

48 Sassen, 'Onder vier oogen', 311-315.

49 Louis Hémon (1880-1913), Maria Chapdelaine: récit du Canada français (1921) en La belle que voila (1923) vertaald als De schone van nooit weer (1960); Marie le franc schreef: Hélier, fils des bois, Prosateurs francais contemporains, 1930. 
Coolen is op dat moment niet bezig aan een roman. Ter voorbereiding van een mogelijk boek over Jeroen Bosch grasduint hij in de Bijbel, de heiligenlevens, het kerkelijk lexicon en de apocriefe evangeliën, de levensbeschrijvingen van Christus die door de R.K. Kerk niet als canoniek erkend worden. Die studie heeft hem geïnspireerd tot het schrijven van legenden, waarvan een aantal in De Gemeenschap gepubliceerd is en die in het voorjaar als een bundel zullen worden uitgegeven. Het boek over Jeroen Bosch zal heel anders worden dan dat van Felix Timmermans over Breughel. Hij vindt dat boek prachtig, maar het is toch te veel de geur, de reuk en de naïeve bewondering van Timmermans. Coolen wil een objectiever boek schrijven. Hij wil de figuur Bosch verklaren uit het ondoorgrondelijke herfsttij der middeleeuwen, "waarvan de levensspanningen mij nog heel wat zwaarder en grootscher lijken dan die van onzen tijd." Hij houdt er echter nog steeds rekening mee dat het niet lukt en dat hij het op moet geven.

Coolen kan zijn literaire opvattingen ook in een eigen rubriek aan de pers kwijt. Dezelfde krant, waarin zijn zaterdagse 'Brieven van De Romeijn' verschijnen, heeft hem ook gevraagd regelmatig 'Letterkundige Vergezichten' te schrijven. De klacht van Van Duinkerken over de onverschilligheid van katholieken ten opzichte van boeken en literatuur heeft effect gehad, want de redactie schrijft bij de introductie van Coolen dat zij hier een taak ziet liggen. De krant is blij dat "een van de op de voorgrond tredende jonge literatoren" bereid is gevonden deze taak op zich te nemen en hoopt dat Antoon Coolen onder "zijn Brabantsche volk" begrip, bewondering en liefde kan wekken voor de edelste der Schone Kunsten.

Het eerste boek dat hij bespreekt is Welaan dan, beminde gelovigen van Van Duinkerken. Het is het laatste van een trilogie. Na in twee delen het geloof tegen de 'ketters' te hebben verdedigd, worden nu de geloofsgenoten zélf bevestigd in hun geloof. Coolen wijst erop dat Van Duinkerken dat doet aan de hand van zeven strijdbare letterkundigen van de Middeleeuwen tot de moderne tijd en dat hij tegelijk kritiek op de conservatieve katholieken uitoefent, die de katholieke jongeren alleen maar dulden als zij vooral maar niets strijdbaars schrijven. De katholieke traditie is nooit anders dan strijdbaar geweest, toont Van Duinkerken aan. Coolen prijst hierom "den strijdbare jongere" en deze "uiterst begaafd en veelzijdig schrijver." 50

In een bijdrage over Aart van der Leeuw vergelijkt hij diens boek De kleine Rudolf met Demasqué der Schoonheid van Ter Braak. "Ziehier tegenover de intelligente hypochondrie van den smadende cynikus niets anders dan den dankbare levensaanvaarding van den van het leven en zijn helderheid vervulde." Volgens Coolen ziet Van der Leeuw achter de tragiek van de wereld en de verschrikkingen van de hedendaagse samenleving toch "de eindelooze schoonheid en beminnenswaardigheid van het leven. ${ }^{51}$ Het is hét adagium van Coolens levensvisie.

\section{Bejubeling van het zuiden}

In de zomer van 1933 krijgt Van Duinkerken de Van der Hoogt prijs van de Maatschappij der Nederlandsche Letterkunde voor zijn bloemlezing Dichters der Contra-reformatie. Coolen schrijft een vurige laudatio in zijn zaterdagse column, waarin hij de nadruk legt op de band van Van Duinkerken met Brabant. Hij ziet in de bekroning een erkenning van de 
jongerenbeweging en een nederlaag voor professor Brom, die steeds alleen maar de negatieve kanten daarvan heeft belicht. Het fundament van de beweging wordt gevormd door Roepingen De Gemeenschap. De vlag in het gewest mag uit, nu Van Duinkerken deze belangrijke prijs heeft gekregen. "Het zwaartepunt van onze beschaving is bezig zich opnieuw naar het Zuiden te verleggen. ${ }^{n 2}$

Coolen draagt daar in ieder geval zijn steentje aan bij, want in zijn 'Brieven van De Romeijn' zingt hij herhaaldelijk de lof van de cultuur en natuur van Brabant. Hij zet zich af tegen de streek waar hij dertien jaar gewoond heeft, het Gooi. Dit gebied was vroeger een even mooi natuurgebied als de Peel, de Kempen of de Meierij, schrijft hij, maar is nu totaal verpest door de forensen. De heide is verkaveld in villaterreinen met vreselijke Engelse namen als My castle, Sunrise, Elly's Home en Kitty's Paradise. Brabant heeft nog zijn lommerrijke wegen en zijn mummelende Dommel en er zijn gelukkig geen "grootsteden", die dat landschap bedreigen. ${ }^{53}$ Ook de Brabantse cultuur krijgt zijn volle bewondering. De jaarlijkse Omgang met de Lieve Vrouw van Den Bosch ziet hij als een manifestatie van een harmonisch gemeenschapsleven. Zoiets zou niet kunnen in Hilversum, dat [in die tijd, C.S.] wel groter en welvarender is dan Den Bosch, maar eenheid en historie ontbeert. Als in Hilversum grote bijeenkomsten plaatsvinden, dan zijn het betogingen die tegen elkaar zijn gericht. ${ }^{54}$

Op een wat bedekte manier reageert hij alsnog op de kritiek van Marsman en de groep rond Forum, als hij schrijft over de houding van intellectuelen, met hun alles doorhebbende schranderheid, die overal van verzadigd zijn en lijden aan een vermoeidheid die cynisch wordt. Deze mensen halen de waarden in het volksleven omlaag. Coolen wil geen oudemannetjes-romantiek bedrijven, maar hij ziet toch ook nog sprookjes, zoals het naderende zomerfeest der folklore in Oisterwijk onder leiding van de folklorist D.J. van der Ven. Hij constateert dat Brabant tegen de verdrukking in zijn volksziel ongerept heeft gehouden. Dit soort feesten zijn tekenen "dat men de uitingen van het volksleven en van de volks. kunst met nadruk zuiver wil houden in een tijd waarin het volksleven door overbeschaving, onverschilligheid en banaliteit juist zoo in zijn beste waarden dreigt te worden gesloopt." 55

\section{Politiek en volkskracht}

Deze eerbewijzen aan het eigene, het "landsche" van Brabant nemen in Coolens 'Brieven van De Romeijn' een steeds belangrijkere plaats in. Ook de begrippen volksziel, volkskracht, volksleven, volksaard, volkskarakter, volkswraak en volksgeheel worden veelvuldig gebruikt in zijn zaterdagse column. Deze termen zijn dan nog niet zo zwaar belast als ze later in de geschiedenis zullen worden, maar ze worden al wel door politieke machten gebruikt, in het bijzonder door tegenstanders van de democratie. De keerzijde van deze

\footnotetext{
50 Coolen, 'Van Duinkerken op den kansel'.

51 Coolen, 'Over Aart van der Leeuw'.

52 Coolen, 'Brieven van De Romeijn', 17 juni 1933.

53 Coolen, 'Brieven van De Romeijn', 8 juli 1933.

54 Coolen, 'Brieven van De Romeijn', 15 juli 1933.

55 Coolen, 'Brieven van De Romeijn', 22 juli 1933.
} 
woorden die zo het eigen volk benadrukken, is natuurlijk dat er anderen zijn, die niet eigen maar volksvreemd of volksvijandig zijn.

Op het moment dat Coolen deze columns schrijft, in de zomer van 1933, worden nog geen honderd kilometer naar het oosten al duizenden communisten en socialisten opgepakt vanwege hun internationale en dus volksvijandige ideeën. In de Nederlandse pers wordt daarover zeer neutraal bericht. De joden als 'vreemd volk' zijn in Duitsland al meteen slachtoffer en niet alleen door rechtstreekse maatregelen van het nazi-bewind, maar ook van onderop. De Bossche krant meldt al op 24 augustus 1933 dat de gemeenteraad van het dorp Grossgründlach op eigen houtje besloten heeft borden te plaatsen met het opschrift 'Joden toegang verboden.' Dit bericht wordt neutraal geplaatst en wijkt daarmee niet af van de gangbare gedragslijn in de confessionele pers, die in het eerste jaar van Hitlers dictatuur zelfs enige sympathie heeft voor bepaalde aspecten van het nationaalsocialisme. Zo waarderen kranten als de protestantse Standaard en de katholieke Maasbode "met name het idealisme en de bevlogenheid, de herwaardering van het organische karakter van de samenleving en de daarmee samenhangende bestrijding van individualisme en materialisme, belichaamd in het 'atomistische' liberalisme en 'goddeloze' marxisme. ${ }^{.56} \mathrm{De}$ Maasbode schrijft zelfs expliciet dat de krant het nationaal-socialisme alléén afwijst vanwege zijn houding tegen de katholieke kerk in Duitsland.

In Nederland wordt het nieuws over de machtsovername van Hitler overigens overstemd door de muiterij op de kruiser De Zeven Provinciën. Deze wordt begin februari 1933 voor de kust van Sumatra gebombardeerd, waarbij veel doden vallen. De affaire heeft zijn weerslag op de Nederlandse bevolking. De roep om een sterk gezag neemt toe. Er is veel kritiek op de werking van de democratie en de tegenstelling tussen stad en platteland wordt scherper. De Dietsche gedachte, waarbij gestreefd wordt naar een Groot-Nederland, leeft niet alleen in Vlaanderen maar ook in Nederland. De belangstelling voor het koningshuis neemt toe, zeker nu kroonprinses Juliana de huwbare leeftijd heeft.

Dit zijn allemaal onderwerpen die de lezers van de Bossche krant bezighouden en die ook regelmatig zullen opduiken in Coolens zaterdagse column. Echter, waar veel journalisten en schrijvers uit de directe omgeving van Coolen - onder andere Ad. Sassen die hem kort daarvoor geïnterviewd heeft - in nationaal-socialistisch vaarwater terechtkomen, vaart Coolen zijn eigen koers. Hij blijft schrijven over de folklore, het volksleven en de volksaard zoals hij altijd gedaan heeft, dat wil zeggen zonder daaraan een politieke kleur te geven. Daarnaast besteedt hij ook aandacht aan de ontwikkelingen in Europa. Hij schrijft dan vooral over de bedreigingen van de vrede in het algemeen. Hij zal, vooral na de inval van Italië in Abessinië, ook kritisch schrijven over Mussolini.

\section{Vlaams avontuur}

In de zomer van 1933 raakt Coolen die zich bijna niet met directe politiek of partijbelangen bezighoudt, toch nog betrokken in een politiek avontuur. Op ro juni organiseert de Nederlandsche Unie [niet te verwarren met de Nederlandse Unie die in het eerste jaar van de bezetting ontstaat, C.S.] weer zijn traditionele Dietsche Landdag en wel in Mechelen. Deze Unie is in 1929 opgericht in Roosendaal en heeft als doel om Nederland en Vlaanderen te verenigen. De landdagen worden afwisselend in Nederland en Vlaanderen gehouden. In Nederland zijn in die tijd veel mensen actief rond het idee van de Groot- 
Nederlandse en de Grootdietse Gedachte. Deze gedachte is vooral geinspireerd door het werk van de historicus Pieter Geyl: Geschiedenis van de Nederlandse Stam. In Brabant krijgt deze gedachte een speciale variant, waarbij Brabant wordt gezien als een schakel tussen Vlaanderen en Holland." Bekenden van Coolen als Gerard Knuvelder en dr. H. Moller, die dan Kamerlid is voor de R.K. Staatspartij, lopen hier warm voor. Zowel aan Nederlandse als aan Vlaamse kant wemelt het in deze bewegingen van mensen met ondemocratische en nationalistische politieke opvattingen. Het is dan ook begrijpelijk dat de Belgische overheid nerveus reageert zo kort na de machtsovername in Duitsland, waarbij het immers ook ging om een combinatie van nationalistische en antiparlementaire krachten.

Coolen heeft zich, misschien wat naief, laten overhalen om te spreken op de Dietsche Landdag. Het feit dat dr. Moller er ook het woord zal voeren, heeft waarschijnlijk de doorslag gegeven. Coolen zal spreken over 'Het sociale element in de Nederlandse Letterkunde' en is van plan om de dag erna door te reizen naar Stijn Streuvels. Bij aankomst in Mechelen is de sfeer gespannen. Hij moet een verklaring ondertekenen dat hij geen politieke kwestie zal aanroeren. Deze wordt hem voorgelegd door "gendarmen in civiel." Op de beiaard van de Rombouts-toren worden 'De Vlaamse Leeuw' én 'Het Wilhelmus' gespeeld. Als na deze provocatie ook nog de Vlaamse activist professor Borms ${ }^{58}$ arriveert is de maat vol: de landdag wordt afgelast en de buitenlanders worden over de grens gezet. "Schandaal op een Dietschen Landdag te Mechelen. Het Kamerlid dr. Moller over de grens gezet. Antoon Coolen en professor Geyl deelen hetzelfde lot," kopt de Bossche krant. Coolen doet zijn relaas en bekent dat het een merkwaardig gevoel is om als "een staatsgevaarlijk wezen" behandeld te worden. Zijn plan om door te reizen naar Streuvels is niet doorgegaan en hij schrijft hem: "Waarschijnlijk hebt Ge in de kranten gelezen, hoe we met drieën door den sterken Belgischen Arm uit Uw schoon Vlaamsche land zijn verwijderd. ${ }^{.59}$ Per omgaand reageert Streuvels wat vaderlijk. Hij vindt het jammer dat het bezoek hierdoor niet is door kunnen gaan en nog wel "in 't schoonste jaargetijde!" Hij heeft de verslagen gelezen in de bladen en zich afgevraagd "in welk gezelschap is die man toch verzeild geraakt!?"w0

Hiermee slaat Streuvels de spijker op de kop. Coolen houdt de lezing die hij voorbereid had over 'het sociale element in de Nederlandsche letterkunde' op 29 juni in Americain te Amsterdam. Ook dr. Moller is dan uitgenodigd door de Vlaams-Hollandse Vereniging 'Guido Gezelle'.6!

\section{Het nationale en het regionale}

In 1933 wordt in Nederland herdacht dat Willem van Oranje vierhonderd jaar geleden geboren werd. Met deze herdenking is iets nieuws aan de hand. In de negentiende eeuw,

56 Van Vree, De Nederlandse Pers en Duitsland, 349.

57 Ten Have, De Nederlandse Unie, 36.

58 August Borms (1878-1946), lid van de Vlaamse beweging; vanwege collaboratie met de bezetter in de Eerste en de Tweede Wereldoorlog gefusilleerd in Etterbeek in 1946. Elschot klaagde deze terechtstelling aan in zijn gedicht 'Borms' uit 1947.

59 AMVC, inv, nr. C 3485, brief Coolen aan Streuvels, 14 juni 1933.

60 FPC, briefkaart Streuvels aan Coolen, 16 juni 1933.

61 Vereeniging "Guido Gezelle." Een lezing van Antoon Cooler' [ingezonden mededeling in rubriek 'Kunst'], in: Algemeen Handelsblod, 22 juni 1933. 
maar ook nog in 1929 bij de herdenking van de oprichting van de Unie van Utrecht, waren de herdenkingen sterk gericht op het verleden en werden de verschillen in het heden van. uit dat verleden verklaard. We herinneren ons nog het stukje dat Coolen in De Gooische Post schreef toen het Brabantse College van Gedeputeerde Staten weigerde om de herdenkingsbijeenkomst in de Dom bij te wonen. Coolen wees er toen op dat de Dom van origine een rooms gebouw was en schreef smalend over een socialistisch raadslid dat weigerde een jacquet aan te trekken. In 1933 is er iets veranderd; nu wordt de Nederlandse samenleving zoals die is gegroeid, meer geaccepteerd. ${ }^{62} \mathrm{Nu}$ wordt Oranje als een voorbeeld gebruikt voor de toekomst van het Nederlandse staatsbestel. Ook in de columns van Coolen is deze omslag te zien; hij ziet de toekomst hoopvol tegemoet. Aan de vooravond van Koninginnedag, 3 I augustus I933, constateert hij dat protestanten, katholieken en ook socialisten elkaar vinden rond de troon. In de gemeenteraad van Zeist hebben zelfs vijf socialistische raadsleden een gelukstelegram mede ondertekend. Dit schept, volgens Coolen, een goede bodem voor de volksaard, die dan minder gevoelig is voor een machts. verschuiving zoals in Duitsland heeft plaatsgevonden. Hij constateert dat het naoorlogs revolutiesentiment een vergissing was. "We zijn een ingedijkt landje, waarop de Europese omwentelingen geen vat hebben." ${ }^{\text {63 }}$

Dijken interesseren hem kennelijk, want kort daarna trekt hij bij de opening van de Afsluitdijk alle registers open in 'Bodem van Volkskracht'. ${ }^{64}$ De dijk is natuurlijk erg voor de vissers, maar "het zwaartepunt van onzen volkskracht ligt historisch bezien in den landbouw." De nieuwe landbouwgrond die nu in het IJsselmeer ter beschikking komt kan het evenwicht tussen stad en platteland weer herstellen. De trek van het platteland naar de industriesteden heeft volgens Coolen vérstrekkende gevolgen voor "ons volkskarakter," want juist in de strijd van de boer tegen de natuur ligt de grote volkskracht. Coolen is toch meer gebiologeerd door het zaaien, groeien en bloeien, dat aan het oogsten vooral gaat. De visser oogst alleen maar, de vis is er al en hoeft 'alleen maar' gevangen te worden.

Het spreken over 'volkskarakters' is in die tijd heel gewoon. Waar dergelijke opvattingen over volkskarakters samengaan met politieke macht die gebaseerd is op rancune, kan echter een levensgevaarlijk mengsel ontstaan. In diezelfde tijd, oktober 1933, wordt in Duitsland verklaard dat het 'Volksschicksal' zal afhangen van het 'Bauernschicksal' en dat de ondergang van de Duitse boer de ondergang van het hele Duitse volk zal betekenen. ${ }^{65}$

Intussen schrijft Coolen met genoegen over de opleving van het volksleven in de oude gilden en hij prijst het standaardwerk dat daarover geschreven wordt door A. Jolles ${ }^{66}$ in opdracht van het Provinciaal Genootschap. Bij het sagenboek van "sagenvader" Sinnighe bij uitgeverij Eigen Volk is het alsof hij in "de ziel van ons volk" leest. De verhalen geven de sfeer van het haardvuur, de schemer en het keukenvertrek, schrijft hij. ${ }^{6}$

Coolen heeft in die tijd minder oog voor het misbruik dat politiek kwaadwilligen van zijn opmerkingen over volkseigen en volkskracht kunnen maken. Hij ziet echter wel dat er ook duistere kanten aan de folklore zitten. Naar aanleiding van een incident in Berlicum bij Den Bosch schrijft hij over het volksgericht, het zogenoemde 'tafelen' of 'toffelen'. Hij vindt dat primitief, humorloos, alleen gericht op kwetsen en lawaai maken. Coolen vergelijkt het met het ontgroenen bij studenten, waarbij dat jaar twee zwaargewonden vielen. Er zijn zelfs al mensen die 'het toffelen' om nostalgische redenen willen idealiseren. Hier moet rigoureus mee gestopt worden, want dit soort zaken wordt het zuiden door de noof 
derlingen dubbel aangerekend. ${ }^{68}$ Deze laatste opmerking is natuurlijk gebaseerd op zijn dertienjarige journalistieke ervaring tussen de 'noorderlingen' in Hilversum en omstreken. Het gaat Coolen echter niet in de eerste plaats om de beschadiging van het imago van het zuiden. Zijn voornaamste drijfveer om dit stukje te schrijven is de afkeer van geweld. Al in een van zijn eerste novellen, Peerke dat manneke, heeft hij de gruwelijkheid van dit wrede volksgericht en de ontreddering die dat veroorzaakt beschreven.

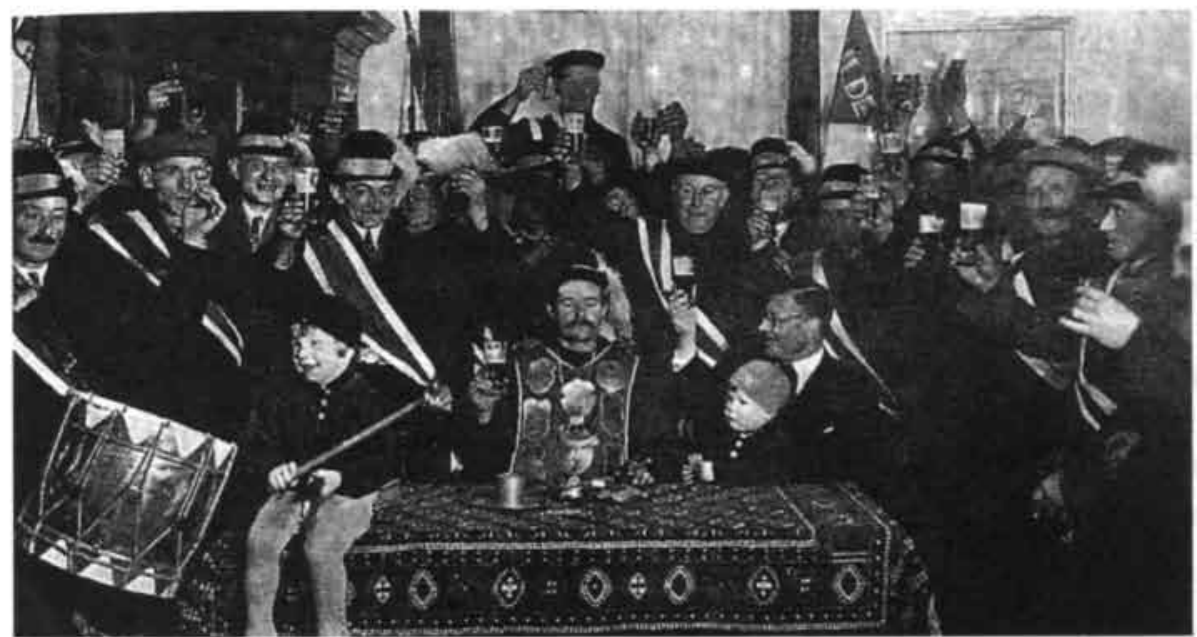

Het gilde St. Anthonius Abt op bezoek in De Romeijn. Coolen met Guido op schoot, Stijn zit op tafel. Coolen wordt later beschermheer van dit gilde. Zijn zoon Guido heeft deze functie later overgenomen.

Coolen is blij weer in Brabant te wonen. Zijn stukjes in de Bossche krant getuigen daarvan. Steeds roept hij: Hier hoor ik bij. Hier wil ik bij horen. Ik ben een van jullie. In werkelijkheid bestaat er echter toch distantie. Coolen voelt zich op zijn gemak daar waar het ritueel en het decorum de sfeer bepalen: in het gilde waarvan hij beschermheer is en later in het bestuur van het Provinciaal Genootschap. Hij is ook graag gastheer bij het jaarlijkse feestdiner van de redactie van De Gemeenschap. Hij voelt zich echter niet thuis bij carnaval, kermissen en andere massabijeenkomsten.

62 Dorsman, Het zoet en het zuur, 11-12. De auteurs stellen in het boek dat deze omslag ook al in 1929 aanwezig was, maar toen was er toch nog oud zeer zoals uit de strubbelingen rond de herdenking in de Dom blijkt.

63 Coolen, 'Brieven van De Romeijn', 30 augustus 1933.

64 Coolen, 'Brieven van De Romeijn', 30 september 1933.

65 Speliers, Als een oude Germaanse eik, 293.

66 Jolles, De schuttersgilden.

67 Coolen, 'Brieven van De Romeijn', 25 november 1933.

68 Coolen, 'Brieven van De Romeijn', 21 oktober 1933. 


\section{Terug in de Peel}

"De reinigende kracht van het natuurgebonden leven" $1933-1934$

In het najaar van 1933 is Coolen al aardig ingeburgerd en heeft hij een plaatselijke kennissenkring opgebouwd. Dat is ook wel nodig vindt hij, want de winter in een dorp is anders dan in een stad. "Men voelt zich hier in het dorpsisolement sterk op elkaar aangewezen en sluit zich bij elkaar aan, vooral gedurende de lange winter."' De verjaardag van zijn vrouw Gerda op 7 september heeft tevens gediend als 'house-warming-party'. Om met veel mensen goed te kunnen kennismaken worden op twee avonden gasten ontvangen. Op de ene avond worden Wiegersma die nu Coolens huisarts is, met zijn vrouw en de dorpsnotaris "aardig, artistiek" - met vrouw en dochter uitgenodigd. Op de tweede avond komen andere kennissen, waaronder de tweede dorpsdokter. Coolen heeft ook nadien veelvuldig contact met Wiegersma. Hij zal hem op zijn verjaardag in oktober 1933 het manuscript van De goede moordenaar in leren cassette cadeau doen. De schilder en de schrijver hebben nu allebei een origineel werk van elkaar.

\section{De man met het Jan Klaassenspel}

Coolen heeft in dit drukke jaar toch de tijd gevonden om een novelle af te maken, die in het najaar van 1933 verschijnt: De man met het Jan Klaassenspel.

Een van de personages is de oude Corneliske Schoonewiel. Hij is vroeger lijnwachter geweest en loopt nu nog elke dag naar de spoordijk om het nummer van de passerende trein te prevelen. Corneliske woont alleen met zijn dochter Nolda. Een zoon van "kwajen oppas" [slecht gedrag. C.S.] is naar het dorp Horst America of misschien wel Pruisen gegaan en zijn vrouw heeft hij "af moeten geven;" ze is aan kanker gestorven.

Nolda heeft al ooit een vrijer afgewezen, waarna ze vanuit de omtrek drie zaterdag. avonden waren komen 'toffelen'. "O, dat getoeter, dof en domp en sarrende hoog. Gebrul op lampeglazen. En de ketelmuziek, steenen tegen de deur en 't raam, en de deurposten volgesmeerd met modder en vuiligheid uit den beerput." ${ }^{2}$

Verschillende weduwnaars hebben al eens iets geprobeerd. De "onkwetsbare" stroper Proens heeft een oogje op Nolda, maar zij wil hem niet. "Nog nie, zee Nolda, al waarde-gij den enigsten mens op de wereld. ${ }^{-3}$ Op een avond laat Nolda een vreemde in huis en "de wind uit het donker van de nacht komt met hem mee naar binnen." Hij is eigenaardig gekleed met een bontkraag, "gestriepte" broek en bemodderde gele schoenen. Corneliske wil hem wegsturen, maar Nolda maakt koffie en een boterham voor hem. Hij demonstreert zijn Jan Klaassenspel en vertelt dat hij uit Scheijndel komt. Nolda merkt op dat hij zich

I LMDC, inv. nr. C 3485, brief Coolen aan Oomes, 8 september 1933.

2 Coolen, De man met het Jan Klaassenspel, 9.

3 Coolen, De man met het Jan Klaassenspel, 15. 
soms tegenspreekt: de ene keer is hij alleen op de wereld, de andere keer heeft hij het over zijn oude moeder. Uiteindelijk gaat hij toch weg, maar laat zijn pak met de poppenkastspullen achter. Nolda speelt mijmerend met de poppen. 's Nachts luistert zij naar het geluid van de wind en denkt aan de man uit Scheijndel die daar buiten ergens rondloopt.

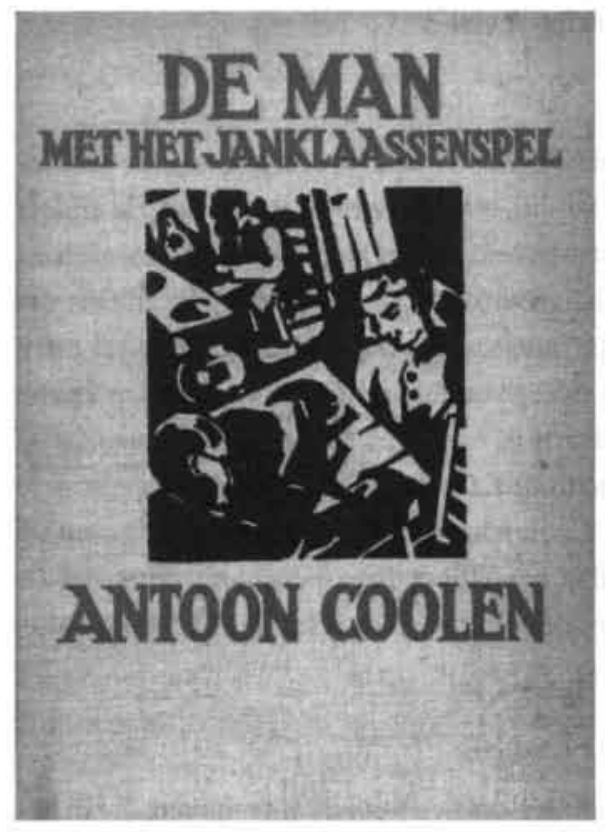

De volgende dag haalt de man zijn pak op. Hij mag van de pastoor voor de schoolkinderen optreden, vertelt hij en terwijl hij boterhammen eet, knipoogt hij tegen Nolda en trekt rare gezichten. Voor de voorstelling bezoekt hij een café, waar hij arg. wanend wordt bekeken. Op de vaststelling dat hij niet van deze kant afkomstig is, antwoordt hij: "Ik ben van alle kantes." Hij wordt dronken en de koster die hem komt halen voor de voorstelling moet eerst mee. drinken. Steunend op elkaar komen ze in de twee klaslokalen, met de opengeschoven tussendeuren. De voorstelling wordt toch een succes. De nonnen lachen om het hardst met de kinderen mee.

Als Nolda 's avonds op haar fiets van een schoonmaakkarwei op een boerderij komt, laat ze de man uit Scheijndel weer binnen. Hij mag nu blijven slapen. Hij speelt voor haar met de poppen; het gaat over een schone jonkvrouw en een vurige minnaar. De man uit Scheijndel "of waar hij vandaan was" blijft hangen. Corneliske vindt het maar niets; er komt praat van. Proens de stroper spreekt hem erop aan. Corneliske staart peinzend in het donkere water van de spoorgraaf. Thuis hoort hij z'n dochter giechelen en liedjes zingen. Ze schenkt "dieje mens uit Scheijndel" borrels. Corneliske denkt veel aan z'n vrouw en loopt rond het water van de IJzeren Man, de plas die overbleef na het uitgraven van het zand voor de spoordijk. Hij krijgt een plezierig gevoel als hij ernaar overbuigt.

De ene keer zegt de zwerver dat hij een zoontje heeft, de andere keer een dochtertje. Dan heeft hij weer twee kinderen: "een jungske en een durske." Opeens zijn het pleegkinderen. Nu heet het weer dat hij zijn moeder nooit heeft gekend. Hij wil Nolda's fiets lenen om een voorstelling in Horst America te gaan geven. 's Ochtends fietst hij weg en Nolda weet dat hij niet meer terugkomt. Corneliske vertelt het rond en weer komen de mensen 'toffelen' vanwege de weggestuurde vrijer uit Scheijndel en het afgesprongen huwelijk. Het duurt drie zaterdagavonden op rij. Na de derde keer zitten er aangeklede stropoppen op het dak. Met een "leer" [ladder, C.S.] en een bonenstaak haalt Nolda die eraf. Ze denkt veel na over haar ongeboren kind, maar ook over het sterven van haar vader:

"Daar zijn dingen, waarvan zij haar angstdroomen heeft. Een donker verblijf in de aarde, zij ziet den ingang ertoe, met het verdriet van het leven daalt men er in af. Ze ziet er haar vader ingaan en wacht tot hij er uit wederkeeren zal. Een klein kind komt er uit. Met klanklooze woorden, zóó zwaar van volle stilte, dat zij die in den verlamden mond niet vormen en zeggen kan, vraagt zij naar haar vader. Hoe kan dit worden verstaan. Zij 
krijgt een antwoord. Een ontkenning. Hoe zijn de getuigen tot haar gekomen, die haar het gezicht openbaren van een kleine man in de lengte gestrekt, de scherpe neus dood in het wit gezicht en de oogen blauw gesloten. Daarmee is het niet geleden. Met de zorg voor een doodkist voor vader is het niet geleden. Kleine handen, die door bloed genaderd zijn, liggen met zwaarte op haar mond en verstommen het geluid in haar keel." ${ }^{\mathrm{A}}$ Als ze kleertjes gaat naaien, wil Corneliske ontkennen wat hij denkt. Hij ziet hoe ze haar handen op haar zwellende buik legt. Hij probeert haar nog aan Proens te koppelen, maar die weet het al. Thuisgekomen zegt hij: "Oe fiets is nooit meer teruggekommen." Nolda antwoordt: "Da's ook nie erg. Een wieg heb 'k harder nodig als een fiets."

Corneliske loopt weer naar het water, maar keert toch weer om. In het schop haalt hij een touw, een "zeelke." Hij loopt ermee naar de zolder en verhangt zich.

"Een lichtstreep kiert over een grauw scherp hoofd, dat diep over de hals geknakt naar de borst gaat trekken, in de schaduw zijn twee onnozele beenkes hangend in de floddering van een broek, de voeten zijn van voren naar elkaar gekeerd, de schemering valt er mee samen. De stilte. De diepe avond." ${ }^{5}$

Zijn dochter vindt hem terwijl ze haar eerste wee krijgt. De verteller besluit met een beeld van de wegfietsende zwerver:

"Over de einder vloeit het licht. In de wielingen van het licht, in de roos van den dageraad, zit een zwart figuur, een gekromden kleinen man, onder de zwaarte van een vracht gebogen naar den driftige dans van knieën. Deze schaduw van dood en leven, den geheimzinnigen dood en het geheimzinnige leven in hun onverbrekelijk en diep verband, bereikt hem niet. Vóór hem blijft een andere lichte einder, daar dartelen lachende kinderen voor hem op, voor zijn ogen, juichend voor zijn handen, waarboven de poppen levend zijn. Kinderen, mijn God, altijd de kinderen. De horizon is licht van hun gedartel en hunne blijheid, de hemel, daar ze van zijn." ${ }^{6}$

\section{Fermate en rondo}

Deze kleine novelle vormt een bijzonder mooi eind, een soort 'fermate', van de reeks peelromans. Het werk is deze keer niet zo makkelijk uit zijn pen gevloeid als bijvoorbeeld Peelwerkers. Zelf zegt hij hierover:

"Ik denk, dat ik deze novelle ongeveer zeven maal heb geschreven, steeds aarzelend, hoe ik beginnen zou, met den zwerver, die langs het huisje komt waarin de vrouw zijner ontmoeting woont, of met die vrouw en haar huisje, waarlangs dan op een goejen dag de zwerver komt. Dit laatste is in den definitieven tekst de aanvang geworden van dit verhaal van een kleine honderd bladzijden, waarvan de compositie mij veel hoofdbrekens heeft gekost." ${ }^{\text {? }}$

Het verhaal is niet alleen een fermate, maar ook een rondo, waarin alle elementen van Coolens vertel- en beschrijvingskunst nog eens terugkomen. Alleen de humor komt door het gegeven van het verhaal minder aan de orde.

7 Coolen, 'Mijn werkmethode', 116. 
Opnieuw komt in deze novelle Coolens fascinatie voor de spoorweg naar voren. De beschrijving van de vroegere lijnwachter, Corneliske, doet denken aan de vrouw van de overwegwachter, Flore, uit Zola's La bête humaine die ook alle tijden en nummers van de treinen kent. Ook Zola beschrijft hoe een spoorlijn door een droefgeestig landschap "de gewaarwording van grote eenzaamheid nog versterkt." ${ }^{8} \mathrm{Al}$ eerder is opgemerkt dat de jonge Coolen als Zola-liefhebber dit boek heeft gelezen.

Ook de vreemde die voor enige tijd in een gemeenschap vertoeft en daarna weer verdwijnt, komt vaker voor in Coolens romans; men kan hier denken aan de kluizenaar in De goede moordenaar. Steeds wordt in het vage gelaten waar de mensen vandaan komen of naartoe gaan. De zoon van Corneliske is naar Pruisen gegaan "zeggen ze." De poppenkastspeler wordt wel "dieje mens uit Scheijndel" genoemd, maar de verteller weet het ook niet zeker, want vaak wordt eraan toegevoegd "of waar was hij vandaan." Bij zijn aankomst kwam hij uit Venlo gelopen, maar hij is ook in "den Bels" geweest. Eigenlijk woont hij in Scheijndel, zegt hij bij zijn aankomst. Al kent de lijnwachter de nummers van de treinen nog zo goed, hij weet niet eens hun bestemming: de ene gaat naar het noorden, de andere naar het zuiden.

Ook andere verhaalgegevens uit vroeger werk komen in de novelle terug. De uitzicht. loze toestand van deze vader en dochter lijkt op de situatie in het verhaal van Peerke dat man. neke en zijn vrouw van tien jaar daarvoor. Ook nu weer wordt er tot driemaal toe 'getoffeld"9 en eindigt het verhaal in grote somberheid. Evenals in het verhaal van Peerke komt ook in deze novelle het geloof of het begrip God niet voor. De R.K. Kerk is alleen vertegenwoordigd door enkele naieve, wereldvreemde 'nonnekes', die een middag veel plezier hebben bij de poppenkastvoorstelling en die niet eens opmerken dat de man van het Jan Klaassenspel zelf stomdronken is. Het einde, met de vader die zich verhangen heeft en de vrouw die niet alleen zwanger is, maar ook nog van haar fiets bestolen, is heel schrijnend. Er is geen troost van het geloof of van een van de sacramenten van de Kerk. Van Duinkerken zou zijn aanval op de 'instinct-causaliteit' uit de tijd van Peerke zo weer kunnen hernemen.

Heel mooi is het verband dat Coolen legt tussen kinderen en de dood, waarbij hij duidt op de kringloop van geboren worden, leven en sterven. Als Nolda in verwachting is, heeft ze een angstdroom. Zij ziet haar vader de donkere aarde ingaan, waarna er een klein kind uitkomt. Daarna ziet zij, als in een "voorschouw", het lijk van haar vader, maar kleine handen "die door bloed genaderd zijn" snoeren haar de keel. Nog voor de geboorte van haar kind zal de vader met "kinderlijke handen naar de genade van het touw" reiken en sterven.

\section{De kritiek}

In De Telegraaf vergelijkt Werumeus Buning de novelle met het pas verschenen boek Harten en Brood van Albert Kuyle. Hij vindt dit laatste boek simplistisch en ongeloofwaardig in vergelijking met de novelle van Coolen, waarin de echte eenvoud en bezieling zit. Coolens personages bestaan los van de schrijver. "Ze zijn onder zijn handen gegroeid en levende schepsels geworden. Hij oordeelt niet, hij laat ons het oordeel." Werumeus Buning noemt in deze niet-katholieke krant het geschetste leven "een tragisch leven, maar geen hopeloos en somber leven; een ruischende kracht, een elementair geweld. Het is dat onmis. kenbaar geluid, dat ons tenslotte een mensch en boek dierbaar maken. Provinciaal, Europeesch, wat zou het." ${ }^{10}$ Het gaat om dit geluid en hiermee geeft hij tevens kritiek op het artikel van Marsman over het Europees peil. 
In een antwoord aan Streuvels die hem een lovende brief had gestuurd, blijkt hoezeer Coolen nog last heeft van de naweeẻn van het regionalismedebat. Het ergert hem dat in de kritieken maar steeds aan dat "vruchteloos debat" wordt gerefereerd. Hij vindt dat Werumeus Buning goed gezien heeft waar het elementaire van zijn werk in gelegen is. $\mathrm{Hij}$ heeft door de haarkloverijen wel veel verdriet gehad."

Ook andere niet-katholieke kranten reageren positief op het boek. Het Algemeen Handelsblad roemt Coolens schilderachtige taal, waardoor de simpele geschiedenis diepte en reliëf krijgt: “De waarachtigheid van zijn visie op het leven is ook hier de groote kracht van zijn proza." ${ }^{12}$ De NRC oordeelt dat de novelle alle vroegere publicaties van Coolen heeft overtroffen. Ook hier uit de recensent bewondering voor de sobere schets van personages, die volkomen levend en menselijk aanvaardbaar zijn. Iets kritischer staat deze stil bij de stijl van Coolen, die tot een procédé geworden is. Het Brabants idioom is gelukkig ingeperkt, "maar het is de tot eentonig dreunend rhythme bewust effectrijk aaneen gerijde nevenschikking van korte volzinnen, als een soort incantatie overwegend meer in den tegenwoordigen en voltooid verleden dan in den onvoltooid verleden tijd verhalend, die hier al te duidelijk tot een manier werd." Deze stijl doet meer aan het nerveus jachtend modernisme van de nieuwe zakelijkheid denken en past eigenlijk niet bij deze romantische "beelding", vindt de NRC. Als Coolen het opzettelijk bedoeld heeft om deze romantiek niet te zoet te maken, dan is dat middel te uiterlijk, maar ook niet nodig want Coolen weet zijn vertelling geestelijk en psychologisch met genoeg realiteit te laden. ${ }^{13}$

De Groene Amsterdammer vergelijkt Coolen met de Vlaming Walschap, die karakter en situatietekening scherper uitbeeldt dan Coolen. Bij Coolen is echter een grote mate van lyriek en van naïeviteit van levensvisie aanwezig, die veel oprechter aandoet dan de hinderlijke tweespalt bij zijn Vlaamse kunstbroeder. Het blad betreurt het dat de zuivere en realistische aanzet van de novelle vervaagt en eindigt in een sfeer van "volslagen onwerkelijkheid, abrupt en helaas ook met een paar geforceerde ont- en opknoopingen." ${ }^{\text {14 }}$

Jan Engelman noemt in het katholieke blad De Nieuwe Eeuw het verhaal een groot werk van aangrijpende menselijkheid, omdat de werkelijkheid zo frappant zuiver, indringend en "concies" is en de levensliefde zo helder bewust en zonder sentimentaliteit. Ook hij haakt in op de polemiek over de regionale roman en het Europese peil: "Tusschen de klot en de dennen wordt het oude drama, de droom en de ontnuchtering, even hevig geleefd als overal elders, alleen maar wat stiller, verlegener, zonder groote woorden en wijde gebaren." 15

8 Zola, Het beest in de mens, 35.

9 Coolen besteedt aan deze vorm van volksgericht nog aandacht in zijn zaterdagbijdrage voor de Bossche krant van 21 oktober 1933 als de novelle op het punt staat om te verschijnen. De aanleiding is een geval in een dorp bij Den Bosch, maar een beetje indirecte aandacht voor zijn nieuwe boek kan geen kwaad. De column is aan het eind van het vorige hoofdstuk beschreven.

10 Werumeus Buning, 'De man met het Jan Klaassenspel'.

II AMVC, inv. nr. C 3475, brief Coolen aan Streuvels, 3 januari 1934.

12. [Recensie De man met het Jan Klaassenspel] in Algemeen Handelsblad.

13 [Recensie De man met het Jan Klaassenspef] in NRC.

14 [Recensie De man met het Jan Klaassenspe] in De Groene Amsterdammer.

15 Engelman, [Recensie] 'De man met het Jan Klaassenspef', 310. 
Jan Nieuwenhuis in de katholieke Maasbode zegt dat Coolen eigenlijk altijd novellen schrijft. Zijn romans zijn eigenlijk samenvattingen van verhalen, die door het regionaal karakter verbonden zijn in een eenheid van plaats. Nieuwenhuis legt een relatie met het geloof en constateert dat de kunstmatige verenging die "het materialistisch en deterministisch levensbeginsel" van het naturalisme in de kunst teweeg bracht nu verleden tijd is. "Want in dit boek, waarin van geen religieus beleven sprake is en nauwelijks van schuldgevoel, blijven de menschen mild beschouwd als schepselen Gods. Een onuitgesproken teederheid houdt dit alles op een waardig plan, een onzichtbare draad verbindt de levens aan elkander, en aan Eén die oordelen zal."16 Hieruit blijkt dat Nieuwenhuis de vroegere kritieken van Van Duinkerken goed heeft gelezen. De strekking van zijn kritiek is gelijk aan Van Duinkerkens beschouwing over De goede moordenaar. Ook Nieuwenhuis lijft Coolen aldus bij de katholieke romanciers in.

Ter Braak gaat in zijn overigens positieve kritiek in Het Vaderland verder in op de discussie over provincialisme en regionalisme. Het stuk begint en eindigt badinerend, met een verwijzing naar een bloemkwekersblad, waarin gemeld wordt dat er een tulp naar Antoon Coolen vernoemd is. Hij schetst de mogelijkheden tot verwarring tussen tulp en schrijver en benadrukt dat beiden "een gehechtheid aan de bodem" koesteren. "Coolen als tulp: dat beeld is lang niet gek. De statige vaste, stevige tulp, ieder voorjaar opnieuw uitbloeiend uit de van vruchtbare bemesting zwangere Peelbodem, heeft ons zeker iets te zeggen."

Ter Braak haalt Coolen aan uit een krantenverslag van een rede die hij in De Violier heeft gehouden. Hij citeert uit de krant:

"En de schrijver zou iets zeer belangrijks opgeven, als hij datgene, wat met geboorte en bloed wordt meegegeven, zou afsluiten. De duitsche litteratuur erkende de kracht van een gezond volkseigen reeds voor de totstandkoming van het tegenwoordig regiem en ze vond deze kracht in Holland vooral in de regionale litteratuur. En niet alleen de grond, de wind, de heide zijn onmisbare factoren, ook het taaleigen is verwant aan het zielseigen. Het idioom is geen kunstmatige aardigheid, maar het kenmerkt de personen van een bepaalde streek."

Ter Braak voegt eraan toe dat deze streek voor Coolen natuurlijk de Peel is. Hij vindt het een "aardige preek voor eigen parochie, waarin Coolen er als de kippen bij blijkt te zijn om de nieuwe koers in Duitsland ook voor Peelgebruik handzaam te maken."

Ter Braak benadrukt "de handigheid, waarmee het [idee] precies op het psychologisch juiste moment wordt gelanceerd. Een jaar geleden zou Antoon Coolen met zijn 'regionalisme' nog zeer weinig succes hebben gehad [...]; maar aangezien het tegenwoordig alles 'geboorte' en 'bloed' is wat de klok slaat, valt zo'n speech in de best denkbare bodem." Ter Braak is het eens met Coolen, dat je om over boeren te kunnen schrijven in de buurt van boeren moet zijn opgegroeid. Er zijn inderdaad te veel idyllische verhaaltjes over boeren geschreven (zoals door I.J. Cremer), maar als Coolen bedoelt "dat de 'gebondenheid aan een streek' voorwaarde is voor de schrijver als zodanig" dan komt hij in opstand:

"Antoon Coolen moet niet zoveel pretenties krijgen, dat hij de hele wereldlitteratuur gaat gelijkstellen met zijn op zichzelf lang niet onverdienstelijk vertelde geschiedenis. sen van agrarische mensen en dingen. En die 'geboorte' en dat 'bloed' moet Antoon Coolen s.v.p. niet laten uitdijen tot een mystiek van de Peel, want daartegen zal ik mij 
als Achterhoeker, die nog nooit een roman over de Achterhoek heeft geschreven, met hand en tand verzetten. Want waar moet men dan met de schrijvers van Californischlers-Gronings-Lettische afkomst naar toe? Moeten zij soms over alle vier hun Peelen tegelijk schrijven? Of moeten zij hun mond maar houden? Of, als zij er één van de vier uitzoeken: welke dan? In dergelijke onoplosbare problemen raken wij door de schuld van de Peel-'raciste' Antoon Coolen morgen aan de dag hopeloos verward." $\mathrm{Na}$ deze inleiding stelt Ter Braak vast dat De man met het Jan Klaassenspel Coolens stilistisch belangrijkste werk is. In sober proza heeft Coolen een bepaalde atmosfeer duidelijk gemaakt, vooral door zijn taal. Hij heeft zich beheerst in het gebruik van het dialect, maar Ter Braak vindt nog steeds dat dialect niet nodig is om mensen uit een bepaalde streek weer te geven. Een groot psycholoog onder de romanciers kan zijn personages karakteriseren zonder deze pittoreske hulpmiddelen. Volgens Ter Braak moet een schrijver er vanaf zien "om de boezeroens te vertonen en de tabakslucht te laten ruiken en het piepen van de wielen te laten horen en de bitterheid der liefde te laten proeven, [...] maar daarvoor is dan ook een meesterschap nodig, dat Antoon Coolen voorshands niet bezit." Coolen is het type van de romanticus, die meer romantische sentimenten in zijn werk opneemt dan zijn beginselverklaring zou doen vermoeden. "Alles verschijnt in een 'donker licht,' zelfs de wanhoopsdaad van Corneliske Schoonewiel."

In Ter Braaks kritiek is ook een bespreking van Herman de Mans Een stoombootje in den mist opgenomen. Aan het eind van het stuk vraagt hij op wat vileine, retorische toon wat Antoon Coolen daar nu van vindt. Ter Braak zelf is weliswaar geboren in een dorp, maar ziet zich toch meer als een echte stedeling, die meer op het geslepene en flitsende is belust dan op het landelijke en nadrukkelijke. Hij is daarom bevooroordeeld. Vindt Coolen De Mans boek ook niet een beetje dubbel en dwars uitvoerig? In een verwijzing naar De Mans joodse afkomst vraagt hij in hoeverre Herman de Mans geboorte en bloed hiervoor verantwoordelijk zijn. De stedeling moet over dit soort romans van bevoegde zijde voorgelicht worden, "en die bevoegde zijde is het beroepsregionalisme, het adviezenbureau voor de geestelijke tulpenhandel, gelijk de bloemkwekers intuïtief hebben beseft."

Tegen zijn gewoonte in reageert Coolen op deze kritiek in De Tijd. Hij zegt dat hij in zijn rede bij De Violier het tegengestelde heeft gezegd van datgene wat in de krant stond. Hij heeft het regionalisme verdedigd, maar niet gezegd dat het de ideale letterkundige kunstvorm zou zijn. Hij heeft het regionalisme willen verdedigen tegen een bepaalde vorm van kritiek en aan willen tonen "dat het in zich niet noodzakelijk minderwaardig behoeft te zijn." Een schrijver wil personages scheppen waarin de "algemeene menschelijkheid" ligt weerspiegeld. Als dat lukt in een gewestelijke roman, "dan heeft de schrijver zijn streekgebondenheid als een krachtig voordeel mee." De schrijver zou een waardevolle bezielings. bron afsnijden, "als hij dit als een minderwaardig provincialisme terug zou wijzen." De reserves die Menno ter Braak heeft, zijn de reserves die Coolen zèlf in De Violier naar voren heeft gebracht. ${ }^{18}$

\footnotetext{
16 Nieuwenhuis, 'Ernst en luim'.

17 Ter Braak, 'Provincialisme-Regionalisme'.

18 Coolen, 'De Streekroman'.
} 
Coolen moet zeer nieuwsgierig geweest zijn wat Van Duinkerken van de novelle vindt. De laatste reageert echter noch per brief, noch met een recensie in De Tijd of in een ander periodiek. Het lijkt er sterk op dat Van Duinkerken zijn mederedacteur van De Gemeenschap in deze moeilijke tijd niet wil afvallen in het openbaar, want het kan bijna niet anders of hij moet de novelle op grond van het gemis aan een katholieke strekking verwerpen. Hij had kunnen aansluiten bij de kritiek van Jan Nieuwenhuis in De Maasbode, die in ieder geval een relatie van het boek met het geloof in God heeft gelegd, en misschien ook bij zijn eigen visie op De goede moordenaar. Uit zijn latere behandeling van de novelle in de biografische schets ${ }^{19}$ van Coolen bij diens vijftigste verjaardag blijkt dat ook wel. Zuinigjes meldt Van Duinkerken dat De man met het Jan Klaassenspel "door menigeen voor zijn beste werkje gehouden" wordt en dat het verhaal enige overeenkomst met 'Het Woud' uit de bundel Zomerland van Streuvels vertoont. Vervolgens doet hij niet veel meer dan een samenvatting geven van de twee hierboven genoemde recensies van Engelman en Werumeus Buning. Van Duinkerken, normaal toch niet zuinig met zijn eigen oordelen, gaat niet in op de intrige en de strekking van het boek. De opmerking dat het boek niet onder doet voor de "tragische lotsverbeelding in Een Hollandsch drama van Van Schendel" kan er nog net vanaf. Het verhaal komt hem niet te pas, want het bevat geen katholieke moraal en de personages kunnen niet dienen als rolmodel voor de bewoners van het nieuwe Brabant.

\section{Conflict bij De Gemeenschap}

Ad. Sassen die in juni 1933 bij Coolen logeerde, is geen lid van de redactie van De Gemeenschap maar levert wel regelmatig bijdragen aan dat blad. Hij behoort duidelijk bij de groep rondom de gebroeders Kuitenbrouwers. In het najaar wordt over een eventuele benoeming van Sassen tot redactielid gesproken. Coolen schrijft aan Van Duinkerken, de niet-formele hoofdredacteur:

"Op De Gemeenschap is de kwestie Sassen niet aan de orde gekomen. Ook Vos woonde de redactievergadering niet bij. Aan het eind van de vergadering, toen ik er zelf over begon zei Kuyle, dat we er in de volgende vergadering over zouden spreken, maar dat er een bindend besluit voor de benoeming van Sassen genomen was, waarop jij intusschen weer teruggekomen was. Omdat Piet Oomes intusschen ook op het kantoor gekomen was heb ik volstaan met te zeggen, dat ik van een besluit in elk geval niets wist en dat ik het mijne over de candidatuur Sassen had te zeggen, waartoe dan in de volgende vergadering gelegenheid is. ${ }^{20}$

Het blad De Gemeenschap staat op een tweesprong. Twee redactieleden van het eerste uur geven steeds meer blijk van een positieve houding ten opzichte van rechts-radicale stromingen en daarmee samenhangende antisemitische opvattingen. Een van de eerste daden van Coolen in het begin van 1933 was een veto uitspreken tegen een samenwerking met het blad De Stormer. Van Duinkerken hakt de knoop door en stelt voor oud-redactielid jan Engelman samen met Louis de Bourbon op te nemen en de Kuitenbrouwers heen te zen den. Coolen is opgelucht en zendt een telegram aan Van Duinkerken waarin hij de onmiddellijke toetreding van Engelman toejuicht. ${ }^{21}$ Daarop roept Van Duinkerken een vergadering van de oude redactie bijeen om het Kerstnummer samen te stellen. Hij heeft professor Pompe, voorzitter van het Stichtingsbestuur van De Gemeenschap, gevraagd om deze vergadering te leiden om onaangenaamheden te voorkomen. ${ }^{2}$ Coolen reageert 


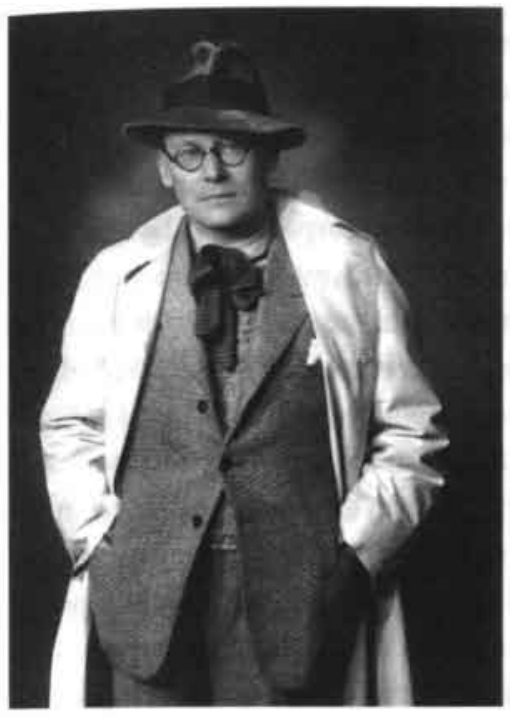

Antoon Coolen begin jaren dertig. De schilder Peter van den Braken heeft naar dit voorbeeld een olieverfschilderij gemaakt. meteen. Hij vindt dat ze elkaar geluk kunnen wensen, want het belang van het blad is op deze wijze het best gediend. Hij bewondert de moed waarmee Van Duinkerken heeft doorgezet. Een dergelijke conflictsfeer is niets voor Coolen: "Om verschillende redenen zal ik er mij over verheugen als de vergadering van morgen achter de rug is." 23

$\mathrm{Na}$ die vergadering zijn de moeilijkheden echter nog niet voorbij. De dissidente groep redactieleden kondigt aan dat zij het blad De Gemeenschap zal vernieuwen en voortzetten. Als het Stichtings-bestuur het er niet mee eens is, zal een nieuw blad gesticht worden. Het bestuur hoort op 12 december 1933 beide partijen in de personen van Van Duinkerken en Albert Kuyle. Van Duinkerken dringt aan op het ontslag van Kuyle, omdat deze onder andere het plan heeft gehad om Coolen uit de redactie te verwijderen. ${ }^{24}$ Het Stichtingsbestuur kiest voor Van Duinkerken. Kuyle en de zijnen, waaronder ook Ad. Sassen, richten zich rond Kerstmis met een pamflet tot de abonnees van De Gemeenschap, waarin zij hun 'aftreden' bekend maken en het tijdschrift De Nieuwe Gemeenschap aankondigen. Ondanks de verwijdering van Kuyle uit de redactie zal Coolen zijn pas verschenen Harten en Brood op een positieve manier in de Bossche krant en voor de KRO radio bespreken. Van Duinkerken schrijft aan Coolen dat het boek van Kuyle hem op sommige plaatsen zeer ontroert, maar dat hij er de hartelijkheid van De schoone voleinding in mist.

Het lijkt wel of Coolen de vijandigheid van Kuyle tegen zijn persoon niet voelt of niet wil voelen. Het kan zijn dat Van Duinkerken hem niet verteld heeft dat Kuyle hem uit de redactie wilde stoten, maar zelfs als hij daar wel van gehoord heeft, zal dat zijn houding niet hebben veranderd. Coolen beschouwt Kuyle als een van de beste schrijvers van zijn generatie, zoals hij onlangs nog tegen Sassen verteld heeft, en wil hem daarom te vriend houden. Hij blijft vriendelijk in zijn richting, hoe onbeschoft Kuyle ook tegen hem te keer gaat.

Door het samen optrekken in het redactionele conflict bij De Gemeenschap lijkt de relatie tussen Coolen en Van Duinkerken weer wat op te leven. Er zijn wel veel formele contacten, maar de frequentie en intensiteit van de briefwisseling waren de laatste jaren beduidend

19 Van Duinkerken, Antoon Coolen, 68-70.

20 BA, brief Coolen aan Van Duinkerken, 8 november 1933.

21 BA, telegram van Coolen aan Van Duinkerken, 18 november 1933.

22 BA, brief Van Duinkerken aan Coolen , 22 november 1933.

23 BA, brief Coolen aan Van Duinkerken, 24 november 1933.

24 Van der Plas, Daarom, mijnheer, 195. 
minder geworden. Coolen koppelt soms het houden van een lezing aan een bezoek aan Amsterdam. Steeds vaker wordt gemeld dat hij per auto mee kan rijden met Wiegersma of met het bevriende echtpaar Te Strake uit Deurne. In de Bossche krant verhaalt hij hoe avontuurlijk zo'n reis in die dagen nog kan zijn. Tot die tijd waren er alleen nog maar spoorbruggen over de grote rivieren; ál het autoverkeer moest over veerponten. Een week voordat de brug op 18 november 1933 geopend zal worden door de minister van Verkeer en Waterstaat strandt de auto waarin Coolen meerijdt tijdens een stormnacht op de noordoever voor Zaltbommel, omdat de pont wegens het slechte weer niet meer vaart. Vlak naast de file ligt de nieuwe brug kant en klaar met alleen een kleine versperring voor de officiële opening een week later. De chauffeurs kleumen bij elkaar als "schimmen op de oevers van de Styx" en overleggen om die versperring opzij te duwen en gewoon over de nieuwe brug heen te rijden, maar niemand durft het. Uit gezagsgetrouwheid wordt besloten om via Gorkum en Breda, ruim honderd kilometer om, naar Deurne te rijden. Als ze tegen de ochtend thuiskomen horen ze op de radio dat vijf minuten na hun vertrek medewerkers van Waterstaat de bijna symbolische versperring hebben verwijderd, waardoor het verkeer verder kon. ${ }^{25}$

Coolen heeft in het jaar 1933 niet stilgezeten. Tussendoor is in de zomer nog een boekje verschenen onder de titel Stijntje, waarin op een hartelijke manier de belevenissen met zijn oudste zoontje staan beschreven. Het is aanvankelijk bedoeld voor het tijdschrift van de Vereeniging Moederschapszorg in Heerlen. Op initiatief van de directeur van de Heerlense opleiding voor vroedvrouwen, dr. Clemens Meuleman, is het kort daarna als een klein boekje uitgegeven. De opbrengst komt ten goede aan het Centraal Katholiek Doorgangshuis voor ongehuwde moeders en is bedoeld om de heerlijkheden van het kinderleven aan te tonen. We komen hierop terug bij de bespreking van een groter boek over Coolens ervaringen met zijn kinderen, Uit het kleine rijk, waarin Stijntje zal worden opgenomen.

\section{Een nieuw jaar: grote productiviteit}

De eerste winter van de Coolens in Deurne is meteen een echte. De hele maand december vriest het en de ijsbanen zijn al vanaf I $_{5}$ december geopend. Coolen wijdt zijn 'Brieven van De Romeijn' aan het ijsvermaak en het schaatsen. Hij ervaart nu - wat hij bij de verhuizing al schreef - dat men in deze tijd in een dorp op elkaar aangewezen is. Hij brengt veel avonden door bij de schilder-dokter Wiegersma. Zijn stukjes in de krant met Kerstmis - "dit innige feest" - en Oudjaar zijn mijmeringen waarin hij in zijn algemeenheid de slechte tijd met het vredige gezins-en dorpsleven laat contrasteren. Nederland ondergaat een golf van nationale opwinding bij de kerstvlucht van De Pelikaan, een vliegtuig van de KLM, op een postvlucht naar Nederlands-Indië. Coolen gaat in op de symboliek van de naam van het vliegtuig.

De Bossche krant waarin deze stukjes staan, concludeert in zijn terugblik op het afge lopen jaar 1933 dat er nog nooit een revolutie was als de nazirevolutie, waarbij zo weinig bloed is gevloeid. De Jodenvervolging blijft wel een donkere smet, schrijft de krant. Zij bekritiseert vooral de opzwepende antisemitische redevoeringen van Goering, die tot uitspattingen leidden. Volgens de krant had Hitler vermanend en waarschuwend moeten optreden om het volk tot bezinning te brengen. Veel landen hebben geprotesteerd, maar Nederland beschouwt het als een binnenlandse aangelegenheid en protesteert niet. 
Het tekent de sfeer van die tijd. Nederland wil angstvallig zijn neutraliteit bewaren en beschouwt Hitler formeel als een bevriend staatshoofd. Alleen de linkse pers is tot nu toe zeer kritisch tegenover het nieuwe bewind.

\section{Verhouding tot Duitsland}

Coolen ziet dat de vertaling van zijn roman Kinderen van ons volk, Brabanter Volk, goed loopt in Duitsland en dat zijn populariteit daar enorm groeit. Hij houdt dan ook intensief contact met vertalers G.K. Schauer, het echtpaar Augustin en de Vlaamse medewerker, Peter Mertens, van Insel Verlag. Hij is zelfs van plan om op 17 april 1934 , zijn verjaardag, naar Berlijn te gaan "voor een presentatieavond van de Union Nationaler Schriftsteller" en bij die gelegenheid Schauer op te zoeken. ${ }^{26}$ Een week later moet Coolen echter al melden dat de bijeenkomst wordt uitgesteld tot de herfst. Dirk Coster die ook uitgenodigd was, wijst hem erop dat reizen naar Duitsland in de huidige politieke omstandigheden eigenlijk niet meer verantwoord is.

Coster heeft er met Van Duinkerken over gesproken. Hij wil een eventueel uitstapje van Coolen naar Duitsland niet bederven door pessimistische overwegingen, maar hij zelf heeft met de kortste formule geweigerd om mee te gaan. "Het komt mij voor dat ik een dergelijke gastvrijheid niet mocht accepteren, zolang onze beste collega's buiten hun vaderland moeten zwerven terwijl deze gehele club mij een vervalste editie leek van de vroegere Penclub in Duitsland." In een themanummer van Chritisch Bulletin over literatuur, politiek en tijdsproblemen schrijft Anthonie Donker in februari r934, dat de Duitse literatuur binnen de grenzen van het rijk "door de heerschende macht uit haar verband gedrukt en verminkt" is. 'Volksfremde' elementen worden uitgesloten, waardoor het Duitse PENcentrum genoodzaakt was om uit de PEN-club te treden, omdat het "rasvooroordeel in strijd is met de beginselen van dit internationaal georganiseerde en georienteerde lichaam." De Duitse staat heeft de horizon van de literatuur doen inkrimpen door 'Deutschtum' als het hoogste aspect van de literatuur te proclameren, schrijft Donker. ${ }^{28}$

Coolen wil in ieder geval in het Duits vertaald worden. Begin 1934 is de oogst nog niet groot; buiten Brabanter Volk door het echtpaar Augustin is alleen het verhaal 'Het goede paard' door Schauer vertaald. Het kan geen kwaad om zijn werk wat te promoten. Later dat jaar prijst hij bij Schauer zijn nieuwe toneelstuk De vier jaargetijden aan als een stuk "dat op het oogenblik in Holland met veel succes wordt gespeeld. De grondgedachten van dit spel zijn: de reinigende kracht van het natuurverbonden leven, de zedelijke waarde der grondgebondenheid, en de zin van den overgeleverden levensgeest der vaderen. Men vestigde er mijn aandacht op, dat om zijn motieven dit spel een soort voorbestemming heeft voor Duitsland. ${ }^{22}$ In bijna dezelfde bewoordingen - ook hier weer met de formulering dat anderen hem erop hebben gewezen - beveelt Coolen dit stuk aan bij een andere vertaler van zijn

25 Coolen, 'Brieven van De Romeijn', 11 november 1933.

26 LMDC, inv. nr. C 3485, brief Coolen aan G.K. Schauer, 6 april 1934.

27 Brief Dirk Coster aan Coolen, 13 mei 1934. Coster, Brieven 1931-1949, 63. Ook later, in november 1939, heeft Coster weer vragen bij een reis van Coolen naar Duitsland vak na de pogroms. Idem, 108.

28 Donker, 'Litteratuur en Politiek in Duitschland', 43-47.

29 LMDC, inv. nr. C 3485, brief Coolen aan G.K. Schauer, 17 december 1934. 
werk, Elisabeth Augustin. Na de première van De vier jaargetiijden in Amsterdam schrijft hij: "Men vestigde er mijn aandacht op, dat dit stuk door zijn aard - de grondgebondenheid van de boer is het hoofdmotief-voor Duitsland zeer geschikt is en welhaast voorbestemd voor een hartelijke en succesvolle ontvangst." ${ }^{30}$ Begin 1935 laat hij zijn vrouw deze aansporing nog een keer herhalen; nu schrijft zij de informatie verkregen te hebben "van bevriende, bevoegde zijde in Berlijn." ${ }^{31}$

Deze toevoeging is eigenlijk overbodig, want het is vanaf r 933 al zonneklaar dat het nazibewind in Duitsland geporteerd is voor een literatuur over boeren, grond en noodlot. In het hierboven aangehaalde artikel van Donker geeft deze een opsomming van het soort boeken waarvoor in 1934 de conjunctuur gunstig is: "Einig Volk; Unter den Eichen; Aus dem Leben eines deutschen Stammes; Deutsche Söhne auf fernem Posten en meer van deze Kitsch." Speliers stelt dat de nazicritici meer geporteerd waren voor het werk van Streuvels dan voor dat van Timmermans, omdat de Schicksalromans van de eerste beter pasten in het nazisjabloon dan het biedermeierige en het anecdotische van de tweede. Daarom deden nazi-uitgevers ook zo veel moeite om de rechten van De vlaschaard in bezit te krijgen. ${ }^{32}$

Elisabeth Augustin-Glaser is geboren in Berlijn en van joodse afkomst. Zij leerde Nederlands van Felix Augustin, een Amsterdammer, die Duits gestudeerd heeft en naar Leipzig verhuisd is. Toen zij onder het nieuwe bewind van Hitler weigerden lid te worden van de Reichsschrifttumskammer zijn ze in de zomer van 1933 naar Nederland verhuisd." Felix Augustin moet niet veel hebben van het 'volkse' en de gebondenheid met de bodem. Een paar jaar later schrijft hij in een recensie van een Oostenrijks boek: "Dat alles is onecht, het doet denken aan een soort romantiseerende 'Heimat-literatuur', zooals die reeds tientallen jaren geleden gefabriekt werd. ${ }^{.34}$ Het echtpaar zal nog wel aan de vertaling van een toneelstuk werken, maar komt niet meer in aanmerking voor de vertaling van een nieuwe roman. In 1936 schrijft Felix Augustin dat hij "door de nieuwe bepalingen" niet meer mag publiceren in Duitsland en dat Insel Verlag met een Oostenrijker in zee zal gaan. ${ }^{35}$ Elisabeth Augustin noemt later in haar herinneringen de namen van zowat alle bekende Nederlandse schrijvers van die tijd, alleen Coolen komt er niet in voor. ${ }^{36}$

In dit jaar, 1934, neemt De Gemeenschap een kritische houding tegenover Nazi-Duitsland aan en durft daar wat openlijker over te schrijven dan de rest van de katholieke pers. Jan Engelman hoopt dat het tot een botsing komt tussen Hitler en Goering en het probleem zo vanzelf opgelost wordt: "Dit is een soort dat zichzelf uitroeit." In zeer felle bewoordingen veroordeelt hij het regime dat op elke afwijkende mening maar een antwoord kent: de kogel op stel en sprong. "Wij leven in het land van Grotius en God beware ons voor den furor teutonicus!" ${ }^{15}$ In de rubriek 'Hagel' wordt de loosheid en holle bombast van Hitlers redevoeringen gehekeld en Van Duinkerken gaat in op de religieuze ontwikkeling in Duitsland. In het streven om alle confessies in Duitsland onder een nationale kerk te brengen wordt de installatie van Rijksbisschop Müller van de Evangelische Kerk een nazimanifestatie. Van Duinkerken schrijft dat de "nieuwgekozen nazipaus" de godsdiensten wil gelijkschakelen, maar dat god zich niet gelijk laat schakelen. ${ }^{38}$ Professor W. Pompe schrijft een driedelige serie over volkseenheid en nieuwe vormen van democratie. Dit laatste artikel heeft door zijn lengte en detaillering wel iets van een vergaderstuk, meldt Coolen aan 
hoofdredacteur Van Duinkerken, maar ondanks die gebreken en het feit dat het niet zo goed geschreven is, kan het volgens Coolen toch vanwege het belang als hoofdartikel worden geplaatst. ${ }^{59}$ De bijdragen van Coolen in De Gemeenschap beperken zich dit jaar tot legenden en soms als voorpublicatie een enkel hoofdstuk van zijn nieuwe roman Dorp aan de rivier.

\section{De monarchie, de natie en het boerengezin}

Coolen becommentarieert de actualiteit af en toe in de Bossche krant waar hij mild de spot drijft met het feit dat dictators nooit lachen. Hij beschrijft hoeveel moeite het Mussolini en Hitler kost om zo bars te kijken als Buster Keaton; en nu begint in Nederland Mussert, de leider van de NSB, ook al zijn best te doen. ${ }^{40}$ Wellicht geinspireerd door het 'vergaderstuk' van Pompe wijdt hij in april 1934 een serieuze aflevering van zijn 'Brieven van De Romeijn' aan de nationale gedachte. ${ }^{41}$ Hierin spreekt hij zich duidelijk uit tegen de grote totalitaire stromingen van zijn tijd en voor de monarchie als bindend element. Het is voor het eerst dat hij zo duidelijk zijn politieke mening geeft. Hij schrijft dat er geen keuze is tussen het communisme enerzijds en fascisme en nationaalsocialisme anderzijds. Degenen die menen dat er aan de twee anticommunistische stromingen toch iets goeds zit, omdat ze in ieder geval de nationale gedachte zijn toegedaan, hebben het fout. Nederland heeft volgens Coolen een nationale levensgeest, die gebaseerd is op de vrijheid die door de Oranjes is bevochten en eeuwenlang bewaakt. Het dictatorschap dat met deze stromingen gepaard gaat, is vijandig aan deze levensgeest omdat het per definitie het gezag van de monarchie terzijde schuift. De nationale gedachte of het nationale gevoel hebben nu juist als ontroerendste kenmerk de trouw en liefde voor het vorstenhuis, stelt hij en verwijst naar de indrukwekkende begrafenis van koningin-moeder Emma enkele weken daarvoor, in maart, en die van de Belgische koning in februari 1934. Aan beide gebeurtenissen heeft hij in zijn zaterdagse 'Brieven' aandacht besteed. Bij gelegenheid van de begrafenis in Brussel heeft hij erop gewezen dat de monarchie nog steeds in de grondslag van het hart geworteld ligt, ook al zeggen de marxisten dat het allemaal literatuur en verbeelding is. Hij besloot toen de column met de opmerking dat een vorstelijk staatshoofd "het bindcement [is] van de nationale saamhorigheid en de waarborg voor de volkseenheid, die een voedingsbron

30 LMDC, inv. nr. C 3485, brief Coolen aan Elisabeth Augustin, 10 november 1934.

31 LMDC, inv. nr. C 3485, brief Gerda Coolen aan Elisabeth Augustin, 28 februari 1935. Felix Coolen tekent hierbij aan dat het hier gaat om berichten vanuit de Nederlandse ambassade in Berlijn van mensen die bevoegd zijn om dit te beoordelen.

32 Speliers, Als een oude Germaanse eik, 297.

33 Speliers, Als een oude Germaanse eik, 159.

34 Felix Augustin over Heinrich Zillich, in: 'Duitschers in Zevenburgen', 196-199.

35 FPC, brief Felix Augustin aan Coolen, 12 maart 1936.

36 Elisabeth Augustin, Het patroon, 49.

37 JE [Jan Engelman], 'Hagel', 484-485.

38 Van Duinkerken, 'Rijksbisschop Ludwig Müller', 817-829.

39 BA, brief Coolen aan Van Duinkerken, 6 juni 1934.

40 Coolen, 'Brieven van De Romeijn', 3 februari 1934.

41. Coolen, 'Brieven van De Romeijn', 7 april 1934. 
voor de volkskracht is." ${ }^{42}$ Men kan over deze zaken cynisch doen en alles als een mythe ontmaskeren, maar het cynisme is volgens Coolen zelf behaagziek en daarom een heel onbetrouwbare gids. Er hebben zich in de geschiedenis een Hollandse volksaard en een Hollandse levensgeest ontwikkeld, die weerbarstig zijn. Daarom kan volgens Coolen hier geen overrompeling plaatsvinden, "noch een marxistische noch een fascistische." Zonder de poging van Troelstra in november 1918 een revolutie te noemen, voegt hij eraan toe dat de meest evenwichtige mensen van de SDAP dat ook beseffen. Zelfs de VARA heeft een "in memoriam' uitgezonden over de koningin-moeder, waarin haar adeldom werd verheerlijkt. Door deze trouw aan een waardevolle overlevering ontstaan goede vaderlanders en op hen hebben extreem politieke bewegingen geen vat.

Het is niet niks dat Coolen zich in de katholieke Bossche krant positief uitlaat over de SDAP, een partij die, een jaar na de muiterij op De Zeven Provinciën, nog steeds in een kwaad daglicht staat. Het valt wel op dat in zijn kritiek op communisme en fascisme met geen woord gerept wordt over de vernietiging van de democratie. Dat begrip staat in die tijd niet in zo'n goede reuk; het nationale scoort veel hoger op de waardeschaal dan het democratische.

Binnen dat nationale is volgens Coolen het boerengezin de allerbelangrijkste pijler. In mei 1934 geeft hij daar duidelijk blijk van. Hij toont zich tevreden dat de grote bedrijven die de Heidemij nog geen halve eeuw daarvoor was begonnen, geen stand hebben gehouden en citeert met instemming een onderzoek van professor Van Vuuren dat de Brabantse norm voor een verkaveling ongeveer I 8 à 20 bunder is. Dit is de omvang die nog in 'gezins. verband' bewerkt kan worden en daardoor het zuiverst het geluk van de mensen dient. "Hier leeft een landelijk volk, dat in zijn trouw aan den grond en aan zijn boerschen levens. geest hoe dan ook zijn sterksten toekomst hebben zal." De gegevens worden gepresenteerd tijdens een excursie van een groep Wageningse studenten, die na afloop op De Romeijn worden genodigd. "Deze jeugd [is] sterk, gezond, levensblij en gevoelig en ontvankelijk voor impulsen," zo luidt Coolens optimistische kijk op deze jongeren. ${ }^{43}$

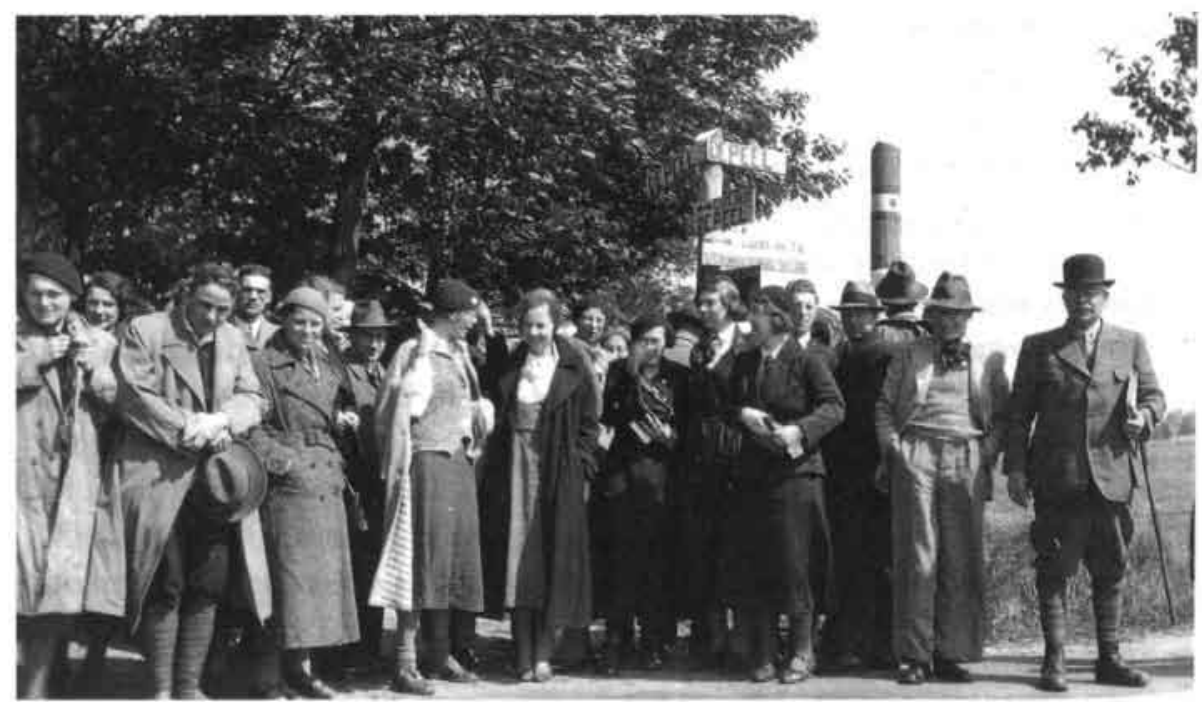

Coolen en prof. Van Vuuren met Wageningse studenten in mei 1934. 


\section{Overlijden vader Coolen}

Op 17 september 1934 overlijdt Coolens vader. Nog op de dag van de begrafenis schrijft Antoon Coolen een bedankbrief voor een condoleance van Van Duinkerken. In deze brief is de genegenheid voor zijn vader zeer voelbaar. De zondag ervoor had vader al pijn, maar om die te vergeten ging hij naar een beschouwing van Van Duinkerken voor de radio luisteren. Coolen is aanwezig geweest bij het sterven:

'Toen ik bij hem zat, wendde hij met groote oogen het hoofd naar mij toe, hij heeft me tot het laatste oogenblik aangekeken en ik heb hem kalm en stil zien sterven [...] Toen hij stierf vielen zijn oogen met rimpels dicht, even vertrok zich zijn gezicht, meteen daarop gleden de rimpels uit de oogleden weg en kreeg het gezicht de uitdrukking van de meest sereene rust [...] Ik bewaar twee kostbare herinneringen, die aan zijn goed leven, en die aan zijn schoonen, goeden dood."

Hij is blij met het ritueel van de begrafenis. In zijn woorden klinkt nog steeds iets door van de euforie voor het teruggevonden land der vaderen, "waar alles van de hartelijkheid der belangstelling en der deelneming sprak, en die geheel geschiedde naar de goede, oude gebruiken, die dit saamhorige volk in eere houdt." ${ }^{\text {44 }}$ Deze formuleringen is hij sinds zijn verhuizing naar Deurne steeds meer gaan gebruiken.

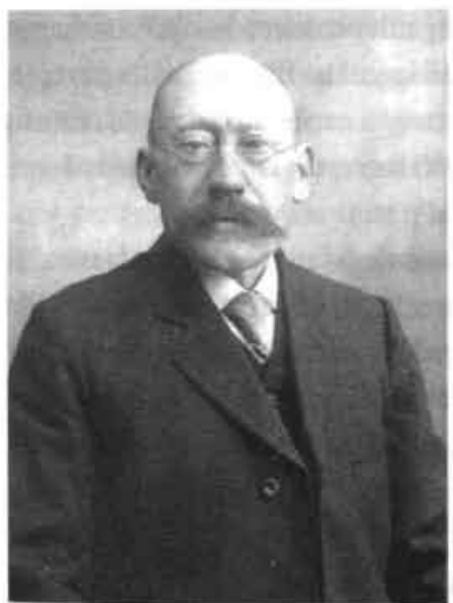

Vader Coolen.

De zaterdag daarna verschijnt voor de eerste keer, de korte vakanties niet meegerekend, geen aflevering van 'Brieven van De Romeijn' op de voorpagina van de Bossche krant. In zijn oudejaarsbijdrage komt hij terug op het overlijden van zijn vader, als hij schrijft over de mensen die het afgelopen jaar gestorven zijn. Het stemt hem niet tot somberheid en pessimisme, want de droefheid over de doden komt juist omdát het aardse leven zo kostbaar is. "Ook hierin wint het leven het van den dood, het leven, dat goed en heilig blijft, hóe geschonden het kan zijn, en dat een kostbaar bezit blijft, hóe geplaagd en gekweld het wordt door den nood der tijden."45

\section{Zegen der goedheid}

In het najaar van 1934 verschijnt Zegen der goedheid, een bundeling van de legenden die Coolen de afgelopen jaren in verschillende afleveringen van De Gemeenschap, in Jaarboeken en Zonneboeken ${ }^{46}$ gepubliceerd heeft. Het is een prachtige uitgave met illustraties

42 Coolen, 'Brieven van De Romeijn', 24 februari 1934.

43 Coolen, 'Brieven van De Romeijn', 26 mei 1934.

44 BA, brief Coolen aan Van Duinkerken, 20 september 1934.

45 Coolen, 'Brieven van De Romeijn', 29 december 1934.

46 De stichting Herwonnen Levenskracht gaf jaarlijks een Zonneboek uit met bijdragen van bekende auteurs en illustrators. 
en omslag van Jozef Cantré. Omdat de legenden historisch niet vastliggen, kan Coolen er zijn volle fantasie op loslaten, zoals hij later ook zal doen in de sprookjes. Van de twaalf legenden zal hij er enkele gebruiken als inspiratie voor toneelstukken.

Ook in deze legenden klinkt de kritiek van Coolen op de gezeten geestelijkheid. "Goar van de gastvrijen" is een gastvrije kluizenaar langs de Rijn, die pelgrims ontvangt. Twee priesters uit Trier komen controleren of het er bij hem niet te losbandig aan toe gaat. Ze vinden de tafel van Goar te overvloedig; zij zelf 'versterven' zich. Op de terugweg komen ze bijna om van de honger en worden uiteindelijk door Goar gered. Ook in 'Theodotus van de herbergiers' maakt Coolen dit 'versterven', een liefhebberij van kwezels, belachelijk. Deze legende speelt zich af in de Romeinse tijd. Ondergedoken christenen worden door Theodotus overvloedig gelaafd en gevoed, met als motto: "De kwellingen zijn vergankelijk, het leven is eeuwig." ${ }^{-47}$

In verschillende verhalen worden goede stervelingen, zoals Isidoor van de boeren, in hun strijd tegen het boze door engelen geholpen. Hovaardigen als de smid Jan Hamers krijgen een lesje; in dit geval van zijn eigen patroonheilige Sint Elooi.

Coolen legt in het boek meer de nadruk op het aardse dan op het godsdienstige. Hij tekent goede mensen in de wisselwerking met de natuur. Of zoals hij zelf zegt: "De bekoring van de heiligenlegenden ligt in hun aardsche vertrouwelijkheid en het geloof in de goedheid van de menschen. ${ }^{.48}$ Uit de accenten in de heiligenlevens worden de voorkeuren van Coolen duidelijk. Hij houdt niet van de ascetische heiligen. Het lijkt wel of hij daar een soort hovaardij in ziet. Soms lijkt een legende alleen maar een aanleiding om een ode aan Brabant te brengen, zoals 'Maria van de Brabantse dorpen'. De eerste regels klinken als een gedicht:

"De wolken hebben Maria gevaren. De wind heeft haar de handen gereikt. Haar eigen ster heeft haar geleid en Maria is op de aarde getreden, die zij blij herkent, omdat zij de zuiverheid der bloemen, de goedheid van het koren, de werkzaamheid der menschen en den vrede der dieren zeer heeft liefgehad."

De beschrijving van de tocht van Maria toont de natuur en de mensen in de volle zomer. Op een andere manier heeft hij daar in de meimaand van 1934 , als het legendeboek pas verschenen is, vorm aan gegeven in zijn 'Brieven van De Romeijn'. Daarin worden alle miraculeuze Maria's, de Onze Lieve Vrouwkes van de steden en dorpen, beschreven. Zijn oordeel is dat de glimlach van die van de St. Jan in Den Bosch het zoetst is. Hij schrijft per slot van rekening voor de Bossche krant. ${ }^{49}$

\section{Ontvangst}

De ontvangst van Zegen der goedheid is positief. Roel Houwink schrijft in de NRC dat Coolen zich met dit boek gelukkig vrijmaakt van de regionale letterkunde, want anders zou het gevaar groot zijn dat ook hij zou vervallen in een would-be provincialisme, zoals Felix Timmermans, Er kleven nog wel enkele "regionale smetten" aan, maar die schaden het geheel niet. Coolen moet goed opletten om niet te gaan schrijven "voor den export." Hij heeft een eenvoud van nature en moet zich niet forceren tot een gemaakte en nadrukkelijke primitiviteit. Het boek is een verademing tussen de vele gecompliceerde en pessimistische romans van die tijd, vindt de protestantchristelijke criticus. Opnieuw krijgt Coolen een compliment in een niet-katholieke krant, als gezegd wordt dat het een groot 
voorrecht is om een schrijver in het midden te hebben die getuigenis aflegt van zijn ervaring met de zegen van de goedheid. "De mensch is maar een zwak vat, doch daarom juist heeft hij den zegen der goedheid zoozeer van noode. Om te leven moet hij hopen en gelooven kunnen in een licht, dat niet uit hemzelven is." Het is een goed boek voor wie bedrukt of terneergeslagen is, zegt Houwink. De illustraties van Cantré worden bestempeld als "neo-primitivisme" en hebben volgens Houwink iets krampachtigs, dat in het werk van Coolen juist volledig ontbreekt. De wending in het werk van Coolen naar het positieve kan van verstrekkende betekenis zijn voor de ontwikkeling van de Nederlandse letteren. Het is nu zaak deze toon vast te houden. ${ }^{50}$

In het liberale Algemeen Handelsblad wordt Coolen geprezen om zijn "beeldende taal en door de overtuigingskracht in een vroomheid, die nooit door valsch gevoel en overdadig sentiment vertroebeld wordt." Het verhaal van St. Elooi wordt het sterkst genoemd. Doordat de verhalen vaak in een Brabantse setting worden geplaatst, heeft het boek toch nog een gewestelijk karakter. De heiligen wandelen tussen dorpelingen en landlieden, die we kennen uit het andere werk van Coolen. Het boek is volgens deze krant dus nog geen vernieuwing."

In eigen kring wordt minder enthousiast gereageerd. Bedankt voor je Heiligenboek, schrijft Dirk Coster, maar ik lees toch liever je gewone werk. ${ }^{52}$ Van Duinkerken schrijft geen kritiek. Later constateert hij dat Coolen meer waarde hecht aan de natuurlijke vroomheid of zelfs de aangeboren goedaardigheid dan deze "in strikt zedekundig opzicht" verdienen. De bundel levert volgens Van Duinkerken een goede bijdrage tot de religieuze psychologie van Coolens geschriften. "Over het algemeen vereenzelvigt Coolen de uitwerking der genade met een versterking der natuurlijke goedheid, mildheid, barmhartigheid en offervaardigheid van het individu. ${ }^{\text {"5s }}$

De bundel krijgt een negatieve reactie van Albert Kuyle. Coolen is daar zeer teleurgesteld over, temeer omdat Kuyle het jaar daarvoor in de redactie van De Gemeenschap er nog het glas op geheven heeft en er een geestdriftige toespraak over heeft gehouden. Kuyle is echter sinds januari r 934 lid van de afgescheiden De Nieuwe Gemeenschap en behoort nu duidelijk tot het andere kamp. Dit verhindert Coolen niet om zijn kritiek op Kuyles boek Harten en brood positief te formuleren. In een openbare recensie in Het Huisgezin schrijft Coolen: “Van dit met meesterschap geschreven boek, geladen en vol van geurend leven, dat in de bedrukten onder de beschermende schaduwen der moederlijke kerk zo heilig blijft, getuig ik met warmte en eerbied, omdat het mijn hart zo diep en sterk geraakt en gewonnen heeft." ${ }^{54}$ In een brief aan Oomes schrijft hij dat sommige delen hem ontroerd hebben.

47 Coolen, Zegen der Goedheid, 216.

48 Interview in: Hooger Leven, 25 maart 1934, geciteerd in: Van Duinkerken, Antoon Coolen, 70.

49 Coolen, 'Brieven van De Romeijn', 19 mei 1934.

50 Houwink, [Recensie Zegen der goedheid]. Dezelfde recensie verscheen ook in het prot. chr. Utrechts Dagblad.

51 [Recensie De man met het Jan Klaassenspef], in: Algemeen Handelsblad.

52 Brief Coster aan Coolen, 9 september 1934, Coster, Brieven 1931-1949, 66-67.

53 Van Duinkerken, Antoon Coolen, 70-71.

54 Coolen, 'Kuyle's sterk debuut als romanschrijver'. 
Hij vindt het gegeven echter maar simpel uitgewerkt - “de schofterige werkgever en de angelieke tegenpartij"- en is van mening dat hij dat zelf in Het donkere licht beter heeft gedaan. ${ }^{55}$ In een persoonlijke brief aan Kuyle complimenteert hij hem met Harten en brood: "er staan bladzijden in die je, zooals je een kind doet, met twee handen zou zegenen." Coolen heeft regelmatig in interviews gezegd dat hij Kuyle een van de beste Nederlandse schrijvers vindt. Het blijft hem nog het hele jaar r 934 dwars zitten dat Kuyle hem in het openbaar bekritiseert. In de laatste brief van Coolen aan Kuyle neemt hij het op voor Van Duinkerken, maar prijst toch ook weer Kuyles nieuwe boek Jonas. ${ }^{57}$ Het toont de ambiguiteit van Coolen. Diep in zijn hart heeft hij niet alleen bewondering voor de schrijfkunst van Kuyle, maar ook voor diens ongebondenheid en openlijke rebellie.

\section{De vier jaargetijden}

In het seizoen r933/1934 wordt Kinderen van ons volk gespeeld door het Nieuw Schouwtoneel onder leiding van Frits Bouwmeester en onder regie van Cor Hermus met Ko van Dijk sr. in de rol van pastoor Vogels, Frits Bouwmeester als de oude Sleegers en Jetty van Dijk-Liecker als Marie. ${ }^{58}$ Het toneelstuk is een bewerking van Coolens roman De schoone Voleinding door Cor Hermus en Kees Spierings. Coolen heeft hierbij wel geadviseerd, maar hij is toch niet zo tevreden over het stuk. Hij besluit een oorspronkelijk toneelstuk te schrijven: De vier jaargetijden. De eerste opvoering vindt plaats op II oktober 1934 in het jubilerend Concertgebouw in 's-Hertogenbosch. Evenals Kinderen van ons volk, wordt het stuk gespeeld door Het Nieuw Schouwtoneel van Van Dijk en Bouwmeester.

De vier Jaargetijden begint in de lente en eindigt in de winter en is een loflied op de boerenstand. De intrige is eenvoudig. Van een boerenfamilie is de zoon, Jan, al zes jaar van huis. In die tijd is hij getrouwd met Anne Marie. Ze hebben samen een kind. Deze stadse vrouw is niet gewenst op de boerderij. In de volle zomer komt Jan voor het eerst zonder zijn vrouw, maar met zijn zoontje, op bezoek in zijn ouderlijk huis. Het jongetje blijft achter bij het hooien en verongelukt. De moeder Anne Marie komt als het lijkje al staat opgebaard in "den herd" en verwijt de ouders dat het niet gebeurd zou zijn als zij er zelf bij was geweest. De boerenfamilie heeft haar kind vermoord, gooit ze er uit, jullie boeren offeren jullie kinderen aan die vervloekte grond. Nadat er grote financiële moeilijkheden op de boerderij zijn geweest, komen Jan en zijn vrouw uiteindelijk toch op de boerderij wonen. De vader heeft voor zijn schoondochter al een tuintje in orde gemaakt en een schaap gekocht. Zij geeft zich gewonnen en aanvaardt dit leven. Er zijn nevenintriges met een jonker die de boerenstand en het boerenleven op een overdreven romantische wijze verheerlijkt, en er is een rijke hebzuchtige boer als rivaal.

Het verhaal is hier summier weergegeven. Coolen illustreert met het stuk uitgebreid een aantal opvattingen. Hierdoor krijgen de dialogen iets uitleggerigs en onechts. Als lezer mist men de kracht van de verteller. De kern van De vier jaargetijden is de band van de boeren met hun grond en de spanning tussen hen en de mensen van buiten, de stadsen, de 'kaaljakkers'. In het stuk wordt via twee personages de relatie tussen boer en niet-boer geschetst. De boerenzoon die naar de stad wil en een stadse trouwt, staat tegenover de jonker die het boerenleven op een groteske manier verheerlijkt. "Vanmiddag ben ik in het veld opzettelijk naar een boer gegaan, die aan het gieren was. Die pittige, versterkende wie rooklucht, die merk je natuurlijk niet aan me." 59 
In de regieaanwijzing van Coolen ziet de jonker eruit als een boer uit een pastoralespel, gekleed in een blauw linnen broek, een wit linnen hemd, op sandalen en met een Panamahoed met neergeslagen rand. De jonker blijft een karikaturale buitenstaander. Hij is verliefd op een boerendochter, maar deze vindt dat hij te veel praat: "Maar boer kende ge niet met woorden zijn. En die de dáád hebben, die zeggen niks." ${ }^{n 0}$

In het personage van de jonker zit iets van Coolens eigen verscheurdheid tussen de streek van zijn jeugd en de stad, maar ook van zijn haat/liefde verhouding met het dorp. In de natuurbeschrijvingen en in die van de wisselwerking tussen mens en natuur spreekt Coolen door de mond van de jonker. Deze heeft gevoel voor de vergezichten en zomerwegen door het landschap en spreekt er zijn verbazing over uit "dat jullie boeren de schoonheid van je land niet ziet. ${ }^{m 6}$ De negatieve kanten - die hij zelf ook uit eigen ervaring kent lat hij uitspreken door de stadse schoondochter Anne Marie: "Jullie boeren! Wat weten jullie en wat zien jullie? Grond, grond en nog eens grond en boeren, die door dien dommen grond bezeten zijn. Daar offeren jullie je kinderen aan." ${ }^{n 2}$ Haar ommezwaai tot acceptatie van het boerenleven wordt tot tweemaal toe ingeleid door de opmerking dat de vrouw op den duur altijd meegroeit met de man en uiteindelijk wordt wat de man is.

De inlijving in de boerenstand wordt gedramatiseerd doordat Anne Marie tenslotte een poffer, de traditionele Oost-Brabantse muts, krijgt opgezet. Als ze zich in de spiegel bekijkt en uit macht der gewoonte de poederdons gebruikt, zegt haar schoonzuster dat dat niet nodig is: "Ge ziet tóch al zo bleek, durske. Bij eenen poffer moet ge zorgen een schoonen frissche rooje, natuurlijke kleur te hebben."

In de winterse slotscène gaat de boerenfamilie zitten kaarten. Knecht Eimerd speelt op de mondharmonica 'Die Lorelei' en de kaarters zingen 'Wij vlieden de woelige straten. En kiezen de rust van de nacht' en over hun liefde voor de natuur. Daarna volgt een regieaanwijzing: "Wind en sneeuw tegen de donkere ramen. Men ziet Anne Marie langzaam het hoofd naar de handen buigen." Ze zal er nooit echt bij horen.

Het tafereel moet bij stadse schouwburgbezoekers, en vooral de vrouwelijke, toch ambigue gevoelens hebben gewekt. Ondanks de vredigheid zullen velen gedacht hebben: ik moet zorgen dat ik daar nooit in terecht kom.

Zoals al vermeld schreef Coolen eerder aan zijn Duitse vertaler: "De grondgedachten van dit spel zijn: de reinigende kracht van het natuurverbonden leven, de zedelijke waarde der grondgebondenheid, en de zin van den overgeleverden levensgeest der vaderen." $\mathrm{Er}$ zijn nog meer aanwijzingen dat Coolen in dit toneelstuk, meer dan in zijn romans en verhalen, een boodschap kwijt wil. In het stuk is een weerslag te vinden van zijn eerder ver-

55 LMDC, inv, nr. C 3485, brief Coolen dan Oomes, 16 oktober 1934.

56 LMDC, inv, nr. C 3485, brief Coolen aan Kuyle, 8 maart 1934.

57 LMDC, inv. nr. C 3485, brief Coolen aan Kuyle, 6 februari 1935.

58 Ter Braak walgt al van te voren: "Ik moet, zij het met walging, naar Kinderen van ons volk van den Peelboef Coolen, dat gedramatiseerd is". Ter Braak, Briefwisseling, deel II, 347.

59 Coolen, De vier jaargetijden, 28.

60 Coolen, De vier jaargetijden, 114.

61 Coolen, De vier jaargetijden, 110.

62 Coolen, De vier jaargetijden, 92.

63 Coolen, De vier jaargetijden, 161. 
melde column in de Bossche krant van mei I 934 over de studiebijeenkomst van Wageningse studenten en professor Van Vuuren. Het ging over de maximale grootte van achttien tot twintig hectare van de boerenbedrijven, die nog door een gezin te bewerken zijn. Hij laat boer Van Eerden zeggen: "Van boeren op die geweldige groote ontginningen heb ik zoo geenen weet, of dat vol te houden is. Maar op zijn eigen zie ik dat gère genoeg, dat die groote bedrijven verkaveld worden. D'r zijn zat menschen goed mee, die met een achttien bunder daar op kannen boeren en huizen en het bedrijf aan kannen met eigen volk. ${ }^{n 64}$

De notaris waarmee de boer in gesprek is, bevestigt dit en zegt dat er weinig heil zit in het aannemen van landarbeiders: "De grond aan de boeren van onze streek, die er zèlf, en als 't kan zelfstàndig, boeren." Tegen het einde van het stuk geeft de jonker een zelfde visie als hij tevreden constateert dat op de pas ontgonnen hei naast zijn land ruimte is voor drie ontginningsboerderijen voor de mensen van hier; bedrijven van twintig bunder. Hij vindt dat het de goede kant uitgaat: "De stad en de groeiende industrie krijgen niet de heele wereld en krijgen onzen grond niet vlot, omdat de boeren er wortelen in slaan." 65

Dit is ook de mening van Coolen. Ook hij ziet als beste oplossing dat boerenbedrijven weer 'terugkeren' naar het oude patroon van een gezinsbedrijf. Het is zijn bijdrage aan de pogingen om een boerenstand in leven te houden. Van die stand staat hij overigens even ver af als zijn jonker, zijn Anne Marie en zijn notarisvrouw uit De schoone voleinding.

Van Duinkerken prijst De vier jaargetijden in een voorbeschouwing voor de première als "een dóór en dóór Brabantsch en dóór en dóór dramatisch stuk, dat de vuurproef van de opvoering nog moet doorstaan. ${ }^{-66} \mathrm{Hij}$ verklapt dat slechts enkele vrienden van Coolen beschikken over een onuitgegeven toneelstuk, Exodus, dat Coolen al schreef toen hij nog maar net twintig jaar was. De verwachting dat hij ooit nog eens met een stuk zou komen is nu verwezenlijkt. Hij wil het niet beoordelen voor de opvoering. Tot een recensie komt het echter niet. Hij zal er pas over schrijven in de biografische schets bij Coolens vijftigste verjaardag. Hij vindt het dan geen stuk met sterke actie, maar het heeft wel iets beminnelijks en naiefs "waardoor het bij de opvoering een gunstigen indruk kon maken zonder nochtans groot succes op te leveren." ${ }^{m b}$

J.W.F. Werumeus Buning in De Telegraaf vindt het daarentegen "een der allerbeste opvoeringen van het seizoen," maar de jonker klinkt volgens hem te veel als "boekentaal uit een spreektrompet." Ook is Coolen wat te breedvoerig, vindt hij. Dat klopt wel, want het spel telt 168 bladzijden, wat betekent dat het stuk tussen de drie en de vier uur moet hebben geduurd. ${ }^{68}$

Ronduit vernietigend is de kritiek in het concurrerende De Nieuwe Gemeenschap door Ad. Sassen, de vriendelijke interviewer van anderhalf jaar geleden. Hij geeft zijn recensie een dialoogvorm tussen Ego en Alter. Alter ziet er wel iets positiefs in: je ziet nog eens een boerenwoning van binnen en je hoort de mensen in hun eigen omgeving hun gemoedelijk dialect spreken. Ego vindt het geen toneel. Het is plaatjes kijken naar een zo natuurgetrouw nagemaakte 'herd' en zelfs die realistische weergave schiet te kort, omdat de spelers geen Brabants kunnen spreken. Maar, vraagt Alter, is het dan geen treffend 'zeitgemässes' theater: Coolen behandelt een brandend vraagstuk, de ontvolking van het platteland. Alter heeft er veel van geleerd. Ook dat is niet waar, zegt Ego, het gegeven is al heel oud en bijvoorbeeld al behandeld door René Bazin in La terre qui meurt. Het stuk De revisor is al een 
eeuw oud en nog steeds modern. ${ }^{69}$ Ego vindt De vier jaargetijden "op zijn beste momenten een gesproken novelle en op zijn slechtste een stukje tendenz-toneel van het mindere genre." 70

In De Opregte Haarlemsche Courant schrijft B. van Noort dat door het sterven van het kind de boer en zijn schoondochter nader tot elkaar zijn gekomen en de afstand is overbrugd. De dood van het jongetje zal daardoor het nieuwe leven mogelijk maken. Hij vindt dat Coolen deze veranderingen van de hoofdpersonen "in dit sterven uitnemend psychologisch heeft gemotiveerd."

\section{Slotakkoord}

Was de novelle De man met het Jan Klaassenspel al een afronding, in De vier jaargetijden heeft Coolen nog een theatraal slotakkoord gemaakt voor de periode van de Peelromans. Alle tonen van de afgelopen tien jaar klinken erin door: de grond, de stad, de vreemden, de kinderdood, de gesloten boerenfamilies, de buitenstaander, de 'kaaljakkers', de natuur in de verschillende jaargetijden en niet te vergeten de onmogelijke of 'moeilijke' liefdes. Hier, aan de vooravond van het verschijnen van zijn bestseller Dorp aan de rivier, ligt een cesuur wat de inhoud van zijn werk betreft. In geen van de volgende romans of toneelstukken zal het boerenleven met zijn specifieke problemen van grond, familie en het erven van rechten nog centraal staan. Alleen in een aantal korte verhalen, later gebundeld in Onder de Canadassen, zal dat thema nog terugkeren. Van de zes grote romans die nog volgen, spelen er drie aan de Maas en gedeeltelijk in Friesland (Dorp aan de rivier, De drie gebroeders en Stad aan de Maas) en drie in een dorpse omgeving (Herberg In 't Misverstand, De vrouw met de zes slapers en De grote voltige). In de laatste drie gaat het meer om de sociale verhoudingen in een dorpsgemeenschap, waarbij de boeren slechts zijdelings een rol spelen.

64 Coolen, De vier joargetijden, 59.

65 Coolen, De vier jaargetijden, 159.

66 Van Duinkerken, 'De vier jaargetijden'.

6) Van Duinkerken, Antoon Coolen, 70.

68 Werumeus Buning, 'De vier jaargetijden'.

69 René Bazin (1835-1932), La terre qui meurt, 1925; Gogol (1809-1852), De revisor, 1836.

70 Sassen, 'Een dialoog over Toneel', 615 -616.

7 Van Noort, 'Antoon Coolen: De vier jaargetijden'. 
268 


\section{Maas en Jordaan}

\section{".. die beginnen iets van de geheimen te zien" $1935-1936$}

Eind oktober, begin november 1934 leeft heel Nederland in een roes vanwege De Londen Melbourne luchtrace: een wedstrijd waaraan het KLM-vliegtuig De Uiver meedoet. Deze nationale opwinding is mede een gevolg van de radio. Dit nog jonge medium brengt een spanning teweeg die de kranten niet kunnen oproepen; de ervaring iets op hetzelfde moment mee te maken geeft een enorm saamhorigheidsgevoel. Na de sombere berichten en de brallende redevoeringen uit Duitsland, die ook door iedereen over de radio worden gevolgd, is deze dagenlange, spannende reportage een welkome afwisseling. "In een grafkelder en in een Hollandsche spoorwegcoupé heerscht gewoonlijk een doodsche stilte," schrijft Coolen in zijn zaterdagse Brief,' maar nu praat iedereen over het laatste nieuws over De Uiver. Voor de etalages van de winkels hangen wereldkaarten waarop de vorderingen van de race staan aangegeven. De normale nuchterheid is helemaal weggevallen, constateert hij; Nederland is één, het gaat om de nationale eer. Weliswaar heeft Engeland gewonnen, maar dat land deed mee met een "race-machine" en Nederland met een gewoon vliegtuig met passagiers en post. Heel Nederland heeft een oktobernacht "met volle maan" wakend aan de radio doorgebracht, toen er urenlang geen contact bestond en het vliegtuig. vermist was. Coolen stelt de namen van de bemanning - Parmentier, Moll en Van Brugge op één lijn met die van Nederlandse zeehelden. Als de bemanningsleden in een telefoongesprek met minister-president Colijn horen van de euforie in Nederland zijn ze stomverbaasd. Een week later schetst Coolen de andere kant van deze massahysterie, misschien enigszins geschrokken van zijn eigen enthousiaste Brief. Hij betreurt het dat alleen dit soort sportieve en daadkrachtige activiteiten worden bejubeld en dat de "grootheid van de geest" veel minder wordt geëerd. Hugo de Groot, Erasmus en de natuurkundigen Kamerlingh Onnes en Keesom zijn veel minder bekend dan Piet Hein en Van Speijk. Een ander negatief effect is dat de race ook weer de militaire wapenwedloop bevordert, want de Britse minister van Oorlog maakt gebruik van het enthousiasme om te pleiten voor uitbreiding van de luchtmacht. ${ }^{2}$

\section{Een nieuwe roman}

Op 17 november 1934 houdt Coolen een lezing in de Muziekschool in Zeist ter gelegenheid van de opening van een schilderijententoonstelling van Lambert Simon. Hij is door Jan Engelman daarvoor gevraagd. Hij leest enkele hoofdstukken voor uit zijn nieuwe boek, Dorp aan de rivier. Het is aardig om te zien hoe Coolen Engelman vraagt om te verklaren waaróm hij bij de opening zal voorlezen. Om misverstanden te voorkomen moet hij in de 
uitnodiging zetten, "dat Lambert Simon door zijn medewerking aan De Gemeenschap relaties heeft met schrijvers en dat hij uit hoofde daarvan een hunner uitnoodigde voor de gasten bij de opening zijner tentoonstelling iets uit diens werk-waarbij je dan Dorp aan de rivier vermeldt - voor te lezen. Vind je niet, dat het in zijn vorm dan minder een reclame lijkt en aannemelijker wordt? ${ }^{3}$

Coolen is in het late voorjaar van 1934 aan Dorp aan de rivier begonnen. Al na vijf weken heeft hij het handschrift voltooid. Het boek is zowel op de linnen band als vanbinnen rijk geïllustreerd met tekeningen en houtsneden van Wiegersma. In juli had uitgever Doeke Zijlstra al voorgesteld om dit boek door iemand anders dan Cantré te laten illustreren; ${ }^{4}$ zoals reeds vermeld was de kritiek op diens illustraties bij Zegen der goedheid niet onverdeeld gunstig geweest. Wiegersma is zeer benieuwd naar het boek. "Dorp aan de rivier ziet er beslist mooier uit dan eenig vorig boek. Wiegersma heeft nauwelijks geduld de verschijning van het boek 'dat hem gek maakt' af te wachten," schrijft Coolen. ${ }^{5}$ Dat komt niet alleen door zijn illustraties, maar vooral ook omdat hij de stof heeft aangedragen voor de roman. Hij heeft in die eerste winter dat Coolen in Deurne woonde veel verteld over de praktijk van zijn vader in Lith, zijn Friese familie en zijn eigen belevenissen.

\section{Hendrik Wiegersma}

De vriendschap tussen de zes jaar oudere Wiegersma en Coolen is voor beiden van belang geweest. Wiegersma is niet opgegroeid in Deurne, maar bracht zijn jeugd door als zoon van een huisarts van Friese afkomst in het dorp Lith aan de Maas. Hij voorziet met zijn fantastische verhalen over zijn familie en zijn eigen praktijk Coolen van nieuwe inspiratie en stof om over te schrijven. Coolen van zijn kant heeft al eens 'reclame' gemaakt voor het werk en de schilderijen van Wiegersma. Bij het verschijnen van een monografie over de dokter-schilder van de kunstcriticus Albert Plasschaert heeft Coolen in januari r 934 een lovende bespreking van het boek én het werk geschreven. Hij vergelijkt Wiegersma met andere beroemde inwoners van Deurne, als de zangeres Aaltje Noordewier-Reddingius, die in die tijd bekend is als de nachtegaal van de Peel, de achttiende-eeuwse predikant J.F. Martinet, auteur van de ooit zo populaire Katechismus der Natuur, en de schilder Otto van Rees. Van Rees woonde met zijn vrouw van 1923 tot 1927 op het Klein Kasteel in Deurne. Coolen constateert dat het dorp Deurne invloed op hen heeft gehad, maar bij Wiegersma is het net andersom. Hij heeft Deurne zelf veranderd en rond zijn persoon heeft mythe-en legendevorming plaatsgevonden. Coolen prijst zijn zielkundige kijk op zijn patiënten en trekt hieruit de conclusie dat Wiegersma daarom zo'n goed portretschilder is. Het stuk besluit met woorden van Helman: "het is een voorrecht in zijn nabijheid en in zijn vriend. schap te leven. ${ }^{* 6}$

Precies in het jaar I917, waarin Antoon Coolen uit het dorp van zijn jeugd is vertrok. ken om als journalist elders te gaan werken, heeft Wiegersma zich in Deurne als huisarts gevestigd. Dat wil niet zeggen, dat zij in 1933 bij de terugkeer van Coolen in het dorp van zijn jeugd totale vreemden voor elkaar zijn. Wiegersma is de huisarts van Coolens ouders. Coolen heeft zich wel eens in een vakantie door hem laten behandelen; hij heeft Wiegersma onder andere een keer een kies laten trekken. ${ }^{7}$ Bovendien kenden ze elkaar van De Gemeenschap en schreven ze elkaar incidenteel brieven.

Wiegersma is op vrij jonge leeftijd al een legendarische figuur. Als arts gebruikt hij 
onorthodoxe onderzoeksmethoden, geeft hij ongebruikelijke medicijnen en behandelingsvoorschriften en zegt hij ronduit waar het op staat. Dit levert hem patiënten uit heel Nederland op; bij het station van Deurne worden op drukke dagen volgnummertjes uitgereikt voor de praktijk. Hij bezoekt zijn patiënten op niet alledaagse vervoermiddelen: per racefiets, te paard, op de motor en al in I 919 met een auto, een witte Oakland. In I922 laat hij door architect Roffelsen uit Helmond - die ook De Romeijn heeft ontworpen - een monumentaal huis in Hollandse renaissancestijl bouwen, De Wieger, thans Museum De Wieger.

Behalve dokter is Wiegersma ook een talentvol tekenaar en schilder. Hij maakt illustraties voor De Gemeenschap en met zijn schilderijen heeft hij al in 1928 een solotentoonstelling in het Stedelijk Museum te Amsterdam. In 1927 portretteert Coolen hem als dorpsdokter in zijn roman Hun grond verwaait. Zo kijkt het dorp dus tegen die excentrieke dokter aan: "Den dokter is hier geweest, om naar't been te komme kijken, den dokter, diejen uitbundigen Mijndersma, 'nen mensch mee vaart en mee ontploffingen, die zijn patiênten, als hij ziet dat ze 't niet meer halen zallen, in d'r gezicht zegt: je gaat kapot." ${ }^{8}$

Coolen en Wiegersma zijn aan het eind van de jaren twintig allebei kunstenaars met landelijke bekendheid. Twee jaar na de grote tentoonstelling van Wiegersma in 1928 wint Coolen de Van der Hoogt prijs. In 1932 worden ze in een adem genoemd door Marsman: "De boeren van Wiegersma zijn de boeren van Coolen, vóórdat Wiegersma ze verbeeldt en Coolen ze uit-beeldt, maar zij zijn onherkenbaar verschillend ná die bewerking." ${ }^{9}$ Eigenlijk heeft Wiegersma nog niet eens zoveel boeren geschilderd, maar Marsman had die boeren nu eenmaal nodig voor zijn stelling, dat de boeren van Coolen aan provincialisme doen denken en die van Wiegersma niet. Volgens hem stond de schilder van die boeren weliswaar met zijn benen in de Brabantse grond, "maar zijn blik is tevens de blik van een modern Europeeër." ${ }^{10}$ Het gevolg van deze kritiek had kunnen zijn dat het een wig tussen de twee kunstenaars zou drijven, maar het schampere artikel heeft ze eerder nader tot elkaar gebracht. Wiegersma is niet gevoelig voor vleierij, maar het artikel zet Coolen toch aan het denken. Van Duinkerken schrijft daarover:

"Ik geloof wel, dat hij [Coolen, C.S.], voor zoover schilderkunst en romankunst te vergelijken zijn, de superioriteit van Wiegersma's verbeelding onmiddellijk erkende en al moet hij zich lichtelijk gegriefd gevoeld hebben door Marsmans opmerking, dien den schilder hemelhoog verhief ten einde den romanschrijver des te dieper neer te halen, hij zocht onmiddellijk bij Wiegersma het voorbeeld, dat hem door Marsman was gewezen."

3 LMDC, inv. nr.3485, brief Coolen aan Jan Engelman, 8 november 1934.

4 FPC, brief Doeke Zijlstra aan Coolen. 3 juli 1934.

5 LMDC, inv. nr. brief Coolen aan Oomes, 16 oktober 1934.

6 Coolen, 'Brieven van De Romeijn', 13 januari 1934.

7 CS, [typoscript] Fennis, Herinneringen, 3.

8 Coolen, Hun grond verwoait, 123.

9 Marsman, 'Derde dimensie', 263.

10 Marsman, 'Derde dimensie', 264.

11 Van Duinkerken, Antoon Coolen, 56. 


\section{Deurne, een trefpunt van kunstenaars}

Coolen, die na de drukte van de krant even heeft moeten wennen aan de dorpse rust in Deurne, weet echter dat De Wieger een trefpunt is voor schrijvers en kunstenaars. Er komen de schilders en tekenaars Otto van Rees, Piet Wiegman, Permeke, Cantré en Kogan, de glazenier loep Nicolas en de beeldhouwer Zadkine. Ook redactieleden van $D e$ Gemeenschap, zoals Jan Engelman, verblijven er vaak. Het is ongelofelijk hoe het toch vrij afgelegen Deurne een trefpunt heeft kunnen worden voor zulk een internationaal gezelschap kunstenaars. Dit heeft toch in de eerste plaats gelegen aan de unieke persoonlijkheid die Wiegersma was.

Diners en feesten worden op De Wieger in grootse stijl gegeven. Coolen en zijn vrouw zijn daar vaak bij aanwezig. Daarnaast hebben Coolen en Wiegersma in de eerste winter in Deurne regelmatig met elkaar gesproken in de bibliotheek van De Wieger. Het is goed om daarbij het beeld van beide personen voor ogen te hebben. De grote dominante, extraverte Wiegersma, die elk vertrek waar hij binnenkomt meteen helemaal vult met zijn aanwezigheid, vormt een scherp contrast met de veel kleinere gestalte van de introverte, zacht sprekende Coolen. Het zal vaak zo geweest zijn dat Wiegersma vertelt en Coolen luistert. Hij luistert naar de verhalen over Wiegersma's vader én hij kijkt naar Wiegersma zelf, zoals hij zich gedraagt in de kring van zijn familie, hoe hij zich beweegt in het dorp en naar de manier waarop hij met zijn patiënten omgaat. Zo ontstaat de inspiratie voor een nieuw boek.

"De zoon, dr. Wiegersma in Deurne, vertelde mij over Lith en de praktijk van zijn vader allerlei verhalen en deze werden voor mij aanleiding tot het boek, waarin ik de vader zag à travers het temperament van de vertellende zoon. Tot het vollopen van het geheel, het voltooien, afronden, met elkaar in verband brengen van gebeurtenissen en aanvullende figuren droeg mijn fantasie bij." ${ }^{12}$

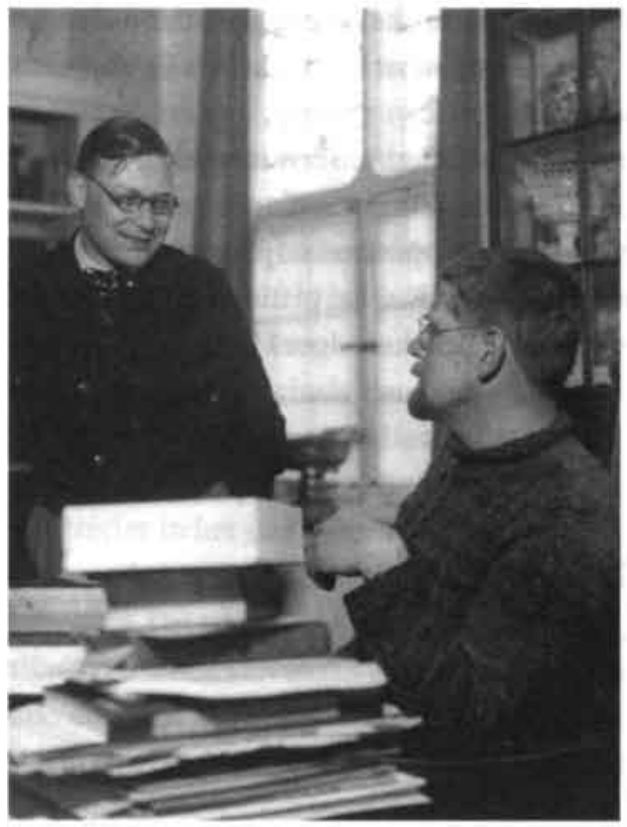

Antoon Coolen en Hendrik Wiegersma.

De opdracht van de nieuwe roman, Dorp aan de rivier, zal dan ook luiden: "Aan Hendrik Wiegersma, aan wien ik de stof dank voor dit werk, wordt dit boek in dankbare vriendschap opgedragen."

Van de aanbieding van Dorp aan de rivier aan Wiegersma op 15 november 1934 wordt een officiële plechtigheid gemaakt, waarbij naast de echtparen Wiegersma en Coolen ook uitgever Zijlstra en zijn vrouw aanwezig zullen zijn. Mevrouw Wiegersma kijkt er naar uit. "Het feest wordt besloten met een etentje. We zullen de Maas ruiken, de snoek opdisschen en de jachtbuit van Dokter v. Taecke eer aandoen. Doe ik je watertanden?" schrijft ze aan fan Engelman. ${ }^{15}$ 


\section{Dorp aan de rivier}

Zoals in de Peelromans de spoorweg langs het dorp en door de Peel loopt en het verre en voorbijgaande symboliseert, zo stroomt in dit boek de Maas naar het dorp toe en buigt er weer vanaf. Met dit beeld begint de roman en, na vele wonderlijke gebeurtenissen, vormt dit ook weer het slotbeeld. Er zijn dan tekenen, zoals hijskranen, beton en grondwerkers, die erop wijzen dat er veranderingen op komst zijn.

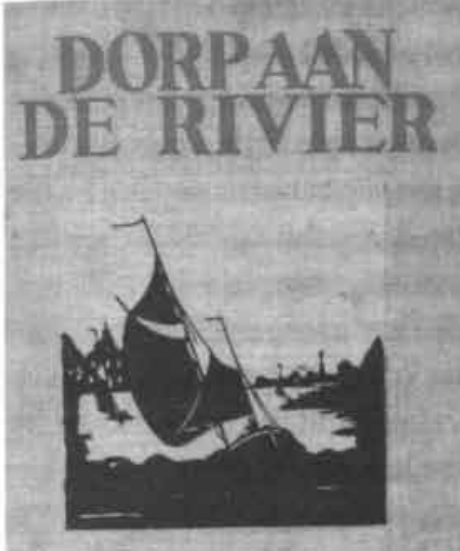

ANTOON·COOLEN

In een zwierig exposé worden het dorp en de personages geintroduceerd, waarbij vaak al een verwijzing wordt gegeven naar hoe het met hen zal aflopen. Zo is daar Pale Pie die ze met een bijl zijn kop insloegen, Willem van der Aa die met zijn kop onder de wielen van de postkoets kwam en Mammeke, het vrouwtje zonder echtgenoot, dat aan de syfilis wegteerde. We maken kennis met de stroper Cis den Doove, die op een arkje in de Maas woont en met Brammetje Peccator, die zo'n grote zonde heeft gedaan dat zelfs de paus in Rome die niet kent. Om die reden gaat hij wel naar de kerk, maar "naderde hij niet tot de heilige sacramenten."

Dokter Tjerk van Taeke, een Fries die naar het dorp is gekomen, leeft in onmin met twee boeren, Janus de Mert en Piet van den Oudendijk. Ook van de burgemeester moet Van Taeke niet veel hebben. Hij gaat liever om met de stroper Cis den Doove. De dokter is beroemd om zijn verlossingen. Bij de vrouw van Thijs van Erpen hield hij zelfs zijn sigaar in zijn mond zonder dat er as af viel. Naar het schijnt heeft hij eens een Russische grootvorstin van een flinke zoon verlost, waaraan hij zijn mooie roodbruine pelsmantel heeft overgehouden. Het dorp weet niet of Van Taeke gelovig is. Hij zegt wel 'God zegene U', maar hij gaat niet naar de kerk op zondag. Hij houdt daar niet van, zegt hij. Hij krijgt al een gevoel van geprikkeldheid zo gauw hij een pastoor ziet.

"Zij verklaarden de wereld, alsof zij zelve bijstand hadden verleend bij hare schepping en deel hadden gehad aan de creatie van de menschelijke ziel, deze domme zelfverzekerdheid tusschen twee sigaren in stond hem tegen, evenals hun diabetes ${ }^{14}$, hun corpulentie en hun predicaties, waarin zij door middel van stemverheffingen en redekunstige zinswendingen het verband trachtten te herstellen met het Evangelisch christendom, waar hun geest en praktijk zoozeer van vervreemd waren. Hij moest er niets van hebben." ${ }^{15}$

12. FPC, brief Coolen aan T. van Toll, 4 december 1958.

13. Brief Nel Wiegersma aan Jan Engelman, 14 november 1934, geciteerd bij: Van der Heijden, Wiegersma en Engelman', 137.

14 Gerard Reve legt in Bezorgde ouders, $(1988,80)$ ook de relatie tussen katholiek en suikerziekte. "Een katholiek die wordt nooit suikerziek," besliste hij, "en als hij het wordt dan is het door een ander: ongeloof en suikerziekte die gaan hand in hand."

15 Coolen, Dorp aan de rivier, 65. 
Van Taeke heeft daarentegen veel op met de 'nonnekes' in het klooster. Hij bezoekt wel eens het Lof in hun kapel en luistert naar het Gregoriaans van hun ijle stemmen. Hij laat offerkaarsen bij het beeld van de Sterre der Zee branden, omdat het zo 'heidens' is.

Op de molen en in het dorp gebeuren gruwelijke ongelukken die overigens weinig rimpelingen in het dorp teweeg brengen. Als een voerman zijn jeugdige bijrijder per ongeluk heeft overreden, legt hij het lichaam zolang langs de kant van de weg; eerst moet de post op tijd naar Oss. Pas 's avonds gaat hij, na het lijk te hebben opgeladen, naar de familie van de overledene en geeft wel een heel speciale invulling aan een slecht nieuws gesprek: "Ja, daar breng ik u wat mee, daar ge af verschieten zalt, wie helpt me dragen. ${ }^{16}$ De doodswake door enkele dorpelingen loopt uit op een drinkgelag, waarbij een van hen zelfs gaat dansen met het lijk. Pale Pie zweert bij het lijk dat hij meer durft dan de rest: hij zal de doek wegtrekken, die Mammeke altijd over haar hoofd draagt om haar aangetast gezicht te verbergen. Als hij dat inderdaad doet, wordt hij in de polder gevonden met opengespleten schedel. Hij is bewusteloos. Zo vegeteert hij nog enkele dagen. Dokter Van Taeke geeft ten aanschouwe van Cis den Doove een paar kleine demonstraties. Kijk, zegt hij, dit zijn nu de hersens van een mens en hij prikt met een fijne speld, waardoor de ene keer een been en de andere keer een arm van de schijndode in beweging komt. De verteller maakt een toespeling op de dodenrivier de Styx: "Hij ligt daar op zijn rug zwemoefeningen te maken, als zal hij straks als hij dood is, de Maas moeten overzwemmen naar de plaats zijner eeuwige bestem. ming."17

Boer Piet van den Oudendijk die de vrouw van de dokter belasterd heeft, moet het bezu. ren. Van Taeke stopt iedere dag in zijn rijtuigje bij de boerderij en legt met zijn dubbelloops jachtgeweer aan op de boer. De voldoening om hem in het vizier te hebben gehad is genoeg. Hij legt zijn knecht uit waarom hij dat doet: "Lasteraars mikken zonder dat ze hun slachtoffer in het oog kijken. Zij kennen geen wroeging! Daarom zal hij iederen dag een beetje doodsangst hebben. Want hij heeft mij in mijn liefde voor mijn vrouw beleedigd. ${ }^{18}$ De boer wordt er tenslotte stapelgek van en belandt in de psychiatrische inrichting Coudewater vol wroeging over de zonde van de laster.

Een andere boer, Janus de Mert op de Bergen, die onder andere de dokter zijn hazen stroopt, wordt ook gruwelijk gestraft. Als de dokter hem op verzoek van zijn kinderen onderzoekt vanwege klachten in de maag, constateert hij maagkanker. Hij rekent drie gulden voor deze visite en zal regelmatig terugkomen met een weinig hoopvol perspectief: "Als de duizend gulden vòl zijn, dan zijt ge dood." Deze voorspelling komt uit, maar voor het zo ver is heeft Janus een afschuwelijke tijd, met dromen die aan die van Fons van Willemien uit De goede moordenaar doen denken. Als het water in de Maas wast, droomt hij dat hij de noodklok op de Bergen luidt: "De klepel is er broos en zonder geluid uitgevallen als een lid dat door de kanker van het lichaam is afgerot en afvalt. De klok geeft geen geluid. Het is benauwd in de alkoof." 19

Het dramatisch hoogtepunt van het boek is een bijna onmogelijke tocht van Van Taeke in zijn Russische pelsjas over het kruiend ijs van de Maas naar een verlossing op de andere oever. De 'nonnekes' komen in de bijtende sneeuwstorm naar de veerdam om te bidden. Als hij terugkomt zegt hij dat ze niet moeten denken dat zij het met hun bidden voor elkaar hebben gekregen. Hij stuurt ze terug naar het klooster, want "anders hebt ge morgen alle- 
maal bronchitis." De volgende dag krijgen ze van hem een taart zo groot als een "wagenwiel." Als de vrouw van de dokter ernstig ziek wordt, strooien de boeren zand op de dijkweg voor het huis om de geluiden van de straat te dempen. Na haar sterven laat de dokter zijn zoons nog een keer het lijk van hun moeder zien in de loden kist: "Gij hebt nu het poppetje gezien, het kastje is dicht. Vergeet niet, hoe zij was. Gij ziet haar nimmer weer." ${ }^{20}$ 's Nachts begraaft hij haar in zijn eigen tuin. Een van zijn zoons ziet hoe hij daarna de kist vult met wat puin en aarde die overblijft van het graf.

Het zilveren ambtsfeest van de dokter, die ook gemeentearts is, leidt tot heftige discussies in de gemeenteraad over de hoogte van het bedrag in de envelop. Vanwege de klachten van de families van de twee boeren die door de dokter respectievelijk krankzinnig en dood zouden zijn gemaakt, overweegt men hem een bedrag van duizend gulden te geven en meteen ook eervol ontslag te verlenen. Sjef de Smid klapt hierover uit de school en Van Taeke neemt op weergaloze wijze wraak. Op de feestdag, als hij voor zijn huis onder een ereboog de serenade van de harmonie en de toespraak van de burgemeester heeft aanhoord en de envelop heeft ontvangen, neemt hij het woord en ... brandt de burgemeester tot de grond toe af.

"Gij echter munt in het aangename zeker niet uit en het is bitter dat, wie men ook is en hoe men ook doet, men bij gelegenheden als deze nooit anders dan huichelachtige conventie ontmoet, die het verraad verbergt. Mucius Scaevola hield zijn hand in het vuur om te laten zien, dat de Romeinen karakter hadden. Ik houd deze enveloppe in het vuur, om te laten zien, dat de Friezen karakter hebben." ${ }^{\text {n }}$

Hij verbrandt het omslag met de duizend gulden en verlaat even later het dorp. Sjef de

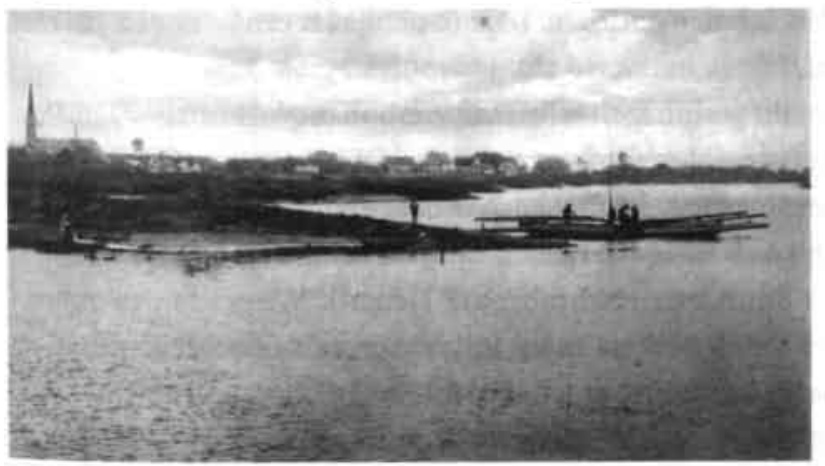

Veer bij Lith
Smid verzucht dat het dorp zo'n dokter nooit meer zal krijgen: we hebben hem door "onze stomheid en kleinheid" verspeeld.

Het boek eindigt met het beeld van de rivier. De Maas stroomt nog steeds naar het dorp toe, glijdt er langs en buigt zich er weer vanaf.

16 Coolen, Dorp aan de rivier, 42.

17 Coolen, Dorp aan de rivier, 93.

18 Coolen, Dorp aan de rivier, 134.

19 Coolen, Dorp oan de rivier, 146.

20 Coolen, Dorp aan de rivier, 231.

21 Coolen, Dorp aan de rivier, 336-337. In latere drukken heeft Coolen hieraan een citaat in het Latijn vooraf laten gaan. Dit is niet opgemerkt door dr. Van Vliet in de wetenschappelijke jubileumuitgave van Dorp oan de rivier in 1997. De ingevoegde passage luidt: "Voor mij staat vast, dat mijn taak nuttig is: Altissimus de coelo creavit medicinam et homo non abhorrebit eam. Dit geldt ook een dokter: vir prudens non abhorrebit eum." (jubileumuitgave 1997, 218). 


\section{Een echte 'Coolen'}

Door de locatie én het onderwerp van het verhaal ligt er ogenschijnlijk een heel nieuwe 'Coolen'. Er is wel eens gesuggereerd dat Dorp aan de rivier en De drie gebroeders door Coolen als een ijverige secretaris zijn opgetekend zoals Wiegersma ze verteld heeft en dat de schrij. ver is opgetreden als een soort chroniqueur van de familie van zijn vriend. Zo stelt Beks: "Wiegersma schreef met de hand van Antoon Coolen een geïdealiseerd zelfportret."22 Deze opvatting is onjuist en doet Coolen geen recht. In zijn Peelromans heeft hij al bewezen dat hij groteske personages kan scheppen en ook dat hij zijn waarnemingen op een heel bijzondere manier in zijn boeken verwerkt. Hij maakt van de sterke verhalen van Wiegersma over zijn vader Jacob Wiegersma ${ }^{23}$ in de rust van zijn schrijfhut een echte 'Coolen'.

In de samenvatting zijn lang niet alle nevenintriges en bijfiguren opgenomen. Coolen heeft de verhalen van Wiegersma aangevuld met zijn eigen scherpe waarnemingen van bestaande karakters. In zijn beschrijving van de vervangers van Van Taeke, dokter De Pater en dokter Rits, grijpt hij de kans om heel afwijkende dokterstypen te schetsen. Vooral in het personage De Pater schetst Coolen zijn afkeer van de groep rond Forum; hij gebruikt bijna dezelfde woorden als in zijn brieven. De Pater voelt zich ver verheven boven de mensen in het dorp en veracht hen. Dit blijkt al meteen uit de manier waarop hij wijdbeens en onverschillig hangend in zijn rijtuig in het dorp aan komt. Van Taeke wijst hem terecht in de woorden van Coolen: "Er zijn knappe mensen, die alles door hebben en daarom alles verachten, maar er zijn er ook, die zijn nóg knapper, die beginnen iets van de geheimen te zien, die verachten naar verhouding minder." Nadat hij De Pater heeft weggestuurd, kiest Van Taeke een boek uit zijn eigen bibliotheek. "Er stonden veel boeken van schrijvers die zeer scherpzinnig zijn en alles kunnen ontleden. Daar nam hij niet een boek van. Hij nam een ander [...] Hij las Vergilius." ${ }^{24}$

Het is bijna zeker dat voor dit personage, De Pater, Slauerhoff model heeft gestaan. Deze was van eind mei tot juli 1929 vervanger voor een zwager van Wiegersma in Beetsterzwaag en had daar enkele amoureuze avonturen. ${ }^{25}$ Een jaar daarvóór verbleef Slauerhoff een week op de pastorie te Lith bij de familie van Heleen Hille Ris Lambers. Met haar fietste hij door het Brabantse land en ontmoette eind juli r 928 Hendrik Wiegersma en Antoon Coolen in Deurne. ${ }^{26}$ Waarschijnlijk werkte Coolen toen in zijn vakantie aan de afwerking van Kinderen van ons volk in zijn ouderlijk huis.

In Mammeke schetst Coolen weer zo'n vrouwelijke randfiguur, die we al kennen als Vuil Leenke of Sandere Mie. Deze vrouwen staan aan de rand van de gemeenschap en worden door het dorp bespot, maar zij blijken steeds veel meer van het dorp te weten dan men denkt. Bovendien zijn ze in hun geest vrijer en meer autonoom dan de andere dorpelingen.

Mammeke is, naast de stroper Cis den Doove, de enige die op voet van gelijkwaardig. heid met Van Taeke praat en zich door zijn barse houding en dure woorden niet laat kisten. Zij heeft haar kinderen alleen groot gebracht. Haar man heeft haar verlaten na haar besmet te hebben met syfilis, maar dat zegt ze niet. Ze is trots op haar zonen, want ze weet dat deze Pale Pie de hersens hebben ingeslagen, omdat die de doek van haar hoofd heeft getrokken. Ze begrijpt de woorden niet als Van Taeke vraagt hoe het met haar dochters, de 'hetaeren', gaat, maar ze neemt wel geld van ze aan nadat ze zich met schipperslieden achter een gesloten deur hebben afgezonderd. Tegen vervanger dokter Rits zegt ze dat ze iets in het bloed hebben van haar eigen vurigheid toen ze haar man bedroog. Ze verdedigt haar weggelopen 
man, gooit de schuld op zichzelf en noemt steeds andere minnaars als oorzaak van haar ziekte. Ja, verzucht ze, ik was knap, toen die kapitein uit Rusland kwam; maar de volgende keer dat ze het er weer over heeft, komt hij uit Polen en daarna weer uit Rotterdam. "Omnis syphiliticus mendax est" [elke syfilislijder is een leugenaar, C.S.], verzucht Van Taeke, als hij Mammeke komt vertellen dat ze de lente niet meer zal halen. Hij voegt eraan toe, dat hij door heeft dat ze haar man niet wil beschuldigen. In één alinea laat Coolen haar na deze uitspraak van de dokter wegkwijnen en sterven. De dokter ontneemt haar iets: haar leven met veel leugens over denkbeeldige minnaars was haar manier van wraak nemen op haar man. $\mathrm{Zij}$ had geen andere middelen om dat te doen, legt de verteller uit: "Zij kan niet met een geweer in een rijtuigje gaan zitten, ze kan een ander geen kanker bezorgen. ${ }^{\text {"27 }}$ Zoals Van Taeke dat kan, mag de lezer erbij denken. Coolen zegt dus dat ieder zijn manier van wraak nemen heeft; het maakt niet uit of je primitief leeft of gestudeerd hebt.

In Brammetje Peccator, de zondaar en filosoof, is Jan Olie uit Het donkere licht te herkennen. Hij vindt overigens aan het eind in Antwerpen een biechtvader - "zoo oud als de straat" - die zijn zonde kent. Deze heeft slechts gezegd: "Ahwèl, absolvo te" [ik vergeef U,C.S.].

Zoals Coolen in De schoone voleinding flink uitpakte met de volledige beschrijving van een zilveren priesterfeest, zo wordt ook nu het dorpsleven met al zijn plezierige maar ook oubollige kanten geschilderd. Er is een soort wetenschappelijke vereniging, de broederschap van de snoek, die bestudeert en bijhoudt wat een enorme snoek in een nabijgelegen Wiel allemaal aanricht. Die snoek is een soort monster van Loch Ness, wiens kracht en omvang door de dorpelingen tot mythische proporties worden opgeblazen. Eens was de snoek over de dijk de Maas ingesprongen en toen was het water van de Wiel een meter gezakt. Toen hij weer teruggesprongen was, kwam de fanfare een serenade brengen met brandende fakkels, meer om hun angst te bezweren dan uit feestelijkheid. Als een van de vervangende artsen op de snoek schiet, slikt deze de kogels gewoon door. De broederschap houdt al die gebeurtenissen bij in "hare geschriften." De leden komen bijeen in herberg De Koffiekan, later Moira genoemd, omdat de waard die naam van een ongevallenverzekering zo mooi vindt. Uit hetgeen volgt kan de lezer opmaken dat dit eigenlijk noodlot, fatum, betekent.

De beschrijving van de geweldige snoek zat al in Coolens hoofd toen hij aan zijn boek Zegen der goedheid werkte. In de legende over 'Joris van de maagden' komt een verschrikkelijke draak voor die in het water verblijft. De beschrijving daarvan lijkt een vingeroefening voor de legendarische snoek uit Dorp aan de rivier. Ook hier dromt het volk samen op de stadswal om naar het meer te kijken waarin de draak is verdwenen. "Het onzichtbare monster was weergekeerd naar de donkere, ondergrondsche gebieden van hel en chaos, waaruit het kwaad rijst, dat zijn slachtoffers zoekt onder de menschen."28

22 Beks, Hendrik Wiegersma, 19.

23 lacob W. Wiegersma (1863 - 1931), huisarts in Lith van 1889 tot 1929.

24 Coolen, Dorp aan de rivier, 90-91.

25 Hazeu, Slauerhoff, 387-400.

26 Hazeu, Slauerhoff, 340.

27 Coolen, Dorp aan de rivier, 323.

28 Coolen, Zegen der Goedheid, 120. 
Het jubileumfeest van dokter Van Taeke staat in het teken van de huichelarij. De hele gemeenteraad zit "in de kerk [...] te jubelen en van dankbaarheid te bidden tot intentie van den jubilaris." De enige die ontbreekt, is de jubilaris zelf: "Ik ga daar niet naar toe. Wânt ik houd daar niet van." ${ }^{29}$ Coolen legt hierdoor een extra accent op de huichelarij van de raads. leden die al biddend immers weten, dat ze de dokter gaan ontslaan. Het koor dat aan het eind van de mis een feestcantate heeft gezongen, komt deze voor het huis van de dokter herhalen. Op de ereboog voor Van Taekes huis staat weer net zo'n onbeholpen gedicht als bij pastoor Vogels in De schoone voleinding:

"Heil U, geneesheer, die vijfentwintig jaren,

Waardig en vol ijver uw plicht hebt betracht.

Dat God U nog vele jaren mag sparen,

En door Zijn beleid U brenge tot kracht."

\section{Stijl en idioom}

De stijl van Coolen maakt de dorpsbevolking tot verteller. Nog meer dan in de Peelromans wordt de lezer daardoor rechtstreeks betrokken bij het verhaal. Coolen heeft het dialect laten varen. Alleen in de dialogen schemert het Brabants taaleigen nog door, vooral in het gebruik van 'gij' en de daarbij horende werkwoordsvorm: Hoe noemde gij die? Kende gij de ziekte van Mammeke? Durfde gij ... De scheiding tussen de verteller, die over de rivier, de natuur en het dorp verhaalt en de dorpelingen, die gissen en commentaar geven, verdwijnt hierdoor bijna helemaal en dat is zeer belangrijk in deze roman, waar eigenlijk 'het dorp' de verteller is. Voortdurend wordt de lezer deelgenoot gemaakt van de buurtpraatjes, de dorpsroddel. De samenspraken worden echter niet gegeven als dialogen. Coolen zegt niet wie het woord voert. Toch horen we duidelijk een van de dorpelingen aan het woord, maar die dorpeling kan evengoed de verteller Coolen zijn. ${ }^{30}$ Heel vaak beginnen die gesprekken als volgt: "Ze zeggen ...," "De praat ging ...," "Er is praat over ..." Soms maakt Coolen gebruik van uitroepen, zonder aanhalingstekens, waarbij in één zin gissingen èn veronderstellingen èn antwoorden worden gegeven:

"De zondige moeder! Was die kapitein een Rotterdammer geweest? Mammeke wist dat misschien niet. Een Rotterdammer? Een Spanjaard misschien, of iemand uit Luik, misschien was het ook een Italiaan geweest. Maar wat voor taal sprak hij dan, Mammeke? Ach, zei Mammeke, hij sprak een maar al te begrijpelijke taal." ${ }^{31}$

Deze nieuwsgierigheid en dat gissen zijn steeds de kenmerken van de dorpsroddel. Men weet nooit precies wat er aan de hand is en laat veel in het midden. Als Cis den Doove een zigeunerin op zijn boot heeft, spreekt men over "de vrouw uit Bosnië of uit Moravië, of waar kwam ze vandaan ..." Enkele bladzijden verder heet het: "Zij kwam natuurlijk niet uit Bulgarije, ze kwam hoogstens uit Savoye." Verderop spreekt men van "die vrouw uit Bohemen of Tirol" en op het laatst van "de zoete verschijning van de Slavische vrouw. ${ }^{\text {"I? }}$ Het boek wemelt van de constructies en woorden die te maken hebben met het gissen; veel gebruikte woorden zijn 'zal', 'zeker' en 'misschien'.

Tenslotte valt op dat Coolen, ondanks de kritiek van Van Duinkerken daarop van tien jaar eerder, nog altijd gebruik maakt van de 'repeterende breuk': de korte, steeds herhaalde zinnetjes die zijn gerangschikt in een nevenschikkende zinsbouw met veel komma's. Hij is van mening dat deze stijlvorm de wijze waarop de mensen in Oost-Brabant praten het 
beste nabootst. Er zijn critici die dat aanvoelen: "Het komt me voor, dat deze wijze van vertellen, overeenkomend met de spreekmanier van boeren in een berookte herberg (hoe vele malen vertellen ze je niet op dezelfde avond precies dezelfde dingen op hun eentonige manier) zeer goed past bij deze dorpspassage van de twintigste eeuw. ${ }^{233}$

\section{De ontvangst}

Dorp aan de rivier wordt een groot succes. Al op 9 december 1934, enkele weken na verschijning, is de eerste druk van 3000 exemplaren uitverkocht. "Ik moet die belangstelling [van de lezer, C.S.] wel hebben, omdat er zozeer van af hangt, of ik me rustig geheel en uitsluitend aan de letteren kan blijven wijden, zonder de belangen van ons gezin schade te doen," schrijft Coolen met een ondertoon van verontschuldiging. ${ }^{34}$

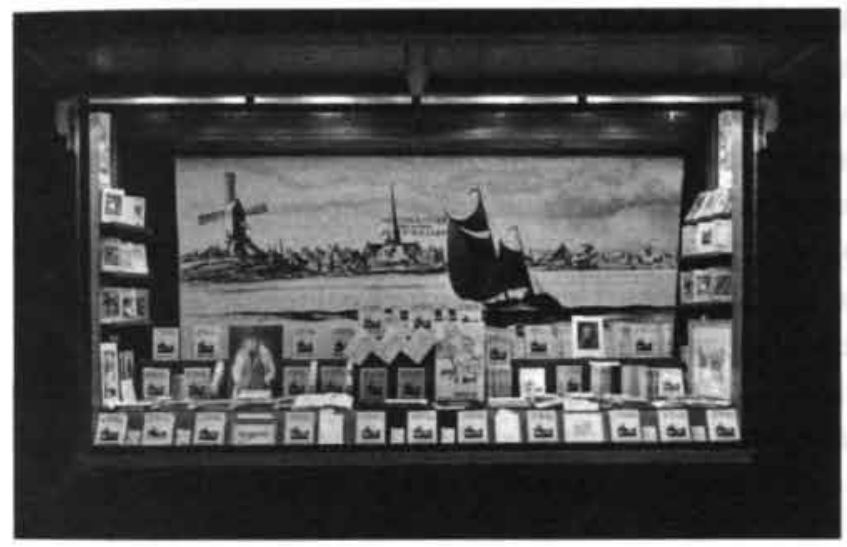

De recensies zijn over het algemeen positief. Pater Van Heugten schrijft als een van de eersten een lovend artikel in Boekenschouw. "Dorp aan de rivier is zoo frisch van vinding. zoo gelukkig van compositie en verhaaltrant dat het iets nieuws en eigens is in Nederland."

Zelfs Menno ter Braak die zich bij veel boeken van Coolen "stevig verveeld" heeft, schrijft dat dit boek boeiend verteld is: "Ik heb een boek van Coolen voor het eerst in één stuk uitgelezen." Hij vergelijkt het met Gösta Berling van Selma Lagerlöf. Van Taeke is een ongelovig katholiek, die Voltaire en Erasmus leest maar toch een vriend van de 'nonnekes' is. Hij is bemind en gevreesd, hij staat "Tenseits von Gut und Böse." Ook nu analyseert Coolen volgens Ter Braak de hoofdpersoon niet, maar is het hem alleen maar om het vertellen te doen. "Maar ik moet zeggen, dat het vertellen deze keer dan ook buitengewoon goed gelukt is." Bij de beschrijving van Mammeke stijgt Coolen als verteller zelfs boven zijn gewone peil uit, oordeelt hij. ${ }^{35}$

De NRC oordeelt negatiever. De recensent vindt de roman gekunsteld. Deze is te traag en bevat teveel herhalingen. Nu Coolen voor zijn brood schrijft, moet hij oppassen geen

29 Coolen, Dorp aan de rivier, 331.

30 Zie ook: Taels, Antoon Coolen. Zijn werk - zijn kunst. Enkele voorbeelden die hij geeft worden hier ook gebruikt.

31 Coolen, Dorp aan de rivier, 61 .

32 Coolen, Dorp aan de rivier, 214, 216, 222 en 226.

33 Van Leeuwen, 'Romantische heldenverering bij Coolen', 137.

34 LMDC, inv. nr. 3485, brief Coolen aan Oomes, 9 december 1934.

35 Ter Braak, Veelschrijvers', 448-451. 
veelschrijver te worden. "Hij schrijft oneindig meer, als hij oneindig minder schrijft." ${ }^{36}$ De recensent van De Literaire Gids begint met te verklaren dat hij niet van het werk van Coolen houdt. Hij bleef het "süsser Kitsch" vinden, verwant aan het werk van Courths-Mahler. Hij is twee keer aan Dorp aan de rivier begonnen en heeft het weer weggelegd. De derde keer geeft hij zich echter gewonnen. Het "lauwe, van zoet sentiment doortrokken bastaardrea. lisme" blijkt plaats gemaakt te hebben voor een vrije fantasie en "een burleske verbeel. dingskracht." Het boek is een hele verademing na het verschrikkelijke Zegen der goedheid. Hij vindt het bij uitstek geschikt voor verfilming ${ }^{37}$

Ook Coolens eerste criticaster, Pieter van der Meer de Walcheren, is enthousiast. "lk ben gelukkig met dit boek zooals ik 't zelden geweest ben met litterair werk. Het is sterk en zuiver, zoo mannelijk-echt, met de ingetogen vurigheid van liefde. Mijn hart is rijker geworden door dit dichterlijk verhaal." Hij verwijst hier, bewust of onbewust, naar het verhaal 'Als het hart maar rijk is', dat Coolen schreef in r 920 vlak voor het verschijnen van Lentebloesem. Hij vindt dat Coolen zijn personages heeft zien leven in zijn eigen hart. Van der Meer wijst nog op een bijzondere stijlvondst van Coolen als hij niet de dokter op zijn gevaarlijke overtocht over het kruiend ijs begeleidt, "maar ons deze prachtige roekeloos. heid laat medeleven door de in welk'n spanning wachtende dorpsbewoners. ${ }^{.38}$

Het heidense, in ieder geval niet-religieuze karakter van de hoofdpersoon leidt tot verschillende reacties. Van Leeuwen prijst juist het mythische karakter van de hoofdfiguur die vrij is "van religieuze en maatschappelijke dogma's." Hij vindt de roman een aanwinst en niet alleen voor Nederland: verschillende fragmenten zullen bij vergelijking met buitenlandse literatuur niet verbleken. Na zich eerst van de realiteit tot de legende te hebben gekeerd, heeft Coolen het ditmaal gezocht in de sage, in de vergroting van gebeurde feiten door de fantasie. ${ }^{39}$

Er zijn echter ook negatieve, moraliserende oordelen. Frans Coenen beschouwt deze verheerlijking van een alles kunnende man als een romantisch ideaal van zwakke zielen "die zich graag verbeelden wat zij hadden willen zijn. ${ }^{m 0}$ Jan Nieuwenhuis ziet in de hoofdpersoon "een soort misvorming van een in aanleg groot karakter." Volgens hem heeft het boek gevaarlijke kanten, "juist nu het verschijnt in een tijd, dat de jeugd van Europa zich een beetje lijkt te schamen voor de zachtheid van het evangelie. ${ }^{n t}$

In het bisdomblad van Den Bosch, Sint-Jansklokken, ergert Uitkijk - pseudoniem van Kees Spierings, de medeschrijver van de toneelversie van Kinderen van ons volk- zich aan de "realistische, bijna platte uitdrukkingen" die erin voorkomen, waardoor het boek strikt voorbehouden moet worden aan volwassenen. Het blad doelt dan op de beschrijving van een geboorte en de hatelijke opmerkingen van Van Taeke aan het adres van de clerus. Er zit totaal geen strekking in het boek, vindt Uitkijk, het is kunst óm de kunst. Nou hoeft een katholiek auteur geen 'tendenz-romans' te schrijven, maar hij kan toch een poging wagen tot godsdienstige of zedelijke infiltratie. Coolen doet dat niet. Als er al een strekking in zijn boek zit is die: "aan te tonen dat een heidensch-georiënteerd naam-katholiek kan uitmunten door zeer aantrekkelijke natuurlijke deugden." Van Taeke is een bruut met een gouden hart. Hij is "een katholiek-in-naam, maar ' $n$ heiden in al z'n godsdienstige, of moet het zijn ongodsdienstige opvattingen." Dit is het oordeel van de recensent en nu gaat hij weer verder studeren op de Katholieke Actie en het Leekenapostolaat, zo besluit hij zijn bijdrage. ${ }^{2}$

Deze laatste kritiek geeft een beeld van hoe de gewone doorsnee katholiek die geen 
landelijk dagblad of cultureel tijdschrift leest, in die tijd wordt voorgelicht over literatuur. Van Duinkerken heeft gelijk met zijn vaststelling van enkele jaren daarvoor, dat men er in katholieke kring alles aan doet om de mensen van de literatuur af te houden, omdat men er bijna altijd wel iets slechts in weet te vinden.

In een van de kritieken klinkt ook de taal van het fascisme over volk en het volkseigene. Albert Kuyle keert zich fel tegen zijn vroegere mederedacteur:

"Antoon Coolen zal niet gelooven, en sterker, hij zal niet inzien, dat zijn Dorp aan de rivier een woekering is op den stam van het volkseigene, van de volksverbondenheid. Een op het volk parasiteerend boek, dat de interesse van den liberale middenstand voedt, en hen op het volk tracteert als op een schaal janhagel, neergezet voor de grove gestalte van een niet tijdig opgeborgen psychopaath." ${ }^{\text {4s }}$

Naast de katholieke en de 'volkse' meetlat voor de roman komt daar later nog die van de medische correctheid bij. In het Roomsch Katholiek Artsenblad van maart 1936 verschijnen twee artikelen over deze roman. Het ene is van dokter Van Berckel en heeft als titel 'Het dorp der Phenomenen', het andere is geschreven door de hoofdredacteur van dit blad dr. Huddleston Slater. Het is nauwelijks te geloven, maar beide heren gaan omstandig uitleggen dat veel van de medische praktijken in deze roman niet kloppen. Het is alsof de Heidemij kritiek levert op de wijze waarop in Peelwerkers het steken van klot beschreven wordt. Coolen reageert in de rubriek 'Hagel' van De Gemeenschap. Dit soort kritiek, van alleen maar roepen: "Dat kan niet," vindt hij de meest "Hollandsche" kritiek die er bestaat. Hij zegt ook iets over zijn intenties met de roman: "Uit exacte medici als zij, schept men geen mythe en geen heros." Aan het slot geeft hij op een ironische toon toe dat de heren doktoren op één punt gelijk hebben: zo'n grote snoek als hij beschreven heeft, dat kan inderdaad niet. ${ }^{44}$

Coolens directe vrienden zijn niet zo enthousiast. Als hij de positieve reactie van Van Heugten in de toonaangevende Boekenschouw aan Oomes meldt, reageert deze zeer negatief. Hij vindt dat Coolen op de verkeerde weg is en de krachten van het christendom verwaarloost. Dorp aan de rivier had volgens hem een katholiek meesterwerk kunnen worden als Tjerk van Taeke een katholiek was geweest. ${ }^{45}$ Coolen antwoordt dat het hem daarom helemaal niet te doen is: "Dorp aan de rivier is veeleer plezierig geschreven als een plezierig boek dan als een katholiek getuigenis. ${ }^{.46}$

Als Coolen aan Van Duinkerken vraagt of er niets gedaan kan worden tegen het "vals

36 Jaarsma, [Recensie Dorp aan de rivier].

37 'Coolen en de film'.

38 Van der Meer de Walcheren, [Recensie Dorp aan de rivier].

39 Van Leeuwen, 'Romantische heldenverering bij Coolen', 134-137.

40 Coenen, [Recensie Dorp aan de rivier].

4) Nieuwenhuis, 'De roman van een dokter'.

42 Spierings, [Recensie Dorp aan de rivier].

43 Kuyle, 'Nieuwe normen', 129-135.

44 Coolen, 'Da kan nie', 277-272.

45 LMDC, inv. nr. 3485, brief Oomes aan Coolen (concept), begin december 1935.

46 LMDC, inv. nr. 3485, brief Coolen aan Oomes, 8 december 1935. 
en angstig alarm" 47 van Kees Spierings gaat Van Duinkerken daar niet op in. Hij besteedt in De Tijd geen aandacht aan Coolens nieuwe roman. Pas veel later oordeelt hij dat Coolen zijn fantasie in Dorp aan de rivier verruimd heeft tot "een meer Keltische wereld." Hij prijst de humor en de fantastische elementen, maar in de zeven pagina's die hij dan aan het boek wijdt, spreekt hij geen oordeel over het boek als geheel uit. ${ }^{48}$

Het succes van het boek is enorm. Binnen een jaar zullen er tien drukken van verschijnen. Coolen is nu een van de bekendste schrijvers van Nederland.

Ook thuis in Deurne wordt Coolen geëerd. Hij heeft het beschermheerschap van het St. Antoniusgilde aanvaard en op 17 januari 1935 , de feestdag van de schutspatroon, komt het gilde de vendelgroet brengen bij De Romeijn. De zoontjes mogen op het paard van de standaardrijder zitten en binnen wordt het glas geheven. De traditie rond het gilde was wat versloft en men wil die nieuw leven in blazen. De deken spreekt namens de gildebroeders: "Wij zijn er van overtuigd dat Uw moreele steun onze vereeniging ten goede moet komen. Wij weten dat de naam Coolen een klank heeft die reikt tot ver over onze grenzen." ${ }^{n 9} \mathrm{Het}$ gilde hoopt nog lang te mogen profiteren van Coolens adviezen, want deze zijn waardevol "door kennis maar niet minder door liefde voor dit volk."

\section{Hagelbuitjes: een andere Coolen}

In de Hagelrubriek van De Gemeenschap laat Coolen een nieuw aspect van zijn schrijverschap zien: dat van de polemiek en ironie. Uit zijn privé-correspondentie blijkt dat hij daar heel bedreven in is, maar het publiek kent die kant van Coolen niet.

In 'Zoo zie je me, zoo zie je me niet' moeten Vestdijk en Du Perron het ontgelden. Coolen analyseert enkele passages over dichtkunst van een van onze "scherpzinnigste dichters" - Vestdijk - en een gedicht van Du Perron - "ook een onzer intelligentici" - en drijft de spot met hun duister taalgebruik. Coolen eindigt: "Hoe aardig en hoe boeiend is dit hemelsch spelen van Muse en Intelligentia in de ijle hoogte, hóóg boven het gelach en het gejoel der domme menschen daar beneden. ${ }^{n 0}$ Het lijkt alsof Coolen, jarenlang in de hoek gezet als 'boerenschrijver', na het succes van Dorp aan de Rivier in de aanval gaat.

In 'Na tien cultuurjaren' bekritiseert hij de Nederlandse bond van toneelschrijvers die volgens Coolen ook wel "de toneelkijvers"genoemd worden. In hun jubileumboek klagen de leden van de Bond dat hun stukken zo weinig worden opgevoerd en dat de opbouwende krachten van de Nederlandse cultuur niet voldoende worden geëerd. Coolen, zelfverzekerd door het succes van zijn Vier jaargetijden en door zijn goede relatie met de directie van het Nieuw Schouwtoneel, vindt dit maar gezeur. Hij schrijft het jubileumboek de grond in, om te sluiten met deze ironische heilwens: "Moge dit boek, dit welgetitelde boek er toe bijdragen, dat de opbouwende krachten onzer cultuur nu eens wél worden geëerd. Tot nóg zoo'n boek over tien jaar, bij leven en gezondheid, en asse we met onze cultuur weer wat verder zijn." ${ }^{\text {"5t }}$

Niet alleen de literaire wereld, ook de gezeten clerus moet het ontgelden. In 'Pastoralia' verhaalt Coolen hoe een Brabantse plattelandspastoor het bidprentje van een man die werd doodgestoken op een volksfeest op zondagmiddag, misbruikt om zijn strijd tegen het Lof-verzuim gewicht te geven. ${ }^{52}$ De pastoor legt in de tekst van het prentje een rechtstreeks verband tussen dit verzuim en de dood van de onschuldige. Hij laat de dode zeggen: "Door 
mijn dood heeft God een treffende conferentie gehouden en met mijn bloed op de drempels der herbergen geschreven: Viert Zondagmiddag!"53 Coolen schrijft dat het Lof bij pastoorsfeesten vaak alleen maar een onderbreking is van het uitgebreide diner. Coolen ziet eigenlijk maar één verschil: de pastoors drinken op zo'n middag wijn en het volk jenever.

In deze rubriek 'Hagel' haalt Coolen, zoals al eerder vermeld, zijn gram tegen zijn oudwerkgever Aleven en de katholieke pers in het Gooi. "Er zullen weinig bedrijven zijn als dit, waar zoo aanhoudend personeel met herrie er uit gaat." Hij spreekt over "den voozen bodem, waarin het apostolisch bedrijf der katholieke pers daar in 't Gooi geworteld ligt."

\section{Reis naar Palestina}

Als Coolen in de zomer van 1935 klaar is met het schrijven van een nieuw toneelstuk, De vreemdeling, en Het Nieuw Schouwtoneel al met de repetities ervan is begonnen, maakt Coolen samen met onder andere Stijn Streuvels een groepsreis naar Palestina.

Het voorstel voor deze reis komt in juli 1935 van Streuvels. Coolen vindt het meteen "iets geweldig aanlokkelijks," maar vraagt zich af waarom Streuvels juist hem als metgezel meewil. Hij vraagt of het de bedoeling is om er samen een boek over te schrijven, maar is dan de voorbereidingstijd niet te kort en hoe lang duurt zo'n reis in zijn geheel? $?^{54}$ Enthousiast, maar onzeker, werpt hij een dag later nog meer vragen op over de hoogte van de kosten en over de uitgever, die hun reisverslag moet uitgeven. ${ }^{55}$ Zijn uitgever Zijlstra vindt het trouwens een goed idee; schrijvers hebben zoiets af en toe nodig om inspiratie op te doen. ${ }^{56}$

Het reisprogramma valt Coolen echter wat tegen. Dat ze met een heel gezelschap reizen heeft voor hem minder bekoring dan met Streuvels alleen. Met zo'n club "waarmee men langs een precies uitgemeten programma 'gesleept' wordt, is de reis ook niet zoo vruchtbaar. ${ }^{n / 7}$ Gezien de uitgave van tussen de vier- en vijfhonderd gulden, vindt Coolen dat de reis zo nuttig, vormend en leerrijk mogelijk moet zijn.

De beslissing valt uiteindelijk toch positief uit en op 16 augustus vertrekt hij vanaf het Zuid-Station in Brussel naar Marseille. Binnen het totale reisgezelschap vormt hij met Streuvels en nog drie andere Vlamingen een groepje van vijf man dat met elkaar optrekt.

47 BA, brief Coolen aan Van Duinkerken, 17 december 1934.

48 Van Duinkerken, Antoon Coolen, 73-79.

49 Geciteerd in: Van der Ven, Ons eigen volk in het feestelijk joar, 42.

50 Coolen, 'Zoo zie je me, zoo zie je me niet', 325-329.

51 Coolen, 'Na tien cultuurjaren', 462 - 464.

52 Het Lof was een kerkdienst op zondagmiddag, die in tegenstelling tot de H. Mis 's morgens, niet verplicht was.

53 Coolen, 'Pastoralia', 563-565. Het betreft hier zeer waarschijnlijk een gebeurtenis die in 1930 heeft plaatsgevonden en die Coolen van Wiegersma heeft gehoord. Wiegersma stuurde, zoals hij wel vaker deed als hem iets dwars zat, op 7 september 1930 een pamflet rond waarin hij de pastoor en de tekst van het bidprentje hekelde. De prent bevindt zich in de collectie van Museum De Wieger.

54 AMVC, inv. nr. C 3475, brief van Coolen aan Streuvels, 19 juli 1935.

55 AMVC, inv. nr. 3475, brief Coolen aan Streuvels, 20 juli 1935.

56 FPC, brief Zijlstra aan Coolen, 26 juli 1935.

57 AMVC, inv. nr. 3475, brief Coolen aan Streuvels, 23 juli 1935. 
De reis wordt door zowel Coolen als Streuvels beschreven. Het verhaal van Coolen verschijnt als serie in De Maasbode. ${ }^{58}$ In de serie geeft hij een overzicht van de toeristische en religieuze plaatsen met veel aandacht voor de verschillende bevolkingsgroepen. Streuvels geeft in zijn verslag ${ }^{59}$ meer aandacht aan het reisgezelschap zelf. Een gezamenlijk reisboek van beide auteurs is er niet van gekomen. Voor Coolen lijkt de reis toch in de eerste plaats bedoeld als vakantie, om er eens helemaal uit te zijn na een slopend jaar. Een vakantie, gekoppeld aan een pelgrimsreis langs de heilige plaatsen, is in die tijd geen uitzonderlijke gebeurtenis en bij welgestelde katholieken zeer in trek. De tocht krijgt een extra accent, omdat de spanningen in het Midden-Oosten in 1935 snel oplopen; er is een dreiging van politiek, religieus en etnisch geweld. ${ }^{60}$

Op ig augustus varen ze uit, na een oponthoud in Marseille vanwege een communistische staking in de haven. Coolen heeft van die vertraging gebruik gemaakt om de stad te bekijken, waarbij hij verzeild raakt in het Quartier Chinois, een beruchte buurt waar de politie geen garanties geeft. ${ }^{61}$ Via Napels, waar veel oorlogsschepen liggen in verband met de voorbereiding van Mussolini's aanval op Abessinië [het latere Ethiopië, C.S.], gaat het naar Athene. Onderweg zijn er volgens Streuvels veel dorpsroddels in hun hut, die ze de naam hebben gegeven van een kajuit op een kleine vissersboot, 'het Kabberdoeske'.

Met gevoel voor de klassieken spreekt Coolen in zijn verslag van een tocht "tussen de verslindende monsters van de Odyssee. ${ }^{\text {"62 }}$ Ook de actualiteit doet zich gelden en hij heeft oog voor het lot van de tegenstanders van Mussolini als hij langs "de kleine rotsachtige, uit de zee opdoemende Liparische eilanden [vaart] waar de Italiaanse politieke ballingen hun sombere bestaan leiden." Coolen heeft in zijn rubriek in de Bossche Krant van dit jaar veel kritiek gehad op Mussolini en zijn aanval op Abessinie..$^{63}$

In Athene wordt onder meer de Akropolis bezocht. In Istanbul hoort Coolen hoe ze daar het hondenprobleem hebben opgelost: de overheid heeft alle honden op een onbewoond eiland gedumpt en ze daar laten verhongeren. "Had ik het voorrecht Slauerhoff te zijn, dan schreef ik daar een short story over," noteert Coolen in zijn reisboek. Ook bij Rhodos merkt hij de oorlogsdreiging op: "Maar aan de kim is de scherpe boeglijn der dreigende oorlogsbodems, de steven die opnieuw is gericht op dit 'strategisch' punt." Op 28 augustus gaat het reisgezelschap in Beiroet van boord en trekt via de stad van duizend-enéén-nacht, Damascus, naar Baalbek en vandaar door de bergwoestijnen van de Libanon naar Nazareth. Door de Jordaanvallei en langs het Meer van Galilea reist de groep per autobus het Heilig Land binnen.

Jeruzalem valt Coolen tegen: "Ge treedt er in de vollen sidderende hitte, in de weeë geuren en stanken en het felle lawaai van het oosten. Arabieren, Joden, Europeanen en kamelen krioelen er door elkaar." ${ }^{n 4} \mathrm{Hij}$ schrijft dat ouders opzettelijk oogziekten op hun kinderen overbrengen om bij het bedelen meer medelijden op te wekken. Hij ziet het antagonisme tussen de Christenen, de Joden, de Armeniërs en de Muzelmannen in een stad vol tegenstellingen. Hij is bang dat de haat tussen Joden en Arabieren onuitroeibaar is, omdat die in een voedingsbodem van eeuwen is geworteld. ${ }^{65}$

Coolen vindt in Tel Aviv, de stad die pas in 1908 is gesticht als tuinstad van Jaffa en in r 935 al 150.000 inwoners telt, het ideaal der Joodse immigranten belichaamd. "Zij vermengen zich hier tot die bijna ondoorgrondelijke eenheid die het ras bezit, die mysterieuze zelfhandhaving van den Jood, die, hoezeer verspreid en verstrooid en hoezeer met alle 
naties ter wereld vermengd, de diepste kenmerken en wezenstrekken van het ras ongerept behield, paradoxaal genoeg tot zijn ongeluk, tot zijn tragedie én zijn grootheid beide."

Voor de terugreis worden nog Jericho en de Dode Zee bezocht. Vervolgens gaat het per trein naar Caïro en Suez. Van hieruit varen ze via Marseille weer naar huis. Streuvels verlangt op het schip al naar "de gemoedelijke lindebomen, de drijvende wolken, de zijpelende regens, de koelte van Vlaanderen." ${ }^{.66}$ Bovendien is het gezelschap elkaar moe. "We hebben te lang dezelfde gezichten gezien; we zijn uitgepraat," schrijft Streuvels. Tics die eerst niet opvallen, gaan nu op de zenuwen werken. "Das Lied ist aus en we zitten hier doelloos te wachten . om van elkaar verlost te zijn. ${ }^{-67}$ Coolen maakt zich onnodig druk over de vraag hoe hij een zijden peignoir voor zijn vrouw door de douane zal krijgen. Alles is goed gegaan, schrijft Coolen bij thuiskomst, "bij de Hollandsche grens had ik iets geleerd van de Vlaamsche vrijmoedigheid om neen te zeggen tegen een douanebeambte." Hij beleeft de reis steeds opnieuw in zijn herinnering, die doorklonken is "van het vele goede lachen dat we hebben gedaan." ${ }^{\mathbf{6 8}}$

Coolen lijkt helemaal niet op zoek te zijn geweest naar inspiratie, zoals zijn uitgever van tevoren had gedacht. Toch is het opmerkelijk dat Coolen, als nauwgezette waarnemer van mensen in speciale situaties, met deze reis literair weinig heeft gedaan. Pas elf jaar later schrijft hij een kerstverhaal waarin iets te bespeuren valt van de sfeer van het MiddenOosten. ${ }^{69} \mathrm{Hij}$ zoekt zijn inspiratiebron liever in de natuur en het dorpsleven, dat hij van nabij kent. Wat zou het interessant zijn geweest als hij ook iets had gedaan met de discussies en roddels uit het Kabberdoeske. Het komt er echter niet van, want hij heeft het vervolg op Dorp aan de rivier al in zijn hoofd. Het reisverslag in De Maasbode is 'slechts' een journalistieke impressie gebleven. Eind december meldt hij aan Streuvels dat hij er nog een artikeltje over heeft geschreven op verzoek van een tijdschrift, met de toevoeging: "Ik hoop, dat dit een beetje beter zal bevallen, dan de misschien te journalistieke feuilletons in De Maasbode."70

Coolen gebruikt zijn impressies van verre landen niet voor zijn literaire werk; zijn

58 Coolen, 'Naar de oevers van de Jordaan', 29 september 1935 de aankondiging en daama 9 afleveringen van 30 september tot en met 17 oktober 1935.

59 Streuvels, Ingooighem.

60 Na de Eerste Wereldoorlog besliste de Volkerenbond dat Palestina Brits Mandaatgebied zou worden. Joden kregen het recht er zich te vestigen. Zo ontstonden er veel kolonies (kibboetzim) en de stad Tel Aviv werd gesticht. Tegelijkertijd groeide het verzet van de Palestijnen en later ook van de Arabische staten. In 1936 brak een burgeroorlog uit, waarbij van alle kanten zeer wreed werd opgetreden.

61 Streuvels, Ingooighem, 111.

62 Coolen, 'Naar de oevers van de Jordaan', in: De Maasbode, 3 oktober 1935.

63 Coolen, 'Brieven van De Romeijn', 16 maart 1935 en 17 augustus 1935.

64 Coolen, In de straten van Jeruzalem:

65 Coolen, 'In de schaduw van het Heilig Graf',

66 Streuvels, Ingooighem, 177.

67 Streuvels, Ingooighem, 183.

68 AMVC, inv. nr. 3475, brief Coolen aan Streuvels, 22 september 1935.

69 Coolen, 'Herinnering aan Bethlehem', in: Deurnesche Courant, december 1946.

70 AMVC, inv, nr. 3475, brief Coolen aan Streuvels, 27 december 1935. 
romans en verhalen spelen toch altijd om 'de eigen kerktoren'. Als hij daarvan afwijkt, kiest hij voor een ander uiterste: de wereld van de legenden en de sprookjes.

\section{De vreemdeling}

Op 27 november 1935 gaat Coolens toneelstuk De vreemdeling in première in de stads. schouwburg van Amsterdam. ${ }^{n}$ Coolen en zijn vrouw worden er heen gereden door het bevriende fabrikantenechtpaar Te Strake uit Deurne, met wie ze na afloop souperen. Ook de echtparen Van Duinkerken en Oomes wonen de première bij.

Het stuk speelt in "een Zuid-Nederlandsche dorpsche omgeving," maar is geen boerenstuk. Het gezin van de smid Elooy Hamers ${ }^{72}$ heeft een dochter Agnes die al jaren verloofd is met onderwijzer Bosch. Deze is afkomstig uit een kleinburgerlijk milieu en is een benepen figuur. Hij stelt zijn jonge verloofde nu al in het vooruitzicht hoe fijn zij zich zal voelen, als ze de vrouw van de dorpsonderwijzer zal zijn. De smid mag hem niet zo. "Ik ben niet zoo stapelgek op schoolmeesters, secretarieambtenaren en gemeenteontvangers. Ik houd meer van valide kerels met de kop van een mán, met de handen van een vént aan hun lichaam, menschen met vonken van binnen en wat ruimte van buiten om hem heen. ${ }^{n 73}$

Zo eentje dient zich al gauw aan in de persoon van Peter Berg, een stedeling uit de welgestelde burgerij, die, na een duistere periode in zijn leven, in de gevangenis heeft gezeten en daar het smidswerk heeft geleerd. Ondanks zijn verleden wordt hij door Elooy aangenomen als knecht. Agnes wordt verliefd op hem en maakt het uit met meester Bosch. Door jaloersheid gedreven vertelt deze dat Berg gezeten heeft voor moord. Als Berg dit aan de smid bekent, stuurt deze hem weg. Agnes, die eerst beloofd heeft dat ze niet de vrouw van Berg zal worden, loopt toch met hem weg. De smid schiet op hem (met het geweer dat, volgens de ijzeren toneelwet, al vanaf het eerste bedrijf prominent aan de muur hangt), maar verwondt Berg slechts. De vrouw van de smid zegt dat hij alleen door het toeval geen moor-

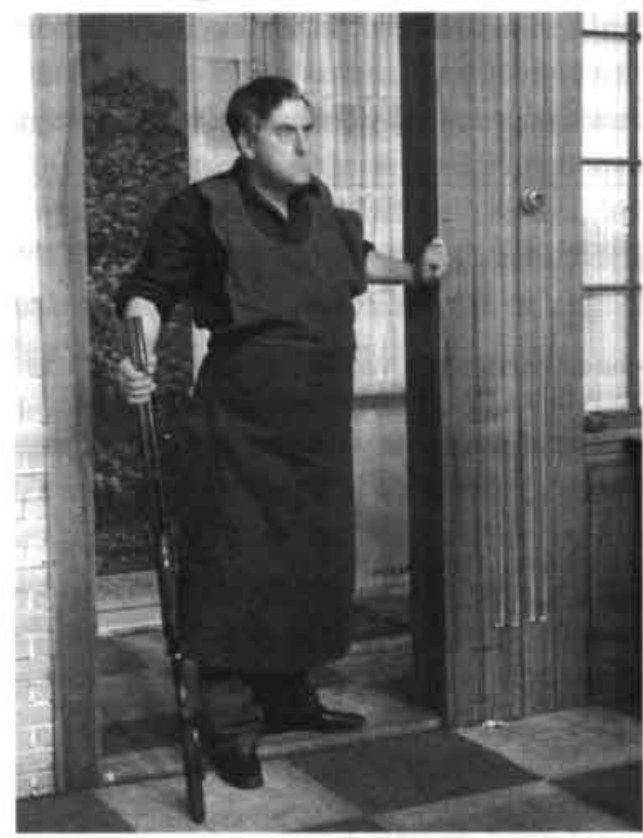

Ko van Dijk sr. in de rol van de smid. denaar is: hij had hem net zo goed dood kunnen schieten. In een dramatische scene wordt meester Bosch door de vader weggestuurd. Vervolgens geeft hij zijn zegen aan de verbintenis van Agnes en Berg.

Het hele stuk is één ode aan de handenarbeid en de mannelijkheid. De vreem deling Berg komt uit een gezin waar de welvaart te danken is aan de handenarbeid van de grootvader, maar omdat zijn ouders al vroeg scheiden, gaat het fout met hem. De smid stelt de vreem. deling hoog boven de onderwijzer Bosch. Peter Berg heeft het kwaad in zichzelf moeten bestrijden "Hij was niet machteloos. Hij werd het báás. Hii werd een màn. ${ }^{774}$ 
Het personage doet denken aan de hoofdfiguur uit Coolens romanopzet voor De Sterkel, waarover hij zeventien jaar eerder schreef:

"Van Ravenstein, de musicus, is onbeperkt in zijn sympathieën en antipathieën, is ook onbeperkt in 't in de praktijk brengen van wat hij zich tot plicht heeft voorgeschreven omdat 't goed, en noodig was voor de dagelijksche verbeetering van zijn bestaan. Hij zou, geloof ik, kunnen heeten l'homme de l'absolu. Hij is een man niet van de theorie, maar van de praktijk, een onharmonisch brok mensch, dat harmonisch wordt.Hij is geteekend net als Milet zijn boeren teekent, met dikke forsche lijnen, en overdreeven, soms. Vooral als hij den drang niet meer weerstaat om zijn groote physieke kracht eens den vrije teugel te laten." 75

De smid veracht de "flinke en ordelijke" maatschappij die vol slappelingen zit die niet in de gevangenis komen, terwijl ze "minder man en heel wat minder gezond zijn" dan Peter Berg. Meester Bosch verdedigt zich en beschrijft hoe hij zelf geploeterd heeft om te kunnen studeren en hoger op te komen. Hij vindt het onrechtvaardig dat zijn meisje met de eerste de beste ontslagen gevangene meegaat, waarop de smid zegt dat een vrouw geen man neemt "om hem te belonen voor zijn goed gedrag." De smid heeft de status van een patriarch uit het Oude Testament, die weet wat goed en slecht is. De sfeer van het stuk doet ook aan Nietzsche denken, vooral wat zijn hekel aan slachtoffers en zielepoten en zijn waardering voor een sterke, vrije man betreft.

\section{Kritiek van twee kanten}

Zowel in krantenrecensies als in persoonlijke brieven krijgt Coolen scherpe kritiek op De vreemdeling. Vooral vanuit de katholieke visie is dat begrijpelijk. In het stuk spelen de katholieke moraal en het geloof geen enkele rol. Er is zelfs geen enkele verwijzing naar kerk of geloof. Hoewel de pedante onderwijzer Bosch ook wel trekjes van Coolen heeft niet alleen wat zijn afkomst betreft maar ook zijn fysieke voorkomen - krijgt dit personage een bijna even onsympathieke rol als Uriah Heep uit Dickens' David Copperfield. Hij is zowel nederig en slijmerig als achterbaks. De lof voor de handenarbeid, de haat tegen halve intellectuelen als schoolmeesters en ambtenaren, gekoppeld aan de verheerlijking van een patriarchale vader als almachtige leider heeft bedenkelijke aspecten in een tijd met een Fuhrer als 'buurman'.

Het is in dit opzicht veelzeggend dat juist een criticus als Chr. de Graaff, die in de oorlog de foute kant zal opgaan, op een fascistische strekking in het stuk wijst. ${ }^{76}$ Kennelijk valt

71 Het wordt gespeeld door het Nieuw Schouwtoneel onder directie van Ko van Dijk sr. en Frits Bouwmeester, met Ko van Dijk in de hoofdrol als smid en Dogi Rugani als zijn dochter.

72 St. Elooy is de patroon van de smeden. In Zegen der goedheid is zijn legende opgenomen. Hierin treedt de heilige op als vreemdeling, die zich als knecht aanbiedt en de smid en zijn vrouw een lesje geeft om hen hun ijdelheid te doen inzien.

73 Coolen, De vreemdeling, 23.

74 Coolen, De vreemdeling, 67.

75 KDC, inv. nr. 101, brief Coolen aan Lutkie, 4 oktober 1918.

76 De Graaff, 'Antoon Coolen zet de klok terug'. Chr. de Graaff is oud-redacteur van De Gemeenschap en onder andere toneelrecensent. Hij wordt enkele jaren later lid van Zwart Front en de NSB; in 1943 krijgt hij de Tobi Goedewagen-prijs als plaatsvervangend hoofdredacteur van de gelijkgeschakelde Arbeiderspers. 
het hem meer op, omdat hij er zelf gevoelig voor is. De Graaff merkt op dat het principieel katholieke uit het werk van Coolen aan het verdwijnen is. Zijn werk hoeft geen getuigenis te zijn, maar men zou het geloof erin moeten vinden. De moraal is volgens De Graaff steeds meer verwaterd "tot een frissche, vroolijke moreele gezondheid, die ik nauwelijks meer kan onderscheiden van hetgeen tegenwoordig door het Duitsche ministerie van volks. voorlichting en propaganda wordt voorgeschreven." De Graaff ziet ook het anti-intellectualisme:

"De schrijver speelt hier de physieke kracht van den knecht uit tegenover de smalle schouders en het 'intellect' van den armen onderwijzer, geheel volgens de nieuwe Duitsche eugenetica. Als hij van den gesmaden 'intellectueel' ook nog een gedoopten Jood zou hebben gemaakt, zou er niets meer aan de 'bruine' sfeer ontbroken hebben." Het blijft vreemd, De Graafs kritiek te lezen in de wetenschap dat de man zelf een propagandist van het nazisme zou worden. Dat verandert niets aan het feit dat er in de kern van zijn kritiek iets waars zit. Er klinkt een hinderlijke ondertoon in het stuk; het natuurlijke, sterke en eenvoudige steekt gunstig af tegen het intellectuele, zwakke en complexe. Het meest valt dit op in de figuur van de bijna bovenwettelijke, mythische smid, die wel iets van het personage Van Taeke uit Dorp aan de rivier heeft en die we als type ook weer zullen tegenkomen in Coolens toneelstuk De klokkengieter (1938). De figuur Houtekiet uit de gelijknamige roman van Walschap is ook een voorbeeld van zo'n held.

Piet Oomes is het volledig eens met de kritiek van De Graaff. "De bijwoning van de pre. mière heeft mij geen enkele genoegen gegeven." ${ }^{n 7}$ Hij vindt dat Coolen op een verkeerd plan is terecht gekomen. Hij verwijt hem een "halfzachte levenshouding", met een opzettelijke ontkenning van de diepere krachten die het Christendom in zich heeft. Om diezelfde reden kan hij Dorp aan de rivier ook niet waarderen. Hij roept zijn vriend op om terug te keren van deze flauwe levenshouding. "Te waardering van een man als Fabricius 'the smiling lady-killer' is vergeef me dat ik het zeg een belachelijk symptoom." De fijn-katholieke Oomes is heel kwaad op zijn vriend. In dezelfde brief verwijt hij hem, dat hij op de premi. ère slechts plichtmatig wat woorden met hem heeft gewisseld: "De wijze waarop je je vrienden aanspreekt en informeert naar de welstand van de kindertjes is onnatuur in optima forma, een man onwaardig." In deze reactie weerspiegelt zich de complexiteit van de tijdgeest: Coolen die het natuurlijke en mannelijke in zijn werk verheerlijkt, wordt hier impliciet verweten dat hij zich onnatuurlijk en onmannelijk gedraagt.

Coolen trekt zich deze harde brief aan, maar vreest dat Oomes wat te zwaar op de hand is "tegenover de omstandigheid dat ik nu eenmaal weinig strijdbaar en apologetisch ben." Volgens hem loopt Oomes het gevaar een zeloot te worden zoals De Graaff, die bij elk stuk te veel gespitst is op de vraag of het in strijd is met het wezen van het katholicisme. Opnieuw uit hij zijn adagium dat de dichter of de schrijver zich geen plicht tot propaganda op laat leggen, noch voor de godsdienst noch voor iets anders: "Laat hem gehoorzamen aan de steun der schoonheid alleen. ${ }^{\text {78 }}$ Een paar dagen later schrijft hij nog een vervolgbrief en gaat hij in op een paar onderdelen van De Graaffs kritiek. Deze had ook gesuggereerd dat het kleine kindertal in het gezin van de smid op Duitse leest geschoeid was. Coolen zegt dat dit alleen om dramaturgische redenen beperkt was gehouden. Hij vraagt zich af hoe je zijn peelromans als De goede moordenaar, Het donkere licht en Peelwerkers kan afdoen als "probleemloze boerentafereeltjes," zoals de criticus heeft gedaan. Hij betreurt het dat de katho- 
lieke bladen de fouten en zwakheden in het stuk zo breed hebben uitgemeten en het goede tot een karikatuur gemaakt, waarbij de schrijver het mikpunt van hun ketterjacht is. ${ }^{79}$

Tussen april en juli r 935 heeft Coolen zeer uitgebreid met Oomes gecorrespondeerd over een klein onderdeel van het stuk: het lied dat Agnes aan het zingen is als de vreemdeling binnenkomt. Coolen zou graag iets hebben dat een zekere stemming heeft en toch gezond is en fris, het liefst een oud overgeleverd en volks liedje. Uiteindelijk kiest Coolen voor 'Mocht ik o Swaentije..' Tijdens de opvoering zal Dogi Rugani echter 'Heer Jesu had een hofken' zingen. Coolen neemt daar genoegen mee, maar kennelijk was hem er toch veel aan gelegen dat in de gedrukte tekst het Swaentje stond. Waarom heeft hij na al die moeite en vele brieven toch toegestemd in een katholiek liedje tijdens de opvoering? Zo'n gedoe om een liedje illustreert dat niet alleen de critici van Coolen bezorgd zijn over het katholieke gehalte van het stuk. Swaentje staat voor liefde en wellust en het geeft geen pas dit een meisje te laten zingen als er een mannelijke vreemdeling binnenkomt, moet de regisseur gedacht hebben.

Sommige katholieken laken het gebrek aan godsdienst in het stuk en andere, pas bekeerde katholieken als De Graaff ergeren zich aan de ideeën die ontleend zouden kunnen zijn aan de nazi-ideologie. Het toont de rijke schakering aan meningen en opvattingen die midden in de jaren dertig opgeld doen. Coolen laat zich minder uit over de toestanden binnen de dictaturen in Italië en Duitsland. Hij is vooral beducht voor de oorlogsdreiging in Europa. In zijn krantenrubriek is dat goed te merken, maar literair trekt hij zich terug in de door hemzelf gecreëerde wereld van de Van Taeke saga.

77 FPC, brief Oomes aan Coolen, 7 december 1935.

78 LMDC, inv. nr. 3485, brief Coolen aan Oomes, 8 december 1935.

79 LMDC, inv. nr. 3485, brief Coolen aan Oomes, 12 december 1935. 



\section{Spanning in Europa 11}

We zijn nog net zo ver als in de barbaarse tijd; men neemt het begeerde met knuppel en knots."

$1936-1937$

\section{Coolens pacifisme}

In 1936 neemt de spanning in Europa dramatisch toe. Nadat in 1935 het Saarland via een plebisciet 'Heim ins Reich' is gekeerd, volgt van Duitse kant een minder democratische stap om het rijksgebied van voor de oorlog te herstellen: Duitse troepen bezetten het gedemilitariseerde Rijnland en staan daardoor weer aan de grenzen van Frankrijk, Luxemburg, Belgiê en Nederland. In juli r 936 ontbrandt in Spanje de strijd tussen de rebellen van Franco en de republikeinse regering en die groeit al snel uit tot een totale burgeroorlog. In oktober komt de As Rome-Berlijn tot stand, nadat Italië in Abessinië in juli een totale overwinning heeft behaald. De invloed van de Volkenbond blijkt op alle terreinen nihil te zijn. Ondertussen wordt in Duitsland de greep van het nazi-regime op het dagelijkse leven steeds groter.

Vooral in zijn rubriek 'Brieven van De Romeijn' in de Bossche krant is te volgen hoe Coolen op deze gebeurtenissen reageert. Wanneer de bevolking van Saarland, het gebied dat na de Eerste Wereldoorlog was ingelijfd bij Frankrijk, stemt voor een terugkeer naar het Duitse Rijk, beoordeelt Coolen dit positief, omdat het de spanning tussen Duitsland en Frankrijk en de daarmee samenhangende oorlogsdreiging vermindert. 'De Saar' is immers rijk aan grondstoffen en zou daardoor een casus belli kunnen zijn. Coolen hoort in de vreugde waarmee de bewoners uitroepen: "Die Saar kehrt Heim!" ook de vervoering van een volk "dat het beste en nobelste eener nationale verbondenheid er in heeft gevoeld."1 Hiermee wordt volgens hem het economische aspect overschreden door een ideëel aspect: "Zoo het bloed zich niet verloochent, de grondverbondenheid van een volk verloochent zich evenmin." Hij fulmineert echter tegen vaderlandsliefde die misbruikt wordt om de volken tegen elkaar op te zwepen via chauvinistische gevoelens en citeert uit een actueel boek uit die tijd, Kooplieden des doods, waarin de wapenindustrie als de grote 'oorlogshitser' wordt aangemerkt.

Vanaf 1935 weerspiegelen de spanningen zich ook in het Nederlandse culturele en politieke leven. Enkele weken voor de première van De vreemdeling veroorzaakt een ander toneelstuk opschudding. Op ro november 1935 is, eveneens in de Amsterdamse stadsschouwburg, het stuk De beul van de Zweed Lagerkvist voor het eerst opgevoerd. Hoewel het handelt over de tegenstelling tussen blank en zwart, is het duidelijk een aanklacht tegen de rassenleer van het Duitse nazisme. De opvoering wordt door NSB-ers verstoord en Mussert schrijft in Volk

1 Coolen, 'Brieven van De Romeijn', 9 maart 1935. 
en Vaderland een fel artikel tegen het feit dat dit soort stukken gesubsidieerd wordt met overheidsgeld. Met name "den zich Katholiek noemenden Van Duinkerken" die in de subsidiecommissie zat, moet het ontgelden. ${ }^{2}$ Van Duinkerken schrijft daarop zijn geruchtmakende Ballade van den Katholiek met de keerzin "Daarom, mijnheer, noem ik mij Katholiek."

In november I935 is de Bond van kunstenaars ter Verdediging van de Kulturele rechten opgericht, met als initiatiefnemers onder anderen het echtpaar Romein-Verschoor. Uit deze groep zal in 1936 het Comité van Waakzaamheid van anti-nationaal-socialistische Intellectuelen ontstaan. Van Duinkerken wordt hier lid van, maar zal later dit lidmaatschap op last van de kerkelijke autoriteiten weer moeten opzeggen, omdat katholieken niet zo nauw mochten samenwerken met andersdenkenden, in het bijzonder met communisten. ${ }^{3}$ Coolen voelt er, desgevraagd, niet voor om als lid toe te treden. Hij wil het oorlogsgevaar niet lokaliseren in één stroming, ook niet als mevrouw Romein-Verschoor aandringt met haar argument dat het fascisme op dat moment het meest dreigende gevaar is. ${ }^{4}$ Mevrouw Romein schrijft in haar memoires dat velen in het comité een communistische mantelorganisatie zagen. ${ }^{5}$

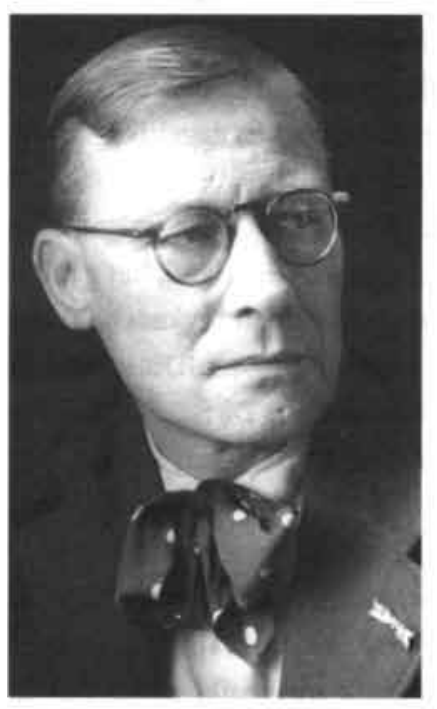

Coolen sluit zich niet aan bij een partij of politieke stroming. In zijn opstelling laat hij zich leiden door één overtuiging en dat is zijn onvoorwaardelijk geloof in pacifisme en zijn afkeer van oorlog en geweld. In deze opstelling is hij steeds consistent geweest. Zijn artikelen als adolescent in De Zuidwillemsvaart ademen al een vurig pacifisme. Hij trekt dan al fel van leer tegen de oorlogshitsers, de partijdige pers die de partijen almaar opzweept of zich zelfs laat verleiden tot betaalde oorlogspropaganda, en de journalisten die langs de slagvelden trekken, de 'Schlachtenbummler', die ervan leven. Later, wat rijper, beschrijft hij in zijn roman Het donkere licht uitgebreid de Eerste Wereldoorlog: de uitzichtloos heid, de vluchtelingen, de smokkel en de soldaten als kanonnenvoer.

Als in het midden van de jaren dertig de nationale comités voor veiligheid worden opgericht, betreurt hij het dat dat tevens leidt tot sympathie voor het militarisme en de (her)bewapening. Coolen wil niet aanvaarden dat geweld tot een oplossing leidt en ergert zich aan het defaitisme waarmee de bevolking het militarisme aanvaardt. Paus Pius XI heeft in I93I in zijn encycliek Quadragesimo Anno geschreven dat het defaitisme voortkomt uit het kille economische systeem. Coolen waarschuwt ervoor dat Europa met deze bewape ning wéér voor de afgrond staat. Als jonge vader kan hij zich de angst van Franse ouders voorstellen, wier dan vijfjarige krullenbollen door de regering al geregistreerd worden voor toekomstige militaire lichtingen. Men kan zijn vredeswil niet bewijzen met bewapening. schrijft hij. ${ }^{6}$ Met deze opvatting zou hij zo het 'gebroken geweertje' op de revers hebben kunnen spelden, maar hij wil nu eenmaal niet bij een politiek getinte club horen. Hij houdt in die tijd wel spreekbeurten voor de jongerenvredesactie in Den Haag, Baarn en Hilversum ${ }^{7}$ en voor het sociaal-democratische Instituut voor Arbeidersontwikkeling. ${ }^{8}$ Eind 
1935 spreekt Coolen enkele malen voor de Vredesaktie van Katholieke Jongeren over de inval van Italië in Abessinie en veroordeelt daar de machtspolitiek van Mussolini.

Elk jaar rond de elfde november is Coolen vervuld van de herdenking van de wapenstilstand van 1918. Hij herinnert eraan hoe de soldaten allemaal vol vaderlandsliefde naar het front vertrokken, maar dat het hen niets opleverde. Alleen bedrijven als Krupp, Skoda, Waffenfabrik Steyer, Schneider-Creusot en de Usines à Gaz hebben ermee gewonnen, evenals de Royal Dutch [Koninklijke Olie, C.S.] uit het neutrale Nederland. Nu vinden de herdenkingen al weer plaats met dreunende militaire stap en de fabrikanten wrijven zich in hun handen, schrijft hij. ${ }^{10} \mathrm{Hij}$ vaart fel uit tegen Huizinga, die in zijn laatste boek geschreven heeft dat de soldaat op het slagveld zijn hoogste ethische functie uitoefent. Hij doelt hier op het boek In de schaduwen van morgen. Huizinga ziet zich genoodzaakt in een volgende druk een noot ter toelichting op te nemen, waarin hij schrijft dat de soldaat handelt uit plicht en dus geen schuld heeft, dat hij meer lijdt dan handelt en dat hij bovendien lijdt voor anderen, onverschillig het gestelde politieke doel. "Is het teveel gezegd, dat iemand die uit plicht, zonder schuld, voor anderen lijdt, zijn hoogste ethische functies vervult?" "

In maart 1936, als Hitler het verdrag van Locarno schendt en het Rijnland weer gaat bezetten, reageert Coolen heel anders dan bij de niet-militaire annexatie van het Saarland. Hij pikt het woord 'eer' uit de toespraak van Hitler, die gezegd heeft dat het de kanonnen zijn die de eer moeten verdedigen. Coolen vraagt zich af of men dan al weer alles vergeten is van de verschrikkingen bij Luik, Antwerpen en de IJzer. Schamper vraagt hij wie zich druk maakt over de eer van het 'menselijk materiaal' op het slagveld, zoals in de anti-oorlogsroman van Erich Maria Remarque, Im Westen nichts neues, is beschreven. Al voor de term bestaat, maakt hij gewag van een militair-industrieel complex, van de relatie tussen de bewapeningsindustrie en de geldmachten. Uit het boek War profits, dat geciteerd wordt in het al genoemde Nederlandse boek Kooplieden des Doods, haalt hij het verhaal aan dat Krupp patenten heeft afgekocht van de Engelse wapenfabriek Vickers, die op dat ogenblik weer levert aan Rusland. ${ }^{12}$

Regelmatig blijft Coolen in zijn rubriek ageren tegen de bewapening en de oplopende oorlogsbegrotingen, zoals bij de bespreking van het boek De geschiedenis van de menselijke domheid van Walter Pitkin. ${ }^{13}$ Hij ziet de oplopende oorlogsbegrotingen als de grootste dom-

2 Van der Plas, Doarom, mijnheer, 219.

3 Van der Plas, Daarom, mijnheer, 232.

4 FPC. brief Annie Romeijn-Verschoor aan Coolen, 12 december 1935.

5 Romein-Verschoor, Omzien in verwondering, deel 1, 287.

6 Coolen, 'Brieven van De Romeijn', 30 maart 1935.

7 LMDC, inv. nr. C 3485, brief Coolen aan Oomes, 20 april 1935.

8 LMDC, inv. nr. C 3485, brief Coolen aan Oomes, 22 october 1935.

9 FPC, brief Bertus Stom aan Coolen, 16 december 1935.

10 Coolen, 'Brieven van De Romeijn', 16 november 1935.

II Huizinga, In de schaduw van morgen, 106.

12 Coolen, 'Brieven van De Romeijn', 21 maart 1936. Waarschijnlijk is bedoeld Excess Profits van W.E. Snelling. Ca. 1920.

B Walter B. Pitkin (1878-1953) schreef in 1921 over de politieke en economische expansie van Japan en later Het leven begint bij veertig (1932). 
heid, omdat ze alleen maar gericht zijn op vernietiging. ${ }^{14}$

Opvallend is, dat Coolen Duitsland nooit apart bekritiseert, maar meestal in algemene zin en in breder verband fulmineert tegen de oorlogsindustrie en de bewapeningswedloop. Italië en de Duce worden wel regelmatig als staat en leider veroordeeld. Coolen doet dit omdat Mussolini dan al daadwerkelijk op oorlogspad gaat. Coolens kritiek is heel ongewoon, omdat de katholieke pers, De Maasbode voorop, in de eerste helft van de jaren dertig met meer sympathie over Mussolini en zijn fascisme schrijft dan over het opkomende nazisme. Het fascisme en het daaraan gekoppelde corporatisme acht men nog wel ver enigbaar met het katholicisme, maar het nazisme niet. De Maasbode gebruikt voor het nazisme regelmatig termen als 'rechts-bolsjewisme', 'nationaal-bolsjewisme' of 'sovjet. bolsjewisme'. ${ }^{15}$ Coolen hoont de Italianen die met bloemen in hun geweren naar Ethiopië trekken vanwege de daar aanwezige bodemschatten. Hij acht de vaderlandsliefde van de Ethiopiërs groter dan die van de Italianen met hun "Apennijnse" bloemen. ${ }^{16}$ Als later Addis Abeba is gevallen en de Negus gevlucht, zegt Mussolini dat dit het grootste feit is in de dertig eeuwen geschiedenis van Italië. Coolen vindt het laf om de moedige Ethiopiërs met bommen en gifgas te bestoken. Hij vraagt zich af of dit nu het veld van eer is, waar iedereen altijd de mond van vol heeft. Allebei de staten zijn lid van de Volkenbond en deze laat de kleinste nu in de steek. "We zijn nog net zo ver als in de barbaarse tijd; men neemt het begeerde met knuppel en knots." ${ }^{17}$

Tijdens een vakantie in de zomer van 1936 in Frankrijk wordt Coolen geconfronteerd met een linkse demonstratie van het Volksfront. Hij ziet mensen "die met verwrongen monden en gebalde vuisten om kanonnen en vliegtuigen voor Spanje schreeuwen" en hij betreurt het dat deze "volksche" beweging het zoete Frankrijk in een oorlog wil storten." In de herfst bij de vogeltrek denkt hij aan de vele vluchtelingen uit de Eerste Wereldoorlog, kinderen uit Duitsland, Oostenrijk en België. Nu dreunen de machines in de wapenfabrieken alweer dag en nacht. ${ }^{19}$ Kort daarna, bij de herdenking van de wapenstilstand in novem. ber, schrijft hij dat hij zich geen illusies maakt en dat de bewapening voor de volgende oorlog alweer in volle gang is. Hij denkt aan de uitspraak van Machiavelli dat de gewapende profeten altijd winnen. ${ }^{20}$

Als in oktober r937 Japan een aanval doet op Kanton in China, wijst Coolen er op dat in Europa oorlogsdreiging heerst, maar dat die dreiging elders al een verschrikkelijke werkelijkheid is. Alles wat de pacifisten voorspeld hebben, gebeurt daar al. In de moderne oorlog zullen ook de burgers getroffen worden, zoals nu in Kanton, waar door luchtaanvallen de straten vol verminkte burgers liggen. Hij vraagt zich af waarom men zo'n negatieve term als pacifist gebruikt voor mensen die voor de vrede zijn. Dat is toch een natuurlijke zaak, zoals ademen. Men noemt iemand die adem haalt toch ook geen "respiratist". Pacifist klinkt volgens hem zo sektarisch en doet denken aan baardige en weke types. ${ }^{21} \mathrm{Hij}$ ergert zich enorm aan de militaire parades bij de dodenherdenkingen op II november, waar in gezwollen taal over het vaderland wordt gesproken. Coolen schrijft dat de soldaten niets begrijpen van vallen voor het vaderland. Hij bestrijdt de uitspraak 'Si vis pacem, para bel. lum' en stelt: "Oorlogsvoorbereiding leidt nimmer tot vrede, altijd tot oorlog." Hij hoopt dat de Wapenstilstand eindelijk zal veranderen in vrede en wijst op de Internationale Bidweek voor de vrede op het feest van Albertus Magnus, Albert de Grote, de Duitser die aan de Sorbonne studeerde en later leraar werd van St. Thomas. ${ }^{2}$ 
De luchtaanval op Guernica door Duitse bommenwerpers in de Spaanse Burgeroorlog schokt hem zeer. Hij beschrijft hoe de vijf en tachtig kinderen die daarbij omkwamen in het bioscoopjournaal getoond worden tussen de hockey- en voetbalflitsen door. Als er één kind ontvoerd wordt heeft het alle aandacht, schrijft hij en doelt daarmee op de kidnapping van de baby van de oceaanvlieger Lindbergh, die de wereld enkele weken heeft bezig. gehouden.

Achteraf kan men constateren dat Coolen enerzijds oprecht bezorgd is over de toename van de internationale spanningen, de bewapeningswedloop en de oorlogsdreiging. Anderzijds ziet hij niet welke grote gevolgen het nazisme in Duitsland zelf heeft. De uitwerking van het bloed- en bodemdenken zal leiden tot een moordende ideologie van uitsluiting, en weldra uitroeiing, van mensen die door de nazi's zijn bestempeld als 'minderwaardige rassen en volksvreemde elementen.'

Coolen kan groot mededogen en deernis hebben voor de machtelozen en verdrukten die hij kent, zoals soldaten, peelwerkers en randfiguren in Brabant en de Peel. Het lijkt erop dat de machtelozen die hij niet kent, zoals joden, Afrikanen of het proletariaat in de grote steden, letterlijk buiten zijn gezichtskring vallen.

Tot zijn verdediging moet gezegd worden dat in die tijd nog slechts weinigen het gevaar onderkennen, ondanks het feit dat het Hitler-regime van meet af aan zijn ware gezicht heeft getoond wat het aanwijzen van binnenlandse vijanden betreft. Meteen vanaf de machtsovername door Hitler in r 933 worden maatregelen tegen joden, socialisten en communisten genomen die het gehele maatschappelijke leven doortrekken. De dagboeken van Victor Klemperer getuigen daarvan. Deze maatregelen zijn ook in Nederland bekend door de verhalen van gevluchte schrijvers en journalisten. Dat ze tot industriële massamoord zullen leiden, kan in het midden van de jaren dertig nog niemand voorspellen.

Coolen schrijft als redacteur van De Gemeenschap nauwelijks over de internationale spanningen. Zijn bijdragen beperken zich tot een aantal 'Hageltjes', maar die blijven circuleren 'rond de kerktoren' en zijn meestal gericht op uitwassen en eigenaardigheden van het roomse leven. Hij hekelt de liedjes die in de katholieke eredienst worden gezongen. ${ }^{23} \mathrm{Hij}$ analyseert sarcastisch kromme teksten als: "Deur des hemels, nimmer dicht. Leid ons langs uw drempel." Een andere keer moet de 'humoristische' pater Gerlach Royen het ontgelden, die het nieuwe weekblad Vrijdag mee moet helpen vullen. ${ }^{24}$ In hetzelfde nummer drijft

Coolen, 'Brieven van De Romeijn', 7 december 1935.

Van Vree, De Nederlandse Pers en Duitsland, 286.

Coolen, 'Brieven van de Romeijn', 16 maart 1935.

Coolen, 'Brieven van de Romeijn', 9 mei 1936.

Coolen, 'Brieven van de Romeijn', 3 oktober 1936.

Coolen, 'Brieven van de Romeijn', 24 oktober 1936.

Coolen, 'Brieven van de Romeijn', 7 november 1936.

Coolen, 'Brieven van de Romeijn', 9 oktober 1937.

Coolen, 'Brieven van de Romeijn', 6 november 1937.

Coolen, 'Kees Pruis in de kerk', 42-44.

Coolen, 'Gerlach de Geestige', 157-158. 
Coolen de spot met twee dominees, die voor Nederland nog slechts redding zien als iedereen lid wordt van de Staatkundig Gereformeerde Partij. ${ }^{25} \mathrm{Zij}$ zouden willen dat ministerpresident Colijn de roomse Mis eerder verhindert dan deze met zijn protestantse medeministers bij te wonen. De dominees zijn overigens wel tegen de NSB, omdat deze partij de geloofsvrijheid wil aantasten.

\section{Vakantie}

Coolen werkt in het voorjaar van 1936 aan zijn tweede Van Taeke roman. Voor het werk daaraan heeft hij zich weer helemaal in zijn schrijfhut teruggetrokken. Voorzover hij niet volledig opgaat in het schrijven aan de roman en de gesprekken daarover met Wiegersma, wordt hij in beslag genomen door huiselijke beslommeringen. De drie kleine zoontjes (nu drie, vier en vijf jaar oud) zijn vaak ziek, onder meer door het vochtige huis De Romeijn. Hij correspondeert nauwelijks en publiceert naast de eerder genoemde 'Hageltjes' alleen zijn normale columns voor de Bossche Courant. Verder voert hij de redactie van het jubileumboek Het Gouden Gymnasium van zijn vroegere school in Heeswijk.

Zijn Duitse vertaler Schauer komt op bezoek en brengt zijn enthousiasme over de Franse schrijver Giono op Coolen over. ${ }^{26} \mathrm{Giono}$ is een bekend schrijver uit de Midi en heeft de Franse vertaling van De goede moordenaar van een lovend voorwoord voorzien. Niet lang hierna zal Coolen een werk van hem vertalen.

De Pinkstervergadering van de redactie van De Gemeenschap kan vanwege ziekte van Coolens kinderen bij uitzondering niet plaatsvinden in De Romeijn; men komt er nu in de zomer bij elkaar. Het gaat er geanimeerd aan toe: Van Duinkerken houdt een speech, brengt een dronk uit en levert een vers. ${ }^{27}$

Als het manuscript van de roman bij de uitgever ligt, gaan Coolen en zijn vrouw samen op vakantie. Terwijl de kinderen in De Krabbebosschen, een kleuterhuis bij Breda, worden ondergebracht, maken zij een reis naar Zuid-Frankrijk, naar de Provence. "In het land van wind, regen en buien [...] wil men er eens uit naar de azuren kust, de blauwe Middellandse Zee, olijfbomen, cypressen en palmen, en naar streken waar men den jongen wijn drinkt en waar men zo heerlijk dorst kan hebben. ${ }^{28}$ Het afscheid nemen van de kinderen valt zwaar, "Krabben die bosschen ook?" hebben de jongens benauwd gevraagd. Tijdens de reis moeten ze bij ieder kind dat ze zien, denken aan hun eigen kinderen. "Kijk daar zijn er drie, net als de onze." Bij het ophalen van de kinderen blijken die al zo gewend aan hun tijdelijke

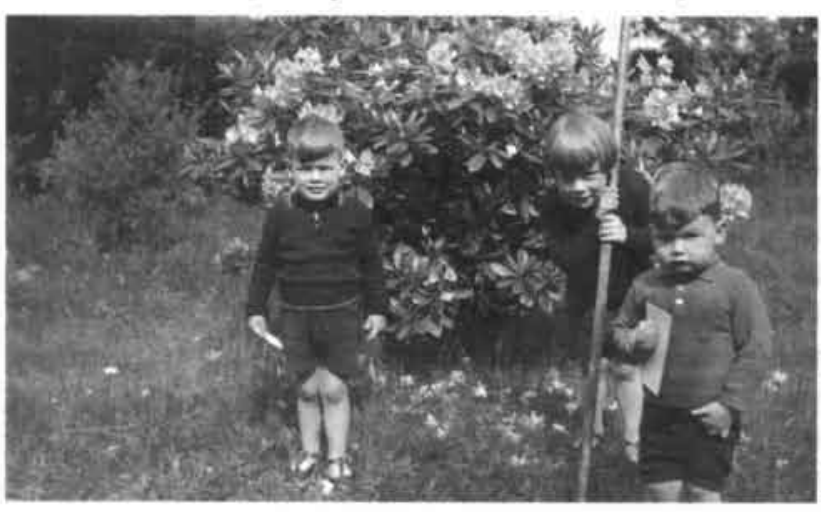

Van links naar rechts: Felix (1933), Stijn (1931) en Guido (1932). omgeving dat ze vader en moeder voortdurend 'juf frouw' noemen. Pas na veertien dagen komen de verhalen over De Krabbebosschen los.

Na terugkomst beginnen Coolen en zijn vrouw toch sterk aan verhuizen te denken. In ieder geval willen ze naar een droog 
plekje in Nederland, maar na hun ervaringen in de mooie zondoorstoofde Provence sluit Gerda zelfs Zuid-Frankrijk niet uit. ${ }^{29}$

\section{De drie gebroeders}

in november 1936 verschijnt Coolens roman De drie gebroeders. In deze maand van oorlogsherdenkingen word Madrid zwaar gebombardeerd door de Duitsers, die Franco te hulp zijn geschoten. Coolen refereert hieraan als hij zijn nieuwe boek aan zijn Hilversumse vriend Oomes opstuurt: "De compositie beantwoordt, helaas, niet aan de illusie die ik ervan heb aangedragen, maar ik hoop toch, dat het boek je in de ontmoediging der harde tijden wat blijhartigheid mag schenken. ${ }^{\text {"30 }}$ Het boek is weer geilllustreerd en van een bandontwerp voorzien door Hendrik Wiegersma, tevens leverancier van de vele sterke verhalen uit de beide Van Taeke romans.

Deze roman is niet zozeer een vervolg op Dorp aan de rivier, als wel een context voor dat boek. In De drie gebroeders leert de lezer dat dokter Tjerk van Taeke, de hoofdfiguur uit Dorp aan de rivier, uit een Fries gezin komt en twee broers heeft, Evert en Wobbe. De Van Taekes zijn een Fries geslacht van plattelandsgeneesheren; ook vader Friso heeft het ambt van zijn vader overgenomen. Tjerk heeft zijn gedrag van geen vreemde, want ook Friso is een opvallend figuur op het Friese platteland, die te paard zijn zieken bezoekt en Rousseau leest, alhoewel hij wel een beetje lacht om de 'zachtaardigheid' van deze filosoof. Evenals zijn zoon beschouwt hij de verlossingen als het mooiste onderdeel van zijn medisch werk en voelt hij zich aangetrokken tot het heidendom, dat roekelozer, boeiender en redelijker is dan het geloof. Hij heeft voor zichzelf dan ook een wapen getekend dat bestaat uit een clisteerspuit verstrengeld met een verlostang. Daaronder staat de spreuk: "Paganum esse non timeo" [Ik ben niet bang om heiden te zijn. C.S.]. ${ }^{31}$ Friso is een kwartaaldrinker, en bestelt een waarnemer als hij "de kleine schade, die ons fit houdt" weer voelt aankomen.

ledereen herinnert zich nog hoe de oude dokter naar het dorp is gekomen. Het was in de tijd van de eerste treinen en Friso had het besluit genomen om ook in een soort 'trein', een karavaan, te arriveren. De beschrijving van deze optocht is een studentikoze variant op de Brabantse 'boerenovertrek', waar een boerenverhuizing eveneens met versierde wagens en muziek plaatsvindt. Voorop rijdt een boerenkar met narren. Zijn drie zoontjes zitten op een namaaklocomotief met een kolenfornuis: "drie roetzwarte koboldjes, drie gnomen, die onderhielden het vuur. ${ }^{32}$ De dokter en zijn vrouw rijden in een sjees. Hij houdt in zijn ene hand de staf met de twee slangen van Asklepios en in de andere de lier van diens vader Apollo, maar legt die symbolen regelmatig neer om uit een grote bokaal de menigte toe te drinken. Achter hem volgen een heraut met de pompeblaren (Friese) vlag, een muziekka-

25 Coolen, 'Gericht der Domineé's', 158-159.

26 LMDC, inv. nr. C 3485, brief Coolen aan Schauer, 19 mei 1936.

27 LMDC, inv. nr. C 3485, brief Gerda Coolen aan De Bourbon, 17 juli 1936.

28 Gitaten uit: Coolen, Uit het Kleine Rijk, 101-115.

29 LMDC, inv, nr. C 3485, brief Gerda Coolen aan De Bourbon, 11 december 1936.

30 LMDC, inv. nr. C 3485, brief Coolen aan Oomes, 19 november 1936.

31 Coolen, De drie gebroeders, 12.

32 Coolen, De drie gebroeders, 32. 
pel en veel boerenwagens en achteraan de "vliegende herberg", van waaruit als bij een brand de gevulde glazen naar voren worden doorgegeven. De verteller merkt op dat de Friezen normaal ingetogen en stille mensen zijn, maar dat zij plotseling, bijvoorbeeld op het ijs, met een onverwachte zwier van feest en felheid meegesleurd kunnen worden. Zelfs de doopsgezinde dominee die aanvankelijk tegen die wilde manieren protesteert, verschijnt enkele uren later op de stoep met zijn vest achterstevoren aan en met aan een lang touw rond zijn nek een vaatje dat voor zijn knieën bungelt. Hij zingt, dwars tegen de muziekkapel in, het 'Io Vivat' uit zijn studententijd.

De vader vertelt fantastische verhalen aan zijn drie zonen over scheepvaart, het zeilen en het schaatsen.

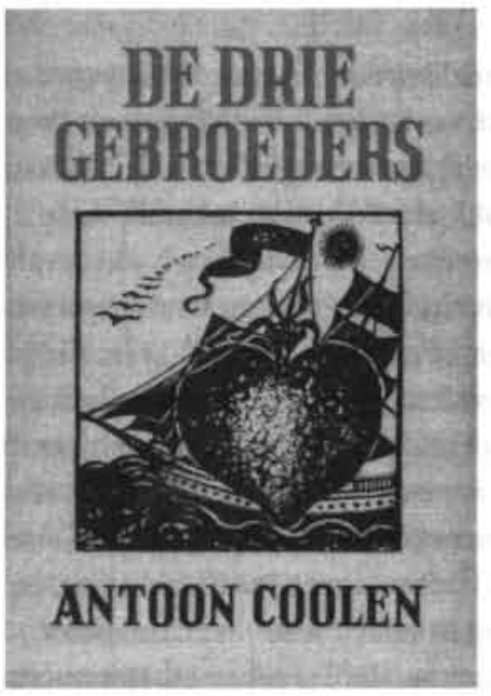

Vader Friso heeft een lelijke zuster, Sjieuwke, waarvan men zegt dat ze als man bedoeld is, maar per vergissing als vrouw is uitgevallen. $\mathrm{Zij}$ is zeer eigengereid: zij wil geen huwelijk, maar wel een kind. Dit wordt geboren in het voorjaar, wanneer de ooievaars op het nest van het voorvaderlijk huis zijn teruggekeerd. Over de vader van het kind zegt zij alleen dat hij een vrije, onafhankelijke Fries is. Zij wil de gemeente een klok schenken op voorwaarde dat die geluid wordt als haar zoon gedoopt wordt, maar de dominee en de kerkenraad weigeren. Zij laat zelf een klok gieten en plaatst die op haar land. huis. Als het kind op zesjarige leeftijd zwaar ziek is, gaat ze in een arrenslee door de nacht om haar broer Friso, de arts, erbij te halen, maar deze moet eerst bij een bevalling assisteren. Als hij de volgende dag komt, is het kind juist gestorven.

De drie zonen van Friso studeren allemaal voor arts in Utrecht. Tjerk gaat naar een dorp in de Maasstreek. Wobbe is een zonderling, die zijn studie afbreekt en over de wereld gaat zwerven, als kolentremmer op een schip. Zoon Tjerk gaat met een katholiek meisje, Elisabeth Varoccio, trouwen en wordt tot verdriet van vader Friso ook katholiek. Nadat Wobbe in zijn kolentremmerskleren aan de vooravond van de bruiloft in het dorp is verschenen, trekt hij de volgende ochtend het rokkostuum van de bruidegom aan, zodat deze in de sjofele kleren van zijn broer in het huwelijk treedt. De bruidegom legt aan zijn geschrokken bruid uit waarom hij dat doet: "Liefste, zei hij, wie anders dan ik, de meest gelukkige, moest den last dragen van den meest schamele, die mijn broer is, en dien ze anders hadden weggestuurd, terwijl hij kwam voor ons? Hoe verlegen moet hij geweest zijn, dat hij mijn kleren nam!"33

Evert wordt plattelandsdokter in het zuidoosten van Noord-Brabant en ergert zich af en toe aan de bijverschijnselen van het katholieke geloof. Als een vrouw na een zware bevalling twee kaarsen laat aansteken bij het beeld van de Heilige Antonius, zet hij het beeld weg en gaat zelf op de kast tussen de kaarsen zitten. In het dorp maakt een rijke man uit de stad misbruik van de vrouwen en meisjes, maar als Evert hem daarop aanspreekt zegt deze dat Everts vrouw, Marijke, hem ook bedriegt met een jonker. Evert verlaat haar en hun dochtertje. 
Vader Friso houdt een groot gastmaal. Op de tafel ligt een schitterend damasten tafellaken waarop de portretten van de genodigden in medaillons van gouddraad, met daaronder hun namen in het Latijn, zijn ingeweven. Evert ontbreekt aan tafel.

De dochter van Marijke, Doutje, ontdekt na haar moeders dood dat ze bedrogen zijn door haar moeders oudere zus Eugenie. Deze heeft jarenlang de brieven van Evert onderschept. Uit de brieven blijkt dat hij had willen terugkomen, maar door het uitblijven van een antwoord heeft hij dat niet gedaan. Doutje is haar hele leven haar verdwenen vader met hart en ziel trouw gebleven.

Broer Tjerk gaat aan het eind van zijn leven van de Maas naar Friesland om er te sterven. Hij geeft aan zijn oudste zoon een boekje waarin de bevallingen staan genoteerd:

"Hier staan de ruim drie duizend verlossingen in opgeteekend, die ik deed op het Brabantsche platteland. Bewaar het als een aandenken. [...] - Ik houd van Friesland. Maar de ware verloskundige met geest en hart heeft op het Friesche platteland zijn omgeving niet. Ik ben dezer dagen in dorpen geweest, die in mijn jeugd zeven, achthonderd zielen telden, en nu nog tweehonderd."

Hij besluit met de oproep: "Blijf het platteland trouw. Gij kunt niets beters zijn dan plattelandsgeneesheer. ${ }^{34}$

\section{Coolen over zijn boek}

In een interview van mei 1936, als hij nog volop aan De drie gebroeders werkt, zegt Coolen:

"Wat mij zeer getroffen heeft bij mijn uitwerking van het motief van Dorp aan de rivier is de parallel der grondgebondenheid, die er bij alle diepgaande verschillen, tussen het Friese en het Brabantse karakter bestaat. Ik ga dat nu weer verder uitwerken in de roman, waaraan ik bezig ben, en die op het ogenblik nog geen titel heeft. Ik wil daarin geven de geschiedenis van een Fries geslacht, - drie zonen van een zelfden vader, die alle drie voor medicus studeren [...] Ik zal daar weer trachten een synthese te bouwen tussen Friesland en Brabant." ${ }^{\text {35 }}$

Uit dit interview met de bekende radiospreker P.J. Ritter jr. blijkt weer hoe Coolen bezig is met de band tussen de mensen en de streek waar ze wonen. Hij beschrijft het verschil tus. sen de bewoners van de Meierij rond Den Bosch, waar de mensen datgene hebben wat men het 'gulle Brabantse' noemt, en de bevolking op de moergrond van de Peel en de Kempen. De Peelstreek heeft een somberder bevolking en die karaktertrek hangt samen met de historische schraalheid van de bodem, "maar de gedempter natuur van deze mensen ontaardt nimmer in pessimisme. Er is in de mensen van de Peel, een vanzelf aanváárden van het leven, een diep levensvertrouwen, dat de grond vormt van het karakter." Hij is niet zo bang voor de invloed van de grote stad, omdat het volk zijn eigen karakter zal bewaren. Vanouds werkt hier de 'overgeërfde boer' met een bezit van 5 tot 8 hectare, met een enkele rijke boer er tussen. Men werkt ongedwongen en makkelijk met elkaar, zoveel mogelijk met eigen familie en bekenden. 'Eigen boer, eigen volk' is de leuze.

33 Coolen, De drie gebroeders, 161.

34 Coolen, De drie gebroeders, 318.

35 Rlitter], 'Bij Antoon Coolen', in: Nederlandsche Bibliografie. Zie ook: FPC, brief Ritter aan Coolen van 15 april 1936, over afspraak eind april voor het interview. 
Coolen heeft zich uitgeleefd in de onderdelen van het boek, de verhalen en de anekdotes die zijn aangedragen door Wiegersma, maar is, zoals hij al meteen aan Oomes schrijft, niet tevreden over de compositie van het boek. Hij zal in latere drukken van het boek de compositie grondig wijzigen. Zo wordt tante Sjieuwke eerder geïntroduceerd en zet hij de tegenhanger van het echtpaar Evert en Marijke, het volkse paar Jan en Leen dat almaar kinderen krijgt, veel sterker aan. De titels van de hoofdstukken worden weggelaten en Coolen heeft geprobeerd het verhaal meer ineen te weven, zoals dat in Dorp aan de rivier het geval was.

De eigen ervaringen van Coolen met zijn kinderen zijn er duidelijk in verwerkt. Zijn kinderen zijn in de vochtige Romeijn steeds ziek en hebben hoge koorts; de precieze en ingeleefde wijze waarop hij het ziekbed van het zoontje van Sjieuwke beschrijft, lijkt op een recente ervaring te berusten. Ook het vertellen van verhalen aan zijn zonen voor het slapen gaan, is in dit boek goed te herkennen. Het verhaal over de schaatser die bevrijd wil worden van zijn eigen schaduw, berust op een oude legende over Adam Hurdrider uit de achttiende eeuw. ${ }^{36}$ Deze rijdt in een wak, waarna zijn lichaam onder het water doorschiet en zijn hoofd over het ijs verder schuift, om bij een volgend wak weer aan elkaar vast te vriezen. Als hij weer op het ijs klautert, blijkt zijn schaduw verdwenen te zijn.

Zoals Coolen het idee voor Kinderen van ons volk kreeg toen hij een 'boerenovertrek', een verhuizing, meemaakte, zo heeft hij ook deze keer veel plezier gehad in de beschrijving van de verhuizing van de Friese dokter. Hij heeft hiermee de overeenkomst tussen de Brabanders en de Friezen willen aantonen; in ieder geval heeft hij willen laten zien dat de laatsten zo stijf niet zijn.

De roman De drie gebroeders staat vol verwijzingen naar Goethe en naar de klassieken. De zoon van Sjieuwke krijgt de achternaam van zijn moeder, evenals de zoon van Goethe. Als zij in haar arrenslee hulp gaat halen voor het zieke kind, voelt zij dat Erlkönig haar achtervolgt. Een alinea later laat de verteller in het midden wie mee rent en van wie de stemmen zijn: "Erlkönig, het noodlot, God, die haar vermaande en haar moedwil strafte, die uit deze vlucht haar kind opving en het wegnam, opdat de vrouwen niet roekeloos zullen voortij. len, maar onderworpen en dienend in het voorrecht van haar moederschap zullen zijn." ${ }^{\text {"3? }}$

Als het kind sterft zegt de verteller: "Onbeweeglijk als de verstarde Niobe, die in hare kinderen boette voor hare zelfverheffing, zat Sjieuwke in haar burcht. Er vloeiden slechts eenmaal tranen langs deze rots, dat was om een kleinigheid, dat was toen Sjieuwke bij zijn bewaarde speelgoed een bromtol en een beer wegruimde, waartusschen hij gestorven was." ${ }^{38}$

De onthechte Wobbe gebruikt Goethe's woorden: "Ich hab' mein Sach auf Nichts gestellt, drum ist's so wohl mir in der Welt." Bij het zeer luxueuze gastmaal wordt verdedigend opgemerkt dat Goethe de bekoring van de dwaasheid in het mensenleven heeft geprezen.

De bewust ongehuwde moeder Sjieuwke, zelf niet de mooiste, neemt twee vrouwen in huis die buiten de gemeenschap staan. De ene heeft een hazenlip en de andere heeft als ongehuwde moeder haar pasgeboren kind vermoord, maar misschien - voegt de verteller er verzachtend aan toe - heeft ze in haar ontzettende angst alleen maar geprobeerd het schreeuwen van het kindje wat te smoren om haar schande niet te verraden. Als het kind ziek is en Sjieuwke hulp gaat halen, moeten de twee vrouwen waken: "Daar zaten zij, de 
twee, nu was het kind doodziek, en die twee hadden een schok van vervoering gevoeld, dat zij die taak kregen! [...]Zij zaten ieder aan een kant van het bedje, de mismaakte en geschonden vestaalschen bij dit heilig vuur. ${ }^{39}$

Om er zeker van te zijn dat de Latijnse ingeweven namen in het damast bij het gastmaal aan het eind van de roman correct zijn, laat Coolen zijn vrouw aan Van Duinkerken, als latinist, vragen hoe precies de genitief luidt van de naam Sjieuwke "op de wijze der humanisten., ${ }^{40} \mathrm{Het}$ wordt in het boek "Haec est imago Siviardae Taquensis et filii sui."

\section{Een goede ontvangst}

De kritiek van Ter Braak op De drie gebroeders is ronduit lovend. Na vastgesteld te hebben dat Den Doolaard en Coolen beiden "geen probleemzoekers" zijn, wijst hij op een belang. rijk verschilpunt. Nadat ze beroemd geworden zijn, hebben zij zich ieder op hun eigen wijze gestabiliseerd. Bij Coolen was hij bang dat deze zich voorgoed op Peelpeil had vastgezet, met andere woorden "zijn litteraire leven zou eindigen, als hij de laatste turf van het Peelgebied had afgegraven." Nu blijkt hij echter de vernieuwing die met Dorp aan de rivier was ingezet, te handhaven. Coolen vertelt de lotgevallen van De drie gebroeders "zonder zich echter veel te bekommeren om de geijkte romanvorm." Het gaat hem om de atmosfeer van het land, hij poëtiseert de omgeving, die zodoende geschikt wordt voor "romantisch geziene wezens." Men is nieuwsgierig naar deze levende karakters.

"Ik kom tot de conclusie, dat hij een zuiver gevoel heeft voor de karakteristieke anekdote, die een persoonlijkheid typeert, maar dat hij tevens alleen in staat is zulk een persoonlijkheid te objectiveren als romanfiguur door de poëtische versluiering der romantiek. [...] de poëtische kleurigheid wordt kernachtiger en zakelijker door de toespitsing op de anecdote, de scherpte der anecdote wordt echter, omgekeerd, ook verzacht door de legendarische atmosfeer, waarin zij wordt veralgemeend en tot fabel gemaakt." ${ }^{\text {4i }}$

Zelfs de immer schimpende Du Perron heeft enige waardering voor het boek. "Toch vind ik die Coolen heel leesbaar, hoewel zonder het minste belang, ${ }^{\text {th2 }}$ schrijft hij aan Greshoff nadat hij Dorp aan de rivier en De drie gebroeders achter elkaar heeft gelezen. In januari 1937 schrijft hij een kritiek op het boek voor Groot Nederland, die pas in het novembernummer geplaatst wordt. ${ }^{43} \mathrm{Hij}$ vindt Coolens boeken verkwikkend na allerlei modeverschijnselen. "De grootste troeven van Coolen zijn: een werkelijke eenvoud, een zekere poëzie en onmiskenbare vertellersgaven." Zijn nadelen zijn het langzame ritme en de "soms wat

36 Koolhaas, 'Een Brabants-Friese schaatslegende van Antoon Coolen', 1998.

37 Coolen, De drie gebroeders, 116.

38 Coolen, De drie gebroeders, 126. In Metamorphosen van Ovidius wordt Niobe gestraft omdat zij zich vanwege haar veertien kinderen hoger acht dan de godin Latona. Al haar kinderen worden gedood en zij zelf verandert in een rots: "Daar zit zij kinderloos [...., versteend in haar verdriet. [...] Haar marmersteen traant tot op heden voort:"

39 Coolen, De drie gebroeders, 112.

40 BA, brief van Gerda Coolen aan Van Duinkerken, 24 juli 1936.

41 Ter Braak, 'Succesboeken', 6 december 1936.

42 Brief Du Perron aan Greshof, 8 januari 1937. Du Perron, Brieven, deel 6, 337.

43 Du Perron, 'Antoon Coolen: De drie gebroeders'. 
kalfachtige bewondering van zijn helden." Ook ergert hem het vertelprocédé. Hij uit precies dezelfde kritiek als Van Duinkerken ruim tien jaar eerder al gaf over de 'repeterende breuk'. Coolen zou de stijl van Van Schendel moeten bestuderen om "zichzelf het 'doorsjouwen, doorkauwen' af te leren." Men hoeft zich bij Coolens boek echter in ieder geval niet te vervelen. Du Perron vindt dit een groot compliment voor een Hollands schrijver. Hij hoopt op een derde deel; daarvoor zijn er nog personages en onopgeloste histories genoeg. Ter Braak is het eens met deze recensie, schrijft hij aan zijn vriend: "Te stuk over Coolen was alleraardigst, en eigenlijk een definitief oordeel over alles, wat hij überhaupt in zijn mars heeft. ${ }^{n 4} \mathrm{Bij}$ alle waardering blijft toch een minzame neerbuigendheid bestaan.

Jan Campert schrijft dat het de laatste jaren in literaire kringen mode is geworden om tegenover Coolen een ietwat geringschattende houding aan te nemen. Hij heeft nooit 20 goed begrepen wat met het zogenaamde Europees peil is bedoeld. Hij vindt dat De drie gebroeders met "groot en onmiskenbaar talent" is geschreven. "Wat Antoon Coolen doet is wat alle grote romanciers hebben gedaan: hij vertelt.".45

Maurits Uyldert signaleert dat het thema van het boek veel overeenkomsten heeft met het werk van de Noor Knut Hamsun. De stijl van Coolen komt overeen met die van de Noor, waar hij licht ironisch en vragenderwijs niet recht op zijn doel afgaat, "maar langs omwegen, en door middel van schijnbaar bijkomstige opmerkingen aan den zin van zijn verhaal richting geeft." Uyldert noemt dit een "stijl der voorgewende onnoozelheid," waarmee Coolen juist zijn diep inzicht in het menselijk hart bewijst. ${ }^{46}$

De Literaire Gids die niet van Coolen houdt, vindt dat het begin van de roman de verwachting wekt dat de auteur over zijn "zwakke romantiek" heen is, maar dat Coolen het al gauw te erg maakt. Ging hij zich vroeger te buiten aan zoete romantiek, nu weet hij geen maat in het burleske. De intocht van de dokter en het huwelijk in het kolentremmerspak zijn volstrekt ongeloofwaardig. Toch zijn de twee Van Taeke boeken beter dan de "süsse Kitsch" van de Peelromantiek. Het is jammer dat zo'n goed verteller er niet in slaagt tot een grotere mate van intelligentheid en zelfbeperking te raken. ${ }^{47}$

Jan Nieuwenhuis constateert dat Coolen af en toe de schijn wekt dat hij de fouten van de leden van de Van Taeke familie min of meer vergoelijkt. Hij waarschuwt de katholieke lezers van De Maasbode. "Dit maakt ook eenige voorzichtigheid met deze boeken gewenscht, uit andere hoofde trouwens evenzeer geboden." Nieuwenhuis vindt de slotsom van het boek goed verwoord in een zin van Coolen: "Er zijn zooveel raadsels, er gebeuren zooveel dingen, waarin wij toch de menselijke ziel niet doorgronden. ${ }^{.48} \mathrm{Nu}$ Coolen zijn auteursidioom vaarwel heeft gezegd, is er toch nog iets van blijven hangen. Hij gebruikt volgens Nieuwenhuis te vaak "aaneenlijmsels" met een overdaad aan nietszeggende kom. ma's en geeft een voorbeeld: "Toen hij weer recht zat, mijn God, wat verscheen daar, een wilde boschpartij van warrige dunne pikzwarte haren, daar zaten schaduwholen in, zoo zat hij met een breede naakte borst, met naakte armen, waarlangs de zwarte, dunne haren als wier afhingen." Coolen heeft dit 'aaneenlijmen' zelf ook opgemerkt, want jaren daarvoor schreef hij al eens aan zijn Duitse vertaler Schauer dat hij blij was met de vertaling van 'De spreuk het goede paard': "Vooral Uw manier om langademige zinnen tot verschillende geserreerde kleine korte zinnetjes uiteen te nemen beteekent een winst op het origineel." Coolen had zich toen bij herlezing geërgerd aan zijn eigen "lange zinnen met hun verve lende interpunctie. ${ }^{-19}$ 
H. Marsman vindt De drie gebroeders een leesbaar boek met uitzondering van de twee onbegrijpelijk kinderachtige verhalen over de schaatsenrijder en de klerenverwisseling van de kolentremmer. Alles blijft echter oppervlakkig, vindt hij, met uitzondering van de beschrijving van de vrouwen Sjieuwke en Doutje. Daar dringt Coolen dieper door en zo'n moment doet voelen "wat er ook van deze stof was te maken geweest." Het eerste gedeelte van de recensie gebruikt hij overigens om nog eens zijn afkeer van de Peelromans te etaleren. Hij verwijt Coolen dat deze het leven van de Brabantse boeren "met de meewarig-sentimenteele blik van een stadsmensch" ziet. Het is allemaal te zachtzinnig en te idyllisch. De beste Peelroman Kinderen van ons volk haalt het volgens hem niet bij Het wassende watervan Herman de Man. De Man is Coolens meerdere in "natuurlijkheid, kernachtigheid en scherpte van blik." 50

\section{Rancune van een oude vriend}

Marsman is niet de enige die vindt dat de stof die Wiegersma heeft aangedragen tot iets groters had kunnen leiden. Twee dagen voor het verschijnen van Marsmans recensie schrijft Wouter Lutkie een brief aan Wiegersma om zijn positieve houding ten opzichte van het Italiê van Mussolini toe te lichten. Uit die brief blijkt dat de twee elkaar vaker ontmoeten, maar dat hun vriendschap sterk onder druk staat. Lutkie heeft niet alleen grote moeite met de opstelling van Wiegersma in het conflict tussen Italië en Abessinië, maar nog meer met het feit dat Wiegersma zich zo begraaft in zijn dorp. Kennelijk is hij niet op de hoogte van de vele internationale kunstenaars die De Wieger bezoeken. De vroegere leidsman van Coolen bestempelt zijn vroegere pupil, zonder diens naam te noemen, als een tweederangs romanschrijver:

"Ten andere ben ik er vast van overtuigd, gelijk ik bij een vorige gelegenheid al gezegd heb, dat ge per vergissing aan de verkeerde kant zijt gaan staan, aangezien Henk Wiegersma niet thuis hoort onder den grooten hoop. Ik ben er zeker van dat gij heel anders zoudt hebben geoordeeld, indien ge, door reizen buitenslands, het persoonlyk contact met oe vrienden in Frankrijk en elders had onderhouden. Henk Wiegersma is nu eenmaal iemand, die af en toe zijn neus buiten het dorp Nederland moet steken. Als hij verdorpst, wordt hij tot een monstrum, omdat hij krachtens zijn aard niet van dorpschen stijl is. Zoo had hij ook voor het verhaal van Dorp aan de rivier een romanschrijver moeten hebben van de kracht van een Balzac, Barbey d'Aurevilly of Dostojefski.

Groet oe vrouw en oe jongens van me. [waarna in handschrift:] En ga op reis. Naar Frankrijk of naar Lith (route: via Nuland). ${ }^{51}$

44 Brief Ten Braak aan Du Perron, 5 februari 1937. Ter Braak en Du Perron, Briefwisseling, deel 4, 89,

45 Campert, [Recensie De drie gebroeders].

46 Uyldert, De drie gebroeders'.

47 'De drie gebroeders'.

48 Nilieuwenhuis], 'Over de familie van Taeke'.

49 LMDC, inv. nr. C 3485, brief Coolen aan Schauer, 12 december 1933.

50 Marsman, 'Roman in tafereelen'.

51 Archief Hendrik Wiegersma, brief Lutkie aan Wiegersma, II februari 1936. 
Lutkie, die natuurlijk goed weet dat Wiegersma en Coolen zeer bevriend zijn, wil dat Coolen op deze indirecte manier te horen krijgt hoe hij over zijn kwaliteit als romanschrijver denkt. De rancune van Lutkie jegens Coolen moet sterker zijn geworden in de loop van 1935, wanneer Coolen in de Bossche Courant regelmatig kritisch schrijft over Mussolini en zijn oorlog tegen Abessinië en Ethiopië. Hij bespot de lichaamstaal van Lutkies held, Mussolini, waarvan hij niet weet of deze pose is of echt, maar wel dat zo'n houding in ieder geval onnavolgbaar is. ${ }^{52}$ Vlak voor zijn vertrek naar Palestina heeft Coolen nog gewezen op de grote gevolgen die deze 'veroveringsoorlog' kan hebben en bekritiseert hij de kranten die altijd partij willen kiezen. Zo is een kronkelredenering in zwang, die Abessinië ervan beschuldigt het welzijn van de mensheid aan te tasten door geen gebruik te maken van zijn grondrijkdommen. De Duce heeft gezegd dat vijf wereld. delen sidderen voor de fascistische macht, maar Coolen vindt dat voorlopig alleen Europa bang moet zijn voor dit fascistisch avontuur. ${ }^{5.5}$ Met dezelfde afkeer waarmee hij tijdens de Eerste Wereldoorlog schreef over de oorlogsjournalisten, de 'Schlachtenbummler', meldt hij nu dat 130 dagbladcorrespondenten in Abessinië het Italiaanse volk warm moeten maken voor de strijd door te wijzen op een schande die gewroken moet worden: een nederlaag van Italië bij Adoea van veertig jaar daarvoor in $1896^{54}$

\section{De Peel en de zee}

In oktober 1936, vlak voor het verschijnen van De drie gebroeders, heeft Coolen in een interview zijn visie gegeven op de Nederlandse literatuur en zijn plaats daarin.5. $\mathrm{Op}$ de vraag of hij nieuwe plannen heeft, zegt hij dat hij nog eens een boek wil schrijven over de grote veranderingen die in zijn streek plaatsvinden. Hij denkt aan een titel als De Peel groeit. Dit boek moet gaan over de toenemende industrialisering, de grote ontginningen, de nieuwe dorpen en het ineenschrompelen van andere plaatsen en het veranderende karakter van volk en streek. Dit boek staat volgens zijn zeggen op stapel. Het zal echter nog twintig jaar duren voordat dit boek er komt. Zij roman De grote voltige verschijnt in 1957 en voldoet precies aan de omschrijving die Coolen in dit interview geeft.

Daarna stipt Coolen in het interview een onderwerp aan waar hij al wat langer over nadenkt: het gemis aan Nederlandse literatuur waarin de zee centraal staat. Hij is daar voor het eerst in 1933 door zijn Duitse vertaler Schauer opmerkzaam op gemaakt, als deze een artikel over de jonge Nederlandse literatuur in Deutsche Zeitschrift heeft geschreven. Coolen is het daarmee eens en schrijft dan al: "Een typisch gemis is inderdaad ons gebrek aan een literatuur waarin iets van het nationaal heroïsme ter zee tot uitdrukking komt. ${ }^{n 56} \mathrm{Hij}$ voegt er aan toe, dat alleen Slauerhoff met Schuim en As en Het verboden rijk en Den Doolaard met De Druivenplukkers aan de begrenzing van het Hollands realisme ontstijgen. Schauer geeft op zijn beurt blijk van een speciale kijk op het boek Het Fregatschip Johanna Maria van Van Schendel.

Coolen neemt deze opvatting over en geeft die zowel in het interview met Ritter in mei 1936 als nu in De Telegraafals volgt weer. Hij vindt de pas overleden Slauerhoff dé romanschrijver van een zeevarend volk, vooral met zijn boek Het verboden rijk. Van Schendels Fregatschip is volgens hem geen roman over de zee. Het boek is door en door calvinistisch Hollands: de tragedie ligt niet in de zee en het schip, niet in de verte, maar thuis. De man sterft als hij het schip eenmaal in zijn bezit heeft. "Typisch Hollandsch is dat, als de man 
het schip eindelijk bezit, hij het naar huis brengt, en ten onder gaat aan zijn bezit. $\mathrm{k}$ zou willen zeggen zooals een boer soms aan zijn grond ten onder gaat waarvan hij zich dienstknecht maakt."

Van Schendel schrijft volgens Coolen romans over de haven, over het thuiskomen, terwijl voor Slauerhoff de haven het punt van vertrek is: zijn verlangen gaat naar de grote verten. Dit is niet typisch Nederlands. Het publiek houdt meer van het vertrouwen van Van Schendel dan van de onrust van Slauerhoff. Coolen zegt dat hij van Slauerhoff houdt als van geen ander van de jongeren. In mei sprak Coolen ook al positief over Slauerhoff, maar nu, vlak na diens dood, gooit hij er nog een schepje bovenop. Daar lijkt iets in te zitten van inlijven bij de eigen groep en losweken van de Forum-groep, maar het is ook mogelijk dat zijn gedachtengang is: zoals ik, Coolen de schrijver over de boeren en hun grond ben, zo is Slauerhoff de schrijver over de zeevaarders (niet de vissers) en de zee.

Naast de romans van Slauerhoff noemt Coolen Het wassende watervan Herman de Man en De herberg met het hoefijzer van Den Doolaard als meesterwerken. Van de Vlamingen acht hij Roelands en Walschap hoog, maar ook van Theun de Vries' Stiefmoeder Aarde houdt hij veel. Dat is een zwaar en moeilijk boek, "maar met hoeveel hartstocht en kracht is het beschreven, dit is Friesland!" Hij bewondert Ter Braaks vernuft in het literaire spel, maar zijn hart verzet zich tegen diens negativisme en alhoewel hij het schrijftalent van Vestdijk erkent, kan hij in de diepere waarde van een roman als Terug naar Ina Damman maar niet geloven.

\section{Reden voor de verhuizing: weg van Wiegersma?}

Het jaar 1937 zal het laatste zijn dat het gezin Coolen in De Romeijn in Deurne doorbrengt. Architect Valk, een beroemdheid in die tijd die ook veel kerken bouwt, heeft voor de familie Coolen een nieuw huis ontworpen dat gebouwd zal worden aan de rand van Waalre. ${ }^{57}$ Gerda Coolen is in verwachting van het vierde kind; zij hoopt sterk op een dochter. ${ }^{58}$ Nog het hele jaar zal het vochtige huis in Deurne zijn tol eisen. Stijn krijgt bronchitis en ook Gerda is ziek tijdens de zwangerschap. Hoe eerder ze er weg kunnen hoe beter. Oomes, die er kennelijk nooit geweest is, wordt gemaand: "Kom toch eens naar De Romeijn kijken voor we verhuizen." 59

Er is wel gesuggereerd dat de reden voor de verhuizing een heel andere is geweest dan het slechte huis. Volgens Louis de Bourbon-over wie zo dadelijk meer - is de verhuizing eerder een vlucht om onder de directe invloed van de dominante Wiegersma uit te komen. Later, ter gelegenheid van Coolens zestigste verjaardag, geeft hij zijn kijk op de verhouding

52 Coolen, 'Brieven van De Romeijn', 18 mei 1935.

53 Coolen, 'Brieven van De Romeijn', 17 augustus 1935.

54 Coolen, 'Brieven van De Romeijn',12 oktober 1935.

55 'Op bezoek bij Antoon Coolen. Een nieuw boek'.

56 LMDC, inv. nr. C 3485, brief Coolen aan Schauer, 14 april 1933.

57 Coolen was eind 1936 actief betrokken bij de restauratie van het Willibrorduskerkje in Waalre als lid van de provinciale Monumentencommissie. Waarschijnlijk heeft hij in die tijd een geschikte bouwplaats gevonden.

58 LMDC, inv. nr. C 3485, brief Gerda Coolen aan De Bourbon, 11 december 1936.

59. LMDC, inv, nr. C 3485, brief Coolen aan Oomes, 22 april 1947. 
tussen Coolen en Wiegersma. Hij vindt dat Wiegersma te zwaar ging wegen op Coolens. kunstenaarschap. Hij wil het duo niet vergelijken met dat van Van Gogh en Gauguin of met de 'ménage fou' van Verlaine en Rimbaud, want daarvoor waren de verhoudingen te verschillend. Beide mannen waren immers hoofd van een groeiend gezin en zagen elkaar soms dagen of weken niet. Er was, volgens De Bourbon, geen dagelijkse ergernis. Bovendien moet Coolen Wiegersma's persoonlijkheid als een versterker van de eigen energie en later zelfs als de energiebron zelf hebben ervaren. Echter, op den duur moest Coolen steeds meer een levensritme volgen dat het zijne niet was en kwam daardoor in ademnood. De Bourbon schrijft dat daar nog bij kwam dat de forsheid van het wezen van Wiegersma zulke donkere schaduwen wierp "dat je steeds weer een paar passen op zij moest treden om ook wat van de zon te zien." De voornaamste oorzaak was echter toch dat iedere kunstenaar een heerser is. Wiegersma was dat in hoge mate, maar ook Coolen wilde als scheppend kunstenaar uiteindelijk niet beheerst worden. De samenwerking rond de verhalen uit De Wieger was een vruchtbaar experiment, waar ook hoogspanning mee verbonden was, maar "ook de vermetelste laborant blijft niet langer dan noodzakelijk binnen de gevaarszône van zijn experimenten." ${ }^{n 0}$

Zoon Guido Coolen gelooft daar achteraf niet zo in. "Er is wel gezegd dat mijn vader daarheen verhuisd is om zich te onttrekken aan de machtige invloed van Hendrik Wiegersma, de ongekroonde koning van Deurne. Ik geloof dat niet." ${ }^{\text {"6l }}$ Volgens hem was de vochtigheid van het huis De Romeijn dé oorzaak.

De verhouding tussen de twee families is in ieder geval vriendschappelijk gebleven. Het vierde kind van het echtpaar Coolen zou Petronella gaan heten als het een meisje zou zijn, naar Nel (Petronella) Wiegersma-Daniels. Het wordt echter een jongen die Petrus Hendrikus [de aangepaste voornamen van het echtpaar Wiegersma, C.S.] gedoopt wordt. De illustratie op het geboortekaartje is gemaakt door Wiegersma: de eerste paus, Petrus, is er op afgebeeld met een enorme sleutel van de hemelpoort. Hieraan hangt een banier met de naam van de nieuwgeborene erop. ${ }^{62}$

\section{Louis de Bourbon}

De man, wiens mening over de verhouding tussen Coolen en Wiegersma hierboven geciteerd werd, is een nieuwe kennis van de familie. Coolen heeft De Bourbon leren kennen in de redactie van De Gemeenschap. Al gauw ontstaat een hechte vriendschap.

De Bourbon is in 1908 in Renkum geboren als achterkleinzoon van Karl Wilhelm Naundorff. Deze Naundorff beweerde dat hij de zoon van Lodewijk de Zestiende was. Over deze kroonprins ging al lang het gerucht dat hij niet in 1793 in de gevangenis overleden zou zijn, maar was ontsnapt. Naundorff overleed in 1845 in Delft. Zijn zoon verwierf het Nederlanderschap en sinds die tijd voert de familie de naam De Bourbon.

Louis de Bourbon studeert rechten in Nijmegen en is, in de tijd dat Coolen hem leert kennen, redacteur bij De Gelderlander. Ook schrijft hij novellen en gedichten. Hij gedraagt zich in woord en geschrift als een edelman en een echte De Bourbon. Op bijeenkomsten toont hij mediamieke gaven, door bijvoorbeeld een verstopt briefje in een boekenkast te kunnen terugvinden als het gezelschap daar sterk aan denkt. Hij voelt zich in Arnhem op de krant wat verstoken van intellectueel contact en ziet uit naar ontmoetingen met Coolen. Deze begrijpt dat heel goed: "Ik ken de schaduwen van het katholieke redactiebureau. De 
veertien Hilversumsche jaren bezorgen me nú nog somtijds angstdroomen in de slaap!" ${ }^{\text {es }}$

De Bourbon houdt het in Arnhem dan ook niet lang uit. In 1936 vertrekt hij met zijn Deense vrouw Gudrun naar Nederlands-Indië om daar voor Het Nieuwsblad van Soerabaja en De Indische Courant te werken. Na medio 1938 te zijn teruggekeerd in Nederland wordt hij via zijn contacten met de griffier van de Brabantse Staten, publicist en cultuurminnaar Vincent Cleerdin, benoemd tot burgemeester van Escharen in het Brabantse Maasland. Hierna worden de contacten met Coolen weer intensief hervat. De Bourbon heeft begin 1936 zelf een aanvaring met Wiegersma gehad. ${ }^{64}$ Dit maakt zijn visie op de verhouding tussen Coolen en Wiegersma uiteraard iets minder betrouwbaar.

In de komende jaren en gedurende de oorlog zal De Bourbon een van de vertrouwensmannen van Coolen zijn.

\section{Reizen naar Duitsland}

Zakelijk gezien gaat het Coolen nu zeer voor de wind. Zijn boeken zijn bestsellers. Daarnaast wordt hij gevraagd in jury's voor literaire prijzen. Samen met A.M. de Jong, P.J. Ritter jr. en C.J. Kelk zit hij op verzoek van Dirk Coster in de jury voor de Kosmosprijs tegen een honorarium van honderd gulden. ${ }^{65}$

Er verschijnen vertalingen in het Engels ${ }^{66}$, het Tsjechisch, het Fins en het Deens. De Deense schrijver Markus Lauesen verblijft in het voorjaar van 1937, na bemiddeling van Coolen, enige tijd in Deurne. Hij woont in een riant tuinhuis, een bijgebouw van huize Gelria van de fabrikant Te Strake. De radiospreker Ritter ontmoet hem bij Coolen thuis. Ze drinken gedrieèn een fles Italiaanse vermouth en worden daarna door mevrouw Coolen aan de maaltijd genodigd. "Wij haasten ons. Want de maaltijd is nergens zoo voortreffelijk en zoo joyeus als in den 'Romein'. ${ }^{n[7}$ Aanvankelijk was er sprake van dat Lauesen werk van Coolen zou vertalen, later is de Deense vrouw van Louis de Bourbon, Gudrun, even als vertaalster in beeld, ${ }^{68}$ maar uiteindelijk is het toch Clara Hammerinck geworden ${ }^{69}$ Een Franse vertaling van De goede moordenaar is al eerder verschenen. De meeste vertalingen verschijnen echter in Duitsland, Coolens grootste afzetgebied. Mede door deze steeds wassende stroom van inkomsten durft hij het aan om een ruime villa in Waalre te laten bouwen.

Een jaar eerder, in februari 1936, kreeg Stijn Streuvels, met twee andere Vlamingen, de Rembrandtprijs voor Nederduitse Letterkunde en Kunst van de Hamburgse stichting FV.S.

60 De Bourbon, 'Antoon Coolen 60 jaar', 644-645.

61 Van der Plas, 'Een man van de dorpskom'.

62 FPC, geboortekaartje Petrus Hendrikus Coolen, 29 juli 1937.

63 LMDC, inv. nr. C 3485, brief Coolen aan De Bourbon, 20 maart 1935.

64 "Of Wiegersma nog boos is weet ik niet, schrijf hem in elk geval eens," schrijtt Gerda Coolen. LMDC, inv. nr. C 3485, brief Gerda Coolen aan De Bourbon, 11 december 1936.

65 Brieven van Dirk Coster aan Coolen, 8 december 1936 en 17 januari 1937. Coster, Brieven

66 'De spreuk het goede paard' verschijnt als The good horse' in: The living Age, NYC. FPC, brief van redactie aan Coolen, 20 mei 1936.

67 Ritter, 'Marcus Lauesen'.

68 LMDC, inv. nr. C 3485, brief Gerda Coolen aan De Bourbon, 11 december 1936.

69 Zij vertaalde De drie gebroeders in 1937 en Kinderen van ons volk in 1953. 
De stichting is genoemd naar Freiherr vom Stein en bestaat nog altijd. Deze prijs wordt mede gefinancierd door de rijke graanhandelaar Alfred Töpfer, een oud-Wandervogel', Tópfer droomt van een Groot-Duitse samenleving, die de traditie van de Hanze zou voortzetten met een krachtig volk, waarin cultuur (de Zuidelijke Nederlanden), commercie en koloniën (Holland) en een volkrijk achterland met boeren als reservoir voor soldaten (Noord Duitsland) voorhanden zouden zijn. ${ }^{70}$ De uitreiking van de prijs wordt georganiseerd door de universiteit van Hamburg die, zoals alle universiteiten, volledig onder controle van het nazibewind staat. De andere gelauwerden zijn de priester-dichter Cyriel Verschaeve en de pas overleden dichter René de Clercq, de Vlaamse activist die Coolen in zijn Eindhovense journalistentijd nog ontmoet heeft. Streuvels weigert de prijs niet, maar weet het bijwonen van de uitreiking, onder een grote hakenkruisvlag, in mei te vermijden. Zijn uitgever neemt de prijs in zijn plaats in ontvangst. Coolen wenste Streuvels toen geluk met de Duitse onderscheiding en voegt eraan toe dat deze overal instemming zal ontmoeten bij de vrienden van de Vlaamse literatuur. ${ }^{n}$

Ondertussen heeft Coolen zelf ook veel contact met Duitsland. De Duitse 'völkische' schrijver Edwin Erich Dwinger vraagt hem om een bijdrage voor een boek over Bolsjewisme en Familie. Coolen zegt toe, ${ }^{n}$ maar de bijdrage is niet gevonden. Dwinger wordt later Reichskultursenator en zal tijdens de oorlog in Weimar spreken over "Bolschewismus als Bedrohung der Weltkultur." Hierbij vergelijkt hij het Slavische volk met termieten, die "hun handelingen verrichten zonder hersenen, eerder vanuit een donker en onbewust instinct."73

Al gauw na de Nederlandse première is er ook in Duitsland belangstelling voor Coolens toneelstuk De vreemdeling. Der Junge Bühnenvertrieb uit Leipzig heeft interesse en eind maart 1936 wordt een contract ondertekend voor de vertaalrechten. ${ }^{74}$ De vertaler is Peter Mertens, de Vlaamse vertaler van Insel Verlag. ${ }^{75}$ Was er tot nu toe, afgezien van een enkel verhaal voor een tijdschrift, nog slechts één werk van Coolen vertaald, namelijk Kinderen van ons volk in 1933, in 1936 kan het Duitse publiek Dorf am Fluss lezen alsmede twee versies van Jan der Schuhflicker ${ }^{76}$ of het toneelstuk Der Fremde gaan zien. De directeur van Insel Verlag, dr. Anton Kippenberg, stuurt met genoegen de positieve kritieken vanuit Duitsland toe en meldt dat Coolen daar al een beroemdheid aan het worden is. ${ }^{n}$

De dictatuur in Duitsland wordt echter steeds knellender en de kritiek van buiten steeds groter. Zelfs de paus, die altijd het communisme als een groter gevaar dan het (Italiaanse) fascisme zag, reageert bezorgd op de ontwikkelingen in Duitsland in zijn brief Mit bren. nender Sorge. ${ }^{78}$ De Nederlandse bisschoppen hebben al eerder negatieve geluiden laten horen en daarbij gewaarschuwd tegen het Staatsabsolutisme. ${ }^{79} \mathrm{Zij}$ dreigen zelfs met het weigeren van de sacramenten aan leden van een fascistische organisatie.

Coolen beseft dat de vertalingen van zijn boeken in Duitsland langs de meetlat van het 'Gesundes Volksempfinden' gelegd zullen worden. In Nederland zelf had Kuyle daar al een voorproefje van gegeven door in zijn kritiek Dorp aan de rivier "een woekering op de stam van het volkseigene" te noemen. ${ }^{80}$ Beschouwde Kuyle het boek dus als een soort ontaarde kunst, De Graaff verweet Coolen dat zijn stuk De vreemdeling juist heel goed paste in de nazi-ideologie. Het stuk wordt in ieder geval niet door Duitse Kulturkammerverboden. Na de snelle vertaling door Peter Mertens wordt het al gauw opgevoerd in Duitsland. Coolen 
woont zelfs een opvoering bij. "Ik heb veel voldoening gehad van de opvoering van en de ontvangst bij Der Fremde in Aken," schrijft hij aan Oomes. ${ }^{\text {at }}$ Na de oorlog kijkt hij daar als volgt op terug:

"Ik weet, dat de Duitschers zich graag beroepen op hun ruim standpunt tegenover andersdenkenden, van ouds trokken ze hun nationaal-socialistische nagels daarvoor in. Aan dat ruime standpunt dankte ik ook alle voorkomendheid, toen ik in 1937 een opvoering van een mijner toneelstukken in het Akener Stadttheater bijwoonde."

Als hij echter na afloop op aandrang van de intendant op het toneel verschijnt om het applaus in ontvangst te nemen, voelt hij plotseling dat de regisseur probeert zijn arm omhoog te rukken. "ganz hoch! ganz hoch, herr Coolen! Slechts door al den tijd, dien ik nodig had om los te komen, met de hand te wuiven, voorkwam ik den nationaalsocialistischen groet." ${ }^{\text {"2 }}$

Aan zijn vertaler Schauer schrijtt hij dat hij de uitgeverij in Leipzig in mei 1937 zal bezoeken. ${ }^{83}$ Hiervan zal hij eveneens pas na de oorlog verslag doen. ${ }^{84}$ Ook in zijn columns in de Bossche krant schrijft hij er niet over. Daar staan wel pacifistische stukken in, maar deze zijn, zoals we gezien hebben, algemeen gesteld of meer tegen het Italiaanse fascisme gericht.

Nog in 1938 maakt Coolen een reis door West-, Noord-en Midden-Duitsland. De reis wordt in de krant aangekondigd. De Nordische Gesellschaft te Lübeck, "die zich inspant Duitschland met de Nederlandsche beschaving bekend te maken," organiseert een reeks voordrachten van Coolen, die op I4 maart 1938 beginnen $\mathrm{zal}^{85}$ Het goedgeschreven sfeerverslag dat hij van deze reis maakt, is echter pas later geschreven en gepubliceerd na de oorlog. Het zou goede kopij geweest zijn op het moment zelf. Hij geeft er echter liever geen

70 Speliers, Als een oude Germaanse eik, 219.

7 AMVC, inv, nr. C 3475, brief Coolen aan Streuvels, 14 februari 1936.

72 FPC, brieven van Edwin Erich Dwinger(1898- 1981) aan Coolen, verzoek om bijdrage: 19 november 1935. dank voor toezegging: 27 januari 1936.

73 Speliers, Als een oude Germaanse eik, 448-449. In 1937 verschijnt een Nederlandse bewerking van Dwingers boek Und Gott schweigt..? onder de titel Hoe lang nog? Met een enquete over Hongerend Rusland' door FJ. Krop.

74 FPC, brieven van 'Der Junge Bühnenvertrieb' uit Leipzig aan Coolen, 19 maart 1936 (verzoek) en 8 april 1936 (dank voor toezegging en contract).

75 Speliers, Als cen oude Germaanse eik, 333-338.

76 Er is behalve een Duitse ook een 'Oostenrijkse' uitgave van de vertaling van Jantje de Schoenlapper. De Oostenrijkse heeft te maken met het onderwerp. De vertaler Kurt Lenzberg herinnert in een voorwoord aan de vele goede zorgen die veel Nederlandse gezinnen in de jaren na de Eerste Wereldoorlog aan Oostenrijkse kinderen hebben besteed. Hij besluit zijn inleiding met de woorden: "Got segne Holland, das Land der guten Traditionen!" Uyldert, 'De drie gebroeders'.

77 FPC, brief Kippenberg aan Coolen 13 mei 1936.

78 Uitgebracht door Paus Pius XI op 14 maart 1937: 'Over de toekomst van de katholieke kerk in Duitsland."

79 Vastenbrief 2 februari 1934 en 6 mei 1936. Joosten, Katholieken en fascisme, 285, 287.

80 Kuyle, 'Nieuwe normen'.

81 LMDC, inv. nr. C 3485, brief Coolen aan Oomes, 22 april 1937.

82 Coolen, Bevrijd Vaderland, 65.

83 LMDC, inv. nr. C 3485, brief Coolen aan Schauer, 21 januari 1937.

84 Coolen, Bevrijd Voderland, 42.

85 'Antoon Coolen naar Duitsland'. 
ruchtbaarheid aan, wat die reis in de ogen van anderen dan weer verdacht maakt. ${ }^{86}$

Coolen wil in deze jaren zoveel mogelijk de deur naar Duitsland openhouden. Hij stemt er bijvoorbeeld in toe dat Peter Mertens van Insel Verlag een van zijn romans kuist om deze aan de fatsoensnormen van het nieuwe Duitsland te laten voldoen. Het betreft het weglaten van een pedofiele misdaad en de daaropvolgende zelfverminking van de dader in Herberg In 't Misverstand. ${ }^{87}$

Tegelijkertijd is Coolen echter ook bezorgd over zijn status in Nederland. Het zit hem nog steeds erg dwars dat Chr. de Graaff hem verweten heeft de nazi-ideologie uit te dragen in De vreemdeling. Hij vraagt aan Van Duinkerken-met wie hij deze jaren overigens erg weinig correspondeert - om De Graaff daar eens over aan te spreken, nu de laatste onlangs weer smalend over het "roomsche vernisje" bij Kinderen van ons volk heeft geschreven. 'Inlijving' als katholiek auteur is Coolen nu welkom als een vorm van bescherming. Coolen beroept zich op Van Duinkerkens getuigenis, die dit boek vroeger een katholieke roman heeft genoemd. Het feit dat De Graaff ook nog banden met De Gemeenschap onderhoudt, vindt hij extra grievend. "Wend ik mij rechtstreeks tot de Graaff, dan loop ik nog het risico der verwarring, als zou ik notabene niet tegen zijn 'ongunstige' critiek kunnen. Misschien bepraat jij deze kwestie eens met hem [...] tot ziens, hopelijk, met Pinksteren op de Romeijn." ${ }^{88}$

\section{Speldenprikjes in de Roomsche familie}

Waarom kiest Coolen niet voor een pittige polemiek in De Gemeenschap? Voelt hij zich toch niet zo op zijn gemak, omdat het gewraakte stuk De vreemdeling nu als Der Fremde ook vee. succes heeft in Duitsland? Of is het toch eerder angst om de aandacht van de Duitse auto riteiten op zich te vestigen als tegenstander van het regiem, waardoor zijn boeken en toneelstukken in Duitsland verboden zouden kunnen worden?

Coolen houdt zich wel bezig met satire en spot in de rubriek 'Hagel', maar beperkt zich daarin nog steeds tot gebeurtenissen in het kneuterige 'rijke Roomsche leven' van die tijd. Zo wil de pastoor van Deurne op de trouwdag van prinses Juliana en Bernhard geen feestelijkheden na het invallen van het donker, vanwege de mogelijkheden tot onzedelijk gedrag. Coolen grijpt dat aan om de gescheiden toneelvoorstellingen, de vrouwen 's middags en de mannen 's avonds, nog eens te hekelen. Het meest bespottelijk vindt hij dat zelfs ouderavonden op de scholen gescheiden worden georganiseerd en hij vraagt zich af waar de naamgeving voor zo'n avond dan nog op slaat. ${ }^{89}$

Een andere keer schrijft hij over het blaadje Volksadel van de stichting Voor Eer en Deugd, waarin een artikel over seksualiteit staat. Hij heeft daar niets op tegen: "Als men meent, dat zulke artikelen, waarin de zaken nu maar eens grondig en openhartig worden besproken, hun nut hebben, dan heeft men voor deze meening misschien wel reden." Het stoort Coolen echter dat deze blaadjes zonder omslag of wikkel op de deurmat liggen, maar nog meer dat ze door schoolkinderen van tien of elf jaar wordt rondgebracht. De missiepa. ters, redemptoristen, die een donderpreek voor gehuwden willen houden, sturen tenmin. ste nog de ongehuwden de kerk uit. Dat is een voorzichtigheidsmaatregel die "die volks. adelende blaadjes met hun artikelen over de geslachtsdaad wel eens een beetje in acht mochten nemen."

In mei bekritiseert Coolen de stichting Volkstoneel, die met drie prijzen van $100,50 \mathrm{en}$ 25 gulden een toneelstuk wil uitlokken, "waarin de problemen van dezen tijd waarachtig 
en pakkend gesteld worden." ${ }^{\text {91 }}$ Verontwaardigd schrifft Coolen dat zo'n stuk alleen door 'vaklieden' wordt geschreven en dat de stichting hun aandriften onderschat als deze denkt dat schrijvers pas in actie komen, wanneer er met een briefje van vijf en twintig wordt gewapperd. Er zitten zelfs professoren en doctoren in de jury, stelt hij verwonderd vast. Coolen adviseert om de prijsuitreiking in "een gepavoiseerde, gezellige roomsche bewaarschool" te organiseren.

\section{Twijfel als redacteur van De Gemeenschap}

Het zijn allemaal huis-, tuin- en keukenonderwerpen, waar Coolen over schrijft. Hij voelt zelf wel dat hij daarin afwijkt van de rest van de redactie van De Gemeenschap. Als hij zich moet afmelden voor de redactievergadering van oktober vanwege "omslachtig werk," schrijft hij aan Van Duinkerken dat er iets knaagt aan zijn geweten. "De anderen moeten het ook als een grief voelen, ik doe er veel en veel te weinig voor. Tegenover jullie strijdbaarheid heb ik mijn passiviteit." ${ }^{92}$ Ook wat het verhalend proza betreft, heeft hij niet meer dan af en toe een ter perse gaand romanfragment geleverd. "Dit, en af en toe een Hageltje, zou ik ook kunnen inzenden, zonder deel uit te maken van de redactie." Hij durft in de redactievergaderingen bijna geen kritische opmerkingen te maken over een 'mager nummer', omdat hij er zelf nooit aan bijdraagt. Hetzelfde constateert hij bij mederedacteur Marnix Gijsen. Hij vindt dat Van Duinkerken het blad maakt, aangezien het "frontmakende en het opvallende" doorgaans van diens signatuur is. Coolen vindt het beter deze twee redactiezetels aan meer toegewijde leden te geven. Hij heeft besloten het redacteurschap neer te leggen, maar wil graag de traditie voortzetten om de redactie bij de Pinkstervergaderingen in zijn huis te ontvangen.

Er komt geen schriftelijk antwoord op deze brief. Misschien heeft Van Duinkerken hem tijdens het diner ter gelegenheid van zijn erepromotie aan de Katholieke Universiteit Leuven op 7 november 1937 overgehaald om lid te blijven. ${ }^{93}$ Later blijkt dat ook Jan Engelman zich heeft ingespannen om Coolen voor De Gemeenschap te behouden. Als Engelman door ruzie met Wiegersma besluit te vertrekken, voelt Coolen zich "labiel genoeg" om ook weg te gaan. ${ }^{94}$ Toch hakt hij de knoop niet door: Coolen blijft tot aan de opheffing van $D e$

86 D. Coster die al in 1934 vond dat je eigenlijk niet moet reizen naar een land waar schrijvers vervolgd worden (zie brief 13 mei 1934), meldt Coolen een paar jaar later een gerucht dat A.M. de Jong ter ore zou zijn gekomen: "dat je even na de pogroms [de 'Reichskristallnacht' 9 november 1938, C.S.] in Duitsland een lezing-tournee zoudt hebben gehouden. De Jong hoopt dat dit niet waar is en vroeg mij daarnaar te willen informeren." Coster, Brieven, deel 2, Brief Coster aan Coolen, december 1938.

87 FPC, brief Peter Mertens aan Coolen, II november 1939.

88 BA, brief Coolen aan Van Duinkerken, 24 april 1937.

89 Coolen, 'Pastoralia'.

90 Coolen, 'Volksadel'.

91 Coolen, 'Pro Deo'.

92 BA, brief Coolen aan Van Duinkerken, 7 oktober 1937.

93 Van Duinkerken krijgt zijn eredoctoraat tegelijkertijd met Stijn Streuvels, Cyriel Verschaeve, Gerard Brom en Marie Belpaire (die afwezig was).

94 LMDC, inv, nr. C 3485, brief Coolen aan Engelman, 5 februari 1938. 


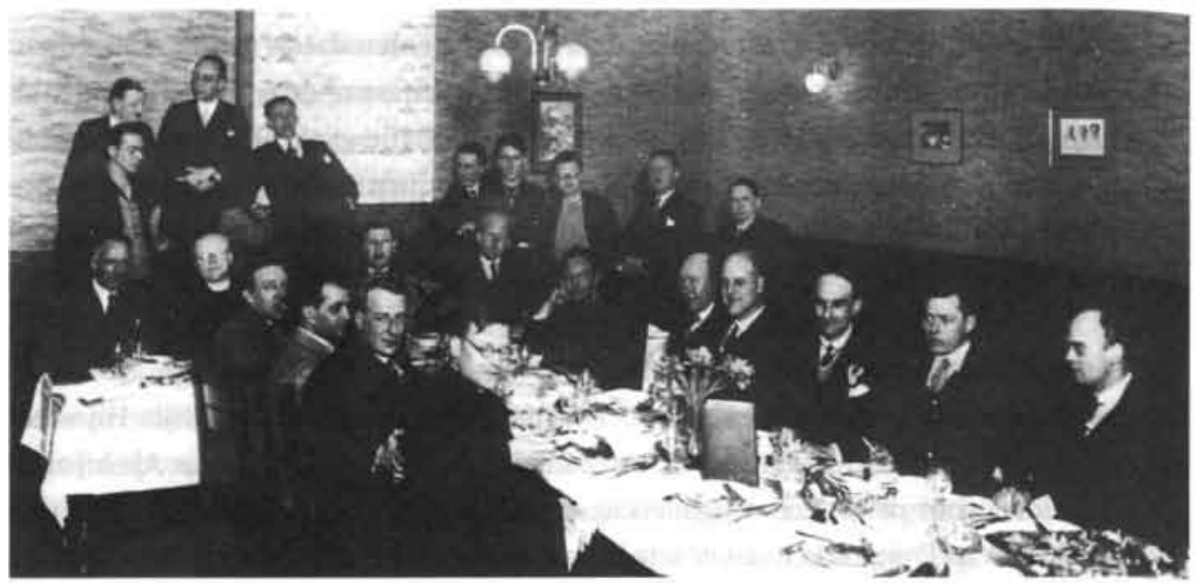

Bij het tienjarig bestaan van De Gemeenschop in 1935 wordt een diner georganiseerd. Aan tafel van links af met de klok mee: Antoon Coolen, Bernard Verhoeven, Charles Eyck, C. Vos, censor R.F. Hegge (met priesterboord), links daarvan waarschijnlijk St. van Schaik, aan het hoofd van de tafel Anton van Duinkerken, W.P.J. Pompe, professor Verbeek, P. Witteman, S, van Ravesteyn, A.J.D. van Oosten, Willem Maas en C.G. Berg. Staand van links naar rechts: Clemens Meuleman, Charles Nypels, Jan Engelman, A. van Domburg, Lambert Simon, Henk Marsman, Wouter Paap, waarschijnlijk H. Nelissen en Kees Strooband.

(bron: Bijvoet, De Gemeenschap, 68.)

Gemeenschap in september 1941 redactielid.

Het is opvallend dat Coolen naar aanleiding van dat eredoctoraat in Leuven in de Bossche Courant weer wel een politieke mening geeft. Hij ziet in Van Duinkerkens erepromotie een bevestiging van de Groot-Nederlandse vriendschap die bestaat dankzij de eenheid van de taal, en vervolgt: "Een Nederlandsch-Vlaamsche eenheid is in den cultureelen, volkschen zin [...] niet meer tegen te houden. België zal in twee nationaliteiten uiteenvallen als men Vlaanderen blijft achterstellen. Deze promotie is voor België gevaarlijker dan welke Dietse toespraak ook waar de Sureté achteraan zit." ${ }^{m 5}$

\section{Vertalen en vertaald worden}

Wat Coolen is voor de Peel is Jean Giono voor de Provence. Deze schrijver woont in Manosque aan de Durance ten Oosten van Avignon. Hij heeft in mei 1936 de Franse vertaling van De goede moordenaarvan een lovend voorwoord voorzien. Coolen kende hem daar voor niet, maar "ik las die inleiding en het was, alsof ik jaren met hem gesproken had en hem al mijn bedoelingen te voren had ingefluisterd. Vergeef mij als ik er mijzelf bij haal: maar is dat geen goed voorbeeld van het internationale in de soms zo gewraakte regionale kunst?"96

Giono is in oktober 1935 door zijn uitgever, Luis Brun van de Editions Grasset, op Coolen geattendeerd: "J'ai dans les mains un bouquin épatant d'un auteur hollandais. [... On dirait un Breughel littéraire. [...] Ce livre, c'est Le Bon Assassin par Antoon Coolen. La tra. duction en est aussi excellente que le texte intéressant. [...] C'est quelque chose de très humain. Je crois qu'il t'émouvra." ${ }^{\text {"g/ }}$ Uit de dagboekaantekeningen van Giono blijkt dat hij veel zorg aan het voorwoord heeft besteed. Hij heeft er acht volle dagen aan gewerkt, maar dan is het hem ook gelukt iets nuttigs toe te voegen: het voorwoord verklaart én comple 
teert de roman van Coolen. ${ }^{98}$ Coolen mag inderdaad trots zijn op deze vijfentwintig pagina's tellende inleiding van Giono, die van zowel warme bewondering als affiniteit getuigt. Giono schrijft: "Dans ce livre, tout est à la même profondeur. le veux dire qu'il y a accord parfait entre la tragédie et le plus minutieux détail. [...] Je ne dirai pas que c'est le grand talent d'Antoon Coolen. C'est plus important que du talent. C'est qu'il est l'expression même de la profondeur à laquelle se passe le drame. Il est l'homme exact. Il est enfant du monde. ${ }^{n 99}$ Als hij aan Coolen denkt, die hij niet kent, ziet hij iemand voor zich vol van bloemen en van lente; een eenvoudig man met kalme gebaren, zwiigend en eenzelvig.

Op de reis die Coolen en zijn vrouw in september 1936 naar de Provence hebben gemaakt zouden ze Giono ontmoet kunnen hebben, maar er is niets gevonden wat daarop wijst.

De overeenkomsten tussen beide schrijvers zijn groot. ${ }^{100} \mathrm{Zij}$ hebben veel aandacht voor de seizoenen en het land, hun personages laten zich leiden door hun instinct en als schrijfvorm hanteren beide een losse structuur die Van Duinkerken een 'straalvertelling' noemt. ${ }^{101}$ Op verzoek van uitgever Boucher werkt Coolen dan ook met plezier aan een vertaling van een boek van Jean Giono Regain onder de titel Weer een Lente. Het eerste exemplaar stuurt hij in september 1937 naar Manosque met een opdracht in niet helemaal perfect Frans: "á maitre Jean Giono. Hommage du traducteur pour qui le traduire de ce livre n'était qu'une joie." ${ }^{102}$ Coolen heeft zich bij de vertaling niet aan de letterlijke tekst gehouden en er eigen invullingen en toelichtingen bijgegeven, waardoor het boek toch een echte 'Coolen' lijkt. ${ }^{103}$

De vertaling krijgt een lovende kritiek van Ter Braak: "Merkwaardige coincidentie: wie niet beter wist, zou gemakkelijk aan een mystificatie kunnen geloven, zo voortreffelijk is Coolen er in geslaagd deze roman in ons taaleigen over te brengen, zozeer ook zijn de stof en de romantiek van de visie van de Fransman Giono en de Nederlander Coolen aan elkaar verwant." Ter Braak bespreekt niet alleen de vertaling maar ook de inhoud: bloed en bodem. Hij schrijft dat Coolen zijn Peelromans al publiceerde "lang voor de opkomst en val van de heer Mussert" en dat uit zijn uitlatingen blijkt, "dat hij ook in 't geheel geen lust heeft door de 'bloedbodemers' te worden opgeslokt." Ook Giono heeft de komst van Hitler

95 Coolen, 'Brieven van De Romeijn', 13 november 1937.

96 'Op bezoek bij Antoon Coolen. Een nieuw boek'.

97 Brief Luis Brun aan Jean Giono, 17 oktober 1937, geciteerd bij: Gallimard, Pléiade, Tôme: Journal, Poèmes, Essais, Parijs 1995, 64.

98 Gallimard, Pléiade, Tôme: Journal, Poèmes, Essais, 100.

99 Jean Giono, 'Preface', bij: Coolen, Le bon assassin, Grasset, 1936; vertaling Marcelle Schlomer. De passage is geciteerd uit de recensie van Le Monde van 8 september 1995 bij de herdruk van dit boek onder de titel La faute de Jeanne le Coq.

100 Jeanne Holierhoek, 'Over en weer: Antoon Coolen en Jean Giono', 40-47.

101 Zie de bespreking van Kinderen van ons volk in hoofdstuk 6.

102 Holierhoek, 'Over en weer', 40. Het boek bevindt zich nog steeds in het huis in Manosque, dat een Gionomuseum is geworden.

103 Jeanne Holierhoek geeft hier vele voorbeelden van: zij vergelijkt de vertaling ook met die van Marcelle Schlomer uit 1936, waarin het dialect van Coolen is weggevallen. 
niet afgewacht om zijn 'bloed-en-bodem'-boeken avant-la-lettre te schrijven, constateert Ter Braak. Het nieuwe is nu dat een politieke groepering het tot reclameartikel maakt. Het probleem is "de veralgemenisering van een genre tot de eng-zuivere en in een 'gezonde' samenleving derhalve enig-mogelijke litteratuur," waarbij dat genre gepaard gaat met "lafhartig geschrijf tegen Joden en emigranten, alsof deze mensen parasieten en bacillenverspreiders zouden zijn." ${ }^{104}$

Deze recensie moet voor Coolen een geschenk uit de hemel zijn. In feite wordt de smet die Du Perron enkele jaren daarvoor op hem gooide, ${ }^{105}$ verwijderd door Ter Braak, die niet alleen de meest felle antifascist van Nederland is, maar ook nog een vriend van Du Perron.

Ter Braak heeft gelijk: Coolen schreef zijn romans al voor de echte opkomst van het nazisme. Als de 'bloedenbodemers' hem willen opslokken zouden ze zijn boeken niet al te nauwkeurig moeten lezen, want kenmerken als het mededogen met de machteloze en de liefde voor het onvolmaakte, die zo ruim in Coolens verhalen vertegenwoordigd zijn, zijn strijdig met de leer van het recht van de sterkste, die het nazisme predikt.

\section{Kerstmis in de Kempen}

Zoals in Engeland de jaarlijkse detectiveroman van Agatha Christie in de decembermaand een traditie wordt - 'A Christie for Christmas' - zo lijkt in Nederland geen Kerstmis te kunnen bestaan zonder een nieuwe bundel kerstverhalen van Coolen. In een mooie blauwe linnen band en met kleurtekeningen en bandomslag van Gerard Baksteen, verschijnt eind 1937 Kerstmis in de Kempen. Daarin staan vijf verhalen: 'Wegen terug', 'Het goede Paard'06. 'Kerstmis op den Mellegenberg', 'De Kerststal' en 'Moeder Marjannes Kerstfeest ${ }^{107}$.

In 'Het goede paard' gaat de vrouw van een kinderloos paar op het feest van Maria Boodschap, 25 maart, ter bedevaart naar Ommel. Zij voelt daar dat haar gebed verhoord wordt. Inderdaad raakt zij in verwachting maar vertelt het nog niet aan haar man. Enige tijd later krijgt het echtpaar zo'n ruzie dat ze niet meer met elkaar spreken. De man haalt daarom het paard in de keuken bij de avondmaaltijd en geeft het te eten. Zijn vrouw jaagt na verloop van tijd met een takje de vliegen weg. In de zomer spreken ze voor het eerst weer, als zij vertelt dat ze een kind zullen krijgen. Ze kunnen het paard ondertussen niet meer missen, omdat het tijdens hun lange zwijgen de enige verbinding was tussen hen beiden. Daarom laten ze een gat in de muur maken tussen de keuken en de stal met een voẹbak eronder. Het paard kijkt vredig toe als met Kerstmis in een eenvoudige wieg het kind ligt, "dat was afgebeden en neergedauwd, verkregen van de hemel die openligt in den doorzongen, heiligen nacht. De man. De vrouw. En het kind." ${ }^{108}$

Dat Coolen ook nog steeds de sfeer van winter in de Peel kan oproepen, bewijst hij in 'Kerstmis op de Mellegenberg' waarin een "goejvrouw" [vroedvrouw, C.S.], een "karnallische mondfiat," ${ }^{109}$ een oude gierige boer met ringetjes in zijn oren tot liefdadigheid weet te brengen. In dit verhaal is sprake van een klok, die bij het vervoer vanuit Aarle lang geleden in de Peel verzonken is en die met Kerstmis luidt. Dit thema komt ook voor in zijn verhaal 'De Kerstklok en de Duivel'. Het verhaal heeft iets van de sfeer van Dickens' Christmas Carol.

In 'Moeder Marjannes Kerstfeest' kijkt de oude Marjanne, die eenzaam in het Liefdesgesticht zit, terug naar de tijd dat haar kinderen nog klein waren, maar ook naar 
haar eigen jeugd. Die is niet makkelijk geweest: haar ouders maakten voortdurend ruzie en toen ze op dertienjarige leeftijd aan een 'dienstje' begon bij een boerenfamilie, heeft de boer zich aan haar vergrepen. Als ze weer thuis is, laat ze haar ouders beloven in ieder geval met Kerstmis nooit meer ruzie te maken. Deze Kerstmis is ze alleen; haar man is overleden en haar kinderen komen niet op bezoek. Op Kerstmorgen loopt ze zo maar weg uit het gesticht naar haar vroegere huis, waar nu een vreemd jong gezin woont. Ze bekijkt de veranderingen die in het huis zijn aangebracht. Als de jonge boer haar met een kar terugbrengt, meent ze een koor van kinderen in de ijle lucht te horen. In een visioen ziet ze de levens van haar zonen en dochters, die mislukt zijn of zich te groot voor hun moeder voelen, weer voor zich. Ze ziet hen weer kleiner worden; de tijd loopt terug. "Ze komen weer bij Marjanne, en God, die ze gaf, maakt hun handen weer klein, de kleine handen waarmee zij vooraf alles hebben goedgemaakt." ${ }^{n 0}$ Terwijl ze aan Kerstmis denkt toen haar eigen kinderen klein waren, sterft ze: "Alles van vroeger komt dichterbij. Zij buigt zich tot dien geheimzinnigen cirkel, waarin de door den dood aangeraakte het kind de handen reikt. Zij zit te schudden en te knikken op de dokkerende kar. Zij weet niet, hoe onder duisternis en regen haar heele gezicht één lach is."

In dit laatste verhaal uit de bundel heeft Coolen veel thema's gebruikt die vaak in zijn werk terugkeren. De kringloop van kinderen die geboren worden en ouderen die sterven, belicht hij steeds opnieuw. De vrouw Nolda in De man met het Jan Klaassenspel ziet in een visioen een klein kind komen uit het graf van haar vader en ook hier is sprake van kleine handen die zich op haar mond leggen. In de visioenen van de drinker Fons van Willemien uit De goede moordenaar veranderen de kleine duiveltjes die over zijn buik dansen ook in kinderen. Bij zijn naderende dood verandert een van die monstertjes in een bruine kever zonder mond en vraagt hem waarom hij geen kinderen heeft. Coolen legt steeds de band tussen jonge (zelfs ongeboren) kinderen en de dood; een soort organisch verband tussen de afgevallen, rottende vrucht en de kiemen van het nieuwe leven in het zaad.

"Dit mooie boek eert den schrijver, den illustrator en den uitgever," schrijft de NRC. De krant vindt dat het zuiver religieuze er niet is opgeplakt, zoals bij zo veel kerstverhalen gebeurt. "Wie deze Kerstverhalen tot zich spreken laat, kan nuchter blijven, maar toch knielen." Veel mensen, zelfs de rationalistische Darwin, schrijft de recensent, verlangen terug naar de beleving van Kerstmis, zoals die als kind ervaren is. Het verhaal over moeder Marjanne vindt hij het mooiste van de bundel. ${ }^{112}$

104 Ter Braak, 'Bloed en Bodem'.

105 "Der romancier des Moorlandes Antoon Coolen hat selbst schon verkündet, das der Regionalismus die einzige wahre Kunstform sei." Du Perron, 'Holländische Literatur'.

106 Reeds in eerdere versie verschenen in 1931 als 'De spreuk het goede paard'. Het verhaal is in die vorm in 1933 in het Duits en in 1936 in het Engels vertaald.

107 Een jaar eerder verschenen in het Kerstnummer van de Nederlandse Spoorwegen.

108 Coolen, Kerstmis in de Kempen, 57.

109 Een fel vrouwmens, dat goed van de tongriem is gesneden.

110 Coolen, Kerstmis in de Kempen, 143.

III Coolen, Kerstmis in de Kempen, 144.

112 [Recensie Kerstmis in de Kempen], in: NRC. 
Aan het eind van het jaar 1937 bereidt Coolen zich met zijn familie voor op de verhuizing naar het nieuwe huis in Waalre. Coolen werkt hard aan een grote nieuwe roman, Herberg In't Misverstand. Dat hij het druk heeft is af te lezen van zijn columns in de Bossche krant. De laatste 'Brieven van De Romeijn' zijn een beetje op de automatische piloot geschreven: een mijmering over het schoentje zetten met Sinterklaas, het verlangen naar sneeuw, een kerstwens en een bede om vrede bij Oudjaar. 


\section{Van de Peel \\ naar de Kempen}

"Niet altijd weten wij wat we doen."

1938-1939

\section{Waalre}

Midden in de winter, op 14 januari 1938 , verhuist het gezin Coolen van het vochtige huis De Romeijn in Deume naar het pas opgeleverde en dus ook nog vochtige De Kempen in Waalre. Het staat aan de Blokvenweg, aan de rand van het dorp. De nieuwe woning bevalt aanvankelijk slecht: "Het nieuwe huis is even ver beneden onze illuzies gebleven als het financieel den heelen bouw door alle begrootingsposten schandelijk bleef overschrijden. Het resultaat is dat wij terugverlangen naar De Romeijn, zoo die, door een verbouwing meer gerief zal hebben," schrijft Coolen al na enkele weken aan Engelman. Hij is benieuwd wat zijn mening is over de architectuur van Valk. Zijn vrouw Ger is wat down, "maar de jongens hebben het koninklijk in een bosch, dat hun domein is."' De positieve invloed op de gezondheid van de kinderen blijft uit; Stijn zal nog het hele jaar blijven sukkelen met bronchitis en daardoor vaak de school verzuimen. ${ }^{2}$

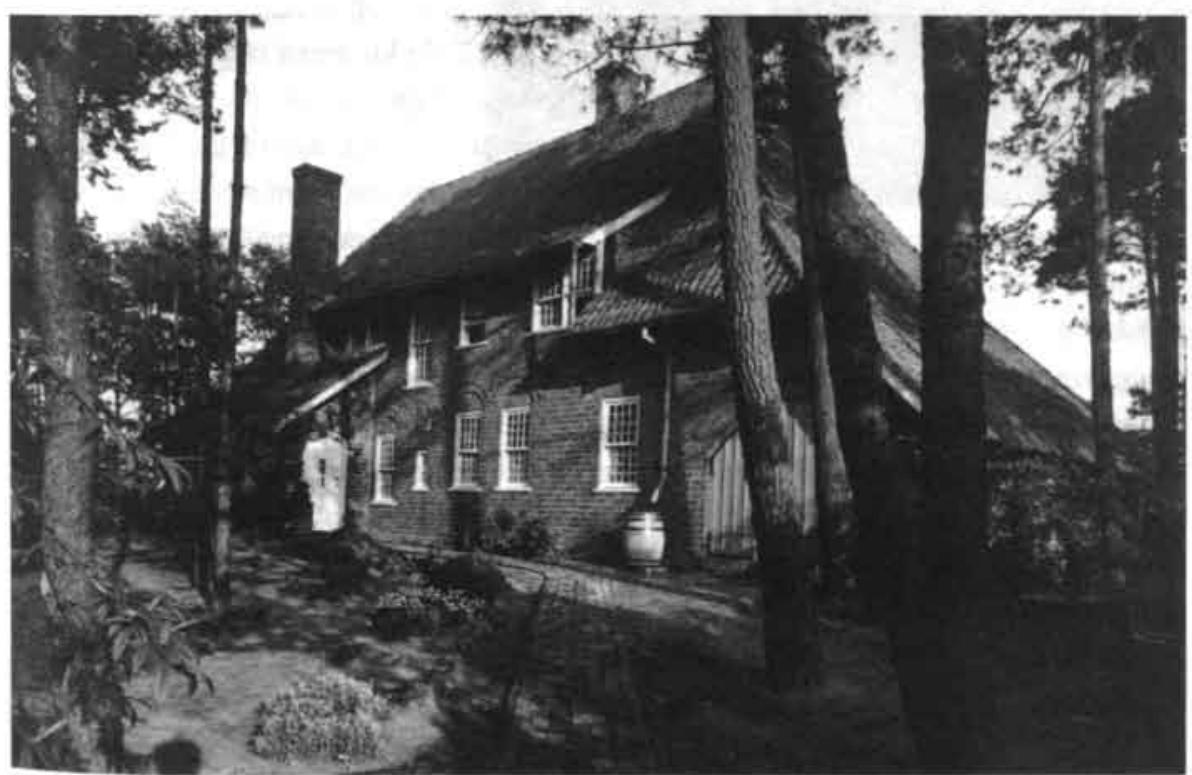

De Kempen in Waalre.

1 LMDC, inv. nr. C 3485, brief Coolen aan Engelman, 5 februari 1938.

2 BA, brief Gerda Coolen aan Nini Asselbergs, 25 oktober 1938. 
Coolen heeft zijn schrijfhut weer meegenomen, schrijft hij aan zijn vriend de dichter Redingius. "Voor mijn werkhuis heb ik van de gemeente een plaatsje gekregen aan de rand van een dennenbosch, waar groene akkers in een kom van blauwe bosschen zich uitstrek. ken, een oord van volmaakte stilte, waar alleen maar natuurgeluiden te hooren zijn: wind en vogels." Toch is er een gevoel van weemoed. "Maar de overgang van Deurne, het peelland, naar de oude Kempen, is niet zonder weemoed geweest, veel liefs bond ons aan De Romeijn." Wederom moppert hij over de architect, die mislukte experimenten met nieuwe materialen heeft verricht, waardoor er nu al weer steeds werklieden over de vloer zijn. Valk heeft een huis als een kasteel gebouwd en helemaal niet op de financiën gelet, zodat de vreugde over de "spatieuze woning" niet zonder schaduw is. Ondanks alles staat er toch weer een nieuw boek op stapel: " $t$ Blijft voorlopig nog wat onvast in den vorm, maar dat komt vanzelf."

Ook tegen Wiegersma klaagt hij over zijn huis dat nog in maart vol arbeiders, schilders, stucadoors en tegelleggers is, "die hun best doen om wat anderen verprutst en verknoeid hebben te herstellen. ${ }^{.4}$ Kennelijk heeft Wiegersma hem gewaarschuwd geen overijlde

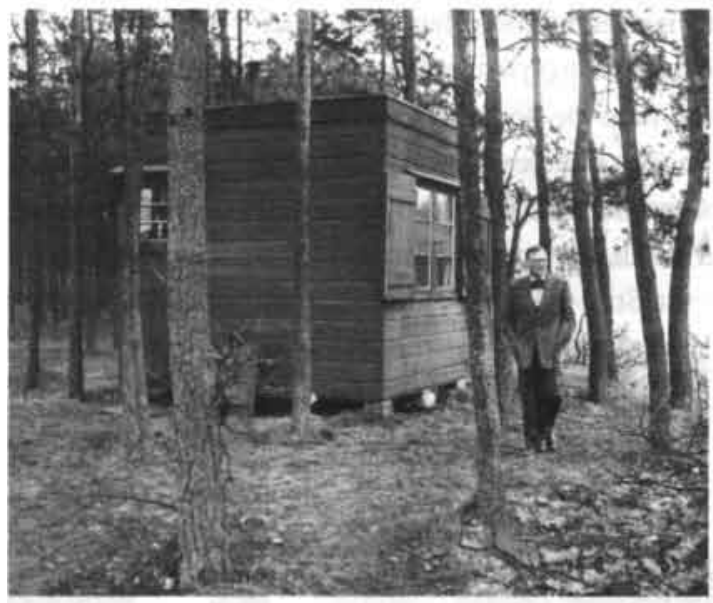

Coolen bij zijn schrijfhut. stappen te doen, bijvoorbeeld door het meteen te verkopen en weer te verhuizen. Coolen belooft dat, maar zegt tevens moeilijk te kunnen berusten in de deceptie die het huis in zo menig opzicht voor hen betekent. Daar komt bij dat hij nu de zorgzame vriend en arts op korte afstand mist, omdat de kinderen nog steeds veel ziek zijn.

Zijn zaterdagse rubriek in de Bossche krant heet van nu af aan 'Brieven van De Kempen'.

\section{De klokkengieter, een 'mannelijk' toneelstuk}

In de drukte van de verhuizing valt ook de première van Coolens toneelstuk De klokkengieter op 22 januari 1938 in de Amsterdamse Stadsschouwburg. ${ }^{5}$ Evenals in De vreemdeling staat in dit stuk een patriarchale meester, zoals in de gildetijd, centraal. De klokkengieter zal voor de laatste maal een klok, een grote Maria-klok, gieten voor de nieuwe kathedraal. Daarna zal zijn volwassen zoon hem opvolgen.

De climax van het stuk is het moment dat de gloeiende 'klokkenspijs', het geheime mengsel van vloeibaar koper en tin, door het openstoten van de smeltoven in de mal gego. ten wordt. Dit is een plechtig ritueel, waarbij steeds de familie en het voltallig personeel aanwezig zijn. Als de klokkengieter op het punt staat deze plechtige handeling voor het laatst te verrichten, kan zijn zoon niet meer wachten en stoot zelf de smeltoven open. Hij wordt door zijn vader zo ruw opzij geduwd, dat hij met zijn handen in het gloeiend brons valt. Diezelfde handen heeft de vader vroeger gezegend.

Als de zoon met een afgezette arm en de andere in het verband uit het ziekenhuis is teruggekeerd, zegt de vader: “Jouw handen werden geschonden door een ander. En ik, ik 
verminkte daar de mijne mee. Jouw geest werd niet geslagen [...] lk heb [...] gezegd, dat mijn handen maar stompen meer zijn. Daar mag ik geen klokken meer mee maken." ${ }^{\text {"6 }} \mathrm{Hij}$ geeft de gegevens voor het maken van de klokkenspijs aan zijn zoon en vertrekt tijdens een hevig noodweer. Zijn laatste woorden luiden: "Wij zijn net als klokken. Als ze een breuk hebben, en hun erts is nog bruikbaar, dan moeten ze overgegoten worden. Daarom moet ik weg. Om overgegoten te worden moet de klok éérst zijn vermorzeld, om in het vuur een nieuw en zuiver erts te worden. Daarom moet ik weg. En alléén zijn."

Het stuk is een bewerking van 'De klokkengieter en het kind', een verhaal dat Coolen al in de bundel kerstverhalen van 1935 gepubliceerd heeft. Coolen schreef het naar een oude Duitse legende. Daarin slaat een klokkengieter een kind dood dat het gewaagd heeft het steekgat van de smeltoven open te stoten en aldus de klok giet. Het is het kind dat hij, na het overlijden van zijn eigen zoon, voorbestemd had om zijn opvolger te worden. In dit verhaal krijgt de klokkengieter de doodstraf, maar hij sterft in zijn cel in de nacht vóór de voltrekking van het vonnis, nadat hij buiten de kerstklok, die door het kind gegoten is en waarvoor het gedood is, voor de eerste keer heeft horen luiden.

Het toneelstuk is evenals De vreemdeling een ode aan de handenarbeid en het vakmanschap. Vrouwen spelen er een ondergeschikte en dienende rol in. De dialogen zijn verklaringen in boekentaal, die uitgesproken worden door personages die eerder archetypen zijn dan mensen van vlees en bloed. "De intrige immers van dit stuk laat zich zelfs tijdens het spel, gemakkelijker denken in novelle-vorm dan als toneelmanifestatie," schrijft de Gooien Eemlander. ${ }^{7}$

Coolens vriend Oomes uit Hilversum zal er weer niet tevreden over geweest zijn, want evenmin als bij De vreemdeling kan hier gesproken worden van een katholiek verhaal. Zeker, er wordt gebeden voor het gieten van de klok die voor de kathedraal bestemd is en die gewijd zal worden op het feest van Maria Boodschap, maar dat is gewoon de katholieke context van het verhaal. Verder is het toch vooral de vertelling over de misstap van een bijna onaantastbare held, die daarna zijn gewone menselijkheid beseft en door loutering zijn weg in de toekomst zoekt. In de slotzinnen van de vertrekkende klokkengieter zitten geen herkenbare katholieke aspecten als vergeving, genade of naastenliefde. De zorg van de patriarch gaat niet in de eerste plaats uit naar het leed dat hij een ander heeft aangedaan, maar naar het herstel van zijn eigen nobele persoonlijkheid. Zowel de smid in De ureemdeling als deze klokkengieter zijn volledig overtuigd van hun eigen morele superioriteit, die alleen maar meer reliëf krijgt door hun misstap. Als zij beseffen hoe makkelijk ze iemand zouden kunnen doden, zijn ze hard voor zichzelf en kiezen voor een louterende daad. Door hun reminiscenties aan de alchemie hebben beide stukken een min of meer esoterisch

3 LMDC. inv. nr. C 3485, brief Coolen aan Reddingius, 22 maart 1938.

4 Archief Hendrik Wiegersma, brief Coolen aan Wiegersma, 18 maart 1938.

5. Het Nieuw Schouw-toneel onder leiding van Ko van Dijk sr. en Frits Bouwmeester. Met Ko van Dijk, Dogi Rugani, Jaques Snoek, Sophie Stein en Frits Bouwmeester. Regie: Cor Hermus.

6 Coolen, De klokkengieter, 7 .

7 'Kunst in de hoofdstad'. 
karakter. Criticus Chr. De Graaff constateerde al in zijn recensie van De vreemdeling dat de smid even overtuigd is van zijn morele superioriteit als de auteur die hem schiep.

Coolen is niet de enige die in die tijd het mannelijke gelijkstelt met het algemeen menselijke en een vitale levenshouding. Polman ${ }^{8}$ wijst erop dat niet alleen Van Duinkerken, maar ook vele andere critici de vrouw niet in staat achtten om het algemeen menselijke te laten zien. Coolen, Den Doolaard, Van Eeden, Marsman en Werumeus Buning worden mannelijke schrijvers genoemd. Het begrip man heeft steeds een positieve betekenis: oprechte mannentaal, een onversierde mannenstijl, mannelijke hartelijkheid. Van vrou. welijke schrijvers worden het 'vrouwelijk verfijnde' en de 'vrouwelijke gratie' gewaardeerd, maar zo gauw zij zich op het sociale of politieke vlak begeven, ontstaat arg. waan. Ook bij Coolen is dit het geval, gelet op zijn negatieve uitlatingen over actieve jonge boerinnen tijdens een congres, zoals hierna bij de bespreking van 'De Oost-Brabanters' zal blijken. Het is opmerkelijk dat Coolen boeken als De kleine Rudolfvan Van der Leeuw en Een zwerver verliefd van Van Schendel als zijn favorieten beschouwt. Van Duinkerken vindt dit typisch vrouwelijke boeken. Als we het werk van Coolen tot nu toe overzien is hij zelf ook op zijn best in 'vrouwelijke' boeken, dat wil zeggen, boeken waarin de mensen ontvanke. lijk zijn voor wat het leven, het instinct, het lot te bieden heeft en die minder hechten aan het maakbare en controleerbare.

Er huizen twee zielen in Coolens borst. In zijn romans, verhalen en novellen zitten in bovenstaande betekenis mannelijke en vrouwelijke aspecten. Als geen ander kan hij het mededogen met verschoppelingen oproepen of de innigheid van het kroningsritueel van een gestorven kindje en de eenzaamheid van een kind tussen ruziënde ouders beschrijven. In de eerste reeks Peelromans overheerst deze kant van zijn gemoed en zijn schrijverschap. Vanaf de roman Dorp aan de rivier met Tjerk van Taeke en de smid in De vreemdeling krijgt de beschrijving van de mannelijke superheld meer aandacht. Maar in een roman gebeurt dat anders dan in een toneelstuk. In de Van Taeke romans bouwt Coolen door zijn stijl een zekere afstand in. De lezer krijgt de dokter te zien door de ogen van de gissende en onwetende dorpelingen: ze zeiden dat den dokter.. wij dachten dat ie op reis was .. het schijnt dat hij in Rusland eens .. enzovoort. Hierdoor wordt in het midden gelaten of de mythische proporties van het personage werkelijkheid zijn of verzinsels, aangedikt door de roddel van de dorpsgemeenschap.

In een toneelstuk vervalt deze mogelijkheid. Coolen heeft die althans niet gebruikt, waardoor de zinnen van de mannelijke held klinken als onwrikbare waarheden. Dit. gevoegd bij de plechtstatige boekentaal, maakt De vreemdeling en De klokkengieter onge nietbaar. Deze toneelstukken missen de raadselachtigheid en het mysterie van de romans, ze zijn een soort leerstukken met bedenkelijke trekjes.

\section{Opnieuw twijfels over De Gemeenschap}

Coolen blijft in de redactie van De Gemeenschap steeds wat aan de buitenkant. Natuurlijk speelt ook de geografische afstand een rol, maar de voornaamste reden is toch dat hij zich niet of nauwelijks inlaat met de conflicten en spanningen die in de wereld van journalisten en schrijvers spelen. Een illustratie hiervan is zijn opstelling bij de vijftigste verjaardag van A.M. de long. Hiervoor is een huldigingscomité opgericht om een geldelijk cadeau in te zamelen en aan te bieden. Coolen treedt toe tot dit comité en op papier lijkt het of ook Van 
Duinkerken er lid van is. In een ingezonden stuk in De Maasbode wordt Van Duinkerken een onprincipiële houding verweten, omdat hij tien jaar daarvoor actief had deelgenomen aan de Anti-Schund publicatie van De Gemeenschap die gericht was tegen De Jong en Querido. Maar Van Duinkerken blijkt de circulaire met het verzoek onbeantwoord gelaten te hebben, waaruit men automatisch geconcludeerd heeft dat hij ermee instemde. "Nimmer zou ik uit eigen beweging zitting hebben genomen in bedoeld comité," schrijft hij daags na het ingezonden stuk in De Tijd.

Coolen verontschuldigt zich uitgebreid bij Jan Engelman, en legt uit waarom hij wel positief geantwoord heeft op de circulaire: "Een weigerend antwoord van mij op deze circulaire was moeilijk, omdat ik met A.M. de Jong zitting heb in de jury van de Kosmosprijs. ${ }^{10}$ Coolen zegt dat hij het belangrijk vindt in die kringen mee te praten en te beslissen en dan valt een weigering niet goed. Hij heeft niet meteen aan de Anti-Schund geschiedenis gedacht. Pas toen hij in De Maasbode las dat Van Duinkerken ook lid was van het comité, werd hij herinnerd aan zijn hekeldicht en "het heele NU-geval." Bij Coolen speelt naast zijn waardering voor De Jong ook een ander motief: A.M. de Jong is een beroemd schrijver en publiceert tevens heel uitgebreide en positieve kritieken op het werk van Coolen. Hij doet dit in de socialistische krant Het Volken vergroot daarmee de bekendheid van Coolen ook buiten de katholieke kring. In dezelfde brief aan Engelman uit Coolen zijn twijfel over zijn redacteurschap en voegt eraan toe dat hij zich 'labiel' genoeg voelt om uit de redactie van De Gemeenschap te stappen als Engelman zou weggaan. Hij herinnert hem er aan dat Van Duinkerken en Engelman hem eind 1937 in Leuven al eens hebben tegengehouden.

Coolen stapt echter niet op. Hij wil toch blijven meepraten en meebeslissen. Ook hier lijkt een zeker eigenbelang mee te spelen. De relatie met De Gemeenschap maakt dat hij (mede) zichtbaar blijft als 'katholiek' auteur. Daarom besteedt Coolen zoveel aandacht aan de jaarlijkse redactievergaderingen, rond Pinksteren, op De Romeijn in Deurne en vanaf 1938 in De Kempen in Waalre. Coolen is liever het bindend harmoniërend element dan lid van het strijdbare deel van de redactie.

Dat hij een goed gastheer is, blijkt uit reacties van de redactieleden. De eerste bijeenkomst in het nieuwe huis op 23 juli 1938 wordt gevierd met een overvloedig feestmaal. De bewaarde menukaart vermeldt:

Pompelmoes met rum - Asti Spumante

Kerrysoep - Vermouth de Torino

Gevulde tomaten, Cromesquis met doperwten - Chianti Brolio

Paddestoelen met geroosterd brood - Monte Fiascone

Reebout met gewreven kastanjes - Ceresuolo 1929

Slagroom met vruchten, kaas, fruit

Koffie, likeur en havanas. "

Polman, De keerzijde van het leven, 176-177.

9. Van der Plas, Daarom, mijnheer, 252. Het ingezonden stuk in De Maasbode is van 3 maart en Van Duinkerkens antwoord in De Tijd van 4 maart 1938.

10 LMDC, inv. nr. C 3485, brief Coolen aan Engelman, 5 februari 1938.

II Van der Plas, Daarom, mijnheer, 256. 
Op een van die bijeenkomsten speelt het gezelschap de restauratie van het koningschap in Frankrijk. Daarbij ontpopt Coolen zich als een geslaagd imitator van de vroegere ministerpresident, Ruys de Beerenbrouck, en wordt door zijn gehoor meteen gedecoreerd met de orde van de Melk-wèg, 'zo genoemd, omdat wij besloten hadden, aan de laiterie van Marie Antoinette te Versailles een ietwat gewijzigde bestemming toe te kennen', schrijft Van Duinkerken achteraf. ${ }^{12}$ Coolens bijdragen aan de inhoud van het tijdschrift blijven schaars. In januari 1938 publiceert hij het verhaal 'Kêhilan'. ${ }^{13}$. Het gaat over een dokter die een Arabische hengst van een circusdirecteur krijgt als dank voor zijn medische hulp.Het verhaal kan gezien worden een 'nabrander' van Dorp aan de rivier.

\section{Vaanderen en verzuiling}

Behalve het verhaal 'Kêhilan' levert Coolen in 1938 slechts twee bijdragen aan De Gemeenschap. Hij laat een rede afdrukken over Hendrik Conscience ter gelegenheid van het feit dat honderd jaar daarvoor diens De Leeuw van Vlaanderen is verschenen. ${ }^{14}$ De rede werd door hem uitgesproken in een academische zitting in de Nederlandse Schouwburg van Antwerpen op Ir juli r 938, de jaarlijkse herdenkingsdag van De Gulden Sporenslag.

Evenals zes jaar daarvoor in het Boekenweekgeschenk verhaalt Coolen over zijn eerste kennismaking met deze schrijver bij zijn 'zoveel oudere vriend' Ouwerling. Hij vindt $D e$ Leeuw van Vlaanderen niet Consciences beste boek. Door dit boek leerden de Vlamingen echter lezen én het gaf "den stoot tot wat in latere meesters de roem van het Vlaamsche proza is geworden, het gewestelijke aardkrachtige, hemelruime en windfrissche boeren verhaal, dat van het zuiden uit geheel de regionale letterkunde van het noorden beinvloed heeft, maar daar stellig niet is overtroffen." Hij noemt Conscience "bovendien een der indrukwekkende zinnebeelden der ziels-en taaleenheid van de Brabanters bezuiden en die ten noorden van de Nederlandsch-Belgische staatsgrens."

Coolen denkt dat de eenheid van de Zuidelijke Nederlanden dieper geworteld en stand. vastiger is dan de huidige staatkundige eenheid: het is "de gemeenschap der kinderen eener volkseenheid."

Het is opmerkelijk dat deze toch politiek getinte uitspraken geen bijval of kritiek krijgen. Zowel Verdinaso als Zwart Front voeren in die tijd actie voor de Groot-Nederlandse gedachte. Coolen bedoelt met deze eenheid toch vooral de Kempen en heeft er zelf geen politieke bedoelingen mee, maar een uitspraak als "het heilige gelijk der zaak [voor] een vrij en groot Vlaanderen," kan toch gemakkelijk misbruikt worden. Het speelt de hedendaagse lezer van dit soort frasen parten dat die weet wat er daarna allemaal gebeurd is. In zekere zin waren deze uitspraken in die tijd even obligaat als die over het verenigd Europa in onze tijd.

In een 'Hagel' schrijft Coolen over de verzuiling in Nederland. Hij constateert dat er bijna geen enkel neutraal of nationaal feest gevierd kan worden of een van de zuilen in Nederland voelt zich gekwetst. Zo is de kerkenraad van de Nederlands Hervormde kerk in Haarlem "pijnlijk getroffen" als bij een openbaar, door het stadsbestuur aangeboden, concert het katholieke lied 'La Procession' wordt gezongen. Coolen schrijft dat bijvoorbeeld bij de film over het regeringsjubileum van Wilhelmina een vals beeld ontstaat. Er mag geen katholiek, protestant, geen socialistisch of wat voor tintje dan ook aanzitten dat voor bepaalde groepen 
kwetsend kan zijn. Hij stelt voor om deze "smalle groep" te negeren en pleit voor tolerantie, waarbij het mogelijk is dat verschillende uitingen van religie of maatschappijbeschouwing naast elkaar blijven bestaan. Processies en de Stille Omgang in Amsterdam moeten even goed kunnen plaatsvinden als een $\mathrm{I}$ mei optocht en om de koningin te eren moet zowel het protestante 'Valerius' Gedenckklank' als het katholieke Te deum' gezongen kunnen worden. ${ }^{15}$

Coolen hoort bij de stroming in die tijd die af wil van de hokjesgeest en de verstikkende sfeer die de verzuiling veroorzaakt heeft. Deze stroming zal zowel tijdens als na de oorlog blijven bestaan en in Coolen een sympatisant blijven vinden.

De voornaamste stem van De Gemeenschap op politiek en levensbeschouwelijk terrein blijft toch die van Van Duinkerken. Deze is door zijn eredoctoraat in Leuven en zijn talloze functies en publicaties het gezicht en de stem van katholiek Nederland. Dat roept reacties op. Zo verschijnt in het Nijmeegs studentenblad Vox Carolina een pamflet waarin een spotprent de toestand bij De Gemeenschap hekelt.

Van Duinkerken staat prekend in een bierpul, die gedragen wordt door "vier sombere huurlingen, paladijnen van het geledigde spreekvat over de lage landen." De schrijvers vinden dat het blad "onder een voortdurend aftakelende redactie" is afgegleden "tot een partijgeschrift voor enkele verouderde jongeren en hunne obscure relaties." De vier sombere huurlingen op de prent zijn Van Oosten, De Bourbon (met kroontje), Engelman (Lekkerman) en Coolen. Deze clan zoekt geen ruzie, maar "koppelt alle knipsels van vrienden en vereerden aaneen tot betoogen voor de spaansche democratie en tegen Hitler, mag daarna weer gerust mee aanzitten aan de koffietafel van roode en Joodsche vriendjes." Van Duinkerken wordt omschreven als een "welgedane conferencier" met "verhit-gorgelende" volzinnen, die even royaal bierglazen leegt als cultuurproblemen aansnijdt. Hij zegt, na een slok genomen te hebben: "neem uw schrijfblok en schrijf: gij zult geen ruzie zoeken."16

Coolen, die inderdaad nooit ruzie zoekt, wordt in het artikel verder niet genoemd. Het is echter wel opvallend dat men hem hier, weliswaar in karikatuur en in commissie, 'links' situeert.

\section{'De Oost-Brabanters'}

In 1938 verschijnt De Nederlandsche Volkskarakters onder redactie van P.J. Meertens en Anne de Vries. ${ }^{\text {" }}$ Het is een bundel waarin verschillende schrijvers een karakteristiek geven van de bewoners van de provincies, streken en steden in Nederland en Vlaanderen. Bij de artikelen zijn foto's van mensen uit de desbetreffende stad of streek geplaatst, waarbij uitgebreid

12. Van Duinkerken, 'Het zoet Navarre', in: Verzamelde geschriften, deel II, 773.

13 Het verhaal is in de jubileumuitgave van Dorp aan de rivier in 1997 als bijlage opgenomen.

14 Coolen, 'Hendrik Conscience, de verteller en zijn volk.

15 Coolen, 'Het pijnlijk treffen'.

16 Van Boven en Mertens, 'Ecclesia Militans'.

17 PJ. Meertens (1899-1985) was directeur van het Bureau der Dialecten- en Volkenkunde-commissie der Koninklijke Akademie van Wetenschappen te Amsterdam. Dit instituut is na 1994 zeer bekend geworden door de romancyclus Het Bureau van Voskuil. De Drent Anne de Vries (1904-1964) schreef in die tijd Bartje (1935) en Hilde (1938). 
wordt ingegaan op hun fysionomie en andere lichaamskenmerken. Zo'n benadering wekt bij de hedendaagse lezer een griezelige bijgedachte aan racisme. Recente studies wijzigen dit beeld in zoverre dat zij aantonen dat de beginselen van de wetenschap over de relaties tussen ras, streek, karakter en cultuur in die tijd onomstreden waren, maar dat de persoonlijke keuzes en de politieke vorm bepaalden of men er fout mee omging. ${ }^{18}$

Coolen levert een bijdrage aan dit boek onder de titel 'De Oost-Brabanters'. Hij begint maar meteen met te zeggen dat het beeld van het vrolijke Brabantse boertje met een pijpje en een petje niet klopt. Immers, niet alle Brabanders zijn boeren en dat vrolijke valt ook wel mee. De Brabander heeft wel humor, maar die heeft hij ontwikkeld om te overleven in de barre tijden van onderdrukking en oorlog. Coolen wijst op de grote saamhorigheid van de mensen en de wederzijdse hulp bij oogst, verhuizing en overlijden. De schutterijen en gilden ziet hij niet zozeer als instellingen van weerbaarheid, maar meer van een zekere volkszwier en volkskleur. De verhouding van die gilden tot de kerk vergelijkt hij met die van een kind dat de moeder niet kan missen. Hoewel de Brabander weinig praat over zijn godsdienst en God vaak aanduidt als "den dieje hierbove," stelt Coolen toch dat het katholicisme het wezenskenmerk van de Brabantse ziel is. ${ }^{19} \mathrm{Hij}$ prijst de schoonheid van het Saksische boerenhuis, maar gaat ook positief in op de vernieuwingen die in Eindhoven en Tilburg plaatsvinden in de nijverheid. Dé stad van Oost-Brabant is toch 's-Hertogenbosch met zijn St. Janskathedraal en Mariadevotie. Het Oost-Brabantse volk is naar het zuiden toe, in de Peel, wat somberder dan in de rest van de streek. Toch vormt het een eenheid, want voor iedere 'Oost-Brabanter' geldt: "Sterk in een traditioneelen levensgeest, beproefd, bevochten maar taai gehandhaafd, aanvaardt hij het leven, eenvoudig en vreugdevol, met den houvast van zijn simpel en vanzelfsprekend geloof." ${ }^{20}$

Omdat de bewoner van Oost-Brabant dicht bij de natuur leeft, heeft hij een zekere traagheid, maar ook een natuurlijke wijsheid. Hij moet niets hebben van gewichtigdoene. rij. Als iemand maar gewoon doet, is de 'Brabanter' meteen hartelijk en daarom voelt de vreemdeling zich doorgaans meteen thuis.

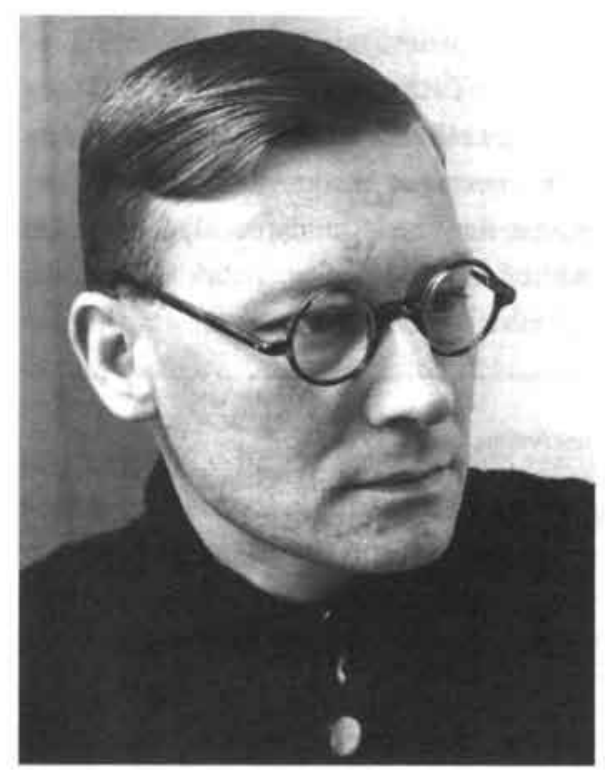

Coolen profileert zich met dit artikel als deskundige inzake Brabant en zal die status zijn verdere leven ook houden. Het is opval. lend dat hij in zijn stuk niet verwijst naar Knuvelders boek Vanuit Wingewesten, terwijl toch veel van de strekking van dit werk is overgenomen. Coolen gebruikt liever Het arme Brabant van Goossens of de werken van Ouwerling als bron. Waarschijnlijk speelt de animositeit tussen Knuvelder en Van Duinkerken en De Gemeenschap hierbij een rol. Knuvelder is hoofdredacteur van Roeping, dat toch een beetje een concurrerend blad is. Aan zijn vrienden bewijst Coolen echter graag een dienst. Hij maakt reclame voor Wiegersma's boek over de 
breischei ${ }^{21}$ in de volkskunst door eruit te citeren. Coolen stuurt zijn vriend de schilder-dokter een overdruk van zijn bijdrage. In het begeleidende briefje spreekt hij de wens uit dat het citaat bijdraagt "aan de belangrijkheid van je verzameling."

Gedurende het jaar 1937 heeft hij in zijn 'Brieven van De Romeijn' in de Bossche krant regelmatig vingeroefeningen gepubliceerd over het eigene van Brabant. Ter gelegenheid van de Boekenweek in mei 1937 schreef hij 'Kent gij Brabant?? ${ }^{23}$ waarin hij de geschiedenis van dit gewest in een notendop weergaf. Alhoewel hij nu in zijn bijdrage aan de bundel schrijft dat niet alle Brabanders boeren zijn, gaat zijn aandacht toch meestal uit naar deze bevolkingsgroep. Hij toont zich bezorgd over de verknoeiing van het Brabantse landschap door de club die dat juist moet voorkomen: de Vereniging Het Brabants Landschap. Deze houdt zich te veel bezig met weggegooide limonadeflesjes en is bezig Brabant in een park te veranderen. Coolen ziet veel liever een soort boerenreservaten, want boeren leven veel meer in harmonie met de natuur. Volgens Coolen verandert het landschap door hun "schoonen arbeid" gedurende de groei, de bloei en de oogst. Met deze opvatting van de boer als landschapsbewaker is Coolen zijn tijd ver vooruit. Pas zestig jaar later wordt die functie hier en daar in Nederland gerealiseerd. ${ }^{24}$

Ook ná het verschijnen van De Nederlandsche volkskarakters blijft Coolen op dit onderwerp hameren. Een jaar later, eind 1939, ontketent hij nog een relletje als hij in de Bossche krant smalend schrijft over "twee villabewoners van mijn dorp" die een natuurwacht willen oprichten. Ze willen mensen aanspreken op het laten slingeren van schillen, een stuk papier of een fles. Coolen vindt dit belachelijk en ziet op die manier de Kempen veranderen in een park als het Gooi. Het spel van de zon op een stuk glas en het tikken van de regen op een weggegooide krant kan ook mooi zijn, vindt hij. De villabouw met daaraan gekoppeld de verharding van wegen is volgens hem de échte boosdoener. Het levert hem boze brieven op van zijn medevillabewoners. ${ }^{25}$

Coolen vindt dat men veel te ver gaat in het onttrekken van grond aan de landbouw ten behoeve van de natuur. De schoonheid ontstaat juist uit het natuurlijk evenwicht tussen natuur en landbouw. Uit deze harmonie tussen natuur en leven komen volgens Coolen "de

18 De volkskundige Jan de Vries werd lid van de Kultuurkamer en voorzitter van het Letterengilde; de volkskundige P.J. Meertens trad na de oorlog voor hem op als getuige à décharge voor het Tribunaal voor Bijzondere rechtspleging. Ook Meertens balanceerde op de rand van collaboratie door als Lector op te treden voor de Kultuurkamer. Barbara Henkes, 'Voor Volk en Vaderland', 86.

19 Coolen, 'De Oost-Brabanters', 288.

20 Coolen, 'De Oost-Brabanters', 292.

21 Een breischei is een houten kokertje dat herders aan hun riem droegen. Het diende om een van de breinaalden in vast te zetten om zo, al lopend achter hun kudde, te kunnen breien. Breien was in die tijd een geliefd tijdverdrijf van herders en tevens een bijverdienste.

22 Archief Hendrik Wiegersma, brief Coolen aan Wiegersma, 18 maart 1938.

23 Coolen, 'Brieven van De Romeijn', 8 mei 1937.

24 Coolen, 'Brieven van De Romeijn', 17 juli 1937.

25 Coolen, 'Brieven van De Kempen', 2 december 1939. Een van de villabewoners is de journalist Zoetmulder die in een ingezonden stuk in de krant Coolen verwijt zijn talent te misbruiken en de wachters plannen in de schoenen te schuiven die ze helemaal niet hebben. Coolen is bang voor asfaltering van de onverharde Blokvenlaan, waaraan hij woont, omdat hij daar nu geen straatbelasting hoeft te betalen. Collectie Tij Kools, brief van S.H.A.M. Zoetmulder aan Carel Swinkels, 5 december 1986. 
gezondste volkskrachten" naar voren. Meer natuur werkt alleen maar het toerisme in de hand en dat is alleen gericht op "verteren". Door het onfatsoen van de "verwilderde toerist" kun je met je kinderen niet eens meer door de bossen gaan wandelen, voegt hij er, kennelijk doelend op vrijpartijen, verontwaardigd aan toe. ${ }^{26}$

Naar aanleiding van een honderdjarige in Boekel, schrijft hij over het verschil tussen zwervers en gewortelden. Deze honderdjarige heeft altijd in hetzelfde dorp gewoond en is even oud als de kerk. Dit soort mensen vormt de levenskracht van de dorpen: "Het is de boersche kracht, die zich wortelt aan den grond welken zij bearbeidt voor het brood der wereld." ${ }^{n 2}$ Iedereen moet echter wel zijn eigen rol blijven spelen, blijkt uit een stukje bij gelegenheid van een congres van jonge boerinnen. Vanuit een mannelijk superioriteitsgevoel schrijft Coolen op een kleinerende toon over de jonge boerin, die een toespraak heeft gehouden over de toestand in Europa. Coolen ziet dat toch liever anders: "Ons landsche meiske wiedt. Het harkt. Het hooit."28 Zo'n meisje zou zo'n toespraak helemaal niet kunnen houden.

Dat sluit wel weer aan bij het standpunt dat Coolen in 'De Oost-Brabanters' inneemt over de positie van de vrouw in de Meierij. Hij is het niet eens met de deskundigen die menen dat er op het platteland een matriarchaat heerst. De vrouw is alleen baas over datgene wat haar rechtstreeks aangaat. "Daarbuiten heeft zij weinig zeggenschap, en zij spreekt van haar man als van 'onzen baas'." Bij belangrijke beslissingen schuift de vrouw de verantwoordelijkheid naar hem en tegen anderen zegt ze: "Daar moete ge voor bij den baas zijn." Coolen concludeert: "Gezond is de Meierijsche, en daarom heeft zij dit gezonde gevoel voor de echtelijke verhoudingen."

\section{Brabantia Nostra}

Brabant timmert in die tijd flink aan de weg. In 1938 neemt een uitgeverij het initiatief om een standaardwerk over Brabant te maken, "waarbij we ons lieten leiden door de gedachte dat de voorname beteekenis van Noord-Brabant in het Nederlandsche leven bij velen nog onvoldoende bekend is." Het werk verschijnt in 1939 onder de titel Zóó is Noord-Brabant, bijdragen tot de kennis van deze provincie. Haar economische beteekenis, haar uiterlijk, haar geschiedenis. Vincent Cleerdin, de griffier der Staten, heeft de gemeenten aangewezen die een bijzondere vermelding verdienen en een aantal onderwerpen aangedragen die behan deling vereisen. Coolen schrijft in dit boek een hoofdstuk met de titel 'Het gelaat der Noord-Brabantse steden/ Figuren van steden en dorpen'. Hij laat daarin zien dat er in Brabant, dat zich een eenheid voelt, toch zoveel verschil in sfeer is, een onderwerp dat hij nog vaak in kranten, brochures en tijdschriften ter sprake zal brengen. Verder bevat het boek bijdragen van Commissaris der Koningin Van Rijckevorsel, Van Duinkerken. Huib Luns, Gerard Knuvelder en dr. P.C. de Brouwer. De formule van dit standaardwerk, waarin de gemeenten en bedrijven grote advertenties hebben geplaatst, wordt ook in andere provincies toegepast. Het is een van de eerste combinaties van public-private partnership.

Vanuit het blad Brabantia Nostra wordt kritiek op dit boek geleverd: het is teveel gericht op de industrie, het onderwijs en dergelijke en schenkt te weinig aandacht aan de diepste gemoedsbewegingen van de Brabander. Hoofdredacteur Ruygers acht beschrijvingen van "het wezenlijk Brabantse" niet langer in goede handen bij "Brabanders-in-ballingschap" als Van Duinkerken en Coolen. ${ }^{29}$ Dit moet Coolen hebben gestoken, want hij heeft het "gewes 
telijk tijdschrift" vanaf het begin lof toegezwaaid, zij het altijd vanaf enige afstand. Bovendien heeft hij zichzelf nooit als een Brabander-in-ballingschap gezien.

Tien jaar na de gedenkwaardige handdruk met de exclamatie 'Brabant' van Coolen en Van Duinkerken komt in Tilburg een initiatief van de grond om het zelfbewustzijn van Brabant te vergroten. Het wordt gedragen door een generatie die zo'n tien jaar jonger is dan Coolen. De initiatiefnemers zijn jonge katholieke intellectuelen, die studeren of net afgestudeerd zijn aan de Katholieke Leergangen in Tilburg, de jonge universiteit van Nijmegen en de nog maar enkele jaren bestaande Katholieke Hogeschool, de voorloper van de huidige Katholieke Universiteit Brabant in Tilburg. De vereniging St. Leonardus van de Leergangen en het Brabants Studentengilde van Onze Lieve Vrouw zijn de ontmoetingsplaatsen voor deze eerste generatie van katholieke academici en leraren, die is opgeleid aan eigen katholieke instellingen. Van het Studentengilde kan elke Brabantse student, ongeacht de universiteit waar hij studeert, lid worden. Het gilde organiseert landdagen in Brabantse dorpen, waar tijdens studieuze zomerkampen tevens een kapel wordt gebouwd, die uiteraard aan Maria gewijd wordt. Als geestelijke leidsman van deze groepering fungeren twee priesters: dr. P.C. de Brouwer uit Hilvarenbeek en pater Siemer uit Tilburg.

Bij de tiende landdag van het Studentengilde in Oirschot in augustus 1935 wordt het besluit genomen een eigen tijdschrift op te richten. Dit is het blad waar we in het voorafgaande al dikwijls naar hebben verwezen. Na enige twijfel wordt gekozen voor de titel Brabantia Nostra. De angst van sommige leden dat die leuze te kneuterig en conservatief zou zijn, wordt bezworen door de uitleg dat de vertaling niet moet luiden "Ons eigen Brabant", maar veeleer "Brabant aan ons! ${ }^{130}$ In oktober 1935 verschijnt het eerste nummer. In de beginselverklaring staat dat Brabant "zienderogen" weer de kern der Nederlanden aan het worden is en dat daarom alle krachten nodig zijn om de verantwoordelijkheid voor het Rijk Gods en voor de volksgemeenschap te kunnen dragen. Het blad gaat in de eerste jaargangen veel aandacht besteden aan de verhouding tussen stad en platteland, de positie van de boeren, de traditie, de positie van het gezin, enzovoort. Er zit in de toon een afwerend en defensief element, dat Van Oudheusden betitelt als hèt kenmerk van Brabantia Nostra. Dat afwerende komt vooral tot uiting in de angst voor de nieuwe verkeersverbindingen over de grote rivieren. Men is bang voor de negatieve invloeden die deze op de Brabanders zullen hebben.." De Mariakapellen die bij de nieuwe bruggen, bij de Moerdijk en Grave, gebouwd worden, zijn dan ook niet alleen een teken voor de niet-katholieke reiziger dat hij katholiek gebied binnenrijdt, maar dienen ook ter bezwering van mogelijke kwade invloeden van buiten.

Op het politieke vlak valt op dat Brabantia Nostra pleit voor een eigen 'volksbestaan' binnen de nationale Nederlandse gemeenschap en niet voor een afsplitsing of scheiding

26 Coolen, 'Brieven van De Kempen', 23 april 1938.

27 Coolen, 'Brieven van De Romeijn', 10 april 1937.

28 Coolen, 'Brieven van De Romeijn', 5 juni 1937.

29 Van Oudheusden, Brabantia Nostra, 226 (citaat uit oktober nr. 1939, 1-5).

30 Van Oudheusden, Brabantia Nostra, 78. De schets van Brabantia Nostra in deze paragraf is voor een groot gedeelte gebaseerd op dit boek.

31 Van Oudheusden, Brabantia Nostra, 103. 
van Nederland. Afsplitsing is ook niet nodig, want de verzuiling maakt het mogelijk om strikt gescheiden van elkaar toch een eenheid te vormen. De voormannen van de verschil. lende zuilen weten dat ze elkaar in Den Haag nodig hebben om coalities te vormen; men is min of meer tot elkaar veroordeeld. Brabant telt in Den Haag echter pas anderhalve eeuw mee. De provincie is lang Generaliteitsland geweest en wordt pas in 1796 als gelijkberechtigde vertegenwoordigd in de Staten-Generaal. Nog later, in 1853 eerst, wordt de bisschoppelijke hiërarchie hersteld. De Brabanders zijn dus nog niet zolang volwaardige Nederlanders in staatkundig en religieus opzicht. Het historisch besef dat door historici en schrijvers in de negentiende eeuw wordt ontwikkeld, is toch nog sterk op Holland gericht. Er wordt een mythe van het Nederlandse nationaal gevoel gecreëerd met behulp van De Gouden Eeuw, Rembrandt, Vondel en het Oranjehuis.

$\mathrm{Nu}$ de emancipatie van de katholieken, en dus van de meeste Brabanders, min of meer voltooid is krijgt men ook in Brabant meer aandacht voor het nationale bestel en de geschiedenis. Een goed voorbeeld is de manier waarop de katholieken de dichter Vondel trachten te 'claimen'; deze dichter van de Tachtigjarige Oorlog en Amsterdam kwam tenslotte uit het zuiden en bekeerde zich tot het katholicisme. Coolens beste vriend Oomes schrijft in die tijd in een biografische schets van Vondel,,$^{32}$ dat deze in 1639 tot de katholieke kerk toetrad, "omdat de leer dier kerk zijn zoekende geest geheel bevredigde." Oomes benadrukt dat bij de feestelijkheden ter gelegenheid van de Vrede van Munster in 1648 een spel werd opgevoerd waarin de verzoening van Noord-en Zuid-Nederland feestelijk werd gevierd: "Het vrolijk spel heette Leeuwendaelers en was van den veel bestreden en strijdbaren katholieken dichter Vondel."

Sinds de herdenking van de vierhonderdste geboortedag van Willem van Oranje in I933 is er ook onder de katholieken veel belangstelling voor het koningshuis. In zijn columns besteedt Coolen veel aandacht aan de bindende kracht van de monarchie.

\section{Coolen en Brabantia Nostra}

Met vreugde heeft Coolen in 1935 Brabantia Nostra in de Bossche krant begroet. ${ }^{33} \mathrm{Hij}$ vergelijkt de titel met de naam die de Romeinen aan de Middellandse Zee gaven: Mare Nostrum. Hij constateert dat de jonge studenten vervuld zijn van de Brabantse gedachte. Het heeft zijn volle instemming dat de jeugd zich niet wentelt in martelaarschap, maar vooruit kijkt. Op deze manier wordt Brabant weer de kern der Nederlanden. Er moet wel voor gewaakt worden dat de industrie het wezen van de provincie niet aantast en dat de landbouw uit zijn crisis komt. Hij blijft het "wakkere" tijdschrift aansporen in de strijd tegen de verloedering van Brabant en tegen de voorschriften van de Vereniging voor Natuurmonumenten. Hij is het echter niet eens met schrijver Jef de Brouwer dat de boeren vroeger vrij waren. Immers, de schamele grond bepaalde wat er wel en niet kon. Coolen vindt dat het "wezenseigene" een plaats moet krijgen binnen nieuwe vormen. Daarna zal het nieuwe Brabant weer even schoon bloeien als het oude. ${ }^{34}$

Bij de opening van de brug over het Hollands Diep bij Moerdijk prijst hij het initiatief van Brabantia Nostra om daar een Mariakapel op te richten, want om de eigenheid van Brabant te behouden is meer nodig dan de traditie van de koffietafel. Ook het volksleven moet behouden worden, voegt hij er aan toe. ${ }^{35}$ Echter, als het plan op tafel ligt, stelt het hem teleur. Tot die tijd waren de kapellen van het Brabants Studentengilde klein en een- 
voudig, schrijft Coolen, maar de tien meter hoge klokkentoren die nu gepland is, heeft niets te maken heeft met eenvoudige volksdevotie. Zo'n toren doet hem eerder denken aan de marathontorens en reclameborden bij sportmanifestaties. ${ }^{36}$

Hoewel Coolen over alle onderwerpen schrijft die Brabantia Nostra ook ter harte gaan, bewaart hij toch afstand tot de organisatie. Hij schrijft graag over zijn streek, maar wil niet beschuldigd worden van chauvinisme. Hij wil de kloof tussen Noord en Zuid niet te veel aanscherpen en zeker niet koketteren met het Brabantse minderwaardigheidscomplex. Coolen vraagt zich af of de Brabander wel zo eenvoudig is. Je mag de trek van een volkskarakter niet zo maar toepassen op een individu, vindt hij. ${ }^{37}$

Van zijn kant beperkt Brabantia Nostra zich tot het roemen van het literaire werk van zowel Coolen als Van Duinkerken, maar zoekt geen toenadering of onderneemt geen pogingen om hen bij de beweging te betrekken. Dat komt ook doordat de beweging bestaat uit studenten en pas afgestudeerden. Ze hebben een clubgeest ontwikkeld met alle parafernalia die bij de toenmalige studentenwereld horen: baretten met jaarspeldjes, academische gebruiken en een familiegevoel rond de Alma Mater met volledig support van geestelijke leiders en een nauw persoonlijk contact met de professoren. Die wereld is heel anders dan die van de ex-seminaristen Van Duinkerken en Coolen, die meteen aan het werk gingen als publicist en verslaggever. De generatie van Coolen, rond de eeuwwisseling geboren, is die van de pioniers in de vroege jaren twintig. De oprichters van Brabantia Nostra studeren in de volle bloei van het 'Rijke Roomsche Leven'.

Ondanks deze verschillen wordt Coolen toch aangetrokken tot deze beweging. De reden hiervoor ligt niet alleen in de liefde voor het gewest Brabant. Afgezien van het gewestelijk chauvinisme past Brabantia Nostra in een nieuwe stroming van 'Vernieuwers'. ${ }^{3 \mathrm{~d}}$ Deze stroming streeft naar nationale eenheid, wil af van de hokjesgeest en verzuiling in Nederland, maar heeft ook kritiek op de werking van de democratie. Gezocht wordt naar een sterker overheidsgezag en daarbij naar nieuwe vormen van ordening in de maatschappij. Men ziet de uitwassen van het kapitalisme, maar wil niet denken in klassentegenstellingen. Men zoekt de oplossing eerder in solidariteit, waarbij het corporatisme, zoals dat in Italië op dat moment voorkomt, als een mogelijkheid wordt gezien. De stroming van 'Vernieuwers' krijgt een organisatorisch kader in de Nederlandse Beweging voor Eenheid door Democratie die medio 1935 wordt opgericht, een paar jaar later gevolgd door De Nederlandse Gemeenschap. Deze beweging wil, in tegenstelling tot het een jaar later opgerichte Comité van Waakzaamheid, stelling nemen tegen alle dictaturen en dus ook tegen het communisme. Een dictatuur is in strijd met de Nederlandse traditie, vindt

32 Oomes, Joost van den Vondel, 43.

33 Coolen, 'Brieven van De Romeijn', 9 november 1935.

34 Coolen, 'Brieven van De Romeijn', 14 december 1935.

35 Coolen, 'Brieven van De Romeijn', 12 december 1936.

36 Coolen, 'Brieven van De Romeijn', I mei 1937. Zie ook: Van Oudheusden, Brabantia Nostra, 186.

37 Coolen, 'Brieven van De Romeijn', 6 juni 1936.

38 Deze term wordt gebruikt door Ten Have in De Nederlandse Unie. In de volgende passage is gebruik gemaakt van zijn hoofdstuk over de Vernieuwing in de jaren dertig. 
Eenheid door Democratie; die traditie moet niets hebben van fanatisme en verwerpt een verabsolutering van de staat als onchristelijk heidendom. In het blad Het Gemeenebest worden de vijf scheidslijnen gehekeld die Nederland verdelen: die tussen arbeiders en burgerij, tussen geloof en ongeloof, tussen noord en zuid, tussen stad en platteland en tussen werkenden en werklozen. Met waardering wordt een rede van Koningin Wilhelmina aangehaald over geestelijke en morele herbewapening. ${ }^{39}$

De grenzen tussen deze 'Vernieuwers' en de rechts-autoritaire en antidemocratische bewegingen zijn poreus. Er zitten voorstanders van een sterk autoritair gezag in én bewonderaars van de corporatistische ordening in Italië.

Brabantia Nostra geeft aan deze stroming een Brabants katholieke kleur. In zijn voorwoord bij de vierde jaargang van Brabantia Nostra geeft Geert Ruygers een plaatsbepaling. Hoewel de problemen in Brabant niet verschillen van die in Nederland, is zijn ideaal het aanbrengen van een katholieke ordening. In de Middeleeuwen bestond deze ordening: de katholieken kenden geen verscheurdheid tussen de gebondenheid aan de aarde en het heimwee naar de eeuwigheid; er was harmonie. Sindsdien is de wanorde hand over hand toegenomen, schrijft Ruygers. Door individualisme en atomisering wordt iedere 'ordegedachte' overstemd door de roep om vrijheid. Zo worden in naam van het heilige, onaantastbare recht van het individu beginselen doorgevoerd die de maatschappij ontwrichten, zoals de scheiding tussen kerk en staat, de godsdienst uit het openbare leven, de kunst buiten de gemeenschap, de vrouw uit het gezin, de ontwikkeling van het kapitaal. De toekomst hangt af van de katholieken: "Of de huidige Europese cultuur - die in diepste wezen nog steeds door het Christendom wordt bepaald - zal gered worden, hangt goeddeels af van de vraag of de katholieke wereld erin slagen zal haar 'orde-gedachte' te doen zegevieren. ${ }^{40}$

In deze laatste zin schuilt de reden waarom Coolen zich niet in de voorste rijen van Brabantia Nostra schaart. De nadruk op het katholieke aspect, die bovendien impliceert dat er bestendige scheidslijnen bestaan tussen geloof en ongeloof, zint hem niet. In 'De OostBrabanters' heeft hij wel geschreven dat het katholicisme "het wezenskenmerk van de Brabantse ziel" is, maar hij heeft dat eerder als een constatering van een etnoloog gedaan. Het slaat niet op hemzelf. Coolen moet niets hebben van de katholieke 'orde-gedachte; deze herinnert hem te veel aan zijn weerzin tegen al die mensen die hem willen vastpinnen op het geloof. Hij houdt nu eenmaal niet van mensen die er een al te sluitend wereldbeeld op na houden. Coolen is het verder op alle punten eens met de stroming van de 'Vernieuwers' van Eenheid door Democratie en geeft daar vooral in zijn journalistieke stukken blijk van. Ook hij schrijft, zoals we gezien hebben, over de kracht van het platteland, verheerlijkt de boerenstand en citeert regelmatig met instemming de pleitbezorger van de boeren, de sociaal geograaf Van Vuuren. ${ }^{41} \mathrm{Hij}$ is het ook eens met de stelling dat in Nederland geen dictaturen kunnen gedijen.

Ook Coolen wil niet eenzijdig kiezen voor de bestrijding van rechtse dictaturen en haalt met instemming koningin Wilhelmina's oproep aan tot "een zedelijke en geestelijke herbewapening." De grondslag voor deze houding ligt in zijn pacifisme. Als in september r938 Chamberlain in München onderhandelt over Hitlers 'laatste' geografische eis, het Sudetenland in Tsjechslowakije, constateert hij sarcastisch dat men nu in de straten van Parijs bidt voor de vrede, waar men nog maar een paar jaar geleden demonstreerde voor bommen en kanonnen tegen de opstandelingen van Franco in de Spaanse Burgeroorlog. 
"Het monster dat al bloed verslindt in Spanje en China komt dichtbij," schrijft hij. Daarom is het goed werk wat Chamberlain doet, want oorlog lost niets op. De vredesactie van Chamberlain bewijst volgens hem dat de pacifisten altijd al gelijk gehad hebben. ${ }^{42}$ "De moeders van de wereld zijn blij," noteert hij als Chamberlain opgelucht gezwaaid heeft met het akkoord dat volgens hem 'peace in our time' betekent. ${ }^{43}$ Echter, als Hitler begin oktober het Sudetenland binnenmarcheert, beseft Coolen al dat slechts het ogenblikkelijke oorlogsgevaar was afgewend en met afgrijzen ziet hij dat dezelfde politiek van militaire herbewapening, die Europa tot de afgrond heeft gebracht, nu weer met volle kracht wordt doorgezet. Dit kan volgens Coolen alleen maar betekenen dat de vrede slechts uitstel van executie is. Dat brengt hem bij de hiervoor genoemde adhesiebetuiging aan Wilhelmina's toespraak, dat alleen zedelijke en geestelijke herbewapening tot vrede leidt: "een vrede zonder wapenen en bajonetten." ${ }^{n 4}$

\section{Herberg In 't Misverstand}

Nog voor zijn vertrek uit Deurne is Coolen aan een nieuwe roman begonnen, maar het werk wordt pas voltooid in Waalre. Als herberg In 't Misverstand in november 1938 verschijnt, heeft Coolen een moeilijk, maar goed werkstuk afgeleverd.

De roman geeft, aan de hand van een aantal stamgasten en een kastelein, een beeld van het leven in een Brabants dorp, maar ook van de vele misverstanden die er tussen de stamgasten onderling en tussen hen en hun partners kunnen bestaan. Het symbool van de Herberg wordt niet voor niets gevormd door twee dragers die met de ruggen naar elkaar cen biervat dragen; ieder wil een eigen kant uit.

De stamgasten houden hun tafel van de herberg vijf avonden van de week bezet. Ze hebben het rijk alleen, omdat andere gasten zich daarbij niet op hun gemak voelen. Na het sluitingsuur wordt vaak nog tot diep in de nacht doorgezakt in de kelder, waar wedstrijden in eieren kapot knijpen en bierton optillen worden gehouden. Soms wordt er zelfs met een revolver geschoten op een met krijt getekende roos op een biervat. Het gezelschap bestaat uit een deftige notaris die graag zijn belezenheid laat blijken, een gemeentesecretaris die nog eens burgemeester hoopt te worden - hetgeen aan het eind van de roman ook lukt - en een postbode die als hij ruzie heeft met zijn vrouw rare kledingstukken - een badmuts of een sjaaltje - draagt, die gelden als "seinborden voor zijn gemoedstoestand." Verder zijn er nog een aannemer, een voerman, een ex-brouwer, een notarisklerk, een steenfabrikant en een schildersbaas/drogist. Af en toe komt mijnheer Gérard, fabrikantenzoon uit de stad en mislukt student. Hij is een hoerenloper die op de meest onverwachte momenten het gezelschap verlaat om zich per auto te laten wegbrengen naar "de roepende transparanten en de lokkende ramen" in Luik of Antwerpen. Kastelein De Rooij is vrijgezel. Eenmaal in de kel-

39 Ten Have, De Nederiandse Unie, 67 - 69.

40 Ruygers, 'Bij den vierden jaargang'.

4) Van Vuuren pleitte, zoals in hoofdstuk 9 vermeld, voor een norm bij de ruilverkaveling van een kleine twintig hectare, zodat het bedrijf in gezinsverband georganiseerd kon worden.

42 Coolen, 'Brieven van De Kempen', 24 september 1938.

43 Coolen, 'Brieven van De Kempen', 1 oktober 1938.

44 Coolen, 'Brieven van De Kempen', 15 oktober 1938. 
der is hij gewoon lid van het gezelschap. Steeds als hij een glas neerzet, zegt hij: "Si voe."

Het gezelschap gaat elk jaar op reis naar de Eifel, maar komt dan niet verder dan het hotel en een paar bierherbergen in de buurt. Elke keer nemen de mannen zich voor om het volgend jaar de Laacher See te gaan bezoeken, omdat dat iets bijzonders moet zijn met die versteende lavapartijen, maar het komt er nooit van.

Losjes verbonden met de belevenissen van de stamgasten in de herberg lopen er enkele verhaallijnen in het dorp. Marjan en Lodewijk hebben een achterlijk dochtertje. Als Marjan na overspel met de broer van de postbode, in een zijkamertje van de herberg, een gezond zoontje baart, ziet onwetende Lodewijk het dochtertje niet meer staan en heeft hij alleen oog voor zijn onechte zoontje. Martien Deijsselbloem, die op een boerderij woont met zijn gierige broers en zus, krijgt verkering. Als hij trouwt krijgt zijn bruid Anna grote moeilijkheden met de schraperige schoonfamilie.

De eigenaardigheden van de stamgasten blijken vrij ernstig te zijn. De postbode die zijn vrouw zó haat dat hij zich ergert aan haar manier van eten, slapen en ademen, loopt voortdurend rond met zelfmoordplannen en toont in de kelder de middelen die hij hiervoor verzamelt: rattekruid, een touw, een dolkmes en een revolver. De voerman Thijs Rooijakkers kan zijn blikken niet af houden van heel jonge meisjes en vecht tevergeefs tegen zijn aandrang: "Tien keer kreeg hij 't weg met bidden en verstand, den elfden keer..." ${ }^{45}$ In de gevangenis heeft hij zich uit schuldgevoel eigenhandig ontmand. Zijn vrouw brengt het aangerande meisje op haar communiedag cadeautjes: een kanten zakdoekje en een kerkboekje getiteld Jezus, de Kindervriend [sic]. Thuisgekomen timmert ze ramen en deuren dicht. Ze wil niemand meer zien en zit in het donker.

Er zijn niet alleen misverstanden tussen de stamgasten, ook de lezer taxeert de dingen soms verkeerd, want het loopt met de meeste personages heel anders af dan men in het begin zou denken. Niet de postbode die er zo vaak mee gedreigd heeft, pleegt zelfmoord, maar de schijnbaar zo evenwichtige en zelfverzekerde notaris, die diep in de schulden blijkt te zitten. Toch krijgt ook de postbode zijn trekken thuis. Zijn oudste zoontje pleegt zelfmoord, omdat hij de eeuwige ruzie tussen zijn ouders niet meer kan verdragen. De klap komt hard aan. Op zijn kamertje vinden ze zijn kerkboek met het prentje van de H. Familie en op de bladzijde ernaast "beduimeld en doorgesleten, het gebed voor vader en moeder." Beide ouders beseffen hun schuld ten opzichte van hun kinderen, als ze als neergeslagen honden vol wroeging en schaamte aan elkaar bekennen: "Wij weten niet, wat we hun aandoen, dat weten we niet." ${ }^{46} \mathrm{Het}$ misverstand tussen Lodewijk en Marjan komt na veel schade tot een oplossing. Nadat het achterlijke kindje gestorven is, biecht Marjan op dat juist dit kind van hem is en het gezonde broertje niet. Lodewijk loopt weg. Als hij weer thuiskomt slaat hij haar eerst bont en blauw, maar accepteert dan de situatie en het kind met de woorden: "Die jongen is van jou, en gij die hem hebt, bent van mij." De verteller besluit hun verhaal met: "Niet altijd weten wij, wat we doen. Zij had dat niet geweten, voor jaren in dat triestige kamertje van de herberg In 't Misverstand. Hij had dat zeker ook niet geweten. toen hij terugkwam en uit radeloosheid haar maar een pak slaag gaf, dat zij verdiend had." ${ }^{\text {th }}$

Het boek eindigt met de geboorte van een kind bij het enige harmonische paar in het verhaal: Martien en Anna. Zij hebben uiteindelijk de boerderij van de familie publiekelijk verkocht in de herberg en zijn daarna op zichzelf gaan wonen. "Er zijn nog oases in de wereld," zo leidt de verteller tot tweemaal toe deze episode in. Martien wordt bij het 
mesten van het veld weggeroepen vanwege de geboorte van zijn tweede kind. Hij fietst door de vroege lente naar huis en rijdt al het jonge leven voorbij - een kalf, een veulen, biggen, bloesem aan de struiken, kuikens, bijen, jonge honden en een zwaluwennest - om zijn nieuwgeborene omhoog te kunnen heffen. Zijn vrouw Anna kijkt gelukkig. Daarna volgt de berustende en meedogende slotalinea:

"Niet omdat de mensen zo goed en zo mooi zouden zijn, moet ge van hen houden, maar omdat ge hun getuige zijt en hun deelgenoot. En het aardsche leven is niet volmaakt, maar het is het aardsche leven. Het bloesemt en draagt vrucht, men kan er niet nederig genoeg tegenover zijn, men kan niet nederig genoeg zijn in het gadeslaan van dat verbazingwekkende, aardsche leven. Het hangt niet uitsluitend van het noodlot af, het noodlot is er een deel van, als de stormen van het land. $\mathrm{Zij}$ schaden, maar zij vernietigen niet, altijd is er weer vrucht en oogst. Daarom heeft het zin te blijven staan, de handen te vouwen en vastberaden te zeggen: het zij zoo." ${ }^{48}$

\section{Een staalkaart van Coolens talent}

De personages in Herberg In 't Misverstand zijn zeer levensecht neergezet en ongetwijfeld hebben bestaande personen als voorbeeld gediend. De roman heeft een motto van Dirk Coster, dat veel zegt over Coolen's wijze van schrijven:

"Slechts voor een zeer klein deel wordt een werk gemaakt. Voor het grootste gedeelte makt een werk zichzelf, de pen heeft op papier slechts te volgen, en hij, die toevallig de schrijver heet, is van allen wel het meest benieuwd, welke mensch hem eigenlijk en tenslotte tegemoet zal treden."

Het boek is een van de rijkste romans van Coolen. Al zijn gaven zijn erin vertegenwoordigd: de beschrijvingen van de natuur, de armoede en het dorpse gekonkel, maar ook de manier waarop hij mededogen en deernis oproept. Er zit ook nog steeds iets in van de befaamde 'instinct-causaliteit', waardoor hij mensen die misstappen begaan met mededogen blijft bezien. Aan het slot van de roman wordt de onwetendheid van de mens over zijn eigen gedrag sterk benadrukt. De ruziënde ouders weten niet wat ze hun kinderen hebben aangedaan en ook Lodewijk en Marjan wisten niet altijd wat ze deden. Er zijn oases in de wereld waar het leven goed is, alhoewel niet iedereen daar evenveel plezier van heeft. Toch is men niet helemaal afhankelijk van het noodlot: de veerkracht van de mens overwint de schade ervan. Het is een boek over het menselijk tekort, waarbij de lezer voortdurend wordt verrast door de motieven en achtergronden van de personages. De hierboven geciteerde slotzin geeft de kern weer van Coolens visie op de mens. Hij gelooft niet in de pure held of het intellect van de mensen die het altijd zo goed weten. Pas door hun gebreken, dwalingen en tekortkomingen worden mensen "beminnenswaardig". Kijk maar naar beroemde werken als de Comédie Humaine van Balzac, het werk van Dickens, de Camera Obscura en De kleine Rudolf van Van der Leeuw, schrijft hij een jaar later. ${ }^{49}$

45 Coolen, Herberg In 't Misverstand, 184.

46 Coolen, Herberg In 't Misverstand, 361.

47 Coolen, Herberg In 't Misverstand, 364.

48 Coolen, Herberg In 't Misverstand, 375.

49 Coolen, 'Brieven van De Kempen', 16 december 1939. 
Herberg In ' $t$ Misverstand bevat veel beschrijvingen van verdwenen gebruiken en volksrituelen. Zo leren we dat de kermis nog een heel andere functie had dan vermaak alleen. Op de boerderijen buiten de dorpskern zaten de boer en boerin met hun gasten binnen aan de borrel, terwijl vóór het huis, aan de straatkant onder de linden, de dochters of zoons die verkering hadden openlijk zaten te vrijen op biezen stoelen: "de kermis was een vrijgeleide voor dit boerse minnespel." Deze gewoonte was tevens bedoeld als een openbare kennis. geving van een vaste relatie; als die verbroken zou worden zou de buurt komen 'toffelen'. In een van de recensies wordt opgemerkt dat de beschrijvingen, zoals van de dorpskermis, te uitgebreid en naturalistisch zijn en alleen interessant voor toekomstige lezers, die zo'n kermis niet (meer) kennen. Gelukkig heeft Coolen ze toch opgenomen. Door zijn scherpe waarnemingsvermogen weten wij, de lezers van nu, hoe zo'n dorpskermis er in de tijd van zijn jeugd uitzag, hoe een bruiloft was georganiseerd, wat de rituelen rond een officièle vrijerij waren en hoe de openbare verkoop van een boerderij in een café verliep. Coolens beschrijving van de kermis biedt een goed voorbeeld. Op de kermis staan bij de kop van Jut "twee Belgische madammen met geverfde lippen, oorbellen van twee en een half ons en gitten kammen." Het orgel wordt gedraaid door een persoon met tatoeëringen en bij de luchtschommels is er maar één de baas: "de zwartharige madam, die daar zit in een blouse van grasgroene kunstzij [...] En niemand keek onverschilliger dan de madam in de kassa, zii] geeuwde af en toe onbeschaamd naar de mensen en zij had een paar gouden tanden."

In de passages over de Deijsselbloemen heeft Coolen de boerenproblematiek verwerkt, waarover hij in die jaren zoveel in de krant schrijft. Hij schetst de problemen die zich voordoen bij de erfopvolging en de verdeling van de kindsdelen en het vaak trieste lot van een boerendochter, die introuwt bij haar schoonfamilie en daar als een vreemde wordt behandeld. Hij belicht ook de andere kant daarvan: die van de moeder die als weduwe op een gegeven moment te veel wordt in de boerderij en naar een 'liefdesgesticht' moet. Dit gegeven heeft Coolen al eens apart beschreven in 'Moeder Marjannes Kerstfeest'. Ook in dit boek kiest hij partij voor het in huis houden van de ouders. "Die oude heilige wet om de sukkelende oudjes bij zich te houden, die eerbiedigden zij, deze onbeschaafde lieden, en het schijnt dat ze zó onbeschaafd zijn, dat hun dat niet zwaar of hard valt." Het is Coolen goed gelukt om de tegenstellingen in het boerenleven te beschrijven. Overtuigend zet hij de achterdochtige, gierige en ongetrouwde broers en zussen tegenover het jonge paar dat in harmonie met de natuur en het boerenwerk leeft. De schraperigheid, achterdocht en misantropie staan tegenover de liefde, de schoonheid en het levensoptimisme.

Herberg In 't Misverstand bevat veel kiemen van latere verhalen. Anna heeft al een affaire met een opzichter van de ontginningsmaatschappij achter de rug, zoals in het latere verhaal 'Erfgoed'. De oude boer, die niet naar de nieuwe kerk in de veenkolonie wil, komt in 'De boer en zijn kerkplavei' terug en de ongelukkige vrouw met haar vijandige schoonfamilie in 'Huwelijk'.

Veel problemen van de personages in de roman liggen in het seksuele vlak: prostituee bezoek, pedofilie en overspel. Ook hier zijn er steeds misverstanden. Zo weet echtgenoot Lodewijk niet dat zijn achterlijk dochtertje een kind van hemzelf is en zijn lievelingszoon. tje juist niet. De al wat oudere kastelein trouwt met de dorpsschone Wilde Maria, die al van iemand anders zwanger is. Als hij dat achteraf merkt, zegt hij verontwaardigd tegen de pastoor dat hij er niet op aangekeken wil worden dat hij móest trouwen; waarop de pastoor 
antwoordt dat dat in de gegeven omstandigheden nog het minst erg zou zijn.

Een merkwaardig hoogtepunt in het boek is de passage waarin de stamgasten elkaar's nachts in de kelder gaan zeggen wat ze echt van elkaar denken. Op deze manier krijgt Coolen de kans om via de stamgasten zijn visie op de verschillende personages weer te geven. Het gaat er genadeloos aan toe, maar de notaris citeert Nietzsche, die gezegd zou hebben: als we voor iets woorden hebben, dan zijn we er overheen. Deze nacht werkt als een soort loutering op de stamgasten; door de spiegel die de anderen hen hebben voorgehouden, ontdekken ze hun eigen aard. Ze moeten bekennen dat mijnheer Gérard eigenlijk nog de eerlijkste was, want hij maakte er nooit een geheim van waar hij naar toe ging. Ze verlangden eigenlijk allemaal dat hij over dat bordeelbezoek zou vertellen "om in de illusie eens iets te beleven, zonder de moed op te brengen, er in de daad schuldig aan te zijn." De stamgasten zijn elkaars "getuige en deelgenoot" geweest en ze wisten vaak meer van hun kameraden dan van zichzelf. Nu ze er woorden voor hebben, zijn ze er overheen en zien ze hun leven anders.

Coolen heeft in Herberg In 't Misverstand zeker ook eigen ervaringen verwerkt. Hij is immers in Waalre al snel lid geworden van een sociëteit: een aantal mannen dat op woensdagavond bij elkaar komt in café De Doelen. Aan een lange tafel achter in de zaak vormen de sociëteitsleden een apart gezelschap, waar vaak een studentikoze sfeer omheen hangt met "een collectief gekoesterd gevoel van eigenwaarde."

Coolen heeft de trend doorgezet die hij in de Van Taeke romans heeft gevolgd en geen gebruik meer gemaakt van zijn speciale idioom in dialectvorm. Wel gebruikt hij nog altijd de stijlfiguur die Van Duinkerken al bij hun kennismaking de 'repeterende breuk' noemde, maar die Coolen als een typisch element in de manier van praten in Oost-Brabant beschouwt. Als Lodewijk voor het eerst zijn pasgeboren zoontje ziet, zegt hij op een halve pagina met steeds andere accenten: "Maar 't is een verdomd schone jongen! Een verdomd schone jongen. [...] Een verdòmd schone jongen. [...] een verdomd schone [...] zón schone jongen [...] Nee, zóne schone!" Dit enthousiasme is schrijnend voor zijn vrouw, maar ook voor de lezer, omdat zij weten dat hij niet de vader van het kind is. Het lijkt of Coolen deze stijl nu reserveert voor wat simpelere figuren zoals Lodewijk, om zo hun rondcirkelende gedachten te schetsen. Wanneer Lodewijk zijn vrouw 'beurs' heeft geslagen, nadat ze hem de ontrouw heeft opgebiecht, wil hij weggaan. Dan volgt weer zo'n alinea, waar met vele herhalingen als bij een litanie de reden van zijn niet weggaan wordt gegeven:

"Maar omdat ze lag waar ze lag op de vloer kon hij nog niet de deur uit. Omdat zij hem met die gedweeë ogen aankeek, kon hij nog niet de deur uit. Hij kwam naar haar toe. Hij nam haar op. Hij droeg haar naar het slaapvertrek en legde haar op het bed. Dat deed hij, omdat zij op die vloer zo hard lag, en omdat zij zulke gedweeë ogen had. En toen de jongen thuiskwam en naar zijn moeder vroeg maakte hij boterhammen voor de jongen. Dat deed hij, omdat hij alles wist te staan en te liggen." ${ }^{\text {51 }}$

Niet lang daarna volgt de al eerder aangehaalde zin: "Niet altijd weten wij, wat we doen." De vrouw weet niet waarom ze haar misstap beging, de man weet niet waarom hij haar zo

50 Collectie Tij Kools, brief Zoetmulder aan Carel Swinkels, 5 december 1986.

51 Coolen, Herberg In 't Misverstand, 363. 
hard sloeg. Hij weet ook niet waarom hij haar opraapt, thuis blijft en de jongen verzorgt. Lodewijk kan niet op de gedachte komen dat iets anders, iets diepers zoals liefde, de oorzaak is van zijn gedrag en dat het niet alleen komt door de harde vloer en de gedweeé ogen.

\section{Kritiek}

Herberg In 't Misverstand krijgt eind november r 938 een zeer lovende kritiek van Simon Vestdijk. Hij vindt dat Coolen zichzelf met de twee Van Taeke romans heeft vernieuwd, waarmee hij zelfs lof heeft geoogst van zijn voormalige vijanden. Zijn reputatie staat nu zo stevig op twee benen - "rechts en links, roomsch en on-roomsch" - dat men de neiging krijgt hem weer kritisch te ondermijnen. Dat lukt echter niet, want Herberg In 't Misverstand dwingt bewondering af, schrijft Vestdijk. Coolen is volgens hem een onbestreden meester in het genre van de realistisch-romantische boerenroman "met hypermenselijke, maar daarom nog allerminst moralistische strekking." Coolen heeft zich met de beide Friese "Gösta-Berling-romans" bevrijd van zijn realisme en zijn fantasie en verbeelding de kans gegeven. Dit nieuwe boek is een Brabants mengsel van romantiek en realisme geworden. Het werk doet aan Selma Lagerlöf, maar meer nog aan Fritz Reuter denken. De roman is uitzonderlijk goed gecomponeerd; de lezer merkt nauwelijks dat er vanuit een centrale conceptie draden geweven worden. Vestdijk prijst de superieure ironie waarmee Coolen de zouteloze gesprekken en gedragingen in de bierkelder weergeeft. De bierkelder is een soort alchemistisch retort waarin Coolen het leven zich ingedikt en verhevigd laat afspelen, buiten de normale burgerlijke beperkingen waarvan het huwelijk de meest kenmerkende is. Alle huwelijken in het boek hebben iets met de herberg te maken, waarbij steeds het kind een belangrijke symboolfunctie vervult. Vestdijk constateert dat Coolen geen "bluboklant" is, waarmee bedoeld wordt dat hij niet schrijft volgens de regels van de Duitse bloed. en-bodemideologie, waarin alleen gezonde en frisse figuren voorkomen. In het boek komt een kwartaalzuiper voor, een mongoloïde idioot, de schizofrene familie Deijsselbloem, de gekke postbode en een pedofiel, schrijft Vestdijk. Hij vergeet dan de hoerenlopende dégeneré meneer Gérard nog. Coolen's techniek van de herhaling vindt Vestdijk een "retorisch. poëtisch trucje". Mede daardoor en door de soms te lange uitweidingen is het boek zo'n honderd pagina's te dik geworden. Hij hekelt ook de natuurgetrouwe beschrijving, als in een schoolopstel, van een dorpskermis, een beschrijving "die alleen van belang schijnt voor lezers uit tijden dat de kermissen uitgestorven zijn." ${ }^{52}$

Taels, die in de inleiding van zijn licentiaatverhandeling over het werk van Coolen in I941 al een citaat van Wies Moens opneemt, dat alle grote kunst door alle tijden heen 'volksch' is, en daar stelt dat ook Coolen's werk uitgaat van alle kracht en heerlijkheid en alle kleurigheid en fleurigheid van het volksleven, bewondert het boek wél volgens de regels van bloed en bodem en van de heimatkunst. Hij negeert het mededogen van de verteller in de slotalinea met het menselijk tekort van alle personages en maakt een onderscheid tussen de gedegenereerden - de "nulliteiten" - in de bierkelder en de edele boer Lodewijk die zo zwaar gestraft is door de misstap van zijn vrouw. Taels ziet dus niet het verwerpelijke van deze man, die het verdriet van zijn vrouw en het lot van hun gehandicapt dochtertje heeft veronachtzaamd en alleen maar oog had voor zijn gezonde kleine stamhouder. In de rij van heimatromans heeft Coolen volgens Taels bewust voor de schrille tegenstelling tussen een decadente sfeer van een bierkelder en een harmonisch gezin geko- 
zen om "het oude thema der schoonheid van den grondverbonden Brabantschen mensch" beter uit te laten komen. $^{53}$

Taels draait de zaak echter om. Herberg In 't Misverstand is helemaal geen heimatroman. Alleen als de essentiële elementen, het menselijk tekort en de misverstanden, eruit gelaten worden zou men het verhaal zo kunnen bestempelen. Het is de zoveelste keer dat geprobeerd wordt om Coolen bij een denkwereld in te lijven die niet de zijne is.

Van Duinkerken heeft het recenseren van dit boek in De Tijd overgelaten aan LI.M. Feber. Deze schrijft, met een verwijzing naar de oorlogsdreiging in Europa, dat de titel van het boek de naam van de wereld van vandaag zou kunnen zijn. Door de vele misverstanden over vrijheid en gebondenheid, persoonlijkheid en gemeenschap "begint het denkend deel van het menschdom zich bewust te worden, hoe het in deze alleronherbergzaamste herberg is terecht gekomen, waar het buitengewoon ongenoeglijk samenzijn ieder ogenblik dreigt uit te slaan tot een krakeel op leven en dood."

Feber gaat uitgebreid in op een uiterst negatieve kritiek van Henri Bruning in Roeping. Bruning heeft Coolen "toe gesnauwd" dat hij met het dooreen vlechten van drie verhalen nog geen roman heeft geleverd. Feber stelt dat je een kunstwerk moet beoordelen naar wat het wél is en niet naar wat het niet is. De enige vraag is of Coolen goed vertelt en of hij overtuigt in het neerzetten van zijn personages. Bruning had geschreven dat Coolen zomaar een beetje over het psychologisch wezen van de mensen heen zweeft en dat hij zijn tekort aan zielkundig indringen camoufleert "met een stortvloed van handig opgedischte anecdoten en grapjasserijen." Feber is het daar volstrekt mee oneens. Coolen heeft als vertellend waarnemer en psycholoog volkomen gelijk, zegt Feber, als hij zijn personages beschrijft zoals ze zijn en "dat is: niet erg diep en niet allerhevigst verscheurd en niet zoo bijzonder bewust van de eeuwige tegenstelling en het kosmisch conflict, waarbinnen zich 's menschen bestaan voltrekt." Feber vindt Coolen een scherp waarnemer, maar geen diepe geest, en Bruning een diep aangelegde geest, maar geen scherp waarnemer van mensen. Coolen laat zich niet van de wijs brengen, concludeert Feber, en laat zich niet verleiden tot het doen van worpen boven zijn kracht, tot een of ander "roman-ondernemen" met kosmische, synthetische of monumentale aspiraties. Coolen weet wat hij kan en hij doet dat goed. ${ }^{54}$

Uyldert constateert dat Coolen met dit boek weer is teruggekeerd naar het genre dat hij met zoveel succes beoefent: de gewestelijke roman. "Hij vertelt op de rustig, eenigszins ironisch-beschouwende wijze van deze primitieve menschen, die in den doolhof van hun driften en begeerten, van hun misverstand en waan, blijven dwalen tot het lot hun neerslaat of bevrijdt. Maar hij doet dit ook nu weer met dien warmen toon van vergoelijking en ruim begrip, die in liefde voor den medemensch zijn oorsprong vindt en die zijn verhalen zoo ongemeen aantrekkelijk maakt., ${ }^{355}$

Voor de protestants-christelijke krant De Standaard zit hier juist het probleem. De krant vindt in het boek te weinig van het geloof terug. Het geloof van Coolen in God was in zijn vorige boeken al zó gelijk aan het geloof in de mensen, dat er geen onderscheid meer

52 Vestdijk, 'Sacramentele bierkelders'.

53 Taets, Antoon Coolen.

54 Feber, 'Roman en vertelling'.

55 Uyldert, "Herberg in 't Misverstand". 
was tussen godsvrucht en naastenliefde. Die houding moest een keervastlopen en dat is nu gebeurd. $^{56}$

Veel later, bij de bespreking van Stad aan de Maas in 1960, schrijft Kees Fens: "Coolen heeft zich altijd een meester getoond op de vierkante meter: hij heeft weinig ruimte nodig om de wereld onder te brengen, in zijn beste roman, Herberg In 't Misverstand, zelfs niet meer dan de kelder van een café." 57

\section{Boekenweekgeschenk}

Voor de Boekenweek van 25 februari tot 4 maart 1939 heeft de Vereniging met de lange naam weer een geschenk in petto. Men heeft aan Victor E. van Vriesland en Emmy van Lokhorst de opdracht gegeven om in betrekkelijk korte tijd drie novellen te verzamelen en te bundelen, die aanvaardbaar moeten zijn voor een groot publiek en ook een behoorlijk literair peil moe. ten hebben. Het worden novellen van Antoon Coolen, Johan van der Woude en Augusta de Wit; deze laatste zal nog voor het verschijnen van de bundel overlijden.

Coolens novelle 'Huwelijk' gaat over Goverdina. Ze woont alleen op haar boerderij en wil geen huwelijk aangaan, omdat ze teveel ellende en verdriet heeft gezien van haar ruziënde en verbitterde ouders, wier grote crayonportretten nog aan de muur hangen. Uiteindelijk valt zij toch voor de boer Frederik. Dezelfde zomer, nog vóór ze zullen trouwen, krijgt hij bij de oogst een ongeluk waardoor hij verlamd raakt en in een wagentje komt te zitten. Tegen het advies van zijn eigen zusters en ouders in trouwt ze toch met hem. Af en toe kijkt ze naar de grote boerentafel waaraan nooit kinderen zullen zitten. Zijn wonden verergeren na een jaar zo erg, dat hij sterft. Haar schoonfamilie vindt al gauw dat ze niet alleen moet blijven en stimuleert een bepaalde kandidaat. Als ze een keer thuis komt en door het raam een nieuwe huwelijkspretendent recht onder het portret van haar overleden man ziet zitten, keert ze op haar schreden terug en loopt in de felle vorst het bos in. Ze gaat zitten en voelt zich verbonden met haar overleden man. De slotzin suggereert dat zij sterft.

Het thema van het kind dat lijdt onder de ruzie van de ouders, dat ook in Herberg In ? Misverstand voorkwam, keert hier terug, maar dan in een latere levensfase van het vroegere kind, waarmee Coolen aan wil geven hoe lang zo iets doorwerkt. Vooral de verschrikkelijke stilte van het doodzwijgen van elkaar na een ruzie en de afkeer van elkaar worden sterk benadrukt. Coolen gebruikt het vele malen in zijn verhalen en romans, zoals in 'Het goede paard'. Ook Goverdina heeft in haar jeugd zitten bidden in het hooi van de hoge schuur dat God haar later voor zoiets zou behoeden.

\section{Uit het kleine rijk}

In september 1939 verschijnt Coolens Uit het kleine rijk, een boek dat geleidelijk is ontstaan. $\mathrm{Na}$ Stijntje schreef hij op verzoek van dr. Clemens Meuleman meerdere bijdragen voor het tijdschrift Moederschapszorg. In het boek gebruikt Coolen heel zijn beschrijvingskunst en observatievermogen om de wereld van zijn kinderen en zijn rol daarin te schetsen. Hii beschrijft de ontwikkeling van de taal en de manier van spelen. Hij doet zelf allerlei dingen die hij eigenlijk niet kan, zoals tekenen, zingen, trommelen en bouwen, omdat zijn lust om met de kinderen te spelen hem daartoe drijft. Met veel liefde vertelt hij over datgene wat 


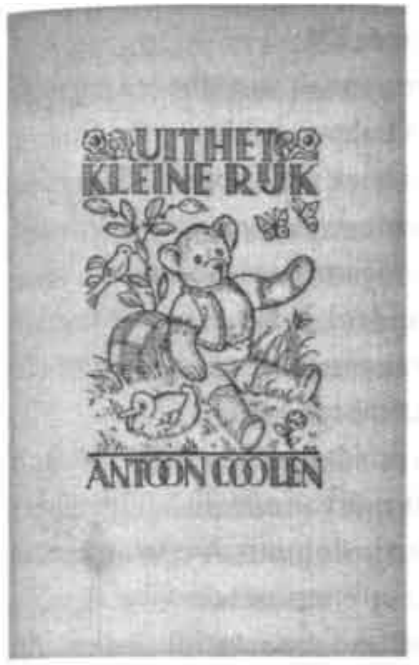

hij wel kan: vertellen.

Het boek is ook een ode aan de Deense sprookjesschrijver en verteller H.C. Andersen. Coolen vindt dat kinderen de meest onmogelijke en fantastische verhalen moeten horen "en niet de realistische ukkepukkerij van 'stoute liesje dat jokte of haar jurkje vuil maakte'." Andersen bewijst dat je sprookjes kunt schrijven die interessant zijn voor kinderen én volwassenen. Coolen wijst op de ironische opmerkingen in de verhalen van Andersen, zoals over het getuigschrift van de professor dat diende "ten bewijze dat hij wàs wat hij was," ${ }^{58}$ of over een kalkoen die aan een ooievaar vraagt "wat die lange dunne benen van hem per el kosten." Hij bewondert de speelse toon van Andersen en geeft als voorbeeld: "Er waren eens vijf erwten in één dop, zij waren groen en de dop was groen, en daarom geloofden zij dat de heele wereld groen was, en dat was juist. ${ }^{\text {"59 }}$ Met plezier vertelt hij hoe Andersen het pure kindergeluk kan beschrijven en glans geven. Een meisje dat een nieuw jurkje krijgt, vraagt verrukt: "Moeder wat zullen de honden wel denken, wanneer ze mii zóó zien?"60

Coolen raadt ouders aan om de moeite te nemen de verhalen uit het hoofd te leren en ze daarna te vertellen. Bij het voorlezen letten kinderen op het boek, de wangen en de lippen van de lezer, maar als je vertelt, kijken ze in je ogen. ${ }^{61}$

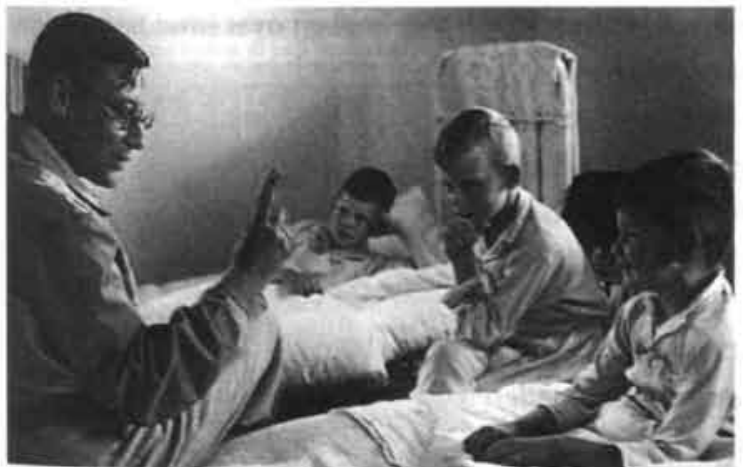

De verteller Coolen en zijn zonen.
De slotpassage bevat een typische Coolen aanval op de 'knappe koppen', die het allemaal zo goed weten. Hij kan niet begrijpen hoe de Noorse schrijver Ibsen in zijn toneelstuk Nora de teleurgestelde heldin haar man en kinderen laat verlaten om, zoals zij zegt, het wónder te zoeken. Hij voegt eraan toe: "Maar de andere Noorsche schrijver,

Hamsun, lacht om de potsierlijkheid der knappe koppen, die een kast vol homogene theaterstukken schrijven over de vrouw, en zegt: Zij verliet haar eigen kinderen om het won-

56 [Recensie Herberg In 't Misverstand], in: De Standaard.

57 Fens, 'Uit een klein rijk'.

58 Coolen, Uit het kleine rijk, 214.

59 Coolen, Uit het kleine rijk, 211.

60 Coolen, Uit het kleine rijk, 209.

61. Coolen, Uit het kleine rijk, 223. 
derbaarlijke te zoeken? Maar wat waren dat dan voor kinderen? ${ }^{\text {n62 }}$

De liefde en de aandacht van Coolen voor zijn kinderen straalt van elke bladzijde. Er zijn meer schrijvers geweest die de eerste jaren van hun kinderen hebben geboekstaafd. Vanwege de aandacht voor de taal doet het denken aan het boek van Cornelis Verhoeven, Een vogeltje in mijn buik. Coolens kinderen groeien op in Deurne en daarom ziet hij door hun ogen weer het dorp van zijn jeugd. Zo zijn de dorpse sinterklaasetalages - "dezelfde, waarvoor ik in mijn jeugd heb gehunkerd" - nog niet veel veranderd. Je ziet er alleen wat suikerwerkbeesten en chocolade harten en geen modelspoorwegemplacementen zoals in de stad. Deze passage schreef hij al voor de Bossche krant in december r 934 .

Zeer levensecht is de angst beschreven als Stijntje een middag zoek is en 's avonds als het donker begint te worden nog niet thuis is. Coolen haalt zich van alles in het hoofd: het kind kan onder het zand bedolven zijn en er zijn ook vennen in de buurt. Angstaanjagende gedachten en geruststellende bezweringen wisselen elkaar op enerverende wijze af.

"Toch stellen wij elkaar gerust, wij moeten niet dadelijk aan een ongeluk denken. Als er een ongeluk was gebeurd, dan hadden we het al lang geweten, dan hadden ze ons gewaarschuwd, dan hadden ze hem thuis gebracht. Ja, maar nu hoor ik ook van de Dommel, de omgeving van een ouden watermolen, dat hij daar wel eens speelt. Maar daar wonen menschen, dan zouden we het toch weten! En van een put hoor ik, met een lagen ringmuur. [...] Die put ligt bij een huis, daar wonen menschen, dan zouden we het weten!"63

Het citaat over Ibsens Nora wordt aangehaald in een positief gestemde recensie van Van Duinkerken. Hij concludeert dat de knappe koppen er aanzienlijk minder van weten dan de goede harten. De Nederlandse literatuur loopt over van boeken over kinderen en kinderpsychologie, maar er is over dit geliefde onderwerp geen boek "dat we met zooveel pleizier en met zooveel bewondering hebben gelezen." Uit het kleine rijk "verwijdert ons wel ver van de onvruchtbare pogingen om het kind Freudiaans te 'duiden' als een knoedel van onaangename complexen." Het is een hartelijk antwoord en een apologie tegen de onzin van het schrale, vindt Van Duinkerken. Hij bedoelt daarmee het neomalthusianisme, het streven naar geboortebeperking: "Een menschelijke verstandigheid, die de wijsheid Gods zoekt te overtreffen door zelf Voorzienigheidje te gaan spelen. ${ }^{\text {664 }}$

Albert Helman vindt dat het boek over de kinderen meer zegt over de schrijver Coolen, die volstrekt ontragisch en ondramatisch geaard is en die een afschuw heeft van de menselijke complicatie, waardoor zijn boeken een idyllische allure blijven houden. De mensen houden daarvan, vooral in oorlogstijd, zegt Helman, kijk maar naar Pallieter dat een product was van de Eerste Wereldoorlog. Hij vindt het moeilijk om in zijn kritiek 'spelbreker' te moeten zijn, maar het moet hem toch van het hart dat hij grote moeite heeft met de veralgemenisering die Coolen aanbrengt. Hij doet of alle kinderen zo opgroeien als de zijne. maar dat is niet zo. "Er zijn duizenden kinderen, het merendeel der kinderen, die nog veel gewoner zijn dan de uwe, o Anacreonitische Peellander. Die niet weten wat een tuintie is, die groot worden zonder dat ze ooit onder een appelboom gestoeid hebben, wier gehele kindsheids-verlangen uitgaat naar het ideaal: zich één keer zat te mogen eten." Hij schrijft dit niet uit "sociale sentimentsmeierij," maar als een waarschuwing tegen de "verburgerlijking" van de dingen, die een bepaalde groep van de medemensen moeten plezieren: "de 
honneponnige, levenszonnige, boemelbaronnige mevrouwen en meneren, die nooit in bepaalde stadswijken komen. ${ }^{-65}$

\section{Dickens en Streuvels}

In een bijdrage aan het kerstnummer van De Gemeenschap van 1939 vergelijkt Coolen de kerstvertellingen van Streuvels en Dickens. Hij bestrijdt de minachting voor deze verhalen en vindt de eenvoud van kerstvertellingen de literatuur zeker niet onwaardig. "Het is [...] niet de geringste van haar vermogens, dat zij het hart verwarmt en den geest doet glimlachen van den eenvoudigen." 'Tragici' als Flaubert en Mauriac schrijven geen kerstvertellingen en Ter Braak en Du Perron ook niet, zal hij erbij gedacht hebben. "Maar Selma Lagerlöf, de vertellende Tolstoj, Dickens, Andersen, zij schreven kerstvertellingen, en het schijnt dat zij ze zoo zuiver schreven omdat ze op dat oogenblik hun eigen ijle en pure kinderstem weer vernamen."

Dickens en Streuvels schrijven allebei over de tegenstellingen op aarde, vooral over die tussen rijken en armen. Bij Dickens zit volgens Coolen de verzoening in de tijdelijke gulheid van de rijken met Kerstmis, als zij de armen laten meedelen. Bij Streuvels treedt deze verzoening tussen armoede en bezit minder uitdrukkelijk naar voren. Als hij deze een enkele keer invlecht in zijn verhaal, schuift de arme de tafel van de rijke opzij en versmaadt die als hem "de hoogsten jubel" van Kerstmis wordt meegedeeld. Bij Streuvels ligt "de christelijk-religieuze kerngedachte" altijd in het kerstverhaal verborgen, bij Dickens is het een humanisme, zij het een humanisme "dat gloeit van hartelijkheid."

Coolen legt uit welke verhalen hij het mooist vindt. Zo bewondert hij 'Kerstmis in Niemandsland' waarin de 'bekering' van Verhelst wordt verhaald. Verhelst is voor de oorlog een kleine boer en na de oorlog fabrieksarbeider. Afgestompt door het werk en de dage-

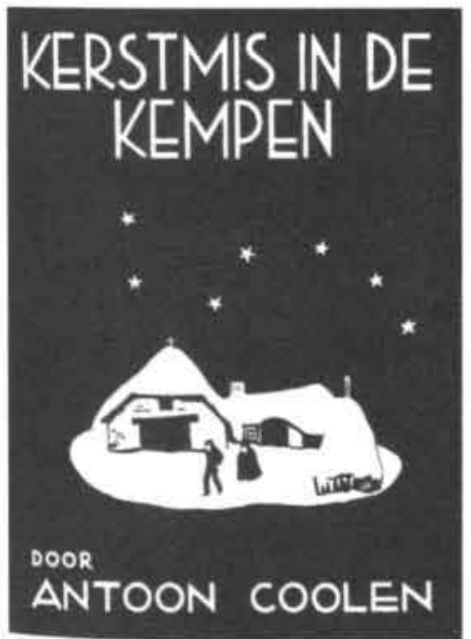

lijkse reis in de arbeiderstrein wil hij met Kerstmis niet naar de nachtmis. Omdat zijn zoontje, Dolfke, een solo zal zingen gaat hij toch. Het zingen van zijn kind brengt hem tot het inzicht dat er andere waarden zijn.

Het andere verhaal, 'Kerstwake', vergelijkt Coolen met 'A Christmas Carol'. Hierin krijgt een hardvochtige boer, op dezelfde manier als Scrooge, de rekening gepresenteerd. Zijn kinderen komen niet thuis op kerstavond. Terwijl hij en zijn vrouw zitten te wachten krijgen ze ongewenst bezoek. Een bende berooft het oude paar van al hun bezittingen. $^{66}$

\footnotetext{
62 Coolen, Uit het kleine rijk, 278.

63 Coolen, Uit het kleine rijk, 257-258.

64 Van Duinkerken, 'Nieuw werk van Antoon Coolen'.

65 Helman, 'Het kleine kinderrijk'.

66 Coolen, 'Streuvels en Dickens'.
} 


\section{Vrede op aarde}

Tijdens deze kerst is de oorlog in Centraal-Europa al volop aan de gang. Coolen heeft er in zijn zaterdagse columns van het najaar 1939 veel aandacht besteed. In dit artikel over de kerstverhalen van Streuvels en Dickens laat hij het vredesaspect weg en gaat hij alleen in op de tegenstelling tussen arm en rijk. Het is een van de eerste stappen van Coolen om zich in zijn literaire werk van de werkelijkheid af te zonderen. Er is wel gezegd dat Coolen zich pas tijdens de Duitse bezetting terugtrekt in de wereld van de sagen en sprookjes. Het enthousiasme waarmee hij in Uit het kleine rijk over sprookjes en vertellen schrijft, is het bewijs dat dat niet helemaal juist is. Al bij het schrijven van het legendeboek enkele jaren eerder is zijn belangstelling voor sagen, legenden en sprookjes gewekt. In de kerstverhalen en sprookjes kan hij zich afsluiten voor de buitenwereld en zich volledig richten op datge. ne waarin Streuvels Dickens overtreft: "de geestelijke bestemming van het Kerstfeest." ${ }^{\text {"6 }}$ 
67 AMVC, inv. nr. C 3475, brief Coolen aan Streuvels, 19 december 1939. 


\section{De Duitse inval}

"Niemand wil oorlog en toch komt hij."

1939-1940

\section{Diksmuide}

De spanning in Europa loopt gedurende de zomer van 1939 voortdurend op. Vanaf eind juni, begin juli begint de Duitse propaganda de zogenaamd kwetsbare positie van de Duitse vrije stad Dantzig, die slechts door een corridor door Pools gebied bereikbaar is, aan de orde te stellen. Op zee zijn er in die maanden steeds incidenten tussen duikboten. In zijn column in de Bossche krant laakt Coolen het dat gejuicht wordt als een vijandelijke boot tot zinken wordt gebracht en dat gehuild wordt als het om een eigen bemanning gaat. Hij vindt de duikboot met zijn torpedo een sluipmoordenaar: "De duikboot is een wreed en moreel niet te rechtvaardigen wapen," want deze kan alleen maar vernietigen en is niet in staat om een schip aan te houden en op te brengen.' Tussen alle berichten over de oorlogsdreiging staat in diezelfde krant een paginagrote advertentie voor "Het Mooie Duitschland," het gastvrije land met de vele kuurbaden. Een week later wordt met naïef optimisme melding gemaakt van de oprichting van een Rijksvereniging voor Duitse joden. Deze vereniging is echter alleen maar een middel om de joden nog beter geregistreerd en zichtbaar te maken.

Op zondag 20 augustus 1939 houdt Coolen een toespraak bij de twintigste Ilzerbedevaart in Diksmuide. ${ }^{2}$ Hierin komen zijn pacifistische denkbeelden sterk naar voren. Hij benadrukt het verschil met de herdenkingen rond de monumenten voor de Onbekende Soldaat in de Europese metropolen, "waar oorlog en wapenstilstand herdacht [worden] met luide militaire parades, die trots betoogen moeten, hoezeer men weer klaar is, als er opnieuw begonnen moet worden." Hier in Diksmuide ligt niet één onbekende soldaat, zegt Coolen, "maar heel de neergevelde garvenlezing der jongelingschap". Men herdenkt hier met stilte en met tranen, met een Misoffer en met een gebed "dat bezweert, dat toch nooit opnieuw moge begonnen worden." Hij richt zich tot degenen die pacifisten weekheid verwijten en een tekort aan vaderlandsliefde. Coolen vindt dat dit verwijt niet vol te houden is op deze plaats:

"Hier verstomt iedere luide en lichtvaardige oorlogsleus bij de verheven en indrukwekkende vredesbede, die gij, u vandaag met uwe dooden vereenigend, als de fluistering van hun gebeente hebt opgevangen en naar de vier windstreken aan de vier zijden in de steenen van dit kruis hebt gehamerd: nóóit meer oorlog!"

Enkele dagen later wordt de oorlogsdreiging almaar groter. Hitler zoekt naar een voorwendsel om Polen binnen te vallen, maar verzekert zich eerst van niet-inmenging van de Russen. Wanneer zijn minister van buitenlandse zaken, Von Ribbentrop, op 23 augustus 
een niet-aanvalspact met Stalin sluit, beseft Europa dat er een oorlog op uitbreken staat, omdat Frankrijk en Engeland hebben beloofd dat schending van de Poolse soevereiniteit niet geduld zal worden. Het niet-aanvalsverdrag komt als een donderslag bij heldere hemel, omdat niet lang daarvoor de Sovjet-Unie nog als mogelijke bondgenoot van Frankrijk en Engeland gold. Op vrijdag I september 1939 valt Hitler Polen binnen. De daaropvolgende zondag verklaren Engeland en Frankrijk de oorlog aan Duitsland.

\section{Nederland neutraal}

De situatie lijkt veel op die van het najaar in r9r4 toen Coolen als volontair bij De Zuidwillemsvaart werkte en zijn eerste schetsjes publiceerde. Ook toen was de allesoverheersende vraag: zullen we er buiten blijven, zal men de Nederlandse neutraliteit ontzien? Alleen marcheerden de Duitse troepen toen rakelings langs de zuidgrens met België, terwijl nu het strijdtoneel verder van ons land verwijderd is. We hebben gezien hoe Coolen als leerling-journalist over de verschrikkingen van de oorlog schreef; over de verspilling van levens, het leed van de verwanten en over de rol van de pers, die het publiek elke dag weer van nieuwe gruwelverhalen voorziet. Ook zag hij de werking van het militairindustrieel complex dat, los van de strijdende partijen, altijd een belang heeft bij een oor$\log$ of de voorbereiding daarop.

Later vormt de Eerste Wereldoorlog af en toe het decor voor zijn romans, bijvoorbeeld in Het donkere licht waar Simon Wijnands als landwachter gemobiliseerd is en Jan Olie betrokken is bij smokkelaffaires. Ook heeft Coolen de sociale onrust en de stakingen beschreven, die aan het eind van de oorlog in Nederland en de Peel voorkwamen. Na die oorlog gelooft hij in het werk van de Volkenbond en vermeldt vaak dat het Vredespaleis in Den Haag staat. Hij ziet in de komst van de tienduizenden vooral Oostenrijkse, maar ook Duitse en Hongaarse kinderen, die in Nederland komen aansterken, een teken van een betere wereld.

Antimilitaristische stromingen zijn in het interbellum vooral in socialistische kringen te vinden, die het oorlogsgeweld zien als een uitwas van het kapitalisme, waarin de machthebbers oorlogen tussen de staten uitlokken en de arbeidersklasse gebruiken als kanonnenvoer. Daarnaast bestaat echter ook de niet aan het socialisme gebonden VrijzinnigDemocratische Bond, die niet nalaat de verschrikkingen van een eventuele tweede wereldoorlog af te schilderen en erop hamert dat de misdadige waanzin van de bewapening moet stoppen. Deze opvatting is door Coolen herhaaldelijk verwoord, maar het is voor hem geen aanleiding geweest zich bij een partij of groepering aan te sluiten. Coolen wil niet kiezen voor een geestelijke of politieke stroming. Daar komt bij dat de bisschoppen op I februari 1933 een streng mandement hebben uitgebracht waarbij het katholieken wordt verboden lid te zijn van verenigingen die een neutraal, liberaal, socialistisch of com. munistisch karakter dragen. Als een katholiek deze verenigingen openlijk aanhangt, staan daar kerkelijke sancties op, zoals het onthouden van de sacramenten. Als hij het echter onopvallend doet, is er niets aan de hand, schrijft L de Jong. "De katholiek die in alle stilte lid bleef van de Vrijheidsbond of van de Vrijzinnig-Democratische bond, deed wel iets wat de bisschoppen afkeurden maar er stonden geen kerkelijke sancties op. ${ }^{33}$ Coolen had er lid van kúnnen zijn; zijn artikelen, die hij jaarlijks rond de herdenking van de wapenstilstand van 11 november 19I 8 schrijft, getuigen daarvan. Echter, zoals gezegd, Coolen wordt niet 
gemakkelijk lid van een beweging; zelfs het toetreden tot een redactie gaat niet zonder moeite. Toch moet hij tegenover deze bond op zijn minst sympathiek hebben gestaan. Men kan denken aan de keer dat hij zich verontwaardigd afvroeg waarom de term 'pacifist' zo'n negatieve klank heeft, terwijl pacifisme de meest gewone en normale levenshouding zou moeten zijn. Men noemt iemand die gewoon ademhaalt toch ook geen respiratist.

Soms lijkt het wel of Coolen de oorlogsdreiging als een boosaardig natuurverschijnsel beschouwt: je kunt alleen maar hopen of bidden dat het overgaat. Zijn krantenwerk en brieven in die bange maanden tussen september 1939 en mei 1940 , waarin voortdurend een uitbreiding van de oorlog in heel Europa dreigt, wekken die suggestie.

Nog op zaterdag 25 augustus, na de bekendmaking van het Von Ribbentrop-Stalin pact, heeft hij in zijn column wanhopig herhaald wat hij in Diksmuide heeft gezegd. Iedereen wil vrede, maar die ellendige leiders niet:

"Wat voor een noodlot hebben de volken dan in hun leiders, welk noodlot scheidt den beveler tot oorlog van den vader, die in de diepte der loopgraaf en in haar modder neerstort onder het kraken der granaat, in het vuur waarvan hij voor 't laatst 't vroom gezicht opdoemen ziet van zijn vrouw en de onbeschrijfelijke argeloosheid der vragende gezichten van zijn kinderen. ${ }^{\mathbf{4}}$

Vlak daarna, op Koninginnedag, donderdag 31 augustus, krijgt Coolen een koninklijke onderscheiding: hij wordt benoemd tot Ridder in de Orde van Oranje-Nassau. Op diezelfde middag om 12.40 precies geeft Hitler het bevel om de volgende ochtend tegen vijf uur het offensief tegen Polen in te zetten.

Op deze eerste oorlogsdag in Oost-Europa schrijft Coolen zijn zaterdagse column voor 2 september, waarin hij weergeeft hoe alles en iedereen in de ban van de oorlog is. Zijn zoontje is er helemaal opgewonden van: "Er komt oorlog, want ik heb twee rijen soldaten gezien." Even later zegt hij na een regenbui: "Nou worden alle kogels nat." Mensen die elkaar normaal niet spreken, praten met elkaar over de toestand en de oorlogskansen. Hij zegt dat de oude mensen in Duitsland somber zijn, maar de jonge officieren niet. Die zijn enthousiast en zeggen dat Warschau van hen is vóór de Engelsen met hun ontbijt klaar zijn. Hij eindigt met een citaat van Gide, die zegt dat jongeren altijd gelijk hebben. ${ }^{5}$

In deze maand, waarin het Derde Rijk Polen binnen marcheert, verschijnt Coolens idyl. lische boekje Uit het kleine rijk. Vanaf deze tijd duikt regelmatig het begrip 'oase' in artikelen en brieven van Coolen op. Hij gebruikt in Herberg In ' $t$ Misverstand tot tweemaal toe de zin "Er zijn nog oases in deze wereld" om de boerderij en het gezin van het harmonische paar Martien en Anna aan te geven. Hij beseft dat het neutrale Nederland in ieder geval voorlopig een oase is in Europa, waarvan de grote landen nu formeel met elkaar in oorlog zijn.

Een week na de inval in Polen roemt hij het mooie najaarsweer en heeft hij het over de "zonbeschenen oases" na de hoogmis . Nederland is nog onzijdig, maar alweer worden er niet zo ver weg vrouwen en kinderen gedood door bommen. Niemand wil oorlog en toch komt hij, schrijft hij. Toch komt hij, herhaalt hij viermaal, en niet om een concreet geschil maar om een zogenaamd heilig beginsel. Dat vindt Coolen het paradoxale aan de oorlogs.

3 De Jong, Het Koninkrijk, deel 1, 67.

4 Coolen, 'Brieven van De Kempen', 26 augustus 1939.

5 Coolen, 'Brieven van De Kempen', 2 september 1939. 
hitsers; zij geven nooit toe dat zij om iets materieels de strijd beginnen maar doen dat zogenaamd altijd om de culturele rechten en de waarde van de mens te verdedigen. Oorlog dient niet om een beschaving te redden, volgens Coolen, maar kan alleen ontstaan omdát de beschaving vernield is. ${ }^{6}$

Deze column van 9 september 1939 kan geïnterpreteerd worden als een verdediging van zijn boeken en zijn kunst tegen het misbruik dat het nazisme ervan maakt. Coolen betoogt dat het nazi-regime slechts voorwendt dat het staat voor verdediging van de heimat, het boerengezin, de moederliefde, de grond en de natuur. Deze houding dient slechts om het volk mee te krijgen. Als het regime eenmaal dit imago heeft verworven, kan het alles van het volk gedaan krijgen. Dan blijkt dat het regime deze waarden aan zijn laars lapt. Het stelt de staat boven het individu. De moeder moet haar zoon afstaan, het kind wordt gestimuleerd zijn ouders te verraden, de boer moet vreemde grond gaan veroveren, enzovoort. Het paradoxale is dan dat de mensen tot al deze verschrikkelijke dingen worden aangezet om ... het gezin, de grond, de hoeve en de gemeenschap te behouden en te beschermen. De staat, de dictator roept op om iets te beschermen dat hij zelf eerst ondermijnd heeft.

Eind september noemt Coolen Nederland geen oase maar een eiland. Zijn boosheid richt zich nu op Rusland, dat de andere helft van Polen inpikt. Deze daad ontmaskert volgens hem het communisme en zijn afzichtelijke lafheid. "Wij op ons eiland wachten en hopen dat krachtens Goddelijk bestel recht en rechtvaardigheid hersteld wordt."7

\section{Franz Herwig en Groot-Duitsland}

$\mathrm{Na}$ de publicaties van een roman, een novelle en de bundel over de ervaringen met zijn kinderen binnen een goed half jaar, heeft Coolen in het najaar van 1939 geen groot werk onder handen. De informele hoofdredacteur van De Gemeenschap, Van Duinkerken, zorgt echter dat hij werk houdt als schrijver en als besturend redactielid.

Van Duinkerken, die eind augustus tijdens een vakantie even geïsoleerd zat in Callantsoog vanwege de algemene mobilisatie, feliciteert hem met zijn koninklijke onderscheiding "waardoor het staatsgezag erkent, dat een romanschrijver, die goede mooie boeken schrijft, voor een land verdiensten heeft." De ridderlijkheid van Coolen is nu door het ridderschap bekrachtigd, voegt hij eraan toe. Hij heeft met ontroering de zo "tragisch-actueel geworden woorden" van Coolen in Diksmuide gelezen. ${ }^{8}$

Aan de twijfels die Coolen begin dat jaar had of hij nog wel lid van de redactie van $D e$ Gemeenschap moet blijven, wordt door Van Duinkerken voorbij gegaan. Hij geeft Coolen opdrachten en betrekt hem ook meer bij het redactiewerk. Van Duinkerken werkt begin 1939, als gevolg van een ziekte, enige tijd thuis en wil de nieuwe jaargang van $D e$ Gemeenschap minder geïmproviseerd dan daarvoor in elkaar zetten: "Ik zal het zoo zien te regelen, dat de vergaderingen tweemaandelijks worden, en niet meer plaatsvinden in een kroeg, want dat was ook al heel weinig serieus. ${ }^{\prime 9} \mathrm{Hij}$ heeft gezien dat Coolen in de Bossche krant een column heeft geschreven naar aanleiding van de dissertatie van dr. H. Spee over de Duitse schrijver Franz Herwig en vraagt hem nu een uitgebreider stuk voor De Gemeenschap te schrijven. Coolen heeft in 1935 al een boek van Herwig vertaald: Sextet im het hemelrijk. In de Bossche krant heeft hij het belang van Herwig voor de Duitse katholieke literatuur benadrukt; zijn bloeitijd viel samen met het ontwaken van de katholieke jonge ren in Nederland en de begintijd van Roeping. Met veel genoegen haalt hij een citaat van 
Herwig aan over verzuurde critici, die vanuit een gefrustreerdheid schrijven omdat ze zelf als schrijver zijn mislukt. ${ }^{10} \mathrm{Het}$ is de bedoeling dat het artikel over Herwig in het maart- of aprilnummer zal komen. Het is echter blijven liggen en in september is het nog niet af. Van Duinkerken dringt erop aan het toch te schrijven.

Het artikel verschijnt uiteindelijk in het novembernummer. De juist begonnen oorlog klinkt er in door als Coolen opmerkt dat een verhaal van Herwig speelt "ten tijde dat Polen de nationale zelfstandigheid nog niet had, die het nu weer verloor." Coolen voelt zich verwant met Herwig. Ook deze man zoekt aanvankelijk zijn toevlucht in de journalistiek, "dien vertwijfelingssprong van zoovelen." Herwig wordt doodgezwegen door de officiële letterkunde, waarvan de leidende figuren de christelijke nationale letterkunde negeren, zeker "zoo ze kwam van katholieken." "Vandaar de hierboven genoemde felle uitval van Herwig naar de verzuurde critici.

Coolen betreurt met Herwig dat de gemeenschappelijke religieuze grondslag van de Middeleeuwen niet meer in Duitsland aanwezig is en dat de tegenstelling eerder de normale situatie is geworden.

"In den scherpen wind van het protestantsche noorden ademt de legende niet, noch het mysteriespel, noch het lied of de sage. Het katholieke volksdeel van het zuiden is de beste bewaarplaats gebleven voor dien kostbaren Duitschen schat. [...] de cultuurkrachten van het zuiden, die in het verleden het Duitsche aanschijn zoo'n luister hebben bijgezet, zijn nog altijd bereid aan het Duitschland van thans die kracht toe te voegen - de noodzakelijke voorwaarde voor een groot-Duitschland." ${ }^{12}$

Herwig gelooft dat de katholieke letterkunde de Duitse letterkunde zal bevrijden van de vervreemding en deze zo weer nationaal maken, door ze te verrijken met de bronnen van de Middeleeuwen. Coolen citeert een romanpersonage uit Sextet: "Als gij het Zuidduitsche meebracht bij de Pruisen [...] dan zoudt gij hen waarschijnlijk helpen. [...] Misschien zou ons hier een scheutje van het Pruisische wezen in het bloed geen kwaad doen, we zijn op elkaar aangewezen en hebben elkander noodig." ${ }^{13}$

Herwig schrijft dit in 1929, als het nog moeilijk te voorspellen is wat er uit dit mengsel zou groeien. Het is eigenaardig dat Coolen de ideeën van de in I93 I gestorven Herwig over een nationaal Groot-Duitsland doorgeeft zonder één verwijzing naar de actuele politieke situatie. Het lijkt er sterk op dat hij een parallel wil trekken met de tegenstelling tussen Noord en Zuid in Nederland.

Coolen kijkt niet vooruit, hij kijkt nostalgisch terug en is daarmee een kind van zijn tijd en vooral van de groep Vernieuwers, waaronder de leden van Brabantia Nostra, voor wie de kernwoorden volk, eenheid, en ordening in een rurale samenleving voorop staan.

6 Coolen, 'Brieven van De Kempen', 9 september 1939.

7 Coolen, 'Brieven van De Kempen', 23 september 1939.

8 BA, brief Van Duinkerken aan Coolen, 10 september 1939.

9 BA, brief Van Duinkerken aan Coolen, 28 januari 1939.

10 Coolen, 'Brieven van De Kempen', 14 januari 1939.

II Coolen, 'Franz Herwig', 562.

12 Coolen, 'Franz Herwig', 564.

I3 Coolen, 'Franz Herwig', 565. 
"Het levensgevoel en het heroīsme van de Middeleeuwen" speelt bij Herwig een grote rol en Coolen deelt die droom van een harmonische samenleving die verloren is gegaan. Het is een logisch gevolg van zijn opvatting dat oorlog niet zozeer een beschaving kapot maakt, maar dat een verdwenen beschaving of een gebrek aan beschaving een oorlog veroorzaakt. Vooral de "grootstad" bergt dit gevaar van beschavingsverlies in zich, zoals Herwig in een van zijn romans laat zien; de zoektocht naar het kernpunt van de stadsbeschaving levert slechts "verrotting en ontbinding" op. "Haar peripherie druipt van etter, haar trams en autobussen, in die atmospheer van regen en asphalt, doemen als moordende fantomen op en sleuren de menschen mee." Het moet Coolen aan zijn tien jaar oude roman Het donkere licht hebben doen denken, als in het werk van Herwig een gevallen meisje - "en vele zusters heeft zij" - voor haar dood nog een keer aan de natuur denkt: "Vóór den val van haar oogen doemen aan een verbeelden horizont geurende, doorwaaiende dennenwouden op en vruchtbare akkers, daar is onder den wind van Gods adem het gebied gelegen, waar de zie] in vrijheid opstaat." Coolen voelt in Herwig een verwantschap in zijn lof voor het "zuive. rend, natuurverbonden leven."

Enkele maanden daarvoor heeft een lezer van De Gemeenschap zich afgevraagd of het nog zin had een cultureel tijdschrift te lezen "nu de barbaarschheid oppermachtig is gebleken." De redactie vindt dat men juist nu niet moet bezuinigen op cultuur: "Wie den triomf van de barbaarschheid vreest, kan dit niet beter doen blijken dan door de rechten van den geest metterdaad te erkennen en te behoeden. ${ }^{14}$ Van Duinkerken heeft onder de schuil. naam André Leffens een fel stuk tegen het fascisme geschreven met als titel 'Praefascisme in Nederland'. Daarin hekelt hij de mentaliteit van allerlei personen en groeperingen die er uiteindelijk toe zullen leiden dat de democratie vernietigd wordt en een totalitair bewind de kans krijgt. Scholten ${ }^{15}$ wijst erop dat het blad De Gemeenschap, vooral in de bij. dragen van Van Duinkerken, steeds ingrediënten van het nazisme heeft bestreden, zoals het antisemitisme en de bedreigingen voor de religie en de cultuur, maar dat het blad nooit een echte verdediger van de parlementaire democratie is geweest. Dit laatste is waar, maar daar moet wel aan worden toegevoegd dat de meeste intellectuelen van die generatie zwij gen over de gevaren die de parlementaire democratie bedreigen. Ook Coolen laat zich over de democratie nauwelijks uit. Hij hekelt wel het ijdele gedrag van dictators, maar zijn grootste vrees is toch de herbewapening en de daarmee gepaard gaande oorlogsdreiging.

\section{De laatste winter voor de bezetting}

In een bedankbriefje aan zijn vriend Oomes voor de felicitaties bij de koninklijke onderscheiding uit Coolen zijn teleurstelling over de ontwikkelingen in Europa. Hij is zich er van bewust "hoe beschaving en civilisatie dicht bij het barbarisme staan." Zijn natuurlijke reactie daarop is zich er van af te keren. Ook in deze brief duikt de metafoor van een oase of een eiland op: "Zo goed en zo kwaad als't kan moeten we ons maar opsluiten in de goede kring van de onzen en in ons werk, waar we maar gewoon mee door moeten gaan, want beter kunnen we niet doen." ${ }^{-16}$

Echt groot werk heeft hij niet onder handen, schrijft Coolen aan Streuvels, hij moet wach. ten "op het zich opdringen van plan en gedachte en op de schrijfdispositie, die geeft, wat gij noemt: het eigen plezier." Coolen heeft dan juist een vertaling van een boerenroman uit 


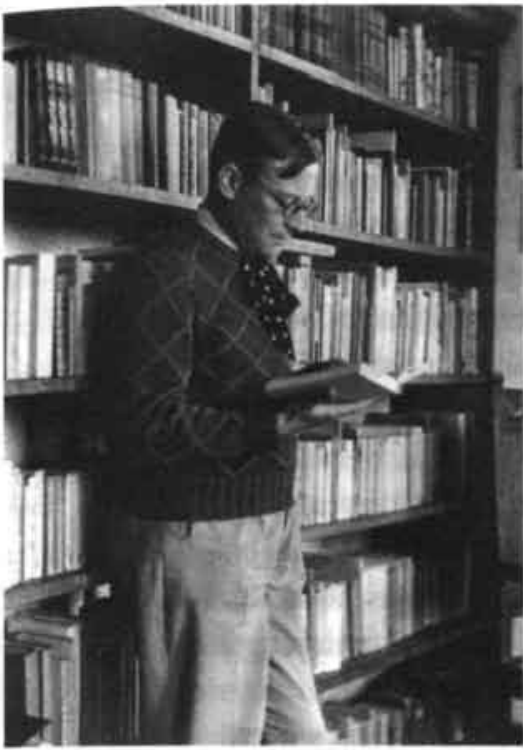

De oase van de geest.

Frans-Canada, Dertig morgen land," afgemaakt. Hij vindt die wel mooi, maar voegt er aan toe dat het veel gaat "over zaad, moederschoot der aarde en den mythische band tusschen boer en bodem." ${ }^{18}$

Af en toe spreekt Coolen voor de gemobiliseerde militairen die in de Peel gestationeerd zijn. Hij woont ook een lezing bij die de folklorekenner D.J. van der Ven voor de soldaten van het grensbataljon de Peel houdt en bericht daarover in de Bossche krant. ${ }^{19}$ Van der Ven vertoont films over de gebruiken in Brabant en Limburg voor de 'Hollandse jongens'. Coolen vindt dat een goede zaak, want folklore laat iets zien van het volkshart en geeft aan dat we ondanks de verschillen één rond de troon zijn. Als die jongens de films zien over het vendelen, de processies, de Meivieringen en de oogstfeesten herkennen zij plotseling het volkshart en kijken daarna anders naar de "rimboe", waarin ze door de mobilisatie verblijven, schrijft Coolen. Hij vindt dit zeer belangrijk voor de mentaliteit van de gemobiliseerden; het doet hen de wezenlijke waarden van het nationale beseffen. Dit is de beste manier want Nederland "is geen volk van mythen en leuzen, van militaire parades." Die soldaten zijn allemaal vaders, zonen en geliefden en de bevolking gaat aardig met hen om. In de strijd tegen het defaitisme is deze folklorefilm van het "bronfrisch, helder volksleven" het beste middel, aldus Coolen.

\section{Neutraliteitspolitiek}

Het valt op dat Coolen in die eerste oorlogsmaanden in het najaar van 1939 wél schrijft over de verschrikkingen van de oorlog, maar de Duitse inval in Polen niet met name noemt. In oktober beschrijft hij wel het lot van de vluchtelingen uit Estland, Letland en Litauen, waar de Sovjet-Unie is binnengevallen, en hij beklaagt Finland dat nu aan de beurt is. Ook de aanval van Italië op Zuid-Tirol noemt hij. Het is weer net als in I9r 4: de wapens, de grote hoeveelheden wapens die zich overal hebben opgestapeld, leiden tot oorlog. ${ }^{20} \mathrm{Een}$ veroordeling van het oorlog zoekende Duitsland en de rol van Hitler komt niet uit zijn pen. Het zou kunnen dat hij niet de kans wil lopen dat zijn boeken een verschijningsverbod in

14 RDG, 'Heeft het nog zin?', 449-450.

15 Scholten, Aspecten, 266-267.

16 LMDC, inv. nr. 3485, brief Antoon Coolen aan Oomes, 29 september 1939.

17 Dertig morgen land verschijnt als feuilleton in de Katholieke Illustratie van april 1939 tot september 1940. Het is een vertaling van de roman Trente arpents van Ringuet, Editions Flammarion, 1938.

18 AMVC, inv, nr. 3475, brief Coolen aan Streuvels, 25 februari 1940.

19 Coolen, 'Brieven van De Kemper', 7 oktober 1939.

20 Coolen, 'Brieven van De Kempen', 14 oktober 1939. 
zijn nieuwe afzetgebied Duitsland krijgen. Eerder is al vermeld dat Coolen aan vertaler Mertens toestaat om een coupure aan te brengen in Herberg In 't Misverstand. ${ }^{21}$

Het kan echter ook zijn dat Coolen zich van kritiek onthoudt om de 'onzijdigheid', de neutraliteit van Nederland te blijven benadrukken. Hij makt zich boos op de internationale persbureaus die deze neutraliteit steeds in gevaar brengen door onbetrouwbare en alarmerende berichten over troepenverplaatsingen, incidenten en aanvalsdata. Deze berichten vergiftigen de internationale verhoudingen, schrijft Coolen. ${ }^{2}$ De onzijdigheid van Nederland heeft een vreedzaam doel, ons land is een oase, waar de goederen van de geest en de zedelijke waarden en normen van de Europese beschaving nog veilig zijn. In Nederland staat niet voor niets het Vredespaleis, voegt hij er weer aan toe. Hij ziet zelfs een mogelijkheid dat België en Nederland een bemiddelingspoging tussen de strijdende partijen ondernemen. Het klinkt wat naïef, alsof er iets te bemiddelen valt bij een oorlog die zo duidelijk gepland en gewild is. Maar hierbij moet wel in ogenschouw worden genomen dat er in die tijd, ook buiten Duitsland, veel begrip is voor de rechtmatigheid van de Duitse aanspraken op bijvoorbeeld Sudetenland en Dantzig. Coolen is er in ieder geval oprecht van overtuigd dat Nederland en dus ook Nederlandse schrijvers een strikte neutraliteit in acht dienen te nemen.

Een week voor het schrijven van zijn column vond in Venlo een ernstig incident plaats, waarbij leden van de Engelse contraspionage en een Nederlandse luitenant op Nederlands grondgebied door de SS werden overrompeld en gearresteerd, waarbij de Nederlander aan zijn verwondingen overleed. ${ }^{23}$ Het begint dus al behoorlijk te spannen aan de grenzen van de 'oase'.

De Nederlandse regering wil de neutraliteit van Nederland zo goed bewaken dat zij geen enkele uitspraak doet over de binnenlandse politiek van Europese landen en zeker niet van Duitsland. Sterker nog, zij wil ook anderen daarvan afhouden. Ten Have geeft hier veel voorbeelden van: een minister die in het buitenland negatief over nazi-Duitsland spreekt wordt door de Eerste Kamer gekapitteld, kamerleden krijgen kritiek van de minister als ze negatief over de jodenvervolging spreken en als de hoofdredacteur van het Utrechts Nieuwsblad zich anti-Duits uitlaat, krijgt hij onmiddellijk de minister-president aan de lijn. ${ }^{24}$

Een ander effect van het angstvallig vasthouden aan de neutraliteit is dat velen de oorlogvoerenden op één lijn gaan stellen en niet willen kiezen tussen de partijen. Ten Have ziet dat vooral gebeuren bij de Morele Herbewapening, die kort daarvoor nog contact had met nazi-Duitsland. Bij deze organisatie staan bemiddeling en verzoening hoog in het vaandel: "Dit kon leiden tot een afstand nemen van het nationaal-socialisme als ideologie, terwijl tegelijk een neutrale, tot verzoening neigende houding tegenover het nationaalsocialistische Duitsland werd ingenomen." 25

\section{De winter van 1939-1940}

Wanneer de strijd in Finland in december verhevigt, wijst Coolen op de boodschap die in sprookjes zit: altijd het leven eerbiedigen. Hij ziet dat deze regel overal geschonden wordt en weer stelt hij vast dat we in Nederland in een oase leven. ${ }^{26}$ Met Kerstmis denkt hij aan de vele gelovigen die in de kerstnacht op hetzelfde moment aanwezig zijn in de Madeleine en de Notre Dame van Parijs, maar ook in de grote Dom van de driekoningenstad Keulen. 
Als al die mensen bidden, terwijl de zware Duitse klok over de Rijn klinkt, dan moet er toch vrede mogelijk zijn, besluit hij zijn zaterdagse kerstcolumn. ${ }^{27}$

Het jaar r 940 begint met een ongekend strenge winter, zodat men zich in Nederland gemakkelijker de toestand van de soldaten op ski's in Finland kan voorstellen. Coolen schrijft dat de sneeuw er "moddergrauw" is en een bloedig zinnebeeld van de verschrikkingen die zich daar afspelen. De Russische troepen noemt hij "te Aziatisch in hun barbarisme." ${ }^{28} \mathrm{Hij}$ blijft hopen dat een algemeen menselijk gevoel uitbreiding van de oorlog nog kan voorkomen. Hij noemt als voorbeeld de Kerstactie in Zwitserland, waar schoolkinderen brieven en pakketjes gestuurd hebben aan de 400.000 soldaten die gemobiliseerd zijn aan de grenzen. Het is "de tyrannie van de oorlog, ${ }^{\text {"29 }}$ schrijft hij, dat je nog niet eens toe kunt geven aan dat "aartsvaderlijk verlangen" om thuis te zijn met Kerstmis. Hij heeft de neiging om zich de Finse soldaat aardiger voor te stellen dan de Russische, maar als hij bedenkt dat deze soldaat ook vader is en door zijn kinderen naar Russische gewoonte aangesproken wordt met 'vadertje ${ }^{30}$, verandert die houding. Het zijn niet de soldaten die fout zijn, maar de leiders, verzucht Coolen niet voor het eerst en hij bedenkt hoe mooi het zou zijn als alle soldaten, bewogen door de kinderstemmen die uit de brieven klinken, hun wapens zouden neergooien en naar huis zouden gaan.

Heel Nederland is in die barre winter op de hand van het moedige en verbeten vechtende Finland. Coolen schrijft dat de Nederlander meer van de poolkou houdt dan van de hitte en ziet in de populariteit van Tollens' verhaal over de overwintering op Nova Zembla een aanwijzing daarvoor. ${ }^{51}$ Als een week later de Elfstedentocht wordt verreden, vergelijkt hij de schaatsers met de Finse soldaten in hun witte pakken. Hij vraagt zich af, in die tijd zonder televisieverslaggeving, wat er gebeurt in het donker op de eenzame vaarten en meren tussen de elf steden. Hij ziet het evenement als een teken van 'volkskracht' en prijst het publiek langs de kant dat koffie aanbiedt: "Want Friezen of Brabanters, we blijven altijd pleizierige, nuchtere en gemoedelijke Nederlanders. ${ }^{25} \mathrm{Hij}$ blijft geloven in de band tussen de bewoners van deze twee provincies, die hij zelf in zijn roman De drie gebroeders heeft gesmeed.

De sympathie voor de Finnen blijkt in de Boekenweek van 1940. Volgens Coolen is er nog nooit zoveel belangstelling voor de Edda-liederen geweest. In deze mythologische lite-

21 FPC, brief Peter Mertens, op papier van Insel Verlag, aan Coolen, 11 november 1939, FPC. De tweede druk van Das Wirtshaus zur Zwietrocht verschijnt in 1941 en blijkt dan vertaald te zijn door Bruno Loetsj. Mertens is volgens Speliers ook al van de vertaling van De Vaschaard gezet, omdat zijn vertalingen niet pasten in het Duitsland van toen. Zie ook: Speliers, Als een oude Germaanse eik, 500.

22 Coolen, 'Brieven van De Kempen', 18 november 1939.

23 De Jong, Het Koninkrijk, deel 2, 97.

24 Ten Have, De Nederlandse Unie, 76-78.

25 Ten Have, De Nederlandse Unie, 81.

26 Coolen, 'Brieven van De Kempen', 9 december 1939.

27 Coolen, 'Brieven van De Kempen', 23 december 1939.

28 Coolen, 'Brieven van De Kemper', 6 januari 1940.

29 Coolen, 'Brieven van De Kempen', 13 januari 1940.

30 Zie ook: Coolen, Uit het kleine rijk, 53 en 62. Coolen is steeds geroerd als een van zijn zonen hem "met den Russischen verkleinnaam 'vadertie' aanspreekt."

31 Coolen, 'Brieven van De Kempen', 27 januari 1940.

32 Coolen, 'Brieven van De Kempen', 3 februari 1940. 
ratuur is, volgens hem, de ziel van het Finse volk bewaard gebleven. ${ }^{33}$

Wanneer de vrede tussen Finland en Rusland medio maart getekend wordt, is Coolen toch somber gestemd. Hoe leg je het aan de kinderen uit, vraagt hij zich af. Als hij schrijft over het feit dat de oorlogshandelingen en dreigingen nu al langer dan een jeugd duren, moet hij ongetwijfeld denken aan zijn eigen kinderen, die vanaf hun kleutertijd niets anders hebben gehoord dan zorgelijke verhalen over oorlog. Vanaf 1935 toen het begon met Italië's avontuur in Abessinië, daarna de Spaanse Burgeroorlog, de oorlog tussen Japan en China, tussen Duitsland en Polen, Duitsland tegen Frankrijk en Engeland, Rusland tegen Finland. Steeds weer zijn het berichten en foto's over dode kinderen: in Spanje liggen ze dood in een park, in Sjanghai worden ze na een bombardement door hun moeders in stukken bijeengeraapt en nu weer blijkt dat in Finland veel kinderen tijdens de evacuatievluchten zijn gestorven van honger of kou. ${ }^{34}$

Het gaat nu lente worden, waarmee de kans op oorlog in het westen van Europa groter wordt, schrijft hij in maart I940.

\section{Vriendschappen}

Vanaf begin januari zijn er geruchten dat Van Duinkerken benoemd zal worden tot hoog. leraar in de Vondelwetenschap in Leiden. De Maasbode heeft op 3 januari 1940 de primeur met het bericht dat de benoeming is te verwachten en ontketent daarmee een echte persrel en een hetze tegen Van Duinkerken, die niet vrij is van antipapistische sentimenten. De zaak ligt heel gevoelig. Protestants Nederland wil de leerstoel voor Vondel, de dichter die in 1639 katholiek werd, maar die ook als de 'hofdichter' van de Staatse kant in de tachtigja. rige oorlog wordt beschouwd, niet overlaten aan een katholieke hoogleraar. Vooral Ter Braak is een groot tegenstander. Du Perron wil eigenlijk helemaal geen Vondelleerstoel, maar een Multatuli-leerstoel. De Bossche krant brengt het bericht al op 4 januari. Coolen die Van Duinkerken bij het verkrijgen van zijn eredoctoraat in Leuven, eind 1937, nog uitgebreid had gehuldigd in zijn zaterdagse rubriek, hult zich nu merkwaardig genoeg in stilzwijgen. Van Duinkerken krijgt in januari aanmoedigende brieven van Vondelkenner Piet Oomes en Louis de Bourbon. De benoeming van Van Duinkerken wordt in april officieel. De briefwisseling tussen Coolen en Van Duinkerken beperkt zich deze maanden tot zakelijke mededelingen over het redactiewerk voor De Gemeenschap.

Terwijl Coolens contacten met Van Duinkerken op een laag pitje staan, nemen die met Louis de Bourbon juist toe. De Bourbon is sinds r 938 burgemeester van de Maasdorpen Escharen en Langenboom in de buurt van Grave. De vriendschap tussen de beide echtpa ren wordt in deze tijd intensiever. Ze gaan bij elkaar op bezoek en hebben gezamenlijke etentjes. De Coolens logeren af en toe in de woning die De Bourbon, zonder bescheidenheid maar misschien ook met lichte ironie, de Princenhof noemt.

Louis de Bourbon heeft begin r 940 een roman voltooid. Wanneer Coolen hem daarmee feliciteert, voegt hij eraan toe dat gevoel zo goed te kennen: eerst is er voldoening en verzadiging, men vindt het iets geweldigs en een dag later komt de vertwijfeling met negatie ve "invectieven [... die de felste criticus ons niet verbetert. ${ }^{n 5}$ Coolen belooft bij zijn uitgever Zijlstra een goed woordje te doen om het boek uit te geven. Zelf heeft hij voor het eerst sinds jaren geen werk om handen, schrijft hij. Het lijkt er veel op dat de oorlogsdreiging een verlammende uitwerking op hem heeft. De Bourbon levert op zijn beurt weer een gedicht 
voor het communieprentije van Felix; de tekening is door zijn beroemde peter Felix Timmermans gemaakt. Zo'n prentje lijkt toch vooral voor de buitenkant, de status, bedoeld, want Coolen en Timmermans hebben elkaar niet vaak ontmoet. Coolen heeft tegen derden meermalen tot uitdrukking gebracht geen hoge pet op te hebben van het werk van Timmermans.

Coolen leest, zoals zo velen in die tijd, De tafelgesprekken met Hitler van Rauschning. ${ }^{36}$ Deze onthullingen over het banale en alledaagse van de leer en de leiders van het nationaal socialisme geven sommigen toch nog de hoop dat alles een wassen neus zal blijken te zijn en dat een algehele instorting van dit Derde Rijk met zo'n leider niet lang meer op zich zal laten wachten. Hij stuurt het boek na lezing naar Wiegersma, ${ }^{37}$ maar schrijft er niet over. Van Duinkerken doet dit wel onder zijn pseudoniem Leffens in het aprilnummer van De Gemeenschap, waarin hij stelt dat Duitsland in ieder geval langer zal bestaan dan Hitler.

Begin april r 940 wordt Noorwegen door de Duitsers onder de voet gelopen. Hierbij is het land verraden door Quisling, een naam die al gauw als soortnaam voor een verrader zal gaan dienen. Deze gebeurtenis maakt de angst in Nederland voor verraad van binnenuit snel groter. Eind april schrijft Coolen over de angst voor een vijfde colonne in Nederland en waarschuwt aldus: "een kleine, parlementair niet eens tot uitdrukking komende groep. kan op een ogenblik dat niemand er op bedacht is, een land in handen spelen van een vreemden bezetter. ${ }^{38}$ Zo denkt de Nederlandse regering er ook over, want op 4 mei 1940 worden 21 Nederlanders geïnterneerd, waaronder veel NSB-ers. Op die dag verschijnt Coolens laatste aflevering van 'Brieven van De Kempen' in de Bossche krant onder de titel 'Lente'. Coolen brengt hierin zijn gevoel voor de wisseling van de seizoenen in verband met de oorlog. "Zoo weinig geschikt als de harde strenge winter voor gevechtsposities was, zozeer leent de zachte zon van het voorjaar er zich toe. Er werd gezegd dan zal het losbarsten. ${ }^{\text {"39 }} \mathrm{Hij}$ krijgt gelijk: nog geen week later, op de vrijdag voor Pinksteren, ro mei, zal het daadwerkelijk gebeuren.

Coolen heeft dan al een artikel voor de juni-aflevering van De Gemeenschap geschreven over François Mauriac en zijn boek Les anges noirs. Coolen neemt afstand van deze collega en streekgebonden schrijver: "De wereld van Mauriac is een droevige wereld, zij is gezien door de diffuse schemering heen van ingehouden tranen." Mauriac heeft volgens Coolen geen humor, in zijn boeken worden de lach en de glimlach niet genoemd. Hij lacht "tegen geen kind, tegen geen lelie des velds." De personages in Les anges noirs zijn op een andere manier aan hun land verknocht dan in het werk van Coolen: "niet in een reinigende natuurgebondenheid, maar met dat bezitsinstinct van boersche hebzucht, dat hun afzich-

33 Coolen, 'Brieven van De Kempen', 2 maart 1940.

34 Coolen, 'Brieven van De Kempen', 16 maart 1940.

35 LMDC, inv. nr. C 3485, brief Coolen aan De Bourbon, 19 februari 1940.

36 Dit boek is vertaald door Menno ter Braak en in het aprilnummer van De Gemeenschap besproken door Van Duinkerken onder het pseudoniem A. Leffens.

37 Archief Hendrik Wiegersma, brief Antoon Coolen aan Wiegersma, 4 april 1940.

38 Coolen, 'Brieven van De Kempen', 27 april 1940.

39 Coolen, 'Brieven van De Kempen', 4 mei 1940. 
telijk maakt. ${ }^{n+0}$

Dit verschil tussen liefde voor de grond en hebzucht naar grond krijgt een actuele illustratie door de uitbreiding van Hitlers Lebensraum met de lage landen aan de Noordzee.

\section{De meidagen}

De tegenstelling tussen het fraaie lenteweer met bloeiende seringen en het gedreun van de vijandelijke vliegtuigen en de alarmerende berichten op de radio herinnert iedereen zich die de Duitse inval heeft meegemaakt. Coolen beschrijft dit in zijn na de oorlog uitgegeven boek Bevrijd Vaderland. ${ }^{41}$

Wanneer hij op de derde oorlogsdag, Pinksterzondag, voor het eerst de Duitsers zelf te zien krijgt, schetst hij ze als figuren in zijn romans: "Ze doen net alsof hun bezigheid, met een kanon sleepen en een vreemd land veroveren [...] eindeloos hoog verheven is boven het gemier, waarmee wij ons in dit dorp bezighouden. ${ }^{242}$ Hij ergert zich aan de haast en de bereidwilligheid waarmee nieuwsgierige Nederlandse burgers de Duitsers helpen bij het kaartlezen.

"Ik nader het troepje en den auto, en waarschuw de menschen, dat het geven van inlichtingen aan den vijand verboden is en dat de vijand er ook niet toe kan verplichten. Ik houd zelfs een kleine toespraak, dat het geen spelletje is, dat hun eigen broers of zonen misschien zich ergens doodvechten en dat zij zich hier haasten om de

Duitschers te helpen."

Tot zijn ontsteltenis ziet hij een eindje verderop vrouwen met koffie en één biedt zelfs iets te eten aan, maar dat is een NSB-vrouw wordt gezegd. Uit de garages van villa's worden auto's meegenomen. De winkels worden op 'legale' wijze leeggeplunderd. Er wordt namelijk betaald met versgedrukt noodgeld. ${ }^{43}$ Op de toren wordt de klok verzet naar de 'Duitse tijd ${ }^{44}$ en de eerste zwart-rode plakkaten met de Duitse adelaar en de kop Bekanntmachung worden aangeplakt. De dinsdag na Pinksteren is Coolen in Eindhoven gaan kijken: "De zomer praalt in het jong, zinderend lommer der boomen." Er klinkt Duitse muziek en het manoeuvreren met de legerwagens doet hem aan de komst van een circus denken. "Het is het gewapende Hagenbeck, elk oogenblik denkt ge door de sonore luidsprekers de prijzen der eerste rangen voor de groote voorstelling te zullen hooren, maar de clowntjes met de zwieppetten nemen het verschrikkelijk ernstig. ${ }^{\text {45 }}$ Hier is de beschouwende verteller aan het woord die in zijn jeugd het circus zijn dorp heeft binnen zien rijden, dat hij later met veel smaak zal beschrijven in De grote voltige. Coolen is niet de enige die deze vergelijking maakt. Ook Victor Klemperer vergelijkt in zijn dagboeken de nazi-manifestaties met de geweldige publiciteit en het uiterlijk vertoon van Barnum, de Amerikaanse circusdirecteur. $^{46}$

De werkelijkheid en gruwelijkheid van de oorlog komen dichtbij, als hij hoort dat uitgeverij Nijgh \& Van Ditmar is vernietigd bij het bombardement van Rotterdam en dat daarbij zijn uitgever en vriend Doeke Zijlstra de dood heeft gevonden. Het bericht schokt hem zeer; de kinderen van Coolen treffen hun ouders in tranen in zijn werkkamer. In verschillende brieven aan zijn kennissen geeft hij uiting aan zijn verdriet. ${ }^{47}$ In zijn oorlogsdagboek noteert hij in een 'In Memoriam' hoe verknocht hij aan zijn uitgever was. Coolen heeft deze Fries leren kennen kort voor het verschijnen van Het donkere licht. Hij heeft met hem 
gezeild op de Friese meren en iets daarvan heeft hij weergegeven in het tweede Van Taeke boek De drie gebroeders. Coolen bewondert de vlotheid en de grote toegankelijkheid van deze uitgever, die zoveel verschillend geaarde schrijvers in zijn fonds had en er ook bevriend mee was. De Forumredactie vergaderde bij hem thuis, maar hij was even zo goed bevriend met Coolen, Van der Leeuw en Walschap. Hij heeft hem vaak verzekerd dat hij De kleine Rudolf, net als Coolen, ver verkoos boven Hampton Court van Ter Braak. Hij vindt Zijlstra te vergelijken met Anton Kippenberg van Insel Verlag.

In die eerste weken van de bezetting komt Coolen door "doffe onlust" niet tot schrijven. "Het is een vreeslijke wereld, waarin wij leven, en wat ons overeind kan houden is alleen de hoop, dat aan deze ellende eens een eind moet komen en dat we misschien voor onze kinderen een toekomst mogen zien aanbreken, waarin het onbevangen levensgeluk weerkeert, waaraan wij slechts nog herinnering hebben - want na 1918 is het eigenlijk nooit teruggekeerd," schrijft hij eind mei aan Oomes. ${ }^{48} \mathrm{Hij}$ probeert de onlust te doorbreken en werkt aan een bloemlezing uit het werk van Andersen.

$\mathrm{Al}$ in juni 1940 is Coolen in de gelegenheid met een auto van het Rode Kruis het nog nasmeulende Rotterdam te bezoeken. Men kan zich nauwelijks oriënteren omdat alles in puin ligt. Hij ziet dat de Rotterdammers druk in de weer zijn met het ruimen van puin, maar ook dat er al Nederlandse meisjes met Duitse soldaten lopen te lachen. ${ }^{49}$

\section{Bezoek Töpfer}

In Bevrijd Vaderland geeft Coolen een uitvoerig verslag van de poging om hem al in de eerste maanden van de bezetting voor een grote Duitse prijs te strikken. Op een "stralende Junizomermorgen" staat Alfred Töper uit Hamburg op de stoep.

Topfer is een Hamburgse graanhandelaar, die met een Nederlandse vrouw is getrouwd. We zijn hem al eerder tegengekomen, in 1935, als hij zich beijvert voor de Duitse Rembrandt-prijs voor Streuvels en deze ook op Het Lijsternest bezoekt. Met zijn vermogen heeft hij tientallen prijzen gesticht, die allemaal ten doel hebben de Nederduitse cultuur te

40 Coolen, 'Francois Mauriac, Les Anges Noirs'.

41 Het boek Bevrijd Vaderland is gebaseerd op aantekeningen die Coolen tijdens de bezetting heeft gemaakt. Het is geen echt dagboek, maar een bewerking van zijn notities voor een uitgave in 1945. Er zal hierna regelmatig uit worden geciteerd.

42 Coolen, Bevrijd Vaderland, 23.

43 Coolen heeft dit verhaal waarschijnlijk gehoord van zijn zus Cato die in Deurne de winkel van hun ouders heeft voortgezet. Dit is precies zo'n winkel als hij in Bevrijd Vaderland beschrijft "met schortenbont, chocola, sardientjes, tandpasta, enzovoort." Zie ook: De Jong, Het Koninkrijk, deel 3, 76-77.

44 Al op 14 mei 1940 wordt de verordening in de kranten afgedrukt. Het is een dubbele aanpassing. De klok moet één uur en veertig minuten vooruit worden gezet om gelijk te lopen met de Duitse zomertijd én de Midden-Europese tijd.

45 Coolen, Bevrijd Vaderland, 26.

46. Klemperer, Tot het bittere einde, deel 1, 486.

47 LMDC, inv. nr. C 3485, brief van Coolen aan De Bourbon, 24 mei 1940; brief aan Van Duinkerken ("een van onze fijnste en trouwhartige vrienden"), 29 mei 1940; brief aan Oomes ("een onvervangbare vriend"). 24 mei 1940.

48 LMDC, inv. nr. C 3485, brief Coolen aan Oomes, 23 mei 1940.

49 Coolen, Bevrijd Vaderland, 34. 
verspreiden, in stand te houden en te bevorderen. Kunstenaars die het negatieve van de verstedelijking en de massificatie beschrijven, hebben daarbij zijn voorkeur. Zijn huis op de Lüneburger heide, Hof Thanssen, is in de jaren dertig een verzamelpunt voor nationa. listische jongeren uit Vlaanderen, Nederland, Skandinavië en de Baltische landen. Na de val van de Muur in 1989, toen de archieven van Potsdamm opengingen, werd duidelijk dat alle tien de stichtingen van Töpfer onder controle stonden van Nazi-kopstukken. De uitreikingen van de prijzen door universiteiten was slechts een dunne dekmantel, omdat deze universiteiten al vanaf 1933 volledig genazificeerd waren. ${ }^{50}$

Al op 17 mei r 940 bezoekt Töpfer Mussert. Met een van hem geleende auto rijdt hij eind mei en begin juni door Nederland om officiële contacten te leggen op wetenschappelijk en cultureel gebied. ${ }^{\text {st }}$ Töpfer heeft zich uit kiesheid in burger gekleed en heeft de auto van het Nederlandse departement een eind verder laten parkeren, om Coolen bij diens buren niet in diskrediet te brengen. Na inleidende woorden over hun wederzijdse kennis, Streuvels, de reden voor de Duitse inval en de toekomst van Nederland in de nieuwe tijd komt hij op het doel van zijn bezoek: of Coolen de kandidatuur wil aanvaarden voor de Rembrandtprijs I940 van de Hansische Stiftung van de Hamburgse Universiteit. Coolen weigert met de woorden: "Ik kan geen onderscheiding aanvaarden uit een land, dat het onze heeft overvallen en wederrechtelijk bezet." ${ }^{52}$ Als Töpfer hem vraagt of hij bang is dat men het hem kwalijk zal nemen, als hij een Duitse prijs aanvaardt, antwoordt hij: "Neen. Maar ik weet, dat ik het mezelf kwalijk zou nemen."

Als hij later, in r945, terugblikt schetst Coolen hoe de prijs naar Vlaanderen ging, naar Raf Verhulst en hoe die in maart 194I werd uitgereikt in aanwezigheid van onder andere Albert Servaes, August Borms, Cyriel Verschaeve en Jozef Muls.

Op I3 juni bevestigt Coolen schriftelijk zijn weigering aan Töpfer. Hij doet dat in bewoordingen die, gelet op de omstandigheden, uiterst hoffelijk gekozen zijn: "In aufrich tiger Erkenntlichkeit für die ehrende Auszeichnung, die in dieser Wahl für mich enthalten ist, kann ich doch unter den gegenwärtige Umständen infolge den Deutschen Besetzung unseres Landes - welche Umstände ihre Bitterkeit mit der Preise über eine solche Unterscheidung verbinden sollten - zu meinen lebhaften Bedauern diese Kandidatur nicht annehmen." 53

Hij schrijft later dat de weigering hem geen enkele moeite heeft gekost. Dat is aannemelijk, mede gezien de bruutheid van de vernietiging van Rotterdam. Toch beseft hij al meteen dat deze weigering gevolgen voor hemzelf en (de afzet van) zijn werk kan hebben. Bovendien heeft hij goede vrienden in Duitsland, die hij heeft leren kennen in de wereld van de uitgeverij, vertalers en het theater. Hij heeft kunnen constateren dat zijn vrienden niet meer in het openbaar durven praten en dat sommige van hen ook een afschuw van het regime hebben. Deze gemengde gevoelens blijken ook uit het motto van Goethe dat hij aan Bevrijd Vaderland meegaf: "Ich habe oft einen bittern Schmerz empfunden bei dem Gedanken an das Deutsche Volk, das so achtbar im Einzelnen und so miserabel im Ganzen ist."

\section{Materiële zorgen snel opgelost}

Bij Nijgh \& Van Ditmar volgt de heer Piek de omgekomen Zijlstra op en Van der Waals wordt zijn letterkundig adviseur. 
Coolen zit zelf behoorlijk in de zorgen. Zijn vaste medewerking aan de Provinciale Noordbrabantse en Bossche Courant wordt tot een kwart teruggebracht. ${ }^{54}$ In Vlaanderen neemt Staf Bruggen ${ }^{55}$ geen toneelstukken meer af, evenmin als het dilettantentoneel in Nederland. De vertalingen staan stil en door het bombardement zijn de voorraden van zijn boeken vernietigd. Ook in Duitsland worden geen nieuwe vertalingen meer voltooid. Het ergst vindt hij echter toch "den centenaarslast van den geestelijken druk." 56

In het najaar van r940 blijkt de verkoop van zijn reeds vertaalde boeken toch weer door te gaan. Kippenberg van Insel Verlag meldt zelfs dat in Duitsland een stijging van de verkoop van zijn boeken is waar te nemen. De vertaling van Herberg In 't Misverstand is een succes. De eerste oplage van 5000 exemplaren is uitverkocht en een tweede staat op stapel. ${ }^{5}$ Gedurende de hele oorlog zullen de inkomsten uit de verkoop van herdrukken door zijn Duitse uitgeverij worden overgemaakt. Ze bedragen tussen de drie-en de vierduizend Reichsmark per jaar. In 1943 neemt dit bedrag zelfs toe als Brabanter Volk, de vertaling van Kinderen van ons volk, in een speciale frontuitgave in 11.000 exemplaren voor de Truppenbetreuung, de welzijnsdienst voor het leger, wordt gedrukt. ${ }^{58}$

Hoe het uitgeven van boeken in Duitsland en Nederland tijdens de oorlog is geregeld en hoe het mogelijk is dat het werk van Coolen dan in Nederland niet meer gedrukt wordt, terwijl zijn vertalingen in Duitsland wel worden uitgegeven, komt zo meteen aan de orde. Nu volgt eerst een beschrijving van de situatie tijdens de bezetting en de werking van de Kultuurkamer.

\section{Positie bepalen}

$\mathrm{Na}$ de toespraak van de Rijkscommissaris Seyss-Inquart op 29 mei 1940 in de Ridderzaal ontstaat er een sfeer van berusting en aanpassing. De rede, waarin de Nederlanders als een broedervolk worden gekenschetst, is verzoenend van toon. Seyss-Inquart belooft dat het Nederlandse volkskarakter niet in het nauw zal worden gebracht, dat Nederland de vrijheid niet wordt ontnomen, dat de Duitse politieke overtuiging niet zal worden opgedrongen en dat de onafhankelijke rechtspraak wordt gegarandeerd. De Duitse troepen gedragen zich correct en Nederlandse militairen komen terug uit krijgsgevangenschap. De burge-

50 De gegevens over Töpfer zijn ontleend aan: Speliers, Als een oude Germaanse eik, 216-225. Speliers baseert zich weer op de studie van Jan Ipema, 'Alfred Topfer- een Nederduitser, Pan-Germaan of GrootNederlande?' in: Wetenschappelijke tijdingen, jrg. 53, nr.1 1994.

51 De Jong, Het Koninkrijk, deel 4, 207-210 en 387.

52 Dit en andere fragmenten komen uit: Coolen, Bevrijd Vaderland, 44.

53 FPC, afschrift brief Coolen aan Töpfer van 13 juni 1940.

54 Er zijn in de krant geen ondertekende artikelen meer te vinden.

55 Staf Bruggen (1893-1964) is medewerker van het Vlaams Volkstoneel, later directeur van de Koninklijke Schouwburg van Gent. Hij was beroemd om zijn vertolking van pastoor Vogels in Kinderen van ons volk, een rol die hij meer dan honderd maal gespeeld heeft.

S6 LMDC, inv. nr. C 3485, brief Coolen aan De Bourbon, 12 augustus 1940.

57 LMDC, inv. nr. C 3485, brief Coolen aan De Bourbon, 10 november 1940.

58 FPC, afschriften van afrekeningen van Insel Verlag. Het totale inkomen van Coolen in 1941 bedraagt volgens zijn belastingaangifte 14.430 gld. De afrekeningen van Insel Verlag voor 1940: 1828 RM; voor 1941: 2273 RM, voor de eerste helft van 1942: 3405 RM. 
meesters roepen via de pers de burgers op tot rust en kalmte en zich te schikken in de nieuwe omstandigheden en de nieuwe orde.

Zoals iedereen heeft ook Coolen na de oorlogshandelingen geïnformeerd naar de toestand bij zijn vrienden en kennissen. Aan Van Duinkerken meldt hij dat veel Nederlandse militairen, die naar België en Noord-Frankrijk waren gevlucht, nu te voet terugkeren. Hij hoopt dat Van Duinkerkens broer Thieu, die nog zoek is, erbij zal zijn. ${ }^{59}$ Hij heeft weer werk onder handen genomen. Dit keer is het geen roman, maar een bloemlezing met inleiding uit het werk van Andersen. Hij heeft diens sprookjes volledig, maar hij wil ook graag een paar gedichten opnemen, alsmede stukken uit zijn Vertellingen van de maan, uit zijn bekendste romans als De improvisator en Maar een speelman, uit zijn reisverhalen en uit een toneelspel. Hij weet dat er een volledige Duitse uitgave is, maar die kan hij zich nu niet laten toezenden, omdat alleen brieven en briefkaarten in het postverkeer zijn toegestaan. Coolen vraagt aan Van Duinkerken of hij in zijn bibliotheek of in een andere in Amsterdam iets van deze werken heeft. ${ }^{60}$ Binnen twee weken stuurt hij een herinnering: "Ongetwijfeld hebt ge er al moeite voor gedaan ..." Coolen zit er erg om verlegen; al had hij maar vast de romans en de reisverhalen. ${ }^{61}$

De kranten hebben de opdracht gekregen de rust en orde in de nieuwe tijd te benadrukken, maar worden verder in het eerste oorlogsjaar relatief clement behandeld. ${ }^{2}$ Dagelijks zijn er persconferenties door een Duitse Pressereferent, die richtlijnen geeft voor de berichtgeving en adviezen voor 'positieve' berichten. ${ }^{63}$

De Telegraaf is gestart met een reeks interviews onder de titel 'Kunstenaars op den drempel van een nieuwen tijd'. Al op 7 augustus 1940 wordt een gesprek met Coolen afgedrukt onder de rustgevende kop: 'Staag doorwerken om door de beproeving heen te komen. Een advies van een rustig en eenvoudig verteller: Antoon Coolen'. Op de vraag wat hij in zijn vrije tijd doet, geeft hij een kort antwoord. Hij zegt dat hij af en toe de dorpssociëteit bezoekt en dat zijn kinderen zijn liefhebberij zijn. Als de interviewer een opmerking over zijn mooie landhuis maakt, zegt hij dat hij er waarschijnlijk niet lang meer zal wonen nu zijn uitgeverij in Rotterdam in puin ligt, waardoor zijn geregelde inkomsten weg zullen vallen,

De interviewer probeert hem in een politieke richting te duwen door op te merken dat in een Europese volksgemeenschap de regio's niet verloren hoeven te gaan en wijst op de eigenheid van Bretagne. Coolen ontwijkt de parallel, gaat niet in op de positie van Nederland in een 'Nieuw Europa' en zegt dat de atmosfeer in zijn boeken een weergave is van heimwee naar de jeugd. Zo is hij gaan vertellen over de Peel, de Kempen en over het land van de Maas. "Zoo leef ik te midden van de dorpsgemeenschap en zit ik aan de ouderwetsche herbergstafel."

Over de literatuur merkt hij op dat hij een tegenstander is van een romankunst die zich in zelfbespiegeling verliest, waarmee hij zeer waarschijnlijk doelt op de romans van Ter Braak en vooral op Du Perrons Land van Herkomst. Coolen vermengt zelf een realistische beschrijving met fantasie en noemt dat de "formule van mijn werk." Hij vindt de Nederlander in de literatuur te veel een Droogstoppel. Jammer, meent Coolen, want dit volk is tot groter dingen in staat. Nederlanders vormen volgens hem een niet alleen fysiek maar ook psychisch sterk volk met een scherpe geest, dat erop uit trekt in de wereld. Opnieuw zegt hij het vreemd te vinden dat hier nooit een roman van de zee geschreven is. 
Het interview met Coolen eindigt met de opmerking dat de mensen de beproeving van deze tijd weer te boven zullen komen, als ze maar de zin van het leven zoeken in zichzelf en in het doorwerken aan de dingen waar ze mee bezig zijn.

Deze boodschap is kennelijk welkom in die tijd. Ze past althans in wat van de gecontroleerde pers wordt verwacht. Daags er na, op 8 augustus, wordt het interview voor een groot gedeelte overgenomen in 'zijn' Bossche krant. Eind augustus verschijnt een soortgelijk kabbelende sfeertekening in De Week in Beeld. ${ }^{64}$ Ook hier vraagt de schrijver van het stuk aandacht voor Coolen's kalmte: "Kan het anders dan dat hij komt te spreken over den Europeeschen oorlog en over Nederlands lot? Een sensitieve geest als de zijne moet wel in hevige deining zijn geraakt door de recente gebeurtenissen, maar toch ... hij ziet de dingen in groot verband, en weet zichzelf terug te vinden in zijn werk." Op een foto zien we Coolen in de weer met een verduisteringsgordijn, wat, volgens het bijschrift, wel toevertrouwd is aan deze schrijver van Het donkere licht.

Het tekent de sfeer in die eerste maanden van de bezetting: het valt misschien allemaal wel mee, als iedereen nu maar gewoon doet wat hij moet doen en de bezettende macht niet onnodig irriteert. In de eerste weken hebben de meeste kranten als motto: kalmte en rust, werken aan de wederopbouw en "strikte inachtneming van onze plichten tegenover de bezettende overheid." ${ }^{-55}$

Opvallend in het Telegraaf-interview is Coolens positieve opmerking over de pas overleden Marsman. Deze verdronk in de meidagen toen de passagiersboot, waarmee hij op weg naar Engeland was, getorpedeerd werd. Op de vraag van de interviewer of de periode van het individualisme is afgesloten, antwoordt hij dat dit voor hemzelf als romancier wel geldt, maar dat de stroming nog niet voltooid is. "Met name een figuur als Marsman zou ons nog veel hebben kunnen geven. Doch dit heeft helaas niet zo kunnen zijn." In werkelijkheid denkt hij heel anders over hem. Een maand eerder, vlak na het bekend worden van de dood van Marsman, schrijft hij aan Van Duinkerken:

"In De Nieuwe Eeuw las ik een fragment uit een beschouwing van Marsman over Nietzsche. Wat zijn dat toch algemeenheden, vaag gefrazeer en litteraire paraphrases in dat dikke, krampachtige proza - met stuipen als 'verhevigde vehementie', dat Marsman is gaan schrijven. Je herinnert je misschien die stalactietengrap van Vestdijk. Je weet dat het mij altijd moeite kost jullie waardeering van Marsman-de dichter buiten 't geding gelaten - te deelen. Misschien beging ik de fout het stukje van Marsman te lezen vlak na de inleiding van Van Eyck op de Mei van Gorter."

Dat stuk van Van Eyck vindt Coolen wél een goed voorbeeld van helder schrijven over moeilijke dingen tegenover de "opgewondenheid van een met literatuur volgepropte ama-

59 BA, brief Coolen aan Van Duinkerken, 2 juni 1940.

60 BA, brief Coolen aan Van Duinkerken, 17 juni 1940.

61 BA, brief Coolen aan Van Duinkerken, 1 juli 1940.

62 Vos, Niet voor publikatie, 454.

63 Ten Have, De Nederlandse Unie, 118.

64 'Antoon Coolen, zooals hij leeft en werkt'.

65 Ten Have, De Nederlandse Unie, 121. 


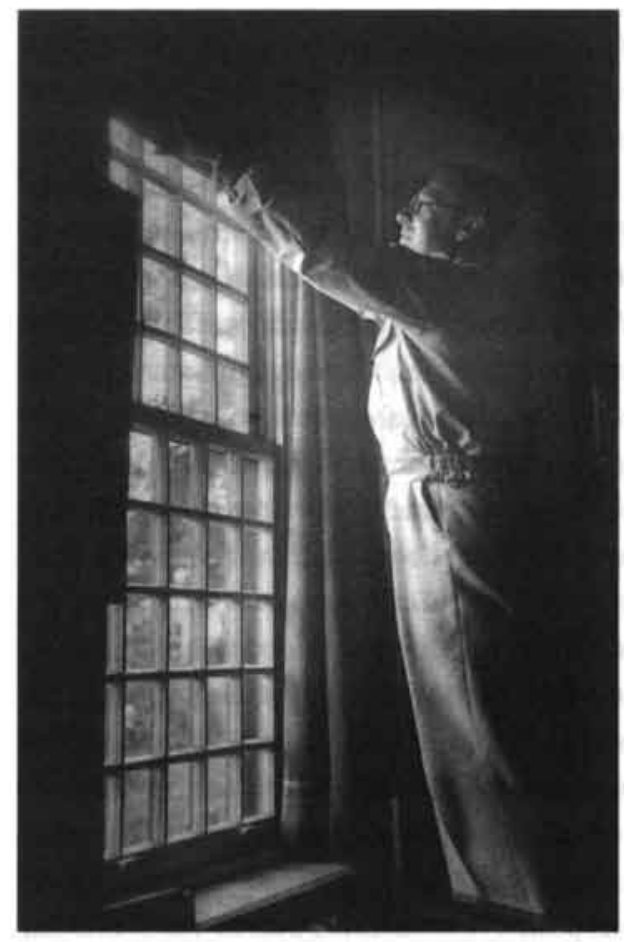

Aanbrengen van de verplichte verduisteringsgordijnen.

teur, aan wien, vrees ik, de wijsgeer Nietzsche geen partij heeft in den voorhof van zijn Zarathustra!" ${ }^{m 6}$

Coolen schrijft terecht 'jullie' waardering, want in het oktobernummer van $\mathrm{De}$ Gemeenschap zal een zeer positief 'In Memoriam' verschijnen van de hand van Louis de Bourbon. ${ }^{67}$ Coolen heeft in augustus zelf aangedrongen op een herdenkingsartikel. Hij schrijft aan Van Duinkerken dat dit misschien raar klinkt na zijn laatste brief, maar De Gemeenschap mag niet achterblijven. Hij vraagt of Van Duinkerken of Jan Engelman het wil schrijven; deze laatste heeft al een stuk in De Nieuwe Eeuw gewijd aan zijn persoonlijke vriendschap met Marsman. Het wordt dus uiteindelijk De Bourbon. Waarschijnlijk wil Coolen als redacteur van De Gemeenschap door een artikel over de 'individualist' Marsman in de eerste plaats een reactie geven op de ideologie van de bezetter. Het ligt echter ook wel in zijn aard om een pas overledene eer te bewijzen, ook al heeft hij persoonlijk een hekel aan een groot deel van zijn geschriften.

Coolen wijdt zijn enthousiasme liever aan zijn eerste criticus: Pieter van der Meer de Walcheren. In een artikel ter gelegenheid van diens zestigste verjaardag schetst hij hem als een belangrijke stuwkracht voor de katholieke jongeren in de jaren twintig. "Hij schreef zijn felle kritieken [...] tegen den smakelozen kerkbouw, tegen de voor devoot doorgaande ziellooze sculptuur, tegen een slappe religieuze schilderkunst, tegen den ganschen stompzinnige cultus der godvruchtige prullaria, tegen de dameskranserij van de roomsche letteren. ${ }^{" 68}$ Coolen schetst hoe Van der Meer als gewezen anarchist en socialist de schellen van de ogen zijn gevallen. Aanvankelijk windt Van der Meer zich op over de tegenstelling tus: sen de welgezeten burgers en de hongerlijders, maar later oordeelt hij dat het socialisme gevulgariseerd wordt. Het doet, volgens Van der Meer, teveel een beroep op het massa. instinct, waarbij het er alleen maar om gaat dat de rollen eens zullen worden omgedraaid. Coolen schrijft dat Van der Meer heeft ingezien dat de christelijke bekommernis om de sociale rechtvaardigheid boven het socialisme uit gaat. Coolen bekritiseert ook de katholieken in het parlement, die Van der Meer bij zijn terugkomst in Nederland aantreft. Vanaf het moment dat ze in de verkiezingen succesrijk zijn en dertig zetels in de Tweede Kamer vullen, worden ze verzadigd, vindt Coolen. "Hart en vurigheid," de trefwoorden van de katholieke emancipatie, zijn verdwenen. Het hoogste goed is gekoppeld aan het democratisch parlementarisme en de uitslag van de stembus. De erfenis van Thijm, de katholieke emancipator uit de negentiende eeuw, is helemaal verdwenen. 
Van der Meer is in 1939, precies tien jaar na zijn vertrek naar Parijs, weer teruggekeerd naar Nederland. Heel wat met de Duitsers of met het fascisme sympathiserende 'Roomse jongeren' liepen bij hem de deur plat om hem voor hun zaak te winnen, schrijft zijn vriend Helman later. ${ }^{69}$ Dit illustreert hoe ingewikkeld de verhoudingen liggen in deze tijd.

Coolen noemt zonder enige kritiek het voorbeeld en de doopvader van Pieter van der Meer, Leon Bloy, die in zijn geschriften fel antidemocratisch, antisociaal en antisemitisch was. Ook Van der Meer de Walcheren zelf is in die tijd moeilijk te plaatsen. Hij schrijft over een "fascisme in verkeerde zin" en accepteert daarmee impliciet een fascisme in de goede zin. Bovendien is hij voor de Groot-Nederlandse en de Dietse gedachte en heeft hij sympathie voor Nationaal Front. ${ }^{70}$ Aan het begin van de bezetting prijst hij de correctheid van de Duitsers en ziet hij een nieuwe wereld aankomen waarin geen plaats is voor de 'lauwe'. "Hier wordt een zware wissel getrokken op de eerlijkheid van Vriend Pieters biograaf," verzucht Helman vele jaren later."

Achteraf bekeken is het voor velen een geluk geweest dat de Duitsers nooit iets gevoeld hebben voor een Groot-Nederland binnen een door Duitsland geleid Europa. Was dat wel zo geweest, dan zouden vele 'twijfelaars' de nieuwe orde van harte omarmd hebben.

\section{De Nederlandse Unie}

Na de eerste verwarrende maand van de bezetting, nu de oorlogskansen van Duitsland op alle fronten in Europa positief zijn, begint in Nederland een wijd verbreid gevoelen te ontstaan dat het Europa van de toekomst Duits zal zijn en dat Nederland zal moeten leven onder een Duitse suprematie. Men herinnert zich nu de belofte die Rijkscommissaris Seyss-Inquart eind mei heeft gedaan, dat Nederland na de oorlog als een relatief vrij broedervolk behandeld zal worden in een nieuw Duits Europa. Vanaf juni beginnen om die reden in de kranten artikelen te verschijnen die oproepen tot nationale eendracht, waarbij ook ingegaan wordt op de positieve kanten van de omwenteling. ${ }^{n}$ Het gekissebis van de jaren dertig is voorbij, schrijven de kranten, en het is nu zaak om met een krachtige eenheidsstaat een positie te veroveren in de nieuwe orde, een nieuw Europa of een nieuwe wereld. Vooral als Frankrijk begin juli capituleert, wordt de leidende rol van Duitsland voor de toekomst van Europa breed uitgemeten.

"Nu heeft dat groote, dikke, logge, schreeuwende Duitschland het fijne, het mooie en edele Frankrijk overwonnen; nu is dat Frankrijk, dat in duizend gevoelige dingen superieur is aan Duitschland, de gretig aanschouwde prooi van Hitler," schrijft Coolen in zijn later gepubliceerd 'oorlogsdagboek'. Hij beseft dat in Europa "de grofheid, het gebrul, het redelooze gegil, de paradepas" zullen gaan overheersen en dat allerlei misdadigers en desperado's nu hun toevlucht kunnen nemen in de SA en de SS, waar ze mogen schieten en

\footnotetext{
66 BA, brief Coolen aan van Duinkerken, 1 juli 1940.

67 De Bourbon, 'Mr. H. Marsman t', 499-503.

68 Coolen, 'Pieter van der Meer de Walcheren', 427- 432.

69. Helman, Vriend Pieter, 210.

70 Daarvoor Zwart Front geheten; de dub van Arnold Meijer.

7 Helman, Vriend Pieter, 209.

n. Ten Have, De Nederlandse Unie, 122.
} 
met hun laarzen trappen "op recht, op moraal, op rede, op deugd, op verstand." Hij haalt hard uit naar de katholieke Maasbode die geschreven heeft dat de nederlaag van Frankrijk te wijten is aan de daar veel gepraktiseerde geboortebeperking: "Het gaat daarom niet aan, aan de betreurenswaardige Fransche onvruchtbaarheid als oorzaak der Fransche nederlaag, de vruchtbaarheid van het nationaal-socialistische Duitschland zegevierend tegenover te stellen."73

De voedingsbodem voor het streven naar een nationale eenheid is in ieder geval uiterst vruchtbaar. Na de verslagenheid en de nederlaag groeit de behoefte om iets te doen. Het streven naar eenheid zou na het verlies van de onafhankelijkheid nog iets van de identiteit in stand kunnen houden, men zou zich af kunnen zetten tegen de verraders van de NSB en het zou de bezetter door een bereidheid tot aanpassing gunstig kunnen stemmen. ${ }^{24}$

Het eenheidsstreven is hét ideaal dat de 'Vernieuwers' in de tweede helft van de jaren dertig nastreven. Nu staan zij met dit ideaal midden in de landelijke aandacht. Van alle organisaties en bewegingen die onder de noemer 'Vernieuwers' te vangen zijn, is Brabantia Nostra al gauw een van de meest actieve. De wortels van het succes van de Nederlandse Unie liggen in de jaren dertig. De gedachten en wensen uit die tijd die Coolen vaak in zijn zaterdagse 'Brieven' verwoordde, krijgen door de bezetting een actuele invulling. Het gaat nu om saamhorigheid, volkseenheid en gemeenschapszin. Vooral hoopt men voorgoed verlost te zijn van de hokjesgeest.

Op 24 juli 1940 wordt de Nederlandse Unie opgericht door het driemanschap De Quay, Van Einthoven en Linthorst Homan. Enkele dagen daarvoor heeft Linthorst Homan de grote zaal van het Concertgebouw in 's-Hertogenbosch toegesproken op een bijeenkomst die georganiseerd is door Brabantia Nostra. Na afloop worden zes coupletten van het Wilhelmus gezongen. ${ }^{75}$ De toestroom van leden is enorm. Men kan nu actief tonen dat men geen lid wil zijn van het fascistische Nationaal Front van Meijer of de nationaal-soci. alistische NSB van Mussert. In oktober staan reeds vierhonderdduizend leden geregistreerd. Het ledental van de Nederlandse Unie loopt tegen het eind van r940 zelfs op tot $600.000 .{ }^{76}$ Het blad Brabantia Nostra doopt zich in augustus 1940 om tot gewestblad van de Nederlandse Unie.

De rijksgeschiedschrijver van oorlog en bezetting in Nederland, L de Jong, heeft gewezen op het verschil in motief tussen het leidend driemanschap van de Unie en de honderdduizenden aangesloten leden. Hij verwijt het driemanschap een verregaande aanpas. sing van Nederland aan de bezetter en aan het Derde Rijk, maar constateert tevens dat de leden in grote aantallen toestroomden om met hun lidmaatschap een daad van verzet te plegen. Het succes van de grote toestroom was dus niet te danken aan het beleid van het driemanschap, maar ontstond volgens hem ondánks hun beleid.

Ten Have heeft deze visie in zijn studie over de Unie afgezwakt. Hij stelt dat het beleid van de Unie de weergave was van de opvattingen van grote delen van de bevolking, en ook van politici. De Unie voerde een tweesporenbeleid met goede en kwade kanten: enerzijds een streven naar onafhankelijkheid, een voorzichtig protest tegen de anti-joodse maatregelen, het stimuleren van een saamhorigheidsgevoel en het fungeren als blok tegen de NSB, en anderzijds verregaande aanpassing door medewerking aan Winterhulp, het instel len van de regel dat joden geen werkend lid konden worden en een antiparlementaire 
gezindheid. ${ }^{n} \mathrm{Al}$ in r94I blijkt dat deze sporen zo uiteen gaan lopen, dat de Unie voor een van de twee zal moeten kiezen. Voor het zou ver zal komen, verbiedt de bezetter de Unie in december r $94 \mathrm{I}$.

We hebben gezien dat Coolen de idealen van de 'Vernieuwers' als saamhorigheid en volkskracht ten volle onderschrijft en ook dat hij de verzuiling en hokjesgeest afwijst. Dat de parlementaire democratie door de Unie niet meer als een strikte noodzakelijkheid wordt beschouwd speelt in de discussies, ook vóór de bezetting, niet zo'n grote rol. Dat de Unie officieel geen enkele verwijzing naar het Oranjehuis maakt, doet Coolen veel meer pijn.

Als ingeburgerd inwoner van Waalre is hij al enige tijd lid van de sociëteit, die bijeen komt in café De Doelen. Hij wordt in de zomer van 1940, zoals veel Nederlanders, lid van een regionale afdeling van de Nederlandse Unie. Het is de eerste maal dat Coolen lid wordt van een massabeweging. Het is niet onwaarschijnlijk dat de leden van de sociëteit elkaar hebben gestimuleerd. Het intensieve verenigingsleven in de Brabantse dorpen en steden blijkt in die tijd een extra stimulans voor de groei van de Unie te zijn geweest, omdat hierdoor de mond-tot-mondreclame nog sneller gaat. Soms worden hele verenigingen tegelijk lid. De afdeling in Waalre staat onder voorzitterschap van ing. H.J.M. Piscaer. De leden vergaderen in groepjes van twintig mensen bij elkaar thuis en houden om beurten een referaat met discussie over een actueel onderwerp en de toekomst van Nederland.

De leden van de sociëteit vormen een hechte clan en dat wordt niet door iedereen als positief beoordeeld. Volgens Zoetmulder zijn ze nogal zelfingenomen ${ }^{78}$ Coolen is goed bevriend met de voorzitter van deze sociëteit, textielfabrikant Van Dijk. Als diens zoon Frans in oktober 1940 trouwt, maakt Coolen een gelegenheidsgedicht, "als tolk van den hechten vriendenkring der Waalresche Sociëteit." Het begint met een aangepast citaat van Vondel en de eerste regels verwijzen naar de oorlog: "Geen Mei van liefde is zoo gestoord geweest, Als d'Uwe door het razend krijgstempeest." ${ }^{\text {79 }}$ Voor Coolen vormt deze kleine kring, naast zijn gezin natuurlijk, een 'oase' in de oorlogstijd.

\section{Hulde van het Provinciaal Genootschap}

Na zijn literaire prijs in I930 en de koninklijke onderscheiding die hij eind augustus 1939 ter gelegenheid van Koninginnedag ontving, valt Coolen in deze eerste bezettingsmaanden voor het eerst een huldiging in het eigen gewest ten deel. Hij krijgt de gouden erepenning van het Provinciaal Genootschap van Kunsten en Wetenschappen in Noord-Brabant. De voorzitter van het Genootschap is Vincent Cleerdin, griffier der Staten en schrijver van geschiedkundige en heemkundige publicaties. Hij kent Coolen al langer en vooral in het laatste jaar voor de oorlog hebben ze veel contact gehad in verband met het werk aan het

73 Coolen, Bevrijd Vaderland, 49-50.

74 Ten Have, De Nederlandse Unie, 136.

75 De Jong, Het Koninkrijk, deel 4b, 500.

76 Ten Have, De Nederlandse Unie, 321.

7 Ten Have, De Nederlandse Unie, 500.

78 Collectie Tij Kools, brief Zoetmulder aan Carel Swinkels, 5 december 1986.

79 WE, typoscript 'Aan het bruidspaar Frans M. van Dijk en Jo L.M. Bazelmans', 22 oktober 1940. 
boek Zóo is Brabant.

Bij de officiële uitreiking in de Statenzaal van het Provinciehuis, het Gouvernements. paleis in Den Bosch, wijst de voorzitter er in zijn toespraak op dat Coolen het Brabantse volk schildert in zijn ware gedaante, "zonder verdoezeling der fouten, maar met de genegenheid van den waren kunstenaar." Hij prijst het Brabantse volk dat in de oorlogsdagen van mei bij haard, huis en hof bleef. Eens zal een kunstenaar dit "welbewuste en onwankelbare blijven" verheerlijken in een kunstwerk, voorspelt Cleerdin. Coolen zegt in zijn dankwoord dat hij, evenals andere schrijvers die vanuit de verbondenheid met een volk schrijven, wel eens bang is dat men hem verkeerd zal verstaan en dat men vindt dat hij te negatief over de Brabanders schrijft. In een metafoor die verwijst naar Les anges noirs van Mauriac, zegt hij dat hij de donkere bladzijden moet schrijven als tegenspel voor de "heldere energieën in de krachten van ons volkschleven [...] waarin de witte engelen onafgebroken den tegenstand der zwarte engelen ondervinden." Die angst verkeerd verstaan te worden is nu verdwenen door de onderscheiding van dit eerbiedwaardig Genootschap. Later, zegt hij, zal hij de penning doorgeven aan zijn zonen met de woorden: "Jongens, ik heb altijd veel van Brabant gehouden, en hier hebt ge het gouden merkteeken, dat het hart van Brabant en het mijne inderdaad sámen hebben geklopt." ${ }^{80}$ De penning is prachtig, schrijft hij aan Oomes, "er zit voor niet minder dan f 350,- aan goud aan." ${ }^{81}$

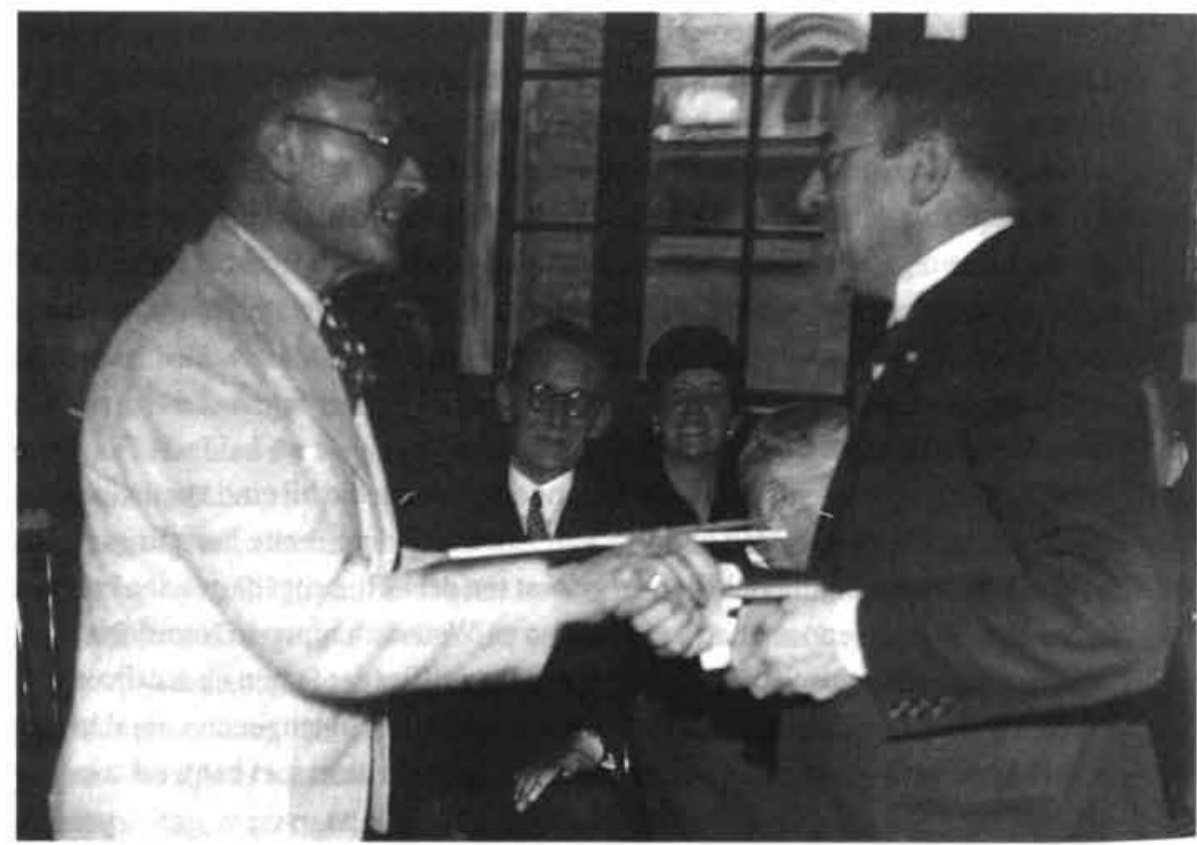

Overhandiging van de prijs van het Provinciaal Genootschap.

In Den Bosch verblijft men nog een uurtje bijeen, "terwijl ververschingen werden aangeboden en onder prettigen kout gebruikt." Enkele dagen later krijgt deze deftige bijeen komst een meer losbandig vervolg in de Waalrese Sociëteit. Hier wordt een gebraden speenvarken op een ladder naar een versierde feesttafel gedragen en Coolen krijgt daarbij een beker ter dronk aangeboden die meer dan een liter inhoud heeft. ${ }^{82}$ 


\section{Een vaderlandslievend verhaal en een literair experiment}

In november 1940 schrijft Coolen het verhaal 'De Zuidwester vertelt' dat in het blad van de Unie wordt gepubliceerd. ${ }^{83} \mathrm{Het}$ is een vaderlandslievend verhaal, waarin de typische aspec. ten van het Nederlandse landschap en de steden en dorpen worden geroemd en dat duidelijk de geest van de Unie ademt. Het bevat veel verwijzingen naar eerdere oorlogen en bezettingen, zoals "weet gij nog, dat Uw Zeeland het Departement van den Scheldemond heette toen Napoleon het gebood zoo te noemen?" en "[...] de vrijheid. Dan ging het om de bevrijding der kwelling van de Fransche bezetting, om de verlossing uit de Spaansche dwingelandij, om uw armslag op zee, om de afschudding van het juk van Napoleon." Wat de zuidwester nu ziet, overtreft echter alles:

"Bij mijn Novemberwederkeren zag ik uw dorpen geteisterd, erger dan ik ze teisteren kan, en van uw steden zag ik er gehavend, erger dan ik ze havenen kan, van uw bruggen zag ik er gekanteld, gestort, gebroken langs de pijlers met den boog in den stroom. Is er een groter storm dan ik ben over u heengegaan? ${ }^{\text {ma }}$

De zuidwester die samen met het water vaak de tegenstander van de Nederlander is, hoopt dat het volk ook in deze storm "dijkzeker" zal blijven staan, zodat ze elkaar nog vaak kunnen bekampen. Het lijkt een curieuze herdenking van een catastrofe zonder de veroorzaker te noemen, maar de goede verstaander zal het begrepen hebben.

Eveneens in november wordt een eigenaardig literair project afgerond met een dineetje in een kelderrestaurant op de Prinsengracht in Amsterdam. "Wel erg sober hoor', schrijft hij aan Oomes, we kregen twee sneetjes brood en één kop koffie. En we waren met zónn drang uitgenodigd. ${ }^{.85}$ Het vindt plaats ter gelegenheid van het verschijnen van Het gele huis te huur, een boek geschreven door tien auteurs. De aanleiding is een verhaal van Bordewijk, geinspireerd op een schilderij van Carel Willink dat een statig grachtenpand voorstelt. ${ }^{\mathrm{B}}{ }^{6}$ De initiatiefnemer, H.J. Smeding, vraagt auteurs met verschillende achtergrond - oud en jong, 'links' en 'rechts', christelijk en niet religieus - zich door dit schilderij te laten inspireren. Aan het boek werken onder andere mee Anna Blaman, die er de oorlogsdagen van mei 1940 in betrekt, Gerard Walschap, Henriëtte van Eyk en Jef Last.

Coolen laat in zijn bijdrage de verteller tegenover het huis wonen en getuige zijn van een akelig voorval. In het buurhuis echter laat hij een gelukkig stel wonen. Het geheel heeft iets van de sfeer van Edgar Allan Poe en van de vorm van de film Rear Window van Hitchcock, waarin ook een verhaal vanuit één camerastandpunt verteld wordt. Deze zelf opgelegde beperking, waarbij de verteller een verhaal moet maken bij datgene wat hij aan de overkant van de gracht zich ziet afspelen, is weer een heel speciale invulling van

80 'Huldiging Antoon Coolen', 91.

81 LMDC, inv. nr. C 3485, brief Coolen aan Oomes, 8 oktober 1940.

82 LMDC, inv. nr. C 3485, brief Coolen aan Oomes, 20 november 1940.

83 Dit is eigenlijk het voormalige Brabantia Nostra. Het blad heet nu De Nederlandse Unie. Uitgave voor het gewest Brabant. Het verhaal wordt later ook opgenomen in Coolen, Bevrijd Vaderland, 59-61 en daarna in: Nieskens en Scheurs, Het Vaderland spreekt tot de jeugd, 135-139.

84 Coolen, Bevrijd Vaderland, 60-6l.

85 LMDC, inv. nr. C 3485, brief Coolen aan Oomes, 8 oktober 1940.

B6 Het verhaal van Bordewijk was gepubliceerd in De Groene Amsterdammer van 9 december 1939 
Coolens stijl: de verteller is getuige en deelgenoot van gebeurtenissen zonder de achtergrond en de motieven van zijn personages te kennen. Eigenlijk schrijft Coolen op dezelfde manier als toen hij in zijn peelromans de dorpelingen liet gissen naar de achtergronden van de notaris, de dokter en de zwervers.

Smeding had gedacht dat iedere auteur in zijn eigen sfeer zou schrijven en hij was benieuwd hoe bijvoorbeeld een 'dorps' schrijver als Coolen zo'n uitermate 'stads' onderwerp zou behandelen. Hij verwachtte zoiets als een katholiek meisje uit de Peel dat in het huis dienstmeisje zou worden en dat dan "na vele innerlijke kwellingen of dwaze ervaringen" weer dit huis zou ontvluchten. Coolen heeft er echter een totaal ander verhaal van gemaakt en bewijst daarmee volgens Smeding zijn kunstenaarschap. Hij vindt de bijdrage van Coolen niet specifiek katholiek, "ofschoon hij naast het benauwende, onheilspellende en tevens schijnheilige een licht en teer element geeft: het andere gelukkige paar in het huis er naast."

De huldiging en de dineetjes werken de 'doffe onlust' bij Coolen niet weg. De oorlog en de bezetting grijpen hem erg aan en ontnemen hem de lust en de creativiteit voor het opzetten van een nieuwe roman. Hij trekt zich terug in 'de schuilkelder van de geest'. 


\section{De Kultuurkamer}

"Mijn standpunt is: principieel en volstrekt weigeren."

$1940-1942$

\section{Partij kiezen}

De posities van Coolen en Van Duinkerken zijn aan het begin van de bezetting heel verschillend. De bezettende macht staat vriendelijk tegenover het werk van Coolen en laat dat al gauw merken. Hij hoeft maar toe te geven om tot een gevierd schrijver van de nieuwe orde te worden verheven. Een Duitse vertaling van Herberg In 't Misverstand staat op het punt van verschijnen. Ook na zijn weigering van de Rembrandtprijs zullen er nog toenaderingspogingen komen vanuit Duitsland.

Bij Van Duinkerken ligt de zaak anders. Hij heeft zich in De Gemeenschap regelmatig negatief uitgelaten over het nationaal-socialisme en heeft nu zelfs de moed om op verzoek van Anthonie Donker in het juninummer van Critisch Bulletin Menno Ter Braak te herdenken, nadat vrienden van deze overleden nazi-hater geweigerd hebben uit angst zich verdacht te maken bij de bezetter.' Het is niet zeker of Van Duinkerken op dat moment al bij de Duitsers te boek staat als tegenstander van hun ideologie, maar hij heeft genoeg Nederlandse tegenstanders die dat met genoegen bekend willen maken.

De schriftelijke contacten tussen Coolen en Van Duinkerken waren de laatste jaren al schaars en heel onregelmatig. Na de meidagen hebben ze naar elkaars wel en wee geinnformeerd, maar verder beperken ze zich tot redactionele zaken voor De Gemeenschap. In de zomer van 1940 hebben ze elkaar enkele keren ontmoet, onder meer in Amsterdam in het Americain. Bij die gelegenheid heeft Coolen hem in een bepaalde zaak om advies gevraagd. Kort daarna verwijt hij Van Duinkerken dat hij met die informatie indiscreet omspringt. ${ }^{2}$ Van Duinkerken antwoordt dat hij niet indiscreet heeft willen zijn. Hij heeft, toen de zaak eenmaal beklonken was, er die ruchtbaarheid aangegeven die hij gewenst achtte, soms als verweer tegen praatjes, maar meestal gewoon als feit. "Op de eerste wijze heb ik het verteld an leden van Nationaal Front, in tegenwoordigheid van Kuyle en Meijer. Op de tweede wijze aan verscheidene litteratoren. Het zou mij spijten, als ik daarin verder ging dan je bedoeling was." ${ }^{3}$

Waarin heeft Coolen advies gevraagd? Er zijn geen verdere gegevens over, maar het is zeer waarschijnlijk dat er in juni aan hem getrokken wordt om lid te worden van Nationaal Front. Al in april 1940 heeft Arnold Meijer zijn organisatie Zwart Front omgedoopt tot Nationaal Front. In de maand juni, nog vóór de Nederlandse Unie van de grond komt, legt hij contacten met Brabantia Nostra en met vooraanstaande Brabanders, om hen te bewegen zich aan te sluiten bij Nationaal Front als tegenbeweging tegen de NSB. Van Oudheusden beschrijft hoe deze besprekingen negatief voor Meijer verlopen, onder meer

1 Van der Plas, Doarom, mijnheer, 283.

2 BA, brief Coolen aan Van Duinkerken, 24 augustus 1940.

3 BA, brief Van Duinkerken aan Coolen, 29 augustus 1940. 
omdat dan juist de nieuwe beweging van de Nederlandse Unie aan het opkomen is, Diverse leden van Brabantia Nostra kiezen echter wel voor het Front. Zo wordt Kees Spierings, de bewerker van Kinderen van ons volk tot toneelspel, gewestleider van Nationaal Front van het district Den Bosch.

Ook Van Duinkerken is in die tijd benaderd om toe te treden. ${ }^{5}$ Het ligt voor de hand dat deze vraag ook aan Coolen is gesteld. Het meest waarschijnlijk is dat Coolen na weigering besloten heeft om wél plaatselijk kaderlid te worden van de Nederlandse Unie. Coolen is niet zo gewend om partij te kiezen en heeft daarom advies gevraagd aan Van Duinkerken. Het meest voor de hand liggend is dat deze tegen Coolen gezegd heeft dat hij dat rustig kan doen. Vervolgens, als het lidmaatschap 'beklonken' is, zal Van Duinkerken tegen diverse mensen gezegd hebben dat Coolen lid is van de Unie, of dat hij in ieder geval géén lid is van Nationaal Front.

Van Duinkerken zelf gaat een moeilijk najaar tegemoet. Zijn inaugurale rede in Leiden bij de aanvaarding van zijn zwaar bekritiseerde Vondel-leerstoel op II oktober I 940 houdt hij voor een vrijwel lege aula, waar voornamelijk familie aanwezig is. ${ }^{6}$ Enkele maanden later, in de kerstnacht, sterft zijn vader. Uit de mooie condoleancebrief die Coolen schrijft, blijkt dat hij niet aanwezig is geweest in Leiden, terwijl hij dat aanvankelijk wel van plan was, want in augustus schreef hij nog aan mederedactielid De Bourbon dat ze elkaar zouden zien bij de oratie van "professor Toon." Coolen prijst in zijn condoleance de goede verhouding tussen Van Duinkerken en zijn vader: "De trots, dien hij in jou stelde, was een beminnelijke deugd in hem, waarvan ik al de stralende warmte gevoelde bij de promotieplechtigheid in Leuven en waarover Piet Oomes mij schreef in zijn brief over de plechtig. heid van je inaugurele rede in Leiden." ${ }^{\text {7 }}$ Hij wenst Van Duinkerken veel sterkte in "dezen grauwen en rampzaligen tijd." Coolen heeft de begrafenis niet kunnen bijwonen, omdat de rouwbrief te laat kwam; die was namelijk geadresseerd aan huize de Kamp in Eindhoven ${ }^{18}$ Bovendien moest hij diezelfde avond naar Grave voor een lezing.

Kort daarvoor heeft Coolen in een brief die over een bestelling van meubels gaat, terloops aan Oomes geschreven dat hij de ariërverklaring heeft getekend:

"Dat ge ook al met die verboden te maken hebt! Vanmorgen heb ik als lid van de bra. bantsche monumentencommissie een verklaring geteekend, dat ik geen Jood ben, dat noch mijn vrouw een Jodin is, dat naar mijn weten, noch een van onze beide ouders of grootouders ooit Joodsch geweest zouden zijn. Maar gij zult ook zoiets hebben moeten teekenen? Ook dit is te onzer vriendelijke beslissing. In Der Stürmer las ik eens: 'Schön im Mutterleibe ist der Jude ein Verbrecher,' groeten."

Waarschijnlijk wil Coolen met dit citaat het absurde van de maatregel aangeven. De Nederlandse autoriteiten sporen aan om de verklaring te ondertekenen. De Leidse hoogleraren die aanvankelijk willen weigeren worden door de Leidse burgemeester (namens de Seceretarissen-Generaal) verzocht te tekenen en eventueel een protest bij te voegen. De initiator van de weigering, professor Cleveringa, gaat ook overstag. Hij houdt enkele weken later een protestrede tegen het ontslag van een joodse collega, waarop de universiteit gesloten wordt. ${ }^{10}$ Griffier Cleerdin zal bij Coolen aangedrongen hebben op ondertekening. In zijn correspondentie met Van Duinkerken en De Bourbon rept hij er echter met geen woord over. Blijkbaar voelt hij zich toch ongemakkelijk over deze ondertekening. Persoonlijke uitnodigingen van de Duitsers heeft Coolen afgeslagen met het formele argu 
ment dat zij Nederland wederrechtelijk hebben bezet. Voor de immense gevolgen die de administratieve scheiding van joden en niet-joden inhoudt, heeft hij kennelijk minder oog, zoals veel Nederlanders op dat moment.

\section{Louis de Bourbon burgemeester van Oss}

In de eerste oorlogsmaanden vindt Coolen in Louis de Bourbon steeds meer een geestverwant. Ook deze kiest voor de oase van het eigen huis als de oorlogsdreiging groter wordt, zoals blijkt uit een gedicht van zijn hand in De Gemeenschap: "Daarbuiten gieren de stormen, / er staat tusschen oosten en westen/ een schaduw met grillige vormen, / en brand woedt in vele gewesten. / Laat mij van de binnenkameren/ de deuren en ramen sluiten, / mijn oude boeken verzamelen/ en niets meer vernemen van buiten. "11

Deze houding van zich afsluiten voor de buitenwereld is tekenend voor de sfeer van het blad De Gemeenschap. Vanaf 1934 heeft de redactie regelmatig een anti-nazigeluid laten horen dat echter meer gericht was op het verdedigen van het geloof en de cultuur dan dat het voortkwam uit de behoefte om de democratie te verdedigen. In tegenstelling tot Joosten, die beweert dat de redactie van De Gemeenschap tot het einde (194I) in deze antinazihouding volhardt, stelt Scholten dat het blad al vanaf 1936 steeds meer de neiging heeft over niet-actuele zaken te schrijven en "in een boven-aards en -tijdelijk perspectief over de actuele rampspoed heen te blikken."12

In een brief van Coolen aan De Bourbon in augustus 1940 is hiervan een weerklank te vinden. Na een opsomming van onheilstijdingen over de gevolgen van de bezetting, zoals de terugloop van zijn inkomsten en vooral de geestelijke druk, denkt ook hij dat er na deze moeilijke tijd "iets schooners" zal aanbreken. Hij wijst op de donkere Middeleeuwen die daarna de Renaissance opleverden, en op de bloedige Franse Revolutie die achteraf voor de maatschappij toch ook een zegen blijkt te zijn geweest. ${ }^{13}$ Coolen staat met deze gedachtegang op het eerste gezicht dicht bij de medewerkers van De Gemeenschap, een zekere PC en mr. D. van Deurne. Zij bezien de situatie na de inval beslist niet perspectiefloos en hopen dat er binnen deze nieuwe orde veel zaken in Nederland radicaal veranderd kunnen worden. Zij constateren tevreden dat maatschappij en gezin ondermijnende clubjes als de neomalthusiaanse bond snel verdwenen zijn uit angst voor de bezetter. ${ }^{14}$ Ook in de rechtervleugel van de Nederlandsche Unie zijn deze geluiden te horen.

Toch is er een belangrijk verschil. Coolen is zo verontwaardigd over de gewelddadige en onrechtmatige overval van Duitsland op een 'onzijdig' klein Nederland, dat hij geen

Van Oudheusden, Brabantia Nostra, 250-253.

Van der Plas, Daarom, mijnheer, 288.

Van der Plas, Daarom, mijnheer, 287.

BA, brief Coolen aan Van Duinkerken, 30 december 1940.

Waarschijnlijk weer een symptoom van Van Duinkerkens slordigheid.

LMDC, inv, nr. C 3485, brief Coolen aan Oomes, 12 december 1940.

De Jong, Het Koninkrijk, deel 4, 794.

De Bourbon, 'Inkeer'.

Scholten, Aspecten, 290-291.

3 LMDC, inv, nr. C 3485, brief Coolen aan De Bourbon, 12 augustus 1940.

Scholten, Aspecten, 166. 
zaken wil doen met de bezetter. Bij hem gaat het eerder om een geloof in een andere, betere maatschappij in een naoorlogs Nederland zonder Duitse machthebbers. De oorlog en de bezetting brengen een schok teweeg, die er hopelijk toe zal leiden dat Nederland daarna kan herrijzen als een frisse natie zonder de verkalkte structuren en zuilen.

Coolen adviseert De Bourbon bij diens literaire werk en doet een goed woordje voor hem bij uitgeverij Kosmos, waar hij in de jury van de debutantenprijs zit. ${ }^{15}$ Met veel plezier schrijft Coolen in november r 940 dat hij een brief van Kippenberg van Insel Verlag heeft gehad met de mededeling, dat de eerste druk van Das Wirtshaus zur Zwietracht van vijfduizend exemplaren vrijwel meteen is uitverkocht en dat een tweede druk in voorbereiding is. ${ }^{16}$ De Bourbon zorgt op zijn beurt voor een uitnodiging voor een lezing in Grave. Dit is de lezing op de avond van de begrafenis van vader Asselbergs. De Coolens zullen logeren bij De Bourbons, maar dit verhindert niet dat Coolen zakelijk blijft over het honorarium. Dat moet veertig gulden bedragen, "want $\mathrm{f} 20$,- is naar den bescheiden kant."

Uit die intensieve correspondentie blijkt ook waar Coolen zelf op dat moment mee bezig is en hoe gedegen hij zijn verhalen documenteert: "Weet jij in je omgeving misschien vlák langs de Maas een nonnenklooster? Zoo niet zou je dan misschien even voor me kunnen informeeren, welke nonnen indertijd in het kasteel van Dussen zijn geweest? 't Is voor de situeering van een kerstverhaal, waarmee ik bezig ben, dus ik had wel graag hierop gauw een antwoord. ${ }^{18} \mathrm{Ze}$ wisselen intensief ervaringen uit over lezen en schrijven. De sfeer lijkt een beetje op die van de eerste jaren van de vriendschap met Van Duinkerken. Coolen leent het gezinsboek met daarin zijn verhaal 'De Boer en zijn kerkplavei' aan hem uit en is zeer benieuwd naar De Bourbons mening over Tribulat Bonhomet van de negentiende-eeuwse Franse schrijver Villiers de l' Isle-Adam. Het is juist dit boek waar Van Duinkerken hem in het begin van hun vriendschap op heeft gewezen en dat Coolen toen "bijtend-mooi, hard en wrang mooi bitter en wreed mooi" noemde. Coolen heeft nu op let. terkundig gebied zelf de rol van raadgever. Hij adviseert De Bourbon steeds bij zijn plannen voor artikelen en boeken, spreekt hem moed in en houdt hem voor, zich niet te laten ont moedigen door onwillige uitgevers. Hij schrijft een inleiding voor een boek van De Bourbon, Twaalf maal Azie. ${ }^{19}$

Coolen gaat zich helemaal aan sprookjes wijden. Voor de gelijkgeschakelde kranten schrijft hij principieel niet meer, voegt hij eraan toe. Kennelijk heeft Coolen al iets vernomen van de plannen tot de oprichting van een Kultuurraad en een Kultuurkamer met gil den voor de verschillende kunstdisciplines. Daarbij circuleert ook zijn naam, want hij meldt uitdrukkelijk aan zijn vriend dat hij principieel niet zal toetreden tot het Letterengilde. $^{20}$

De neiging tot afzijdigheid, die zijn eerder aangehaalde gedicht suggereert, brengt De Bourbon niet in praktijk. Hij is op dat moment nog burgemeester van Escharen, maar solliciteert eind 1940 naar een grotere gemeente, die bovendien de laatste jaren vaak en nega tief in het nieuws is geweest: het sterk geïndustrialiseerde Oss. De Bourbon onderhoudt evenals Coolen nauwe contacten met Vincent Cleerdin, de griffier der Staten van de provincie Brabant. Deze vervult een belangrijke functie bij burgemeestersbenoemingen. De Bourbon schrijft zelf veel later in een brief aan Van Duinkerken dat hij op aandringen van Cleerdin en de Commissaris der Provincie, Van Rijckevorsel, solliciteerde naar het burge meesterschap van Oss. Zij zouden een dringend beroep op hem hebben gedaan om Oss 
aldus uit de greep van de NSB te houden. Er was al een NSB-er voorgedragen bij de secretaris-generaal mr. Frederiks, maar De Bourbon had bij de Beauftragte der Provinz, dr. Ritterbusch, zo'n koninklijke indruk achtergelaten dat hij de benoeming kreeg. Volgens Cleerdin had Ritterbusch gezegd: "Man sieht ihm den königlichen Ursprung aus den Gebärden und man hört es aus seiner Stimme und aus seinen Worten." ${ }^{21}$

Coolen leeft zeer mee en is nieuwsgierig naar de uitslag van de sollicitatie van De Bourbon naar het burgemeesterschap van Oss. ${ }^{22}$ Als de benoeming begin april I94I bekend wordt gemaakt, reageert Coolen zeer enthousiast, maar tegelijk ook bezorgd. ${ }^{23} \mathrm{Hij}$ is niet zozeer verontrust, omdat De Bourbon deze promotie te beurt valt onder Duitse bezetting, maar veel meer door het kwetsbare van die positie. ${ }^{24}$ Coolen herinnert hem eraan hoe de vorige burgemeester van Oss het mikpunt van spot was voor de hele pers en daarmee de Brabantse eer bezoedelde in de zogenoemde Osse kwestie. ${ }^{25}$ Opnieuw hekelt hij de gelijkgeschakelde pers. Cynisch merkt hij op dat de kranten voor de oorlog een paar

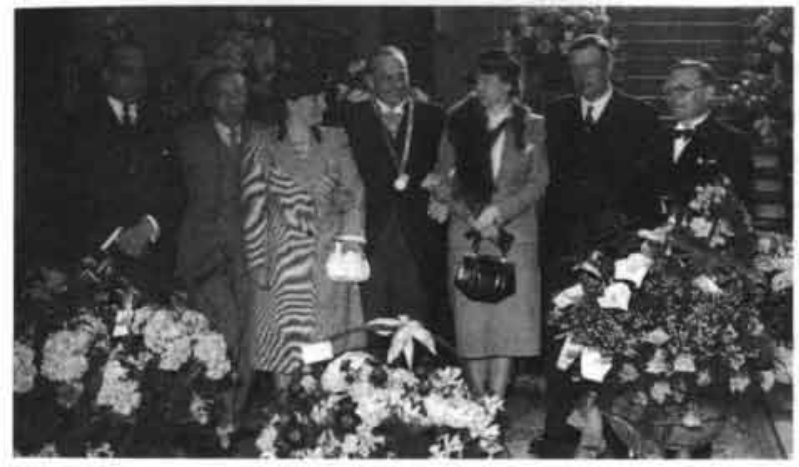

De inhuldiging van Louis de Bourbon in Oss. Van links naar rechts Jan Engelman, C. Vos, mevrouw de Bourbon, Louis de Bourbon, Gerda Coolen-de Jong, Antoon van Duinkerken en Antoon Coolen. jaar met die kwestie zijn bezig geweest, terwijl ze nu onder de bezetter zeer gehoorzaam zijn en elke vorm van debat vermijden. De kranten accepteren de dictaten die ze opgelegd krijgen. Coolen prijst Oss als een goed en nijver stadje en memoreert de boeken van de overleden archivaris Cunen, waaraan hij in de Bossche krant

15. LMDC, inv, nr. C. 3485, brieven Coolen aan De Bourbon, 3 september en 26 november 1940.

16 LMDC, inv. nr. C 3485, brief Coolen aan De Bourbon, 10 november 1940.

17 LMDC, inv. nr. C 3485, brief Coolen aan De Bourbon, 26 november 1940.

18 LMDC, inv, nr. C 3485, brief Coolen aan De Bourbon, 17 december 1940. Het kerstverhaal met de nonnen vlak aan de Maas is er niet van gekomen. Het kasteel in Dussen zal later als een van de inspiratiebronnen dienen voor De vrouw met de zes slapers.

19 Verschenen bij Amsterdamsche Boek- en Courantmaatschappii, 1941.

20 LMDC, inv. nr. C 3485, brief Coolen aan De Bourbon, 15 april 1941.

21 LMDC, inv. nr. B 783, brief De Bourbon aan Van Duinkerken, 3 april 1959.

22 LMDC, inv. nr. C 3485, brief Coolen aan De Bourbon, 21 februari 1941.

23 LMDC, inv. nr. C 3485, brief Coolen aan De Bourbon, 28 april 1941.

24 Het begrip 'burgemeester in oorlogstijd' bestaat dan nog niet; dit is pas na de oorlog ontstaan. Men onderscheidt tijdens de oorlog goede en foute (lees NSB-) burgemeesters.

25 In Oss was in de jaren dertig een bende actief (met als een van de bekendste leden Toon de Soep). De plaatselijke politie kreeg versterking van de marechaussee. Deze rolde de bende op, maar maakte zich gehaat bij de bevolking. Toen de marechaussee een geval van seksueel misbruik meende te ontdekken warbij de clerus en een joodse fabrikant zouden zijn betrokken, werd dit een nationale rel met antisemitische trekken. De katholieke minister Goseling, die de marechaussee daarna overplaatste, moest eind jaren dertig onder druk van de Kamer aftreden. 
vaak aandacht heeft geschonken. Coolen is in september aanwezig bij de installatieplechtigheid van De Bourbon als burgemeester van Oss.

Op dat moment is de positie van een burgemeester al grondig gewijzigd. Vanaf I septem. ber $194 \mathrm{I}$ is het zogenoemde leidersbeginsel in de besturen van provincies en gemeenten ingevoerd. Deze Duitse verordening houdt in dat gemeenteraden en provinciale staten worden opgeheven. Lokale wethouders en provinciale gedeputeerden worden zo gereduceerd tot medewerkers van respectievelijk de burgemeesters en de provinciaal Commissarissen. ${ }^{26}$ De burgemeesters komen onder toezicht te staan van de Commissaris der Provincie, maar de secretaris-generaal van Binnenlandse Zaken, mr. Frederiks, is te allen tijde bevoegd om aanwijzingen te geven. Deze Frederiks had wel de verordening aan. vaard, maar was anti-NSB. Hij verwachtte dat Nederland weer vrij zou worden en dat dan een aantal verkalkte vooroorlogse toestanden verdwenen zou zijn. ${ }^{27}$ Een willoos werktuig was hij bepaald niet. Zo heeft hij van april 194 I tot februari 1942 , tegen de zin van de nationaal-socialistische Commissaris der Provincie Utrecht, de benoeming van een NSB-burgemeester voor Amersfoort tegengehouden. Tenslotte wordt door ingrijpen van de Rijkscommissaris de NSB-benoeming doorgedrukt. ${ }^{28}$ De gedeputeerden die opstapten gaven vaak aan de ambtenaren van de provincie de raad om te blijven zitten, omdat hun werk niet van politieke aard was, maar meer een technisch en administratief karakter droeg.

In de provincie Noord-Brabant lag de situatie iets anders. De Commissaris Van Rijckevorsel en zijn gedeputeerden trokken zich van de verordening niet veel aan. In verband met de sfeer in de provincie is het rapport van belang dat de Beauftragte in Den Bosch schrijft over Van Rijckevorsel:

"Hij voert de politiek van de kerk en van de koningin uit. Men kan hem blijven bewonderen, hoe handig hij dat doet. [...] Hij wil zo lang mogelijk zijn positie behouden omdat hij het spel nog niet als ten gunste van Duitsland beslist beschouwt en omdat de kerk van hem verlangt vol te houden. Hij is een opmerkelijke tegenspeler, geestelijk buig. zaam, diplomatiek geslepen - een man die het masker draagt dat hij wil dragen [.... als deze man valt, zal veel verzet in de provincie gebroken zijn." ${ }^{29}$

\section{Schrijven, vertalen, redigeren}

De Bourbon wordt in Oss met vreugde ingehaald. Nog in de maand van zijn installatie voeren amateurs een toneelstuk op dat eerder geschreven was door hun pas benoemde burgemeester. Coolen is daarbij aanwezig, maar hij vindt het stuk niet zo goed. "Te weinig handeling en in de dialoog te veel lyriek," schrijft hij en dat ligt niet aan de amateurtoneelspelers, maar aan het stuk. ${ }^{30}$ Hier hoort men de gearriveerde schrijver zijn tien jaar jongere collega beoordelen. Het is des te meer opvallend, omdat juist op het toneelwerk van Coolen zelf vaak dit soort kritiek is gekomen: te traag, te literair, te weinig handeling, te uitgesponnen lyrisch. Er zou ook een gevoel van jaloezie achter kunnen zitten. De Bourbon heeft een prachtige positie en doet het literaire er als 'hobby' bij, terwijl Coolen. de gevierde schrijver, niet meer toe komt aan het 'grote werk' en ook geen maatschappelijke positie meer heeft. 


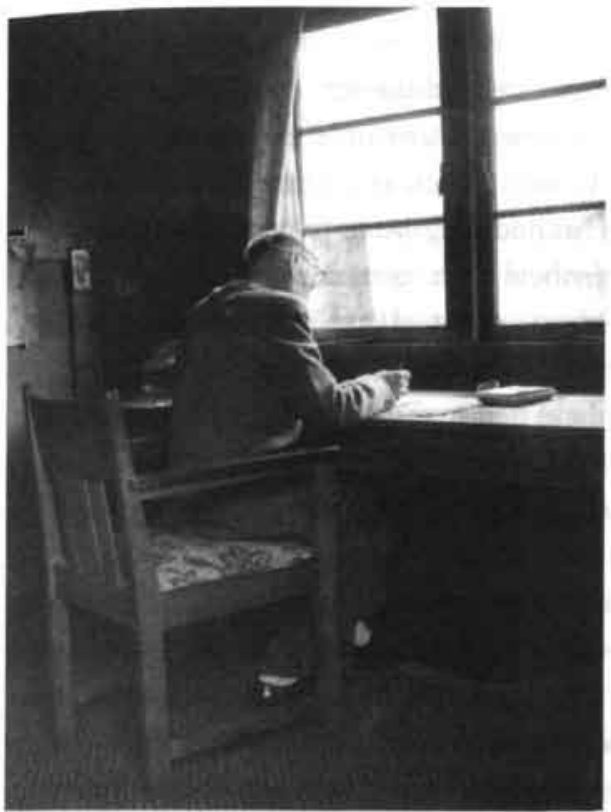

Coolen in zijn schrijfhut.

Coolen moet van zijn pen leven en gaat stug door met zijn letterkundige activiteiten. In september $194 \mathrm{I}$ is de sprookjesbundel gereed. Daarnaast werft hij op verzoek van de uitgeverij Kosmos medewerkers voor een boek over 'Land en Volk van Noord-Brabant'. Hij vraagt Van Duinkerken en A.M. de Jong en meldt dat het geheel met foto's van Martien Coppens zal worden geillustreerd. ${ }^{31} \mathrm{Het}$ feit dat hij de socialistisch georiënteerde De Jong vraagt, illustreert hoe tijdens de bezetting de grenzen tussen de zuilen vervagen.

Op uitnodiging van Godfried Bomans neemt hij deel aan de redactie van een complete Dickensvertaling voor het Spectrum. Coolen zal- bijna vanzelfsprekend vanwege zijn bekendheid als schrijver van kerstverhalen - Christmas Carols voor zijn rekening nemen. Deze vertaalopdracht schept de mogelijkheid om inkomsten te hebben zonder bij het Letterengilde te zijn aangesloten. De eerste bijeenkomst van alle vertalers onder voorzitterschap van Bomans vindt plaats in het Parkhotel te Amsterdam op 21 oktober 194I. De jeugdige Bomans is een bewonderaar van Coolen. In de uitnodigingsbrief zegt hij dat hij het boekje Uit het kleine rijk in donkere dagen gelezen heeft en dat het hem toen de suggestie van zomerlicht heeft gegeven. Hij zou het graag met Sinterklaas geven aan het meisje waarmee hij gaat trouwen, maar kan het in Nijmegen nergens vinden. ${ }^{32}$ Coolen stuurt hem prompt een exemplaar met opdracht. De onstuimige Bomans kan niet wachten tot Sinterklaas; zijn meisje leest hem er nu elke dag uit voor "alsof het de Gewijde Boeken der Openbaring" zijn. ${ }^{33}$

Later in december 194I komt Bomans, na een lezing in Helmond, nog bij Coolen op bezoek na zich door "het voltallig personeel" van het hotel te hebben laten uitleggen hoe hij in Waalre kan komen. Met ironie vertelt hij dat er veel beroemdheden zijn in Helmond, onder andere Ad. Sassen, de vroegere medewerker van De Nieuwe Gemeenschap, interviewer van Coolen. Deze Sassen ontpopt zich nu als adviseur van de Cultuurkamer en heeft Bomans met trots het 'sippeteeken' van zijn familie laten zien. ${ }^{34}$

26 De Jong, Het Koninkrijk, deel 5a, 238.

27 De Jong, Het Koninkrijk, deel 5a, 240.

28 Hillenius, 'Bezettingstijd'.

29 De Jong, Het Koninkrijk, deel 5, 242. Het gaat over een rapportage van eind 1941.

30 LMDC, inv. nr. C 3485, brief Coolen aan De Bourbon, 24 oktober 1941.

31 Het boek zal echter pas in 1950 verschijnen.

32 FPC, kopie brief Bomans aan Coolen, 15 oktober 1941.

33 FPC, kopie brief Bomans aan Coolen, 12 november 1941.

34 FPC, kopie brief Bomans aan Coolen vanuit Hotel Tilburg' te Helmond, 19 december 1941. 


\section{Duitse toenaderingen}

In de loop van dit eerste bezettingsjaar wordt het steeds duidelijker dat er een moment zal komen, waarop elke schrijver zich voor of tegen de 'nieuwe orde' zal moeten uitspreken. $\mathrm{Na}$ zijn weigering om de Rembrandtprijs te aanvaarden is Coolen kennelijk nog niet meteen uit de gratie. Hij krijgt nog een uitnodiging voor "einen Tee-empfang" bij Rijkscommissaris Seyss-Inquart ter gelegenheid van een concert van de Weense Staatsopera en het Weens Philharmonisch Orkest op kasteel Oud-Wassenaar op 17 oktober $1940 .{ }^{35}$ Coolen gaat er echter niet op in. "Achteraf betreur ik het een beetje, die uitnodiging niet aangenomen te hebben en de gelegenheid den man te zien, te hebben verzuimd," schrijft hij later in Bevrijd Vaderland. ${ }^{36}$ Zo'n uitnodiging is eigenlijk een belediging, voegt hij eraan toe, want hoe kun je iemand uitnodigen in zijn eigen land dat je enkele maanden daarvoor met geweld bezet hebt.

Toch geven de machthebbers de pogingen niet op om Coolen aan zich te binden. Na het afslaan van deze uitnodiging volgt in het voorjaar van $194 \mathrm{I}$ een derde poging. In $\mathrm{I} 94 \mathrm{I}$ komt dr. Edgar Schmidt-Burgk, cultuurintendant van de Rijkscommissaris, bij Coolen op bezoek. Hij nodigt hem uit om in Keulen een letterkundige voordracht te houden in het kader van de Nederlandse kunstweek aldaar. De intendant is vergezeld van een "beginnend, jong, zwak schrijver, Nederlander en nogal warhoofdig," schrijft Coolen in zijn oorlogsdagboek. ${ }^{37}$ Coolen heeft Schmidt-Burgk ontmoet toen hij in 1937 de première bijwoonde van de Duitse versie van zijn toneelstuk De Vreemdeling in Aken, waarbij de regisseur op het podium Coolens arm omhoog trok voor de Hitlergroet. Wanneer Coolen ook weigert op deze uitnodiging in te gaan, wordt de toon van de intendant dreigender. Deze zegt dat de autoriteiten al lang genoeg geduld met hem hebben gehad, dat het eigenlijk al te laat is, "maar dat men mij [Coolen, C.S.] nog in de gelegenheid wil stellen mijn keuze te doen."

De discussie die hierop volgt heeft Coolen zelf weergegeven in zijn oorlogsdagboek, Bevrijd Vaderland. Coolen bestrijdt de beschuldiging van de cultuurintendant dat Nederland altijd tegen Duitsland is geweest. Coolen betoogt dat, vóórdat Duitsland zich massaal tot het nationaal-socialisme bekeerde, er nauwelijks een kloof was tussen beide landen. Hij wijst op de vele Wagner- en Bachverenigingen, de UFA-films die in de bioscopen draaiden en de operatrein naar Duisburg. Ook de pers, waartegen nu zo'n hetze-propaganda wordt gemaakt, was helemaal niet zo anti-Duits vóór de bezetting. Voor het huidige Duitsland kan echter geen Nederlander kiezen zonder zijn geweten geweld aan te doen, zegt Coolen, waarop de meegekomen Nederlandse schrijver hem toebijt: "Dank u." Coolen motiveert waarom hij niet naar Duitsland kan gaan: "Gij zijt ons land binnen gevallen en houdt het bezet onder een valsch voorwendsel. Uw bezetting heeft zich tijdens haar duur ontwikkeld tot een catastrophale uitputtingsramp voor ons volk en ons land, dat gij uitholt." Hij refereert vervolgens aan de woorden van de Rijkscommissaris zelf, dat culturele betrekkingen tussen landen slechts mogelijk zijn voor twee volkomen vrije volken. "En wij zijn niet vrij, niet alleen door het zeer autoritaire gezag van den bezetter, maar ook niet door het opdringen aan ons leven van de nationaalsocialistische levensbeschouwing, ook weer tegen de uitdrukkelijke belofte van den rijkscommissaris in."

Schmidt-Burgk bestrijdt vervolgens dat Duitsland onder een vals voorwendsel Nederland is binnengevallen. Het was de bedoeling ons land tegen Engeland te beschermen. Het feit dat Nederland als enig bezet land een Rijkscommissaris en een burgerlijk 
bestuur (Zivil-Verwaltung) heeft gekregen, bewijst dat Duitsland goede bedoelingen met Nederland heeft. Wie meestrijdt heeft later voordeel van de Duitse overwinning, wie zich afzijdig houdt krijgt geen kans meer, zegt hij. Tot tweemaal toe vraagt hij of Coolen de consequenties van zijn keuze overziet. Na met minachting gesproken te hebben over Coolens keuze - "een vlucht in 't sprookje" - wil hij het gesprek toch nog vriendelijk laten eindigen met het verzoek er nog eens over na te denken en de beslissing schriftelijk te melden. Coolen zegt dat dat niet nodig is, want zijn standpunt staat vast. Hij geeft te verstaan dat hij afwijzend staat tegenover een te vormen letterengilde. Relativerend besluit Coolen dit hoofdstuk met een dialoogje met zijn op één na jongste zoon Felix:

"Hij heeft tusschen vader en moeder na het vertrek der heeren een woord opgevangen, en vraagt mij nu:

-Vader, u wordt toch geen lid van de cultuurkamer?

- Neen jongen.

-Want wij sterven liever, hè vader?"

We moeten er ons van bewust zijn, dat Coolen de eindredactie van dit dagboek pas voltooit in 1945 . Voor de lezer van ruim een halve eeuw later klinkt het al weer anders dan voor iemand die zojuist de bevrijding achter de rug heeft. Uit het verslag blijkt in ieder geval dat Coolen zijn principiële argument, dat hij in mei r 940 tegen Töpfer naar voren bracht, handhaaft. Hij spoort ook anderen aan om niet mee te doen aan nazi-organisaties. De schilder Peter van den Braken, de jeugdvriend uit de Eindhovense en Maastrichtse tijd, heeft gevraagd of Coolen een tentoonstelling van hem wil openen. Als hij Coolen daarna meedeelt dat hij een afwijzend standpunt tegenover het gilde voor Bouwkunst, Beeldende Kunsten en Kunstnijverheid heeft ingenomen, antwoordt Coolen in mei r94I:

"Dit standpunt en geen ander moeten wij innemen, zelfs al komen we op een verloren post te staan. Ik heb hetzelfde standpunt ingenomen toen ik een uitnoodiging van den cultuurintendant van den rijkscommissaris principieel weigerde en toen ik een verzoek om toetreding tot het letterengilde principieel afwees. ${ }^{38}$

Kennelijk was het geduld van de bezetters met de weigerachtige Coolen nog niet uitgeput. Al snel krijgt Coolen wéér een Duitse uitnodiging, nu rechtstreeks van de directeur van het Bremer Schauspielhaus, dr. H. Koch. ${ }^{39}$ Voor de opening van het nieuwe seizoen zal op 22 augustus 194I de première van een nieuwe uitvoering van De Vreemdeling plaatsvinden. De titelrol wordt weer gespeeld door Wolfgang Engels, die ook bij de eerste opvoering in Freiburg deze rol speelde. Zoals elk jaar, schrijft Koch, heeft het Bremer Schauspielhaus bij de start van een seizoen een representatief werk gekozen "das richtunggebend für die ganze künstlerische Arbeit des neuen Jahres sein soll." De burgemeester en de senaat van Bremen zullen ook aanwezig zijn en met dezelfde post is ook Coolens uitgever Kippenberg uitgenodigd. Deze eerste brief van 6 augustus wordt al na vijf dagen gevolgd door een twee-

35 FPC, Originele uitnodiging.

36 Coolen, Bevrijd Vaderland, 96.

37 Coolen, Bevrijd Vaderland, 65.

38 WE, kopie brief Coolen aan Peter van den Braken, 15 mei 1941.

39 FPC, brief dr. H Koch, directeur en chef dramaturg Bremer Schauspielhaus aan Coolen, 6 augustus 1941. 
de, ${ }^{40}$ waarin Koch vraagt of Coolen ter inleiding van het stuk twee, liefst verschillende, artikelen in het Duits kan sturen voor de twee Bremer kranten. Hij laat Coolen volledig vrij wat de inhoud betreft: "vielleicht anecdotisch, vielleicht auch feuilletonistisch oder autobiografisch" of wat dan ook. Koch is ervan overtuigd dat de pers in Bremen ze graag publiceert, ondanks de "Papierknappheit."

Op de dag na de première bericht een teleurgestelde Koch dat hij het bericht van verhindering van Coolen zojuist heeft ontvangen. Coolen geeft hierin als reden dat hij de uit. nodiging pas heel laat heeft ontvangen. Jammer, schrijft Koch, want het was een grote "Theatertriumphe" die aan het slot een dozijn open doekjes kreeg. Hij zal de recensies opsturen, belooft hij. De eerste brief heeft hij ondertekend "mit Deutschem Gruss," de laat. ste met "Heil Hitler!"41

Coolens afwezigheid valt in verkeerde aarde bij de Duitse autoriteiten. Zij vatten het op als een protest, want half november 194I worden de opvoeringen van Der Fremde op last van hogerhand gestaakt. De vertaler van Coolen, Peter Mertens, schrijft dat hij er niets van begrijpt en geen enkele gegronde reden heeft kunnen ontdekken. ${ }^{42} \mathrm{Hij}$ heeft alleen vernomen dat er tegen het stuk zelf geen bezwaren waren en leidt daaruit af dat die bezwaren dus wel de schrijver moeten gelden. Hij weet kennelijk niet dat hij het bij het juiste eind heeft en dat Coolen in ongenade is gevallen. Hij heeft geen flauw benul van wat er aan de hand is geweest en vraagt aan Coolen om inlichtingen. "Ge begrijpt, dat er veel meer van afhangt dan een paar opvoeringen van dit stuk." Mertens weet uit vroegere ervaringen dat er vaak een "dwaas misverstand" in het spel is. Als Coolen hem nu maar snel informatie geeft, dan kan hij waarschijnlijk alles gauw oplossen.

Het is wat naief van deze "zachtmoedige Peter Mertens." ${ }^{43} \mathrm{Hij}$ ziet waarschijnlijk niet in dat sommige mensen niets met de autoriteiten van een bezettende macht te maken willen hebben. Mertens werkt als Vlaams balling al sinds 1920 bij Insel Verlag en heeft in opdracht van Kippenberg ook Streuvels en Timmermans vertaald. Bij de machtsovername van Hitler in 1933 is hij Duits staatsburger geworden. Mertens vervult een zelfde, wat naieve, bemiddelende rol bij de Duitse verfilming van De Vlaschaard van Streuvels. Als Streuvels zich bij hem beklaagt dat de film te veel naar de Duitse propaganda wordt getrok. ken, biedt Mertens zijn hulp aan. De persoon die hij wil beïnvloeden, de assistent-scenarist. blijkt echter al lang ontslagen te zijn. ${ }^{44}$

Toch is Coolen als schrijver in Duitsland nog niet op een zijspoor gezet, zoals Mertens vermoedt. Integendeel, men wil Coolen bij de filmindustrie betrekken. In april $194 \mathrm{I}$ is hij al benaderd over een mogelijke verfilming van Dorp aan de rivier door de NV Filmmaatschappij Cinetone in Amsterdam. Hij gaat hier niet op in. ${ }^{45}$ Eind oktober 194I krijgt hij via het adres van Cinetone een uitnodiging om deel te nemen aan een "AutorenArbeitsgemeinschaft", georganiseerd door Terra Filmkunst in samenwerking met het Reichsministerium für Volksaufklärung und Propaganda. ${ }^{46}$ Het is de bedoeling dat een kleine kring van vier of vijf schrijvers zich ergens in januari 1942 gedurende twee weken verdiept in de film en zijn artistieke mogelijkheden. Het wordt geen cursus, maar de schrij vers zullen in nauw contact met dramaturgen, regisseurs en producenten met de wereld van de film vertrouwd worden gemaakt. Terra betaalt naast reis- en verblijfkosten een ver- 
goeding van duizend Rijksmark. Er staat geen verplichting tegenover om uitsluitend voor de firma Terra te gaan werken, maar men verwacht wel "dass sich aus diesem persönlichen Kontakt ein hoffentlich erfreuliches Mitarbeiter-Verhältnis ergibt."

Coolen bericht dat hij verhinderd is, waarop Terra schrijft te hopen dat zich later nog een mogelijkheid voor zal doen en hem op de hoogte te zullen houden. ${ }^{47}$

Coolen is dus niet afgeschreven in Duitsland, ook niet door de machthebbers, want Terra wijst uitdrukkelijk op de samenwerking met het ministerie van Goebbels. Het woord 'samenwerking' is hier nogal misleidend; het betekent eerder dat Terra volledig onder controle staat van dit ministerie.

In de tijd van deze briefwisseling en twee dagen voordat Peter Mertens zijn verontruste brief aan Coolen schrijft, op 25 november I941, wordt in Den Haag het officiële besluit genomen om een Kultuurkamer op te richten. Na de inwerkingtreding in r 942 zullen kunstenaars en journalisten zich niet langer kunnen verontschuldigen om 'uitnodigingen' niet aan te nemen en zullen 'dwaze misverstanden' niet meer kunnen ontstaan. De bezetter en hun Nederlandse uitvoerders zijn heel duidelijk over hoe zij het toetreden tot de Kultuurkamer interpreteren. Aanmelding als lid van de Kultuurkamer betekent dat de betrokkene de richtlijnen en regels van de nieuwe orde respecteert, ook in de kunst. Dit wil niet zeggen dat alle schrijvers die toetreden, dit ook werkelijk doen. Velen zullen lid worden om legaal te kunnen blijven publiceren.

\section{Wiegersma, volkskunst en sprookjes}

Cultuurintendant Schmidt-Burgk heeft tijdens het geprikkelde onderhoud met Coolen gezegd, dat deze volkomen vrij is om te doen wat hij wil. Hierop heeft Coolen geantwoord dat dat niet waar is en dat Nederland een Duitse politiestaat is, waar ieder ogenblik iemand binnen kan komen om hem te arresteren. Hij geeft als voorbeeld de arrestatie "van een mijner vrienden en diens zoon" die zijn weggevoerd zonder de familie mee te delen waar ze naar toe zijn gebracht. Bij het horen van de naam is de Duitser zeer verbaasd en belooft er werk van te maken. ${ }^{40}$

Het gaat hier om Hendrik Wiegersma en zijn zoon Pieter, die op 25 maart r 94 I met nog twee andere inwoners van Deurne zijn opgepakt en in Breda vastzitten. ${ }^{49}$ De Wieger wordt op wapens doorzocht. Na twee weken wordt de medicus-pictor weer vrijgelaten, nadat ook

40 FPC, brief dr. H. Koch aan Coolen, 11 augustus 1941.

41 FPC, brief dr. H. Koch aan Coolen, 23 augustus 1941.

42 FPC, brief Peter Mertens aan Coolen, 27 november 1941.

43 Hedwig Speliers noemt hem zo in Als een oude Germaanse eik, 333-338.

44 Speliers, Als een oude Germaanse eik, 464.

45 FPC, brief Cinetone Amsterdam aan Coolen, 9 april 1941.

46 FPC, brief Terra Filmkunst GMBH Produktion, Potsdam-Babelsberg 2 aan Coolen, Cinetone Amsterdam, 31 oktober 1941.

47 FPC, brief Terra Filmkunst aan Coolen, Wyire, Hollandsch/Limburg [sic], 3 december 1942, als reactie op bericht van verhindering van Coolen van II november 1942

48 Coolen, Bevrijd Vaderland, 67.

49 Van de Haterd, 'Leven en werk', 23. 
veel patiënten om zijn vrijlating verzocht hebben. Zijn zoon Pieter komt pas in mei vrij.

Niet lang daarna wordt de familie Wiegersma door een nieuw ongeluk getroffen. In augustus I94I verdrinkt de I8-jarige zoon Wieger Wiegersma bij een boottocht in de Biesbosch. Bij de begrafenis is ook Wouter Lutkie aanwezig. Deze geeft een beschrijving in zijn typische stijl: "De vader, de vader; vastgesnoerd aan het hoofdeind van de kist, als één met de kist." ${ }^{50}$ Een aristocratisch trekje van deze vader is dat hij voor zijn zoon een eigen stukje grond heeft laten wijden. "Ik wil niet dat mijn zoon tussen al die mensen van het dorp op het kerkhof komt te liggen," moet hij gezegd hebben."1

Lutkie blijft om Wiegersma heen cirkelen. Hij zou hem graag in zijn kring van het blad Aristo- trekken, maar dat lukt hem niet. De belangstelling van Lutkie voor Wiegersma is ongetwijfeld verhevigd vanwege het boek over Volkskunst dat de laatste kort daarvoor heeft gepubliceerd. Wiegersma is al jarenlang een verzamelaar van handgesneden wandelstokken, pijpenkoppen en vooral breischeien. ${ }^{52} \mathrm{Hij}$ bewondert de simpele en eerlijke kunst van het gewone volk. De definitie van Volkskunst die hij in dit boek geeft, moet niet alleen om zijn inhoud bij Lutkie zijn aangeslagen, maar ook vanwege de zelfverzekerde staccatotoon die Wiegersma met Lutkie gemeen heeft:

"Zonder apodictisch te zijn, durf ik beweren, dat de kunst van het volk een expressionistisch karakter móét dragen; dit volgt uit de wereldbeschouwing van haar makers, uit haar genesis. [...] In wezen is de volkskunst een voortgezette kinderkunst; haar eigenschappen zijn behouden kinderlijkheden. $\mathrm{Zij}$ is in tegenstelling tot het anthropocentrische realisme, het werk van den theocratischen geest, van hem die zijn blik ten hemel richt, mythen, sagen en legenden kent, dicht staat bij God. ${ }^{553}$

Wiegersma's Volkskunst in de Nederlanden krijgt in het nationaal-socialistische blad De Schouw een positieve bespreking van Henri Bruning. Volgens hem geeft het boek een magistraal beeld van "de volksche kunst, en daarmede van volkskracht." Nico de Haas schrijft echter in De Waag dat Wiegersma plagiaat pleegt en zwaar leunt op het werk van Max Picard, dat hij afdoet als "Expressionistische Bauernmalerei." De Haas vindt dat Wiegersma kiest voor een dubieuze volksgemeenschap, “die aan geen bloed of bodem gebonden is, een boerenvijandige, raslooze gemeenschap. ${ }^{154}$ In zo'n volksgemeenschap kunnen zelfs negers, chinezen en vuurlanders geplaatst worden, omdat men er altijd uitkomt met God als bindmiddel.

Coolen wenst Wiegersma geluk met het boek en prijst de inleiding. Hij heeft geconstateerd dat hij niet in de valkuil is getrapt van de nieuwe invulling die aan het volkse wordt gegeven: "je definitie [is] ontdaan en gezuiverd van die goedkoope mythen, al zo ellendig platgetrapt, die haar en de volkschheid en de tutti quanti voor een politiek gevlei op het oogenblik zoo dom en onzinnig vervalschen. ${ }^{55}$ Er zijn er meer die niet in de volks. manie trappen. Frans Valkenier bijvoorbeeld vindt dat het woordje 'volks' een stokpaardje aan het worden is voor mensen die over kunst en cultuur schrijven en vermoedt achter "volks een moeras van domheid." ${ }^{56}$ Het onderwerp is zeer in de mode. De volkskundige Jan de Vries, die op dat moment voorzitter van het Letterengilde is, brengt in dat jaar I $94 \mathrm{I}$ het boek De wetenschap der volkskunde uit, waarin hij in de sprookjes van Grimm "den nauwen samenhang met de heidense mythen der Germaanse oudheid" meent te kunnen bespeuren. ${ }^{57}$ Hier zien we hoe iemand zich laat inkapselen door de nieuwe orde en een wetenschappelijke basis verschaft aan de mythologie van het nazisme. 
Frans Babylon beschrijft veel later de paradox dat mensen die een afkeer hadden van de bloed-en-bodemretoriek, zich uit protest tegen de bezetter toch bezonnen op de traditionele beschavingswaarden en folkloristische 'eigen-aardigheden'. ${ }^{58} \mathrm{Zo}^{\mathrm{k}}$ kon Coolen in die tijd toch werken aan zijn Land en Volk van Brabant en Wiegersma aan zijn Volkskunst in Nederland. Daar komt bij dat beiden zich al vóór de oorlog met deze onderwerpen bezighielden.

In de loop van de oorlog wordt de volkskunde steeds meer gekoppeld aan de Germaanse volksaard en cultuur en politiek misbruikt, schrijft de hedendaagse volkskundige Dekker. Hij geeft een voorbeeld van het opportunisme waarmee met volkskunde kan worden omgegaan. Zo heeft Gerda Schaap kennelijk de verzameling van Wiegersma op het oog als zij schrijft "dat de volkskunst alleen daar op het platteland werd aangetroffen, waar van oudsher voldoende Germaans bloed aanwezig was." Ten zuiden van de grote rivieren is de volkskunst ontaard en vertoont ze volgens haar overeenkomsten met de "religieuze en erotische kleinplastiek van gevangenen en krankzinnigen." ${ }^{59}$ Hieruit blijkt dat de volkskunde makkelijk plooibaar is. Was Wiegersma een sympathisant van de bezetter geweest, dan zou zijn verzameling geprezen zijn als een bewijs van de continuïteit van de oeroude gebruiken in het volk. Hij zou ongetwijfeld een plaats hebben gekregen op de grote propagandatentoonstelling 'Eeuwig levende teekens', die in 194I in Den Haag wordt georganiseerd. Hier worden Germaanse symbolen op boerenhuizen en gebruiksvoorwerpen getoond om de stamverbondenheid en de koppeling met een mythische voortijd te bewijzen. ${ }^{60}$

De besmetting van het woord 'volks' weerhoudt Coolen er in ieder geval niet van om volkssprookjes te schrijven voor De Gemeenschap: in juni naar een Duits origineel 'De Zeemeermin en de Moeder' en de maand daarop een Javaanse legende 'De vrome en de gastvrije'. In dat laatste behandelt Coolen een van zijn geliefde thema's: vrome mensen hoeven niet perse goede mensen te zijn.

In november 194I moet De Gemeenschap op last van de bezetter stoppen. In de laatste nummers wordt kritiek geuit op het staatsabsolutisme en de nieuwe orde. Er wordt gepleit voor een terugkeer naar de meer corporatieve samenleving van de Middeleeuwen. Scholten constateert dat deze laatste nummers weer vrijwel identiek zijn aan de eerste. Centraal staat opnieuw "een pleidooi voor terugkeer, voor herstel, voor reconstructie van

50 Lutkie, 'Met Lazarus de arme ..., in: Onze rol spelen.

51 Van der Plas, Interview met Friso Wiegersma'.

52 Breischei: zie hoofdstuk 12, noot 19.

53 Wiegersma, Volkskunst, 18.

54 Venema, Schrijvers, deel 3 De harde kern, 225-226.

55 Archief Hendrik Wiegersma, brief Coolen aan Wiegersma, 25 oktober 1941.

56 Valkenier, 'Notities'. 153.

57 De Vries, De wetenschap der volkskunde, 7.

58 Babylon, 'Coolen in mijn jeugd', 680.

59 Dekker, 'Ideologie en volkscultuur', 46-47. De (nationaal-socialistische) Volksche Werkgemeenschap maakte gebruik van mensen met enige volkskundige achtergrond als Gerda Schaap en de hiervoor genoemde Nico de Haas.

60 Rooijakkers, 'Mensen en dingen', 122. 
een samenleving vanuit rooms-katholieke beginselen, waarbij geestdriftig beleden verwantschap de lof der Middeleeuwen doet zingen. ${ }^{m 1}$

In deze tweede oorlogszomer werkt Coolen aan zijn sprookjesbundel die hem de moge. lijkheid geeft zijn gedachten te verzetten. Het is een heerlijke arbeid, meldt hij aan een vriend, die "toevlucht bood voor menig kwaad uur., ${ }^{n 2}$ Later schrijft hij in het voorwoord van de vierde druk: "Ik maakte er een aanvang mee in het begin van de Duitsche bezetting, dien vreeselijke tijd, toen ik niet een 'vlucht' in het sprookje zocht zonder meer, maar mij wel op de onsterfelijke waarde ervan bezon." Het begrip 'toevlucht' is positiever dan het woord 'vlucht'. Coolen is kennelijk gestoken door de smalende opmerking van de cul tuurintendant, die hem in r $94 \mathrm{I}$ verweet dat hij vlucht in sprookjes.

Sprookjes uit alle landen verschijnt in het najaar van $194 \mathrm{I}$. De bundel wordt door Chris de Graaf in het licht van de nieuwe orde bekritiseerd. Deze criticus, die nog maar enkele jaren daarvoor Coolen verweet dat de moraal van zijn stuk De Vreemdeling niet te onderscheiden was van datgene wat door het Duitse ministerie van volksvoorlichting en propa. ganda wordt voorgeschreven, is nu zelf zeer coöperatief jegens de Duitsers. Hij werkt als chef kunstredactie bij de gelijkgeschakelde Maasbode en later bij het Algemeen Handelsblad. Hij verwijt Coolen dat hij het volkseigene teveel verwaarloost in de sprookjes. Ook de inleiding van Coolen moet het ontgelden: "Het is wel merkwaardig, hoe Coolen, een geboren verteller, die slechts zeer zelden betoogt, hier plotseling welsprekend wordt en een weten. schappelijke allure aanneemt, om toch maar vooral het volkseigene uit het sprookje, zoo niet weg te redeneeren, wat trouwens onbegonnen werk zou zijn, dan toch als een te verwaarlozen bijkomstigheid af te doen." De Graaff vindt dat juist sprookjes niet alleen aan het algemeen menselijke appelleren, zoals Coolen beweert, "maar zoveel meer tot een bepaald ras, tot eenen bepaalden stam tot een bepaald volk., ${ }^{63}$ Coolen reageert daar in zijn voorwoord bij de naoorlogse vierde druk op door te stellen dat sprookjes internationaal zijn; je ziet varianten van hetzelfde verhaal terug bij alle volken. Daar komt nog bij dat de meeste Europese sprookjes uit het Oosten stammen.

De kritiek van De Graaff toont aan dat men in de oorlog niet kán wegvluchten in de wereld van de sprookjes. Deze zijn immers, evenals de volksgebruiken, voor de nazi's verbonden met het mythische bloed-en-bodemdenken.

Ook in de al eerder genoemde studie van Taels over Coolens werk weerspiegelt zich de tijd. geest. Hij schrijft in de inleiding: "In de Duitsche Blut- und Bodenkunst zag hij [Coolen, C.S.] de mogelijkheid van zijn eigen streven naar een innig met land en volk verbonden kunst, boven een verachterd provincialisme uit, bevestigd." Taels zegt dat er misschien wel grotere kunstenaars zijn dan Coolen, maar dat, nu men ook in het Nederlandstalig gebied tot het inzicht is gekomen dat grote kunst door alle tijden heen "volksch" is geweest, er geen enkele rechtvaardiging nodig is om een zo zuiver en rasecht vertegenwoordiger der 'Heimatkunst' als Coolen te bestuderen. ${ }^{64}$ Coolen heeft de studie zelf gezien, want op 30 oktober 1942 zendt hij deze ter beoordeling naar Oomes.

Deze zinnen geven weer hoe aanhangers van de nieuwe orde en wetenschappers Coolens werk annexeren. Het is ook een verklaring voor de herhaalde uitnodigingen door officiële kringen. Coolen hoeft maar toe te happen om een van de meest vooraanstaande 
schrijvers in de westgouw van het Duitse Rijk te worden, en bovendien, als hij zou willen, toonaangevend in de nieuwe kunst-en cultuurorganisaties. Coolen geeft zijn eigen positie goed weer als hij na afloop van de oorlog over Felix Timmermans zegt: "Juist omdat hij geen Nazi was, achtten de Duitsers zijn adhaesie van zoveel belang. Van Kettman, Beversluis en Eekhout maakten zij geen werk, die waren voor ons toch allemaal verdacht. ${ }^{m 5}$ Dit is precies de reden waarom de bezetter werk van Coolen blijft maken.

\section{Van Kultuurraad naar Kultuurkamer}

Coolen beseft heel goed dat hij in de gaten wordt gehouden. Steeds meer wordt duidelijk dat alle schrijvers zich ten gunste van de bezettende macht moeten uitspreken, als ze tenminste legale publicatiemogelijkheden willen behouden.

Reeds bij de voorloper van de Kultuurkamer wordt de naam van Coolen genoemd als een van de mogelijke leiders. Seyss-Inquart heeft al in juni 1940 met professor Snijder en dr. Tobi Goedewaagen ${ }^{66}$ gesproken tijdens zijn thee-ontvangsten op kasteel OudWassenaar. Snijder wordt voorzitter van de Nederlandsche Cultuurkring die op 28 september 1940 wordt geinstalleerd. Deze Kring verandert later in een Kultuurraad. Hierna ontstaat de strijd om de baantjes binnen zo'n Raad, waarbij de onderlinge achterdocht tussen de kunstdisciplines opvalt. De letterkundige I.A. van der Made werpt zichzelf op als leider voor het letterengilde. Hij klaagt tegen Goedewaagen dat hij overal wordt buitengehouden en vreest dat er weer personen benoemd worden op basis van hun politieke verleden of de deining die ze hebben weten te veroorzaken. "Moeten wij straks geregeerd worden door een letterkundige, die door dr. Hannema, zijnde vakkundig op het gebied der Beeldende Kunsten, is uitgekozen?"'bl

Een maand later, in maart I94I, ondersteunt Henri Bruning het voorzitterschap van Van der Made, zij het niet helemaal van harte: "De keus is uiterst beperkt, en eigenlijk zou ik geen der letterkundigen kunnen noemen, die voor deze functie in het bijzonder geschikt is-tenzij dan Van der Made." Volgens hem is Van der Made in de literaire wereld een "zeer aannemelijke verschijning" en hij verwacht van de zijde van de NSB geen redelijke bezwaren. Bruning noemt als tweede mogelijkheid Jan de Vries, maar hij ziet een gevaar dat deze te politiek is en te weinig inhoudelijk. Kennelijk is ook aan Coolen gedacht als mogelijk leider van het Letterengilde van deze Raad, want Bruning geeft uitgebreid aan waarom hij tegen een voordracht van Coolen is:

"Een figuur als Coolen (gesteld, dat hij op dit moment een dergelijke beslissende stap zou durven ondernemen) heeft toch steeds dit nadeel, dat hij, als schrijver van regio-

61 Scholten, Aspecten, 172.

62 LMDC, inv. nr. C 3485, brief Coolen aan Reddingius, 22 februari 1942.

63 De Graaff, 'Bezonken Verdichtsels'. Zie ook: Van Duinkerken, Antoon Coolen, 85.

64 Taels, Antoon Coolen, III.

65 Coolen zegt dit in: Critisch Bulletin, juni 1948. Geciteerd bij: Venema, Schrijvers, deel 1 Het systeem, 181.

66 Goedewaagen is in 1895 geboren in een gegoed Amsterdams milieu en heeft filosofie gestudeerd. Hij keerde zich in de jaren dertig tegen het Comité voor Waakzaamheid en werkte vanaf 1939 mee aan het fascistische blad De Woag. Al snel na de bezetting wordt hij voorzitter van de Raad van Voorlichting van de Nederlandse Pers en daarna door Seyss-Inquart benoemd tot secretaris-generaal.

67 NIOD, inv. nr. 102, brief Van der Made aan Goedewaagen, 12 februari 1941. 
nale en boerenromans, de literatuur toch wel zeer eenzijdig vertegenwoordigt, waarbij nog komt, dat hij - meer gevoelensmensch dan intellect - in literaire kwesties een weinig gefundeerd oordeel heeft. Ik vrees, dat een dergelijke figuur door zijn benoeming tot leider van het Letterengilde - ook al beoogt hij dit geenszins - een versterking bete kenen gaat van de tendenzen die in de N.S.B. organen zoo vaak tot uitdrukking komen, en dat hij, zelf zijn standpunt niet scherp en overtuigend kunnende omschrijven, de situatie op den duur meer vertroebelt dan verheldert. Van der Made is reeds veel meer gericht - en bovendien een actief, levendig, zeer strijdbaar persoon (en gehard). ${ }^{n 68}$

Brunings denigrerende toon over de persoon van Coolen herinnert aan die van zijn kritiek op Herberg In 't Misverstand. Het is niet helemaal duidelijk wat Bruning bedoelt met zijn opmerking over de NSB-organen. Waarschijnlijk heeft hij de kleinburgerlijkheid en bekrompenheid van deze beweging op het oog en koppelt hij daaraan de gedachte dat een schrijver van regionale en boerenromans niet de volle breedte van de Nederlandse literatuur binnen de nieuwe orde kan vertegenwoordigen.

Ondanks de voorspraak van Bruning krijgt Van der Made het voorzitterschap niet. Uit wrok meldt hij zich in april I94I bij de Waffen-SS. ${ }^{69}$ Uiteindelijk zal de tweede keus van Bruning, dr. J. de Vries, voorzitter worden; echter niet van een Kultuurraad maar van een Kultuurkamer.

De Kultuurraad is geen lang leven beschoren. Vanuit Duitsland wordt door Goebbels geëist dat er, naar Duits model, een Kultuurkamer komt. In Duitsland bestaat al sinds november 1933 de Reichsschrifttumskammer. Deze organisatie valt onder het ministerie voor Volksaufklärung und Propaganda en controleert met behulp van de geheime diensten SD en de Gestapo de 2500 uitgevers, de 25.000 boekhandelaars, de 12.000 leden van het Reichsverband Deutscher Schriftsteller, de 20.000 nieuwe titels per jaar, de meer dan een miljoen lopende titels in de boekhandels, de 50 literatuurprijzen en de rooo literaire lezingen, die er per jaar worden gegeven. ${ }^{70}$

In Nederland valt de Kultuurkamer in het begin onder het Departement van Opvoeding, Wetenschap en Kultuurbescherming, onder leiding van secretaris-generaal Van Dam. Al gauw moet Van Dam echter de Kultuurbescherming afstaan aan het departement van secretaris-generaal dr. Tobi Goedewaagen, het Departement van Volksvoorlichting en Kunsten, zodat het gehele beleid inzake kunst, cultuur en de pers onder Goedewaagen valt.

\section{Meedoen of weigeren?}

Op 25 november $194 \mathrm{I}$ wordt de officiële instelling van de Kultuurkamer aangekondigd, maar deze zal pas in het voorjaar van 1942 in werking treden. Tot nu toe was er bij de Gilden voor de verschillende kunstdisciplines nog geen verplichting tot lidmaatschap, maar voor de Kultuurkamer wordt een verplichting om toe te treden in het vooruitzicht gesteld. Voor kunstenaars en schrijvers betekent dit dat er gekozen moet worden. Men kan niet afzijdig blijven: ook wanneer men zich niet aanmeldt als lid is dat een beslissing. Men wordt gedwongen voor of tegen het regime te kiezen. De Kultuurkamer is geen belangenvereniging, maar een "staatsorgaan", zoals Goedewaagen later in zijn installatietoespraak zegt, "en staat onder toezicht, leiding van de centrale macht, die haar een eigen taak, een verordenende en beschikkinggevende bevoegdheid heeft gegeven." ${ }^{n / 1}$ 
Nu is het voor een schrijver zaak, goed op de hoogte te zijn van wat de anderen doen. In de dagen na de aankondiging informeert men bij elkaar, over de grenzen van de verzuiling heen, hoe schrijvers zich moeten opstellen. Al op 28 november schrijft Coolen aan De Bourbon: "Tegenover de cultuurkamer moeten we hetzelfde standpunt innemen als tegenover de gilden: het dreigement verandert niets aan het princiep. Ik spreek Dinsdag o.a. Van Duinkerken, Helman, Tielrooy, Top Naeff en zal dan wel hooren hoe de stemming is. Ik schrijf je daarvoor. Maar mijn standpunt is: principieel en volstrekt weigeren." ${ }^{\text {"T }}$ Ook polst hij Oomes: "Wat zeg je van de Koeltoerkammer?"73

Eind I 941 en begin 1942 vinden vele besprekingen van letterkundigen plaats. Er ontstaat een begin van literair verzet, waaraan onder andere Jeanne van Schaik-Willing, Engelman, Van Duinkerken, Donkersloot, Binnendijk, Nijhoff, Van Randwijk en Werumeus Buning deelnemen. ${ }^{74}$ Ook Coolen is daar af en toe bij aanwezig. De dreiging van de bezetter jaagt schrijvers van heel verschillende pluimage bijeen. Henk van Randwijk herinnert zich een bijeenkomst bij Jan Engelman rond de kerstdagen van 194I, waarbij ook Geerten Gossaert (professor Gerretson) aanwezig is. Na een verhitte discussie over de rol van de kunst en de cultuur in de maatschappij, waarbij de standpunten mijlenver van elkaar liggen, blijkt Gossaert het protest tegen de Kultuurkamer toch te willen steunen, omdat de eenheid van denken tegenover de bezetter nog altijd veel groter is dan het onderlinge verschil. ${ }^{75}$ Iedereen informeert bij iedereen hoe diens houding is. Bomans refereert in een brief van I februari 1942 aan een overleg in Waalre. Hij heeft daarna ook gesproken met professor Fred Sassen [niet te verwarren met Ad. Sassen, C.S.]. Deze zegt ook nee tegen de Kamer, "maar voor hem zit er geen offer aan vast," zoals bij jou en mij, schrijft Bomans dan Coolen. Hij heeft het aanbod van Coolen om te bemiddelen bij een Duitse vertaling van Erik of het klein insectenboek bij Insel Verlag doorgegeven aan Spectrum, dat tot zijn verbazing zijn blijdschap deelt. ${ }^{76}$

Dat kan dus blijkbaar in die tijd: actie ondernemen tegen de Kultuurkamer en tegelijkertijd een Duitse vertaling bij Insel bepleiten. In juli blijkt de "Duitse Erik" bij uitgeverij Spectrum te zijn uitgekomen. Bomans verzoekt Coolen die door te sturen aan Knippenberg [sic] van Insel. De verkoop van Erikin Nederland ligt stil, schrijft hij, maar die van de Duitse vertaling niet. ${ }^{7}$ Van Coolen wordt nog in 1942 een fragment uit De drie gebroeders opgenomen in Das Niederlandbuch onder het pseudoniem Anton. ${ }^{78}$ Het is niet

78 Anton, ps. voor Coolen, fragment Die drei Brüder, in: Walter Söchting, Das Niederlandbuch, Frankfurt am Main 1942, 204-209. Geciteerd bij: Venema, Schrijvers, deel 1 Het systeem, 181. 
bekend of hij daar toestemming voor heeft gegeven, of dat het buiten hem om is geplaatst. Op 22 januari 1942 treedt de Kultuurkamer officieel in werking, onder leiding van de volkskundige prof. dr. Jan de Vries. De toneelspelers vormen de eerste groep die zich moet melden. Inmiddels is een comité van actie opgericht dat een adres aan de Rijkscommissaris Seyss-Inquart gaat schrijven. Sommige schrijvers, zoals Van Deyssel, weigeren dit adres te ondertekenen. In het comité heeft eerst Werumeus Buning gezeten, maar deze, afkerig van 'indiaantje spelen', is vervangen door Anthonie Donker. Op 15 februari 1942, vijf dagen voordat de toneelspelers en radiomensen zich voor de Kultuurkamer moeten aanmelden, verschijnt het adres aan de Rijkscommissaris. Hierin staat dat de Nederlandse kunstenaars de oprichting van de Kultuurkamer als feit 'memoreren', maar dat de gedachte achter deze Kamer en de manier van organiseren in strijd zijn met het wezen van het kunstenaarschap. Toetreding tot een instelling die kunst ondergeschikt maakt aan politieke beginselen, "waarbij het kunstleven geregeld wordt door met autoritaire macht beklede leiders en waarvan al of niet toelating niet uitsluitend afhangt van de mate van kunstenaarschap (bv een joodse afkomst), is niet overeen te brengen met de geestelijke levensvoorwaarden voor de kunst. ${ }^{79}$

Er staat niet dat de ondergetekenden zullen weigeren toe te treden, maar ondertekening geeft natuurlijk wel aan dat men negatief staat tegenover de nieuwe maatregel. Sommigen twijfelen of ze niet toch lid van de Kamer moeten worden: "Moet ik reageren op nevengaand schrijven?"vraagt Godfried Bomans. Hij wil alles doen om het nationaal-socialisme te bevechten, "maar doe ik dat wanneer ik bijvoorbeeld op deze aanbieding niet inga? Als niemand van 'ons' meer voor de microfoon komt en de aether geheel vrij is voor Blokzijl en zijn trawanten, is ons volk daar dan mee gediend? ${ }^{* 80}$

Ook Coolen ondertekent het adres, na lichte aandrang van Albert Helman (Lou Lichtveld) en Anthonie Donker (professor Donkersloot). Er rouleren ondertekenings. lijsten en Coolen stuurt er een door naar H. Wiegersma, tegen wie hij eerder heeft gezegd niet te willen tekenen. Hij schrijft dat hij toch getekend heeft "om niet door een geisoleer. de weigering een afgrond van misverstand te wekken.[...] Mocht hun beroep en mijn onderteekening voor jou aanleiding zijn je dan niet afzijdig te houden, dan kun je tekenen op bij; gaande strook. ${ }^{\text {"81 }}$ Het is tekenend voor de angst en de twijfel van die dagen. De angst om alleen te komen staan, los van de vakgenoten, is, althans op dat moment, nog groter dan de vrees voor de represailles van de bezettende macht bij een negatieve houding.

In deze tijd zitten Coolen en Van Duinkerken bij dezelfde actievergaderingen en ondertekenen ze hetzelfde adres. Wat ze echter niet weten is dat de autoriteiten de een, Coolen, graag tot de Kultuurkamer zien toetreden, maar dat de ander, Van Duinkerken, al zou hij willen, daar niet zou worden toegelaten vanwege zijn antinazistische gezindheid. Van Duinkerken staat op een lijst met joodse en marxistische auteurs en, zoals al gauw zal blij: ken, ook op een lijst van potentiële gijzelaars. ${ }^{82}$

\section{Een andere 'baan'}

Uit een brief aan de Hilversumse dichter Joan Reddingius blijkt de malaise waarin Coolen verkeert. Hij blikt terug op twee oorlogszomers, waarin hij respectievelijk de Andersenbloemlezing samenstelde en de sprookjesbundel schreef. Hij leest geen kranten

"omdat ik er te zeer het gehuil in hoorde der wolven buiten. [...] Te schrijven over wat 
rondom ons gebeurt, ook in ons arm land en met ons verkommerd en ik vrees zelfs verhongerend, onterfd en gedenationaliseerd volk, ach, ik denk dat we zwijgend daarover ook elkaar verstaan. [...] Die sprookjes hebben mij veel voldoening gegeven, tot werk echter van volkomen eigen conceptie kan ik niet komen."

0ok bij de uitgeverij stagneert veel, "Maar de voorloopig ergste stagnatie dreigt de cultuurkamer te worden, stelt die het nog mogen publiceren afhankelijk van het lidmaatschap ervan, dan staat het publiceren voor mij voorlopig toch stop. [...] lk lees veel, gij zult het ook doen, er zijn veel schrijvers, sterke geesten in wier toevlucht het 'gehuil der wolven' niet doordringt." ${ }^{83}$ Weer gebruikt Coolen het woord 'toevlucht'.

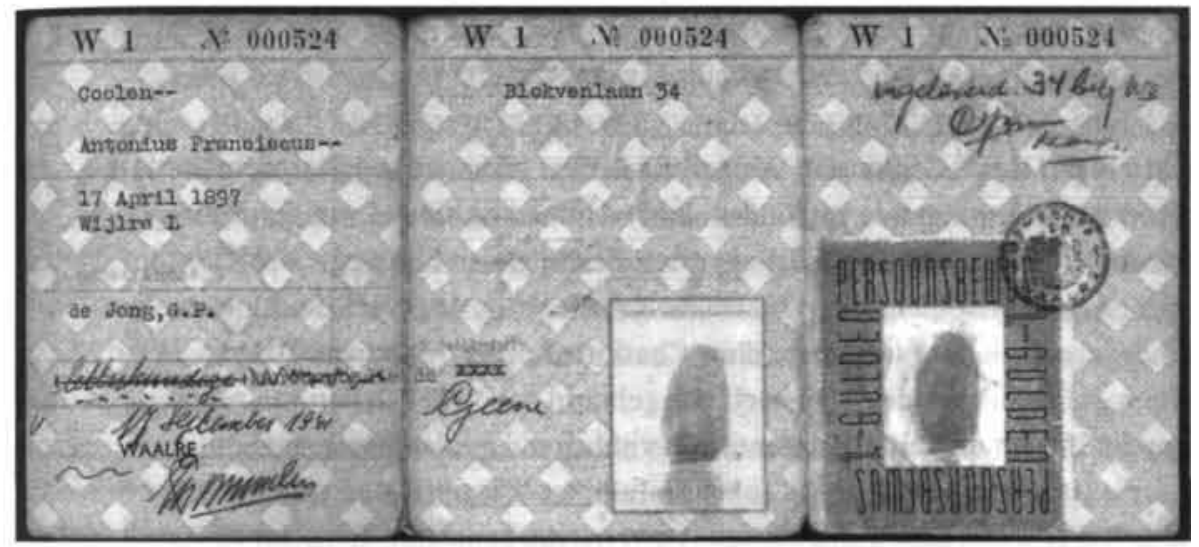

Het persoonsbewijs van Coolen met doorgestreept beroep

Uit deze brief blijkt dat Coolen vastbesloten is geen lid te worden van de Kultuurkamer. Daarnaast is hij ook bezig een alibi voor te bereiden. Als hij niet langer het beroep van schrijver uitoefent, zo redeneert hij, dan hoeft hij zich ook niet te melden.

Coolen wordt zogenaamd propagandist en reclameleider voor een linnenfabriek. Dit is een kameraadschappelijk opzetje met zijn vriend van de dorpssociëteit, Jos van Dijk sr., de eigenaar van een linnenweverij. De fabriek, met daaraan vast het statige woonhuis van de fabrikant, ligt aan de markt van Waalre. ${ }^{84}$ Er is een arbeidscontract bewaard, getekend op 12 februari 1942 , dat ingaat op I maart 1942 en een salaris vaststelt van $\mathrm{f}$ 100,- per jaar voor zolang de oorlog als een bedrijfsverlammende toestand duurt. Dit bedrag is een eis van de

79 De Jong, Het Koninkrijk, deel 5b, 727.

80 FPC, kopie brief Godfried Bomans (op briefpapier van zijn vader mr. J.B. Bomans) aan Coolen, 10 februari 1942, kopie.

8I Archief Hendrik Wiegersma, brief Coolen aan Wiegersma, 13 februari 1942. Op de strook staat: "Onderteekening van den brief aan den Rijkscommissaris dd 15 Februari 1942 opsturen naar Lou Lichtveld. Daniel Willinkplein 45 Amsterdam-Z."

82 Venema, Schrijvers, deel 1 Het systeem, 255.

83 LMDC, inv. nr. C 3485, brief Coolen aan Reddingius, 22 februari 1942.

84 Het linnenbedrijf stopt met de werkzaamheden op 1 juli 2001. Het familiebedrijf heeft dan 127 jaar bestaan. De laatste WALRA-directeur is Bart van Dijk (1956). 'De Walra-adviseuse komt niet meer', in: NRC Handelsblad, 10 november 2000. 
Kultuurkamer. Na de oorlog zal dit worden verhoogd tot $f$ 4000,- oplopend tot $f 6000$ per maand.

Deze overeenkomst ziet er serieus uit, maar in een concept dat Coolen zelf heeft geschreven, ${ }^{85}$ komt duidelijk tot uiting dat het hier om een vrij studentikoos fake-contract gaat. Zo wordt bijvoorbeeld gezinspeeld op het bon-vivant-gedrag van zoon Frans van Dijk bij het artikel over de declaraties:

"Hierbij leggen wij er de nadruk op, dat wij matigheid waarderen en dat $U$ niet het voorbeeld gelieve te volgen van onze firmant F. Van Dijk. [...] Reeds thans wenschen wij vast te leggen, dat $\mathrm{U}$ op den dag, waarop $\mathrm{U} U \mathbf{w}$ dienstbetrekking bij ons vijf en twintig jaar zult hebben vervuld, een wandelstok met inscriptie zal worden overhandigd door den heer Jos van Dijk sr. De aanname van welk huldeblijk zal worden verzoet door de kruik bols, waarvan het vergezeld zal gaan." ${ }^{86}$

Op 6 maart meldt Coolen aan Wiegersma dat het adres aan de rijkscommissaris met ruim 1900 handtekeningen is verzonden. Lichtveld had op uitstel van de maatregel gehoopt, maar Coolen heeft gehoord dat al verschillende gilden zijn opgericht. "De toneelspelers zijn na een zwaar dreigement bezweken goeddeels, op ongeveer twintig procent na, waaronder zooals ik hoor uit Amsterdam, Charlotte Köhler, Albert van Dalsum en Jan Musch, die voet bij stuk houden." Hij heeft ook gehoord dat op het stellen van een culturele daad zonder lid van de Kultuurkamer te zijn vijfduizend gulden boete staat; hij is nieuwgierig naar de precieze bepalingen. Coolen besluit met Wiegersma en zichzelf moed in te spreken: "De gebeurtenissen zijn iederen dag verre van bemoedigend, maar van een wisselspel van feiten en kansen mag ons geloof en ons vast vertrouwen in zo'n groote zaak [...] niet afhankelijk zijn. Daarom behoud ik moed en jullie doen dat ongetwijfeld ook. ${ }^{\text {g7 }}$

\section{De druk neemt toe}

Ondanks zijn nieuwe 'baan' werkt Coolen door aan de bundel Land en Volk van Brabant. Hij is er al vanaf $\mathrm{r} 94 \mathrm{I}$ aan bezig. Hij zit A.M. de Jong achter de vodden om zijn bijdrage en stimuleert hem door te zeggen dat in Brabant altijd het Kempische en het Meijerijsche worden benadrukt en dat hij al een beschouwende bijdrage van ir. Heymeier heeft over de Westhoek. ${ }^{88}$ Het is opvallend dat hij in zijn brieven aan A.M. de Jong niet over de Kultuurkamer rept en de indruk wekt dat het boek binnen enkele maanden zal verschijnen, terwijl hij zeker weet dat dit niet het geval zal zijn. Ook Van Duinkerken heeft hij al een paar keer gemaand om zijn bijdrage te leveren. Deze heeft het te druk met allerlei andere zaken en komt zelfs niet even aan in Waalre als hij in Eindhoven heeft gesproken Coolen schrijft bij de aanmaning dat hij het spijtig vindt dat ze elkaar niet ontmoet hebben, maar wijdt geen woord aan de Kultuurkamer. ${ }^{89}$

Het lijkt of de vertrouwensrelatie iets minder hecht is dan vroeger, maar misschien beseft Coolen wel dat voor Van Duinkerken, die zich regelmatig negatief over nazi Duitsland heeft uitgelaten, de kaarten heel anders liggen dan voor hem. Toch is het vreemd dat Coolen op dit punt zwijgt, want het is juist kenmerkend voor deze tijd dat schrijvers. die door de aard van hun werk grote individualisten zijn en hun werk in afzondering verrichten - elkaar voortdurend op de hoogte houden. Coolen doet dat wel met De Bourbon. Reddingius en Lou Lichtveld (Albert Helman). Met de laatste heeft hij ook persoonlijk con- 
tact. Vanuit Amsterdam is Lichtveld en niet Van Duinkerken zijn voornaamste inlichtingenbron. Hij waarschuwt Coolen dat sommige schrijvers dubbel spel spelen en dat anderen opportunistisch zijn.

Aan De Bourbon, die op dat moment in het ziekenhuis ligt, schrijft Coolen dat Lichtveld een kleine kern van getrouwen heeft genoemd: Anthonie Donker, Halbo Kool en A. Roland Holst. Coolen heeft hem geantwoord, zo verzekert hij De Bourbon, dat daar ook Louis de Bourbon, Henk Wiegersma en Jan Engelman bij genoemd behoren te worden. ${ }^{90}$ Het is opvallend dat Coolen in dit rijtje Van Duinkerken niet noemt. Hij doet dit weer wel in een brief aan Wiegersma en zijn vrouw een paar weken later.

Eindelijk stuurt Van Duinkerken zijn bijdrage voor Land en Volk van Brabant in: 'De Ballade van den Dollen Dries'. In zijn dankbriefje wijdt Coolen weer geen woord aan het al of niet toetreden tot de Kultuurkamer en geeft hij alleen informatie over de stand van zaken rond het boek. ${ }^{\text {gl }}$ Het is extra eigenaardig omdat juist die tijd zeer spannend is. Immers, drie dagen eerder, op 20 maart, is het bericht in de pers verschenen dat schrijvers zich vóór I april 1942 moeten aanmelden. ${ }^{92} \mathrm{Het}$ is mogelijk dat Coolen er niet over schrijft, omdat hij vermoedt dat Van Duinkerkens brieven geopend worden door de censuur. Het kan echter ook zijn dat hij het onderwerp niet noemt vanwege de herinnering aan de vaak nogal 'dwingende adviezen' van Van Duinkerken. Coolen wil nu liever zelf de teugels in handen houden.

Eind maart logeert Coolen een nacht op De Wieger en met de Paasdagen heeft hij Lou Lichtveld en zijn vrouw in Waalre te logeren. Deze is blij als Coolen hem het definitieve standpunt van de Wiegersma's kan meedelen. "Wij beiden en de kleine kern, waarvoor ik sprak, waaronder Van Duinkerken en Jani Roland Holst, zijn ook op ons standpunt blijven staan," schrijft Coolen aan Henk en Nel Wiegersma. Hij vervolgt: "Vanavond zal ik Jan Engelman ontmoeten en diens beslissing hooren." ${ }^{m 3}$

85 De begeleidende brief hiervan is gedateerd op 29 maart 1942. Het contract is dus geantidateerd, om zodoende te kunnen bewijzen dat Coolen al bij het ondertekenen van het adres aan de rijkscommissaris op 15 februari 1942 geen schrijver van beroep meer was. Het bewijs hiervoor is dat het officiële contract letterlijk het concept van 29 maart volgt met uitzondering van de ingangsdatum die in het concept 15 maart is en in het officièle contract van 15 februari is gesteld op 1 maart 1942. WE, kopie contract CoolenVan Dijk.

86 WE, bijlage bij brief Coolen aan Jos van Dijk, 29 maart 1942.

87 Archief Hendrik Wiegersma, brief Coolen aan Wiegersma, 6 maart 1942.

88 LMDC, inv, nr. C 3485, brief Coolen aan A.M. De Jong, 7 maart 1942. Coolen heeft in november en december 1941 al drie keer aangedrongen op een bijdrage "die een weerspiegeling van den West-Brabantschen gezichtskaart nastreeft." Op 21 maart bedankt hij hem voor de uiteindelijk toch gekomen inzending en wenst hem succes met zijn Breero-boek.

89 BA, brief Coolen aan Van Duinkerken, 6 maart 1942.

90 LMDC, inv. nr, C 3485, brief Coolen aan De Bourbon, 20 maart 1942.

91 LMDC, inv. nr. C 3485, brief Coolen aan Van Duinkerken, 23 maart 1942. Hij schrijt dat er tekening begint in te komen. De hele opzet van het boek kan Coolen niet verwezenlijken, sommige dingen vallen nu eenmaal anders uit dan verwacht, maar het "geeft in vele facetten weerspiegeling van land en volk van ons gewest."

92 De Jong, Het Koninkrijk, deel 5b, 741.

93 Archief Hendrik Wiegersma, brief Coolen aan Henk en Nel Wiegersma, 8 april 1942. 
Meer zorg klinkt door in zijn brief aan Oomes: "Wij leven voort in grote zorg, die op 't ogenblik ons aller zorg is, maar met een onverwoestbaar vertrouwen. De fatale datum van 1 april ben ik gepasseerd als propagandaleider bij de Walralinnenfabriek, ik heb de litteratuur vaarwel gezegd, de lier aan de wilgen gehangen en ben nu kantoorbediende. ${ }^{n 4}$

\section{Van Duinkerken gegijzeld}

Op 24 april r 942 heeft Coolen nog een lunchafspraak met Van Duinkerken in Den Haag. Ruim een week later, op 4 mei om half zeven in de ochtend, wordt Van Duinkerken thuis opgehaald door de Sicherheitspolizei en met een aantal prominente cultuurdragers als gijzelaar geinterneerd in het klein seminarie Beekvliet te St. Michielsgestel in Noord-Brabant.

$\mathrm{Na}$ de internering van Van Duinkerken heeft Coolen meteen, in de tweede week van mei, een bezoek gebracht aan diens echtgenote $\mathrm{Nini}$. Hij logeert dan op de kamer van een van de kinderen. Weer thuis bedankt hij haar voor de gastvrijheid en spreekt zijn bewondering uit voor haar kalmte. Hij belooft voor sigaretten te zorgen voor de straffe roker Van Duinkerken. Hij kan daar aan komen via een vriend die in het ziekenhuis ligt [hij bedoelt hiermee De Bourbon, C.S.]. Verder schrijft hij: "Hier wordt verteld, dat Willem in St. Michielsgestel den moed er in houdt, zeer onderhoudend voor de anderen is en zelfs lezingen geeft." ${ }^{25}$ Dit klopt ook, want Beekvliet is een heus cultureel centrum waar Van Duinkerken vooral met de letterkundigen Vestdijk en P.H. Ritter jr. literaire avonden organiseert.

Het is eigenaardig dat Coolen geen rechtstreeks contact met Van Duinkerken opneemt, hetgeen toch goed mogelijk is, want de geïnterneerden mogen post en pakketjes ontvangen. Op r juni vraagt Coolen per brief aan Nini om hem op de hoogte te houden en of hij misschien via haar sigaretten kan opsturen. ${ }^{96}$ Nini zelf wordt geïnformeerd door een stroom brieven van haar man, die haar bijna dagelijks schrijft. Er zijn geen brieven bewaard waarin zij informatie doorgeeft aan Coolen.

Pas op 17 juni schrijft Coolen zelf een brief aan Van Duinkerken. Hij schetst de kalmte van Nini in Amsterdam toen hij er logeerde en beschrijft uitgebreid hoe de zoontjes van Van Duinkerken op Coolens gedeelde logeerkamer kartonnen bootjes van zeephulzen in de wastafel lieten varen. Over zijn eigen toestand schrijft hij: "We houden stand in de moeilijkheden, die niet gering zijn en waaraan de druk zich nog toevoegt van een grauwen zomer met veel troostelooze regens. 's Avonds lees ik veel, ik heb me nog eens extra vermeid in je vroege werk." Coolen wenst Van Duinkerken veel moed en twijfelt er niet aan dat hij nog geleerder de gijzeling zal uitkomen dan hij er in ging."

De brief toont de positieve kant van Coolen. De hele opbouw is moedgevend: de geruststelling over de toestand van zijn vrouw, de anekdotes over zijn kinderen, zijn persoonlijke bewondering en de liefde voor de literatuur. Het optimistische einde heeft echter een wrange bijsmaak, want iedereen weet dat de gijzelaars vastzitten om eventueel als represaille voor aanslagen vanuit het verzet gefusilleerd te worden. Hetgeen enkele maanden later ook daadwerkelijk gebeurt als, na een aanslag op Duitse soldaten in Rotterdam op 7 augustus, vijf Nederlandse burgers, waaronder een gijzelaar uit Beekvliet, worden geëxecuteerd. 
Coolen geeft nog af en toe lezingen, maar is niet bezig met nieuw werk. Aan de dichter Reddingius schrijft hij: "Overigens heb ik wat nieuw werk betreft de lier aan de wilgen gehangen. Ik ben geen lid van de cultuurkamer." Tot nu toe vallen de materiële problemen op het platteland wel mee, maar "honderdmaal kwellender zijn die welke den geest benauwen." Hij schrijft dat hij in de afgelopen winter vaak de Zweedse dichter en prozaschrijver Werner von Heidenstam aanhaalt, die in mei r 940 is overleden: "Een ongeluksnacht overzendt God aan de sterke menschen om ze goed en groot te maken en opdat een klein volk des te grooter oprijst uit zijn ellende, grooter en machtiger dan de groote volken in hun gouden staat." 98

$\mathrm{Na}$ de gijzeling van Van Duinkerken dreigt nu ook gevaar voor een andere vriend van Coolen. Louis de Bourbon heeft tijdens zijn burgemeesterschap in Oss steeds geprobeerd zoveel mogelijk verzet te bieden tegen de maatregelen van de bezetters. Tijdens een opname in het ziekenhuis besluit hij ontslag te nemen als burgemeester, maar hij trekt dit weer in als hij hoort dat men hem gevangen wil nemen. Coolen reageert geschrokken en schrijft dat hij blij is dat De Bourbon die ontslagaanvraag weer ongedaan heeft gemaakt. Hij raadt hem aan in ieder geval niet meer te publiceren in kranten en tijdschriften; de meeste zijn toch niet de moeite waard om in te kijken. ${ }^{99}$

Coolen herhaalt steeds tegen zijn vrienden dat hij niet alleen uit principe niet meer in kranten schrijft, maar dat hij ze ook niet meer leest. Hij heeft sterk de neiging zich helemaal af te sluiten van de buitenwereld. Zoals hij echter al gauw zal merken, bemoeit de buitenwereld zich wel met hem.

\section{Een dreigende aanmaning}

Die zomer komt ook Coolen zelf in de gevarenzone terecht, als hij op Ir juni r 942 een dreigende brief krijgt van het departement van Goedewaagen. Deze heeft de taak om druk uit te oefenen op de niet-aanmelders.

Aan de oproepen om zich bij de Nederlandse Kultuurkamer aan te melden wordt immers maar door weinig echt bekende schrijvers gehoor gegeven. De uiterste aanmelddatum van I april is al lang verstreken. Het Departement van Volksvoorlichting en Propaganda geeft daarom de namen van de niet-aanmelders door aan dr. Joachim Bergfeld, Leiter der Abteilung Kultur. Het briefhoofd van de aanmaning aan Coolen om zich alsnog aan te melden geeft de plaats van Bergfeld in de organisatie van de rijkscommissaris aan. Onder de adelaar met het hakenkruis luidt die:

Der Reichskommissar

für die besetzten Niederländischen Gebiete

94 LMDC, inv. nr. C 3485, brief Coolen aan Oomes, 12 april 1942.

95 BA, brief Coolen aan Nini Asselbergs, 16 mei 1942.

96 BA, brief Coolen aan Nini Asselbergs, 1 juni 1942.

97 BA, brief Coolen aan Van Duinkerken, 17 juni 1942.

98 LMDC. inv. nr. C 3485, brief Coolen aan Reddingius, 26 mei 1942.

99 LMDC, inv. nr. C 3485, brief Coolen aan De Bourbon, 4 juni 1942. 


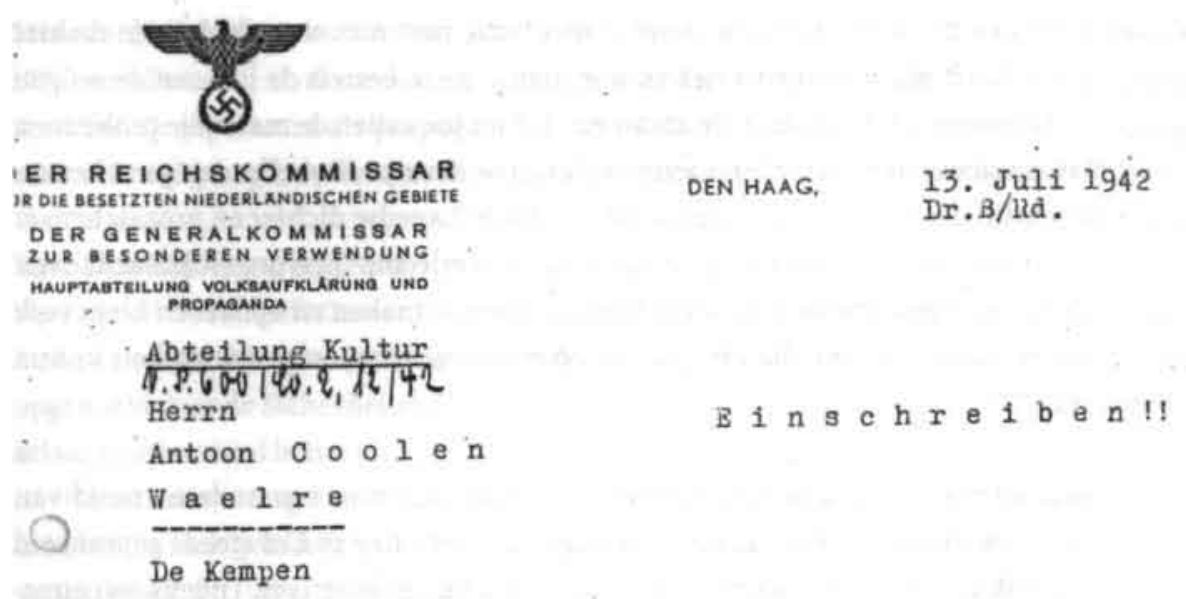

Der Generalkommissar zur besonderen Verwendung

Hauptabteilung Volksaufklärung und Propaganda

Abteilung Kultur.

Ironisch schrijft Coolen later dat je dit briefhoofd eigenlijk hardop moet voorlezen: "dan krijgt het laarzen." De tekst van de brief luidt aldus :

"Wie mir die Niederländische Kulturkammer mitteilt, liegt dort bis jetzt noch nicht Ihre Meldung zur Schrifttumsgilde vor. Ich bitte hierzu um Ihre Äusserung.

Wie Ihnen bekannt sein wird, ist die Voraussetzung zur weiteren Ausübung einer Tătigkeit auf dem Gebiet der Niederländischen Kulturkammer die Mitgliedschaft bei der Kammer bzw. die Meldung zur Kammer.

Ich nehme an, dass das Fehlen Ihrer Meldung irgendwie auf einem Versehen beruht. Sollte das aber nicht der Fall sein, so bitte ich um Ihren umgehenden Besuch nach vor. heriger telefonischer Anmeldung. Ich darf Sie darauf aufmerksam machen, dass die Niederländische Kulturkammer errichtet worden ist aufgrund einer Verordnung des Herrn Reichskommissars und dass es mir obliegt, für die Durchführung dieser Verordnung zu sorgen.

Im auftrag:

(w.g. Bergfeld)

Leiter der Abteilung Kultur."100

Coolen beschrijft in Bevrijd Vaderland zijn antwoord van I $_{5}$ juni aldus: "Mijn antwoord op de brief is een ontwijking: Ik beoefen de letteren niet langer, ik heb een beroep in de kantooradministratie aangenomen, en daarom heb ik recht noch plicht, om mij voor een lidmaatschap bij de cultuurkamer te melden. Daarop krijg ik een maand rust, en dat is vol doende om de heele cultuurkamer te vergeten."

\section{Wel melding, geen aanmelding als lid}

Op r 3 juli krijgt Coolen een tweede, nu aangetekende, brief van Bergfeld. Deze bevestigt de ontvangst van Coolens antwoord van ${ }_{5}$ juni, waarin hij stelt het beroep van schrijver niet meer uit te oefenen. Echter, de conclusie van Coolen dat hij zich op grond van dit feit niet 
meer hoeft te melden voor de Kultuurkamer is een vergissing: "Da sich von Ihnen Bücher im Verkehr befinden, sind Sie auch meldepflichtig bei der Kammer." Bovendien moet Coolen niet op de zaken vooruit lopen, schrijft Bergfeld, want of hij aangenomen wordt als lid is een beslissing van de Nederlandse Kultuurkamer zelf. Bergfeld vindt dat door alle correspondentie de zaak al genoeg vertraging heeft opgelopen en stelt daarom een termijn. Coolen moet zich binnen drie dagen na ontvangst van de brief melden bij de Kultuurkamer, Den Haag, Boschstraat 44 en Bergfeld wil zelf een kopie van de aanmelding. ${ }^{102}$

Coolen gebruikt die termijn van drie dagen om met verschillende mensen te overleggen wat hem te doen staat en bedenkt tenslotte een 'handigheidje.. ${ }^{103}$ Dit handigheidje zit als volgt in elkaar. Op 17 juli, drie dagen na de ontvangst van het aangetekend schrijven, meldt Coolen zich per brief bij de Kultuurkamer, maar doet geen aanvraag om lid te worden. ${ }^{104}$ Hij meldt zich, maar hij meldt zich dus niet áán als lid.

"Ik wijs U er echter op, dat dit [schrijven] niet inhoudt een aanvrage om als lid van de Nederlandsche Cultuurkamer te worden opgenomen. Ik beschouw mijn letterkundige werk als afgesloten, beoefen niet verder de literatuur en ben sedert I maart, belast met de bedrijfspropaganda, in dienst van de firma Van Dijk, Manders en Co te Waalre." ${ }^{105}$ Op het feit dat er boeken van hem in omloop zijn, gaat Coolen in deze brief wijselijk niet in. Desondanks krijgt hij de inschrijvingsformulieren met Ariërverklaring en al toegestuurd. Deze worden door Coolen oningevuld teruggezonden. Hij verwijst in een begeleidend schrijven van 27 juli naar de eerste brief van Bergfeld, waarin alleen sprake is van het uitoefenen van bezigheden op het gebied van de Kamer. Hij herhaalt dat hij die bezigheden per I maart heeft neergelegd, maar voegt eraan toe: "Mocht het in omloop zijn van boeken, zonder toetreding, in strijd zijn met de desbetreffende verordening, dan gelieve $U$ zich voor het terugnemen dier boeken te wenden tot de firma Nijgh \& Van Ditmar, Van Alphenstraat 63, Voorburg, die ze in omloop brengt." ${ }^{106}$

Er zijn geen boeken uit de handel genomen. Coolen schetst na de oorlog hoe het in de praktijk ging: "Men heeft eenvoudig herdrukken geblokkeerd door het verstrekken van papier afhankelijk te stellen van een alsnog voldoen aan de meldingsplicht. En zoo kreeg men vanzelf de volledige liquidatie der Bücher im Verkehr." ${ }^{107}$

100 FPC, brief Bergfeld aan Coolen, 11 juni 1942.

101 Brief Coolen aan Bergfeld, 15 juni 1942. Van deze brief is geen kopie aangetroffen, maar Bergfeld verwijst er naar in zijn brief van 13 juli 1942 en geeft dan in het Duits dezelfde samenvatting. Zie ook: Coolen, Bevrijd Vaderland, 85. Coolen schrijft 'cultuur' nog met een c; ook Goedewaagen heeft volgens L. de Jong nog enige tijd geprobeerd de $c$ te handhaven.

102 FPC, brief Bergfeld aan Coolen, 13 juli 1942. Het woord 'Einschreiben!l' met de twee uitroeptekens betekent 'Aantekenen'. Het is een opdracht voor degene die de brief moet versturen. Dit is wel eens misverstaan; men dacht dat het een bevel was om in te schrijven voor de Kultuurkamer.

103 Coolen, Bevrijd Vaderland, 85-86.

104 De term 'melden' versus 'aanmelden als lid' leidt tot misverstanden in de geschiedschrijving van De Jong. Zie de slotparagraaf van dit hoofdstuk.

105 NIOD, archief van de Nederlandse Kultuurkamer, brief Coolen aan Kultuurkamer, 17 juli 1942.

106 NIOD, archief van de Nederlandse Kultuurkamer, brief Coolen aan de Nederlandse 'Cultuurkamer', 27 juli 1942.

107 Coolen, Bevrijd Vaderland, 86. 
Coolen heeft zich dus niet aangemeld als lid, hij heeft zich gemeld met de mededeling dat hij het beroep van schrijver niet meer uitoefent. Met bewondering citeert hij later de wijze waarop Roland Holst zich 'gemeld' heeft. Deze schrijft aan de Kultuurkamer, dat hij gehoord heeft dat de leiding een eventueel lidmaatschap moet goedkeuren en vervolgt dan: "Het moet mij van het hart, U te verzekeren, dat Uw afkeuring door mij op hoogen prijs zal worden gesteld." ${ }^{108}$ Aan Bergfeld uit Holst zijn verwondering over het feit dat de verandering van Cultuur in Kultur "sich auf dem Wege von Polizeimassnahmen durchset. zen würde. Als Westeuropäer fällt es einem Hollander nicht leicht, sich von diesen, seiner Art fremden Auffassungen einen Begriff zu bilden. ${ }^{n 09}$ Coolen noemt dit antwoord in Bevrijd Vaderland Roland Holsts "dichterschap waardig, koninklijk en van onbuigzamen, glanzenden trots." Coolens eigen antwoord was meer dat van een diplomaat. De strekking was echter dezelfde: een weigering zich te laten annexeren.

\section{Kopfschüttelnd Abschied nehmen}

De machthebbers hebben kennelijk geen zin om de ook in Duitsland populaire schrijver aan te pakken en laten hem met rust. Zijn weigering is echter niet onopgemerkt gebleven. In september 1942 verschijnt een scherp artikel van Karl Vietz in de Essener National Zeitung met de titel 'Literaten im Schneckenhaus. Aus der Arbeit der Niederländischen Kulturkammer.' Hierin worden namen genoemd van kunstenaars die zich meteen als lid aangemeld hebben. Het is niet erg als een "haltloser Literat" als Leonard Huizinga zich terzijde houdt, schrijft de krant, dat spaart de Kultuurkamer alleen maar administratieve arbeid. Tegen Coolens opstelling kijkt Vietz duidelijk anders aan:

"Aber mit Befremden wird gewiss auch mancher deutsche Freund des holländischen Schrifttums davon Kenntnis nehmen, dass Antoon Coolen den Beitritt zur Kulturkammer mit dem Bemerken ablehnte, er habe den Posten eines Reklamechefs in einem Industriewerk übernommen und werde nie mehr schreiben. Augenscheinlich handelt Coolen unter geistlichen Einflüssen. Er weiss also wohl selbst am Besten, was das Buch seines Glaubens über jene sagt, die ihr Talent vergeuden. Er war zu hohem Rang berufen, das ist kein Zweifel. Er verzichtet nun selbst darauf, um nicht einmal den Anschein zu erwecken, als bekenne er sich zum neuen europäischen Geist. Es wird niemandem einfallen, den Dichter Coolen von seinem Linsengericht weg an eine reicher gedeckte Tafel zu führen. Man kann nur kopfschüttelnd Abschied nehmen."110

Het eigenaardige is dat het voor de Duitse lezer - zelfs in oorlogstijd - geen afscheid, laat staan een 'hoofdschuddend' afscheid is. De verkoop van Coolens vertalingen gaat in Duitsland gewoon door. Dat is weer een voordeel van het zeer bureaucratisch georganiseerde regime van de Reichsschrifttumskammer. Deze beoordeelt het gedrag van schrijvers uit het bezette gebied niet, maar stelt wel vast of de vertaalde boeken al of niet het stempel 'entartete Kunst' dragen. Bovendien beschouwt de bezetter Coolen nog steeds niet als verloren, want ook in de volgende oorlogsjaren zullen nog toenaderingen volgen. De afrekeningen van Insel Verlag bereiken op de normale wijze de auteur in Nederland. Van Ham, het hoofd van de afdeling Boekwezen op het Departement van Goedewaagen, ergert zich daar behoorlijk aan. Als een jaar later voorgesteld wordt om de betalingen van lopende vertalingen en herdrukken van niet aangesloten auteurs door te laten gaan om anderen, zoals boekhandelaars en uitgevers die wél aangesloten zijn bij de Kultuurkamer, niet te 
duperen, wijst Van Ham op Coolen en de hele rij vertalingen. Van Ham vraagt zich af of het niet mogelijk is om te verhinderen dat deze gelden Coolen bereiken. "I

\section{Nasleep na de oorlog}

De kwestie van de Kultuurkamer krijgt na de oorlog een vervolg. Er ontstaat een misverstand naar aanleiding van de woorden 'melden' en 'aanmelden' (als lid). De rijksgeschiedschrijver dr. L de Jong schrijft aanvankelijk dat er na de eerste brief van Bergfeld aan Bloem, Bordewijk, Coolen, Kelk, A. Roland Holst en mevrouw Székely-Lulofs het volgende gebeurde: "Coolen, Kelk en mevrouw Székely-Lulofs meldden zich toen aan, maar schreven dat zij zulks als een pure formaliteit beschouwden, aangezien zij geen literaire werkzaamheden meer verrichtten." ${ }^{m 12}$

In de tweede druk is de naam van Coolen weggelaten, nadat Antoons zoon F.P. Coolen uit Zwolle hem op het verschil heeft gewezen. In deel 13 van de Jongs geschiedschrijving, het deel met correcties en aanvullingen, staat: "Antoon Coolen en de Kultuurkamer. Coolen heeft zich na de eerste brief van Bergfeld niet aangemeld, wèl na de tweede waarin met de SD werd gedreigd. Hij deed Bergfeld toen echter weten dat zijn aanmelding bepaald geen vraag inhield om als lid te worden erkend."113

Coolen heeft dus duidelijk gesteld dat hij geen lid wilde worden en heeft de inschrijfformulieren ook nog eens blanco teruggestuurd. Door de onzorgvuldige formulering in de eerste druk van de officiële geschiedschrijving is er altijd een scheiding blijven hangen tussen de zogenaamde 'aanmelders' en de schijnbaar meer principiële weigeraars. Mulder neemt in zijn standaardwerk over kunst tijdens de bezetting de eerste versie van De Jong over en noemt Coolen samen met Kelk en mevrouw Székely-Lulofs als aanmelders, met de toevoeging dat ze niet meer zullen publiceren, tegenover Bordewijk, Bloem en Roland Holst die alleen maar gemeld hadden dat ze geen lid wilden worden. Door op dezelfde pagina op te merken dat veel schrijvers van folklore en folkloristische (streek)romans zich tot de nieuwe orde voelden aangetrokken, plaatst Mulder Coolen nog meer in de verdachte hoek. Zo'n beeld blijft hangen en wordt nog maar moeilijk gecorrigeerd, ook al schrijft Mulder een pagina verder dat Coolen en Th. De Vries "felle tegenstanders" worden van hun bewonderaar Goedewagen. ${ }^{\text {"4 }}$

Of ze zich nu hebben gemeld of aangemeld, voorop staat dat alle zes deze schrijvers géén lid zijn geworden van de kamer, ook Kelk en Székely niet. Het onderscheid dat De

107 Coolen, Bevrijd Vaderland, 86.

108 Deze vaak geciteerde brief (onder andere in Coolen, Bevrijd Vaderland, 86 en in: De Jong, Het Koninkrijk, deel 5b, 744) circuleerde reeds in juli 1942 door Nederland. Roland Holst heeft op het nippertje aan arrestatie weten te ontkomen door onder te duiken.

109 Brief Roland Holst aan Bergfeld. In het Duits geciteerd in: Coolen, Bevrijd Vaderland, 96. In vertaling gedteerd in: De Jong, Het Koninkrijk, deel 5b, 744.

110 Coolen, Bevrijd Vaderland, 87. Het origineel van het artikel berust bij FPC.

111 Venema, Schrijvers, deel 1 Het systeem, 180. Het briefje van Van Ham zat gehecht aan een nota van Miranda d.d. 25 april 1943.

II2 De Jong, Het Koninkrijk, deel 5b, 744.

113 De Jong, Het Koninkrijk, deel 13, 106.

114 Mulder, Kunst in crisis, 242-243. 
Jong tussen de twee drietallen heeft gemaakt, is onterecht. Het heeft tot gevolg gehad dat in vele publicaties en boeken de suggestie is gewekt dat Coolen zich vrijwillig heeft aan. gemeld als lid van de Nederlandse Kultuurkamer. ${ }^{115}$

Antoon Coolen heeft, zowel in zijn brieven aan de autoriteiten als aan zijn persoonlijke vrienden, duidelijk te kennen gegeven dat hij zich als schrijver niet wil voegen naar de regels van het nieuwe regime. Achteraf doet hij daar niet heldhaftig over. In Bevrijd Vaderland beschrijft hij zijn handelen met termen als 'ontwijken' en 'een handigheidje' en hij geeft ook openlijk blijk van zijn bewondering voor de koninklijke en onbuigzaam trotse manier waarop Roland Holst geweigerd heeft. Coolen heeft het op zijn manier gedaan. Niemand weet hoe lang de oorlog nog zal duren en velen gaan er zelfs al vanuit dat Europa voortaan onder Duitse invloed zal voortbestaan. Voor Coolen staat nu echter een ding vast: hij zal onder dit bewind buiten de Kultuurkamer het beroep van schrijver niet meer kun. nen uitoefenen. 
115 Behalve in de studie van Mulder komt het misverstand ook weer terug in het hier al meermalen geciteerde werk van Venema, Schrijvers, deell Het Systeem, 381; bij Lewin. Het clandestiene boek, 74; bij P. Calis. Het ondergronds verwochten, 29-30; bij Frank van den Boogaard, Een stoottroep, 74. 


\section{Burgemeester van Waalre?}

"Het benoemingsbesluit moet nu nog door de spitsroeden van de bezettende macht."

eind $1942-1944$

\section{Problemen van collega-schrijvers}

Ondergedoken is een te groot woord, maar Coolen heeft zich na de briefwisseling met Bergfeld en de Kultuurkamer uit voorzichtigheid toch maar elders opgehouden. Er is een brief met het poststempel van Utrecht van 25 juli 1942 aan Oomes, waarop staat "Op zekeren dag. Ergens in Nederland." Coolen schrijft: "Die kwestie, waarover 's Zondagsmorgens bij jullie een kleine twijfel mij hinderde, is nu helemaal in orde. De bescheiden zijn gekomen en bij verder doorreis wordt het antwoord gepost, precies en geheel zoals ik het je zei..-1 Al gauw ontdekt hij dat hij zich niet ongerust hoeft te maken. Er worden geen maatregelen tegen hem genomen, ondanks zijn afwijzende reacties.

Zijn bitterheid is groot als hij merkt hoe verwante schrijvers zich door de bezetter laten huldigen. In zijn eerder geciteerde brief aan de gegijzelde Van Duinkerken schrijft hij:

"En dan is in een feestelijke academische zitting in het Koninklijk Kunstverbond te Antwerpen Timmermans de Hamburger Rembrandtprijs overhandigd. Ook in Lier is de bekroonde gehuldigd: een gedenksteen, een straat naar hem genoemd, een herinneringsboom geplant, en zijn Vlomsche humor liet den Fee als nimmer niet in den steek: 'De hemel is net als Lier, dat geloof ik, en in dit geloof wil ik leven en voorlopig nog niet sterven."'?2

Later schrijft hij in Bevrijd Vaderland dat hij niet begrijpt hoe Felix Timmermans de Rembrandtprijs van 1942 heeft kunnen aannemen. Hij gelooft niet zo in het excuus dat het gezien moet worden als een reactie op de anti-Vlaamse gezindheid van de Walen. Dat Timmermans dit nationaal-socialistische Duitsland "de hand drukt en er vriendschap mee sluit alsof er niets aan de hand is, dat is mij een raadsel en dat is mij een gruwel. ${ }^{n 3}$ Coolen vraagt zich na de oorlog af of de argeloosheid van Timmermans bewust of berekend was. Hij vindt hem in ieder geval naïef en dat

"naïvisme, een der bekoorlijkheden van zijn werk, is een trek in den Vlaamsche landaard. Ze zijn zoo argeloos (ook Claes en de Pillecyn). Nu zet Duitschland, den Noord-Germaanschen Lebensraum overstroomend, zijn deuren wijd open voor zijn vazallen wier land het nam: daar komt de Vlaamsche kunstenaar, gewend aan Fransche geringschatting en de onoverkomelijkheid der Fransche grenzen, en ziet zich

I LMDC, inv. nr. C 3485, brief Coolen aan Oomes, 25 juli 1942.

2 BA, brief Coolen aan Van Duinkerken, 17 juni 1942.

3 Coolen, Bevrijd Voderland, 88-90. 
op de Duitsche podia geëerd en mondig in dit midden zelf van Europa, en daar kunnen ze niet tegen: dankzij Duitschland weet de wereld weer, dat er een Vlaanderen is!" Bij deze strenge beoordeling moet er rekening mee gehouden worden, dat deze 'dagboek. notitie' van 1942 pas na de oorlog gepubliceerd is, nadat Coolen door Streuvels die zichzelf vrijpleit van banden met de bezetter, op de hoogte is gebracht van de gang van zaken tijdens de bezetting. ${ }^{4}$ Want in 1942 moet Coolen zich verlaten op berichten uit de gecontroleerde pers en kan hij niet anders denken dan dat Streuvels zwaar collaboreert. Streuvels heeft om te beginnen in oktober 194I een eredoctoraat van de universiteit van Münster gekregen. Bovendien wordt geschreven dat hij aanwezig was op het grote Dichtertreffen in Weimar, wat overigens niet waar was. Verder wordt in de zomer van 1942 zijn roman De vlaschaard verfilmd onder de titel Wenn die Sonne wieder scheint, hetgeen door de nazi's goed uitgebuit wordt met berichten in de Deutsche Allgemeine Zeitung van 18 juli 1942 en Der Volkische Beobachter van 13 augustus $1942 .{ }^{5}$ Coolen leest er over in het Duitse maandblad Der Norden van augustus 1942, waarin Streuvels uitgebreid bejubeld wordt: "Al wat Streuvels aanpakt wordt goud onder zijn toverhanden. Dit goud moet gewonnen worden voor het Duitse volk. ${ }^{\prime 6}$ De originele dagboekaantekeningen die niet zijn bewaard, zullen dus zeer waarschijnlijk minder vleiende opmerkingen over Streuvels hebben bevat. De berichten over Streuvels in bladen als Der Norden moeten Coolens somberheid en gevoel van verlatenheid hebben vergroot.

Coolen probeert de moed erin te houden, iets waar hij zelf zijn vrienden in brieven vaak toe aanspoort. Hij werkt mee aan een boek over heiligenlevens, dat uit moet komen bij Paul Brand. ${ }^{7}$ Hij beseft dat anderen het moeilijker hebben dan hijzelf. Daarom probeert hij de gegijzelde Van Duinkerken in St. Michielsgestel wat op te monteren met citaten van die andere beroemde gevangene aan het eind van de vorige eeuw, Oscar Wilde. Coolen heeft in die dagen De Profundis van Wilde gelezen, dat hij in de gevangenis schreef. "De waarde van het boek - die schuilkelder voor den geest - zul jij sterker nog ervaren dan wij," voegt hij eraan toe. Opnieuw kiest hij zijn geliefde metafoor van het toevlucht zoeken van zijn geest in oorlogstijd. ${ }^{8}$ Van Duinkerken stuurt hem in augustus een afschrift van 'De wuivende', een ontroerend gedicht over de manier waarop hij zijn vrouw nakijkt na een bezoek aan Beekvliet op 22 juli I 942 :

"Mijn vrouw is de wuivende, die met haar zakdoek

in 't licht langs het korenveld gaat,

$\mathrm{Zij}$ zendt mij een uiterste teeken van liefde nu zij mij gedwongen verlaat. ${ }^{.9}$

In diezelfde tijd gebeurt er iets verschrikkelijks met het gezin van zijn collega en vroegere huwelijksgetuige Herman de Man. De Man verbleef in Zwitserland toen de oorlog uitbrak en is daar gebleven. Zijn gezin, dat in Nederland achterbleef, verkeerde tot nu toe in een schemerige gevarenzone. Hun status van 'gedoopte joden' bood maar een betrekkelijke bescherming. Het gevaar wordt op zondag 26 juli 1942 ineens acuut, nadat in alle roomskatholieke kerken een bisschoppelijke brief en een protesttelegram zijn voorgelezen tegen de jodenvervolging. De bezetter neemt hierop het besluit alle katholiek gedoopte joden op te pakken en te deporteren. Eva de Man wordt op zondag 2 augustus met vier van haar kin- 
deren door Nederlandse politiefunctionarissen in haar huis in Berlicum bij Den Bosch opgepakt en via Vught, Amersfoort en Westerbork, waar al een elders opgepakte zoon aanwezig is, naar Auschwitz getransporteerd en meteen na aankomst op 9 augustus vergast. Twee kinderen waren op die zondag niet thuis en hebben de oorlog overleefd.

Wouter Lutkie, die niet ver van de familie De Man in Nuland woont en steeds contact heeft gehouden, heeft op die vroege zondagochtend nog van alles ondernomen om deportatie te voorkomen, onder meer via zijn contacten met een officier van de Sicherheitsdienst in Den Bosch en met de bisschop. ${ }^{10} \mathrm{Het}$ geeft aan hoe ingewikkeld de verhoudingen liggen. Een facistisch geörienteerde priester, meer Mussolinivereerder dan volgeling van Hitler, pleit voor een katholiek gezin van joodse afkomst bij de Duitse autoriteiten en bij het hoofd van zijn bisdom, waar hij al een kwart eeuw mee in onmin leeft.

Coolen heeft weinig contact met de familie. Er is een brief bewaard van Eva de Man, die hem in 1940 meedeelt dat haar man in Zwitserland zit." Toch moet hij in ieder geval over deze deportatie gehoord hebben.

\section{Hoop en angst}

Deze informatie over vrienden, collega-auteurs en hun families is niet opwekkend. Coolen ergert zich aan schrijvers die zich laten eren door de Duitsers, maar ziet ook met angst wat er met tegenstanders van het regime en met de joden gebeurt. Het einde van de oorlog is niet in zicht. Hij blijft echter hoop koesteren en doet mee aan de 'nationale sport' van die tijd om elk teken te interpreteren als een verzwakking van de Duitsers en een spoedig einde van de oorlog. Hoewel hij geen onmiddellijk uitzicht op dat einde heeft, ziet hij toch wel verschijnselen die in de goede richting wijzen, schrijft hij in het najaar van 1942 aan Oomes. Ondertussen worden klokkentorens leeggehaald en zijn de deportaties eindeloos. Moed houden is het enige dat erop zit. ${ }^{12}$ Tegen het einde van het jaar spreekt hij de hoop uit dat 1943 het bevrijdingsjaar zal worden: "Er zijn zekere tekenen, gretig waargenomen door ons, vertrouwende optimisten, en die ik voeg bij indrukken en mededelingen, die ik bij een bezoek uit Duitsland ontving." ${ }^{13}$ Hij weet echter ook dat die bezoeker, waarschijnlijk een vertegenwoordiger van Insel, niet representatief is voor de doorsnee-Duitser en zijn optimisme verdwijnt helemaal als hij naar de radio luistert. Zo geeft hij later zijn indrukken weer in zijn 'oorlogsdagboek': "Deze winternacht heb ik Goebbels gehoord, uren aan een

4 Coolen schrijft meteen na de oorlog op 22 mei 1945 een brief aan Streuvels waarin hij vraagt wat er allemaal met de schrijvers in Vlaanderen is gebeurd. Streuvels antwoordt op 6 juni 1945. Zie hoofdstuk 16.

5 Speliers, Als een oude Germaanse eik, 465.

6 Speliers, Als een oude Germaanse eik, 526.

7 LMDC, inv. nr. C 3485, brief Coolen aan Oomes, 20 juli 1942. Kennelijk hoopt hij dat de oorlog snel over is: Met de heiligen het jaar rond zal pas in 1948 verschijnen.

8 BA, brief Coolen aan Van Duinkerken, 17 juni 1942.

9 Van Duinkerken, Verzamelde Geschriften, deel III, 952-953.

10 Vaartjes, Herman de Man, 478. Vaartjes verhaalt hoe laks de plaatselijke overheid, maar ook de bisschop, is geweest. Met enige moeite zou een onderduik te regelen zijn geweest.

II. Vaartjes, Herman de Man, 385.

R. LMDC, inv. nr. C 3485, brief Coolen aan Oomes, 30 oktober 1942.

13 LMDC, inv. nr. C 3485, brief Coolen aan Oomes, 19 november 1942. 
stuk, en ik beken mij in zooverre zijn dupe, dat ik moe van hem ben, dat ik hoofdpijn van hem heb en dat ik door hem een heelen slapelooze nacht heb doorgebracht." ${ }^{14}$

Coolen doelt hier op de beruchte speech van Goebbels voor invaliden van het front, verpleegsters en arbeiders met zijn tien vragen - "Seit Ihr bereit [...] Seit Ihr entschlossen [...] - waarop steeds een donderend "Ja!" volgt. De laatste vraag luidt: "Wollt Ihr den totalen Krieg?" Coolen beseft dat Goebbels de Duitsers wel móét oproepen: "Niets is van deze manifestatie verder af, dan zelfvertrouwen en overwinningszekerheid. De gebeurtenissen in Afrika, de nederlaag bij Stalingrad, de dag aan dag heviger bombardementen van de voortdurend in kracht toenemende, doodelijke luchtmacht van den vijand, slaan het Duitsche gemoed met somberheid en schrik."

Hij spot met het Algemeen Handelsblad dat deze redevoering van Goebbels een meesterstuk van psychologisch inzicht noemt. Coolen stelt zich voor hoe het publiek - de verpleegsters met de invalidenkarretjes door een aparte uitgang - zich door de verduisterde straten van het nachtelijk Berlijn naar huis voortbeweegt en zich afvraagt of er vanuit Engeland een repliek zal komen. Dat hoeven ze niet te doen, vindt hij: die repliek "komt morgen weer met meer bommenwerpers boven Duitschland en dat is het beste antwoord."

Vooral dit laatste is er een bewijs van hoe iemand onder de directe oorlogsomstandigheden verandert. Hoe ver weg is nu de pacifistische Coolen die in de jaren dertig de bombardementen op vrouwen en kinderen in Spanje en China hekelde. Ondanks zijn 'innere Emigration' en zijn toevlucht naar de (sprookjes)literatuur heeft deze 'schuilkelder voor de geest' hem toch niet helemaal kunnen beschermen tegen de geestelijke invloed van het oorlogsgeweld, ook al leest hij geen kranten.

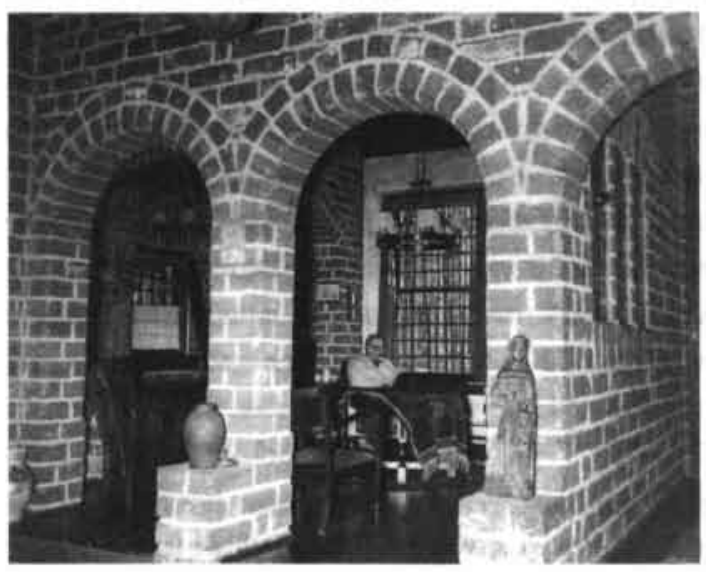

Het interieur van 'De Kempen'.

Coolen blijft zijn oase cultiveren. De eenenveertigste verjaardag van zijn vrouw Gerda in september I942 wordt gezellig en stijlvol gevierd. De dames worden "in "t lang" verwacht, schrijft hij aan zijn vriend De Bourbon. ${ }^{15}$ Coolen heeft zelfs een soort vakantiegevoel. "Nu heb ik altijd vakantie, onderbroken slechts dan als ik volle lust tot werken heb, en dat is nog honderd procent vreugd," vertelt hij aan Oomes. Badinerend voegt hij eraan toe dat zijn vrouw,

die als vele huisvrouwen zonder personeel is komen te zitten, het veel moeilijker heeft. Een klein lichtpuntje is er, als vlak voor Kerstmis 1942 Van Duinkerken vrijkomt. Coolen schrijft hem een hartelijke verwelkomingsbrief, na tevergeefs gebeld te hebben. ${ }^{7}$ Er komt slechts een klein kaartje terug; Van Duinkerken heeft het heel druk met zijn correspondentie. Hij komt zeker een keer naar Waalre en is van plan in januari 1943 in Utrecht een etentje te organiseren met de redactieleden van De Gemeenschap "om de thuiskomst te vieren en de toekomst te regelen." ${ }^{\text {18 }}$ 
Hier stokt voor lange tijd het schriftelijk contact tussen Coolen en Van Duinkerken, waarschijnlijk uit angst voor de censuur. Pas tweeëneenhalf jaar later, nadat ook Noord Nederland bevrijd is, wordt de briefwisseling hervat. Coolen zal echter regelmatig in Amsterdam komen, onder andere bij Lou Lichtveld (Albert Helman) op het Daniël Willinkplein (het latere Victorieplein). Helman woont hier in de zogenoemde 'wolkenkrabber' waar ook professor Donkersloot (Anthonie Donker) en het echtpaar RomeinVerschoor wonen. ${ }^{19}$ Coolen en Van Duinkerken hebben de rest van de oorlog wel regelmatig contact in besloten bijeenkomsten van schrijvers die geen lid van de Kultuurkamer zijn geworden. Beiden treden regelmatig op in huisbijeenkomsten, waar lezingen en voordrachten worden gegeven.

\section{Ambitie voor burgemeesterschap}

De relatie van Coolen met de schrijver/burgemeester De Bourbon wordt steeds hechter. Ze zien elkaar vaak en onderhouden een intensieve briefwisseling. De Bourbon vervult zijn burgemeesterschap in Oss nog steeds op een vrij openlijk anti-Duitse manier. Hij treft eigen voorzieningen voor de armenzorg en negeert daarmee de officiële Winterhulp. Hij werkt niet mee aan de maatregelen van het Gewestelijk Arbeidsbureau voor gedwongen arbeidsinzet van mannen in Duitsland. Hij houdt zich bezig met allerlei illegale activiteiten, die zeker niet met het burgemeesterschap te combineren zijn. Zo brengt hij 's nachts joden naar onderduikadressen, onder andere op de pastorie van Maren.$^{20} \mathrm{Nadat}$ hij in mei 1942 bijna was gearresteerd, kijkt De Bourbon eind 1942 actief uit naar een andere betrekking.

Tijdens een etentje op 29 december 1942 bij De Bourbons is er gesproken over de mogelijkheid dat Coolen burgemeester zou worden van Waalre. Het moet een eigenaardig gesprek zijn geweest. Wat is er nu aantrekkelijk aan een burgemeesterschap onder de Duitse bezetter, die juist in die tijd steeds bruter en repressiever wordt? De verhalen van De Bourbon kunnen niet rooskleurig zijn, want hij heeft almaar problemen met de bezetter. De Bourbon wil geen burgemeester meer zijn en Coolen denkt erover het te worden.

Wat hield het burgemeesterschap in die tijd in? Het ambt werd tot lang na de Eerste Wereldoorlog voornamelijk vervuld door telgen uit regentengeslachten. Het was een erefunctie, die men niet in de eerste plaats om het geld nastreefde. In de loop van de jaren dertig komt er een nieuwe groep kandidaten, die vanuit een ambtelijke en meer technocratische achtergrond het vak van bestuurder wil uitoefenen.

14 Coolen, Bevrijd Voderland, 95.

15 LMDC, inv. nr. C 3485, brief Coolen aan De Bourbon, 10 september 1942.

16 LMDC, inv. nr. C 3485, brief Coolen aan Oomes, 9 september 1942.

7 BA, brief Coolen aan Van Duinkerken, 22 december 1942.

18 BA, briefkaart Van Duinkerken aan Coolen, 31 december 1942.

19 Van Verre, Tony van Verre ontmoet Helman, 63.

20 Den Ridder, Heldenrol voor burgemeester, 29. Een van de overlevenden, Bob Zadok Blok, heeft er voor gezorgd dat De Bourbon postuum de Yad Vashem-onderscheiding ontving van de staat Israël. De onderscheiding werd vijfentwintig jaar na zijn dood, op 11 november 1999, in Oss uitgereikt aan De Bourbons kinderen. 
Coolen geeft daar al in 1938 in Herberg In 't Misverstand een mooi voorbeeld van. In deze roman komt het personage voor van een ijverige gemeentesecretaris die hogerop wil. "Op de provinciale griffie hielden ze rekening met hem. Hij had ook al eens iets gepubliceerd over streekplannen, over ruilverkaveling en over het belang der kennis van de staathuishoudkunde voor de gemeente-administratie [...] Zeker, hij maakte kansen op een prachtige burgemeestersplaats." Als hij aan het eind van de roman inderdaad wordt benoemd, mijmert hij: "Met een paar dagen ging hij naar de griffie voor de eedsaflegging. Dan kwamen de voorbereidingen voor de installatie, en het feestelijk inhalen in de gemeente, dat willen de mensen, daar onderwerp je je aan." 21

In de tijd dat Coolen deze roman schrijft, heeft hij veel contact met griffier Vincent Cleerdin in verband met de publicatie Zóo is Brabant, die in 1939 verscheen. Reeds toen heeft Coolen met de gedachte gespeeld om, naast zijn schrijverschap, de functie van burgemeester erbij te doen. Hij heeft in ieder geval een beetje in de keuken kunnen kijken van het provinciaal bestuur en de verhouding daarvan met de lokale autoriteiten, zijnde de burgemeesters, want de status en de macht van de wethouders stellen dan nog niet zo veel voor. Voor een burgemeestersbenoeming zijn goede relaties met de provincie een vereiste. De relatie met de griffier is al goed, maar wordt nog beter als Cleerdin ook voorzitter wordt van het Provinciaal Genootschap en in die hoedanigheid in oktober r 940 Coolen de gouden erepenning aanbiedt.

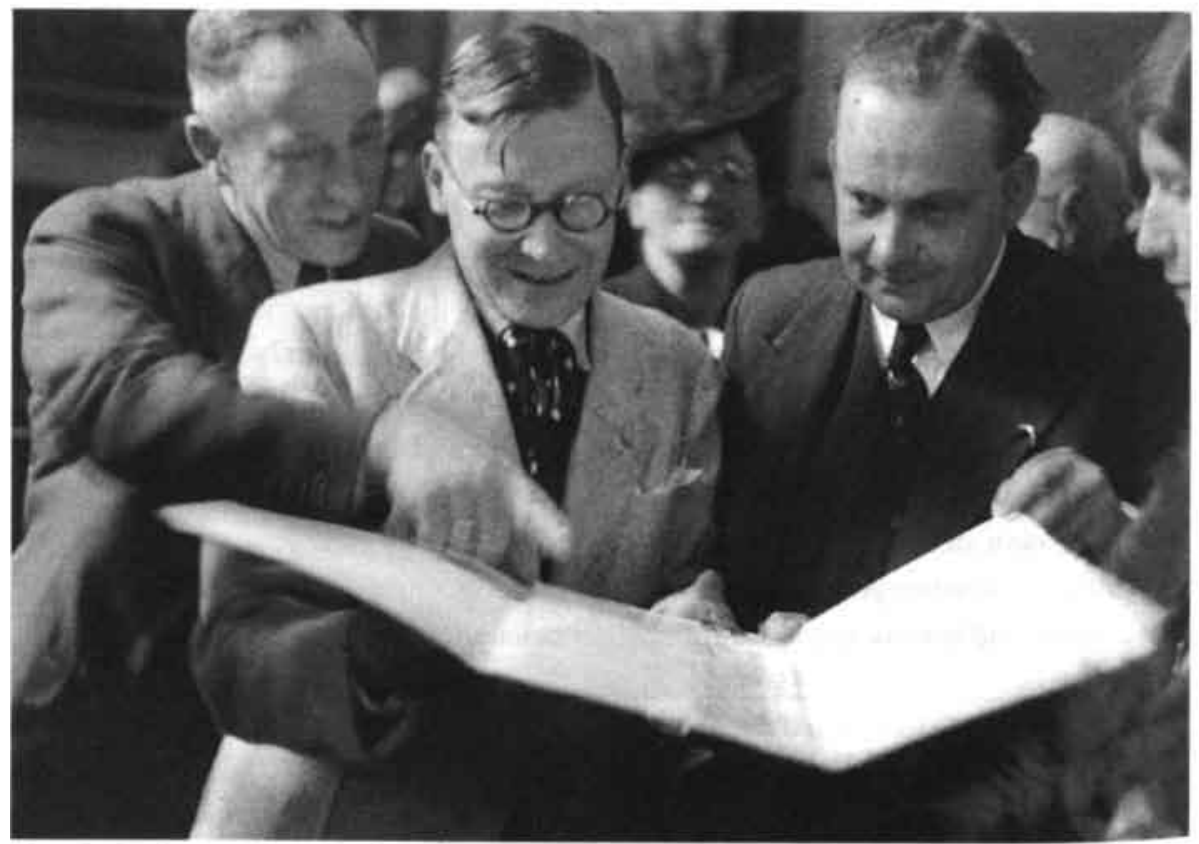

Cleerdin, Coolen en De Bourbon bekijken de oorkonde van het provinciaal Genootschap in oktober 1940.

Vincent Cleerdin (1888-1946) behoort aanvankelijk, evenals Lutkie en de hoofdredacteur van de Maasbode Thomsom, tot de bewonderaars van de katholieke integralisten Bloy en Kralik. Lutkie heeft de jonge Coolen ook voor deze richting willen winnen. Cleerdin werkt mee aan het blad van Lutkie, Aristo-, en uit in de jaren dertig regelmatig zijn bewondering 
voor Mussolini. Zoals de meesten uit die kringen is hij echter anti-NSB. ${ }^{2} \mathrm{Hij}$ blijft ook in de oorlog publiceren. In de winter van $1942 / 43$ schrijft hij een deeltje voor de Heemschutserie, Het Brabantsche Dorp, waarin hij met instemming het initiatief van Commissaris der Provincie jhr. dr. A. van Rijckevorsel noemt om de traditie in de bouw van boerderijen te beschermen door een Bouw-, Woning-en Welstandstoezicht. ${ }^{23}$

De Bourbon heeft indertijd op aandringen van Cleerdin en Commissaris Van Rijckevorsel in I94I gesolliciteerd naar het burgemeesterschap van Oss om een benoeming van een NSB-er te voorkomen. Ondanks het negatieve rapport van de Beauftragte over Van Rijckevorsel, waarover in het vorige hoofdstuk is geschreven, zit de Commissaris begin 1943 nog steeds op zijn plaats. Op het departement is de anti NSB-er mr. Frederiks nog steeds secretaris-generaal.

Zie hier enkele hoofdrolspelers die veel te maken hebben met een burgemeestersbenoeming: een bevriende griffier met veel gevoel voor het Brabants eigene, een Commissaris die geestelijk buigzaam en diplomatiek is en een Secretaris-Generaal die naar betere tijden streeft. Het zijn allemaal mensen bij wie een figuur als Coolen zich thuisvoelt.

\section{Aanleiding tot de sollicitatie}

Hoe is Coolens sollicitatie naar het burgemeesterschap van Waalre nu in zijn werk gegaan? Bij wie heeft het initiatief gelegen? In het Rijksarchief in Den Bosch bevindt zich geen sollicitatiebrief van Coolen naar de burgemeesterspost in Waalre. Het archief van de Commissaris der Provincie bevat wel materiaal waaruit afgeleid kan worden dat het initiatief voor de sollicitatie zeer waarschijnlijk bij de provincie heeft gelegen. Het betreft de correspondentie rond nieuw benoemde burgemeesters. Deze moeten vanaf oktober 1940 de toespraak, die ze bij hun installatie willen houden ter goedkeuring voorleggen aan de Commisaris der Provincie.

Van Rijckevorsel laat ze door een ambtenaar in het Duits vertalen en legt ze daarna voor aan de Beauftragte in Vught. In de eerste oorlogsjaren zijn dat kabbelende toespraken, maar dat verandert als eind 1942 de eerste NSB-ers worden benoemd.

Begin december 1942 houden NSB-ers in Drunen en Gemert hun installatietoespraken. Het lijkt er veel op dat deze onervaren bestuurders een model voor een toespraak hebben gekregen, want de opbouw is steeds dezelfde. Vaste elementen zijn: de vaststelling dat zij niet van adel zijn of niet 'het zoontje van'; zware dreiging tegen degenen die hen willen tegenwerken en het prijzen van de nationaal-socialistische mantelorganisaties als Winterhulp, Arbeidsdienst en de Landstand. ${ }^{24}$

Als Van Rijckevorsel één dag voor de installatie de rede ontvangt van de nieuwe NSBburgemeester G. Jacob in Vlijmen schrikt hij erg van de toon en inhoud. Het is te laat om de rede tegen te houden. Hij stuurt hem enkele dagen later door, niet naar de Beauftragte

21 Coolen, Herberg In 't Misverstand, 218.

22 Joosten, Katholieken en fascisme, 233.

23 Cleerdin, Het Brabantse dorp, 55.

24 RANB, inv. nr. 130.01, conceptteksten van de toespraken van Ramaeker in Drunen, december 1942 en van I.F.A. Vogels in Gemert, 10 december 1942. 
in Vught, maar naar secretaris-generaal Frederiks van Binnenlandse Zaken. Hij acht de rede zeer bedenkelijk en vraagt aan Frederiks te beoordelen of er een opmerking tegen Jacob moet worden gemaakt. ${ }^{25} \mathrm{Hij}$ heeft een groot aantal passages groen aangestreept.

Jacob zegt dat er van nu af aan mensen van de nieuwe orde tot burgemeester benoemd zullen worden, die het ambt uitoefenen "volgens de richtlijnen en voorschriften, die de NSB [...] pleegt te geven." Vroeger werd je, volgens Jacob, alleen burgemeester als je een dubbele naam en geld had, maar nu is dat anders. "Ik ben door de NSB ingezet, niet op eigen initiatief, en sta hier dus op de eerste en voornaamste plaats als lid der Beweging, van wien verwacht wordt, dat hij geheel in den geest dier Beweging het ambt, waartoe hij geroepen werd, ook zal vervullen." In zeer felle bewoordingen spreekt hij over een gestorven dorpsgenoot, die omwille van zijn politieke overtuiging "als een hond in een zandkuil" werd begraven. Hij heeft met de kameraden gezorgd voor een passend graf. Met genoegen constateert hij dat nu voor het eerst in de geschiedenis van Vlijmen "de oranje-blanje-bleu vlaggen en de zwart-rode vlaggen" naast elkaar wapperen van het gemeentehuis en de gemeentetoren.

Frederiks antwoordt de Commissaris dat het onder de omstandigheden niet wenselijk is om opmerkingen te maken: "Het verdient intusschen wel aanbeveling dat Uwerzijds nauwlettend op de ambtshandelingen van dezen functionaris acht wordt gegeven." 26

Deze briefwisseling vindt plaats in dezelfde tijd dat Coolen bij De Bourbons over de sollicitatie naar de post in Waalre heeft gesproken. Het is heel aannemelijk dat de Commisaris en zijn griffier Cleerdin zo zijn geschrokken van de toon en de voornemens van die eerste NSB-burgemeesters, dat zij mensen zijn gaan benaderen voor posten die op korte termijn zullen vrijkomen zoals die in Waalre. Enkele weken na het dineetje bedankt Coolen De Bourbon voor de gezellige ontvangst, maar ook "voor de ongetwijfeld warme voorspraak bij Cleerdin en voor je waarschuwing [attent maken op, C.S.] met betrekking tot een solli. citatie in Waalre. Al acht ik op 't oogenblik de kansen niet groot, toch zal ik je raad volgen en solliciteeren. Wel had ik nog graag je raad, hoe zoo'n sollicitatie dient te worden ingekleed en hoe geadresseerd."27 De Bourbon heeft Coolen dus op de vacature Waalre geattendeerd.

\section{Een waarschuwende toespraak}

In februari 1943 stuurt een groot aantal Brabantse burgemeesters een protestbrief aan secretaris-generaal Frederiks met een afschrift aan Commissaris der Provincie Van Rijckevorsel. De burgemeesters protesteren tegen de gedwongen arbeidsdienst van de burgers en de maatregelen die zij in dit verband moeten uitvoeren. Zij wijzen er op dat zij zich steeds correct hebben gedragen tegenover de bezetter, maar dat ze hun ambt moeten neer leggen als de maatregelen doorgaan. De Bourbon is een van de vijfentwintig burgemeesters die zo'n protestbrief heeft geschreven, evenals burgemeester Uyen van Waalre wiens pensionering de aanleiding is voor Coolens sollicitatie. ${ }^{28}$

Terwijl de sollicitatie van Coolen in het voorjaar van 1943 bij de burgerlijke autoritei. ten in behandeling is, wordt de positie van De Bourbon in Oss steeds benarder. Hij is bij illegale acties al een paar maal aan het gevaar ontsnapt en verschijnt daarom tegen de afspraak in niet op Coolens verjaardag op 17 april. Geeft niet, antwoordt Coolen aan Gudrun de Bourbon, die namens haar man een verontschuldiging stuurt en hij bedankt voor de 
cadeautjes: de "koele kruik" ligt in de kelder en de fles Bourgogne ligt bij de verwarming. ${ }^{29}$

Eind mei wordt de situatie zo kritiek dat De Bourbon zijn formele positie en zijn daadwerkelijk gedrag niet langer meer kan combineren; hij dient zijn ontslag in. Op maandagmiddag 24 mei 1943 houdt hij een toespraak tot zijn hoofdambtenaren en de afdelingschefs van de gemeente Oss. ${ }^{30}$ In deze lange rede van ruim vijf bladzijden licht hij zijn aftreden toe en geeft daarmee tegelijk een goed beeld van de situatie waarin een burgemeester zich in die fase van de bezetting bevindt.

Hij leest eerst zijn ontslagbrief voor die hij op 20 mei aan de Commissaris der Provincie en aan de secretaris-generaal heeft gestuurd. De Beauftragte van Brabant heeft hij persoonlijk en mondeling ingelicht.

In de brief heeft hij geschreven dat hij de laatste weken een steeds hevigere gewetensstrijd heeft moeten voeren bij de uitoefening van zijn functie. Vooral na de jongste maatregelen van de Duitse overheid als "het arresteeren van jeugdige personen, de deportatie van studenten, het weder in krijgsgevangenschap voeren van oud-militairen, het uitvaardigen van een aanmeldingsplicht voor alle mannen van 18 -35 jaar, de verbeurdverklaring van radiotoestellen" acht hij het waarnemen van een bestuursfunctie niet langer verenigbaar met zijn "gevoelens van nationale eer" en met de "liefde voor mijn vaderland." Van de vooroorlogse taak van de burgemeester is niets meer overgebleven. De sociale taak is door de W.H.N. [Winterhulp Nederland, C.S.] en de N.V.D. [Nederlandsche Volksdienst, C.S.] overgenomen, "welke als instrumenten van nationaal-socialistische propaganda" worden gebruikt. De administratieve taak beperkt zich voornamelijk tot het verstrekken van gegevens voor de 'Arbeitseinsatz', waaraan een Nederlands ambtenaar, naar zijn gevoel van recht en eer, niet kan meewerken.

Nog veel erger vindt De Bourbon het dat het zwaartepunt van de taak van de burgemeester is overgebracht naar zijn hoedanigheid als politiegezagsdrager, waardoor hij een afhankelijk werktuig is geworden "van de nationaal-socialistisch gereorganiseerde Nederlandsche politie." Hij constateert dat nu de situatie is ontstaan, waarvan in de laatste alinea van de richtlijnen voor burgemeesters, de 'Aanwijzigingen', vastgesteld door de Ministerraad in 1937, sprake is. Die alinea luidt: "In het algemeen kan worden gezegd, dat ambtenaren hun taak moeten neerleggen, wanneer het hun door de vijandelijke autoriteiten onmogelijk wordt gemaakt die taak te blijven vervullen in het belang van de eigen bevolking en op een wijze, die vereenigbaar is met de trouw aan het eigen land."

Hij zegt dat hij op zaterdag 22 mei, dus ná zijn ontslagverzoek, nog een politie-alarmeringsbericht heeft ontvangen met de opdracht om mee te werken aan het opsporen van arbeidsplichtigen. Na een onderhoud met de Commissaris der Provincie op de ochtend

25 RANB, inv. nr. 130.01, brief Commissaris der Provincie Van Rijckevorsel aan secretaris-generaal Frederiks, 15 december 1942.

26 RANB, inv. nr. 130.01, brief Frederiks aan Van Rijckevorsel, 22 december 1942.

27 LMDC, inv. nr. C 3485, brief Coolen aan De Bourbon, 16 januari 1932.

28 RANB, inv, nr. 130.01, protestbrieven burgemeesters aan secretaris-generaal Frederiks, februari 1943.

29 LMDC, inv. nr. C 3485, brief Coolen aan De Bourbon, 3 mei 1943.

30 LMDC, inv. $\mathrm{nr}$. B 783, typoscript rede 'Mijne vrienden hoofdambtenaren en afdeelingschefs' van De Bourbon, 23 mei 1943. De Bourbon heeft een afschrift van deze rede naar Coolen gestuurd. 
voor de toespraak heeft hij nog diezelfde dag een brief aan de secretaris-generaal geschreven dat hij op grond van gewetensbezwaren "geen enkele uitvoering kan geven" aan de opdracht in het alarmeringsbericht. Om te voorkomen dat hij verantwoordelijk is voor het eventueel toch wegvoeren van mensen door de politie, die onder zijn bevel staat, deelt hij de secretaris-generaal mee dat hij vanaf deze ochtend Ir uur demissionair is en niet meer aansprakelijk of verantwoordelijk is voor ambtelijke bevelen.

Tot slot richt hij zich in een persoonlijk woord tot de ambtenaren. Hij verwijst naar het woord van de bisschoppen die in ondubbelzinnige taal te verstaan hebben gegeven dat aan het Nederlandse volk onrecht is bedreven. Hij weet ook wel dat dat onrecht niet dateert van 20 mei 1943, maar tot die tijd voelde hij zich in staat om "dat onrecht van Uwe medegemeentenaren goeddeels af te wenden, althans $i k$ wist mij aan de medewerking eraan te onttrekken." Nu wordt het onrecht echter op zo grote schaal ingezet en wordt zoveel medewerking van vooral de burgemeesters geëist, dat het "niet meer geoorloofd is de verantwoordelijk gestelde posities te blijven bezetten." Hij weet dat hij door af te treden de belangen schaadt van de bevolking van Oss, maar die belangen kunnen en mogen hem niet dwingen "in de positie van een onrechtpleger, in de positie van een landverrader."

De positie van burgemeester is trouwens als gevolg van de laatste reorganisaties door het Duitse gezag zo veranderd, zegt hij, dat het behartigen van werkelijke gemeenschapsbelangen bijna onmogelijk is geworden. Zijn werk voor de armen is overgenomen door de "bloedarme instellingen" W.H.N. en N.V.D. Hij herinnert eraan hoe al een paar keer rechtsvervolging tegen hem is ingesteld vanwege het inzamelen van geld voor ledikanten of voor hulp in de huishouding. Een burgemeester mag nu alleen nog maar handlanger zijn van de bezetter door diensten te verlenen aan de Sicherheitspolizei, de Gewestelijke Politiepresident, die onder SS-commando staat, en het Gewestelijk Arbeidsbureau voor de arbeidsdienst in Duitsland.

De nieuwe golf van arrestaties van "onschuldige arbeiders en andere personen" heeft hem uiteindelijk tot deze stap gebracht. Met een oproep tot voorzichtigheid maar ook tot het hoog houden van de beginselen van katholieke Nederlanders besluit hij met een citaat in het Latijn: "Melius vitam quam causas vitae perdere; het is beter het leven te verliezen dan datgene, wat aan het leven zin, beteekenis en schoonheid geeft. Vaart wel!"

\section{De sollicitatie springt af}

Na deze toespraak duikt De Bourbon onder. Coolen stuurt enkele dagen later een bemoedigende brief aan zijn vrouw Gudrun, waarin hij haar zegt vertrouwen te hebben in de moed van Louis. Hij wenst haar sterkte in haar "stroo-weduwlijke" staat en vraagt de groeten over te brengen aan Louis in zijn "exil. ${ }^{31}$ In juni feliciteert hij de nog steeds ondergedoken De Bourbon in een rechtstreekse brief met zijn "moedige en rechtschapen beslissing." Hij heeft de rede bij zijn "mannelijk afscheid van de ambtenaren" gelezen en vindt de beweegreden van De Bourbon duidelijk. Coolen nodigt hem uit om bij zijn ouders op de Zeilberg in Deurne onder te duiken. "Het is er eenvoudig en zéér netjes" met een verzorging "die waarschijnlijk in verwennerij ontaardt." Gerda Coolen voegt er nog een paar regels aan toe, waarin ze hem aanspoort voorzichtig te zijn: "Ze loeren op je. ${ }^{.32}$ 
Coolens sollicitatie naar de post van Waalre is nog steeds in behandeling. De formele ambtelijke voorbereiding van de sollicitatie is al enige tijd rond. Op I5 mei 1943 heeft de Commissaris der Provincie, Van Rijckevorsel, officieel om inlichtingen over Coolen verzocht bij de waarnemend (loco)burgemeester van Waalre Van der Palen, ${ }^{33}$ bij de Officier van Justitie in 's-Hertogenbosch en bij de kantonrechter in Eindhoven. Van der Palen antwoordt dat Coolen pas sinds begin januari r 938 in Waalre woont en

"tot heden zeer weinig omgang heeft gehad met de plaatselijke bevolking. Hij is een zeer bekend letterkundige, die wat zijn ontwikkeling betreft wel de nodige bekwaam. heden zal bezitten, om het ambt van burgemeester behoorlijk te kunnen vervullen. De nodige ijver en tact kunnen eveneens bij hem aanwezig worden geacht. Betrokkene bouwde zich vóór zijn vestiging alhier een kapitaal landhuis, wat hij sedertdien bewoond [sic]. Naar uiterlijke omstandigheden te beoordelen, moet hij voldoende financieel onafhankelijk worden geacht voor de eventuele vervulling der betrekking." In een bijlage wordt vermeld dat Coolen partijloos is. Bij het kopje 'diploma's' staat de aantekening: "Voor zover bekend in het bezit van de akte van bekwaamheid als onderwijzer bij het lager onderwijs." ${ }^{34}$ Dit laatste is een vergissing.

De officier van justitie, mr. C.J. van Arkel, schrijft dat Coolen geen strafregister heeft en niet voorkomt in de administratie van het parket, en dat de sollicitant hem persoonlijk niet bekend is. ${ }^{35}$

G.J. Jansen van het kantongerecht van Eindhoven acht Coolen niet geschikt voor het ambt van burgemeester. Een reden geeft hij niet en uit zijn formulering blijkt dat hij eigenlijk ook geen reden kan hebben, want "zijn ijver, tact en financiële positie zijn mij onvoldoende bekend om daarover inlichtingen te verstrekken." ${ }^{36}$

In juli r 943 denkt Coolen dat hij zeker kan zijn van zijn benoeming. De felle en dramatische afscheidsrede van De Bourbon voor de ambtenaren in Oss heeft hem echter aan het denken gezet. De Bourbon geeft hierin immers onomwonden te kennen dat een burgemeester in deze tijd niet veel anders meer kan zijn dan een uitvoerend werktuig van de nazi's. In een lange brief aan de ondergedoken ex-burgemeester verwoordt Coolen zijn twijfels:

"Gij zult wel mijnen zwaren kommer begrijpen nu bij mij de zaak naar Waalre haar doorgang heeft gevonden. De griffier had ik, na jouw bezoek, mijn verminderde animo en mijn bezwaren geschreven, maar bij een onderhoud dat ik met hem had vond hij:

31 LMDC, inv. nr. C 3485, brief Coolen aan Gudrun De Bourbon, 27 mei 1943.

32 LMDC, inv. nr. C 3485, brief Coolen aan De Bourbon, 21 juni 1943. De enveloppe met adressering is niet bewaard, waardoor niet duidelijk is of deze brief via een omweg is terechtgekomen. De inhoud is bezwaarlijk en daarom is het sturen of ontvangen niet zonder risico.

33. Wethouder en arbeidersafgevaardigde, op wie patriottisch niets is aan te merken. CS. [typoscript] Zoetmulder, Antoon Coolen en Waalre, 8.

34 RANB, inv. nr. 130.01, brief Van de Palen aan Commissaris der Provincie, 21 mei 1943.

35 RANB, inv. nr. 130.01, brief Van Arkel aan Commissaris der Provincie, 1 juni 1943.

36 RANB, inv. nr. 130.01, brief G.J. Jansen aan Commisaris der Provincie, 2 juni 1943. Dezelfde persoon zal een jaar later positief adviseren over het lidmaatschap van Coolen van het Tribunaal voor bijzondere rechtspleging. 
toch doen, en overreede [sic] mij met zijn beweegredenen. En ook met de secretaris. generaal had ik een onderhoud van dezelfde strekking, waarna hij het benoemingsbesluit heeft opgemaakt. Gij die mijn gevoelen voor je collegaschap gedeeld hebt zult beseffen, dat ik, eenmaal op gang, verontschuldigd ben voor dit doorzetten, waarbij nog komt dat het dorpse, landelijke Waalre niet die strijdpunten heeft welke Oss heeft, en gij zult er nimmer in zien wat het niet zijn kan, het ontbreken van die reserveloze solidariteit die er onder vrienden moet zijn, en ook niet een desavouering van je besluit. Want voor een gewetensconflict geplaatst zal bij mij ook puur het gewetens. voorschrift beslissen. Het benoemingsbesluit moet nu nog door de spitsroeden van de bezettende macht. Wel, als het doorgaat, ligt over het geval een zware schaduw.. die der laatste ontslagen in mijn omgeving en die van jouw afwezigheid vooral bij de installa. tie, want daar had ik mij zeer op verheugd! lets feestelijks zal er nu moeilijk nog kun. nen zijn. Intussen zou je me even raad kunnen schaffen voor de formulering van het inleidend dankwoord onder de huidige omstandigheden: (het provinciaal bestuur \& secretaris generaal?). ${ }^{.37}$

Coolen denkt dus nog steeds dat de sollicitatieprocedure vooral een zaak is tussen hem en de Nederlandse functionarissen, met wie hij goed overweg kan: Van Rijckevorsel, Cleerdin en Frederiks. In de zomer van 1943 worden echter in de installatietoespraken van nieuwe burgemeesters heel andere mensen bedankt: de Rijkskommissaris, de leider Mussert, Beauftragte Thiel, en de districtleiders van de NSB.

Ook in augustus 1943 verkeert Coolen nog steeds in de veronderstelling dat hij het ambt van burgemeester binnenkort zal bekleden. Pas dan, acht maanden na zijn sollicitatie, vertelt hij het aan Oomes. Hij leidt het in met een opmerking dat de hoofdbron van zijn inkomen, Nijgh, droog staat.

"Daarom was ik er verre van afkeerig van een oud idee opnieuw te kunnen opvatten, wat ik vroeger reeds eens met den griffier van onze provincie had bepraat. In Waalre is de burgemeester wegens het bereiken van den pensioengerechtigden leeftijd heengegaan, en, lach niet, want je raadt het al, na sollicitatie heb ik van den secretaris-generaal van binnenlandsche zaken, die mij daartoe op het departement ontbood, de mededeling gekregen, dat hij bereid was mij te benoemen en dat hij 't benoemingsbesluit gereed zou maken. De benoeming moet echter de Duitsche goedkeuring hebben, praat er daarom nog maar niet over, want die Genehmigung blijft altijd riskant, zeker in mijn geval. Zoowel met den griffier als met den secretaris-generaal is de zaak in den breede besproken, wees gerust over mijn integriteit en over de consideraties, die zich doen gelden. In Waalre zou het, geloof ik, wel vreugde en op het ogenblik zelf opluchting geven. ${ }^{38}$

Uit deze passage blijkt dat Coolen dus al veel langer rondliep met het idee om burge meester te worden - hij spreekt immers van "het oude idee" - en bovendien dat het financiële aspect wel degelijk een rol speelt. ${ }^{39}$ Loco Van der Palen heeft Coolens financiële onafhankelijkheid dus niet goed getaxeerd.

Het gesprek met secretaris-generaal Frederiks van Binnenlandse Zaken is goed verlopen. In september 1943 schrijft Frederiks een uitgebreide brief aan de Generalkommissar dr. 
Prinsen, waarin hij uitgebreid uitlegt waarom de NSB-er R.M. Schregardus niet benoemd mag worden in Waalre en waarom Coolen een uitstekende kandidaat is. Uit deze brief krijgen we een indruk van de sollicitatiebrief van Coolen die verloren is gegaan. Frederiks schetst Coolens hele curriculum vitae vanaf het gymnasium in Heeswijk tot zijn internationaal succes als schrijver, de gouden penning van de provincie Brabant en zijn lidmaatschap van de monumentencommissie. Hij legt veel nadruk op zijn persoonlijke kwaliteiten:

"Er ist ein ausgezeichneter Redner, der viele Vortrage gehalten hat. Er versteht es mit Leuten jeden Schlages umzugehen und empfindet sozial. Er interessiert sich besonderes für Schutz und Pflege des Dorflebens. Die Belange der Dorfgemeinschaft wird er auf Grund seiner Lebenserfahrung mit sachverständigem Blick erkennen und eifrig vertreten."

Dat Coolen geen ervaring heeft met het lokale openbaar bestuur is niet zo'n probleem; hij kan steunen op een "tüchtigen Sekretär."

"Durch seine Grosszügige Art, Menschen und Dinge zu betrachten und seine umfassende Allgemeinbildung wird Herr Coolen des Uebergewicht zu erhalten wissen und kann ihm austandslos die Leitung der Gemeinde Waalre anvertraut werden.

Ich bitte Sie denn auch, baldmöglichst Ihren Sichtvermerk zu der Ernennung des Herm Coolen erteilen wollen." 40

Coolens inschatting, dat de Duitse goedkeuring voor zijn benoeming riskant is, klopt. De politieke factor bij burgemeestersbenoemingen wordt steeds belangrijker. Naarmate de oorlog minder in het voordeel van de Duitsers verloopt, is de repressie tegen de bevolking in de eerste helft van 1943 sterk toegenomen. De bezetter heeft in zo'n situatie burgemeesters nodig op wie hij blindelings kan vertrouwen. Het toetsen van dit vertrouwen doen de Duitsers zelf. Het onderhoud met de Beauftragte, de heer Thiel, vindt een maand na de brief van Frederiks plaats op maandag 18 oktober 1943 om 12 uur in Haus Roucouleur, het bureau van deze functionaris in Vught. ${ }^{41}$ Hoe het onderhoud met Thiel is geweest, vertelt Frans van Dijk van de Linnenfabriek Walra en vriend van Coolen uit de sociëteit De Doelen veel later aan Zoetmulder. ${ }^{42}$ Van Dijk houdt rekening met het feit dat die Beauftragte een relatie van Coolen is geweest van voor de oorlog. Waarschijnlijk vergist Van Dijk zich en verwart hij Thiel met diens voorganger, Fritz Ritterbusch, een letterkundige, die goed met De Bourbon kon opschieten. ${ }^{43}$ Coolen heeft van tevoren tegen Frans van Dijk gezegd dat hij geen blad voor de mond zal nemen. Na afloop vertelt hij aan Van Dijk dat het een hevige woordenwisseling geweest is en dat de Duitser met de vuist op tafel heeft geslagen. Van Dijk onderschrijft hiermee de lezing die Coolen later zelf heeft gegeven.

37 LMDC, inv, nr. C 3485, brief Coolen aan De Bourbon, 15 juli 1943.

38 LMDC, inv. nr. C 3485, brief Coolen aan Oomes, 13 augustus 1943.

39 RANB, inv. nr. 130.01, map 277, overzicht burgemeestersalarissen 1946. Het salaris van een burgemeester voor een gemeente als Waalre met 6500 inwoners bedroeg in 1946 tussen de 4500 en 5500 gulden.

40 NIOD, inv. nr. 10la, brief SG Frederiks aan GK Prinsen, 15 september 1943.

4) FPC, uitnodigingsbrief Rijkscommissaris aan Coolen, 14 oktober 1943.

42 CS, [typoscript] Zoetmulder, Antoon Coolen en Waalre, 8-9.

43 LMDC, inv. nr. B 783, brief De Bourbon aan van Duinkerken, 3 april 1959. 


\section{Coolens versie}

Coolen heeft deze episode niet opgenomen in zijn boek Bevrijd Vaderland. Hij heeft de geschiedenis wel op schrift gesteld in zijn brieven aan Oomes. Na de oorlog heeft hij naar aanleiding van zijn conflict met Van Doorne de zaak nog eens uitvoerig beschreven in een brief aan Frater Amator van Hugten uit Deurne. In deze brief geeft Coolen zijn versie van de gebeurtenissen:

"Toen in 1943 burgemeester Uyen met pensioen ging, ontbood de griffier mij naar Den Bosch en besprak met mij het feit dat het ogenblik voor de sollicitatie was aangebroken. Hij drong er op aan dat ik zou solliciteren, omdat het voor het dorp beter zou zijn dat niet een NSB'er er de heengegane burgemeester zou opvolgen. Ik heb me tot een sollicitatie bereid verklaard onder uitdrukkelijk voorbehoud dat ik geen enkele concessie tegenover de Duitsers zou doen, een opvatting waarmee Cleerdin het volkomen eens was. Ten overvloede heb ik tevoren nog overleg gepleegd met Van Duinkerken, met wie ik in het geestelijk verzet één lijn trok, en met Lou Lichtveld, die een vooraanstaande plaats innam in de Amsterdamse illegaliteit. Beiden waren het met de sollicitatie eens. Ik heb toen gesolliciteerd en de gemeentesecretaris van Waalre in kennis gesteld. $\mathrm{Na}$ een onderhoud met de secretaris-generaal van Binnenlandse Zaken, dhr. Frederiks, ben ik benoemd en heeft Frederiks het benoemingsbesluit ondertekend. Ook Frederiks heb ik mijn voorbehoud, dat ik tot geen enkele concessie tegenover de Duitsers bereid was, meegedeeld en de heer Frederiks vond dit juist. Bij de Beauftragte, de heer Tiel [sic], ontboden, stelde deze mij de vraag of ik bereid was de gemeente in de geest der nieuwe orde te besturen. Deze vraag heb ik ontkennend beantwoord. Zijn vraag hoe ik tegenover de Duitse bestuursmaatregelen stond heb ik beantwoord, dat ik ze uit zou voeren in zoverre ze in overeenstemming waren met de Nederlandse belangen, zodat ik uitvoering zou weigeren indien ze daarmee in strijd waren. De vraag of ik geloofde aan de Duitse overwinning heb ik ontkennend beantwoord, waarop hij heftig zijn eigen geloof in die overwinning beleed en mij vroeg of ik met een plaat voor mijn voorhoofd liep. De vraag of ik in de Duitsers de vriend of de bezetter zag, heb ik beantwoord met de mededeling dat ik in de Duitsers de bezetter zag en zelfs de harde bezetter. Waarop hij me zei dat de Duitsers genoodzaakt waren hard te zijn tegen hen die in hen de bezetter zagen, doch vriendelijk waren voor hen die bereid waren in hen vrienden te zien. Tenslotte verweet hij mij dat ik in het enig mogelijke alternatief, nationaal-socialisme of bolsjewisme, het bolsjewisme koos, en liet me uit met de opmerking, dat ik wel zou begrijpen dat het onderhoud vruchteloos was geweest. Ik ben dan ook niet benoemd." ${ }^{n 4}$

\section{Burgemeester: goed of fout?}

Als Coolen alleen met Nederlandse vertegenwoordigers zaken had moeten doen, en met een militair bewind op afstand, dan was hij zeker burgemeester geworden.

Coolen zelf stipt in Bevrijd Vaderland het verschil aan tussen de Militärverwaltung in België en de Zivilverwaltung in Nederland. In Nederland bemoeiden de Duitsers zich ook met burgerlijke zaken, omdat men van begin af aan besefte dat een "regering Mussert" tot niets zou leiden. In het eerste deel van zijn sollicitatie heeft Coolen alleen gesproken met "nette mensen," in ieder geval met personen die anti-NSB zijn.

Cleerdin, weliswaar met bedenkelijke banden met Lutkie en het blad Aristo-, heeft hem 
gelauwerd, de Commissaris der Provincie probeert te redden wat er te redden valt en ook de secretaris-generaal Frederiks van Binnenlandse Zaken is geen nazi. Seyss-Inquart had geleerd van de fouten in Noorwegen, waar te snel de top van alle departementen was genazificeerd. Eind I94I waren er in Nederland nog maar vier van de tien SG's Duitsgezind of NSB-er. Op alle terreinen verliep de gelijkschakeling zeer geleidelijk. ${ }^{45}$

Het is in dit licht dat Coolen, tot kort voor het onderhoud met de Beauftragte, gedacht heeft dat er een mogelijkheid was redelijk zelfstandig als burgemeester binnen deze nieuwe orde te kunnen functioneren. Het financiële aspect speelt hierbij zeker een rol. Gestimuleerd wellicht door de al lang gekoesterde wens een schrijvende burgemeester te worden, zoals tot voor kort zijn vriend in Oss, en ook gedreven door het verlangen naar maatschappelijke waardering, heeft hij de sollicitatie doorgezet. Het kan bijna niet anders of hij heeft oog in oog met een vertegenwoordiger van de bezettende macht, de Beauftragte, pas ten volle beseft wat de consequenties van de aanvaarding van het burgemeesterschap in deze tijd zouden zijn. Op dat moment is de tekst van de afscheidsrede van De Bourbon als een concrete werkelijkheid tot hem doorgedrongen. Hij ziet dan in dat deze meer is geweest dan een proeve van fraaie retorica, maar een precieze schets van de positie van een burgemeester die als willoze marionet van de bezetter gaandeweg gedwongen zou worden opdrachten uit te voeren die niet stroken met zijn opvattingen.

Dit neemt niet weg dat het toch frappant blijft dat in de eerste helft van 1943 de negatieve ervaringen van De Bourbon in Oss en de sollicitatieactiviteiten van Coolen voor het burgemeesterschap van Waalre gelijk lopen. Nergens in de intensieve correspondentie van die periode blijkt ook dat De Bourbon negatief over deze sollicitatie denkt of dat hij Coolen over diens ambitie een verwijt maakt. Integendeel, hij heeft hem er zelf op geattendeerd.

Het raadsel van dit gedrag is onoplosbaar als men blijft redeneren "in de ban van goed of fout." Onder deze titel heeft de historicus J.C.H. Blom in 1983 zijn oratie gehouden, waarin hij ervoor pleit, de politiek-morele maatstaf van de tweedeling goed of fout, samenhangend met verzet en collaboratie, los te laten bij de bestudering van Nederland tijdens de bezetting. Na de voltooiing van het standaardwerk van $L$. de Jong levert dit zwart-wit-denken geen nieuwe gezichtspunten meer op. Blom pleit ervoor om voortaan meer nadruk te leggen op de analyse van gedrag en de achtergrond van mensen in de oorlog. Waarom handelen mensen zoals ze doen? Kan het niet zijn dat de meeste mensen vrij consistent zijn en hun gedragingen en opvattingen uit de vooroorlogse jaren voortzetten? Blom neemt van E.H. Kossmann het begrip 'accommodatie' over, waarmee hij de manier wil aangeven waarop iedere groep of individu zich aanpast aan de nieuwe situatie. "De wijze waarop dat geschiedde, hing nauw samen met eigen omstandigheden en de eigen overtuiging en opvattingen, ${ }^{n 46}$ schrijft Blom. Hij constateert dat de overgrote meerderheid van de bevolking "trachtte door een teruggetrokken en afwachtend, ja zelfs ontwijkend, gedrag de vertrouwde levenswijze te handhaven en in ieder geval moeilijkheden te voorkomen..47

44 FPC, brief Coolen aan frater Amator van Hugten, 12 juni 1947.

45 De Jong, Het Koninkrijk, deel 5a, 237.

46 Blom, 'In de ban van goed of fout?', 68.

47 Blom, 'In de ban van goed of fout?', 70. 
We herkennen hierin de woorden die Coolen gebruikt: toevlucht, oase, schuilkelder van de geesten ontwijking. Het is zijn grondhouding, niet alleen tijdens de bezetting, maar ook daarvoor bij de kwesties over het regionalisme, de katholieke leer en het weigeren om partij te kiezen bij conflicten. Coolen ontwijkt confrontatie, strijd en ruzie.

De Bourbon schuwt het conflict en de strijd niet, komt steeds meer in botsing met het ambt van burgemeester en denkt er dus mee te stoppen. Dit belet hem echter niet om neutraal met Coolen te discussiëren over een mogelijke sollicitatie naar datzelfde ambt. De Bourbon is, zoals de meeste mensen in die tijd, niet in 'de ban van goed of fout'. Hij raakt zelf steeds meer betrokken bij het verzet, maar ziet mensen die daar niet actief aan meedoen niet automatisch als collaborateurs.

Het afwijkende in Coolens gedrag van deze periode is, dat hij zelf initiatief neemt. Tot dan toe heeft hij steeds moeten reageren op toenaderingspogingen van de bezetter; nu zet hij zelf een stap. Wat zijn motieven ook zijn geweest (het salaris, maatschappelijk aanzien, voorkomen dat er een NSB-er wordt benoemd), hij heeft aan het eind van de procedure gevoeld dat zijn keuze laakbaar is en een stap op een hellend vlak betekent.

\section{Hoop op bevrijding}

Als Oomes later suggereert om Bernard Verhoeven te laten bemiddelen voor een andere burgemeesterspost reageert Coolen afwijzend: "Voorlopig is het niet nodig. Ik sprak slechts met de bezorgdheid van iemand die, zij 't lelijk, inteert, en om je te laten zien, dat ook materieel de benoeming niet onwelkom zou zijn." ${ }^{\text {48 }}$

Hij stelt zich maar weer in op het einde van de oorlog: "Geruchten over wapenstilstand en onderhandelingen zijn ook in Waalre doorgedrongen. Er is hoop op, al is het verstandelijk onzin." Die hoop wordt ook levend gehouden door een kleine groep auteurs. Al in de zomer van 1943 had Albert Helman een idee voor een toneelstuk, een herdenkingsstuk voor de bevrijding, dat gespeeld zal worden door acteurs die geen lid van de Kultuurkamer zijn geworden. In september 1943 komen de schrijvers bijeen: Albert Helman, Maurits Dekker, Antoon Coolen, Jeanne van Schaik-Willing en A. Defresne. Ondanks de moeilijke verbindingen en het verborgen houden van manuscripten vormt dit werk "een lichtpunt in die grauwe dagen, reeds te mogen werken aan iets positiefs voor de toekomst. ${ }^{\text {"49 }}$

Coolen onderhoudt zijn contacten goed. De kinderen van Albert Helman hebben in augustus bij hem gelogeerd en kort daarvoor is Van Duinkerken op bezoek geweest, die met zijn zoon een wandeling door Brabant maakt..$^{50}$

Het gehele jaar 1943 gonst het van geruchten over het einde van de oorlog. Er worden plannen gesmeed voor uitgaven, boeken en publicaties. In november wordt al weer aan de verzuiling gewerkt. Romme lanceert een zogenaamd Persplan voor één groot katholiek dagblad na de oorlog en legt dit onder andere voor aan kardinaal De Jong; Van Duinkerken is de beoogde hoofdredacteur. ${ }^{51}$ Het zal er niet van komen, want Van Duinkerken ziet in die monopoliepositie een bedreiging voor de persvrijheid en de vrijheid van discussie binnen de katholieke gemeenschap. Ook op andere manieren werkt men in die tijd aan de reconstructie van de zuilen na de oorlog. Zo neemt Coolen in december 1943 een keer deel aan een gespreksgroep over 'Kunstbeoefening voor katholieken'. ${ }^{52}$ De participatie van Coolen in dit initiatiefgroepje is op het eerste gezicht eigenaardig: zó geporteerd voor een club van 
katholieke schrijvers is hij nu ook weer niet. Zijn belangstelling zal eerder zijn voortgekomen uit de behoefte om in die onzekere tijd de contacten met andere schrijvers te onderhouden.

Met de kerstdagen hebben de Coolens vrienden over de vloer gehad. De vertaalster Marcelle Schlomer is er en ook Van Duinkerken is onverwacht op bezoek geweest. In januari 1944 komen De Bourbons enkele dagen logeren. Louis duikt regelmatig op vanuit zijn schuilplaats. "Ik vind dit samenzijn met vrienden heerlijk, en ik zeg het niet zonder bedoeling aan jullie," schrijft Coolen uitnodigend aan Oomes en zijn vrouw. Met Kerstmis hebben ze een dronk op de bevrijding uitgebracht en op de grammofoon het Wilhelmus gedraaid. De angst neemt echter toe: "Zo af en toe ben ik wel eens in een andere omgeving, waar een late telefoon de mensen opschrikt en de gezichten verbleken als een auto stopt op een ongewoon uur. Zo is de werkelijkheid van de angst van ons langzamerhand verkommerd volk." ${ }^{53}$ Coolen tobt steeds meer over kleding en voedsel. Daarnaast zijn er aldoor problemen met de dienstboden. ${ }^{54}$ Eind februari, als hij op doorreis naar Rotterdam even bij Oomes is geweest, benadrukt hij achteraf weer het belang van vriendschappen. Deze zijn "een oase in de dikwijls harde woestenij dezer kwade dagen." 55

\section{Zonder vaste woonplaats}

Nadat de sollicitatie van Coolen naar het burgemeesterschap van Waalre in oktober 1943 voorgoed van de baan is, duurt het nog enige tijd voor er iemand anders wordt benoemd. De gemeente wordt al vanaf mei 1943 bestuurd door loco-burgemeester Van der Palen. Pas op I maart 1944 treedt een overtuigd NSB-er als burgemeester aan. Het is, ondanks het bezwaar van Secretaris Generaal Frederiks, toch R.H. Schregardus geworden, een oud-officier van de Koninklijke Landmacht. Bij zijn installatie bedankt hij uitdrukkelijk de Beauftragte Thiel. Hij dreigt degenen die hem willen tegenwerken: "Zij zullen verdwijnen, daar ik geen tegenwerking duldt [sic]." Hij laat er geen twijfel aan bestaan waar zijn prioriteit ligt: "Voor ons land bestaat alleen nog een andere toekomst, als Duitsland dezen oorlog zegevierend beëindigd [sic]. Om dit te bereiken moet eenieder gaarne of ongaarne mede werken en daarvoor moeten alle andere belangen, óók die van Waalre tijdelijk wijken." ${ }^{56}$ Al gauw oefent hij een waar schrikbewind uit en laat actief mensen opsporen voor de arbeidsdienst. ${ }^{57}$

48 LMDC, inv, nr. C 3485, brief Coolen aan Oomes, 29 oktober 1943. Na de oorlog komt hij hier nog een keer op terug en schrijft dat hij ondanks zijn slechte financiele positie het niet gedaan heeft voor de "weelde van de vrijheid." Brief Coolen aan Oomes, 12 december 1945

49 Helman, 'Inleiding bij het toneelstuk Vrij Volk', 10.

50 LMDC, inv. nr. C 3485, brief Coolen aan De Bourbon, 15 juli 1943.

51 Van der Plas, Daarom, mijnheer, 340.

52 BA, brief Coolen aan Van Duinkerken, 29 maart 1949. Zie ook hoofdstuk 18.

53 LMDC, inv. nr. C 3485, brief Coolen aan Oomes, 6 januari 1944.

54 Regelmatig beklaagt Coolen zich tegenover Oomes over de dienstmeisjes: te veel ziek, kleine diefstalletjes. LMDC, inv. nr. C 3485, brief Coolen aan Oomes, 13 augustus 1943 en 20 april 1944.

55 LMDC, inv. nr. C 3485, brief Coolen aan Oomes, 17 januari 1944.

56 RANB, inv. nr. 130.01, typoscript concept-installatierede van R.H. Schregardus, 15 februari 1944.

57 CS, [typoscript] Zoetmulder, Antoon Coolen en Waalre, 9. 
Toch waagt De Bourbon, die als verzetsman gezocht wordt, het om Coolen in deze nu gevaarlijke gemeente op te zoeken. Op de verjaardag van Coolen in april 1944 logeren De Bourbons opnieuw bij hem. Later beschrijft De Bourbon de angst als tijdens dit bezoek de bel gaat. Het is echter de broer van Coolen, Nard, van wie De Bourbon weet dat hij in het verzet zit. ${ }^{58}$ De broer zet de radio aan, die meldt dat in een buitenaf gelegen villawijk van Eindhoven een SS-er is vermoord. De broer zwijgt, maar De Bourbon noteert: "Maar ik heb, tijdens het luisteren naar het bericht, één ondeelbare seconde zijn blik in de mijne gevangen. Ik heb niets gezien dan een haast onmerkbare glimlach en het nauwelijks bewegen van het hoofd als bevestiging van de vraag in mijn blik." ${ }^{59}$

Vanaf mei 1944 gaan de drie oudste jongens naar kostschool. Coolen is van plan een aantal (huiskamer)lezingen te gaan houden in het noorden en Den Haag, tussen I 5 en 2 I mei, "als Churchill althans niet mijn plannen met de zijne doorkruist," schrijft hij eind april aan Oomes. ${ }^{60}$ Later in zijn oorlogsdagboek verwoordt hij het zo: "Ik had een reisplannetje, het was even dikwijls weer opgenomen als het uitgesteld was. Maar iedereen waarschuwde: men kan door de invasie worden verrast." ${ }^{n 1}$

Hij zal echter nog iets eerder dan gepland vertrekken. Op de avond van 13 mei wordt de waarschuwing doorgegeven dat de volgende dag dertig mannen uit Waalre een zogenaamd spitbevel van de burgemeester zullen krijgen. Zij zullen zich op I 5 mei moeten melden voor graafwerk in de provincie Zeeland voor de Atlantikwall, de verdediging tegen de verwachte aanval van de geallieerden van over zee. Volgens het oorlogsrecht is deze opdracht ongeoorloofd, omdat dit verbiedt krijgsgevangenen of mensen uit veroverd gebied te dwingen tot acties rond de oorlogvoering.

De burgemeesters hadden al eerder aanwijzingen van de provinciaal Beauftragte gekregen om mannen van 18 tot 45 jaar voor een periode van twee weken gedwongen in te schakelen. In mei r 944 wordt deze periode verlengd tot vier weken en in juni zal de leeftijdsgrens ook nog opgeschoven worden tot 50 jaar. De maatregel krijgt de naam 'Gemeinde-Einsatz'.

Het heeft niet veel gescheeld of Coolen had als burgemeester voor de gewetensbeslis. sing gestaan of hij deze maatregel had moeten uitvoeren. Het zou een beslissing met levensgevaarlijke consequenties zijn geweest, want van de acht Brabantse burgemeesters die weigeren, komen er zeven om het leven. De meeste van hen zijn via Vught naar Duitse concentratiekampen gevoerd en daar omgekomen. ${ }^{62}$

Het is Coolen nu in ieder geval duidelijk wat hem te doen staat. Hij is verdwenen vóordat de handlangers van NSB-burgemeester Schregardus aan de deur komen om de persoonsbewijzen op te halen. De gevolgen zijn niet gering: als straf wordt de inboedel uit het huis gehaald en veel van het interieur vernield. Het gezin Coolen zal de hele zomer verspreid zijn. Gerda Coolen logeert met de jongste zoon Peter bij de familie Te Strake in Deurne. Als de grotere jongens niet op kostschool zijn, verblijven Felix en Stijn bij de familie Wiegersma. Guido is in huis bij de familie Tromp die ook in Deurne woont.

Coolen schrijft cynisch in zijn oorlogsdagboek: "Wie voor de Duitschers niet spitten wil, verliest het eigendomsrecht op de bedden zijner kinderen, die elders maar een onderkomen moeten zoeken. Zoo heeft het spitbevel het gezin uiteengejaagd. 'Ons nationalisme, uw redding, ons socialisme uw toekomst,' zoo lees ik op de affiches tegen muren, schut- 
tingen en aanplakborden. ${ }^{-63}$

Van mei tot september zwerft Coolen door Nederland. Af en toe zijn er geheime ontmoetingen met zijn gezin: "Vught - Een zeer zonnige, zeer warme dag, en ik heb net mijn kinderen ontmoet. ${ }^{" 64}$ Hij vindt een schuilplaats bij zijn vertaalster, Marcelle Schlomer, in Marlot, een vrij nieuwe wijk in Den Haag. ${ }^{65}$ Van hieruit stuurt hij eind mei via een advocaat een officiële brief aan de burgemeester van Waalre, met de mededeling dat hij niet in staat is om spitwerkzaamheden te verrichten. ${ }^{66}$ Aan de heer van der Linden, directeur van het postkantoor en vader van Leny, zijn latere secretaresse, stuurt hij op 31 mei een felicitatie vanwege zijn zilveren ambtsjubileum. Het spijt hem dat hij niet aanwezig kan zijn, maar als hij was gaan spitten "dan ook was ik dien dag in ballingschap geweest en misschien had ik dan zelfs geen pen meer kunnen hanteeren." ${ }^{n 6}$ Zoals altijd maakt Coolen zich er in dit soort persoonlijke brieven niet met een Jantje van Leiden af. Ook onder deze moeilijke omstandigheden schrijft hij twee kantjes vol. Na gewezen te hebben op het belang van de posterijen spreekt hij zijn hoop uit op een spoedige bevrijding "van de nachtmerrie, die nu dag én nacht vergiftigt." De brief is geschreven op zijn eigen postpapier, waarvan hij kennelijk een stapeltje heeft meegenomen naar het noorden.

De ellende wordt voor de Coolens nog vergroot, als er op 30 mei een bericht van uitgeverij Nijgh \& Van Ditmar ${ }^{68}$ komt dat de maandelijkse uitkeringen moeten stoppen, omdat door een gedurig verminderde verkoop van boeken de rekening een somber beeld vertoont. Vanwege de lange duur van de overeenkomst "en niet het minst ook met het oog op onze allerprettigste, nooit verstoorde relatie" wil men het besluit zo soepel mogelijk laten verlopen. Men stelt voor de beëindiging van de betalingen pas op 3 I december I944 te laten ingaan.

Tijdens zijn 'onderduik' reist Coolen veel met de trein. Daarbij laat zijn gewoonte om mensen te observeren hem niet in de steek. Hij zorgt er wel voor dat hij zelf niet te veel opvalt.

58 De oudste broer Willem (W.J.) Coolen deed volgens zijn zoon "licht ondergronds werk" als het doorgeven van berichten en koeriersdiensten. Hij had altijd een EHBO-tas bij zich die kon dienen als alibi. Willem Coolen leek sterk op zijn broer Antoon. Hij is nog even opgepakt toen Coolen in de zomer van 1944 was ondergedoken, omdat men dacht dat hij de schrijver was. Een andere broer Nard (Leonardus) Coolen speelde ook een rol bij de ondergrondse vanwege zijn kennis van zend- en radioapparatuur. Bij onraad warschuwde hij contacten door een bepaald voorwerp buiten aan het huis te hangen. Interview met de heer Sjef Coolen (zoon van W.J.) in Deurne, 11 januari 2000.

59 De Bourbon, 'Antoon Coolen 60 jaar', 649-650.

60 LMDC, inv. nr. C 3485, brief Coolen aan Oomes, 20 april 1944.

6 Coolen, Bevrijd Vaderland, 117.

62 Opvallend is de opstelling van Frederiks. Deze zei dat, als hij burgemeester was, hij zou weigeren de maatregel uit te voeren. L. de Jong. Het Koninkrijk, deel 7, 1288-1289. Over de Brabantse burgemeesters: ibidem, 1293.

63 Coolen, Bevrijd Vaderland, 117 en 127.

64 Coolen, Bevrijd Vaderland, 122.

65 Van Duinkerken, Antoon Coolen, 96.

66 FPC, kopie van brief Coolen aan burgemeester Waalre, 27 mei 1944.

67. WE, brief Coolen aan Van der Linden, 31 mei 1944.

68 FPC, brief Nijgh \& Van Ditmar aan Coolen, 30 mei 1944. 
"Men kan hem in die tijd, vrijwel onherkenbaar, ontmoeten in een burgerlijk colbertkostuum, zonder vlinderdas, en met een hoed waaraan alle zwier ontbrak," schrijft zijn vriend Oomes later. ${ }^{69}$ Coolen ziet gevangen genomen Canadese piloten op het perron in Utrecht en schetst als contrast met de gewichtigdoenerij van de Duitsers deze mensen, die kort daarvoor nog in een vrije wereld leefden: "blootshoofds, losjes in hun blauwgrijze uniform van ontwapenden, exotischer in het leeren jasje met schapenbont en in de met bont gevoerde bruine laarzen. ${ }^{.70} \mathrm{Hij}$ ziet hoe de sympathie van de perronwandelaars naar de gevangenen uitgaat.

Bij een treincontrole tussen Delft en Den Haag wordt een jonge man opgepakt door de Nederlandse helper van een geüniformeerde Duitser. Over een man met een NSB-speldje in dezelfde coupé, die nu door iedereen wordt aangekeken, schrijft hij: "Hij beseft, dat ook hij als medeplichtige wordt beschouwd aan de misdaad, die aan onze als wild opgejaagde jeugd wordt gepleegd. ${ }^{\text {"n }}$ In Hilligersberg waarschuwt een pastoor aan het eind van de Mis dat buiten een persoonsbewijzencontrole wordt gehouden en sluist mensen via de pastorie naar buiten. ${ }^{2}$ Coolen ziet ook de tegenstellingen die er tussen de mensen aan de 'verkeerde kant' bestaan. De welgedane man in WA-uniform - "de stof is zoo degelijk, de staande kraag, de roode nek met de voegen en naden, de heldere handen van den man in rang, en de vreugd zijner glimmende rijlaarzen" - onderscheidt zich duidelijk van een pover NSBgezinnetje: "Hij steekt wat dun in zijn kleeren, net als zijn vrouw die ook te vet piekerig haar heeft, hij maakt dien indruk van Jan van het proletariaat. ${ }^{73}$ Hij ziet de gevangenentransporten in Vught en Utrecht en vraagt zich af of er niet een dag komt dat iedereen uit de trein stapt en die SS-ers de hersens inslaat. Bijna nog meer dan aan deze SS-ers ergert hij zich aan de landwachten, Nederlanders die bij de stationsuitgangen mensen aanhouden en degenen met valse persoonsbewijzen aan de Duitsers overdragen, maar zelf er op uit zijn om levensmiddelen af te pakken en er zwarte handel mee te drijven. ${ }^{74}$ Coolen zet deze personen en situaties net zo haarscherp neer als hij daarvoor deed in zijn romans.

Hij onderhoudt contacten met andere schrijvers en neemt deel aan vergaderingen van het Letterkundig Verzet ${ }^{75}$, de groep waaruit later De Vrije Kunstenaar voortkomt.

Hoe bizar de tijdsomstandigheden zijn, blijkt uit de volgende gebeurtenis, die Kafka nauwelijks zou hebben kunnen verzinnen. Half juli 1944, wanneer Coolen zich verborgen houdt, terwijl de inboedel van zijn huis door Nederlandse handlangers van de bezetter kort en klein is geslagen en de geallieerde troepen zich opmaken om richting Parijs te trekken, stuurt het Departement van Volksvoorlichting en Kunsten aan Coolen een vragenlijst met het verzoek om Nederlands toneelwerk mee te helpen propageren! ${ }^{76}$

Coolen verklaart dat de brief hem via een omweg heeft bereikt en dat daarom zijn antwoord wat verlaat is. Hij voegt eraan toe dat het verzoek hem verbaasd heeft. Hoe kan hetzelfde departement, dat maatregelen heeft getroffen waardoor de uitgaven en herdrukken van zijn toneelstukken en ander werk "reeds sedert jaar en dag verboden is," nu vragen om propaganda te maken voor Nederlands toneelwerk, waaronder dat van Coolen zelf? Bovendien zou hij de gevraagde informatie niet eens kunnen geven,

"omdat, toen ik eenige weken geleden voor een dag of tien op reis was gegaan en intusschen een oproep aan mij werd gezonden om vier weken graafwerk aan de Zeeuwsche kust te verichten en ik daarop niet van mijn reis terugkeerde, door politie uit 
Eindhoven mijn heele huis met de aanrichting van een ware ravage van onder tot boven is leeggehaald tot en met vloerzeilen, lampen, lichtleidingen, schakelaars, stopcontacten, ingebouwde kasten toe."

Zijn gezin heeft her en der een onderkomen moeten zoeken en Coolen mist dus alle bescheiden "die voor de invulling van Uw vragenlijst zouden noodig zijn." Uit het antwoord blijkt dat het geen strikt persoonlijk verzoek aan Coolen is geweest, maar een algemene vragenlijst, die door een misschien niet erg oplettende ambtenaar aan alle (toneel)schrijvers is gestuurd. Coolen maakt er gebruik van om zijn woede via een officieel kanaal te uiten.

\section{Dolle dinsdag, 5 september 1944}

De radioberichten van maandag 4 september over een snelle en succesvolle opmars van de geallieerden vanuit Frankrijk naar het noorden en de bevrijding van Antwerpen brengen euforie in heel Nederland teweeg. Coolen hoort de berichten bij een vriend op een van zijn onderduikadressen in het noorden door een verborgen radiotoestel en wil meteen naar het zuiden vertrekken om over de rivieren te komen. $\mathrm{Zijn}$ vrienden raden het hem af, omdat hij dan regelrecht op het gebied af gaat waar het zal spannen. De meesten denken dat de oorlog nu toch over een paar weken afgelopen zal zijn en hij dus onnodig risico loopt. Coolen gaat toch : "'t Kan zijn. Maar in het Zuiden zijn de mijnen. Daar zullen we dan samen de overwinning vieren. ${ }^{n}$ Deze beslissing heeft hem een scheiding van zijn gezin van driekwart jaar en een hongerwinter bespaard, want al gauw zal het bijna onmogelijk zijn om nog over de grote rivieren naar het zuiden te geraken.

In een zeer langzame trein, bijna zonder passagiers, bereikt hij Den Bosch en kan vandaar niet verder. Het emplacement staat vol Duitse legertreinen. Buiten voor het station is het een chaos. Een jongenssoldaat in Feldgrau vraagt hem of ' $t$ waar is dat de Engelsen in Breda zijn en de Amerikanen in Maastricht. ${ }^{78}$ Voorlopig blijft hij in Vught, waar hij enkele dagen logeert bij Cleerdin, en hij ziet daar de hele week de terugtocht van de Duitsers en vluchtende NSB-ers. Met vermaak beschrijft Coolen de vrachtwagens met van alles erop en eraan, zodat het net rijdende uitdragerswinkels zijn. Er rijden ook veel gestolen autobus-

69 Oomes, Ontmoetingen, 19.

70 Coolen, Bevrijd Voderland, 118.

7 Coolen, Bevrijd Vaderland, 120.

72 Ibidem.

73 Coolen, Bevrijd Vaderland, 122.

74 Coolen, Bevrijd Vaderland, 128.

75 FPC, verklaring intellectuelen inzake Van Doome kwestie, 1 oktober 1946. In deze verklaring in verband met de Van Doome kwestie (zie hoofdstuk 16) wordt vastgesteld dat Coolen heeft deelgenomen "aan het verzet der Nederlandsche letterkundigen tegen de maatregelen van den onderdrukking," De verklaring is ondertekend door 25 intellectuelen waaronder Van Duinkerken, V. van Vriesland, Emmy van Lokhorst, C.J. Kelk, Maurits Dekker, de jurist A. Pitlo, Halbo Kools. Clara Eggink, D.A.M. Binnendijk en professor Donkersloot.

76 FPC, brief van DVK, nr. 4802, afd. TD-H aan Coolen, 14 juli 1944. Alleen het antwoord op dit verzoek is bewaard: brief van Coolen aan het Departement van Volksvoorlichting en Kunsten, 31 juli 1944.

7 Coolen, Bevrijd Vaderland, 129.

78 Ibidem. 
sen met de Belgische en Brabantse plaatsnamen van hun reguliere routes er nog op. Hij sig. naleert zelfs een stoomwals, vol met vluchtende soldaten. Hij ziet dat de Beauftragte aan het inpakken is op Roucouleur aan de Glorieuxlaan in Vught. Er zijn geruchten over een bevrijdingsactie van het kamp Vught, maar later zal helaas blijken dat, na vele executies, de rest van de gevangenen met treinen naar Duitsland is weggevoerd.

\section{Bevrijding in Deurne}

Na enkele dagen oponthoud in Den Bosch en Vught reist Coolen met een elektrische trein, die vrijwel geheel leeg is, naar Eindhoven. Daar heeft hij geluk: hij kan mee op een Duitse trein, die met gewonden op weg is naar Kaldenkirchen. Als er een vliegtuig boven cirkelt, moet alles en iedereen de spoorberm in, maar er komt geen aanval. Uiteindelijk nadert hij het dorp waar hij als jongen zo vaak naar die treinen en rails heeft gekeken: "Dan begin ik de huizen te herkennen, wegen en wegjes, heggen en boomen, het jeugddorp, het kinderland. En als ik Deurne bereikt heb weet ik dat ik het bereikt heb met den laatsten trein uit de noordelijke richting." ${ }^{\text {79 }}$

De bevrijders komen niet zo vlug als aanvankelijk gedacht, maar het front nadert. Hij ziet op zondag 17 september, de dag van Operatie Market Garden, de luchtvloot overko. men. Men heeft te veel tegenslag gezien om van vreugde te dansen "op de dauwzachte gazons van de tuin," maar de volgende dag komen de berichten dat het tweede Britse leger al in Valkenswaard is. Als Eindhoven bevrijd is, wil men de vlaggen al te voorschijn halen; maar's avonds volgt nog een zwaar bombardement op die stad. "De stad, gisteren nog vervuld van gejubel, is nu vol rouw en geweeklaag," schrijft Coolen in zijn 'dagboek'. ${ }^{80}$

Bij de beschrijving van de gebeurtenissen in Deurne valt het Coolen zelf op dat hij. ondanks het feit dat hij al weer zes jaar in Waalre woont, weer schrijft over ons dorp, "omdat ik er als kind ben opgevoed en het ouderhuis er staat." Hij herinnert zich zijn schooltijd: "De zanderige warmte van rulle wegen, waarlangs Maandagfrisch de jongens in den zonnige morgen naar school kwamen met een seringentak in den mond of in het knoopsgat van het kieltje dat naar stijfsel rook. Die geur van stijfsel en van seringen is voor mij de geur gebleven van den zomer in de dorpen." Hij filosofeert over jeugd en oorlog en beseft dat hij eigenlijk nog maar kort geleefd heeft en nog veel te weinig zijn liefde, nee zijn drift voor het leven heeft beleden. Hij wil de jeugd omhelzen en zich vastklemmen aan het kind. Als hij de kanonnen in Eindhoven hoort dreunen, verneemt hij als in een hallucina. tie "het gerucht van den mespunt, waarmee mijn moeder een kruis teekende op het korstje van het brood, voor ze het aansneed. ${ }^{n 1}$ De hele passage is doortrokken van weemoedig verlangen naar het dorp van zijn jeugd.

Deurne komt midden in de strijd te liggen. Coolen beschrijft gedetailleerd hoe het nieuws en de geruchten zich verspreiden. Hij ziet de vluchtelingen die van Ommel en Vlierden naar Deurne komen met hun schamele huisraad: "wat is 's menschen hebben en houden toch een armzalig iets. ${ }^{\text {"82 }}$ De angst leeft dat de Engelsen langs het kanaal optrekken naar Helmond en Deurne links laten liggen. Bij de uiteindelijke strijd om de bevrijding van Deurne verblijven Coolen en zijn vrouw met hun zoons Guido en Peter in de schuilkelder van de familie Tromp. Felix en Stijn zijn bij de Wiegersma's. Zeer overtuigend beschrijft Coolen in Bevrijd Vaderland de plotseling opkomende bloedstollende angst over de twee 
jongens die niet bij hen zijn en de 'slapeloze' nacht vol korte horror-dromen. De jongens blijken ongedeerd. 's Avonds wordt eindelijk "de profijtelijke, geelgeglazuurde kruik met het bekoorlijk etiket" aangebroken. Ze praten met Engelse officieren. Deze zijn heel anders dan de Duitse die tot een kaste behoren met als enige doel Krieg und Sieg. Dit zijn Engelse heren, die voor de gelegenheid noodgedwongen soldaat zijn, vindt Coolen.

\section{Thuis in Waalre: anticlimax en verbittering}

In oktober kan het gezin met speciale doorlaatpassen via Vlierden, Ommel, Asten, Heeze, Geldrop en Eindhoven terug naar Waalre. Het kerkje van Ommel, de beroemde, vaak door hem beschreven Mariabedevaartplaats, staat er nog, "maar je kijkt er dwars doorheen en zijn torenspits is het kwijt." ${ }^{83}$ De villa De Kempen is hol en helemaal leeg. Niet alleen de losse spullen zijn verdwenen, maar ook vaste spiegels, kasten en kelderrekken; alles, tot aan het speelgoed van de kinderen toe, is weg. Gelukkig heeft hij voor zijn onderduik een groot gedeelte van zijn bibliotheek in veiligheid gebracht, want de achtergelaten boeken zijn ook allemaal verdwenen. Hij ergert zich aan het faeces-geklieder, dat in alle achtergelaten huizen wordt aangetroffen. Hij vindt dit typisch voor de Duitse soldaat. "Ik vrees, dat het zelfs typisch is voor den Duitscher in het algemeen, die overigens scatologische termen en uitdrukkingen met zo'n voorkeur en zo'n welbehagen uitspreekt." ${ }^{\text {"34 }}$

De familie Coolen is weer herenigd en thuis, maar het welbehagen in de vrede is maar van korte duur. In alles wat Coolen in het najaar van 1944 schrijft of zegt, klinkt meer verbittering en teleurstelling dan vreugde door. De vreugde over de bevrijding wordt bovendien al gauw gedempt, omdat de opmars van de geallieerden stokt. De rivieren vormen de frontlijn tussen een bevrijd zuiden en de rest van Nederland, dat nog een afschuwelijke hongerwinter tegemoet gaat.

Bij de familie Coolen wordt Kerstmis I 944 gevierd in een onverwarmd huis. Bitter noteert hij dat in een huis niet ver van hem vandaan een groot kerstdiner met avondtoilet wordt gehouden: "Daar ontbreken licht noch warmte, daar ontbreekt niets, alles is vooroorlogsch, ja, in den algemeenen nood zijn er deze Kerstoases nog wel degelijk bij de onaangetasten en de onaantastbaren. Dat zijn zeker de uitverkorenen Gods, door en door roomsche families, gefrequenteerd door den clerus. ${ }^{n 85}$

In deze cynische passage geeft Coolen zijn gemoedstoestand weer. Zijn weigering om toe te treden tot de Kultuurkamer heeft hem materieel veel gekost. Het uiteindelijke resultaat is dat hij nu zonder gasten in een koud, leeggeroofd huis zit, terwijl anderen, waarvan hij vindt dat ze minder principieel hebben gehandeld, van de oorlog rijk zijn geworden. Hij ergert zich vooral aan het bedrijfsleven, dat wel erg makkelijk grote orders van de Duitsers in de wacht heeft gesleept. Coolen doelt hier, zonder de naam te noemen, op de autofabri-

79 Coolen, Bevrijd Vaderland, 133.

80 Coolen, Bevrijd Vaderland, 136.

81 Coolen, Bevrijd Vaderland, 137.

82 Coolen, Bevrijd Vaderland, 140.

83 Coolen, Bevrijd Vaderland, 154.

84 Coolen, Bevrijd Vaderland, 156.

85 Coolen, Bevrijd Vaderland, 167. 
kant Hub van Doorne, die in Deurne woont.

Dit geluid laat Coolen ook horen in de toespraken voor Radio Herrijzend Nederland, waar hij vanaf oktober 1944 aan meewerkt. Kort voor Kerstmis heeft hij gesproken over eenheid en zuivering na de bevrijding. Hij vergelijkt de bezetting met de overwintering op Nova Zembla, waar Van Heemskerk en de zijnen met Kerstmis de noodrantsoenen moesten aanspreken. Op dat moment wisten zij in die lange donkere poolnacht dat het nog weken zou duren voor ze de zon weer zouden zien. Zo ook hebben de goede Nederlanders steeds geweten dat eens de nacht voorbij zou zijn. ${ }^{86}$ In januari 1940 , toen de oorlog in Finland woedde, refereerde hij ook al aan dit verhaal. Toen zag hij in de populariteit ervan een bewijs dat de Nederlander meer van de poolkou houdt dan van de tropenhitte. ${ }^{87}$

Vervolgens spreekt hij over de zuivering en zegt dat echte loutering ondenkbaar is, als niet eerst de smaad en de besmetting van de NSB zijn uitgewist. Echter, voegt hij eraan toe, die smaad en besmetting zijn verder uitgevlekt. Ook buiten de NSB zijn er hele en halve opportunisten geweest, die twee wegen hebben opengehouden. Zij zagen een kans bij een uiteindelijke Duitse overwinning, maar stonden ook heel slim "een soepbeen" af aan het verzet om ook na een Duitse nederlaag goede papieren te hebben. Weer doelt hij op Van Doorne. Coolen acht deze mensen nog lager dan de NSB-ers. De laatste hadden tenminste nog de moed voor hun overtuiging uit te komen. Ze accepteerden orders en geloofden in een nationaal herstel. De opportunisten geloofden alleen maar aan hun eigen welzijn en vooral aan hun portemonnaie.

Het is een sombere jaarwisseling. Het zuiden is bevrijd, maar aan de andere kant van de Maas is het oorlog en in de Ardennen woedt die zelfs weer op volle kracht in het voordeel van de Duitsers. Coolen is door de frontlijn afgesneden van zijn literaire vrienden in het westen van Nederland, met wie hij het laatste halfjaar juist zo veel contact heeft gehad. Hij heeft nog niets gehoord uit Vlaanderen en verkeert in de veronderstelling dat zelfs zijn grote leermeester Streuvels, evenals Timmermans en Claes, gecollaboreerd heeft met de Duitsers. Het is in die stemming dat Coolen een doel zoekt en vindt om zijn verbittering en teleurstelling kwijt te kunnen. Het doel is de fabrikant Van Doorne, de wapens zijn zijn scherpe pen en een nieuwe krant. 
86 Geluidsarchief NOS, 'Eenheid en Zuivering', toespraak Coolen voor Radio Herrijzend Nederland, 14 december 1944.

87 Coolen, 'Brieven van De Kempen', 27 januari 1940. 



\section{Vrede en toch strijd 16}

"De principiële man wilde geen lid zijn van een door de vijand verplicht gestelde instelling. Hij zei dan ook néé."

$1945-1946$

\section{Van Doorne}

In de schuilkelders van Wiegersma, Tromp en Te Strake, in september 1944, is Coolen bijgepraat over de toestand in zijn vroegere woonplaats Deurne. Na afloop van de oorlogshandelingen rond Deurne duurt het nog enkele weken voor hij met zijn gezin naar Waalre kan. In die tijd spreekt hij veel mensen. Uit hun verhalen blijkt dat de oorlog de eenheid van de Deurnese gemeenschap heeft aangetast: er lopen diverse praatjes en verhalen over mensen die te Duitsgezind zouden zijn geweest. Ook de namen van de autofabrikant Hub van Doorne en burgemeester Lambooy worden hierbij genoemd. Hier ligt de kiem van een conflict tussen twee partijen waarvan Coolen en Van Doorne de boegbeelden zijn.

Coolen ging vóór de oorlog, in de jaren dat hij in Deurne woonde, vriendschappelijk met Van Doorne om en had bewondering voor deze self-made man. Hij schreef wel eens toespraken voor hem en schonk hem zijn boek Zegen der goedheid met een opdracht ter gelegenheid van Van Doornes vijfendertigste verjaardag op 1 januari 1935 . Dit past overigens wel in het 'inburgeringsproces' dat Coolen in die jaren in de Deurnese gemeenschap doorliep. Hij wilde graag bij de plaatselijke notabelen horen en in die kringen was Van Doorne een rijzende ster. Ook in de oorlog heeft Coolen nog regelmatig contact met Van Doorne. Zo heeft hij hem gefeliciteerd met de opening van de bioscoop, die in november I94I met financiële steun van Van Doorne tot stand was gekomen. Coolen deed hierbij het voorstel om de zaal Taxandria te noemen. Het werd echter Bio-Vink, naar de uitbater P. Vink. Volgens de dochter van Hub van Doorne zijn haar vader en Coolen tot op de laatste dag van de oorlog goede kennissen van elkaar geweest en heeft men nooit iets van vijandigheid gemerkt. Op de dag van de bevrijding is dit volgens haar van de ene op de andere dag veranderd. $^{\prime}$

Wat is de diepere oorzaak voor deze omslag? Hoe komt het dat een man als Coolen, wars van strijd en conflict, nu een openlijke en persoonlijke aanval op Van Doorne inzet en daarmee ook nog een krantenstrijd ontketent die meer dan twee jaar zal duren?

Deze zaak kan niet los worden gezien van Coolens eigen wedervaren gedurende de bezetting. Coolen heeft verschillende Duitse aanbiedingen afgewezen, hij heeft niet gewoon als schrijver kunnen publiceren en in het laatste oorlogsjaar is zijn huis leeggeplunderd en een groot deel van zijn boekenbezit verdwenen. Zijn voornaamste grief is echter, dat hij al in de eerste maanden na de bevrijding van het zuiden ervaart dat de hooggespannen verwachtingen die hij in zijn 'geestelijke schuilkelder' heeft gekoesterd, illusies blijken te zijn.

1 Interview met de heer en mevrouw Hohman-van Doorne door C. Slegers, Deurne 13 maart 2000. 
Als groot contrast staat daar het wedervaren van Van Doorne tegenover. Diens DAF-fabriek draaide zoals veel Nederlandse bedrijven continu voor de Duitse Wehrmacht en daar was niet veel tegen te doen. Erger is de verdenking dat het bedrijf ook actief orders verzameld zou hebben in het Duitse Rijk. Een ex-NSB-er, Van Soeten, zou voor het bedrijf acquisitie hebben gepleegd in Duitsland. Coolen krijgt van verschillende zijden belastende papieren over dit onderwerp toegespeeld.

Daarnaast zou Van Doorne de pro-Duitse journalist W.A.M. van Heugten aan een baan als hoofdredacteur van Het Nieuwsblad van Deurne hebben geholpen. Zijn voorspraak ging gepaard met een forse lening aan de uitgever. Van Heugten was in het begin van de oorlog lid van Brabantia Nostra en voorzitter van de plaatselijke afdeling van de Nederlandse Unie, een organisatie waar Coolen zelf in Waalre ook lid van was. Van Heugten wordt echter al na enkele maanden weggestemd en keert de Unie eind r 940 de rug toe. ${ }^{2}$ Van Heugten kwijt zich zo goed van zijn taak als hoofdredacteur dat hij met zijn krant op 22 december I943 van het Departement van Volksvoorlichting en Kunsten de Goedewaagen-prijs heeft gekregen. Deurne heeft daardoor de hele oorlog een krant gehad die actief het belang van de bezetter heeft gediend en niet betrekkelijk passief was, zoals de meeste gelijkgeschakelde kranten. Het steekt Coolen nog het meest dat Van Doorne meer dan strikt noodzakelijk met Duitse officieren zou zijn omgegaan en veelvuldig met hen zou hebben gedineerd in zijn eigen restaurant Lido te Mierlo-Hout. Dit is veelzeggend. Coolen heeft zelf de toenaderingen van de Duitsers Töpfer en Schmidt-Burgke in correcte, enigszins hoffelijke bewoordingen afgewezen. Hij neemt het Van Doorne kwalijk dat deze niet dezelfde 'nob. lesse' in het verkeer met de bezetter in acht heeft genomen.

Coolen weet ook dat Van Doorne contacten heeft gehad met het verzet en dit ook regelmatig en daadwerkelijk ondersteund heeft. Dit laatste is door Coolen in een radiotoespraak al ironisch betiteld als het toewerpen van een 'soepbeen' aan het verzet. Hij vindt de steun van Van Doorne opportunistisch en ziet daarin alleen maar een middel om bij het einde van de oorlog twee wegen open te houden.

Coolen houdt zijn ergernis niet binnenskamers. Zijn betrokkenheid bij een nieuw opgerichte krant in Deurne verschaft hem een podium om er uiting aan te geven.

\section{Het begin van de persstrijd}

Coolen heeft bij Wiegersma mensen ontmoet die in de oorlog de illegale krant De Vrije Pers hebben gemaakt, onder wie de journalist Frank Krämer. Hij raakt enthousiast voor het idee met hen een naoorlogse krant te beginnen. Het Deurne's persfonds wordt opgericht en de krant zal Deurnesche Courant gaan heten. Coolen is voorzitter van dit fonds. De redactie van de krant wordt gevormd door de heren M.J. Hendriks, Joh.A.M Schenk en Harry Swinkels. De uitgever is Noud v.d. Eijnde, tevens boekhandelaar in de Molenstraat. Geldschieters zijn Wiegersma, tandarts Berkvens, notaris Tromp [dezelfde bij wie Coolens zoon Guido tijdens de oorlog langere tijd was ondergebracht, C.S.] en baron De Smedt, de eigenaar van het groot kasteel dat bij de bevrijding door de Engelsen beschoten is en daarna afgebrand. Aanvankelijk wil men pastoor Witlox vragen om voor de Deurnesche Courant een 'Ten geleide' te schrijven. Deze weigert en vertelt dat er nóg een nieuwe krant in Deurne komt, waarvoor hij al beloofd heeft te schrijven. 


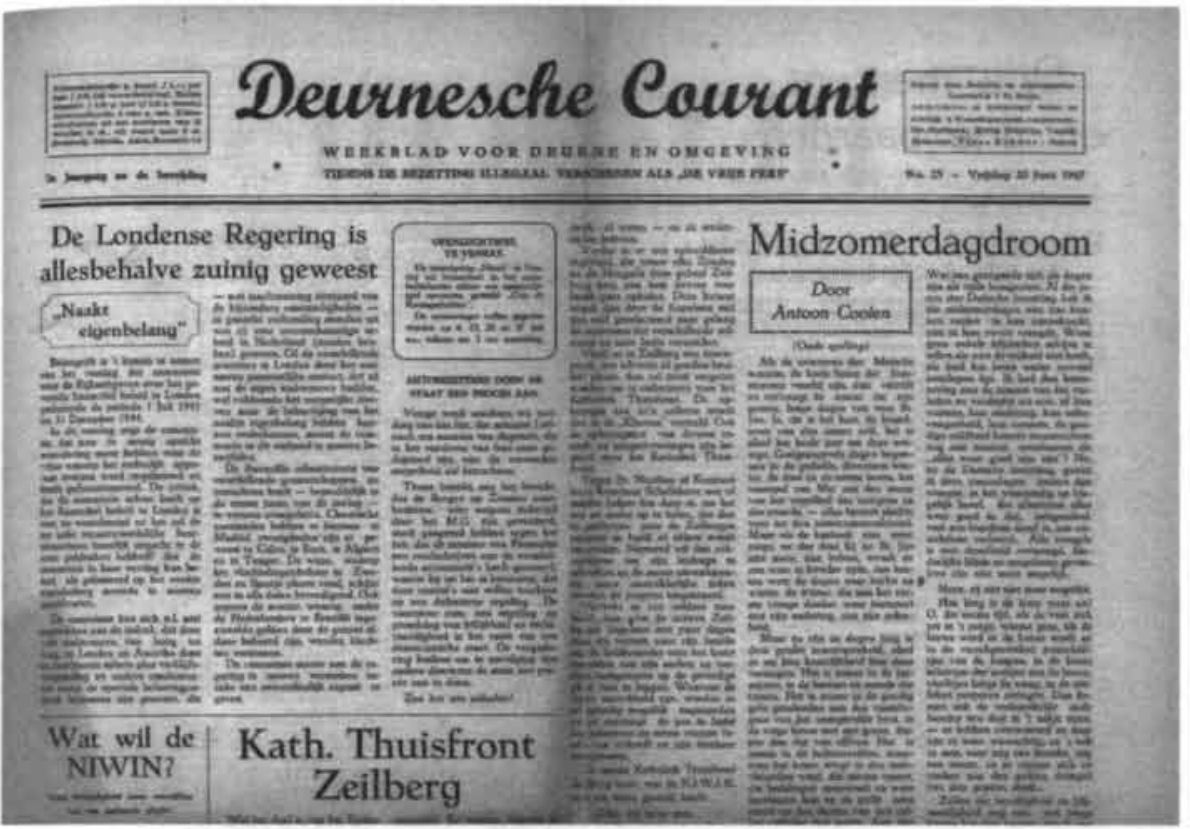

Inderdaad zullen in de tweede helft van januari 1945 in het toch niet zo grote Deurne twee kranten gaan verschijnen: de Deurnesche Courant en Het Licht. P. Mulder is hoofdredacteur van de laatste krant die de steun geniet van de burgemeester, een vriend van Van Doorne. Burgemeester Lambooij heeft niet mee gedaan aan het burgemeestersprotest van februari $1943 \mathrm{en}$ is in functie gebleven. In het laatste oorlogsjaar is hij dus steeds meer een werktuig van de bezetter geworden. Hij heeft ook een spitbevel uit moeten geven in mei 1944. Toen niemand kwam opdagen, is hij gearresteerd. Van Doorne trommelde een aantal mensen op die vrijwillig zijn gaan spitten om de burgemeester vrij te krijgen. Dit is gelukt en hij werd door Van Doorne in zijn auto opgehaald. Vlak voor de bevrijding zou Lambooy nog gezegd hebben - nadat hij zelf drie weken ondergedoken had gezeten - dat die onderduikers toch maar een luizenleven hadden gehad. ${ }^{3}$

Hiermee zijn de leidende figuren van de twee kampen in het dorp voorgesteld. Rond de Deurnesche Courant scharen zich journalisten uit de illegale pers, mensen met academische beroepen als de arts Wiegersma, tandarts Berkven en notaris Tromp en de schrijver Antoon Coolen. Achter Het Licht staan de lokale overheid, de geestelijkheid en het geld, respectievelijk burgemeester Lambooij, pastoor Witlox en Hub van Doorne. Tussen de beide kampen ontstaat een strijd, waarvan de naweeën nog tot het eind van de eeuw merkbaar zijn.

\section{Het Licht en de Deurnesche Courant}

Het Licht komt als eerste uit, op 20 januari 1945 . Het openingsartikel is inderdaad door pastoor Witlox geschreven onder de titel 'Procedamus in Pace!' (Laten we voortgaan in vrede, C.S.]. Uit de datering blijkt dat het al sinds tweede Kerstdag klaar ligt. Ook burge-

2 Van Oudheusden, Brabantia Nostra, 269.

3 Open brief van een illegaal werker aan Lambooy, Deurnesche Courant, 2 februari 1945. Aan de reputatie van Lambooy is zijn hele leven een smet blijven kleven. 


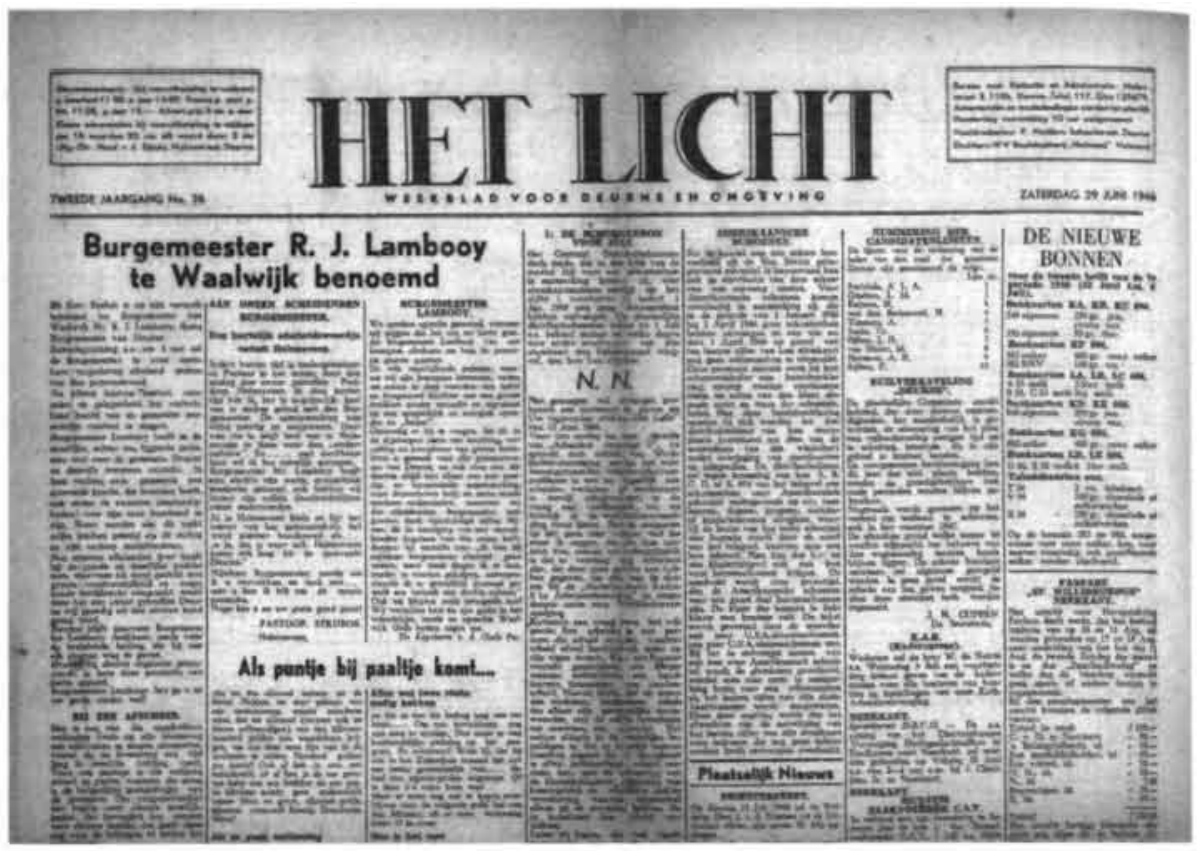

meester Lambooy levert een bijdrage, waarin hij oproept tot eenheid en stelt dat daarvoor een goede pers onontbeerlijk is.

Zes dagen later, op vrijdag 26 januari 1945 , verschijnt het eerste nummer van de Deumesche Courant. In een bericht aan de lezers deelt de redactie mee dat ze niet goed kan uitleggen of een tweede krant in Deurne wel nodig is in een tijd van papierschaarste. Wat ze echter wel weet, is dat ze het wettelijk recht heeft om uit te komen, "aangezien ons licht niet verleden week is opgekomen, doch dat De Vrije Pers sedert maanden voor de bevrijding het waarachtig licht der voorlichting onder zijn talrijke lezers heeft verspreid." De Vrije Pers, waarin M.J. Hendriks een van de hoofdrollen speelde, verscheen als ondergronds blad tijdens de oorlog in een oplage van vijfhonderd exemplaren en werd meestal gestencild in de kelder onder het patronaat van Deurne. Er verschijnen vlak na de oorlog veel kranten en blaadjes. Meestal geeft het Militair Gezag alleen toestemming als zo'n blad voortkomt uit de illegale pers. Voor Het Licht maakt men kennelijk een uitzondering.

Naast dit kader met schimpscheuten aan het adres van Het Licht is het openingsartikel van Coolen geplaatst onder de kop: 'Gezuiverde Toekomst'. ${ }^{4}$ Coolen begint met de herinnering aan zijn jeugd en schetst de groei van het dorp. Hij kapittelt Het Nieuwsblad van Deurme dat in de oorlog partij heeft gekozen voor de vijand. Coolen heeft geen goed woord over voor degenen die veel geld aan de vijand verdienden, ook niet als die wel eens een 'bedragje' af hebben gestaan aan 'illegale acties'. Meer nog dan de particulieren valt hij de gezagsdragers zwaar, want van hen eist hij onvoorwaardelijke onkreukbaarheid en integriteit. Hij vergelijkt de burgemeesters die op een of andere manier met de bezetter meewerkten met de burgemeesters die na weigering geëxecuteerd werden of in de kampen omkwamen: "Wie voor den vijand moest doen werken en door het zoeken van behendige compromissen hem terwille was, hij trede nu liever terug, nu we den rouw nog dragen der indrukwekkende rij van hen die vielen onder verraderlijke kogels, omdat zij weigerden." 
Vervolgens uit hij zijn verbazing dat een medewerker van het foute Nieuwsblad, die positief had geschreven over de graafwerkzaamheden in De Rips, nu weer voor Het Licht schrijft: "Toen tapte hij uit het gewenschte vaatje, nu uit een ander. Zullen wij zóó de toekomst ingaan?"

\section{Persoonlijke vete}

Met Coolens inleidende artikel is de toon gezet en wordt een onoverbrugbare kloof tussen de partijen geslagen. Coolen is voorzitter van de stichting die de Deurnesche Courant uitgeeft, maar levert ook tal van bijdragen.

In het tweede nummer, veertien dagen later, schetst Coolen onverbloemd het verschil tussen hemzelf als principieel man en Van Doorne als schipperaar. De toon van dit artikel is wat pedant en tegelijkertijd verongelijkt. Degenen die integer zijn gebleven zijn alles kwijt, schrijft hij, en de schipperaars zijn rijk geworden en maken na de oorlog ook nog eens goede sier als Oranjegezind vaderlander.

Coolen durft het zo hoog te spelen, schrijft hij, omdat hij veel aanwijzingen heeft. Leden van het verzet hebben Van Doorne meteen na de bevrijding willen arresteren, maar het Militair Gezag stond dat niet toe omdat hij geen NSB-er was en er geen harde bewijzen waren van collaboratie. In het najaar van 1944 hebben verschillende DAF-employees allerlei belastende stukken, brieven en memoranda aan Coolen overhandigd. Er gaan geruchten dat op het DAF-terrein papieren worden verbrand om sporen uit te wissen.

Er heerst een sfeer van bijltjesdag, waarin natuurlijk ook andere rekeningen vereffend worden. Van die belastende stukken komt er echter geen een boven tafel. Om de sfeer te proeven een fragment uit Coolens stuk 'Niet om de dankbaarheid':

"De principiële man wilde geen lid zijn van een door de vijand verplicht gestelde instel-

ling. Hij zei dan ook néé. Hij offerde inkomen en bezit, weerstond bedreigingen en ver-

leidingen en verloor tenslotte zijn hele hebben en houwen [...] Als alles voorbij zou zijn, dan zou het vaderland zijn dankbaarheid wel tonen. Maar toen alles voorbij was, bleef die dankbaarheid wel mooi uit."

De man die schipperde, verdiende veel geld, maar hij deed het op een manier dat ze hem niets konden maken. "Hij verwierf met vrij veel gemak een gelegenheidsbaantje en zelfs een uniform, hij zocht de vriendschap van de Engelschen en het goede voetje bij het Militair Gezag."

Als Coolen zichzelf bedoelt met de eerste persoon, en de verwijzing naar de "bedreigingen en verleidingen" maakt dat aannemelijk, dan schildert hij zijn eigen toestand na de bevrijding van het zuiden te negatief af. Het vaderland bedankt Coolen inderdaad niet met materiële gaven, maar dat kan ook niet want er is niets en het is nog volop oorlog. Inmiddels heeft hij wèl het eervolle aanzoek gekregen om zitting te nemen in het Tribunaal voor de Bijzonder Rechtspleging (waarover later meer) en spreekt hij regelmatig voor Radio Herrijzend Nederland. Dit immaterieel eerbewijs moet hem toch goed hebben gedaan na alle ellende.

5 Coolen, 'Aan den arbeid', in: Deurnesche Courant, 2 februari 1945. 
Deze activiteiten leveren echter geen geld op en Coolen zit ondertussen met zijn leegge roofd huis, vier schoolgaande kinderen en povere bronnen van inkomsten. Misschien duikt af en toe toch bij hem de gedachte op, dat als hij op dezelfde manier geschipperd had en dus prijzen van de bezetters had aangenomen, toegetreden was tot de Kultuurkamer en door had kunnen blijven publiceren, hij ook rijk had kunnen zijn. Coolen wilde dat niet en hij kon dat niet, maar zo'n gedachte levert toch wrok op en verklaart voor een deel de zeer scherpe en bittere toon van zijn beschuldigingen.

Het is maar een gedeeltelijke verklaring, want bij de bestudering van zijn bijdragen aan de Deurnesche Courant ontstaat steeds sterker de indruk dat er nog iets anders speelt. Voelt hij toch dat hij met zijn burgemeesterssollicitatie te lang tegen zijn geweten is ingegaan? Beseft hij misschien dat ook hij 'geschipperd' heeft en dat zijn woede eigenlijk niet helemaal oprecht is? Dan is zijn motivatie in de persstrijd niet helemaal zuiver. Deze innerlijke onvrede zou dan een verklaring zijn voor de agressieve toon van zijn artikelen. We komen hier op terug.

\section{Lid van het Tribunaal voor bijzondere rechtspleging}

De zelfverzekerdheid waarmee Coolen zich tegen Van Doorne keert, kan voor een deel verklaard worden uit de bijzondere status die hij sinds enige tijd geniet. Op 8 januari I 945 , dus enkele weken vóórdat de Deurnesche Courant en Het Licht verschijnen, wordt Coolen voorgedragen bij de Commissaris der Koningin, als lid van het Tribunaal voor bijzondere rechtspleging, arrondissement 's-Hertogenbosch, dat in Eindhoven gevestigd is. ${ }^{6} \mathrm{Naast}$ de voorzitter mr. A.J. Guépin (secretaris directie Philips) bestaat dit Tribunaal uit de volgende leden: J.M. De Haas (fabrikant), dr. J.F.H. Custers (natuurkundige Philips), A. Coolen (letterkundige), C.H. de Bever (architect BNA) en mevrouw H. Verweij-Jonker (zonder beroep, oud-raadslid van de SDAP-fractie in de gemeenteraad van Eindhoven). In het najaar is informatie over de potentiële leden ingewonnen. Dezelfde kantonrechter, G.J. Jansen, die in 1943 over Coolen moest rapporteren bij de sollicitatie naar het burgemeesterschap van Waalre, moet nu weer advies uitbrengen. Tegen enkele voorgedragenen bestaat bezwaar. maar "de overige [waaronder Coolen, C.S. | waren zonder onderscheid principieel tegen de bezetter," aldus Jansen.?

Deze voordracht en het lidmaatschap van het Tribunaal moeten Coolen juist in deze beginfase van de persstrijd een grote morele opkikker hebben gegeven. Al gauw zal hij echter zien dat de kleine vissen met kleine vergrijpen (groenteleverantie, collecteren voor Winterhulp) wel worden veroordeeld of al veel te lang in Vught in voorarrest hebben gezeten, terwijl de grote vrij uitgaan. Mevrouw Verweij-Jonker - "Ik zat er in, omdat er ook een vrouw in moest zitten" - bevestigt dit. Zij herinnert zich Coolen als een mild lid van het Tribunaal. Hij had, evenals zij zelf, te doen met de schlemielen, die vanuit hun ellende op het verkeerde paard gewed hadden. ${ }^{8}$ Later constateert Belinfante dat de Tribunalen in het Zuiden "aan hen, die uitsluitend het lidmaatschap van de partij of van een mantelorganisatie te verwijten viel, soms strengere straffen oplegden dan later de tribunalen in het deel van het land boven de rivieren."

Coolen zal twee jaar lid zijn van het Tribunaal. Ook de persstrijd zal twee jaar duren. Zoals een veenbrand lijkt hij soms even wat gedoofd, om dan ineens weer op te laaien. Eén zo'n 
opleving vindt al plaats vóór de bevrijding van heel Nederland in mei 1945 . Geïrriteerd door allerlei prikacties van de gemeente tegen de Deurnesche Courant - de krant krijgt bijvoorbeeld geen uitnodigingen voor vergaderingen en er wordt gedreigd met stopzetting van de papiertoevoer - schrijft Coolen een kritiek op het gedrag van burgemeester Lambooy in oorlogstijd. De directe aanleiding is een plan van oud-illegale werkers om een gedenkteken voor de gevallenen op te richten. Coolen vraagt zich af of dat wel kan in een dorp waar de eendracht zoek is en zoveel zaken de gemeenschap verdeeld houden. "Een der punten van het dispuut is het hoofd der gemeente, van wie wij nog steeds niet de erkenning hebben gehoord van fouten die gemaakt zijn." Vervolgens laakt hij de vriendschap van de burgemeester met Van Doorne: "Ik [acht] voor het gemeentelijke, dorpsche leven van het na-oorlogse Deurne zorgwekkend en zelfs funest [...] de vriendschap van het hoofd der gemeente met een industrieel, die tijdens de bezetting in hooge mate, ernstig, intensief, voor miljoenen met den vijand heeft gecollaboreerd. ${ }^{.10}$

\section{De persstrijd in een stroomversnelling}

Enkele maanden na Coolens forse uitspraak gebeurt er iets waaruit blijkt dat de Deurnese bevolking niet zo zwaar tilt aan de beschuldigingen die Coolen tegen Van Doorne inbrengt. Hub van Doorne wordt op 4 augustus 1945 gekozen tot voorzitter van de Oranjevereniging in Deurne. Coolen spreekt er verontwaardigd over in de sociëteit van Waalre en zegt daar onder meer dat Van Doorne al een oranje jasje had klaar liggen voor het geval de Duitsers de oorlog zouden verliezen. Ook in de Deurnesche Courant steekt hij niet onder stoelen of banken dat volgens hem de Deurnese bevolking de kop in het zand steekt.

Voor Van Doorne, die zich voorheen in het openbaar afzijdig heeft gehouden, is dan de maat vol en hij gaat in de tegenaanval. In de editie van Het Licht van zaterdag i september I945, daags na Koninginnedag, staan op de voorpagina vier ingezonden stukken naast een grote foto van Wilhelmina. Boven de brieven staat de wat raadselachtige kop 'Troebel oranje opgehelderd!' De brieven van mr. O. Assmann (hoofd van de afdeling Politiezaken der Nederlandse Binnenlandse Strijdkrachten) en ir. F.J. Philips (president-directeur van Philips) zijn gericht aan de redacties van de Deumesche Courant én Het Licht. De brief van Hub van Doorne is bedoeld als Open Brief aan Antoon Coolen. Het Licht heeft Coolen de brief van Assmann een dag eerder gestuurd en hem de gelegenheid geboden erop te reageren. Het antwoord van Coolen is de vierde brief op de voorpagina.

6 In die tijd hielden drie instanties zich bezig met economische collaboratie: de zuiveringsraden voor het bedrijfleven (Besluit Zuivering Bedrijsleven Staatsblad F 160); de bijzondere gerechtshoven (artikel 102 Wetboek van Strafrecht) en de tribunalen, ex art. 1 van het Tribunaalbesluit. De zuiveringsraden konden alleen ontzetten uit het recht om leidende functies te bekleden, de tribunalen konden bovendien verbeurdverklaring en internering opleggen en de gerechtshoven ook nog gevangenisstraf. Belinfante wijst erop dat geen wetsbepaling een driedubbele berechting belette en dat competentie-afbakening geboden was; bovendien was artikel 102 W.v.S. zo ruim geformuleerd "dat het iedere vorm van hulpverlening bestrijkt, zonder enige begrenzing." Belinfante, In plaats van bijttjesdag, 397.

7 RANB, inv. nr. 130.01, brief G.J. Janssen aan Commissaris der Koningin, 16 november 1944.

8 Telefonisch interview C. Slegers met dr. H. Verweij-Jonker, Utrecht, 13 juli 1999.

9 Belinfante, In plaats van bijttjesdag, 474.

10 Coolen, 'Gedenkteeken voor de Gevallenen', in: Deurnesche Courant, 13 april 1945. 
Assmann verklaart dat hij vanuit zijn functie de aanklacht van de DAF-employees goed heeft onderzocht en vervolgens geconstateerd dat deze ongegrond is. Hij voegt er nog aan toe dat tijdens de bezetting geen productie-uitbreiding bij DAF heeft plaatsgevonden. Het bedrijf dat tijdens de bezetting miljoenen had kunnen verdienen, is zelfs teruggelopen tot een bedrijf dat met verlies werkt. Bovendien heeft DAF, ondanks het Duitse toezicht, toch steeds de Nederlandse belangen en die van de Nederlandse onderdanen gediend. Tot slot meldt hij nog dat hij door het Militair Gezag op de vingers is getikt vanwege het onderzoek 'op eigen houtje', omdat de regering in Londen volkomen op de hoogte was van het doen en laten van de fabriek tijdens de oorlog. Hij betreurt het dat Coolen zich niet heeft laten voorlichten en dus te lichtvaardig "een te goeder naam en faam bekend staand ingezetene van Deurne" heeft aangevallen.

Coolen antwoordt op dezelfde pagina dat hij van al deze zaken op de hoogte was toen hij de artikelen schreef en dat deze brief geen aanleiding is om er één letter in te veranderen. De redactie van Het Licht plaatst onder deze brief een nawoord, waarin gesteld wordt dat de aantijgingen van Coolen hiermee gelogenstraft zijn. Coolen heeft maar één doel, en dat is ophitsing van de gemoederen in Deurne. De publieke opinie heeft zich volgens de krant echter niet laten beïnvloeden, zoals blijkt uit de verkiezing van Van Doorne tot voorzitter van het Oranjecomité. Het Licht is ervan overtuigd dat Van Doorne zijn recht zal vinden.

Ir. Frits Philips protesteert in zijn brief als voorzitter van de Eindhovense Fabrikantenkring en verdedigt het lid Van Doorne als een zeer goede Nederlander, die steeds spontaan en openlijk optrad tegen iedere maatregel van de bezetter die de belangen van Nederland en van zijn arbeiders zou schaden. "Daarbij getuigde hij van een felheid, die, vooral waar zijn fabriek vanaf het eerste oogenblik onder speciale Duitsche militaire contrôle stond ongetwijfeld ernstige gevaren met zich meebracht." Volgens Philips heeft Van Doorne steeds gestreden tegen de invloed van de NSB en het Nederlands Arbeidsfront, een nationaal-socialistische vervanging van de vakbonden. Hij heeft de invloed van het NAF tegengehouden door nooit een fabrieksappél te houden of een sociale voorman te benoemen. De reputatie van Van Doorne in de fabrikantenwereld was goed, aldus Philips. Hij vindt de aanvallen van Coolen des te afkeurenswaardiger, "omdat hier een schrijver, die zonder verantwoordelijkheid voor het wel en wee van vele menschen door den oorlog ging, een industrieel zwart maakt, die uit den aard van zijn functie deze verantwoordelijkheid dagelijks had te dragen."

Tenslotte is daar Van Doorne zelf met rechts onder aan de pagina een open 'Brief aan den Heer Antoon Coolen'. Hij schrijft dat hij aanvankelijk niet op de beschuldigingen is ingegaan, omdat hij dacht dat het schrijven van Coolen toch geen invloed zou hebben in Deurne en ook omdat hij de gespannen verhoudingen niet verder wilde toespitsen. $\mathrm{Nu}$ Coolen echter doorgaat met hem te belasteren, zal hij hem het antwoord geven dat hij zelf uitlokt. Zijn fabriek was niet uitgebreid in de oorlog; zijn werknemers hadden nooit Duitse levensmiddelenpakketten gekregen en de ex-NSB-er Van Soeten was juist principieel geweest door zijn partijlidmaatschap na de Duitse inval neer te leggen en had daardoor zelfs het gevaar gelopen in een concentratiekamp te komen." Van Soeten hoefde niet te werven voor de fabriek, want deze werd vanaf het begin van de oorlog overstelpt met Duitse orders. 
Aanvankelijk dacht hij nog, schrijft Van Doorne, dat Coolen misleid was en te goeder trouw zijn artikelen schreef. Nu echter blijkt dat hij de waarheid bewust verdraait en ook nog fantaseert, is de maat vol. "Nu ik vernomen heb, dat $\mathrm{U}$ in de sociëteit van Waalre verteld hebt, dat U mij bij Schimmelpenninck in Eindhoven in gezelschap van een Duitsch officier had aangetroffen, nu moet ik wel concluderen dat U bewust leugens verspreidt! Ook Uw verhaal over het 'oranje-jasje' is uit de duim gezogen." Hoe kan Coolen nu zeggen dat zijn "goedheid" - Van Doorne doelt hierbij op het 'soepbeen' voor het verzet - alleen maar te danken is aan het vele geld dat hij verdiend heeft? Vóór de oorlog heeft hij van diezelfde Coolen een boek gekregen, "waarin U zelf de opdracht had geschreven: 'Aan Hub van Doorne in de vreugde toen ik den zege Uwer goedheid zag."'12 Van Doorne denkt nog steeds dat Coolen een goed vaderlander is, waaraan hij ironisch toevoegt: "Ik heb U dit zelf een paar maal voor de radio hooren verklaren." Hij wil echter nog wel eens zien wie van hen tweeèn het meest voor het vaderland heeft gedaan en is direct bereid om alles voor te leggen aan een onpartijdige commissie, "ook al was mijn plaats honderdmaal moeilijker dan de Uwe." Na dit aanbod van arbitrage dreigt hij met gerechtelijke stappen als Coolen zijn beschuldigingen niet herroept.

Vanaf dit moment neemt ook de redactie van Het Licht, die zich tot nu toe afzijdig heeft gehouden, deel aan de strijd. Hoofdredacteur Mulders schrijft een artikel, 'Het kaartenhuis van beschuldigingen', waarin hij constateert dat de tweespalt in Deurne wordt veroorzaakt door een kleine groep, "waarvan de woordvoerder een onomstreden begaafdheid bezat, om zijn gedachten op papier te zetten." Wat er nu gebeurt, is gifspuiten en modder gooien. Mulder vraagt zich af of waarom Coolen geen andere mogelijkheden gebruikt om zijn politieke grieven te uiten. Als hij echter met dit ene geval perse de Deumesche Courant wil vullen, dan moet hij dat maar doen. Het Licht zal zijn schaarse papier niet gebruiken voor het weerleggen van aantijgingen die toch niemand gelooft. ${ }^{\text {is }}$

Het antwoord aan Van Doorne verschijnt in Coolens 'eigen' krant van 7 september 1945. Coolen herroept zijn beschuldigingen niet:

"Doe gij rustig de stappen, die de wet $\mathrm{U}$ het recht geeft te doen. [...] Maar zie, wij komen niet tot rechtsherstel, tot herstel van het rechtsgevoel, tot de bedrijfsrust ook, zoo noodig bij de inschakeling der industrie in onze wederopbouw, als wij door berusting er toe zouden meewerken de gedachte te voeden, dat de kleinen aan de straf voor hun evidente misdaden niet ontsnappen, maar dat er voor de grooten, wier geval moeilijker en verwikkelder ligt, genoeg wegen openstaan - ook vooral die der compensatie van het vele goed doen - om te bereiken, dat zij worden ontzien."

Het Licht heeft volgens Coolen geblunderd door te schrijven dat hij inlichtingen uit het

11 Coolen had geschreven dat Van Soeten ingezet werd om orders te werven in Duitsland; juist omdat hij daar vanwege zijn verleden goede connecties had. Later reageert S. Zoetmulder in een ingezonden brief (4 september 1945) in Het Licht, dat hij tijdens zijn verblijf in diverse gevangenissen in de oorlog nooit iemand is tegengekomen die zijn opsluiting te wijten had aan het blote feit van uittreding uit de Beweging.

12 Bedoeld is het boek Zegen der Goedheid dat Van Doorne in januari 1935 voor zijn verjaardag van Coolen kreeg.

13 Mulders, 'Het kaartenhuis van beschuldigingen', in: Het Licht, 1 september 1945. 
bedrijfsonderzoek uit de eerste dagen na de bevrijding heeft gebruikt en doorgespeeld aan zijn 'kliek' in Deurne, "Nee, licht van een Licht. Ik heb gezegd, dat ik die inlichtingen zou kunnen geven aan de kliek." Overigens geeft hij toe dat dit eerste onderzoek ongelukkig is geweest: "In die paar dagen, toen de binnenlandsche strijdkrachten in Uw fabriek zich vrijheden veroorloofden, welke zij zich meenden te moogen veroorloven, in een bedrijf dat zij beschouwden als een moffenbedrijf. In die dagen ontbrak de noodige beheersing."

Vervolgens kraakt hij Assmann af als vertegenwoordiger van een officiële instantie. Die meneer, met wie Van Doorne voor zo ver hij weet bevriend is geraakt, is gewoon een ambteloos burger die zich, zoals zovelen na de bevrijding, ineens verdienstelijk maakt door een baantje te nemen bij de binnenlandse strijdkrachten.

Tenslotte richt hij zich tot Van Doorne persoonlijk. Dat deze een oranje jasje klaar had liggen voor de bevrijding, neemt hij terug en of het restaurant waarin hij at met een Duitse officier Schimmelpenninck was laat hij in het midden; het ging niet om het restaurant, het ging om het gezelschap.

"Wel, durft gij zeggen, dat gij niet met Duitschers at in Uw eigen restaurant Lido? Met groote regelmatigheid, soms dagen achtereen, zwenkte de auto de DAF-poort uit, om met de Duitsche gasten naar Lido te rijden [...] Dit voortdurend uit lunchen en dineeren gaan met Duitschers is inderdaad het verschijnsel der beste verhoudingen, die met de Duitschers bestonden. Kunt gij niet begrijpen dat ik de hand, die de Duitschers den schotel toereikte en naar hen het glas ophief ten dronk, een beetje wantrouwend aankijk als zij den voorzittershamer hanteert in het Oranjecomité?"

Coolen laat merken dat hij vanuit het bedrijf over bepaalde zaken is ingelicht; bijvoorbeeld over de personeelspakketten die Van Soeten zou hebben meegebracht uit Duitsland. Volgens Coolen is dit een strijdpunt geweest in de leiding van de fabriek. Hij vraagt zich af hoe Van Doorne overtuigd kan zijn van een goede vaderlandse houding bij Van Soeten.

"lk weet niet, wat gij dan wel onder vaderlanderschap verstaat. Ik begin al te twijfelen aan goed vaderlanderschap van iemand, die midden in den oorlogstijd, bij een Wehrmachtsbetrieb een betrekking van exportagent aanneemt, met de taak Duitsland te bereizen. Gij zult mijn bekwaamheden daartoe met recht in twijfel trekken, maar voor geen ton, geen tien, had ik zo'n baan aanvaard." ${ }^{14}$

De boosheid van Coolen, zo kort na de oorlog, is in te voelen. De situatie bij de DAF wijkt echter niet erg af van wat in de rest van het bedrijfsleven gangbaar was. L de Jong concludeert later dat een ruime heroriëntatie van het bedrijfsleven op Duitsland onvermijdelijk was, als men een drastische daling van het nationaal inkomen en van de werkgelegenheid wilde voorkomen. Volgens hem werkte in de eerste twee jaren van de bezetting een kwart, vervolgens bij inkrimpende bedrijvigheid ongeveer een derde en tenslotte in de lente van I 944 meer dan de helft ten behoeve van de Duitsers. Hij voegt eraan toe "dat van het total aan Duitse orders meer dan de helft, vermoedelijk zelfs veel meer dan dat, bestemd is geweest voor de Wehrmacht." Belinfante zegt dat het bijna niet mogelijk is om een scheiding aan te brengen tussen werk dat wel en niet als een bijdrage aan de oorlogvoering func tioneerde, want "zelfs de vervaardiging van voor het normale leven bestemde producten ontlastte de Duitse industrie van de verzorging van een deel van de behoeften van de burgerbevolking en maakte arbeiders vrij voor de productie van oorlogstuig. ${ }^{15}$ De onderne- 
mer die daaraan niet wilde meewerken had geen andere keus dan zijn onderneming te sluiten. Sommigen hebben, volgens Belinfante, die consequentie getrokken, maar de meeste zijn doorgegaan en beriepen zich op het algemeen belang.

\section{Rechtszaak}

Coolen heeft met dit laatste stuk van 7 september Van Doorne dus uitgedaagd om juridische stappen te ondernemen. Deze zal dat ook doen. Hij start weldra een civiele procedure op verkorte termijn bij de Rechtbank in 's-Hertogenbosch.

De administratieve rompslomp groeit Coolen ondertussen boven het hoofd. Op het postkantoor van Waalre heeft hij regelmatig de accuratesse kunnen waarnemen van de achttienjarige dochter van de postkantoorhouder en kerkmeester Hendrik van der Linden. Deze was in de oorlog actief in het verzet; onder meer door het gidsen van Engelse piloten. Bij zijn afwezigheid, zogenaamd wegens ziekte, verving zijn dochter Leny hem. Zoals we gezien hebben stuurde Coolen hem nog een felicitatie met zijn zilveren jubileum in juli 1944 vanuit zijn onderduikadres. In september, als de correspondentie met een van de advocaten van Van Doorne begint, vraagt Coolen aan het loket van het postkantoor: "Leny, wil je mijn secretaresse worden?"16 Haar eerste werk is de correspondentie in de Van Doorne zaak en het uittikken van het manuscript van Bevrijd Vaderland. Zij zal voor de rest van zijn leven zijn secretaresse blijven.

Nu er een rechtszaak op komst is, heeft Coolen ook een raadsman nodig. Hij heeft al regelmatig met juridische zaken te maken als lid van het Tribunaal in Eindhoven. Hier pleit vaak de jonge advocaat mr. G.J.P. Cammelbeeck. Deze is afkomstig uit Den Haag, waar hij Coolen ook al tijdens de bezetting een keer ontmoet had, "toen hij een lezing gaf in het huis naast dat van mijn ouders. ${ }^{\text {"17 }}$ Vanaf mei 1944 werkt Cammelbeeck bij een Eindhovens advocatenkantoor. Zijn wijze van optreden bevalt Coolen en hij vraagt hem als raadsman in het civiele proces dat Van Doorne tegen hem gaat aanspannen.

Voor het zover is worden nog diverse hatelijkheden gewisseld, waarbij ook burgemeester Lambooy prikken uitdeelt. Hij heeft het in de gemeenteraad over "een mijnheer, die met Deurne heel weinig uitstaande heeft" als hij Coolen bedoelt. ${ }^{18}$ Waarop Coolen in de krant reageert met te zeggen dat hij al met Deurne te maken had, "toen U nog niet wist of vermoedde dat $U$ het eenmaal kiezen zoudt als het doelwit van Uw ambtelijke ambi. ties!! $!^{m 19}$

Op 22 november 1945 is de dagvaarding verzonden voor de Zaak van H.J. van Doorne contra Antoon Coolen, letterkundige, M.J. Hendriks, redacteur, J. Schenk en A.H. Swinkels. De zaak zal dienen voor de Enkelvoudige Kamer van de Rechtbank in 's-Hertogenbosch. De radslieden van Van Doorne zijn mr. J.J.A. van der Putt en mr. K.J.M. Witlox.

14 Coolen, 'Antwoord aan Van Doome', in: Deurnesche Courant, 7 september 1945.

15 Belinfante, In plaats van bijltjesdag, 391-392. Citaten uit: De Jong, Het Koninkrijk, deel 1, 196; deel 7, 115.

16 Interview Cees Slegers met mevrouw L. de Bont-v.d.Linden, Waalre, mei 1997.

7 Collectie Cees Slegers, brief Cammelbeeck, 28 februari 1992.

18 Collectie Tij Kools, notulen raadsvergadering Deurne, 31 oktober 1945.

19 Coolen, in: Deurnesche Courant, 9 november 1945. 
De zitting vindt plaats op r 8 januari 1946 voor de rechtbank in Den Bosch. De uitvoerige pleidooien van de raadslieden worden in de week daarop uitgebreid verslagen door de twee kranten in Deurne. Mr. Witlox deelt volgens Het Licht meteen een plaagstoot uit. Hij kondigt aan zich te beperken tot de juridische aspecten van de zaak. Hij zal Coolen niet volgen "in zijn belleteristischen wellust om deze civiele procedure te heffen in de sfeer der romantiek en zelfverheerlijking, maar wel zal hij hem gaarne volgen in de interniteit der openbare dorpsche verhoudingen." 20

De eisende partij, Van Doorne, stelt dat Coolen in het tijdvak half maart tot 9 november 1945 negen artikelen heeft geschreven, waarin de eiser is aangeduid als:

"ronselaar,

lid van een firma die draaihartig is,

iemand, die bij het Herrenvolk zeer gunstig bekend staat, profiterend collaborateur,

iemand, die oorlogsorders van de vijand najoeg door daarvoor speciaal aangesteld personeel met NSB-verleden,

iemand, die dure raspaarden kocht, zijnde een typische vorm van luxe jacht in een noodtijd, die rijkgeworden NSB-ers eveneens hadden

die als slappeling en collaborateur voor zuivering in aanmerking komt;

die het Nieuwsblad van Deurne aan een verraderlijk on-Nederlandse nationaal-socialistische redacteur heeft geholpen (niet met vooropgezet doel maar uit nalatigheid) die ook schuld heeft als nette collaborateur, die nu zijn luxe paard roskamt;

die zich het genoegen gunde raspaarden te rijden, terwijl het land krom lag onder den bezetter;

die, als hij anderen goed deed, dit deed ter compensatie van het eigen geweten en het algemene geweten, ter veiligstelling:

die zijn productie verveelvoudigde en voor de Duitse orderjacht een Duitsgezinde man had, kersvers uit de NSB, die het personeel aanmoedigde met levens- en genotmiddelenpakketten, door de Duitsers beschikbaar gesteld;

die tijdens de bezetting voor millioenen met de vijand heeft gecollaboreerd ten bate van diens oorlogsuitrusting;

die listig zorgde ook papieren gereed te hebben, voor het geval van een Duitse nederlaag;

die met de Duitse heren at in goede 'cameraderie';

wiens goeddoen een paravent is, waarachter zijn collaboratie verborgen moet blijven; die zijn goede naam verspeeld heeft;

die de Duitsers diensten heeft aangeboden en van hen diensten gevraagd heeft en verkregen;

die zich gedekt heeft naar twee kanten;

die van twee wallen gegeten heeft." ${ }^{\text {21 }}$

Over het verwijt van Coolen, dat Van Doorne niet met vooropgezet doel maar uit nalatig. heid "Het Nieuwsblad van Deurne aan een verraderlijk on-Nederlandse nationaal-socialistische redacteur [Van Heugten, C.S.] heeft geholpen," stelt de advocaat van Van Doorne dat niemand kon weten dat Van Heugten zo de verkeerde kant op zou gaan. Ook Coolen niet, zo voegt hij er aan toe, want deze heeft nog in november I94I, een half jaar na de aanstel. 
ling bij Het Nieuwsblad van Van Heugten, een boek van hem nauwgezet doorgelezen en van aantekeningen voorzien en persoonlijk aan Van Heugten overhandigd met de opmerking dat hij het tot zijn oprechte spijt "op artistieke gronden" niet voor uitgave kon aanbevelen. $^{22}$

De eisende partij brengt naar voren dat onderzoeken door het Militair Gezag en de Afdeling Politiezaken van de NBS, Nederlandse Binnenlandse Strijdkrachten, niets strafbaars bij het bedrijf van Van Doorne aan het licht hebben gebracht, en dat de publicaties dus onwaar zijn. Men vraagt de rechtbank de publicaties als onwaar te verklaren en dus als "smadelijk, lasterlijk en beledigend voor de eiser" en de vier gedaagden ieder 25.000 gulden te laten betalen als schadevergoeding en bij eventuele nieuwe publicaties rooo gulden per overtreding. Daarboven dienen de gedaagden veroordeeld te worden tot vergoeding van de kosten van het geding.

Cammelbeeck brengt als verweer voor Coolen cum suis naar voren dat men wel voor de waarheid van de publicaties kan instaan en brengt ter staving daarvoor een groot aantal 'producties' in het geding. Aangezien de eiser het lasterlijke en beledigende van de artikelen afhankelijk stelt van de onwaarheid ervan, kan, nu de waarheid is bewezen, van laster of belediging geen sprake meer zijn. De gedaagden achten hun uitlatingen overigens niet grof of grievend, maar waardig van toon. Door de openbaarheid van het zuiveringsvraag. stuk kunnen uitlatingen die in normale omstandigheden als objectief beledigend zouden gelden, nu wel gebruikt worden; in ieder geval hebben zij niet de bedoeling gehad om te beledigen. De gedaagden erkennen dat Van Doorne ongetwijfeld in het bezit is van uitstekende en achtenswaardige eigenschappen, maar hij heeft als hoofd van zijn bedrijf tijdens de bezetting gefaald. Speciaal de gedaagde Antoon Coolen heeft met zijn artikelen beoogd Van Doorne ervan te overtuigen dat hij zich terug moet trekken uit het Oranjecomité van Deurne en zich ook verder op de achtergrond moet houden in het openbare leven, omdat er rond zijn persoon verschil van mening bestaat in het dorp.

Voorts wijst de verdediging erop dat de zuiveringsraden van het bedrijfsleven nog niet bestonden toen de artikelen werden geschreven en dat zelfs het noodparlement nog niet bestond. Daar komt bij dat de pers een belangrijke taak heeft bij de zuivering als openbare zaak. De gedaagden betwisten de betrouwbaarheid van de onderzoeken van het Militaire Gezag en de afdeling Politiezaken van de NBS.

Tenslotte stelt de vertegenwoordiger van de gedaagden dat de goede naam van Van Doorne niet is aangerand. De laatste heeft immers op 3 I augustus I 945 zelf geschreven dat de artikelen toch geen invloed hebben op de inwoners van Deurne. Tamelijk snerend wordt daaraan toegevoegd, dat Van Doorne de algemene achting van dát deel van de Deurnese bevolking dat "naar den brode en naar intellect" los van hem staat, door zijn gedrag tijdens de bezetting al heeft verloren "en als Vaderlander dus geen goeden naam bezit." Iets wat je niet hebt, kun je ook niet verliezen, bedoelt hij.

20 Mr. Witlox, in: Het Licht, zaterdag 26 januari 1946.

21 De gegevens komen uit het officiële vonnis van de arrondissementsrechtbank van 's-Hertogenbosch, rolnummer $410 / 1945$.

22 Mr. Witlox, in: Het Licht, zaterdag 26 januari 1946. 
De rechtbank concludeert dat de eer en de goede naam van Van Doorne zijn aangetast, maar dat van smaad en a fortiori van laster geen sprake kan zijn. De uitlatingen hebben echter wel door hun uiterst grievende en onterende inhoud het karakter van een zogenaamde 'enkelvoudige belediging'.

De rechtbank is het eens met Coolen cum suis dat de pers een belangrijke taak heeft bij een openbare zaak als de zuivering, maar de pers mag de haar hergeven vrijheid niet misbruiken; zij moet het woord van de dichter waarmaken dat "de ware vrijheid luistert naar de wetten." De gedaagden hadden pas mogen publiceren als dat nog het enige wettige middel was om het doel na te streven. Men had zich eerst tot een bevoegd tribunaal kunnen wenden of de inwerkingtreding van de zuiveringsraden voor het bedrijfsleven kunnen afwachten.

Coolen en de zijnen hebben twee redenen aangevoerd waarom ze met hun actie zijn begonnen. Dat waren het optreden van Van Doorne in het Oranjecomité en zijn belang bij het concurrerende dagblad Het Licht. Daarnaast was er nog een streven om de burgemeester te treffen. De rechtbank acht deze redenen niet van voldoende gewicht om de campagne te rechtvaardigen en verwerpt een beroep op het algemeen belang.

De rechtbank oordeelt noch over het door Van Doorne aangedragen feit dat hij bij het einde van de oorlog door sabotage "met een batig saldo ten gunste van Nederland zijn rekening met den vijand sloot," noch over de vraag of van hem tijdens de bezetting een andere houding kon worden geëist.

De gedaagden worden veroordeeld om duizend gulden - "des dat de een betalende de anderen zijn bevrijd" - aan Van Doorne te betalen. De rechtbank legt hen geen verbod op om in de toekomst soortgelijke handelingen te verrichten, omdat de beledigende aard steeds op zich moet worden bekeken en omdat de krant anders onder een voortdurende censuur van Van Doorne zou komen te staan. Omdat beide partijen op meerdere punten in het ongelijk zijn gesteld, dragen zij beiden hun eigen kosten. ${ }^{23}$

De rechtbank hecht eraan om naast de lange litanie van verwijten aan Van Doorne, die hiervoor is weergegeven, ook nog een lang citaat uit de Deurnesche Courant van 27 juli I 945 in het vonnis op te nemen. Hierin had Coolen de vriendschap tussen een collaborateur als Van Doorne en het hoofd van de gemeente, burgemeester Lambooy, funest genoemd voor het dorpse leven in het naoorlogse Deurne.

Hoewel Coolen en de zijnen veroordeeld worden tot in feite 250 gulden per man (slechts één procent van de eis) voelen zij zich toch moreel de winnaars. Immers, de kern van hun actie en beschuldiging is door de rechtbank niet weerlegd. Daarom zijn ze ook niet voor laster, maar voor enkelvoudige belediging veroordeeld. Bovendien zijn er geen beletselen voor publicaties in de toekomst. Coolen is wel tevreden over het proces. Hij wist dat de veroordeling wegens belediging bijna onvermijdelijk was, schrijft hij aan Oomes. Hij voegt eraan toe dat de mensen in Deurne zeggen: "Mijnheer van Doorne heeft het verloren, maar Antoon Coolen moet rooo gulden betalen." 24

In het personeelsblad van de DAF, Het Schakeltje, wordt het proces daarentegen als een overwinning van Van Doorne beschouwd. Onder de ironische titel 'De Schoone Voleinding' wordt de zaak afgedaan als een staaltje dorpspolitiek van negen personen die geprobeerd hebben in de heer Van Doorne de burgemeester te treffen. 
De rechtszaak is achter de rug, maar de krantenstrijd nog niet. Nog steeds schrijft Coolen lange artikelen in de Deurnesche Courant, waarbij opvalt dat hij zich nog al eens herhaalt, misschien vanuit het principe 'frappez, frappez toujours'. Het lijkt erop of hij hier bewust of onbewust het excuus heeft dat het 'grote werk', een nieuwe roman, niet wil lukken.

Hij kijkt op de rechtszaak terug in een artikel dat vier kolommen beslaat: 'Lessen van het proces ${ }^{25}$. Hierin meet hij breed uit dat hij slechts voor de beledigende toon is veroordeeld, maar dat zijn beschuldigingen overeind zijn gebleven of niet zijn weerlegd. Eerst waren het allemaal leugens, nu zijn het geen leugens, maar heet het, dat hij het verkeerd heeft begrepen. Natuurlijk hebben ze voor de Duitsers gewerkt, natuurlijk hebben ze daaraan verdiend, natuurlijk hebben ze wel eens met ze gegeten, natuurlijk hebben ze nieuwe machines gekocht en daarmee de bewapening van de Duitsers verhoogd. Dat was echter allemaal maar schijn, in werkelijkheid deden ze het voor het nationaal belang, schrijft Coolen sarcastisch.

Coolen geeft ook nog commentaar in andere kranten en tijdschriften. In het weekblad De Uitkijk en in De Stem van Nederland voegt hij aan de bekende onderwerpen [de hypotheek voor Het Nieuwsblad van Deurne met zijn foute hoofdredacteur, de oud-NSB-er als acquisiteur en het verschil in behandeling van de grote en kleine vissen, C.S,] nog extra informatie toe. Hij vertelt dat Van Doorne in Deurne goede sier maakt door de duizend gulden schadevergoeding uit het proces te schenken aan het Wit-Gele Kruis, "waar ze met ontroering en dankbaarheid werd aanvaard." 26

\section{Coolen wekt wrevel}

De strijd tussen de kranten laait weer op als Coolen in de zomer van 1946 een negatief artikel schrijft bij gelegenheid van het vertrek van burgemeester Lambooy naar Waalwijk." Dat artikel wordt door lezers van Het Licht, waaronder een illegaal werker, beschouwd als een trap na.

Het felst is Noud van den Eijnde. Deze boekhandelaar en uitgever gaf in de beginperiode de Deurnesche Courant uit en vanaf I september 1945 merkwaardigerwijze óók Het Licht. Later geeft hij alleen nog maar Het Licht uit. In een stuk, rijk doorspekt met verwijzingen naar boektitels van Coolen, verwijt Van den Eijnde Coolen dat hij zijn relatie met Deurne veel te positief voorstelt. Hij doet zich voor als Deurenaar, maar hij heeft niet meer dan een vijftiental jaren in Deurne gewoond. Toen hij na dertien jaar Hilversum terugkwam in Deurne, ging hij anders schrijven en concessies doen aan een bepaalde smaak. Hij maakte niet meer de Peellandse mensen met deugden en hartstochten tot zijn personages, maar zocht de abnormalen, een duidelijke verwijzing naar de Van Taeke romans. Dit werd hem door de "kinderen van ons volk" zo kwalijk genomen dat hij weinig genoegen had van zijn vestiging in Deurne. "Hij aardde niet meer in dit volk, dat zich door hem min of meer verguisd voelde." Coolen is daarom gedesillusioneerd naar Waalre vertrokken om vanuit dat 'Wolderen' via

23 Vonnis gewezen door mr. J.K. Schellenbach op 8 februari 1946.

24 LMDC, inv. nr. C 3485, brief Coolen aan Oomes, 27 februari 1946.

25 Coolen, 'Lessen van het proces', in: Deurnesche Courant, februari 1946.

26 Coolen, in: Stem van Nederland, 2 maart 1946.

27 C. [Coolen], in: Deurnesche Courant, 5 juli 1946. 
zijn privé-vriendschappen partij te kiezen in Deurnese aangelegenheden. Het schrijven in Waalre is niets geworden, ook het laatste boek is niet gelukt: "In Bevrijd Vaderland tracht hij den inspirerende rauwen grond te hervinden, doch vermocht niet diep genoeg te graven." ${ }^{n}$

Dit artikel geeft iets weer van de sfeer die onder een deel van de Deurnese bevolking heerst. Het aanzien van Van Doorne in Deurne is niet gering, zoals bijvoorbeeld valt af te lezen aan zijn verkiezing voor het Oranjecomité. De goodwill stijgt zelfs, omdat hij zich steeds meer als een mecenas manifesteert. De wrevel van de dorpsbewoners tegen iemand van buiten die zich met hun zaken bemoeit, moet Coolen niet vreemd zijn. Hoe vaak heeft hij zo'n personage niet in zijn romans beschreven. De vervangende dokter De Pater, de nieuwe kapelaan bij pastoor Vogels, de stadse 'kaaljakkers' Havé, de jonker die een romantische boer wil zijn en de weduwe van de notaris Van Heyste, die zo graag nader wil kennismaken met de vrouw van Godefridus de moordenaar. Allemaal willen ze zich op de een of andere manier met de dorpelingen bemoeien. Sommigen zijn betweters en voelen zich ver boven hen verheven, anderen zouden er zo graag bij willen horen. Wat bij deze romanpersonages niet lukte, lukt nu ook niet helemaal bij Coolen. Hij wordt een buitenstaander, een schrijver uit 'Wolderen'.

Coolen geeft echter ook na de rechtszaak de strijd niet op. In De Stem van Nederland ${ }^{29}$ schrijft hij dat er kort voor de bevrijding van het zuiden nog achtentwintig Mercuri-overvalwagens, die in opdracht van de Gestapo Nijmegen voor de SS waren geproduceerd, van het zuiden naar het noorden waren gestuurd en daar "ongetwijfeld in dien vreeselijken laatsten oorlogswinter nog hun sinistere diensten hebben gedaan." Coolen heeft, als lid van het Tribunaal voor Bijzondere Rechtspleging, ervaren dat vooral de kleine vissen gestraft worden. Een collaborateurtje krijgt een kwitantie van 440 gulden uit een Duitse Kasse onder de neus gedrukt, terwijl Van Doorne alleen al in 1942 voor 7 miljoen aan orders van de Wehrmacht binnen had, schrijft hij.

$\mathrm{Na}$ het vertrek van burgemeester Lambooy fungeert de loco-burgemeester als waarnemer. Deze A. Swinkels is een neef van Coolen. Door de affaire zijn zij in verschillende kampen terechtgekomen. Swinkels is het niet eens met Coolens aanvallen op Van Doorne en Lambooy. Coolen laat echter niet af en gaat zich zelfs ook met andere Deurnese zaken bemoeien.

Hij richt zich, niet via de Deurnesche Courant maar in een persoonlijke brief, voor een heel ander zaak tot Swinkels: de benoeming van de gemeentesecretaris. Coolen vindt dat de minst bekwame is benoemd en vraagt zich af wat de beweegredenen daarvoor zijn geweest. In deze uitgebreide brief refereert hij aan de toespraak van de koningin en constateert dat er van de door haar gewenste onpartijdigheid niets terechtkomt. Er gebeuren dingen die schadelijk zijn "voor de belangen van het dorp, dat nog altijd mijn liefde behoudt [...] Ik leg U dit als mijn groote moeilijkheid voor en omdat wij daarin tegenover elkaar staan, zou ik willen, dat $\mathrm{U}$ mij den weg wees om over deze moeilijkheden heen te komen." ${ }^{30}$

$\mathrm{Zijn}$ neef, de waarnemend burgemeester, reageert ijzig. Hij wenst niet op de interpellatie in te gaan, omdat hij ze ongepast vindt. Hij wil best eens van gedachten wisselen in de hoop dat er voor Deurne iets goeds uit kan komen. Hij vindt dat Coolen "ons mooie dorp" in het land in opspraak heeft gebracht en het is voor hem daarom heel moeilijk om nog te geloven dat Coolen nog genegenheid voor Deurne heeft. Hij wil hem echter graag tonen op 
welke manier hij met vrucht voor Deurne zou kunnen werken. ${ }^{31}$ Swinkels vindt dat het nu, in november 1946 , tijd wordt om de persstrijd tot een einde te brengen.

\section{Bemiddelingspogingen}

Door de Van Doorne-partij wordt Van Duinkerken bij de zaak betrokken. Op dezelfde dag dat Swinkels de bovenstaande brief aan Coolen schrijft, logeert Van Duinkerken toevallig bij de advocaat van Van Doorne, mr. Jo van der Putt. Deze stelt hem voor een gesprek te organiseren tussen Coolen, Van Duinkerken en Van der Putt zelf. Daags daarna stelt Van Duinkerken dit aan Coolen voor en deze gaat ermee akkoord. ${ }^{32}$ Van Duinkerken wil niets anders dan misverstanden uit de weg ruimen, maar in zo'n gesprek zal "ongetwijfeld de vraag naar de gewenschtheid eener voortgezette polemiek uitvoerig behandeld worden." Van Duinkerken citeert hierbij uit een brief van Van der Putt aan Cammelbeeck: "Ter voorkoming van een nieuwe procedure ben ik bereid, op korten termijn de zaak met Uw client en U te bespreken, desgewenscht in het bijzijn of onder leiding van een neutrale derde, - of zelfs van een niet-neutrale derde, zooals bijv. Anton van Duinkerken. ${ }^{n 33} \mathrm{Er}$ dreigt dus een tweede gerechtelijke procedure tegen Coolen.

Van Duinkerken heeft Van der Putt op 20 november 1946 geantwoord dat Coolen geen bezwaar heeft tegen zo'n gesprek. Hij merkt in deze brief ook nog op: "Van de mededeeling, dat de vraag naar de strafbaarheid van den heer Van Doorne ter bevoegder plaatse wordt onderzocht, nam ik goede nota." Hij voegt eraan toe dat dit waarschijnlijk ook voor Coolen een belangrijk punt is. Coolen is volgens Van Duinkerken sterk teleurgesteld in het feit dat mensen van wie het gedrag in de oorlog sterk afkeurenswaardig was, na de oorlog grote invloed uitoefenen. Hij is het met Van der Putt eens dat Coolen nu zijn talenten misschien weer eens aan andere zaken moet besteden. Hij wil echter nog geen oordeel vellen, maar zal een arbiterschap graag aanvaarden.

Coolen reageert per omgaande enthousiast op het voorstel om Van Duinkerken als arbiter te laten optreden. Hij heeft in een afschrift ook de zinsnede van Van der Putt over de "draagwijdte van zijn talent" gelezen en geeft toe dat het misschien wel waar is dat deze zaak hem buiten verhouding bezighoudt. Hieruit blijkt dat hij zelf ook voelt dat hij een beetje aan het doorslaan is. Vervolgens gooit hij echter in een lange volzin al zijn gram tegen Van Doorne eruit. Deze man heeft de krant waar Coolen bij betrokken is met gebruikmaking van de meest smakeloze middelen en door de oprichting van een tegenblad doorkruist, schrijft hij bitter. ${ }^{34}$ Uiteindelijk gaat de hele bemiddelingspoging niet door. Er komt ook geen tweede proces.

28 Van den Eijnde, in: Het Licht, zaterdag 13 juli 1946.

29 Coolen, in: Stem van Nederiand, oktober 1946.

30 Collectie Tij Kools, kopie van brief Coolen aan den Edelachtbare Heer A. Swinkels, waarnemend burgemeester. Aanhef: "Mijn waarde neef", 5 oktober 1946.

31 Collectie Tij Kools, kopie van brief waarnemend burgemeester Swinkels aan Coolen, "Waarde neef", 6 november 1946.

32 BA, brief Van Duinkerken aan Coolen, 5 december 1946.

33 BA, fragment uit een brief van mr. J. v.d. Putt aan mr. Cammelbeeck d.d. 19 november 1946; geciteerd in brief van Van Duinkerken aan Antoon Coolen, 5 december 1946.

34 BA, brief Coolen aan Van Duinkerken, 6 december 1946. 
Op 15 januari 1947 doet ook loco-burgemeester Swinkels een bemiddelingspoging en richt zich met twee gelijke brieven tot de Deurnesche Courant en Het Licht. Hij gelooft dat beide bladen het belang van Deurne willen dienen, maar dat daar in de praktijk niets van terecht komt. Integendeel, er is steeds vertroebeling van de goede sfeer en de rust, waaraan Deurne na de oorlog zo'n behoefte heeft. De nieuwe burgemeester - die nog niet bekend is - moet met een schone lei kunnen beginnen. ${ }^{35}$

Ook deze poging loopt op niets uit. Een voorstel voor een gesprek in maart 1947 onder neutrale leiding wordt getorpedeerd door de eis van Het Licht dat de Deurnesche Courant vóór die bijeenkomst aan de bevolking van Deurne haar excuus aanbiedt "voor de tweespalt en oneenigheid door haar gesticht. ${ }^{n 36}$ Swinkels geeft deze voorwaarde zelfs niet door aan Coolen.

\section{Einde van de persstrijd en Coolen weg bij Tribunaal}

In april r 947 vraagt Swinkels opnieuw aan beide kranten, nu in iets verschillende bewoordingen, om de sfeer in Deurne niet langer te bederven. ${ }^{37}$ Meteen na ontvangst van de brief belt Coolen naar Swinkels om te informeren, wat die voorwaarde van Het Licht die in de aan hem gerichte brief niet vermeld stond, inhoudt. Swinkels weigert de voorwaarde te noemen. Coolen bevestigt dit in een brief en stelt vast dat de bereidverklaring om tot een oplossing te komen dus door Het Licht is afgesneden. Het Licht stelt dus het belang van de eigen kring "boven het algemeen belang van ons dorp. ${ }^{n 8}$ Het belang van ons dorp staat voor het bestuur van het persfonds juist voorop, schrijft voorzitter Coolen. Het bestuur dankt Swinkels voor zijn bemoeienis.

In diezelfde tijd spreken zowel de Bedrijfszuiveringsraad als het Tribunaal voor de Bijzondere Rechtspleging zich uit over de handelwijze van DAF en Van Doorne tijdens de bezetting. Beide organen spreken Van Doorne onvoorwaardelijk vrij van rechtsvervolging, Dit is voor Coolen de directe aanleiding om op te stappen. Op 30 mei 1947 maakt hij in de Deurnesche Courant zijn ontslagname als lid van de Vierde Kamer van het Bossche Tribunaal bekend en geeft tevens een toelichting. Hij blijft erbij dat Van Doorne twee wegen heeft opengehouden voor de naoorlogse situatie. Ook het tribunaalsbesluit, waar hij overigens niet bij betrokken was, heeft volgens hem wat dit betreft een zekere tweeslachtigheid. Er staat een bepaling in, welke "bij economische samenwerking het beroep openlaat op het uiteindelijke beoogen van vaderlandsche belangen. Deze bepaling houdt een onmisbaren waarborg in voor de twijfellooze gevallen der goeden, maar staat evenzeer de twijfelachtige gevallen der handigen ten dienste," schrijft Coolen. ${ }^{39}$

Coolen laat ook zijn brief aan de voorzitter van dit tribunaal, Steensma, afdrukken. Hierin wijst hij op de grote verschillen in vonnissen en "hoe schrijnend dit was voor het rechtsgevoel. De controverse in de bijzondere rechtspleging tusschen politieke delinquenten, de delinquenten der strafbare lidmaatschappen, 'kleine' luiden doorgaans, en de economische collaboratie der industrieelen houdt voor mij een te grote rechtsongelijkheid in. ${ }^{40} \mathrm{Hij}$ kan het niet langer met zijn geweten in overeenstemming brengen dat alleen de eerste groepen gevonnist worden, terwijl hun steun aan de vijand vaak niets betekende in vergelijking met de andere groep, die nu straffeloos blijft.

Coolen is niet de enige die het bedrijfsleven verwijt te hebben samengewerkt met de 
bezetter en tegelijkertijd het verzet te vriend te hebben gehouden met enige giften. Het "Bureau ter behartiging der Belangen van Aannemers en Bouwers, die géén werk hebben uitgevoerd voor de Duitsche Weermacht" heeft al in r945 een Open Brief aan de Nederlandse Regering geschreven. Hierin wordt de vraag gesteld of het waar is "dat die aannemers, welke grof geld aan de weermacht verdienden, op uitgerekende wijze eens wat geld gevende aan de illegale partij, of wat geld ter beschikking stelden voor de [bestrijding van de] Jodenvervolging, dit nu als een brevet van onschuld kunnen gebruiken?"mi

De gang van zaken rond de Tribunalen en de Bijzondere Gerechtshoven is bijzonder stroef verlopen. De meeste Tribunalen zijn pas heel laat op gang gekomen: in juli 1946 is nog maar tien procent van de gevallen berecht. ${ }^{42}$ In juli 1947 , in de tijd van het uittreden van Coolen, wachten nog 18.000 politieke delinquenten op een veroordeling. ${ }^{43}$

Het landelijk blad De Uitkijk constateert dat het uittreden van Coolen uit het Eindhovense Tribunaal weinig aandacht heeft gekregen in de landelijke pers en neemt de motivering en de brief van Coolen uit de Deurnesche Courant over. ${ }^{44}$

De roep om met de zuivering, die een grote mislukking wordt, te stoppen wordt eind 1947 steeds groter. Men wil er vóór de feesten ter gelegenheid van het vijftigjarig regeringsjubileum van Koningin Wilhelmina in 1948 een streep onder zetten. De tribunalen worden uiteindelijk op r juni 1948, een jaar na Coolens uittreden, opgeheven. Coolen heeft dan alweer een andere eervolle 'bijbaan' gekregen. In maart 1947 is hij benoemd in een Werkcomité voor het tot stand brengen van een Nationaal monument op de Dam in Amsterdam. ${ }^{45}$

Nog een laatste maal haalt Coolen uit naar Van Doorne. Rond bevrijdingsdag 1947 schrijft hij twee cynische artikelen in de Deumesche Courant. In het eerste wordt gewezen op de enorme verschillen in welvaart, de "oase van schier onbeperkte levensluxe naast den barren jammer, van hen, die nauwelijks een stoel en een deken hebben in hun kippenhokken." Weer wordt benadrukt dat de bijzondere rechtspleging ten volle is neergekomen op de schouders van de kleine man en dat de grote "die duizend maal meer voor hen lde bezetters] deed en er duizendmaal meer het eigen belang mee diende, door een weefsel van geheimzinnige machten beschermd wordt en onaantastbaar is. ${ }^{46}$ Coolen haalt de Franse

35 Collectie Tij Kools, kopie van brief Loco-burgemeester Swinkels aan de Deurnesche Courant en Het Licht, I5 januari 1947.

36 Collectie Tij Kools, kopie van brief N. van der Eijnde aan Swinkels, 11 maart 1947.

37 Collectie Tij Kools, kopieēn van brieven van Swinkels aan Deurnes Persfonds en Het Licht, 9 april 1947.

38 Collectie Tij Kools, kopie brief Coolen aan Swinkels, 10 april 1947.

39 Coolen, Verantwoording', in: Deurnesche Courant, 30 mei 1947.

40 Brief Coolen aan mr. Steensma, gepubliceerd in: Deurnesche Courant, 30 mei 1947.

41 Van der Plas, Mooie vrede, 84.

42 Van der Plas, Mooie vrede, 119. Gegevens uit: de Volkskrant, 23 augustus 1946.

43 Van der Plas, Mooie vrede, 125. Gegevens uit: de Volkskrant, 5 juli 1947.

44 Van der Plas, Mooie vrede, 86. Gegevens uit: De Uitkijk, 28 juni 1947.

45 In het Comité zitten verder onder andere Roland Holst, Andriessen, Van Eyck en Anton van Duinkerken. Het comité is in maart 1947 opgericht, maar de eerste vergadering is pas op 20 december 1948. Van der Vegt, Adriaan Roland Holst, 516.

46 Coolen, 'Het tweede bevrijdingsfeest', in: Deurnesche Courant, 2 mei 1947. 
schrijver Vercors aan die gesteld heeft dat in Frankrijk de schrijvers harder aangepakt worden dan de industriëlen die hebben gecollaboreerd en dat alles wordt opgeofferd aan de koopmansgeest. ${ }^{47}$

$\mathrm{Na}$ de herdenking van de bevrijding betreurt Coolen het dat deze zo uiterst sober is gehouden. Hij vindt het argument dat dit gebeurd is omdat later in dezelfde week, op 12 mei, de inhuldiging van de nieuwe burgemeester zal plaatsvinden, niet opgaan. Grote groepen in Deurne blijven zich afzijdig houden zolang de feestelijkheden plaatsvinden onder een leiding [lees Van Doorne, C.S.] die men niet juist acht. Coolen vindt dat de herdenkingen op deze manier steeds weer het oud zeer naar boven zullen halen, waardoor in het dorp geen eenheid en eensgezindheid kunnen ontstaan.

Coolen is vanaf die tijd lid van het herdenkingscomité in zijn woonplaats Waalre en tevens voorzitter van de provinciale herdenking. Het Willibrorduskerkje in Waalre functioneert als gedachteniskapel voor álle Brabantse gevallenen.

Na het verschijnen van deze aflevering van de Deurnesche Courant op vrijdagmiddag 9 mei is voor Van Doorne de maat vol. Midden in de Schoolstraat geeft hij redacteur Krämer een vuistslag in het gezicht. Daarna stormt hij het gemeentehuis binnen waar hij loco-burgemeester Swinkels aantreft in gesprek met tandarts Berkvens, vriend van Wiegersma en Coolen.

Volgens het verslag in de Deumesche Courant vliegt Van Doorne vervolgens Berkvens naar het oor. Berkvens is met de burgemeester in gesprek over het feit dat Van Doorne ook weer de leiding zal hebben bij de inhuldiging van de nieuwe burgemeester. Zoals in het verder zeer ironische verslag in de Deurnesche Courant wordt uitgelegd, doet Van Doorne dit niet in zijn functie als voorzitter van het Oranjecomité maar als voorzitter van Deurnes Belang. De standsorganisaties hebben zelf verzocht of hij de leiding van deze middenstandsvereniging op zich wil nemen. ${ }^{48}$

Uit alles blijkt dat de meerderheid in het dorp geen problemen heeft met Van Doorne.

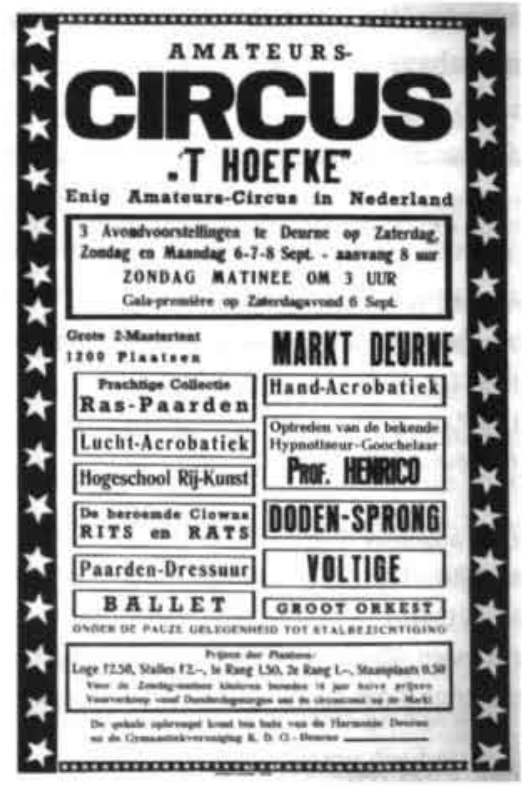

Deze is ook beschermheer van de Deurnese Harmonie en al gauw de belangrijkste animator en sponsor van het amateurcircus het Hoefke.

Op I augustus 1947 verschijnt de Deumesche Courant voor het laatst. In een redactioneel artikel staat dat de uitgave voorlopig gestaakt wordt. Enerzijds geschiedt dit omdat de papierschaarste weer zou nopen tot halvering van de omvang, anderzijds omdat de nieuwe burgemeester zijn ambt aanvaard heeft en men hem zoals eerder beloofd - niet wil confronteren met tweedracht.

Coolen schrijft een 'Ten Voorlopig Afscheid' en blikt hierin terug op de affaire vanaf het begin. "Het was in dien vreeselijken winter toen het Zuiden van ons land bevrijd was en het 
Noorden nog de verschrikking der Duitse bezetting doorstond, dat ik de uitnoodiging ontving, het inleidend artikel te schrijven voor de Deurnesche courant."

Hij verhaalt over het succes van de krant en meldt met trots dat Radio Herrijzend Nederland, de omroep voor het bevrijde Zuiden, die anders nooit melding maakte van lokale bladen het frisse geluid van de Deurnesche Courant heeft geprezen.

Toen volgden echter de ontgoocheling en de tegenwerking van mensen die iets te vrezen hadden van een strikt gezuiverde toekomst. Inmiddels zijn twee jaren verstreken, die hem toch ook voldoening hebben gebracht. Hij kreeg van velen juist begrip, steun en sympathie in de strijd "van moeite zwaar."

Een klein jaar later stopt ook de krant Het Licht. In een klein kader van het nummer van I9 juni 1948 wordt de reden gegeven: "Overdrukke werkzaamheden, gebrek aan belangstelling en medewerking van diverse zijden en daarmee gepaard gaande grote geldelijke offers, hebben ons genoodzaakt dit besluit te nemen. De uitgever Noud van de Eijnde." Het gebrek aan belangstelling zou wel eens kunnen voorkomen uit het feit dat Het Licht zijn voornaamste bestaansgrond, tegengas bieden aan de Deurnesche Courant, was kwijtgeraakt.

Op dezelfde pagina wordt bericht dat Circus het Hoefke, dat nog maar een jaar geleden zijn première beleefde, binnenkort zal optreden buiten de gemeentegrenzen van Deurne en wel in Helmond en Eindhoven. Over dit amateurcircus wordt al in augustus 1947, vlak na het einde van de Deumesche Courant, lovend geschreven. Men noemt het een unicum in het land. Bij de eerste opvoering op 6 september 1947 zijn zowel de gehele Deurnese geestelijkheid als het voltallige college van B en W met hun dames aanwezig. In redevoeringen worden zowel Van Doorne als oud-burgemeester Lambooy toegesproken. Van Doorne en zijn familie worden bedankt, omdat ze steeds alle mogelijke steun hebben gegeven aan het culturele leven in "ons dorp" ${ }^{49}$ De bevolking van Deurne is, evenals de rest van Nederland, het napraten over de oorlog voorlopig beu. Men wil zich liever bezighouden met prettige zaken.

Tien jaar later zullen het circus én zijn beschermheer een centrale rol spelen in de op een na laatste roman van Antoon Coolen.

\section{Een literaire verwerking van het conflict}

Voor het Winteravondboekvan 1946 schrijft Coolen het verhaal 'De boer en de haardtegels'. Hij neemt het enkele jaren later in gewijzigde vorm op in zijn verhalenbundel Onder de Canadassen onder de titel 'De schouwtegels'. Het is een verhaal over het irrationele in de mens en over een geheimzinnige voorbestemming. Het doet sterk denken aan de 'instinctcausaliteit' die Van Duinkerken bespeurde in Coolens vroege Peelromans. Nol Verbonk uit De goede moordenaar weet niet waar de drang vandaan komt die hem bijna een tweede moord doet begaan.

In het verhaal 'De schouwtegels' wordt boer Maessen ongeremd driftig, als er over de mooie tegels in zijn haard gesproken wordt. Slechts één man mag er over praten en die aan-

47 Coolen, 'Dat noem ik immoreel', in: Deurnesche Courant, 14 maart 1947,

48 'Achtergrond van het incident', in: Deurnesche Courant, 16 mei 1947.

49 Het Licht, 13 september 1947. 
hoort hij rustig. Dat is J. van Sprundel:

"een man die elken dag een boord droeg, die zoo'n zachtmoedig mannenbaardje had, thuis een herbarium verzorgde en aan dierkunde deed en die over de geschiedenis van het dorp en de oude vijftiend'eeuwsche kerk en toren een artikel had geschreven in een gewestelijk geschiedkundig tijdschrift." ${ }^{50}$

Een opkoper, Karp, toont belangstelling voor de haardtegels. "Zijde gij een reiziger in kunstmest of van de astrantie?" ${ }^{\text {5l }}$ vraagt de boerin wantrouwig. Zo gauw Karp het doel van zijn bezoek bekend maakt en vervolgens te sterk aandringt op het verkopen van de tegels, wordt hij door de boer in elkaar geslagen.

Daarop volgt een merkwaardige rechtszaak, waarbij de advocaat van de mishandelde opkoper clementie vraagt voor de boer, omdat zijn woede voortkomt uit "een raadselachtig psychisch affect," waarvan iedereen, ook hijzelf of de rechter, de dupe zou kunnen worden. Zijn cliënt hoeft geen schadevergoeding. Het enige wat hij wil is het recht om de tegels tegen een normale prijs te kunnen kopen. Nog vóór de uitspraak slaat de boer zijn tegels kapot, omdat hij ze in ieder geval niet aan Karp gunt. Van achter de tegels komt een loden koker te voorschijn.

In de koker zit een perkament uit de achttiende eeuw, waaruit blijkt dat een voorvader van de boer de tegels met geweld en een rechtszaak in bezit heeft gekregen, en dat hij benieuwd is welke van zijn nazaten door dezelfde "coppighe sottigheit" de tegels weer via het gerecht en met geweld uit handen gerukt zullen worden. Hij gaat ermee naar Van Sprundel. Als deze de tekst voor de boer verklaard heeft, verliest de boer zijn belangstelling. Hij heeft meer aandacht voor een opgezette roerdomp, die de geleerde man in zijn kamer heeft staan. Hij denkt niet meer aan zijn tegels en zegt: "Ik heb ze wel 'es gehoord in het voorjaar, 't is eigenlijk schrikkelijk om te hooren." Ja, zegt van Sprundel, ge hoort ze eerder dan ge ze ziet.

Bij het afscheid kijkt van Sprundel de boer aan met een fijn lachje. De boer lacht terug, maar onderweg naar huis wordt hij nijdig over zijn eigen lachen. Hij is niet meer kwaad over zijn tegels, maar om zijn lachen. Zo eindigt het verhaal:

"En eindelijk moest hij stil blijven staan en maar grinniken, tevergeefs met de hand voor den mond om het geluid in te houden, en eindelijk lachen, lachen, zoo schandalig en onverdommelijk lachen als hij deed, dat hij ervan schaterde en dacht van zijn leven niet meer te zullen kunnen ophouden ....52

Coolen heeft in 1948 de eerste versie van het verhaal van 1946 flink gewijzigd voor de bundel Onder de Canadassen. De introductie van de haardtegels krijgt de lezer nu te zien door de ogen van een jongetje dat een kan melk moet gaan halen. De figuur van Splunder, onmiskenbaar een portret van Ouwerling, komt in de eerste versie niet voor. Hierdoor krijgt het einde een heel andere wending. In het Winteravondboek eindigt het verhaal met de tekst van het oude perkament; in de bundel volgt dan nog de opmerking over de roerdomp en het onbedaarlijke lachen daarna. De eerste versie is niet lang na de rechtszaak met Van Doorne geschreven. In de tweede versie is een literaire verwerking van het conflict te herkennen.

In beide versies heeft Coolen gebruik gemaakt van zijn eigen ervaringen uit het proces tegen Van Doorne. De minutieuze beschrijving van de rechtszaak in Den Bosch, het gedrag 
van de magistraten en de onwennigheid van degenen die moeten verschijnen, is weer een fraai staaltje van het vermogen van Coolen om zijn indrukken haarscherp weer te geven.

In de tweede versie is de psychologische kant van het verhaal meer uitgewerkt. De advocaat van de tegenpartij noemt tot tweemaal toe het psychisch "affect" bij de koppige boer en wijst de rechter erop dat ook zij onder bepaalde omstandigheden elkaar een "gat in den schedel" zouden kunnen slaan. Bij ieder normaal mens zit ergens wel een zwak plekje, zoals bij Siegfried op zijn rug waar een eikeblaadje was gevallen toen hij zich doopte in het drakenbloed en bij Achilles aan zijn hiel, waaraan zijn moeder hem vasthield toen ze hem in de Styx onderdompelde.

Coolen heeft het, bewust of onbewust, over zichzelf als hij over de irrationele, opvliegende boer schrijft: "Er zijn menschen die zoo'n redeloos teer punt kunnen hebben, waarin ze als stieren zijn voor eenen lap wanneer ge er maar over spreekt, dat ze blind van woede maakt als ge 't aanraakt en waarbij ze misschien te razender worden omdat ze wellicht in hun ziedende drift ergens toch dat stekende begrip hebben zitten, hoe onmenschelijk onredelijk en halsstarrig ze zijn."

Coolen heeft altijd een scherp oog gehad voor het falen van zijn personages en voor de 'gewoonheid' van mensen, voor hun gebrek aan heldhaftigheid, hun kleinheid en hun kwetsbaarheid. Hij heeft dat in zijn werk met mededogen beschreven. Daarin is hij een meester. Coolen weet dat hijzelf ook zijn zwakke plek heeft, namelijk zijn onvermogen tot polemiseren als zijn eigen persoon in het geding is. Meestal kiest hij er dan voor om zich stil te houden en er niet op in te gaan. Dat hebben we gezien in zijn houding tegenover het gedrag van zijn vroegere hoofdredacteur Aleven en bij het regionalismedebat. Tegenover de bezetter in de oorlog is hij consequent in zijn afwijzing, maar hij doet dat beheerst en op een correcte manier. Coolen ontwijkt het conflict, hij zoekt een toevlucht in een oase of een schuilkelder voor de geest. Het zijn begrippen die hij in de oorlog vaak heeft gebruikt. Als hij toch gaat strijden en polemiseren, zoals in de persstrijd tegen Van Doorne, slaat hij door en kwetst zichzelf én de ander.

In alle andere conflictsituaties heeft hij de strijd vermeden en er alleen in persoonlijke brieven aan vrienden wat over gemopperd. Hij weet dat hij zich niet moet mengen in een polemiek, omdat hij dan, zoals alle mensen die het conflict schuwen, een agressie in zichzelf losmaakt, die hij niet in de hand heeft.

Slechts één keer heeft hij zich laten gaan. Bij de openlijke persstrijd en de aanval op Van Doorne is hij steeds meer als persoon in het geding gekomen. Hierdoor is hij stukken gaan schrijven die tegen zijn natuur in gaan en waarmee hij dicht komt bij beledigen en schelden. Coolen beseft dat hij, evenals de boer "met een wreed en hevig pleizier" iets moois in het hart van zijn huis kapot slaat, bij zichzelf ook iets aan het kapot slaan is. Het gaat om het meest waardevolle wat hij heeft: zijn het mededogen en begrip voor de grote en kleine fouten bij zijn medemens, van wie hij 'getuige en deelgenoot' is. Deze eigenschappen zijn

50 Coolen, 'De schouwtegels', in: Onder de Canodassen, 49.

51 Coolen kent zijn Multatuli. De weduwe Zipperman (kennis van juffrouw Pieterse) heeft een dochter die getrouwd is met "iemand van de assurantie, of 't kadaster, of zo-iets." Later schrijtt hij: "Die heren van 't kadaster - of van de assurantie - zyn zo gek nog niet." Multatuli, Volledige Werken, deel 2, 552 en 570.

52 Coolen, 'De schouwtegels', 86. 
de 'schouwtegels' van zijn hart. Het verraden van die eigenschappen voelt hij als zijn eigen fout. Coolen kon het niet opbrengen getuige en deelgenoot te zijn van de 'falende' Van Doorne, omdat hij ook geen milde getuige kon zijn van zijn eigen falen, toen hij solliciteerde naar het burgemeesterschap in een fase van de bezetting toen dat eigenlijk niet meer paste, Pas oog in oog met de Duitsers kwam hij tot inkeer.

Het is een fout die je niet meteen helemaal herkent, zoals je de doffe roep van de roerdomp hoort, maar hem niet ziet. Coolen is niet meer kwaad over het gedrag van Van Doorne, dat blijkt later duidelijk in De grote voltige. Hij is kwaad op zijn eigen manier van reageren, omdat hij daarmee zichzelf innerlijk heeft beschadigd.

\section{De nasleep}

De kwestie van Doorne smeult nog lang na en flakkert in de tweede helft van de twintigste eeuw regelmatig weer op. Zowel in Deurne als in Nederland houdt zij de gemoederen bezig. In het laatste kwart van de jaren veertig dooft de belangstelling echter tijdelijk uit. Nederland en vooral ook Brabant willen werk maken van de wederopbouw, het herstel van de economie. Bovendien gaat de kwestie van het onafhankelijkheidsstreven van Indië een grote rol spelen in de publieke opinie. Het starten van een koloniale oorlog (ook al heette die eufemistisch politionele actie), de rechtvaardiging daarvan en het al of niet mogen weigeren daar als soldaat aan deel te nemen, waren onderwerpen die in de pers al gauw de volle aandacht kregen. Van zuivering of vervolging van het bedrijfsleven kwam niet veel meer terecht.

Cammelbeeck schrijft later: "Er is eigenlijk niks gebeurd. Het eerste kabinet na de oorlog, het kabinet Schermerhorn-Drees, had een programma van herstel en vernieuwing. Het herstel is uitstekend geslaagd dankzij een hele hoop van die bedrijven die gecollaboreerd hadden, en van vernieuwing is geen donder terecht gekomen.".53

In de jaren vijftig worden de gebroeders Van Doorne impliciet geprezen in het boek van Toon Kortooms via de personages Beekman en Beekman. Koningin Juliana rijdt met keizer Haile Selassi in een Dafje, bestuurd door Van Doorne. Antoon Coolen schrijft in 1957 het al eerder genoemde boek De grote voltige waarvan de held geïnspireerd is op Hub van Doorne: Wigbert Benner, het zoontje van een dorpssmid die het brengt tot groot industrieel, mecenas van het dorp en oprichter van een amateurcircus. Het boek wordt wel als satire aangemerkt, maar dat is het nauwelijks. We komen daar nog op terug bij de behandeling van De grote voltige.

Over de oorlog, de vervolging en de collaboratie wordt in de jaren vijftig niet zo veel geschreven. Pas in de jaren zestig wordt door het proces Eichmann, de televisie-serie De Bezetting van dr. L. de Jong en het boek van Presser over de jodenvervolging, de Tweede Wereldoorlog weer volop in de belangstelling geplaatst, vooral de vraag wie toen 'goed' was en wie 'fout'. In die sfeer komt J.B. Charles in zijn boek Van het kleine koude front terug op het conflict tussen Coolen en Van Doorne, wanneer Van Doorne in mei 196r benoemd wordt tot ridder in de orde van de Nederlandse Leeuw. Charles zegt uit dossiers van Coolen te weten dat Van Doorne zijn diensten áánbood en dat Van Doorne nog overvalwagens heeft geleverd en snel naar boven de rivieren heeft gebracht toen de geallieerden al opruk. ten. ${ }^{\text {s4 }}$ In de artikelen die ten grondslag lagen aan dit zijn boek noemt Charles Van Doorne 
nog ' $\mathrm{X}$ ', omdat het hem niet om personen maar om principes gaat en omdat zijn zegsman, Antoon Coolen, inmiddels in november $196 \mathrm{I}$ is overleden. De secretaris van de DAF-directie, de heer W.R.A. van Eekelen, zet de zaak weer in de schijnwerpers door in een open brief in een aantal landelijke dagbladen te schrijven over "een gelogen verhaal van Antoon Coolen," waarbij hij ook wijst op de veroordeling van Coolen wegens belediging in 1946.

Charles antwoordt ook in het openbaar en hoeft nu niet meer over ' $\mathrm{X}$ ' te schrijven, maar kan de naam noemen. Hij verklaart verschillende brieven en rapporten van besprekingen van de Van Doornes met de Duitsers in bezit te hebben, geeft daaruit nadere informatie over de kwestie met de overvalwagens en bewijst hiermee dat Coolen niet heeft gelogen. Over de uitspraak van de Bossche rechter van 8 februari r 946 zegt hij, deze niet te willen betwisten. "Coolen had beter gedaan, zich met zijn advocaat in verbinding te stellen vóór zijn artikelen in De Deurnesche Courant verschenen, en niet pas nadat hij zich aanvechtbaar had gemaakt." Gezien de aantijgingen móest Coolen wel veroordeeld worden, concludeert ook Charles, maar gedurende de hele rechtszitting is het punt dat DAF voor de Duitsers heeft gewerkt niet weersproken. Ook het geval met de overvalwagens is niet weerlegd.

Charles is het eens met Coolens redenering over een 'batig saldo': "Coolen betwistte niet, dat $\mathrm{H}$. van Doorne later een positief kontakt met de illegaliteit kan hebben gehad, maar hij meende dat later positief gedrag niet voor schuldvergelijking met vroegere kollaboratie in aanmerking komt." Hij memoreert dat Coolen ontslag nam uit het Tribunaal, "toen hij bijvoorbeeld een groenteman heeft zien veroordelen die voor $\mathrm{f} 400$,- groenten geleverd had aan een Wehrmachtsbataljon en die bij de behandeling van zijn zaak niet kon bogen op naderhand in zijn winkel gepleegde sabotage, noch kon wijzen op een krachtig fundament dat hij, voor de Nederlandse ekonomie van na de bevrijding, door te kollaboreren had opgebouwd." Naar aanleiding van deze open brievenwisseling herinnert Tegenbosch zich in december 1962 in de Volkskrant $t^{55}$ een gesprek met Coolen in 1957 , waarin Coolen zich al veel meer begrijpend en verontschuldigend tegenover Van Doorne opstelde. Hierover later meer bij de behandeling van Coolens boek De grote voltige.

De kwestie kost het Eindhovens studentenblad Lancet bijna de kop, als dit blad de zaak naar aanleiding van de publicatie van Charles in 1962 weer oprakelt. "Verontwaardiging bij Eindhovense burgers en studenten over vuilspuiterij," kopt het blad Groot Eindhoven. ${ }^{\text {s6 }}$ Het blad vermoedt dat de achtergrond in het artikel ligt "in een vuurrode en een anti-roomsche geesteshouding bij een klein kliekje studenten in Eindhoven."

De zaak Van Doorne blijft in het nieuws. De toneelgroep Sater voert vijftien jaar later een satirisch stuk op met de titel Opkomst en neergang van een Hollands familiebedriff, waarvan de première op 13 november 1976 in de stadsschouwburg van Utrecht plaatsvindt. Het stuk is gebaseerd op de publicaties van Coolen en van J.B. Charles. De gebroeders Van Doorne overwegen gerechtelijke stappen, maar zeggen na de première hier geen behoefte aan te hebben. De aantijgingen uit het stuk zijn weliswaar "onjuist en verwerpelijk," maar het toneelstuk doet geen afbreuk aan het DAF-bedrijf. Een rechtszaak voegt niets toe aan

\footnotetext{
53 Collectie Cees Slegers, brief Cammelbeeck, 28 februari 1992.

54 Charles, Van het kleine koude front, 157-162.

55 Tegenbosch, 'Poging tot begrip'.

S6 'Lancet snijdt in eigen vlees'.
} 
de groei en bloei van het bedrijf waar op dat ogenblik achtduizend mensen werken. "Het bedrijfsbelang gaat voor het persoonlijk belang," zegt de woordvoerder van DAF. ${ }^{57}$ Het weekblad Vrij Nederland wijdt in december 1976 twee paginalange artikelen aan de kwestie. $^{58}$

Als het Provinciaal Genootschap van Kunsten en Wetenschappen medior 979 plannen smeedt voor een Coolen-manifestatie in 1980 ontstaat er onrust in de Deurnese culturele raad vanwege het begrip 'promoten'. Men acht Coolen niet de geschikte figuur om Deurne te promoten. Men vindt dat amoreel door de twist en tweedracht die nog steeds bestaat in het dorp. Tij Kools komt in het Weekblad voor Deurne op voor de houding van Coolen tijdens en na de oorlog. ${ }^{59}$ Deze Deurnese publicist zet enkele jaren later de hele affaire, zeer goed gedocumenteerd en gelardeerd met vele kopieën van de voorpagina's uit de jaren veertig, nog eens op een rij. ${ }^{60}$

De affaire komt ook nog voor in een literair werk. Ton van Reen voert in zijn boek Gevallen ster (1999) Coolen op als romanpersonage. In een gesprek met de hoofdfiguur Lucas in de jaren vijftig kijkt Coolen terug op de tijd kort na de oorlog en zegt: "Grote industriëlen gingen vrijuit, zogenaamd omdat er zoveel mensen van hun bedrijven afhankelijk waren. Daarom ben ik uit de Raad van Zuivering gestapt. Ik wilde dat die grote jongens net zo goed zouden hangen als de kleintjes."61

Aan het eind van de twintigste eeuw, als de honderdste geboortedag van Coolen en die van Van Doorne, in respectievelijk I 997 en 200o, herdacht worden, blijkt dat de kwestie nog steeds scherpe kanten heeft en de bevolking van Deurne verdeeld houdt. Dit blijkt alleen al uit het feit dat bij beide gelegenheden angstvallig vermeden wordt om de zaak aan te stippen. 
57. Van Doornes ondernemen geen stappen'.

58 Mulder, 'Van Doorne I', 4 december 1976; 'Van Doorne II', II december 1976.

59 'Rechtzetting culturele raad gevraagd'.

60 Kools, De na-oorlogse relatie, Deurne 1986.

61 Van Reen, Gevallen ster, 64. 
452 


\section{Bevrijd Europa}

Ik spreek slechts aarzelend over het onderwerp zo gauw het politiek raakt waarvan ik weinig weet."

$1945-1947$

De Deurnese persstrijd heeft Coolen de eerste jaren na de oorlog heel wat energie gekost, vooral door de grote psychische druk die ermee gepaard is gegaan. Na het thematische hoofdstuk over Coolens perspolemiek in de eerste naoorlogse jaren en het daaruit voortvloeiende proces wordt nu de chronologie hervat. Bij het lezen over de soms zeer emotionele belevenissen die Coolen in deze jaren op literair en persoonlijk gebied ook nog meemaakt, moet men zich steeds realiseren dat deze plaatsvinden tegen een achtergrond van boosheid en ruzie rond de Van Doorne zaak en de Deurnese persstrijd.

\section{Viij Volk}

Wanneer op 5 mei 1945 eindelijk de bevrijding voor heel Nederland een feit is, kan Coolen door de persstrijd in Deurne niet de vreugde voelen die hij in de donkere bezettingsjaren heeft verwacht.

Reeds op 6 juni 1945 wordt in de Amsterdamse Stadsschouwburg het toneelstuk Vrij Volk opgevoerd, in aanwezigheid van onder andere Prins Bernhard, de burgemeester van Amsterdam en de commandant van de Binnenlandse Strijdkrachten. Coolen is een van de schrijvers van een collectief dat al in de zomer van 1943 aan de voorbereiding werkte. De opvoering kan worden gezien als de voortzetting van een traditie. In 1648 werd ter gelegenheid van het einde van de tachtigjarige oorlog op de Dam het gelegenheidsstuk Leeuwendaelers van Vondel opgevoerd. De opzet van Vrij Volk is gemaakt door Albert Helman, die in een voorwoord bij de gedrukte uitgave fel van leer trekt tegen de meelopers onder de kunstenaars tijdens de bezetting.

Volgens Helman zijn de kunstenaars in oorlogstijd in drie groepen te verdelen. De eerste groep is die van de opportunisten en onnozelen, die terugdeinsde voor elk risico en bij het minste dreigement zwichtte voor de vijand en braaf deed wat die beval. Daarnaast was er de groep van onverschilligen en labielen die meedeed onder het mom van "kunst heeft niets met politiek te maken," "een kunstenaar moet zijn werk blijven doen" of "niemand kan van ons eisen dat wij helden zijn." Een derde kleine groep, bestaande uit "de artistiek en sociaal meest waardevolle figuren die onze kunstwereld kent," wees elke toenadering tot de Duitsers en de Kultuurkamer af. Onder deze kunstenaars hebben de "herscheppende" artiesten het nog het moeilijkst gehad; acteurs en musici hebben nu eenmaal een publiek nodig. Het stuk wordt dan ook opgevoerd door loyaal gebleven acteurs, die de Amsterdamse Stadsschouwburg min of meer 'overnemen' van hun foute collega's. Helmans indeling is bijna dezelfde als die in het blad De Vrije Kunstenaar van januari 1944, waarin een verdeling in vier groepen kunstenaars wordt gemaakt, gebaseerd op hun houding tijdens de bezetting. Alleen wordt daar nog een onderscheid gemaakt tussen de 
mensen die na aanmelding bij de Kultuurkamer wél of niet de Ariërverklaring tekenden.'

Vrij Volk ademt, hoe kan het ook anders, een vaderlandslievende sfeer. Het is geen toneelstuk in de klassieke zin, want de samenhang tussen de taferelen wordt gevormd door de geschiedenis van Nederland tijdens vijandelijke invallen. De vijf schrijvers hebben ieder een episode voor hun rekening genomen.

Helman schrijft over de verhouding tussen de Batavieren en de Romeinen in het jaar 69. Ook toen al werd er gecollaboreerd. Als een Bataaf denkt door diensten aan de Romeinen te verlenen burgerrechten te verkrijgen, roept een stamgenoot: "Ge denkt er beter van te worden, want ge bedoelt niet onderhandelen, maar handelen met den vijand." Helman laat Claudius met zijn mannen afspreken bij de Grebbeberg, de plaats waar in de meidagen van $1940 \mathrm{zo}$ zwaar is gevochten.

Maurits Dekker schrijft over het Leidens Ontzet. Hierin worden collaborateurs zeer negatief afgeschilderd en wordt gezinspeeld op vergelding: "Ik heb een flinke bijl voor hem klaar staan en als straks de Spanjool weg is." ${ }^{3}$

Coolen behandelt het rampjaar I672, Jeanne van Schaik-Willing schrijft over de aftocht van de Fransen in $18 \mathrm{r}_{3}$ en Aug. Defresne over de juist afgelopen Duitse bezetting. In dit laatste tafereel houdt de acteur Albert van Dalsum in zijn rol als verzetstrijder voor zijn Duitse rechters een lange slotmonoloog.

Het gedeelte van Coolen is nogal 'uitleggerig', met tal van overeenkomsten tussen het rampjaar in de zeventiende eeuw en de Duitse bezetting. In beide gevallen was Nederland niet op een aanval voorbereid. Hij laat een personage zeggen dat de Waterlinie geen cent waard is en dat men zo door Nederland heen kan wandelen, omdat de vestigingen net kaartenhuizen zijn, de kanonnen na tien schoten al van hun vermolmde affuiten vallen en er niet genoeg kogels zijn of alleen maar kogels die niet passen. Het zijn dezelfde verhalen die ook over de stellingen bij de Grebbenberg en de Peel werden verteld in r 940 . In een lange discussie tussen de Prins van Oranje en de Engelse en Franse gezanten etaleert Coolen zijn opvattingen over onafhankelijkheid en de waarde daarvan. De gezanten komen namens de koning van Frankrijk, die op dat moment in het kasteel van Heeswijk kwartier houdt. Hij wil de prins van Oranje paaien: "de consideratie in de voorstellen adresseert zich bijzonder tot het Huis van Oranje. Engeland en Frankrijk bieden in deze voorstellen u aan, in plaats van het ambt van stadhouder, $u$ in overeenstemming met uw waardigheid tot souverein te maken van het overblijvende gedeelte der republiek, en zijn bereid uw troon gezamenlijk te beschermen. ${ }^{.4}$ Hierop roept de prins verontwaardigd dat hij liever de stadhouder blijft die hij is, dan de soeverein die ze van hem willen maken. Op de vraag of hij de Britse bescherming dan niet op prijs stelt, antwoordt hij: "Wij, in Nederland achten onafhankelijkheid hóóger!"

Hier horen we de echo's van de gesprekken van Coolen tijdens de oorlog met verschillende Duitsers die hem eer of bescherming kwamen aanbieden. Het lijkt er veel op dat Coolen de weergave van zijn gesprekken met Töpfer en Schmidt-Burgke voor Bevrijd Vaderland in dezelfde tijd heeft geschreven als deze toneelscène. De sfeer komt helemaal terug in deze onderhandeling van de Prins van Oranje met de gezanten van de Franse koning. In beide gevallen proberen vertegenwoordigers van een vreemde mogendheid een wig te drijven tussen de bevolking en het huis van Oranje. 
In een voorwoord bij de gedrukte tekst stelt Maurits Dekker dat het stuk geen meesterwerk is. Hij voegt eraan toe dat het dat ook niet kan zijn door de opzet, de omstandigheid van schrijven en de deelname van vijf auteurs, "maar het demonstreert eensgezindheid, liefde tot vrijheid, bereidheid tot samenwerking en er wordt een verlangen naar een betere wereld in uitgedrukt, dat verder wil reiken dan de behoeften van dit ogenblik." ${ }^{5}$

De kritieken zijn niet erg geestdriftig. Godfried Bomans noemt in de Volkskrant de bijdrage van Coolen aan het toneelstuk knap van compositie. Hij vindt de episode over de Batavieren en de Romeinen het zwakst. Hij ziet slechts teveel Bataven die met dunne schildjes flink door elkaar lopen en elkaar nobele en verheven gedachten toeroepen. ${ }^{6}$

Metro schrijft: "Antoon Coolen, die, losgescheurd van de trage schoonheid van zijn romans kennelijk met zijn opdracht geen raad wist, schreef iets dat men zou kunnen noemen een Ware Vaderlandsche Historie Aanschouwelijk Voorgesteld, en slaagt er slechts één moment in om met een eenigszins onwaarschijnlijke greep - als de boerin op een ton klimt om een toespraak te houden - iets beter dan vervelend te zijn. ${ }^{77}$ Het Vrije Volk is daarentegen zeer positief en noemt Coolens eerste tafereel "zeer levendig." ${ }^{8} \mathrm{De}$ Waarheid vindt dat Coolen een kleurrijke, schilderachtige voorstelling heeft gemaakt, "waarbij de prins en de regenten ieder hun deel kregen." ${ }^{-9}$ Het Parool meldt dat vooral de stukken van Maurits Dekker en A. Defresne een geestdriftig onthaal vonden: "Meer dan eens moest het spel voor luide toejuichingen worden onderbroken." 10

Er is echter ook meteen al kritiek op de medewerkenden. De mededeling op de aanplakbiljetten, dat het stuk geschreven, gespeeld en geregisseerd is door kunstenaars die de Kultuurkamer afwezen, klopt niet, schrijft Ons Vrije Nederland." Van de honderd medewerkers waren er minstens zestien die de Kultuurkamer vanwege hun afkomst niet kónden afwijzen, omdat ze er a priori niet zouden zijn toegelaten. Volgens dit blad waren er ook acteurs bij die zich wel degelijk hadden aangemeld.

Charles Boost schrijft in Het Kompas dat hij boos is op de indeling van Helman waar de aanmelders in één adem uitgemaakt worden voor onnozelen, onverschilligen en labielen. De principiële weigeraars hebben het gelijk en het recht aan hun kant, maar niets geeft hen het recht om zo te oordelen over de niet-weigeraars. ${ }^{12}$

De hele voorstelling staat in het teken van de acteurs. Als iemand pas veel later op de avond op het idee komt de schrijvers ook voor het voetlicht te halen, blijft Coolen in de zaal. Samen met Helman schrijft hij daags daarop een brief op poten aan de regieraad. Zij

1 Venema, Schrijvers, deel 3a De kleine collaboratie, 217.

2 Coolen, Defresne, Dekker, Helman en Van Schaik, Vrij Volk, 24.

3 Coolen, Defresne, Dekker, Helman en Van Schaik, Vrij Volk, 37.

4 Coolen, Defresne, Dekker, Helman en Van Schaik, Vrij Volk, 7.

5 Coolen, Defresne, Dekker, Helman en Van Schaik, Vrij Volk, 14.

6 Bomans, Toneelspelers vieren hun vrijheid'.

7 'Is de tooneelschrijfkunst failliet?'.

8 Blijstra, 'De première van het toneelstuk "Vrij Volk"'.

9 Brusse, "Vrij Volk". Een plechtige manifestatie'.

10 'De kunst treedt aan. Première van "Vrij Volk".

II Van der Plas, Mooie Vrede, 298.

12 lbidem. 
betreuren het dat het effect van het stuk ernstig afbreuk is gedaan door de zeer lange monoloog van Defresne aan het slot. De vier andere schrijvers hadden terwille van "de eenheid en de aesthetische werking" allemaal offers gebracht en flinke stukken geschrapt. De monoloog van Defresne is tegen de afspraken in niet verkort maar verlengd. Bovendien constateren zij dat de toneelspelers weer in hun oude stijl vervallen en vooral met zichzelf bezig zijn.

"Wij hadden op deze avond n.l. het duidelijke gevoel er maar zo'n beetje bij te hangen, zijn zowel bij de open doekjes en de huldigingen als bij het feest nagenoeg vergeten, slechts ter elfder ure scheen iemand zich nog te herinneren, dat wij ook nog bestonden en heeft men getracht sommigen van ons voor het voetlicht te halen. Terecht heeft naar onze mening Ant. Coolen, die in de zaal was, dan ook geweigerd voor het voetlicht te komen. Ook op het feest liepen wij rond als verloren schapen, die door de toneelspelers noch met de verwachte collegialiteit noch met de verdiende hoffelijkheid behandeld werden." ${ }^{13}$

Defresne stond na afloop wel op het toneel, schrijven Helman en Coolen. Ze kennen daarvoor de nodige 'foefjes' niet; bij de vele aanwijzingen van de regieraad zou een weinig regie in dit opzicht op zijn plaats zijn geweest. Ze hebben de brief "zonder boosheid of rancune" geschreven, ze willen alleen maar schoon schip maken met de eigen gevoelens en daarmee ruim baan geven voor de samenwerking in de toekomst.

De ambiance waarin het stuk is opgevoerd en de ruzies erna dragen er niet toe bij dat Coolen zijn somberheid kwijtraakt. Ook buiten Deurne heerst enkele weken na de bevrijding al tweespalt. Alle oproepen tot 'eenheid' in politiek, vakbeweging en culturele wereld kunnen dat niet verhullen. Coolen lijdt bovendien nog een persoonlijk verlies: op 26 juni I945 overlijdt zijn moeder, op wie hij zeer gesteld was.

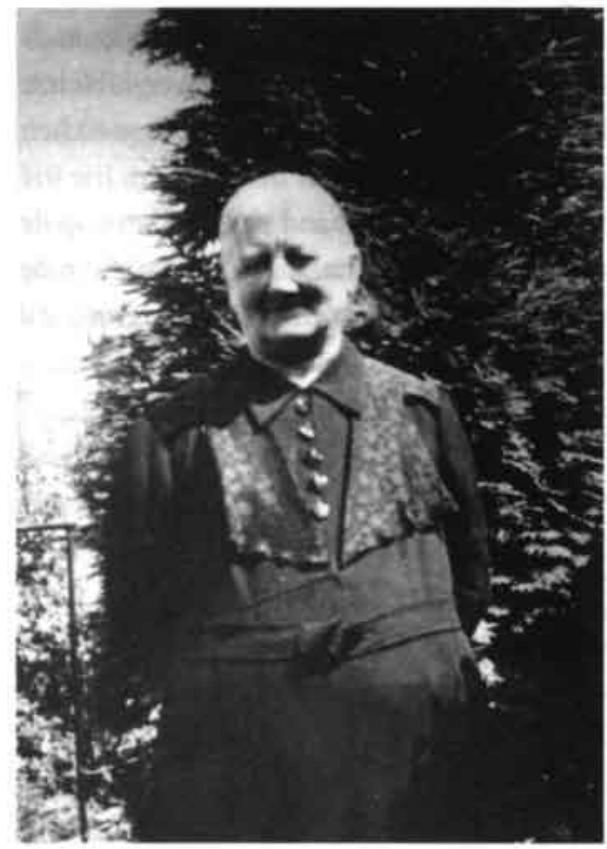

Moeder Maria Coolen-Swinkels.

\section{Coolen en Streuvels}

Het is meer dan vijf jaar geleden dat Coolen zijn laatste brief aan zijn vriend en leermeester Streuvels heeft geschreven. Die eindigde met de uitnodiging "als ge komt bestel ik de dorpsfanfare voor een serenade. ${ }^{14}$ Hoewel Vlaanderen en ZuidNederland al bijna driekwart jaar bevrijd zijn, is er nog steeds geen contact geweest. Het lijkt wel of Coolen het vragen van informatie uitstelt, omdat hij bang is dat de verhalen die hij tijdens de oorlog heeft gehoord, waar zouden zijn en dat Streuvels inderdaad te nauw met de bezetter heeft samengewerkt. Pas op 22 mei 1945 gaat hij er eens goed voor zitten en schrijft een lange brief.

$\mathrm{Na}$ enkele opmerkingen over Streuvels werk vertelt hij hoe de toestand 
in Nederland tijdens de bezetting is geweest, hoe Nederland is leeggeplunderd en leeggezogen, hoe jonge mannen en jongens werden opgejaagd en weggevoerd in beestenwagens en wat er met de Nederlandse schrijvers is gebeurd. Hij vermeldt zijn eigen weigering van de Rembrandtprijs en noemt met bitterheid Verhulst en Timmermans, die hem wel aannamen. Hij schrijft dat hij ook na een Duits bevel geen lid is geworden van de Kultuurkamer en dat door de hele "cultuurkamerellende" geen nieuw boek of herdruk van hem in Nederland is uitgekomen. "Gij hebt daar geen last van gehad, ik zag de Lijsternestserie," voegt hij er scherp aan toe.

Vervolgens vertelt hij over zijn weigering om te gaan spitten in het voorjaar van 1944 [in de brief schrijft hij abusievelijk 1943. C.S.], waardoor zijn hele huis is leeggehaald. Evenals in zijn brief aan het departement in juli 1944 , somt hij opnieuw alles op wat is weg. gehaald: "huisraad, bedden, keukengerief, vloerkleden, gordijnen, boekenkasten, vaste spiegels uit de muren gebroken, lichtleidingen, planken uit de zolderkasten, kelderrekken, lampen, alles en alles, tot de buitenlantaarn, de voordeurbel en de vlaggenstok toel" Gelukkig zijn dankzij zijn vrouw nog duizend boeken in veiligheid gebracht. Tenslotte komt de hamvraag. Coolens toon wordt hier bijna inquisitorisch:

"En nu gij. Mag ik nu mijn vraag stellen. Ik heb in het Duitsche maandblad Der Norden telkens van U gelezen o.a. in verband met de verfilming van De Vlaschaard, waarover veel drukte werd gemaakt als een Deutsch-Flämisch cultureele samenwerking. Ik las ook, dat gij met Timmermans en Claes op de bijeenkomst van den Europäischen Schriftsteller Verband in Weimar waart, waar Joseph Goebbels u drieèn met name noemde in zijn welkomstwoord. Ik hoorde ook van een eeredoctoraat eener Duitsche universiteit, dat gij zoudt hebben aangenomen en las van een gelukwensch, dien Goebbels u zond. Deze tegemoetkomingen worden hier niet enkel beschouwd als tegemoetkomingen aan Duitschland (in den zin van pro en anti van 1914-18). Zij worden beschouwd als tegemoetkomingen en adhaesie aan het Duitsche nationaalsocialisme, wat ze, zijn ze waar, ook zijn. De Duitschers lieten geen scheiding tusschen hen en de Nazi's toe: zij waren de Nazi's, in merg en been, en de Nazi's maakten propaganda met $\mathrm{U}$ en Timmermans (Timmermans is voor mij evident). Ik weet echter hoe infaam leugenachtig de Duitschers in hun propaganda waren, en daarom vraag ik U, of dit alles wel waar is en hoe gij 't opheldert. Ik heb in deze dingen zóó stelling genomen als de stelling tusschen goed en kwaad, dat ik in geen litteraire en vriendschapsbetrekking een bitterder ontgoocheling zou kennen: ge weet niet hóe ik Stille Avonden, dat jubelboek van Ingoyghem, heb herlezen.

Tot ik van U mag hooren! Met alle groeten en wenschen, Uw Antoon Coolen." ${ }^{15}$

Streuvels antwoordt na twee weken, begin juni, en geeft uitgebreid inichtingen over zijn wedervaren in de oorlog. ${ }^{16} \mathrm{Hij}$ schrijft Coolen dat België geen Kultuurkamer kende en dat

B NT, brief Coolen en Helman aan de regieraad van het Toneelgezelschap 1945, p/a den Heer H. Van Meerten, 8 juni 1945.

14 AMVC, inv. nr. C 3475, brief Coolen aan Streuvels, 25 februari 1940.

15 AMVC, inv. nr. C 3475, brief Coolen aan Streuvels, 22 mei 1945.

16 FPC, brief Streuvels aan Coolen, 6 juni 1945. 


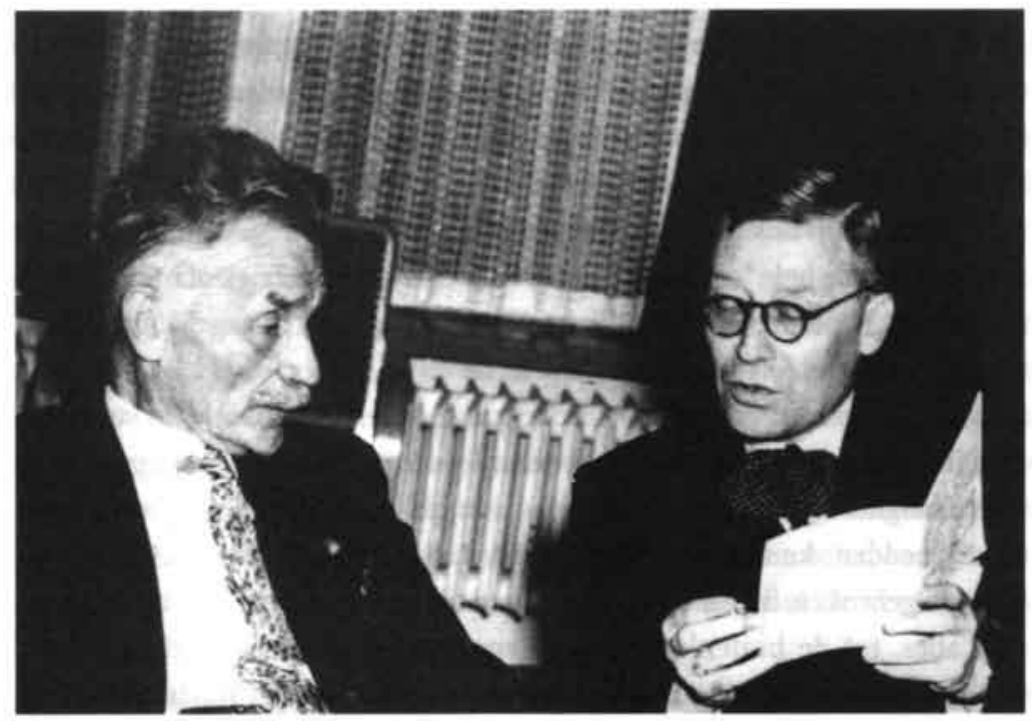

Coolen en Streuvels.

zelfs anti-Duitse schrijvers als Teirlinck, Vermeylen en Toussaint boeken hebben uitgege. ven. Met de verfilming van De Vlaschaard heeft hij de schijn tegen, maar hij wijst erop dat het contract al in 1937 getekend was. Hij is geen lid geweest van de Europäische Schriftstellerverband en het eredoctoraat van de universiteit van Münster is bij hem aan de deur afgegeven, terwijl hij niet thuis was. Daarnaast heeft hij minstens tweehonderd uitnodigingen voor spreekbeurten en artikelen afgewezen, die duizend Reichsmark per stuk zouden hebben opgeleverd. Streuvels heeft zich op eigen verzoek door de krijgsauditeur laten horen en deze heeft hem verzekerd dat Streuvels zich correct heeft gedragen.

Meteen na ontvangst van deze brief haast een opgeluchte Coolen zich Van Duinkerken en De Bourbon op de hoogte te stellen. Mocht hij in de bezettingstijd zijn twijfels geuit hebben over Streuvels, nu heeft deze hem volledig overtuigd. "Hij heeft zich correct, fier en moedig gehouden en letterlijk alles geweigerd, waarmee men hem lastig viel. Felix Timmermans ligt met een zware hartziekte te bed. En bij Ernest Claes is de boel [door woedende landgenoten, C.S.] kort en klein geslagen en in brand gestoken. ${ }^{17}$ Aan De Bourbon schrijft hij dat Streuvels misbruikt is door de Duitse propaganda en dat hij nooit in Weimar geweest is. Streuvels' rustige antwoord heeft Coolen volledig overtuigd. ${ }^{18}$ Streuvels heeft zich kordaat verzet, meldt hij ook aan Oomes, de Duitsers hebben veel leugens over hem verspreid. ${ }^{19}$ Coolen verspreidt het nieuws verder via een artikel in De Vrije Kunstenaar. ${ }^{20}$

Pas tijdens het schrijven van dit artikel, eind oktober 1945, beantwoordt Coolen de brief van Streuvels van juni. Hij had al wel een mondelinge reactie gegeven via Streuvels' uitgever uit Kortrijk, die hij in de zomer ontmoet had. ${ }^{21} \mathrm{Hij}$ kondigt aan dat hij het misleidende en leugenachtige gedrag van de Duitsers met betrekking tot Streuvels gaat rechtzetten in De Vrije Kunstenaar. Hij is heel blij met de conclusie van de krijgsauditeur, die hij volkomen juist acht. Coolen vergelijkt de situatie met de Eerste Wereldoorlog en constateert dat de zaak nu veel scherper ligt. Hij snapt niet waarom het oorlogsdagboek van Streuvels van augustus 1914 indertijd zoveel stof deed opwaaien, want hij vindt die geschriften nog 
steeds objectief. Op Streuvels vraag om meer informatie over Herman de Man en zijn familie is Coolen kort. Hij weet dat Herman de Man een regeringsopdracht in Engeland had voor Radio Oranje. Over Eva de Man en haar kinderen meldt hij niet veel meer dan dat ze veel te lijden heeft gehad. " $\mathrm{Zij}$ is door een vriendenkring geholpen, maar hoe het nu met haar gezin is weet ik niet, want al sedert jaren heb ik geen contact met haar." Dit is een eigenaardige formulering, omdat het op dat moment toch al wel zo goed als zeker is dat zij met de weggevoerde kinderen vergast is. Streuvels neemt er geen genoegen mee en weet kennelijk het adres van De Man zelf op te sporen. Deze schrijft hem in december een brief: "Maar laat ik over mijn eigen misère zwijgen, mijn arme vrouw en kinderen hebben het zóóveel erger gehad, voor zij verlost werden van deze aardsche hel, in de gaskamers in Polen."22

De Man schrijft ook nog dat hij Streuvels bij Radio Oranje in Londen heeft moeten verdedigen tegen aanvallen. Het is hem niet gelukt Streuvels te rehabiliteren, maar de aanvallen werden wel gestaakt. De Man voegt een artikel van Godfried Bomans uit de Volkskrant ${ }^{23}$ bij, waarin Streuvels eerherstel krijgt. Het artikel van Bomans is volledig gebaseerd op het stuk van Coolen in De Vrije Kunstenaar, dat op zijn beurt weer helemaal uitging van de verdedigingsbrief van Streuvels zelf. Bomans prijst de vastheid van karakter van Streuvels en roemt de achtenswaardige houding van "onzen Antoon Coolen, wiens gehele oeuvre in het Duits vertaald is, doch die koppig weigerde één voet over de grens te zetten, elke aanbieding, hoe voordelig ook, onbeantwoord liet, en zelfs een grote literatuurprijs, hem door de stad Hamburg aangeboden, van de hand wees."

Het jaar daarop spant Coolen zich in voor een koninklijke Nederlandse onderscheiding voor Streuvels ter gelegenheid van diens 75 ste verjaardag. Hij heeft hiervoor bij minister Gielen een verzoek ingediend, schrijft hij aan van Duinkerken. ${ }^{24}$ Hij neemt aan dat Van Duinkerken het met hem eens is dat zo'n onderscheiding een goede indruk zal maken. Hij schrijft er niet bij op wie, maar geeft wel aan dat het geen gewoon lintje moet worden. Streuvels heeft in België al de hoogste onderscheiding die er is: Commandeur in de Leopold Orde, dus mag die uit Nederland er niet een zijn die ook een referendaris ontvangt. Hij vraagt Van Duinkerken om dit initiatief te steunen.

Later relativeert Streuvels' biograaf Speliers in zijn studie over de verhouding van Streuvels met nazi-Duitsland diens eigen verdediging en stelt dat Streuvels veel vriendelijker tegenover het bewind stond dan wordt aangenomen. In september en oktober 1944 werden de poorten van Het Lijsternest met hakenkruizen beklad. Ook is Streuvels in die tijd niet uit eigen beweging naar de krijgsauditeur gegaan, maar heeft hij wel degelijk een oproep gekregen. In mei en juni r945, dus tijdens de briefwisseling tussen Coolen en

17 BA, brief Coolen aan Van Duinkerken en Nini Asselbergs, 23 juni 1945.

18 LMDC, inv. nr. C 3485, brief Coolen aan de Bourbon, 24 juni 1945.

19 LMDC, inv. nr. C 3485, brief Coolen aan Oomes, 16 juli 1945.

20 Coolen, 'Stijn Streuvels'.

21 Speliers, Als een oude Germaanse eik, 522.

22 Brief De Man aan Streuvels, 22 december 1945, geciteerd in: Vaarties, $U$ hebt mij de weg gewezen, 84-88.

23 Bomans, 'Vlaamsche schrijvers tijdens de bezetting'.

24 BA, brief Coolen aan Van Duinkerken, 2 september 1946. 
Streuvels, woedt in Vlaanderen een tweede repressiegolf, waarbij veel brandstichtingen en geweld plaatsvinden tegen personen die van collaboratie worden verdacht. Streuvels zou toen veel vertalingen en bijdragen aan nazi-kranten verwijderd of verbrand hebben. ${ }^{25}$

De episode illustreert, evenals de zaak Van Doorne, hoezeer menigeen gepreoccupeerd was met het zuiveren van eigen en andermans reputatie en het bewijzen van eigen vader. landslievendheid.

\section{Bevrijd Vaderland}

Coolen heeft tijdens de bezetting veel aantekeningen gemaakt, schrijft hij aan Streuvels. ${ }^{26}$ Uit de berg papier heeft hij een keuze gemaakt voor de publicatie van een boek over zijn oorlogservaringen. Hij gebruikt ook de brieven, die hij in de oorlog schreef, als basismateriaal voor zijn boek. Zo vraagt hij aan Oomes een brief terug "die ik je indertijd schreef na het bezoek van den cultuurintendant van Seijss-Inquart [sic]." ${ }^{\text {"27 }}$ Als het boek eind r 945 ter perse is blijkt dat de oplage, vanwege de papierschaarste, slechts vijfduizend exemplaren zal bedragen. Dat aantal is wel klein, "als je gehoopt had het hele volk te bereiken," schrijft hij teleurgesteld aan Oomes. ${ }^{28}$

Bevrijd Vaderland verschijnt in februari $1946,{ }^{29}$ niet lang na de geruchtmakende rechts. zaak met Van Doorne. Een van de eerste gesigneerde exemplaren is voor zijn verdediger mr. Cammelbeeck met als opdracht: "In ons gezamenlijk verweer tegen de desillusies in 't Bevrijd Vaderland." ${ }^{30}$ Vol trots schrijft hij aan Oomes dat de koningin haar luxe editie "met belangstelling en waardering" heeft gelezen. Hij klaagt echter ook dat hij het te druk heeft met kleine dingen en daardoor aan "een langademige correspondentie noch aan schrijven van literair werk" toekomt."

Coolen beschouwt dit boek dus niet als een literair project. Daarmee doet hij zichzelf enigszins tekort, want zijn vertelkunst is er duidelijk in aanwezig.

In een kleine dertig paragrafen verdeeld over de vijf oorlogsjaren geeft Coolen zijn impres. sies van de oorlog. Het boek is opgedragen aan de Koningin: "Dico hoc opus Reginae nostrae." Met deze opdracht, bovendien in het Latijn, claimt Coolen als het ware een offi. ciële status voor zijn boek. Daarbij kan overigens aangetekend worden dat voor de katholiek in het woord 'Regina' ook een connotatie met de Maagd Maria besloten ligt. Zij werd 'Regina Coeli' genoemd en het 'Salve Regina' was een van de bekendste Mariahymnen uit de katholieke liturgie.

In dit oorlogsdagboek schrijft Coolen voor het eerst iets over zijn reizen in 1937 naar Leipzig en in 1938 door West-, Noord- en Midden-Duitsland. Hij beschrijft de doodse stilte in restaurants waar veel gezwegen en gestaard werd, de eeuwig marcherende SS- en SAmannen en de grote rood-zwarte vlaggen van de partij met als contrast de uiterst "behaag. zieke" aanplakbiljetten en tijdschriften van een beminnenswaardig Duitsland:

"Romantische Zuid-Duitsche landschappen, bloemenweien met lammeren, Kinderund Mutterheime, zonnige jeugdspeelplaatsen, wijnboeren in de bergen, het gejodel der Tyrolerinnen, gezonde mannen met blijmoedige koppen en sportieve, ontbloote lichamen [...] mandolinespelende Hitlermädel, idyllen am schönen Rhein, Deutschland! Deutschland! - doch in waarheid zag je nergens een echten glimlach van levensgeluk." 
Coolen zag zo'n glimlach niet bij de Hitlerjeugd en ook niet op het gezicht van de poenige ss-kerels voor de Joodse winkels. Hij merkte wel de angst: "Ik was bij een vriend, en toen wij over deze dingen spraken, begon hij te fluisteren in zijn eigen huiskamer, stond op en deed de deuren dicht. ${ }^{32}$

Coolens fascinatie voor treinen komt ook in Bevrijd Vaderland weer tot uiting. Hij woont in Waalre niet ver van het 'Bels lijntje' dat de Duitsers weer operationeel hebben gemaakt. Er worden gevangenen, munitie en materieel over vervoerd, maar af en toe gebeurt er iets geheimzinnigs. Een keer komt er 's nachts een trein vanuit het zuiden, waaruit voortdurend wordt geschoten. Tevoren was bevolen dat niemand in de buurt van de spoorlijn mocht komen. "Toen was hij onder een onophoudelijk geweervuur als een spooktrein in den nacht bliksemsnel langs het station voorbijgeraasd. ${ }^{n 33}$ Over die treinen die rijden door de nacht doen lugubere verhalen de ronde. Een stationschef heeft een goederenwagon gezien vol met lijken die met hun kin aan vleeshaken hingen. De schrijver vraagt zich af wat dat betekent. "Het kan nauwelijks de bedoeling zijn, die lijken in Duitschland te begraven. Want als men ze begráven wilde, waarom dan niet achter het front of onder weg? En als men uit piëteit ze in den vaderlandsche grond wil begraven, waarom dan zulk een onmenschelijk vervoer, dat met iedere gedachte van piëteit spot?"

Dit gruwelijke onderwerp komt vaker aan de orde. De schrijver vertelt hoe Duitse soldaten hun provisorisch begraven gesneuvelden van de eerste oorlogsdagen weer opgraven en op een vrachtwagen kieperen.

"Ach moeders, die uw zoon aan den Führer geeft en aan het vaderland, daar weet gij niets van, dat de mannen van vaderland en Führer op het oogenblik zoo omspringen met wat onder uw hart heeft gerust en aan uw borst is gevoed - dat zij al evenmin eerbied hebben voor den dood van uw kind, als zij eerbied hebben voor zijn leven. Käthe Kollwitz, die van u een piëta maakte met dit arm, nutteloos lijk in uw schoot, heeft men abgelehnt, ge weet ook wel, Duitsche moeders, waarom: omdat dit entartete kunst was volgens die lieden, die daar met ijzeren staven in de lijken woelen van uw kinderen. ${ }^{34}$ Wanneer Frankrijk capituleert en Hitler Parijs bezoekt, beschrijft Coolen de foto's in de kranten. Hitler staat in gepeins verzonken bij het graf van Napoleon in de Dôme des Invalides. De hele entourage dient om het overwinnaarschap van Hitler "in een van

25 Speliers, Als een oude Germaanse eik, 526.

26 AMVC, inv. nr. C 3475, brief Coolen aan Streuvels, 31 oktober 1945.

27 LMDC, inv. nr. C 3485, brief Coolen aan Oomes, 16 juli 1945.

28 LMDC, inv. nr. C 3485, brief Coolen aan Oomes, 12 december 1945. Felix Coolen zegt later dat de beoogde oplage 25.000 was en dat er op de zwarte markt 100 gulden per exemplaar voor werd geboden. Kroon, 'Ik herinner mij".

29 In de eerste druk staat evenwel 1945 als verschijningsjaar. Men heeft kennelijk het jaar van de bevrijding willen aanhouden.

30 Groeneweg, Antoon Coolen: Derde van der Helst, 51.

31 LMDC, inv. nr. C 3485, brief Coolen aan Oomes, 27 februari 1946.

32 Coolen, Bevrijd Vaderland, 42-43.

33 Coolen, Bevrijd Voderland, 46.

34 Coolen, Bevrijd Voderland, 48. 
Napoleon afgekeken gebaar" te accentueren. In één zin schetst hij de kitsch van dat gedrag: "Zonder eenigen twijfel is Hitler klein, bekommerd en pathetisch genoeg, om zich op dit oogenblik bezig te houden met de gedachte, of het Duitsche volk en de wereld, die deze foto's zullen bekijken, zich zullen afvragen, wat er in hem moet zijn omgegaan daar voor Napoleons tombe. ${ }^{.35}$

In Bevrijd Vaderland is een essay opgenomen waarin Coolen zeer uitvoerig een boek van Wilhelm Kotzde van Kottenrodt navertelt. In Het Godshuis Aller Duitsers pleitte deze voor een mythische, ontchristelijkte samenleving. De tijd van het op de joodse religie voortbouwende Christendom is volgens Kotzde voorbij en hij legt uit waar de wortels van de noordelijke rassen wèl liggen. Hij spreekt van de Noordmens als superieur tegenover de Oostmens en de Zuidmens. De Noorderbreedte en de natuur zijn door God voor de Germanen geschapen. Alle symbolen van het Christendom zijn gestolen van de Germaanse mythologie. Zo komt het kruis al in de steentijd voor en zijn de zonnewendeen de goden Odin en Freya respectievelijk vervangen door kerstmis, Jesus en Maria. Katholieke priesters zijn niet te vertrouwen, want zij dienen de kerk uit Rome, een stad die in het inferieure zuiden ligt. Vanaf de Middeleeuwen, toen alles nog goed was en er geen onderscheid bestond tussen zangers, bouwers, dichters en boeren, tekent zich een duidelijke lijn af van Luther, via der Olle Fritz [Frederik de Grote, C.S.], Goethe en Bismarck naar Hitler. De nieuwe godsdienst zal gevormd worden door de plechtigheden van de Partij met spreekkoren en mysteriespelen, de Festspiele van Wagner, oogstdankfeesten enzovoort. Het hele boek is een poging om de nazi-ideologie een religieuze achtergrond en een metafysische inhoud te geven.

Coolen vindt het beangstigend dat deze Kotzde ook geschiedenisboeken voor de Duitse jeugd heeft geschreven. Want het Duitse volk is, volgens hem, toch al van nature tot een minderwaardigheidsgevoel geneigd en zoekt compensatie in de mythe van de superioriteit. Het boek van Kotzde voedt dit nog met religie en een metafysische inhoud. "Met een nederlaag van het Duitsche volk roeit men dit niet uit, zij wordt in de ontgoochelde jeugd een mystiek martelaarschap. ${ }^{36}$ Coolen denkt dat het Duitse probleem van 1918 niets was vergeleken bij wat het naoorlogse probleem straks zal zijn.

Ondanks de afkeer van de Duitse superioriteit, die Coolen hier laat merken, schemert er ook iets van fascinatie voor het onderwerp door. Ook Coolen bewondert de organische eenheid van de Middeleeuwen, ook hij heeft gevoel voor het religieuze dat in de jaargetijden, de natuur en de oogst aanwezig is: de cyclus van leven en dood, sterven en geboren worden.

In het hoofdstuk 'Todenjacht' geeft Coolen een ooggetuigenverslag vanuit de 'wolkenkrabber' aan het Daniël Willinkplein van een razzia op joden. Hij geeft de sfeer van machteloosheid weer. Hij beschrijft hoe de mensen, de gezinnen en kinderen verzameld worden. Hij ziet hoe er ook Nederlanders bij zijn die de Duitsers helpen: "Die mogen meedoen, die mogen ook koppelriemen aan hebben en ook laarzen, waarmee ze hun modderige leven doorschrijden." Dan volgt een passage, waarover problemen ontstaan.

"Ik behoor tot hen, die geen Jodenvrienden zijn, wij hebben iets tegen de hebbelijkheden van het ras. Maar zie eens, waarom blijft dat troepje Joden zoo kalm bijeengedre 
ven op dat stukje nachtelijk trottoir? Zij worden bewaakt. En al werden ze niet bewaakt, dan nog zouden ze 't waarschijnlijk niet wagen tè vluchten. Maar ze worden bewaakt. Van afstand tot afstand staan, tot een haag om het plein, donkere gestalten in uniform, de beenen uiteen, natuurlijk, en in laarzen, natuurlijk, en met koppeiriemen en geweer. Wij hebben iets tegen de hebbelijkheden van het Joodsch ras, maar wat we hebben tegen die schurftige gelaarsde kerels, dat kunnen wij niet eens onder woorden brengen. Om hen, naar mijn bedoeling althans, maar ze kunnen het niet vernemen, in hun menschelijkheid een beetje te bemoedigen, fluister ik hier voor het glasraam het den Joden daar beneden toe: Joden, ik heb iets tegen de hebbelijkheden van jullie ras, maar wat of jullie zijn, dokter of advocaat of venter of kleerekoop, ik stel jullie zoo oneindig veel hooger dan jullie vervolgers, deze Germanenzonen van het Duitsche volk. Deze gelaarsde lieden, zij zijn thuis, in Bremer en Kölner strasse, bakker of slager of hebben er een hoedenwinkel of een zaakje in garnituren, deze duizenden en duizenden, die hier en overal in de steden der bezette landen op menschenjacht zijn. De Duitsche weermacht schiet dood, de duitsche doldrieste jeugd gooit bommen, de Duitsche Zivil-bezetting verpest overal de atmosfeer,- dan resten er nog die massa's, die uit al hun straten de niet te tellen horden zenden der Duitsche gemeene en misdadige politie. Niemand blijft achter, alles grijpt in elkaar, opdat deutsch die Erde sei! Daar staat ze, die politie, ik kan niet zeggen, hoe ver we hen beneden jullie stellen, wat een misselijken indruk ze alleen reeds om jullie vervolging maken." ${ }^{37}$

Vervolgens richt de schrijver zich "rechtstreeks" tot de "jodenkindertjes" en zegt dat er in Nederland een dichter is, die verzen maakt over de boodschap van de engel aan Maria en over het bezoek van Maria aan haar nicht Elisabeth. Deze dichter over het joodse meisje Maria, voegt hij er aan toe, heeft ook een gedicht gemaakt met de regels: "Er is een Lam dat bloedt, er is een Lam dat bloedt." Die dichter is het ermee eens dat jullie hier als schapen bijeen gedreven worden en naar Polen vervoerd, "want hij vereert jullie beulen en de allergrootste beul Hitler." Coolen bedoelt hier de katholieke dichter Gerard Wijdeveld. ${ }^{\text {sB }}$

\section{Dagboek of positionering}

Coolen heeft in zijn romans steeds zijn opmerkingsgave gemengd met zijn stilistische kwaliteiten, waardoor die typische Coolen-stijl is ontstaan. Ook in Bevrijd Vaderland is de lezer medegetuige van de verteller. Hij heeft ook in dit 'documentaire' boek zijn voorliefde voor het symbolisch geladen, bijna mythische verhaal de ruimte gegeven. Een voorbeeld hiervan is de 'spooktrein' die al vurend door de nacht raast. Door deze literaire verwerking zijn de stukken als directe bron voor de gebeurtenissen minder betrouwbaar dan onverkorte, rechtstreekse dagboeknotities in telegramstijl.

In het boek is Coolen op zijn best als hij vertelt: over de meidagen in 1940, over de

Coolen, Bevrijd Vaderland, 52-53.

Coolen, Bevrijd Vaderland, 81.

Coolen, Bevrijd Vaderland, 107.

Gerard Wijdeveld (1905-1997). De strofe "Er is een Lam dat bloedt" komt uit het gedicht 'Lied' uit de bundel Het Voorschot, Bitthoven 1935. Het is ook opgenomen in Michel van der Plas (samenstelling), Religieuze Poëzie der Nederlanden, Utrecht-Antwerpen z.j. (Prisma-boeken nr. 119). 
dodenakker, over zijn belevenissen in de treinen tijdens de bezetting, over Dolle Dinsdag en de bevrijding. De passages waarin hij niet als waarnemer, maar zelf als handelend en sprekend persoon optreedt, hebben een ander karakter. Vooral in de hoofdstukken waar Duitsers hem proberen over te halen een prijs te aanvaarden, op een uitnodiging in te gaan of zich te melden voor de Kultuurkamer wordt de toon een tikje onnatuurlijk en vraagt de lezer zich af: zou hij dat echt zo gezegd hebben? Over de strekking van de gesprekken, zoals Coolen die heeft weergegeven, bestaat geen twijfel. Hij heeft op cruciale momenten geweigerd medewerking te geven aan de bezetter.

Coolen heeft de gang van zaken rond zijn burgemeesterssollicitatie niet opgenomen in dit boek. Formeel had hij zich er op kunnen beroepen dat zijn handelwijze ook hier consistent was: toen het er in de slotfase op aan kwam, deed Coolen geen concessies en weigerde hij tegenover de Beauftragte te beloven dat hij de gemeente volgens de regels van de nieuwe orde zou gaan besturen.

Het weglaten van zijn burgemeesterssollicitatie in dit dagboek kan gezien worden in de geest van de tijd. De mensen komen na de bevrijding al gauw 'in de ban van goed of fout' bij het nagaan van wat iemand in de oorlog heeft gedaan. Coolen is door zijn werk voor het Tribunaal voor Bijzonder Rechtspleging en zijn conflict met Van Doorne ook zelf in de ban van goed of fout. Kennelijk is hij bang dat hij door het beschrijven van de sollicitatie in een kwaad daglicht komt te staan. Wat tijdens de oorlog nog gewoon bespreekbaar was met zijn vriend en verzetsman De Bourbon heeft nu het zeer negatieve etiket 'burgemeester in oorlogstijd' gekregen.

De diepere oorzaak voor het weglaten van deze passage lijkt echter toch dat hij zelf beschaamd is over het feit, dat hij tegen beter weten in een paar stappen te ver is gegaan in zijn 'accomodatie' aan de nieuwe toestand.

\section{Kritiek en lof}

In juni 1946 schrijft Aug. Defresne - de medeschrijver van het toneelstuk Vrij Volk die na de première wél voor het voetlicht kwam - in De Groene een kritisch artikel over de passage in Bevrijd Nederland, waarin de razzia op de joden wordt beschreven, die hiervoor geciteerd is. Hij beschuldigt Coolen van heimelijk antisemitisme en zegt er spijt van te hebben ooit met hem te hebben samengewerkt. ${ }^{39}$ Vooral het gebruik van het woord ras wordt Coolen kwalijk genomen. Coolen reageert twee weken later. Hij schrijft dat het hem er juist om te doen was te laten zien "hoe nietig al onze gevoeligheidjes tegen Joden zijn bij het vreselijke drama, dat zij doorstonden en waarin tussen hen en ons niets anders bleef dan de grote band van menselijkheid, die ons met elkaar verbindt. ${ }^{\circ 40}$ Defresne neemt hier genoegen mee, maar raadt Coolen aan om de passus in vervolgdrukken weg te laten.

Dit is later ook gebeurd: in de volgende druk staat op die plaats een noot van de auteur. Hierin legt Coolen op dezelfde manier als hierboven uit wat hij bedoeld heeft. Hij laat het stuk vervallen om "zelfs de schijn te vermijden van het geringste voorbehoud in een veroordeling van anti-semitisme en rassenhaat." Die schijn wordt trouwens door het boek zelf voldoende weersproken, voegt hij eraan toe, want van alle bevolkingsgroepen hebben de joden het meest geleden onder de Duitse barbarij. ${ }^{41}$

De ongelukkige formulering van Coolen komt niet uit de lucht vallen. Ook in Nederland heerste voor de oorlog een latent anti-joods gevoel, dat na de bevrijding zeker 
niet verdwenen was. De gewraakte passage van Coolen zou samengevat kunnen worden in de kreet die in de oorlog in Amsterdam gebruikt zou zijn: "Rotmoffen, blijf met jullie poten van onze rotjoden af."

Van zijn vriend De Bourbon krijgt hij een lovende kritiek op Bevrijd Vaderland: Coolen heeft er "het beste genre journalistiek" in gecreëerd. De Bourbon vindt het geen echt dagboek, maar men kan er het lot van Nederland tijdens de bezetting in volgen. Hij denkt aan de Journals I en II van François Mauriac en ziet overeenkomsten als hij diens beschrijving van Hitler na de moord op Röhm vergelijkt met Coolens passage over Hitler bij het graf van Napoleon.

Vóór de lezer bij deze lof in de recensie is aangekomen, heeft hij echter wel eerst twee kolommen moeten doorwerken, waarin de Bourbon uitlegt dat hij eigenlijk nooit zo gek is geweest op het verhalende werk van Coolen. Daarom vindt hij dit laatste boek, in tegenstelling tot wat "de massa" vindt, ook zo goed. De Bourbon heeft steeds gewacht op de rijpere vruchten van het talent van Coolen, en zo'n vrucht ligt nu voor hem. Het boek zal door het ontbreken van een "story" wel een teleurstelling zijn voor "zoo menig figurant uit de achterhoede van de lezerstros," maar niet voor De Bourbon. "Coolen heeft de hoogtepunten van dezen oorlog gevat in het raam eener historische, vooral cultuurhistorische, critiek. En hij geeft daarbij blijk van een diep geschiedkundig inzicht, van een rijpe bekendheid met de staatkunde en de internationale verhoudingen en niet het minst van een verrassende kijk in de psyche van den enkeling, groot of klein, machthebber of onderdaan." Hij concludeert dat men Coolen niet zoals vroeger wel gebeurde van provincialisme kan beschuldigen, maar dat toch in sommige passages de Brabander te herkennen is. ${ }^{42}$

\section{Vriend en biograaf}

Van Duinkerken reageert enthousiast op Bevrijd Nederland dat Coolen hem toegestuurd heeft. Het boek bevestigt zijn indruk dat Coolen als essayist onderschat wordt en hij vindt het hoofdstuk 'Het Godshuis aller Duitsers' daarvan het bewijs. ${ }^{43} \mathrm{Hij}$ kan jammer genoeg geen een van zijn eigen uitgaven opsturen, schrijft hij, want die zijn allemaal al uitverkocht. Van Duinkerken schrijft, vertaalt en redigeert alleen al in het jaar 1946 zeven boeken en is ook nog bezig met de organisatie van de herdenking voor mei 1946 . Evenals bij de bevrijding zit hij weer in het comité, dit keer voor Het Spel der Bevrijding van A. den Doolaard, in het Olympisch Stadion, naar een idee van Carel Briels. ${ }^{44}$

Ondanks deze overstelpende drukte kwijt Van Duinkerken zich toch zeer nauwgezet van zijn taak als ... biograaf van Coolen. De Maatschappij der Nederlandse Letterkunde geeft een reeks monografieën uit onder de titel 'Schrijpers van heden'. In de redactie van deze reeks zit onder andere A. van Duinkerken. Ter gelegenheid van de vijftigste verjaardag

39 Defresne, 'De bevrijde Antoon Coolen'.

40 Coolen, 'Heeft Defresne slecht gelezen?

41 Coolen, Bevrijd Vaderiand, derde druk 1981, 140.

42 De Bourbon, 'Bevrijd Vaderland'.

43 BA, brief Van Duinkerken aan Coolen, 27 maart 1946

44 Van der Plas, Daarom, mijnheer, 365. 
van Coolen die op komst is, is besloten een schets van leven en werk, met een korte bloemlezing uit te geven. Door de papierschaarste zal dit boek sterk vertraagd worden. Hoewel het voorwoord dateert van november 1946 , zal het pas in 1949 verschijnen.

Coolen is er erg blij mee, omdat de nadruk zal komen te liggen op zijn grote romans van voor de oorlog. Van Duinkerken pakt het serieus aan en vraagt veel gegevens aan Coolen. "Je latere biograaf moet in het boekje allerlei kunnen vinden, dat verloren gaat, als het nu niet genoteerd wordt. ${ }^{45}$ Het lijkt wel of het woord biograaf alleen al een zenuw raakt bij Coolen. Hij reageert daar zeer sceptisch op. Hij vertrouwt erop dat Van Duinkerken sober en bescheiden met de biografische gegevens zal omgaan en schrijft met afkeer over ene dr. Jules Persijn die, ook al is hij persoonlijk in Deurne geweest, toch dwaze verzinsels over Coolens jeugd vertelt; zo zou hij een zoontje van een dorpsbakker zijn geweest. Hij acht zoiets bij Van Duinkerken uitgesloten, maar hij houdt in het algemeen niet van zulke detailleringen.

Toch verstrekt hij tegelijkertijd precieze feitelijke informatie over zichzelf en zijn familie, zoals geboorte- en verhuisdata. In navolgende brieven worden steeds aanvullingen gegeven, zoals titels van vertalingen en aanvullingen op de bibliografie.

Het is heel duidelijk dat hij vooral een beeld van zichzelf wil schetsen als letterkundige, met zo min mogelijk persoonlijke gegevens. Zo vraagt hij of Van Duinkerken de namen van de pastoor en de getuigen bij zijn huwelijk niet weg kan laten en alleen het huwelijk met datum vermelden, ${ }^{46}$ iets waar Van Duinkerken geen gehoor aan geeft.

\section{Overlijden van Herman de Man en Felix Timmermans}

Het verzoek van Coolen om onder andere de naam van zijn huwelijksgetuige Herman de Man weg te laten uit zijn biografie, wijst erop dat hij liever niet meer met hem geidentificeerd wordt. De relatie tussen Coolen en De Man is overigens nooit hecht geweest, waarschijnlijk vanwege de wat lossere levenswandel van de laatste. Herman de Man komt in deze tijd, november 1946, bij een vliegtuigongeluk om het leven. Pas als Streuvels in een brief aan Coolen om een reactie vraagt, schrijft deze dat dit ongeluk na de ramp met zijn gezin "wel zeer tragisch is."47

In dezelfde brief wijdt Coolen ook een enkel woord aan de eveneens pas overleden Felix Timmermans. Zijn rouwbeklag klinkt wat dubbelhartig. Coolen denkt dat Timmermans de jaren na de oorlog zeer ontgoocheld moet zijn geweest "na den glorietijd van het succes onder de Duitschers." Het is voor hemzelf het bitterst geweest, vindt Coolen. Hij betreurt het dat Timmermans zich niet heeft hersteld, want hij heeft toch mooie blad. zijden geschreven die klonken "als orgelmuziek." Hij denkt daarbij vooral aan "Boerenpsalm'. Timmermans is een kunstenaar van wie ik veel heb gehouden, besluit hij niet 20 heel oprecht.

Eind 1947 schrijft Coolen echter aan M.E. Tralbaut in een dankbriefje $e^{48}$ voor het toesturen van het boek Zo was de Fé, dat de houding van Timmermans in de oorlog een bittere ontgoocheling voor hem was en dat hij dat na zijn dood niet wil verdoezelen. Pogingen uit Vlaanderen om zijn mening te veranderen hebben hem niet overtuigd en deze van Tralbaut evenmin. Hij stuurt hem het hoofdstuk over Timmermans uit Bevrijd Vaderland toe en vermeldt er bij, dat hij nog niet wist van Timmermans' ziekte toen hij het schreef. Zijn toon blijft echter verbitterd als hij schrijft: toen wij streden tegen de Kultuurkamer 
lagen hier de boeken van Felix Timmermans in grote stapels voor de ramen. Een maand later, als Tralbaut geantwoord heeft dat Timmermans toch geen landverrader is geweest, schrijft Coolen: "Dat zeggen wij in Nederland ook niet." ${ }^{49} \mathrm{Hij}$ is echter van mening dat men niet moet ontkennen dat Timmermans fout gehandeld heeft; pas dan kan men, voor zijn nagedachtenis, bepleiten dat er verzachtende omstandigheden waren. Coolen vindt het maar vreemd dat Timmermans niet van te voren op de hoogte zou zijn geweest van de uitreiking van de Rembrandtprijs, want "mij heeft men van tevoren namens de Hamburgse Senaat gevraagd." Hij gelooft al helemaal niet in Talbauts bewering dat Timmermans bij weigering een vreselijk lot zou hebben getroffen en dat hij dan had moeten onderduiken om niet in een concentratiekamp te komen. Kijk maar naar mij, schrijft Coolen, ik kreeg het hoffelijke antwoord: "Wir können Ihren Standpunkt würdigen."

\section{7: jaar van uitersten}

Het jaar 1947, waarin eindelijk een eind komt aan de persstrijd met Van Doorne, wordt voor Coolen zeer enerverend en zelfs dramatisch. Aan het begin ervan is hij niet alleen druk bezig met het persklaar maken van een novelle die als geschenk voor de Boekenweek begin maart zal uitkomen, maar bereidt hij ook een reis naar Tsjecho-Slowakije voor. Ondertussen is hij zeer benieuwd naar de drukproeven van de monografie over zijn leven en werk. Hij heeft dringend behoefte aan literaire erkenning en vraagt daarom aan Van Duinkerken of zijn boek Bevrijd Vaderland niet kan meedingen naar de literatuurprijs van de stad Amsterdam. ${ }^{50}$ Deze prijs is eigenlijk bestemd voor werk uit r946. Daarom wil Coolen een verklaring van zijn uitgever dat het boek pas in 1946 is verschenen, ook al staat 1945 vermeld als jaar van uitgave.

Wanneer Van Duinkerken Coolen met gepaste trots het vertaalde gedicht 'Odysseus' Hartsgeheim' van Maurras in boekvorm toestuurt, kan Coolen het niet laten op het foute oorlogsverleden van Maurras te wijzen, terwijl Van Duinkerken in het voorwoord toch schrijft dat dit gedicht voor hem in de hongerwinter een grote troost is geweest. Coolen wijst op de negatieve kritiek van Mauriac op Maurras en op de Action Française, waarvan Maurras lid was. In de Eerste Wereldoorlog heeft deze actie, volgens Mauriac, bijgedragen aan de overwinning, maar de beweging heeft in de periode r918-1940 een "chute luciférienne du nationalisme maurassien" gemaakt. Hij raadt Van Duinkerken aan om het nieuwe deel van Mauriacs Journaal te lezen (Le Baillon Denone), waarin deze zich blootgeeft "zooals wij toch allen waren, verholen luisterend naar den Engelschen zender terwijl de Duitsche laarzen kraakten boven zijn hoofd." ${ }^{\text {"51 }}$ Het staat er niet, maar tussen de regels door zou men kunnen lezen dat Coolen tegen Van Duinkerken zegt: hoe kon je nou in die tijd een gedicht van een landverrader vertalen.

BA, brief van Duinkerken aan Coolen, 19 oktober 1946

48 AMVC, inv. nr. C 3475, brief Coolen aan M.E. Tralbaut van 6 december 1947.

49 AMVC, inv. nr. C 3475, brief Coolen aan Iralbaut van 19 januari 1948.

50 BA, brief Coolen aan Van Duinkerken, 17 januari 1947.

5] BA, brief Coolen aan Van Duinkerken, 8 januari 1947. 


\section{De dood van Peter}

Donderdagmiddag 27 februari gaat Peter Coolen, 9 jaar oud, spelen met zijn vriendje, Heintje Dircksen. Na de strenge vorst die de hele winter heeft geheerst, is het gaan sneeuwen. Als de kinderen aan het eind van de middag bij het invallen van het donker niet thuis zijn, gaat men zoeken en velen uit het dorp Waalre zoeken mee. Uiteindelijk vindt men de voetsporen naar een bevroren waterput voor het vee in een weiland. De jongens blijken via de betonnen ring op de ijskap te zijn geklommen, maar, omdat deze door de invallende dooi al los van de randen was gekomen, is die omgeslagen en zijn de jongens eronder geschoten. Met veel moeite worden de lijkjes er onderuit gehaald. Peter wordt opgebaard in de hal van De Kempen. ${ }^{52}$ Een neef herinnert zich de handjes met de afgeschaafde knokkeltjes. ${ }^{53}$

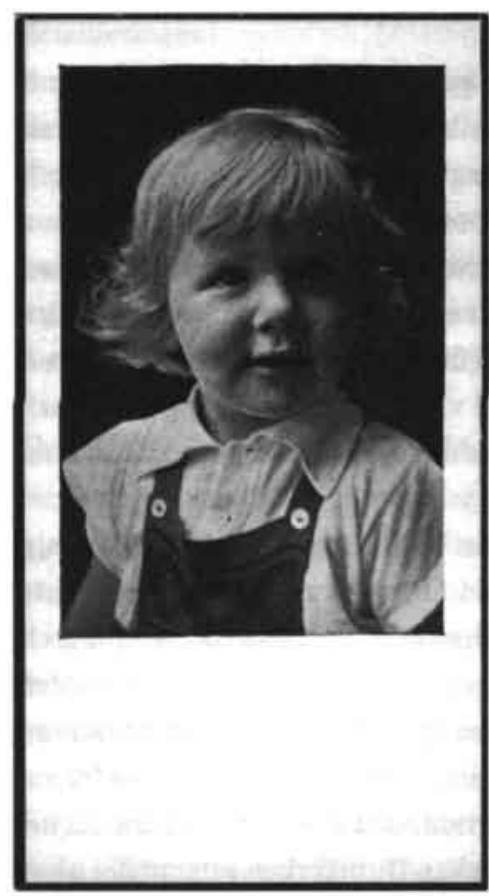

Peter Coolen.
In de Deurnesche Courant van 7 maart verschijnt een kort verslag van de begrafenis. De belangstelling is overweldigend en een lange stoet wordt door verkenners over de besneeuwde wegen van Waalre geleid. Het is een van de laatste keren dat de lokale gewoonte wordt gevolgd, waarbij achter de kist eerst een voor een de mannelijke familieleden lopen, gevolgd door alle andere mannelijke belang. stellenden en pas daarachter de vrouwelijke familieleden. Een ooggetuige vertelt: "Achter de laatste mannen wordt dientengevolge de vrouwengroep voorafgegaan door de eenzame en schokkend bedroefde figuur van Peters moeder. ${ }^{.54}$ Dit beeld moet zeer schrijnend zijn geweest en men vraagt zich af waarom men die gewoonte op die dag niet al verlaten heeft. Gerda Coolen-de Jong heeft geen dochters. Ook zijn er geen grootmoeders meer om haar op deze tocht te ondersteunen en de verhouding tot haar schoonzussen is afstandelijk. Haar eenzaamheid moet groot zijn geweest.

Door de kerk gaat een golf van emotie als het gedachtenisprentje wordt uitgereikt. Hierop heeft Coolen de tekst uit De schone voleinding laten afdrukken, waar hij beschrijft hoe een kind onder nagenoeg dezelfde omstandigheden als zijn zoontje verdrinkt: "Dit is nu gebeurd, niets is er anders door. Het had ook evengoed niet gebeurd kunnen zijn: een hand die een schoudertje wendde, voetjes die de richting ingestuurd werden voor een ander spel. ${ }^{55}$ Het is bijna griezelig om de overeenkomsten te zien met het voorval in zijn boek dat hij vijftien jaar eerder, in 1932, schreef. Zelfs de tijd en het jaargetijde komen overeen: "Het was nu in den tijd, de daagen gingen weer zoo zoetjes aan het lengen, half Februari wier het klaarder weer met eenige windstille daagen van vorst en avonden dat den hemel diep en fonkelend roos was." 


\section{$+$}

In Memoriam

Peter Hendrik Coolen

geboren te Deurne 29 Juli 1937, overleden te Waalre ten gevolge van een noodlottig ongeval $27 \mathrm{Fe}$ bruari 1947, in den leeftijd van negen jaren.

Dis is nu gebeurd, niets is er anders door. Het had evengoed ook niet gebeurd kunnen zini een hand die een schoudertie nen zijn; een hand die een schoudertic
wendde, voetjes, die derichting ingestuurd wendde, voetjes, die de richting
werden voor een ander spel.

De gebeurtenis was zod klein, maai nu gasn er mannen door den nacht, die soeken met lantaarns langs de wegen.

De vench gevalien sneeuw heeft geen spoor yan kinderklompkes. Waar, waas spoor van kepan 1 Na kan het poede

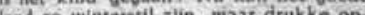
land so wintement gewonden stemmen zijn een beweeglink geluid. dat hier is, dat daar is, dat het wiegelend licht det stallantaarns rolgt. Dit doordwaalt deo nacht, en zachter dan zacht valt uit de nachtelijke schaduwen de fijne, teedere sneeuw daaraver en over den roep van stemmen. Stemmen, die roepen. Die vragend en tevergeefs den naam van een kind roepen.....

Ulit, ..De Schoone Voleinding."

Heet, zilin Engel beeft de schreden

Van ous kind tot $\mathrm{U}$ geleid,

Uit den tekst van Peter's Communieprentie.
In 1939 heeft hij in Uit het kleine rijk de angst beschreven van de ouders als Stijntje een middag kwijt is. Van de vele mogelijkheden voor ongelukken noemde hij toen, naast zandinstortingen, de vennen, de Dommel en een watermolen, ook een put met een lage ringmuur. Toen stelden de ouders zichzelf gerust: "Die put ligt bij een huis, daar wonen menschen, dan zouden we het weten!" De put waar Peter nu verdronken is, ligt echter in een verlaten weiland.

Het grote verschil met de gebeurtenis in de roman is gelegen in de zingeving. In De schoone voleinding konden de ouders er in berusten dat ze hun dochtertje 'af moesten geven' om het goed te maken, om de misdaad van de vader te vereffenen. Het kind moest het goed maken bij Giel. Coolen en zijn vrouw zullen zich vertwijfeld afgevraagd hebben wat de zin van de dood van hun Peterke zou kunnen zijn.

\section{Boekenweek - De ontmoeting}

De begrafenis van Peter valt midden in de Boekenweek van I947, die dat jaar van I tot 8 maart wordt gehouden. ${ }^{56}$ Coolen heeft het traditionele boekenweekgeschenk geschreven, maar dat weet het publiek nog niet. De commissie voor propaganda van het Nederlandse boek heeft in de zomer van 1946 een prijsvraag uitgeschreven voor de beste novelle of korte roman. Een jury, waarin onder andere Clara Eggink, Anne H. Mulder, Ed. Hoornik en Victor E. van Vriesland zitting hadden, hebben De ontmoeting uitgekozen. Het boek werd ingezonden onder het motto: "Ships that pass in the night". Nu is een tweede prijsvraag uitgeschreven, dit keer voor de lezers. $\mathrm{Zij}$ moeten raden wie De ontmoeting heeft geschreven. ${ }^{\text {st }}$

52 Ook Wiegersma, die vijf jaar eerder zijn zoon Wieger verloren heeft, komt afscheid nemen. Hij was zeer geêmotioneerd en "zo klein als een kind," herinnert Coolens secretaresse, mevrouw Leny de Bont-v.d. Linden zich. Gesprek mei 1997.

53 Interview Cees Slegers met de heer Hans Coolen te Son, 19 januari 2000.

54 CS, [typoscript] Zoetmulder, Antoon Coolen en Waalre.

55 Coolen, De schoone voleinding, 120.

56 Het boekenbal vond plaats op 4 maart. Hier werd het oude wijnlied 'Breng de Bekers' gezongen door Van Duinkerken en twee onbekenden. Kelk, lk kéék alleen, 90.

57 De inzenders waren in alfabetische volgorde: Antoon Coolen, Henriette van Eyk, S. Franke, Hidde Heringa, J.W. Hofstra, Leonard Huizinga, Jef Last, Jan Mens, M. Revis, Jaap Romijn, B. Stroman en S.F. Witstein. Deze namen stonden op een formulier, dat uit het boek gescheurd kon worden en na invulling van de vermoedelijke auteur kon worden ingestuurd. 


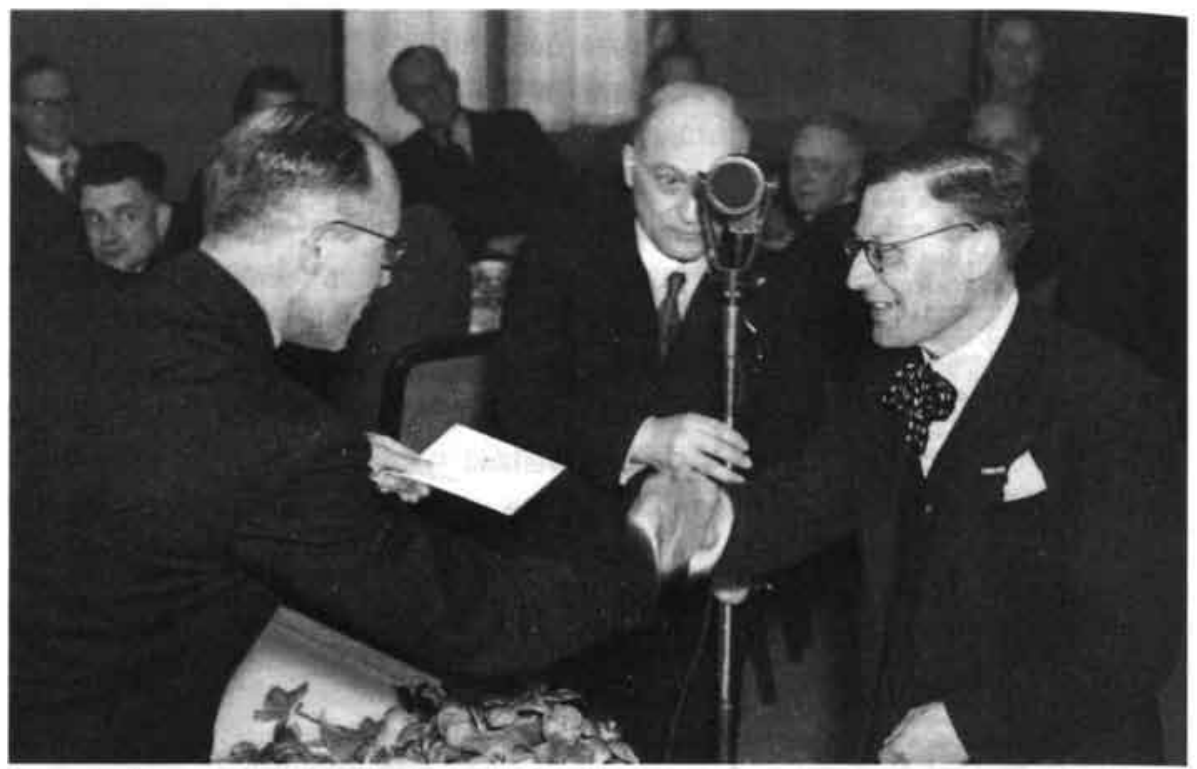

Bekendmaking van de schrijver van De ontmoeting.

De ontmoeting speelt in de lente en zomer van 1944 in het zuiden van Nederland, dus tijdens de invasie en de nadering van de geallieerde troepen.

Een jonge boer krijgt in het verzet de naam Maurits. Hij is getrouwd. Zijn vrouw - "verre van knap, zij het dat haar mond iets moois en lokkends had" - zegt verwijtend dat jonge vaders niet in het verzet moeten gaan. Als hij echter naar zijn slapende kinderen kijkt, denkt hij: "Wie zouden het eerder moeten doen en wie zouden het ernstiger doen dan juist de jonge vaders?" 58

In de verzetsgroep ontmoet hij een knappe verpleegster, Margareta, die koerierster is. Ook hier weer krijgt de beschrijving van de mond veel aandacht: “de vochtige, rode glans van een jonge, volle, vlezige mond. ${ }^{n 9} \mathrm{Zij}$ is tevens werkstudente en gewend tussen de jonge mannen van de faculteit te leven. Maurits kijkt tegen haar op; hij weet niet eens wat een faculteit is. Hij voelt zich tot haar aangetrokken. Op een nacht moet hij haar naar een schuilhut brengen, waar ze slapen op aparte veldbedden. In het donker vertelt hij over vrouw en kinderen, vooral over de grappige voorvallen met de laatsten. Ze liggen ieder "in de eigen, begrensde en beschermde wereld," ${ }^{60}$ maar slapen doen ze geen van beiden. Thuisgekomen belooft hij dat hij nooit meer weg gaat.

Op een gegeven moment wordt Maurits opgepakt door de Duitsers. Hij is verraden door een onbetrouwbaar lid van de verzetsgroep, Don José, een man met veel talenten en tegelijkertijd psychopatische kanten. Hij kan subtiel schrijven over het fragiele leven van een kikker, die hij van tevoren met veel genoegen heeft doodgetrapt. Hij is aanwezig bij executies van verzetsmensen die hij zelf verraden heeft. Als hij alleen is, moet hij er van huilen en wijdt hij er een gedicht aan.

Als Maurits in augustus kaal en vermagerd thuiskomt, staat het koren hoog en zijn de geallieerden op weg naar Parijs. Zijn vrijlating heeft hij te danken aan Margareta. Zij heeft de Duitsers omgekocht, niet met geld maar met iets anders, heeft Don José veelbetekenend verteld. Thuis bij het eten is Maurits afwezig. Hij vraagt zich af waaraan hij het te danken 
heeft dat hij vrij is. "Ben je dan vergeten, dat ik je verteld heb, dat de kinderen er avond aan avond voor hebben gebeden?" zegt zijn vrouw.

Maurits wordt steeds actiever in het verzet. De verrader Don José wordt bij een geimproviseerd tribunaal van de verzetsgroep ter dood veroordeeld en geëxecuteerd. Tijdens de executie kijken Maurits en Margareta elkaar nadrukkelijk aan via een koper omrande spiegel. De afbeelding van deze scène staat op het omslag van de eerste druk. Maurits ziet in haar ogen dat ze hem iets te kennen wil geven, wat met geen woorden te uiten is. ${ }^{61}$

Maurits wordt deze laatste weken van de oorlog roekeloos. Hij wil zich wreken op de Duitsers vanwege datgene wat ze Margareta hebben aangedaan. Tegelijkertijd lijkt het ook een soort doodsdrift, omdat hij niet meer weet wat hij met zijn verscheurde gevoelens tussen zijn gezin en de koerierster moet aanvangen. Als Margareta hem tegen zichzelf wil beschermen, treft ze hem aan op de spoorbaan, waar hij net door de Duitsers betrapt wordt bij het saboteren van de rails. Hij wordt door de Duitsers met geweerkolven doodgeslagen. "Zijn blik ving nog dat beeld der streep van een spoorlijn, die langzaam om een keerpunt draaide."

Meteen daarna zien de Duitsers Margareta en schieten haar dood. Vervolgens gaan ze naar de boerderij van Maurits en steken die in brand. Zijn vrouw staat erbij met haar kinderen om zich heen en de jongste op de arm met trappelende voetjes. "Moeders hand greep die voetjes en hield ze bijeen vlak boven de ronding van haar reeds weer zwellende schoot. ${ }^{\text {"62 }}$

De NRC oordeelt dat het een geslaagde novelle is, "die zich echter langs vrij conventionele lijnen beweegt. Het zou ons verbazen als dit het werk van een debutant was, de uitwerking van dit boeiende verhaal verraadt de hand van den vakman, die knap, men zou bijna zeggen, handig, vorm weet te geven aan zijn materie."63 Volgens de krant is het ook geen echt verzetsverhaal. Het gaat steeds meer om de man Maurits, die door zijn ontmoeting in het verzet niet meer de baas is over zijn eigen gevoelens. Zijn roekeloos gedrag op het eind lijkt op zelfmoord, omdat hij zich niet meer weet te redden uit de duistere verwikkeling van zijn gevoelens en driften. Aan de ene kant staan zijn vrouw, zijn kinderen en het zuivere, eenvoudige leven en aan de andere kant staat het verzet met het door hem bewonderde meisje, dat zich voor hem heeft laten vernederen. De recensent raakt hier, zonder het begrip te noemen, de 'instinct-causaliteit' aan, het steeds terugkerend motief in Coolens werk.

Dit boek, zo pal na de oorlog geschreven, zit vol aanknopingspunten met Coolens eigen wedervaren aan het eind van de oorlog. Het verhaal speelt in dezelfde tijd dat Coolen zich schuilhield in het Westen van mei tot september 1944. Hij zal het gegeven van de vluchtige ontmoetingen tussen mannen en vrouwen in het verzet, Engelandvaarders of neergeschoten geallieerde vliegers nog vaak herhalen. Daarbij gebruikt hij steeds het beeld van schepen die elkaar in de nacht passeren.

\footnotetext{
58 Coolen, De Ontmoeting. 17.

59 Coolen, De Ontmoeting, 23.

60 Coolen, De Ontmoeting, 57.

61 Coolen, De Ontmoeting, 115.

62 Coolen, De Ontmoeting, laatste zin, 127.

63 'Het geschenk: een verzetsnovelle'.
} 
Coolen heeft zelf deze mengeling van gevoelens meegemaakt. Aan de ene kant de angst, vrees en ongerustheid over vrouw en kinderen en aan de andere kant de roes en de vrijgevochtenheid van het milieu van het verzet. ${ }^{64}$ Deze tegenstrijdigheid in gevoelens zit ook in het verhaal, namelijk als Maurits van zijn vrouw te horen krijgt dat hij zijn vrijlating te danken heeft aan het gebed van haar en de kinderen, terwijl hij op dat moment weet dat hij die te danken heeft aan de zonde. Eigenlijk is het zelfs een dubbele zonde: Margareta is niet zomaar met iemand naar bed geweest, maar met de vijand.

Bij de beschrijving van de verrader, en vooral zijn jeugd, moet men denken aan het verhaal van Theun de Vries, WA-man. Die beschrijving heeft op zijn beurt weer trekjes van Sartre's L'enfance d'un chef. Theun de Vries schreef zijn novelle in 1943 en ze verscheen in I944 als ondergrondse uitgave. Het verhaal zal zeker gecirculeerd hebben in de kringen waar Coolen toen ondergedoken zat.

Coolens stijl heeft echter nog diepere wortels en reikt terug naar zijn leeservaringen uit zijn jeugd, toen hij de anti-oorlogsverhalen las van Leonid Andrejew. Als het meisje dood langs de spoorbaan ligt, gebruikt Coolen evenals de Rus de tegenstelling tussen bloemen en oorlog: "Langs het lokkig haar om het stil en bleek en bebloed gezicht schuurde een stijve witte trosbloem in de wind op en neer." Eveneens in navolging van Andrejew in Desmar. ten van België eindigt Coolen zijn verhaal met een verwijzing naar moederschap en nieuw leven.

\section{Vijftigste verjaardag en Tsjecho-Slowakije}

Coolen krijgt weinig tijd om thuis het verlies van Peter te verwerken. In de eerste week van maart 1947 is er de drukte van de Boekenweek en aan het eind van die maand maakt hij een korte reis naar Tsjecho-Slowakije. Dit land kent na de bezetting door de Duitsers een ongekende opleving van de eigen identiteit. Schrijvers en kunstenaars genieten er hoog aanzien. De regering Masaryk heeft zelfs een kasteel aan de schrijvers beschikbaar gesteld om er te kunnen werken. Het land is bevrijd door de Russen en hoort volgens het verdrag van Jalta tot de Russische invloedssfeer. Het maakt een korte periode door als vrij en democratisch land. De boeken van Coolen zijn zeer populair in Tsjecho-Slowakije. Vanaf 1937, toen Kinderen van ons volk er verscheen, zijn al zijn belangrijke romans er in vertaling uitgebracht. De meeste werken zijn vertaald door Lida Faltová en uitgegeven door Bohumil Janda. In januari wordt hij door Janda uitgenodigd om enkele lezingen te komen geven in Praag en Brno. ${ }^{65}$ Op 12 maart krijgt hij via zijn tussenpersoon Jan Bouman de reisbescheiden met in het begeleidende briefje een verwijzing naar de dood van zijn zoontje: "en ik hoop dat je niettegenstaande de moeilijke dagen, waarin je verkeert, toch lust en gelegenheid zult kunnen vinden te genieten van het prachtige land en de charme van de Tsjechen." ${ }^{-66}$

De Deumesche Courant van 14 maart bericht over deze reis: "Op uitnoodiging van den Tsjechischen Minister van Voorlichting zal de heer Coolen een dezer dagen naar Praag vertrekken voor het houden van een drietal voordrachten over Nederland." $\mathrm{Na}$ afloop verschijnt een verslag van Coolens veertiendaags verblijf in 'zijn' krant. ${ }^{67}$

Begeleidster en vertaalster Ella Kazdova zal een tweede reis voor het hele gezin van Coolen in augustus 1947 voorbereiden. 


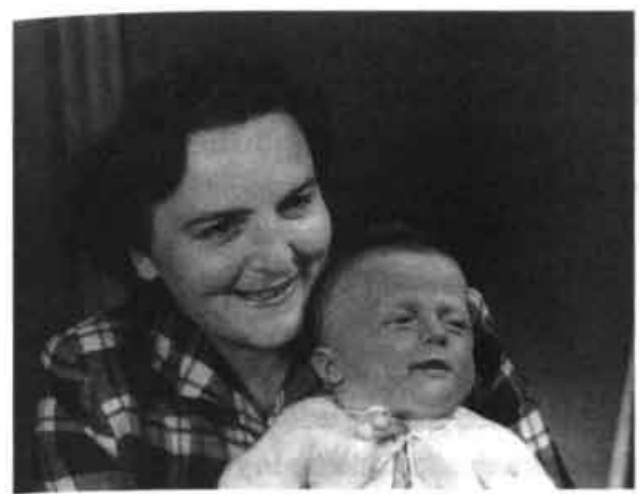

Ella Kazdova met haar zoontje.

Tijdens Coolens reis in maart treft zijn vrouw Gerda voorbereidingen voor zijn vijftigste verjaardag op 17 april en nodigt enkele vrienden uit. Door Coolens verblijf in Praag heeft ze haar verdriet enige tijd alleen moeten verwerken. Na de dood van Peter leeft ze teruggetrokken in hun huis. ${ }^{68}$

Op de verjaardag is onder andere Streuvels met zijn vrouw aanwezig geweest. Later schrijft Coolen hem dat er geen tafelredevoeringen zijn gehouden, omdat hij vindt dat die zo gauw tot academische debatten leiden. ${ }^{69}$ Wie wel was uitgenodigd, maar niet kwam opdagen is Louis de Bourbon. Het gaat niet zo goed met deze vriend van Coolen. Heeft Coolen door de oorlog een knak gehad, Louis de Bourbon heeft dat nog veel meer. Hij werd aan het eind van de oorlog door de Duitsers wegens verzetswerk bij verstek ter dood veroordeeld. Na de bevrijding is hij weer burgemeester van Oss, maar hij wordt in juni 1946 op eigen verzoek eervol ontslagen. Ondanks goede contacten met minister Beel, ${ }^{70}$ die naarstig op zoek is naar katholieke kandidaten voor burgemeestersposten in het Westen en Noorden van het land, lukt het niet een andere post te krijgen. Naar De Bourbons eigen zeggen ging een benoeming in Hilversum niet door omdat hij het niet te nauw nam met zijn katholieke plichten. Hierna breekt voor hem een tijd aan van solliciteren, scheiding en een nieuw huwelijk.

Coolen onderhoudt in deze jaren een zeer intensieve correspondentie met De Bourbon. Des te opvallender is het dat De Bourbon zo nonchalant is in het nakomen van zijn vriendschappelijke plichten. Zo is hij ook niet aanwezig op de begrafenis van Peter op 3 maart. Toch is hij de eerste aan wie Coolen op 4 april meldt dat hij weer terug is uit Praag. Hij nodigt hem nog eens expliciet uit: "we rekenen op je voor het etentje ter gelegenheid van mijn vijftigste verjaardag. ${ }^{\text {"n }}$ De Bourbon laat ook nu weer verstek gaan. Als Coolen hem daar verontwaardigd over aanspreekt en zegt dat zijn geboortedatum bovendien in bijna al zijn boeken vermeld staat, antwoordt De Bourbon daags na Coolens verjaardag op een manier die zijn ongeordend leven illustreert. Hij is de wanhoop nabij, want ondanks de uitnodiging

64 Het kan ook zijn dat Coolen inspiratie geput heeft uit de verhouding die De Bourbon tijdens zijn onderduik aanknoopte met de dochter van de schilder bij wie hij ondergedoken zat in Mook.

65 BvdB, brief ISLA/ Janda via tussenpersoon Jan Bouman aan Coolen, 10 januari 1947.

66 BvdB, brief Jan Bouman aan Coolen, 12 maart 1947.

67 'Antoon Coolen in Tsjechoslowakije'.

68 LMDC, inv. nr, C 3485, brief Coolen aan Oomes, 19 november 1947.

69 AMVC, inv. nr. C 3475, brief Coolen aan Streuvels, 20 juni 1947.

70 Giebels acht de suggestie van Jacques Gans dat Beel van De Bourbon een onderduikadres heeft gekregen aanvaardbaar. Beel gaf in augustus 1944 geen gehoor om graafwerk te verrichten bij viegveld Welschap. Giebels, Beel, 77 .

7 LMDC, inv, nr. C 3485, brief Coolen aan De Bourbon, 13 april 1947. Aan dit diner namen onder andere Streuvels en Van Duinkerken deel. 
dacht hij dat het feest veel later zou zijn. Van vorige keren herinnert hij zich vagelijk "dat het later in het voorjaar was, met meer groen aan de bomen en bloeiende bloemen in de tuin rond De Kempen." Pagina's lang put hij zich uit in verontschuldigingen. Hij had in een literatuurgeschiedenis kunnen kijken. Hij heeft opdrachten in boeken van Coolen nagekeken: "Daarentegen zocht ik op de voorpagina's van boeken, die je me dedicadeerde op zo menigen hoogdag, die ons samenbracht." Toen vond hij in Het donkere licht de datum van 17 mei en daar heeft hij zich aan vastgeklampt. ${ }^{72} \mathrm{Hij}$ stelt voor om het feest "entre nous" nog eens kleintjes na te vieren. Of dat doorgegaan is, is niet bekend. Kort daarna is hij echter weer bezig met zijn materiële sores. Hij is bezig een schadevergoeding te krijgen voor zijn manuscripten die in de oorlog verloren zijn gegaan en vraagt aan Coolen een verklaring "waarin de waarde van mijn letterkundige werk summierlijk wordt omschreven." ${ }^{73}$ Coolen doet dat prompt en krijgt als dank enkele publicaties van De Bourbon toegestuurd.

Toch ontstaat een verwijdering tussen beide mannen, voornamelijk, zoals later zal blijken, doordat Coolen de leefwijze van De Bourbon afkeurt en zich het lot van de verlaten echtgenote Gudrun aantrekt. Het meest steekt hem echter toch de reden waarom De Bourbon niet aanwezig was bij de begrafenis van Peter. Pas drie jaar later zal hij hem daarover schrijven.

"In Eindhoven vertelde mij, kort na Peterkes begrafenis, een kelner van Schimmelpenninck, zoomaar omdat hij wist dat wij vrienden waren, dat ge in den nacht vóór Peterkes begrafenis (hij noemde die niet, maar den datum en preciseerde die nog) daar gelogeerd had in gezelschap. Dat was niet in overeenstemming met de reden, die je in den gevoeligen brief, die je toen schreef opgaf. [...] Toen dacht ik: Zóó dicht in de buurt 's avonds van te voren en den vriend op zúlk oogenblik geen uur afgestaan van wat je toen bezig hield. ${ }^{n 74}$

Het is typisch voor de 'binnenvetter' Coolen om ruim drie jaar met deze grief rond te lopen alvorens hem te uiten. Hij heeft het er ook nooit met zijn vrouw over gehad, want hij vraagt om er niet over terug te schrijven "anders leest Gerda het."

In oud-verzetskrant Het Parool constateert Max Nord bij Coolens vijftigste verjaardag dat het Coolen aan verguizing noch aan waardering heeft ontbroken in zijn schrijversloopbaan. Hij vindt dat Coolen in Nederland de plaats inneemt, die in België door Streuvels, in Skandinavië door Selma Lagerlöf, in Duitsland door Fritz Reuter en in Frankrijk door Jean Giono wordt ingenomen, zij het dat hij ze niet allemaal evenaart. Nord vindt dat het genre van de streekroman door allerlei amateurs in diskrediet is gebracht. Coolen vormt hierop de uitzondering, maar de officiële literaire kritiek van de laatste jaren, van Du Perron, Ter Braak, Donker, Nijhoff, Greshoff en Binnendijk, heeft nauwelijks aandacht besteed aan de streekroman en dus ook niet aan de zijne. Alleen Vestdijk heeft in Muiterij tegen het etmaal iets positiefs gezegd over Herberg In ' $t$ Misverstand. Nord besluit zijn stuk met de vaststelling dat Coolen zijn vak beheerst en boven veel collega's uitsteekt. Men hoeft geen minnaar te zijn van het genre om dat te erkennen. "Met dat al is men gerechtigd bij zijn vijftigste verjaardag den schrijver o.a. van Kinderen van ons volk, Het donkere licht (bekroond door de Mij. der Letterkunde), De goede moordenaar, Dorp aan de rivier en De drie gebroederste doen weten van de waardeering die zoovelen in den lande zijn werk toedragen. ${ }^{75}$

Zo'n kritiek gevoegd bij de positieve ontvangst van zijn boeken Bevrijd Vaderland en De 
ontmoeting alsmede het enthousiasme waarmee hij in Tsjecho-Slowakije wordt behandeld geven Coolen zijn eigenwaarde als schrijver en letterkundige terug. In deze tijd stopt hij met de persstrijd in Deurne en stapt tevens op als lid van het Tribunaal. Hij voelt weer waar zijn wezenlijk talent ligt: niet op het polemische, het politieke of het juridische vlak, maar in de literaire verbeelding van de werkelijkheid.

Eind augustus 1947 bezoekt Coolen opnieuw Praag, nu samen met zijn vrouw en kinderen. Vanaf zijn 'zwerfperiode' aan het eind van de oorlog zijn er eigenlijk alleen maar problemen geweest. De reis doet het hele gezin goed. ${ }^{76}$ Coolen wordt in Praag als een groot schrijver ingehaald en geëerd. C.J. Kelk, die dat jaar ook Praag bezoekt, schrijft later over een ingenieursmevrouw die 'Hollanders' verzamelt zoals een ander postzegels: "Zij raakte niet uitgepraat over het bezoek van Antoon Coolen, die hier een geliefd schrijver bleek te zijn. Zijn boeken lagen in alle winkels en uit alles bleek: het voornamelijk agrarische land aanvaardde grif de rustieke eenvoud van Coolens verhalen. ${ }^{n 7}$

De reis is goed voorbereid door Ella Kazdova; zij mag gerust een fan genoemd worden. Zij is op dat moment bezig met een vertaling van Bomans' Erik, of het klein insectenboek. Coolen heeft haar in mei Uit het kleine rijk toegestuurd: "Het boek zal u op de hoogte brengen met ons gezin toen het nog in zijn jeugd was." ${ }^{78}$

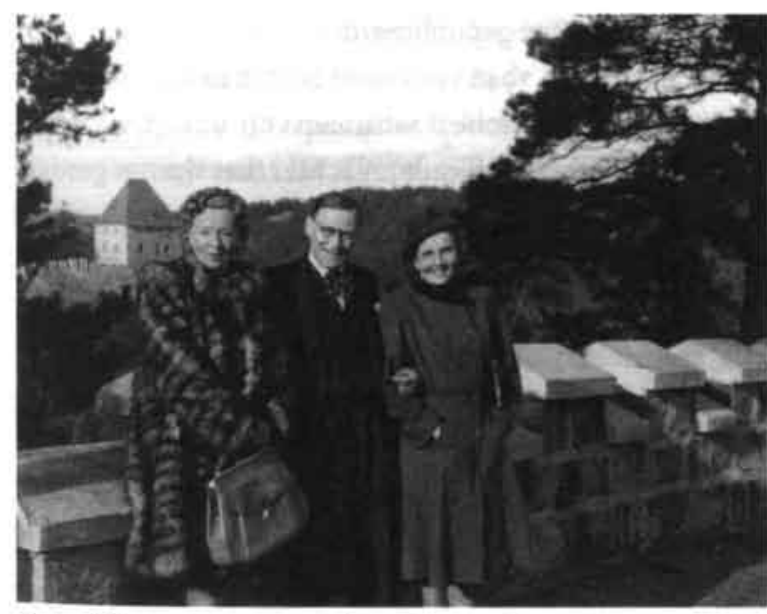

Coolen tijdens zijn eerste bezoek aan Tsjecho-Slowakije in maart 1947, rechts Ella Kazdova.
Uit de intensieve briefwisseling die aan de reis voorafgaat, blijkt onder andere dat er plannen zijn voor een Tsjechische verfilming van Dorp aan de rivier. Aan Jiri Pober, hoofdredacteur van een politiek en cultureel weekblad, zendt Coolen een synopsis, maar schrijft in de begeleidende brief: "Uit vroegere ervaringen in ons eigen land weet ik alleen, dat filmen nooit doorgaan. ${ }^{79} \mathrm{De}$ officiële uitnodigingsbrief

72 LMDC, inv. nr. B 783, brief De Bourbon aan Coolen, 18 april 1947.

73 LMDC, inv. nr. B 783, brief De Bourbon aan Coolen, 21 april 1947.

74 LMDC, inv, nr. C 3485, brief Coolen aan De Bourbon, 8 mei 1950.

75 Nord, 'Antoon Coolen wordt vijftig jaar'.

76 LMDC, onv. nr. C 3485, brief Coolen aan Oomes, 19 november 1947. "In Praag geweest, wat het gezin goed deed, zeker Gerda, die na Peterkes dood niet buiten kwam."

$n$ Kelk, Ik kéék alleen, 98.

78 BvdB, brief Coolen aan Ella Kazdova, 31 mei 1947. Het boek zal het jaar daama in een vertaling van Kazdova verschijnen. 
aan de leden van het gezin Coolen om ook mee te reizen als gasten komt vrij laat. In een merkwaardig Engels beschrijft Coolen de spanning bij zijn zonen als hij hem openmaakt: "three boys were trooping round me with leaped hearts waiting for the opening." ${ }^{80}$

Zoon Felix Coolen herinnert zich dat er bij aankomst op het vliegveld, op I 4 augustus I 947 , veel mensen stonden te wachten zoals bij de aankomst van een filmster. De eerste nacht brengen ze door in hotel Splendid en daarna wordt de familie ondergebracht op het slot Dobris. Op de hotelkamer ligt een welkomstbrief klaar van Ella Kazdova: "Welkom in onze oude stad van honderd torentjes! Ik heb de eer $U$ hiermede voorzichtig op het programma te voorbereiden, die zich van zijde van Uwe bewonderaars, lezers, vertaalsters en andere rare pizangs op U binnen aanstaande dagen gaat neerstorten."

De reis wordt een groot succes en meteen bij thuiskomst stuurt Coolen een dankbrief aan Ella Kazdova: "We hadden een prachtige vlucht door een zonnigen, blauwen hemel, ten deele boven de wolken, die, stralend in het zonlicht, als een blank sneeuwveld aandeden, en ten deele in een open lucht met een prachtig uitzicht, dat vooral Guido enthousi. ast makte toen hij bij de vlucht boven Duitschland vele puinhopen, staketsels van dakloo. ze kerken en ontelbare bomkraters zag. ${ }^{\text {"82 }}$

Coolen gaat meteen aan de slag om de impressies van de twee reizen in een boek te vatten. Tijdens het schrijven informeert hij bij Ed. Hoornik, die hem eerder wel eens om een bij drage heeft gevraagd, of Vrij Nederland interesse heeft voor enkele reisimpressies uit Tsjecho. Slowakije. ${ }^{85}$ Enkele fragmenten zijn in afleveringen gepubliceerd.

Als het boek Tsjechische Suite in het najaar van r 948 verschijnt is er in het land veel veranderd. In februari 1948 heeft zich een communistische staatsgreep voltrokken, waardoor Tsjecho-Slowakije een vazalstaat van de Sovjet-Unie wordt en achter 'het ijzeren gordijn' verdwijnt.

\section{Tsjechische Suite}

In de negen hoofdstukken (in de tweede druk wordt een tiende hoofdstuk over de Karelsbrug toegevoegd) die Tsjechische Suite telt, geeft Coolen een reisimpressie met veel culturele, historische en ook enkele politieke uitstapjes.

Het boek opent met een beschrijving van de bergen, de dorpen en de wijn. Natuurlijk kan hij het niet laten om het reizen per trein te beschrijven. Voor de boemeltjes die drie uur over veertig kilometer doen, heeft Coolen een verklaring. Dat komt omdat zo'n treintje zich af laat leiden door een mooi laantje van donkere sparren: "Weet je wat, denkt hij, ik rijd een eindje met dat laantje mee, dat is aardig voor de passagiers. ${ }^{n 84}$ Op een wandeling bij de spoorbaan "had ik ook hier de uit mijn kindertijd overgehouden neiging om bij het zien van de roestigbruine rails met het glimmende glijvlak over de geteerde bielzen in het grint te droomen over die romantische vraag: vanwaar? waarheen?"

De drie zonen, inmiddels tussen de veertien en zeventien jaar, maken boottochtjes en gaan mee kerkjes kijken. Ze krijgen ijs, zmrzlina, en de verteller vraagt zich af hoe je zo'n woord met zo'n "openingsstoet van medeklinkers" uitspreekt.

Groot is zijn angst als hij met zijn zoons aan de rand van een diepe put staat. Hij houdt ze vast aan de ceintuur van hun jasjes. Dezelfde angst komt op, als een zoon wat lang onder water blijft bij het zwemmen tijdens een boottocht. Het neuriën van een melodietje stokt: "Tout va très bien .." Daarna de angst: ' $\mathrm{O}$, kind, waar ergens in de diepte ben je?' Pas een pagi- 
na later kan de verteller de tekst van het liedje verder neuriën "... madame la marquise. ${ }^{\text {pBs }}$

Aangrijpend is Coolens reconstructie van de gebeurtenissen in Lidice, het dorp waarvan de mannelijke bevolking als vergelding voor de moord op het SS-kopstuk Heydrich door de Duitsers werd uitgemoord. Hij vertelt hoe de Duitsers de niets vermoedende inwoners van het dorp 's nachts uit hun bed hebben gehaald en hoe de mannen en de jongens ouder dan vifftien jaar werden gescheiden van hun families: "Zoo gingen ze onder den sterrenhemel van den zomernacht, de moeders met de kinderen naar het schoolgebouw, de mannen en de jongens verderop naar het erf van de Horakhoeve. ${ }^{n 66}$ De laatsten wordt alles van waarde en de identiteitspapieren afgenomen. Het zijn er honderddrieënzeventig, van wie de oudste vierentachtig is en de jongste vijftien en twee maanden. Zij zien dat de vrouwen en kinderen met vrachtauto's worden weggevoerd en dat het dorp in brand wordt gestoken. Daarna zien ze dat soldaten matrassen aansjouwen en die als kogelvangers rechtop tegen de muren van de boerderij zetten. Vervolgens moeten er tien mannen voor de matrassen gaan staan. Steeds wordt een rij van tien mannen neergeschoten, waarop het vuurpeloton "met den dreunstap der laarzen" enkele schreden achterwaarts doet en een nieuwe rij voor hun neergemaaide dorpsgenoten treedt. Dit gaat door totdat er zeventien rijen liggen. "Zij lagen daarginds, daar, waar nu de wind zoo weemoedig en klagend door het gras waait. Daar lagen zij als rijen garven op het gemaaide veld. ${ }^{\text {87 }}$

De Duitsers hebben zelf foto's gemaakt van hun "dodenoogst" voor thuis. Het meest schokkend is nog, schrijft Coolen, dat de Duitsers meteen na de moord een officieel communiqué hebben uitgegeven waarin de represaillemaatregel bekend werd gemaakt. "De Duitsche regeering gaf daarmee te kennen, dat het een uitdrukking was van het moorddadige terreursysteem, dat zij openlijk beleed en verdedigde als leerstelsel van den staat." ${ }^{88}$ Coolen beschuldigt het hele Duitse volk, in al zijn geledingen, van medewerking aan het Nazi-stelsel: "Het heeft het gewild, het heeft het gehoorzaamd, het heeft het toegejuicht, het heeft van zijn roof geprofiteerd." ${ }^{\text {"89 }}$

Bij zijn indrukken van Praag speelt de politieke situatie een rol. Hij ziet in een park een Russische tank, die daar als oorlogsmonument staat. Hij vindt het geen mooi monument, maar beschrijft met sympathie hoe de tank op eigen kracht op zijn voetstuk is gereden. Als de tank boven is aangekomen en de dreunende motor wordt afgezet, "schudde ze, als een broedlustige gans, die op haar eieren gaat zitten, nog even heen en weer, voor ze goed zat." ${ }^{90}$

79 BvdB, Brief Coolen aan Jiri Pober, 17 april 1947.

80 BvdB, brief Coolen aan Jiri Pober, 5 augustus 1947.

81 BvdB, brief Ella Kazdova aan Coolen, 13 augustus 1947.

82 BvdB, Brief Coolen aan Kazdova, 5 september 1947.

83 BvdB, brief Coolen aan Ed. Hoomik, 29 september 1947.

84 Coolen. Tsjechische Suite, 32.

85 Coolen, Tsjechische Suite, 51.

86 Coolen, Tsjechische Suite, 110.

87 Coolen, Tsjechische Suite, 118-119.

88 Coolen, Tsjechische Suite, 131.

89 Coolen, Isjechische Suite, 134.

90 De tank zal tijdens de 'Fluwelen Revolutie' van 1990 rose geschilderd worden als protest tegen de Russen en het communistisch regime. 
Coolen benadrukt dat in Jalta was afgesproken dat de Russen Praag mochten bevrijden. Daarom moet het westen het niet raar vinden dat de vlag met hamer en sikkel voor de Tsjechen een vrijheidssymbool is geworden. Bovendien herinneren deze zich maar al te goed hoe Engeland en Frankrijk hun land in 1938 in de steek hadden gelaten. Een dokters. vrouw zei tegen hem dat de woorden van Chamberlain nog steeds in hun harten staan gebrand. Deze zei in het Engelse Lagerhuis, dat Engeland niet in de oorlog kon gaan voor de Tsjechen, "waarvan het nauwelijks iets wist."

Coolen wordt in Tsjecho-Slowakije ook aangesproken op het militaire optreden van Nederland in Indonesië [tijdens zijn verblijf start de eerste politionele actie, C.S.]. De wijze waarop dat gebeurt lijkt erg veel op de manier waarop de Sovjet-Unie zich met Tsjecho. Slowakije bemoeit, namelijk door het instellen van een regering van stromannen die vervolgens vraagt om troepen om de orde en rust te herstellen..$^{92}$ "Het beleid van de Nederlandsche regeering ten aanzien van Indonesië vond in Tsjechië algemeene afkeuring, maar men vroeg en luisterde naar de verklaring van dit beleid (voor zoover die verklaring te geven was, want de regeringsvoorlichting liet veel te wenschen over)," stelt Coolen vast." In de stad trekt een "fel en groot aanplakbiljet" zijn aandacht. Het betreft reclame voor een Tsjechische vertaling van Multatuli's Max Havelaar, die daar pas is uitgekomen.

Voorzichtig voegt Coolen steeds aan zijn verhalen toe dat het slechts de impressies van een toerist zijn. Zijn indruk is dat het samengaan met communisten binnen een democratisch concept als winst wordt beschouwd. De communisten regeren nu mee op verantwoordelijke posten en vormen niet langer een oppositie met alle onrust en stakingen van dien. Echter, zo zegt hij nogmaals, "het is niets dan een indruk en ik spreek slechts aarze. lend over het onderwerp zo gauw het politiek raakt waarvan ik weinig weet. ${ }^{\text {"94 }}$

\section{Veelzijdig boek}

Bij lezing van Tsjechische Suite wordt het gemis van een 'reisboek' over de reis naar het Midden-Oosten in 1935 nog eens extra ervaren. Coolens vaardigheden om landschappen, steden en mensen te beschrijven heeft hij volledig uitgebuit. Van veel hoofdstukken in dit boek straalt het genoegen van de reis nog af.

Het hoofdstuk over Lidice is een toppunt van vertellertalent en inlevingsvermogen. Vooral de beschrijving van de scheiding van de gezinnen is hartverscheurend [en, zoals de gebeurtenissen in Srebrenica van 1995 bewijzen, helaas nog steeds actueel, C.S.]. Hij heeft de mooie metafoor over de rijen doden als garven op een gemaaid veld, vifftien jaar eerder omgekeerd gebruikt in De schoone voleinding. Hier beschrijft hij het spoor van een maaimachine: "En achter dit spoor, dat naar de verte versmalt en verkleint, bezwijkt, als vallende mannen, het koren en ruischt in baren toe gestrekte rijen neer, waar de vele en snelle bindsters het toe garven binden en toe schoven zetten. ${ }^{195}$ Ook in zijn rede in Diksmuide, een week voor het uitbreken van de Tweede Wereldoorlog, heeft Coolen deze metafoor gebruikt. Toen sprak hij van "de neergevelde garvenlezing der jongelingschap," die daar herdacht werd.

Nieuw voor Coolen is dat hij zich in dit boek opvallend vaak politiek uitlaat, weliswaar steeds door zichzelf onderbroken met de mededeling dat hij van politiek geen verstand heeft. Hij ziet de sympathie van de jonge Tsjechoslowaakse democratische staat voor de Sovjet-Unie, die tenslotte de Duitsers verdreven heeft. 
Zijn teleurstelling is groot als tijdens het schrijven van dit boek een eind komt aan de zelfstandigheid van de jonge Tsjechische staat. In februari 1948 vindt een communistische staatsgreep plaats en kort daarna is het land volledig een vazalstaat van de Sovjet-Unie. In een slothoofdstuk herhaalt hij ten overvloede nog een keer dat zijn indrukken over politiek met de nodige aarzelingen zijn weergegeven: "Ik ben geen politicus. Ze [zijn indrukken, C.S.] voorzien de ontwikkeling van de politieke gebeurtenissen in Februari 1948 niet en zijn er ook geheel onafhankelijk van. ${ }^{-96}$

Van Duinkerken prijst het boek uitbundig in een brief ${ }^{77}$ aan Coolen en later ook in een recensie. In de kritiek schrijft hij dat Coolen "mede geschoold is bij het beste proza van de tachtigers." ${ }^{98}$ Zo'n reactie doet Coolen zeker in deze tijd goed en hij dankt Van Duinkerken voor de positieve recensie: "De omstandigheden van den laatsten tijd verhoogen het gevoel van zekerheid niet, en het is niet zonder huiver, dat men na zoo langen tijd voor het eerst weer een boek bij een vriend op tafel legt." Hij voegt er aan toe dat Streuvels, die een paar weken daarvoor bij hem op bezoek was, het 'boekje' ook zeer waardeert. Hij bewondert Streuvels zeer en het meest nog "om dat ongebroken behoud dier volkomen gaafheid tusschen zijn leven en zijn kunst. [...] Hoe lang gaat dat gave, sterke en grootsche werk nu al mee, nadat het er op geleken heeft, dat het na den vorigen oorlog zou worden verdrongen?" Hierin klinkt iets door van de twijfel van Coolen over zijn eigen vooroorlogse werk en de opkomst van de nieuwe generatie. Daarom treffen hem de loftuitingen van Van Duinkerken en Streuvels des te meer. ${ }^{99}$

De gedachten over de toekomst maken hem echter somber. Zijn geloof in de toekomst en in het overwinnen door de 'zachte krachten' heeft een knak gehad. Hij bewonderde de Tsjechen zo om hun kinderlijke naiveteit tegenover de politiek en moet nu weer zien hoe het geweld van de macht sterker is. Als hij eind 1948 benaderd wordt door Theun de Vries voor een initiatiefcomité voor de vrede weigert hij, omdat hij de controverse Europa/USA versus Rusland te versimpeld vindt. Hij gelooft niet dat er aan de ene kant allemaal oorlogsophitsers zitten en aan de andere kant allemaal duiven. ${ }^{100}$

De gevolgen van de communistische coup in Tsjecho-Slowakije zijn, commercieel gezien, voor Coolen rampzalig. Juist op het moment dat hij, na twee ellendige naoorlogse jaren, er weer bovenop begint te krabbelen, ziet hij een land met veel vrienden, veel lezers en een groot afzetgebied voor zijn boeken achter een ijzeren gordijn verdwijnen. Hoe snel

91 Hierna kon Hitler ongehinderd het Sudetenland inrijden. Hitler gebruikte als voorwendsel dat de Sudetenduitsers in Tsjechië slecht behandeld zouden worden.

92 Giebels, Beel, 217.

93 Coolen, Tsjechische suite, 201.

94 Coolen, Tsjechische Suite, 188.

95 Coolen, De schoone voleinding, 97-98.

96 Coolen, Tsjechische Suite, 231.

97 BA, brief Van Duinkerken aan Coolen, 14 oktober 1948.

98 Van Duinkerken, 'A. Coolen als reisverhaler'.

99 BA, brief Coolen aan Van Duinkerken, 8 november 1948.

100 LMDC, inv. nr. C 3485, brief Coolen aan Theun de Vries van 5 november 1948. 
dat gaat is af te lezen uit zijn correspondentie met Ella Kazdova, die op een gegeven moment alleen nog heimelijk via tussenpersonen kan verlopen. Tsjechische Suite dat al op de flap van een van zijn vertalingen staat aangekondigd, zal niet meer verschijnen in het land waar het over gaat. 


\section{Katholiek schrijver}

na de oorlog

"Er is eigenlijk geen verboden terrein voor de katholieke romancier." 1948-1949

In 1948 heeft Coolen al heel wat gepubliceerd: het oorlogsdagboek Bevrijd Vaderland, het boekenweekgeschenk De Ontmoeting en zijn reisboek over Tsjecho-Slowakije. Daarnaast heeft hij, wat hij zelf noemt, 'klein werk' onderhanden, zoals een sprookjesboek voor grote mensen, een bundel vertellingen en een aantal bijdragen aan een heiligenboek.

Ander 'klein werk' vormen zijn bijdragen aan de Katholieke Illustratie. Vanaf 1947 heeft hij daar geregelde inkomsten van. De artikelen zijn rijk verlucht met foto's en gaan allemaal over Brabant of over het platteland in zijn algemeenheid. Hij schrijft over boeren, boerenhuizen, de roggeoogst, de lente, de boomgaarden, de stal, de winter in en om de boerderij, het St. Oedenrodense peppelland en verder nog een hele reeks portretten van Brabantse steden, de Peel en de Beerse Overlaat.

In zijn woonplaats Waalre is kort na zijn terugkomst uit Tsjecho-Slowakije, in september 1947, zijn herdenkingsspel voor de Brabantse gevallenen opgevoerd. Het betreft een massaspel voor amateurs onder regie van Kees van Iersel. Aanvankelijk zouden de massaregisseur Carel Briels en mensen van de radiohoorspelkern er bij betrokken zijn, maar dit is vanwege de kosten niet doorgegaan.' Dergelijke massaspelen worden in de eerste jaren na de oorlog op veel plaatsen gespeeld, vaak met honderden figuranten en veel militair materieel. Het spel van Coolen in Waalre is kleinschaliger. Hierin vervult de Brabantse maagd de vertellersrol: "Gods zon van Mei scheen over de gansche lage landen uit een vredigen hemel van het puurste blauw [...] toen de kreet klonk: oorlog!" Het geheel is niet vrij van bombast, met spreekkoren van Duitse soldaten en aan het slot de zegevierende Prinses Irene-brigade als reddende engel.

Coolen zit in het Stichtingsbestuur van de herdenking der Brabantse gevallenen en blijft ook hierdoor emotioneel betrokken bij de verwerking van de oorlog. Coolen is dus druk bezig, maar toch is hij niet tevreden. Hij vindt dat zijn tijd te veel wordt versnipperd en dat hij er daardoor niet aan toekomt weer eens een roman te schrijven. In november 1947 klaagt hij hierover bij Oomes. "Ja Piet, het vorig jaar [...] konden gij noch wij weten, wat ons te wachten stond in dat jaar, waarvoor wij toen de beste wensen uitspraken. Al schrijvende zie ik het buiten sneeuwen en zie ik weer dat sneeuwlandschap terug waarin ons Peterke met zijn sleetje verloren liep." ${ }^{2}$ Coolen schrijft jaarlijks rond deze tijd een uitgebreide verjaardagswens aan Oomes. Na de oorlog worden deze brieven jaren op rij een

I CS, [kopie typoscript] Zoetmulder, Antoon Coolen en Waalre.

2 LMDC, inv. nr. C 3485, brief Coolen aan Oomes, 19 november 1947. 
verzuchting over stilstand en het niet toekomen aan het echte werk: een nieuwe roman. Er klinkt steeds een neerslachtige toon in door.

\section{Coolen en het katholicisme}

Natuurlijk is die sombere stemming voor een groot deel te verklaren uit het verlies van zijn zoontje en de voortdurende druk van zijn betrokkenheid bij de persstrijd in Deurne. Er is echter nog iets anders dat aan hem knaagt. Al twee jaar worden praatjes rondgestrooid over zijn geloofspraktijk, waarbij de vraag wordt gesteld of Coolen zijn plichten als katholiek wel naar behoren vervult.

De zaak is begonnen vlak na de oorlog, als hij toch nog even in beeld is als mogelijk bur. gemeester van Waalre. Het ambt is daar, na het verdwijnen van de NSB-burgemeester, weer vacant. Aan De Bourbon die dan weer voor korte tijd burgemeester van Oss is, schrijft Coolen in die tijd: "Jij wilt er dus van af, van je ambt, en ik ben er na aan toe het toegewezen te krijgen of niet. Want ernstige mededinger is Allard Derricks, die alles op haren en snaren zet, een audiëntie vroeg en kreeg bij den minister." ${ }^{3}$ Er blijkt kritiek te zijn op Coolens gedrag als katholiek en deze wordt geuit door het plaatselijk schoolhoofd. Het zal nooit boteren tussen onderwijzers en Coolen. Uiteindelijk heeft Coolen toen zelf besloten om de sollicitatie in te trekken. Ondanks de stiigende gezinsuitgaven, heeft hij het toch niet gedaan, want toen puntje bij paaltje kwam, "schrok ik bij een hernieuwde uitnoodiging tot sollicitatie zoo voor het verlies van het heerlijk bezit der dagelijkse vrijheid terug, dat ik de sollicitatie heb teruggenomen." ${ }^{-4}$ Ook de genoemde Derricks wordt het niet. Er komt iemand van buiten, de heer Mol, die eerder burgemeester van Dussen was en die Coolen nog kent uit de provinciale Monumentencommissie.

De kritiek op de geloofspraktijk van Coolen komt in die jaren niet alleen van een dorpsschoolhoofd. Ook in de kolommen van het blad van het aartsbisdom Utrecht, Omhoog, wordt Coolen aangevallen op zijn katholicisme. De schrijver is Albert Kuyle. Het bereik van dit blad is hoog, want de kerkelijke bladen beschikken kort na de bevrijding over veel papier en worden veel gelezen. ${ }^{5} \mathrm{Al}$ op 22 juli 1945 verdedigt het weekblad Christofoor Coolen tegen deze roddel:

"Wij hopen, dat men geleerd heeft, de beteekenis der kunstenaars iets ruimer en iets grooter te zien dan men voor de oorlog gewend was en dat men niet te werk gaat met het verspreiden van ordinaire lasterpraatjes over gemis aan sensus catholicus [...] lk zinspeel in het bijzonder op het geval van den katholieken romanschrijver, die, woonachtig in een klein dorp, daar iederen zondag, voor iedereen waarneembaar, met zijn gezin naar de kerk gaat, en van wien men zich nochtans niet ontziet, bij allerhande dagblad-en tijdschriftredacties de beschuldiging te lanceren, dat hij niet meer zou practiseeren als katholiek." ${ }^{n}$

Het nieuwe Nederland dat uit zijn as is verrezen, blijkt nog veel kenmerken van het vooroorlogse te hebben. De teleurstelling van Coolen over de niet objectieve zuivering en de terugkeer van de hokjesgeest is groot. Die geest weerspiegelt zich in de pers. Tijdens de oorlog zijn er onder de verzetsbladen als Vrij Nederland, Het Parool, Trouw, De Ploeg, De Vrije Kunstenaar en De Vrije Katheder ook twee met een katholieke signatuur: Christofoor en Je Maintiendrai. Het blad Je Maintiendrai komt voort uit katholieke ex-leden van de Nationale Unie, met Geert Ruygers als voorman, Christofoor is meer een blad van katholieke jongeren. 
Ook het blad Je Maintiendrai zoekt in die tijd contact met Coolen, maar in hun richting is Coolen afhoudend: "'t gedram van die Je Maintiendrai menschen begint me te vervelen. $\mathrm{Zij}$ moeten niet denken dat zij met een bijdrage van mij in hun blad mij een plezier doen - en ik zie er van af er hun een plezier mee te doen." Hier speelt de achtergrond van het blad een rol. De redactie heeft wortels in de Nederlandse Unie en Brabantia Nostra en heeft kennelijk geredeneerd dat Coolen dus bij hen hoort.

\section{De Linie}

Op 28 maart 1946 verschijnt het eerste nummer van het blad De Linie, dat onder leiding van jezuieten de katholieke levenshouding weer op alle terreinen gaat propageren. Het blad heeft de wind in de rug, want de bisschoppen van Den Bosch en Breda hadden zich al op 21 december 1944 met een herderlijk schrijven tot de gelovigen gericht, waarin ze pleitten voor een terugkeer van de katholieke organisaties en een verbod voor katholieken op het toetreden tot nieuwe verenigingen. Na de bevrijding van heel Nederland heeft het Episcopaat bij de verkiezingen in mei r 946 de katholieken opgeroepen om op de Katholieke Volkspartij te stemmen. ${ }^{8}$ De Linie zet al snel de aanval in op Coolen en andere katholieke schrijvers als Jan Engelman en Bert Voeten.

Het initiatief tot oprichting van De Linie is uitgegaan van pater J.C. Creyghton s.j.. Deze man, in r 901 geboren, is sinds r 922 lid van de Sociëteit van Jezus. Hij was enthousiast over de door Romano Guardini geïnspireerde katholieke jeugdbeweging Quickborn en had van daruit contacten met de Duitse Wandervögel. Deze jongeren beleden hun voorkeur voor de ongerepte natuur en hun afkeer van sigaretten en drank. ${ }^{9}$ Eind jaren dertig schreef hij voor De Maasbode. Tijdens de oorlog was hij werkzaam in een retraitehuis in Maastricht. Na de oorlog wil Creyghton zijn journalistieke ervaring gebruiken om een katholiek blad op te richten, dat in de eerste plaats een strijdmiddel tegen het communisme zal zijn. Creyghton gelooft in sterke persoonlijkheden als Léon Bloy en Pieter van der Meer de Walcheren. ${ }^{10}$

$\mathrm{Er}$ is na de oorlog echter ook een stroming onder katholieken en protestants-christelijken die een 'doorbraak' tussen de kerkelijke en de socialistische zuilen wil bereiken. In feite zien we dezelfde tegenstelling als in het begin van de twintigste eeuw: de strijd tussen integralisten en modernisten, tussen rechts en links, tussen behoudend en vooruitstrevend. Meteen na de bevrijding van Nederland heeft Coolen zich aangesloten bij een groepje katholieke schrijvers die zich niet wilde laten terugdringen in de oude zuilen. Hiertoe behoren onder andere Jan Engelman, Cola Debrot, Rein Blijstra en Louis de Bourbon. "Van Duinkerken is de informele leider en stelt voor dat "wij met elkaar in contact blijven en

3 LMDC, inv. nr. C 3485, brief Coolen aan De Bourbon, 24 juni 1945.

4 LMDC, inv. nr. C 3485, brief Coolen aan Dirk Coster, 16 juni 1947.

5 Van der Plas, Daarom, mijnheer, 360.

6 Van Duinkerken, Antoon Coolen, 96-97.

7 BA, brief Coolen aan Van Duinkerken, 10 juli 1945.

8 Brief Episcopaat van 4 mei 1946, geciteerd in: De Tijd, 13 mei 1946.

9 Boersema, De Linie, 7.

10 Boersema, De Linie, 22.

11 Groeneweg, 'Antoon Coolen en het katholicisme', 75. 
enige malen per jaar samen komen ter bespreking van onze collectieve houding in de komende ontwikkeling., ${ }^{12}$ Ook dan zien de modernistische katholieken mogelijkheden voor een synthese tussen socialisme en christendom. De bladen Je Maintiendrai en Christofoor pleiten voor het zogenoemde 'personalistische socialisme'. Dit is een visie op het socialisme waarbij het collectivisme en de staatsinvloed iets meer naar de achtergrond verdwijnen en waarin vooral de rechten van de persoon worden verdedigd. Zij streven naar verbindingen met de nieuwe socialistische partij, de PvdA. Deze twee bladen nemen het initiatief om te komen tot een Nederlandse Volksbeweging in april r $945 .{ }^{13} \mathrm{Al}$ snel blijkt echter dat bij de verkiezingen van mei 1946 de oude zuilen weer terugkeren. Hiermee verdwijnt de eenheid die in het verzet was ontstaan.

Zo gauw het blad De Linie begint te verschijnen, blijkt dat veel medewerkers voortko. men uit kringen van integralisten en ook uit fascistisch georiënteerde organisaties als Zwart Front en het blad De Nieuwe Gemeenschap. Redactiesecretaris is A. Th. Mertens, die we nog kennen als rechtenstudent en hoofdredacteur van het Nijmeegse studentenblad Vox Carolina met de spotprent met Van Duinkerken in de bierpul en Coolen als een van de ondersteuners. We zien er Kropman, de politieke redacteur van De Tijd, die in r 920 overstapte naar De Nieuwe Eeuw van Pieter van der Meer de Walcheren. Kropman was daarna met Lutkie lid van het erecomité bij de huldiging van de integralist Kralik. Ook Albert Kuyle, die nota bene een tijdelijk schrijfverbod heeft, publiceert er in met ondertekening K. Zijn aartsvijand Van Duinkerken valt hij aan, omdat deze bij een tentoonstelling samen op één podium heeft gestaan met Theun de Vries. Deze laatste is volgens Kuyle als com. munist een supporter van de beulen van de Hongaarse kardinaal Mindszenty. ${ }^{14}$

De Linie is een strijdblad, dat zich in de eerste plaats tegen het communisme keert, maar daarnaast evenzeer tegen geloofsgenoten, die niet recht in de leer zijn en de Thomistische wereldorde en de katholieke moraalleer geweld aan doen. Een berucht voorbeeld is de aanval van Creyghton op de katholieke dichter Bertus Aafjes vanwege een episode uit Een voetreis naar Rome. De kop in De Linie van 23 augustus 1946 luidt: "Vastberaden verzet tegen de propagandisten van zonde en heidendom. Ook al dichten zij nog zo fraai als Bertus Aafjes." Creyghton doelt vooral op de passage waarin de hoofdpersoon de nacht in een hotel doorbrengt met een meisje en haar 's morgens weer verlaat. De rel die over deze dichterlijke one-night-stand ontstaat is zeer groot. Dat geldt ook voor het effect op de verkoop: de eerste druk is in een paar weken uitverkocht, een unicum voor een dichtbundel.

Van Duinkerken laat een scherp protest tegen Creyghton horen in De Tijd. Het is al zo moeilijk om het katholieke volksdeel voor dichtkunst te interesseren, schrijft hij. Aangezien "onze dichters stelselmatig voor onbetrouwbare halve-garen worden gehouden," zocht een relatief groot aantal van hen "een klankbodem bij nationaal-socialistische organisaties," omdat ze meenden dat ze daar wel werden gehoord. "Niet de dichters zelf isoleren zich. Zij worden geïsoleerd." Van Duinkerken bedoelt hiermee dat de katholieke clerus zelf, door zijn nimmer aflatend waarschuwen tegen slechte boeken, de dichters en schrijvers de kerk uit heeft gejaagd. ${ }^{15}$

\section{'Splendid isolation'}

Welke rol speelt Coolen nu zelf in deze strijd tussen behoudende en vooruitstrevende katholieken? Zijn naam wordt regelmatig genoemd en hij zou zich dus in het debat kun- 
nen mengen. Echter, evenals in de tijd van het regionalismedebat onthoudt Coolen zich ook nu van publiek commentaar. Alleen uit persoonlijke brieven blijkt wat hij er van denkt. Opnieuw zijn het anderen, vooral Van Duinkerken, die hem verdedigen tegen de aanvallen.

Gedurende het hele jaar I946, waarin De Linie begint te verschijnen, is het steeds weer Van Duinkerken die aangevallen schrijvers als Aafjes, Coolen en Engelman verdedigt. Daarbij wijst hij er onder andere op dat de medewerker K. [Kuyle, C.S.] een auteur is die door de Eereraad voor Letterkunde tot I januari I 949 van openbare publicatie is uitgesloten.

Coolen zelf vermoedt dat ook de Deurnese pastoor er achter zit. "Van een officiële of niet officiële breuk met de kerk is geen sprake - maar ik weet uit welke hoek de wind waait, er wordt ijverig met het praatje gecolporteerd door sommige clerici die in de strijd der Deurnesche verhoudingen tegenover mij staan - als je eens wist hoe grof en plompverloren hun strijdmethoden zijn." ${ }^{16}$

Als Kuyle in het blad Omhoog wéér een negatief artikel over de geloofspraktijk van Coolen heeft geschreven, reageert Van Duinkerken daarop in De Tijd: "Het is nu januari 1947 en het bedoelde praatje [...] wordt nog steeds rondgestrooid. Een der meest eminente katholieke boekhandelaren van Nederland verzekerde mij, er zeer ernstig van onder de indruk te zijn gebracht, omdat het hem met grote stelligheid werd verteld. Nochtans is het laster."

Van Duinkerken is er van overtuigd dat er "van zekere zijde" een consigne is gegeven, dat inhoudt dat iedere dichter die in de oorlog 'goed' was, nu automatisch als geen goed katholiek of als geen goed dichter wordt aangemerkt. In een eerste artikel, van 2 januari, heeft hij namen weggelaten, maar in een vervolgartikel van II januari 1947 noemt Van Duinkerken wél namen. Het consigne komt volgens hem van propagandisten van het voormalige Zwart Front. Daarna noemt hij namen van belasterde auteurs en dichters, onder wie Coolen.

Aan Coolen schrijft Van Duinkerken dat hij diens naam wel heeft móeten noemen in De Tijd om de infame actie van Kuyle tegen katholieke schrijvers en kunstenaars te ontmaskeren. Hij weet niet of Coolen deze zaak volgt, maar raadt hem aan zich op de hoogte te stellen. Van Duinkerken vermoedt kennelijk, en met reden, dat Coolen zich op dit gebied wat afzijdig houdt. Voor de oorlog reageerde Coolen soms nog dezelfde avond op een artikel van Van Duinkerken in De Tijd, zoals in de Serenitas-affaire. Tijdens de oorlog heeft hij vaak tegen vrienden gezegd dat hij geen kranten meer leest. Het kan zijn dat die opmerking bij Van Duinkerken is blijven hangen. Hij waarschuwt Coolen vooral geen

12 LMDC, inv. nr. VD 3261, brief Van Duinkerken aan De Bourbon, 14 mei 1945.

13 Boersema, De Linie, 15-16.

14 Kiuyle] in: De Linie, 11 februari 1949. Geciteerd in: Boersema, De Linie, 189. Kardinaal Mindszenty (18921975) werd in 1948 door het communistisch regime van Hongarije gevangen genomen op beschuldiging van staatsgevaarlijke activiteiten.

15 Van Duinkerken, 'Een voetreis naar Rome'.

16 LMDC, inv, nr. C 3485, brief Coolen aan Oomes, 19 november 1946. De Vaamse schrijver Walschap, die veel meer een polemist was dan Coolen, brak officieel met de Kerk in zijn essay $\mathrm{Nu}$, vaarwel dan, 1939

17 Van Duinkerken, 'Uitgedaagd verweer'. 
schriftelijke verklaringen af te geven "waarin je beweert, je niet bewust te zijn, door Kuyle belasterd te worden of iets van dien aard. Er worden blijkbaar zulke stukken verzameld." ${ }^{\text {"k }}$

Coolen gaat in zijn antwoord niet echt op de zaak in. Hij vindt het maar niets dat deze zaken in het openbaar behandeld worden: "Met zulke artikelen, die b.v. ook moeilijk uit de handen der jongens te houden zijn, zit men midden in het embarras der opspraak." ${ }^{19}$ Van de andere kant mag Kuyle ook geen vrijbrief krijgen. Hij belooft nooit een schriftelijke verklaring af te geven en bedankt Van Duinkerken voor zijn "warmgestemde verdediging."

Godfried Bomans twijfelt aan de consigne-theorie van Van Duinkerken en informeert daarnaar bij Coolen. Bomans heeft in die tijd regelmatig contact met Coolen, omdat ze samen werken aan een boek met verhalen over 'liefde, dood en minne'. Ook Bomans ziet Coolen als iemand die zich ver van het strijdgewoel houdt: "Ik denk vaak aan de Wijze uit Waalre, die in splendid isolation vanuit zijn burcht op dit gewoel neerziet met den Glimlach van Goethe, der dieser Welt auch schon lange war abhanden gekommen." ${ }^{20}$

De hoofdredacteur van de Volkskrant heeft aan Bomans gevraagd stelling te nemen in de controverse tussen Van Duinkerken en De Linie. Bomans informeert daarom bij Coolen of Van Duinkerkens visie juist is: "Ik bedoel dit: of je van meening bent dat 't gerucht, als zou je van het Katholiek geloof eenige distantie genomen hebben, het resultaat is van een soort consigne, uitgegeven door de bij monde van Van Duinkerken gesignaleerde centra le." ${ }^{\text {2l }}$ Coolen antwoordt dat hij niet weet of er een centraal consigne is afgegeven. Hij vindt het roeren en stoken van de voormalige "Zwart-Fronters" wel heel merkwaardig. Hij herinnert zich een gesprek met Van Duinkerken in 1943 , waarin deze toen al voorspelde welke uitweg Kuyle's ressentiment zou zoeken en van welke verdachtmakingen hij gebruik zou maken. Coolen vindt Kuyle als criticus corrupt en onbetrouwbaar. Hij stelt dat het de katholieke dag-en weekbladpers niet tot eer strekt om zo'n rancuneus hypocriet als Kuyle de gelegenheid te bieden Van Duinkerken er van te beschuldigen dat hij het gelaat van katholiek Nederland schendt. ${ }^{22}$

Coolen heeft Kuyle ook na zijn vertrek bij De Gemeenschap nog lange tijd bewonderd om zijn schrijfkunst, zelfs als Kuyle zich negatief over hem uitliet. Vanaf nu zijn ze echter voorgoed elkaars opponenten.

Enkele maanden later roemt Bomans in zijn rubriek in de Volkskrant het katholicisme van Coolen "dat, nimmer leerstellig betogend, nochtans in de vanzelfsprekendheid, waarmee hij de christelijke levensbeschouwing in zijn figuren weet te doen uitbloeien, meer werfkracht bezit dan de ietwat nadrukkelijke agressiviteit, die tegenwoordig schijnt in zwang te komen."23

De agressiviteit vanuit De Linie (lees Kuyle) jegens Coolen blijft aanhouden. In het voorjaar van 1949 dreigt er weer een belastend artikel in De Linie te verschijnen, weet Van Duinkerken. Die informatie krijgt hij via Letterenredacteur Boeren van dat blad. Nu gaat het niet over Coolens katholicisme, maar over zijn relatie tot de Duitsers tijdens de bezet. ting. Van Duinkerken betreurt het dat de almaar uitgestelde monografie over Coolen van zijn hand nog steeds niet verschenen is, omdat hij daarin uitgelegd heeft hoe de onenig. heid tussen Coolen en Kuyle is ontstaan. ${ }^{24}$ Die uitleg zou van pas komen, "juist nu telkens het gerucht opduikt, dat in de Linie een publicatie over jou zal komen, waarin je beschul digd wordt, geld van de Duitsers te hebben aangenomen." ${ }^{25}$ Deze onthulling wordt al 
wekenlang aangekondigd zonder dat de echte onthulling volgt, wat volgens Van Duinkerken een vorm van chantage is. Coolen antwoordt dat hij al door Janus van Domburg, redacteur van De Tijd speciaal belast met film, is gewaarschuwd. Het is kennelijk de bedoeling dat Van Domburg Coolen verdedigt als het nodig is: "Ik heb hem wat gegevens gestuurd waarom hij vroeg, en hij is zeker wel gereed als Kuyle in De Linie voor den dag komt. ${ }^{\text {"26 }}$ Coolen zelf tilt er niet zo zwaar aan, al neemt zijn aversie tegen Kuyle er alleen maar door toe. Hij vindt Kuyle een "griezel" die een vals, rancuneus spel speelt.

Deze 'griezel' zit echter alweer in een initiatiefgroep, die een vereniging van katholieke schrijvers, Scriptores Catholici, wil oprichten. Zijn motief hiervoor is duister, maar waarschijnlijk wil hij door een strenge ballotage voor deze club de scheiding der geesten bij de katholieken zichtbaar maken. Bij de groep onder leiding van de schrijver Dick Ouwendijk zijn ook Jan Derks, de hoofdredacteur van De Tijd, Gabriël Smit en Bernard Verhoeven betrokken. ${ }^{27}$ Ook het aartsbisdom Utrecht heeft er wel oren naar.

Van Duinkerken vraagt zich in Roeping af of er wel behoefte is aan zo'n vereniging. In dit artikel refereert Van Duinkerken aan de Kultuurkamer. Schrijvers laten zich niet in een dwingend verband organiseren. Men kan ze niet op afroep een gelegenheidsspel laten schrijven. Schrijvers hebben geen behoefte aan een tuchtraad, een arbiter of een vakorganisatie. Hij pleit voor spontaniteit, zoals nu bij de Groot-Kempische Cultuurdagen en vroeger bij De Gemeenschap. ${ }^{28}$ Verontwaardigd schrijft hij aan Coolen, dat de groep zelfs Bomans niet katholiek genoeg vindt, maar dat 'foute' schrijvers als Chris de Graaff en Gerard Wijdeveld meteen lid moeten worden.

Van Duinkerken gaat er nog steeds vanuit dat Coolen deze zaken nauwelijks volgt. $\mathrm{Nu}$ spoort hij hem aan tot actie: "Misschien krijgt de zaak in het geheel geen gevolg, doch zou ze levendig in discussie komen in de bladen, dan is het wellicht goed, dat ook jij ergens je stem laat horen. Een bond kan op het ogenblik meer kwaad dan goed aanrichten. ${ }^{n 29}$

Coolen reageert op deze regelrechte oproep tot actie voorzichtig. Ook hij is tegen de oprichting van een vereniging van katholieke letterkundigen. Hij zal er te zijner tijd graag over schrijven, zegt hij [wat echter niet zal gebeuren, C.S.]. Hij herinnert Van Duinkerken eraan dat hij er eigenlijk al ooit over geschreven heeft. In december 1943 heeft hij met onder andere Bernard Verhoeven deelgenomen aan een discussie op de pastorie van deken Reintjes in Maarssen over "kunstbeoefening door katholieken." Hier kwam ook de vraag

18 BA, brief Van Duinkerken aan Coolen, 17 januari 1947.

19 BA, brief Coolen aan Van Duinkerken, 18 januari 1947.

20 FPC, kopie brief Bomans aan Coolen, 31 december 1946, Bomansgenootschap.

21 FPC, kopie brief Bomans aan Coolen, 16 januari 1947, Bomansgenootschap.

22 FPC, afschrift brief Coolen aan Bomans, 30 januari 1947.

23 Bomans, 'Antoon Coolen vijftig jaar'.

24 Van Duinkerken doelt op de affaire in 1933 binnen De Gemeenschap, waar Coolen ageerde tegen een plan van Kuyle om samenwerking te zoeken met het blad De Stormer.

25 BA, brief Van Duinkerken aan Coolen, 23 maart 1949.

26 BA, brief Coolen aan Van Duinkerken, 29 maart 1949.

27 Van der Plas, Daarom, mijnheer, 405.

28 Van Duinkerken, 'Is er een behoefte aan een vereniging'.

29 BA, brief van Van Duinkerken aan Coolen, 23 maart 1949. 
naar voren over een naoorlogse organisatie van katholieke kunstenaars. Coolen heeft toen een prae-advies geschreven op verzoek van de secretaris van kardinaal De Jong, die het aan zijn superieur ter kennis heeft gebracht. "Ik heb me daarin over de vraag van een vereeniging van Katholieke letterkundigen uitgesproken." Hij vermeldt niet hoe de opdracht luid. de en wat zijn uitspraak was, maar wel dat hij zich daarna heeft teruggetrokken en het contact aan Bernard Verhoeven heeft overgelaten. Geen wonder dus dat deze naam nu opduikt en dat Verhoeven "zijn initiatief van toen thans voortzet met de zonderlinge groep" die Van Duinkerken noemt. ${ }^{30}$

Aartsbisschop de Jong had al in 1942 aan rector van Helvoort gevraagd om een rapport over dit onderwerp. In juni 1943 liet hij via zijn secretaris weten dat het terrein genoegzaam verkend was. Hij wilde kennelijk niemand op de tenen trappen en niet verder gaan, "omdat Uw plannen ten nauwste samenhangen met de kwestie van het herstel onzer katholieke sociale organisaties [en] zeer velen toch meenen, dat het eenige juiste standpunt is, dat na den oorlog eerst hersteld moet worden wat de bezetter wederrechtelijk ophief, om daarna zelf te beslissen, hoe het verder gaan zal." ${ }^{31}$ De voorbereidingen gingen toch door want in januari 1944 schrijft Van Helvoort dat een commissie bezig is met een plan "wat men na den oorlog zal kunnen ondernemen op de verschillende terreinen van kunst." In deze commissie zaten naast Coolen deken Rientjes, rector van Helvoort, professor Granpré Molière, ir. De Bruijn, professor Snijders, H. Andriessen, B. Verhoeven, jhr. Van Nispen tot Sevenaer, dr. Knipping o.f.m., Joan Colette, H. van den Eerenbeemt, Albert van Dalsum en F. Berends. ${ }^{32}$ De secretaris van de aartsbisschop vond het een goed stuk - "geen kunstenaarslyriek" - maar de aartsbisschop had voorlopig geen tijd. In I946 werd deken Rientjes voorzitter van de Stichting Nederlandsche Katholieke Kunst.

Ook een tweede poging van Van Duinkerken om Coolen tot openlijke stellingname te brengen mislukt, wanneer in de zomer van 1949 zich weer een affaire afspeelt in het katholieke schrijverskamp. Deze keer is Gabriël Smit het slachtoffer.

In een gedicht in Roeping wordt kritiek geleverd op zijn geloofspraktijk. Smit zou te positief hebben geschreven over het Nieuw Vlaams Tijdschrift en over de zeventigjarige schrijver Herman Teirlinck. ${ }^{33}$ Van Duinkerken stuurt Coolen een afschrift van zijn brief aan hoofdredacteur Munnichs, waarin hij deze verwijt dat de lezers hier gesuggereerd wordt dat Smit aan godsdienstverzaking doet. Hij voegt eraan toe dat hij een afschrift aan Coolen stuurt, van wiens hand juist in die tijd een toneelspel in afleveringen in Roepingverschijnt, "in de vaste overtuiging, dat hij het verder afdrukken van zijn spel, St. Geerten Minne, in Roeping verbieden zal." Van Duinkerken besluit de brief met de opmerking dat hij geen genoegen neemt met een gestameld excuusje; hij wil volledig eerherstel voor Smit. ${ }^{4}$

Hiermee heeft hij Coolen dus voor het blok gezet. Deze kan nu immers bijna niet anders dan verdere publicatie van zijn stuk verbieden. Coolen belooft Van Duinkerken dat hij geen toestemming voor verdere publicatie van zijn toneelspel zal geven, voordat Munnichs met een "zeer mannelijke en loyale herroeping en volledig eerherstel" is gekomen. ${ }^{35}$ Aan Munnichs schrijft Coolen dat het gedicht "een reputatie-schennende eerroof en een grove laster" voor Gabriël Smit inhoudt. ${ }^{36}$ 
Vervolgens dwingt Van Duinkerken Munnichs om de zaak bij de lezers van Roeping recht te zetten. Het verwijt dat Munnichs hem gemaakt heeft, namelijk dat Van Duinkerken demagogie gebruikte door Coolen in het conflict te betrekken, wijst hij af. "Ik heb Coolen niet willen beïnvloeden, maar ik heb vertrouwd op zijn gevoelens, die ik raden kan. De zak verontwaardigde hem zo mogelijk nog dieper dan mij en zijn reactie moet Gij werkelijk als geheel persoonlijk verantwoord beschouwen." Hij geeft toe dat het sturen van een 'doorslag' van zijn brief aan Coolen de indruk kan hebben gewekt dat hij Coolen tot partij wilde maken en zegt dat te betreuren. ${ }^{37}$

Munnichs gaat overstag en belooft een verklaring tegenover de lezers van Roeping te plaatsen. Coolen is blij dat de kwestie uit de wereld is en geeft Munnichs, vooruitlopend op zijn verklaring, toestemming om het tweede bedrijf van St. Geerten Minne te plaatsten. ${ }^{38} \mathrm{De}$ verklaring die uiteindelijk in september [het meinummer van Roeping is weer eens ernstig vertraagd, C.S.] verschijnt, stelt niet veel voor. Van Duinkerken vindt het slechts een "schoorvoetend" toegeven dat men het betreurt dat het gedichtje geplaatst is. Hij heeft echter besloten een punt achter het incident te zetten. Coolen moet maar zien wat hij doet. Als hij er nog over wil schrijven, hoeft hij dat niet voor hem of voor Smit te doen. "Mij persoonlijk kan het hele geval niet meer schelen. Het beneemt mij alleen de lust met Roeping nog samen te werken. ${ }^{-39} \mathrm{Had}$ dat maar eerder gezegd, zal Coolen gedacht hebben, want de hele kwestie ligt hem toch niet zo na aan het hart.

\section{De romancier en het leven}

Aan het eind van de jaren veertig en het begin van de jaren vijftig verplaatst de discussie over schrijvers en katholicisme zich. Stonden aanvankelijk de geloofsbeleving en de geloofspraktijk van de schrijver centraal, nu leeft de discussie over de inhoud van het werk weer op. Waarover mag de katholieke romancier schrijven en waarover niet? Het is een discussie die sterk doet denken aan het verschil van opvatting over het boek Serenitas van Helman in 1930. Toen stelde Van Duinkerken dat een katholiek schrijver praktisch over elk onderwerp en iedere menselijke activiteit kan schrijven. Coolen was het met die stelling eens, maar schreef toen aan in een brief Van Duinkerken dat hij het boek in kwestie

$30 \mathrm{BA}$, brief Coolen aan Van Duinkerken, 29 maart 1949.

31 RAU, Archief Aartsbisdom Utrecht, inv. nr. 449, brief secretaris mgr. De Jong aan rector van Helvoort, 5 juni 1943.

32 RAU, inv, nr, 449, bijlage H 'De na-oorlogse organisatie der Katholieke Kunstenaars in Nederland' (21 januari 1944) bij het rapport van de Stichting Nederlandsche Katholieke Cultuur aangeboden op 29 april 1944.

33 Het gaat om een artikel van Gabriël Smit in de Volkskrant van 24 februari 1949. Smit was daarvoor ook al aangevallen in het Oudejaarsnummer van De Linie, eind 1948. Hierin werd hem veranderlijkheid van inborst verweten. Het hekeldicht tegen Smit verscheen in Roeping, jrg. 26, nr. 3/4, 268 onder de titel: Tu quoque, Gabriel!' Er komen passages in voor als: "iij nam 't onkruid in je schoot, toen Satan zaaide met de dood."

34 BA, brief Van Duinkerken aan Munnichs, 23 juni 1949.

35 BA, brief Atoon Coolen aan Van Duinkerken, 28 juni 1949.

36 BA, afschrift brief Antoon Coolen aan Munnichs, 2 juli 1949.

37 BA, afschrift brief Van Duinkerken aan Munnichs, 28 juli 1949.

38 BA, brief Coolen aan Van Duinkerken, 2 augustus 1949.

39 BA, brief Van Duinkerken aan Coolen, 3 september 1949. 
heel slecht vond. Coolen zal zich nu ook in het openbaar op het standpunt stellen dat een katholiek over alles kan schrijven.

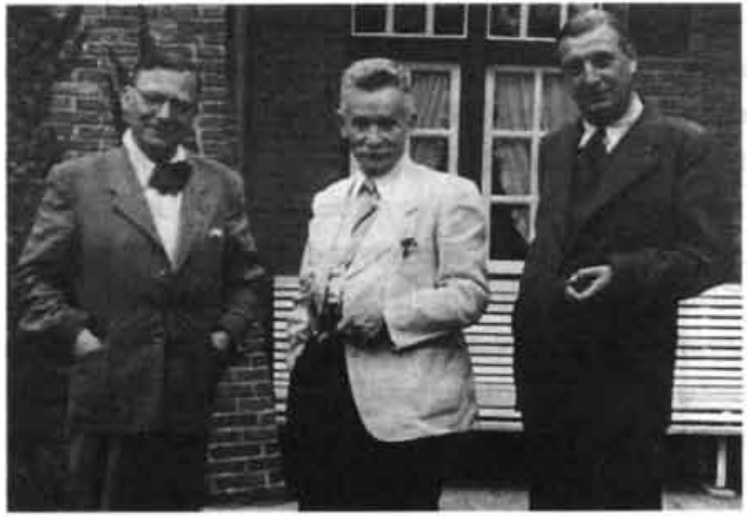

Coolen, Streuvels en Van Duinkerken.

In 1950 spreekt hij zich duide. lijk uit op een feestelijke bijeenkomst ter gelegenheid van het gouden jubileum van het blad Dietsche Warande en Belfort. Deze wordt gehouden aan de Belgische kust, in Mariakerke bij Oostende. In het weekend van 20 en 21 mei I950 verza. melen zich hier honderd schrijvers, dichters, critici en lezers. Op de eerste avond bijt Antoon Coolen het spits af met een lezing. ${ }^{40} \mathrm{Na}$ hem spreken Johan Daisne, Gaston Duribreux en Paul Lebeau. Allemaal gaan ze in op het thema 'De Romancier en het Leven.' De inleidingen worden in de volgende aflevering van het jubilerende blad gepubliceerd.

Coolen houdt zijn gehoor voor dat iedereen die een roman schrijft zich met het leven bezig houdt. Als een schrijver dat niet zou doen, zou de roman levenloos zijn. Een romanschrijver geeft echter nooit het héle leven, zelfs Balzac niet in zijn grote cyclus de Comédie Humaine. De wereld van Balzac is groter dan die van veel andere romanschrijvers, maar zij blijft betrekkelijk. Bovendien blijft zij zijn wereld, "zooals de wereld van iederen roman schrijver diens eigen wereld in de eigen betrekkelijkheid en het eigen klimaat is. Zij allen geven een segment van het leven." Mauriac doet dat binnen het typisch regionalistisch klimaat van de Garonne, Graham Greene in zijn kosmopolitische Angelsaksiche wereld en Dostojevski in zijn Russische wereld. Al die schrijvers leggen hun eigen kijk op het leven in de roman:

"Als ik bijvoorbeeld graag het landelijke leven beschrijf, een zekeren eenvoud van smart en van geluk, de reacties op de beslissende levensmomenten, als ik graag den onderstroom van primitieve drijfkrachten in het menschelijk bewustzijn naspoor en den eenvoudigen metaphysischen weerslag erin naga van, laat ik ook maar weer zeg. gen: een primitief, maar hecht eeuwigheidsgevoel of -besef, dan zal dat weinig indruk maken op den romanschrijver van de intellectueel toegespitste, cerebrale of wijsgeerige probleemstelling. Vergiliaansch en Sartreaansch verdragen elkaar niet."

Deze opvatting verwoordde Coolen al lang daarvoor op een literaire manier in Dorp aan de rivier. Als dokter Van Taeke zijn arrogante, intellectuele vervanger De Pater heeft weggestuurd zoekt hij troost bij zijn boekenkast: "Er stonden veel boeken van schrijvers die zeer scherpzinnig zijn en alles kunnen ontleden. Daar nam hij niet een boek van. Hij nam een ander [...] Hij las Vergilius. ${ }^{* 41}$

Uit de koppeling van "de primitieve drijfkrachten" in de mens aan een "eeuwigheids gevoel" blijkt dat Coolen zich toch iets van de visie van Van Duinkerken op de "katholi citeit' van zijn romans heeft eigen gemaakt. 
Coolen ziet het afreageren van de ervaring en het uitschrijven van wensdromen als twee polen van de romankunst. Hij volgt hierin Mauriac, die zegt: "Onze romanpersonages [...] zijn dikwijls de zondebokken, die we beladen met al de zonden welke we niet hebben bedreven, of de Uebermenschen en halfgoden, die we met de taak belasten de heldendaden te verrichten, waarvoor we onszelf te zwak voelen."

De hedendaagse roman gaat niet meer over karakters, maar over de ziel en haar roerselen. Deze gaat daarin heel ver, vindt Coolen. De Freudiaanse psychoanalyse wordt op die manier tot bellettrie gemaakt. Daarbij ziet hij de laatste tijd nog iets anders naar voren komen, namelijk de onverbloemde behandeling van het kwaad. Deze is ook te constateren bij de katholieke auteur en in de katholieke roman. Spottend zegt hij dat hij in zijn jeugd dikwijls over de 'slechte roman' heeft horen spreken. Toen was het wóórd 'roman' bijna een synoniem voor slechtheid. Het is goed dat dat nu niet meer gebeurt, want schrijvers zijn volstrekt autonoom. "Juist de schrijver die het leven transcendent ziet, kan onverschrokken en onverbloemd het kwaad behandelen." Er is immers steeds het tegenspel van iets dat groter is: de genade en "die geheimzinnige onbegrensde goddelijke barmhartigheid." Schrijvers bekommeren zich om het kwaad en moeten dit in hun romans behandelen, stelt Coolen. Hij haalt een uitspraak aan van de vroegere president van Tsjechoslowakije, Masaryk ${ }^{42}$ : "Kunstenaars denken over het leven en zijn vraagstukken niet minder na dan de philosophen [...] en ze doen het concreter, en op het gebied van de zielkunde leert hij [Masaryk, C.S.] meer van de romans dan van de academische psychologie."

Coolen concludeert dat datgene wat de schrijver voortbrengt, "geboortig is uit dat geheimzinnig huwelijk van den kunstenaar met de werkelijkheid." Dat pakt bij tragische schrijvers als Mauriac anders uit dan bij niet-tragische zoals Aart van der Leeuw, maar bij beide komt het voort uit liefde voor het leven.

"En wat mij betreft, hoop ik, dat de laatste gedachte op de laatste pagina van mijn laatste roman, verschenen nog voor den oorlog, mij weer leiden moge op de eerste bladzijde van den eersten roman dien ik, nà den oorlog, nog eens hoop te schrijven: 'men kan niet nederig genoeg zijn in het gadeslaan van dat verbazingwekkende aardsche leven."' Zo besluit hij zijn rede met een verwijzing naar de slotalinea van Herberg In 't Misverstand, de roman die hij twaalf jaar daarvoor schreef, en met het uitspreken van zijn hoop op inspiratie voor een nieuwe roman.

Nog nooit heeft Coolen zo duidelijk aangegeven hoe hij tegen de romankunst aankijkt en hoe hij daar zelf mee omgaat. Later prijst hij in een brief aan Oomes het psychologisch inzicht van Graham Greene en stelt dat Mauriac gelijk krijgt, "dat er eigenlijk geen verboden terrein is voor de katholieke romancier. ${ }^{43}$

40 Coolen, 'De romancier en het leven', 325-329.

41 Coolen, Dorp aan de rivier, 90-91.

42 Thomas G. Masaryk (1850-1937) was de eerste president van de nieuwe republiek Tsjechoslowakije die na de Eerste Wereldoorlog ontstond. Masaryk was een vrijzinnig filosoof, die een afkeer had van ieder autoriteitsgeloof. De afkondiging van de pauselijke onfeilbaarheid in 1870 was voor hem aanleiding de katholieke kerk te verlaten.

43 LMDC, inv. nr. C 3485, brief Coolen aan Oomes, 25 november 1950. 
De kunstenaar is niet getrouwd met een geloofsleer of ideologie, maar met de werkelijkheid en de liefde voor het leven. Wat dat betreft is er geen verschil tussen een gelovig of ongelovig schrijver, lijkt Coolen te zeggen, alleen worden in het geval van de gelovige schrijver de genade en de goddelijke barmhartigheid genoemd als krachten die het kwaad overstijgen. Ook deze passage moet, gezien zijn vroegere recensies over de peelromans, zeker de goedkeuring hebben gehad van Van Duinkerken, die ook onder het gehoor is.

Tot een inhoudelijke discussie over de lezingen is het die avond in Mariakerke niet meer gekomen. Na afloop wandelt een deel van het gezelschap nog naar 'de dijk', de boulevard langs de zee, waar Streuvels en Duribreux wedijveren om het beste commentaar op de fluorescente zee. Later op de avond is Van Duinkerken het middelpunt. Hij pasticheert de dichters Gezelle, Van de Woestijne en Van Ostaijen op het thema 'witloof' en geeft daarna "een onvergetelijke Redemptoristen-sermoen" ten beste. ${ }^{44}$

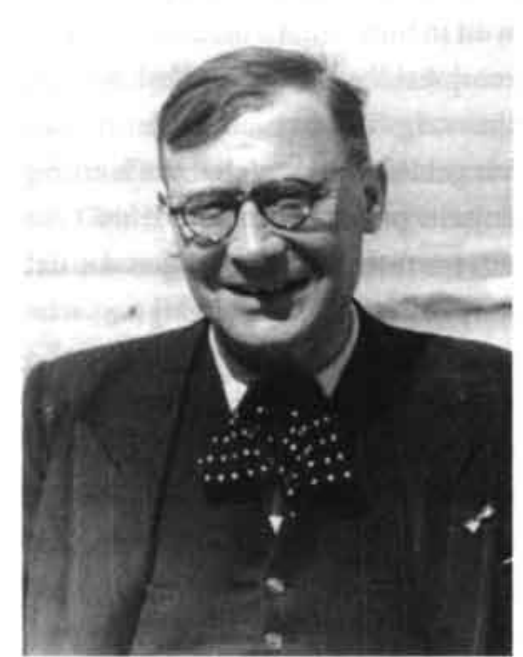

Coolen aan het strand van Mariakerke.

Coolen heeft zich nooit zo druk gemaakt over de buitenkant van het geloof en de officiële kerk. Zijn eerste brieven aan Lutkie tonen naast geloofstwijfels ook een afkeer van de gevestigde kerk en de overal aanwezige schijnheiligheid. Hij heeft zich ook nooit veel aangetrokken van de kritiek dat zijn romanpersonages te weinig katholiek zouden zijn. Coolen twijfelt niet zozeer aan zijn geloof in God. Hij plaatst wel vraagtekens bij het reilen en zeilen van de officiële katholieke kerk. In dit opzicht is hij enigszins verwant aan Henk Wiegersma. Het grote verschil met zijn vriend is dat Coolen niet die 'artistieke' losheid heeft om in dit opzicht zijn eigen gang te gaan. Hij let toch veel meer op zijn status en wil zich ook niet al te ver van het katholieke establishment verwijderen. Coolen behoort zeker tot een nieuwe stroming van een meer humanistisch getint katholicisme, maar laat dit naar buiten toe niet blijken.

Louis de Bourbon geeft veel later een heel andere interpretatie. Volgens hem twijfelden in die tijd veel katholieke schrijvers aan hun geloof. Zowel Van Duinkerken - "na een borreltje" - als Coolen gaven toe dat ze twijfelden of nog erger. Antoon Coolen "heeft het nooit openbaar durven maken, maar hij geloofde absoluut niet meer. Dat wéét ik. Nachtenlang heb ik daar met 'm over gesproken, maar hij durfde er gewoon niet voor uit te komen, uit angst dat zijn lezers zich van hem af zouden wenden en hij brodeloos zou worden." ${ }^{\text {45 }}$

\section{Bekende Brabander}

Het is maar de vraag of Coolens lezers zouden zijn weggelopen vanwege zijn geloofstwij fels. Zij kijken toch in de eerste plaats naar het verhaal dat hij te vertellen heeft. Wat wel in gevaar zou zijn gekomen, is zijn netwerk. Na de oorlog treffen we Coolen, als beroemd schrijver, steeds vaker tussen de 'geestelijke en wereldlijke autoriteiten'. Hij krijgt een 
nieuw sociaal leven, namelijk dat van de algemeen geachte schrijver en cultuurdrager, die vooral bij Brabantse evenementen en herdenkingen niet vaak ontbreekt. Coolen is hiervoor de ideale figuur, omdat in zijn persoon het Brabantse, het nationale en het katholieke samenkomen. Als voorzitter van de jaarlijkse herdenking van de gevallenen ontvangt hij onder andere de Commissaris der Koningin, De Quay. Als beschermheer van het Deurnese gilde St. Antonius Abt maakt hij zich regelmatig druk of de aanwezige autoriteiten wel goed bedankt worden en voegt voorzichtigheidshalve een concept voor een dankbriefje voor pastoor van Dinther bij; dan hoeven de gildeleden het zo maar over te schrijven. ${ }^{46} \mathrm{Zijn}$ lidmaatschap van het Tribunaal brengt een nieuwe kennissenkring voor hem mee.

Vanuit de provinciale Monumentencommissie kent hij de nieuwe burgemeester van Waalre, de vrijgezel Mol. Wanneer de laatste in 1948 in het huwelijk treedt, organiseert Coolen samen met leden van de Waalrese Sociëteit de intocht en het 'opnemingritueel' in de gemeente naar analogie van de boerenovertrek in Kinderen van ons volk en de doktersverhuizing in De drie gebroeders. Bij de ambtswoning staat Antoon Coolen klaar om de echtelieden uit te nodigen zich aan het inhuldigingsritueel te onderwerpen. Door de "luimige toelichting van Coolen wordt het geheel een groot succes," schrijft Zoetmulder. ${ }^{47}$

Landelijk neemt Coolen zitting in diverse jury's, zoals die van de poëzieprijs van de stad Amsterdam in 1945 en in die van de Kruseman Romanprijsvraag in r947. Die activiteiten vreten tijd: zo moet hij in de laatste maanden van 1947 tweeënveertig inzendingen lezen en beoordelen, waarvan er vele in handschrift zijn opgestuurd. ${ }^{48} \mathrm{Hij}$ bezoekt veel literaire en uitgeversbijeenkomsten.

Coolen levert bovendien nog een bijdrage aan het gedenkboek ter gelegenheid van het gouden regeringsjubileum van Wilhelmina in $\mathrm{r} 948$. Hij besteedt het grootste deel hiervan aan de beschrijving van de jeugd van Wilhelmina. Uit de Katholieke Illustratie haalt hij het versje van de Betuwse dichter Bernard van Meurs aan: "Willemientje, aorig kiendje, waar ik zoveul goeds van heur." Hij bewondert de min die het pasgeboren prinsesje vroeger verzorgde. Zij was "stevig, landsch en boersch" en past daardoor geheel in het realistische sprookje van het Hollands koningshuis. De manier waarop de jonge prinses met de poppen speelde, doet Coolen denken aan Prutske van Streuvels. Nu zij zelf grootmoeder is, wordt het land "een bloemhof van Oranje" bij het feest van "de gouden regeering van de goede Wilhelmina." 49

\section{Liefde, dood en minne}

In 1948 verschijnt een bundel met drie verhalen van Coolen en één van Bomans. Het boek is, in tegenstelling tot ander werk van Coolen, niet uitgegeven bij Nijgh \& Van Ditmar, maar bij H. Bergmans in Tilburg. Coolens verhalen zijn een mengeling van zijn legenden en sprookjes.

44 Dietsche Warande en Belfort, 1950, 311.

45 De Wael, 'Nee! Ik laat me er niet onder krijgen'.

46 WE, kopie brief Coolen aan secretaris Gilde Deurne, 17 augustus 1948 en 2 september 1955.

47 CS, [kopie typoscript] Zoetmulder, Antoon Coolen in Waalre, 14.

48 BA, brief Van Duinkerken aan Coolen, 16 december 1947.

49 Coolen, 'De goede koningin', 59-69. 
In 'De ridder met de kruik' komt een woeste ridder via zijn trawanten terecht bij een kluizenaar, een heilige man. Voor de 'grap' biecht hij, om de kluizenaar te laten schrikken van zijn zonden. Deze vraagt echter bij elke gruwelijke zonde steeds alleen maar En verder?, totdat de ridder zijn kleinste dagelijkse zonden heeft opgebiecht. Hij wil de grap afmaken en vraagt wat voor boete hij moet doen. De kluizenaar suggereert een boetekleed, bidden of versterven, maar de ridder wijst dat alles af. Tenslotte vraagt de kluizenaar hem een kruik te vullen met water uit de beek. Dan blijkt dat het water niet in de kruik wil. De helft van het verhaal wordt dan ingenomen door de jarenlange vergeefse tocht van de ridder, op zoek naar water waarmee de kruik zich laat vullen. Eindelijk als oudere man teruggekomen bij de kluizenaar hoort hij dat het een wonder van God is geweest om hem te beproeven. De ridder heeft berouw en huilt; als er een traan in de kruik valt vult die zich met water. De ridder is dood.

Coolen vermeldt als bron van dit verhaal het middeleeuwse gedicht Ridder met het Bariseel, maar hij heeft er veel eigens in gestopt. De combinatie van een moordenaar en een kluizenaar heeft hij ook gebruikt in De goede moordenaar en evenals bij Nol Bonk komt bij deze ridderlijke moordenaar de moordzucht niet in de eerste plaats voort uit het verlangen naar het gewin, maar van binnenuit. Hij spreekt van "den roes van misdaad en bloed als een booze, maar prikkelende zoetheid" die als een bedwelming aanvoelt. De neutrale houding van een priester tijdens de biecht komt ook voor in De schoone voleinding. Wanneer in die roman Godefridus van den Breemortel, die Giel Sleegers met een beugelbal vermoord heeft, pastoor Vogels bezoekt, geeft deze hem troost en hoop voor de toekomst. De pastoor vertelt over de goede moordenaar naast Christus aan het kruis en over een man die biecht. te dat hij had gemoord, waarop de priester alleen maar vroeg: "Hoe vaak, mijn zoon?" ${ }^{50} \mathrm{De}$ priester zegt dat niet uit automatisme of ironie, maar om aan te geven dat hij niet schrikt van een zware zonde; als een biechteling maar berouw toont is voor alles vergeving mogelijk.

In het verhaal 'De doode te gast' snoeft een jonker in de dorpssociëteit dat hij niet gelooft aan het leven na de dood. Geheel in de geest van het naturalisme beweert hij dat het geweten en het instinct geheel afhankelijk zijn van datgene waarmee ze gevoed zijn: "met de rede of met de levering van mythen en angstbeelden." ${ }^{51}$ Op weg naar huis gaat hij het knekelhuis op het kerkhof binnen en zegt tegen een schedel dat hij hem uitnodigt voor het avondmaal. 's Avonds krijgt hij inderdaad een gast "met een gezicht als het geel van was. kaarsen"op bezoek. In een lang tafelgesprek overtuigt de levende dode de jonker ervan dat er leven na de dood is. Het verhaal doet denken aan de Tales of the unexpected van Edgar Allan Poe. Het gegeven komt ook voor in Mozarts opera Don Giovanni, waar de held geconfronteerd wordt met De Stenen Gast, de man die hij eerder vermoord heeft.

In het laatste verhaal van Coolen vervult een pater "die op termijn is" lop reis binnen het gebied dat een klooster bestrijkt, C.S.] na lang aandringen de rol van liefdesboodschapper. Onderweg valt hij langs de weg in slaap. Als hij aankomt bij de geliefde aan wie hij de boodschap moet overbrengen, blijkt deze een stokoud dametje te zijn. Bij terugkomst in het klooster wordt hem verteld dat een pater met zijn naam al vijftig jaar geleden vertrokken is en nooit meer teruggekeerd. Hij begrijpt dat zijn leven een slaap van vijftig jaar is 
geweest, "als een gericht en een vermaan. Omdat hij eens zich in aardsche aangelegenheden had gemengd."

De titel van het boek Liefde, dood en minne lijkt te slaan op de drie verhalen van Coolen, al is de oorspronkelijke titel Genade, dood en minne eigenlijk meer geschikt; het gaat in het eerste verhaal immers meer om genade dan om liefde. Het vierde verhaal, geschreven door Bomans, gaat over een duel in Russische officierskringen.

\section{Met de heiligen het jaar rond}

Coolen werkt in deze tijd ook mee aan een groot project. Hij zit, samen met onder andere Van Duinkerken, in de redactie van een vierdelig standaardwerk Met de heiligen het jaar rond. In dit omvangrijke werk van zo'n veertienhonderd bladzijden is voor elke dag van het jaar de bijbehorende heilige beschreven. Het boek bevat bijdragen van Coolen, Van Duinkerken, Louis de Bourbon, Frank Valkenier [soms ook onder zijn eigen naam prof. dr. F van der Ven, C.S.], Bernard Bekman [Coolens oud-collega uit Hilversum, C.S.], Pieter van der Meer de Walcheren, P.C. Boeren, Piet Oomes, Annie Salomons, Walter Breedveld en [de inmiddels overleden, C.S.] Vincent Cleerdin We zien hier veel namen terug uit de kringen van De Gemeenschap en ook van Brabantia Nostra.

Wie we niet in deze rij tegenkomen is Albert Kuyle. Ook hij had het jaar daarvoor nog plannen voor een heiligenboek, maar toen hij daar bij Bomans advies over inwon, reageerde deze geprikkeld met de constatering, dat het wel heel eigenaardig was dat juist hij over nastenliefde zou gaan schrijven, bij wie deze deugd zelf helemaal ontbrak. ${ }^{52}$ Des te opvallender is het dat de tekenaar Karel Thole, die in de oorlog artikelen van Kuyle illustreerde met paginagrote antisemitische spotprenten, wèl aan dit project deelneemt met twaalf prenten. Thole werkt nu bij De Linie als tekenaar van politieke prenten. P.C. Boeren werkt bij De Linie als redacteur Letteren en schreef de 'gewone' recensie over Aafjes' Voetreis, voordat Creyghton zijn aanval begon.

Coolen levert vijf bijdragen aan het standaardwerk. Hij beschrijft de levens van Simeon de Pilaarheilige, de Drie Koningen, Catharina en Birgitta van Zweden en van Marie Adolphine. Hij houdt er van juist over deze levens waarover nauwelijks iets bekend is, de legende te schrijven, omdat hij daarin ruimte heeft zijn fantasie te gebruiken. Hij deed dat al in de legendenbundel Zegen der Goedheid en zal begin jaren vijftig met een bundel Gouden Legenden (Legenda Aurea) komen. Vooral het verhaal over de Drie Koningen fascineert hem bijzonder. Al in de Bossche krant wijdde hij er bijna elk jaar rond hun feestdag op 6 januari een column aan. Hij heeft zelf in de jaren dertig in de Dom van Keulen de kostbare reliekschrijn gezien, waarin hun schedels bewaard worden.

\section{Onder de Canadassen}

In het najaar van 1949 verschijnt Onder de Canadassen, een bundel van negen novellen en verhalen die Coolen tussen 1934 en 1946 geschreven heeft. Het woord Canadassen staat

50 Coolen, De schoone voleinding, 22.

51 Coolen (en Bomans), Liefde, dood en minne, 66.

52. Van der Plas, Daarom, mijnheer, 376. 
voor de Canadese populier, die schuin gewaaid en eeuwig ritselend met zijn bladeren zo karakteristiek is voor het Oost-Brabantse landschap. Het boek is opgedragen aan Stijn Streuvels, omdat het vijftig jaar geleden is dat diens boek Lenteleven verscheen. Op enkele verhalen wordt hier wat dieper ingegaan. Het verhaal 'De Schouwtegels' is hiervoor al behandeld in verband met het conflict met Van Doorne.

In 'Caspar van den Haarlemmermeer' ${ }^{53}$ staat de gebondenheid aan de grond centraal. Caspar is een wat zonderlinge peelwerker - "eene aparte" - die zwerflust in het bloed heeft. Jarenlang graaft hij mee aan de ringdijk van de Haarlemmermeerpolder. Elk jaar in de lente loopt hij met zijn schop en zijn spullen in een kussensloop van de Peel naar de Haarlemmermeer. $\mathrm{Na}$ een dik half jaar hard werken en een verblijf in arbeidersbarakken loopt hij tegen de winter weer terug. Prachtig is de beschrijving van de tocht door het dal van Aa en Dommel, via Vught, Den Bosch, Bommel naar het noorden. Als zijn vrouw vraagt om daar te gaan wonen, weigert hij, want dan kan hij niet meer thuis komen en zijn thuis is de Peel.

De novelle 'Erfgoed ${ }^{154}$ gaat over de onmogelijke liefde tussen de boerendochter Marjanne en Lowie, een Hollandse opzichter van de ontginningsmaatschappij. Hij heeft haar voor het eerst gezien bij het aren lezen, net als de Bijbelse Ruth op het oogstveld. De vader van Marjanne heeft echter al met de vader van de huwelijkskandidaat die hijzelf op het oog heeft, onderhandeld over de bruidsschat. Na de weigering van zijn dochter heeft hij een gesprek met Lowie, waarin hij smalend doet over de liefde. "Liefde? Ik weet niet wat het is dan 'nen hoop onverstand, een paar uur geduld in de kou om het meiske twee minuten te zien, maar, eens getrouwd, is er dat met een half jaar glad af." Marjanne is een boerendoch. ter, zegt haar vader, en die kun je niet met een handwerkje in een burgerhuisje zetten.

De afgewezen opzichter krijgt het volksgericht van het 'toffelen' over zich heen en verlaat de streek. Hij schrijft nog een paar brieven aan Marjanne, maar die worden door haar vader in de kachel gegooid, zodat zij denkt dat Lowie haar voorgoed vergeten is. Na jaren komt er nog een derde brief, die de boer niet zo gauw kan verbranden; deze wordt wel bewaard. Kort daarna brengt de postbode een rouwbrief met het doodsbericht van Lowie. Haar vader bekent dan dat hij twee brieven heeft verbrand en geeft haar de derde. In deze aangrijpende brief schrijft Lowie dat hij een ernstige operatie moet ondergaan, waarbij de kans op slagen of mislukken half om half is. Hij heeft uit haar niet antwoorden begrepen dat zij op het land en de boerderij van haar vader en voorvaderen wil blijven. Hij geeft haar haar woord terug en zegt haar vaarwel:

"Mijn Ruth van het oogstveld! Zo heb ik je genoemd, sinds ik je op het oogstveld tussen de schoven zag - omdat ik dacht, dat ge net als Ruth je geboorteland zoudt verlaten om je liefde te volgen. Toch blijft ge mijn Ruth van het oogstveld, ook nu. Want volgde Ruth niet haar liefde, om in saamhorigheid met de familie waartoe zij was gaan behoren te trouwen met Boaz en het erfgoed van het geslacht der haren te behouden, de akker, waarop zij tussen de schoven ging?" ${ }^{\text {55 }}$

Verbitterd vraagt Marjanne haar vader hoe hij dat achterhouden van de brieven in godsnaam heeft kunnen doen. "Niet omdat we 't niet goed met oe meenden," is zijn antwoord. Haar moeder valt hem bij en zegt: "de ons [die van ons, C.S.] menen het allemaal goed met oe, Marjanne." 
Ze beseft dat Lowie alles gedaan heeft wat hij kon om haar weg te krijgen. Nu ze er alleen voor staat, komt ze tot het (onlogische) besluit dat ze terug moet gaan naar haar eigen wereld: "nu is zij aan haar boerenwereld teruggegeven en behoort er meer aan toe dan ooit." Met Nieuwjaar zal zij ja zeggen tegen de huwelijkskandidaat van haar vader. Het verhaal eindigt met een opsomming: zij zal in de lente de deuren openen voor het jonge vee, zij zal hooien, zij zal de garven binden tussen de schoven. "Aan deze trouw offerde zij zichzelf, zij bond er zich zo veel hechter aan met deze onverbrekelijke banden: de man, het huis en de kinderen, die op zouden groeien tot zonen en dochters voor het land omdat het moet."

De oerversie van dit verhaal is geschreven in 1936 voor een uitgave van het Groot Nederlands Boerenboek. Dat was in de tijd dat Coolen volop bezig was met de problemen van de boerenstand, de ontginningen en de omvang van de boerenbedrijven. Hij werkte toen ook aan het toneelstuk De vier jaargetijden, waarin eveneens de kwestie van het erfgoed en de verhouding tussen boeren en burgers behandeld wordt.

Het thema van het bijbelverhaal Boaz en Ruth heeft een speciale aantrekkingskracht op Coolen. Al in de tijd van Lutkie, in de zomer van 1920, las hij samen met zijn verloofde over Mara, dat is Naomi, de schoonmoeder van Ruth. Ook in een sprookje van Andersen valt hem deze passage over Ruth op en hij gebruikt ze in Uit het kleine rijk. ${ }^{56}$

Waarschijnlijk heeft hij bij de aanpassing van het verhaal voor deze bundel gebruik gemaakt van een gedicht over Ruth, waar hij in het voorjaar Van Duinkerken om gevraagd heeft. ${ }^{57}$ Bij de inleiding van zijn Gouden Legenden een paar jaar later, in 1951, schrijft Coolen dat hij het boek Ruth een van de mooiste verhalen van het oude testament vindt. Hij houdt van "deze innige, gelovige en gewijde pastorale, waarover de adem Gods strijkt als de adem van den wind over de velden. ${ }^{.58} \mathrm{Het}$ is het verhaal over boerenleven, erfgoed en familie dat Coolen zelf zo vaak op zijn eigen manier heeft geschreven.

Het slot van Coolens verhaal is, zeker voor de hedendaagse lezer, moeilijk te begrijpen. Welke vrouw, die zo bedrogen is door haar vader die haar bovendien nog 'uitgehuwelijkt' heeft aan een boerenzoon die ze niet mag, gehoorzaamt nog gedwee na de dood van haar geliefde? Aan welke trouw offert Marjanne zich op? Aan de trouw aan haar geboortegrond? Als dat zo is, dan reageert zij juist tegengesteld aan Ruth, die juist het land van haar vaderen verliet en met haar schoonmoeder naar het land van Boaz reisde. Het slot lijkt op dat van het toneelspel De Vier Jaargetijden. In dit toneelstuk wordt in de laatste scène een burgermeisje een poffer opgezet en moet ze de rouge voor haar wangen afzweren. In dit verhaal gaat de burgerjongen dood en wordt het bijna verloren boerenmeisje weer 'trouw' aan haar familie en geboortegrond. Een vrouw kan kennelijk wel in de boerenstand ingelijfd worden, met een man gaat dat moeilijker; de ingenieur Lowie gaat dood, de romantische jonker uit het toneelstuk blijft een malloot.

53 Oorspronkelijk verschenen in 1941, in: Herwonnen Levenskracht.

54 Oorspronkelijk verschenen als 'Het Heilig Erfgoed', in: Het Groot Nederlands Boerenboek, 1936.

55 Coolen, Onder de Canadassen, 139.

56 Coolen, Uit het kleine rijk, 208-209.

5 BA, brief secretaresse Coolen aan secretaresse Van Duinkerken, 5 april 1949.

58 Coolen, Gouden Legenden, VI. 
Een juweeltje in de bundel Onder de canadassen is 'De boer en zijn kerkplavei'. Een pastoot kan het niet goed hebben, dat de mensen achter in de kerk tegen een pilaar geleund de mis zonder veel aandacht bijwonen. Hij stelt een gepensioneerde veldwachter als suisse ${ }^{59}$ aan, die de hangers met zachte aandrang naar een kerkbank begeleidt. Boer Willem van der Vranden weigert koppig en blijft op de kerkplavei staan. De pastoor zet hem de volgende zondag eigenhandig na de preek buiten de kerk, waarna de boer, die nooit een mis verzuimd heeft, niet meer in de kerk wordt gezien. De pastoor voelt zich schuldig, omdat hij iemand tot onkerkelijkheid heeft aangezet. In een gesprek met de dochter van de boer blijkt echter dat de oude Van der Vranden elke week te voet in Gemert naar de kerk gaat: anderhalf uur heen en anderhalf uur terug.

In de winter wordt de pastoor opgebeld door zijn collega uit Gemert, die meldt dat hij gevraagd is om Van der Vranden te komen bedienen, die bij hem elke week in de kerk komt. De pastoor gaat het zelf doen, maar de boer is onwillig. Hij vertelt dat zijn vader op diezelfde plavei stond, toen hij zijn "derde communie" deed vierenzestig jaar geleden. "Da's langer dan gij oud bent," zegt hij tegen de pastoor. Bij de begrafenis staat de pastoor bij de begroeting van het lijk bij de kerkplavei en probeert er de sporen van het leven van deze boer aan af te lezen. "Zoo'nen plavei, zoo'n voetstuk, misschien had die dezen eenvoudige van geest gedragen en getild tot onzen lieven Heer zelf, voor wien hij hier op neerknielde." De pastoor plant een klimroos bij het graf.

Ook hier gaat het dus om een (koppige) gebondenheid aan een plaats, dit keer zelfs met een heiligend effect. Coolen kan zo'n boer ook zelf gezien hebben, want Frans Babylon herinnert zich dat Coolen, in de tijd dat hij op De Romeijn woonde, altijd op een van de ach. terste banken in de kerk zat. Mogelijk zit er echter ook wel iets van de boer in Coolen zelf die op deze manier de afstand tot de clerus letterlijk in acht neemt.

Niet alle verhalen in de bundel zijn melancholisch. Een heel zonnig verhaal is 'Vincent, die alles kon'. Als de buurt het feest wil organiseren voor zijn gouden bruiloft krijgen de buren niet de kans om de traditionele ereboog te bouwen. Dat heeft hij zelf al gedaan. "- Versierde gij voor oe eige? Vroegen de voorbijgangers, die eens kwamen kijken. - Ik doe 't voor ons Cornelia, riep hij terug." ${ }^{60}$

Alle verhalen in deze bundel gaan over boeren en boerenfamilies. In de romans, behat ve in Kinderen van ons volken De schoone voleinding, spelen zij vaak slechts een bijrol, omdat de hoofdpersonages peelwerkers, arbeiders en dorpelingen zijn.

Zo zien we de gierige boerenfamilie, die in Herberg In 't Misverstand een bijrol had, op de voorgrond in het verhaal 'De Wijze Gek. ${ }^{.61}$ De ongelukken die mogelijk zijn op de boerderij met de maai- of de dorsmachine spelen in deze bundel enkele malen een belangrijke rol, zoals in het verhaal 'Huwelijk' en ook in 'Stiefkind'. Ook het veel gebruikte thema van een eeuwige ruzie tussen echtelieden en de effecten daarvan op hun kinderen komt hier terug, namelijk in de novelle 'Huwelijk'.

Trots stuurt Coolen de bundel naar Van Duinkerken en schrijft dat de meeste verhalen, na zijn grondige bewerking, zo goed als nieuw zullen zijn. Alleen 'Huwelijk' uit het boekenweekgeschenk van 1939 is ongewijzigd gebleven, op enkele correcties na. ${ }^{62} \mathrm{Op}$ de flaptekst staat dat vier verhalen in de oorspronkelijke versie zijn afgedrukt en dat de andere vijf 
bijna geheel werden herschreven. Van Duinkerken is zeer enthousiast en schrijft al na enkele dagen dat dit een hoogtepunt in zijn werk is, vergelijkbaar met de novellenbundels van Streuvels. ${ }^{63}$

Van Duinkerken ziet in de onverzettelijkheid van de "hoofdige boer" in "De boer en zijn kerkplavei' meteen zijn grootmoedigheid. Hij vindt in deze bundel een reeks boerenvertellingen die op "heel bijzondere wijze de zielkundige inhoud van het 'fides'-begrip belichten." Alhoewel Coolen er volgens hem geen andere bedoeling mee had dan boeiende verhalen te vertellen, want, zo besluit hij: "Hij is geen polemist. Hij is alleen maar de beste verteller onder de katholieke schrijvers van Nederland." ${ }^{\text {64 }}$

Coolen is trots op deze bundel novellen, maar als hij zijn vriend Oomes hierover schrijft, klaagt hij toch weer dat het 'grote werk' uitblijft. ${ }^{65}$ Dat laatste laat hij in zijn brief aan Van Duinkerken achterwege. Het lijkt wel alsof hij zich voor Van Duinkerken wat groter en zelfbewuster wil voordoen. Hij wil deze vriend, die ook zijn recensent is, in ieder geval niet op het idee brengen dat hij op dood spoor zit.

\section{Problemen met Stijn}

Vol trots vertelt Coolen in een interview met de Nieuwe Haagsche Courant hoe snel de ontwikkeling bij zijn kinderen gaat. Het ene moment komen ze nog vragen om een verhaaltje te vertellen en het andere moment vertalen ze zelf gedichten uit het Frans en lezen Homerus als de krant. ${ }^{66}$ Guido en Felix zitten allebei op het gymnasium. Felix houdt van gedichten en kan die lezen en waarderen. Hij vindt vaders werk prachtig. De andere zoon, Guido, houdt van spannende verhalen en kan het werk van vader daarom minder waarderen. ${ }^{6}$ Het boek over hun eigen jeugd, Uit het kleine rijk, kregen ze niet te lezen. Stijn noemt hij niet. Deze is nu bijna 19 jaar en heeft al een hele rij scholen achter de rug. Hij heeft het gymnasium eerst verruild voor de HBS en is daarna naar de school voor heilpedagogie in Bilthoven gegaan. Daar leidde zijn gedrag tot veel complicaties. Eerder had Coolen bij Streuvels geïnformeerd naar de naam van een internaat in Kortrijk voor Stijn, omdat de Vlaamse humaniora niet dat "opgevijzelde en overladene" hebben van de Nederlandse gymnasia. In die brief schreef hij al dat hij ook dacht aan de 'werkgemeenschap', de speci-

59 Suisse betekent Zwitser, en slaat op de Zwitserse Garde van het vaticaan. De functionaris werd uitgedost met een fantasieuniform, een hellebaard en een sjerp met de woorden 'Eerbied in Gods huis'. De functie was tot ver in de jaren zestig van de twintigste eeuw algemeen gebruikelijk en wordt ook nu nog in sommige kerken gehandhaafd.

60 Coolen, Onder de Canadassen, 178.

61 Geschreven een jaar na Herberg In 't Misverstand in 1940, in: Zonneboek van Herwonnen Levenskracht.

62 BA, brief Coolen aan Van Duinkerken, 29 november 1949.

63 BA, brief Van Duinkerken aan Coolen, 3 december 1949.

64 Van Duinkerken, 'Grondslag der standvastigheid'.

65 LMDC, inv. nr. C 3485, brief Coolen aan Oomes, 25 november 1949.

66 'Bekende landgenoten thuis'.

67 Van der Plas, 'Een man van de dorpskom'. Guido Coolen vertelt dat hij het eerste boek van zijn vader pas in zijn laatste gymnasiumjaar heeft gelezen. Gêne weerhield hem ervan; die boeken waren meer iets voor mensen buiten hun huis. In het huis was vader de verteller toen ze klein waren. Hij heeft nooit met hem over zijn boeken gepraat. Later waren de rollen omgedraaid, toen vertelde Guido, als marineofficier, verhalen over zijn reizen aan zijn vader. 
ale schoolvorm van Kees Boeke in Bilthoven. ${ }^{\mathrm{Bg}}$ Hier blijkt trouwens weer uit dat Coolen tot de meer verlichte katholieken behoort, want De Linie voert op dat moment actie tegen Boeke en zijn werkgemeenschap.

Vanaf 1948 studeert Stijn aan de kunstacademie in Den Bosch. Hij heeft het daar echter zo verbruid dat "met Paschen al het verzoek volgde, ondersteund door alle leraren, om hem van school weg te nemen. ${ }^{.69}$ In juni r 949 onderneemt Coolen pogingen om Stijn met zijn eigen voorspraak én die van Van Duinkerken, die daar sinds oktober 1948 benoemd is als hoogleraar cultuurgeschiedenis, aan de Jan van Eyck-academie in Maastricht als student geplaatst te kriigen.

Coolen gelooft er eigenlijk zelf niet in, want Stijn is kopschuw voor elke regelmaat en inspanning en voelt niets meer voor deze richting. In november 1949 blijkt er nog steeds een impasse te zijn. Maastricht is niet doorgegaan en na diverse zwerftochten komt steeds de vraag: Wat nu? ${ }^{70}$ Gerda Coolen, die nog steeds zwaar lijdt onder het verlies van Peter, trekt vaak partij voor Stijn. De affaire leidt tot spanningen in het huwelijk.

\section{Canonisatie: een voorlopige balans}

Coolens faam als beroemd Nederlands en vooral ook Brabants schrijver krijgt extra glans door een zeer lovende publicatie. Het boek over Coolens leven en werk, geschreven door zijn vriend Van Duinkerken, verschijnt na twee jaar vertraging in mei r 949 . Het maakt deel uit van de Reeks Schrijvers van Heden, die onder auspiciën van de Maatschappij der Nederlandse Letterkunde wordt uitgegeven. Coolen wordt hiermee op 52 -jarige leeftijd ingelijfd in de canon van de Nederlandse literatuur.

In ruim honderd bladzijden schetst Van Duinkerken Coolens portret. Het is geschreven op de sympathieke toon van een vriend. Met veel liefde wordt aandacht besteed aan de romans en de verhalen van Coolen. Met nadruk wijst Van Duinkerken erop dat Coolen "onmiskenbaar een katholieke romancier" is. De verhalen van Coolen zijn geen religieuze vertelsels met een godsdienstige strekking, maar toch is er geen sprake van "noodlots-aanbidding", want Coolen voorkomt dit door een "innig-katholiek" gegeven." Eeuwen van Christendom hebben geleerd dat alles ergens goed voor is. Het sterkste voorbeeld hiervan is de berusting van een ouderpaar bij de dood van hun kind, dat het goed moest gaan maken voor de moord die de vader gepleegd heeft. Hierdoor worden menselijke instincten ten goede gericht om zo het noodlot te keren, schrijft hij.

Hier horen we een echo van Van Duinkerkens kritiek uit de jaren twintig op de 'instinct-causaliteit' in het vroege werk van Coolen. Zoals hij al eerder deed in zijn recensies, weerlegt hij die kritiek nu en plaatst de 'instinct-causaliteit' in een christelijke context. Natuurlijk speelt ook mee dat ten tijde van het schrijven de hetze vanuit De Linie tegen katholieke schrijvers woedt. Van Duinkerken wil nog eens bewijzen dat Coolen een katholiek schrijver is.

Zoals eerder vermeld ${ }^{2}$ prijst Van Duinkerken toch het meest het meegevoel van Coolen met zijn personages, zijn 'misericordia'. "Dit betekent, dat men hart heeft voor den ellendige: miseri cor. Coolen heeft hart. Hij mag leven in een tijdperk, waarin het soms als tekort aan intelligentie wordt beschouwd, niet cynisch te zijn: hij weet, dat het een scha delijk gemis aan verbeeldingskracht is, geen hartelijkheid te kunnen opbrengen voor zijn medemensch. ${ }^{n 3}$ Het morele gehalte van Coolens werk ligt, volgens Van Duinkerken, in 
zijn positieve benadering van de "onbaatzuchtige offervaardigheid," zowel bij pastoor Vogels als bij Tjerk van Taeke.

Coolen is heel blij met dit boek en laat zijn secretaresse meteen vragen of Stijn Streuvels en Wiegersma er al een rechtstreeks hebben toegezonden gekregen, omdat hij er anders zelf voor zal zorgen. ${ }^{74}$ Wat later laat hij weten dat het toch wel een bijzonder gevoel is, alsof je zelf onbescheiden toehoorder bent bij een causerie over jezelf die niet voor jou maar voor anderen bestemd is. "Waar ik je zeer erkentelijk voor ben in je uitnemende geschrift, dat is de warme aandacht van geest en hart waarmee je mijn werk van bladzij tot bladzijgevolgd hebt in de samenvatting van die vriendschap die tusschen persoon en werk geen distinctie maakt, - en je weet hoe iemands werk hem wel zeer na aan het hart ligt." 75

De blijdschap van Coolen is wel begrijpelijk. Van Duinkerken heeft datgene wat hij waardeert in Coolen sterk benadrukt. Hij maakt daarbij gebruik van de recensies die hij bij het verschijnen van de verschillende boeken zelf heeft geschreven. We hebben gezien dat hij over werk van Coolen waarover hij niet zo enthousiast was, geen recensies schreef. Over deze boeken en novellen houdt hij zich nu wat op de vlakte en volstaat hij met te verwijzen naar anderen. Het meest opvallend doet hij dat bij de Man met het Jan Klaassenspel. Ook nu komt er geen woord van lof. Hij beperkt zich tot de constatering dat sommigen deze novelle tot Coolens beste werk rekenen.

Van Duinkerken concludeert dat Coolen zich na zijn laatste roman in 1938 bezonnen heeft op de werking en de verbeeldingskracht van de volksfantasie en hij hoopt dat Coolen hierdoor nog eens toekomt aan zijn droom om het leven van Jeroen Bosch te beschrijven. Hij vindt de romans van Coolen van grote betekenis "voor de cultureele zelfstandigwording van het oude Generaliteitsland." Over het letterkundig peil oordeelt hij wat voorzichtiger. Coolen is geen vernieuwer van de roman of de prozastijl en daarom moet zijn werk niet volgens die normen beoordeeld worden, schrijft Van Duinkerken. Hij stelt vast dat letterkundige hiërarchieën door tijdgenoten zelden onfeilbaar zijn. Hij vindt de beste boeken van Coolen een aanwinst voor de literatuur "om wille der verbeeldingskracht" en noemt hem een van de beste hedendaagse vertellers, in ieder geval de meest dichterlijke en de meest hartelijke. "Het is geenszins ondenkbaar, dat wij zijn beste werk nog te verwachten hebben." ${ }^{76}$

Het is inderdaad niet 'ondenkbaar'. Het overzicht van Coolens leven en werk maakt echter eén ding duidelijk: het hoogtij van zijn werk tot nu toe ligt in de gouden decade vanaf Kinderen van ons volk in 1928 tot Herberg In 't Misverstand in 1938. In de tien jaar daarna is

68 AMVC, inv. nr. C 3475, brief Coolen aan Streuvels, 15 december 1946.

69 BA, brief Coolen aan Van Duinkerken, 28 juni 1949.

70 LMDC, inv. nr. C 3485, brief Coolen aan Oomes, 25 november 1949.

7 Van Duinkerken, Antoon Coolen, 53.

72 Zie: 'Coolen als vrijdenker' in hoofdstuk 5 van deze biografie.

73. Van Duinkerken, Antoon Coolen, 101.

74 BA, brief secretaresse van Coolen aan Van Duinkerken, 31 mei 1949.

75 BA, brief Coolen aan Van Duinkerken, 29 juni 1949.

76 Van Duinkerken, Antoon Coolen, 104. 
geen roman van zijn hand verschenen. Boeken als Bevrijd Vaderland, Tsjechische Suite en de novelle De Ontmoeting en ook nu weer de bundel Onder de Canadassen worden wel goed ont. vangen, maar voldoen niet aan de verwachtingen die de gemiddelde lezer van Coolen heeft. Zoals blijkt uit zijn brieven aan Piet Oomes, is ook Coolen zelf niet helemaal tevreden. Hij wil weer 'groot werk' maken en bedoelt hiermee een roman, maar de inspiratie en de vlotheid van schrijven daarvoor mist hij. Ondertussen dient zich een nieuwe generatie romanschrijvers aan met Blaman, Van het Reve en Hermans.

Coolen blifft denken over een grote nieuwe roman, maar bezint zich ook op andere terreinen. Steeds meer manifesteert hij zich als kenner van Brabant en geeft daar zowel journalistiek als literair blijk van. Daarnaast richt hij zijn aandacht steeds meer op het schrijven van toneel, waarbij hij zijn kennis van de geschiedenis van Brabant en de legenden kan combineren met zijn ervaring van het schrijven van stukken als De vreemdeling en De klokkengieter.

Coolen is vastbesloten zich hiermee weer midden op het Brabantse podium te plaatsen. De conclusie van Van Duinkerken dat zijn romans veel hebben betekend voor de emancipatie van Brabant doet hem goed en stimuleert hem om zijn schrijftalent op verschillende manieren voor deze provincie in te zetten. 


\section{Op het Brabants podium}

Wat mijn werk betreft blijft het moeilijk de draad te hervinden met een verleden, waarvan zulk een caesuur scheidt."

$1950-1951$

\section{Dat kan ik beter}

Als de "jonggekroonde vorstin" Juliana en Prins Bernhard op dinsdag 6 september 1949 voor het eerst Brabant bezoeken en 's avonds in de Casino-Schouwburg in Den Bosch, met als gastheer het provinciaal bestuur, het spel Feest van Brabancia krijgen te zien, ergert Coolen zich buitengewoon aan de amateuristische opzet van dit stuk. Het is geschreven door een priester, rector Harry Beex. Deze heeft ook al enkele liedjes geschreven, waaronder het officieuze Brabants volkslied dat begint met de strofe "Toen Hertog Jan kwam varen, te peerd parmant, al triomfant ...," gevolgd door het keervers "Harba Lorifa."

Coolen, door de biografie van Van Duinkerken bestempeld tot een van de cultuurdragers van Brabant, geneert zich en spreekt er Commissaris der Koningin De Quay op aan. Hij vindt zo'n stuk niet representatief voor de Brabantse cultuur. Aan Van Duinkerken schrijft hij dat hij van plan is de Commissaris er nog eens een lange brief over te schrijven. Het wordt echter geen brief, maar een zeer uitgebreide recensie in Edele Brabant.'

Coolen trekt fel van leer. Velen zullen volgens hem de Fritz Hirsch-achtige operette- of revuetoon wel aardig hebben gevonden en niet ieder stuk hoeft hoge kunst te zijn, maar dit was overwegend te zoet, te fondant en te veel pastel. Altijd komt men weer aandragen met de oude rijmkroniek, het naamdicht op de letters van Brabant: Beata dat is saligh, Regalis dat is conincklijk enzovoort. Hij vindt dat getuigen van zelfoverschatting, want dat gedicht sloeg op het glorieuze oude Brabant met als hoofdstad Brussel: "Haalt men de met deze metaphoren befonkelden, dichterlijken staatsiemantel van dat grote machtige Brabant uit het museum dan vallen voor ons huidige gewest de glorieuze plooien wel wat wijd en praalzuchtig."

Nadat hij kolommen lang op elk detail kritiek heeft geleverd, volgt een soort sollicitatie naar dit type opdrachten in de toekomst. De fout is geweest, schrijft hij, dat het provinciaal bestuur de opdracht gegeven heeft aan een gelegenheidsauteur, in plaats van aan een gewestelijk auteur, een letterkundige, een vakman, een dichter, van wie men weet dat hij zich op het gewestelijke bezint, die historisch besef heeft en die de banden met het vorstenhuis kent, enzovoort. "Men had, als de juiste keuze van zulk een auteur moeilijk was, zich tot alle gewestelijke schrijvers kunnen wenden in hun verband van de

1 Een tweewekelijks tijdschrift onder leiding van de Hilvarenbeekenaar Jan Naaijkens. Het blad vormde een overgang tussen Brabantia Nostra, dat in 1945 was gestopt, en Brabantia dat in 1952 zal starten. 
Hilvarenbeekse cultuurdagen." Deze schrijvers zouden er dan gezamenlijk of via een soort eindredacteur wel uitgekomen zijn en zij zouden dat graag anoniem hebben gedaan, waarbij alle persoonlijke ijdelheid opzij zou zijn gezet. Brabant is nu onder de maat gebleven en dat bekommert hem zeer. ${ }^{2}$

Coolen wil zeggen: waarom is voor zo'n belangrijke gebeurtenis als het bezoek van de nieuwe koningin een stuk van een amateur gespeeld, terwijl er vaklieden voorhanden zijn zoals ik.

Hij weet dat de Commissaris plannen heeft op het gebied van toneel en muziek in Brabant. Coolen zit in het bestuur van het toneelgezelschap van Pierre Balledux, maar laat al jaren verstek gaan bij de vergaderingen. Rond Balledux speelt zich in die tijd een conflict af, dat morele, financiële en politieke aspecten heeft. Men verwijt hem onder andere dat hij sectarisch katholiek toneel brengt. Een adviseur van kardinaal de Jong schrijft "dat een opgenomen contact met den commissaris van Noord-Brabant de Heer de Quaai [sic] tot gevolg had dat een nieuw gezelschap daar oogenblikkelijk aan het werk kan met de zekerheid, mits het werk goed zou zijn, van provinciale subsidie. Alleen de Heer Balledux mocht geen stap meer in Brabant zetten."

\section{Huispoëet van De Kersouwe}

De verwijzing naar de schrijversbijeenkomsten bij de Groot-Kempische Cultuurdagen in Hilvarenbeek ${ }^{4}$ is een dekmantel voor Coolens eigen aspiraties. Wanneer Coolen dit felle artikel schrijft is juist de ruzie met Roeping achter de rug. In augustus is in dat blad de laatste aflevering van de publicatie in drie afleveringen van Coolens toneelstuk Sint Geerten Minne verschenen. Iedereen die Roeping leest, en dat zijn in ieder geval de leden van de spraakmakende Brabantse culturele en katholieke elite, weet dat er een stuk van Coolen op de planken ligt over een Brabants onderwerp.

Het bestuur van de Heeswijkse theatergroep die na de oorlog bijbelse stukken speelde in het openluchttheater De Kersouwe bij het plaatselijke kasteel, hapt meteen toe en zoekt de schrijver in Waalre op. Coolen geeft met genoegen zijn toestemming. Het spel wordt op zondagen in juli en augustus van 1950 uitgevoerd. ${ }^{5}$ Hiermee is een traditie gestart die acht jaar zal duren.

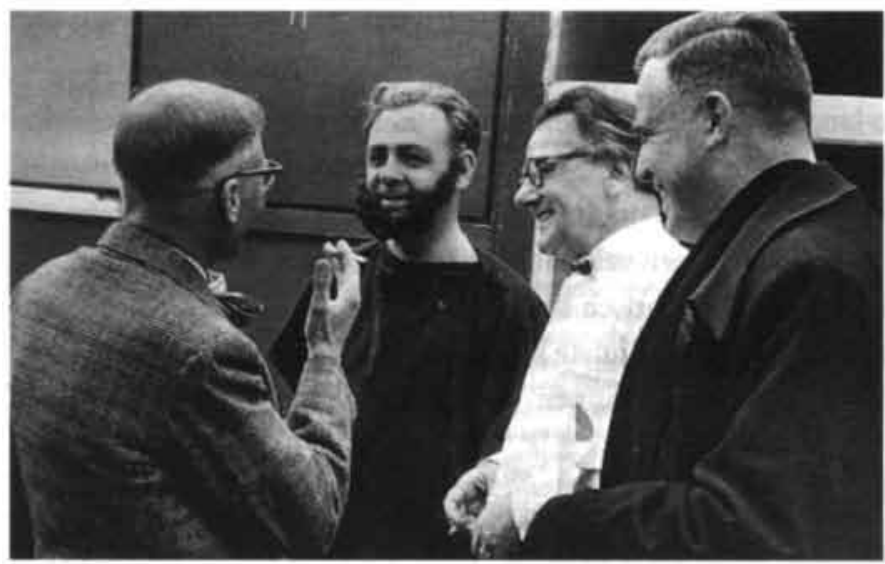

Coolen met regisseur en acteurs van De Kersouwe. 
$\mathrm{Na}$ Sint Geerten Minne schrijft Coolen bijna elk jaar een nieuw stuk geinspireerd op legenden, heiligenlevens en sprookjes: De zeven rozen wordt opgevoerd in 1951, Het meisje in de toren in 1952, Genoveva van Brabant in 1953 en in 1955. Sint Cunera van Rhenen in 1954, Sawitri in 1956 en Mars en Venus in 1958. Na het derde seizoen, op 28 oktober 1952, wordt aan Coolen de titel Poiètes van de Kersouwe verleend.

Het wordt voor Coolen, als huispoëet, een jaarlijks terugkerende druk om een nieuw stuk af te hebben vóórdat de spelers in de winter aan hun repetities beginnen. Hij slaagt daar niet ieder jaar in. Aan Mars en Venus begint hij pas eind maart, maar toch lukt het nog het in juli van hetzelfde jaar in première te laten gaan.

\section{Legenden in toneelvorm}

In de openluchtspelen van Coolen is de sfeer van zijn bundels Zegen der Goedheiden Gouden Legenden terug te vinden. De verhalen zijn een mengeling van historie en fantasie. In Sint Geerten Minne lopen geschiedenis en mythe door elkaar. Het stuk speelt in de Frankische tijd en gaat over de dochter van Pepijn van Landen die in 654 een klooster stichtte in Geertruidenberg. Geerten wijst een huwelijksaanzoek van een edelman af en kiest voor het klooster. De afgewezene sluit een pact met de duivel om haar voor zich te winnen, met als inzet zijn ziel. Als dit mislukt en hij dus verdoemd dreigt te worden, redt zij hem toch nog door haar goedheid.

De zeven rozen is een Noors sprookje waarin een vrouw op haar trouwdag een heks raadpleegt, die er voor moet zorgen dat zij geen kinderen zal krijgen; zij wil een luxe leven leiden. Coolen had dit sprookje al eerder bewerkt in de bundel Sprookjes van alle Landen onder de titel 'De vrouw die geen schaduw had'.

Het gegeven van Het meisje in de toren komt voor in het sprookje Rapunsel van de gebroeders Grimm, maar ook in Oosterse sprookjes.' Het is een braaf stuk over een prins in wiens omgeving niet over de liefde mag worden gepraat. Omdat de prins van zijn dorre gouverneur wel de taal van de vogels leert, komt hij er achter dat ergens een prinses leeft in dezelfde omstandigheden als hij.

Het stuk waar Coolen de meeste eer mee inlegt is een bewerking van de eeuwenoude legende van Genoveva van Brabant. Hierin staat de huwelijkstrouw centraal. Genoveva blijft haar man Siegfried trouw als Golo haar tijdens een kruistocht van Siegfried probeert te verleiden. Als dit niet lukt belastert hij haar en Siegfried gelooft dit als hij terugkomt. Genoveva, die al zwanger bleek te zijn bij Siegfrieds vertrek, wordt door haar wel erg goedgelovige echtgenoot met haar 'bastaard' ter dood veroordeeld. Twee jagermeesters krijgen

2 Coolen, 'Feest van Brabancia'.

3 RAU, Archief Aartsbisdom Utrecht, inv. nr. 449, brief kapelaan J. Van den Boogerd aan Kardinaal de Jong. ongedateerd [september 1949].

4 Op de Groot-Kempische Cultuurdagen en de rol van Jan Naaijkens komen we nog terug verder in dit hoofdstuk.

5 Heijman, 'Antoon Coolen en Heeswijk', 632.

6 Coolen, Sprookjes uit alle landen, vierde druk 1949, 9.

$7 \mathrm{Er}$ is ook een Duitse bewerking, die Granand maakte naar aanleiding van Washington Irvings The Alhambra. In Liebesmärchen komt een wonderlier voor die in twee stukken breekt. Het ene stuk brengt aan de voet van de Alpen Mozart voort en het andere stuk Beethoven bij de Rijn. 
de opdracht Genoveva en haar kind in het woud om te brengen. Pas na vele jaren verneemt Siegfried de ware toedracht. Gelukkig blijkt dan dat de jagers haar en haar kind hebben gespaard. Zij keert terug. Golo wordt op haar voorspraak niet gedood, maar verbannen en moet als boete een voettocht naar het Heilig Land maken.

In Sawitri. Oosters spel van liefde en dood is de hoofdpersoon een koningsdochter uit Madras die een bruidsreis maakt om een echtgenoot te kiezen. Zij vindt in het Mediawoud de zoon van een blinde verbannen koning. Thuisgekomen vertelt een ziener dat deze huwelijkskandidaat een jaar na haar huwelijk zal sterven. Zij negeert deze boodschap en trouwt toch. Als de vorst van de dood, Yama, haar echtgenoot komt halen en hem reeds zijn strik heeft omgedaan, wordt deze Yama door het zien van haar liefde vermurwd. De echtgenoot wordt weer levend door de grote onbaatzuchtige liefde en een list van zijn vrouw.

In Mars en Venusstrijden twee ridders, een zachtaardige dromer en een strijdbare krijgs. man, om de zelfde vrouw. De zachtaardige en vredelievende wint, omdat hij sterker in de liefde is. Coolen heeft het gegeven ontleend aan Het Verhaal van de Ridder uit de Kantelbergse vertellingen, dat op zijn beurt weer een bewerking is van de Teiside van Boccaccio.

\section{De ontvangst}

De opvoeringen zijn steeds een groot succes. Het publiek stroomt ieder jaar op de zondagen in juli en augustus van heinde en verre toe. De zomers van r 952 en 1954 worden geteisterd door veel regen, wat natuurlijk een ramp is voor een openluchttheater. Veel hangt af van het tijdstip waarop de buien beginnen. Zo start het seizoen 1954 slecht. "Maar op een Zondag, dat het pas om half vier begon te regenen zat het theater helemaal vol en het publiek is tot de laatste man gebleven de drie uren lang dat in de stromende regen gespeeld is," schrijft Coolen trots aan Van Duinkerken. ${ }^{8}$

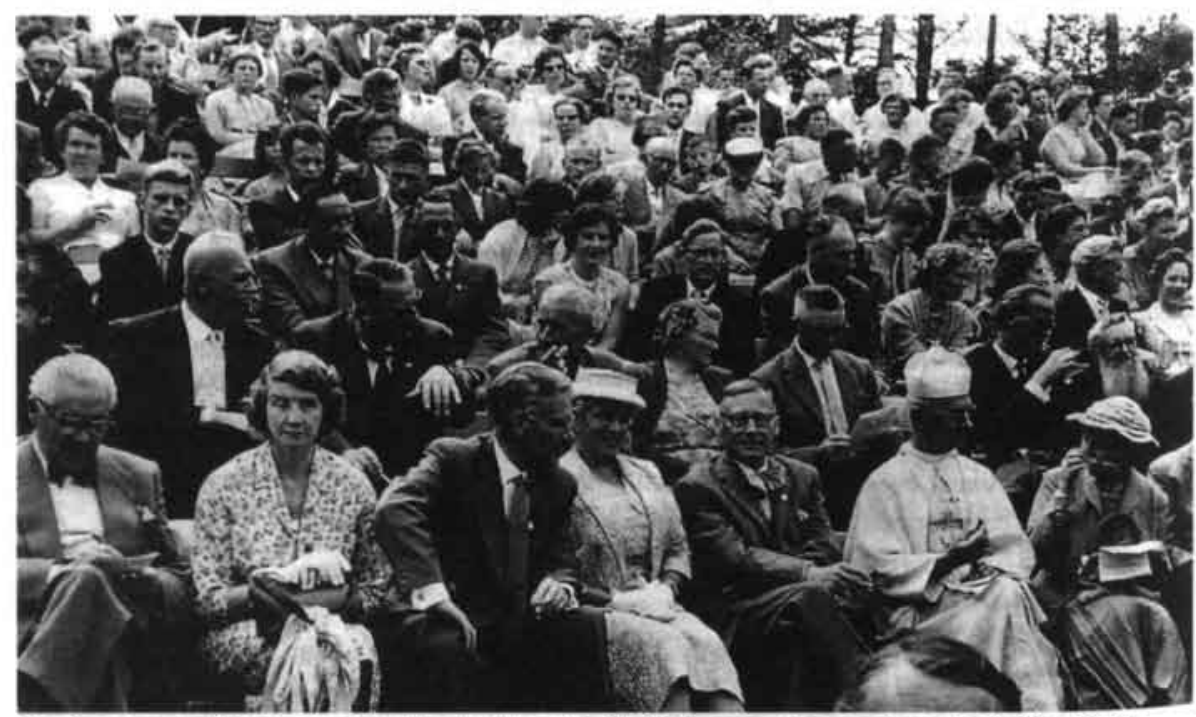

Op de graszodentribune van natuurtheater Heeswijk. Van links naar rechts op de eerste rij: Piet Oomes. Gerda Coolen-de Jong, het burgemeestersechtpaar van Heeswijk-Dinther, Antoon Coolen, de prelaat van de Abdij van Berne, M.J. Onderstijn en barones Van den Boogaard te Brugge. 
De populariteit van openluchtspelen is in die tijd enorm. In 1956 worden er alleen in Brabant al veertien verschillende openluchtspelen opgevoerd. De meeste zijn geschreven door Brabantse auteurs als Jan Naaijkens, Kees Spierings, Willem Hoffman, J. Keijsers en Antoon Coolen. ${ }^{9}$ Andere plaatsen waar in de open lucht wordt gespeeld zijn Oisterwijk, Hilvarenbeek en Best. Heeswijk spant echter toch de kroon, schrijft Kees Spierings, omdat Coolen de stukken speciaal op de mogelijkheden van het theater schrijft, waardoor het spel organisch in de plaats, de omstandigheden en het materieel opgaat. ${ }^{10}$ In hetzelfde artikel klinkt ook voorzichtige kritiek, als Spierings over Genoveva schrijft dat het stuk, ondanks de lange dialogen en een enkel melodramatisch aspect, toch boeide door "de romantische inslag, mooie tekst en verzorgd spel, costumering en decors." Bij die voorzichtigheid moet in acht genomen worden dat het artikel in Brabantia staat. Coolen is redactielid en bovendien bestuurder van Het Noordbrabantsch Genootschap, dat het blad uitgeeft.

Er zijn ook scherpere recensies. Zo wordt Cunera in de Volkskrant afgekraakt," terwijl Coolen zelf juist zeer tevreden is over dit stuk. Naar zijn mening werkt het goed door de sterke tegenstellingen in de scènes, een handeling die flink opschiet en de korte dialogen. Daardoor merken volgens hem de toeschouwers bijna niet dat het drie uur duurt. De journalist Zoetmulder, die 25 jaar in de Provinciale Toneeladviescommissie van de provincie Brabant heeft gezeten, is achteraf minder enthousiast. Hij herinnert zich later dat in de commissie vaak met scepsis is gekeken naar de kwaliteit van Coolens stukken, ook al werden ze nog zo goed gespeeld. Hij geeft toe dat het vocaal-dramatisch een moeilijk genre is, omdat de grote afstand tussen de spelers en het publiek op het 'zodenpodium' een natuurlijke dialoog bijna onmogelijk maakt. Hij vindt echter dat in het algemeen "toneel niet de sterkste zijde van de begaafde en zo veelzijdige schrijver geweest is. ${ }^{12}$ Het stuk Cunera van Rhenen is door de adviescommissie, volgens Zoetmulder, zelfs op de zwarte lijst gezet, dat wil zeggen dat het geen subsidie ontvangt bij een opvoering. ${ }^{13}$

\section{Het toneel in Coolens werk}

Het oordeel van Zoetmulder roept de vraag op naar de plaats van het toneel in Coolens oeuvre. Al op het gymnasium in Heeswijk is Coolen door pater Knaapen enthousiast gemaakt voor het toneel. Tijdens zijn eerste jaren als journalist in Hilversum in 1922 heeft hij Exodus geschreven, dat meer een 'leesstuk' over zijn worsteling met de liefde en het geloof is dan een toneelstuk. Bij die gelegenheid schrijft hij aan Lutkie dat hij wel gelooft in de realistische komedie over "het leven dat we zelf hebben," maar helemaal niet in de mysteriespelen van die tijd en de bijbehorende uitdossing van de spelers, de verheven taal en de fraaie verzen. Pas in 1934 schrijft hij zijn volgende stuk, De vier jaargetijden, als reactie op de bewerking van Kinderen van ons volk van Cor Hermus en Kees Spierings waar hij

8 BA, brief Coolen aan Van Duinkerken, 21 augustus 1954.

9 Spierings, 'Het openluchtspel in Noord-Brabant', 299-305.

10 Spierings, 'De Brabantse openluchtspelen', 80.

11 LMDC, inv, nr. C 3485, brief Coolen aan Oomes, 31 augustus 1954.

12 CS, [kopie typoscript] Zoetmulder, Coolen en Waalre.

13 Collectie Tij Kools, brief Zoetmulder aan Carel Swinkels, 5 december 1986. 
niet zo tevreden over is. In de tweede helft van de jaren dertig volgen De vreemdeling en $D_{e}$ klokkengieter. Kort na de oorlog schrijft Coolen mee aan bevrijdings- en herdenkingsstukken die nogal bombastisch aandoen en daarom beter met de mantel der liefde kunnen worden bedekt.

Echter, ook in deze nieuwe reeks spelen zijn de dialogen traag, lang en voorspelbaar. Een voorbeeld vormt de volgende zin uit Genoveva, waarin Siegfried tegen Golo zegt dat hij geliefd is bij zijn lijfeigenen: "En bij de lijfeigenen, waaronder er zijn, die je op handen dra. gen sinds je, het bleef niet voor mij verborgen, enigen van hen, om het hun mogelijk te maken te trouwen, in de gelegenheid stelde zich vrij te kopen en een klein bezit het hunne te zien worden." ${ }^{14}$ Je moet wel een heel knappe amateur zijn om deze boekentaal met al die tussenzinnen en komma's ongeschonden uit je mond te laten rollen!

Sommige stukken ademen een pacifistische sfeer. De kortstondige vreugde die Coolen voelde over de bombardementsvluchten op Duitsland aan het eind van de oorlog is helemaal verdwenen. In de openluchtspelen komt de vredelievendheid van zijn 'Brieven' in de Bossche krant van vóór de oorlog, opnieuw naar voren. In de jaren vijftig dreigt de spanning tussen Oost en West opnieuw uit te lopen op oorlog. In het stuk Sawitri zegt een verban. nen koning: "Hij die geweld met geweld keert, vervalt zelf in de ondeugd, die hij verafschuwt. Geweld stellen tegenover geweld is het rampzalige stellen tegenover het rampzalige,- dit is mij als vorstenwijsheid geleerd. Geweld is geen oplossing. Het voegt vergoten bloed aan vergoten bloed toe; het leidt altijd tot tyrannie tegenover de verslagene. ${ }^{n 15}$ In het spel Mars en Venus wordt het militarisme zelfs ronduit belachelijk gemaakt. De zelfingenomenheid en de ijdelheid van Mars wekken de spotlust van de vrouwelijke hoofdfiguur. "Helden moet je vooral de achting geven, dat ze helden zijn. Dat vinden ze heerlijk." Zij voegt er aan toe dat, waar Mars regeert het mensdom vermindert, maar waar Venus regeert, daar vermeerdert het. ${ }^{16} \mathrm{Om}$ de sfeer van onschuld en hoop op de toekomst te vergroten laat Coolen aan het slot van zowel De Zeven Rozen als Genoveva van Brabant spelende kinderen optreden.

De nieuwe serie toneelstukken van de jaren vijftig verschilt in vorm en inhoud van de vooroorlogse spelen. Beide series vertonen echter hetzelfde gebrek: de gekunsteldheid van de dialogen. Bij een openluchtspel valt deze nog meer op vanwege de gedragenheid die het acteren in de buitenlucht nu eenmaal met zich meebrengt. Het voornaamste manco van zijn toneelstukken is echter dat Coolen zijn grootste gave, het vertellen, er niet in kwijt kan. Zijn waarnemingsvermogen en de daaraan gekoppelde beschrijvingskunst komen in een toneelstuk niet tot hun recht. Evenals De vreemdeling en De klokkengieter krijgen de openluchtspelen daardoor iets bezwerends; er wordt teveel een boodschap uitgedragen. Coolen kan er zijn mooiste stijlmiddel, de gedachten en opmerkingen van de getuigen, de verteller of de dorpsbewoners, niet in toepassen. De lezer van de romans en de novellen krijgt inzicht in een diepe laag, die voor de toeschouwer bij een spel verborgen blijft.

\section{Culturele en economische opleving van Brabant}

Coolen heeft, naast zijn literaire werk, al voor de oorlog aan verschillende boeken óver Brabant meegewerkt, zoals De Nederlandse Volkskarakters en Zóó is Brabant. Er staat nog een boek op stapel met de titel Land en Volk van Brabant, waar hij tijdens de oorlog al aan bezig 
was. We meldden al dat hij inmiddels bestuurslid is geworden van het Noordbrabants Genootschap voor Kunsten en Wetenschappen.

Coolen wordt steeds meer de zelfbenoemde woordvoerder en hofpoëet van een provincie die haar vleugels uitslaat. Onder leiding van de eerste naoorlogse Commissaris der Koningin, De Quay, die in het begin van de oorlog lid was van het driemanschap van de Nederlandsche Unie, vindt een economische en culturele opleving van Brabant plaats. De industrie wordt ontwikkeld om de leegloop in de agrarische sector op te vangen, maar tegelijkertijd wordt er voor gewaakt dat het sociale en culturele leven daardoor niet ontwricht wordt.

Al in 1947 is door het College van Gedeputeerde Staten van Noord-Brabant een Welvartsplan uitgegeven, waarin deze overgang en de consequenties ervan worden geschetst. Op een bekende kaart van Brabant uit die jaren zien we een groot aantal cirkels met een straal van zes kilometer rond industriesteden of nog te ontwikkelen industriecentra. Het provinciaal bestuur zit met het probleem, dat er snel iets gedaan moet worden aan de bevolkingstoename en de beperkte opnamecapaciteit van de landbouwsector. Dit kan niet anders dan door een bevordering van de industrie. Het overwegend katholieke bestuur ziet echter grote gevaren in massahuisvesting in de steden of industriewijken. Men kiest daarom voor een 'gedecentraliseerde concentratie': elke arbeider moet vanuit zijn dorp of uit het buitengebied op de fiets naar het werk kunnen gaan en 's avonds weer in zijn eigen omgeving kunnen terugkeren. Een afstand van zes kilometer is daarvoor het maximum." Deze gedachte weerspiegelt de tegenstelling tussen stad en platteland, waarbij het ideaal van de dorpsgemeenschap hoog verheven wordt boven het negatieve van de stad.

Ondertussen ijvert De Quay ook voor de vestiging van een Technische Hogeschool in Eindhoven, de oprichting van een eigen Brabants orkest en een zuidelijke toneelgroep. Alle drie de instellingen worden aan het begin van de jaren vijftig gerealiseerd. Er is een algemeen gevoel van vooruitgang en een wil om de schouders er onder te zetten. Zelfs in het vroeger zo terugblikkende Brabantia Nostra wordt geschreven dat het klagen over achterstelling, het jubelen over eigen voortreffelijkheid en het folkloriseren van het leven maar eens gedaan moeten zijn en dat het blad nu een naar alle richtingen bundelend, zuiverend en bevruchtend werk moet verrichten. ${ }^{18}$

\section{Land en Volk van Brabant}

In deze atmosfeer verschijnt de bundel Land en Volk van Brabant. Coolen is daar bijna tien jaar mee bezig geweest. We hebben gezien hoe hij al in het eerste oorlogsjaar A.M. de Jong vroeg om een bijdrage over West-Brabant, omdat het Kempische en het Meijerijsche in dit soort boeken altijd zo worden benadrukt. Zowel De Jong als twee andere medewerkers aan het boek zijn bij de verschijning niet meer in leven.

Vincent Cleerdin is op 15 juli 1946 overleden. In zijn inleiding wijt Coolen de vroegtij-

14 Coolen, Genoveva, 21.

15 Coolen, Sawitri, 19.

16 Coolen, Mars en Venus, 48-49.

17. Walravens, 'Lonkend perspectief, 15.

18 Van Oudheusden, Brabantia Nostra, 329. 
dige dood van Cleerdin aan de lichtvaardige beschuldigingen van collaboratie met de Duitsers in de naoorlogse verwarring; door het dralen van bevoegde instanties kwam eer. herstel te laat. Uitgebreid prijst Coolen de verdiensten van Cleerdin, met wie hij vele intensieve contacten heeft gehad bij het schrijven van boeken over Brabant [en ook in verband met zijn sollicitatie naar het burgemeesterschap in Waalre, zoals we nu weten, C.S.). Coolen wijst erop dat Cleerdin francofiel was en "anti-teutoons". Cleerdin publiceerde onder andere een bloemlezing uit het werk van Léon Bloy, een figuur waar Coolen overi. gens nooit mee is weggelopen.

Een andere medewerker, de schrijver en journalist Uri Nooteboom, is op I 2 april I 945 bij Zutphen tijdens een autotocht in de gevechtszone door een Duitse kogel getroffen. Coolen heeft het boek, waaraan Nooteboom toen bezig was, voltooid. ${ }^{19}$

A.M. de Jong werd op 17 oktober 1943 in zijn woning gedood door Nederlanders op bevel van de bezetter in het kader van de zogenoemde Silbertanne-moorden. Coolen schrijft in de inleiding, dat De Jong herhaaldelijk gepoogd heeft om het regionalisme te overstijgen en zijn interesse verlegde naar "de sociale en socialistische probleemstelling," maar vindt dat zijn Brabantse romans tot het beste van zijn werk behoren. Toch ontbreekt er iets aan: "Ongetwijfeld heeft hij de grote, dieper gelegen drijfkrachten in het Brabantse wezen veronachtzaamd en niet onderkend en ging hij dat waardevolle voorbij, wat in zijn afspiegeling van het Brabantse leven een rijker facet en aan zijn werk een dieper inhoud had kunnen geven." Coolen bedoelt hier misschien het geloof, maar het is ook mogelijk dat hij zoiets als de volksaard voor ogen heeft. Beide zaken zijn overigens voor Coolen innig met elkaar verweven in een soort levenshouding of levensaanvaarding. Hij waardeert weer wel De Jongs beschrijving van buitenmaatschappelijke figuren en vagebonden en zijn zuivere waarneming van het West-Brabantse landschap, de dorpen en de stadjes. Op de keper beschouwd is deze typering vrij negatief of op zijn minst zuinig tegenover de man, die ondanks grote meningsverschillen, zijn lof over Coolens werk nooit onder stoelen of banken heeft gestoken. Wellicht heeft Coolens zuinig oordeel ook te maken met de afkeer die Van Duinkerken van De Jong had.

Het boek bevat bijdragen van schrijvers uit de kringen van Brabantia Nostra (Luc van Hoek, Frank Valkenier, dr. P.C. de Brouwer, Paul Vlemminx), van A. van Duinkerken ('De legende van Dolle Dries') en van Coolen zelf ('De boer en zijn kerkplavei'). De foto's zijn van Martien Coppens, waarvan een is ondertiteld 'Onder den zwaai der Canadassen'.

Met zijn uitgebreide inleiding van 2I pagina's geeft Coolen een nieuw visitekaartje af: dat van de beschrijver én de promotor van Brabant. Hij heeft daarvoor al enige malen meegewerkt aan bundels met een volkskundige of sociografische inslag, ${ }^{20}$ maar deze inleiding, geschreven in 1949 , heeft een alomvattend karakter. Het boek loopt daarmee vooruit op het standaardwerk over Brabant dat binnen enkele jaren zal verschijnen. ${ }^{21}$

Coolen geeft in de inleiding een overzicht van de ontwikkeling van de godsdienst. Hij wijst op heidense rudimenten in de afweer van boze geesten, zoals het hagelkruis tegen onweer en de benamingen van plekken als Heksenberg, Duivelsven en Kattenbosch. Hii behandelt de kerstening van de heidense elementen via de Willibrordusputten, de heilige eiken die niet werden omgehakt maar tot Maria-eiken uitgeroepen, de Paasvuren als vervanging van de heidense lentevuren, enzovoort. Bij de beschrijving van de kerstening 
noemt hij St. Geertrui (of St. Geerten), de dochter van Pepijn van Landen, waar hij net een toneelstuk over heeft geschreven, maar ook St. Oda. Naar beide heiligen zijn Brabantse plaatsen genoemd: Geertruidenberg en St. Oedenrode.

De staatkundige, bouwkundige en geestelijke ontwikkelingen krijgen ruime aandacht. Coolen benadrukt de invloed van de zuidelijke schilderkunst op de noordelijke. We moeten geen pretenties hebben, relativeert Coolen en natuurlijk zijn de invloeden wederzijds. Een zuidelijk chauvinisme is niet op zijn plaats. Toch kan hij het niet laten om Jan Engelman aan te halen, die betoogt dat de bloei van de Gouden Eeuw in het Noorden zijn voedingssappen nog trok uit het inmiddels gescheiden zuiden. Dat de wortels werden losgeslagen leidde uiteindelijk "tot de negentiende eeuwse inschrompeling in het eenmaal machtige bolwerk Holland tot het burgerdom op pantoffels met de goudse pijp, de Hildebrandse figuur van leven van de Kegge's en de Stastokken." 22

Coolen wijst op het feit dat er ondanks het Generaliteitsverleden van Brabant toch banden zijn met de Oranjes, vooral zichtbaar in steden als Willemstad, Breda en Tilburg. De band van het zuiden met het noorden, die het duidelijkst was toen Brabant bij de inval van de Fransen aan het eind van de achttiende eeuw trouw bleef aan het noorden, wordt veroorzaakt door het leed dat het zuiden heeft verdragen. Deze paradoxale redenering van de historicus Nuyen, heeft Coolen al ooit gebruikt. In zijn boek De schoone voleinding schreef hij over de trouw aan het huis en de herd waarin zoveel geleden is en waar het overleden kindje heeft opgebaard gestaan.

De verschillen tussen streken en dorpen worden heel precies beschreven. Volgens Coolen leidt het samenwonen van mensen gedurende een langere tijd in een zelfde gebied tot overeenkomsten en tot iets 'eigens'. Uitdrukkelijk vermeldt hij erbij dat hier volstrekt geen sprake is van een mythe of zoiets als "bloedmystiek": dit eigene ontstaat uit de alledaagse handelingen en gewoonten. Deze voorzichtigheid is natuurlijk geboden in de tijd dat de volkskunde zich moet bevrijden van de invloeden die oorlog en fascisme erop hadden uitgeoefend via de bloed-en bodemleer. Zo komt er in de inleiding geen enkele verwijzing voor naar de volkskundige D.J. van der Ven, die tijdens de oorlog zijn kennis volledig heeft ingepast in de nieuwe orde. Vóór de oorlog heeft Coolen hem veelvuldig genoemd in zijn column in de Bossche krant.

Coolen schrijft ook over de taal in West- en Oost-Brabant. Deze is volgens hem beïnvloed door het geloof: in het westen door de Statenbijbel en in het oosten door de kanseltaal van de katholieke pastoors.

Tegenover de industrie neemt Coolen verrassend genoeg een heel andere houding aan dan in de jaren twintig en dertig. Waarschijnlijk heeft hij ervaren hoezeer een idealisering van de boer en het boerenleven op drijfzand berust. Zijn houding zal ook beïnvloed zijn door het elan rond het welvaartsplan en het streven naar een sociaal-culturele inbedding ervan. De meisjes die naar de fabriek fietsen, schildert hij nu niet af als nuffige juffertjes. Zij groeten

19 Nooteboom (voltooid door Coolen), Het Land van de Sniedersen.

20 Coolen, 'De Oost-Brabanters' (1938); 'Het gelaat der Noord-Brabantse steden' (1939). Daarnaast vele artikelen voor de Katholieke Illustrotie tussen 1947 en 1949.

21 De Quay e.a. red., Het nieuwe Brabant 1952.

22 Coolen e.a. red., Land en volk van Brabant, 16. 
de dorpsbevolking die op het land blijft werken en zij blijven ermee verbonden. Al geldt dat niet voor hun klederdracht, want men gaat niet als boerinnetje naar de fabriek in de stad, schrijft Coolen. Deze passage klinkt heel wat vriendelijker dan zijn stukje van nog maar enkele jaren daarvoor, in 1947, in de Katholieke Illustratie, waarin hij schreef dat alle arbeid buiten de boerderij de vrouw 'ontvrouwelijkt'. Langer geleden werd in Het donkere licht Marie in haar stadse kleren langs het spoor op weg naar het station en de fabriek nog negatiever beschreven. Coolen geeft zelf een verklaring voor zijn omslag. Terugkijkend constateert hij dat de ontwikkeling van Philips aanvankelijk te snel en te schokkend was voor de 'landse' jeugd en vooral voor het vrouwelijk deel ervan. Het werk van de Eucharistische Kruistocht van de Brabantse priester Frencken heeft echter veel goeds gedaan voor de fabrieksjeugd. Nu vinden het land, de stad en de bevolking een nieuw evenwicht.

Tot slot wijst hij er met nadruk op dat het boek niet bedoeld is als een afgrenzing van de andere provincies in Nederland, want in het vaderlandse huis zijn vele woningen. Hij wil juist de scheiding tussen noord en zuid doorbreken. De verwachtingen die hij daarover aan het eind van de oorlog koesterde, toen de voedselactie 'Zuid helpt Noord' zo goed verliep, zijn echter te groot geweest. Coolen hoopt dat de bundel begrip kweekt voor de Brabantse wezensaspecten, "met het behoud waarvan Brabant zijn beste bijdragen zal blij" ven geven in de rij der provincies, die het boeiend geheel samenstellen van het Nederlandse volk."

\section{De Bourbon}

Sinds medio 1947 is er geen contact meer geweest tussen Coolen en De Bourbon. Coolen had zich geërgerd aan het gedrag van De Bourbon. Deze woont sinds 1946 samen met een vrouw in een kunstenaarskolonie in Mook en is in april 1948 gescheiden van zijn vrouw Gudrun, met wie de Coolens ook hele goede contacten onderhielden. Door deze turbulente levenswandel 'vergeet' De Bourbon zoals we zagen aanwezig te zijn op cruciale momenten in Coolens leven. Nu zijn tweede huwelijk is gestrand, gebruikt De Bourbon Coolens drieënvijftigste verjaardag "als aanleiding tot een nieuwe poging tot reconstructie onzer vriendschap. [...] Onze verwijdering - om voor mij nog steeds onbegrijpelijke redenen - en "ce silence prolongé' hebben mij meer gedrukt dan ik zeggen kan." Hij "dirigeert" nu een rechtskundig adviesbureau voor oorlogsgetroffenen. ${ }^{23} \mathrm{Hij}$ wil Coolen graag tête à tête ontmoeten en dan "reposée" met elkaar praten. "Fixeer" maar een afspraak, schrijft hij. ${ }^{24}$

Coolen antwoordt hem dat de verwijdering en scheiding van Gudrun voor hem aanleiding voor de lange contactonderbreking zijn geweest. Echter, het verzwijgen door De Bourbon van de echte reden waarom hij niet op de begrafenis zijn zoontje is geweest, was de oorzaak dat Coolen zo lang niets heeft laten horen. Van een kelners van een Eindhovens hotel had hij gehoord dat De Bourbon daar in de nacht vóór Peterkes begrafenis had gelogeerd "in gezelschap [...]. Toen dacht ik: zóó dicht in de buurt's avonds van te voren en den vriend op zúlk oogenblik geen uur afgestaan van wat je toen bezig hield!"m5

$\mathrm{Na}$ deze eerste uitwisseling komt weer een regelmatige correspondentie op gang. Hieruit blijkt dat De Bourbon niet goed meer uit het dal kan klimmen. De rollen tussen Coolen en De Bourbon zijn omgedraaid. Keek Coolen vroeger op tegen de man van de wereld en burgemeester, nu is Coolen zelf een algemeen gerespecteerd burger en bekende Brabander. 


\section{Het prijzencircus}

Niet alleen in het maatschappelijk verkeer, ook in de literaire wereld wordt Coolen een autoriteit door zijn lidmaatschap van een tiental jury's en commissies. De commissies adviseren vaak uitgeverijen. Coolen zit al vanaf 1946 met Albert Helman en professor J.B. Tielrooy in de redactiecommissie voor de Tuinspiegel-reeks, een uitgave van de Amsterdamse Boek- en Courantmaatschappij, en oordeelt daar over uit te geven nieuw werk. Zo schrijft hij in 1947 aan Tielrooy: "De novelle van Harry Mulisch stuur ik je per gelijke post terug met eenige notities die je er aan gehecht vindt." In potlood staat er bijgeschreven: "afgewezen." ${ }^{\text {"26 }}$ Met Van Duinkerken en Elsschot zit hij in de adviescommissie voor de reeks de Muiderkring en vanaf 25 oktober 1949 is hij lid van het hoofdbestuur van het Prins Bernardfonds.

Gaat het bij de bovenstaande commissies meestal om het stimuleren van en kansen bieden aan jong talent, anders is het gesteld met het lidmaatschap van jury's voor prijzen aan gevestigde collega's. Coolen zit na de oorlog in de jury voor de Poëzieprijs van de gemeente Amsterdam voor 1945, de Romanprijsvraag van Kruseman in 1946 en de Novelleprijsvraag voor het Boekenweekgeschenk van de CPNB in 1949. In de jaren vijftig zal hij nog vaker voor zo'n jurylidmaatschap gevraagd worden."

Het eigen werk wil echter niet vlotten. Ook in het najaar van 1950 sombert Coolen, nu al voor de vijfde keer, over het uitblijven van inspiratie voor 'het grote werk ${ }^{28}$. Hij betreurt het overlijden van zijn vriend professor Kippenberg, de directeur van de Insel Verlag, met wie hij na al het gebeurde nog "een warme, zij het zeer openhartige en klare briefwisseling" heeft gehad. Het laatste wat hij voor Kippenberg heeft gedaan is het schrijven van een artikel over de Duitse schrijver Hans Carossa voor een gedenkboek ter gelegenheid van diens zeventigste verjaardag. ${ }^{29}$

Het is interessant om te zien hoe Coolen en Van Duinkerken elkaar in dit prijzencircuit op de hoogte stellen van hun werk. Als Coolen voorzitter is van de jury voor de Martinus Nijhoff-prijs voor vertalingen zit Van Duinkerken in de commissie van advies voor de

23 In de zomer van 1950 wordt De Bourbon directeur van het rayon Eindhoven bij de Eerste Nederlandse Verzekeringsmaatschappij tegen invaliditeit.

24 LMDC, inv, nr. B 783, brief De Bourbon aan Coolen, 24 april 1950.

25 LMDC, inv, nr. C 3485, brief Coolen aan De Bourbon, 8 mei 1950.

26 LMDC, inv. nr. C 3485, brief Coolen aan Tielrooy, 6 oktober 1947. Het gaat hier om de novelle Tussen hamer en aambeeld van Mulisch.

27 Coolen adviseert voor het Boekenweekgeschenk in de jaren 1952, 1957 en 1958; hij zit in jury's voor de Romanprijsvraag van Sijthoff in 1951, de P.C. Hooftprijs in 1953 (toegekend aan Bordewijk); van 1954 tot 1961 zit hij in de jury voor de Reina Prinsen Geerligs-prijs en van 1955 tot 1961 in de jury voor de Martinus Nijhoff-prijs voor vertalingen; voor de Prozaprijs van de gemeente Amsterdam in 1957 en voor de Provinciale Prijs voor schone kunsten van Noord-Brabant in 1960. Michaêl e.a., Nederlandse literaire prijzen, 324.

28 LMDC, inv, nr. C 3485, brief Coolen aan Oomes, 23 november 1950.

29 Coolen, 'Hans Carossa zum siebzigsten Geburtstag.' Hans Carossa behoort tot de groep schrijvers van de innere Emigration; zij weken niet uit maar encanailleerden zich niet met het nazi-regime. Carossa werd eind 1941 desondanks, terwijl hij in een zomerhuisje van Kippenberg in Weimar logeerde, door Goebels tot voorzitter van het Europäisch Schriftstellerverband benoemt. Hij heeft zich daarna afzijdig gehouden door verhinderd te zijn op bijeenkomsten. Speliers, Als een oude Germaanse eik, 442. 
Provinciale Prijs voor Schone Kunsten van Noord-Brabant. Van Duinkerken attendeent Coolen dan op zijn twee rijmvertalingen die na 1945 verschenen zijn. Quasi-bescheiden voegt hij eraan toe dat er misschien mooiere vertalingen van losse gedichten zijn, maar dat hij toch graag ziet dat Coolen even de aandacht van de jury van de Nijhoffprijs vestigt "op het weinig bekende feit, dat ik deze beide poëzie-vertalingen van lange, samenhangende werken vervaardigde. ${ }^{\text {"30 }}$ Als reactie stuurt Coolen meteen de inmiddels gedrukte uitgave van het Genoveva-spel en vraagt tevens naar de originele teksten van de twee vertaalde gedichten. Hij herinnert zich de vertalingen nog en verzekert dat ze in de jury zeker een punt van bespreking zullen uitmaken. Tot een bespreking zal het wel gekomen zijn, maar tot een vertaalprijs voor Van Duinkerken komt het niet. Voor Coolen pakt de verstandhouding beter uit, want hij zal de Provinciale prijs voor Schone Kunsten wèl ontvangen.

\section{Gouden Legenden}

Hierboven is afgeweken van de chronologische lijn om te laten zien hoe druk Coolen het in de jaren vijftig heeft met het schrijven van toneelstukken, jurering en lidmaatschappen van besturen. Daar tussendoor neemt hij allerlei opdrachten aan. In 1950, niet lang na het schrijven van een herdenkingsboek over boekhandel Van Piere, werkt hij aan een gedenk. boek over de stad Eindhoven. Ook dit is weer een opdracht en hij vindt het "een wat moei. zame arbeid," schrijft hij Oomes. Het spijt hem dat hij nog steeds niet aan een grote roman kan beginnen. "Ik vertel wel hier en daar in novellen en heb wel zin om maar breejer te beginnen." 31

Voor Oudjaar van 1950 maakt Coolen een vertelling, 'Juffrouw Annelies', die ongeinspireerd en wat oubollig is. ${ }^{32}$ Twee wat oudere vrijgezellen zoeken op oudejaarsavond op een schutterige manier toenadering tot elkaar en besluiten te gaan trouwen. Dat betekent pech voor de familie die een suikertante verloren ziet gaan. De naam van de bruidegom in spe moeten we in de gaten houden: Cordewever. De naam voor de hoofdpersoon uit het nieuwe grote werk dat komen gaat is er al.

Het is opvallend dat juist in de periode dat Coolen beweert dat katholieke schrijvers over alles moeten kunnen schrijven, hij zelf veel bezig is met religieuze verhalen. Aan het eind van de jaren veertig zat hij in de redactie van het omvangrijke boek Met de heiligen het jaar rond en vanaf de lente van 1950 werkt hij opnieuw aan een boek over heiligenlevens." Het wordt echter een boek dat niet alleen over heiligen zal gaan, maar over god, gewone mensen en zondaars. De verhalen hebben de religieuze inhoud gemeen. Het boek zal Gouden Legenden gaan heten. Door de correspondentie met Van Duinkerken is het wordingsproces goed te volgen. Duidelijk zichtbaar is hoe nauwgezet Coolen bij de voorbereiding te werk gaat. In diezelfde tijd moet hij ook de literatuurstudie verrichten voor het boek over Eindhoven én voor een groot gedenkboek over het Verzet. Op die manier zit hij nooit voor "een schone werktafel" om aan die grote roman te beginnen. Toch blijft hij opdrachten aannemen. Hij doet dit behalve vanuit materiële motieven om zijn levensstij] te kunnen behouden ook om de status. Tegelijkertijd vormt het opdrachtwerk echter ook een excuus voor het uitblijven van literair werk, omdat hij als verteller tijdelijk droog staat.

Voor de samenstelling van het legendenboek kiest Coolen uit de bijbel, maar ook uit de Legenda Aurea, een geschrift uit de dertiende eeuw over heiligen, waarvan de meeste ver- 
halen legenden zijn. Het boek heeft vooral in de religieuze kunst veel invloed gehad. Veel schilderijen en beeldhouwwerken in de Europese kathedralen en kloosters zijn op de verhalen uit dit boek gebaseerd. Aan Van Duinkerken vraagt hij suggesties voor Engelse en lerse verhalen en voor verhalen van onder andere Tsjechov en Richard Hugh. ${ }^{34}$ Aan de beantwoording is af te lezen dat Van Duinkerken bij dit soort vragen in zijn element is en dat hij graag doceert. Bijna per kerende post ${ }^{35}$ zendt hij vele suggesties, waarvan Coolen er enkele overneemt: het verhaal 'De student' van Tsjechov en 'De potsenmaker van Onze Lieve Vrouw', in de vertaling van Victor E. van Vriesland. Wanneer Coolen hem kort daarna een vertaalprobleem voorlegt, krijgt hij daags daarna een compleet college. ${ }^{36} \mathrm{Als}$ het boek bijna klaar is, vraagt Coolen nog om een suggestie voor een protestants verhaal "dat bij het niveau van de bundel past ${ }^{\text {"37 }}$ en nog een uit de moderne Angelsaksische literatuur. Dit laatste wordt een verhaal uit Tortilla Flat van John Steinbeck: 'Een handelaar voor St. Franciscus'.

In de inleiding van het boek schrijft Coolen dat men over de huidige tijd "nauwelijks ongunstig genoeg kan oordelen. Overal ziet men in de geestesuitingen dat nihilisme, dat duidelijk zijn verband toont met dien tijd, die aan de onbelemmerde en beestachtigste heerschappij van het ondermenselijke was onderworpen. ${ }^{38}$ Voor Coolen is de heerschappij van het "ondermenselijke" na 1945 niet afgelopen. De gebeurtenissen in de wereld en in zijn privé-leven hebben hem pessimistisch gemaakt. Daarom benadrukt hij in de inleiding zo dat er behoefte is aan literatuur met een spirituele inhoud.

De verhalen uit de Legenda Aurea zijn intact gelaten. "Niets is weggewerkt, niets is verbeterd," zodat de "critiekloze lichtgelovigheid" van die tijd goed tot uiting komt. De koning die Christophorus na vreselijke martelingen laat onthoofden, geneest zijn blindheid door het bloed van de martelaar in naam van diens God op zijn ogen te strijken. Hierna is hij plotseling bekeerd en "voortaan zal hij allen den kop afslaan, die niet in Christus geloven." De bundel is dus geen bundeling van zoete verhaaltjes. Op verzoek van de uitgever heeft Coolen zijn verhaal 'Isidoor van de Boeren' uit zijn vroegere bundel Zegen der goedheid toegevoegd.

De illustraties zijn gemaakt door voormalig Zwart-Front-tekenaar en nu cartoonist van De Limie, Karel Thole. Het is eigenaardig dat Coolen hier kennelijk geen probleem mee heeft. Thole werkte ook al mee aan het boek Met de heiligen het jaar rond. Toen was Coolen

30 BA, brief Van Duinkerken aan Coolen, 19 augustus 1954.Bedoeld zijn de vertalingen Kerk in bladergroen naar Francis Jammes en Odysseus' Hartsgeheim naar Charles Maurras. Van der Plas wijst er op dat het eigenaardig is dat Van Duinkerken deze zeer 'foute' Maurras vertaalde midden in oorlogstijd. Van der Plas, Daarom, mijnheer, 348.

3) LMDC, inv. nr. C 3485, brief Coolen aan Oomes, 19 november 1950.

32 Coolen, 'Juffrouw Annelies'.

33 BA, brief Coolen aan Van Duinkerken, 19 april 1950 [op de brief staat 19 maart, maar uit de context blijkt dat het 19 april moet zijn].

34 BA, brief Coolen aan Van Duinkerken, 12 januari 1951.

35 BA, brief Van Duinkerken aan Coolen, 17 januari 1951.

36 BA, vier brieven over en weer Van Duinkerken en Coolen, 20-24 maart 1951.

37 BA, brief Coolen aan Van Duinkerken, 14 april 1951.

38 Coolen, Gouden Legenden, V. 
slechts een van de redactieleden, maar nu betreft het een werk dat hij helemaal zelf samen. gesteld heeft.

\section{Geschiedenis en fictie van oorlog en verzet}

Een andere opdracht brengt Coolen opnieuw terug naar de oorlogstijd. Na de bevrijding zijn een tijd lang verschillende bladen van oud-verzetstrijders verschenen, zoals De Vrije Stem, Ons Baken, Strijdt! en De Zwerver. Dit laatste weekblad kwam voort uit de Landelijke Organisatie voor Onderduikers (LO) en de Landelijke Knokploegen (LKP). De organisaties LO en LKP besluiten een gedenkboek uit te geven en vragen Coolen om het lot van de onderduiker te beschrijven. De titel van het boek wordt Het Grote Gebod. De LO groeide, volgens de verantwoording van het boek, tijdens de oorlog uit tot de 'moederorganisatie' van het verzet, met naar schatting 15.000 medewerkers. De LO kwam oorspronkelijk voort uit het christelijk geïnspireerd verzet, vandaar de verwijzing in de titel naar het grote gebod: "God liefhebben boven alles en de naaste als zich zelve. De LKP bleef klein met ongeveer 750 leden medio 1944. Maar de laatste deed veel van zich spreken vanwege de talloze gewapende acties. ${ }^{39}$ Het boek, dat dus niet het totale verzet bestrijkt, ziet er uit als een monument met twee delen van elk zo'n zevenhonderd bladzijden van glanzend papier met vele foto's en uitgebreide registers van gevallenen, maar ook van provocateurs en verraders.

In het tweede deel zijn langere bijdragen opgenomen over de achtergronden van het verzet. Coolens hoofdstuk over de verzorging van de onderduiker is bijna een boek op zich: het telt een kleine tweehonderd pagina's. Het werk aan dit hoofdstuk 'De verzorging van de onderduiker' voor het gedenkboek over het verzet heeft hem veel zoek-en ordenwerk gekost. Coolen schrijft heel negatief over de medewerking die de hogere ambtenaren en de secretarissen-generaal aan de Duitse maatregelen en registraties voor de arbeidsinzet hebben verleend. Hij noemt naast het gedrag van de secretaris-generaal Hirschfeld ook dat van secretaris-generaal Frederiks laakbaar, maar vermeldt er wel bij dat het voor de hogere ambtenaren moeilijker was om verzet te bieden dan voor de lagere. ${ }^{40} \mathrm{Hij}$ schetst hoe het verzet in 1943 steeds krachtiger optrad naar aanleiding van de strenger wordende Duitse maatregelen. Bij het schrijven van deze passages zal hij regelmatig gedacht hebben aan zijn sollicitatie naar een burgemeesterschap in dat jaar.

In dit gedenkboek heeft Coolen een gruwelijke gebeurtenis uit de oorlog beschreven. In een bos bij Vierhouten werd tijdens de bezetting een groep van vier volwassen joden en een joods jongetje door de Nederlandse Landstorm ontdekt. Zij moesten hun eigen graf graven. Na mishandeling werden ze in de graven gegooid en dood geschoten. Na de oorlog bleek bij de lijkschouwing dat van het vermoorde kind de benen verbrijzeld waren. Bij de rechts. zaak gaven de SD-ers, waarvan er een Frankenstein heette, op een laffe manier elkaar de schuld. ${ }^{4 \prime}$

Coolen heeft dit verhaal nog tijdens het schrijven van het gedenkboek bewerkt tot een verhaal, 'Voorval in een kerk'. Een geestelijke die 's avonds in zijn kerk moet zijn, voelt dat er nog iemand aanwezig is. De kerkdeur slaat dicht en meteen daarna vindt hij een dode in het koor. Hij herkent hem als degene die kort daarvoor bij hem gebiecht heeft. Even later meldt zich degene die wegvluchtte. Hij kent de dode van vroeger. Hij is er in Polen getuige van geweest hoe deze SS-er een gevlucht joods gezin heeft afgemaakt. Deze avond heeft hij 
hem voor het eerst weer gezien en hem op zijn misdaad aangesproken. De oorlogsmisdadiger is daarop de kerk ingevlucht. Hij heeft hem niet vermoord, maar de man is als gevolg van de schrik over de confrontatie met de ooggetuige uit zijn verleden aan een attaque overleden en daarna gevallen. De ooggetuige is niet katholiek en hij vraagt aan de geestelijke wat er met dit "monster" na zijn dood zal gebeuren. De priester zegt dat de man kort daarvoor bij hem gebiecht heeft. "Wie zegt $u$, dat hij zichzelf niet als een monster heeft aangeklaagd en veroordeeld, erger dan u en dodelijker, al verraste de dood hem, toen een getuige verscheen tussen hem en zijn geweten."

De beschrijving van de slachting is bijna precies hetzelfde als in het Gedenkboek. Ook in dit verhaal gaat een echtpaar in een omhelzing in het graf liggen en wordt een nog gillend kind op lijken in een graf gegooid, waarna het met een pistool wordt doodgeschoten. Het slot van het verhaal met de passage over de biecht past helemaal in de toespraak, die Coolen ongeveer in diezelfde tijd in Mariakerke heeft gehouden. Hierin ligt de mogelijkheid besloten van goddelijke genade en van barmhartigheid, ook voor dit 'monster'. Later zal Coolen voor dit verhaal een internationale prijs krijgen. ${ }^{42}$

Ondanks dit geslaagde verhaal blijft hij erover dromen weer aan een grote roman te beginnen: "Wat mijn werk betreft blijft het moeilijk de draad te hervinden met een verleden, waarvan zúlk een caesuur scheidt. Streuvels blijft vertrouwen op iets vernieuwds als uit De ontmoeting en 'Voorval in een kerk'. Zelf heb ik de illusie om nog eens een roman te maken, mogelijk toch in aansluiting aan het vroegere werk, maar je weet nooit als je eenmaal achter een eindelijk weer eens schone werktafel zit." ${ }^{43}$

\section{Groot-Kempische Cultuurdagen}

Voorlopig is Coolens werktafel niet schoon en zijn agenda niet leeg. Naast alle vergaderingen en commissies neemt hij in die jaren ook deel aan bijeenkomsten waar ruimte is voor gezelligheid, cultuur en scherts. De naam van de Groot-Kempische Cultuurdagen is al een paar maal gevallen. Deze dagen zijn enorm populair en iedereen van enig belang in het zuiden laat zich hier zien. Men kan er schrijvers en andere Brabantse cultuurdragers ontmoeten, maar ook politici als Jan de Quay en KVP-ministers. Zelfs Koningin Juliana heeft de dagen bezocht.

De dagen zijn gestart in de zomer van 1947 in de abdij van Postel, vlak over de Belgische grens bij Reusel, tijdens een bijeenkomst van de Vereniging van Kempische Schrijvers. Vanaf die tijd wordt Hilvarenbeek elke zomer de plaats van een grote bijeenkomst, waar in een programma met spreekbeurten over culturele onderwerpen steeds de verhouding tus-

39 Coolen, 'De verzorging van den onderduiker', in: Het grote gebod, deel I, IX.

40 Coolen, 'De verzorging van den onderduiker', 211.

4) Coolen, 'De verzorging van den onderduiker', 235.

42 Coolen, 'Voorval in een kerk'. Coolen heeft het verhaal al vóór mei 1951 geschreven; in een brief aan Oomes van 7 mei 1951 maakt hij er melding van. Pas in 1954 verschijnt het in een bundel van Prisma. Uit de briefwisseling blijkt dat Van Duinkerken het pas in oktober 1954 leest. Later is het ook nog verschenen in de Katholieke Illustratie. Het verhaal verschijnt in 1952 in het Engels als 'Incident in a church', in: World Prize Short Stories, selected from the NY Herald Tribune competition. Het wordt dan in 23 landen in vertaling opgenomen.

43 LMDC, inv. nr. C 3485, brief Coolen aan Oomes, 7 mei 1951. 
sen noord en zuid centraal staat. Daarnaast zijn er feestelijke programmapunten zoals een grote koffietafel onder de linden van het Vrijthof, muziek en toneeluitvoeringen. De grote animator van het geheel, Jan Naaijkens, schrijft bijna elk jaar een speciaal toneelstuk of wagenspel dat tijdens de dagen wordt opgevoerd. Hij is van 1946 tot 1950 de hoofdredacteur van Edele Brabant en verzorgt lange tijd voor de KRO-radio het Brabants Halfuur.

De sfeer is meestal gemoedelijk, maar soms worden er felle debatten gevoerd. Zo was er in 1949 na een redevoering van Gabriël Smit een heftige polemiek, "aangestoken door Anton van Duinkerken en aangeblazen door Antoon Coolen, Albert Westerlinck en André Munnichs. ${ }^{\text {44 }}$ Vast onderdeel van de Cultuurdagen vormt de besloten schrijversavond op zaterdag, een studentikoze parodie op een academische zitting, waarbij elk jaar een eredoctoraat wordt verleend door de Pickwickclub. ${ }^{45}$ In 1949 promoveerde tijdens dit scherts. ritueel Van Duinkerken en in 1950 Emiel van Hemeldonck. Antoon Coolen is in 1951 de derde die voor deze eer is uitgekozen. De aanwezigen zingen het Pickwicklied:

"De wereld barst van vuil vernijn

En stinkt van kwade streken

Hoe schoon zouden de mensen zijn

Als zij op Pickwick leken.

Refrein:

Komt drinken wij nu kloek en fel

Ter eer van Samuel.".46

Daarna wordt de promotierede gehouden door Jan Naaijkens en de Laudatio door Anton van Duinkerken. Hierna is het de gewoonte dat het bier rijkelijk vloeit, maar in dit geval waarschijnlijk meer door de kelen van Van Duinkerken, Naaijkens en andere aanwezigen, want Coolen is geen bierdrinker. Het jaar daarop wordt Godfried Bomans doctor honoris causa pickwick club. Later volgen nog mensen als Jan de Quay, Gabriël Smit, prof.dr. L. Rogier, Albert van Dalsum, Gerard Walschap, Ernst van Altena en de staatssecretaris van O.K. en W., Louis van de Laar.

De Cultuurdagen van r95 r zijn onder meer gewijd aan de afstand tussen schrijver en publiek. Professor Geyl spreekt over cultuuruitwisseling tussen Noord en Zuid. Coolen leest voor uit eigen werk en dat was volgens Kapteijns "een bijna symbolische triomf van het juiste begrip en de goede smaak." ${ }^{n 7}$ Overigens heeft Coolen geen grote rol gespeeld op de Cultuurdagen; hij heeft er verder nimmer als officiële spreker het woord gevoerd. Tegen het eind van zijn leven krijgt hij er de literaire prijs voor zijn roman Stad aan de Maas.

Jan Naaijkens herinnert zich dat Coolen in het begin meestal samen met Van Duinkerken naar Hilvarenbeek kwam. Later kwam hij slechts wanneer hij op een of andere manier een rol in het programma had. Coolen gedroeg zich volgens hem bij dit soort gelegenheden heel formeel en afstandelijk. Zijn manier van praten en formuleren viel veel bezoekers wat tegen. Men heeft in die tijd zonder televisie een heel ander beeld van de schrijver van Peelwerkers en De Goede Moordenaar. ${ }^{48}$ Ook Jan Starink herinnert zich Coolens optreden op de Cultuurdagen:

"Hij sprak hoffelijk en innemend, met die vleug ironie die paste bij zijn wat bleke Erasmiaanse gezicht en de glimlachende mondhoeken. [...] Met zijn verzorgde, bijna gestileerde gebaren leek hij allerminst de auteur van boeren-epiek, maar veeleer poèet die schept vanuit een brede achtergrond van eruditie en nogal sceptisch levensbesef." 


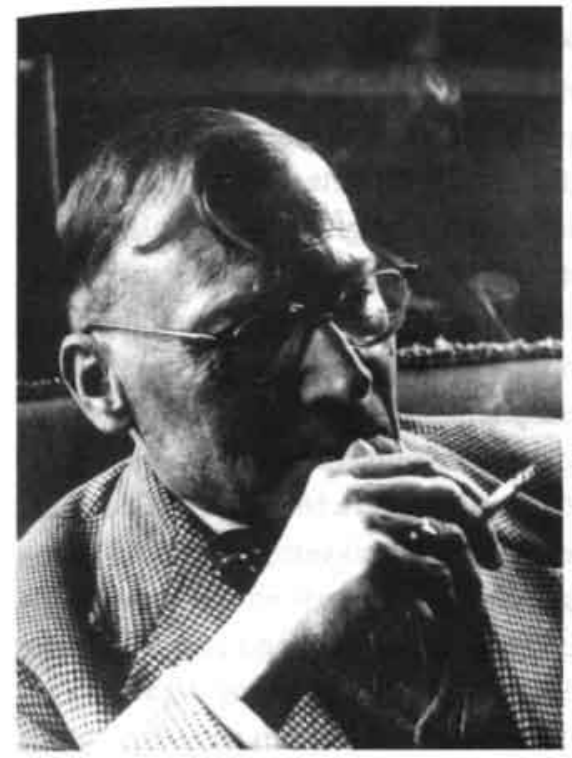

Dat is toch het grote verschil met de hoofdfiguren van deze dagen. De bezoekers en de genodigde autoriteiten voelen zich op hun gemak bij de joyeuze Van Duinkerken, de geestige Bomans en de hartelijke Naaijkens. Coolen is een algemeen gerespecteerd burger, maar op dit soort bijeenkomsten is een sceptische poëet niet de eerste waar de autoriteiten op af lopen. ${ }^{50}$

\section{Geschiedenis van Eindhoven}

De afwerking van Coolens boek over Eindhoven heeft veel voeten in de aarde gehad. De zaak dateert al van 3r december 1945, toen burgemeester Verdijk zijn ambt neerlegde. Het boek "heeft erg gesleept tengevolge van de treuzelende opdrachtgevers, die nota bene met $\mathrm{f}$ 1000,-voor het héle werk in zee waren gegaan, auteur, drukker en alles, en 't zijn allemaal grote fabrikanten," constateert hij geërgerd. ${ }^{51}$ Intussen gaan Coolens eigen inkomsten achteruit door de terugloop van de verkoop van zijn boeken. Tegelijkertijd worden zijn kosten alleen maar hoger door de studerende zoons, de hogere kolenprijzen en belastingen. Hij heeft daarom zijn huis De Kempen te koop gezet om kleiner te gaan wonen. De verkoop laat voorlopig op zich wachten, want het zal nog tot maart 1953 duren voordat hij verhuist.

In september I95I verschijnt dan het lang verwachte boek over Eindhoven. Oud-burgemeester Verdijk, aan wie het is opgedragen, is kort daarvoor op is juni overleden. Hij was burgemeester geworden van de nieuwe gemeente Groot-Eindhoven, die op r januari 1920 ontstond. Hierbij werden de dorpen Woensel, Strijp, Tongelre, Stratum, Gestel en Blanthem bij het in oppervlak zeer kleine stadje Eindhoven gevoegd..$^{52}$ Op dezelfde manier waarop

44 Naaijkens, Biks 5, 13.

45 Pickwick is een figuur van Dickens uit The Pickwickpapers. In dit spel is ook Godfried Bomans, als voorzitter van het Dickensgenootschap, betrokken. Zoals gemeld werkte Coolen in de oorlogsjaren mee aan de vertaling van Dickens voor de Prisma-serie.

46 Naaijkens, Biks 5, 44-45.

47 Kapteijns, 'Hilvarenbeek', 324-325.

48 Jan Naaijkens tijdens interview met Cees Slegers, mei 1999.

49 Starink, 'Antoon Coolen, provincie of wereld?, 16.

50 Dit is ook postuum nog zo. Bij de presentatie van de bundel Brabant dichterlijk belicht met gedichten en prozastukken over Brabant in mei 2000 zegt de Commissaris der Koningin dat Van Duinkerken zijn lievelingsschrijver is. Niemand merkt op dat dé beschrijver van de Brabantse natuur, landschappen en de dorpen, Coolen, in de bundel ontbreekt.

51 LMDC, inv, nr. C 3485, brief Coolen aan Oomes, 7 mei 1951.

52 De kleinste geannexeerde gemeente had acht maal de oppervlakte van Eindhoven; het grootste dorp was zelfs 36 maal zo groot. Coolen, Groei van een stod, 26. 
Coolen het verschil tussen het eigene van streken, dorpen en zelfs buurten heeft beschre. ven in de inleiding van Land en Volk van Brabant, schetst hij nu de moeilijkheden die daarvan het gevolg zijn bij het tot stand komen van de herindeling rond Eindhoven. De dorpen weten niet "hoe breed ze de onderlinge verschillen zullen uitmeten, om aan te tonen, dat hun vereniging tot één gemeente onmogelijk is en de noodlottigste gevolgen zal hebben."

De geschiedenis van Eindhoven is een typisch representatief gedenkboek voor de stad en een eerbetoon aan burgemeester Verdijk. Men ziet er de moeite aan af waarmee Coolen getracht heeft de veelheid aan cijfers, gegevens en onderwerpen te vangen in een lopend verhaal. Het is in enkele opsommende gedeelten plichtmatig, maar in andere delen weer zeer leesbaar. In de beschrijving van de houding van de burgemeester in de oorlog, zijn gevangenneming tijdens een vergadering van de Vereniging van Nederlandse Gemeenten en zijn gedwongen ontslagname is Coolen weer op zijn best als verteller. De NSB-vervanger van Verdijk wordt niet met name genoemd. Het is de veearts en directeur van het Eindhovens gemeentelijk slachthuis $\mathrm{H}$. Pulles, de man die model stond voor het personage Vlimmen uit de gelijknamige roman van A. Roothaert. Het lijkt erop dat Coolen alle verwijzingen naar zijn collegaschrijver wil vermijden. ${ }^{54} Z$ eer ironisch is het verslag van het bezoek van Mussert aan Eindhoven. De NSB had een foto gemaakt van zijn auto voor een stoplicht, waar de werknemers van Philips vlak voor het begin van de werktijd stonden te wachten om over te steken, om op die manier te suggereren dat heel Eindhoven was uitgelopen om de Leider te zien.

Het boek is volgens het blad Brabantia geslaagd. "Er was nodig de fantasie van een auteur als Coolen, gepaard aan de nuchterheid van een man die maanden in de archieven werkte en zich met de kracht der wanhoop door rijen van cijfers kon heen worstelen, om ons dit wonderlijke beeld van het groeiende Eindhoven voor te stellen; en dan in een taal en een vorm, die voor de 'roman' Eindhoven alleszins verbluffend mooi en passend zijn. Het gedenkboek is wat de herindelingskwestie betreft nog steeds actueel, want vijftig jaar later, bij de herindelingsplannen rond het jaar 2000 , worden weer dezelfde argumenten gehanteerd.

Echt 'klein werk' is Coolens medewerking aan het boek De doolhof, dat door acht auteurs wordt geschreven. Het was een idee van uitgever Uitman van Wereldvenster en Max Dendermonde. Aan de uitgave is alweer een prijsvraag verbonden: welke auteur schreef welk hoofdstuk? Het boek komt zonder overleg of teamwerk tot stand. De afspraak is alleen dat Henriëtte van Eyck zal beginnen en dat Vestdijk het slothoofdstuk schrijit. Vestdijk grijpt hier de kans om kritiek uit te oefenen op de vorige zeven hoofdstukken. Bii een daarvan spreekt hij over "een bijna weldadig aandoende ouderwetse verteltrant" en bedoelt daarmee zeer waarschijnlijk het hoofdstuk van Coolen.

\section{Redactielid Brabantia}

De culturele opleving in Brabant op vele terreinen, de Groot-Kempische Cultuurdagen, de opvoeringen van zijn stukken in het 'natuurtheater' De Kersouwe in Heeswijk brengen Coolen, meer dan voor de oorlog, in contact met Brabantse organisaties als het Provinciaal Genootschap, het provinciaal bestuur, Brabantia Nostra, Brabants Heem en gemeentebesturen. 
Coolen heeft bij Brabantia Nostra nooit een rol gespeeld. Hij was meer betrokken bij de landelijke tijdschriften van en voor jonge katholieken, zoals Roeping en De Gemeenschap. Van dit laatste was hij redacteur vanaf 1933 tot aan de opheffing ervan door de bezetter in I 94 I.

Het blad Brabantia Nostra is aanvankelijk verschenen van 1935 tot 1942 . Deze zeven jargangen zijn na de oorlog nog even gevolgd door een achtste, maar het blad ging in de malstroom van kranten en blaadjes en door de papierschaarste ten onder. Vanaf 1946 werd het in een meer populaire tweewekelijkse editie voortgezet onder de naam Edele Brabant. Hoofdredacteur was Jan Naaijkens uit Hilvarenbeek. We kwamen hem hiervoor al tegen als groot animator van de Kempische Cultuurdagen.

Na vier jaar bleek ook Edele Brabant niet te handhaven. Men probeerde het nog een keer met Brabantia Nostra in de oude formule. Dit werd de negende jaargang, die liep van september 1950 tot augustus I951. In het laatste nummer wijst Lambert Tegenbosch op de impasse en pleit voor een nieuwe bezinning op doel en taak van het blad: "Het is altijd nog beter een huis dat onbewoonbaar werd te slopen als een gevel zonder achterbouw ten koste van veel nutteloos gebruikte energie in stand te houden."

Op dat moment is de Commissaris der Koningin in Brabant, De Quay, is al enige tijd bezig culturele organisaties bij elkaar te brengen, onder meer binnen een Culturele Raad. Hij spoort aan tot meer coördinatie, speciaal op het gebied van publicaties en tijdschriften. Dit is de directe aanleiding voor de besturen van Brabantia Nostra en het Provinciaal Genootschap voor Kunsten en Wetenschappen om nader contact met elkaar te zoeken. Coolen werd reeds in 1940 door dit Genootschap onderscheiden en bij die gelegenheid toegesproken door de toenmalige secretaris Cleerdin. Sinds 17 februari 1951 is Coolen bestuurslid van dit Genootschap, dat elk jaar een publicatie uitgeeft met een overzicht van de activiteiten en enkele artikelen, de zogeheten 'Handelingen'. In een gecombineerde vergadering van de besturen van Brabantia Nostra en het Provinciaal Genootschap op I3 december I95I wordt besloten om gezamenlijk een blad uit geven. De naam van het blad wordt Brabantia. ${ }^{57}$

Een derde organisatie die zich veel met de geschiedenis van Brabant bezighoudt, Brabants Heem, valt er buiten en doet niet mee. Waarschijnlijk is de oorzaak hiervan de sociale scheiding. Er is altijd een zekere kloof geweest tussen de 'heren' van het Genootschap en de 'boeren' van Brabants Heem.

Antoon Coolen neemt plaats in de redactie van Brabantia om de letterkunde te behartigen. De redactie bestaat verder uit professor F. van der Ven (Frans Valkenier) voor het soci-

53 Coolen, Groei van een stad, 28.

54 Roothaert (1896-1967) woonde tijdens de bezetting in de Antwerpse voorstad Deurne. Hij schreef in 1942 het boek De vlam in de pan over zijn ervaringen als militair tijdens de meidagen van 1940. Hierin leverde hij felle kritiek op de toestanden in het vooroorlogse leger in Nederland. De bezetter propageerde dit boek en stuurde er 15.500 van naar de Nederlandse vrijwilligers aan het Oostfront. Roothaert werd na de oorlog door de Centrale Ereraad veroordeeld tot 500 gulden boete en openbaarmaking van het vonnis. Walch. 'Anton Roothaert', 104.

55 'Boekbespreking Groei van een stad', 89-90.

56 Tegenbosch, 'Losse notities', 322.

57 Het blad Brabantia is sinds die tijd onafgebroken blijven verschijnen. Wel is de naam veranderd in Brabant Cuttureel. 
ale aspect en de bekende schoolboekenschrijver A. Commissaris voor de historie. Redactiesecretaris is de directeur van het Genootschap, M. van der Griend. De meeste redactieleden zijn ook betrokken bij het schrijven van het standaardwerk over Brabant dat vanaf 1952 zal verschijnen.

\section{Ook redactie Roeping vernieuwd}

Een maand eerder heeft het blad Roeping zichzelf vernieuwd. De $28 \mathrm{e}$ jaargang krijgt een nieuwe redactie met onder andere Gabriël Smit, Michel van der Plas, Lambert Tegenbosch en Paul Haimon. Het doel van de redactie is "een overzicht te geven van al hetgeen door katholieken binnen het Nederlandse taalgebied in letterkundig opzicht wordt voortgebracht." ${ }^{58}$ Daarnaast zal ook aan andere takken van kunst aandacht gegeven worden. De redactie betreurt de sfeer in katholiek cultureel Nederland en de persoonlijke kwaadsprekerij van de laatste jaren. Er zijn te veel middelpuntvliedende krachten: noord en zuid, links en rechts, humanisme of integraliteit. Roeping wil met zijn brede redactie een bin. dende kracht vormen. De eerste aflevering bevat een uitgebreid artikel van Van Duinkerken. $^{59}$

Coolen reageert niet enthousiast op het eerste nummer. Aan Van Duinkerken schrijft hij wat schamper dat de aanwezigheid van Henri Bruning in hetzelfde nummer hem (Van Duinkerken) kennelijk niet hindert. Coolen ergert zich daar echter behoorlijk aan leen 'foute' schrijver hindert hem kennelijk meer dan de 'foute' tekenaar Thole, C.S.] en hij weigert om abonnee te worden. De redactie heeft hem om een reactie op dit eerste nummer gevraagd, maar hij geeft die niet. Hij wil niet de "spanningen en lager gelegen tegenstellingen teweeg brengen die Roeping nu juist wil opheffen." In zijn brief aan Van Duinkerken geeft hij wel uitgebreid zijn mening over Bruning. Het treft hem heel pijnlijk dat een schrijver uit de foute katholieke hoek ${ }^{60}$ weer een podium krijgt. Dat dit podium uitgerekend Roeping moet zijn, het blad dat zo veel te maken heeft met zijn start als schrijver en waarin hij Van Duinkerken leerde kennen, maakt het nog erger. Daar komt nog bij dat Coolen zich nog heel goed de afbrekende recensie van Bruning over Herberg In 't Misverstand herinnert.

Wat zou natuurlijker zijn dan over deze zaak te schrijven als kersverse Brabantia-redacteur belast met letterkunde? Wederom blijkt echter Coolens afkeer van een openlijke pole. miek; hij schrijft niet over het nieuwe Roeping en het optreden van Bruning erin. Kopschuw geworden na de Van Doorne zaak, waarmee hij zichzelf meer kwaad heeft gedaan dan Van Doorne, schuwt Coolen nu de openlijke aanval. Hij schrijft zijn agressie van zich af in zijn brief aan Van Duinkerken. De satirische en ironische stijl van deze brief zou niet misstaan hebben in een artikel, vandaar een wat langer citaat:

"Mij ronken nog Brunings tirades in de ooren uit zijn kultuurkamerrede voor het let. terengilde in 1943: 'De strijd van het Groot Germaansche rijk voor Europa is stellig ook onze strijd, al was het slechts omdat wij niets zijn zonder Europa en Europa niets is zon. der het rijk, zonder den realistischen en diep vitalen levenswil van den Duitschen noordrasmensch.' De polemiek in die rede, 'de Duitsche noordrasmensch schept zich zijn orde wederom uit het levensbewustzijn van zijn ras,' hij 'veracht het onrecht als een eerloosheid die den mensch niet waardig is,' de verdediging van 'rede en redelijkheid van mythe en bloed, van bodem en ras,' het is allemaal van het allooi van Kotzde 
Kottenrodt, waarover ik in Bevrijd Vaderland schreef. Het onthult het oordeelkundig en critisch inzicht van Bruning als van generlei waarde, ook in zijn 'scherpe' critiek op het Christendom met dat aanleunen tegen Ter Braak, Nietzsche, Ortega y Gasset en Bernanos. Ik weet niet, hoe jij zijn bijdrage in dit eerste Roeping nummer vindt, maar ik vind deze wijsheden met Zarathustra-allures eigenlijk toch maar pseudodiepzinnige kletspraat. ('Het probleem van den mensch is, dat hij tegen het probleem van den mensch niet is opgewassen, het is grooter dan hij. Dit is tevens zijn specifieke tragiek en een lot, waaraan het dier ontkomt. Het dier is de oplossing van zijn probleem.' Toe maar! Dit is iets waar bij ons Stijn aan toe is.) In Brunings bijdrage aan Roeping heft zich de 'lagere tegenstelling' niet op, zooals in sommige verzen van Eekhout. Moeilijk mijn tegenzin tegen Brunings naargeestigheid overwinnend, die ik zijn hoofdtrek vind, blijf ik, als hij er aan meewerkt, liever van Roeping afzijdig, ook als abonné."6l

Coolen is zich ervan bewust dat deze gedachten geen kerstpacifisme bevorderen. Hij beschouwt deze brief als een gesprek onder elkaar en wil de redactie van Roeping er niet mee lastig vallen. Hij neemt overigens aan dat Van Duinkerken het een wel van het ander weet te scheiden.

Van Duinkerken heeft een duidelijke uiteenzetting teruggeschreven, maar deze is verloren gegaan. Hierin heeft Van Duinkerken het voorbeeld in Frankrijk genoemd: het Comité National des Ecrivains Français dat een lijst heeft gepubliceerd van foute schrijvers, waarmee ze niet in eenzelfde blad of tijdschrift willen staan. Kennelijk heeft Van Duinkerken Bruning vergeven, maar voor Coolen weegt de zaak veel zwaarder. "Wat voor zin heeft het, een met ' $n$ totalitaire instelling en nieuwe Orde-nonsens belast auteur weer binnen te halen. ${ }^{62}$ Als Coolen iets ter publicatie heeft zal hij het in ieder geval niet naar Roeping sturen, maar naar Dietsche Warande en Belfort, een mogelijkheid waarop Van Duinkerken hem heeft geattendeerd.

Van publiceren komt echter niet veel, noch in Brabantia, waar hij zich als redacteur voornamelijk bezighoudt met de beoordeling van het aanbod, noch in Dietse Warande en Belfort. ${ }^{63}$ Een verklaring hiervoor is dat hij hard werkt aan een nieuw spel voor Heeswijk en dan het schrijven van zijn bijdrage voor een standaardwerk over Brabant. Brabant neemt hem zo in beslag dat Brabantia het nakijken heeft.

58 Redactie Roeping. 'Verantwoording', I.

59 Van Duinkerken, 'Christelijke inspiratie in de romantiek', 16-23.

60 Coolen was trouwens al vóór de oorlog anti-Bruning: in een brief aan Van Duinkerken van 20 maart 1928 heeft hij het over het "verrajersstuk" van Bruning in het blad NU.

61 BA, brief Coolen aan Van Duinkerken, 22 december 1951.

62 BA, brief Coolen aan Van Duinkerken, 5 januari 1952.

63 De eerste jaargang van Brabantia bevat vooral artikelen over cultuurhistorie, archeologie en enkele gedichten, waaronder twee sonnetten van Frans Babylon 'In de Peel', waarvan het eerste is opgedragen aan Coolen en zijn vrouw. 
524 


\section{De muziek van de verloren tijd}

"De verknoeide bladzijden van de eerste eeuwhelft doorvlekken die van de tweede en doordrenken ze met hun angsten."

1952-1953

\section{De nieuwe en oude generatie}

Terwijl Coolen op verzoek van het provinciaal bestuur werkt aan een beschrijving van de Brabantse dorpen en landschappen groeit langzaam het idee voor een nieuwe grote roman. Door de vele activiteiten op letterkundig gebied komt hij er voorlopig niet toe om hem te schrijven. Althans, dat zegt hij zelf steeds als hij klaagt dat zijn bureau nooit leeg raakt door het vele 'kleine werk'. De werkelijkheid is dat hij eerder vlucht in dit werk uit angst voor het moeizame schrijfproces aan een nieuwe roman.

"Het succes van Coolens gepubliceerde romans is groot. Hoewel hij in mei klaagt dat de verkoop terugloopt,' behoort Coolen in 195 I samen met Anne de Vries, A.M. de Jong, Jan de Hartog, Ina Boudier-Bakker en A. den Doolaard nog altijd tot de meest gelezen auteurs. ${ }^{2}$

De status van Coolen als gearriveerd schrijver wordt in die tijd nog eens benadrukt door een lang interview met het protestantchristelijke weekblad De Spiegel. ${ }^{3} \mathrm{Hij}$ vertelt dat hijna de oorlog nog geen tijd en concentratie heeft gevonden voor een nieuwe roman, door de vele maatschappelijke en culturele beslommeringen, maar hij ziet weer uit "naar de grote roman, het omvangrijke verhaal." Eerst moet echter zijn bijdrage voor Het nieuwe Brabant af. Hij laat zich in dit interview meteen als een promotor van dit gewest kennen. Hij roemt de culturele opleving in de openluchttheaters, bij de harmoniekorpsen, de gilden en de zangkoren. "In een stad als Eindhoven is een arbeiderskoor, dat de grote Hollandse polyphone meesters zingt." De provincie en de steden brengen grote offers voor Het Brabants Orkest. Er verandert veel in Brabant en Coolen wil meehelpen om de cultuurspreiding te bevorderen.

In dit interview uit 1952 spreekt Coolen wél over Streuvels, Graham Greene, Julien Green en George Bernanos, maar niet over de nieuwe generatie Nederlandse schrijvers als Hermans, Blaman, Van het Reve en Mulisch. Toch dient zich deze generatie met enig rumoer aan, waardoor de literatuur in Nederland op een andere manier in het nieuws komt. In I 95 I ontstaat een rel rond het boek $I k$ heb altijd gelijk van W.F. Hermans, resulterend in een proces wegens belediging van het katholieke volksdeel. Aanleiding is een pas-

1 LMDC, inv, nr. C 3485, brief Coolen aan Oomes, 7 mei 1951.

2 Anbeek, Na de oorlog, 131.

3 Klap, 'Kunst en streekcultuur in het Nieuwe Brabant'. 


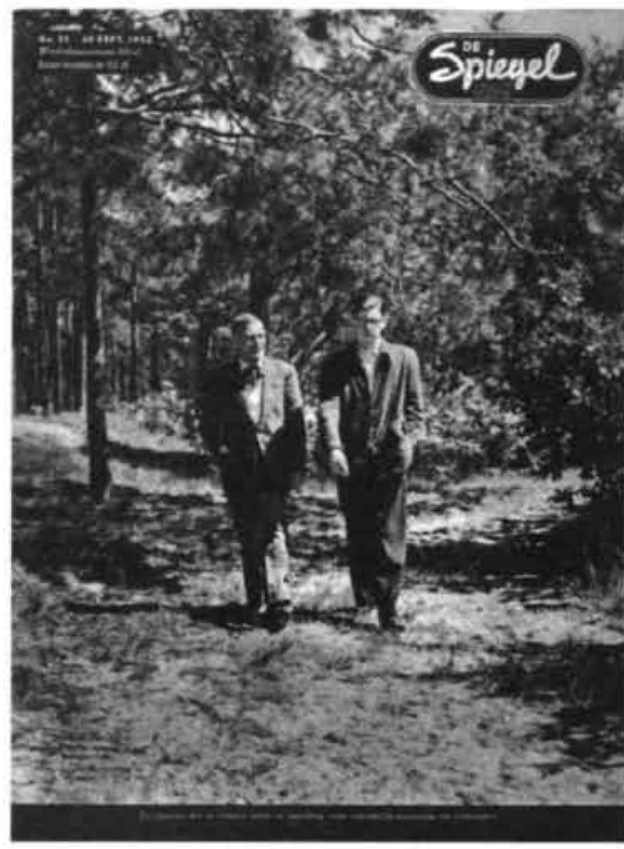

Coolen met zoon Felix, op de cover van De Spiegel.

sage waarin katholieken "het meest schunnige, belazerde, onderkruiperige, besodemieterde" deel van het Nederlandse volk worden genoemd. In datzelfde jaar weigert staatssecretaris Cals een beurs toe te kennen aan Simon [later Gerard Kornelis, C.S.] van het Reve op grond van enkele seksuele passages in diens verhaal Melancholia. Enkele jaren eerder wil Anna Blaman de Van der Hoogt prijs van de Nederlandse Maatschappij der Letterkunde voor haar Eenzaam Avontuur niet accepteren, omdat de jury in het rapport enkele bedenkingen tegen het boek had geopperd.

Coolen behoort tot de gevestigde auteurs die met deze nieuwe garde geen affiniteit hebben. Hij zit nog steeds in landelijke jury's en houdt regelmatig spreekbeurten, maar aan een "kermis der letteren" als de landelijke Boekenmarkt heeft hij een hekel. Hij houdt niet van het geroezemoes en de collectieve nieuwsgierigheid "die [-H] weinig distantie makt tussen een schrijver en een wielrenner." Over de nieuwe Nederlandse literatuur is hij niet enthousiast:

"Simon van 't Reve ken ik onvoldoende. Vestdijk en Blaman heb ik wel gelezen. Vestdijks El Greco roman heb ik altijd een bijzonder goed boek gevonden, maar in veel van zijn andere romans staat zijn volkomen indifferentiatie mij tegen, zelfs in $D c$ Koperen Tuin, waar nochtans een prachtig musicusfiguur in voorkomt, maar aan 't slot waarvan het vocabularium rond een dronken zoon bij het lijk van diens moeder voor mij weer zoo met alle zonden tegen de goede smaak, ontluisterend is.

Eenzaam Avontuurvan Anna Blaman, moet, zegt men, een knap boek zijn. Maar ik lees er in of ik in lijm zwem. Hermans vind ik slaapverwekkend vervelend. Deze schrijvers zijn anti-burgerlijk, en hun visie en stijl en hun tergend discours zijn van een grauwer en kleiner burgerlijkheid dan men zich voorstellen kan." 4

Coolen heeft behalve met Bordewijk überhaupt niet veel op met de Nederlandse literatuur. Hij leest liever Evelyn Waugh, Graham Greene, Albert Camus, Julien Green, George Bernanos en ook altijd nog de negentiende-eeuwse romanschrijvers. Hij vindt het in Nederland maar een koffievisite "in het benauwde huis, waarvan de ramen niet open schijnen te kunnen." Hij maakt een uitzondering voor zijn collega-verteller Johan Fabricius, aan wie de brief gericht is. De laatste valt buiten de "bijt der nederlandsche letteren" en heeft volgens Coolen een onvaderlands weidse fantasie.

Opvallend is de uitvoerigheid waarmee Coolen zich uitlaat over andere Nederlandse schrijvers tegenover Fabricius. Hierdoor springt extra in het oog, dat hij dit soort onderwerpen, althans op schrift, minder aanroert tegenover zijn vrienden Van Duinkerken en 
Oomes, Coolen bezoekt geen bijeenkomsten van schrijvers als de Boekenmarkt, maar zit wel in allerlei clubjes die het werk van schrijvers moeten beoordelen. Dit is op zichzelf al een activiteit die afstand schept. Als dit aspect gevoegd wordt bij zijn afstandelijke houding en afgelegen woonplaats, dan is het duidelijk dat Coolen niet zo zeer geīsoleerd wórdt, maar dat hij zich zelf isoleert ten opzichte van de nieuwe schrijversgeneratie.

Met zijn geestverwanten blijft hij goede contacten onderhouden. Te Ingooighem houdt hij in het najaar van r95I een feestrede bij de tachtigste verjaardag van Stijn Streuvels. Hij schrijft ook een bewonderend artikel over hem in een Duits tijdschrift.

Coolen weet hoe hij zijn verwantschap in de eerste volzin moet neerzetten. Terwijl hij het artikel schrijft in zijn werkhut hoort hij "das Rauschen der fallenden Hälme auf den Feldern, die für mich die tägliche Welt bedeuten: die Bauern ernten das Korn." Hij vertelt het Duitse publiek hoe hij Streuvels altijd met zomer en zon heeft geassocieerd, omdat hij als eerste werk van Streuvels in zijn jeugd De Oogst las. Het is interessant om te zien hoe hij Streuvels plaatst tegenover het naturalisme en realisme. "Das geschah in den Tagen nach dem franzözischen Naturalismus, der sich in den nördlichen Niederlanden in einen meistens trübsinnigen grauen Realismus mit deterministischer Einstellung verwandelte." Het was in feite een nabloei van het Franse naturalisme, schrijft Coolen, waarbij voor alles de mensen aan de schaduwkant van het leven en van de maatschappij beschreven werden.

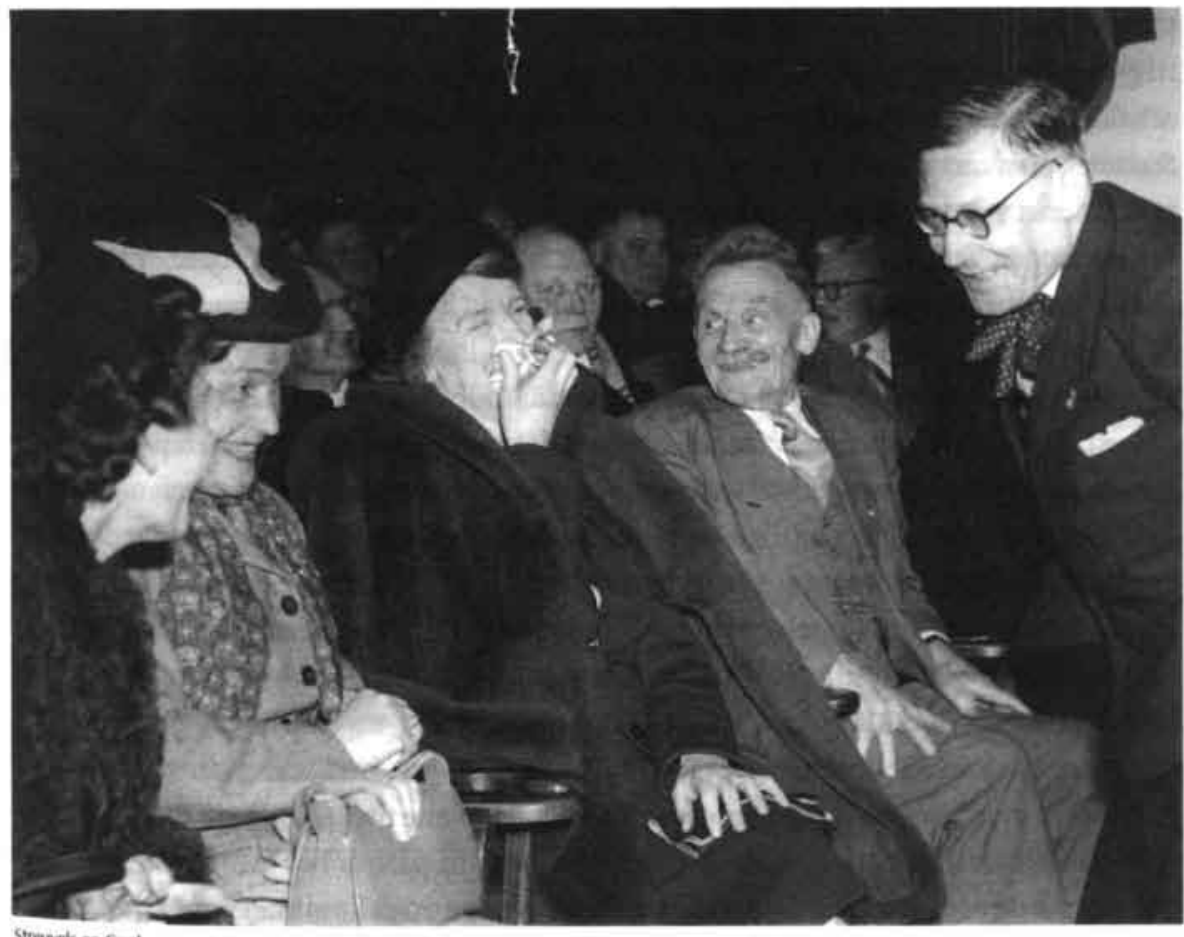

Strenvels en Coolen.

4 LMDC, inv. nr. C 3485, brief Coolen aan Johan Fabricius, 21 mei 1952. 
In het zuidelijk deel van de Nederlanden was er dan het werk van Streuvels, die een einde makte aan de koele, 'objectieve', beschrijving van de werkelijkheid. Hij komt met een nieuw realisme: "die singende Freude bei der Beschreibung einer unerschöpflichen Wirklichkeit." In de noordelijke Nederlanden kan, volgens Coolen alleen het werk van Jacobus van Looy hier en daar ermee vergeleken worden. Dit werk is echter veel minder episch en speelt buiten de grenzen van Nederland nauwelijks een rol.

Vervolgens geeft hij een aantal voorbeelden uit het werk van Streuvels, waarin de grote kracht van een in de natuur gelegen noodlot wordt geschetst. Deze kracht speelt met de mensen als met een bal, maar dat doet niet af aan de "sinnbetäubende Lust und Freude am Leben." De natuur verschijnt in duizendvoudig spiegelbeeld in de beschrijvingen van Streuvels, waarvan De Vlaschaard het meesterwerk is.

Streuvels schrijft over boeren en over het proletariaat. Bij de boeren gaat het om de strijd tussen de mens en de natuur, waarbij de onbuigzame natuur de sterkere is. In zijn vertellingen over het proletariaat staat het sociale probleem op de voorgrond. Hier belicha. men de arbeiders de harde primitieve kracht. Coolen is kennelijk beducht om Streuvels af te schilderen als een socialistisch kunstenaar, want hij voegt er enigszins tegenstrijdig aan toe dat zijn "proletarische kunst," ondanks de sterk revolutionaire tendens die erin zit, niet over een brandend sociaal probleem gaat.

De psychologie in het werk van Streuvels is volgens Coolen niet analytisch. Bovendien is het geen psychologie van grote hartstochten (Leidenschaften), maar eerder van primitieve zielsangsten (Seelenängsten). Ze is echter altijd synthetisch en trefzeker: zijn personages zijn echte "bloedwarme" mensen. Streuvels kruipt, volgens hem, in de huid van de arbeider en legt vervolgens al diens bewegingen met zijn scherpe psychologie vast. Streuvels kan met niemand in de Nederlands-Vlaamse literatuur vergeleken worden. Zijn schrijfkunst staat op dezelfde hoogte als die van de Rus Maxim Gorki. Coolen bewondert het vermogen van Streuvels om in de innerlijke wereld van mensen door te dringen, niet alleen bij volwassenen maar ook, en vooral, in die van het kind. ${ }^{5}$

Met dit artikel geeft Coolen ook een beeld van zichzelf. De gedachten over het noodlot, de natuur, de sociale problemen, maar vooral over de psychologie zijn een weerspiegeling van zijn eigen opvattingen over de romankunst. Hij heeft een hekel aan 'tendens-romans', maar ook aan de romans waarin op een psychoanalytische, Freudiaanse manier de hoofdpersonen worden beschreven. Vooral de psyche van het kind en de ontwikkeling van de seksualiteit wil hij daaraan niet blootstellen, zoals we in zijn volgende roman zullen zien.

\section{Het nieuwe Brabant}

Al vanaf I 948 heeft Commissaris De Quay rondgelopen met een plan om een standaardwerk over Brabant te doen uitgeven met als algemene titel Het nieuwe Brabant. De uitgave van dit omvangrijke driedelige boek over Brabant past in het elan dat de provincie Brabant na de oorlog ten toon spreidt. In het najaar van 1952 komt het eerste deel uit: Het Brabantse land. In 1953 en 1954 volgen nog Het Brabantse volk en De Brabantse geest. De bijdragen van Coolen staan allebei in het eerste deel en behandelen het Brabantse landschap en het Brabantse dorp. Ze beslaan samen een kwart van dit vierhonderd pagina's tellende deel. 
In deze bijdragen hervat Coolen zijn literaire werk op een heel eigen manier. De sociografische hoofdstukken die hij schrijft, vormen een unieke mengeling van wetenschap, journalistiek en literatuur. Het is niet onwaarschijnlijk dat hij door dit werk de kracht en het zelfvertrouwen hervonden heeft voor het voltooien van zijn nieuwe roman die in I $953 \mathrm{zal}$ verschijnen.

Het lijkt wel of Coolen alles wat hij tot nu toe in zijn romans en verhalen over het landschap van Brabant heeft geschreven in dit essay weer oproept voor een lyrisch portret van deze provincie. Natuurlijk zijn de teksten over de landschappen uit zijn literaire werk het meest doorleefd: de Peel, De Kempen, De Meierij en het Maasland, die samen het landschap van Oost-Brabant vormen. Misschien verraden daardoor de beschrijvingen van Midden-en zeker West-Brabant toch iets meer van de studeerkamer en is de toon wat academischer. Dit is echter eigenlijk te streng geoordeeld, want van iedere bladzijde gloeit de warmte en het enthousiasme over het Brabantse landschap de lezer tegemoet.

Bij de beschrijving van de zes regio's van Brabant schuwt Coolen de vergelijking met verre streken niet. Hij wil in het regionale iets universeels laten zien, zoals hij ook deed in zijn exotische sprookjes. Zo waan je je, volgens hem, in de stuifzandheuvels van de Loonsche en Drunense Duinen in de Sahara of de Egyptische woestijn: "Men zou niet verbaasd zijn op de kam van een hogen, verren heuvel plotseling het silhouet te zien verschijnen van een kameel, die langs de door den wind scherp getrokken lijn der heuvelhelling kwam afdalen met het stilte-omvangen klingelen van zijn klokjes." ${ }^{1 n}$ de Biesbosch kan men zich voelen "als een reiziger op de Congo of op de Amazonerivier."7 Ook de Maaskant bood avontuur. Als daar bij hoogwater werd geroepen: "De Beerse komt" [de vloedgolf van de Beerse overlaat, C.S.], dan vluchtte men met brik en bolderkar en het water kwam er vlak achter aan "zoals wolven in de Russische wintersteppen achter de troika. ${ }^{n 8}$ De uitgestrektheid in de nieuwe polders van het overlaatgebied onder Lith en Lithoyen is van zo'n eenzaamheid "dat men zich in Canada zou kunnen wanen in een gebied, waar men op kolonisten wacht."

Coolen zwelgt niet in nostalgie. Het hele stuk is doordrongen van het vooruitgangsdenken dat Brabant in die tijd kenmerkt. Het zeer kleinschalige landschap van de "zandboerkes" was een afspiegeling van hun tobbend en miserievol leven. Het was een vicieuze cirkel van te weinig geld, geen vee, dus geen mest en schrale grond. "Het is deze gedachte, die van het Brabants landschap van beakkerde zandgronden, weikes, veldjes, bos en hei en afgeplagd veen en moer valt af te lezen." 10

De goede oude tijd heeft nooit bestaan, zoals Ouwerling vroeger al met cijfers heeft aangetoond. Onderwijzers en geestelijken, zoals Ouwerling, Van den Elsen en pastoor Roes, hebben gezorgd dat het bruine Brabant, van hei en bunt, een groen Brabant werd van

5 Coolen, 'Flanderns Grösster Epiker'.

6 Coolen, 'Het Brabantse landschap', 108-109.

7 Coolen, 'Het Brabantse landschap', 129.

8 Coolen, 'Het Brabantse landschap', 133-134.

9 Coolen, 'Het Brabantse landschap', 138.

10 Coolen, 'Het Brabantse landschap', 73. 
weiden en akkers. De vooruitgang is gekomen door de verbeterde wegen, die aanvankelijk zandpaden waren, door de kanalen en de spoorwegen, waarnaast ook korte tijd de regionale tramverbindingen en de ontginningswerken een rol hebben gespeeld. De trams vindt hij minder romantisch dan de spoorwegen. Tramlijnen zijn gevaarlijk doordat ze nauwelijks gescheiden zijn van het andere verkeer, maar ze brengen wel een "gemoedelijke levendigheid." We herinneren ons hoe hij in zijn columns voor de Bossche krant schreef over de tramwagonnetjes, die huppelend van dorp naar dorp reden door de Meijerij. Voor de spoorbanen heeft hij nog steeds een grote voorliefde:

"Van de landschapsgedachte van de Peel kan ik den spoorweg niet scheiden, hij maakt er deel van uit. Het uitliggen van de rails over den spoordijk, de telegraafdraden, die windharpen, waarvan het trillen doorzoemde en doorzong in het hout der A-benige telegraafpalen, versterkten nog dien indruk der kimloze verte van deze verlatenheid, en de seinklok was als het geluid ervan."

De stalen kabelmasten van de PNEM-centrale die vanuit Geertruidenberg het landschap accentueren, wekken die romantische gevoelens minder: "Ze zijn van een foeilelijke brutaliteit en maar rare gasten midden in hei en weide en korenland. ${ }^{12} \mathrm{Hij}$ vindt ze niet te vergelijken met de houten telegraafpalen die het wel aardig konden doen in een bocht van de weg. Coolens smaak krijgt hiermee iets voorspelbaars. Dat wat in zijn jeugd al bestond . spoorwegen, telegraafpalen - vind hij mooi, maar wat nadien kwam - regionale tramverbindingen, stalen masten - vindt hij lelijk.

De beschrijving van de Peel komt merkbaar rechtstreeks uit het hart: "Nooit elders in Brabant heb ik tegenover een landschap gestaan, dat zijn gedachte zo diep aan mij opdrong: een mengeling van grootse, trage romantische, vegetatieve wording, van eenzaamheid, verlatenheid, barheid, barsheid, grauwheid, kommervol hard werken, - en schoonheid tenslotte ook." ${ }^{13}$ Hij schetst de ontwikkeling vanaf de keuterboeren, die daat op een Vergiliaanse wijze boerden, dat wil zeggen dat ze hun as en vuilnis op de grond brachten en die grond om het jaar braak lieten liggen. ${ }^{14}$ Zeer poëtisch is zijn beeld van de groei van de nieuwe dorpen tussen de oude op de west- en oostrand van de Peel: "En te midden van de boerennederzettingen, evenals aardbeischeuten met de moederplant eerst nog met de dorpen vanwaar ze waren uitgegaan verbonden, ontstonden nieuwe dorpskernen van kerk en school en herberg en winkels en ambachten. ${ }^{15}$

Is de Peel het merkwaardigste, de Meijerij vindt hij het fraaiste landschap van Brabant. Hij beschreef het al eens heel mooi bij de voettocht van Caspar van den Haarlemmermeet in de bundel Onder de Canadassen.

Voor West-Brabant citeert hij de secretaris van 'Ons Landschap', die zegt dat boer en boom daar vijanden zijn. De boeren bezitten geen bos en willen geen bomen op hun akkers, en als er een keer een paar bomen op een landbouwperceel staan moet 'Ons Landschap' voortdurend strijd voeren om ze te behouden.

Veel liefelijker wordt de Maaskant geschilderd. De zeeman heeft geen idee wat een rivier is, citeert hij Guy de Maupassant. Een zeeman kent alleen de harde ruwe zee, die schreeuwt en brult. "Maar de rivier is zwijgend, zij gromt niet, zij stroomt zonder geluid, en die eeuwige beweging van water dat stroomt is indrukwekkender dan de golven van de oceaan. ${ }^{16}$ Coolen ziet de toekomst van het Brabantse landschap met vertrouwen tegemoet. De ingenieurs van de Heidemij en Grondmij zijn volgens hem natuurvrienden. Et 
zijn veranderingen nodig, want de Brabanders willen ook niet meer leven als de wevers en aardappeleters van Van Gogh. Het ziet er nu nog wat kaal uit, na de ruilverkavelingen, maar het nieuwe cultuurlandschap moet even tijd hebben om de natuur er vorm aan te laten geven.

Het hoofdstuk 'Het Brabantse dorp' begint, evenals Vincent Cleerdins boekje uit 1944, met erop te wijzen dat Brabant niet alleen zanddorpen heeft, maar ook zijn dorp aan de rivier. Coolen wil zich kennelijk niet als chauvinistische peelbewoner laten kennen, want de Maasdorpen worden als eerste beschreven. Sommige onderdelen, zoals de beschrijving van de kastelen en de modernisering van de Deurnese markt, zijn bijna letterlijk terug te vinden in zijn roman De vrouw met de zes slapers, die het jaar daarop zal verschijnen. Hij legt uit hoe de spoorwegen onbedoeld de dorpen verfraaiden. Omdat de stationnetjes meestal een eind buiten het dorp lagen, ontstond er tussen de oude kern en het station een ruim gebouwd kwartier rondom een stationslaan, die vaak meer allure had dan de oude dorpsstraatijes."

De ontginningsnederzettingen in de Peel zijn echte dorpen geworden met een kerk en een school, maar bij het fabrieksdorp Bata bij Best is dit volgens hem niet gelukt. Het middelpunt is daar de fabriek. Zelfs als een arbeider op een zomeravond voor zijn deur staat ziet hij nog steeds de fabriek. Coolen kan zich voorstellen dat hij dan "de fiets pakt en eens naar Rooy, of Liempde of Son of Breugel of Oirschot fietst, om in of voor een echte dorpsherberg aan het dorpsplein eens een glas bier te drinken en in een écht Brabants dorp eens écht thuis te zijn." ${ }^{18}$

Met deze twee omvangrijke en met warmte geschreven hoofdstukken heeft Coolen na zijn literaire oeuvre en de publicaties over volkskarakters en land en volk van Brabant zijn naam voorgoed gevestigd als dé kenner en beschrijver van Brabant. Het regionalisme in zijn literaire werk heeft hij steeds als secundair gezien, omdat de literatuur zich niets aantrekt van de plaats waar de handeling zich afspeelt. Hij heeft alleen steeds de opvatting bestreden dat zijn werk voor niet-Brabanders oninteressant zou zijn. Als dichterlijk sociograaf laat hij zich echter graag indelen bij de Brabant-deskundigen.

11 Coolen, 'Het Brabantse landschap', 86.

12 Coolen, 'Het Brabantse landschap', 123.

13 Coolen, Het Brabantse landschap', 83.

14 "Gij kunt het stoppelland ook om het jaar laten liggen, dat de vermoeide grond op krachten komt als braakland, [...] Toch wisselbouw is makkelijk, wees niet te kieskeurig alleen om dorre grond flink te bemesten of over 't van dracht vermoeide land het asvat om te keren." Vergilius, Het boerenbedrijf, 751752.

15 Coolen, 'Het Brabantse landschap', 88.

16 Coolen, 'Het Brabantse landschap', 131-132.

7 In Deurne staat Coolens vroegere woonhuis De Romeijn in zo'n buurt. Deze tekst komt bijna letterlijk terug in: Coolen, De vrouw met de zes slapers, 48.

18 Coolen, 'Het Brabantse dorp', 171. 


\section{Van Duinkerken naar Nijmegen}

Aan het begin van 1953 is de aandacht van intellectueel katholiek Nederland gericht op Van Duinkerken. Enkele maanden voor zijn vijftigste verjaardag is hij benoemd tot hoog. leraar in de Nederlandse en algemene letterkunde aan de Katholieke Universiteit van Nijmegen, als opvolger van Gerard Brom. Op 15 december 1952 wordt een grote afscheidsbijeenkomst gehouden in de aula van de Universiteit van Amsterdam, waar de 'hele' let. terkundige, journalistieke en wetenschappelijke wereld aanwezig is. Coolen is verhinderd; hij moet op die dag spreken in Den Bosch.

Roeping komt met een speciaal nummer dat geheel gewijd is aan Van Duinkerken. Coolen heeft een bijdrage geleverd waarin hij zijn vriendschap met Van Duinkerken beschrijft. Als uitgangspunt hiervoor heeft hij de tafelrede gebruikt die hij heeft gehouden na afloop van de inaugurale rede bij Van Duinkerken thuis. ${ }^{19}$

Het artikel blikt met vertedering terug op hun beider jeugd. Met nostalgie beschrijft hij de begintijd van Roeping, toen er een atmosfeer was "als van een jonge, beloftenvolle lente op het eigen erf." Hij vertelt hoe de gedichten van de hem nog onbekende Van Duinkerken hem boeiden en hoe ze zich aan elkaar in het Parkhotel te Amsterdam voorstelden met het wachtwoord 'Brabant'. 'Tusschen Van Duinkerken en mij is Brabant een hechte binding geweest, - misschien moet ik zeggen: een Brabantsche bepaaldheid," schrijft hij. Hij verhaalt over de wandelingen die hij met hem maakte in de landelijke omgeving van zijn dorp en hoe hij ziet dat Van Duinkerken zich dan gemakkelijk onderhoudt met een dorpse kastelein. Coolen betreurt het, evenals Gabriël Smit elders in het nummer, dat Van Duinkerkens tafelredes niet zijn opgeschreven en uitgegeven.

Groot is zijn bewondering voor de enorme productie van zijn vriend en hij vertelt de anekdote dat Van Duinkerken hem ooit, toen Coolen vergeten was om treinlectuur mee te nemen, aanbood snel even een boek te schrijven als de stationschef de trein even wilde laten wachten. Alle spanningen bij de katholieke jongeren hebben de verhouding tussen Coolen en Van Duinkerken niet kunnen verstoren. Hun dertigjarige vriendschap is als belegen wijn. Hij hoopt dat de nu vijftigjarige even oud wordt als Streuvels.

\section{Verhuizing}

Het grote huis De Kempen aan de Blokvenlaan in Waalre is verkocht en in maart 1953 verhuist Coolen naar een kleinere woning iets verderop in dezelfde laan, meer in de richting van het dorp. ${ }^{20}$ De interviewster van Libelle [Coolen is een gezocht onderwerp voor de familiebladen, C.S.] vindt het van buiten maar een zeer eenvoudig stenen gebouw. Op het bordesje staat een klein beeld van een schrijvende figuur met een ganzenveer. Over de werkkamer is zij echter verrukt. Deze heeft een glazen achterwand met uitzicht over de velden en spiegelglas op de muur er tegenover, zodat het lijkt of je buiten zit."

Als Coolen zijn adreswijziging aan Oomes stuurt, vraagt hij hem meteen of hij Het nieuwe Brabant wil bespreken. ${ }^{22}$ De brief is neerslachtig van toon. Coolen woont nu al vijftien jaar in De Kempen en dit is precies de periode waarin hij geen grote roman heeft geschreven, want Herberg In 't Misverstand heeft hij er slechts voltooid. Oomes voelt zijn somberheid aan en schrijft voor Coolen's zesenvijftigste verjaardag een bemoedigende brief. Coolen is daar bijzonder blij mee en stort zijn hart uit: 


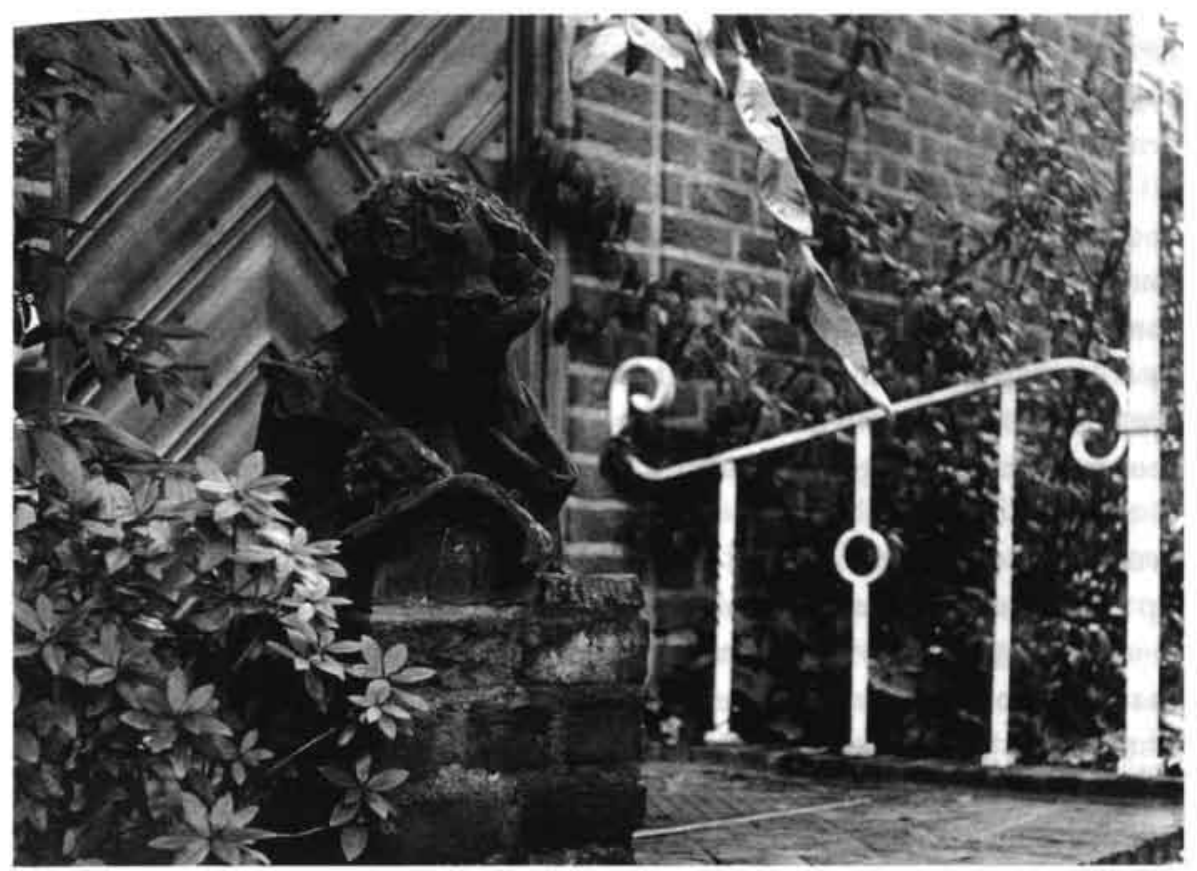

Bordes met beeldje voor het nieuwe huis.

"Bijzondere dank voor de bemoedigingen over het werk, - ik heb dat nodig ik ben dikwijls meer dan depressief niet alleen en niet vooral om besognes, belastingen en materiele zorgen, ook om andere redenen en het maakt mij soms wanhopig de toestand te ontberen, warin ik vlot tot conceptie en vlot tot breeduit schrijven kom als in de oude tijd. Het is ook materieel zo brood- en broodnodig bij de uitgever, dat geldelijk geweten." ${ }^{23}$

Het lijkt wel of de verhuizing hem heeft aangezet om de balans op te maken, want enkele maanden later, nadat hij gemeld heeft dat de voorstellingen van zijn nieuwe stuk voor het openluchttheater van Heeswijk, Genoveva van Brabant, achter elkaar zijn uitverkocht, geeft hij toe dat zijn productie toch eigenlijk wel meevalt:

"Ik hoor altijd van mijn 'zwijgen', jaar en dag nu al. Men merkt niet de Tsjechische Suite, mijn boek over Eindhoven, de bijdrage aan het gedenkboek van de LO-LKP, een boekdeel op zichzelf, en deze toneelspelen elk jaar; en elk ding op zichzelf betekent omvangrijke arbeid. Dit jaar is zeker niet onproductief." ${ }^{24}$

Toch spreekt hij vooral zichzelf moed in, want het zijn niet de anderen die hem zijn 'zwijgen' verwijten, maar hij zelf. Hij wil perse 'groot werk' leveren in de vorm van een roman. Hij heeft het concept hiervoor al vijf jaar in zijn hoofd. In 1948 heeft hij in een interview al aangekondigd dat zijn nieuwe roman "den eigenaardigen titel" van De vrouw met de zes sla-

19 Coolen, 'Van Duinkerken als vriend', 23-28.

20 Blokvenlaan 18a, later hernummerd in 24.

21 Van Raephorst, 'Antoon Coolen'.

22 LMDC, inv. nr. C 3485, brief Coolen aan Oomes, 9 maart 1953.

23 LMDC, inv, nr. C 3485, brief Coolen aan Oomes, 22 april 1953.

24 LMDC, inv. nr. C 3485, brief Coolen aan Oomes, 19 augustus 1953. 
perszal dragen en een beknopte weergave van de inhoud gegeven. ${ }^{25} \mathrm{Pas}$ nu, in de zomer van I953 kan hij melden dat eerste hoofdstukken van een nieuwe "zotte roman" zijn geschreven en dat het boek eind dat jaar zal verschijnen ${ }^{26}$

De rede die de historicus L.J. Rogier dat jaar tijdens de Groot-Kempische Cultuurdagen houdt, zal nog een extra stimulans voor Coolen zijn geweest. Rogier constateert hier dat de sombere boeken vol zelfkritiek op het gewest Brabant van Ouwerling en Maas toch iets goeds hebben voortgebracht: "Dat straks de romanschrijver Antoon Coolen zich min of meer leerling zou noemen uit hun school, pleit echter weer voor hen, want in Coolen bereikte de Brabantse streekroman een graad van eerlijkheid en tegelijk van diepte, die voor gezonde lezers de gedachte aan gewilde vertekening uitsluit."27

\section{Even terug naar het Gooi}

Op zaterdag 22 augustus 1953 houdt Coolen ter gelegenheid van de opening van de tentoonstelling 'Schrijvers in het Gooi' een rede in de burgerzaal van het monumentale Raadhuis van Hilversum. ${ }^{28}$ Op dezelfde manier als in het vriendschapsartikel bij Van Duinkerkens jubileum eerder dat jaar klinkt er heimwee in door. Het lijkt alsof de oudere, gearriveerde schrijver terugverlangt naar de tijd in Hilversum waar de ene na de andere roman uit zijn pen vloeide.

Hij verhaalt over zijn jongste journalistenjaren in Eindhoven en Maastricht vóórdat hij naar Hilversum kwam. Toen hij hier arriveerde, had hij een "letterkundig schoon geweten." Ook nu weer spreekt hij over "de lentelijke atmosfeer" van het uit Brabant stammende tijdschrift Roeping. Hij bekent dat het ruigere landschap van de Peel en de Kempen hem meer zegt dan het lieflijke Gooi, "het lustoord, om het overdreven uit te drukken met het gemillimeterde gras." Dat betekent echter niet dat hij er in zijn werk regionaal aan verbonden blijft; "het strikte regionalisme heb ik trouwens in mijn latere werk nooit beoefend." Hij wil zeggen dat zijn 'regionalisme' niet aan één regio gebonden is. Toen hij in 't Gooi woonde, schreef hij over de Peel en in de Peel schreef hij over de Maaskant en Friesland. Vanuit de Kempen heeft hij echter niet over 't Gooi geschreven.

Coolen denkt dat nu in plaats van de geografische afstand, de afstand in de tijd een rol gaat spelen. Hij zoekt nu inspiratie in de herinnering, want "zij beinvloedt niet uitsluitend in terugschouwende zin. Zij kan evenzeer evocatief en vernieuwend zijn voor de verbeel. ding en in het vinden van litteraire motieven." Met deze zinnen kondigt hij impliciet zijn nieuwe roman De vrouw met de zes slapers aan, die doordrenkt is van jeugdherinneringen.

\section{De vrouw met de zes slapers}

Eind 1953 verschijnt dan eindelijk het 'grote werk': De vrouw met de zes slapers, een roman in twee delen van ieder zeven hoofdstukken. Enigszins defensief wordt op de flaptekst aan. gekondigd dat dit boek niet hoort tot "de romans die zich hartstochtelijk bezighouden met de tijdsproblematiek en de sombere veroordeling van ons gefolterd tijdsgewricht." Die flaptekst en betiteling zijn echter maar ten dele juist. Zeker, de "zotte roman" is voor een deel een sprookje met kasteel, freule, grafkelder, Oosterse schone en al, en in de schets van de verschillende "dormeurs" worden grappige en trieste dorpsfiguren ten tonele gevoerd. In het boek zit echter ook een zeer ernstige en melancholieke terugblik op de eerste helft van de eeuw verwerkt. 
In een kasteel bij een dorp woont een freule die er om beurten een man uit het dorp laat slapen. Er is vroeger iets gebeurd, waardoor zij bang is in het holle huis. De slapers, de 'dormeurs', worden 's nachts door de freule in hun kamer opgesloten.

De voornaamste van deze zes dormeurs is de gemeenteontvanger Jan Cordewever. Hij heeft vroeger als kind op het kasteel gespeeld. Zijn vader had toen een winkel met op de ene spiegelruit het opschrift kruideniers- en koloniale waren en op de andere grutterswaren en manufacturen. De mooiste herinneringen heeft hij aan de tochten in de zomervakanties met de huifkar van de winkel om boodschappen te brengen in het buitengebied en de afgelegen boerderijen. Als jongen dacht Cordewever aan plezierige dingen, die er nog niet waren, maar die later zouden komen. De verteller zegt dan:

"Want een heden is er eigenlijk niet. Het wezen zelf van de tijd is dat hij voorbijgaat, heeft een wijsgeer eens gezegd, en dat van de duur, dat hij niet duurt. Er is niets, dat tot een stilstand en een blijven wordt bereikt, er zijn alleen maar verwachtingen en herinneringen. [...] Wij beleven de dingen niet op het ogenblik, de verwachting wordt pas in de herinnering vervuld. ${ }^{29}$

Als Cordewever vroeger als jongen boodschappen op het kasteel had gebracht, ging hij altijd weer node naar "de gruwelen van zijn grauwe huis" dat gelegen was in "de afschuwelijke dorpsstraat." Hij heeft liefdesverdriet en het jaar daarop gaat hij naar een jongenspensionaat, waar Frans wordt gesproken en waar hij opvallend goede punten voor muziek krijgt. In de vakanties schept Cordewever op met zijn kennis van literatuur. Hij volgt de avondbijeenkomsten van de volksmissie van de paters redemptoristen. 's Nachts sluipt hij de kerk binnen en houdt er zelf een preek. Hij laat het woord 'dood' een paar keer galmen en geeft vervolgens een aardrijkskundige toelichting op het bergmassief van de Himalaja. Daarna legt hij uit wat de eeuwigheid is: als een vogeltje één keer per millennium zijn snaveltje schuurt aan dit gebergte en het zou een biljoen Himalaja's met de grond gelijk hebben gemaakt, dan was er nog maar een oogwenk van de eeuwigheid voorbij. Tenslotte toetert hij hard en langdurig in zijn zakdoek, zoals paters dat doen, en stopt die in zijn linkermouw.

Cordewever wordt ouder en het dorp verandert. De gebeurtenissen in het dorp worden nauwgezet in de gaten gehouden door de vertegenwoordiger A.H. Forster en de horloger en heemkundige J.W.G. Jeurissen. Zij schrijven elkaar briefkaarten, waarop zij, als in een Griekse rei, de actualiteit van commentaar en veel uitroeptekens en vraagtekens voorzien. De postbode loopt er altijd eerst mee langs de onderwijzer om ze te laten vertalen of verklaren. Na de gemeenteraadsverkiezingen staat er bijvoorbeeld op een kaart: "Amice, opnieuw gaan we een periode van Dunkelmänner in, - a-politicus te salutat! t.t. A.H. Forster. Het antwoord luidde: Mundus vult decipi, - decipiatur! T.t. J.W.G. Geurissen." Forster heeft bij de volkstelling aangegeven dat hij atheïst is, maar hij gaat wel naar de kerk. Daar blijft hij achterin staan met de armen gekruist voor de borst om te laten zien dat

Ritter, 'Bij Antoon Coolen', maart 1948.

LMDC, inv. nr. C 3485, brief Coolen aan Donkersloot, 17 juni en 5 augustus 1953.

Rogier, 'Over de toekomst van Midden-Nederland', 633.

Coolen, 'De Glimlach van het Gooi'.

Coolen, De vrouw met de zes slapers, 14. 
hij niet uit een kerkboek bidt. Als er iets met het kerkbestuur aan de hand is of een of ande. re ruzie met de pastoor dan luiden de teksten op de briefkaarten: "Wat zegt het Vaticaan?" Soms staan er alleen maar woorden met veel uitroeptekens als "Savonarola!!!" of "Galilei!!!" Tijdens de [volks]missiedagen luidt de tekst: "Verlos ons van de preektoon, Heer; geef ons natuur!! en waarheid!!!??!! weer." ${ }^{30}$ Later, als de goede pastoor Willekes sterft en zijn bibli. otheek gecatalogiseerd wordt, komt Forster eens neuzen en koopt een paar van zijn boeken. "Dat verwonderde de mensen wel, ze dachten, dat hij alleen slechte boeken wilde hebben en de pastoor had natuurlijk alleen maar goeje." ${ }^{\text {31 }}$

Het tweede deel van het boek speelt in het heden, begin jaren vijftig. Als Cordewever 'dormeur' wordt is hij getrouwd en heeft hij een bijna volwassen zoon. Hij en zijn vrouw zijn volkomen van elkaar vervreemd. Wanneer bij zijn ambtsjubileum als gemeentesecretaris de burgemeester de saamhorigheid prijst, lacht Cordewevers vrouw onbewust ironisch en de zoon denkt hoe pijnlijk het is opgegroeid te zijn in die toenemende vervreemding. Ze zijn alle drie eenzaam en soms als de ouders dat beseffen, zijn ze het schreien nabij "over al de tijd van hun leven, die er onherroepelijk mee voorbij en voor elkaar verloren was." ${ }^{32} \mathrm{De}$ inwoners van het dorp zien ze vaak ieder aan hun eigen kant in het huis voor de ramen staan staren. "Zo stonden die twee mensen daar met dat bewoond huis vol eenzaamheid tussen hun beiden in." 33

Evenals het huwelijk van Cordewever is de geschiedenis van de eerste helft van deze eeuw slecht verlopen. De verteller herinnert zich hoe wij, de "geborenen van de vorige eeuw," optimistisch waren na de Eerste Wereldoorlog: "Na die doodvermoeide november van doorregende, droeve stilte over de modder van de loopgraven en roestende mortieren, kwam er een nieuwe lente met blauw koren op de velden en gele brem op de bermen." ${ }^{\text {"4 }}$ Men dacht aan een "verlate schok van de overgang van de stervende eeuw in de nieuwe." De eeuw begon zo mooi en aanvankelijk dacht men nog dat de Eerste Wereldoorlog een vergissing was, een narimpeling bij de overgang naar de nieuwe eeuw. Nu er echter zelfs al een Tweede is gevolgd zullen we er niet zo gauw mee klaar zijn, denkt de verteller. Cordewever spreekt van een verknoeiing van de hele eerste helft van deze eeuw, de levenstijd van hen die in de vorige werden geboren. Die knoeiboel werkt nog lang na, want "de verknoeide bladzijden van de eerste eeuwhelft doorvlekken die van de tweede en doordrenken ze met hun angsten." ${ }^{\text {"35 }}$

Cordewever weet nog goed hoe de goede pastoor Willekes, die de mensen altijd aan. spoorde om in hun leven al te worden gelijk de tekst op hun doodsprentje, in augustus r9r 4 met tranen in de ogen de oorlog aankondigde en "hoe toen in de warmte van augustus de geelbruine schoven stonden op de velden en wachtten om te worden binnengehaald in de schuren." Hij herinnert zich ook de meimaand waarin de Tweede Wereldoorlog begon, "een mei zo vroeg, zo warm, zo lang, zo blauw, zo vol van zon, en waarin het koren al zo hoog stond dat je er in kon schuilen." ${ }^{36}$

In dit tweede deel worden de levens van de andere 'dormeurs' belicht en worden de verschillende bewoners van het kasteel geportretteerd. Er heeft vroeger nog een Marokkaanse vrouw, Fatma, gewoond als eerste echtgenote van de baron. Zij is overleden. Ooit schijnt er een jonge vrouw haar baby in de slotgracht te hebben verdronken. Als ook de freule sterft, wordt zij bij Fatma in de grafkelder van de familie bijgezet. 
De vrouw van Cordewever, die hem verlaten had, komt terug. Zij leiden weer opnieuw ieder hun eigen leven in het zelfde huis en niemand weet hoeveel inspanning het hen kost om, als ze bij elkaar in een vertrek zijn, "niet hardop het verlangen te kennen te geven, dat de ander zal weggaan."

Jacob Cordewever heeft nog steeds "die gedachte, dat er geen heden is, dat het wezen zelf van de tijd is, dat hij beweegt en voorbijgaat, en van de duur, dat hij niet duurt. Het geluk is alleen maar in de verwachting en in de herinnering. ${ }^{\text {"37 }}$

\section{De muziek van de verloren tijd}

In het verhaal heeft Coolen zijn eigen jeugddromen over het kasteel in Deurne gemengd met een verhaal dat hij gehoord heeft van de burgemeester van Waalre, Mol, wiens vorige standplaats Dussen was. In het kasteel daar heeft vroeger een jonkvrouwe Surringa gewoond, die als beveiliging elke nacht een man bij toerbeurt in haar huis liet slapen. ${ }^{38}$ Later claimt De Bourbon, dat hij de vader van het idee is. Hij verwijt Coolen "schertsend" dat hij in een interview tegenover Clare Lennart met geen woord heeft gerept over het feit dat het idee van De vrouw met de zeven slapers mede van De Bourbon afkomstig was. Hij plaatst een kanttekening als hij ziet dat hij zich vergist: "zes, bedoel ik; zie je nu, hoe ik meeleef, want aanvankelijk waren het er zeven! ik heb zelfs vermoed, dat je het vergeten was: mijn verhaal over het kasteel + ruine in Loon op Zand. ${ }^{\text {39 }}$

Of nu Dussen of Loon op Zand model heeft gestaan is van minder belang, want de sféér is helemaal die van het kasteel van Deurne uit Coolens jeugd. Hij heeft er in Bevrijd Vaderland, naar aanleiding van de vernietiging van het kasteel in de oorlog, gevoelvol over geschreven als

"een oord van grote bekoring, daar aan den belommerden oever der blondoverbrugde Aa. Weinig dingen hebben mijn jeugd zulke machtige indrukken en indrukken van romantiek gegeven als dit kasteel en zijn omgeving. De zomer praalde er onder de hooge boomen in doom en nevelen, die het spiegelbeeld versluierden in de grachten, tot de zon hen warm doorbrak - en hoe klaarde het huis dan op! - of, na een dauwbedampten avondval, de koele maan, die betooverd zichzelve zag in dien omgekeerden hemel der diepte, - en hoe werd in nacht en slaap het kasteel met zijn vele vensteren dan geheimzinnig, ${ }^{40}$

De nieuwe roman van Coolen is één grote zoektocht naar de verloren tijd en in geen van zijn vroegere boeken speelt de muziek zo'n prominente rol. Muziek is een kunstvorm die

\footnotetext{
30 Coolen, De vrouw met de zes slapers, 43.

31 Coolen, De vrouw met de zes slapers, 44.

32 Coolen, De vrouw met de zes slapers, 118.

33 Coolen, De vrouw met de zes slapers, 121.

34 Coolen, De vrouw met de zes slapers, 113.

35 Coolen, De vrouw met de zes slapers, 247.

36 Coolen, De vrouw met de zes slapers, 248-249.

37 Coolen, De vrouw met de zes slapers, 251.

38 CS, [kopie typoscript] Zoetmulder, Coolen en Woalre, 15.

39 LMDC, inv. nr. B 783, brief De Bourbon aan Coolen, 13 januari 1956.

40 Coolen, Bevrijd Voderland, 151.
} 
niet voorstelbaar is zonder tijd. Niet alleen bestrijkt een muziekwerk zelf de tijd van de uitvoering, maar het is samen met de reuk ook een van de oudste 'vervoermiddelen' van het geheugen. Oude, demente mensen, die hun kinderen niet meer herkennen, leven op en glimlachen bij een deuntje uit hun jeugd. In de roman zegt Cordewever: "Muziek is ookiets dat uit de verte komt [...] en het is de verte, die je er in hoort."41 Met dat 'ook' doelt hij op de herinnering. Duidelijk trekt Coolen de parallel tussen de spoorrails met de trein die uit de verte komt en er ook weer in verdwijnt en de 'muziek' in de zoemende telegraafpalen en de tingtang van de seinklok. Steeds zijn het verwijzingen naar iets buiten het hier en nu: ver weg en elders in het verleden of de toekomst.

Het is een kernpunt in Coolens werk: de relatie van het vaste punt en het voorbijgaande. ${ }^{2}$ Het is de eenzame man of jongen aan de spoorbaan, een beeld dat hij vele malen heeft gebruikt. Het is het dorp aan de rivier, waar het water naar toestroomt en weer van weg vliedt. Vaak is de man de komende en gaande en is de vrouw de blijvende. Bij Mammeke uit Dorp aan de rivier zien we dat op een dubbele manier. Zij zegt dat ze haar ziekte heeft opgelopen van de kapiteins op de rivierboten, maar de lezer weet dat haar man de veroorzaker is. Ook hij heeft haar evenals haar verzonnen kapiteins verlaten. Het simpele 'vrouwke' van de goede moordenaar Nol Bonk krijgt veel bezoek van voerlui, terwijl haar man in de gevangenis in Leeuwarden zit. Ook het slot van De man met het Jan Klaassenspel vertoont het patroon van de vrouw als constante en de man als passant. De vrouw die zwanger is gemaakt door een zwerver, waarna hij ook nog haar fiets heeft gestolen, heeft geen fiets meer nodig maar een wieg. $\mathrm{Zij}$ is aan het huis en de grond gebonden, de zwerver komt van ver en verdwijnt weer snel trappend aan de horizon.

In de correspondentie of publicaties van Coolen komt de naam Proust niet voor, maar het is bijna ondenkbaar dat hij bij het schrijven van dit boek niet door hem beinvloed is geweest. De gedachten van het personage Jacob Cordewever komen overeen met die van de ik-figuur uit $A$ la recherche du temps perdu als deze zegt dat "les vrais paradis sont les paradis qu'on a perdus." ${ }^{43}$ De gedachten van de schrijver Coolen konden wel eens sterk beinvloed zijn door de opmerking die Proust enkele pagina's na bovenstaande passage maakt: dat het literaire kunstwerk misschien wel de enige manier is om ons 'ware leven' te ontdekken en dat er niets is dat meer leugenachtig is dan de zogenaamde realistische kunst. dat wil zeggen de kunst die pretendeert realistisch te zijn. ${ }^{44}$ Een aanwijzing dat Coolen het werk van Proust kent, zou kunnen zijn dat Cordewever de ouder geworden barones met madame de Sevigné vergelijkt. De grootmoeder en moeder van Marcel uit $A$ la recherche du temps perdu zijn bewonderaars van deze brievenschrijfster uit de zeventiende eeuw. Ook in de romancyclus van Proust speelt de muziek een voorname rol.

De toon van De urouw met de zes slapers is melancholisch. Jan Cordewever fantaseert vaak over leuke dingen, die er nu niet zijn, maar pas later komen, want volgens hem is er eigenlijk geen heden. "Wij beleven de dingen niet op het ogenblik, de verwachting wordt pas in de herinnering vervuld," zegt hij steeds. Als je de dingen nooit op het moment zelf beleeft, maar pas achteraf in je herinnering, ben je dus nooit echt gelukkig op het moment zelf. Dan blijft er hooguit achteraf een weemoedig gevoel bestaan over geluk dat er eens was, 
maar toen niet zo beseft werd.

De verteller uit de roman én het personage Cordewever, maar ook de schrijver Coolen bevinden zich in deze jaren in een situatie waarin ze terug kunnen kijken op twee grote oorlogen in Europa. Zij zijn van een generatie die als adolescent de Eerste Wereldoorlog en op middelbare leeftijd de Tweede heeft meegemaakt. Voor de schrijver Coolen komen daar nog bij de Van Doorne kwestie, de omwenteling in Tsjecho-Slowakije, de koloniale oorlog van Nederland in Indiē en de blokkade van Berlijn als opmaat voor de Koude Oorlog. Die laatste oorlog is bovendien op dat moment al weer zeer héét in Korea. Dit 'heden' in combinatie met die herinneringen kan geen al te grote verwachtingen inhouden voor de toekomst. Uit de brieven aan Oomes weten we dat Coolen in die tijd tamelijk droefgeestig gestemd is. Toch heeft hij perse willen voorkomen dat de roman gelezen kan worden "als een sombere veroordeling van ons gefolterd tijdsgewricht," zoals op de flap staat. Misschien zegt hij dat wel in de eerste plaats omdat hij niet geassocieerd wil worden met de nieuwe garde, met schrijvers als Mulisch, Hermans, Van het Reve en Blaman, die het onheil van die tijd wèl in hun werk opnemen en die de levensaanvaarding en religieuze ondergrond afwijzen.

Coolen heeft met dit nieuwe boek willen aansluiten bij zijn vroegere werk. Dat is hem ook wel gelukt in die zin dat er veel 'oude bekenden' in voorkomen. Jan Cordewever lijkt op de verliefde schooljongen uit 'Dat sprookje, het feodale kasteel' uit de vroege jaren twintig. In de briefkaartschrijvers Jeurissen en Forster herkennen we de 'schoolmeesters' die in veel eerdere boeken van Coolen optreden. Deze keer zit er in hun hilarische pedanterie ook een kritische ondertoon, vooral in de richting van de officiële kerk. Ook de schets van het heilig Sjoke, een vrijgezelle naaister, "die na de dood van haar ouders alleen zat te wonen in haar proper witgepleisterde huis in een geur van heiligheid en van overdadige bloemen voor Sint Jozef in maart, voor Onze Lieve Vrouw in mei en oktober en voor het Heilig Hart van Jezus in juni," heeft Coolen al ruim dertig jaar eerder gemaakt. In Lentebloesem (r92r) staat het verhaal 'Kwezelke' waarin Leentje het kwezelke witte rozen koopt bij haar buurman de bloemist. Het verhaal loopt wat anders, maar de gegevens zijn hetzelfde: een kwezel, witte bloemen voor de meimaand en een aanbidder. De aanbidder is in de roman van 1953 een van de dormeurs, Jan Lucas, die ondanks zijn spot met haar kwezelarij verliefd op haar wordt. In deze passage ${ }^{45}$ geeft Coolen een staaltje van zijn humoristische beschrijvingskunst, gecombineerd met zijn grote kennis van heiligenlevens en legenden. Sjoke fantaseert over de meest gruwelijke onderdelen uit de verhalen over martelaressen en schrikt niet terug voor zelfverminking als de verloving een keer uitraakt. Zo gooit ze Spaanse peper op haar oogleden en steekt haar handen in ongebluste kalk, omdat de heilige Rosa van Lima, een naaister zoals zij, precies hetzelfde had gedaan toen zij zoveel aanzoeken kreeg van mannen. Een slimme kapelaan vervangt bij Sjoke de boeken met heili-

\footnotetext{
41 Coolen, De vrouw met de zes slapers, 120.

42 Van Duinkerken, 'In Memoriam'.

43 Proust, A la recherche du temps perdu, deel III, 870.

44 Proust, $A$ la recherche du temps perdu, deel III, 881.

45 Coolen, De vrouw met de zes slapers, 154-168.
} 
genlevens door kookboeken en daarna volgen de verloving en het huwelijk van Sjoke en Jan. Zij vindt het goed dat Jan 'dormeur' op het kasteel blijft, want zij herinnert zich dat er ook heilige slapers zijn geweest, niet zes maar zeven, die sliepen in een grot en moesten daarna een grote taak vervullen.

Behalve reeds bekende personages laat Coolen in De vrouw met de zes slapers ook thema's uit zijn eerdere werk terugkeren. De zes dormeurs spelen een zelfde verbindende rol als de stamgasten in Herberg In't Misverstand. Ook in deze roman presenteert Coolen weer slech. te huwelijken, ruzie en drankmisbruik.

Een grote tegenstelling tot het kille huwelijk van de Cordewevers vormt het Pallieterachtige paar Govert van Engelen en zijn Engelien. Zij zijn Maaskanters en hebben elkaar leren kennen bij het hooien. Zij heeft zich naakt achter een hooiopper aan hem getoond Er is toen niets gebeurd, maar Govert zou gezegd hebben: Gij bent een "Te Deum ${ }^{46}$ waard. $\mathrm{Nu}$ zij getrouwd zijn, bedrijven zij de liefde met de gordijnen open. Het is duidelijk dat dit paar een uitzondering vormt op het adagium van het boek dat het geluk alleen in de verwachting of in de herinnering is te vinden. Govert en Engelien blijven niet mijmeren over die zomer aan de Maaskant, maar beleven het geluk elke dag opnieuw. Govert blifft zingen. Als er een feest is zingt hij echter geen 'Te Deum', maar het lied 'Het geloof van den boer'.

Cordewever is een filosoof. Hij vindt dat de schepping een meesterstuk der beperking is, maar hij is daar toch liever getuige van dan dat hij in "de chaos van het ongeschapene "nf $^{\text {"n }}$ zou zijn gebleven. Hoe meer hij op leeftijd komt, hoe meer zijn zintuigen in dat geschapene zijn gedrenkt. Hierdoor ontstaat de verrukking die de boer uitzingt in zijn lied over het geloof. We weten dat Coolen zich neerslachtig gevoeld heeft tijdens het schrijven van dit boek. ${ }^{48}$ Vooral in het commentaar van de verteller klinkt dit door. Iedereen verknoeit zijn tijd, iedereen is schuldig aan het verdriet van anderen in deze roman behalve dan Govert en zijn Engelien. De lichtpunten in het boek worden gevormd door de muziek, de kinderen en dit Maaskantse paar. Cordewever noemt de muziek die je zelf speelt "een troost, waarmee geen troost is te vergelijken. ${ }^{-49} \mathrm{Hij}$ speelt stukken uit het klavieruittreksel van Haydns Schöpfung en verbaast zich erover dat het jubelende duet van Adam en Eva geschreven werd door de ongelukkig getrouwde Haydn. "Haydns huwelijk was ongelukkig, dat kun je als schooljongen leren, zijn vrouw vergalde hem zijn leven, voor haar bleef het precies hetzelfde of haar man schoenen maakte of symfonieën." Hoe kon een man wiens vrouw hem het leven vergalde iets componeren "ter verheerlijking van de aardse en hemelse Godsgezegende schone liefde tussen man en vrouw?" Na Haydn speelt hij Beethovens 'Die Wuth über eine verlorene Grosche', ${ }^{50}$ Als zijn eigen zoon al wat ouder is, speelt Cordewever 'Träumerei' uit Kinderszenen van Schumann en 'Jimbo's Lullaby' uit Children's Corner van Debussy. De muziek vormt nog de enige band met die gelukkige herinnering van zijn vroegere vaderschap. De muziek en het kind zijn de constanten in het boek.

Driemaal krijgt Cordewever bloemen aangereikt door een kind. De eerste maal zijn het langstelige korenbloemen, ${ }^{51}$ de tweede maal is het een arm vol bloeiende brem ${ }^{52}$ en helemaal aan het eind van het boek krijgt hij voor de derde maal bloemen van een kind. Hij ziet 
het als een mooi detail van het meesterwerk dat de schepping is. Hij kijkt naar de kasteelruine "waar het geluk van zijn verwachting nu het geluk van zijn herinnering is." ${ }^{53}$ Driemaal komt een uitdrukking terug over het kind in de man, die steeds verder wordt uitgebreid. De eerste keer staat er "In de man gaat het kind niet dood," ${ }^{n 4}$ op de volgende pagina "In de man sterft het kind niet, het is alleen maar ingesluimerd" en op de laatste pagina van het boek "In de man sterft het kind niet, het sluimert slechts, tot het door andere kinderen wordt gewekt." Coolen heeft ook zijn twee laatste openluchtspelen met een kinderscène besloten. Nu de herinnering aan de kindertijd van zijn eigen kinderen alweer vervaagt, idealiseert hij die ongerepte tijd in een mensenleven. Daarnaast gebruikt hij het beeld van een kind ook vaak als metafoor voor het nieuwe leven in de cirkelgang van leven en dood.

Het is veelzeggend dat Cordewever zich bij het kind met de korenbloemen afvraagt of Freud gelijk heeft. Hij kan niet geloven - en hier is hij onmiskenbaar de spreekbuis van Coolen zelf - dat het mooie en knappe van dit zuivere wezen "alleen maar biologisch [is] in zijn jonge fasen van lust en onlust, die verschrikkelijke woorden voor wat we weer menen ontdekt te hebben, omdat wij overal onze onbescheiden, wetenschappelijke, bevuilende neus te diep insteken." 55

\section{De kritiek}

De reacties op De vrouw met de zes slapers zijn zeer uiteenlopend. De $N R C$ constateert dat een ernstig schrijver als Coolen nooit lopende bandwerk produceert. Coolen heeft zich volgens deze krant misschien afgevraagd heeft of er nog wel behoefte is aan regionale verhalen. Men heeft wel eens de indruk gehad dat Coolen zich in het defensief gedrongen voelt. Ook nu blijkt dat weer, omdat Coolen volkomen onnodig op het omslag heeft laten zetten dat het boek geen sombere veroordeling van 'ons gefolterd tijdsgewricht' is. De recensent vindt dit aanbeveling noch waarschuwing. Ieder vogeltje zingt zoals het gebekt is en van geen enkele schrijver wordt verwacht dat die zich specialiseert in de 'roman noir'. Men kan onmogelijk zeggen dat Coolen zich vernieuwd heeft. Eerder heeft zijn kunst zich verstild op een manier die aan Arthur van Schendel doet denken. Zijn verhaal van de verborgen liefde is gebouwd op de overtuiging van de niet ontgoochelde, maar wel ouder wordende man, dat het geluk er alleen is in de verwachting en de herinnering. Hij neemt met romantische melancholie afstand van de tijd. De krant associeert de roman met "de romantische sfeer van ver dromerig geluk" van Le Grand Meaulnes ${ }^{56}$. De roman blijft met een streng vol-

46 Lofzang tot God uit de katholieke liturgie.

47 Coolen, De vrouw met de zes slapers, 251.

48 LMDC, inv. nr. C 3485, brief Coolen aan Oomes, 22 april 1953.

49 Coolen, De vrouw met de zes slapers, 120.

50 Coolen, De vrouw met de zes slopers, 186-187.

51 Coolen, De vrouw met de zes slapers, 51.

52 Coolen, De vrouw met de zes slapers, 125.

53 Coolen, De vrouw met de zes slapers, 251.

54 Coolen, De vrouw met de zes slapers, 175.

55 Coolen, De vrouw met de zes slapers, 52.

56 Roman van Alain-Fournier (1886-1914), een lievelingsboek van Coolen. 
gehouden monotonie toch bekoren, ondanks een wat wijdlopige beschrijvingskunst. Dat is te danken aan de zachte ironie van Coolen: "Hoever zijn we hier verwijderd van een provinciale vertelkunst van dik hout zaagt men planken. ${ }^{57}$

Garmt Stuiveling brengt in herinnering dat het genre van de streekroman voor de oor. $\log$ nog al eens kritisch en argwanend bekeken werd. Hij heeft er echter bezwaar tegen om een genre in zijn geheel kansen en kwaliteiten te ontzeggen. Van Coolen moet hij erkennen, dat deze binnen dit genre uitzonderlijk goed werk heeft geleverd. De roman is "sterk van structuur en vooral hartelijk van toon." Hij ziet het boek als streekroman, als tijdsbeeld en als sprookje. Het sprookjesachtige wordt vertegenwoordigd door het kasteel en zijn bewoners, omdat Coolen de lezer steeds niet meer vertelt dan de gewone dorpelingen weten. Het tijdsbeeld krijgt gestalte in de verhalen over de twee wereldoorlogen en de veranderingen die in het dorp plaatsvinden. Door de beschrijvingen van de dormeurs en hun gezinnen wordt een beeld van de dorpsgemeenschap gegeven zoals in een streekroman. Toch heeft Coolen, volgens Stuiveling, deze drie kenmerken tot een eenheid weten te maken in het personage van Jacob Cordewever, een figuur, die volgens hem, dichter staat bij Van Schendels proza dan bij het vorige werk van Coolen. "Pas volgende romans zullen ons met zekerheid antwoord kunnen geven op de vraag, of dit boeiende en merkwaardige boek een uitzondering is, of het begin vormt van een nieuwe periode in Coolens werk. ${ }^{.59}$

Diametraal tegenover Stuivelings oordeel staat de kritiek van Greshoff. De laatste heeft nog nooit zoiets "wezenloos, zouteloos, geestesloos en vormeloos" onder ogen gekregen. Hij snapt niet dat een schrijver als Coolen de lezers op zo'n "wolkig niemendal" onthaalt. Hij klaagt dat de lezer aan het eind van het boek nog niets weet van de bewoners van het kasteel: "De freule is een schim en blijft een schim." Greshoff is dus niet gevoelig voor het sprookjesachtige in het boek. Hij vindt het een "spookachtig geschrift" en vermoedt dat het allemaal wel symbolisch bedoeld zal zijn. Hij heeft er zelfs niet de "ouderwetse schijnpoêzie van het sprookjesachtige" en ook geen spoor van "maeterlinckigheden" in ontdekt, alhoewel hier en daar wel iets van de eerste proeven van Van Lerberghe en Maeterlinck is te merken. Hij vindt het een "paskwillig boek, zonder begin, zonder einde en zonder middenstuk, zonder heffing en daling, zonder samenhang zonder iets wat uit de verte op leven, op échtheid of dingen en mensen gelijkt. Het heeft geen betekenis, geen ontwikkeling, geen vorm, geen verborgenheden. ${ }^{59}$

De schrijver Bordewijk, die volgens Dubois een groot zwak voor Coolen heeft, wordt heel boos over deze kritiek. Hij vindt die ontoelaatbaar en oppert het plan tegen dit soort literaire kritiek het strafrecht in te schakelen. ${ }^{60} \mathrm{Het}$ is er niet van gekomen, maar die sympathie voor het werk is wederkerig, want Coolen zit dat jaar in de jury die de P.C. Hooft prijs aan Bordewijk toekent.

Het Vrije Volk vindt het boek een geslaagd verhaal. Coolen ontroert waar hij achter de dorpsperikelen het hele wereldgebeuren weet te schilderen. Opnieuw wordt de vergelif; king met Van Schendel, maar ook met Aart van der Leeuw gemaakt, zij het dat deze vergelijking in het nadeel uitvalt van de laatste twee. De recensent verwijt hen mooischrijverij die "hun fraaie zinnen een lichtelijk weemoedige klank" geeft, waarbij ze als kostbare druppels in het luchtledige vallen en waardoor de concrete mededeling er maar bekaiid van af komt. Bij Coolen is dat niet het geval. ${ }^{61}$

Lambert Tegenbosch is ook enthousiast. Hij vindt het boek een authentieke Coolen en 
prijst hem, omdat hij ondanks de bitterheid der tijden nog reden tot genieten ziet. ${ }^{62}$ Hans Warren betreurt het juist dat Coolen zich niet heeft weten los te rukken uit de sprookjesen legendenwereld om terug te keren naar de "ontstellende werkelijkheid."

In Coolens 'eigen' blad Brabantia vergelijkt de dichter Frans Babylon het boek met "langbelegen wijn." ${ }^{64}$ Het keurend proeven is voor hem een bijzonder feestelijke aangelegenheid geweest. Het boek heeft volgens hem een "herfstelijke mengeling van ingehouden verdriet en geluksbejubeling, van zacht realisme en fijne poëzie." Alle rijpe eigenschappen van Coolen als mens en als schrijver zitten er in. Hij noemt speciaal zijn christelijk geloof. Hierdoor ziet Coolen de mensen met al hun driften en ondeugden "welke hij scherp kent" en beschrijft hij ze met een nobele wijsheid vol deernis en humor. "Een weldadig boek vol eeuwigheidsruis," besluit Babylon.

\section{Terug naar de oase}

Bij het verschijnen van De vrouw met de zes slapers wordt benadrukt dat dit de eerste roman van Coolen na zo'n lange tijd is. Critici en lezers zoeken naar de aansluiting bij het oude werk. Coolen heeft echter misschien wel te veel zijn best gedaan om die aansluiting erin te kriggen. In de roman zit de kern verstopt van wat een vernieuwde Coolen had kunnen zijn. De hoofdfiguur Cordewever en zijn levensreis door de eerste helft van de eeuw zou meer diepgang hebben gekregen als de slapers, het kasteel en de freule en alles daaromheen meer op de achtergrond waren gebleven.

De autobiografie van Coolen zelf zou hier nog veel meer st of voor hebben kunnen leveren. Hij zou dan stuiten op de katholieke moraal, zijn eigen ervaringen rond seksualiteit en zijn opvattingen over politiek en maatschappelijke ontwikkelingen. Hij verwerkt deze nu slechts mondjesmaat in het boek. Zo zijn in de mijmeringen van Cordewever vaag pacifistische opvattingen te herkennen.

Coolen geeft zich echter niet bloot. Hij zet zich af tegen het exhibitionisme van schrijvers als Vestdijk, Van het Reve, Hermans, Blaman en Mulisch. Zijn ergernis over de genadeloze kritiek van Greshoff uit Coolen in een persoonlijke brief aan Laurens van der Waals, de uitgever bij Nijgh \& Van Ditmar. ${ }^{65}$ Aanleiding is de nieuwe herdruk van Mijnheer Visser's hellevaart van Vestdijk. Greshoff had de figuren in Coolens laatste roman schimmen genoemd. Coolen schrijft dan: "Visser's geresigneerde vrouw is minder dan een schim in het ijle en Visser's zieltje en gepasseerde dag zijn toch van een verschrikkelijke banaliteit. Het burgerlijke en de copiëerlust des dagelijksen levens komen door de deur der dieptepsychologie toch weer binnen. Mij is het net, of het niet eens een echt boek is."

\footnotetext{
57 'De verwachting en de herinnering'.

58 Stuiveling, 'Coolen Redivivus', 107-108.

59 Greshoff, 'Een roman van schimmen."

60 Dubois, Een soort van geluk, 47.

61 'De vrouw met de zes slapers: een geslaagd verhaal'.

62 Tegenbosch, 'Na 16 jaar zwijgen'.

63 Warren, 'Coolen schreef roman voor 't eerst in 15 jaar'.

64 Babylon, [Boekbespreking De vrouw met de zes slapers], 88-89,

65 WE, kopie brief Coolen aan Laurens van der Waals, 27 november 1954.
} 
Een interessante studie over die tijd heet Terug naar het behouden huis. Hierin beschrijft Ido Weijers hoe de generatie van "I900" zoals vertegenwoordigd in de wetenschappers van de fenomenologisch georiënteerde Utrechtse School, komt te staan tegenover de "cynischen en landerigen" en de "lusteloze schimmen" van de nieuwe schrijversgeneratie van "I 940. " De generatie van rgoo hoopt op een nieuwe organische samenleving, met een "behouden huis" als toevluchtsoord, zoals de overwinteraars op Nova Zembla hadden. Deze droomt van "de samenleving als een gelukkig, besloten gezin, een behouden huis, dat lijkt de bood. schap van haar wederopbouwverhaal. [...] De generatie van 'r940' ervaart dat huiselijk beeld als beklemmend, dat is de kern van haar 'landerigheid'. ${ }^{n 6}$ Deze landerigheid uit zich in pessimisme bij Hermans, ironie bij Van het Reve en scepsis bij Anna Blaman. De titel verwijst ook naar de novelle van W.F. Hermans, Het behouden huis (I95I). Dit huis is ook een toevluchtsoord, maar het biedt geen veiligheid: alle verschrikkingen en de chaos van een oorlog zijn er aanwezig.

We hebben gezien dat Coolen na de bevrijding van het zuiden ook de metafoor van het behouden huis heeft gebruikt. Hij vergeleek toen de overwintering op Nova Zembla en de lange poolnacht met de donkere tijd van de bezetting. ${ }^{67}$

Coolen heeft veel gemeen met de intellectuelen van de Utrechtse School, die "de traditionele leerstelligheid en autoriteit van de kerk op vele terreinen van het denken afwij. $z^{2 e n}{ }^{n 8}$ en die zoeken naar nieuwe wegen om naast de materiële opbouw ook een geestelij. ke opbouw van Nederland te bewerkstelligen. Deze intellectuele elite van 1900 oefent vanachter de schermen veel maatschappelijke invloed uit en zit dicht bij het centrum van de politieke macht. Deze elite wordt vooral gevormd door beoefenaars van de menswetenschappen als de psycholoog Buytendijk, de pedagoog Langeveld, de psychiater Rümke, de jurist Pompe en vele anderen. Deze mensen ontmoeten elkaar in allerlei netwerken van maatschappelijke organisaties, als de gezondheidszorg, de reclassering en justitie. Er zijn ook veel katholieken bij betrokken uit de kringen van de Doorbraakbeweging en het Thijmgenootschap. Ook Van Duinkerken kan via een "Nijmeegse tak" tot deze elite gerekend worden. ${ }^{69} \mathrm{Hij}$ is degene die de term 'lusteloze schimmen' voor de nieuwe schrijvers. generatie hanteert.

Weijers maakt de mooie vergelijking dat de Nederlandse samenleving zich na de oorlog probeert te gedragen als een gelukkig gezin, waarvoor de menswetenschappers van de Utrechtse School het boek over de omgangsvormen hebben geschreven. "In die sfeer van toewijding aan 'onze gezamenlijke taak' ploffen de nieuwe romans als vreemde curiosa door de brievenbus, ongegeneerde en onbegrijpelijk kritische indringers waar men geschrokken van op kijkt, produkten van de jeugd die het thuis niet langer uithoudt. ${ }^{70}$

In dat 'gezin' worden vertellers als Coolen gelezen. Zijn nieuwe roman De vrouw met de zes Slapers krijgt, in tegenstelling tot de andere goed verkopende vertellers van die tijd, veel aandacht op de literatuurpagina's van kranten en tijdschriften. ${ }^{71}$

De wetenschappers van de Utrechtse School willen fungeren als het intellectuele geweten van de wereld. Coolen ambieert echter geen rol als 'geweten'. Hij wil een veelgelezen en gewaardeerd romanauteur zijn. Dat lukt hem ook met dit boek, in tegenstelling tot de nieuwe generatie schrijvers, wier boeken op dat moment nog slecht verkopen. 


\section{De schandalen en De vrouw met de zes slapers}

Waarom zet Coolen zich in zijn brief aan zijn uitgever zo af tegen Vestdijk? Vestdijk is van dezelfde generatie als Coolen. Hij behoorde voor de oorlog tot de Forum-groep, die Coolen niet welgezind was, hetgeen Vestdijk overigens niet verhinderde om in 1939 een positieve kritiek op Herberg In 't Misverstand te schrijven. Vestdijk staat in 1953 sámen met de jongere generatie in de literaire belangstelling met zijn roman De schandalen. Hij staat niet tegenover de anti-idealistische jongeren of de 'landerigen', maar is er eerder een voorloper van. Anbeek wijst op passages uit Vestdijks roman Else Böhler uit 1936 die zo in De avonden van Van het Reve hadden kunnen staan. ${ }^{2}$ Toch is het geen jalousie de métier die Coolen zo negatief doet reageren op Vestdijk. Coolen heeft immers evenmin te klagen over verkoopcijfers en ook over hem wordt volop geschreven.

De sleutel tot Coolens afkeer ligt in een aantal boeken van Vestdijk: de Anton Wachterromans, De schandalen en Mijnheer Visser's hellevaart. Deze romans zijn juist de werken waarin Vestdijk zijn eigen jeugd en adolescentie fileert en analyseert of verkennend afdaalt in de krochten van de menselijke geest en de seksualiteit. In een interview vlak voor zijn dood zegt Coolen nog dat hij huivert om té veel te weten over een mens. ${ }^{73}$ Misschien wil hiij ook liever niet teveel weten over zich zelf; we wezen daar al op bij de vaag gehouden hoofdpersoon Jan Cordewever uit De vrouw met de zes slapers. Vestdijk beschrijft de morbide en perverse gedachten en activiteiten van zijn personages, Coolen schildert daarentegen enkel de gevolgen: Marie uit Het donkere licht als een toonbeeld van ellende in het café, met haar vriend en zijn kornuiten die een abortus 'regelen', of Cornelia Schoonderwiel die na het wegvluchten van haar minnaar op haar fiets alleen maar zegt dat ze nu eerder een wieg dan een fiets nodig heeft. Het is vooral het gebied van de seksualiteit waar Coolen omheen loopt, want op ander gebied zijn er perverse handelingen genoeg. Bij de moord van Nol Bonk op Pietje Pinksteren wordt de lezer geen detail bespaard en de lichamelijke afkeer tussen ruziënde echtparen wordt minutieus beschreven, evenals het vreselijke afsterven van Fons de bakker.

Deze voorbeelden komen overigens uit Coolens vooroorlogse romans. Na de oorlog trekt hij de lijn van De goede moordenaar of Herberg In't Misverstand niet door. In zijn romans uit de jaren vijftig is het perverse of het seksuele helemaal weggedrongen, zoals in De vrouw met de zes slapers. In datzelfde jaar 1953 publiceerde Vestdijk zijn roman De schandalen.

Zowel in De vrouw met de zes slapers als in De schandalen is de angst van die tijd terug te vinden. Mulisch wijst in De toekomst van gisteren op die angst: "Angst voor het kommunisme, angst voor de atoombom, angst voor de russen, angst voor de chinezen, angst voor de seksualiteit, angst voor de dood, angst voor de verandering, angst voor de jeugd, angst

66 Weijers, Terug naar het behouden huis, 23.

67 CS, geluidsband Coolen voor Radio Herrijzend Nederland, Kerstmis 1944.

68 Weijers, Terug naar het behouden huis, 18.

69 Simons en Winkeler, Het verraad der dercken, 135.

70 Weijers, Terug naar het behouden huis, 85 .

71 Anbeek, Na de oorlog, 145.

72 Anbeek, Na de oorlog, 152-153.

73 Mertens, 'Het laatste gesprek met Antoon Coolen'. 
voor de kanker, angst voor de angst, angst voor niets. ${ }^{.74}$ Vestdijk beschrijft in datzelfde jaat in De schandalen de angst voor een volgende oorlog en maakt, volgens Mulisch, het boek daarmee tot een spiegel van zijn tijd. Vestdijk voert tijdgenoten op en trekt van leer "tegen een bepaald ondefinieerbaar milieu" dat niettemin duidelijk herkenbaar is: een milieu van vage collaborateurs, fanatieke nakaarters over "Indië, kankerende prollen in tweed-pak. ken, kortom: de onderwereld der reactie, de neo-fascisten, en hij neemt dit soort prettiq ruim," vult Kouwenaar aan. ${ }^{75}$

In beide boeken staat een geheimzinnige wereld centraal. Bij Coolen is dat het kastel met zijn bewoners, bij Vestdijk een duister netwerk van invloedrijke figuren in het bedrijfsleven, de pers, de kunst en de wetenschap. Coolen trekt zich in De vrouw met de zo slapers terug in de oase van zijn jeugd en stelt weemoedig vast hoe ijdel de hoop op een betere wereld aan het begin van de nieuwe eeuw was. De personages in De schandalen van Vestdijk kijken vooruit en hebben angst voor de komende oorlog. Een van hen zegt dat die angst zo groot is dat ze verlangen naar de oorlog, want "dan zijn ze tenminste van de angst af, voorlopig. Vallen er morgen bommen op Nederland, dan is dat een pak van hun hart Hoe zwaarder hoe beter. Een atoombom zou een volksfeest ontketenen. ${ }^{76}$

Vestdijk bonst op de deuren van 'het behouden huis', waar hij al weer neofascisten en fatsoensrakkers vermoedt, die uit angst een derde wereldoorlog dreigen te veroorzaken Coolen zwerft rond de slotgracht van het kasteel en beschrijft met veel gevoel de twee oor logen die het met zijn bewoners te verduren heeft gehad, maar ook de beklemmende sfeer in het 'bewoond huis' vol eenzaamheid bij de ouders van Cordewever.

De kritiek die Vestdijk op De schandalen krijgt is dermate grof dat hij in een zware depres sie belandt en pas drie jaar later in 1956 zijn volgende roman Het glinsterend pantser schrijit. De kritiek op De vrouw met de zes slapers is veel milder en het verkoopsucces is groter. Coolens nieuwe roman De grote voltige zal eind 1957 verschijnen.

Coolen blijft de rest van zijn leven tegen Vestdijk ageren. In 1956 probeert hij via Van Duinkerken te verhinderen dat Nederland Vestdijk voordraagt voor de Nobelprijs. Na de mislukkingen van de kandidatuur van Stijn Streuvels vindt Coolen het jammer dat Vestdijk nu het visitekaartje wordt van de Nederlandse literatuur. "Want behoudens enkele romans van niveau als Het viifde zegelen Rum-eiland, is er in het werk van Vestdijk toch' $n$ hele sleep van benauwd Hollandse gevallen als Mijnheer Visser's hellevaart, Schandalen en eigenlijk de vervelende Ina Damman en Anton Wachter-geschiedenissen," schrijft hij aan Van Duinkerken. ${ }^{n}$ Een jaar later schrijft Coolen aan De Bourbon dat alleen Vestdijks roman De kelner en de levenden volgens hem nog enigszins in aanmerking komt voor een lofprijzing. ${ }^{78}$ In juni 1958 probeert Coolen Vestdijk uit de PEN-club te krijgen, omdat deze openlijk het beleid afvalt. ${ }^{79}$ Toch stuurt hij aan diezelfde Vestdijk in oktober 1958 weer een telegram om hem te feliciteren met zijn zestigste verjaardag, zoals hij dat ook deed in 1948 met zijn vijftigste. ${ }^{80}$ Vijf en een half jaar later, in $196 \mathrm{r}$, zit de kwestie hem nog steeds dwars. "Indertijd, toen Vestdijk Nederlands kandidaat voor de Nobelprijs was, werd Camus de bekroonde en je kon met de gedachte aan al de door Anton Wachter in bed gehadde verpleegstertjes niet anders zeggen dan: ja, natuurlijk, vanzelfsprekend," schrijft Coolen eent half jaar voor zijn dood aan Oomes. Hij voegt eraan toe dat hij alle Anton Wachter romans graag cadeau geeft voor één hoofdstuk van Julien Green. ${ }^{\text {Bt }}$ 
Coolen ervaart het werk van Vestdijk als een ontkenning van alles wat hem dierbaar is, zowel in literair als in moreel opzicht. Het kasteel waarover Coolen schrijft is echter ook geen symbool van een behouden huis. Hier woont geen gelukkig gezin; het is een verblijfplaats van elkaar passerende individuen. Er is evenmin geborgenheid en huiselijkheid als in het ongelukkige huwelijk van de hoofdfiguur Cordewever. Coolen heeft zich met $D e$ vrouw met de zes slapers teruggetrokken in 'de oase' van zijn jeugd.

74 Mulisch, De Toekomst van Gisteren, 50.

75 Anbeek, Na de oorlog, 91.

76 Vestdijk, De schandalen, 60.

7 BA, brief Coolen aan Van Duinkerken, 16 november 1956.

78 LMDC, inv. nr. C 3485, brief Coolen aan De Bourbon, 3 mei 1957.

79 LMDC, inv. nr. C 3485, brief Coolen aan Willem Brandt (secretaris PEN-club), 18 juni 1958.

80 LMDC, inv. nr. C 3485, telegram Coolen aan Vestdijk, 17 oktober 1948. De tekst luidt: "Gelijk [sic] met het 5 e kruisje en de wens van nog vele anderen komma en van nog schone boeken. Anton [sic] Coolen." Idem, telegram [een gelukstelegram met voorbedrukte engeltjes] Coolen aan Vestdijk, 17 oktober 1958. De tekst luidt: "Gefeliciteerd met het zesde kruisje en de hartelijkste wensen voor een pacht tot voorlopig het zevende. Anton [sic] Koolen [sic]."

81 LMDC, inv. nr. C 3485, brief Coolen aan Oomes, 27 april 1961. 


\section{Voltige of \\ omwenteling?}

21

"Het feodalistische gevoel is het plattelandsvolk hier in de ziel blijven zitten." 1954-1957

\section{Buitenlandse contacten}

Ook voor Coolen zijn de spanning tussen de machtsblokken en de scheiding die het Ijzeren Gordijn teweeg brengt persoonlijk voelbaar. Zijn contacten met zijn Tsjechische vertaalster Ella Kazdova verlopen zelfs even als in een spionageroman. Aan het begin van de jaren vijftig spreekt Kazdova in een Praagse winkel een zakenman aan. Zij heeft aan een speldje op zijn revers gezien dat hij Nederlander is. Zij vraagt hem de groeten aan Coolen over te brengen en te zeggen dat met haar alles goed gaat, maar dat haar man in de gevangenis zit. De zakenman verzoekt Coolen om bij een eventueel antwoord vooral zijn naam niet te noemen, omdat hij anders Tsjecho-Slowakije niet meer in mag. ${ }^{1}$

"Hoe afschuwelijk is het het leven onder zulk een druk te zetten, dat men tot deze fluisterende mededelingen zijn toevlucht moet nemen," antwoordt Coolen haar. ${ }^{2}$ Vanaf 1953 komt de briefwisseling met Kazdova weer op gang. Haar man is weer uit de gevangenis. Onder het nieuwe regime mag zij echter geen literatuur meer vertalen. Alleen "medicijnse artikels" zijn toegestaan. ${ }^{3}$ Coolen stuurt haar De vrouw met de zes slapers toe. Uit haar reactie blijkt hoe ze van het werk van Coolen houdt en zijn waarnemingsvermogen bewondert. Ze schrijft hoe nauwkeurig Coolen de mensen rond het kasteel getekend heeft. Door de scherpe details over hun leven en zwakheden, ziet de lezer ze levend voor ogen. "Ie voelt hoe de auteur van de mensjes houdt." Ze zou willen dat ze in het Tsjechisch kon zeggen hoe mooi ze het boek vindt. Ze heeft Tsjechische Suite herlezen en herinnert zich hoe weinig Coolen sprak toen hij in Tsjechië was. Hij deed alsof hij de dingen zomaar bekeek, "maar intussen was iedere indruk zo in je ziel doorgedrongen; dat er een heel boekje kon ontstaan die je liefde voor dit zielige landje zo uitstraalt, dat je er van kon huilen. Ik heb je 20 lief voor dit boekje." Uit dat boek blijkt dat Coolen alles begrepen heeft en onthouden. Dus, schrijft ze, ben jij een gevaarlijk mens, want je doorziet alles. Het uitgeven van nieuw werk van Coolen in haar land zal niet makkelijk zijn, voegt ze er aan toe, want er is alleen belangstelling voor "jonge liedenliteratuur." We zullen nog even moeten wachten tot de "weersomstandigheden" zullen veranderen, voegt ze er cryptisch vanwege de censuur aan toe. $\mathrm{A}$ contacten blijven gedurende de jaren vijftig bestaan.

Tot reizen naar Oost-Europa komt Coolen niet meer. Wel reist hij regelmatig naar West-Duitsland, onder andere met Anthonie Donker en met P.J. Meertens, om er lezingen

1 BvdB, brief Rijkens (Wassenaar) aan Coolen, 19 september 1950.

2 BvdB, brief Coolen aan Rijkens, 13 september 1950.

3 BvdB, brief Ella Kazdova aan Toon en Gerda Coolen, 18 januari 1954.

4 BvdB, brief Ella Kazdova aan Coolen, 17 maart 1954. 
te houden. In 1952 heeft hij Bremen bezocht. In 1954 spreekt hij in Bentheim en in Bong voor een Duits-Nederlandse bijeenkomst van het Erasmus-Leibnitz-genootschap tot bevordering van de menselijkheid.

\section{Ships that pass in the night}

In 1954 wordt voor de tiende maal bevrijdingsdag gevierd. De bevrijding in 1945 is weliswaar pas negen jaar geleden, maar met de echte bevrijdingsdag erbij gerekend is dit dus de tiende. Ter gelegenheid van deze dag verschijnt een speciaal tijdschrift: Nationale Snipperdag. Het is een bundeling van negen letterkundige en algemene tijdschriften en daarmee een unieke gebeurtenis in Nederland. De uitgave is een protest tegen de degradatie van de nationale feestdag tot een nationale snipperdag. De regering had kort daarvoor op 3 februari 1954 besloten dat er slechts één nationale feestdag zou zijn, namelijk konin. ginnedag op 30 april. De ontwikkeling van de industrie en de wederopbouw van het land zouden twee feestdagen vlak na elkaar niet toelaten. Schrijvers van alle richtingen, zoals Theun de Vries, Harry Mulisch, Anthonie Donker, Jan Engelman, Jan Romein, Anton van Duinkerken, Aug. Defresne, Bert Voeten, J.B. Charles en vele anderen werken aan de uitgave mee.

Coolen levert het verhaal 'Ontmoeting in Niemandsnacht" met als motto "Ships that pass in the night." Deze woorden hadden al eerder dienst had gedaan als motto, namelijk bij het anoniem ingezonden manuscript waarmee hij in 1947 auteur van het Boekenweek. geschenk was geworden.

De hoofdpersoon, een verpleegster, denkt bij elke dodenherdenking terug aan een ingrijpende oorlogservaring. $\mathrm{Zij}$ is tijdens die gebeurtenis koerierster in het verzet en bevindt zich in een verlaten, door de Duitsers geëvacueerd dorp. Het verhaal speelt zich af in de onoverzichtelijke situatie van de Corridor door Brabant in de richting van de Maas in september en oktober 1944 .

De verpleegster is niet bang, want ze heeft al veel vermomde Engelse en Canadese piloten begeleid in de trein, steeds alert om bij het minste onraad de aandacht van hen af te leiden. Ze vertrouwt daarbij op haar intuitie en bedenkt achteraf wat een broos en onzeker geleide "die koene helden van de lucht" hebben gehad. Plotseling is er haar 'bevrijder', een jonge Engelse soldaat. Hij moet vier uur wachten op een terugkerende patrouille en dan zal het er op los gaan. Ze drinken thee en whisky uit zijn veldfles. Hij haalt uit de boekenkast een deeltje van Longmans Green-editie van Shakespeare, Macbeth, en leest de zin: "I have almost lost the taste of fear, I have supped full with horrors." Hij blijkt een Oxford-student te zijn. Hij is vanaf de invasie in Cherbourg nog niet uit de kleren geweest en verlangt naar een echt bad. Het meisje denkt: "Hij wil zich wassen, wie weet, hoe kort voor zijn dood" Buiten klinkt onafgebroken trommelvuur. Bij het afdrogen van zijn rug denkt ze: "Als ik een kind baar, moet het zón $\mathrm{n}$ jongen worden." Later beseft ze dat de woorden van geboorte haar invielen bij het dodelijke vuren buiten. Als ze in elkaars armen liggen en aan alle kanten door de dood omringd zijn, denkt ze "aan zijn vaderschap van het kind, dat ik het leven zou willen geven." De soldaat sneuvelt een paar uur nadat hij bij haar vertrokken is. Zijn laatste woorden zijn: "We meet again after all is done" [uit Macbeth, C.S.]. "Ik kon, als hij] gewild had, zijn vrouw geweest zijn, zonder de gewone begeerten, ánders, en zonder 
berouw later." Nu kan ze hem slechts na zijn dood ontmoeten bij het graf.

jaren later bij de jaarlijkse herdenking op de Engelse begraafplaats, waar ze nog steeds 'haar' graf verzorgt, blijkt er vroeger ook een verloofde in Engeland te zijn geweest. De secretaris van het oorlogsgravencomité stelt haar voor: "Miss Margaret Price, his fiancée." Ze schrikt er van, maar verdedigt in gedachte die vier nachtelijke uren. Als ze de kinderen van haar zuster de volgende dag op het bevrijdingsfeest in de draaimolen ziet, geeft ze een ervan spontaan een kus. Daarvoor is toen gevochten, beseft ze: voor de kinderen. Zij vindt dat zij en de verloofde Margaret zich op die manier toch als moeder kunnen beschouwen. Het verhaal eindigt met een metafoor, waarin de bevrijding met een bevalling wordt vergeleken:

"Geen pijn is te vergelijken met die, waarmee we er ons, bebloed uit bevrijdden, geen licht met dat, waarin we er weer uit opstonden onder die rood-wit-blauw doorvlagde buiten van een nieuwe mei [...] Ik huil, Margaret, ik huil, zó blij als ik ben, om hem, om doden en levenden, om het moederschap van ons beiden."

In dit verhaal kiest Coolen evenals in De ontmoeting [het Boekenweekgeschenk van 1947 met gelijkluidend motto, C.S.] het thema van een vluchtige relatie tussen een verpleegster en een jonge man in oorlogstijd. De wat oudere verpleegster wordt heen en weer geslingerd tussen de gevoelens van moeder en minnares, waarbij uiteindelijk het moederlijke wint. Bij zijn binnenkomst ziet ze een stoere reus, pas als hij zijn uitrusting en helm heeft afgelegd ziet ze hoe jong hij is. Bij het afdrogen van zijn rug heeft ze ook tweeslachtige gedachten: ze zou een kind als hij willen baren én ze beseft dat dít kind straks dood in regen en modder zal liggen. Ze voelt haar onmacht om hem te beschermen tegen de dood, zoals ze op haar 'broze' manier de piloten in de trein beschermd had. Het vrijen eindigt ook 'moederlijk': "Ik vroeg hem: neem mij in je armen. Tezelfdertijd streelde ik zijn hoofd met een gedachte aan sussende woorden als: stil maar, stil maar ..." ${ }^{6}$

Dit verhaal, geschreven in de tijd van het Mandement van de bisschoppen, waarin katholieken uitdrukkelijk wordt verboden om naar niet-katholieke omroepen te luisteren of lid te zijn van niet-katholieke verenigingen of vakbonden, weerspiegelt niets van de moraal of geloofsleer van de kerk. Het beschrijft de eenzaamheid van mensen in oorlogstijd en de schrille tegenstelling van het dodelijk geweld tegenover de kracht van de menselijke liefde en de onschuld van kinderen.

\section{Brabantse activiteiten}

Begin 1955 schrijft Coolen in Brabantia een artikel over de naoorlogse poëzie in Brabant. ${ }^{\text {? }}$ Hij bespreekt twee bloemlezingen van Brabantse dichtkunst, die kort na elkaar zijn uitgekomen: Brabantia Nova van Frans Babylon (1954) en Hedendaagse Brabantse dichters van Harry Kapteijns (195I). In deze kritiek is goed te zien hoe Coolen is meegegaan in het andere denken over Brabant. Hij is het eens met de kritiek van beide bloemlezers op de vroege-

7 Coolen, 'Brabantia Nova', 
re Brabantia Nostra dichters die het leven "folkloriseerden" door de feestelijke kanten ervan te benadrukken met schuimende potten bier. Coolen schrijft dat veel dichters zich op die manier hebben afgezonderd binnen een zelfgenoegzame gewestverheerlijking of een gewestelijke zelfgenoegzaamheid. Hij waarschuwt echter om het kind niet met het badwater weg te gooien, want tussen vele epigonen bevinden zich echte dichters. Hij vindt Paul Vlemminx er zo een: een sterk dichter die tevens het meest heeft van het Brabants eigene. Coolen noemt hem na Van Duinkerken de meest oorspronkelijke en begaafde Brabantse dichter uit het toenmalig reveil, de tijd van Roeping in de jaren twintig. Hij prijst ook Harriet Laurey en Jan Elemans. Laurey is zuidelijk herkenbaar en heeft een hart dat niets dan zingen kan. Bij Elemans treffen hem de motieven uit het boerenleven, het boerenhuis en de akker.

Coolen ontvangt zelf ook lof. In diezelfde tijd krijgt hij de Provincieprijs voor Schone Kunsten voor 1954 . De prijs is bedoeld voor beroepskunstenaars op het terrein van toneel en letteren. Coolen krijgt hem niet voor zijn toneelstuk, maar voor zijn sociografische bijdragen aan Het nieuwe Brabant én voor zijn nieuwe roman De vrouw met de zes slapers. Jan Naaijkens krijgt de prijs voor amateurs op grond van zijn grote verdiensten op toneelge bied. In de commissie van advies zaten onder andere Van Duinkerken en Harry Kapteijns.

Commissaris der Koningin De Quay betrekt bij de officiële uitreiking op 26 februari r 955 nogal omstandig de voorzitter van de jury, Van Duinkerken, in zijn lofrede op Coolen. Lachend zegt hij tegen Van Duinkerken dat deze gelukkig de laatste jaren niet zoveel over Brabant heeft gepubliceerd, zodat men hem veilig tot voorzitter heeft kunnen benoemen. Hij noemt Van Duinkerken "een machtig stuk Brabantse cultuur."

In zijn toespraak ter gelegenheid van de uitreiking maakt Van Duinkerken een badinerende opmerking over de openluchtspelen door deze als een liefhebberij van dorpsbewoners te kenschetsen. Uit de briefwisseling die over deze van tevoren toegestuurde toe spraak is gehouden, blijkt hoezeer hij Coolen daarmee op zijn tenen trapt. In een lange brief legt Coolen uit dat het in zijn geval anders ligt. Hij schrijft zijn stukken wel voor het natuurtheater van Heeswijk, maar geeft ze vervolgens ook in druk uit "voor een langer toekomstig leven ook buiten het gewest." Coolen zegt er het beroepstoneel mee te willen bereiken, zoals dat voor de oorlog ook gebeurde met zijn "realistische toneelstukken" als Kinderen van ons volk, De vier jaargetijden en De vreemdeling. Hij herinnert Van Duinkerken er aan dat deze stukken bij het Nieuw Schouwtoneel drie à vier jaar op het repertoire stonden en veel buiten het gewest in het noorden en westen van Nederland werden gespeeld. De vreemdeling is bovendien nog opgevoerd in Aken, Freiburg, Bonn, Bremen en Frankfurt en daarnaast nog twee seizoenen in het Prager Stadttheater. Hij verwijst naar de inleiding die hij bij Genoveva van Brabant heeft geschreven, waaruit blijkt dat hij met het stuk meer dan "een gewestelijk streven" heeft beoogd. Het is alleen de omvangrijke en kostbare bezetting met vele figuranten die maakt dat zo'n openluchtspel alleen door het lekentoneel wordt gespeeld. Een beroepsopvoering zou niet te betalen zijn. Bovendien beperkt de belangstelling in Heeswijk zich niet tot de Brabantse gemeenschap, maar komen er ook bussen vanuit Den Haag, Groningen, Limburg, Vlissingen en Leuven. ${ }^{10}$

Van Duinkerken belooft de inleiding van Genoveva te zullen lezen. Hij zal "wellicht een kleine inlas (hoogstens een alinea) over deze aangelegenheid aanbrengen." "Hij houdt woord en past zijn rede aan. Na zijn constatering dat de bezoeker van een voorstelling op 
de markt van Hilvarenbeek iets anders verwacht dan de bezoeker van de schouwburg op het Leidseplein, vraagt hij zich af of zo'n zomerspel de bezoeker niet dichter bij de oorspronkelijke bronnen van de dramatische kunst brengt dan een goed verzorgde voorstelling in de schouwburg. "Hoe zulk een terugvoering van het gewestelijke thema naar de oorspronkelijke dramatische beleving door het volk dat zulk een thema schiep, ook de theatrische kunst kan verfrissen, toont voor de ervaren lezer de korte inleiding die Antoon Coolen meegaf aan zijn spel over Genoveva van Brabant."."

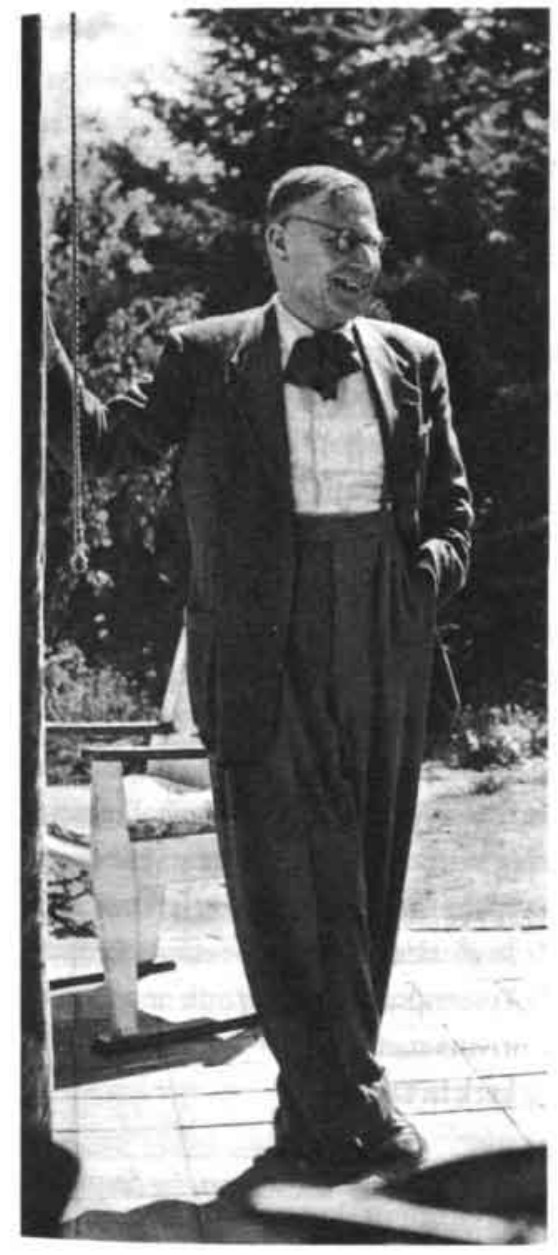

In Brabant weet men Coolen als beroemdheid te vinden voor de meest uiteenlopende gelegenheden. Bij het jureren van de kersenfeesten in Mierlo loopt hij een longontsteking op, zodat hij van 4 juli tot 9 augustus 1955 het bed moet houden. ${ }^{13}$

Als beschermheer van het Gilde St. Antonius Abt woont hij kort daarna de Gildedag bij. Na afloop evalueert hij het geheel nauwgezet in een brief aan de secretaris. ${ }^{14} \mathrm{Hij}$ stelt voor om in het vervolg bij de Gildemis niet alleen met trommels de kerk in te gaan, maar er ook de vendelgroet te brengen en de trom te roffelen bij de consecratie. De gilden hebben dit privilege, stelt hij. Hiervoor is wel overleg nodig met de pastoor van Dinther, maar "de uitleg van dit ceremo. nieel zal hem zeker treffen." Hij informeert of de heer Van de Mortel, voorzitter van de Brabantse Gilden, wel een attentie heeft gehad. Coolen wil hem dan zelf een bedankbrief schrijven.

Coolen is altijd zorgvuldig in dit soort zaken. Hij is er ook op gebrand de contacten met de Brabantse elite goed te onderhouden en daarbij de plichtplegingen in de juiste folkloristische vorm te gieten.

8 De redevoering en dankwoorden, in: Brabantia, jirg. 4, 1955, 85-101.

9 Cor Hermus en Kees Spierings bewerkten de romans Kinderen van ons volk en De schoone voleinding tot het toneelstuk Kinderen van ons volk. Coolen was daarbij adviseur.

10 BA, brief Coolen aan Van Duinkerken, 19 februari 1955.

II BA, brief Van Duinkerken aan Coolen, 21 februari 1955.

12. Van Duinkerken, 'Stand en toekomstkansen', 100.

B LMDC, inv, nr. C 3485, brief Coolen aan Oomes, 8 oktober 1955.

14 WE, kopie brief Coolen aan J. Kuyten, secretaris van het St. Antonius abt gilde te Deurne, 2 september 1955. 
Verder houdt het werk aan een opdracht hem dit jaar bezig. Hij broedt op een nieuwe roman, maar eerst moet het gedenkboek af over de kousenfabriek, in de volksmond De Sok, van Jansen de Wit in Schijndel. Coolen maakt er een gedegen werk van dat de titel krijgt Van Breischei tot 75 gauge. Het komt op tijd klaar en wordt fraai uitgegeven en rijk geil. lustreerd. ${ }^{15}$

Coolen gaat uitgebreid in op de geschiedenis van dorp, streek en bedrijf. Hij benadrukt dat in Schijndel een echte zeeheld geboren en gestorven is, Joan van Amstel, die nog naast Michiel de Ruyter gevochten heeft en afkomstig was uit 't Lutteleind. ${ }^{16}$ Tijdens de oorlog laten de bedrijfsleiding en het personeel zich niet tot de nieuwe orde overhalen. Het bedrijf wordt, volgens Coolen, eerder een hoofdkwartier van het verzet. Uitgebreid beschrijft hij het nieuwe product dat de bevrijders hebben meegebracht: de nylonkous. Natuurlijk kan Coolen het niet laten om in dit Andersen-jaar een vergelijking te maken tussen de onzichtbare nylonkous en de onzichtbare kleren van de keizer. In de Engelse en Franse reclame spreekt men van 'the bare leg' en 'le bas nu'.

In een bespreking van het gedenkboek in Brabantia wordt er de nadruk op gelegd, dat het bedrijf indertijd is begonnen met de levering van de lange priesterkousen. Uitermate pikant is dat er nu 'nonnekes' betrokken zijn bij de afwerking van wufte nylonkousen."

Het jubileum van de fabriek wordt gevierd op 14 september 1955 in aanwezigheid van Coolen en zijn vrouw Gerda. Daarna gaan ze op vakantie in het Zwarte Woud. Ze wandelen en zwemmen daar veel en drinken er veel wijn. ${ }^{18}$ Later in het jaar bezoeken ze, samen met het fabrikantenpaar van Jansen de Wit, Stijn Streuvels in Vlaanderen ${ }^{19}$ en daarna het eeuwfeest van Dietsche Warande en Belfort in Antwerpen, waar ook Teirlinck, Claes, Streuvels, Van Duinkerken, Donkersloot en LJ. Rogier aanwezig zijn.

Er is ook reden om de boog wat te ontspannen. Tevreden meldt hij aan Oomes ${ }^{20}$ dat hij door "de start van de autobus" [bedoeld wordt de eerste omnibus van zijn werk, uitgegeven door de Arbeiderspers, C.S.] meer financiële armslag krijgt. Van deze eerste omnibus worden 155.000 exemplaren verkocht. ${ }^{21} \mathrm{Hij}$ hoopt daardoor rust te krijgen om te werken aan zijn nieuwe roman, "waaraan ik op het punt sta te beginnen." Eerst moet echter Heeswijk weer worden voorzien van een nieuw toneelstuk. Tussendoor vindt hij ook nog tijd voor het schrijven van een lovend artikel over het Christus-met-de-apostelen-altaar dat zijn vriend Hendrik Wiegersma gemaakt heeft voor de kerk in Deurne. ${ }^{22}$

Tussen alle lof die Coolen deze jaren ten deel valt, duikt ook kritiek op. In de rubriek 'Journaal' van Roeping wordt een stukje van een vraaggesprek van Van Duinkerken met Albert Kuyle uit 1928 [sic] opgenomen. Waarom dat nu geplaatst wordt is niet duidelijk. Op de vraag wat Kuyle van Coolen denkt, antwoordt deze: "Coolen dwingt zich de croniqueur der Brabantsche dramatiek te zijn, maar dat kan niet, uit hoofde, dat hij volmaakt is losgeslagen van het Brabantsche volk. Hij heeft geen techniek, geen compositie, geen zinsbouw, geen typisch eigentijdsche taalkleur."23

Het is heel opvallend dat zo'n krtitisch stukje vanuit Roeping komt. Het kan een reactie van de verjongde redactie zijn op de gearriveerdheid van Coolen en wellicht ook op zijn nog steeds voortdurende afwezigheid in de kolommen van het tijdschrift. Of dat voort komt uit zijn weigering rond 1950 vanwege de kwestie met Gabriël Smit en zijn afkeer van 
Henri Bruning is niet duidelijk. Des te eigenaardiger is het dat een goed jaar later Roeping breed uitpakt met een positief gestemd jubileumnummer ter gelegenheid van Coolens zestigste verjaardag.

\section{Nobelprijs?}

Ook in 1956 is Coolen weer druk met commissielidmaatschappen en jury's. Hij zit al sinds het begin van 1956 in de reorganisatiecommissie van het Provinciaal Genootschap, hij is lid van het bestuur van het Prins Bernhardfonds en het Provinciaal Anjerfonds. Als redactielid van Brabantia publiceert hij het juryrapport van de literatuurprijs voor de GrootKempische Cultuurdagen, die toegekend wordt aan Lambert Tegenbosch. In september 1956 opent Coolen de jaarmarkt in Lith, de gemeente die zich ondertussen als 'Dorp aan de rivier' afficheert. De organisatie had gehoopt dat ook Wiegersma erbij zou zijn, maar deze is verhinderd. Coolen doet hem per brief uitgebreid verslag van de vele persfotografen en de aanwezigheid van de radio in het kleine dijkdorp. Niemand spreekt meer over Lith, de naam 'Dorp aan de rivier' is al volledig ingeburgerd. De bakker verkoopt er zelfs gebak in de vorm van een snoek onder de slogan: "Antoon Coolen werd groot door onze snoek, maar deze is lekkerder dan die in zijn boek." De man die model heeft gestaan voor Sjef de Smid stoort zich niet aan de dingen in het boek die niet kloppen met de werkelijkheid. De kern is volgens hem waar: hij ging voor dr. Jacob Wiegersma door 't vuur. Tegen de pers heeft Coolen 'opgebiecht' dat nog geen tien procent van het boek echt gebeurd is; de rest is allemaal verzonnen. ${ }^{24}$

In november 1956 verkeert de wereld in angst over het neerslaan van de Hongaarse opstand in Boedapest door de Sovjet Unie. Radiomedewerkers in Boedapest schreeuwen zich hees om hulp en ingrijpen van het westen. Vlak voor de crisis in Hongarije, in september 1956, heeft Coolen enkele malen contact met zijn voormalig vertaalster Ella Kazdova in Praag. Hij zendt haar op verzoek een keer een medisch handboek. ${ }^{25}$ De correspondentie is zakelijk en handelt over de regeling van de kosten. In december, na de crisis, schrijft Kazdova dat ze aan een meisje uit Amsterdam gevraagd heeft de groeten te doen aan Coolen. Ze dringt er op aan om haar terug te schrijven "anders spring ik in een KLM-vliegtuig." ${ }^{26}$ Coolen schrijft haar terug

15 Coolen, Van Breischei tot 75 gauge.

160 Ok Vondel heeft aandacht aan deze Brabantse zeeheld besteed. "Ter eeuwige gedachtenisse van [...] Joan van Aemstel, zeekapitein, gestorven te Schindel." Vondel, Verzameld Werk, Wereld-Bibliotheek-uitgave, deel 10,620.

17 [Recensie Van breischei tot 74 gauge], 24.

18 LMDC, inv, nr, C 3485, brief Coolen aan Oomes, 8 oktober 1955.

19 LMDC, inv. nr. C 3485, brief Coolen aan Oomes, 19 november 1955

20 LMDC, inv. nr. C 3485, brief Coolen aan Oomes, 19 november 1955.

21 Anbeek, Na de oorlog, 131.

22 Coolen, 'Een groot kunstwerk van Hendrik Wiegersma', 134-136.

23 Rubriek 'Journaal', in: Roeping, januari 1956, 571.

24 Archief Hendrik Wiegersma, brief Coolen aan H. Wiegersma, 29 september 1956.

25 BvdB, brief Coolen aan Kazdova, 15 september 1956; brief Kazdova aan Coolen, 26 september 1956.

26 BudB, brief Kazdova aan Coolen, 11 december 1956. 
dat Gerda weer voor de klas staat als invalster voor een zieke lerares ${ }^{27}$ Over Hongarije rept hij met geen woord.

Coolen zit in het bestuur van het PEN-centrum Nederland, maar dit bestuur neemt geen initiatief. Gewone leden van de PEN roepen een bijeenkomst uit in de Poort van Cleve op 10 november 1956 , omdat het PEN-bestuur niets doet. ${ }^{28}$ In het PEN-bestuur zitten voorzitter Victor E. van Vriesland, vice-voorzitter professor Donkersloot, secretaris W.S.B. Klooster (pseudoniem Willem Brandt), Hans Redeker, G. van der Graft, Kitty de Josselin de Jong Henriëtte Laman Trip-de Beaufort, Ben Stroman, A. Kossmann en Antoon Coolen. In de anticommunistische stemming die in die dagen in Nederland heerst, waarvan vernielingen bii het partijbureau van de CPN en De Waarheid getuigen, wordt een poging ondernomen om Theun de Vries vanwege zijn communistische sympathieën uit de PEN-club te stoten. ${ }^{29}$

Temidden van al deze consternatie moppert Coolen tegenover Van Duinkerken over de initiatieven die Van Vriesland heeft ondernomen om Vestdijk voor te dragen voor de Nobelprijs. Van Duinkerken zegt dat men al veel verder is dan Coolen vermoedt. Het Zweedse bestuur heeft al vragen gesteld aan Nederlandse hoogleraren. Er is al een gezamenlijke actie van de hoogleraren voor Vestdijk waartegen Van Duinkerken zich niet heeft verzet. Hij zegt de keuze van Vestdijk een slag in de lucht te vinden. Daarom heeft hij zich op het standpunt gesteld dat, als men internationaal succes wil, men beter Coolen had kunnen voorstellen. "Dit is mijn overtuiging. Ik weet zo goed als jij, dat het evenwel niet zal gebeuren." Als Vestdijk de prijs krijgt, dan is dat om een bijkomstige reden, bijvoorbeeld om Nederland ook eens aan de beurt te laten komen. Enigszins paradoxaal voegt hij eraan toe: "Een deel van zijn [Vestdijk, C.S.] romans acht ik waarlijk superieur, ook met het bui. tenland vergeleken. Er is bij mijn weten wel enig bezwaar aangetekend, echter is er geen neven-kandidaat gesteld of genoemd. ${ }^{-30} \mathrm{Na}$ Coolens dood schrijft Donker: "Als men eens beproefd had en volgehouden hem voor een Nobelprijs voor te dragen, zouden zijn kansen niet gering zijn geweest, en hij zou meer dan één winnaar van deze prijs, die wel eens vaker in de 'regionale' sfeer viel, zichtbaar hebben overtroffen."

De voordracht van Vestdijk haalt het niet. De Franse schrijver Albert Camus zal in dat jaar (1956) de Nobelprijs krijgen.

\section{Zestig jaar}

Het lag eigenlijk in de bedoeling dat de nieuwe roman van Coolen bij gelegenheid van zijn zestigste verjaardag in april 1957 gepresenteerd zou worden, maar het wordt een half jaar later. Al in januari verschijnt, als een opmaat voor alle publicaties in april, een positief getoonzet interview in De Tijd. ${ }^{32}$ Herman Hofhuizen schetst Coolen als een zeer vriendelijk maar toch enigszins ontoegankelijk man en vermoedt dat veel lezers een volkomen verkeerd beeld hebben van deze auteur. Antoon Coolen is niet de vleesgeworden Brabander of de vaandeldrager van Brabantia Nostra. Coolen zegt in het gesprek dat hij zich meer ziet als lid van de groep katholieke jongeren rond Roeping en De Gemeenschap, zij het dat hij niet zo strijdbaar was als de rest, op een enkel scherp 'Hageltje' in De Gemeenschap na. Het is frappant dat Coolen, die zich altijd verzet heeft tegen het etiket van 'katholiek romancier', toch liever wordt gezien als lid van een katholieke beweging dan als Brabander.

Bij zijn verjaardag blijkt dat Antoon Coolen in ieder geval geen vergeten schrijver is. 


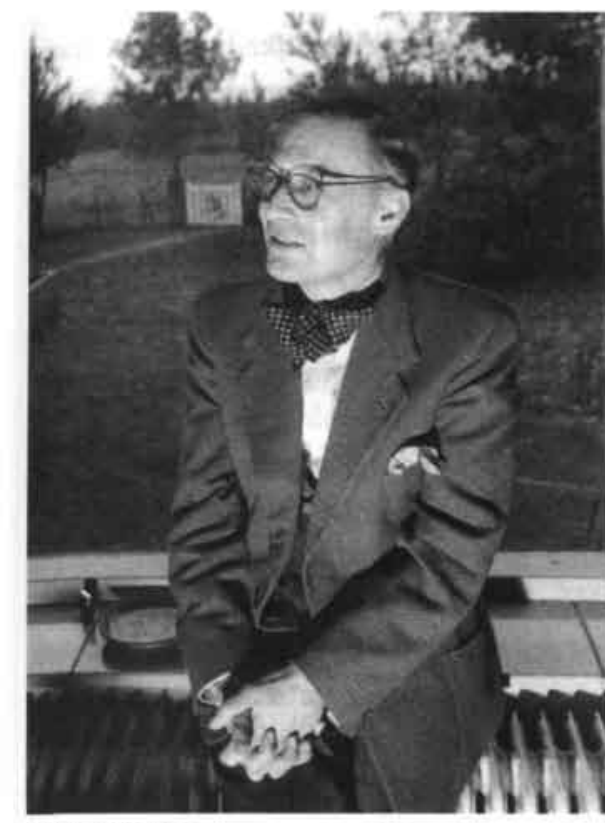

Coolen zestig jaar.

Alle kranten en tijdschriften publiceren uitgebreide overzichtsartikelen over zijn leven en werk. Jan van Sleeuwen schrijft in De Maasbode dat Antoon Coolen in het interbellum de romankunst voor eenzijdigheid heeft behoed. Als tegenwicht voor het rationeel-psychologisch genre waren zijn romans emotioneel en narratief van aard. Hij onderscheidt zich van streekromanschrijvers als De Man, Eekhout en De Vries door een poëtische toets en een sterk atmosferische gevoelstoon. ${ }^{33}$ Ad Bevers wijst in de Volkskrant op het internationale succes van Coolens romans in de jaren dertig en ziet in de bekroning van 'Voorval in een kerk' een voortzetting van dat succes. Bevers is geen vriend van de literatuur der nieuwe generatie, van Schierbeek, Hermans en Vinkenoog. Hij verstopt drie titels van deze schrijvers in zijn ironische vraag: "Wiens hoofd staat nog naar Coolens winteravondsprookjes nu het Boek Ik zo lang te water gaat tot het altijd gelijk heeft en niets maar kan schelen?"34

In de NRC wordt Coolen vergeleken met Streuvels. Streuvels heeft met zijn West-Vlaamse taal de provinciale literatuur doorbroken. Coolen heeft dat op zijn manier gedaan met Dorp aan de rivier en Herberg In ' $t$ Misverstand. Coolen heeft zich door zijn werk zeer verdienstelijk gemaakt voor het nieuwe "oude land van Hertog Jan," concludeert de krant. "Maar met dat oude land dankt hem ook Holland, het hele Nederlandse taalgebied voor dat wat hij gaf en hopelijk nog lang zal mogen blijven geven als kunstenaar en mens." ${ }^{35}$ Garmt Stuiveling noemt Coolen in het Haags Dagblad een modern schrijver, juist omdat hij het platteland niet als een serie romantische plaatjes bekijkt. ${ }^{36}$

Niet alle artikelen zijn lofredes. Har Scheepens toont minder enthousiasme en verwijt Coolen een zekere wereldvreemdheid:

27 BvdB, brief Coolen aan Kazdova, 21 december 1956.

28 Nord, Achterwoarts, 127.

29 Van de Waarsenburg, In gesprek met Theun de Vries.

30 BA, brief Van Duinkerken aan Coolen, 21 november 1956.

31 Donker, [Over Coolen en de Nobelprijs].

32 Hothuizen, 'Antoon Coolen, een geboren verteller.

33 Van Sleeuwen, 'Antoon Coolen zestig jaar'.

34 Bevers, 'Bij de zestigste verjaardag'. De titels zijn Het boek ik van Bert Schierbeek, Zo lang te water van Simon Vinkenoog en $l k$ heb altijd gelijk van W.F. Hermans.

35 'Antoon Coolen zestig jaar'.

36 Stuiveling, 'Jeugdervaringen als inspiratie'. 
"Er kunnen oorlogen woeden, het spoor van een verschrikkelijke brand kan dwars door de Meierij lopen, de doden kunnen langs de weg liggen en de tanks brullen en bul. deren - wanneer de rommel opgeruimd is, schrijft Coolen De Vrouw met de Zes Slapers - en de mensen, die hij dan creëert weten van geen oorlog, leven nog precies zo, als honderd jaar geleden onze voorvaderen volgens Coolen gedaan hebben - in een idylle."37

Het blad uit Coolens begintijd, Roeping, besteedt evenals Brabantia waarvan hij nu redacteur is, uitgebreid aandacht aan zijn zestigste verjaardag. Roeping ${ }^{38}$ pakt uit met een kleine honderd bladzijden en Brabantia ${ }^{39}$ met veertig.

Van Duinkerken, die aan beide themanummers meewerkt, schrijft in Brabantia een uitgebreid verhaal over Coolen en de moraal. ${ }^{40}$ Het uitgangspunt hierbij is dat in Coolens werk steeds het lot van de eenling afhankelijk is van diens plaats in de samenleving. Desintegratie betekent altijd onheil en geluk is saamhorigheid in het werk van Coolen, concludeert Van Duinkerken. Hij verwijst naar een van zijn eerste novellen, Peerke, de uitgestotene. Coolen schept zijn verhalen en personages uit een moraal van hartelijkheid. De grondslag daarvoor is een gemeenschapsethiek. Op dezelfde manier blijft Coolen met zijn werk buiten de politiek en de maatschappelijke discussies. Zijn werk heeft als waarde dat het barmhartig is; waar priester en leviet voorbijgaan biedt hij olie voor de mishandelde langs de weg. "Wie kunst voortbrengt blijft samaritaan in een land, waar het organisatorische en politieke 'doen' belangrijker wordt gevonden dan het artistieke 'maken'." Uit het lange artikel van twaalf pagina's blijkt hoe goed Van Duinkerken het werk van Antoon Coolen kent. Hij doorspekt zijn verhaal met veel voorbeelden en citaten.

In Roeping beschrijft hij zijn kennismaking met Coolen. Dit artikel eindigt met een variatie op verhaal voor Brabantia. Na gesteld te hebben dat Antoon Coolen niet vechtlustig is maar zeker ook niet laf, doch barmhartig, schrijft hij:

"Hij speelt niet de barmhartige samaritaan in een gewest, dat priesters en levieten bij de vleet bezit. Hij is niet barmhartig, omdat hij romanschrijver is. De verhouding ligt andersom. Hij schrijft, omdat hij soms een spanning niet verduren kan tussen het werkelijke en het ware, het nabije en het verre, de miserie en de hemel.".41

Louis de Bourbon schrijft in Roeping een bijdrage in de vorm van een brief. Deze bevat hele alinea's die nauwelijks te begrijpen zijn, omdat ze refereren aan vrolijke avonden met hun beide echtgenoten, de beide "Gees" Gerda en Gudrun. Hierin valt weer op hoe Coolen in kleinere kring, onder vrienden, een heel ander persoon is dan de gereserveerde heer zoals de buitenwereld hem kent. Ook de journalist Bekman uit de Hilversumse tijd brengt dat in dit themanummer naar voren. De Bourbon herinnert aan de "onbedaarlijke pret" bij de vele voordrachten die ze samen improviseerden voor andere genodigden op feesties in de huiselijke kring. Hij verhaalt een anekdote uit de oorlogstijd, waarbij er een "opérationmaquisard" op De Bourbon is uitgevoerd met de beide 'Gees' als zogenaamd ziekenhuispersoneel. Coolen ging daarvoor op de loop, "jij woeste moffentemmer, omdat je een vriend niet kon horen huilen'!! (sic, sic)." De uitroeptekens en de sic's zijn van De Bourbon. De Bourbon is inderdaad tijdens zijn onderduik geopereerd in De Kempen, waarna hijdoor zijn vrouw Gudrun en Gerda Coolen is verpleegd.

In zijn terugblik op de oorlog wijst hij op de keuze tussen goed en fout waar iedereen voor stond en hoe deze keuzen vriendschappen verstevigden of vernietigden. De vriend- 
schap tussen hem en Coolen is hecht geworden door het absolute wederzijdse vertrouwen in de 'foutloze' keuze van de ander:

"lemand zou kunnen opwerpen, dat jij persoonlijk niet van de een of andere 'ondergrondse' groepering deel hebt uitgemaakt. Ik kan daarop antwoorden, dat je deel uitmaakte van alle ondergrondse groeperingen, want je vocht, voor allen uit, op een eenzame post in een voorposten-sector, die de gevaarlijkste was van het hele front, bovenof ondergronds, n'importe. ${ }^{\text {42 }}$

Het is alsof De Bourbon wil zeggen dat het eenzame beroep van schrijver altijd de aandacht van de macht trekt en dat elke stap moet worden overwogen. Uit alles blijkt dat ze de hele oorlog goede vrienden zijn gebleven.

Een opvallende bijdrage levert Daan van de Meeberg, die het werk van Antoon Coolen in het licht van de sociale wetenschap beschouwt. Het werk van Coolen leert meer over de Peel dan verschillende proefschriften over dat gebied. Hij vindt vooral het verhaal 'De Boer en zijn kerkplavei' een goed voorbeeld van 'religiografie'. Het zou opgenomen moeten worden in een handboek voor pastorale sociologie. Het werk van Coolen heeft grotere verdiensten dan vele rapporten van provinciale opbouworganen of sociografieën geschreven in opdracht van de Stichting Maatschappelijk Werk ten Plattelande. Coolen heeft ook invloed gehad op het sociaal charitatieve werk. ${ }^{43}$

Frans Babylon herinnert zich hoe hij als kind in de hoogste klassen van de fraterschool van Deurne en later op de plaatselijke ULO de schrijver Coolen zag. Hoe deze in zich zelf gekeerd door de velden wandelde, met een boekentas door de dorpsstraten liep op weg naar het station of op een van de achterste banken onder het zangkoor in de dorpskerk zat. Tussen de somber geklede dorpelingen vielen zijn beige kostuum en de "ietwat opzichtig geschikte pronkdas met noppen" wel op. Babylon zag zijn kleding en gereserveerde houding als "een opvallende maar net voldoende distinktieve kamoeflage om gevrijwaard te blijven tegen een al te hinderlijke nieuwsgierigheid van merendeels ongeëmancipeerde plattelanders. ${ }^{24}$

Ook Louis de Bourbon schrijft over Coolens gereserveerdheid in zijn krant De Gelderlander. Coolen reageert daar als volgt op:

Tegenover mensen, die me niet liggen kan ik me lelijk sluiten en als ik bij lezingen op een zekere nonchalance in de ontvangst en de verzorging stuit, bevries ik tot het nulpunt en word ik steeg. En de jovialen, die me in de pauze komen vertellen dat ze ook Brabanters zijn en daarmee een soort van wij-samen-weten-het-wel pretenderen, brengen me wat dat betreft helemaal van de kaart. De indruk die je weerlegt, zal dus wel dikwijls juist zijn geweest." ${ }^{\text {45 }}$

31 Scheepens, 'Antoon Coolen'.

38 Roeping, Jrg. 32, april 1957.

39 Brabantia, Jrg. 6, april 1957, 93 - 137.

40 Van Duinkerken. 'Antoon Coolen en de moraal', 96-108.

41 Van Duinkerken, 'Omgang met Antoon Coolen', 628.

42 De Bourbon, 'Antoon Coolen 60 jaar', 648.

43 Van de Meeberg, 'Antoon Coolen en de sociale wetenschap', 666-67.

44 Babylon, 'Coolen in mijn jeugd en daarna', 677-687.

45. LMDC, inv. nr. C 3485, brief Coolen aan De Bourbon, 3 mei 1957. 


\section{Werken in De Pauwhof}

Coolens verjaardag zelf is niet met een feest gevierd. De afronding van zijn roman, die rond deze tijd had moeten verschijnen, wil niet vlotten. Alle aandacht en eerbetoon hebben de druk om dit werk te publiceren nog vergroot.

Hij besluit begin mei elders aan De grote voltige te gaan schrijven "om over een dood punt in mijn nieuwe boek heen te komen."16 Dat 'elders' is De Pauwhof in Wassenaar, een instituut waar schrijvers en geleerden in alle rust kunnen werken. ${ }^{47}$ Toch wil hij daar ook wel eens de zinnen verzetten, want op dinsdag 14 mei 1957 bezoekt hij een lezingenavond van het Anjerfonds in Kasteel Oud-Wassenaar waar Bomans spreekt. Deze noteert de ontmoeting in zijn dagboek en geeft een beeld van de schrijver zoals hij die avond tegenover hem zit:

"In de zaal ook Antoon Coolen. 'Na jaren weer 'ns een spreker gehoord,' hoorde ik hem zeggen, maar hij woont ook achteraf. Met hem naar 'De Pauwhof', alwaar een fijn soupertje ons wachtte, een verrassing van mevrouw Musaph. Toon schijnt na vijftien jaar zwijgen weer op dreef te zijn, was althans bezig met een nieuw boek. Hij vertelt goed, heel langzaam en uitvoerig, zonder iets over te slaan of zich naar de pointe te haasten. Het nadeel is, dat hij in de geringste reactie aanleiding ziet tot een nieuw verhaal, zodat er van een gesprek eigenlijk geen sprake is. Het ging maar door, eerst de geschiedenis van een smid in Deurne, toen de lotgevallen van een juffrouw in Grave, direct daarop een verhaal over een postbode die hij in Vught had meegemaakt. Coolen is een man, die geinteresseerd is in wat de mensen beleefd hebben, in het verleden dat ze bij zich dragen, maar toont niet de minste belangstelling in de man, die daar levend voor hem zit. Zo schrijft hij ook: vanuit het geheugen, niet vanuit het oog. Tekenend is ook, dat hij al die verhalen van anderen heeft, hij ziet niet zelf. Hij onthult daarbij ook niets van eigen bewustzijnsleven. Hij kiest voor zijn werk de onderwerpen, waarbij zijn tekort aan mensenkennis en introspectie niet ter zake doet: streek-epiek, sprookjes, kinderen. Op schrift aanvaardt men dit, omdat deze keuze het gebrek niet aan de orde stelt. Maar als hij lijfelijk voor je zit, wordt het anders. Je zou dan iets van Coolen willen horen, maar dit komt niet, hij blijft de grote doorgever." ${ }^{48}$

Bomans doet Coolen met deze veralgemeniserende beschrijving van zijn gedrag ernstig tekort. Coolen schrijft wel degelijk vanuit datgene wat zijn oog heeft waargenomen. Uit de manier waarop Coolen zijn personages beschrijft, blijkt ook dat hij over een grote men senkennis en veel invoelingsvermogen beschikt.

Bomans is kennelijk geirriteerd als hij deze dagboeknotitie schrijft. Hij heeft iets aparts in het gedrag van Coolen gezien. Bomans denkt dat Coolen alleen maar aan het tobben is over het bijschaven en herschrijven van zijn roman. Wat hij echter niet kan weten is dat Coolen op dat moment kampt met een veel groter probleem: zijn huwelijk. Na de bespre king van De grote voltige zal blijken hoe Coolen zijn literaire en privé-problemen met elkaar verbindt.

\section{De grote voltige}

In Coolens roman De grote voltige worden een dorp in de jaren vijftig en zijn bewoners gein. troduceerd door de ogen van bovenmeester Heberlé van de openbare school. Op zijn school zitten slechts dertig protestantse kinderen. Hij is op weg naar het station om drie logeetjes 
op te halen. Heberlé is in het dorp een buitenstaander, over wie allerlei praatjes de ronde doen. Hij heeft een dwergachtig vrouwtje en men vraagt zich af wat precies de verhouding is met zijn drie vrouwelijke logées. Voyeur Kreukniet houdt het allemaal bij.

Tijdens de wandeling is onderweg overal het stempel te zien dat de grootindustrieel die hier woont en een fabriek in de naburige stad heeft, op het dorp gedrukt heeft. Het parochiehuis, het Wit-Gele Kruis en de klokken in de toren zijn allemaal giften van Wigbert Benner. Ook het Gemeentelijk Wigbert Benner Sportpark is een geschenk aan de gemeenschap. De letters zijn door Wigbert, als gewezen smidsjongen, zelf gesmeed.

Dan komt mijnheer Heberlé een jongen op een metershoog eenwielertje tegen en dat doet hem denken aan Benners grootste trots: het amateurcircus van het dorp. Heberlé laat zijn gedachten gaan over die wonderlijke feodale drievoudige gemeenschap van mijnheer Benner, die van zijn bedrijf, die van zijn dorp en die van zijn circus. Deze laatste clan staat het dichtst bij hem en is daarom het meest benijdenswaardig.

Heberlé groet de eeuwig zieke vrouw, Paulien Lievenoogen, die altijd voor het raam ligt en vroeger als jongensachtig meisje uit een boom is gevallen bij het eksters uithalen. Een prentje van de H. Lidwina van Schiedam, die ook haar hele leven ziek was, hangt boven haar bed. Hij groet pastoor Van Genabeek, die op een paard aan het dressuur rijden is. Diens lijfspreuk luidt dat de zaligheid op aarde ligt op de rug van een paard. Naast het Witte Huis van Benner staat in een parkje het vervallen kasteeltje van de jonker die daar woont met zijn kok, een wijnkenner die graag de Franse klassieken citeert. Het gaat niet zo goed met de jonker, net zo min als met zijn vriend Tom Jonkergauw. Deze was vroeger al een deftig jongetie, want zijn vader was eigenaar van de strohulzenfabriek. Nu is hij getrouwd met de dochter van een kantonrechter en vervult hij de functie van bedrijfsleider op een textielfabriek. Voor zijn huwelijk is het steeds aan en uit geweest en hij heeft zich vlak voor de bruiloft nog proberen te verdrinken. Zijn huwelijk is zeer ongelukkig. De jonker en Tom Jonkergauw zijn bevriend en houden lange nachtelijke gesprekken. Aangekomen bij het station hoort Heberlé door de radio van de stationsrestauratie de huldiging van de tweeduizendste arbeider op de fabriek van Benner. Heberlé beseft dat deze de reden is waarom hij daarstraks de dorpsharmonie, waarvan Benner beschermheer is, in de bus heeft zien stappen.

Deze wat wijdlopige inleiding wordt gevolgd door een bijzonder sterk tweede hoofdstuk. Hierin komt de lezer veel van de zojuist voorgestelde personen tegen, maar nu als kind aan het begin van de eeuw. Deze alternerende vorm tussen heden en verleden wordt gedurende het hele verhaal volgehouden. "Toen wij, de ouderen van nu, kinderen waren, was ons dorp nog een afgelegen oord." Een bedelaar in narrenpak met belletjes rent door het dorp, er worden plakkaten voor een circus aangeplakt - "die felgekleurde bladzijde uit het jeugd-

46 LMDC, inv. nr. C 3485, brief Coolen aan De Bourbon, 3 mei 1957.

47 De Pauwhof was een landhuis waar 'beoefenaars van kunsten en wetenschappen' mochten verblijven die in hun eigen omgeving niet voldoende rust vonden 'voor studie en scheppende arbeid". Mevrouw J. Overvoorde-Gordon (1881-1957) stelde het huis voor veertien gasten open, tien jaar na de dood van haar man mr. Dr. J.C. Overvoorde (1865-1930). Zie; Hans de Vries, De Pauwhof 1940-1992, Leiden 1995: Ab Visser, Het klooster Sint-Juriaan: Pouwhof herinneringen, Utrecht 1974.

Bomans, Werken, I, 757-758. 
album" - en er wordt bij Versteijnen een kind geboren. Van de kansel wordt tegen het circus gepreekt. Het circus wordt als iets zondig weggezet, waarbij vooral de gevaren van de 'andere kunne' fel belicht worden. De slappe liberale burgemeester laat zijn oren hangen naarde geestelijkheid en geeft geen toestemming. Het circus gaat toch door op het weiland van boer en caféhouder Minderhoudt dat midden in het dorp ligt. De jonge Wigbert Benner ziet het lossen van het circus op het station, de intocht met olifanten en ook de vrouwen en meisjes die bij het circus horen. De hel gekleurde rokken en de oorbellen zijn heel vreemd. Er zijn ook meisjes met uitstaande rokken en pijpekrullen,

"net alsof het kinderen waren maar met een gezicht, dat ouder leek dan dat van een kind. Ze zijn blond en zó mooi, dat ge er uw ogen niet van af kondt houden, er waren er bij met verboden blote halzen, en daar hangt aan een kettinkje een kruisje in; hoe kan dat? Zou zo'n kruisje gewijd zijn? Nee, dat had natuurlijk geen priester willen wijden, meenden zij, want telkens dachten de jongens aan de oneerbare kunne in het zondige circus. ${ }^{\text {"199 }}$ Na de voorstelling blijft Benner nog met een gloeiend hoofd op de banken zitten en piekert over de zonde en de andere kunne. Hij concludeert dat zo iets moois geen zondigheid kán zijn. De volgende dag krijgt Benner straf op school, omdat hij een programma van het circus met 'onzedelijke' afbeeldingen onder zijn rekenboek heeft liggen. Broeder Hugolinus verbrandt het en Benner moet voor de klas knielen met een stapel atlassen op zijn gestrek. te armen. De volgende dag is hij verdwenen; het circus achterna zoals later zal blijken.

In het hoofdstuk 'Morgenrood', dat door de alternerende vorm van de roman pas veel later aan de orde komt, zien zijn kameraden, die graag bij het station rondhangen en met hun oor op de spoorstaven gaan liggen om de trein aan te horen komen, Benner terugkomen met een Duits petje op. Hij gaat niet meer naar de fraterschool, maar naar de openba. re. Als zijn vader overlijdt, neemt hij de smederij over en gaat ook fietsen en motoren verkopen. Ineens is zijn zaak echter gesloten. Pas na enige tijd horen de dorpsbewoners dat hij in een naburige stad, waar ook al ooit het bedrijfje van twee mensen is uitgegroeid tot een reusachtige gloeilampfabriek, een constructiewerkplaats is begonnen. Al heel gauw, als de fabriek goed draait, komt hij weer terug in het dorp wonen, in het huis van de oud-burgemeester aan de kleine laan naar het station. Hij is getrouwd met een eenvoudige vrouw, afkomstig uit een boerenherberg. Benner en het dorp worden één.

Het verhaal over het dorp en de hoofdfiguren springt in de tijd dus steeds heen en weer tussen de vooroorlogse periode en de jaren vijftig. In de hoofdstukken over de jaren vijftig maakt de lezer het optreden van het amateur-circus van de volwassen, gearriveerde Benner mee. De paardenliefhebber Pastoor van Genabeek is de spreekstalmeester en de dochter van Benner, Annelies, rijdt het hogeschoolnummer. Onder de genodigden bevinden zich een kanunnik met paarse sjerp en kalotje, veel provinciale en nationale beroemdheden en zelfs een minister. Benners vrouw weet niet goed wat ze tegen hem moet zeggen. "Ze verlegde, met haar zwarte handschoenen aan, af en toe maar eens die geweldige bos rode en witte en paarse en gele gladiolen en lachte zwijgend als de minister de mond eens opendeed en drie woorden zei." 50

In deze hoofdstukken wordt ook verhaald hoe het verder gaat met de leeftijdgenoten uit Benners jeugd. Een van hen is de ongelukkige Jonkergauw, die nachtenlang met de onverschillige jonker, die ver boven zijn stand leeft, discussieert over wijn, paarden en het 
ongelukkig huwelijk van 'een vriend', waarmee hij zichzelf bedoelt. Hij rijdt steeds met veel drank op in zijn auto naar huis en rijdt zich op een gegeven moment dood.

Paulien Lievenoogen gaat naar Lourdes en zuivert iemand die ten onrechte voor moord heeft gezeten van alle blaam. De gissingen in het dorp over Heberlé met zijn drie gratiën en zijn kleine dwergvrouwtje houden aan. Men kan zich niet voorstellen dat hij echt van dat kleine vrouwtje houdt en veronderstelt dat hij wel iets zal hebben met die drie logeetjes. Sommigen denken dat het verpleegsters zijn, want "die kennen het klappen van de zweep, en het verwondert niemand, dat ze er vrije opvattingen op na houden in de omgang ook met getrouwde mannen. ${ }^{n 1}$ De fatsoensrakker Kreukniet bespiedt hen, maar voert ook actie tegen het nieuwe zwembad. Hij ligt voortdurend in de bosjes te spieden naar onzedelijkheid. Thijs Jacob Versteijnen, van wie de lezer de geboorte en de doop heeft meegemakt aan het begin van de roman, vermoordt zijn vader om een motor te kunnen kopen.

Benner koopt het kasteeltje met het park van de jonker en maakt er een dorpspark van. Alleen een bank met inscriptie herinnert aan de jonker. Ter gelegenheid van de opening trakteert Benner het dorp ook nog op een voorstelling van een groot beroepscircus dat zijn tenten zal opslaan op de legendarische wei van Minderhout. Voorafgaande aan de voorstelling wordt Benner in een speciale raadsvergadering tot ereburger van het dorp benoemd, waarna de burgemeester hem ook nog een hoge koninklijke onderscheiding uitreikt. Pastoor van Genabeek vraagt of hij als niet-raadslid in de rondvraag het woord mag hebben en deelt mee dat Benner een gewichtige pauselijke onderscheiding heeft gekregen.

De voorstelling wordt een groot succes. Zelfs de oude frater Hugolinus verdiept zich in het programma met de foto van een luchtig gekleed paardrijdstertje. Annelies Benner treedt als gast op met haar beroemde paard Omar en rijdt de grote voltige: de dans op een galopperend paard. $\mathrm{Na}$ afloop van de voorstelling blijkt zij te zijn verdwenen. $\mathrm{Zij}$ is er vandoor met de ster van het circus, monsieur Soulet. Deze heeft een contract met het Cirque d'Hiver in Parijs, waar ze samen zullen gaan optreden.

De geschiedenis herhaalt zich. Zoals eens de smidsjongen Wigbert Benner wegliep gaat nu zijn dochter er met een circusartiest vandoor. Zij trouwen in Bagneux. Benner ziet geen opvolger in zijn schoonzoon, monsieur Soulet, die alleen maar van paarden houdt. $\mathrm{Hij}$ hoopt op een kleinzoon die de zaak kan voortzetten.

\section{Tijdsbeeld en sleutelroman}

De samenvatting doet geen recht aan de vorm van roman. Door de in de tijd alternerende hoofdstukken begrijpt de lezer pas beetje bij beetje wat nu precies de achtergrond is van die meneer Benner. Op dezelfde manier worden ook de bijfiguren voorzien van een verleden.

In de hoofdfiguur Wigbert Benner is de Deurnese fabrikant Hub van Doorne te herkennen, het mikpunt van Coolens aanvallen in de Deurnesche Courant van tien jaar daarvoor. Coolen doet ook geen moeite dat te verbergen, want in plaats van de obligate opmerking voor in een boek dat alle personen aan de verbeelding van de auteur zijn ontsproten

49 Coolen, De grote voltige, 163-164.

50 Coolen, De grote voltige, 169.

51 Coolen, De grote voltige, 49. 
en alle gelijkenissen op toeval berusten, houdt hij de mogelijkheid van gelijkenis wel open. Er staat: "Uit de werkelijkheid, die de schrijver bezighoudt, dringen zich verschijnselen en figuren aan zijn verbeelding op. Deze speelt er haar zelfstandig spel mee, en de figuren knijgen gestalte en lotgeval, die zij hun toebedeelt. A.C." Echter, het motto van Evelyn Waugh dat hij op dezelfde pagina opneemt, mystificeert weer: "I am not I: thou art not he or she: they are not they."

Wie verwacht dat dit boek een definitieve afrekening met zijn tegenstander van weleer zou zijn, komt bedrogen uit. Het portret is eerder met bewondering geschreven. In het hoofdstuk 'Morgenrood' beschrijft Coolen de ontwikkelingen in het interbellum via de carrière van Benner. De verteller trekt een parallel met Carnegie, die eveneens als gewone loopjongen en stoker begonnen was. Ook Benner telde als gewone jongen nu mee in de stad "tussen die zaken-en geldmannen en gestudeerde koppen." ${ }^{52}$

Hij had geen geleerdheid, zegt de verteller, maar hij had datgene waar de geleerdheid naar zoekt en moeizaam op uitkomt van nature. Vol bewondering wordt Benner vergeleken met grote uitvinders als Galileï, die door het slingeren van een hanglamp de tijdmeting uitvond: "Benner zag het, hij vond het denkbeeld en hij zag de toepassing." Hij wordt ook vergeleken met de twee ondernemende mensen die in een kleine stad, vijf zes uur gaans van hun dorp al lang daarvoor begonnen waren met een gloeilampenfabriek en nu met hun grote gebouwen de hele stad veranderd hadden. Zeer herkenbaar is de positie van Van Doorne als voorzitter van Deurnesch Belang in de roman opgenomen:

"Nu hadden alle verenigingen in het dorp twee leden als afgevaardigden in een geza. menlijk bestuur, dat alles besprak en besliste wat in ons dorp moest gebeuren, dat was gemakkelijk voor mijnheer Benner, die voorzitter van dit bestuur was en daarmee alles in handen had, want ze volgden altijd zijn goede raad en beslissingen op." 53

Toch is deze passage in de context van het boek eerder een kritiek op de volgzame dorpelingen dan op Benner. Ook van de buurman van Benner, de kale jonker, die de oude machthebbers en de voorbije tijd representeert, horen we die kritiek op de volgzaamheid van de dorpsbevolking. Deze dorpelingen hebben, volgens hem, nog een feodaal gevoel:

"Het wijzigde het bezit van twaalf weeldepaarden en het spelen ermee [in het circus] tot een groot offer voor de gemeenschap, verbeeld je zo iets, en de woorden hadden mijnheer Brenner werkelijk ontroerd. Misschien bevrijdden ze hem van een schuldgevoel, dat stokpaardje van de tegenwoordige psychologie. De plotselinge rijken vragen aan de gemeenschap, er alsjeblief wat fleuriger uit te zien, dat kan zo goed; ze willen groot en gul wegdelen, om niet het verwijt te voelen van hun souverein bezit. ${ }^{.54}$

De naam Benner, die Coolen aan de hoofdpersoon heeft gegeven, lijkt een tegenhanger van het pseudoniem Willer dat Coolen in zijn jonge jaren bij De Zuidwillemsvaart gebruikte. Een 'willer' is iemand die nog iets wil. Benner lijkt te zeggen 'ik ben er'; het is de naam voor een arrivé. De voornaam Wigbert zou dan nog kunnen wijzen op de wig, de tweespalt, die Van Doorne in de dorpsgemeenschap zou hebben veroorzaakt. Als Coolen het zo bedoeld heeft, dan is het toch alleen voor een binnenpretje, want in de roman is Benner op geen enkele manier een man die twist of tweedracht zaait. Integendeel, hij is degene die harmonie in de gemeenschap brengt.

Het hoofdstuk 'Morgenrood' eindigt met de terugkomst in het dorp van de vroegere smidsjongen Benner in de jaren dertig. Hij heeft het moeilijk, omdat hij moet opboksen 


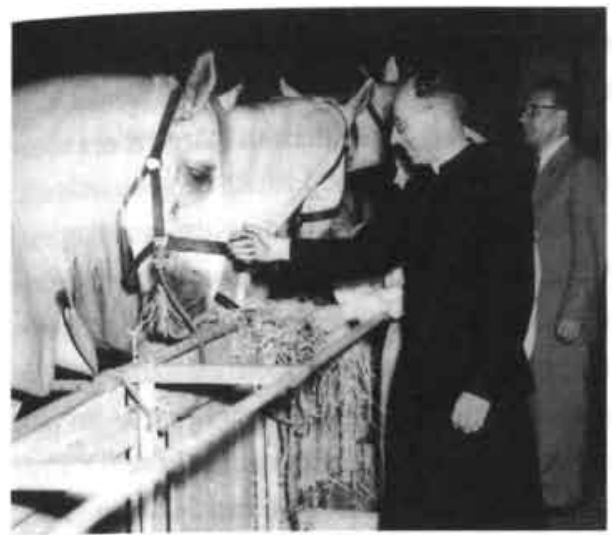

Hub van Doorne en pastoor van Dinther bij de parden. (foto uit: Van Dixhoorn, 't Hoefke. Een dorp speelde circus, Eindhoven 1995) tegen de crisis. Het lukt hem, maar "de nieuwe tijd moest nog door veel weeën, door ineenstortingen en vernietigingen. $\mathrm{Nu}$, daar rees hij uit op. Hij verbrandde zichzelf om zo te zeggen als de vogel Phoenix, het industriële tijdperk herrees uit de as." ${ }^{\text {"55 }}$ Deze formulering heeft Coolen al eerder in zijn boek gebruikt [zie hieronder bij de fabrieksarbeid van meisjes, C.S.]. Het is alsof hij er mee wil zeggen: over die oorlog is genoeg gepraat en we kijken nu naar de toekomst en het nieuwe Brabant. De hele jaren veertig komen in de roman niet voor.

Het lijkt er veel op dat Coolen in Benner een verbeterd portret van zowel zichzelf als van Van Doorne heeft willen geven. Benner is een synthese van de succesvolle romancier/artiest en 'kunstenmaker' en de geslaagde industrieel. Beiden hebben een soort burgemeestersallure: Van Doorne meer in de rol van 'baas' en weldoener van het dorp en Coolen als gezaghebbende en patriarchale 'burgervader'. Van Doorne was kennelijk een betere evenwichtskunstenaar dan Coolen en slaagde er beter in de voltige tussen deze verschillende rollen in de praktijk te brengen.

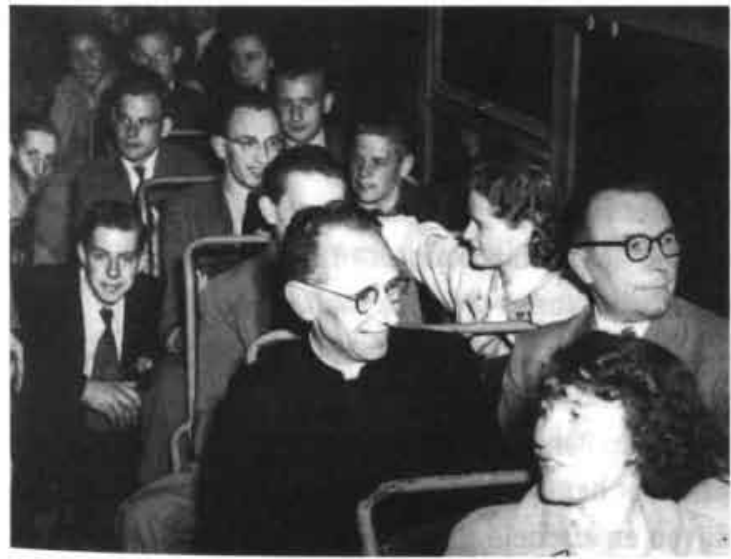

Hub van Doorne en pastoor Van Dinther op reis met de medewerkers van amateurcircus 't Hoefke.

(foto uit: Van Dixhoorn, 't Hoefke. Een dorp speelde circus, Eindhoven 1995)

\section{Het circus}

Coolen heeft het leven en de hobby's van Van Doorne goed gevolgd. De beschrijvingen van de circusvoorstellingen in de roman komen bijna letterlijk overeen met de volgorde in de programma's van het werkelijk bestaande circus 't Hoefke. Dochter Annelies is in werkelijkheid een tweeling: Anny en Tiny van Doorne. Zij speelden een centrale rol in het circus en werden daarna ook bekend als hogeschoolrijdsters. De parochiegeeste-

52 Coolen, De grote voltige, 317.

53 Coolen, De grote voltige, 300.

54 Coolen, De grote voltige, 186.

55 Coolen, De grote voltige, 321. 
lijke, Pastoor van Dinther, was inderdaad de spreekstalmeester. Ook de 'echte' voorstellingen werden bezocht door de toonaangevende elite van die tijd. Kort na het uitkomen van De grote voltigewoonden zelfs prins Bernhard en de prinsessen Beatrix en Margriet een voorstelling bij. ${ }^{56}$

Coolen heeft al schrijvende zijn onmin met Van Doorne naar de achtergrond gedrongen en werpt zich met veel plezier op de beschrijving van een dorpsgemeenschap, die zich met alle middelen inzet om een verantwoorde circusvoorstelling te maken. De aanhankelijk. heid van de medewerkers, de bemoedigende telefoontjes van Benner naar de artiesten voor en na hun optreden in de kleedkamers en het weldoende rondgaan van mevrouw Benner met koek voor de bejaarden winnen het van de ironie over het feodale van de nieuwe rijke.

\section{Emigratie}

De grootscheepse ruilverkaveling in de jaren vijftig kan in de toekomst de kinderen van de grote boerengezinnen toch niet genoeg land bieden. Op voorlichtingsavonden wordt gesproken over emigratie naar Canada of Australië. De verhalen over de onafzienbare bunders korenvelden, waarop met vier of vijf combines tegelijk wordt geoogst, hebben een grote aantrekkingskracht. ${ }^{57}$

Tijdens zo'n vergadering laat Coolen ook Benner optreden. Hij komt later binnen, wordt meteen naar de bestuurstafel geleid en vraagt, na even naar de gedachtewisseling geluisterd te hebben, het woord. Hij wijst erop dat de jonge boer "in de bergloods met stalen kapconstructie een halve machinebankwerker" ${ }^{58}$ is en dat er dus niet veel omscholing nodig is om in de montagehallen van zijn bedrijf te komen werken. De industrie is niet zo maar iets: "zij is een noodzaak en een levensbelang." Dus jonge boeren die niet willen emigreren kunnen bij hem komen werken, zegt Benner en hij dankt het bestuur van de boe renbond dat hij dit in de vergadering mocht komen zeggen.

Heel raak schetst Coolen de positie van Benner in zo'n scène: de gehaastheid waarmee hij binnenkomt, "met al zijn werk achter zich en vóór zich," en de eerbied waarmee het boerenbondbestuur hem verwelkomt. Er is een oude boer, 't Gofferke, de enige die Benner bij zijn voornaam noemt, die zegt nooit in de fabriek te willen gaan werken. Hij gelooft niet in de verhalen dat oude mensen vastgeworteld zijn en niet verplant kunnen worden. Hij neemt zijn wortels mee met een beetje grond en schudt die er ginds wel vanaf en dan zal hij daar best kunnen aarden. De reactie van Benner is er een van een grootmoedige verhe venheid: "De boeren hadden allemaal met hem [t Gofferke, C.S.] moeten lachen en mijnheer Benner, die nooit lang kon blijven en afscheid nam, had ook gelachen en was naar hem toegegaan, om hem hartelijk de hand te drukken." 59

Na enige tijd komen er touringcars in het dorp die de 'landverhuizers' naar Canada, Ontario komen ophalen. Eén familie neemt ook de vitale grootvader, 't Gofferke, mee. Voor het vertrek is hij heel opgewonden en wil iedereen nog even alles laten zien: het huis, de kelder, de stal. Bij het weggaan wil hijzelf de voordeur dichtdoen en als ze op het marktplein in de bus moeten stappen, loopt hij nog gauw even de kerk in om aan zijn kleinkinderen de doopvont te laten zien waar hij gedoopt is. Nadat hij ook nog even gezocht heeft waar zijn ouders begraven liggen, krijgen ze hem tenslotte in de bus. Als zijn vrouw tegen de anderen roept dat hij eindelijk kalm is, blijkt hij dood te zijn. De emigranten-aalmoeze- 
nier regelt dat de oudste zoon kan achterblijven voor een vervroegde begrafenis en met de KLM de boot met emigranten nog inhaalt als die in Southampton aanlegt.

Coolen slaagt er in dit hoofdstuk 'De verdwenen vader' in om de moderne problemen van ontginning, ruilverkaveling, industrialisatie en emigratie te vlechten door de oude verhoudingen van de familie, de grond en de dorpsgemeenschap. De smidsjongen is grootindustrieel, maar wil nog steeds één zijn met zijn dorp. De geestelijkheid zien we terug als emigranten-aalmoezenier. De oude boer blijkt echter toch niet meer te 'verplanten'.

\section{Coolenland}

In de roman vinden we Coolens beschrijvingskunst ruimschoots terug. In het jeugdhoofdstuk 'De Hardloper' bespiedt een groepje jongens het huis waar een bevalling plaatsvindt. Ze hebben er de 'goejvrouw', de vroedvrouw, naar binnen zien gaan. Even later zien ze haar samen met de man van het huis een teil met bloedwater weggooien en weer even later wordt de nageboorte begraven. De jongens vermoeden iets omdat de 'goejvrouw' erbij is, maar tasten volledig in het duister over wat er nu aan de hand is: "een teil zo rood, dat men denken moest aan iemand, die golven bloed had opgegeven en toen droevig stierf." ${ }^{n 6}$ Een van de jongens herinnert zich dit beeld als de nieuwgeborene gedoopt wordt en denkt dan aan dat menselijk bloed. "En dat er nou een kindje was en dat het was gedoopt, dat zelfs had hem over dat bloed niet gerustgesteld." ${ }^{\text {"1 }}$ De verteller laat in het midden wie deze 'een van de jongens' is; wat sta je daar te suffen vraagt Dookske Lamoen aan "die jongen."

Het is de enige keer dat de verteller geen naam noemt. Zoals middeleeuwse schilders zichzelf wel eens in een hoekje van een groot schilderij afbeeldden, zo heeft Coolen hier zichzelf geportretteerd: de schijnbaar afwezige, maar scherp waarnemende schooljongen, die gevoelig is voor het noodlot dat dit pasgeboren kind boven het hoofd hangt. Later zal de dopeling, die in de roman zo nadrukkelijk met bloed en onheil is geïntroduceerd, zijn vader ombrengen om van diens spaargeld een motor te kunnen kopen.

Coolen laat Benner in zijn toespraken bij de vele huldigingen vaak verwijzen naar zijn eenvoudige jeugd en zijn moeilijke zwerversjaren. Het contrast met de fabrikantenzoon lonkergauw en de jonker wordt dan nog groter. De eerste trouwde in die tijd met een mis met drie heren en een zangkoor uit de stad, "en er lag een loper door de middengang van de kerk tot buiten aan de straatkeien." Jonker van Weede van Lawieck studeerde toen in Utrecht. Samen zitten ze nu avonden lang in "het bouwvallige renaissance slotje" te filo-

56 Van Dixhoorn, 't Hoefke, 141.

57 Aanvankelijk was deze voorlichting primitief en eenzijdig en leek meer op propaganda. In de loop van de jaren vijftig werd ook gewezen op de problemen na aankomst, o.a. door aanhaling van het Duitse gezegde: 'De eerste generatie gaat dood, de tweede heeft nood en de derde heeft brood.' Van Stekelenburg, De grote trek, 59.

58 Coolen, De grote voltige, 121.

59 Coolen, De grote voltige, 123.

60 Coolen, De grote voltige, 48.

61 Coolen, De grote voltige, 102 
soferen over wijn, dood en paarden. Ooit heeft Benner op het slotje gedineerd en zijn hand boven zijn glas gehouden toen de wijn werd ingeschonken. Jaren later is de bediende Gaston daarover nog steeds geschokt: "Ce m'sieur Bennèr [...] c'est un homme de génie, c'est un grand homme, un Carnegie. Mais il a un manque essentiel, il n'aime pas le vin. ${ }^{62}$

Het is juist dit detail dat de dochter van Van Doorne, mevr. Hohmann-van Doorne, zich herinnert van de tijd rond de persstrijd. Uit de clan rond Coolen, Wiegersma, Berkvens zou ooit de opmerking zijn gekomen over Van Doorne en de zijnen: ach die drinken maar bier. ${ }^{63}$

De jonker vergelijkt de belangstelling van Benner voor zijn slotje met de liefde voor het circus. Het is weer een jongensdroom die Benner wil waarmaken. Benner is hier op jongensklompen voorbijgekomen en hoort nu weer zijn kinderstem, voelt zijn nieuwsgierig. heid naar dit sprookje. Het bezit er van zal een kinderdroom verwezenlijken. "Het feodalistische gevoel is het plattelandsvolk hier in de ziel blijven zitten; het ziet zijn groten als van een andere natuur. ${ }^{\text {"64 }}$

Hierin komen lijnen uit het hele oeuvre van Coolen bij elkaar. De personages Benner en Cordewever, maar ook de personen Van Doorne en Coolen hebben in hun jeugd gefantaseerd over het kasteel in hun dorp Deurne. Van Doorne heeft vroeger zelfs nog een trapauto gemaakt voor de kleine freule. 'Het kasteel' was er al in Coolens vroegste verhaal 'Dat sprookje, het feodale kasteel' uit 1924 , het keerde terug in De vrouw met de zes slapers en nu opnieuw in zijn voorlaatste roman. Het is nóg een aanwijzing voor de gedachte dat Benner een synthese van Van Doorne en Coolen is.

\section{De kritiek}

De kritieken op De grote voltige zijn heel wisselend. De recensent Paul Kuypers. van de Helmondsche Courant vindt het een rancuneus boek. Coolen heeft de figuur Benner bewust vaag gehouden, omdat hij anders niet om het feit heen kon dat hij eens bevriend is geweest met Van Doorne en daarna met hem in een publieke vijandschap heeft geleefd. Als hij dat gebruikt zou hebben zou het boek een "geromantiseerd pamflet" zijn geworden, waarbij hij zichzelf niet buiten schot zou hebben kunnen houden en daar is Coolen te beschaafd en te voorzichtig voor, schrijft hij. Kuypers heeft jaren geleden al vernomen dat Coolen bezig was met een roman over de sociaal economische en culturele ontwikkeling van het gewest, maar hij vindt de beschrijving van de zwenking van het gewest maar summier. Het boek beschrijft vooral Benner en maakt daarmee zijn pretenties niet waar. Coolen die toch zo bekend is om zijn mildheid, waarmee hij zelfs echte of vermeende moordenaars verguldde, laat dat bij Benner na. Deze wordt geschetst als iemand die van niet tot iet is gekomen en daarna de adoratie van het dorp koopt. De roman is daarom niet vrij van persoonlijke rancune en Coolen weet heel goed dat je vanaf de schoot van de muze niet moet gaan zitten ruziën, besluit de recensent. ${ }^{65}$

Zijn vriend Piet Oomes bespreekt het boek voor de KRO radio en is een en al lof. Het is eigenlijk geen recensie maar een verkooppraatje, dat aldus eindigt: "Ge vindt deze superieure roman in alle boekwinkels van het land." ${ }^{.66}$

Harry Kapteijns vergelijkt in Brabantia het werk van Coolen met dat van Vestdijk. Hij constateert dat de romanfiguren van Coolen met name in zijn nieuwste boek dichter bijde werkelijkheid staan. Coolens personages zijn volledig bestaanbaar, terwijl die van Vestdijk 
daarentegen alleen kunnen bestaan in de grillige en groteske fantasie van de schrijver zelf. Toch voldoen de personages van Coolen aan zijn intentie en interpretatie van het leven. Hij leidt ze naar wat hij als de vervulling van het leven ziet: een genezende barmhartigheid. Hij verwacht dat de critici verdeeld zullen zijn. Een gedeelte vindt er te weinig persoonlijks, te weinig oorspronkelijks in en het andere deel zal het boek juist prijzen om zijn kroniekachtige objectiviteit. Het zou wel interessant zijn om te weten waar Coolen de werkelijkheid volgt en waar hij afwijkt om het werk van zijn verbeelding te volgen. Hij raadt de lezers aan om naast dit boek, eigenlijk nog liever in afwisseling, Coolens hoofdstukken in Het nieuwe Brabant over het landschap en het dorp te lezen. Kapteijns vindt dat het boek grote documentaire waarde heeft, niet als geschiedschrijving, maar door het voelbaar maken van de sfeer waarin zich de ontwikkelingen voltrekken. Hij vindt het boek prachtig geschreven. Vorm en inhoud bereiken een eenheid en weerspiegelen het ethos van de kunstenaar Coolen. ${ }^{6}$

In Het Vaderland wordt, na enige waarderende woorden over de mens Coolen, die geen "reclametent gehuurd [heeft] op de kermis der ijdelheid" en slechts bescheiden deelneemt aan het vreemd gewriemel van het letterkundige leven, met zijn nieuwe roman de vloer aangeveegd. De recensent weet dat tienduizenden lezers enthousiast zijn. Hij vindt De grote voltige echter niet boeiend. Het is maar een traag verhaal met ledepoppen van personages en saaie opsommingen zonder een eigen kijk of een eigen toon. Na driehonderd zeven en zestig pagina's houdt men niets anders over dan een gevoel van ijlte. "Het eentonige gedreun van de verteller heeft opgehouden en in de stilte, welke daardoor ontstaat, kunnen wij ons niet meer herinneren waarover hij het aldoor gehad heeft." De toon van de bespreking doet sterk denken aan die van Greshoff, die op dezelfde manier over De vrouw met de zes slapers schreef. ${ }^{68}$

Hans Warren daarentegen vindt het een fantastisch boek en acht de uitvoerigheid van de beschrijving nergens vervelend. Het is een echt leesboek, waarvoor men rustig de tijd moet nemen. Coolen heeft volgens hem terecht geen rekening gehouden met de hedendaagse jachtige lezer, die alleen maar romans van hoogstens honderdvijftig bladzijden grote druk wil zien. ${ }^{69}$

Lambert Tegenbosch schrijft dat Coolen de figuur Benner oningevuld heeft gelaten, waardoor deze raadselachtig is, als een soort god. Hij bewondert de wijze waarop Coolen met iets de spot kan drijven: mild en toch afdoende, bijna dodelijk. Er zijn eigenlijk geen bij-en hoofdfiguren. De kleine drama's, comedies en tragedies vullen het boek en er is, volgens hem, niet één groot drama. Tegenbosch zegt dat degenen die voorpublicaties in tijdschriften hadden gelezen benieuwd waren naar wat Coolen nu met de figuur Benner van

\footnotetext{
62 Coolen, De grote voltige, 78.

63 Mevrouw Hohmann-van Doorne in gesprek met C. Slegers op 13 maart 2000, Deurne.

64 Coolen, De grote voltige, 80.

65 [Paul Kuypers], 'De grote voltige'.

66 WE, typoscript lezing Oomes voor KRO radio op zondag 24 november 1957 in de rubriek Het Boekhuis.

67 Kapteijns, 'Antoon Coolen, De grote voltige', 23-24.

68 'De grote voltige. Nieuwe roman van Antoon Coolen'.

69 Warren, De grote voltige'.
} 
plan was, vooral omdat iedereen wist wie er mee bedoeld was. Maar zoals gezegd blijft Benner vaag en raadselachtig. Tegenbosch noemt de naam Van Doorne uitdrukkelijk niet. ${ }^{0}$

Des te opmerkelijker is een artikel dat Tegenbosch een jaar na de dood van Coolen schrijft in de Volkskrant, als de van Doorne kwestie weer wordt opgerakeld door J.B. Charles. Tegenbosch herinnert zich in dat artikel, dat hij in 1957 in een gesprek met Coolen zijn verbazing heeft uitgesproken over de 'hommage' die Coolen in zijn boek bracht aan Van Doorne en zijn circus ' $t$ Hoefke. Coolen zou tegen hem gezegd hebben dat hij tijdens het schrijven vrij was geweest van rancune. Hij vond dat hij te forse taal had gebruikt in de Deurnesche Courant en begreep dat de rechter hem daarvoor had moeten veroordelen. Hij bleef echter wel bij zijn mening dat Van Doorne tijdens de bezetting dingen had gedaan waarvoor hij zich zou moeten schamen. Het wonderlijkste in dit gesprek in 1957 was dat Coolen vervolgens aangaf, dat hij het gedrag van Van Doorne "begréép en verontschuldigde." Volgens hem was van Doorne een "weergaloos technisch genie," bij wie het niet ging om het geld verdienen: "hij had die vreemde belangeloosheid van de verstrooide, geheel in hun denken opgaande geleerde." Deze 'verstrooidheid' is Coolen op den duur meer gaan intrigeren dan zijn verontwaardiging over de collaboratie groot was, schrijft Tegenbosch. Hij vindt dat de beschrijving van Benner er een is zonder warmte, liefde, bewondering en meegevoel, maar eerder een van "bijna starre aandacht." Coolen heeft het oorlogsverleden van Van Doorne willen begrijpen in het licht van de alles verslindende werking van diens genie. Zijn visie verklaart het gedrag niet, maar vraagt "respect voor het buitenmaatse."

Dit refereert aan Nietzsche's idee van 'Jenseits von Gut und Böse', dat eerder gebruikt werd voor Van Taeke in Coolens roman Dorp aan de rivier. Coolen zelf heeft tijdens de oorlog ook even gedacht dat hij dit buitenmaatse representeerde en pas later ingezien dat hij eerder had moeten kiezen tussen goed en kwaad.

De titel van het boek krijgt zo een derde betekenis. De grote voltige heeft zich niet alleen tijdens een paardennummer en in de provincie Brabant voltrokken. Het boek gaat ook over de omwenteling die de personen Van Doorne en Coolen na de oorlog hebben meegemaakt.

\section{Het motief}

Zowel Coolen als Van Doorne hebben iets gepresteerd dat de normale kaders van hun dorp te buiten ging. Beiden zijn in hun jonge jaren enige tijd weg geweest; beiden zijn er in de jaren dertig weer teruggekeerd. Van Doorne heeft zich er toen echter voorgoed gevestigd als de nieuwe 'feodale' heer, terwijl Coolen na vijf jaar naar Waalre verhuisde. Nu, op zestigjarige leeftijd, overheersen bij de schrijver meer de overeenkomsten van hun gemeenschappelijke jeugdervaringen dan de verschillen uit de naoorlogse tijd. Niets herinnert in De grote voltige aan de oorlog. Heel vaag krijgt men een associatie met de auto's van de Duitse officieren wanneer, bij een groot diner na afloop van een circusvoorstelling, de auto's van de autoriteiten de oprijlaan van het Witte Huis in zwenken. Slechts één keer is er een verwij zing naar het 'militair-industrieel complex' als het welkomstwoord van de paardenmin. nende pastoor Van Genabeek bij een voorstelling wordt verstoord door een overvliegende straaljager. "Dat storende geluid was hier te meer vergeeflijk, omdat de fabriek van mijnheer Benner zoveel luchtmachtorders had voor de levering van ongelooflijk snelle tankapparaten, die de straaljagers in minder dan een oogwenk van benzine voorzien; - dat had met 
hulde in de krant gestaan. ${ }^{n / 2}$ Men neemt dit lawaai graag voor lief, want men dankt er het circus en de paarden aan. Het een grijpt in het ander, zegt de verteller.

Coolen heeft niet de bedoeling scherpe spot op de figuur Benner los te laten. Hij heeft andere motieven voor het schrijven van deze roman. Hij loopt al sinds 1953 , dus vóór het uitkomen van De vrouw met de zes slapers, rond met een idee om een roman te schrijven over de grote omwentelingen in Brabant. Hij heeft in die tijd het idee gekregen om de figuur Van Doorne tot de 'as' te maken waar omheen de grote omwenteling, de voltige, in Brabant zich voltrekt. Van Doorne staat in de eerste helft van de jaren vijftig zeer in de belangstelling. In 1953 krijgt hij een eredoctoraat in Delft en in 1954 bezoekt keizer Haile Selassie van Ethiopië samen met de koningin de Daf-fabriek. Godfried Bomans beschrijft in de Volkskrant? op komische wijze een foto waarop het gezelschap in een "gemotoriseerd karretje," bestemd voor het vervoer van militair personeel en materieel, wordt rondgereden door de fabriek. In de laadbak zitten koningin Juliana en keizer Haile Selassie en de broers Hub en Wim van Doorne. Het karretje wordt bestuurd door jonkheer Van der Goes, leider van de Technische Dienst. Bomans associeert deze foto met een illustratie van Hans Tegener bij een sprookje van Andersen. De eenvoudige smidszonen, die aan het eind van het sprookje in een karos met vier appelschimmels vertrekken: "Een jonkheer aan het stuur, een keizer en een koningin als medepassagiers, zo zitten daar de twee zoons van een arme dorpssmid uit Deurne bij elkaar en kijken de beschouwer vergenoegd in het gezicht." Coolen heeft het sprookjesachtige hiervan ingezien. Hij gebruikt in Benner de figuur Van Doorne als metafoor voor de Provincie Brabant: op dezelfde manier als de smidsjongen tot grootindustrieel, uitvinder en eredoctor uitgroeide, zo veranderde het bruine en donkere Brabant van het begin van de eeuw in het groene, lichte en bedrijvige Brabant van de jaren vijftig.

In de figuur Benner/Van Doorne zijn het oude en het nieuwe verweven. Hij vertegenwoordigt een continuïteit in de overgang van het agrarische naar de industrie. Zijn liefde voor het circuspaard als 'vercultuurde' versie van het landbouwpaard, wordt voortgezet in de geindustrialiseerde vervaardiging van het nieuwe 'mechanische paard': de auto.

Een ander motief voor het schrijven van dit boek komt voort uit een vaag schuldgevoel. Coolen heeft iets goed te maken met Van Doorne én met zichzelf. Zijn grieven tegen Van Doornes 'pacteren' met de vijand zijn niet los te zien van zelfverwijt over zijn eigen beoordelingsfout over de mogelijkheid om nog te kunnen functioneren als burgemeester. Zijn haat in die eerste jaren na de oorlog heeft iets in hemzelf kapotgemaakt op dezelfde manier als de boer uit het verhaal zijn 'Schouwtegels' vernielde. De grote voltige is een poging om deze zelfbeschadiging te restaureren.

De roman De grote voltige is echter niet alleen een sleutel voor gebeurtenissen in Deurne en Brabant en de verhouding tussen Coolen en Van Doorne. We zullen zien dat het personage lonkergauw ook een sleutel naar het persoonlijke leven van Coolen in die tijd bevat.

70 Tegenbosch, 'Nieuwe roman van Antoon Coolen'.

71 Tegenbosch, 'Poging tot Begrip'.

72 Coolen, De grote voltige, 170.

73 Bomans, 'De grote directeur'. 



\section{De praalwagen van de dood}

"Goededag, nuttige leden van de maatschappij."

$1958-1961$

\section{De grote afwezige}

Coolen hoort in Brabant tot de toonaangevende elite en speelt op diverse terreinen van het culturele leven een vooraanstaande rol, maar hij is niet echt gelukkig. Als twee van de drie zonen het huis uit zijn, verruilt het echtpaar Coolen de statige villa De Kempen voor een kleinere woning aan dezelfde laan. Gerda Coolen neemt weer een baan als invalster in het onderwijs.

Als het werk aan De grote voltige op een dood punt zit, treft het gezin een ramp. Stijn krijgt in maart 1957 een ernstig auto-ongeluk. Zijn ouders regelen, ook financieel, zijn revalidatie. Hij komt voor enige tijd weer thuis wonen. Kort daarna verlaat Coolen zijn huis om in De Pauwhof in Wassenaar verder aan zijn roman te werken.

Het huwelijk is sinds de dood van Peter in 1947 glansloos geworden. De conflicten met de oudste zoon Stijn, waarbij Gerda partij kiest voor haar oudste, hebben de echtelieden nog verder van elkaar verwijderd.

We kijken even terug. Tijdens de kennismakingstijd in de jaren twintig schreef Coolen aan Van Duinkerken dat Gerda een paar jaar verloofd is geweest met een "man van het wereld. se type [...] ruig, sportief, met een imponeerend fiesiek" en dat ze bij hem [Coolen] meer geestelijke inhoud vond en "beschaving van gemoed en hart." Als ze echter met Coolen is, mist ze toch weer dat andere. Ze besluiten dan niet uit elkaar te gaan, maar in sterke vriendschap voort te leven. Mocht ze toch nog iemand anders vinden, zo schreef Coolen aan zijn vriend Van Duinkerken, dan treedt hij gewoon terug "zonder vermageringen en zelfmoord-aankondigingen. ${ }^{.1}$ Als ze vier jaar na deze brief trouwen zal Gerda's leven, naast de zorg voor de kinderen, toch vooral in dienst van Coolens werk komen te staan.

In het meer autobiografische werk van Coolen, zoals Bevrijd Vaderland en Tsjechische Suite, komt Gerda nauwelijks voor. Alleen in Uit het kleine rijk eert hij haar door op te sommen wat zij allemaal voor de kinderen doet, waarbij hij zijn eigen activiteiten slechts kinderspel noemt. ${ }^{2}$ In Bevrijd Vaderland merkt de lezer even door de opmerking van zijn zoontje, dat Coolen met zijn vrouw gepraat heeft over de Kultuurkamer. Tijdens zijn onderduik ontmoet hij zijn kinderen in Vught, maar uit niets blijkt zijn betrokkenheid bij zijn vrouw. In Tsjechische Suite beschrijft hij allerlei avonturen en ook weer angsten over zijn jongens.

1 BA, brief Coolen aan Van Duinkerken, 30 december 1925.

2. Coolen, Uit het kleine rijk, 54 . 
Wederom blijkt uit geen enkele passage dat zijn vrouw hem ook vergezelde. Misschien wil hij zijn vrouw afschermen van de buitenwereld. Zijn genegenheid voor zijn kinderen en vrienden blinkt echter wél overal doorheen. Coolen heeft in zijn literaire werk getoond juist zo'n grote gave voor de beschrijving daarvan te hebben. In zijn werk is zijn vrouw de grote afwezige.

\section{Een literaire bekentenis}

Als Bomans Coolen in De Pauwhof ontmoet, ziet hij duidelijk dat er iets met hem aan de hand is. Hij interpreteert Coolens gedrag echter verkeerd. Coolen worstelt nog met een ander probleem dan het voltooien van de kopij voor De grote voltige. Enkele weken na dit etentje met Bomans schrijft Coolen vanuit De Pauwhof een bekentenis aan zijn vriend Oomes:

"Er is geen reden om jou te verhelen, dat er ook iets anders toe meewerkt, en sterk, een vrouwelijke invloed, wees gerust, intéger, maar mooi, móói. Verklaar de behoefte eraan uit de confessionele ondertoon in de figuur van Jonkergauw [personage uit De grote vol. tige, C.S.] uit het gedeelte van het boek, dat je in typoscript las. Mijn lieve vriend, ik moet voortdurend denken aan wat je me eens schreef wat wonder er in de gevoelens van de gerijpte leeftijd mogelijk is. Geloof me, het drenkt je wezen en daarmee je pen, het werk wordt om zo te zeggen roserood. Zinspeel er niet op in een brief, tenzij in een brief aan het Pauwhofadres op korte termijn."

Oomes heeft hier met begrip op gereageerd, want enkele weken later dankt Coolen hem voor zijn meeleven en zingt weer de lof van zijn geheime vriendin: "Ze is me zo genegen, zo warm, zo vol begrip en toegewijdheid, zo veel, zoals ik in DGV heb geschreven, van wat God bedoeld heeft toen hij de vrouw schiep, opdat de man niet alleen zou zijn. En over het integere stel ik je opnieuw gerust." ${ }^{n 4}$

In het najaar van 1957 blijft hij Oomes op de hoogte houden van zijn verhouding met deze Maria, soms ook aangeduid als M. Ze sukkelt met haar gezondheid en heeft al diverse operaties achter de rug. In oktober 1957 ligt ze weer in een ziekenhuis. Coolen bezoekt haar vaak tijdens zijn reizen voor lezingen. Enthousiast schrijft hij aan Oomes dat hij diens brief over De grote voltige aan Maria heeft laten lezen, die er zo "hartveroverend" op reageerde. $\mathrm{Zij}$ zal zeker zondag naar het radiopraatje van Oomes luisteren en woord voor woord in zich opnemen. En weer looft hij haar:

"Ze is vroom en bidt en vangt daarmee ook de andere moeilijkheden op, waarvoor wij geen uitkomst zien. Waarom dit alles, waarom aan de ene kant een voortdurende frustrering, altijd opnieuw gevoed, een leemte, leegte, bitterheid, eenzaam zijn, en aan de andere kant die overvolheid, grootte van hart, mildheid eindeloos begrip, harmonie en alle eenzaamheid voor immer verbannen." 5

Hij voegt er een citaat uit Pan van Knut Hamsun aan toe: "vraag het aan het stof van de weg, vraag het aan de schepen op zee, vraag het aan de raadselachtige God van het leven." Coolen citeert hier uit het gedeelte waarin de legende van het gevangen meisje in de toren wordt verteld. $\mathrm{Zij}$ is verliefd op degene die haar gevangen houdt. Ze weet niet waarom ze verliefd op hem is: "Vraag het de wind en de sterren, vraag het de God van het leven, want geen ander kent het antwoord. [...] Vraag het het stof op de weg en het vallende loof, vraag het de raadselachtige God van het leven; want geen ander kent het antwoord." Ook het 
'roserood' komt uit deze legende: "Een zalige rozerode herinnering vaart door mij heen als ik je gedenk, de herinnering is als een glimlach die over je wordt uitgestort."

Steeds waarschuwt Coolen ervoor dat Oomes in zijn antwoorden niet op dit onderwerp moet zinspelen. Hij is gewend uit de brieven van Oomes aan Gerda voor te lezen of er mededelingen uit te doen. Hij wil niet dat er ongewenste opmerkingen tussen zitten die uitleg nodig hebben.

Coolen verwijst in zijn brief aan Oomes zelf naar de "confessionele [bekennende, C.S.] ondertoon" in het personage Jonkergauw uit De grote voltige. Daarom is het geoorloofd voorzichtig een brug te slaan tussen Dichtung en Wahrheit. Een nadere beschouwing van de gesprekken bij de open haard tussen de jonker en Jonkergauw werpt een heel ander licht op zowel Coolens naoorlogse werk als zijn huwelijk. Het eerste gesprek neemt dertien pagina's in beslag, het tweede vijf.

In deze gesprekken doet Jonkergauw het voorkomen alsof hij zelf een heel harmonisch huwelijk heeft, maar dat hij een vriend heeft die het slechter heeft getroffen. "Eros schiet soms met gouden pijlen en soms met pijlen van lood." De jonker speelt de komedie mee, terwijl uit alles duidelijk is dat Jonkergauw zichzelf bedoelt met die vriend. Jonkergauw voelt zich na een glas wijn gauw op zijn gemak. De jonker zegt dat het gesprek van mannen onder een glas wijn tot de hoogtepunten van het leven behoort. De vreugde van de wijn doorgloeit je en makt je van binnen "roserood." Als de jonker over de spreuk uit de Koran spreekt, warin staat dat het paradijs op aarde in de boeken der wijzen ligt, in de armen van een vrouw en op de rug van een paard, voelt Tom Jonkergauw zich "roserood worden, de gelukkige echtgenoot, die hij was." Hij vertelt over zijn vriend uit zijn knapen- en jongemannentijd, waarmee hij vroeger heel vertrouwelijk was, maar die nu ergens in het noorden van het land woont. Deze is verkeerd getrouwd en Jonkergauw krijgt nu klaagbrieven van hem. De pijlen van lood hebben hem getroffen en hij heeft ervaren dat de vrouw niet altijd de liefelijke helft van het menselijk geslacht is. Die vriend zou jaloers zijn op de eenzame jonker, zegt Jonkergauw, want het alleen zijn zou hem redden van "een veel verschrikkelijker eenzaamheid, waaraan je met zijn tweetjes in een huis kunt lijden. ${ }^{n 8} \mathrm{Na}$ nog een paar glazen wijn besluit Jonkergauw die vriend eens een brief op poten te schrijven.

Op een late avond komt Jonkergauw voor een tweede gesprek. Onnodig verontschuldigt hij zich dat zijn vrouw, die vermoeid op bed ligt, er op aangedrongen heeft dat hij toch maar naar de jonker moet gaan. Tijdens het gesprek rinkelt tweemaal de telefoon. Beide keren snelt Jonkergauw er naar toe en zegt dat het zijn vrouw zal zijn. De eerste keer zegt hij dat ze zijn stem nog wilde horen, de tweede keer dat ze hem er aan herinnert dat hij de volgende dag vroeg op moet. "Ze was bang, dat hij er niet aan zou denken, zo bezorgd was ze voor hem." Ook nu doet de jonker net alsof hij niet in de gaten heeft dat er een knallende ruzie plaatsvindt en praat weer mee over de niet-bestaande verre vriend die weer een

3 LMDC, inv. nr. C 3485, brief Coolen (vanuit De Pauwhof) aan Oomes, 7 juni 1957.

4 LMDC, inv, nr. C 3485, brief Coolen (vanuit De Pauwhof) aan Oomes, 18 juni 1957.

5 LMDC, inv. nr, C 3485, Brief Coolen aan Oomes, 20 november 1957.

6 Hamsun, Pan, 136-138.

Coolen, De grote voltige, 81 .

8 Coolen, De grote voltige, 82. 
"Jobsbrief" heeft gestuurd. Jonkergauw tast in zijn zakken om er uit voor te lezen, maar zegt dat hij hem thuis heeft laten liggen.

Hij vertelt dat de toestand binnen het huwelijk van zijn vriend steeds erger is geworden: "die twee daar bezweken aan de tyrannie van hun samenzijn, en hun scènes waren verwoestend." ${ }^{-9}$ Ze konden niet uit elkaar, want "er waren kinderen uit die band, en die staan dan ontheemd, dat zijn dan de verplaatsten." Nogmaals herhaalt Jonkergauw dat de vrouw niet altijd de lieflijke helft van het menselijk geslacht is.

"Het was daar zo: zij aanvaardde om zo te zeggen alleen maar. Zij wachtte af. Zij eiste, zij kwam hem niet tegemoet. De eerste om te groeten? Liever sterven. Hij van zijn kant begreep haar moeilijkheid niet en schrompelde in,-misschien moest hij juist tegemoet gekomen worden. [...] Ze zei: kijk eens naar je ellendige gebreken, zó ben je! Ze zei niet: dit zijn je menselijke gebreken, maar zo ben je niet, je eigenlijke ik is zoveel beter en hoe kan het mij treffen. Zachtheid, tegemoetkomend geduld, een lachend ja, - zijn vriend dacht, dat God de vrouw zo bedoeld had, toen Hij haar schiep, opdat de man niet alleen zou zijn." 10

Zijn vriend is een man "die zich blijvend het kind herinnert, dat hij eenmaal was. Dat kan bedolven liggen onder de ene beroerdigheid na de andere, [...] hij geloofde, dat de vrouw dat sluimerend kind weer wekt, dat ze er om zo te zeggen de lijn van doortrekt. Ja dat was misschien een weke opvatting. Maar de mannen zijn net als vrouwen uit de vrouwenschoot geboren."

Aan het eind van het gesprek kijken de jonker en Jonkergauw naar de sterrenhemel en spreken over de onmetelijkheid van het heelal: "Zeg dat aan je vriend, zei de jonker, laat hem met die mateloze maat zijn huiselijk gekrakeel meten en inzien, hoe nietig het is."

Door deze verwijzing komen ook fragmenten uit De vrouw met de zes slapers in een ander licht te staan. De muzikale Cordewever vraagt zich af hoe het kan dat Haydn, ondanks zijn slechte huwelijk, zulke mooie muziek kon componeren over de liefde van Adam en Eva in Die Schöpfung. De verteller Coolen doet echter iets vergelijkbaars als hij in deze roman de liefde van het Maaskantse paar Govert en Evelien beschrijft. Hij laat hen naakt als Adam en Eva vrijen in een hooiopper. Govert zegt dat zij een 'Te Deum' waard is maar hij zingt 'Het lied van den boer'.

Het 'roserood' komt ook voor in de aankondiging van de scheppingsdag van Adam en Eva. In de Engelse versie The Creation zegt Uriel:

"In rosy mantle appears, by music sweet awak'd,

The morning young and fair."

De warmte en toegewijdheid, die God bedoeld zou hebben toen hij de vrouw schiep, is aldus verwoord in The Creation:

"With fondness leans upon his breast

The partner for him form'd,

A woman, fair and graceful spouse.

Her softly-smiling virgin looks,

Of flow'ry spring the mirror.

Bespeak him love, and joy, and bliss."

We zullen zien dat ook in Stad aan de Maas, Coolens laatste roman, het gegeven van een 
muzikale man met een slecht huwelijk terug komt in het personage van Caspar Teleman.

De personages Cordewever, Jonkergauw en Teleman zijn alle drie van de leeftijd van hun schepper. Ze zijn niet gelukkig. Cordewever en Teleman zoeken troost in het verleden of de muziek. Jonkergauw krijgt na een van zijn nachtelijke gesprekken met de jonker een verdacht ongeluk.

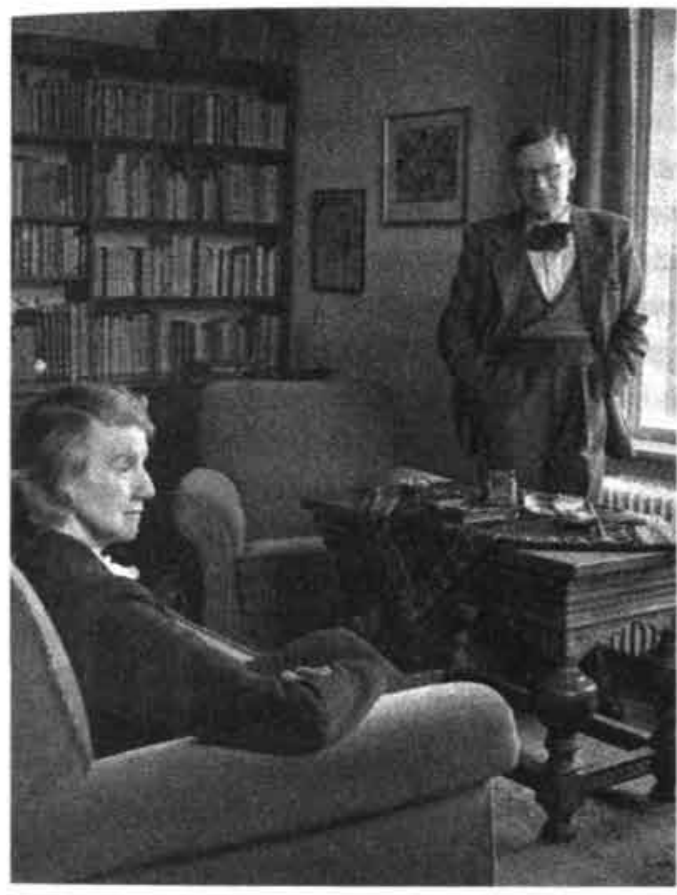

Coolen en zijn vrouw in hun nieuwe huis.
Coolen speelt met al deze romanfiguren een literair spel. Zo zitten kanten van hemzelf in zowel de jonker als in Jonkergauw. In Jonkergauw zijn echter ook weer kenmerken te vinden van de zwierige fabrikantenzoon Frans van Dijk. Het dichtst bij Coolen komt het personage Cordewever uit zijn vorige roman De vrouw met de zes slapers. Bij de Coolens komen geen ruzies met knallende deuren en gebalde vuisten voor. De manier waarop hij de situatie van het echtpaar Cordewever beschrijft, zal niet veel verschillen van zijn eigen huwelijk in die jaren: "Zo stonden die twee mensen daar met dat bewoond huis vol eenzaamheid tussen hun beiden in."

\section{Het onbekende meisje}

Nog steeds blijft de laatste fase van de oorlog in Coolens fantasie een rol spelen. In 1958 verschijnt voor de derde maal een verhaal van zijn hand waarvan een ontmoeting in oorlogstijd de kern vormt. In 'Het onbekende meisje'12 vertelt de jurist Beeke aan de ik-figuur een verhaal uit het verzet, dat tevens een liefdesverhaal is.

Beeke komt in het verzet in contact met een zekere Jean Jacques, een klein, lelijk mannetje met mooie, intelligente ogen. De laatste is niet uit liefde tot het vaderland in het verzet gegaan, want het vaderland zat hem tot hier. Hij vindt echter dat je het aan je menselijke waardigheid verplicht bent om degene, die je woning binnendringt en daar als een beest te keer gaat, te verstaan te geven dat je daar niet van gediend bent. Bovendien haat hij de 'nazi-Duitser' als de pest.

Als hij een keer samen met Beeke wapens aan het begraven is, worden ze gestoord door

9 Coolen, De grote voltige, 187.

10 Coolen, De grote voltige, 187-188.

11 Coolen, De grote voltige, 190.

12 Coolen, 'Het onbekende meisje', 63-67. 
een patrouillerende Duitser. Jean Jacques schiet hem dood. In zijn portefeuille vinden ze een foto van zijn vrouw en kind. 's Avonds in de schuilhut blijkt dat Jean Jacques graag in een illusie leeft. Hij heeft lege sigarettendozen van dure importmerken bewaard en schenkt water in mooie geslepen borrelglazen; niet om er van te drinken maar om ernaar te kijken. Zijn grootste illusie komt voort uit zijn correspondentie met een meisje, Mariette, dat hij nooit gezien heeft. De briefwisseling is gestart nadat Jean Jacques iets voor haar ouders had gedaan. Beeke mag de brieven lezen en ziet dat het echte liefdesbrieven zijn. Nu dreigt de illusie van het "dwaas avontuur" verstoord te worden, want ze zijn "het hellend vlak afgegleden naar onze ontmoeting." Jean Jacques wil niet dat zij hem ziet van. wege zijn lelijkheid, maar hij wil haar ook niet zien om zijn illusie te behouden, want "ik zou het haar niet vergeven als zij lelijk was."

De knappe Beeke moet hem vervangen bij de afgesproken ontmoeting in een restaurant. Bij binnenkomst komt een gedrongen lelijke vrouw op hem af die zo gauw ze praat en lacht, een prettig gezicht krijgt. Zij is Mariette niet, maar haar vriendin Suze. Mariette zit verderop aan een ander tafeltje. Zij is een heel knap meisje. Suze stelt ze aan elkaar voot en laat hen na korte tijd alleen. Tijdens het eten blijkt dat niet Mariette, maar Suze de briefschrijfster is. Suze heeft alleen Mariettes naam geleend. Het is dus een gesprek van twee 'vervangers'. Ze besluiten zowel Suze als Jean Jacques in de waan te laten. Mariette geeft echter geen foto mee. Die krijgt Jean Jacques wel te zien "als het daartoe tijd is," zegt ze.

Jean Jacques leeft helemaal op bij het relaas van Beeke. De ontknoping van het verhaal is de dood. Suze komt om in een vrouwenkamp. Mariette wordt op straat doodgeschoten na verraad. Verzetsmensen maken een foto van haar in haar met bloemen bedekte doods. kist. Jean Jacques krijgt deze foto. Niet lang daarna komt hij als tolk van de geallieerden in Duitsland om bij een verkeersongeluk. De foto van het meisje zat op het dashboard.

Nadat Beeke dit verhaal verteld heeft, klinkt op de radio een koor: 'Litanie pour les défunts'.

\section{Herinnering aan eigen onderduik}

In de novelle De ontmoeting uit 1947 en het verhaal 'Ontmoeting in Niemandsnacht' uit I954 zijn de ontmoetingen tussen de twee geliefden reëel. In dit verhaal is er slechts een ontmoeting van twee 'stand-ins'. Het motto 'ships that pass in the night' gebruikt Coolen nu niet, maar het zou op het derde verhaal nog meer van toepassing zijn. In dit verhaal, dat ongeveer in dezelfde tijd verschijnt als De grote voltige, zit nu wél een verwijzing naar de collaboratie van het bedrijfsleven. Jean Jacques neemt ontslag bij een staalconstructiefabriek die voor de Duitsers werkt en gaat in het verzet ondánks het vaderland, "waarin straks de onverbeterlijke kooplieden, die nationale heffe, niet om onzen strijd, niet om ons bloed, noch om den geest, doch slechts om hun handel bekommerd zouden zijn. ${ }^{\text {is }}$

Een opvallend detail is de koppeling van het beeld van een dood meisje aan dat van bloemen. In De ontmoeting wiegt een bloem naast het gezicht van het neergeschoten meisje op het talud van een spoorbaan. In dit latere verhaal worden de dood en bloemen ook in één beeld gevangen: "Zij is als een vlam, zei Jean Jacques, neen, als een lelie tegen het vuile, Duitse grauw dat haar doodde. ${ }^{.14}$

Coolen heeft in mei r 944 zijn huis moeten verlaten en heeft daarna tot Dolle Dinsdag, 5 september, door Nederland gezworven en op verschillende adressen ondergedoken gezt 
ten. Ondertussen zijn handlangers van de vijand zijn woning binnengedrongen en daar "als een beest tekeer gegaan." Wat Jean-jacques in overdrachtelijke zin over het vaderland zegt, is bij Coolen persoonlijk gebeurd. Coolen heeft in die onderduiktijd in artistieke en intellectuele kringen vertoefd. De vluchtigheid en losheid van de contacten in een tijd van spanning en de vele ontmoetingen brengen een sfeer teweeg die erotiserend kan werken. Het is zeer wel aan te nemen dat hij zelf een ervaring heeft gehad die moeilijk uitwisbaar is. De aanwezigheid, in een heel andere sfeer, van vrouwen, koeriersters, studentes en verpleegsters kan hem geconfronteerd hebben met verleidingen. Zijn positie als bekende schrijver, huisvader en katholiek maken het echter bijna onmogelijk om daar op in te gaan. Het zou een verklaring kunnen zijn voor het steeds terugkerende motief van schepen die elkaar in de nacht passeren.

Waarschijnlijk doelt zijn vriend De Bourbon hierop als hij, in 1957, na het echtpaar Coolen als eenheid te hebben geprezen, wijst op moeilijkheden: "Dat je zelf, in elke, ook de moeilijkste, episode van je leven, de hemel weet tegen welke declinerende krachten in, aan die eenheid onwrikbaar bent blijven hechten, behoort, voor mijn gevoel, tot de schoonste aspecten van je rijke, sterk-gedifferentieerde en daarom zo boeiende persoonlijkheid." ${ }^{15}$

Een ander motief in dit verhaal is de illusie. Jean Jacques koestert zijn illusie, die hij meer acht dan de werkelijkheid, "zoals hij het gedicht meer achtte dan het woord, den klank meer dan de snaar." ${ }^{16}$

Coolen herinnert zich de illusies die hij in de oorlog in zijn 'oase' heeft gekoesterd. Het was zijn manier om de nare werkelijkheid minder te hoeven voelen. Nu vlucht hij daar weer in. Hij zoekt eerder de oase van zijn geest dan de intimiteit van zijn huwelijk.

\section{Verfilming van Dorp aan de rivier}

Coolen heeft in april 1958 een kijkje genomen bij de opnames voor de verfilming van Dorp aan de rivier. Hij is slechts zijdelings betrokken bij de film waarvoor Hugo Claus het scenario schrijft. Coolen maakt zich zorgen over de uitbeelding van zijn karakters. Op zijn verjaardag schrijft hij een uitgebreide brief aan regisseur Fons Rademakers. ${ }^{7}$ De invulling die acteur Max Croiset aan de rol van Van Taeke geeft, bevalt hem niet. Hij betreurt het dat ze daar met zijn drieën niet over gepraat hebben. Wat hij mist in de Van Taeke die Croiset neerzet, is de "raadselachtigheid en mannelijke hooghartigheid." Er zit, volgens Coolen, in het personage Van Taeke ook iets hards: tegenover de tendresse is er een sadisme, een kwelzucht, die bij hem iets superieurs krijgt als bij een wraakgod. Aan zijn uitgever schrijft Coolen echter dat hij, ondanks zijn bedenkingen, wel het vertrouwen heeft dat het een goede film wordt: "Ik zag ook enige stukjes film van de opnamen tevoren, en vond die wel goed. ${ }^{-18}$

13 Coolen, 'Het onbekende meisje', 64.

14 Coolen, 'Het onbekende meisje', 76.

15 De Bourbon, 'Antoon Coolen 60 jaar', 642.

16 Coolen, 'Het onbekende meisje', 76.

17 FPC, brief Coolen aan Fons Rademakers, 17 april 1958.

18 LMDC, inv. nr. C 3485, brief Coolen aan Laurens van der Waals, 20 mei 1958. 
Op 18 september $195^{8}$ gaat het regisseursdebuut van Fons Rademakers in première, ${ }^{19} \mathrm{De}$ hoofdrollen worden gespeeld door Max Croiset als Tjerk van Taeke, Mary Dresselhuys als zijn vrouw en Bernard Droog als Cis den Dove. Coolen deelt zijdelings in de hulde. "Bij die huldiging vond ik het aardig, niet zo in het zonnetje te komen. De anderen hadden de film gemaakt, niet ik," schrijft hij anderhalve week later aan zijn uitgever. Hij heeft er wel spijt van dat hij er zich niet meer mee bemoeid heeft. "Ik was een keer in de studio, maar hield mij terug in het vertrouwen, dat de leek in de vakman stelt, niet vermoedend, dat ze met adviezen te helpen waren geweest." De film had volgens hem wel goede en fraaie beelden, maar het brokkelige zou te voorkomen zijn geweest "door meer de lijn van het boek te volgen en door de Maas meer mee te laten spelen. Ook waren nu onbegrijpelijke scènes naar mijn gevoel gemakkelijk begrijpelijk te maken geweest." ${ }^{20}$ De gemiste kansen bij de verfil. ming blijven hem nog lang dwars zitten: "Was nu maar de overtocht over de ijsgang van de Maas het dramatisch hoogtepunt. Maar dat is feitelijk veel te slap studiowerk en het ging me zeer aan 't hart, dat je in de hele scène de Maas niet te zien krijgt, laat staan enige ijsgang. Met een werkelijk kruiende Maas was hier iets groots te bereiken geweest." ${ }^{\text {"I }}$

Zijn oordeel is echter niet helemaal negatief: "De film Dorp aan de rivier was te fragmentarisch en te eenzijdig in het karakter van de dokter, waarvan de harde tegenkant te veel was weggelaten. Maar overigens had zij toch veel sfeer en een reeks bijzonder sterke beelden, die naar mijn mening veel waardering verdienen." ${ }^{n 2}$

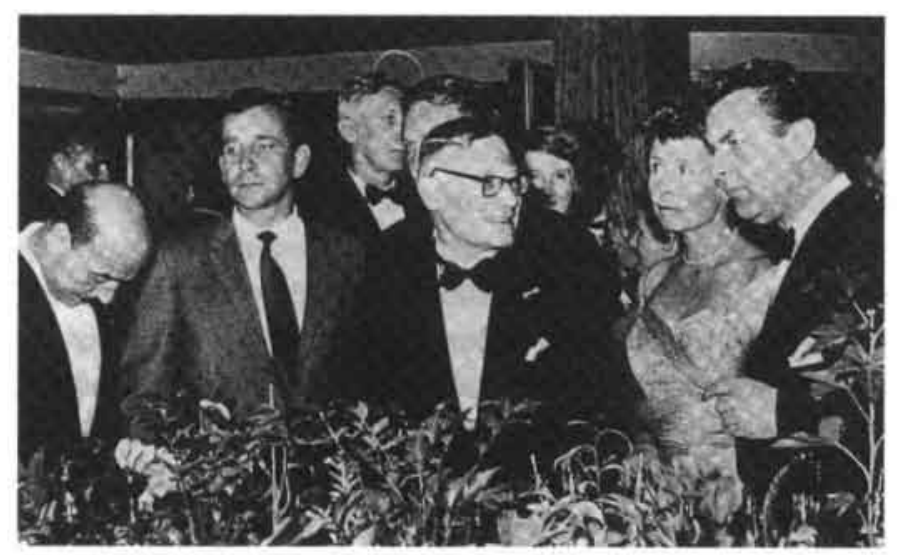

Bij de première van de film Dorp aan de rivier. Vooraan van links naar rechts: Jan Teulings, Jan de Hartog, Antoon Coolen en boven zijn schouder zijn vrouw Gerda, Mary Dresselhuys en regisseur Fons Rademakers.

De kritieken in de Nederlandse pers zijn niet zo enthousiast. De film is niet lang na de première uit de roulatie genomen en daarna opnieuw uitgebracht met een verbindend commentaar, waarin de voice-over van een verteller de anekdotes aan elkaar praat. In het buitenland wordt Dorp aan de rivier een groot succes. ${ }^{23} \mathrm{Hij}$ wordt geselecteerd voor het filmfestival in Berlijn, waar hij met veel succes wordt vertoond. Ook in Zwitserland wordt hij goed ontvangen. De film krijgt later in Amerika de Golden Globe Award en een Oscarnominatie voor de beste buitenlandse speelfilm. 


\section{Research aan de Maas}

In de jaren 1958 en 1959 werkt Coolen tussen al zijn andere activiteiten door aan onderzoek en materiaalverzameling voor een nieuwe roman die weer aan de Maas zal spelen. Hij kan niet aan 'een leeg bureau' werken, want voortdurend wordt er een beroep op hem gedaan voor lezingen, artikelen en bijdragen. In zijn brieven klaagt Coolen daar wel aanhoudend over, maar het lijkt er toch veel op dat hij zichzelf daar zeer geschikt voor acht. Als deze aanvragen naar anderen zouden gaan, zou hij zich eerder gepasseerd voelen dan opgelucht.

Af en toe is er ook een zeer welkome onderbreking. Kort na de première van de film eert de stad Eindhoven Coolen met de Cultuurprijs r 958 voor zijn roman De grote voltige. "Ze hebben er op het stadhuis meer dan een formaliteit van hadden gemaakt," schrijft hij aan Van Duinkerken, "de burgemeester slaagde er in de uitreiking van de prijs tot iets anders te maken dan een 'ambtelijk uitvoeren van een besluit." Coolen is erg blij met het bedrag van 2500 gulden dat aan de prijs verbonden is, want dat is "meer dan het dubbele van die van de provincie en niet ver beneden het bedrag van de staatsprijs, naar de royale kant. Men heeft dat in Eindhoven niet klein gezien." ${ }^{24}$ Zijn tijd blijft versnipperd en hij klaagt:

"Er staat weer zoveel op het programma: De Kogge, de Poorters van Woudrichem, de Muiderkring, het Provinciaal Genootschap, allemaal vlak bij elkaar, en dan nog Nederland in den Vreemde, Kempische Cultuurdagen. Al dit soort dingen legt zoveel beslag op je, dat je van het een in het ander valt wat je allemaal van het werk afleidt, en de voorzomerdagen zijn voor mij gewoonlijk het gunstigst. ${ }^{\text {"25 }}$

Het werk aan de nieuwe roman vordert dus traag. Al in het voorjaar van 1958 heeft hij aan zijn uitgever geschreven: "Er is nog geen voortgang met Stadje aan de Maas. [...] Maar ik houd me toch gereed, om althans eens een tijdje naar Grave te gaan en te zien, of de atmosfeer de stof glans verleent en wat er nog meer voor den dag komt dan men mij heeft verteld., ${ }^{26}$

Coolen heeft geruime tijd daarvoor in Het nieuwe Brabant (1952) met bezieling geschreven over de Maaskant en de vestingstadjes. In 1958 is hij lid geworden van de Vrije Poorters van het vestingstadje Woudrichem. Na een rondleiding heeft hij in Brabantia een artikel over het verval en het isolement van deze vestingstadjes geschreven. ${ }^{27}$

In Grave wordt Coolen rondgeleid door de journalist Wouters, chroniqueur van de Graafse samenleving en kenner van de plaatselijke historie. ${ }^{28}$ Deze vertelt hem veel over de belegeringen die de stad gekend heeft en het belang van de bocht in de straten, zodat er geen schootsveld voor de aanvallers was. Evenals in Dorp aan de rivier zal ook in Stad aan de

19 Camera Eddy van den Enden, muziek Jurriaan Andriesen. Een productie van NV Nationale Filmproductiemaatschappij Utrecht. De buitenopnamen werden op locatie in Lith en omgeving gemaakt.

20 LMDC, inv, nr. C 3485, brief Coolen aan Laurens van der Waals, 29 september 1958.

21. FPC, brief Coolen aan Johan Fabricius, 27 december 1959

22 FPC, brief Coolen aan P. Braun, 16 maart 1959.

23 'Grave gezien door een temperament'; Van Vliet, 'Nawoord', 238.

24 BA, brief Coolen aan Van Duinkerken, 5 november 1958.

25 LMDC, inv. nr. C 3485, brief Coolen aan Oomes, 11 mei 1959.

26 LMDC, inv. nr. C 3485, brief Coolen aan Laurens van der Waals, 20 mei 1958.

27 Coolen, 'Nieuw leven in een oud stadje', 53-60. 
Maas een belangrijke rol voor een arts zijn weggelegd en wederom wil hij zijn fantasie laten prikkelen door de verhalen uit de praktijk. Met dit doel bezoekt hij de 77.jarige huisarts in ruste A.J. Kanters. Hij neemt de gesprekken op met een bandrecorder.

Het bijzondere aan het stadje is de veelheid aan instituten die er gevestigd zijn: een rijkspsychiatrische inrichting en twee blindeninstituten [Coolen las enige van zijn romans en novellen in op geluidsbanden van het blindeninstituut, C.S.]. Bovendien is er een garnizoen geweest. De inwoners van Grave mogen daar zelf graag mee spotten in het gezegde: 'De wijzen leven hier van de gekken, de zienden van de blinden en de vredelievenden van de oorlogszuchtigen.' Ze kunnen echter niet goed hebben als anderen dat constateren of schrijven. ${ }^{29}$

Een jaar later, in het voorjaar van 1959 , is Coolen nog steeds bezig met voorbereidend onderzoek. "Ik ben de laatste tijd veel in Grave. Ik was eergisteren met een Maasvisser op diens schokkertje bij het uitzetten van angelrepen voor de palingvangst. Ik bereid een nieuw boek voor over deze streek. Maar het zit nog niet in elkaar." ${ }^{30}$ Nog in juni 1960 is hij aan het schaven: "Zelf ben ik op het ogenblik druk bezig met dat Maasstadje, nieuwsgierig, hoe het schrappen, verscheuren en opnieuw beginnen uiteindelijk worden zal., ${ }^{31}$

\section{Stad aan de Maas}

"Daar lag de oude vestingstad aan de Maas; de voorbije eeuwen sluimerden binnen wat er van haar omwalling nog was overgebleven. [...] Uit de ene oneindigheid gekomen stroomde de brede rivier langs dat menselijk leven en bedrijven naar de andere oneindigheid, groots en standvastig." ${ }^{32}$

De lezer krijgt via een rondleiding van stadsarchivaris Jerome Krielers, vrijgezel en historicus, een indruk van het stadje en sommige bewoners. Winkelierster Hermine Bexkens van textielzaak De Rijzende Zon is na haar veertigste met de Duitser Kurt Weber getrouwd. $\mathrm{Hij}$ is volgens zijn zeggen in de oorlog gedeserteerd en kan niet terug naar Duitsland. Het modehuis Dufrontin is van een rijke en gierige familie. De zestigjarige directeur van de bank, Caspar Teleman, een zeer muzikaal man, heeft een ongelukkig huwelijk.

Het stadje heeft ook een achterbuurt, het Quartier Latin. Hier wonen de bezembinder Douxdieu en zijn levenslustige vrouw Moelke met hun drie dochters. Moelke "moederde stevig over haar drie dochters; - haar zorg was, de meisjes te vermanen, dat ze geen voorbeeld moesten nemen aan die vent van niks, die hun vader was." ${ }^{335}$ De actiegroep Stadsbelang staat op de bres voor het behoud van het monumentale karakter van het stadje. De stad had vroeger een garnizoen. Toen dat in 1890 werd opgeheven werden de kazernes gebruikt als psychopateninrichting voor vrouwelijke patiënten. Deze zouden hier werken en in de gezinnen worden verpleegd. Er zijn ook nog twee blindengestichten, zodat men in de stad spreekt van onze psychopaatjes en onze blindjes, zoals vroeger over onze soldaatjes. In het stadje wordt veel aan muziek gedaan, niet in het minst door de blinden. $\mathrm{Bij}$ het twaalf-en-een-halfjarig bestaan van de varkensverzekeringsvereniging Sint Antonius Abt wordt een culturele daad gesteld: de opvoering van De barbier van Sevilla van Rossini onder muzikale leiding van Caspar Teleman, met in de hoofdrol "Germanje's fors gespierde telg" Kurt Weber.

Het stadje kent, naast de gestoorde vrouwen van het gesticht, ook zijn eigen dorpsgekken. De postbode die op de meest onverwachte momenten het woord 'boezem' uitspreekt, 
en de koster die niet goed kan hebben dat Teleman overdag op het orgel speelt, zijn ook niet helemaal in orde. De laatste geeft wel eens de zegen aan de vroegkomers in de mis en probeert soms illegaal biecht te horen. Na een ruzie met de deken werpt hij zich van het kerkdak, maar hij wordt gered doordat hij is blijven haken aan zijn broek.

Appi Gottlieb die met zijn paarden rouw en trouw rijdt, verheugt zich op elke begrafenis. Hij praat tegen zijn paarden Noortje en Kees: "Vandaag geen bruidje. Maar een dode, zei Appi. [... Jullie weten er alles van. Geen trippelpasjes op hoge benen. Maar de treurmars van Chopin." ${ }^{34}$ Appi gaat nooit mee de kerk in, maar drinkt een paar borrels in het café ernaast. "Van dat rust zacht op planken en harde grond en in een kistje van benauwen onder de aarde had hij nooit veel begrepen." Na de Mis begint het pas echt: "Nou kwam het fijnste, de langzame rit naar het kerkhof, waarvoor er zo heerlijk tijd was tussen de straatjes, tussen de mensen, die stil waren voor hun deur." Hij ziet de neringdoenden op de stoepen staan: "Goededag, nuttige leden van de maatschappij, dacht Appi, en de groeten van de dode." Hij heeft altijd "dat gevoel van een optocht, hij voorop met de praalwagen van de dood." Hij ziet de gierige Dufrontin en denkt al aan diens rouwbrief en "aan de mis met drie heren, de halve kerk in het zwart en een palfrenier naast mij." Dufrontin gunt zichzelf geen borrel, maar Appi wel: "En hoe lekker is een borrel in de morgen, en wat een weertje, wat een aller Godsgezegendst begrafenis-weertje!"35

In een van de huisjes in de nauwe straatjes ligt Rosemarietje. Ze is zestien jaar en spastisch. Ze heeft een waterhoofd en de geestelijke ontwikkeling van een kind van zes. Sedert enige tijd heeft ze ook "de maandelijkse verschijnselen van haar leeftijd," maar die zijn nu al enkele maanden weggebleven. Het kind blijkt zwanger gemaakt door haar broer. Dokter Meerdink denkt aan "de raadselachtigste dingen van het trieste menselijke bedrijven, dat hij met meewarigheid gadesloeg" in sloppen en stegen, maar ook in de afgelegen boerenhoeven. Samen met een bevriende arts verlost hij het meisje later in het gasthuis van de Zusters van Onze Lieve Vrouw van Altijddurende Bijstand via de keizersnede. Het

28 Informatie van zijn zoon Frans Wouters, in: KRO-gids Studio, 3 maart 1990. Rond 1990 was er veel aandacht voor het boek Stad aan de Maas in verband met de televisieserie De Brug. De serie, die losjes gebaseerd was op onder andere deze roman van Coolen, veroorzaakte een rel. Enkele Brabanders, onder wie Carel Swinkels, vonden dat het resultaat niets met het werk van Coolen te maken had. Swinkels, Help me de brug over?

29 Interview Frans Wouters, in: Studio, 3 maart 1990.

30 Archief Hendrik Wiegersma, brief Coolen aan Hendrik Wiegersma, 29 april 1959. In de roman wordt de palingvangst beschreven in aanwezigheid van Jentje de zouaaf, die de Maas toch boven de Tiber verkiest en die de goede vangst toeschrijt aan het feit dat hij, als zouaf van de Paus aan boord is. Coolen, Stad aan de Maas, 92-100.

31 LMDC, inv. nr. C 3485, brief Coolen aan Theun de Vries, 8 juni 1960. Nu pas stuurt Coolen hem, via de uitgever, Tsjechische Suite dat hij hem al in 1948 beloofd had. Ook nu weer stipt Coolen hun verschil in politieke richting en maatschappijvisie aan. Hij denkt dat ze het op veel punten oneens blijven, maar dat vooral het hoofdstuk over Lidice "ontmoetingspunten" tussen hun beiden zal geven. Hij is benieuwd naar het nieuwe boek van de Vries: Het motet voor de kardinaal.

32 Coolen, Stad aan de Maas, 8.

33 Coolen, Stad aan de Maas, 25.

34 Coolen, Stad aan de Maas, 68.

35 Coolen, Stad aan de Maas, 72-73. 
kind blijkt gezond en wordt door een kinderloos echtpaar geadopteerd.

Terwijl de bouw aan de brug over de Maas doorgaat, verandert er veel in het stadje. De man van Moelke Douxdieu blijkt een geslachtsziekte te hebben en komt in een invalidenwagentje terecht. Dit verhindert Moelke niet er voor te zorgen dat een van haar dochters een prachtige bruiloft heeft. $\mathrm{Al}$ is haar dochter dan niet "in de klare zij," ze heeft wel een lichtblauwe jurk van crêpe chiffon. Moelke zelf draagt "iets donker effens, wat stond bij haar figuur." De feesttafel is rijker gedekt dan ooit het geval is geweest bij de rijke Dufrontins, waar Moelke's dochter Sjaantje meid is.

De gevierde Kurt Weber pleegt overspel. Na de dood van zijn vrouw blijkt zelfs dat hij bigamist was. Bij de begrafenis van Webers vrouw wordt Appi voor het eerst niet ingeschakeld: er komt een begrafenisondernemer uit Nijmegen. De postbode Sjamot verdrinkt in de Maas, maar zijn lijk wordt niet gevonden. Als er een uitvaartdienst wordt gehouden staat Appi op de markt te kijken. Hij is op het geluid van de rouwklok afgekomen. De weduwe had hem beloofd dat hij de begrafenis zou hebben gehad, maar er is nu niets te vervoeren. Appi hangt zich op in het koetshuis. Zijn vrouw vindt hem met "de hals geknakt, zijn kin op de trui, de armen slap, onder de opgeschoven broekspijpen de afgezakte sokken, de voeten in de vetleren schoenen naar elkaar gekeerd." In zijn broeksband zit een briefje met de tekst: "Dierbare vrouw, vaarwel. Mijn laatste wil is met [de paarden, C.S.] Noortje en Kees naar het kerkhof te worden gereden." ${ }^{36}$ Dit is volgens de verteller ook de reden dat hij niet voor de "zachtere dood" in de Maas heeft gekozen. Appi wilde niet het lot delen van Sjamot en nooit gevonden worden.

Als de nieuwe brug geopend wordt door de minister is het feest in het stadje. Dokter Meerdink wandelt er rond met de pleegouders van het geadopteerde kindje, dat al kan lopen. Het meisje maakt zich even los en loopt een steegje in. "Moeder, daar ligt een ziek kindje," zegt ze bij terugkomst. Zij noch haar adoptiemoeder beseffen dat ze zojuist haar natuurlijke moeder heeft gezien. Ze lopen verder en luisteren naar Händels Halleluja dat door de verzamelde koren en het blindenorkest wordt uitgevoerd. De dokter denkt aan de onvruchtbaarheid van de pleegmoeder "en aan het verband tussen het een en het ander, de schadeloosstelling, die ze kreeg in dit mooie kind, dat voortgekomen was uit een zijsteeg van het raadselachtige leven."

\section{Coolenstad}

Met een motto van Pascal heeft Coolen de universaliteit van deze roman willen aangeven: "Le monde entier est notre ville, mais nous sommes particulièrement citoyens de la ville où nous habitons." Het stadje is bevolkt met echte Coolenpersonages. Dit keer is de stads. archivaris, vrijgezel, historicus en rondleider Jerome Krielers de gids voor de lezer. Alle pedanterie en schijngeleerdheid van de onderwijzers en briefkaartschrijvers uit eerdere romans keren terug in dit personage. De gierigheid wordt nu in beeld gebracht via de middenstandsfamilie Dufrontin, die scherp wordt getekend door de ogen van hun meid Sjaantje, de dochter van Moelke. Haar middageten krijgt ze op een bordje. Het bestaat uit drie boterhammen, twee met iets en een met niets. Sjaantje krijgt in de keuken een inval waar haar hart van bonst. Ze ziet het gezicht van haar levenslustige moeder voor zich en loopt terug naar de eetkamer van het gezin en vraagt: "Welke van mijn boterhammen is die met iets?" 
had hen in bezit. ${ }^{\text {"38 }}$ Later zegt dokter Meerdink tegen Dufrontin: "Laat je niet door je geld bezitten. Bezit zelf je geld!"m9

Zoals in De vrouw met de zes slapers speelt ook nu weer muziek een belangrijke rol. "De liefde voor de muziek was in het stadje een ieder aangeboren. ${ }^{\text {"40 }}$ De stadskoren hebben aan stemmenmateriaal geen gebrek. De blinden hebben hun eigen symfonieorkest dat Eine kleine Nachtmusik van Mozart speelt, en de stadsbewoners hun fanfare met Dichter und Bauer op het repertoire. De opvoering van opera's en oratoria vormt steeds de achtergrond van het verhaal. Als Jerome Krielers over de kerken vertelt die afwisselend in Spaanse of Staatse handen zijn geweest, dan illustreert hij dat aan de hand van de gezangen: "het 'Te Deum' en 'Een vaste burg'; om beurten." In het Quartier Latin klinkt de serenade van Tosselli op accordeon en op het volgende stadsfeest worden na het succes van Figaro de twee korte opera's Paljas en Cavalleria Rusticana opgevoerd. Bij de opening van de brug wordt een kreupel feestlied gezongen op de wijze van 'Waar in 't bronsgroen eikenhout': "Waar de uiterwaarden mals/ Van de vruchtbre weit/ Welig langs de groene Maas/ Liggen uitgespreid." In het lied is ook nog sprake van een stoomgemaal. De tekstdichter heeft zich daar een dichterlijke vrijheid veroorloofd, "omdat het woord elektrisch niet in de maat van de zangregel was te vangen. ${ }^{.41}$

Veel personages in Stad aan de Maas zijn herkenbaar uit vorig werk. Moelke Douxdieu met haar drie dochters en haar slappe, diefachtige echtgenoot lijkt op Mammeke uit Dorp aan de Rivier. Alleen zijn nu de rollen omgekeerd: droeg Mammeke een theedoek over haar hoofd om de gevolgen van de syfilis te verbergen, nu is het de overspelige echtgenoot die de lasten draagt. De levenslustige, hedonistische kant heeft Moelke gemeen met Vuil Leenke uit Peelwerkers. Als haar man in het ziekenhuis ligt praat zij heel hartelijk met het bezoek van de andere patiënt op de kamer over haar dochters, "drie bloeiende blommen." Ze spreekt de andere zieke en zijn bezoek moed in en troost hen. Als deze op hun beurt zeggen dat ze hopen dat Douxdieu ook vlug naar huis mag, doet ze net alsof ze het niet hoort. Bij het afscheid zegt ze alleen maar tegen hem: "Nou dan ga ik maar! Het beste."

In de oude zouaaf herkennen we Brammetje Peccator, maar hij heet nu Jentje van Wiechem. De Paus heeft tegen hem gezegd dat de Hollanders ijzervreters zijn, want daar in Rome denken ze dat het hier allemaal Holland heet. In de "biechtspiegel" die de soldaten hadden, stond dat zij niet mochten kijken naar "gevaarlijke voorwerpen," waarmee volgens hem de vurige Italiaanse meisjes bedoeld werden. Hij zou Moelke wel eens bij de Paus willen zien, zegt hij tegen de visser Willem, maar een vrouw bij de Paus, dat betekent een

36 Coolen, Stad aan de Maas, 253. Zie ook: FPC, briefje zonder datum van nonkel Fik van Stijn Streuvels, die als testament één papiertje achterliet: "Ik wil begraven worden met een dienst te negen en een half (overigens natuurlijk dood)."

37 Coolen, Stad aan de Maas, 109.

38 Coolen, Stad aan de Maas, 42.

39 Coolen, Stad aan de Maas, 224.

40 Vergelijk Vondels: "De liefde tot zijn land is ieder aangeboren." Met de verwijzing naar deze slotzin van de Gijsbregt lijkt Coolen te willen zeggen dat het universele van de muziek het echte vaderland is.

41 Coolen, Stad aan de Maas, 270.

42 Coolen, Stad aan de Maas, 201. 
sluier voor het gezicht "en boven van voren alles weg." Dat zou moeilijk bij Moelke zijn, zegt de visser. In het personage Bardoel tenslotte is, evenals in De grote voltige, in deze roman een zoon aanwezig die waarschijnlijk zijn vader heeft vermoord.

Evenals in Dorp aan de rivier is nu een reis naar een bevalling een dramatisch hoogtepunt. De tocht van dokter Meerdink met zijn collega naar het ziekenhuis waar de keizersnede zal plaatsvinden, doet sterk denken aan de tocht van Van Taeke over het kruiend ijs van de Maas. Wel zijn de meteorologische omstandigheden in deze nieuwe roman vol. strekt anders: hier gaat het om een autotocht door een zwaar zomeronweer.

Opvallend is dat in dit geval de mogelijkheid van abortus zelfs niet genoemd wordt. De dokter zegt tegen de ouders van het ongelukkige meisje, de grootouders van het pasgeboren kind, dat hij een goed pleegezin heeft gevonden. Op de vraag wie de pleegouders zijn antwoordt hij dat het beter is dat ze dat niet weten, maar dat het heel lieve mensen zijn die goed voor hun kleindochtertje zullen zorgen. Hij drukt hen op het hart om even geduld te hebben en de zusters niet lastig te vallen, dan is hun dochter over enkele dagen weer thuis. Uit de geheimhouding voor buurt en zusters en door de verzuchting van een van de doktoren dat een wet op de adoptie hard nodig is, wordt duidelijk dat de hele affaire illegaal verlopen is. ${ }^{43}$

\section{Praalwagen van de dood}

Tegenover het nieuwe leven dat in een "zijsteeg van het raadselachtige leven" geboren wordt, staat de dood zeer centraal in het boek. In het voorjaar vinden spelende kinderen een dode pasgeborene in de stadsgracht, een gebeurtenis die in De vrouw met de zes slapers ook voorkomt, maar dan in de gracht van het kasteel. Heel dichterlijk beschrijft Coolen de schrik van de kinderen.

"De bladeren van de canadassen ruisten in de zachte wind, een wielewaal zweefde boven het onderhout. De kinderen keken hem na in zijn vlucht, toen staarden zij weer naar het lijkje. Zij stonden in de zonneschijn en de schaduw, die tussen de boomstammen en over het jonge lover speelden. Zij begonnen te fluisteren. ' $t$ Is dood, zeiden ze, ' $t$ is dood." ${ }^{\text {"4 }}$

Dokter Meerdink constateert dat het kind tegen het ochtendgloren geboren moet zijn:

"Toen moeten in de morgenwind de kreet van de barende en het eerste vergeefse kinder-

geschrei verloren geklonken hebben, zoals de roep van vogels, die in deze tijd met het

licht in het bos op zoek gaan naar bouwst of voor hun nest en voedsel voor hun jongen. ${ }^{-15}$ De dood is voortdurend aanwezig en de verbindende schakel daartussen is Appi Gottlieb, de koetsier voor rouw en trouw. De beschrijving is echter lang niet altijd somber, maar integendeel soms heel hilarisch. Sommigen die dood willen, zoals de koster die van het kerkdak springt, of die dood gewenst worden, zoals Douxdieu door zijn vrouw, gaan niet dood. Douxdieu sterft zelfs niet nadat hij is aangereden en evenmin later, als blijkt dat hij een geslachtsziekte heeft in een vergevorderde staat. Aan het eind van de roman duwt de koster met de zelfmoordneigingen zelfs het invalidenwagentje van Douxdieu.

Veel andere personages sterven wel. Sjamot, de postbode met zijn geheimzinnig uitgesproken woord 'boezem', verdrinkt bij het vissen. Het hiervoor genoemde pasgeboren kind wordt dood gevonden. Vader Bardoel valt van een trap of is vermoord. Een wethouder sterft en krijgt ondanks alle haat en nijd die hij heeft opgeroepen, toch een mooi bidprentje. Het 
overlijden van Hermine Bexkens, de bedrogen vrouw van "Germanjes fors gespierde telg" Kurt Weber, is ongewild de oorzaak van Appi Gottliebs zelfmoord. De beschrijving van Appi als hij zich verhangen heeft, doet sterk denken aan die van Corneliske Schoonewiel uit De Man met het Jan Klaassenspel. In beide gevallen wordt de schamelheid van het menselijk lichaam geschilderd: het geknakte hoofd, de dunne beentjes in de broekspijpen en de naar binnen gekeerde voeten.

Alleen Jentje van Wiechem, de meer dan negentigjarige zouaaf, lijkt onsterfelijk, maar hij is dan ook voorzichtig. Als de lijkkoets met de dode Appi voorbijkomt neemt hij even zijn pet af, maar zodra de koets voorbij is zet hij hem gauw weer op, want "er woei een lelijke wind, en hij wilde op zijn leeftijd geen kou vatten." ${ }^{\text {46 }}$

\section{De kritieken}

De streekkrant De Gelderlander schrijft dat men in Grave het boek wel als een sleutelroman zal gaan beschouwen en dat men proberen zal na te gaan wie voor welk personage heeft gestaan. De recensent acht dat niet nodig. Het verhaal is een mengsel van Wahrheit und Dichtung en had in elk besloten stadje in Nederland kunnen spelen. De krant vindt Stad aan de Maas een echte Coolen met al zijn kwaliteiten en tekortkomingen, "maar vol liefde voor de mens, het land en het eigene." ${ }^{n 7}$

Het Parool bewondert het onmiddellijk herkende en herkenbare proza van Coolen met zijn eigen ritme en melodie. Die muzikale toon is meeslepend: "Ge geeft $\mathrm{u}$ aan maat en toonval weer onmiddellijk gewonnen." De lezer blijft lang nadat het boek is uitgelezen in de stemming die de schrijver ervan heeft gewekt. Die stemming "is er een van verstild geluk, dat tegelijk droevig is en blij, verslagen en getroost." ${ }^{-48}$

Kees Fens schrijft in De Tijd dat Coolen geen speurder is naar achtergronden en te weinig gebruik makkt van zijn vrijheid van romanschrijver. "Hij is de kronikeur van het dagelijks leven zoals zich dat aan de inwoners voordoet, met alle raadsels, vermoedens en gissingen die gebeurtenissen in een gemeenschap veroorzaken." Met dit procédé heeft Coolen volgens hem een eigen romankunst geschapen. Hij paste het volmaakt toe in zijn "voortreffelijke roman" De vrouw met de zes slapers waar de lezer slechts via gissingen en vermoedens van de dorpsbewoners iets meer te weten komt. Dit komt volgens hem voort uit de levenshouding van Coolen, "die het mysterie eerbiedigt en de laatste verklaring van alles niet aan de mens voorbehoudt." In De grote voltige en ook nu weer in Stad aan de Maas wijkt Coolen af van dit procédé. In deze romans wordt de lezer soms even door een alwe-

43 Coolen, Stad aan de Maas, 158. Mevrouw dr. H. Verwey-Jonker, zegt later (in een telefoongesprek met C. Slegers op 13 juli 1999) dat ze over dit onderwerp met Coolen stevig van mening heeft verschild. Zij vond Coolen beslist geen ouderwets schrijver, maar op dit punt heeft hij volgens haar vanuit zijn principieel katholiek geloof niet de mogelijkheid van een abortus overwogen. Mevrouw Verwey zat kort na de oorlog samen met Coolen in het Tribunaal voor Bijzondere Rechtspleging. In 1958 zat zij in de jury die de prijs van de stad Eindhoven aan Coolen toekende voor De grote voltige.

44 Coolen, Stad aan de Moas, 86.

45 Coolen, Stad aan de Maas, 88.

46 Coolen, Stad aan de Maas, 256.

47 'Grave gezien door een temperament'.

48 'Stad aan de Maas drama van allure'. 
tende verteller in vertrouwen genomen. Fens vindt de inleiding, waarbij geen steentje van de stad wordt overgeslagen, te lang. Een verbinding van de verschillende gebeurtenissen ontbreekt. Van de bouw van de brug bijvoorbeeld heeft de lezer niets gemerkt, maar de opening ervan sluit toch de roman. "Men zou haast zeggen: Coolen moest eens eindigen."

Volgens Garmt Stuiveling heeft Coolen de factor van het roomse geloof volledig opzij geschoven. In zijn boeken komen de grofste overtredingen van de christelijke geboden voor, maar de schrijver haalt er geen strenge pastoor bij:

"De schrijver heeft met een vergevingsgezinde glimlach naar de dwaze en soms trieste mensenwereld gekeken; hij oordeelt niet, hij verwondert zich; zijn verontwaardiging en zijn wanhoop liggen achter hem, hij kent alleen nog de stilzwijgende mengeling van mededogen en ironie, die oude en wijze mensen soms bereiken, ongeacht hun kerkelijke of onkerkelijke gezindheid."

Deze speelse en hartelijke wijsheid vindt hij het beste aspect van deze roman, want het verhaal zelf laat de lezer in de steek. De vele figuren verdringen elkaar en de personen missen een diepere dimensie. Stuiveling vergelijkt deze roman met het ouderdomswerk van Van Schendel, waarin ook alleen de gedragingen van de personen worden geschetst. De roman wordt op die manier een kroniek en de menselijke handelingen zijn nog slechts feitelijke gebeurtenissen. "En daarmee verliest de literatuur stellig een van haar essentiële functies: de mens in de spiegel van de medemens te laten ervaren hoe hij is. ${ }^{50}$ Ook Carel Swinkels vindt dat Coolen te veel uitlegt, waardoor de psychologische uitdieping van de roman helemaal verdrongen wordt door de historiserende opzet. ${ }^{51}$

Vanuit Grave wordt niet erg enthousiast gereageerd op de roman. Men vindt dat het stadje er te negatief in wordt afgeschilderd. Men heeft erg zijn best gedaan om Coolen de verworvenheden van de nieuwe tijd te laten zien en nu speelt het boek in de achterlijke periode van 1929. Bovendien zijn veel personen uit deze kleine gemeenschap herkenbaar. In de Graafsche Courant wordt in een ingezonden brief de schrijver op zijn plicht gewezen "naam en faam te respecteren van levenden en doden." Coolen verklaart op verzoek van de redactie nog maar eens dat zijn boek een mengsel is van waarheid en verdichtsel. De 77 . jarige dokter Kanters die model stond voor dokter Meerdink, is wel tevreden met het boek, evenals de plaatselijke boekhandel, want iedereen in Grave wil het boek kopen om te weten wat er in staat. Dat laatste geldt ook voor de rest van Nederland, zodat nog voor het eind van $196 \mathrm{r}$ een vierde druk verschijnt.

Het is duidelijk dat de critici van deze tijd anders oordelen dan de meeste lezers. De critici verlangen psychologische uitdieping, de lezers willen een verhaal.

\section{Somberte}

Tijdens het moeizame scheppingsproces van de roman schrijft Coolen dat hij zijn zoveel oudere literaire voorbeeld Streuvels om zijn vitaliteit benijdt. "Streuvels schreef mij, dat het de mooiste herfst was, die hij bij zijn leven kende en hij beleeft de oude dag als een Godsgeschenk." Enigszins mismoedig vervolgt hij: "Ik heb het druk met commissie en jury en bestuur van dit en dat. Het letterkundig werk gaat stug en stroef, met horten en stoten. Maar ik maak me niet wanhopig en zet het maar wat trager door-schoon ik binnenkort weer aan een boek voor een jubilerend bedrijf moet beginnen, de AaBee-fabrieken in Tilburg. ${ }^{\text {"52 }}$

In het voorjaar van 1960 heeft hij weer veel vergaderingen en lezingen en verzucht 
darbij dat hij zich "van de trage arbeid aan het Graveboek" zo moeilijk los kan maken.53 Zijn stemming wordt steeds tobberiger:

"Ik heb inderdaad dat gevoel, dat de tijd steeds sneller gaat, helling af, en dat ik aldoor meer tijd nodig heb voor het werk, zo traag gaat het, telkens opnieuw. Ik denk met spijt eraan, dat het niet meer zo vlot als vroeger. Maar de gedisponeerdheid is ook niet gunstig. Nogal innerlijk getob en last van downstemming. ${ }^{54}$

Toch mag hij wat zijn populariteit betreft niet klagen. In de jaren vijftig is Coolen een alom gerespecteerd en veel gelezen schrijver. Hij is zich er echter wel van bewust dat hij in het literaire debat en in de nieuwe ontwikkelingen geen rol meer speelt. Jonge schrijvers als W.F. Hermans en Harry Mulisch gebruiken de Tweede Wereldoorlog als inspiratiebron voor hun romans.

Coolen is inmiddels een schrijver van de vorige generatie. Het cynisme, de verbittering en het nihilisme van de jonge schrijvers spreken hem niet aan. Hij voelt echter intuittief heel goed aan, dat de boodschap die zij in hun boeken uitdragen, niet ver van de waarheid staat. Zoals zovelen heeft Coolen al tien jaar lang de angst en de druk gevoeld, die de dreiging van een atoomoorlog met zich meebrengt. In De vrouw met de zes slapers heeft hij teruggeblikt op de twee vorige oorlogen die hij opmerkelijk genoeg in De grote voltige geheel buiten beschouwing laat. Nog opvallender is dat in dit laatste boek, dat toch bedoeld is als een beschrijving van de veranderingen in Brabant, de dreiging van de Koude Oorlog volledig afwezig is. Coolen beschrijft de ruilverkaveling, de industrialisatie en de wens tot emigratie alsof Brabant onder een stolp staat. In het boek dringt niets door van de spanningen die zich in Hongarije, het Suezkanaal en de Sinaĩ-woestijn hebben ontladen. Coolen schermt zich daar voor af en kiest voor Coolenland, waar het buitenland voor de dorpelingen een vaag, amorf gebied is. De verandering is dat na de hannekenmaaiers die in Pruisen gingen werken nu hele boerengezinnen per boot naar Canada verhuizen. Dat voor sommige van hen de oorlogsdreiging in Europa ook een reden voor vertrek zou kunnen zijn, blijft onderbelicht. Uit zijn brieven blijkt dat Coolen zich zorgen maakt over de koude oorlog, maar tot een verwerking in zijn literaire werk komt het niet. De veranderingen in Brabant die hij beschrijft, zijn randgebeurtenissen. Zijn romans blijken sprookjes geworden, die verhalen hoe een smidsjongen uitgroeide tot captain of industry of hoe de mensen in een klein stadje hun lief en leed ervaren.

De diepere oorzaak van zijn somberte ligt niet alleen in het besef van het tanen van zijn literaire creativiteit. Zijn "innerlijk getob en downstemming" komen ook voort uit het leven met een geheim. Zijn druk programma van lezingen en vergaderingen dient ook om zijn vriendin te kunnen ontmoeten. De ontmoetingen met $\mathrm{M}$. monteren hem op, maar daarna wil het werk in zijn eigen huis 'vol eenzaamheid' minder vlotten.

49 Fens, 'Uit een klein rijk'.

50 Stuiveling, 'De tijd verandert'.

51 Swinkels, 'Stad aan de Maas'.

52 LMDC, inv. nr. C 3485, brief Coolen aan Oomes, 19 november 1959.

53 LMDC, inv. nr. C 3485, brief Coolen aan Oomes, 24 maart 1960.

54 LMDC, inv. nr. C 3485, brief Coolen aan Oomes, 30 april 1960. 


\section{De Vondelprijs}

Al vóór het verschijnen van Stad aan de Maas is Coolen er van op de hoogte dat hem de joost van den Vondelprijs 1960 in Duitsland zal worden toegekend. In een vertrouwelijke brief schrijft Van Duinkerken hem, dat een internationale jury, waarin hij ook zitting heeft, dit heeft besloten op 29 juli 1960 . In de jury zaten de gouverneur van Antwerpen Richard de Clerq en Lode Bakelmans voor Vlaanderen, dr. P.J. Meertens en Van Duinkerken voor Nederland en prof. dr. Schulz Kemminghausen "en een folklorist uit Hamburg, wiens naam mij niet wil te binnen vallen, doch die een fatsoenlijk man is." Omdat Van Duinkerken het voorstel heeft gedaan en "dit achtenswaardige gezelschap" er mee instemt, rust nu op hem de taak vertrouwelijk te informeren of Coolen de prijs van 5000 DM wil aanvaarden. Voor alle zekerheid voegt hij er aan toe: "Hoewel ik reden heb om te geloven, dat mijn lidmaatschap van deze jury voor jou voldoende waarborg geeft, dat volstrekt alles blijft geweerd en bestreden wat zweemt naar genegenheid voor het nazidom, dien ik mij toch te kwijten van de vertrouwelijke taak. ${ }^{.55}$ De Vondelprijs wordt gegeven "aan kunstenaars van allerlei professie en aan cultuurdragers, wier arbeid geacht kan worden, van belang te zijn voor de Beneluxlanden en Westelijk Duitsland tezamen." Het geld

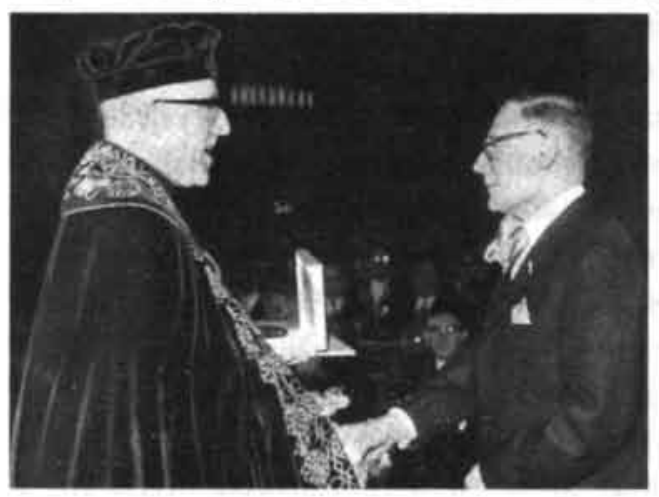

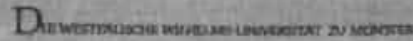
vatrutruev

JOOST-VAN-DEN-VONDEL-PREIS

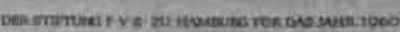

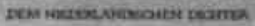

\section{ANTOON COOLEN}

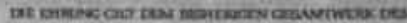

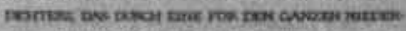

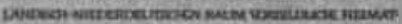

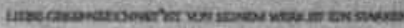

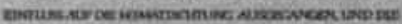

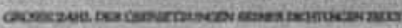

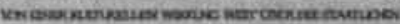
conpersiaver

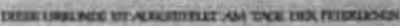

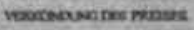

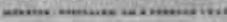

Wirive voor de prijs wordt beschikbaar gesteld door een rijke Hamburgse familie via hun Stiftung FVS te Hamburg. Waarschijnlijk is dit de reden dat Van Duinkerken naar het nazidom verwijst, want dit is dezelfde stichting namens welke de heer Töpfer Coolen in 1940 de Rembrandtprijs kwam aanbieden. De prijs dient om de culturele verbondenheid van de Nederduitse regio met het naburige Nederlands-Vlaamse cultuurgebied te benadrukken. De prijs wordt voor het eerst uitgereikt. Tegelijk met Coolen zal ook de Vlaamse cultuurfilosoof prof. dr. Max Lamberty de prijs ont vangen.

Op woensdag 8 februari r $96 \mathrm{I}$ vindt de uitreiking plaats tijdens een academi sche feestzitting in het Slot van Münster. In zijn dankwoord zegt Coolen dat voor hem "dieser trübe Wintertag sich in einem sonnigen Tag des Lebens umwandelt. ${ }^{556}$ Deze zin snede is bijna letterlijk dezelfde als die hij in zijn dankwoord voor de Eindhovense prijs gebruikte. Later op 
de dag spreekt hij ook nog in de historische Friedenssaal waar de Vrede van Münster in 1648 werd getekend. Coolen refereert hierbij aan het stuk Leeuwendaelers dat Vondel ter gelegenheid van deze vrede schreef.

\section{Het laatste jaar}

Coolen heeft geen tijd om na de uitreiking van de Duitse prijs in januari 1961 achterover te leunen. In februari en maart verschijnen twee artikelen van hem in Brabantia. In het eerste bespreekt hij een fotoboek van Martien Coppens met een inleidende tekst van Van Duinkerken, ${ }^{57}$ in het tweede de kroniek die Streuvels over de families Gezelle en Lateur heeft geschreven ter gelegenheid van zijn naderende negentigste verjaardag op 3 oktober 1961. Hij plaatst de opdracht van Streuvels in facsimile bij het artikel: "Aan Antoon Coolen dees late getuigenis, tevens gewetensonderzoek en ... zwanezang van Stijn Streuvels. ${ }^{58}$

Voor zijn vierenzestigste verjaardag in april krijgt Coolen van zijn zoon Felix het juist verschenen A burnt out case van Graham Greene. Hij vindt dit een sterk boek, "agressief en antidogmatisch." In dezelfde tijd leest hij ook Julien Greens Chaque homme dans sa nuit, waarin hem vanaf de eerste bladzijde dat magische treft, dat Julien Green sterker heeft dan Graham Greene en Mauriac. Hij broedt op een idee voor een nieuwe roman: "Vanzelf zou ik graag met een nieuw boek komen in het jaar, waarin ik 65 word. Maar deze gedachte is een bijkomstige ijdelheid en ik forceer niets." ${ }^{-59}$ Later dat jaar komt hij er nog een keer op terug. De abt van het Trappistenklooster in Tilburg heeft hem een idee aan de hand gedaan. Hij denkt nu aan een boek waarin de lotgevallen beschreven worden van een bekeerde joodse familie Löb, die in de oorlog uit het Trappistenklooster is weggevoerd. ${ }^{60}$

In de zomer van I961 krijgt Coolen de romanprijs van de gemeente Hilvarenbeek voor Stad aan de Maas. Bij de uitreiking tijdens de Groot-Kempische Cultuurdagen op zondag 23 juli leest Van Duinkerken, als voorzitter, het juryrapport voor. Hij grapt dat Coolen de Hilvarenbeekse prijs nu pas krijgt, bij het derde lustrum van de Groot Kempische Cultuurdagen, omdat de jury bij vorige gelegenheden voorbehoud maakte om nog hogere waarderingen voor Coolens werk in binnen-en buitenland niet te belemmeren. ${ }^{61}$ Het is niet duidelijk of Van Duinkerken bedoelt dat de Hilvarenbeekse prijs een belemmering voor Münster of voor de Nobelprijs in Oslo zou zijn geweest, maar de troost is wel erg schamel.

Het verhindert Coolen echter niet om met Van Duinkerken verder te draaien in de Brabantse prijzencarrousel. In diezelfde tijd zitten ze weer samen in de commissie van advies voor de provinciale prijs van Noord-Brabant voor Schone Kunsten, die op zaterdag 29 juli wordt uitgereikt aan Gerard Knuvelder. Deze verwijst in zijn dankwoord naar pro-

55 BA, brief Van Duinkerken aan Coolen, 8 augustus 1960.

56 Gedenkschrift zur Verleihung des Joost van den Vondel-Preises 1960, 24.

57 Coolen, 'Brabant edel en schoon', 112-114.

58 Coolen, 'Hebbelijkheden in de Gezelle-Lateurfamilie', 139-152. Op Coolens exemplaar stond het nummer V. Hij kreeg het eerste boek buiten de familie en was daar erg trots op.

59 LMDC, inv. nr. C 3485, brief Coolen aan Oomes, 27 april 1961.

60 LMDC, inv. nr. C 3485, brief Coolen aan Oomes, 5 september 1961.

61 Van Duinkerken, Hemeidonck en Naaijkens, 'Rapport', 212-216. 
fessor Gerretson die, toen hij de Constantijn Huygensprijs kreeg, gezegd zou hebben dat schrijvers op moeten letten voor prijzen en beter outcasts kunnen blijven. ${ }^{2}$ In deze zaal betekenen die woorden waarschijnlijk een oproep aan dovemansoren.

Tussen de bedrijven door heeft Coolen weer een jubileumboek over een bedrijf geschreven, ditmaal voor de AaBee wollenstoffen- en wollendekenfabrieken NV aan de Koningshoeven in Tilburg. Het fraai uitgegeven boek in een, uiteraard, stoffen omslag bestaat uit twee delen. Het grootste deel omvat driehonderd pagina's en is een vertaling van een Deens boek over de geschiedenis van de kleding. Daarna volgen twee hoofdstuk. ken van Coolen zelf.

In zijn eerste hoofdstuk, 'Na de New Look', blijkt Coolen goed op de hoogte van de modetrends van 1960 en $196 \mathrm{I}$ en wijst op de voorbeeldfunctie van idolen als Farah Diba, de jonge vrouw van de Perzische sjah, Brigitte Bardot, die trouwde in een jurk van Brabants Bont, en Paola, de vrouw van prins Albert van België. Als hij over mannenkleding schrijft, bewijst hij zijn belangstelling en aandacht voor het detail hiervan.

In zijn tweede bijdrage, 'Het Aabe-bedrijf', beschrijft hij nauwgezet de situatie tijdens de bezetting en grijpt de gelegenheid aan om aan te tonen dat een bedrijf heel wat moge lijkheden had om de bezetter te dwarsbomen. "De Duitsers lieten dikwijls allerlei maatregelen naast elkaar voortbestaan en de Duitse diensten, elk grondig op zichzelf, werkten langs elkaar heen." ${ }^{n 3}$

Inmiddels is het de tijd van de publiekrechtelijke bedrijfsorganisatie waarvan prof. dr. F. van der Ven, alias Frank Valkenier van Brabantia, een van de voorvechters is. Aan het slot van het boek komt de corporatieve geest van die dagen naar voren. Coolen prijst de goede samenwerking tussen werknemer en werkgever binnen dit bedrijf, dat helemaal past in zijn geloof in samenwerking en harmonie: "economisch welzijn van het bedrijf en mense lijk welzijn van de bedrijfsgemeenschap beïnvloeden elkaar gunstig. ${ }^{.64} \mathrm{Het}$ socialisme met zijn klassenstrijd en belangentegenstelling ligt hier mijlenver vandaan.

In de zomer verblijft Coolen enige tijd in het Trappistenklooster Koningshoeven bij Tilburg om het leven van de Cisterciënzers [de officiële naam van de Trappisten, C.S.] te bestuderen. Op $3 \mathrm{I}$ augustus $196 \mathrm{I}$ houdt hij daarover een tafelrede op een studentenreünie in Heeswijk ter gelegenheid van het 75 -jarig jubileum van het gymnasium. Hij belicht het verschil "tussen de stilte van het Cistercienzer silentium en het levendige der Norbertijner luidruchtigheid." In september heeft hij enige tijd "moezelwijn drinkend" rust genomen in een buitenhuisje van de Bredase oogarts Gerard Wiegersma, een broer van de medicus-pic tor uit Deurne:

Op 2 oktober $196 \mathrm{I}$ reist Coolen met zijn vrouw naar West-Vlaanderen om zijn Streuvelsboek aan te bieden aan zijn leermeester die dan negentig jaar wordt. Hij wordt bij Breskens met de auto afgehaald door Linie-redacteur A.Th. Mertens en zijn vrouw. Voordat ze vanuit Breskens verder rijden houdt Coolen een korte siësta, omdat hij zich vermoeid voelt tijdens zulke lange verplaatsingen. 's Avonds, na een Dubonnet en een avondmal bij kaarslicht in het huis van Mertens, zitten de twee echtparen tot middernacht bijeen. ${ }^{65}$ 


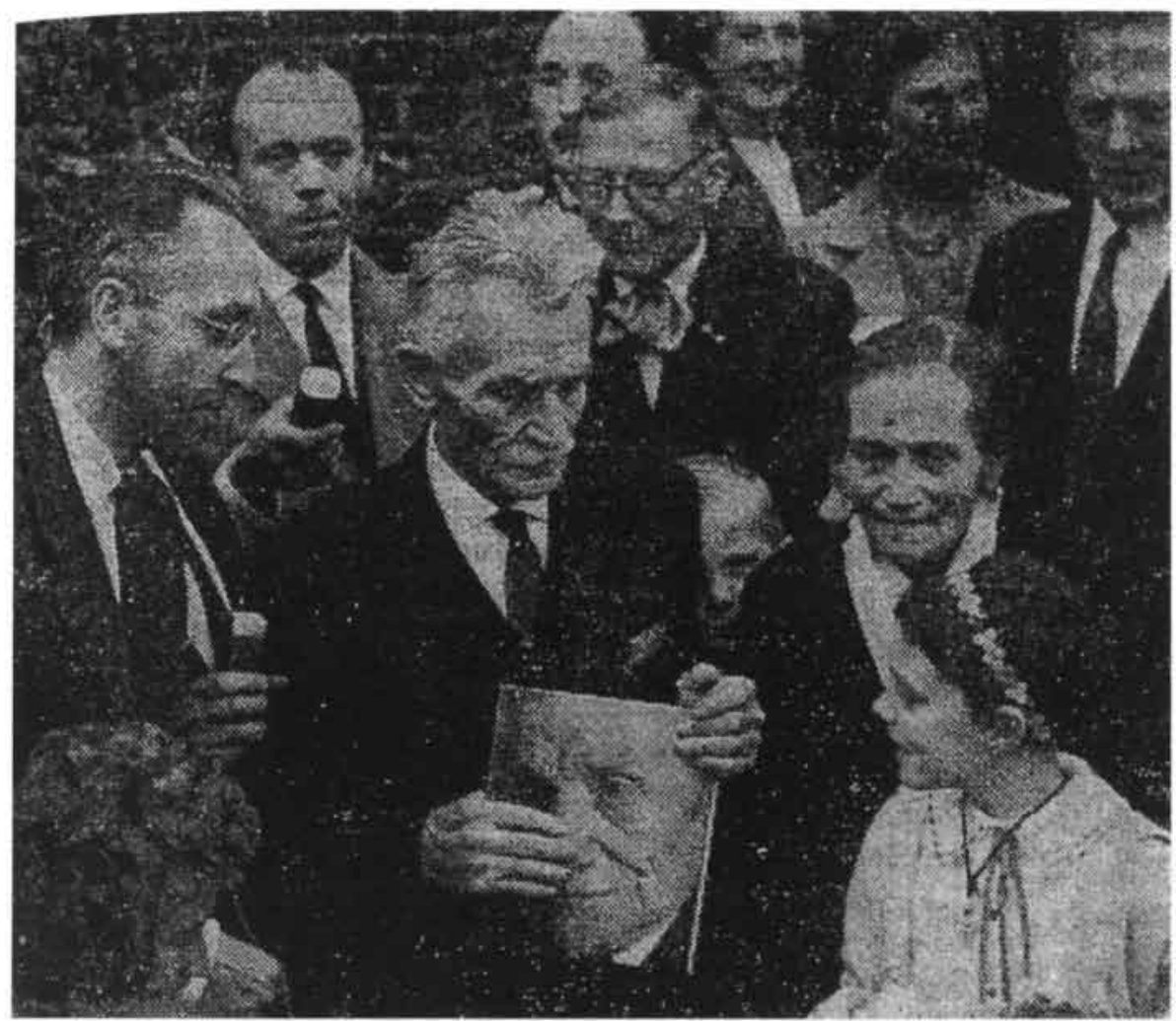

De volgende dag overhandigt Coolen het jubileumboek aan de negentigjarige Streuvels tijdens een plechtigheid in de tuin van het Lijsternest te Ingooighem. De populariteit van Streuvels moet enorm zijn, want een postbode in het uniform van 1880 levert een wagen met 50.000 gelukwensen uit Vlaanderen en Nederland af. Coolen brengt met dit jubileumboek een hommage aan zijn leermeester. Het is een fotoboek waarbij Coolen de tekst heeft geschreven. Zijn passage over de begrafenis van de mentor van Streuvels, Hugo Verriest, krijgt achteraf een sinistere bijklank. Deze luidt aldus: "Onder regen en storm werd Vlaanderens zonnekind ten grave gedragen. Nooit zag Streuvels een menigte volks zich zo stoicijns laten natregenen." Ruim een maand later zal Coolen onder gelijke weersomstandigheden zelf begraven worden.

\section{Ongeluk op de spoorbaan en overlijden}

Op woensdag i I oktober I 96 I gaat Coolen per trein naar Amsterdam voor een vergadering van het Prins Bernhard Fonds. Hij heeft zich echter vergist in de datum; de afspraak is pas de volgende dag. Hij heeft in zijn laatste jaar wel vaker last van dit soort verstrooidheden.

62 In de jury zitten Van Duinkerken (voorzitter), Antoon Coolen, prof. dr. K. Meeuwese, Jan Naaijkens, Bernard Verhoeven en J. van Hulsbeek (sec.) Rapport en toespraak Knuvelder, in: Brabantia, jrg. 10 (1961), 217-229.

63 Coolen, 'Het Aabebedrijf', 340.

64 Coolen, 'Het Aabebedrijf', 382.

65 Mertens, 'Het Laatste Gesprek met Antoon Coolen'. A.Th. Mertens was voor de oorlog redactielid van het Nijmeegs studentenblad Vox Carolina. 
Zijn secretaresse merkt dat hij soms de deur uitgaat en niet meer weet waarnaar hij op weg is. ${ }^{66}$ Zijn zoon vertelt dat Coolen in de zomer van $196 \mathrm{I}$ soms een verhaal vertelde en zich dan afvroeg of hij dat gedroomd had, het zelf ergens geschreven had of dat het echt gebeurd was.

Als hij zijn vergissing constateert, neemt hij de trein van 12.13 uur terug naar Eindhoven. Volgens zijn eigen verklaring gaat hij rond één uur naar het toilet en voelt dan tocht op het balkon, maar kan niet meer zeggen of het raampje openstond of de hele deur. Dat laatste is in die tijd nog mogelijk, omdat de deuren niet automatisch sluiten. In de, vol. gens de krant, verwarde verklaring zegt hij zich verder niets te herinneren, behalve "dat hij in de berm naast de spoorbaan tot bewustzijn kwam en dat hij een lange weg had afgelegd naar de boerderij van de heer Van Steenis. ${ }^{.67}$

Als Coolen daar aankomt is het inmiddels vier uur. Dit betekent dus dat hij drie uur bewusteloos langs de spoorbaan heeft gelegen in de buurt van Waardenburg. In de boerderij van de familie Van Steenis constateert de Waardenburgse arts Zijlker een lichte hersenschudding en een gebroken schouder. De trein reed ruim honderd kilometer op het moment dat hij eruit viel. De seindraden hebben waarschijnlijk de val gebroken, waarna hij de spoordijk is afgerold. Omdat de verwondingen niet zo ernstig zijn, hoeft hij niet naar het ziekenhuis. Hij wordt thuis verpleegd.

$\mathrm{Na}$ de eerste schok overheerst een gevoel van opluchting. Dat Coolen redelijk goed terecht is gekomen, lijkt een geluk bij een ongeluk. Van Duinkerken, die hem eerst per telegram al zijn wensen voor beterschap heeft gestuurd, wenst hem in een lange brief geluk met het behoud van zijn leven. Kenmerkend voor Van Duinkerken is dat hij uitgebreid beschrijft hoe het ongeluk zich volgens hem heeft toegedaan, gewend als hij is om de historische of literaire werkelijkheid naar zijn hand te zetten. Het lijkt erop dat hij Coolen wil gerust. stellen dat het niet ligt aan een 'absence' of een andere oorzaak bij Coolen zelf: "Blijkbaar heeft te Zaltbommel iemand de schuifdeuren van het Diessel [sic] portier laten openstaan tegenover een open raampje. In zulk geval is bij normale treinsnelheid de tocht sterk genoeg om iemand, die even struikelt of buiten de evenwichtsstand van zijn voeten terecht komt, naar buiten te zuigen." Hij voegt eraan toe dat Coolen maar blij moet zijn dat de trein niet in de andere richting reed, want dan was hij op de harde rails terecht gekomen en niet op de verende seindraden. ${ }^{68}$

Uit de rest van de brief blijkt wel dat hij zich niet ongerust maakt over de toekomst. Hij bedankt Coolen voor het fotoboek over Streuvels en herinnert hem eraan dat Coolen samen met hem en Emiel van Hemeldonck zou optreden voor de Kempische schrijvers op zaterdag II november. Van Duinkerken belooft dat Coolen toch het onderwerp van de avond zal blijven, "zij het dan in een redevoering van mij." Hij vraagt of hij van tevoren mededeelbare gegevens over zijn gezondheidstoestand wil verschaffen, "als ze maar gunstig zijn." Dan kan Van Duinkerken aan de vergadering berichten dat het goed met hem gaat en eventueel precies meedelen hoe het staat met de schouder, of hij nog in bed ligt, enzovoorts. In zijn rede wil hij vooral de hoofdmotieven van Coolens boeken bespreken, in de trant zoals hij dat voor Brabantia in 1957 heeft gedaan. "Het is buitengewoon jammer, dat we het niet overeenkomstig afspraak samen kunnen doen, maar laten we hopen op het allerbeste." 
Op de dag van de bijeenkomst van de Kempische schrijvers zal Antoon Coolen echter al twee dagen overleden zijn. Op donderdag 9 november 1961 krijgt hij plotseling een hartaanval. Hij wordt naar het St. Josephziekenhuis in Eindhoven gebracht, waar hij vroeg in de avond om half zeven overlijdt.

Reeds de volgende dag brengt het Eindhovens Dagblad een eerste ontdane reactie van Anton van Duinkerken. Deze schrijft dat hij de volgende dag met Coolen zou spreken voor de Kempische schrijvers. Op zijn vraag hoe het met hem ging, had Coolen geantwoord dat hij aan de schrijvers moest meedelen dat het goed ging. Op een voorstel van Van Duinkerken om vlug op ziekenbezoek te komen, was hij niet ingegaan. Hij vroeg Van Duinkerken daar nog maar even mee te wachten. Dit antwoord had Van Duinkerken wel enigszins bevreemd, maar Coolens overlijden is toch onverwacht: "Het bericht komt helemaal plotseling voor mij, het was een van mijn beste vrienden." ${ }^{n 9}$

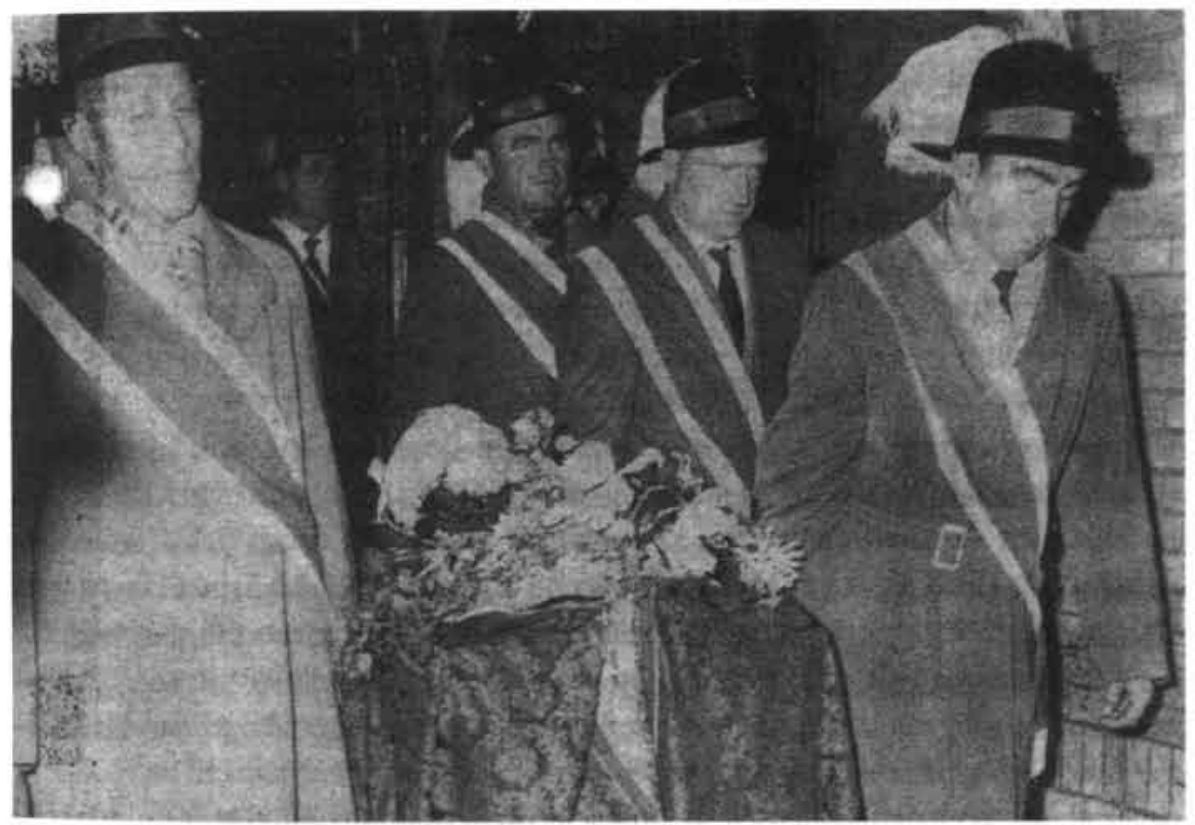

\section{Begrafenis}

Op maandag 13 november 196r wordt Antoon Coolen in Waalre begraven tijdens een gierende novemberstorm met vlagen regen. Op het carillon van het oude St. Willibrorduskerkje, waar Coolen zo vaak de herdenking van de Brabantse gevallenen heeft geleid, wordt het 'Wilt heden nu treden' gespeeld. Jan Engelman beschrijft de binnenkomst van de baar aldus:

"Het was doodstil in de kerk van Waalre. Plotseling gingen de grote deuren open. Het hoge geluid van in de regen zwiepende takken woei naar binnen, het gekraak van grint

66 Mevrouw L. de Bont- van der Linden te Waalre in gesprek met C. Slegers, mei 1997.

67 'Antoon Coolen uit trein gevallen'.

68 BA, brief Van Duinkerken aan Coolen, 23 oktober 1961.

69 'In Memoriam Antoon Coolen. Typisch Brabants dichter', in: Eindhovens Dagblad, 10 november 1961. 
onder de wielen van de lijkwagen en daarna een laag, geheimzinnig grommen, door de meesten niet herkend. Een minuut later kwam het antwoord: de leden van het St. Antonius-gilde uit Deurne kwamen binnen achter hun trotse vaandel en het zachte geroffel van hun tamboers, ernstig onder hun groene hoeden met witte pluimen. Even daarna droegen acht uitverkorenen, vergezeld van een erewacht met musketten en hellebaarden, traag en plechtig over het middenpad de lijkbaar waarop de stoffelijke resten rustten van wie hun beschermheer was: de schrijver Antoon Coolen. Het gewest dat hij in al zijn boeken verheerlijkte, nam van hem afscheid in de persoon van zijn hoogste autoriteit, gouverneur Kortmann, maar zó en niet anders moet hij zich deze laatste hulde het liefst hebben gewenst: gedragen door de schutters van een aloud gilde. ${ }^{70}$

$\mathrm{Na}$ afloop van de Mis dragen de gildebroeders de kist tijdens het 'In Paradisum' de kerk uit. De belangstelling is enorm. Naast vertegenwoordigers van overheden zijn veel mensen aanwezig uit de wereld van kunst en cultuur: Anton van Duinkerken, Gerard Knuvelder, Hendrik en Pieter Wiegersma, Gabriël Smit, C.J. Kelk, Jan Engelman, Walter Breedveld, A. van Domburg, Piet Oomes en de schilder en jeugdvriend Peter van den Braken. Er zijn kransen van de Stiftung FVS Hamburg, de gemeente Waalre, het Prins Bernhard Fonds en van de jury van de Martinus Nijhoffprijs.

De oudste zoon Stijn Coolen spreekt een kort dankwoord aan het graf. Verder zijn er geen toespraken. Van Duinkerken schrijft later in Brabantia dat het een vaste regel is dat op een rooms kerkhof geen "gedachtenis-redevoering" wordt uitgesproken. Het steekt hem echter dat dit binnen de kerk ook niet is gebeurd: "Het is niet de gewoonte van gewijde redenaars, zich op de kansel nader te bekommeren om de profane letteren dan om te waarschuwen tegen het kwaad, dat zij somtijds aanrichten kunnen. De katholieke kerk is geen instelling, die dankbaarheid betuigt aan romanschrijvers." Hij vraagt zich af waarom er geen hartelijk woord van een geestelijke over de "doorlichte geloofsdiepten" in het werk van Coolen afkon. De kerk is nog altijd bang van romanliteratuur, moet hij constateren."

C.J. Kelk ervaart, als niet-katholiek, die dienst heel anders. Hij herinnert zich later dat de begrafenis volgens de oeroude regels verliep, waarbij hij zelfs Jan Engelman, die in zijn ogen toch een vrijdenker was, zag knielen: "Het moet er toch wel geducht ingeheid zijn, dacht $i k$, dat verstandige mensen die middeleeuwse riten nog altijd volgen, altijd nog bevreesd zijn voor het hellevuur." ${ }^{\text {/2 }} \mathrm{Hij}$ realiseert zich dat hij zich bij Coolen nooit afgevraagd heeft of hij wel echt katholiek was. "Ik heb het meen ik bij het rechte eind gehad hem voor een naief gelovige zuiderling te verslijten die zich om geloofszaken niet druk maken: ze hebben de waarheid, en daarmee uit."

De condoleance wordt gehouden in het woonhuis dat kleiner is dan De Kempen, dat Kelk zich herinnert van een eerder bezoek. Het is er zo vol dat hij en ook anderen niet binnen kunnen komen. Op de terugweg in de trein vertelt een oude vriendin, die zeer nauw bekend is met het gezin Coolen, dat de schrijver het de laatste jaren van zijn leven minder gemakkelijk gehad heeft dan men geneigd is te denken.

Op het bidprentje dat bij Coolens begrafenis wordt uitgedeeld, is de slotalinea van Herberg In't Misverstand afgedrukt:

"Niet omdat de mensen zo goed en zo mooi zouden zijn, moet ge van hen houden, maar 
omdat ge hun getuige zijt en hun deelgenoot. En het aardsche leven is niet volmaakt, maar het is het aardsche leven. Het bloesemt en draagt vrucht, men kan er niet nederig genoeg tegenover zijn, men kan niet nederig genoeg zijn in het gadeslaan van dat verbazingwekkende, aardsche leven. Het hangt niet uitsluitend van het noodlot af, het noodlot is er een deel van, als de stormen van het land. Zij schaden, maar zij vernietigen niet, altijd is er weer vrucht en oogst. Daarom heeft het zin te blijven staan, de handen te vouwen en vastberaden te zeggen: het zij zoo." ${ }^{\text {73 }}$

\section{In memoriam}

In de pers wordt de overledene met liefde herdacht. Trouw schrijft dat een van Nederlands meest bekende en geliefde auteurs is overleden. Zijn boeken hadden iedereen iets te bieden, zowel de eenvoudigen van geest als de meer gecompliceerde lezers. "Maar dat wil allerminst zeggen, dat zijn verhalen het leven ontweken of het leven eenvoudiger maakten. Integendeel: bij Coolen vindt men de volle tragiek van de mens." Volgens de criticus was Coolen niet alleen een van de beste maar ook van de zuiverste auteurs van het land. ${ }^{74}$

Gerard Knuvelder wijst op de zeer persoonlijke dood van Coolen. Hij krijgt een ongeluk dat 'normaal' dodelijk zou zijn, maar hij overleeft en schijnt zelfs geheel te herstellen. Plotseling en onverwacht sterft hij dan toch. "Het is een leven-en-sterven als hij zelf had kunnen beschrijven in een van zijn romans." Hij zou het behandeld hebben met een superieure humor, die speelt met de tragiek van het leven. ${ }^{75}$

C.J. Kelk schrijft zeer bewonderend over het schrijverschap en vooral de vertelkunst van Coolen. Het verschil met Streuvels is dat Coolen niet dat "bovenaardse" had alsof hij meer zag dan het menselijke. In de verhalen van Coolen wordt een blijvende liefde voor mensen geschetst. Hierdoor heeft hij zich een blijvende plaats in de Nederlandse letteren verworven. $^{76}$

Na een eerste spontane reactie in het Eindhovens Dagblad daags na het overlijden schrijft Van Duinkerken een uitgebreid in memoriam voor zijn vriend in De Tijd. Hij belicht enkele aspecten van Coolen die niet zo bekend zijn: zijn belezenheid in het werk van Nietzsche, zijn kennis van muziek, zijn politieke ontwikkeling en zijn humor. Sterk benadrukt hij de tegenstelling van het vliedende en het bewegende tegenover het stabiele en het onvergankelijke in Coolens werk. ${ }^{n}$

In het Eindhovens Dagblad wordt naast de reportage van de begrafenis een gedicht afgedrukt van Lodewijk van Woensel:

70 Engelman, 'Afscheid Antoon Coolen'.

7 Van Duinkerken, 'Ter gedachtenis aan Antoon Coolen'.

72 Kelk, Wie ik tegenkwam, 88-92.

73 Coolen, Herberg in ' $t$ Misverstand, 375.

74 'A. Coolen: een groot verteller'.

75 'In Memoriam Antoon Coolen', in: Eindhovens Dagblad, 10 november 1961.

76 Kelk, 'Bij de dood van Antoon Coolen'.

77 Van Duinkerken, In Memoriam Antoon Coolen'. 
Ik wacht vergeefs op zijn vertrouwde stem, die stierf bij 't sterven van de veldgewassen, nóg zingen zijn geliefde canadassen, maar in mineur, een somber requiem.

Nu slaan de deuren van zijn wereld dicht, van 't kleine rijk, waarmee hij ons verblijdde, maar door de klaarheid van het donkere licht zien wij zijn land en volk van Brabant beide.

Ik sta hier eenzaam op een kerkplavei en zie de laatste kaarsen langzaam branden, In 't gouden schijnsel valt een najaarswolk.

Wij bidden fluisterend: 'God sta hem bij en voer hem binnen in Uw sprookjeslanden' wij vragen het, wij, kinderen van ons volk. ${ }^{78}$

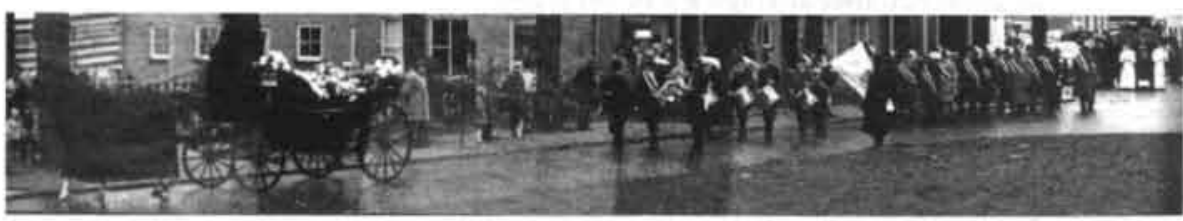


78 Eindhovens Dagblod, 14 november 1961. Lodewijk van Woensel is een pseudoniem van de Eindhovense dichter Louis Vrijdag (1913-1994). 



\section{Summary}

\section{Antoon Coolen (1897-1961). Biography of a writer}

Antoon Coolen was born in Wijlre in the south of the Dutch province Limburg. When he was six years old, his family moved to Deurne, a village in the middle of De Peel, the moors of Eastern Brabant. In a sense, it was a homecoming, since his parents could trace their roots back to that region. Deurne and its surroundings made quite an impression upon Coolen, so much so that they would be the setting for most of his stories and novels.

As a schoolboy, he was influenced by Hendrik Ouwerling (I86I-1932), an older schoolmaster, regional historian and journalist. Ouwerling had liberal inclinations and was highly critical of local politics and the Roman Catholic Church. The young Coolen read many books from Ouwerling's vast library; books written by naturalists, modernists and liberals like Zola, Multatuli, Streuvels, Querido, Ibsen, Andrejev and Nietzsche. This was quite exceptional in the catholic atmosphere of Brabant, where priests sermonized to their flocks about the spiritual dangers of 'evil books'. After four years of boarding school (gymnasium) in Heeswijk, he left school inigr 3 and had but one aim: to become a writer. In the first months of World War I, he wrote columns and short stories during an apprenticeship at Ouwerlings newspaper De Zuidwillemsvaart.

At the end of 1914 , Coolen published a collection of these columns in his first book, Opinies. The book caught the attention of a 27 -year-old student-priest, Wouter Lutkie (1887-I968), who offered guidance to the young journalist. This was the beginning of a long correspondence (from I9I4 to 1922), which has been a rich source for this biography. The letters show how Coolen struggled with his first novels and stories, with his doubts about faith and religion and with his attitude toward women.

Lutkie was part of a critical but conservative movement in the Roman Catholic Church, the so-called 'Integralists'. Later on he became an admirer of Mussolini. Coolen's ideas, on the contrary, were, as we have seen, more oriented toward the 'Modernists'. He used Lutkie as a sparring-partner to sharpen his ideas during the 'Sturm und Drang' period of his youth.

During World War I Coolen was a journalist in Eindhoven, and then briefly in Maastricht. After some conflicts with the editor in I9I9, he quit his job and left Brabant for a position at the catholic newspaper De Gooische Post in Hilversum. Finally, seven years and many frustrated attempts after his first book, he published a collection of short stories entitled Lentebloesem. However, the book's lukewarm reviews were a difficult trial for Coolen.

After publishing some stories in the literary magazine Roeping. Coolen became involved in the network of young catholic intellectuals and artists. Here he met Anton van Duinkerken (ps. for Willem Asselbergs, 1903-1967). Their first meeting was somewhat mythical: while shaking hands they uttered just one word: Brabant! That auspicious introduction was the beginning of a life-long relationship between the two very different writers.

In this early stage of their relationship they encouraged each other, but the younger 
Van Duinkerken soon became Coolen's literary and religious conscience. Van Duinkerken saw the characters in the novels as bad examples of Brabant Catholics, and revealed this in his public criticism of Coolen's early novels. The relationship of the two men was like that of a twin-star: they depend upon each other for light and centering guidance. Van Duinkerken was afraid that Coolen was influenced too much by Nietzsche. Van Duinkerken was an apologist, a defender of the official Roman Catholic doctrine, but he was also a critic of the rigid hierarchy of the Church. Coolen's first aim was to be an author whose books touch the reader. He had no religious or ideological message. He was a witness of his characters and he shared their ups and downs in life, he had compassion for them.

With Kinderen van ons volk (People of Brabant, 1928) Coolen wrote his first best-seller. It was the beginning of a golden decade in which Coolen published a successful novel nearly every year. The earlier novels all took place in de Peel, the land of his youth. In these novels he describes the seasons, the landscape, and the work of farmers and peat-diggers. But this world is not simply arcadian and peaceful; the high rate of child mortality and unemploy. ment in wintertime make life difficult. There were sharp contrasts between the simple happiness of family life and the jealousy and murder in a love affair. In the debates between an atheist notary and the parish priest, two very sympathetic people, the reader will recognise elements of the doubts from the letters of the young Coolen to Lutkie.

Het donkere licht (The dark light, I929) gives an impression of the influences of World War I and the impact of industrialisation on young people in the villages around the city. The description of the suffering of Marie, a character who had an illegal abortion, has no condemning moralistic message in it. On the contrary: Coolen's look is compassionate; he has no need to condemn the girl.

We also notice this point of view in De goede moordenaar (The good murderer, 1931). Coolen describes the strange instinctive compulsion in a man to kill someone. The novel is devoted to the memory of the medieval painter Jeroen Bosch, and the devils, monsters and colours of some scenes evoke images of the paintings of the Final Judgement.

In 1929 Coolen married Gerda de Jong (I901-1964), a teacher. In 1931, I932 and 1933 their first three sons were born. They were named for three famous Flemish writers: Stijn (Streuvels), Guido (Gezelle) and Felix (Timmermans). In 1933 the family moved to Deume in Brabant, the village of his youth. They settle in De Romeijn, the house of Hendrik Ouwerling, who died in October 1932.

During his thirteen-year stay in Hilversum, Coolen wrote novels and stories that were set in the moors of De Peel. After taking up residence in the middle of De Peel, he chose another scenic backdrop: the banks of the river De Maas. His newer novels were inspired by Hendrik Wiegersma, a village-doctor and painter. He told many stories about his Frisian family of doctors. Wiegersma was an unorthodox surgeon, who attracted people from all over the country. His house in Deurne was a meeting point for artists and writers, not only from Holland but also from all over Europe. Coolen's novels Dorp aan de rivier (Village on the riverside, 1934) and De drie gebroeders (The three brothers, 1936) present a burlesque view of a village community and a doctor's family. 
In the meantime, Coolen was member of the editorial board of De Gemeenschap. The informal leader of this monthly magazine for progressive roman-catholic intellectuals was his friend Anton van Duinkerken. The yearly Easter meetings were held in Coolen's house De Romeijn. Shortly after the birth of his fourth son, Peter, they moved to a newly constructed house, De Kempen, in Waalre in 1938 . Here he published his last novel before the war; it would also be his last big novel for the next fifteen years.

Herberg In 't Misverstand (1938, translated by Jacobine Menzies-Wilson as The Cross Purposes, London 1948) was a novel with magnificent plot development and structure. In the end it turns out that every character is a completely different person from the reader's expectations.

The years of the Second World War had an enormous impact on Coolen's work and life. Already in the first few months of the war Coolen was offered to accept the prestigious Rembrand-prize of the University of Hamburg. Like all institutions in the Third Reich, this university was completely under control of the Nazis. Just like Streuvels and Timmermans, Coolen was very popular in Germany. The Nazis used these novels as exemplary 'Heimatromans', novels that depict family life, the work of farmers and the strong relation with the land ('Blut und Boden'). Coolen refused to accept the prize. His reasoning was that he could not accept a prize from a regime that had illegally occupied his country.

In 1942 he avoided conscription as a member of the 'Kulturkammer' by announcing that he was no longer a writer, but head of public relations of a linen factory. In fact he had made a fake contract with the director, a friend of Coolen.

More and more Coolen isolated himself from the outside world. He stopped reading the newspapers. He wrote fairy-tales and kept notes in a kind of war diary.

In 1943 , when the terror of the occupational power increased and raids were organised to arrest workers for the German war industry, he was asked by Dutch officials (the provincial governor and the national secretary of internal affairs) to apply to be mayor of his village, Waalre. This plan was designed to prevent the appointment of an NSB-mayor (NSB: national-socialistic movement in the Netherlands). When he, in the final interview with the German authorities, refused to cooperate, they stopped the proceedings.

In May 1944 he was forced underground when he ignored a call up for digging on the German defence works in Zealand. His house was plundered completely by Dutch collaborators. While Coolen lived at various places in the west of Holland, his wife and children stayed at the homes of different friends in Deurne.

When the Allied troops invaded Brabant in September 1944, Coolen went back to his family. He escaped just in time, immediately before the northern part of the Netherlands was cut off from the liberated south. After the liberation of Brabant, Coolen's feelings were mixed. Soon, as a member of the 'Tribunaal voor speciale rechtspleging' (Tribunal for Extraordinary Justice), he was confronted with all kinds of people who had co-operated or collaborated with the Germans. He noticed that the 'little fish' got caught while the bigger ones escaped.

Soon Coolen was contributing to a new newspaper, the Deurnesche Courant, and began attacking Van Doorne, the famous director of the DAF (automobile industry in 
Eindhoven). Coolen blamed him for his overly cooperative attitude towards the Germans and for collaborating with the German war industry. Van Doorne defended himself in another newspaper Het Licht. There would be a bitter press war in the small village Deurne for more than two years.

Coolen, who normally hated to operate in public controversies, could hardly stop this polemic. Finally in 1947 he ended the debate. It seemed to him that he had been going on for too long and that he had done enough damage to his own mind.

In February 1947 his youngest son, Peter, died in a tragic accident. Peter and a friend drowned under the ice of a well in the fields. Coolen had described a similar accident earlier in his novel De schoone voleinding (1932). The passage was printed on the memory-card that was handed out during the funeral.

Meanwhile Coolen became successful again as a writer. After the war he published his 'war diary' Bevrijd vaderland (1945).

In the same year he was invited to visit Czechoslovakia. His fame in that country was enormous. Shortly after Peter's funeral he visited Prague for the first time. In August he stayed with his wife and children for a few weeks as a guest of the Czech writers' association. However, the communist coup in 1948 put an end to these friendly relations, as well as to the flow of royalties from his books.

In post-war Brabant there were ambitious plans for social, cultural and economic development. The new provincial governor, De Quay, initiated a variety of programs. One of those programs was the printing of a three-volume publication, Het Nieuwe Brabant (New Brabant, 1952-1954). The book offered a presentation of the history, the present and the future of Brabant. Coolen wrote two essays about the landscape and the villages in this province.

At the same time he wrote plays for an open-air theatre in Heeswijk. These summer theatres were very popular in the fifties. Coolen had already written theatre plays before the war. It was the weakest side of his talent, for in a play, Coolen couldn't use his exceptional skill for compassionate characterization that illuminated his novels.

His short story Incident in a Church (1952) was a great international success and was awarded the World Prize for short stories in the New York Herald Tribune competition. Streuvels advised Coolen to continue with this literary form. But Coolen was bound to the great novel.

Fifteen years after Herberg In 't Misverstand, Coolen published another great novel, De vrouw met de zes slapers (The woman with the six guardians, r953). It is a mysterious, fairy-like story about the relationships among people in a castle and those of a village. Here more than in his other novels, Coolen gives the reader a view on his youth in Deurne. The critics were divided. A new generation of writers had started to publish; authors like Van het Reve, Mulisch, Hermans and Anna Blaman described a completely different world. These later writers were more cynical and paid more explicit attention to their characters' psychological motivations.

Coolen lacked the enormous inspiration and energy he had when he was writing his Peel novels. He complained about it in letters to his friend Piet Oomes. There was also 
loneliness in his marriage. After the death of their youngest son Peter, Coolen and his wife became more and more remote to each other. They lived in the same house but in their own worlds. The situation was reflected in some scenes in his last three novels.

In 1957 Coolen tried to present the development of Brabant in a literary way in De grote voltige (The big tumble or rotation). In alternating chapters he describes the rise of the son of a blacksmith to a famous captain of industry and a Maecenas of the village. It is clearly a portrait of his former adversary in the press war, Van Doorne, but it is written without bitterness or vengeance.

In his last novel, Stad aan de Maas (A Town on the River Maas, 196I), he gave a depiction of the influence of modern times on a little town during the construction of a bridge.

In the last year of his life, in February 1961, he was honoured by the University of Münster in West Germany. Coolen was given the Vondel-prize, a prize to emphasise the cultural relation between the region of the Lower-Rhine and the Low Countries. In the summer he was also awarded in Hilvarenbeek for his last novel.

In October, Coolen, who was very absent-minded during his last years, had an accident during a trip by train. Looking for the lavatory he opened the wrong door and fell from the moving train. He was lying on the side of the railway dike for three hours. His injuries were not that serious and he seemed to make a quick recovery. But a month later, on November gth, I96I, he died quite suddenly on a heart attack.

The Guild of St. Anthony, the Abbot from Deurne escorted their protector to the graveyard and many Dutch writers attended the funeral. They all read the 'In Memoriam'-card with the closing sentences of Herberg In 't Misverstand, Coolen's credo about mankind and life:

"You ought not to love people because they are good and beautiful, but because you are their witness and their partner. And our earthly life is not perfect, but it is our earthly life. It blossoms and bears fruit, we cannot be sufficiently humble in our thought about this amazing earthly life. It does not depend altogether on fate, fate is a part of it, like the storms of the country. Therefore it is sensible to stand fast, with folded hands and to say with determination: So be it." 



\section{Archivalia en \\ niet-gedrukte bronnen}

Gebruikte afkortingen

AAU Archief Aartsbisdom Utrecht (zie Rijksarchief Utrecht)

AKC Archief Kabinet van de Commissaris der Provincie/Commissaris der Koningin (zie Rijksarchief Noord-Brabant)

AMVC Archief en Museum voor het Vlaamse Cultuurleven

BA Archief Bernard Asselbergs

BvdB Collectie Bertus van den Belt

CS Collectie Cees Slegers

FPC Archief Antoon Coolen beheerd door F(elix) P. Coolen

KDC Katholiek Documentatiecentrum

LMDC Letterkundig Museum en Documentatiecentrum

NIOD Nederlands Instituut voor Oorlogsdocumentatie

NTI Archief Nederlands Theaterinstituut

RANB Rijksarchief Noord-Brabant

RAU Rijksarchief Utrecht

WE Collectie Stichting Waalre's Erfgoed

Archivalia

\section{Archief Abdij van Berne, Heeswijk}

Prijsuitreikingen aan leerlingen, 1904-1906, inv. nr. 23, boekje 54 .

Archief en Museum voor het Vlaamse Cultuurleven, Antwerpen

Brieven Coolen aan Streuvels, r929-I96r, inv. nr. C 3475.

Brieven Coolen aan Timmermans en Tralbaut, inv. nr. C 3475.

Gelukwensen Coolen aan Walschap en Teirlinck, inv. nr. C 3475.

\section{Archief Bernard Asselbergs (zoon van Anton van Duinkerken), Amsterdam}

Complete briefwisseling Coolen - Van Duinkerken, r924-r 96 r.

\section{Archief Antoon Coolen beheerd door drs. Felix P. Coolen (zoon van Antoon Coolen), Zwolle}

Chronologische verzameling brieven aan Coolen.

Afschriften van brieven van Coolen (in ordners per jaar).

Recensies. 


\section{Krantenknipsels.}

Manuscripten van romans, novellen en verhalen.

Typoscript radiorede van Jan Engelman, 'De goede moordenaar', voor de KRO, 4 maart 1932.

Typoscript toneelstuk Coolen Sint Cunera van Brabant (niet uitgegeven).

\section{Archief Nederlands Theaterinstituut, Amsterdam}

Brieven en knipsels over het kunstenaarsverzet en de opvoering van Vrij volk in juni 1945.

\section{Archief Hendrik Wiegersma, beheerd door diens zoon Pieter Wiegersma}

Brieven (12 stuks) Wiegersma aan Coolen en Coolen aan Wiegersma Brief Lutkie aan Wiegersma, 1936.

\section{Collectie Bertus van den Belt, Zwolle}

Privé-collectie.

Briefwisseling Coolen - Ella Kazdova (Tsjecho-Slowakije), r947-r957.

Collectie Sjef Coolen (zoon van oudste broer van Antoon Coolen, W.J. Coolen), Deurne

Privé-collectie van familiebescheiden.

Brief Cato Coolen aan Maria Swinkels, november 1891.

\section{Collectie Tij Kools, Veghel}

Privé-collectie.

Knipsels, kranten en (kopieën van) brieven over de Deurnese persstrijd in 1945-1947.

Brieven van en aan Carel Swinkels en S.A.H.M. Zoetmulder.

Uitgebreide briefwisseling tussen H. Maas en J.J.M. Heeren.

\section{Collectie Cees Slegers, Helvoirt}

Privé-collectie typoscripten, geluidsband en recensies.

Typoscript Mr. G. Cammelbeeck, Terugblik op het Van Doorne-conflict naar aanleiding van een gesprek met Ronald Groeneweg, Vreeland 28 februari 1992.

Typoscript F. Fennis, Herinneringen aan Antoon Coolen in zijn Hilversumse jaren, Ankeveen april 1969 .

Typoscript S.A.H.M. Zoetmulder, Antoon Coolen en Waalre, Waalre 1988.

Geluidsband van een toespraak van Antoon Coolen voor Radio Herrijzend Nederland in november 1944 .

\section{Collectie Stichting Waalre's Erfgoed, Waalre}

De stichting heeft de collectie van verzamelaar G. Remery uit Eersel overgenomen. De collectie is geordend op de soort van documenten.

Boeken.

Eerste drukken. 
Foto's.

Enkele (kopieën van) brieven, waarin tijdgenoten terugblikken op Coolen na diens dood: de schrijvers De Bourbon (brief van 16 maart 1969) en Kortooms (brief van september 1971) en de schilder en jeugdvriend Peter van den Braken (brief van november 1970).

Typoscript Piet Oomes, 'De grote voltige door Antoon Coolen. Een hoogtepunt in de reeks van zijn Brabantse romans' uitgesproken voor de KRO radio op zondag 24 november 1957 in de rubriek Het Boekhuis.

\section{Katholiek Documentatiecentrum, Nijmegen}

Archief Lutkie, inv. nr.Ior, Briefwisseling tussen Coolen en Lutkie, 1914-1922; Enkele brieven Lutkie aan H. Ouwerling, J. Heeren, dr. H. Moller en Lies Staels.

Archief Moller, inv. nr. 117.

\section{Letterkundig Museum en Documentatiecentrum, Den Haag}

Collectie Antoon Coolen, inv. nr. C 3485 .

Collectie Anton van Duinkerken, inv. nr.VD $326 \mathrm{r}$.

Collectie Louis de Bourbon, inv. nr. B 783 .

Brieven van Coolen aan P. Oomes, 1933-1961 (nog niet geordend).

Kortlopende briefwisselingen Coolen met en incidentele brieven aan en van Nederlandse schrijvers, uitgevers, redactie van De Gemeenschap en vertalers, inv. nr. C 3485 .

\section{Nederlands Instituut voor Oorlogsdocumentatie, Amsterdam}

Correspondentie van de secretaris-generaal van het Departement van Volksvoorlichting en Kunst, dr. T. Goedewaagen, inv. nr. ro2, 1a.

Correspondentie en aantekeningen van de secretaris-generaal mr. K.J. Frederiks, inv. nr. Iora, rc en ze.

Archief van de Nederlandse Kultuurkamer.

\section{Rijksarchief Noord-Brabant, 's-Hertogenbosch}

Archief van het Kabinet van de Commissaris der provincie/Commissaris der koningin, inv. nr. 130.01: Concepten installatietoespraken van nieuw benoemde burgemeesters in oorlogstijd, map 276; Briefwisselingen naar aanleiding van burgemeesterssollicitaties, map 276; Gegevens over weggevoerde burgemeesters in oorlogstijd, map 281; Salarissen burgemeesters, map 282 .

\section{Rijksarchief Utrecht}

Archief Aartsbisdom Utrecht, Correspondentie secretaris van Kardinaal de Jong, inv. nr. 449 .

\section{Stadsarchief Helmond}

Inventaris van de papieren van J.J.M. Heeren, zeventiende eeuw tot 1967. Hierin opgenomen: 
Ingekomen brieven betreffende allerlei onderwerpen afkomstig van H.J.J. Maas, inv. nr.1; Archivalia afkomstig van Hendrik Ouwerling: ingekomen brieven bij H. Ouwerling, inv. nr. 93.

\section{Streekarchief Peelland, Deurne}

Archief Koninklijke Harmonie Deume, inv. nr. 7.

\section{Interviews en gesprekken}

De heer Bertus van den Belt, Zwolle.

Mevrouw Leny de Bont- van der Linden (secretaresse van Antoon Coolen), Waalre. drs. Felix P. Coolen (zoon van Antoon Coolen), Zwolle.

De heer J.G.M. (Hans) Coolen (zoon van Antoon Coolens broer Jan Coolen, 1909-1996), Son en Breugel.

De heer Sjef Coolen (zoon van Antoon Coolens broer W.J. Coolen, 1892-1982), Deurne. drs. Ronald Groeneweg, Rotterdam.

De heer en mevrouw Hohmann-van Doorne, Deurne.

De heer Jan Naaijkens, Hilvarenbeek.

drs. Jan van Sleeuwen, Vught.

De heer Lambert Tegenbosch, Heusden.

drs. Gé Vaartjes, Boskoop.

mevr. dr. Hilde Verwey-Jonker, Utrecht (telefoongesprek). 


\section{Gedrukte bronnen en literatuur}

A. Coolen: een groot verteller', in: Trouw, 12 november 196r.

Anbeek, Ton, De naturalistische roman in Nederland. Synthese stromingen en aspecten, Amsterdam 1982.

Anbeek, Ton, Na de oorlog. De Nederlandse roman $1945^{\circ}$ 1960, Amsterdam 1986.

Andrejew, Leonid, De roode lach, Amsterdam z.j.

Andrejew, Leonid, De smarten van Belgiē, Amsterdam 1918 (voorwoord december 1917).

Andrejew, Leonid, De gouverneur, Amsterdam r 961 .

Antoon Coolen en de waarheid en waarschijnlijkheid van het roman-gebeuren', in: De Maasbode, 7 mei 1936.

'Antoon Coolen in Tsjechoslowakije', in: Deurnesche Counant, 4 april 1947 .

'Antoon Coolen naar Duitschland', in: Noordbrabantsch Dagblad, 18 oktober 1937.

'Antoon Coolen uit trein gevallen. Lichte hersenschudding en schouderfractuur', in: Het Parool, 12 oktober $196 \mathrm{r}$.

'Antoon Coolen zestig jaar', in: NRC, 17 april 1957.

'Antoon Coolen, zooals hij leeft en werkt. Een interessant bezoek aan de Kempen te Waalre', in: De Week in Beeld, 30 augustus 1940.

AO-redaktie (bijdragen van I. Notermans, G.E.J. Peters en lacq. Sinninghe), Antoon Coolen. De stem van het oude Brabant, AO-reeks nr. 886, Amsterdam 17 november 196r.

Asselbergs, Willem Zie Anton van Duinkerken.

Augustin, Felix, 'Duitschers in Zevenburgen', in: Critisch Bulletin, jrg. 8 (juni 1937), 196-199.

Augustin, Elisabeth, Het patroon. Herinneringen, Amsterdam rogo.

Babylon, Frans, [Boekbespreking De vrouw met de zes slapers\}, in: Brabantia, jrg. 3 (1954), 88-89.
Babylon, Frans, 'Coolen in mijn jeugd en daama', in: Roeping, jirg. 32 (april 1957), 677-687.

'Bekende landgenoten thuis. Bij Antoon Coolen, de Brabander die land en volk beschrijft', in: Nieuwe Haagsche Courant, r 9 juli r 949.

Bekman, Bernard, 'De journalist Coolen', in: Roeping, jig. 32 (april r957), 634-636.

Beks, Maarten, Hendrik Wiegersma, enkeling in meervoud, Venlo r 982.

Belinfante, A.D., In plaats van bijltjesdag. De geschiedenis van de bijzondere rechtspleging na de tweede wereldoor. $\log$. Assen 1978 .

Bertrand, Cor (red.), Antoon Coolen Kind van ons Volk. 1897-1997 (Herdenking honderdste geboortedag Coolen), Asten 1997.

Beulens, Bert (red.). Antoon Coolen 1897-196x (Artikelen, gedichten en foto's bijeengebracht en ingeleid door Bert Beulens), Deurne r 980.

Beulens Bert, 'De glimlach van het Gooi', in: Jansink (red.), Antoon Coolen, Deurne 1997, 16-23.

Bevers, Ad, 'Bij de zestigste verjaardag van Antoon Coolen', in: de Volkskrant, 16 april 1957.

Blom, J.C.H., 'In de ban van goed of fout? Wetenschappelijke geschiedschrijving over de bezettingstijd in Nederland' (Oratie december 1983 ). Opgenomen in de bundel Crisis, Bezetting en Herstel. Tien studies over Nederland 1930-1950, (Nijgh en Van Ditmar Universitair) 1989.

Bloy, Léon, Joumal $1896-t 899$, tome I, Paris 1924 .

Bloy, Léon, Les dernierres colonnes de l'Eglise, Paris 1926 (oorspr. 1903).

Blijstra, R., 'De première van het toneelstuk "Vrij Volk"', in: Het Vrije Volk, 7 juni 1945.

'Boekbespreking Groei van een stad, in: Brabantia, jirg. I (1952), 89-9o.

Boersema, B.R.C.A., De Linie, $1946-1963$. Een weekblad in handen van Jezuieten, Amsterdam 1978. 
Bomans, Godfried, 'Toneelspelers vieren hun vrijheid", in: de Volkskrant, 6 juni 1945. Opgenomen in: Werken, deel IV, I $_{4}$.

Bomans, Godfried, Vlaamsche schrijvers tijdens de bezetting. Eerherstel aan Stijn Streuvels', in: de Volkskrant, 15 december 1945. Opgenomen in: Werken, deel IV, 43-45.

Bomans, Godfried, 'Antoon Coolen vijftig jaar', in: de Volkskrant, 19 april 1947. Opgenomen in: Werken, deel IV, 121.

Bomans, Godfried, 'De grote directeur' (Parlevink), in: de Volkskrant, to november 1954. Opgenomen in Werken, deel IV, 194.

Bomans, Godfried, 'Antoon Coolen, terugblik en voorspelling', in: Nieuwe Buitelingen, Amsterdam 1955. $158-163$.

Bomans, Godfried, Werken, deel I t/m VII, Amsterdam 1996-1999.

Boogaard, Frank van den, Een stoottroep der letteren, Den Haag 1987.

Bourbon, Louis de, 'Inkeer', in: De Gemeenschap, jirg, t6 (februari 1940), 83 .

Bourbon, Louis de, 'Mr. H. Marsman $\uparrow$ ', in: De Gemeenschap, irg. 16 (oktober 1940), 499-503.

Bourbon, Louis de, 'Bevrijd Vaderland. Antoon Coolens nieuwste schepping. Zeldzame vogel in Nederland' in: Elsevier en in: De Drie Landen, 28 sep. tember 1946 .

Bourbon, Louis de, 'Antoon Coolen 60 jaar', in: Roeping. jrg. 32 (april 1957), 637-653.

Boven, P.M.H. van en Anth. Mertens, 'Open brief aan dr. A. van Duinkerken', in: pamflet 'Ecclesia Militans', in: Vox Carolina, Nijmegen 11 april 1938.

Braak, Menno ter, 'Waarom Ketters?', 1930 Opgenomen in: Verzameld Werk, deel I, 357-358.

Braak, Menno ter, 'De moderne ketterjager', 1930. Opgenomen in: Verzameld Werk, deel 1, 387-399.

Braak, Menno ter, 'Provincialisme-Regionalisme', in: Het Vaderiand, 18 februari 1934. Opgenomen in: Verzameld Werk, deel 5, 106-112.
Braak, Menno ter, 'Veelschrijvers', in: Het Vaderland, 24 februari 1935. Opgenomen in: Verzameld Werk, deel 5. $448 \cdot 456$.

Braak, Menno ter, 'Succesboeken', in: Het Vaderland, 6 december 1936. Opgenomen in: Verzameld Werk, deel $5,275 \cdot 280$.

Braak, Menno ter, 'Bloed en Bodem. Jean Giono: weer een lente door Antoon Coolen vertaald, in: Het Vaderland, 14 november 1937.

Braak, Menno ter, Verzamela Werk, deel t- 6 , Amsterdam, 1950.

Braak, M. ter en E. du Perron, Briefwisseling 1930:1940, deel 1-4, Amsterdam 1962-1967.

Brand's Bierbrouwerij N.V., Honderd jaar Brand. De historie van een Limburgse brouwerij 1871-1971, Wylre 1971.

Bresser, Jan Paul, 'Kraanvogels in de Zwarte Peel. Terug naar het Brabantse Deume van de jaren dertig', in: Elsevier, 20 december 1997, 38.43.

Bresser, Jan Paul, 'Vader en pleegzoon. Ton van Reen in het spoor van Antoon Coolen', in: Elsevier, 13 februa ri 1999.99.

Brusse, Jan B., "Vrij Volk". Een plechtige manifestatie:' in: De Waarheid, 7 juni r945-

'Bij Antoon Coolen. Van Nick Carter-verslinder tot romanschrijver, "De Peel is de tragedie van de armoe $\mathrm{de}^{\prime \prime}$, in: De Maasbode, 13 juni 1930.

Bijnen, Bert, 'Humor en enige andere aspecten in De goede moordenaar van Antoon Coolen', in: lansink (red.), Antoon Coolen, Deurne t997,6r-70.

Bijvoet, Th. A.P. e.a. (red.), De Gemeenschap, $1925-1941$. Schrijversprentenboek 24, 's-Gravenhage 1986.

Calis, Piet, Het ondergronds verwachten, Amsterdam r.989.

Calis, Piet, Speeltuin der Titaanties, schrijvers en tijdschrif ten tussen 1945 en 1948, Amsterdam 1993.

Campert, Jan, [Recensie De drie gebroeders], in: NRCoch. tendblad, 22 november 1936 .

Charles, J.B., Van het kleine koude front, Amsterdam 1978 (oorspr. 1962). 
Cleerdin, Vincent, Omtreiken en Figuren, 's-Hertogenbosch 1914 .

Cleerdin, Vincent, Sagen van Brabant, Rotterdam 1929.

Cleerdin, Vincent en anderen, Zoo is Brabant. Een bijdnage tot de kennis van deze provincie, haar economische betekenis, haar uiterliik, haar geschiedenis, Amsterdam 1939.

Cleerdin, Vincent, Het Brabantse Dorp, Heemschutserie deel 44. Amsterdam I 944.

Coenen, Frans, [Recensie Dorp aan de rivier], in: Groor Nederland, irg. 33 (juni r 935), 669-670.

Coolen, Antoon. Zie aparte bibliografie hierachter.

Coolen bekroond. Het donkere licht een roman over het lot van het fabrieksmeisje in de grote moderne grootindustrie', in: De Maasbode, 12 juni 1930.

'Coolen en de film' (over Dorp aan de rivier), in: De lite raire gids, april 1934

Coolen de Oudere, Antoon, Helvoirt aan de Leye (van een biografie voorzien door Willem Hoffman), Baarm 1976.

Coster, Dirk, Brieven 1905-1930, Brieven 193I-1949. Brieven 1950-1956 (verzorgd door Henriētte LT. de Beaufort), in: Verzamelde Werken, Leiden 1961.

Dam, J.P.A. van den, en J.M.W.G. Lucassen, H.J.J. Maas, $1877 \cdot 1958$. Onderwijsman, literator en journalist, Tilburg 1976 .

de Bossche Krant (of Courant). Zie Provinciale NoordBrabantsche en 's.Hertogenbossche Courant.

'De drie gebroeders', in: De literaire Gids, december 1936

De gong. personeelsblad ter gelegenheid van het 125 . jarig bestaan van Nijgh \& Van Ditmar, Den Haag, 5 oktober 1962 .

'De grote voltige. Nieuwe roman van Antoon Coolen: afwezigheid van eigen opvatting', in: Het Vaderland, 5 april 1958 .

De kunst treedt aan. Première van "Vrij Volk", in: Het Farool, 7 juni 1945.

De roofmoord te Deurne', in: De Zuidwillemsvaart, 1 juni rgto (Rechtbankverslag van de zitting van 31 Mei te Roermond)
'De verwachting en de herinnering' (Recensie De urouw met de zes slapers), in: $N R C_{7} 5$ december 1953.

'De vrouw met de zes slapers: een geslaagd verhaal. Antoon Coolen schrijft "open briefkaart" over zijn dorp', in: Het Vrije Volk, $2 \mathrm{r}$ januari 1954.

Defresne, A., 'De bevrijde Antoon Coolen', in: De Groene Amsterdammer, 15 juni 1946.

Dekker, Ton, 'Ideologie en volkscultuur: een geschiedenis van de Nederlandse volkskunde', in: Ton Dekker, Herman Roodenburg en Gerard Rooijakkers (red.). Volksculturr. Een inleiding in de Nederlandse etnologie, Nijmegen 2000, 13.65.

Deurnesche Courant, lover Van Doorne Kwestie| 26 janu. ari $1945-1$ augustus 1947.

Deyssel, Lodewijk van, in: Nieuw Holland. Opgenomen in: Verzameld Werk, deel 4, Amsterdam z.j.

Dilling, K., De Peelstreek. Een Nederlandsch gebied voor landverhuizing en voedselproductie, (Uitgave der Nederlandsche Heidemaatschappij) Wageningen z.j. [waarschijnlijk 1920).

Dixhoorn, Frits van, 't Hoefke. Een dorp speelde circus, Eindhoven 1994

Donker, Anthonie, 'Litteratuur en Politiek in Duitschland', in: Critisch Bulletin, jrg. 5 (februari r934), $43 \cdot 47$.

Donker, Anthonie, [over Coolen en de Nobelprijs], in: De nieuwe stem, maandblad voor cultuur en politiek, jrg. 17 (januari 1962).

Dorsman, L, E. Jonker en K. Ribbens, Het zoet en het zuur. Geschiedenis in Nederland, Amsterdam 2000.

Douwes, Johan, 'Frankrijk lyrisch over roman van Antoon Coolen uit 1931', in: Troum, 13 september 1995.

Dubois, P., Een soor van geluk Memoranda III, Amsterdam 1989 .

Dubois, Piere, 'Antoon Coolen zestig jaar: Elementaire en natuurlijke wijsheid', in: Het Vaderland, 17 april 1957.

Duinkerken, Anton van, 'Op wandel met de Ravenzwarte', in: Roeping, irg. 2 (1923/1924), 138.

Duinkerken, Anton van, 'Het Lied van Brabant', in: Rocping, jrg. 2 (1923/24), 54-55. 
Duinkerken, Anton van, 'Peerke dat manneke', in: Roeping, irg. 5 (1927), $284-288$.

Duinkerken, Anton van, 'Een katholieke roman', in: De Gemeenschap, jig. 7 (1929), 102-105.

Duinkerken, Anton van, 'Het epos van de gloeilamp' in: De Trid, $x$ december 1929 .

Duinkerken, Anton van, Antoon Coolen. Winnaar van den Duizend-gulden-prijs', in: De Tijd, 12 juni 1930.

Duinkerken, Anton van, 'Het boek van de week: Serenitas, in: De Tijd, 26 november 1930.

Duinkerken, Anton van, 'Het boek als geschenk. Beroemde schrijvers en hoe zij het werden', in: De Tijd (Ochtendblad), zondag 30 november 1930.

Duinkerken, Anton van, 'Peelwerkers' (Het Boek van de Week), in: De Tijd, 3 december r 930.

Duinkerken, Anton van, 'De goede moordenaar' (Het Boek van de Week), in: De Tijd, r6 december r93r.

Duinkerken, Anton van, 'Provincie of Europa?', in: De Tijd op Zondag, 18 juni 1932.

Duinkerken, Anton van, 'De Schoone Voleinding' (Het Boek van de Week), in: De Tijd op Zondag, 25 november 1932 .

Duinkerken, Anton van, 'De vier jaargetijden', in: De Tijd, g oktober 1934 .

Duinkerken, Anton van, 'Rijksbisschop Ludwig Muller', in: De Gemeenschap, jrg. to (oktober 1934). $817-829$.

Duinkerken, Anton van, 'Nieuw werk van Antoon Coolen. Uit het kleine rijk', in: De Tijd, 17 december 1939.

Duinkerken, Anton van, 'Een voetreis naar Rome. Het veelomstreden dichtwerk van Bertus Aafjes', in: De Tijd, 5 oktober 1946 .

Duinkerken, Anton van, 'Uitgedaagd verweer. Het funeste consigne. Feiten en teksten', in: De Tijd, It januari 1947.

Duinkerken, Anton van, 'A. Coolen als reisverhaler. Zijn Tsjechische suite. Het menselijk geluk', in: $D e$ Tijd, zaterdag 16 oktober 1948. Opgenomen in: Verzamelde Geschriften, deel III, 925-928.
Duinkerken, Anton van, Antoon Coolen. Een inleiding tot zijn werk met enkele teksten, handschrift, portretten en ech bibliografie, (Reeks Schrijvers van Heden onder auspicièn van de Maatschappij der Nederlandse letterkun. de) Den Haag r 949 (Voorwoord 23 oktober 1946 ).

Duinkerken, Anton van, 'Is er een behoefte aan een vereniging van katholieke letterkundigen in

Nederland?, in: Roeping, jirg. 24 (februari 1949), 129 136.

Duinkerken, Anton van, 'Grondslag der standvastig. heid. Vertelsels van Antoon Coolen. Onder de Canadassen', in: De Tijd, 10 december 1949.

Duinkerken, Anton van, 'Christelijke inspiratie in de romantiek', in: Roeping, jirg. 27 (november 1951), 1623.

Duinkerken, Anton van, 'Stand en toekomstkansen van letteren en toneel in Noord-Brabant', in: Brabantia, jing. 4 (1955), roo.

Duinkerken, Anton van, 'Antoon Coolen en de moraal', in: Brabantia, jrg. 6 (april r957), 96-108.

Duinkerken, Anton van, 'Omgang met Antoon Coolen', in: Rocping, jrg. 32 (april 1957), 619-628.

Duinkerken, Anton van, Ter gedachtenis aan Antoon Coolen', in: Brabantia, jrg, Io (r96r), 233-236

Duinkerken, Anton van, In memoriam Antoon Coolen. De grote levenswaarde van zijn werk', in: De Tijd, ro november r 961 .

Duinkerken, Anton van, Verzamelde Geschriften, ded I Vertelling en vertoog, deel II Debat en polemiek, deel III Historie en kritiek, Utrecht/Antwerpen 1962.

Duinkerken, Anton van, Brabantse Herinneringen, Utrecht/Antwerpen 1964

Duinkerken, Anton van, Emiel van Hemeldonck en Jan Naaijkens, Rapport van de jury betreffende de romanprijs van de Groot-Kempische Cultuurdagen te Hilvarenbeek', in: Brabantia, jrg. 10 (196r), 212 216.

Durnez, Gaston, Felix Timmermans een biografie, Tielt 2000.

Engelman, Jan, 'De goede moordenaar', Ityposcript van) radiorede $\mathrm{KRO}, 4$ maart 1932 . In FPC (zie archivalia). 
Engelman, Jan, 'Recensie] De man met het Jan Klaassenspel, in: De Nieuwe Gids, 28 maart 1935. 310.

Engelman, Jan, 'De Kunst op Straat', in: $D e$ Gemeenschap, jirg. 13 (september 1937), 425-429.

Engelman, Jan, [IE] rubriek 'Hagel', in: $D e$ Gemeenschap, jrg to (juli 1934), $484-485$.

Engelman, Jan, 'Afscheid Antoon Coolen', in: de Volkskrant, 14 november $196 \mathrm{r}$.

Feber, L.J.M., 'Roman en vertelling: beoordeel een kunstwerk naar wat het is', in: De Tijd, 3 februari 1939.

Fens, Kees, Uit een klein rijk: Stad aan de Maas, nieuwe roman van Antoon Coolen', in: De Tijd, 20 november 1960 .

Gallimard, Pléiade, Töme: Joumal, Poèmes, Essais, Paris 2995.

Gedenkschrift zur Verleihung des Joost van den Vondel. Preises 1960 der gemeinnützigen Stiftung FVS zu Hamburg durch die Westfalische Wilhelmus. Universität zu Münster an Antoon Coolen und Professor Dr. Max Lamberty Hamburg 196r.

Giono, Jean, 'Preface', in: Antoon Coolen, Le Bon Assassin, Paris r936, 1-XV.

Giebels, Lambert J., Beel. Van vazal tot onderkoning. Biografie 1902-1977, Den Haag/Nijmegen 1996.

Graaff, Chr. de, 'Antoon Coolen zet de klok terug', in: De Nieuur Eeuus 5 december 1935.

Graaff, Chr. de, 'Bezonken Verdichtsels', in: $D e$ Maasbode, ir januari 1942.

's-Gravesande, G.H., Sprekende schrijvers, 's-Gravenhage 1979.

'Grave gezien door een temperament', in: $D e$ Gelderlander, 17 november 1960 .

Greshoff, I., "Een roman van schimmen. Coolens "De vrouw met de zes slapers", in: Het Vaderland, I3 februari 1954

Groeneweg, Ronald, Antoon Coolen: Derde van der Helst. Een onderzoek naar vergeten worden, (doctoralscriptie Erasmus Universiteit, ongepubliceerd typoscript) Rotterdam 1992.
Groeneweg, Ronald, 'Eenleek schrijft een "medische" roman. Antoon Coolens Dorp aan de rivier en de kritiek van twee rooms-katholieke artsen', in: O'dokter (blad van de medische faculteit, Erasmus Universiteit), juli 1992.

Groeneweg, Ronald, 'Geen enkele concessie. Antoon Coolen en de Tweede Wereldoorlog', in: Biografie Bulletin, jrg.3 (1993) nr.1, 246-259.

Groeneweg, Ronald, 'Antoon Coolen en het katholicisme', in: Jaarboek van het Katholiek Documentatic Centrum, jirg. 23. Nijmegen 1993. 55-81.

Groeneweg, Ronald, 'Boertje in Holland, heertje in Brabant', in: Jansink (red.), Antoon Coolen, Deurne 1997. 38.52.

Hamsun, Knut, Pan. Uit de papieren van hitenant Thomas Glahn, Amsterdam 1975 (oorspronkelijk 1894).

Haterd, Lex van de, 'Antoon Coolen. De Deurnese jaren 1933-1938', in: Jansink (red.), Antoon Coolen, Deurne $1997,24 \cdot 34$.

Haterd, Lex van de, 'Leven en werk van Hendrik Wiegersma. Een curieus heer', in: Hoogbergen (red.), Hendrik Wiegersma, Tilburg 1998, r1-32.

Have, Wichert ten, De Nederlandse Unie Aampassing, vernieuwing en confrontatie in bezettingstijd 1940 1941, Amsterdam 1999 .

Hazeu, Wim, Slauerhoff. Een biografie, Amsterdam/ Antwerpen 1995.

Heeren, H.M., Legendevorming rond Antoon Coolen. Geboren Zuidlimburger', in: PNHC, 27 juni 1930.

Heeren, J.J.M., 'Ouwerling en Coolen', in: Brabantia, jrg. 6 (april 1957), 110-117.

Heijden, Marcel van der, 'Brabant krijgt literair een eigen stem', in: Van den Eerenbeemt (red.), Geschiedenis wan Noord-Brabant, deel 2 1890-1945 Emancipatic en industrialisering. Amsterdam/ Meppel r996, 397-406.

Heijden, Marcel van der, 'Wiegersma en Engelman. Een vriendschap in brieven', in: Hoogbergen (red.), Hendrik Wiegersma, Tilburg 1998, 125-155.

Heijman, H., 'Antoon Coolen en Heeswijk', in: Roeping, jrg. 32 (april 1957), 629-633. 
Hello, Ernest, L'homme, la vic, la science, Part, Paris $19 \times 8$ (oorspr.1872).

Hello, Ernest, Le Siècle. Les Hommes et les Idées, Paris 1920 (oorspr. 1895).

Helman, Albert, 'Het kleine kinderrijk', in: De Groene Amsterdammer, 13 januari 1940.

Helman, Albert, 'Inleiding' bij; Antoon Coolen e.a. Vrij Volk(toneelstuk), Amsterdam I juni r 945.

Helman, Albert, Mijn vriend Pieter, BeverenAntwerpen $\mathrm{rg} 8 \mathrm{o}$.

Henkes, Barbara, 'Voor Volk en Vaderland. Over de omgang met wetenschap en politiek in de volkskunde', in: Volkseigen. Ras, culturer en wetenschap in Nederland. 1900-1950. (Elfde Jaarboek Nederlands Instituut voor Oorlogsdocumentatie) Amsterdam $2000,62-94$.

'Het drama te Deurne', in: De Zuidwillemsvaart, woens. dag 13 april rgro.

'Het geschenk: een verzetsnovelle' (Letterkundige kroniek), in: NRC, 1 maart 1947.

Het Gouden Gymnasium (Iubileumboek Abdij van Berne), Heeswijk 1936.

Het Licht, lover Van Doorne kwestiel 20 januari 1945 . 13 september 1947 .

Heuvel, Hans van den, Gerard Mulder en Willem Breedveld, Het vrije woord: de illegale pers in Nederland, 1940-1945, 's-Gravenhage 1990.

Hillenius, D., 'Bezettingstijd', in: VNG-magazine, 22 oktober 1999.

Hofhuizen, Herman, 'Antoon Coolen, een geboren verteller', in: De Tid, 19 januari 1957.

Holierhoek, Jeanne, 'Over en weer: Antoon Coolen en lean Giono', in: Filter, tijdschrift voor vertalen en vertaalwetenschap, jirg. 6 (december 1999), 40-47.

Hollenberg, P., Gerlachus van den Elsen ord. Praem, Emancipator van de boerenstand 1853-1925. 's-Hertogenbosch 1956.

Hoogbergen, Th.G.A.(red.), Hendrik Wiegersma $189 \mathrm{I}$ rg69: medicus-pictor, Tilburg 1998.

Houwink, Roel, [Recensie Zegen der goedheid], in: NRC, 5 mei 1934 -
Huiskamp, R., 'Hendrik Nicolaas Ouwerling', in: Brabantse biografieén, deel 2, Amsterdam/Meppel/'sHertogenbosch 1994, 99-102.

Huizinga, J., In de schaduw van morgen, Haarlem 1936 (oorspr. 1935).

'Huldiging Antoon Coolen', in: Jaarboek Provinciaal Genootschap Noord-Brabant, 's-Hertogenbosch 1940. $87-91$.

Hurk, Alph. W. van den, 'Antoon Coolen als Heeswijkse gymnasiast', in: Berne XXXVIII, Heeswijk, juli 1985 .

Iddekinge, P.R.A. van, 'Spreekbuizen van de haat', in: Schuursma e.a. (red.), De Eerste Wereldooriog, deel 4 , Amsterdam 1975/1976, 594-599.

"Is de tooneelschrijfkunst failliet? "Vrij Volk": een plechtige manifestatie van vervelendheid, in: Metro, 26 juni r 945 .

Iven, Willem, Mensen in de Peel, (Uitgeverij De Distelbosch) 1978 (oorspr. 1975).

laarboek, Als het wintert, Bilthoven r93r.

laarboek Provinciaal Genootschap Noord-Brabant, 's-Hertogenbosch 1940.

Jaarsma, [Recensie Dorp aan de rivier], in: NRC. 4 december 1934 .

Jager, J.L de, 'De streekromancier als sociograaf: H.H.J. Maas $(1877-1958)$ over de Peel', in: Romantropologie. Essays over antropologie en literatuur, (uitgave 16. Antropologisch-sociologisch centrum UVA) Amsterdam 1979, $112-129$.

Jansink, Gerard (red.). Antoon Coolen $1897-1961$ (lezingenbundel bij gelegenheid van de honderdste geboortedag van Antoon Coolen), Deurne 19 april 1997.

Jolles, J.A., De Schuttersgilden en Schutterijen van Noord. Brabant, deel 1 en 2, 's-Hertogenbosch 1933-1934.

Jong, A.M. de, [Recensie Hun grond verwaait], in: Het Volk, 27 februari 1928 .

Jong, A.M. de, [Recensie Het donkere licht], in: Het Volk, 19 december 1929 .

Jong, A.M. de, 'Peelwerkersvan Antoon Coolen', in: Hitt Volk, 26 mei $193 \mathrm{I}$. 
long, A.M. de, 'Het nieuwste boek van Antoon Coolen. De Goede Moordenaar', in: Het Volk, 18 januari 1932.

Jong, A.M. de, 'Boek van schoone menschelijkheid. Evangelisch zuiver Katholicisme: De Schoone Voleinding', in: Het Volk, januari 1933.

Jong L de, Het Koninkrijk der Nederlanden in de Tweede Wereldoorlog, deel $1 \mathrm{tm} 8$,'s-Gravenhage $1969-1978$.

Jong, Dom. P. de, Onze Lieve Vrouw van Ommel en Het klooster Mariaschool, Achelse Kluis r960.

joosten, LM.H., Katholieken en fascisme in Nederland 1920-1940, Hilversum 1964.

Kapteijns, Harry, 'Hilvarenbeek', in: Brabantia Nostra, irg. 9 (augustus 195I). 324-325.

Kapteijns, Harry, 'De streekroman', in: Brabantia, jrg. 5 (1956), 257-264.

Kapteijns, Harry, 'Antoon Coolen, De grote voltige', in: Brabantia, jrg. 7 (januari 1958), 23-24.

Kéchichian, Patrick, 'Coolen entre Dieu et diable. Giono l'a salué voici soixante ans. On réédite son seul roman traduit. Un chef-d'oeuvre', in: Le Monde, 8 september 1995 .

Kelk, C.J., 'Bij de dood van Antoon Coolen', in: De Groene Amsterdammer, 18 november 196r.

Kelk, C.J., Ik kéek alleen, Brugge r968.

Kelk, C.J., Wie ik tegenkwam, 's-Gravenhage r $98 \mathrm{r}$.

Klap, Kees, 'Kunst en streekcultuur in het Nieuwe Brabant', in: De Spiegel, nr. 51, 20 september 1952, $\mathrm{II} \cdot 13$

Klemperer, Victor, Tot het bittere einde. Dagboek r933. 1945. Amsterdam 1997.

Knuvelder, G., Vanuit Wingewesten, Hilversum r 930.

Koelewijn, Jannetje, 'Waarom kunnen wij geen televisiedrama maken dat meer is dan een streekverhaal waarvoor een blik Nederlandse acteurs is opengetrokken?: De KRO wordt weer katholiek met Antoon Coolen', in: Vrij Nederland, 10 februari 1990.

Koolhaas, Marnix, 'Een Brabants.Friese schaatslegen de van Antoon Coolen', in: SchaatsSport, nr.3, okto ber 1998, 28-29.
Kools, Tij, De na-oorlogse relatie tussen Antoon Coolen en Huub van Doome, (uitgave Tij Kools) Deurne 1986.

Kroon, Theo, 'Ik herinner mij', deel 3 'Antoon Coolen' [Interview met drs. Felix Coolen], in: Katholiek Nieuusblad, $2 \mathrm{r}$ april 1989 .

[Kuitenbrouwer, Henk], 'Hagel', in: De Gemeenschap, jirg. 9 (1933), r98.

'Kunst in de hoofdstad' [Recensie De klokkengieter], in: De Gooi-en Eemlander, 23 januari 1938.

Kusters, Wiel, 'Limburg', in: Willem van Toorn (red.), Querido's letterkundige reisgids van Nederland, Amsterdam 1983.

Kuyle, Albert (pseudoniem van Louis Kuiten. brouwer), 'De achterban', in: De Gemeenschap, jig. 5 (1929), 3 I4.

Kuyle, Albert, 'Les Femmes savantes', in: De Gemeenschap, jrg. 5 (1929), 495-496.

Kuyle, Albert, Alarm, Utrecht 1933.

Kuyle, Albert, 'Nieuwe normen', in: Houwink (red.), Rondom het boek 1936 (Boekenweekgeschenk van 1936), $129-135$.

Kuypers, Paul, [P.K.], 'De grote voltige. De nieuwe roman van Antoon Coolen. Geschrift rond de figuur van dr. Hub. Van Doorne', in: Helmondsche Courant, 30 november 1957 .

"Lancet" snijdt in eigen vlees. Verontwaardiging bij Eindhovense burgers en studenten over vuilspuite rij', in: Groot Eindhoven, [najaar] 1962.

Leeuwen, Fred van (red.), Pierre Kemp (Schrijvers. prentenboek 7), Amsterdam $196 \mathrm{t}$.

Leeuwen, W.L.M.E. van, 'Romantische heldenvere ring bij Coolen', in: Critisch Bulletin, jrg. 6 (mei 1935), 134-137.

'Lentebloesem', in: Algemeen Handelsblad, 31 augustus 1921.

'Lentebloesem', in: De Haagsche Post, 19 oktober 1921.

Lewin, Lisette, Het clandestiene boek 1940-1950, Amsterdam 1983.

Lichtveld, Lou, zie Albert Helman.

Lutkie, Wouter, Doctor Moller, bundel overdrukken uit de Nieuwe Tilburgsche Courant, 1921. 
Lutkie, Wlouter]., Onze rol spelen. Een bloemlezing uit het werk van Wouter Lutkie pr (Met een voorwoord van Henk van Gelre en een inleiding van L.A. van der Linden), Nuland $z$;.

Lutkie, W[outer]., Vincent Cleerdin en Richard Kralik, Richard Kralik, Oisterwijk 1926.

Maas, A.C., 'Het toneelwerk van Antoon Coolen', in: De Vacature, 14 en 28 augustus 1975.

Maas, H.H.J., Het goud van de Peel, Laren 1944 (oorspr. rgog).

Maas, H.H.J., Peelomnibus: De verstoteling. Landelijke cenvoud. Het goud van de Peel (gepresenteerd en ingeleid door Toon Kortooms), De Bilt zj.

Man, Herman de, 'Uit de school van meester Streuvels' (rubriek 'Eigen en Vreemde Letteren'), in: De Maasbode, 1929.

Martens, F., Kent u ze nog .. De Deurenaren?, Zaltbommel 1974 .

Marsman, H., 'Der Weg zurūck: Korte aantekeningen over nieuwe Hollandse romankunst', in: De Nieuwe Eeuus 9 juní 1932.

Marsman, H., 'Derde dimensie en Europees peil', in: De Nieuwe Eeuw, 23 juni r932. Opgenomen in: Verzameld Werk, deel III Critisch Proza, Amsterdam $1938,263$.

Marsman, H., 'Roman in tafereelen', in: De Groene Amsterdammer, 13 februari 1937.

Meeberg, Daan van de, 'Antoon Coolen en de sociale wetenschap', in: Rocping, irg. 32 (april 1957), 666671.

Meer de Walcheren, Pieter van der, 'Lentebloesem door Anton [sic) Coolen', in: De Nieuwe Eeuu, oktober 1921, 19.

Meer de Walcheren, Pieter van der, [Recensie Dorp aan de rivier), in: Roeping, irg. I4 (oktober 1935). 4449.

Meer de Walcheren, Pieter van der, Mensen en God, deel 1, Utrecht r940; deel 2, Utrecht 1944 .

Meer de Walcheren, Pieter van der, Mijn Dagbock rgoo-19II, Brugge z.j (achtste druk met naschrift van Kerstmis r954 en januari 1957).
Meertens, P.J. en Anne de Vries (red.), $D e$ Nederlandsche Volkskarakters, Kampen 1938.

'Meneer Coolen', in: Brabantia, irg. 6 (april 1957), 131.

Mertens, Anthonie (A.M.), 'Het laatste gesprek met Antoon Coolen', in: De Linie, 18 november $196 \mathrm{r}$.

Michaèl, Hubert, e.a. (red.), Nederlandse literaire prij. zen $1880-1985$, 's-Gravenhage 1986 .

Middendorp, [Recensie Hun grond venwaait], in: De Groene Amsterdammer, 14 januari 1928.

Monté, Gerard, 'Antoon Coolen en zijn spel met de werkelijkheid', in: Maatstaf, jig. 44 (1996) nr. to, 93-100.

Mortel, Jan van den en Marjo Bouwmans, Zeilbery. Van Gehucht tot parochie, Deurne r 989.

Mulder, Gerard, 'Van Doorne I. Antoon Coolens eenzame strijd tegen meneer Hub en meneer Wim. "De hand die vandaag de voorzittershamer van de Oranjevereniging hanteert, hief gisteren nog het glas met de Duitschers.", in: Vrij Nederland, 4 december 1976 .

Mulder, Gerard, 'Van Doorne II. Antoon Coolens kleine oorlog tegen meneer Hub en meneer Wim. 'Durft gij zeggen dat gij niet met Duitschers at in uw eigen restaurant Lido?", in: Vrij Nederland, it december 1976 .

Mulder, J.W., Kunst in crisis en bezetting. Een onderzoek naar de houding van Nederlandse kunstenaars in de periode 1930-1945. Utrecht 1978 .

Mulisch, Harry, De toekomist van gisteren, Amsterdam t972.

Multatuli, Volledige Werken, deel I-7. Amsterdam r973.

Naaijkens, Jan, Biks 5. Een verslag over de GrootKempische Culturrdagen te Hilvarenbeek van $1947^{\circ}$ 1971 , 's-Gravenhage [etc.] juni 1971 .

Naaijkens, Jan, Leer mij ze kennen _- de Brabanders, Leiden 1967. 
Nationale Snipperdag, april r954. Hieraan doen mee: Boek van Nu, Critisch Bulletin, De Gids, Kroniek van Kunst en Kultuur. Maatstaf. De Nieuwe Stem, Ontmoeting, Fodium en Roeping. Dit nationale tijdschrift werd uitgegeven in plaats van de afzonderlijke aprilnummers van 1954 ter gelegenheid van de Tiende Bevrijdingsdag 5 Mei 1945-5 Mei 1954.

Nieskens, I. en A. Schreurs (red.), Het Vaderland spreekt tot de jeugd (met een voorwoord van oudminister prof.dr. G. Van der Leeuw). Utrecht/Antwerpen z.j. [1947].

Nietzsche, Friedrich, De Antichrist, Amsterdam 1973.

Nietzsche, Friedrich, De urolijke wetenschap, De wil tot lijden en de medelijdenden, Amsterdam 1994.

'Nieuw materiaal', in: De Maasbode, 8 december 1929.

Nifieuwenhuis], Jan, 'Een roman van Antoon Coolen', in: De Maasbode, 3 r juli 1926.

Nieuwenhuis, Jan, 'Uit 't land van de klot: het nieuwe boek van Antoon Coolen', in: De Maasbode, 22 november 1930 .

Nilieuwenhuis], Jan, 'De Boekenweek. Een cadeautje van de schrijvers aan hun begunstigers: in: $D e$ Maasbode, 7 mei 1932.

Nlieuwenhuis], Jan, 'Ernst en luim: een die er is, en een die er nog moet komen' (Recensie De man met het Jan Klaassenspel, in: De Maasbode, 25 november 1934.

Nlieuwenhuis], Jan, De roman van een dokter. Met wat vertelsels uit het dorp', in: De Maasbode, 16 maart 1935 .

N[ieuwenhuis], Jan, 'Over de familie van Taeke: Antoon Coolen's verhalen van het Friesche genees. herengeslacht', in: De Maasbode, 23 januari 1937.

N[ieuwenhuis], Jan, 'Het regionalisme. Verhalen uit de Kempen' [Recensie Herberg In 't Misverstand], in: De Maasbode, 4 februari 1939.

Noort, B. van, 'Antoon Coolen: De vier jaargetijden', in: De Opreghte Haarlemsche Courant, 13 oktober 1935.

Nooteboom, Uri, Het Land van de Sniedersen. Biografische roman uit de Kempen, Dommelen 1948. Voltooid door Antoon Coolen.
Nord, Max, 'Antoon Coolen wordt vijftig jaan: betee kenis van zịn werk', in: Het Parool, 15 april 1947.

Nord, Max, Achtenwaarts, Amsterdam 1998.

Oomes, Piet, Joost van den Vondel, (Davids Fonds Keurreeks, nt. 19) Amsterdam 1938.

Oomes, Piet, Ontmoetingen, Brugge [etc.] 1957.

Oomes, Piet, 'De grote voltige door Antoon Coolen. Een hoogtepunt in de reeks van zijn Brabantse romans', uitgesproken voor de KRO radio op zondag 24 november 1957 in de rubriek Het Boekhuis. Typoscript van de lezing in WE (zie archivalia).

Oomes, Piet, 'Antoon Coolen. Persoonlijke herinneringen', in: Roeping, jirg. 35 (r960), 36r-363.

'Op bezoek bij Antoon Coolen. Een nieuw boek op verschijnen. Voorkeur voor Slauerhoff als romanschrijver', in: De Telegraaf, 22 oktober 1936.

Oudheusden, J.L.G. van, Brabantia Nostra; een geweste. lijke beweging voor fierheid en 'schoner' leven 1935 . 195I, Tilburg 1990.

Ouwerling, H.N., Uit donkere gewesten, (Turfjes serie nr. 3 door Tij Kools) Deurne 1976 (oorspr. 1907).

Ouwerling, H.N., Geschiedenis der dorpen en heerlijkhe den Deurne, Liessel en Vlierden, Deurne 1933

Ovidius, Metamorphosen, Amsterdam 1993.

Perron, Eddy du, 'Holländische Literatur', in: Die Sammlung, augustus 1934. Opgenomen in: Verzameld Werk, deel 6, 641-655.

Perron, Eddy du, 'Antoon Coolen: De drie gebroeders'. in: Groot Nederland, november 1937. Opgenomen in: Verzameld werk, deel $6,213-216$.

Perron, Eddy du, Brieven, Amsterdam $1977 \cdot 1984$.

Perry, Jos, Roomsche kinine tegen roode koorts. Arbeidersbeweging en katholieke kerk in Maastricht 1880 - 1920 , Amsterdam 1983.

Plas, Michel van der, Mooie vrede cen documentaire over Nederland in de jaren 1945-1950, Utrecht 1966.

Plas, Michel van der, Interview met Friso Wiegersma', in: Elseviers Weekblad, 7 juni 1986. 
Spierings, Kees, 'Het openluchtspel in NoordBrabant, seizoen 1956', in: Brabantia, jrg.5 (1956), 299-305.

'Staag doorwerken om door de beproeving heen te komen. Een advies van een rustig en eenvoudig verteller: Antoon Coolen', in: De Telegruaf, 7 augustus 1940.

'Stad aan de Maas drama van allure: boek vol verhalen van Coolen', in: Het Parool, 25 november r 960.

Starink, J., Antoon Coolen, provincie of wereld?. (Inleiding bij Tentoonstelling t.g.v het vijftigjarig bestaan van de R.K. Openbare Leeszaal en Bibliotheek te Tilburg 30 mei tot 14 juni 1964) z.p. z.j..

Stekelenburg, H.A.V.M. van, De grote trek. Emigratic vamuit Noord-Brabant naar Noond-Amerika. 1947 . 1963. Tilburg 2000.

Streuvels, Stijn, De Oogst, Amsterdam 1972 (oorspr. 1900).

Streuvels, Stijn, Ingooighem, Brugge r 980 .

Stuiveling, Garmt, 'Teugdervaringen als inspiratie', in: Haagsch Dagblad, 13 april 1957.

Stuiveling, Garmt, 'De tijd verandert', in: Haagsch Dagblad, 3 december 1960 .

Stuiveling, Garmt, 'Coolen Redivivus', in: Het Boek van $\mathrm{Nu}$, jig. 53/54 (2000), 107-108.

Swinkels, Carel, 'Stad aan de Maas; een nieuwe streekroman van Antoon Coolen', in: De Linie, 3 december 1960 .

Swinkels, Carel, Help me de brig over? Klein zwartboek: im piam memoriam amici Antoon Coolen, (uitgeveri) Tij Kools) Deurne r990.

Taels, Joris, Antwon Coolen. Zijn werk - zijn kanst, (Proefschrift Katholieke Universiteit Leuven, niet uitgegeven) $194 \mathrm{r}$.

Tegenbosch, Lambert, 'Losse notities over het Brabants studentengilde', in: Brabantia Nostra, jrg. 9 (augustus 1951), 322.

Tegenbosch, Lambert, 'Na I 6 jaar zwijgen', in: Oost. Brabant, 30 januari 1954 .
Tegenbosch, Lambert, 'De Streekroman. Bij de zestig. ste verjaardag van Antoon Coolen', in: Roeping, jig. 32 (april 1957), 656-665.

Tegenbosch, Lambert, 'Nieuwe roman van Antoon Coolen "De grote voltige" vertelt van de industria lisering en een wonderlijk industrieel genie', in: Oost-Brabant, 16 november 1957.

Tegenbosch, Lambert, 'Poging tot begrip' [over de Van Doorne kwestie], in: de Volkskrant, 6 december 1962.

Tolstoj, LN., Anna Karenina, Amsterdam I995.

'Uit Brabant' [Recensie De rauwe grond en Hun grond verwaait], in: De Niruwe Leidsche Courant, 12 okto ber 1929.

Uyldert, Maurits, [ter gelegenheid van de CW. van der Hoogt prijs\}. Letterkundige Kroniek, in Handelsblad, 22 juni 1930.

Uyldert, Maurits, 'De drie gebroeders', in: Algemeen Handelsblad, 16 januari 1937.

Uyldert, Maurits, 'Herberg in 't Misverstand', in: Algemeen Handelsblad, 27 maart 1939.

Vaartjes, Gé, $U$ hebt mij den weg gewezen. Brieven van Herman de Man aan Streuvels, Amsterdam 1996.

Vaartjes, Gé, Herman de Man. Een biografie, Soesterberg 1999.

Valkenier, Frans. Zie Frans van der Ven.

'Van Doornes ondernemen geen stappen tegen Sater'. in: Eindhovens Dagblad, 17 november 1976.

Vegt, J. van der, Adriaan Roland Holst. Biografie, Baarm 2000.

Ven, D.J. van der, Ons eigen volk in het feestelijk jaar, Kampen z.j.

Ven, Frans van der (pseud. Frans Valkenier), 'Notities. Rechtsbegrippen van den Olympus', in: Brabantia Nostra, jirg. 7 (maart 194r), 153.

Venema, Adriaan, Schrijvers, uitgevers en hun collabona tie, deel 1 Het Systeem, Amsterdam 1988.

Venema, Adriaan, Schrijvers, uitgevers en hun collabona tie, deel 2 De harde kem, Amsterdam 1989. 
Venema, Adriaan, Schrijvers, uitgevers en hun collaboratic, deel 3 a De kleine collaboratie, Amsterdam 1990.

Venema, Adriaan, Aristo revisited, Baarn 1990.

Vergilius, Het boerenbedriif, 'Georgica', in: Verzamelde Gedichten, Amsterdam 1988.

Verhoeven, Cornelis, Herinneringen aan mijn moeder. taal, Baarn 1978 .

Vermeulen, Hans, De Maasbode; de bewogen geschiede nis van 'De beste courant van Nederiand', Zwolle 1994.

Verre, Tony van, Tony van Verre ontmoet Albert Helman, Bussum r 980.

[Verslag vergadering Commissie van de Maatschappij der Nederlandsche Letteren], in: De Maasbode, ri juni 1930.

Vestdijk, Simon, 'Sacramentele bierkelders', in: NRC, 26 november 1938 .

Vestdijk, Simon, De Schandalen, 's-Gravenhage/ Rotterdam 1983 (oorspr. 1953).

Vlerken, Peter van, 'Glimlach in barre Brabantse tijden. Antoon Coolen 25 jaar geleden overleden', in: Eindhovens Dagblad, 8 november 1986.

Vliet, H.T.M. van, 'Nawoord' en 'Verantwoording', in: Antoon Coolen, Dorp aan de rivier, (jublileumuitga. ve ter gelegenheid van de rooste geboortedag van Antoon Coolen) Amsterdam 1997, 229-261.

Vos, R., Niet voor publikatie: de legale Nederlandse pers tijdens de Duitse bezetting, Amsterdam 1988.

Vree, Frank van, De Nederlandse Pers en Duitsland. 1930-1939. Een studie over de vorming van de publieke opinic, Groningen 1989 .

Vries, Jan de, De wetenschap der volkskunde, (serie Hoeksteenen onzer Volkskultuur) Amsterdam ז941.

Wael, Willem de, 'Nee! Ik laat me er niet onder krijgen: Het leven is vaak droevig' linterview met Louis de Bourbon], in: De Gelderlander Pers, 17 augustus 1974.

Walch, Frans, 'Anton Roothaert', in: Brabantse Biografieèn, deel 3. Amsterdam/Meppel 1995, I02. 106.
Walch, Frans, Roothaert, een biografie, Baarn 1996.

Walravens, Jan, 'Lonkend perspectief of afschrikwek. kend toekomstbeeld? Het Welvaartsplan voor Noord-Brabant (1947-1949)', in: In verband met Brabant (Jubileumboek PON), Tilburg 1997, 15-34.

Warren, Hans, 'Coolen schreef roman voor 't eerst in Is jaar', in: Provinciale Zeeuwsche Courant, 30 januari 1954 .

Warren, Hans, De grote voltige. De ontwikkelingsgang van een brabantse dorpsgemeenschap. Antoon Coolen: de rijke ervaring van meer dan vijftig jaar' (Letterkundige kroniek), in: Provinciale Zeeuwsche Courant, december 1957.

'Week-end van Dietsche Waranda en Belfort', in: Dietsche Waranda en Belfort, jubileumnummer 1950, 311 .

Werkman, Hans, Tjerk van Taeke, Cis den Dove, Mammeke, de Pale Pie', in: Nederlands Dagblad, 23 augustus 1997 .

Werumeus Buning, J.W.F., 'Het Donkere Licht. Sober en sterk proza, met zijn kracht en gebreken. Antoon Coolen's natuurliike zuiverheid en onnatuurlijke literatuur' (Kroniek der Letteren), in: De Telegraaf, 17 juni 1930.

Werumeus Buning, I.W.F., [Recensie De man met het Jan Klaassenspel], in: De Telegraaf, 28 december 1933.

Werumeus Buning J.W.F., 'De vier jaargetijden. Een eenvoudig stuk in een mooie opvoering", in: $\mathrm{De}$ Telegraaf, oktober 1934 .

Weijers, Ido, Terug naar het behouden huis. De Utrechtse School en de Nederlandse roman 1945-1955. Rotterdam r 991 .

Wiegersma, Hendrik, Volksizunst in de Nederlanden. Klein-beeldhouwwerk, Deurne $194 \mathrm{I}$.

Zaal, Wim, De Herstellers, lotgevallen van de Nederlandse fascisten en van Wouter Lutkie's tijdschrift Aristo, Utrecht [etc.] 1966.

Zola, Emile, Het beest in de mens, Amsterdam 1996 (oorspr. La bête humaine, 189o). 


\section{Bibliografie Antoon Coolen}

Achter de boekuitgaven is tussen [.] aangegeven naar welke druk de pagina's in de tekst verwijzen. Als er geen vermelding is, verwijzen de pagina's naar de eerste druk.

Voor deze bibliografie is dankbaar gebruik gemaakt van Ton Renes' Bibliografie van Antoon Coolen en van de bibliografie in Antoon Coolen: Derde van der Helst van Ronald Groeneweg, die in samenwerking met Felix Coolen tot stand is gekomen.

\section{Romans, novellen en bundels}

Opinies,

Aug. Pellemans, Helmond 1914.

Lentebloesem.

Het Nederlandsch Boekhuis, Tilburg 1921.

Drukgeschiedenis: 2 (1937).

Perke dat manneke,

Dekleine librye, Edam 1926.

(later herschreven als Peerke, den haas;zie 1935)

De ramue grond,

De Waelburgh, Blaricum 1926 ,

Hun grond venwaait,

De Waelburgh, Blaricum 1927.

Drukgeschiedenis: 2 Keuromnibus (1964).

Jantie den schoenlapper en zijn Weensch kiendje,

De Waelburgh, Blaricum 1927: [5e]

Drukgeschiedenis: 2 Nijgh \& Van Ditmar, Rotterdam (1939), 3 (1946), 2 |=4 (r962), 5 (1975).

Kinderen van ons volk,

Paul Brand's Uitgeversbedrijf, Hilversum, 1928. [5e]

Drukgeschiedenis: 2 (1930), 3,4.5 (193r), 6 (1933), 7 (1934), 8.9 (r935), to (1939), 1t (1940), 12 (194r), 13 (1942), 14 (1945), 15 (1948), 16 (1949), 17 (1952), 18 (1958), 19 (1960), 19 (1962), 20 (1964), 21 (1967), 22 (1968), 23 (1972), 24 (t976), 25 (t977), 26 (1980), Grootdrukuitgave, Eindhoven (1982), 27 (1983), 28 (r990).

Het donkere licht,

Nigh \& Van Ditmar, Rotterdam, 1929. [2e]

Drukgeschiedenis: 2,3 (1930), 4,5,6 (1931), 7,8 (r932), 9,10 (1941), 11 (1950), 12 (1958), 13 (1964), 14 (1969), 15 (1970), 16 (1971), 17 (1972), 18 Arbeiderspers (1973), 19 herdruk Grote Letter Bibliotheek Amsterdam (x975).

\section{Akelwerkers,}

Nijgh \& Van Ditmar, Rotterdam, r930. |5e|

Drukgeschiedenis: 2 (r933), 3 (r934), 4 (r936), 5 (r938), 6 (r941), 7 (r942), 8 (r947), 9 (r949), ro (r953), 1r (r959), r2 Omnibus Arbeiderspers (r962), $1_{3}$ (1963), $1_{4}$ (1966), I5 Nederlandse Boekenclub (1970), 16 herdruk Nederlandse Boekenclub (1971), 17 (1971), 18 (1975), 19 grootdruk-uitgave, Eindhoven (1976), 20 (1978), 21 (1980). 
De goede moordenaar,

Nijgh \& Van Ditmar, Rotterdam, 1931.

Drukgeschiedenis: 2 (1932), 3 (r939), 4 (r940), 5 (r941), 6 (r942), 7 (r948), 8 (r951), 9 (1960), ro (r963), it (r964), 12 (1967), 13 (1978), 14 grootdruk-uitgave, Eindhoven (r98r).

De schoone voleinding,

Paul Brand's Uitgeversbedrijf, Hilversum 1932.

Drukgeschiedenis: 2 (1932), 3 (1939), 4 (1940), 5 (1942), 6 (1948), 7 (1950), 8 (1959), 9 (1967), 10 (1968), I1 (1973), 12 herdruk Belgiê (1973), 13 (1990).

De man met het Jan Klaassenspel,

Nijgh \& Van Ditmar, Rotterdam 1933.

Drukgeschiedenis: 2 (1946), 3 Omnibus (1962), 4 (r964), 5 (1975).

\section{Dorp aan de rivier,}

Nijgh \& Van Ditmar, Rotterdam 1934.

Drukgeschiedenis: 2,3 (1934), 4,5,6,7,8,9, Io (1935), II (1938), I2 (1942), 13 (1948), 14 (1951), 15 (1955), 16 (I957), 17.18,19 (1958), 20 (1959), 21 (1960), 22 (196r), 23 (1962), 24 (1963), 25 (1965), 26 (1967), 27 (1969), Herdruk (1968), 28 (1971), 29 (1972), 30 (1973), 31 (1974). 32 (1976), 33 (1977), 34 (1978), 35 (1979). 36 (1983). 37 (r985), 38 (1988), Boekenclub (1989), grootdruk-uitgave (1991), 39 (1995), 40 (wetenschappelijke jubileumuitgave 1997).

Stijntic,

1.1. Romen en $\mathrm{Zn.,} \mathrm{Roermond,} \mathrm{1934.} \mathrm{(Later} \mathrm{opgenomen} \mathrm{in} \mathrm{Uit} \mathrm{het} \mathrm{kleine} \mathrm{rijk,} \mathrm{1939)}$

Zegen der goedheid,

Nijgh \& Van Ditmar, Rotterdam 1934- Ill. Jozef Cantré.

Peerke den Haas,

Tweede, herschreven uitgave van Peerke dat manneke. Bigot en Van Rossum, Amsterdam 1935 (Uilenreeks nr. 9).

Drukgeschiedenis: 2 (1935), 3 (1937), 4 (1938), 5 (1941), 6 (1947).

\section{Kerstuertellingen,}

Nijgh \& Van Ditmar, Rotterdam r935. III. Pol Dom.

De drie gebroeders,

Nijgh \& Van Ditmar, Rotterdam 1936.

Drukgeschiedenis: 2 (r942), 3 (1948), 4 (1951), 5 (1955), 6 (1962), 7 (r964), 8 (r966).

\section{De weg terug.}

H. Nelissen, Amsterdam 1936. (In 1937 opgenomen als 'Wegen terug' in Kerstmis in de Kempen.

Drukgeschiedenis: 2 (r948).

\section{Kerstmis in de Kempen,}

Nijgh \& Van Ditmar, Rotterdam 1937. Ill. Gerard Baksteen.

Drukgeschiedenis: 2 (1946) III. P. Wiegersma.

\section{Herbery In 't Misverstand,}

Niigh \& Van Ditmar, Rotterdam 1938. [5e]

Drukgeschiedenis: 2 (1938), 3,4 (1939), 5 (1945), 6 (1946), 7 (1955), 8 (1959), 9 (1969), 10 (1972), 11, herdruk Nederlandse Boekenclub (1973), 12 (1980), 13 (r990).

Uit het kleine rijk,

Niigh \& Van Ditmar, Rotterdam 1939.

Drukgeschiedenis: 2 (1947), 3 (1949), 4 (1952), 5 (1956), 6 (1962), 7 (1973). 
Sprookjes uit alle landen,

1. Philip Kruseman, 's-Gravenhage 1941. Ill. Rie Reinderhoff.

Drukgeschiedenis: 2,3 (1941), 4 (1949).

Van de koe, die aan St. Antonius verkocht werd en De boer en zijn kerkplavei,

Missiehuis St. Antonius, Kaatsheuvel 1942. 'De boer en zijn kerkplavei' is in 1949 opgenomen in: Onder de Canadassen)

Kerstmis in de Pannenschop,

Boekhandel M.F. van Piere, Eindhoven 1944.

\section{Bevrijd Vaderland,}

Nigh \& Van Ditmar, Rotterdam 1945/6.

Drukgeschiedenis: 2 (1946), 3 (1981), 4 Nederlandse Boekenclub (1986).

Perke den haas, Jantje de schoenlapper en zijn Weens kiendje, Huwelijk, De man met het Jan Klaassenspel, Het Kompas, Antwerpen 1946. ('Huwelijk' is in 1949 opgenomen in: Onder de Canadassen)

De ontmoeting.

Geschenk t.g.v. de Nederlandsche Boekenweek van 1-8 maart 1947. De Vereeniging ter bevordering van de belangen des boekhandels, Amsterdam 1947. II. Cuno van den Steene.

Drukgeschiedenis: 2 (1963), $3(1964), 4$ (1968), $4|=5|(1975), 5[=6](1985)$, als feuilleton in: Trouw in 1985 .

Tsjechische suite,

Nijgh \& Van Ditmar, Rotterdam/'s-Gravenhage 1948.

Drukgeschiedenis: 2 (1951).

Vam en over een honderdjarige. Gedenkboek boekhandel van Piere,

Eindhoven 1948 .

Moeder Marjanne's Kerstfeest,

Het wereldvenster, Amsterdam 1948. Ill. Henk Krijger. (In 1937 opgenomen in Kerstmis in de Kempen)

Sprookjes voor grote mensen,

Het Wereldvenster, Amsterdam 1948. Ill. Henk Krijger.

Drukgeschiedenis: 2 (1953).

Onder de Canadassen,

Niigh \& Van Ditmar, Rotterdam/'s-Gravenhage 1949. Later verschenen als Wegen door het land 2 (1957) en Erfgoed 3 $(\mathrm{t} 984)$.

Gouden legenden. Verhalen van God en heiligen, vromen en zondaars.

Meulenhof, Amsterdam 1951. Ill. Karel Thole.

Groei van een stad. Groot Eindhoven onder zijn eersten burgemeester,

Van Tuyl uitgeverij, Zaltbommei 1951.

Triptiek van Kerstmis,

Nijgh \& Van Ditmar, 's-Gravenhage 1952. Ill. Ruth v.d. I/ssel-Salingen.

De urouw met de zes slapers,

Nijgh \& Van Ditmar, 's-Gravenhage november 1953.

Drukgeschiedenis: 2 (1953), 3 (1954), 4 (1956), 5 (196r), Omnibus Arbeiderspers (1964), 6[-7] (1966), Herdruk België $(1967), 6[=9](1968), 7[=10](1971), 8[=11](1978), 7[-12](1980), 8[-13](1991)$.

Nieuwe sprookjes uit alle landen,

1. Philip Kruseman, 's-Gravenhage, 1953. Il. Rie Reinderhoff. 
Van Breischei tot 75 gauge. Het verhaal van een kousenfabriek, 1830-1955,

Schijndel r955.

De grote voltige,

Nijgh \& Van Ditmar, '5-Gravenhage 1957.

Drukgeschiedenis: 2 (1958), 3 (r963), 4 (r981), 5 (1990).

Stad aan de Maas,

Nijgh \& Van Ditmar, Den Haag/Rotterdam 1960. [6e]

Drukgeschiedenis: 2,3,4 (1961), 5 (r963), Herdruk Nederlandse Boekenclub (1970), Herdruk (r971), 6.7 (1974), 8

(1979), 9 (1982), ro (1990)

\section{Toneelwerken}

Exodus, $[1922]$ niet uitgegeven, typoscript in LMDC (zie Archivalia)

De vier jaargetijden, Nijgh \& Van Ditmar, Rotterdam 1934

De ureemdeling, toneelspel in vier bedrijven, uitg. P. Vink, Antwerpen |r935|z.j. |4e].

De klokkengieter, toneelspel in drie bedrijven, uitg. P. Vink, Antwerpen 1940.

Vrij Volk. Herdenkingsstuk bij de bevrijding van ons land in mei 1945 . Inleiding: Albert Helman; eerste bedrijf door Albert Helman; tweede bedrijf door Maurits Dekker; derde bedrijf door Antoon Coolen; vierde bedrijf door leanne van Schaik-Willing en het vijfde bedrijf door A. Defresne. Uitgave van Maurits Dekker en Albert Helman, Amsterdamsche Boek-en Courantmij, Amsterdam r 945 .

Sint Geerten Minne, Toneelspel in drie bedrijven, in: Roeping, jrg. 24 (maart-augustus 1949), 205-232; $311-338$ en 363. 377. Ons Leekenspel, Bussum t950.

De zeven rozen, een sprookjesspel in drie bedrijven, Antwerpen/Zaltbommel 1952.

Het meisje in den toren, sprookjesspel in drie bedrijven, Bussum 1952.

Genoveva van Brabant, toneelspel in vier bedrijven, Amsterdam 1954

Sint Cunera van Rhenen, typoscript, niet uitgegeven. FPC (zie archivalia).

Sawitri. Oosters spel van de liefde en de dood, 's-Gravenhage 1958.

Mars en Venus, N.V. Vinks Uitgeverij, Alkmaar 1958.

\section{Bijdragen aan boeken}

'Hoe ik er toe kwam', in: Bockenweekgeschenk 1932, 32-38.

'Heeswijk Lustwarande in het Hart van Brabant', in: Berne - Heeswijk, Verleden - Heden, Heeswijk 1934, 223-231.

[red.] Het Gouden Gymnasium. Herinneringen van oud-leerlingen aan het Gymnasium 'Sint Norbertus' te Heeswijk. Gerangschikt en ingeleid door Antoon Coolen, Uitgegeven door de Abdij van Berne 1936.

'Inleiding', in: Het Gouden Gymnasium, 5-I4.

'De Oost-Brabanters', in: Meertens, P.J. en Anne de Vries (red.), De Nederlandsche Volloskarakters, Kampen 1938, 278.292. 
'Het gelaat der Noord-Brabantse steden/ Figuren van steden en dorpen', in: Cleerdin, Vincent en anderen, Zóo is Brabant, Amsterdam 1939 .

'Huwelijk', in: Drie novellen, uitgave van de Vereeniging ter bevordering van de belangen des boekhandels, Boekenweekgeschenk, februari 1939, 13-57.

Het gele huis te huur, en verhuurd aan tien schrijvers. Verzameld en ingeleid door H.J. Smeding (1899-1979). De schrijvers waren E. Borderwijk, Elisabeth Zernike, H.J. Smeding, Anna Blaman, Gerard Walschap, Henriette van Eyk, Jef Last, Anne H. Mulder, Antoon Coolen en Emmy van Lokhorst. Coolens bijdrage staat op pagina 112-130. Amsterdam r940. Drukgeschiedenis: 2 (1978).

'Inleiding', in: Louis de Bourbon, Twaalfmaal Azie,, Amsterdamsche Boek-en Courantmaatschappij x941, 5-7.

'De goede koningin', in: De gouden kroon, Haarlem 1948, 59-69. Gedenkboek bij gelegenheid van het gouden regeringsjubileum van H.M. Koningin Wilhelmina. Met o.a. bijdragen van Ina Boudier-Bakker, Antoon Coolen, Anton van Duinkerken, dr. P.H. Ritter Jr.

Liefde, Dood en Minne, [met Godfried Bomans], verlucht door ].F. Doeve, Bergmans, Tilburg 1948.

Uri Nooteboom, Het Land van de Sniedersen. Biografische roman uit de Kempen, Dommelen 1948 . Voltooid door Antoon Coolen.

Met de Heiligen het jaar rond. Een boek van vele schrijvers (waaronder Coolen), geredigeerd door Dom I. Huyben OSB, Dom H.J. Scheerman OSB, Antoon Coolen en Anton van Duinkerken. Vier delen. Uitgeverij Heideland, Hasselt en Paul Brand, Bussum 1948 .

Coolen beschrijft vijf heiligenlevens: 'De H. Simeon Stylites' (deel I, 47-50), 'De H. Driekoningen' (deel I, 5I-54), 'De H. Catharina van Zweden' (deel I, 423-426). De Z. Marie Adolphine' (deel 3.5.9) en 'De H. Birgitta van Zweden' (deel 4.36-39).

'Mijn werkmethode', in: Van Duinkerken, Antoon Coolen, Den Haag 1949, II5-II7.

'Voorwoord', in: Land en volk van Brabant. Bijdragen van Brabantse schrijvers, dichters en geleerden, verzameld en ingeleid door Antoon Coolen, Amsterdam/Antwerpen 1950, 5.6. Voorwoord gedateerd najaar 1949. Met foto's van Martien Coppens.

'Inleiding', in: Land en volk van Brabant. Bijdragen van Brabantse schrijvers, dichters en geleerden, verzameld en ingeleid door Antoon Coolen, Amsterdam/Antwerpen 1950, 11-31.

'De boer en zijn kerkplavei', in: Land en volk van Brabant. Bijdragen van Brabantse schrijvers, dichters en geleerden, verzameld en ingeleid door Antoon Coolen, Amsterdam/Antwerpen 1950, 191-220.

'De verzorging van den onderduiker', in: Het grote gebod. Gedenkboek van het verzet in LO en LKP, deel II. Kampen/Bilthoven $1951,190-378$.

De doolhof, (red. Adriaan van der Veen). Bijdragen van Anna Blaman, Antoon Coolen, Max Dendermonde, Henriette van Eyk, Hella Haase, Alfred Kossman, Adriaan van der Veen en Simon Vestdijk. Bussum 1951.

Coolen schrijft hoofdstuk VI, 118-141.

'Het Brabantse landschap', in: prof. dr. J De Quay, Aug. C.I. Commissaris, Antoon Coolen, Ds. B. ter Haar Romeny en prot. dr. F. van der Ven (red.). Het nieuwe Brabant, deel I Het Brabantse Land, 's-Hertogenbosch 1952, 7 1-146.

'Het Brabantse Dorp', in: prof. dr. J De Quay, Aug. C.I. Commissaris, Antoon Coolen, Ds. B. ter Haar Romeny en prof. dr. E. van der Ven (red). Het nieuwe Brabant, deel I Het Brabantse Land, 's-Hertogenbosch 1952, 147-173.

'Voorval in een kerk', in: C.J. Kelk (red.), Nederlandse Verhalen, Utrecht 1954.

'Over de vreugde van het lezen', in bundel: Over het geluk van het lezen, Den Haag 1957, 19-23. 
'Het onbekende meisje', in: C. . Kelk (red.), Moderne Nederlandse Verhalen, Utrecht z.j. $\{1958\}, 63-67$. Hierin ook verha len van onder andere Blaman, Mulisch, Vestdijk, Aafjes, Den Doolaard, Bordewijk en Alberts.

'Na de New Look', in: R. Broby- Johansen, Kleding en het AaBe ervan, Tilburg 1961, 307-319. [2] Omslag: originele wol. len AaBe-ruit.

'Het AaBe bedrije, in: R. Broby- Johansen, Kleding en het AaBe envan, Tilburg 1961, 323-383. [2]

Begeleidende tekst, in: fotoboek Stijn Streuvels, Desclee de Brouwer, Brugge 196r. Inleiding van Herman Teirlinck.

\section{Artikelen en verhalen}

"n Ongeluk', in: De Engelbewaarder, augustus 1912. (opstel ingezonden onder de naam C. Coolen).

'Militaire opsnijerij en landelijke eenvoud', in: De Zuidwillemsvaart, 27 maart 1915.

'Bij Nilliske', in: De Zuidwillemsvaart, 3 april 1915.

'Reisschetsen deel I en deel II', in: De Zuidwillemsvaart, 29 mei en 5 juni 1915.

'Omkooperij', in: De Zuidwillemsvaart, 16 juni 1915.

'Schlachtenbummierij' deel r en 2, in: De Zuidwillemsvaart, 9 en 23 oktober 1915.

'Kerstvrede', in: De Zuidwillemsvaart, 24 december 1915.

'Tanneke' [Kerstverhaal], in: De Zuidwillemsvaart, kerstmis 1916.

'Staking in de Peel', in: Eindhovensch Dagblad, maandag $x 1$ augustus r9rg. [Anoniem, waarschijnlijk Coolen]

[Recensie Wouter Lutkie's Nooddnuft en Liefdedwang], in: De Gooische Post, 28 juli 1920.

'Als het hart maar rijk is', in: De Gooische Post, 24 december 1920.

'Kerkramen en paneelen van Lodewijk Schelfhout', in: Roeping, irg. 3 (oktober 1924), 46-52.

'Van het zegenend geluk', in: Roeping, irg. 3 (oktober 1924), 80-82.

'Tantje den Schoenlapper en zijn Weensch Kiendje,' in: Roeping, jrg. 3 (november en december 1924), 190-240 en 243262.

'Dat sprookje het feodale kasteel', in: Roeping, jig. 3 ( 1925$), 424-437$ en 483.493 .

'Uw wil geschiede', Katholieke Illustratie, Kerstmis 1926; herplaatst na zijn dood met Kerstmis r96r.

'Dit voorbijgaan', in: Wereldknoniek Kerstboek, 1926.

'Een ernstig woord aan onze katholieke meisjes en haar ouders', in: De Gooische Post, Ir februari 1929.

'Ons lantie stierf', in: Het Offer (Maandschrift gewijd aan den eeredienst van het Heilig Sacrament, de Mis van Eerherstel en de Norbertijner Missies), jrg. 18 (oktober 1929), 231-235. Uitgeverij Berna ut Lucerna.

'Ergerlijke literaire diefstal' (ingezonden brief), in: De Maasbode, 5 december 1929.

'Literaire diefstal' [ingezonden brief], in: De Maasbode, 12 december 1929. 
'Waarom zelf toenadering zoeken?', in: De Tijd, 6 maart 1930.

'De spreuk het goede paard', in: Jaarboek Als het wintert, Bilthoven, 1931. (Het is een vroege versie van 'Het goede pard' in de bundel Kerstmis in de Kempen, die in 1937 zal verschijnen.)

'Van Duinkerken op den kansel' (Letterkundige Vergezichten), in: Het Huisgezin, 1 juli 1933.

'Over Aart van der Leeuw' (Letterkundige Vergezichten), in: Het Huisgezin, 29 juli 1933.

'Kuyle's sterk debuut als romanschrijver' (Letterkundige Vergezichten), in: Het Huisgezin, 6 januari 1934.

'De Streekroman. Het genre noch meerder - noch minderwaardig', in: De Tijd, avondblad, 8 mei r 934.

'Kees Pruis in de kerk', in: De Gemeenschap, jrg. II (januari 1935), 42-44.

'Gerlach de Geestige', in: De Gemeenschap, jrg. Ir (maart 1935), I57-158.

'Gericht der Dominee’'s', in: De Gemeenschap, jrg. II (maart 1935). 158-159.

'Zoo zie je me, zoo zie je me niet' [rubriek 'Hagel'], in: De Gemeenschap, jrg. II (1935), 325-329.

Na tien cultuurjaren' [rubriek 'Hagel'], in: De Gemeenschap, jrg. I1 (1935), 462-464.

'Pastoralia', in: De Gemeenschap, jrg. 11 (1935). 563-565.

'Naar de oevers van de Jordaan', in: De Maasbode, 29 september 1935.

Tussen de verslindende monsters van de Odyssee', in: De Maasbode. 3 oktober 1935.

'In de straten van Jeruzalem. Het oude antagonisme tusschen den Islam en de joden', in: De Maasbode, 9 oktober r 935.

'In de schaduw van het Heilig Graf. Teeken van tegenspraak', in: De Maasbode, 13 oktober 1935.

'Da kan nie' Irubriek 'Hagel'], in: De Gemeenschap, jrg. 12 (1936), 27 1-272.

'Pastoralia', in: De Gemeenschap, jrg. 13 (januari 1937), 62-63.

'Volksadel', in: De Gemeenschap, jrg. ${ }_{3}$ (februari 1937), 108.

'Pro Deo', in: De Gemeenschap, jirg. 13 (mei 1937), 285-286.

'Hendrik Conscience, de verteller en zijn volk', in: De Gemeenschap, jrg. 14 (juli/augustus 1938), 337-346.

'Het pijnlijk treffen', in: De Gemeenschap, jrg. 14 (oktober 1938), 509-5ro.

'Onder het Diksmuider kruis', in: De Gemeenschap, jrg. 15 (september 1939), 38r-384.

'Franz Herwig', in: De Gemeenschap, jirg. 15 (november 1939), 560-571.

'Streuvels en Dickens', in: De Gemeenschap, jrg, I5 (december 1939), 577-588.

'Francois Mauriac, Les anges noirs', in: De Gemeenschap, jrg. 16 (juni 1940), 265-277.

'Pieter van der Meer de Walcheren', in: De Gemeenschap, jrg. I6 (september 1940), 427-432.

'De Zuidwester vertelt', in: De Nederlandse Unie. Uitgave voor het gewest Brabant, november 1940. Later opgenomen in: Coolen, Beurijd vaderland, 59-61 en in: J. Nieskens en A. Schreurs (red.). Het vaderland spreekt tot de jeugd, 
'De zeemeermin en de moeder', in: De Gemeenschap, jirg. 17 (juni 1941), 296-304.

'De vrome en de gastvrije', in: De Gemeenschap, jrg, 17 (juli/augustus 1941), 354-358.

'Stijn Streuvels', in: De Vrije Kunstenaar, 17 november r 945.3 en 4.

'Heeft Defresne slecht gelezen?', in: De Groene Amsterdammer, 29 juni 1946.

'De boer en de haardtegels', in: Winteravondboek, uitgave: JH. Gottmer, Haarlem 1946, 213-230. (later in gewijzigde vorm als 'De schouwtegels' opgenomen in Onder de Canadassen, 1948, 43-86.)

'Herinnering aan Bethlehem', in: Deumesche Courant, december 1946.

'Hans Carossa zum siebzigsten Geburtstag', in: Gruss der Insel an Hans Carossa, Frankfurt a.M. 1948.

'De Limburgse Sagendichteres. Marie Koenen zeventig jaar', in: Rocping, jrg. 24 (januari r949), 4 r-44.

'Feest van Brabancia. Het Brabants spel bij het koninklijk bezoek', in: Edele Brabant, jrg. 4 (30 september 1949), 5-6.

'De romancier en het leven', in: Dietsche Warande en Belfort, r950, 325-329.

Tuffrouw Annelies', in: Haagsche Courant, zaterdag 30 december 1950.

'Flanderns Grösster Epiker. Stijn Streuvels zu seinem 80. Geburtstag', in: Das literarische Deutschland, 5 oktober 1951.

'Anton van Duinkerken als vriend', in: Roeping, jirg. 29 (januari r953), $23-28$.

'De glimlach van het Gooi'. Rede uitgesproken ter gelegenheid van de tentoonstelling 'Schrijvers in het Gooi' in de burgerzaal van het raadhuis te Hilversum op zaterdag 22 augustus 1953 . Gedrukt in 525 exemplaren, waarvan 25 op speciaal Oud.Hollands papier.

'Ontmoeting in niemandsnacht', in: Nationale Snipperdag, april 1954, 63-72. Gezamenliike uitgave van Boek van NU, Critisch Bulletin, De Gids, Kroniek van Kunst en Kultuur, Maatstaf, De Nieuwe Stem, Ontmoeting, Podium en Roeping ter gele. genheid van de Tiende Bevrijdingsdag 5 Mei 1945-5 Mei 1954. (Eerder verschenen in Podium, 1953).

'Brabantia Nova', in: Brabantia, jrg. 4 (1955). 3-11.

'Een groot kunstwerk van Hendrik Wiegersma', in: Brabantia, jrg. 4 (1955), 134-136.

'Nieuw leven in een oud stadje', in: Brabantia, jrg. 8 (1958), 53-60.

'Brabant edel en schoon' |bespreking fotoboek van Martien Coppens], in: Brabantia, jrg. ro (februari 196r), $112-114$ 'Hebbelijkheden in de Gezelle-Lateurfamilie', in: Brabantia, jrg. 1o (maart 1961), 139-152.

\section{'Brieven van de Romeijn' en 'Brieven van de Kempen' (van juni 1933 tot mei 1940)}

Zie volledige lijst hierachter. 


\section{Vertalingen}

jantie den schoenlapper en zijn Weensch kiendie,

1936: Duits: Jan, der Schuhflicker aus Brabant und sein Wiener Kind. [vert, door Kurt Lenzberg]. IlL. Alfred Mahlau. WienAmsterdam-Leipzig, Frans Leo u. Comp.

1936: Duits: Jan, der Schuhflicker aus Brabant, [vert. door Wolfgang Cordan] Amsterdam, Tiefland-Verlag. [Pantheon Akademische Verlangsanstalt]

Kinderen van ons volk,

1933: Duits: Brabanter Volk, [vert. door Elisabeth u. Felix Augustin], Leipzig, Insel-Verlag.

1951: ze druk.

1937: Tsjechisch: Romance z Brabantu, [vert. door Lida Faltová]. Praha, Melantrich.

1953: Deens: Under Guds Himmel, [vert, door Clara Hammerich]. Kobenhavn, Jespersen og Pio.

Het donkere licht,

1942: Tsjechisch: Temné svétlo, [vert. door R.J. Vonka]. Praha, Papikovo Nakladatelstvi.

1946: ze dr. [uitg. Jana Papika].

Peelwerkers,

1946: Tsjechisch: Raselinâri, |vert. door Lida Faltová\}. Praha, Papikovo Nakladatelstvi.

\section{De goede moordenaar,}

1936: Frans: Le bon assassin, (vert, door Marcelle Schlomer). Préface de Jean Giono. Paris, Bernard Grasset.

1994: 2e dr. [Grasset].

1939: Tsjechisch: Dobrak urah, [vert. door Lida Faltová]. Praha, Symposion.

1942: Hongaars: A jó Gyilkos, |vert. door Madelon Lulofs]. Budapest, Ar Athenaeum Hiadára.

1943: Portugees: O Bom Assassino, (vert, door Maria Archer). Livraria Taveres Martins.

1957: Catalaans; El bon assassi, Traduit del neerlandès per Marcelle Schlomer; Ferran Cassyameres, Barcelona, Aymà S.A. Editora.

De schoone voleinding,

1943: Tsjechisch: Koruna Zivota, [vert. door Lida Faltová]. Praha, Melantrich.

De man met het Jan Klaassenspel,

1941: Duits: Der Mann mit dem Kasperletheater, [vert. door George Kurt Schauer]. Amsterdam, Tiefland-Verlag. 1948: Tsjechisch: [opgenomen in: Peerke straspytel). Zie Peerke den Haas.

Dorp aan de rivier,

1936: Duits: Das Dorf am Fluss, |vert. door Hermann W. Michaelsen], Leipzig. Insel-Verlag.

1938: $2 \mathrm{edr}$.

1937: Tsjechisch: Ves u Reky, |vert. door Lida Faltová.. Praha, Europsky Literárni Klub.

1937: Fins: Kyla joen Ranella Painoksesta, [vert. door Eino Kivinevi]. Arvi a Karisto oy.

1943: Tsjechisch: in één band met De drie gebroeders: Vesnicky Lekar, [vert. door Lida Faltová). Praha, Sfinx Bohuszil landa.

1950: Noors: Landsbyliv [vert, door Käre Langvik Johanenssen]. Oslo, Tanum.

t954: Frans: Village au bord de l'eau, [vert. door G.S. Solpray]. Paris, Calmann Levy.

196r: Slowaaks (in combinatie met De drie gebroeders): De dina pri rieke; Traja Bratia. Bratislava, Slovenské vydava. telstvo krásnej literatury.

1961: Spaans: Un pueblo o orillas del agua. Madrid, Ediciones y Publicaciones Espanoles S.A.

De drie gebroeders,

1937: Deens: De tre Broders, [vert, door Clara Hammerich], Kobenhavn, lespersen og Pio.

1937: Duits: Die drei Bnider, [vert. door Bruno Loets]. Leipzig, Insel-Verlag.

1938: Zweeds: De tre Brōdema, [vert. door Harald Hernström]. Helsingfors, Söderström en Co.

1942: Tsjechisch: Tri bratri, [vert. door Lida Faltová], Praha, Europsky literámi Klub.

1943: Tjechisch (in combinatie met Dorp aan de rivier) Vesnicky Lekar, |vert door Lida Faltová]. Praha, Sfinx Bohuszil landa. 
1943: Frans: Trois frènes, [vert. door L. Roelandt]. Bruxelles, Charles Dessart.

1961: Slowaaks (in combinatie met Dorp aan de rivier, zie boven).

Pecrke den Haas,

1941: Duits: Peerke der Hasenfuss, [vert. door Werner Ackermann]. Illustr. van Z.H. Stöcker. Amsterdam, TieflandVerlag. [Pantheon Akademische Verlangsanstalt].

1948: Tsjechisch: Peerke straspytel, [vert. door Miroslav Drápal]. Praha, Sfinx Bohuszil Janda.

\section{Herberg In 't Misverstand,}

1940: Duits: Das Wirtshaus zur Zwietracht, [vert. door Bruno Loets]. Leipzig. Insel-Verlag.

1941: $2 \mathrm{e}$ druk.

1942: Tsjechisch: Hoscoda Unesvánu, [vert. Door Lida Faltová]. Praha, Europsky literárni Klub.

1948: Engels: The cross purposes, [vert. door Jacobine Menzies.Wilson]. London, Collins.

Uit het kleine rijk,

1948: Tsjechisch: Z Malého Královstvi, [vert. door Ella Kazdová). Praha, Miada fronta.

1950: Duits: Aus der kleinen Weit, [vert. door Bruno Loets]. Wiesbaden, Insel-Verlag.

De ontmoeting.

1948: Tsjechisch: lopgenomen in:| Peerke straspytel. Zie Peerke den Haas.

De urouw met de zes slapers

1955: Duits: Die Frau mit den sechs Wächterm, [vert. door Walter Hjalmar Kotas). Köln, Greven Verlag.

Voorval in een kerk

1951: Engels: Incident in a chunch.

Dit verhaal is vertaald in 23 talen. 


\section{Brieven van De Romeijn en Brieven van De Kempen}

Antoon Coolen schreef van juni 1933 tot mei r 940 een wekelijkse column voor de zaterdag-editie van de Provinciale Noord-Brabantsche en 's-Hertogenbossche Courant, eerst vanuit zijn huis De Romeijn in Deurne en vanaf januari 1938 vanuit zijn huis De Kempen in Waalre. Hij sloeg maar weinig weken over (aangegeven met - achter de datum).

\section{Brieven van De Romeijn}

3 juni r933: Herkenning in het land der vaderen. to juni 1933: Boven en beneden de rivieren.

17 juni 1933: De Brabanter Antoon van Duinkerken bekroond.

24 juni 1933: De gilde viert.

I juli 1933: Uw vacantieoord!

8 juli r 933 : Natuur-reserve.

15 juli r933: Ziel der stad.

22 juli 1933: Het laatste sprookje.

29 juli t933: Schemering over de klompenbeurs.

5 augustus 1933: In een Fransche spiegel.

12 augustus 1933: Lied van den korenoogst.

t9 augustus r933: Feest onder de linden.

26 augustus r933: H.N. Ouwerling's nagelaten boek.

Woensdag 30 augustus 1933: Trouw tusschen koningin en volk.

2 september 1933: "Ansichten" seizoen.

9 september r933: Choralen onder de echo's van

dondergranaten.

16 september 1933 : Roem van Tilburg.

23 september 1933: Tegenspraak van Prinsjesdag.

30 september 1933: Bodem van volkskracht.

7 oktober 1933: Schreeuw van het dagblad.

14 oktober 1933: Vervulling van de herfst.

21 oktober 1933: Volksgericht van het tafelen.

28 oktober 1933: Koninkrijk van het kind.

4 november 1933: Onze schuttersgilden en schutterij-

en.

II november 1933: Den minister vóór ....

18 november 1933 :

25 november 1933: Sagenvader Sinnighe.

2 december 1933: Studenten en de geest van Brabant.

9 december 1933: Voorspel tot den winter.

t6 december r933: Lied van sneeuw en ijs.

23 december 1933: Kerstnacht, schooner dan de dagen.

30 december 1933: Keerpunt tusschen oud- en nieuwjaar.

6 januari 1934: De Drie Koningen zijn gekomen

13 januari 1934: Medicus-pictor Hendrik Wiegersma.

20 januari r 934: Onze vrienden de stoomtrams.
27 januari 1934: Er kwam een vogel gevlogen.

3 februari r934: Mogen zij lachen?

to februari 1934: Vreugd van Carnaval.

17 februari 1934: Illuzies van het aangifte biljet.

24 februari 1934: Toen de koning stierf.

3 maart 1934: Mensch en natuur.

ro maart 1934:Zijde en keerzijde.

17 maart 1934: Feestelijke klanken over het gewest.

24 maart 1934: De lieve oude dame uit Holland.

$3 t$ maart 1934: Klokken van Paschen.

7 april 1934: Bevestiging van de nationale gedachte.

14 april 1934: Onze burgervaders!

21 april 1934: Met het genootschap op excursie.

28 april 1934: De lente trekt naar den zomer op.

5 mei 1934: De ziel van den wijn.

12 mei 1934: Museum van nieuwe religieuze kunst.

19 mei r 934 : Brabantia Mariana.

26 mei 1934: Geografie met het hart.

2 juni 1934: Conjunctuur van het gemak.

9 juni 1934 : Vreugden van de kermis.

16 juni 1934: Brabantsche volkshumot.

23 juni 1934: Lied van den regen.

3o juni r934: Noodlot van de snelle wenteling.

7 juli r934:

I 4 juli 1934: Hoe zal 's Bosch feest vieren?

$2 \mathrm{r}$ juli r 934 : Tuberculosebestrijding in Noord-Brabant.

28 juli r 934 : Het feest van de Abdij van Berne.

4 augustus r934: Behoud van het Noordbrabants landschap.

11 augustus 1934 :

18 augustus r934:

25 augustus 1934: Het boek over de schutterijen voltooid.

I september 1934: Greep naar den Brabantse geest.

8 september 1934: Fruit op de schaal.

15 september 1934: Stemmen van het vorstengraf.

22 september r934:

29 september 1934: In en om de Baronie.

6 oktober r934: Bezoek aan het kerkje te Asselt.

13 oktober 1934: Voltooiing van de herfst.

20 oktober 1934: Dr. P.C. de Brouwer bij diens zesde kruisje. 
27 oktober 1934: Londen-Melbourne.

3 november 1934: Van den anderen kant.

ro november 1934: Verrassing na de laatste ronde.

17 november 1934: Stad van honderdduizend.

24 november 1934: Aan de voeten van den kelner.

$t$ december 1934: Kinderoogen voor de winkelruit.

8 december 1934: Streekplan voor het Peelgebied.

15 december 1934: Voor het brood der behoeftigen.

22 december 1934: De mensch hoort bij de menschen.

29 december 1934: Gedachten van den oudejaarsavond.

5 januari 1935: Van Driekoningen-avond.

12 januari 1935: In Memoriam Willem Nieuwenhuis.

19 januari 1935: Hot-Jazz in Diepenbrocks stad.

26 januari 1935: Propheten in eigen land.

2 februari r935: Lessen van de zakagenda.

9 februari 1935: Bekoring van den ouderdom.

16 februari 1935 : Tolbestorming.

23 februari 1935 : Uit het kleine rijk.

2 maart 1935: Van de blijde herhaling.

9 maart 1935: Gewapende vaderlandsliefde.

16 maart 1935: Om het zwarte keizerrijk.

23 maart 1935: Liefde voor het boek.

30 maart 1935: Defaitisme en defaitisme,

6 april r 935 : Maand van stilte.

13 april 1935: Brabant op zoek naar zijn vlag.

20 april 1935: Jubel van Paschen.

27 april 1935:Regendag.

4 mei 1935: Tusschen bloemen en tranen.

11 mei r935: De zaak van den lach.

18 mei 1935: Helden en heldenvereering.

25 mei 1935: Geschiedenis van Heesch bij Oss.

$t$ juni r 935 : Eeuw van het kind.

8 juni 1935: Pinksterhoogdag.

15 juni 1935: Met weldenkendheid op vakantie.

22 juni r 935 : Hollandse polyglotterie.

29 juni r935: Ethiopie onder protectoraat.

donderdag 4 juli 1935 : feestnummer.

vrijdag 5 juli r 935 : Aan den vooravond.

8 juli r 935: verslag der feestelijkheden.

13 juli 1935: Praeludium in Die Festo.

20 juli 1935 : Indrukken uit een feestvierende stad.

27 juli 1935: Vreugde om de vreugderijke.

3 augustus t935: Stad van hecht gemeenschapsleven.

ro augustus 1935: De pastoor van Cucugnan.

I7 augustus 1935: Verwaarloosde gezichtspunten.

24 augustus 1935: Brabant blijve zijn eigen land.

32 augustus 1935: Uit kinderland.

7 september 1935: De man met de gouden hersenen.

14 september 1935 :

21 september 1935: Warenhuis van wijsheid.

28 september 1935: Rond den oogst der akkers.

5 oktober 1935 : Is bouwkunde bouwen of kunde?

12 oktober 1935: Schaduwen van Adoea.

19 oktober 1935: Bij het film-jubileum.

26 oktober 1935: Week voor veilig verkeer.

2 november 1935: Allerzielen.
9 november 1935: Brabantia Nostra!

16 november 1935: Bij het eeregraf ..

23 november 1935: Bij een proefschrift.

30 november 1935 : Sinterklaas in 't kleine rijk.

7 december 1935: Domheidsmacht.

14 december 1935; Tol aan de vooruitgang.

21 december 1935: Eeuwe-Aljechin.

28 december 1935: Lichtende dagen in den donkeren winter.

4 januari r936: De Heilige Drie Koningen komen.

11 januari 1936: De dissertatie van dr. B, van den Eerenbeemt.

18 januari 1936: Het rapport van Vuuren.

25 januari 1936: Goudschemering.

1 februari 1936: Prins carnaval mag komen.

8 februari 1936: Pluk den dag!

15 februari 1936: Bekoring van den winter.

22 februari 1936: Menschen in 't café.

29 februari 1936: Genoegen van foto's.

7 maart 1936: Problemen en versche broodjes.

I4 maart 1936: Verrukligen van het pyrament.

21 maart 1936: Wereld verdwazing.

28 maart 1936: De Lente komt.

4 april r936: De laatste eenzaamheid.

11 april 1936: Bij den afgewentelden steen.

18 april 1936: De Bossche Vliegweek herdacht.

25 april r936: .. en van Mechelen tot's-Hertogenbosch.

2 mei 1936: Geestelijk tegenwicht.

9 mei r936: Gedenkwaardige stonde.

16 mei r936: Meizang.

23 mei 1936: Glorie van het landschap.

30 mei 1936: , het huis waar zij gezeten waren.

6 juni 1936: Te veel voor den spiegel.

13 juni 1936: Bij de opening van de Waalbrug.

20 juni 1936: Dorpskermis.

27 juni r 936 : Sterren.

4 juli 1936 tot en met 22 augustus 1936: geen columns.

5 september 1936: Na de vacantiereis.

12 september 1936: Het bruidskoor klinkt door het

Wilhelmus!

19 september 1936: In gesprek met Erasmus.

26 september 1936 :

3 oktober 1936: De kinderen van Parijs.

so oktober 1936: Stemmen van de stilte.

17 oktober 1936: Het herlevende vendelzwaaien.

24 oktober 1936: Vogels.

31 oktober 1936: Bezoek aan kerkhof.

7 november 1936: Gewapende propheten.

14 november 1936: Koning en mijnwerker.

21 november 1936: Speelgoed in kinderland.

28 november 1936 : De Aalster windmolen.

5 december 1936: Het heerlijk avondje.

12 december 1936: Het Hollands Diep opnieuw over-

brugd. 
19 december 1936: Kerstnummers. 26 december 1936 :

2 januari 1937:

9 januari 1937: De prinses in de gouden koets.

16 januari 1937: Een nieuw leven kreeg gestalte. Heden en verleden te lande.

23 januari 1937: De laatste stoomtram.

3o januari 1937: llluzies van den winter.

6 februari 1937: Economisch technisch instituut.

13 februari 1937 : Honderdjarigen.

20 februari r937: Gilden in 't zuidelijk zustergewest.

27 februari 1937: Fabel van de dure vrijheid.

6 maart 1937:

13 maart 1937: Boerenopstand.

20 maart 1937: Het woord is aan ....

27 maart 1937; Stormend alleluja van Paschen. 3 april r937: De vijftigduizendste Bredanaar. 10 april 1937: Zwervers of gewortelden.

17 april 1937: Ziel der dingen.

24 april 1937: Lenteregen.

1 mei 1937 : Een 'Monumentale' kapel bij den Moerdijk? 8 mei 1937: Kent gij Brabant?

I5 mei r937: Lied der aarde.

22 mei 1937: Betalende gasten.

29 mei r937: In memoriam Ko van Dijk.

sjuni 1937: Een boerinneke neemt het woord.

12 juni 1937: Sprookje van het Vughtse raadhuis.

19 juni 1937: Het nieuwe Brabant.

26 juni 1937: Midzomerdagdroom.

3 iuli 1937: Spelevaren.

to juli r937: Boerenverstand en teeltbeperking.

17 juli 1937: De zorgenrijke schoonheid van Brabant.

24 juli 1937: Indrukken van het St. Franciscusspel.

31 juli 1937: Verbeterde Aa.

7 augustus 1937 :

14 augustus 1937:

21 augustus 1937 :

28 augustus 1937 : Het taaleigen der reclame.

4 september r 937: Louis-Far.

II september 1937: De Bieman.

18 september 1937: De vrouw op de Moerdijk-brug.

25 september 1937: Lof van den herst.

2 oktober 1937: Na het jubileumjaar der leergangen.

9 oktober 1937: Eien wensch? --Vréde!

16 oktober 1937: Theepraatje.

23 oktober 1937: Het land van Utopia.

30 oktober 1937: Anecdoten van groote mannen.

6 november 1937: Herdenking van den Wapenstil. stand.

13 november 1937: Vlaanderen en wij.

20 november 1937: Rondom de Peel.

27 november 1937: Tegenstelling tussen stad en land. 4 december 1937: Schoentjes onder de schouw.

11 december 1937 :

18 december 1937 :

Vrijdag 24 december 1937: [kerstwens; lijkt van Coolen]
31 december 1937 : Gesprek met het oudjaar.

8 januari r938: Prins en pers.

I5 januari r 938 : De blijde verwachting.

\section{Brieven van De Kempen}

22 januari 1938: Klokken in de nacht.

29 januari 1938: Van Soestdijk ..

5 februari 1938 : Toen ' $t$ kindje binnenkwam.

12 februari 1938: Vermoeide aarde.

19 februari 1938: Alles vloeit.

26 februari 1938 : Om de kinderen.

5 maart 1938: Smarten in Rusland.

I 2 maart 1938: De dood verrast kinderen.

I9 maart 1938: Geertruidenberg 725 jaar stad.

26 maart 1938: Lentedag.

2 april 1938: Dialoog voor den boekwinkel.

9 april 1938: Bloesem- en bollenreis.

16 april 1938: Bloemige hof van Pasen.

23 april 1938: De Brabantse boer en de zorg voor 'ongerept:

30 april r938: Schemering van omwentelingen in de Peel.

7 mei 1938 : De boerenwoning in de Meierij.

14 mei 1938: Nog steeds de spelling.

21 mei 1938: De Jubileerende Brabantse Scheldestad.

28 mei 1938: Een eeuw na de Leeuw van Vlaanderen.

4 juni 1938: De VVV Utopia's in 't VVV Kohaije.

$\mathrm{r}$ I juni 1938 : De zomer is gekomen.

I8 juni 1938: De gilden op Welschap.

25 juni 1938: Boek over Helmonds Kasteel-Raadhuis.

2 juli 1938: Kleine reizen door het Markiezaat.

9 juli r 938: Kommer en vreugde om het koren.

I6 juli 1938: De leeuw op Antwerpse Groote Markt.

23 juli 1938: Kinderwandeling.

30 juli r 938 :

6 augustus 1938 :

13 augustus 1938 :

20 augustus 1938 :

27 augustus 1938 :

3 september 1938: Brabantse volkskunst.

ro september 1938: Groot feest in het kleine land.

17 september 1938 :

24 september r938: Bedreigde vrede.

I oktober 1938 : Kansenspel.

8 oktober 1938 :

15 oktober 1938 : Weerkracht van den geest.

22 oktober 1938: Reclame in het landschap.

29 oktober 1938: Nieuwe wegen in het oude land.

5 november 1938: Markt onder het Bossche klokkenspel.

12 november 1938 : leugd aan den arbeid.

19 november 1938 : Kinderen in de eeuw van het kind. 26 november 1938 : De dingen van iederen dag.

3 december 1938: Vertelling van den decemberregen. ro december 1938: Tusschen twee werkelijkheden.

17 december 1938: Blijder tijden voor de Maasstreek. 
24 december 1938: Vreugde van Kerstmis. 3 I december 1938: Afscheid van het oudjaar.

7 januari 1939: Glasschilderkunst in de Peel. 14 januari 1939: Een proefschrift over Herwig.

21 januari 1939: Een Britsche parapluie. 28 januari r939: St. Willibrord in Brabant. 4 februari 1939: Het kleine meisje met de grooten leeuw.

II februari 1939: Blanke morgens. 18 februari 1939: Het verfilmde sprookje. 25 februari 1939: Achtdaagse van het boek. 4 maart 1939: Menschen in den trein.

11 maart 1939: Lied van de lentestormen. 18 maart 1939: Leeft als koningskinderen tezamen. 25 maart 1939: Het welkom tot den vreemdeling. 1 april r939: Gevaarlijk leven.

8 april t939: Jubel van Paschen.

15 april 1939: De adem der oorlogsgodin. 22 april r939: Wandelen en wandelaars. 29 april 1939: Uitgebannen uit den tijd. 6 mei r939: Over de vrijheid van meningsuiting. I3 mei 1939: Kleine verhalen van het geld. 20 mei 1939: Kindercommuniedag. 27 mei 1939: De dood naast den beschonkene. 3 juni 1939: Vraagstukken van het platteland. 10 juni 1939: Duikbotenwee.

17 juni r939: Het huis.

24 juni r939: Hoogheid van de zomerdagen.

I juli 1939: Een bijzondere plechtigheid in de Peel. 8 juli 1939: Brabants groen.

15 juli 1939: Van de baldadigheid der jeugd.

22 juli r939: Ideaal wonen.

29 juli 1939: Korenoogst.

5 augustus r939: Willibrordherdenking.

12 augustus r939: L.M. Jhr. Van Sasse van I/sselt.

19 augustus 1939: De goede stad Oss.

26 augustus 1939: Avond aan den IJzer.

2 september 1939: Tusschen vrede en oorlog. 9 september 1939: Uitzicht van den oorlog. 16 september 1939: De honderdjarige spoor. 23 september 1939: Wij, op ons eiland. 30 september 1939: Genoegens in droompaleis. 7 oktober 1939: Mars en de folklore.

t 4 oktober 1939: Tegenstellingen en verwarringen. 2 r oktober r 939 : Reis door den herfst.

28 oktober 1939: Het Deurnesche St. Willibrordraam. 4 november 1939: Pleidooi voor de poffer.

11 november 1939: Dr Hendrik Moller, 70 jaar. 18 november 1939: Wijsheid der onzijdigheid. 25 november 1939: De dooden begraven. 2 december 1939: Natuurwacht in de Kempen. 9 december 1939: Omdat gij mij liet leven .. 16 december 1939: Ziekte der verveeldheid. 23 december 1939: Nij sijt wellecome. 3o december 1939: De mantel van het nieuwe jaar.
6 januari 1940: Morgenrood van het nieuwe jaar. 13 januari 1940: Lieve soldaat.

20 januari 1940: De dagen van de week.

27 januari 1940: De barre winter van nu. 3 februari 1940: Elfstedentocht.

ro februari 1940: Breda's booze plannen. I7 februari r 940 : Winter's wederkeer.

24 februari 1940. Platina bruiloft.

2 maart 1940: Lof van het boek.

9 maart 1940:

16 maart 1940: Kinderen en de oorlog.

23 maart 1940: Lentelied van Paschen.

30 maart 1940: Noodhoorn over de Kempen.

6 april r940: De sevenste Bliscap voor den Sint Jan

13 april 1940: De nieuwe voorzitter van het

Genootschap.

20 april r940: Het edel ambacht.

27 april 1940: Verraad van het vaderland. 4 mei 1940: Lente. 


\section{Index van geografische namen}

$\mathrm{Aa}$, de $198,496,537$.

Aarle (Rixtel) 314 .

Abessiniê (Ethiopië) 33, 242, 284, 293, 294, 303, 304, 354

Achterhoek, de 253.

Addis Abeba 294.

Adoea 304.

Afrika 18 .

Afsluitdijk 244

Aken $309,376,552$.

Alkmaar 214 .

Amazone, de 529.

Amersfoort $374,400$.

Amerika, USA 35, 45, 479, 580 .

Amsterdam 34, 56, 67, 85, 93, 116-118, 149, 169, 194, 204 , $205,234,243,258,271,286,291,318,323,328,360$, $367,369,375,378,387,388,389,390,403,412,443$. $453,465,467,493,513,532,554,555,593$.

Antwerpen 56, 152, 205, 277, 293, 322, 331, 399. 419 . 590.

Apenijnen 294.

Arnhem 306, 307

Asten 18.412.

Athene 284 .

Auschwitz 401 .

Australiē 40, 566 .

Avignon 312.

Aziè 40.

Baalbek 284 .

Baarn 292.

Bagneux 563.

Beek en Donk 36.

Beerse (Overlaat) 481,529 .

Beesterzwaag 276

Beiroet 284 .

Beigiè (Den Bels) 29, 55, 66, 177, 195, 208, 210, 233, 243. $250,291,294,312,322,346,352,360,457,459,472$, 474.592.

Bentheim 550.

Bergen (N.H.) 77 .

Bergen op Zoom 43, 126, 150 .

Berlicum (N.Br.) 187, 205, 244, 401.

Berlijn 233, 234, 257, 258, 291, 402, 539, 580 .

Berne 33.35 .

Best $82,507.531$.

Bethlehem 285 .

Biesbosch, de $380,529$.

Bilthoven 499, 500 .

Blanthem 519.

Blaricum 136.

Boedapest 555 .

Boekel 326.
Bohemen 278 .

Bonn 552.

Bosniể 278.

Boxtel 32, 79 .

Brabant 32, 41, 43, 48, 55, 61,77, 80, 85, 93, 95, 98, 99, 107 . 108, 111, 113-126, 129, 130, 133-140, 142, 144, 146 , $147,149-152,154,156,157,164,168,172,177,180$, $182,183,185,186,191,192,196,201,211,219-221$, $227,234,235,240,241,243 \cdot 245,251,254,265,266$, $271,278,282,295,297 \cdot 300,303,323 \cdot 330,337,351$. $353,365,366,372,374,375,381,388,390,404,411$, 414, 448, 481, 493, 496, 502-505, 507, 508.511, 514. $520-523,525,528-534,550-553,557,570,571,573$. $589,591,597$.

Breda 32, 96, 130, 177, 256, 296, 379, 419, 483,511.

Bremen $377,419,483,511$.

Breskens 592.

Bretagne 52,360.

Breugel 531.

Brno 472.

Brussel 259, 283, 503 .

Bulgarije 278

Bussum 100, 104, 112

Canada 351, 529, 566, 589 .

Cannes 35.

Canterbury 164.

Caìro 285

Cherbourg 550.

China 40, 220, 294, 331, 354, 402.

Colmar 210.

Congo 212, 529 .

Culemborg 155 .

Damascus 284 .

Danzig 345, 352 .

Delft 234, 306, 418, 57x.

Den Bosch (zie 's-Hertogenbosch).

Den Haag 202, 292, 328, 346, 379, 381, 390,416, 417, 418, 552.

Deurne $17 \cdot 30,32,35,36,39,55,56,62,67,111,113,127$, 135. 165, 187, 191, 193, 199, 200, 202, 203, 208, 209. $214,230,235-238,256,261,270-272,276,282,286$, 305.307, 310, 318, 321, 331, 340, 357, 379, 408, 412, $416,420,425-428,431-442,444,445,448,450,453$. $456,466,475,482,485,493,531,537,553,554,559$. $560,568,571,596$.

Diksmuide $345,348,478$.

Dommel, de 24 I, 340, 469,496 .

Drenthe 27,230.

Drunen 405.

Duisburg 376. 
Duitsland $35,56,220,221,233 \cdot 235,242 \cdot 244,252,257$. $258,269,289,291,294,295,307 \cdot 311,345-355,358$, $359,363,364,369,371,376-379,384,394,399-403$. $408,420,433,434,459 \cdot 461,474,476,549,590$.

Dussen 372, 373. 537 .

Edam 129, 136.

Eindhoven 18, 23, 68, 69, 7x, 77-81, 86, 90, 177, 186, 308, $324,356,370,409,416,419-421,430,433,445,449$. 474, 509, 514, 519, 520, 525, 533, 534, 581, 594, 595 .

Eifel, de 332 .

Engeland $56,126,269,346,354,376,402,454,478,550$.

Escharen $307,354$.

Estland 351 ,

Etterbeek 243.

Europa/Europees 217-220, 239. 242, 250, 289, 291, 292. $302,304,322,326,330,331,337,342,345 \cdot 347,350$, $350,354,360,363,396,400,453,479,522,539,589$.

Eijgelshoven 71 .

Finland 352:354, 422 .

Frankfurt 552.

Frankrijk 35, 48, 50, 52, 74, 76, 177, 215, 229-231, 291. $294,303,322,346,354,360,363,364,419,444,454$. $461,474,478,523$.

Freiburg 377,552 .

Friesland 27, 29, 267,297-300, 353.534.

Garonne, de 490.

Geertruidenberg 505.530.

Geldrop 421.

Gemert 405, 498.

Gemonde 79. 101, 105.

Gent 359.

Gestel 519 .

Ginneken 137

Gooi, het $85,113,161,165,214,241,283,325,534$.

Gorkum 256.

Grave 29. 327, 354. 370, 372, 560, 581, 582, 587, 588 .

Grebbeberg, de 454 .

Griekenland 190 .

Griendsveen 25 .

Groningen 552.

Grossgründlag 242.

Guernica 295.

Haaren $32,46,48,53,54,76$.

Haarlem 214.322.

Haarlemmermeer 496 .

Halt, de 195 .

Hamburg 308, 357,459.590, 596 .

Hammerfest 170 .

Heerlen 256

Heeswijk 32,34-37, 296,411,454,504,506,520,523,532, $552,592$.

Heeze 421 .

Helden-Panningen 21.

Helenaveen $25,82$.
Helmond $18,28,30,31,34,36,39,46,64,75,82,99,190$, $193.208,271,375,420,445$.

Helvoirt 23.

's-Hertogenbosch (Den Bosch) 31-34, 48, 70, 78, 85, 90, 93, 95, 97, 105, 156, 157, 174, 187, 190, 205, 241, 244, $262,264,280,299,324,364,366,370,374,400,401$, $409,412,419,420,435,436,446,483.496,500,503$. 532.

Hilvarenbeek 19. 327, 504, 507.517.518,521, 553.591.

Hilversum 29.91, 92, 95, 99, 104, 111, 113, 124, 125, 128, $135,136,140,149,153,156,163,165,172,183,187$. $189,190,194,199,204,214,223,224,230,236-238$, $241,245,292,319,439,473,507,534$ -

Hillegersberg 418 .

Himalaja 535 .

Hoeven 32.

Holland $56,77,98,114,119,125,167,170,171,218,238$, $243,252,257,260,281,308,328,511,585$.

Hongarije $346,555,556,589$.

Horst America 247,248.

Ijmuiden 56 .

IJsselmeer 244.

Ilzer, de 293.

Ingooighem 202, 527, 593 .

Israêl 403 .

Istanbul 284.

Italie r $95,242,289,293,294,303,329,330,351,354$

Jalta 472.

Japan 293. 354 .

Jericho 285 .

Jeruzalem 284 .

Jordaan, de 269,284 .

Kaldenkirchen 420 ,

Kanton 294.

Katwiik 77.

Kempen, de 94, 183, 241, 299, 314, 317, 318, 322, 325 . $360,388,529.534$.

Keulen 352, 376.

Korea 539.

Kortrijk 458, 499.

Langenboom 354 .

Laren 77, 123, 124.

Leeuwarden 206, 207, 538.

Leiden 75, 97, 107. 370 .

Leipzig 258, 308, 309, 460 .

Letland 351 .

Leuven $311,312,321,323,354,370,552$.

Libanon 284 .

Lidice 477,448 .

Liempde 53 x.

Lier 33, 399.

Liessel 30 .

Limburg 17, 18, 25, 29, 102, 156, 176, 351, 379, 552 
Lille 93.

Litauen 351 .

Lith $270,272,276,303,529,555$.

Lithoyen 529 .

Lobith 176 .

Locamo 293.

Loch Ness 277.

Londen 25.269, 459 .

Loon op Zand 537.

Loonsche en Drunense Duinen 529.

Lorient 52.

Lourdes 177,225 .

Lubeck 309 .

Luneburger heide 358 .

Luik 278, 293.331.

Lutteleind 554 .

tuxemburg 291.

Maarssen 487 .

Maas, de 31, 267, 269, 270, 272-275, 277, 372, 373, 422 , $550,580,58 x-584$.

Maasland/kant 29, 298, 307, 360, 529, 530, 534, 540 .

Maastricht $64,69-71,74,75.77,78,86,97,419,483,500$, 534.

Madras 506.

Madrid 297.

Manosque $312,313$.

Maren 403.

Mariakerke $490,492,517$.

Marseille $283-285$.

Mechelen 242, 243 .

Meerveldhoven 79 .

Meierij 34, 41, 81, 238, 241, 299, 326, 388, 529, 530, 558 .

Melbourne 269 .

Middelandse Zee 296.

Midden-Oosten 284,285 .

Mierio $18,19.553$.

Mierlo-Hout 426 .

Moerdijk 125, 134, 156, 185, 327, 328.

Mook 512 .

Moravië 278 .

Munster $328,400,458,590,591$.

Munchen 330.

Naarden 238.

Napels 284 .

Nazareth 284 .

Nederland $47,52,55,61,70,85,175,183,204,213,215$, $218,220,232,242,243,256 \cdot 259,269,280,282,291$, $293,295,296,314,322,323,327-330,346-355,358$. $360,363,364,371,372,376-379,381,385,394,399$, $412,417,419,421,431,448,453,454,457,459,464$. $470,482,483,486,512,522,525,528,532,539,544$. $546,550,556,578,590,593$.

(Nederlands-)Indië 256, 307, 546 .

Noordwijk aan Zee ro7.

Noordzee 356.
Noordpool 40.

Noorwegen $167,170,355,413$.

Nova Zembla $353,422,544$.

Nuland r04, 105, 303, 401 .

Nijmegen $48,85,93,106,306,323,375,440,532,584$.

Oirschot $327,531$.

Oisterwijk 241, 507.

Ommel 198, 199, 206, 314, 420,421.

Ontario 566.

Oostende 490 .

Oostenrijk 24, 258,294,309, 346.

Oslo 591 .

Oss $274,371-374,391,403,405,406-410,413,473,482$.

Peel, de $18,21,24-27,31,32,36,37,54,61,62,82,83,97$, 99, $111,113,133-136,140,141,158,161,165,173-177$. $180,187,188,190-195,198,200,201,211,212,232$. $241,247,249,252,253,267,270,273,295,299,301$, $303,304,312,314,317,318,324,346,351,360,367$. $454,481,496,529-531.534,559$.

Palestina 283, 304

Parijs 25, 28, 154, 155, 169, 172, 231, 238, 330. 352, 363 . $418,461,470,563$.

Polen $104,277,345,346,347-349,351,354,463,516$.

Postel 517.

Potsdam 358, 379 .

Poznan 104.

Praag 472.478, 549,552,555.

Provence, de $238,296,312,313$.

Pruisen 27, 195, 247, 250, 349, 589.

Purmerend 219.

Renkum 306.

Reusel 517.

Rhenen 505.

Rhodos 284 .

Rips, de 429.

Rome $273,291,484,485,585$.

Roosendaal 242.

Rotterdam 45, 61, 128, 140, 150, 170, 172, 277, 356-358, $360,390,415$.

Rusland (Sovjet-Unie) 35, 66, 67, 277, 293, 294, 309, 320, $348,351,354,476-479.555$.

Rijn, de $262,353,460,505$.

Rijnland 291, 293.

Saarland 291, 293.

Sahara 529.

Salette, la 50, 51 .

Savoye 278.

Scheldemond 367 .

Schiedam 56r.

Schijndel (Scheyndel) 34, 247, 248, 250, 554 .

Sjanghai 354.

Skandinaviê r I 4, 239, 358, 474 .

Someren 18. 


\section{Son rgr.}

Southampton 567.

Spanje 294, 331, 354, 402 .

Srebenica 478 .

St. Michielsgestel 390, 400 .

St. Oedenrode (Rooy) 481, 511, 531.

Stratum 519.

Strijp 75. 519.

Sudetenland 330, 331, 352, 479 .

Suez 285, 589 .

Sumatra 242.

Tel Aviv 284, 285 .

Tiber, de 583 .

Tilburg 31, 67, 85, 91, 93, 104, 116, 117, 136, 223, 235. $324.327,493,511,588,592$.

Tirol 278, 351 .

Tongelre 519.

Transvaal 56.

Trier 262.

Tsjecho-Slowakije 330, 467, 472-479, 48r, 539,549.

Utrecht $82,85-87,90,91,117,126,127,155,171,172$, 236, 244, 298, 378, 399, 402, 4I8, 449, $482,487,489$. 505.

Valkenswaard 420,460 .

Venlo $18,28,38,352$.

Venray 36.

Versailles 138 .

Vierhouten 516.

Vlaanderen $68,69,125,130,183,242,243,251,285,312$. 323, $358,359.399,401,422,456,466,554,590,592$. 593.

Vlierden 21, 198, 420,421.

Vlijmen $405,406$.

Vlissingen 552.

Voorburg 393.

Vught 198, 199, 401, 405, 406, 4II, 416-420, 430, 496 . 560,573 .

Waalre 29, 203, 305, 307, 316, 317, 321, 331, 365, 375. $385,387-389,393,399,402-406,409-417,420,421$, $426,430,433,435,439,440,444,46 \mathrm{r}, 468,469,48 \mathrm{r}$, $482,486,493,504,510,532,537,570,595,596$.

Waalwijk 428,439 .

Waardenburg 594.

Wageningen 260, 266.

Warschau 347.

Wassenaar 560, 573.

Weimar 308, 400, 457 .

Wenen $87,94,98,114,233$.

Westerbork 401 .

Westfalen 27.

West-Indiê 75 .

Willemstad $5 \mathrm{rr}$.

Woensel 79, 102.
Woudrichem 581 .

Wijlre 17-20, 379.

Zaltbommel (Bommel) 256, 496, 594 . Zeilberg 22, 28, 64, 408 .

Zeist 244, 269.

Zevenbergen 20, 29.

Zuid-Willemsvaart (kanaal) 25, 33, 34 .

Zutphen

Zwarte Woud 554.

Zwitserland 353, 401, 580.

Zwolle 395 . 


\section{Index van persoonsnamen}

Aafjes, Bertus, (1914-1993) 484,485, 495.

Aalst, Jozef van, (ps, van Lambert Bijnen, priester/dichter $1893-1984)$ ) $22,139$.

Adolphine, Marie 495.

Aengenent, mgr. J.D.J. (r873-1935) 214-216.

Alain-Fournier, (ps. van Henri-Alban Fournier 18861814) 541 .

Alberdingk Thijm, K.J.L., (zie Lodewijk van Deyssel)

Albert, prins, (1934) 592 .

Albertus Magnus, ( 1 193-1280) 294.

Aleven, Clemens, dir. Gooische Post $112,172,214,234$. 237.

Altena, Ernst van, (1933-1999) 518.

Ammers-Küller, Jo van, (1844-1966) 220.

Anbeek, Ton, (1944) 525, 545, 547, 555 .

Andersen, H.C., $(1805 \cdot 1875) 339.341,360,386,571$.

Andrejew, (ook gespeld als Andrejeff, Andreev of Andrejev) Leonid Nikojajevitsj, (1871- 1919) 65-67. $73,74,472$.

Andriessen, H., (1892-1981) 443.488.

Andriessen, Juriaan, $(1925 \cdot 1996) 581$.

Arc, leanne d', (1412-1431) 229 .

Aristoteles (384-322 voor chr.) I 45 .

Arkel, C.1. van, officier van Justitie 409 .

Assman, 0. 431, 432, 434 .

Asselbergs, W.J.M.A., (zie Duinkerken, Anton van)

Asselbergs A.J.J.A., (vader van Anton van Duinkerken, 1877 -1940) 133.370, 372.

Asselbergs-Amolds, L.J.A. (Nini, t903-1990, echtgenote van Anton van Duinkerken) 173, 202, 317, 390, 391, 459.

Asselbergs, Bernard, (1945) 607.

Augustin, Felix, vertaler 234, 257-259.

Augustin-Glaser. Elisabeth, (schrijfster/vertaalster, 1903) 207, 234, 257-259.

Augustinus, Aurelius, $(354 \cdot 430) 79,122,161,213$.

Aurelius, Marcus, (Romeins keizer, $\mathrm{r} 2 \mathrm{I}-\mathrm{I} 80$ ) 76 .

Babylon, Frans, (ps. van F.G.J. Obers, 1924-1968) 381 , $498,532,543.551,559$.

Bach, Johan Sebastiaan, $(1685-1750) 238.376$.

Bakelmans, Lode 590.

Bakker, Henri, (1878-1933), luchtvaartpionier 33.

Bakker, Pietje den 208.

Baksteen, Gerard 314.

Balledux, Pierre, toneelproducent 504.

Balzac, H. de, (I799-1850) 53.303.333.490.

Barbey d'Aurevilly, J.A., (1808-1889) 113, 150, 303.

Bardot, Brigitte, (1934) 592.

Bartels, kapelaan in Deurne 59.60.

Bartels, personage in Het donkere licht 174,178 .

Baudelaire, Charles Pierre, (1821-1867) 150.
Bazelmans, Jo L.M. 365 .

Bazin, René, (1835-1932) 266, 267.

Beatrix, prinses, $(1938) 566$.

Beekers, Nel 22.

Beel, L.J.M., (1902-1977) 473 .

Beethoven, Ludwig von, (1770-1827) 505. 540 .

Beex, Harry, priester/redacteur Brabantia Nostra 503.

Bekman, Bernard, journalist 24, 25, 39, I12, 113,235 .

$237.495,558$.

Beks, Maarten, (1929) 276, 277.

Belinfante, A.D., (1911-2000) 430, 431, 434,435.

Belpaire, Marie, (1853-1948) 311 .

Belt, Bertus van den $607,608,610$.

Benedictus XV, paus, (1854-1922, pontificaat van 1914 1922) 49.90.

Berckel, dokter van 281 .

Berends, J. 488 .

Berg, C.G. 312 .

Bergfeld, Joachim 39r-393.395. 399.

Bergmans, H. 493.

Berkelmans, Marie 208.

Berkvens, tandarts Deurne 426, 427, 444, 568 .

Bernanos, Georges, (r888-1948) 523.525. 526 .

Bernardus van Clairvaux (1090-1153) 145.

Bernhard, prins, (1911) 310,453,503. 566 .

Bever, C.H. de 430.

Bevers, Ad, (rgri) 557.

Beversluis, Martien, (ps. van M.B. Versluis 1894-1966)

$138-140,383$.

Bijnen, Bert, (zie Jozef van Aalst).

Bijland, Aleida $183,205$.

Bijvoet 312 .

Binnendijk, D.A.M., (1902-1984) 203,385, 419, 474 .

Birgitta van Zweden, (1302-1373) 495 .

Bismarck, Otto von, $(1815 \cdot 1898) 462$.

Blaman, Anna, (r $905^{-1960)}$ 367. 502, 525. 526, 539. 543. 544 .

Blijstra, Rein, (rgor-1975) 455.483.

Bloem, J.C., (1887-r966) 2r9. 395.

Blokzijl, Max (1884-1946) 386 .

Blom, J.C.H., (r943) 413 .

Bloy, Léon, (1846-1917) 46-51, 54, 60-62, 65, 66, 68, 71,

$73.87-90,113,121,144,363,404,483,510$.

Boaz, personage uit boek Ruth 497.

Boccaccio, Giovanni, (1313-1375) 506.

Boeddha 232.

Boeke, Kees, (1884:1965) 500.

Boerebach, Ben, romanist 174 .

Boeren, P.C., (1909-1994) 486, 495.

Boersema, B.R.C.A. (r943) 483.485 .

Bomans, Godfried, (1913-r971) 375, 385-387, 455, 459 . $475,486,487,493,495,518,519,560,561,571,574$. 
Bont-van der Linden, Leny de, secretaresse van Coolen $417,435,469,595,610$.

Boogaard, Frank van den 397.

Boogaard te Brugge, baronesse van den 506.

Boogerd, J. van den 505.

Boost, Charles, (19r2) 455 .

Bordewijk, F., (1884-1965) 367.395.513.526, 542 .

Borms, August, (1878-1946) 243.358.

Borsten, onderwijzer 24.

Bosch, letoen, (ca. 1450-1516) 206, 210, 211, 216, 235. 240, 501 .

Boudier-Bakker, Ina, (1875-1966) 167, 525 .

Bourbon, Louis Henri Charles Jean Adelberth de. (rgo8. 1975) $\mathrm{x} 6 \mathrm{r}, 254,297,305 \cdot 307,323,354,355.357,359$. $362,363,370-375 \cdot 385,388-391,402-409,411,413$ $417,458,464,465,473 \cdot 475,482,483,485,492,495$. $512,513.537,546,547,558-560,579$.

Bourbon, Gudrun de 307, 373, 406, 408, 409, 474, 512, 558.

Bouman, Jan 472,473 .

Bouwmans, Marjo 23.

Bouwmeester, Frits, (1885-1968) 264. 319.

Boven, P.M.H. van, $(1913 \cdot 1997) 323$.

Braak, Menno ter, (1902-1940) 148, 149, 185, 213, 217 . 2 r8-220, 240, 252, 253, 265, 279, 301-303, 305. 313. $315.341,354.355,357,360,369,474.523$.

Braken, van den, Maria Gordina, grootmoeder van de schrijver 18.

Braken, Peter van den, (1896-1979) 69, 7t, 73, 77, 377 . 596.

Brand, Henri, brouwer 20.

Brand, Mathieu, brouwer 20.

Brand, Paul, (r885-1968) 166, 223, 224, 400.

Brandt, Willem, (ps, van W.S.B. Klooster), (rgo5) 547. 556.

Braun, P. 58 1.

Breedveld, Willem, (ps. van P.M.E. van den Bogaert, rgor-1977) 495, 596.

Briels, Carel, (1916-1983) 465, 481 .

Brom, Gerard, (t882-1959) 93. 241. 311 , 352.

Brouwer, P.C. de, (1874-1961) 326, 5 ro.

Bruch, Max (1838-1920) 127 .

Brueghel, Pieter, (1564-1637) 119. 188, 190, 312.

Brugge, van (bemanning de Uiver) 269.

Bruggen, Staf, ( $1893-1964) 359$.

Bruijn, ir. de 488 .

Brun, Luis, uitgever Grasset 312,313.

Bruning, Gerard, (1898-1926) 48, 95, 138.

Bruning, Henri, (rgoo-1983) r24, 137, 139. 337, 380, 383 . $385,522,523.555$.

Brusse, Jan, (r921-1996) 455 .

Busken Huet, Conrad. (1826-1886) 40.

Buytendiik. F.I.I. $(2887 \cdot 1974) 544$.

Caesar, Julius. (roo-44 voor chr) 57 .

Calderón, (i600-168r) 34

Calis, Piet, (r936) 397
Cals, 1.M.LTh., (1914:197r) 526 .

Cammelbeeck, G.JP. advocaat 435, 437, 441, 448, 449, 460 .

Campert. Jan, (1902-1943) 302, 303.

Camus, Albert, (1913-1960) 526, 546, 556.

Cantré, Jozef. (1890-1957) 224, 262, 263. $270,272$.

Carnegie, Andrew, (1835-1919) 564, 568 .

Carrossa, Hans, (1878-1956) 513.

Catharina van Zweden, ( $\mathrm{r} 33 \mathrm{r}-138 \mathrm{r}) 495$.

Cauwelaert, Frans van, (1880-196r) 68 .

Chamberlain, Arthur Nevil, (1869-1940) 330, 331.

Charles, J.B., (ps. van Willem Nagel, 1910-1983) 448-450, 570.

Chesterton, G.K., $(1874-1936) 24$.

Christie, Agatha, (1891) 314 .

Churchill, Winston, (1874-1965) 416 .

Claes, Ernest, (1885-1968) 129, 233. 399, 422, 457. $45^{8}$, 554.

Claudius (ro voor chr. - 54 na chr) 454 .

Claus, Hugo, (1929) 182, 579 .

Cleerdin, Vincent, (1888-1946) 44, 48, 49, 94, 95, 119. $307,326,365,366,370,372,404 \cdot 406,410,412,419$, 495, 509. 510, 521, 531 .

Clemenceau, Georges Eugène Benjamin, (1841-1929) 77.

Clercq, René de, (1877-1932) 68,69, 308.

Clercq, Richard de 590.

Cleveringa, R.P., (1894-1980) 370.

Coenen, Frans, (1866-1936) 280.

Cohen, Alexander, ( $1864-196 \mathrm{r}$ ) 50.

Collette, Joan 106, 488 .

Colijn, Hendrik, (r869-1944) 269, 296.

Commissaris, Aug.C.J., (r897-1957) 522.

Confucius, (551-479 voor chr.) 232.

Conscience, Hendrik, (1812-1883) 30, 37, 54, 126, 127. $322,323$.

Coolen, Antonius Franciscus, (1897-1961) passim.

Coolen, Aurelius Augustinus, (Stijn, zoon van de schrij) ver, $1931-1983) 202-205,228,245,256,296,305,317$. $340,416,420,469,499 \cdot 50 r, 523,573,596$.

Coolen, Catharina Adesta, (Cato, zus van de schrijver. 1895-1977) 19. 35, 191، 357.

Coolen, Cato (kloosterzuster) 17 .

Coolen, Felix Paulus, (zoon van de schrijver, 1933) 209. $237,259,296,377,395,416,420,461,476,499,526$, $591,607,610$.

Coolen, Guido Lodewijk, (zoon van de schrijver, 1932) $206,214,245,296,306,416,420,426,499$.

Coolen, jantje (jonggestorven broer van de schrijuer, 1907-1907) 22.

Coolen, Johannes, (bet-overgrootvader van de schrijver, $1744-1823) 18$.

Coolen, Johannes Hendricus Antonius, (vader van de schrijver, 1858-1934) $17 \cdot 23,191,261$.

Coolen, Johannes Antonius (Jan, broer van de schrijver, 1909-1996) 20, 21. 
Coolen, Josephus Petrus Gerardus, (Sjef, broer van de schrijver, 1904-1976) 20, 191.

Coolen, Leonardus, (overgrootvader van de schrijver, 1780-1846) 18.

Coolen, Leonardus Adrianus, (Nard, broer van de schrij. ver $1902-198 \mathrm{r}$ ) 20, 191, 416, 417 .

Coolen, Maria Francisca, (Miet, zus van de schrijver, 1899-1971) 20, 22, 191.

Coolen, Michiel, borghemeester van Asten, zeventiende eeuw 18 .

Coolen, Peter Hendricus, (Peterke, zoon van de schrijver $1937-1947) 306,307,416,420,468,469,472-475,481$, $500,512,573$.

Coolen, Wilhelmina Godefrida, (zus van de schrijver, 1894-1897) 19, 20.

Coolen, Wilhelmus, (grootvader van de schrijver, 1824 * 1889) 18

Coolen, Wilhelmus Johannes, (Willem, broer van de schrijver, 1892-1982) 19, $21,191,417$

Coolen - de long, Gerda (echtgenote van de schrijver, 1901-1964) 127-130, 138-140, 150, 153, 155, 165, 168. $170,172-175,194,204,228,247,259,297,301,305$. $307,317,373,402,408,416,420,468,473 \cdot 475,500$, $506,549,554,556,558,573,574,577,580,592$.

Coolen-Swinkels, Maria Goordina, (moeder van de schrijver, 1866-1945) 17-19. 59, 65, 191, 456.

Coolen, f.G.M., (Hans, neef van de schrijver, zoon van Johannes Antonius) r9r, 469,6ro.

Coolen, Sjef, (neef van de schrijver, zoon van Wilhelmus Johannes) r $9,173,417,608,6 \mathrm{ro}$.

Coolen de Oudere, Antoon, (1875-1905) 23.

Coornhert, D.V., (1522-1590) 119.

Coppens, Martien, (rgo8-r986) 375. 510, 591.

Coster, Dirk, (1887-1956) 173, 180, 181, 204, 257, 263. $307,311,333,483$.

Couperus, Louis, (1863-1923) 60, 65, 69, 146 .

Courths-Mahler, Hedwig, (r867-1950) 280 .

Cremer, I.1., (1827-1880) 154, 155. 252.

Creyghton s.j. J.C., (1901-1975) 483,484,495.

Crobach, huisarts Deume 22.

Croiset, Max, (1912-1993) 579, 580.

Custers, J.F.H., natuurkundige Philips 430.

Daisne, Johan, (ps. van Herman Thiery, 1912-1978) 490. Dalsum, Albert van, (1889-1971) 388, 454, 488, 518 .

Dam, I.P.A. van den 39.

Dam, van, Secr. Generaal 384.

Darwin, Charles, (1809-1882) 72, 138, 146, 147, 315.

Daudet, Alphons, (1840-1897) 150, 238.

Debrot, Cola, (1902-198r) 483 .

Debussy, Claude (1862-1918) 540 .

Defresne, Aug, (1893-Ig6r) 414, 454-456, 464, 465, 55 O.

Dekker, Maurits, (I896-1962) 414, 419, 454, 455 .

Dekker, Ton, volkskundige $38 \mathrm{r}$.

Dendermonde, Max 520.

Deurne, D. van 37 I.

Derks, Jan, (1912-1963) 487.
Derricks, Alard 482 .

Deyssel, Lodewijk van, (ps, van K.J.L. Alberdink Thijm, $1864-1952) 40,43,60,188,386$.

Diba, Farah 592.

Dickens, Charles, (1812-1870) 189, 287, 314, 333, 341, $342,375,519$.

Diepen, mgr. A.F., (1860-1943) 95, 104

Dijk sr., I.J.H.(Ko) van, (188r-1937) 264, 286, 319.

Dijk, los van 387-389.

Dijk, Frans van 365, 388, 411, 577.

Dijk, Bart van, (1956) 387 .

Dijk-Liecker, Jetty van 264 .

Dilling, K. 33 .

Dinther, van, pastoor Deurne 493. 553, 556, 556.

Dircksen, Heintje, (r937-r947) 468.

Dixhoorn, Frits van (-2001) 565.567.

Dobbelsteen, L.A. 34

Domburg, A. (Janus) van, (1895:1983) 312,487,596.

Dongen, Kees van, (1877-1968) 50 .

Donker, Anthonie, (ps. van professor N.A. Donkersloot, rgo2-1965) 218, 257, 258, 369, 385, 386, 389, 403, 419 . 474. $535,549.550,554,556,557$.

Doolaard, A. den, (ps. van Cornelis Spoelstra, rgor1994) 30r, 304, 320, 465, 525 .

Doorne, H.l. (Hub) van, (1900-1979) 412, 419, 422-423. $425-427,429-450,460,464,467,496,522,563-566$, $568,570,571$.

Doorne, Wim van 571 .

Dorsman, L, (1955) 245.

Dostojewski, F.M., (1821-188t) 239, 303, 490.

Drees, Willem, (1886-1988) 448 .

Dresselhuys, Mary, (1907) 580 .

Dreyfuss, Alfred (1859-1935) 52.

Droog, Bernard 580 .

Dubois, P. H., (1917-1999) 220, 221, 542,543.

Dudok, W.M., (1884-1974) 112 .

Duinkerken, Anton van, (ps. van W.J.M.A. Asselbergs, 1903-1968) 29, 36, 37, 40, 43, 51, 72, 98, 99, 109, 113. $115-127,129-13 x, 133,136 \cdot 153,155 \cdot 158,161,164$ 171, 173-175, 177, 179-181, 185, 186, 188, 189, 193. 195, 200-205, 211-219, 231-237, 240, 241, 250, 252. $254,255,257-259,261,263,264,266,271,278,28 \mathrm{r}$ $283,286,292,296,301,302,310-313,320-323,326$, $327,329.337,340,341,348,349,350,354,355.357$. $360-363,369-373,375,383,385,386,388-391,399$ $403,4 \mathrm{Ir}, 412,414,415,417,419,443,445,458,459$. $465-467,469,473,479,483-490,492,495,497-503$. $506,510,513 \cdot 515,517 \cdot 519,522,523,526,532-534$. $539.544,546,547,550,552-554,556-559,573.590$ 。 591. 593-597.

Duribreux, Gaston, Vlaams schrijver, (1903-1986) 490. 492.

Durnez, Gaston, (1928) 33, $183,233$.

Dwinger, Edwin Erich, (1898-198r) 308, 309.

Eckhart, Meester, mysticus, (1260-1327) 67.

Eeden, Frederik van, (1860-1932) 73-75, 171, 320. 
Eijnde, Noud van den, uitgever Deurne 426, 439. 441 . 443. 445.

Eekelen, W.R.A. van, dir. secr. DAF 449.

Eekhout, $\tan$ H. (1900-1978) 205. 383. 557.

Eerenbeemt, Herman August Leonard van den, (r8901951) 488.

Eggink, Clara, (rgo6-r99r) 4r9, 469.

Einthoven, van 364 .

Elemans, Jan, (1924) 552 .

Elsen O.praem., Gerlacus van den, 'de boerenapostel, (r853-1925) 30. 37.529.

Elsschot, Willem, (ps. van A.). de Ridder, $1882-1960$ ) 243.513.

Emma, koningin der Nederlanden, (t858-1934) 259.

Enden, Eddy van den, cameraman $58 \mathrm{I}$.

Engelman, Jan, (1900-1972) 115-117, 119, 122, 124, 125. 155. 169, 171, 174, 186, 211, 217, 251, 254, 259, 269, $271,272,311,312,317,321,323,362,373,385,389$, $483,485,511,550,595-597$.

Engels, Wolfgang, acteur 377.

Erasmus, Desiderius, (1469-1536) 148, 269, 279.

Eyck, Charles, (1897-1983) 214, 312.

Eyck, P.N. van, (1887-1954) 361, 443 .

Eyk, Henriëtte van, (1899-1980) 367, 469, 520 .

Fabricius, Johan, (r899-198s) x88, 218, 239, 288, 526 , $527,58 \mathrm{r}$.

Faltová, Lida, Tsjechisch vertaalster 472 .

Faulkner, William, (1897-1962) 215.

Feber, L.J.M. (1885'1964) r50. 337.

Fennis, Frans 112, 113, 128, 171, 172, 271.

Fens, Kees. (1929) 338. 339. 587.589 .

Flaubert, Gustave, (1821-1880) 341 .

Forel, Auguste Henri, (1848-1931) 86, 87 .

Franc, Marie Le, 239.

Franco, Francisco, (1893-1975) 297, 330.

Franck, César, (1822-1890) I72.

Franke, S. 469.

Frankenstein, SD-er 516.

Frederik de Grote, (1712-1786) 462.

Freya, Germaanse godin 462 .

Frederiks, K.J., (1881-196r) 373, 374, 405-407, 410-413, $415,417,516$.

Frencken, F.B.J., (1886-1946) 96, 130, 177. 512.

Freud, Sigmund $54 \mathrm{r}$.

Fuchs, hospita 112.

Gans, Jacques 473.

Galileì, Galileo, (1564-1642) 564.

Gauguin, Paul, (1848-1903) 306.

Genoveva van Brabant 505, 506, 508, 532.

Gerlach Royen, o.f.m., pater 295.

Gerretson (zie Gossaert)

Geurts, P..H., hoofdredacteur De Tijd 47 .

Geyl, Pieter, (1887-1966) 243. 518.

Gezelle, Guido, (1830-1899) 35, 243, 492, 591 .

Gide, André, (1869-1951) 347 .
Gijsen, Marie, (1856-1936) 98,118, $120,122,180$.

Gijsen, Marnix, (ps. van J.A. Goris, 1899-1984) 129. 311. Ginkel, van 80 .

Giono, Jean, (1895-1970) 215, 296, 312,313.474.

Goebbels, Joseph, (1897-1945) 379, 401, 402.

Goedewagen, Tobi, (1895-1980) 383, 385, 391. 393. 395 .

Goering, Hermann, (1893-1946) 256, 258.

Goes Naters, jhr. M.M. van der, (r900) 571.

Goethe, Johann Wolfgang von, $(1782-1832) 75,146,300$, 358,486 .

Gogh, Vincent van, (1853-1890) 1r9, 194, 200, 205, 21t, 306, 531 .

Goossens, rector Th., (1882-1970) 324 .

Gorki, Maksim, (1868-1936) 239. 528.

Gorter, Herman, (1864-1927) 36r.

Goseling, C.M.J.F., minister $37 x$.

Gossaert, Geerten. (ps. van F.C. Gerretson, 1884-1954) 385,592 .

Graaff, Chr de, (1890-1955) 205, 287-289, 308, 310, 319. $382,383,487$.

Graft, Guillaume van der, (ps. van W. Barnard, 1920) 556.

Granand 505.

Granpré Molière, M.J. (architect, 1883-1972) 488.

's-Gravesande, G.H. (1882-1965) 204, 205.

Green, Julien, (1900-1998) 526, 546.

Greene, Graham, (r904-1991) 490, 491, 525, 526.

Greshoff, Jan, (1888-1971) 76, 78, 301, 474, 542,543, 569 .

Grieg. Edvard, (1843-1907) 79 .

Griendt. Gebroeders van de, peelontginners 25.

Griend, M. van der, redactiesecretaris Brabantia 522.

Grimm, gebroeders 380, 505 .

Groeneweg, Ronald 46r, 483, $6 \mathrm{ro}$.

Groot, Hugo de, Grotius (1583-1645) 258, 269.

Guardini, Romano, (1885-1968) 483.

Guépin, A.J., dir. secr. Philips 430.

Haas, J.M. de, fabrikant 430.

Haas, Nico de, medewerker De Waag 380, $38 \mathrm{r}$.

Haastert, H.A.M. van, (t887-) 48, 169 .

Hahn, Albert. (1894-1953) 68.

Haile Selassi, de Negus (1892-1975) 294, 448, 571 .

Haimon, Paul, (x916-1996) 522.

Ham, van, hoofd afdeling boekwezen 394.

Hamburget, Salomon, (zie Herman de Man)

Hammerinck, Clara 307.

Hamsun, Knut, (ps, van Knut Pedersen, 1859-1952) 220, $302,339,574,575$.

Hāndel, Georg Friederich, (1685-1759) 584 .

Hanlo, Jan 23.

Hannema 383.

Happak-Metzler, Theresia, vertaalster 233, 235.

Haren, Hans van (ps, van Hans de Jong) $128,172$.

Hartog, Jan de, (r914) 525, 580.

Haterd, Lex van de $46,47,379$.

Hauptmann, Gerhart, (1862-1946) 48.

Have, Wichert ten 243, 329, 331, 352, 353, 361, 363-365. 
Haydn, Joseph, (1732-1809) 540, 576.

Hazeu, Wim 277.

Heeren, H.M., (1888-1967) 31, 36, 37. 39, 190, 191, 193. Hegener, Fischer Verlag 234.

Hegge, pater R.F. 3 I2.

Hein, Piet, (eigenlijk Pieter Pierszoon Heijn, 1577-1629)

269.

Heidenstam, Carl Gustav Werner von, (1859-1940) $39 \mathrm{r}$. Heijden, Marcel van der, (r931) 95.

Heijermans, Herman, (1864-1924) 58, 106.

Heijman, H. Th. 35. 505 .

Helman, Albert (pseudoniem van Lou Lichtveld, 1903. 1996) 51, 92,93, 126, 169, 188, 194, 195, 214, $218,239$. $270,340,341,363,385-389,403,412,414,415,453$. 457.489 .513$.

Hello, Ermest, (1828-1885) 46,48-55. 57, 58,60, 6r, 63, 66, $68,93,113,121,144,156,157$.

Helvoort, rector van 488,489 .

Hemeldonck, Emiel van, (1897-1981) 518, 591, 594.

Hémon, Louis, (1880-1913) 239.

Hendrichs s.j., pater F., (1862-1938) 64, 65.75, 86. 90. Hendriks, directeur De Zuidwillemsvaart 64.

Hendriks, M.J. 426, 428, 435.

Henkes, Barbara, (1955) 325 .

Heringa, Hidde 469.

Hermans, pater Hyacinth 204.

Hermans, W.F., (rg2I-I996) 502, 525. 526, 539, 543. 544. 557.589.

Hermus, Cor, (1890-1963) r91, 264, 319, 507, 533.

Herwig, Franz 348-350.

Heugten, W.A.M. van 426, 436, 437 .

Heugten s.j., Pater J. van, (1890-1963) 168, 279, 281.

Heydrich, Reinhard, (r904-1942) 477.

Hille Ris Lambers, Heleen 276.

Hillenius, D., (1928) 375 .

Hirsch, Fritz 503.

Hirschfeld, H.M., (1899-1961) 516.

Hitchcock, Alfred, (1899-1980) 367 .

Hitler. Adolf, (1889-1945) 234, 242, 256-259, 293, 295. $313,323,330,331,345,346,351,355,356,363,378$, $401,462,463,465,479$.

Hoek, Luc van 510.

Hofdijk, W.J., (1816-1888) 37.

Hoffman, Willem, (1908-199r) 507.

Hofhuizen, Herman 556, 557.

Hofstra, J.W. 469.

Hohmann, J.425, 610.

Hohman-van Doorne, M. 425, 568, 569, 6 ro.

Holierhoek, Jeanne 313.

Hollenberg, P., (-1979) 31, 33.

Hollidee, H., (ps. van Elard Albert Rovers, 1848-1908) 58.

Homeros, (ca 800-ca 750 voor chr.) r9o.

Hoornik, Ed., (1910-1970) 213,469, 476, 477.

Houwink, Roel, (1899-1987) 262, 263.

Huddleston Slater, W.B. $28 \mathrm{t}$.

Hugh, Richard, (r900-) 515.

Hugo, Victor, (1802-1885) 53 .
Hugten, frater Amator van 412,413.

Huiskamp, R. 3 I.

Huizinga, Johan, (1872-1945) 293.

Huizinga, Leonard (1906-1980) 394.469.

Hulsbeek, J, van 593.

Hulsman, Annie 180.

Hulsman, Bernard 112, 170, 172, 235.

Hurk, van den, Alph.W., (r9r1) 33. 37.

Huysmans, J.K., (1848-1907) 62, 150, I6I.

Ibsen, Hendrik, (1828-1906) 48, 58, 60, 108, 146, 339 . 340.

Iddekinge, P.R.A. van, (1934-2000) 57 .

Iersel, Kees van 481 .

I]sbouts, Wilhelmina, overgrootmoeder 18.

Ipema, Jan 359.

Irving, Washington, (1783-1859) so5.

Iven, Willem, (1933) 25 .

Jaarsma, D.Th. $28 \mathrm{r}$.

Jacob, G., NSB-burgemeester 405, 406.

Jammes, Francis, (Frans schrijver, 1868-r938) 515.

Janda, Bohumil, Tsjechisch uitgever 472,473 .

Jansen, G.J. 409, 430, 431.

Jansen-de Wit, kousenfabrikant 554 .

Jolles, J.A., (1874-1946) 244, 245 .

Jonckbloet. W.J.A., (1817-1885) 60 .

Jong, A.M. de, (1888-1943) 154, 155, 181-183, 189, 200, 201, 210, 211, 232, 233, 307. 311, 320, 321, 375, 388 ,

389. 509, 510,525 .

Jong, Gerda de, (zie Gerda Coolen - de Jong).

Jong, Hans de (zie Hans van Haren)

Jong, Johannes kardinaal de, (1885-1955) 414, 488, 489. 504, 505 .

Jong L de, (1914) 346, 347, 353, 357, 359, 364, 365. 371 . $375,387,389,393,395,396,413,417,434,448$.

long, Martin J.G. de, (1929) 215.

Jong. Dom. P. de rg9.

Joosten, L.M.H., (1929) 49, 107, 185, 187, 309, 405.

Josselin de Jong, Kitty de 556.

Juliana, prinses later koningin der Nederlanden, (1909) $242,310,448,503,517$.

Kafka, Franz, (1883-1924) 418.

Kamerlingh Onnes, H., (1853-1926) 269.

Kanters, A.]. $5^{82,588 .}$

Kapteijns, Harry, (1917-1987) 220, 221, 518, 519, 551, $552,568,569$.

Kazdova, Ella, Tsjechisch vertaalster $472,473,475-477$. $480.549,555.557$.

Keaton, Buster, (1896-1966) 259.

Keesom, W.H., (1876-1956) 269.

Keijsers, J. openluchttoneel 507.

Kelk, C.J.4 (1901-1981) 307, 395, 419, 469, 475, 596, 597.

Kemp, Mathias, (1890-1964) 72,75, 167.

Kemp, Pierre, (1886-1967) 71, 72,75.

Kersten, Piet 121. 
Kettman jr., G. 383.

Kippenberg, Anton, (1874:1950) 233. 308, 309, 357, 359.

$372,377,378,385,513$.

Klap, Kees 525 .

Klemperer, Victor, (1881-1960) 295. 356.357.

Kloos, Willem, $(r 859-1938)$ 40. $58,60,146$.

Knaapen, I.M.I. 34,507.

Knipping o.f.m., Baptist, (1899-) 488.

Knuvelder, Gerard, (1902-1982) 95, 124, 156, 168, 169. $177,185,186,243.324,326,591,596,597$.

Koch, H. dramaturg $377: 379$.

Koch, Pyke, (1901-1991) 219.

Koenen, Marie, (1879-1959) 70, 75.

Kogan, Moissej ( $1897-1943 / 44) 272$.

Kohler, Charlotte, (1892-1977) 388.

Köhnen, Janus 22.

Kollwitz, Käthe (1867-1945) 461.

Kool, Halbo C., (r907-1968) 389. 4 I9.

Koolhaas, Marnix 301.

Kools, Tij 450, 45I, 608.

Kortooms, Toon, (1916-1999) 448.

Kossmann, A., (1922-1998) 556.

Kossmann, E.H., (1922) 413.

Kotzde, Wilhelm, (ps. van Wilhelm van Kottenrohdt,1878-1948) 462, 522, 523.

Kouwenaar, Gerrit 546.

Kralik, Richard, (r852-1934) 47.48, 87-90, 404, 484 .

Kràmer, E. 426.444.

Krop, F.1. 309.

Kropman, G.C.J.D. 169,484 .

Kuitenbrouwer, Henk, (r900-1974) 113, 117, 169, 234, $236,237,254$.

Kuitenbrouwer, Louis, (zie Albert Kuyle)

Kusters, Wiel, (1947) 19,41, 71 .

Kuyle, Albert (pseudoniem van Louis Kuitenbrouwer, $1904-1958) 117,124,126,168,169,171,173,180,186$, $187,213,214,234,235,239,250,254,255,263-265$. $281,308,309,482,484,485-487,495,554$.

Kuypers, Paul, recensent 568,569 .

Kuyten. J.553.

Laar, Louis van de, staatssecretaris O.K. en W. $5 \times 8$.

Laat, Johanna de 18.

Lagerkvist, Per, (1891-1974) 291.

Lagerlöf, Selma 279. 336, 341, 474 .

Laman Trip-de Beaufort. Henriètte, (1890-1982) 556.

Lamberty, Max, (1893-1975) 590.

Lambooy, burgemeester $427,428,43 x, 435,438-440,445$.

Lamsweerde, H.C.J.A. baron van (zie Merlet, Herluf van).

Langeveld, M.J. (pedagoog, 1905-1989) 544 .

Laserre, Henri 52.

Last, lef, (1898-1972) 367.469.

Lateur, Frank (zie Streuvels).

Laudy, Alphons, (1875-1970) 40,87-89, 149.

Lauesen, Markus, Deens schrijver 307.

Laurey, Harriet, (1924) 552.
Lautenslager, Piet 71 .

Lebeau, Paul, (Vlaams schrijver, 1908-1982) 490.

Leffens, André, (dubbel pseudoniem van Van Duinkerken) 350, 355 .

Leeuw. Aart van der, (1876-1931) 204, 239-241, 320, 333. 357.491 .542$.

Leeuwen, Fred van, 71.

Leeuwen, W.L.M.E van 279, 280, $28 \mathrm{x}$.

Lennart, Clare, (ps. van Clare Helena van den BoogaardKlaver, 1904-1972) 537 .

Lenzberg, Kurt, vertaler 309.

Leo XIII, paus (1810-1903. pontificaat van 1878-1903) 49.

Leonardo da Vinci 163.

Leopold, Jan Hendrik, (1865-1925) 138.

Lepper, J.L.M. (Jan) de, vriend van Van Duinkerken 139. Lerberghe, Charles van, (Frans/Belgisch dichter, $186 \mathrm{r}$ 1907) 542 .

Lewin, Lisette 397.

Lichtveld, Lou, (zie Helman, Albert).

Lichtveld-Mengelberg, Leni 214

Lindbergh, Charles, (1902-t974) 295.

Linden, Hendrik van der, dir. postkantoor Waalre 417 . 435.

Linden, Leny van der,(zie: Leny de Bont-van der Linden)

Linnebank, pater 60.

Linthorst Homan, J. ( $\left.1903^{-}\right) 364$.

Löb, familie 591.

Lodewijk de heilige $(1214-1270) 229$.

Lodewijk XV1 306.

Loetsj, Bruno 353.

Lokhorst, Emmy van, (1891-1970) 338.419.

Looy, Jacobus van, (1855-1930) 35. 528 .

Lucassen, J.M.W.G., 39.

Luns, Huib Marie, (188r-1942) 326 .

Luther,Maarten, (1483-1546) 462 .

Lutkie. Wouter. $(1887-1968) 25,36,37,46-55,57-82,85$. 91, 93-108, 113, 133.135, 145-147, 165, 170, 171, 185 . 187, 303. 304, 380, 381, 401, 404, 412, 484,492 .

Maas, H.J... (1877-1958) 30. 32, 36-39.57.83.534.

Maas, Willem, (1897-1950) 169. 312.

Maas-Bonebakker, Toni r 69 .

Machiavelli, Niccolò. (I469-1527) 294.

Made, J.A. van der 383,384 .

Maeterlinck, Maurice, (1862-1949) 89, 542.

Maistre, Joseph de (1753-1821) I13, I17.

Man, Herman de, (ps, van Salomon Hamburger, 1898 . 1946) 86, 168-172, 183, 189, 205, 217-220, 253. 303. $305,400,401,459,466,557$.

Man, Eva de $400,401,459$.

Mara, (bitter; de naam van Naomi in het bijbelboek Ruth) 96,497 .

Margriet, prinses, (1943) 566.

Maria (Onze Lieve Vrouw, de Maagd Maria) 50, 59. 97. 199, 241, 241, 262, 314, 319. 324, 327, 328, 421, 460, 463. 539.583 . 
Marie Antoinette (1755-1793) 322 .

Marsman, H., (1899-1940) 201, 217-219, 239, 250, $27 \mathrm{r}$,

$303.312,320,36 \mathrm{x}-363$.

Martens, F. 2 I.

Martinet, J.F., (1729-1795) 270,

Masaryk, Thomas G., (1850-1937) 49r.

Masaryk, Jan, (zoon van Thoma, 1886-1947) 472 .

Maupassant, Guy de, (1850-1893) 530 .

Mauriac, François, (1885-1970) 150, 220, 239, 341, 355.

$357,366,465,467,490,49 \mathrm{x}$.

Maurras, Charles, (1868-1852) 467, 515 .

Meeberg, Daan van de 559.

Meekel, Kees, (1883-1953) r69.

Meer de Walcheren, Pieter van der, (1880-1970) 48-51. $68,79,90,91,95,99-101,106,107,111,124,137,169$ $171,217,280,281,362,363,483,484,495$.

Meer de Walcheren, Christine van der, (1876-1953) 79. t69.

Meer de Walcheren, Anne-Marie van der, (1912-1976) 169.

Meertens, P... (1899-1985) 323. 549. 590 .

Meerwijk, Jantje van 23.

Meeuwese, Karel,(1914-1991) 593.

Meijer, Amold, (t905-1965) 363.364.369.

Melati van Java (ps. van N.M.C. Sloot, 1853-1927) 106. 107.

Mens, lan, (1897-1967) 469.

Merlet, Herluf van (ps. van H.C.).A. baron vam Lamsweerde, 1900-1965) 137.

Mertens, Anthonie M. 323,484, 545, 592, 593 .

Mertens, Peter, (1892 Geraardsbergen - 1955 Leipzig) $233,234,257,308,310,311,352,353.378,379$.

Meuleman, Clemens 256, 312, 338 .

Meurs. Bernard van 493.

Michael, Hubert 513.

Michel, Ernst 95.

Middendorp, criticus 155 .

Millet, Jean-François, $(1814-1875) 78$.

Mindszenty, kardinaal, (1892-1975) 484, 485 .

Mirabeau, H.G.V. comte de, (1749-1791) 60.

Moens, Wies (1898-) 336.

Mohammed, (570-632) 232.

Mol, burgemeester 482, 493.537.

Molenaar m.s.c., M. 95.

Moll, (bemanning de Uiver) 269.

Moller, Hendrik, (1869:1940) 93-96, 107, 115-117, 122 -

124, 130, 133, 136, 137, 139, 149, 169, 243.

Monté, Gerard r 99.

Mortel, Jan van den 553.

Mozart, Wolfgang Amadeus, (1756-1791) 494. 585.

Mucius Scaevola (rond 500 voor chr.) 275.

Mulder, Anne H. 469, 505.

Mulder, Gerard, 451.

Mulder, J.W. 395. 397.

Mulder, P. hoofdredacteur Het Licht 427, 433 .

Mulford. Prentice, (1834-1891) 75 .
Mulisch, Harry, (1927) 513. 525, 539, 543. 545-547, 550, 589 .

Muller, Ludwig, Rijksbisschop Duitsland (1883.) 258, 259.

Muls, Jozef, (Vlaams schrijver, 1882-1961) 358 .

Multatuli, (ps. van Eduard Douwes Dekker, 1820-1887) 39-41, 51, 54, 57-60, 68, 69, 75, 108, 138, 145, 152, 354 . 447,478 .

Munnichs, André, (r912-1985) 488, 489. 518 .

Musch, Jan, (acteur, 1875-1960) 388 .

Mussert, A.A., (1894-1946) 259, 291, 364, 410,412, 520.

Mussolini, Benito, (1883-1945) 49, 51, 99, 107, 186, 242, 284, 293, 294, 303, 304, 404.

Naaijkens, Jan, (1919) 503. 505. 507, 518, 521, 552, 591, 593.610.

Naeff, Top. (1878-1953) 385 .

Naomi, (personage uit boek Ruth) 96, 497.

Napoleon, Bonaparte, (1769-1821) 50, 367, 461, 462,465.

Naundorff, Karl, Wilheim, (onbekende afkomst - 1845 ) 306.

Nelissen, H. 312.

Nicolas, J.A.H.F. (Joep), (1897-1972) 202, 272

Nieskens, 1. 367.

Nietzsche, Friedrich, (1844-1900) 47, 68, 72, 75, 78, 108, $138,139,145-150,287,335,361,362,523,570$.

Nieuwenhuis, Jan 193, 194, 200, 201, 215, 252, 253, 254. $280,281,302,303$.

Nieuwenhuis, Willem, (1886-1935) $137,169,214$

Nijhoff, Martinus, (1894-1953) 217, 219, 385, 474.

Niobe 301 .

Nispen tot Sevenaer, jhr. van 488.

Nolens, mgr. W.H., (1860-1931) 186.

Noorderwier-Reddingius, Aaltije, (Deurne 1868 Hilversum 1949) $187,270$.

Noort, B. van 267.

Nooteboom, Uri, (1903 1945) 510, 511 .

Nord, Max, (1916) 474, 475, 557.

Nuyen, W.J.F, (arts/historicus, 1823-1899) 511 .

Nypels, Charles, (1895-1952) 312.

Oberhausen, dr. 98.

Odin. god uit de oud-noorse mythologie 462 .

Oomes, P.G. (Piet), (1898-1984) 236, 237, 239, 247, 254. 263, 265, 271, 281, 286, 288, 289, 297, 300, 305. 309. 319. 328, 329. 350, 351. 354, 357, 367, 370, 382, 385 . 390, 391, 399. $401-403,410-412,414-416,418,419$, $438,439,460,461,473,475,481,485,491,495,499$. $501,502,513-517,519,525,526,532,533,539.546$. $547,553-555.568,569,574,575,581,596$.

Oomes, Nettie 237.

Oosten, A.J.D. van, (1898-1969) 205, 234, 312, 323.

Ortega y Gasset, José, (1883-1955) 523.

Ostayen, Paul van, (1896-1928) 492.

Oudheusden, 1.LG. van 327, 329, 369, 371, 427. 509 .

Ouwendijk, Dick 487. 
Ouwerling, H.N., (1862-1932) 25, 27, 30-34, 36-39, 41, $54^{-}$ $56,61,62,64,108,139,145,153,187,190,191,216$, $235,238,239,322,324,446,529,534$.

Ovidius, (43 voor chr. - ca 18 na chr.) 301 .

Paap. Wouter, (rgo8-1981) 312 .

Palestrina, Giovanni, (ca r525-1594) 34, 238.

Palen, van der, loco-burgemeester Waalre 409, 4 ro, 415. Panhuysen, Jos 129.

Parmentier, Dirk, (gezagvoerder de Uiver, r904-1948) 269.

Pascal, Blaise, (1623-1662) 584

Paola, prinses, (1937) 592.

Pasteur, Louis, (1822-1895) 229.

Pellemans, August 39, 46 .

Permeke, Constant, (1886-1952) 272.

Perron, Eddy du, (1899-1940) 204, 217-220, 282, 301-303. $314,315,341,354,360,474$.

Perry, Jos, (1950) 69, 71 .

Persijn[s], Jules, (leider Dietsche Warande en Belfort, 1878-1933) 466 .

Philips (bedrijf) 20, 177, 186, 511, 520 .

Philips, E.J., (rgo5) 431, 432.

Picard, Max, (Duits schrijver en cultuurfilosoof, 1882 1965) 380 .

Picasso, Pablo, (1881-1973) 50.

Piek, uitgever 358 .

Piere, van, boekhandelaar 23.514.

Pillecijn. Filip de, (1891-1962) 399.

Piscaer, H.J.M. 365.

Pitkin, Walter, (1878-1953) 293.

Pitlo, A., (1901-1987) 419.

Pius IX, paus, (t792-1878, pontificaat $1846-1878) 49$.

Pius X, paus, (1853-1914. pontificaat 1903-1914) 47 .

Pius XI, paus, (1857-1939. pontificaat 1922-1939) 292, 309.

Plas, Michel van der, $(1927) 117,123,139,151,167,185$. $215,219,255,293,307,321,369,371,381,385,415$. $443,455,463,465,483,487,495,499,515,522$.

Plasschaert, Albert, ( $1874-1939) 270$.

Pober, liri $475,477$.

Poe, Edgar Allan, (1809-1849) 76, 121. 367, 494.

Poirters, Adrianus of Adriaen, (1605-1674) 98, 190.

Poll, M.J.M. (Max) van, schrijver/politicus 169 .

Polman, Mariêlle 20r, 213.320, 321 .

Pompe, W.P.J., (1893-1968) 254, 258, 259. 312, 544.

Potgieter, E.)., (1808-1875) 58.

Prinsen, Generalkommisar $4 \mathrm{rr}$.

Proust, Marcel, (1871-1922) 29: 538, 539.

Pruis, Kees 295.

Pulles, H.A. 520.

Putt, J.J.A. van der, advocaat 435,441 .

Quay, J.E. de, (rgor-1985) 364, 493, 503, 504, 509, 51r, $517,518,521,528,552$.

Querido, Israël, (1872-1932)65-69, 82, 113,122, 145, 154 . $182,211,213$.
Quisling, V.LA., (1887-1945) 355 .

Rademakers, Fons, (1920) 579. 580.

Raephorst, Marijke van 533 .

Ramaeker, NSB-burgemeester 405 .

Ramuz, C.F., (1878-1947) 119.

Randwijk, H.M. van, (rgog-rg66) 385 .

Ras-van den Eerenbeemt ro4.

Rauschning, H., (1887-1982) 355 .

Ravestein, Max van (ps. van N.M.C Sloot, zie Melati van Java)

Ravesteyn, S. van, (1889-1983) 312.

Reddingius, Joannes, (Deurne 1873 - 1944) 187, 239. 318 , $319,383,386,387,388,391$.

Redeker, Hans, lid PEN-bestuur 556.

Reen, Ton van, (r94I) 450, 451.

Rees, Otto van, (1844-1957) 169, 270, 272.

Remarque, Erich Maria (ps. van E.P. Remark, r898-r970) I55. 293.

Rembrandt, (1606-1669) 328 .

Remery, Gaston 69. 73.

Renan, Ernest, (1823-1892) 229.

Renes, T. 39.

Reuter, Fritz, (1810-1874) 336, 474.

Reve, Gerard van het, (1923) 273, 502, 525, 526, 539,543. 545 .

Reve, Karel van het, (1921-2000) 67.

Revis, M., (ps. van Willem Visser, 1904-1973) 469.

Reyneke van Stuwe, Jeanne, (1874-1951) 37.

Ribbentrop, Joachim von, ( 1893 - 1946 ) 345 .

Ridder, W.A.H. den 403.

Rientjes, deken 487,488 .

Rijckevorsel, jhr. A. van, Commissaris der Koningin in Brabant 326, 372, 374, 405-407, 409, $4 \mathrm{rO}$.

Rijkens, 549.

Rimbaud, A. (1854-189r) 155, 306.

Ringuet, Frans/Canadees schrijver 351 .

Ritter jr., P.H., (1882-1962) 23. 200, 201, 299. 304. 307. $390,535$.

Ritterbusch, Fritz, Beauftragte in Brabant $4 \mathrm{I}$.

Roelands, Vlaams schrijver 305.

Roes, André 113.

Roes, pastoor H.W., (1864:I941) 32, 165, 529.

Roffelsen, Cor, architect 36, 271.

Rogier, L.J. (1894-1974) 27, 34, 35, 38, 47, 49, 52, 53 . $61,65,87,518,534,535,554$.

Röhm, Ernst, (r887-1934) 465 .

Roland Holst, A., (1888-1976) 389, 394-396, 443.

Roland Holst-van der Schaik, Henriëtte, (1869-1952) 169.

Romein, Jan, ( $1893-1962) 292,403.550$.

Romein-Verschoor, A, (1895-1978) 292, 293, 403.

Romijn, Jaap (Jacob Pieter), 1912-1986) 496.

Romme, C.P.M. ( 1896 -) 414

Rooijakkers, Gerard, (r962) I41, 381.

Roothaert, Anton M.H., (1896-1967) 520, 52 I.

Ros, Martin, (r937) 111. 
Rosa van Lima, (1586-1617) 539 .

Rossini, Gioacchino, (1792-1868) 582.

Rossum, Wim van, 169 .

Rousseau, Jean lacques, (1712-1778) 60, 75, 146, 297.

Rugani, Dogi, actrice 289, 319.

Rümke, H.C.. (1893-1967) 544.

Ruth, hoofdfiguur uit bijbelboek Ruth 96, 496, 497.

Ruusbroeck, Johannes van, (1293-1381) 67.

Ruygers, Geert (G.J.N.M.), (1911-1970) 326, 330, $331,482$. Ruys de Beerenbrouck, Charles, (1873-1936) 322.

Ruyter. Michiel de, (1607-1676) 554 .

Salomons, Annie, (1885-1980) 495.

Sande, J. van der 29.

Sartre, I.P., (1905-1980) 472, 490.

Sassen, Ad., (1906-1942) 165, 235, 239, 242, 254, 255, 266 ,

267.375 .

Sassen, Alfred, (1894-I971) 385 .

Schaap, Gerda 381 .

Schaik, A.H.M. van (r94I) 49, 93, 95, 105.

Schaik, St. van 312.

Schaik-Willing, Jeanne van, (1895-1984) 385, 414, 454. 455.

Schauer, George Kurt, (1899-1984) 233, 235, 257, 296, 297. 302, 303-305, 309.

Scheepens, Har 557, 559 .

Schellenbach, I.K. 439.

Schendel, Arthur van, (1874-1946) 239, 254, 301, 304. $305,320,541,588$.

Schenk, Joh.A.M. 426, 435 .

Schermerhorn, W..(1894-1977) 448.

Schierbeek, Bert, (1918-1996) 557.

Schlomer, Marcelle, vertaalster 215, 313, 415, 417.

Schmidt-Burgk, Edgar, cultuurintendant 376, 379, 426, 454.

Scholten, Harry, (1936-1987) 235. 350, 351, 371, 381, 383.

Schopenhauer, Arthur, (1788-1860) 75, 78, 146.

Schrama, N.G., (1925) 47, 49, 57, 195 .

Schreurs, A. 367.

Schregardus, R.M., NSB-burgemeester 411, 415, 416 .

Schulz Kemminghausen 590.

Schumann, Robert, (1810-1856) 540.

Servaes, Albert, (Vlaams schilder, 1883-1966) 358.

Sevigné, madame de, (1626-1696) 538 .

Seyss-Inquart, (1892-1946) 359, 363.376, 383, 386, 460 .

Shakespeare, William, (1546-1616) 550 .

Siemer, F., (1887-1966) 327.

Simons-Mees J.A., (1863-1948) 35 .

Simons, Ed 545.

Simon, Lambert, (1905-1990) 269, 312.

Sinnighe, J.R.W., (r904-) 244.

Slauerhoff, Jan Jacob, (x898-1936) 218, 219, 276, 277. 284, 304, 305 .

Slegers, Cees (1944) 173.

Sleeuwen, Jan van, (1918) 557,610 .

Sloot, N.M.C. (zie Melati van Java en Max van Ravestein)

Smedt, baron de 426 .
Smeding, H.J., (x 899-1979) 367.368.

Smit, Gabriël, (1910-1981) 487.489, 518, 522, 532, 554 . 596.

Snelling, W.E. 293.

Snieders, August, (Bladel 1825-Borgerhout 1904) 24, 30 . Snieders, Reinier, (Bladel 1812 -Turnhout 1888 ) 30.

Snijder, G.A.S., (1896-1992) 383 .

Snijders, J. Th. (1910-1996) 488.

Snoek, Jacques, acteur 319.

Söchting, Walter 385 .

Soep, Toon de 373.

Soeten, van 426, $432-434$.

Spee, Hubert 348.

Speliers, Hedwig, (1935) 245, 258, 259, 309, 353, 359, $379.385,401,459.461,513$.

Speijk, I.C.J. van, (1802-1831) 269.

Spierings, Kees, (r898-) 190, 191, 264, 280-282, 370, 507, 553.

Spinoza, Baruch de (1632-1677) 78, 146.

Staels, Lies(je) 79, 80, 82, 86, 87, 90-94, 96, 100-106, 111 , 153.

Stalin, Jozef, (1879-1953) 346.

Starink, Jan, (1927) 518, 519.

Steenis, van, landbouwer 594.

Steensma, voorz. Tribunaal 442, 443.

Stein, Friedrich Freiherr von, (1818-1885) 308.

Stein, Sophie, actrice 319.

Steinbeck, John, (1902-1968) 515.

Stekelenburg, H.A.V.M. van, (1929-1999) 567.

Stientje, Grad rg9.

Stilgebauer, Edward (1868-1936) 75 .

Stols, uitg. 150.

Stom, Bertus 293.

Strake, Te 256, 286, 307,416, 425 .

Streuvels, Stijn, (ps, van Frank Lateur, 1871-1969) 25, 30,

$35,37,38,54,60,66,68,73,82,93,115,119,120,167$. 169, 183, 193, 202-207, 220, 228, 229, 233, 239, 243. $251,254,258,283 \cdot 285,307,308,311,341-343,350$, $351.357,358,378,400,401,422,456-461,466,467$. $473,474,479,490,492,493,496,499,501,517,525$. $527,528,532,546,554,585,588,592,594$.

Strindberg, August, (1849-1912) 102, 146 .

Stroman, Ben, (1902-1985) 469. 556.

Strooband, Kees 312.

Stuiveling, Garmt, (1907-1985) 542, 543, 557, 588, 589 .

Surringa, jkvr. 537.

Swinkels, A, wrnmd. burgemeester Deurne 440-444.

Swinkels, Carel,(I92I-1996) 325, 335, 365, 507, 583, 588 , 589.

Swinkels, A.H. (Harry) 426, 435.

Swinkels, Godefridus, (grootvader van de schrijver) 18.

Swinkels, Maria Goordina, (zie Coolen-Swinkels).

Székely-Lulofs, Madelon, (1899-1958) 395.

Taels, Joris, (1919) 279, 336, 337, 382, 383 .

Taxil, Léon 89.

Tazelaar 139, 149. 
Tegenbosch, Lambert, (1926) 220, 221, 449, 521, 522 , $542,543.555 .569-571,610$.

Tegener, Hans $57 x$.

Teirlinck, Herman, (1879-1967) 458,488.554.

Theeuwes, Sjef 170 .

Thiel, Beauftragte in Brabant $410-412,415$.

Thole, Karel, (1914-2000) 495.515. 522.

Thomas a Kempis, (1380-147r) 62,67, 98 .

Thomas van Aquino $(1225-1274) 86,123,213,294$.

Thompsom, M.A., (hoofdredacteur De Maasbode van 1898 tot 1912$) 47,65,404$.

Tielrooy, J.B., ( $(8866 \cdot 1953) 385.513$.

Timmermans, Felix, (1886-1947) 33.119, 120, 183.220, $233,237,240,258,262,355,378,383.422,457,458$, 466,467 .

Tollens, Hendrik, (1780-1856) 229. 353.

Tolstoj, LN.,(1828-1910) 58-60,73-76, 145, 156, 157,166, 167,341 .

Toorop, Jan, (1858-1928) 219 .

Topfer, Alfred 308, 357- 359, 377, 426, 454, 590.

Tosselli, Enrico, (componist, 1883-1926) 585 .

Toussaint [van Boelaere], Ferdinand Victor van, ( 1875 1947) 458 .

Tralbout, M.E., (1902.) 466, 467 .

Trip, T. 169.

Troelstra, Pieter Jelle, (1860-1930) 260.

Tromp, notaris Deurne 416, 420, 425-427.

Tsjechov, A.P., (1860-1904) 515.

Undset. Sigrid, (1882-1949) 220.

Uyen, burgemeester 406,412 .

Uyldert, Maurits, (1881-1966) 190, 191, 302, 303, 309. 337.

Vaartijes, Gé 171, 183, 205, 40I, 459, 610.

Valk, architect 305. 317.318.

Valkenier, Frans, (ps. van F.J.H.M. van der Ven, r9o7 1999) $380,381,495,510,521,592$.

Vastenhoven, J.J.M. van 172.

Veghel, van 34.

Vegt, J. van der 443 .

Ven, D.f. van der, $(1891-1973) 241,283,351,511$.

Ven, F.J.H.M. van der, (zie Frans Valkenier).

Venema, Adriaan, (1941-1993) 381, 383, 385, 387,395 . $397,455$.

Verbeek, hoogleraar $3 \times 2$.

Vercors, (ps. van lean Marcel Bruller, rgo2-1991) 444 .

Verdijk, A.A.M.,(1877-1951) 519. 520.

Vergilius, (70-19 voor chr.) 276, 490, 531 .

Verhoeven, Bernard, (1897-1965) 117, 122, 124, 155, 169 . $3+2,414,487,488,593$.

Verhoeven. Cornelis, (1928-200r) 135. 340.

Verhulst, Raf, (1866-1941) 358,457.

Verlaine, P.M. $(1844-1896) 150.306$.

Verne, Jules, $(1828-1905) 24$.

Vermeulen, Hans, (1946) 195.

Vermeylen. August, (1872-1945) 458
Verre, Tony van, (1938-2000) 403.

Verriest, Hugo, (1840-1922) 593 .

Verschaeve, Cyriel, (1874-1949) 308, $311,358$.

Verviers, E., hoofdredacteur Katholieke Staatkunde 107.

Vervoort, hoofdredacteur Meijerijsche Courant 80.

Verweij-Jonker, H., (rgo8) 430, 431, 587, 6ro.

Vestdijk, Simon, (1898-1971) 282, 305, 336, 337, 36r,

$390,474,520,526,543,545-547,556,568$.

Vesters, J.A., (1844-1881) 24 .

Vietz, Karl 394

Vigny, Alfred comte de, (1797-1863) 174.

Villiers de I'Isle-Adam, Jean Marie comte de, ( 1838 . 1889) $113,150,372$.

Vink, P. 425 .

Vinkenoog, Simon, (1928) 557.

Visser, Ab, (1913-1982) 561 .

Vlemminx, Paul (ps. van Ferdinand Smulders, rgo7. 1972) $186,510.552$.

Vliet, H.T.M. van, (1950) 275.581.

Vloodt, P.F. Thom v.d. 80 .

Voeten, Bert, (1918-1992) 483,550.

Vogels. J. 199.

Vogels, J.F.A., NSB-burgemeester 405.

Vondel, Joost van den, (1587-1679) 119, 126, 237. 328, $329,354,365.370,453.555 .585 .591$.

Voltaire, (ps: van François-Marie Arouet, 1694-1778) 60, 145. $148,229,279$.

Vos, Cornelis, (redactiesecretaris De Gemeenschap, 1891-1955) r69, 312, 373.

Vos, R. 361 .

Voskuil, J. 323.

Vree, Frank van, (r954) 243, 295.

Vries, Anne de, (1904-1964) 323.525.

Vries, Hans de $56 \mathrm{x}$.

Vries, Jan de, (1890-1964) 325, 380, $381,383,384,386$.

Vries, Theun de, (1907) 217, 218, 305, 395. 472, 479,484, $550,556,557,583$.

Vriesland, Victor E. van, (1892-1974) 338, 419, 469, 515 . 556.

Vuuren, van, hoogleraar Wageningen 260, 266, 330, 331 .

Waals, Laurens van der, uitgever 224, 358, 543. 579. 581 . Waarsenburg van de, H., (r943) 557.

Wael, W. de 493.

Wagner, Richard, (1813-1883) 376.

Walch, Frans $2 \mathrm{t}$.

Walravens, Jan, (Vlaams schrijver, 1920-1964) 509.

Walschap, Gerard, (1898-1989) 251, 288, 305, 357, 367 , 485,518 .

Warren, Hans, (r 921 ) 543, 569 .

Waugh, Evelyn, (1903-1966) 526, 564

Weijers, Ido, (r948) 544, 555 .

Werumeus Buning, J.W.F, (1891-1969) 189, 250, 251 . $254,266,267,320,385,386$.

Westerlinck, Albert, (ps. van I.J.M. Aerts, Vlaams priester/schrijver, $1914-1984) 518$.

Wiegersma, Gerard, (broer van Hendrik) 592. 
Wiegerma, Hendrik (Henk), (1891-1969) 37, 187, 202, $211,218,219,239,247,256,270,272,276,283,296$. $297,303,305,306,311,318,319,324,325,379 \cdot 381$, $386 \cdot 389,416,420,425 \cdot 427,469,492,501,554,555$. $568,583,596$.

Wiegersma, Jacob, vader van Hendrik, (1865-1931) 276 . 277.555.

Wiegersma-Daniels, Nel , vrouw van Hendrik, (1892t962)272, 273. 306, 389.

Wiegersma, Friso, zoon van Hendrik $38 \mathrm{r}$.

Wiegersma, Pieter, zoon van Hendrik, (r920) 379. 380. 596.

Wiersma, Wieger, zoon van Hendrik, (r923-194I) 380, 469.

Wiegman, Piet 272.

Wierdels, F., (r862-1935) 234-236.

Wijdeveld, Gerard, (1905-1997) 169, 186,463,487.

Wijnbergen, A.I.M.J. baron van 93.

Wilde, Oscar, (1854-1900) 400 .

Wilhelmina, koningin der Nederlanden, (1880-1962) $322,330,331,431,493$.

Willem van Oranje, (1533-1584) 243.328.

Willink, Carel, (1900-1983) 367 .

Wilt, Rob de 124.

Winkeler, Lodewijk, (195I) 545 .

Wit, Augusta de, (1864-1939) 338 .

Wit, kapelaan de 165 .

Witlox, hoofdredacteur De Tijd 194.

Witlox, K.J.M., advocaat $435-437$.

Witlox, pastoor 426,427 .

Witstein, Sonja F., (1920-1978) 469 .

Witteman. P.) 312.

Woensel, Lodewijk van, (ps, van Louis Vrijdag, 1913. 1994) 597.599 .

Woestijne, Karel van de, (1878-1929) 211, 492 .

Woude, Johan van der, (1919-1997) 338 .

Wouters, Frans 583 .

Zaal, Wim, (t935) 79, 186, 187.

Zadkine, Ossip. (1890-1967) 272.

Zanden, Nol van der 208, 209

Zijlstra, Doeke, (1889-1940) 224, 270-272, 283, 356, 358 .

Zillich, Heinrich 259.

Zijlker, arts 594 .

Zoetmulder, S.H.A.M 325, 335, 365, 409, 411, 415, 433. $469,481,493,507.537$.

Zola, Emile, (1840-1902) 28, 29, 48, 50, 53. 58-60, 68-70, $78.86,91,145,147,179.250,251$.

Zurk, Johanna Wilhelmina van, overgrootmoeder van de schrijver 18 . 


\section{Curriculum vitae auteur}

Cees (Cornelis Petrus Martinus) Slegers werd geboren op 30 augustus 1944 in Cromvoirt, gemeente Vught. Na aan het St. Janslyceum in 's-Hertogenbosch het HBS-b diploma behaald te hebben, studeerde hij van 1962 tot 1969 sociologie aan de Katholieke Hogeschool Tilburg, thans KUB geheten. Tijdens zijn militaire dienstplicht was hij vicevoorzitter van de Vereniging van Dienstplichtige Militairen.

Van 197 I tot 1983 was hij werkzaam bij een landelijk pedagogisch centrum dat de integratie van vormingswerk en beroepsbegeleidend onderwijs voorbereidde. Daarna was hij enige jaren directeur van de Jeugd- en Jongerenraad Noord-Brabant. Vanaf 1987 is hij directeur van de Raad voor Welzijn, Onderwijs en Cultuur van Noord-Brabant.

Hij vervulde in de jaren tachtig diverse bestuursfuncties op sociaal en cultureel terrein in 's-Hertogenbosch. Daarnaast is hij actief als trompettist, medewerker en tekstschrijver van gelegenheidsvoorstellingen voor amateurs.

Cees Slegers woont in Helvoirt, is getrouwd en vader van twee dochters. 


\section{Bijdragen tot de geschiedenis van het Zuiden van Nederland}

Een uitgave van de Stichting Zuidelijk Historisch Contact

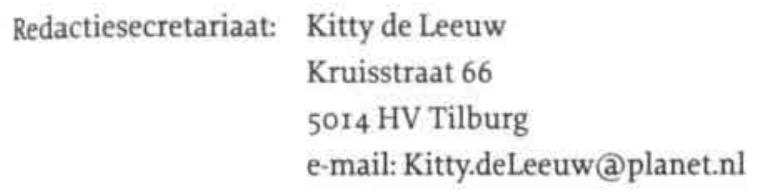

De Stichting Zuidelijk Historisch Contact heeft sinds 1964 drie reeksen uitgegeven. De eerste reeks ( 12 delen) is niet meer verkrijgbaar. Uit de tweede reeks (Ioo delen) zijn nog enkele delen verkriigbaar. De derde reeks is gestart in 1995.

Derde reeks

Dr. Th. G.A. Hoogbergen, Brabant beschouwd en beschreven. Noord-Brabant vanaf 1100 , in staatkundig, sociaal-economisch, politiek, cultureel en religieus perspectief. Samenvatting van 112 studies (Tilburg 1995) $€ 22,25$

C.G.W.P. van der Heyden, Het heeft niet willen groeien. Zuidelingen- en kindersterfte in Tilburg 1820-1930. Omvang, oorzaken en maatschappelijke context (Tilburg 1995). Uitverkocht.

Dr. Th.G.A. Hoogbergen (ed), fotografie Olaf Smit, Brabantse Monumenten Leven. Beschrijving van tachtig gerestaureerde kleine monumenten met negentig foto's (Tilburg 1996) $€ 22,25$

Dr. H.A.V.M. van Stekelenburg, "Hier is alles vooruitgang". Landverhuizing van Noord-Brabant naar Noord-Amerika 1880-1940 (Tilburg 1996) € 22,25

Dr. J.W.M. Peijnenburg, Joannes Zwijsen, bisschop 1794-1877 (Tilburg 1996) $€_{31,50}$

H.Th.M. Roosenboom, De dorpsschool in de Meierij van 's-Hertogenbosch van r648 tot 1795 (Tilburg 1997) $€_{3 \mathrm{I}, 50}$

Dr. Ineke Merks-van Brunschot, Broeders Penitenten, 300 jaar 'Burgers in Pij', en de ontwikkeling van eigentijds vrijwilligerswerk in organisatie-sociologisch perspectief (Tilburg 1996) $€_{31,50}$ 
Jos van der Lans, Hans de Kuyper (ed) In verband met Brabant. Beschouwingen bij het vijftigjarig bestaan van het $P O N$, (z.p., z.j. [I997]) $€_{22,25}$

Ria Wijnen-Sponselee, Het Wit-Gele Kruis in Noord-Brabant 1916-1974. Intermediair tussen medische verworvenheid en sociale acceptatie, (Tilburg 1997) $€ 22,25$

Dr. Theo Hoogbergen, Dr Ton Thelen (ed) Hendrik Wiegersma, medicus-pictor 1891-1969, (Tilburg 1997) $€ 22,25$

Dr. Ir. A.H. Crijns, Van overgang naar omwenteling in de Brabantse land-en tuinbouw 1950 1985 (Tilburg 1998) €22,25

P.J.M. Martens, Schokkermannen en bootvissers. De ankerkuilvisserij op Hollands Diep en Haringvliet (Tilburg 1999) Uitverkocht

Dirk Vellinga, Erfstukken. Zuidwest-Nederland van 1900 naar 2000 (Tilburg 1999) $€ 9,00$

Dr. H.A.V.M. van Stekelenburg, De Grote Trek. Emigratie vanuit Noord-Brabant naar NoordAmerika 1947-1963(Tilburg 2000) €22,25 
KERNREDACTIE
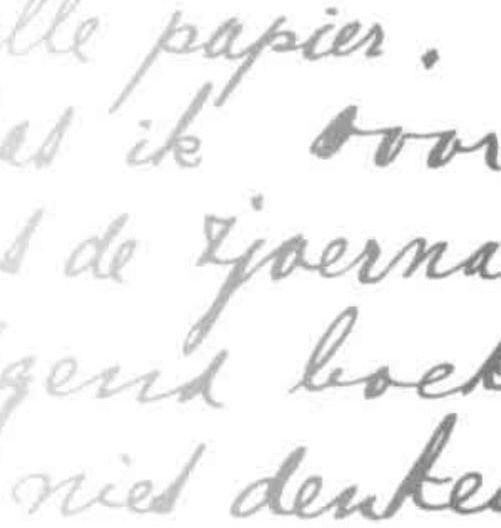

prof. dr. Arnoud-jan Bijsterveld, hoofdredacteur dr. Kitty de Leeuw, redactiesecretaris drs. Joost Rosendaal

dr. Ton Thelen

\section{REDACTIERAAD}

prof. dr. Jan Bank prof. dr. Helma Houtman-De Smedt prof. dr. Jos Koldeweij prof. dr. Wiel Kusters prof. dr. Peter Nissen prof. dr. Maarten Prak prof. dr. Walter Prevenier prof. dr. Peter Rietbergen (onder voorbehoud) prof. dr. Karel Veraghtert prof. dr. Louis Vos
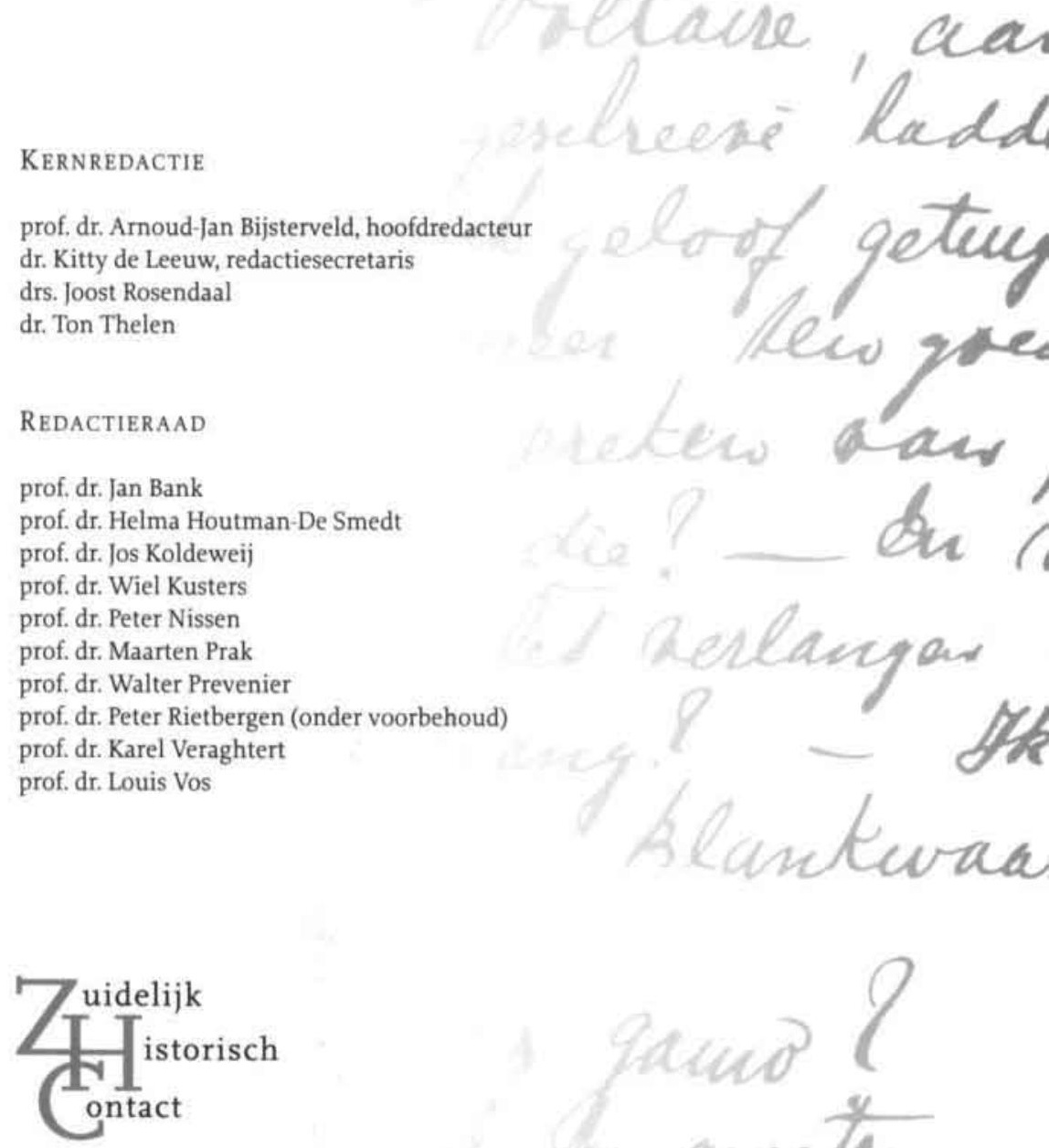

Bijdragen tot de geschiedenis van het Zuiden van Nederland 
